Felipe de Araujo Contier

\title{
O EDIFÍCIO DA FACULDADE DE ARQUITETURA E URBANISMO NA CIDADE UNIVERSITÁRIA: PROJETO E CONSTRUÇÃO DA ESCOLA DE VILANOVA ARTIGAS
}

Tese apresentada ao Instituto de Arquitetura e Urbanismo da Universidade de São Paulo para obtenção do grau de Doutor em Ciências

Área de concentração: Teoria e História da Arquitetura e do Urbanismo

Orientador: Prof. Dr. Renato Luiz Sobral Anelli

São Carlos 
AUTORIZO A REPRODUÇÃO TOTAL OU PARCIAL DESTE TRABALHO, POR QUALQUER MEIO CONVENCIONAL OU ELETRÔNICO, PARA FINS DE ESTUDO E PESQUISA, DESDE QUE CITADA A FONTE.

Contier, Felipe de Araujo

C7620 edifício da Faculdade de Arquitetura e Urbanismo
na Cidade Universitária: projeto e construção da escola de Vilanova Artigas / Felipe de Araujo Contier;

orientador Renato Luiz Sobral Anelli. São Carlos, 2015.

Tese (Doutorado) - Programa de Pós-Graduação em Arquitetura e Urbanismo e Área de Concentração em Teoria e História da Arquitetura e do Urbanismo -- Instituto de Arquitetura e Urbanismo da Universidade de São Paulo, 2015 .

1. Faculdade de Arquitetura e Urbanismo da Universidade de São Paulo. 2. João Batista Vilanova Artigas (1915-1985). 3. Cidades Universitárias. 4. Ensino de Arquitetura (história). 5. Arquitetura Moderna (São Paulo). I. Título. 


\section{FOLHA DE JULGAMENTO}

Candidato: Arquiteto e Urbanista Felipe de Araujo Contier

Título da tese: "O edifício da Faculdade de Arquitetura e Urbanismo na Cidade Universitária: projeto e construção da escola de Vilanova Artigas”.

Data da defesa: 19/06/2015

Comissão Julgadora:

Resultado:

Prof. Tit. Renato Luiz Sobral Anelli (Presidente)

(Instituto de Arquitetura e Urbanismo - IAU/USP)

Prof. Assoc. João Marcos de Almeida Lopes

(Instituto de Arquitetura e Urbanismo - IAU/USP)

Prof. Tit. Carlos Alberto Ferreira Martins

(Instituto de Arquitetura e Urbanismo - IAU/USP)

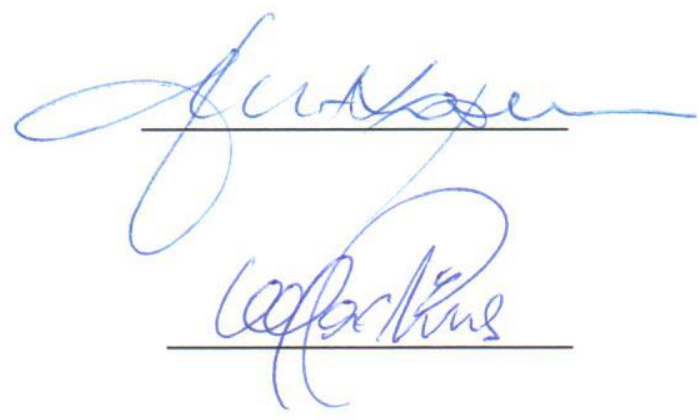

Prof. Assoc. José Tavares Correia de Lira

(Faculdade de Arquitetura e Urbanismo - FAU/USP)

Prof. Dr. João Masao Kamita

(Pontifícia Univ. Católica do Rio de Janeiro - PUC/RJ)

Profa. Dra. Sylvia Ficher

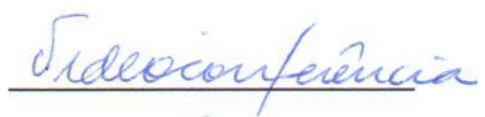

(Universidade de Brasília - UnB)

Coordenador e Presidente da Comissão de Pós-Graduação do Programa de PósGraduação em Arquitetura e Urbanismo: Prof. Dr. Márcio Minto Fabrício 



\section{AGRADECIMENTOS}

À FAPESP e ao CNPq, que financiaram esta pesquisa.

Ao meu orientador, Renato Anelli, pela confiança, generosidade e respeito com que sempre tratou este trabalho.

Ao Sérgio Ferro e sua inseparável companheira Ediane, que me inspiraram e me apoiaram.

Aos professores que contribuíram com suas arguições nos exames de qualificação e defesa: Sylvia Ficher, João Masao Kamita, Ana Luiza Nobre, José Tavares Correia de Lira, Carlos Alberto Ferreira Martins e João Marcos de Almeida Lopes.

Aos professores, pesquisadores e interlocutores, Ana Paula Koury, Dalva Thomaz, Ana Clara Giannecchini, Cibele Rizek, Miguel Buzzar, Luis Espallargas Gimenez, Maria Lucia Gitahy, Monica Junqueira Camargo, Lucio Gomes Machado, Abilio Guerra, Joana Mello, Eneida de Almeida, Ana Lúcia Cerávolo e Katie Lloyd Thomaz.

À família de João Vilanova Artigas, em especial, à Rosa Artigas e ao Marco Artigas Forti.

Aos entrevistados Sérgio Ferro, Vladimir Brega, Vera Lúcia Rizkallah, Rosa Artigas, José Castanho, Sérgio Assumpção, Abdias Nogueira da Silva, Celso Lamparelli, Jon Maitrejean, Paulo Mendes da Rocha, José Luiz Mendes Ripper, André Mehes e Luciano Bernini (in memoriam).

A todos os servidores, órgãos e seções consultados da Universidade de São Paulo, por sua paciência e colaboração. Em especial à Eliana de Azevedo Marques, à Valéria, à Satiko, à Iracema (in memoriam) e à Gisele, da Biblioteca, à professora Helena Ayoub e à Luciene Ribeiro dos Santos, do Departamento de Projeto, à Magali, da Acadêmica, à Kênia e à Bianca do Expediente, ao Emerson Lima da Seção de Aluno, à Paula Noia e à Eunice do 
GEEF, e à professora Claudia Terezinha Oliveira, todos da Faculdade de Arquitetura e Urbanismo. À Sabrina Fontenelle e ao Centro de Preservação Cultural. Ao Reginaldo, ao Oswaldo e ao Sérgio Assumpção da Superintendência dos Espaços Físicos da USP. E aos servidores do Instituto de Arquitetura e Urbanismo de São Carlos, em especial ao Marcelo Celestini, Alessandro Souza, Mara Lino e Felipe Romano.

Aos colaboradores, Natalia Gaspar, Carime Centurione, Wagner Conde, Mônica Andrade, Maria Jeydjane Gomes, Nicole Cahali e João Lucas Domingos.

Aos amigos com quem dividi as angustias e prazeres deste trabalho: Carolina Heldt, Eduardo Orsolini, José Luís Neves, Lucas Keese, Gustavo Ferrão, Maria Carlotto, Diego Kapaz, Marina Ayra, Tainá de Paula, Beatriz Tone, Diego Beja Inglez de Souza, Dinalva Roldan, Carolina Laiate, Eduardo Costa, Carolina Lunetta, Raquel Gomes, Daniela Sönksen, Alexandre Leitão Santos, Magaly Marques, Adriana Leal de Almeida e Wellington Ramalhoso. Especialmente aos que me prestaram inestimável ajuda na reta final e na revisão após a defesa deste trabalho, Juliana Braga, Raphael Grazziano, João Sodré, Paula Dedecca, Rafael Urano e Inês Bonduki.

À Ester Zemel, por seu cuidado.

Aos meus pais, Luiz Augusto e Silvia Helena e seus cônjuges, Miriam Castanho e Milton Kagaya, meus sogros e demais familiares, pela paciência e pelo apoio ao longo de todos esses anos.

E, muito especialmente, à Raquel, minha companheira de todos os momentos e a maior apoiadora deste trabalho, cuja interlocução e colaboração foram fundamentais e imensuráveis.

A todos, minha sincera gratidão. 
"Haja hoje para tanto ontem. E amanhã para tanto hoje. Sobretudo isso".

Paulo Leminski 



\section{RESUMO}

O projeto de João Batista Vilanova Artigas (1915-1985) para o edifício da Faculdade de Arquitetura e Urbanismo da Universidade de São Paulo, concebido entre 1960 e 1961 e construído na Cidade Universitária entre 1966 e 1969, atravessou um período de ruptura na ordem política do país que marcou sua produção material e sua valoração histórica.

Marco inquestionável da arquitetura moderna brasileira e, em particular, da escola de Vilanova Artigas, a explicação histórica dessa obra se mostra indissociável da luta pela reforma do ensino de arquitetura, das políticas para obras públicas do Estado de São Paulo e do debate sobre o subdesenvolvimento no segundo pós-guerra.

Esta tese, organizada em quatro capítulos, busca, primeiramente, interpretar a trajetória de seu autor até o momento da inauguração do edifício, argumentando que a pesquisa arquitetônica de Artigas baseada no concreto armado aparente, iniciada em meados da década de 1950, manteve seu vínculo com a nova monumentalidade, porém, deslocando o foco representativo da identidade nacional para a própria construção.

Em seguida, este trabalho examina o processo de distinção de Vilanova Artigas no campo institucional da FAU e sua relação com o campo profissional. Para isso, recorre à história da faculdade, criada em 1948, a partir do curso de arquitetura da Escola Politécnica da USP, na qual se observa o crescimento do protagonismo de Vilanova Artigas, consagrado com seu projeto para o novo edifício da escola e sua liderança na reforma do ensino. Seu papel busca ser explicado à luz da atuação de seus pares, professores, arquitetos e engenheiros, bem como dos obstáculos políticos e acadêmicos enfrentados por ele.

O encontro das hipóteses arquitetônicas radicais de Artigas com o fecundo território para experimentações da Cidade Universitária de São Paulo é discutido em seguida, tomando 
como referência a história desse campus e o caráter excepcional das Cidades Universitárias de modo geral. São então destacados o Plano de Ação do Governo do Estado (PAGE, 1959-1963), responsável por uma mudança de paradigmas nas obras públicas do Estado de São Paulo que resultou na promoção da arquitetura moderna feita em escritórios particulares, e o Fundo para Construção da Cidade Universitária Armando Salles de Oliveira (FCCUASO), um órgão público de planejamento e administração direta das obras na Cidade Universitária, criado pelo PAGE, que teve papel relevante na construção do edifício da FAU.

O último capítulo deste trabalho analisa aspectos artísticos, técnico-construtivos e políticos da produção do edifício da FAUUSP. A trajetória de Vilanova Artigas, a história da FAU e os planos para a Cidade Universitária são retomados em uma narrativa detalhada que vai dos primeiros croquis do projeto à inauguração do edifício, tragicamente simultânea ao afastamento de Artigas da universidade, em 1969.

Palavras-chave: Faculdade de Arquitetura e Urbanismo da Universidade de São Paulo; João Batista Vilanova Artigas (1915-1985); Cidades Universitárias; Ensino de Arquitetura (história); Arquitetura Moderna (São Paulo). 


\section{ABSTRACT}

The architecture project of João Batista Vilanova Artigas (1915-1985) for the building of the Faculty of Architecture and Urbanism of the University of São Paulo, designed between 1960 and 1961 and built between 1966 and 1969, passed through a period of disruption in the political order of the country that interfered on its production and historical meaning.

Being an unquestionable landmark of Brazilian modern architecture and, in particular, of the Artigas' school, the historical explanation of this work is inseparable from the struggle to reform the architecture education, the policies for public works in the State of São Paulo and from the debate about architecture in the context of the post-war underdeveloped world.

This four chapters thesis seeks, first, to interpret the trajectory of Artigas until the inauguration of the building, arguing that his architectural research based on exposed concrete that began in the mid-1950s, maintained its link with the new monumentality, however, shifting the representative focus of national identity for the construction itself.

Then, this study examines the distinction process of the architect in the institutional field of FAU and its relationship with the professional field. For this, we refer to the history of FAU, created in 1948 from the architecture course of the Polytechnic School of USP. We seek to explain the role that Vilanova Artigas obtained both with his design for the new building of the school and with his leadership in the educational reform, in the light of the performance of their peers, professors, architects and engineers, as well as the academic and political obstacles faced by the architect.

The confluence of Artigas' radical architectural hypothesis and the fertile territory for experiments of the campus of São Paulo is discussed in the third chapter, from the perspective of the history of this campus and the exceptional character of the Cidades Universitárias in general. We then highlight the Action Plan of the State Government - PAGE 
(1959-1963), which was responsible for a paradigm shift in public constructions of the State of São Paulo that resulted in the promotion of modern architecture made by private offices. PAGE created the Fund for Construction of the campus (FCCUASO), a public agency of direct administration of constructions that planned and executed the constructions on the campus, playing a decisive role in the construction of the building of FAU.

The last chapter of the present thesis analyses some or the artistic, technical-constructive and political aspects of the production of the studied work. The trajectory of Vilanova Artigas, the history of the Faculty of Architecture and Urbanism and the plans for the campus are resumed in a detailed narrative from the early drawings until the opening of the building and the dismissal of the Artigas from the university, in 1969.

Key-words: Faculty of Architecture and Urbanism of the University of São Paulo; João Batista Vilanova Artigas (1915-1985); University campus; Architecture Education (history); Modern Architecture (São Paulo) 


\section{SUMÁRIO}

$\begin{array}{lr}\text { APRESENTAÇÃO } & 15\end{array}$

INTRODUÇÃO: A ESCOLA DE VILANOVA ARTIGAS $\quad 19$

REALISMO E MONUMENTALIDADE NA TRAJETÓRIA DE VILANOVA ARTIGAS 41

MORAL CONSTRUTIVA (1937-1943) 41

MONUMENTALIDADE MODERNA (1943-1956) 54

REALISMO CONSTRUTIVO OU BRUTALISMO CABOCLO? (1956-1964) 69

A FACULDADE DE ARQUITETURA E URBANISMO

SOBRE SUAS ORIGENS

A ESCOLA DE ANHAIA MELLO (1948-1952) 103

ASCENSÃO DE VILANOVA ARTIGAS (1953-1958)

REFORMA DO ENSINO (1959-1963) 134

A ESCOLA FRATURADA (1964-1969) 148

$\begin{array}{ll}\text { CIDADE UNIVERSITÁRIA } & 167\end{array}$

A NOÇÃO DE CIDADE UNIVERSITÁRIA (1826-1940) 167

CONSTRUÇÃO DA CIDADE UNIVERSITÁRIA DA USP (1941-1958) 189

ARQUITETURA E PLANEJAMENTO DE OBRAS PÚBLICAS (1959-1969) 220

PROJETO E CONSTRUÇÃO DO EDIFÍ́CIO DA FAUUSP 253

DESENHO (1960-1966) 253

CANTEIRO (1967-1969) 297

O EDIFÍCIO CONSTRUÍDO

CONCLUSÕES

$\begin{array}{ll}\text { BIBLIOGRAFIA } & 341\end{array}$

ANEXO I - RESUMO DAS CADEIRAS FAU 357

ANEXO - PROFESSORES FAU 369

$\begin{array}{ll}\text { ANEXO - DISCIPLINAS FAU } & 371\end{array}$ 


\section{APRESENTAÇÃO}

Iniciada como um mestrado, esta pesquisa, a princípio, propunha um estudo de caso brasileiro a partir da chave de análise desenvolvida por Sérgio Ferro em seus estudos sobre o Convento de La Tourette, de Le Corbusier, em que um edifício de arquitetura moderna é analisado em seu processo de produção, indissociavelmente artístico, técnico, econômico e social. ${ }^{1}$ Por trás dessa proposta, havia um claro interesse em desmistificar a figura do autor bem como afirmar a parcialidade predominante na historiografia da arquitetura em detrimento da realidade complexa e contraditória da prática profissional. Com a indicação para virar um doutorado direto, a pesquisa se ampliou em alguns pontos, graças a contribuições diversas, e se restringiu em outros, de acordo com a disponibilidade de materiais e a inviabilidade de outras expectativas. Surgiram novas referências teóricas. Michael Baxandall e Pierre Bourdieu assumiram papel importante ao lado de uma legião de autores que já me socorria. A profusão de novos trabalhos sobre Vilanova Artigas às vésperas do prazo conclusão, por conta da efeméride do centenário do arquiteto, me desnorteou com novos materiais, colocando em dúvida muito do que já estava feito. Não obstante todas essas etapas e todas as descobertas feitas ao longo do caminho, acredito que, de modo geral, esse trabalho se manteve coerente com o espírito inicial.

Como na maioria das teses de história da arquitetura, a questão de fundo é o presente da profissão e não o passado em si mesmo. No auge da pretensão de um arquiteto recémformado na FAUUSP, mas de uma geração já distanciada dos formadores da escola, me perguntava sobre nosso endereço histórico. De onde estamos partindo e como chegamos

\footnotetext{
${ }_{1}^{1}$ FERRO, Sérgio; KEBBAL, Chérif; POTIÉ, Philippe; SIMONNET, Cyrille. Le Couvent de la Tourette. Marseille, Parenthèses, 1987. Esse livro é apenas um dos resultados da pesquisa liderada por Sérgio Ferro na École Nationale Supérieure d'Architecture de Grenoble, ao logo de mais de dez anos.
} 
até aqui? Se a abordagem materialista de Ferro sugeria um caminho pouco explorado para entender a engrenagem sobre a qual a possibilidade artística na arquitetura se apresenta, as perguntas sobre o nosso endereço histórico me levaram, inevitavelmente, ao próprio edifício da FAUUSP. Formou-se assim uma intrincada relação entre o objeto e o método de trabalho, que implicaria em grandes riscos, mas também em hipóteses promissoras. Afinal, se entendida amplamente como a escola de Vilanova Artigas, a FAU podia ser tomada como ponto de partida da abordagem crítica de Ferro, tanto no que se quis superar quanto no método para se superar. Ou seja, era uma possibilidade de repensar o suposto conflito entre Ferro e Artigas, cultivado nos anos 1970 e 1980 - durante a ausência dos dois protagonistas, diga-se de passagem -, sem neutralizar suas posições e nem as aceitar como antagônicas por princípio.

Se a arquitetura é a menos livre de todas as artes, operando não apenas os óbvios interesses funcionais dos edifícios, mas também complexos e intangíveis interesses imobiliários, industriais e financeiros, isso não significa que as determinações externas bastem para explicar uma obra. Por outro lado, uma análise restrita à autonomia disciplinar parece ser um viés igualmente insuficiente - se não mais perigoso, a depender dos limites atribuídos à disciplina - por forçar uma separação ideológica entre a arquitetura e as demais "disciplinas" ao invés de relacioná-las. Para uma explicação histórica da obra arquitetônica, tal como proposta por Baxandall ${ }^{2}$, nem as determinações externas, nem a autonomia disciplinar parecem bastar. A necessidade de relacionar as múltiplas determinações da arquitetura pode soar uma conclusão um tanto óbvia. Porém, ainda hoje, esse campo de pesquisas se mostra incipiente e carece de um corpo metodológico consolidado. ${ }^{3}$ Que documentos buscar e como interpretá-los? Como relacionar técnicas, comportamento estrutural, materiais, custos, atuações empresariais, políticas de governo, cultura arquitetônica, ensino, contexto histórico, intenção autoral e uma série de outros temas na análise de uma obra, sem cair em narrativas caducas que não contribuem umas com as outras para a compreensão integral da obra?

Ao longo da pesquisa foi ficando claro que cada objeto requer seu próprio instrumental, de acordo com o material disponível e os conteúdos mobilizados por sua história. No caso da FAU, isso implicou em dedicar dois capítulos específicos, um sobre a própria faculdade e

\footnotetext{
2 BAXANDALL, Michael. Padrões de intenção: a explicação histórica dos quadros. São Paulo: Cia. das Letras, 2006.

${ }^{3}$ Convidado para inaugurar o campo da História da Construção, John Summerson acreditava ser este o caminho natural para as novas pesquisas em história da arquitetura, uma vez que já havia certo domínio sobre o estudo das trajetórias, do mecenato e dos efeitos visuais da arquitetura. SUMMERSON, John. "What is the history of construction". Journal of the Construction History Society, n. 1, 1985. Passados trinta anos, a Construction History Society se desenvolveu de sobremaneira, incorporando proficuamente questões sobre trabalho, gênero, materiais e uma infinidade de outros temas. Contudo, raros desses estudos buscam lidar com a dimensão estética e não parece haver qualquer convergência de métodos nem mesmo de referências teóricas.
} 
outro sobre a Cidade Universitária, além dos capítulos sobre o arquiteto e sobre a produção do edifício.

Essas especificidades, contudo, não representaram um afastamento da obra, mas reaproximações concretas. A pertinência da FAU para a história da arquitetura está ancorada no fato de ser uma escola de arquitetura bem como ser uma obra pública, parte de um território de experimentações e de um plano de governo. E é somente a partir dessa configuração concreta que podemos especular sobre o material simbólico e o significado das escolhas de projeto.

Tal olhar não visa apenas desmistificar, mas também contemplar a relativa liberdade conquistada por arquitetos em meio a tantos interesses e agentes envolvidos na construção de um edifício. Mais uma vez, a FAU de Artigas se revela um caso excepcionalmente oportuno para se entender o papel do arquiteto na sociedade e seu poder. Não me refiro apenas ao poder prosaico de dar formas a ícones ou representar alegorias. Nem mesmo o misterioso poder, também muito concreto, de influenciar o comportamento e a psicologia de quem habita sua obra. Mas um poder mais abstrato, que ultrapassa e desafia a atribuição estrita do arquiteto e do qual Artigas parecia estar muito ciente: o poder de interferir econômica e culturalmente no complexo industrial da construção, determinando a mão de obra e os materiais empregados, a ocupação do solo, a distribuição do programa de necessidades, a rentabilidade do investimento e, desse modo, dirigir a modernização do país. Artigas, mais do que seus colegas e antecessores, percebeu que esse poder estava associado ao desenho e a um domínio que resistia e se sobrepunha às especialidades que ameaçam fragmentar a obra: o controle de sua aparência. Na verdade, aparência de aparência, pois se trata justamente do controle de uma série de decisões heterogêneas que, projetadas, resultavam na aparência de um edifício. É por isso que a interpretação histórica do edifício da FAUUSP depende do julgamento das decisões de projeto levando em conta não apenas a forma, mas também seu processo de produção.

No tumultuado arco temporal da construção da FAUUSP (1960-1969), em meio a mudanças radicais de comportamento, institucionalização de instrumentos de planejamento e busca por uma alternativa dentro do subdesenvolvimento em plena guerra-fria, uma anedota da corrida espacial pode ilustrar a opção low-tech de certa cultura marxista na qual o nosso arquiteto estava inserido. Segundo ela, enquanto os norte-americanos teriam investido muito tempo e dinheiro em pesquisa para chegar a uma caneta capaz de escrever em condições extremas de temperatura, pressão e falta de gravidade, russos teriam simplesmente levado o lápis ao espaço. Na discussão sobre arquitetura moderna e subdesenvolvimento, a escola de Artigas deu sentido a um sentimento coletivo difuso, atribuindo dignidade à simplicidade e à baixa tecnologia do concreto armado, tomado como a opção mais adaptada às 
condições terceiro-mundistas que incluíam uso intensivo de mão de obra, esquecimento das técnicas tradicionais de construção, especialização da engenharia, etc. Se o concreto já estava intimamente ligado ao processo de modernização das relações de produção na construção e à história da arquitetura moderna brasileira, tratava-se, naquele momento, de usá-lo como material histórico.

O fenômeno que observamos no edifício da FAU é o do encontro efêmero, instável e reativo entre a formação crítica das vanguardas artísticas e a delicada liberdade de decisão num setor econômico tão importante como o da construção civil. Uma espécie de anomalia na lógica funcionalista do capitalismo que permitiu, ao menos em tese e por um breve tempo, que arquitetos acreditassem estar disputando as estratégias de modernização do país enquanto técnicos-artistas.

Por este prisma, o edifício da Faculdade de Arquitetura e Urbanismo nos permite entender o protagonismo da escola de Vilanova Artigas na crise da arquitetura moderna no Brasil, para a qual - e da qual - o edifício se tornou um cânone. Se estivermos certos, esse cânone pode também ajudar a explicar, por sua diferença, o tempo de hoje, nascido daquele, no qual a liberdade na arquitetura se restringe a uma faixa cada vez mais estreita de controle da aparência da obra e, mesmo assim, sempre supervisionada por instrumentos de planejamento e gestão, agora deslocados para outras disciplinas. 


\section{INTRODUÇÃO:}

\section{A ESCOLA DE VILANOVA ARTIGAS}

A presente tese é dedicada ao estudo da produção de uma obra de arquitetura: a Faculdade de Arquitetura e Urbanismo da Universidade de São Paulo, na Cidade universitária. Não se trata de uma obra qualquer e sim do cânone de uma escola de arquitetura, chamada de escola paulista, escola brutalista ou escola artiguista. Apenas isso seria suficiente para ampliar imensamente o escopo da pesquisa. Mas, além disso, esse edifício é também um monumento da Faculdade de Arquitetura e Urbanismo, que ele abriga e representa. Instituição essa que não apenas ocupou o edifício, mas participou do planejamento da Cidade Universitária e definiu o campo no qual o professor e arquiteto Vilanova Artigas foi escolhido para projetar o edifício. Como já é possível antecipar, a presença de Artigas, apesar de não ser o foco da tese, se destaca em todos os ângulos sob os quais podemos analisar o edifício.

As relações intrincadas entre autor e obra, programa e ensino, encargo e diretrizes, doutrina e cânone é o que melhor define o assunto que trataremos a partir do processo de produção material e imaterial da obra. Por isso podemos dizer que o tema deste trabalho é a "Escola de Vilanova Artigas", termo cuja ambiguidade traduz as múltiplas dimensões desse objeto.

Nesta introdução buscaremos demonstrar, através de uma rápida revisão bibliográfica, como a Escola de Vilanova Artigas foi introduzida na história da arquitetura brasileira e de que modo suas duas dimensões principais - o edifício e a doutrina - contribuíram para o seu significado. Em seguida, destacaremos dessa produção bibliográfica a questão que estimulou esta pesquisa. 
Apesar da intensa atividade profissional de João Batista Vilanova Artigas no início da década de 1940 - que discutiremos no primeiro capítulo - suas "casas wrightianas" não lhe renderam grande repercussão fora do mercado imobiliário paulistano. Como se sabe, o Brasil era extremamente carente de publicações e de cultura arquitetônica, principalmente de tendências modernas, para onde a produção de Artigas começava a apontar. Nem mesmo sua participação na fundação do IAB/SP, no ensino da Poli e criação da FAU, renderam a Artigas uma projeção de sua obra para além dos círculos paulistas.

É muito sintomático que suas primeiras obras tenham sido publicadas no Brasil no número de estreia da revista Habitat, de 1950, encabeçada por Lina Bo Bardi e, mais que isso, após a adesão de Artigas aos cânones racionalistas bem-sucedidos no Rio de Janeiro. Desse modo, além de selecionar os projetos recentes de Artigas e excluir suas "casas wrightianas", Lina introduziu algumas das categorias mais persistentes na interpretação de sua obra, tais como a primazia da prática, o cuidado com os pormenores, o humanismo, a moral severa, a oposição à aparência de modernidade "que já hoje se pode definir num estilismo", a continuidade entre interior e exterior, rigor, correspondência de forma e espaço, clareza, abertura, integração das funções, mudança de hábitos. ${ }^{1}$

Durante a década de 1950, os projetos de Artigas ganharam espaço em revistas como Arquitetura e Decoração, Módulo e, principalmente, na revista Acrópole, que teve um importante papel na divulgação da arquitetura feita em São Paulo. ${ }^{2}$

Foi nesse contexto que Henrique Mindlin incluiu Artigas num panorama da arquitetura moderna brasileira, com o livro Arquitetura moderna no Brasil, de 1956. Mindlin deu grande destaque à obra recente de Artigas $^{3}$, minimizando seu interesse inicial por Frank Lloyd Wright, do qual o brasileiro teria absorvido apenas um "senso de continuidade espacial". Artigas foi retratado por sua "busca de um marco adequado a uma sociedade integrada e harmônica". Decorreria desta visão doutrinária, mas ao mesmo tempo imbuída de "consistente percepção poética", "sua preferência por uma expressão clara e honesta dos

\footnotetext{
1 BARDI, Lina. "Casas de Vilanova Artigas". Habitat, n, 1, São Paulo, out-dez 1950, pp. 2-16. Republicado em XAVIER, Alberto (org). Depoimentos de uma geração: arquitetura moderna brasileira. São Paulo: Cosac Naify, 2003, pp. 348-349.

${ }^{2}$ A respeito das revistas especializadas do período, ver: DEDECCA, Paula. Sociabilidade, crítica e posição. O meio arquitetônico, as revistas especializadas e o debate do moderno em São Paulo (1945-1965). Dissertação de mestrado em Arquitetura e Urbanismo. Orientador: José T. C. de Lira. São Paulo: FAUUSP, 2012.

${ }^{3}$ Esse destaque pode ser mensurado pelo número de obras selecionada no livro: Oscar Niemeyer (ENBA, 1934), 19 projetos; Affonso Eduardo Reidy (ENBA, 1930) e Henrique Mindlin (EEM, 1932), 9 projetos cada; MMM Roberto, 8 projetos; Rino Levi (Roma, 1926), 6 projetos; Lucio Costa (ENBA, 1924) e Francisco Bolonha (ENBA, 1945), 5 projetos cada; João B. Vilanova Artigas (EPUSP, 1937); Sérgio Bernardes (FNA, 1948); Paulo Antunes Ribeiro (ENBA, 1935), 4 projetos cada; Gregori Warchavchik (Roma, ?); Carlos Frederico Ferreira (ENBA, 1935); Álvaro Vital Brazil (ENA, 1933, EPRJ, 1933); Olavo Redig de Campos (Roma, 1931), 3 projetos cada; Lina Bo Bardi (Roma, 1940); Oswaldo Artur Bratke (EEM, 1931) e Alcides Rocha Miranda (ENBA, 1932), 2 projetos cada; e Plínio Croce e Roberto Aflalo, Ícaro de Castro Mello e Eduardo Kneese de Mello, Hélio Duarte e outros, com apenas um projeto. Entre os paulistas Artigas ficou atrás apenas de Rino Levi e do próprio Mindlin. Os projetos publicados foram: a casa Heitor de Almeida, em Santos; o edifício Louveira e a casa do arquiteto, em São Paulo; e o terminal rodoviário de Londrina.
} 
métodos e técnicas contemporâneos, em vez de submissão à paisagem e uma fusão com a natureza". ${ }^{4}$

A partir de 1956, uma série de fatores, que discutiremos detalhadamente nos próximos capítulos, levaram Artigas a uma nova fase de sua obra. A recepção positiva dos novos projetos do arquiteto por parte da crítica foi acompanhada de seu protagonismo nos debates sobre a reforma do ensino de arquitetura no Brasil e das primeiras obras públicas de toda uma geração de arquitetos formados em São Paulo. Em 1960, Bruno Alfieri, editor da revista Zodiac, foi o primeiro a sugerir a pertinência do termo "brutalismo" - já bastante divulgado por Reyner Banham - para caracterizar a produção recente de Vilanova Artigas. ${ }^{5}$

O texto introdutório de Alfieri naquela edição dedicada à arquitetura brasileira foi acompanhado de outro texto, do professor Flávio Motta, que contextualizava a produção arquitetônica no Brasil a partir da geografia e da história do país. Naquela ocasião, o crítico e professor da FAU, retratou seu amigo como um desbravador bandeirista, cujo espírito prático conduziu a uma linguagem depurada como a dos pioneiros paulistanos. A obra de Artigas foi caracterizada pela "economia de meios de construção, onde, às vezes, o arquiteto se mistura intimamente com a atividade do mestre de obras e do operário". Flávio Motta deu especial atenção à "expressão da energia que penetra na matéria" e ao "esforço para chegar a novas formas por meio de processos construtivos independentes da instabilidade da nascente indústria construtiva". ${ }^{6}$

Mais do que destacar a obra e a personalidade de Artigas, Flávio Motta identificava uma produção local coletiva e alternativa à arquitetura carioca, já desgastada pelas criticas ao formalismo. Se até então o arquiteto havia merecido elogios episódicos por sua produção individual, destacando sua correção técnica e sua atenção aos materiais, ele passava agora a ser visto como protagonista de uma "intensa atividade doutrinária", de proporção semelhante à de Lucio Costa, no Rio de Janeiro, de modo que a ideia de escola já estaria presente. $^{7}$

Esse é um resumo das principais contribuições ao significado da obra de Artigas antes do conhecimento do projeto da FAU. Como veremos no terceiro capítulo, em 1963, encerravase o PAGE e a Cidade Universitária havia se tornado o "maior canteiro de obras do país". Mas, das dezenas de projetos concluídos, de diversos arquitetos, apenas uma pequena ${ }^{4}$ MINDLIN, Henrique. Arquitetura moderna no Brasil. Rio de Janeiro: Aeroplano, 1999, p. 56, grifo nosso.

\footnotetext{
${ }^{5}$ ALFIERI, Bruno. "João Vilanova Artigas: ricerca brutalista", Zodiac, n. 6. Milão, 1960. Neste artigo, Bruno Alfieri pondera os sentidos do termo "brutalismo" e menciona as casas Rubens de Mendonça, Olga Baeta, o Ginásio de Itanhaém e o Estádio do Morumbi.

${ }^{6}$ MOTTA, Flávio. "Introduzione al Brasile", Zodiac, n. 6. Milão, 1960, p. 67. Tradução livre do italiano.

${ }^{7}$ Essa é a interpretação de: DEDECCA, Paula Gorenstein. "A ideia de uma identidade paulista na historiografia de arquitetura brasileira". Revista Pós, n. 32, São Paulo, dezembro, 2012, p. 90-101.
} 
parcela das obras havia sido iniciada. A FAU não teve esta sorte e há registros da publicação do projeto. De todo modo, Geraldo Ferraz foi um dos primeiros a destacar uma perspectiva coletiva da arquitetura paulista, criada a partir do Plano de Ação do Governo do Estado (PAGE). Para Ferraz, o conjunto de obras públicas promovidas pelo Estado de São Paulo entre 1959 e 1962 era uma espécie de redenção dos arquitetos paulistas que não haviam tido oportunidade de expor em Brasília suas teses arquitetônicas debatidas nas escolas de arquitetura e no departamento paulista do IAB, que apontariam para soluções menos formalistas, baseadas na "coordenação construtiva". Teses essas visíveis nos diversos projetos para Cidade Universitária, entre os quais, o edifício da FAU se destacava. ${ }^{8}$ Com o golpe civil-militar de 1964, Artigas foi perseguido e ficou exilado por quase um ano. Retomando suas atividades no segundo semestre de 1965, o arquiteto foi membro do Júri da 8 $^{\text {a }}$ Bienal de São Paulo e expôs seus trabalhos em uma sala hors concours. Lá, foi apresentada uma maquete da FAU, como informava o número da Acrópole, dedicado àquela Bienal. ${ }^{9}$ Mas ainda levaria muitos meses e haveria muito conflito até que a construção do edifício fosse iniciada. Curiosamente, mesmo durante as obras (1967-1968) o projeto permaneceu fora das publicações e até mesmo dos debates sobre o ensino que mobilizavam a FAU. ${ }^{10}$

Conforme discutiremos detalhadamente no segundo capítulo, o edifício foi inaugurado no início de 1969 e, logo em seguida, Artigas foi afastado compulsoriamente da Universidade. A obra passava a ser amplamente noticiada em revistas e jornais, como Veja, Manchete e Folha de S. Paulo e conhecida pela crítica num momento extremo de tensão. O sentimento de injustiça e perseguição se refletiu no sentido de liberdade e contestação que a obra foi recebida. A ausência de portas, guarda corpos, revestimentos e a subversão hierárquica do programa funcional foram tomadas como gestos de enfretamento aos limites impostos pela nova realidade política. O edifício da FAU tornava-se cânone da escola paulista, já identificada por Motta e Ferraz, e monumento da Faculdade de Arquitetura e Urbanismo. Com a ausência de Artigas na FAU, sua atividade doutrinária foi substituída por um cânone, cujas formas e estratégias projetuais, não por acaso, passariam a ser repetidas por um séquito de arquitetos formados naquela escola: a Escola de Vilanova Artigas.

\footnotetext{
${ }^{8}$ FERRAZ, Geraldo. “Uma cidade universitária no Brasil: CUASO”, Zodiac, n. 11. Milão, 1963.

${ }^{9}$ Acrópole, n. 322, p. 25.

${ }^{10}$ Além da $8^{\underline{a}}$ Bienal de São Paulo, só há registro de que o projeto foi apresentado foi no $2^{\circ}$ Encontro Arquitetos, Professores e Estudantes de Arquitetura, realizado em Porto Alegre, em abril de 1960. Cf. PEREIRA, Miguel. "Sobre o Projeto da Faculdade de Arquitetura e Urbanismo da Universidade de São Paulo", Cadernos de Estudos. FA-UFRS, 1960. Republicado em: Arquitetura e os caminhos de sua explicação. São Paulo: Projeto Editores Associados, 1984.
} 
O projeto da FAU rendeu uma série de prêmios e homenagens a Artigas. Ainda em 1968, Artigas recebeu o 1ำ Prêmio de Arquitetura na II Bienal de Artes Plásticas da Bahia. Em 1969 participou da X Bienal de São Paulo com o trabalho "Edifícios para fins de Ensino", com o qual ganhou um diploma na Categoria Ensino e o Grande Prêmio Internacional "Presidente da República", atribuído pelo Banco Nacional da Habitação e por júri internacional. Na edição especial que a revista Acrópole $(1970)^{11}$ dedicou ao arquiteto foi publicado seu texto "Sobre escolas" e por conta dessa mobilização em torno do tema, a União Internacional dos Arquitetos (UIA) Ihe ofereceu, em 1972, o prêmio Jean Tschumi, conferido à crítica de arquitetura e/ou ensino de arquitetura, pela "atividade didática na FAUUSP durante sua carreira". Por receber um prêmio dessa magnitude ${ }^{12}$ foi escolhido "Personalidade do Ano de 1972" pelo IAB-Guanabara. A partir de então, passou a receber ainda mais homenagens, incluindo uma sala especial para exposição dos trabalhos recentes na XII Bienal de São Paulo (1973). Logo, o edifício da FAU foi identificado como obra-prima do arquiteto.

Justamente nesse momento surgia a tese de doutorado de Yves Bruand, defendida na França, em 1973, e que logo passou a circular no Brasil (muito antes da primeira edição de seu livro em português). ${ }^{13}$ Era o trabalho mais completo sobre a arquitetura contemporânea no Brasil, abrangendo diversas fases, correntes, obras e arquitetos. Com uma leitura externa e minuciosa, a tese foi decisiva ao incluir definitivamente Vilanova Artigas no mais alto patamar da arquitetura brasileira bem como por definir precisamente seus discípulos e suas principais ideias.

Com recorte entre o início do século XX e o início da década de 1970, o trabalho de Bruand compilou uma quantidade inédita de informação sobre movimentos, arquitetos e projetos a partir de periódicos especializados. Mas foi por seu esforço em sistematizar análises, definir conceitos, agrupar e periodizar tal produção que o trabalho se tornou referência obrigatória para todos os subsequentes. No que diz respeito à importância de Bruand para a conceituação da Escola de Vilanova Artigas, basta dizer que foi ele quem consagrou o termo "brutalismo paulista". ${ }^{14}$

\footnotetext{
${ }^{11}$ Acrópole, n. 377, 1970.

${ }^{12}$ Artigas foi o primeiro brasileiro a receber um prêmio da UIA, seguido por Joaquim Cardoso, Lúcio Costa e Jaime Lerner.

${ }^{13}$ BRUAND, Yves. L'Architecture Contemporaine au Brésil. Lille: Services de Reproduction de Theses: Université de Lille III, 1973. Posteriormente publicado no Brasil como BRUAND, Yves. Arquitetura contemporânea no Brasil. São Paulo: Perspectiva, 1981.

${ }^{14}$ A reflexão de Bruand sobre o "brutalismo paulista" partia da análise das matrizes inglesa e corbusiana, sendo, grosso modo, a primeira uma postura ética de retorno aos princípios das vanguardas modernas, e a segunda, caracterizada por uma linguagem plástica associada ao concreto aparente.
} 
É interessante notar como a aproximação de Artigas com o racionalismo carioca perdeu força após a inauguração da FAU, ao mesmo tempo em que um interesse pela fase "organicista" do arquiteto - até então menosprezada pela crítica e, ao que tudo indica, por ele próprio - surgia juntamente com o sucesso de sua fase brutalista. Como veremos, Artigas contribuiu para estabelecer um vínculo entre as duas fases através da noção de "moral construtiva". No entanto, a passagem do chamado racionalismo (na verdade uma aproximação com a nova monumentalidade) para o brutalismo, que talvez seja a principal operação do arquiteto, foi muitas vezes desconsiderada.

Bruand situou a obra de Artigas no capítulo "à margem do racionalismo", dividindo-a em dois momentos: um de "influência organicista"15 e outro de "aparecimento do brutalismo" - este dividido em dois pontos, "a obra de Vilanova Artigas depois 1945" e "os discípulos de Vilanova Artigas". Para Bruand as variações estilísticas de Artigas representavam tomadas de posições filosóficas individuais traduzidas em termos utilitários no plano prático. Nesse sentido, se a fase wrightiana esteve ligada a uma concepção democrática liberal, seu brutalismo refletiria uma posição disciplinadora para o rápido crescimento dos países não industrializados no segundo pós-guerra.

Bruand descreveu e analisou minuciosamente a obra então recente de Artigas e especialmente o projeto da FAU, "que se traduziu num estilo pessoal que fez escola". ${ }^{16}$ Foi Bruand quem primeiro notou uma continuidade entre os projetos para os ginásios de Itanhaém e Guarulhos e o projeto da FAU. Foi ele também quem destacou a divergência entre Artigas e Niemeyer:

"Comentando seu projeto durante uma conversa informal e comparando sua maneira com a de Niemeyer (a quem admira profundamente), o autor sem dúvida alguma deixou escapar a palavra-chave:

'Oscar e eu temos as mesmas preocupações e encontramos os mesmos problemas, declarou ele, mas enquanto ele sempre se esforça para resolver as contradições numa síntese harmoniosa, eu as exponho claramente. Em minha opinião, o papel do arquiteto não consiste numa acomodação; não se deve cobrir com uma máscara elegante as lutas existentes, é preciso revelá-las sem temor"."17

\footnotetext{
${ }^{15}$ Além das primeiras casas de Artigas, esse tópico reúne obras de Rino Levi, Oswaldo Bratke e Sérgio Bernardes.

${ }^{16}$ BRUAND, Yves. Op. Cit., p. 302.

${ }^{17}$ BRUAND, Yves. Op. Cit., p. 302.
} 
No final da década de 1970, começaram a surgir novas publicações sobre história da arquitetura brasileira ${ }^{18}$, entre as quais obras escritas por pessoas ligadas à $F A U$, ex-alunos ou professores. Um exemplo notável da importância que Artigas adquiria para a nova geração pode ser visto no livro Arquitetura brasileira (1979), de Carlos Lemos, que literalmente encerra uma história da arquitetura brasileira iniciada no século XVI e pensada sob a égide dos costumes e da tradição popular, com o edifício da FAUUSP, que seria a grande obra de Artigas e síntese de todos os esforços por uma arquitetura moderna e nacional, desde o Ministério da Educação e Saúde. ${ }^{19}$

Para Lemos, Artigas era o responsável pela definição de uma arquitetura paulista, tanto por seu papel na formação dos novos arquitetos quanto pela influência de sua obra, caracterizada pela plasticidade do concreto armado aparente, pela interligação fluida dos espaços externos e internos, pela concisão, onde tudo está à vista e de onde surgem espaços inesperados e muito claros em sua intenção. ${ }^{20}$

Em 1982, Sylvia Ficher ${ }^{21}$ e Marlene Milan Acayaba publicaram Arquitetura moderna brasileira, um livro interessado na difusão desta produção pelas diversas regiões do Brasil, antes e depois da construção de Brasília. ${ }^{22}$ Seguindo a organização de Bruand, Vilanova Artigas foi apresentado ao lado de Oswaldo Bratke e Rino Levi no período anterior à capital federal, tornando-se o principal arquiteto da Região Sul no período pós-Brasília. Desde a década de 1950, a arquitetura de São Paulo era caracterizada, segundo as autoras, pelos princípios do funcionalismo estrito e do interesse tecnológico na industrialização da construção, bem como pelo emprego extensivo do concreto armado aparente em volumes compactos.

Para as autoras, a FAU era a obra que melhor sintetizava os caminhos que a arquitetura paulista tomou nas décadas seguintes. As autoras ampliaram o escopo da pesquisa sobre a continuidade dos elementos formais da FAU, sugerida por Bruand, em outras obras de Artigas, incluindo projetos de menor escala: os volumes fechados e as empenas suportadas por pilares de forma irregular, como nas residências Baeta (1956) e Mendonça (1957). Não

\footnotetext{
${ }_{18}$ Até então, o mercado editorial de arquitetura era muito incipiente. As únicas referências eram Brazil Builds, de Philip Goodwin (1943), Modern Architetcure in Brazil, de Henrique Mindlin (1956), Lucio Costa: sobre arquitetura, organizado por Alberto Xavier (1962), e Quatro séculos de arquitetura, de Paulo Santos (1965).

${ }^{19}$ LEMOS, Carlos A. C. Arquitetura brasileira. São Paulo: Melhoramentos / Edusp, 1979.

${ }^{20}$ LEMOS, Carlos A. C. Op. Cit.

${ }^{21}$ Trabalhou no escritório de Artigas entre 1971 a 1974.

${ }^{22}$ FICHER, Sylvia; ACAYABA, Marlene M. Arquitetura moderna brasileira. São Paulo: Projeto Editores, 1982, p. 51-52.
} 
obstante essa genealogia autorreferente, as autoras identificaram também um vínculo com a ordenação clássica na composição da fachada da FAU. ${ }^{23}$

Os trabalhos de Bruand (1973), Lemos (1979), e Ficher e Acayaba (1982) foram fundamentais para atribuir um protagonismo ao projeto da FAU na história da arquitetura moderna no Brasil - protagonismo esse que ficou implícito nas discussões subsequentes sobre "brutalismo", "funcionalismo", "industrialização", "regionalismo", etc.

Nos últimos anos de sua vida, a lei de anistia, de 1979, permitiu que Artigas reassumisse sua vaga na FAU. Contudo, ao longo desses 10 anos, a carreira na universidade havia mudado radicalmente e Artigas foi readmitido na condição de auxiliar de ensino. Para aposentar-se como professor titular da escola que ajudou a criar, Artigas teve de prestar concurso e apresentar seu memorial no qual foram recolhidos seus textos, projetos e depoimentos. Nesse período Artigas registrou suas impressões e memórias sobre sua obra em diversos depoimentos. Tais registros, feitos post factum, influenciaram a maioria dos comentários posteriores.

Em 1984, com o título de professor titular da FAU, Artigas foi nomeado para um segundo prêmio da UIA, desta vez o prêmio Auguste Perret, destinado à tecnologia aplicada na arquitetura. Falecido em janeiro de 1985, o prêmio lhe foi entregue postumamente.

Até aquele momento, apesar da grande visibilidade conquistada como arquiteto e professor, o conjunto da obra de Vilanova Artigas ainda era pouco conhecido. Apenas no final de sua vida algumas revistas começavam a reunir seus projetos, normalmente por recortes temáticos - arquitetura escolar, esportiva, habitacional, etc. ${ }^{24} \mathrm{O}$ primeiro contato mais amplo com sua obra, incluindo projetos de toda a carreira do arquiteto, se deu através da exposição realizada no Centro Cultural São Paulo ${ }^{25}$ em razão de seus 70 anos de idade e da consequente aposentadoria compulsória da USP. Inaugurada em maio de 1985, Artigas não chegou a vê-la, apesar de ter acompanhado sua preparação e orientado a equipe composta por Dalva Thomaz, Glória Maria Bayeux, Álvaro Puntoni, Rosa Artigas, entre outros. O catálogo da exposição foi publicado como um número especial da revista Módulo (1985). Finalmente, sua morte impulsionou uma onda de publicações, entre as quais destacam-se o primeiro número da revista Arquitetura e Urbanismo (1985) e a $72^{\mathrm{a}}$ edição da revista Projeto (1985). ${ }^{26}$

\footnotetext{
${ }^{23}$ Idem, ibidem.

${ }^{24}$ São exemplos: Acrópole n. 377 (1970), A construção em São Paulo n. 1751 (1981) e n. 1910 (1984), Projeto n. 42 (1982) e n. 66 (1984)

${ }^{25}$ A exposição foi posteriormente levada ao Rio de Janeiro, Belo Horizonte e até para Cuba.

${ }^{26}$ Foram publicadas uma série de homenagens, depoimentos pessoais e análises de seus colaboradores e admiradores, como Fábio Penteado, Eduardo Corona, Ruth Zein (Com respeito a Artigas), Carlos Lemos (Artigas, o mestre), Milton Vargas (Meu 26
} 
Após essa enxurrada de material sobre a obra de Artigas, a discussão sobre a definição, a origem e a relação da arquitetura paulista com as demais expressões de arquitetura moderna no Brasil, se tornou urgente para os críticos do final da década de 1980. O regionalismo crítico estava em voga.

Se uma narrativa regionalista já podia ser vislumbrada nas interpretações de Flávio Motta (1960) e Carlos Lemos (1979), que aludiram ao espírito violento e desbravador do "povo paulista" presente na obra de Vilanova Artigas, os primeiros trabalhos dedicados exclusivamente à produção paulistana reforçaram essa leitura. Arquitetura moderna paulistana (1983), de Alberto Xavier, Carlos Lemos e Eduardo Corona, e Residências em São Paulo: 1947-1975 (1986), de Marlene Milan Acayaba, não propunham uma discussão teórica. Ao invés disso, traziam seleções coerentes de obras que reforçavam a ideia de estratégias de projeto comuns em São Paulo. Isso levou outros autores a pensar numa origem autóctone da arquitetura moderna em São Paulo. Na maioria das vezes a referência à casa bandeirista ficou implícita, mas, outras vezes, compareceu explicitamente como mito de origem, oferecendo, desse modo, uma alternativa à historiografia hegemônica da arquitetura moderna brasileira, tão dependente do barroco mineiro ou das influências estrangeiras. Em algumas leituras no mínimo polêmicas, o concreto armado foi pensado como uma referência à taipa de pilão. A rígida geometria e as plantas voltadas para o interior das casas bandeiristas, misto de acampamento e fortaleza, expressão das necessidades práticas do bandeirista, ajudaram a explicar a negação da cidade e a reprodução da urbanidade no interior das casas "brutalistas".

Um importante documento desse debate "Sobre a escola paulista" foi o número 17 da revista Arquitetura e Urbanismo (1988). Nele, Abrahão Sanovicz defendeu que a arquitetura feita em São Paulo era um desenvolvimento da experiência carioca dentro de características regionais de São Paulo e que Artigas foi um discípulo da escola carioca, "o grande discípulo de Oscar Niemeyer, no Brasil". ${ }^{27}$ As diferenças entre os dois se restringiriam ao modo como cada um usou o concreto: mais poético no caso de Niemeyer, mais construtivo no caso de Artigas. Na mesma linha, Ruy Ohtake concluiu que a escola paulista era parte da Arquitetura Moderna Brasileira, uma das mais significativas manifestações de toda cultura nacional. ${ }^{28}$ Júlio Katinsky, tentando resgatar o legado de Artigas, trouxe uma formulação diferente para esse problema. Para ele, a ideia de uma arquitetura paulista representava uma "perigosa

amigo Artigas: duas recordações), Paulo Mendes da Rocha (A presença de Artigas), Hugo Segawa (Artigas, o mestre desconhecido), Marlene Acayaba (Vilanova Artigas, amado mestre).

${ }^{27}$ SANOVICZ, Abrahão. "Sobre a Escola Paulista", $A U$, n. 17, abril/maio, 1988, p. 56.

${ }^{28}$ OHTAKE, Ruy. "Sobre a Escola Paulista", AU, n. 17, abril/maio, 1988, p. 57. 
montagem ideológica”. ${ }^{29}$ Afinal, nem essa linguagem era restrita a São Paulo - havendo significativas manifestações no Sul, Nordeste e até mesmo no Rio de Janeiro, onde a presença de Reidy frequentemente fica ofuscada pela de Niemeyer - nem o foco de Artigas havia deixado de ser o problema nacional em sua fase pós 1956. O risco de se aproximar ou afastar as obras por um viés exclusivamente formal era deixar em segundo plano as posições políticas que incidiam sobre as decisões de projeto.

Dalva Thomaz e Rosa Artigas (historiadora e filha do arquiteto) concentraram seus esforços na crítica à noção de brutalismo - termo repudiado por Artigas $^{30}$-, alegando que o rótulo ignorava os contextos dos diversos brutalismos, contribuía para esvaziar o conteúdo ético das obras e resumia as linguagens arquitetônicas modernas a um estilo ou moda. ${ }^{31}$

Independentemente das posições divergentes, o intenso debate comprovava que a escola paulista e a ascensão de Artigas sobre ela, eram fatos.

Foi somente após a sistematização e doação do acervo de Vilanova Artigas à biblioteca da FAUUSP, iniciada com a preparação do memorial para o concurso de professor titular e com a montagem da exposição, que os primeiros trabalhos acadêmicos sobre o arquiteto foram empreendidos. Entre eles os de Miguel Buzzar ${ }^{32}$, Maria Beatriz de Castro ${ }^{33}$, Dava Thomaz ${ }^{34}$ e Maria Luiza Corrêa. ${ }^{35}$ Desses, o mestrado de Dalva Thomaz, resultado de seu contato direto com o material original, foi o mais sistemático e abrangente, tornando-se fonte obrigatória de todos os trabalhos posteriores.

Salvo algumas exceções, como a dissertação de mestrado de Marcos Gabriel ${ }^{36}$ e a tese de doutorado de Dalva Thomaz ${ }^{37}$, a maioria dos trabalhos acadêmicos mais recentes sobre ${ }^{29}$ KATINSKY, Júlio. "Arquitetura Paulista. Uma perigosa montagem ideológica”, AU, n. 17. São Paulo, abril/maio 1988, p. 66-
71.

${ }^{30}$ Por exemplo: "As últimas residências que [Milan] construiu em São Paulo revelam uma tendência para o que a crítica, em especial a européia, chama de brutalismo. Um brutalismo brasileiro, por assim dizer. Não creio que isto se justifique de todo. $\mathrm{O}$ conteúdo ideológico do brutalismo europeu é bem outro". Texto de Artigas em homenagem a Carlos Millan, apresentado na

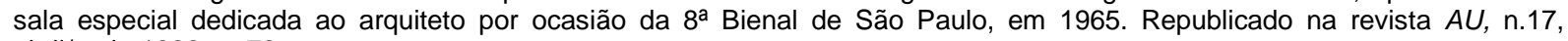
abril/maio 1988, p. 78.

31 ARTIGAS, Rosa Camargo; THOMAZ, Dalva. "Sobre brutalismo, mitos e bares (ou de como se consagrar uma impropriedade)". AU, n. 17, São Paulo, abril/maio, 1988, p. 61-63.

${ }^{32}$ BUZZAR, Miguel Antonio. João Batista Vilanova Artigas: elementos para a compreensão de um caminho da arquitetura brasileira (1938-1967). Dissertação de mestrado. Orientador: Paulo Bruna. São Paulo: FAU-USP, 1996

${ }^{33}$ CASTRO, Maria Beatriz de. Vilanova Artigas modernité éthique, tradition esthétique. Tese de doutorado. Paris, 1997. Esta tese, apesar de constar no índice da biblioteca da FAUUSP, não foi encontrada. Tentativas de localizar a autora ou de identificar a universidade foram igualmente frustrantes.

${ }^{34}$ THOMAZ, Dalva. Um olhar sobre Vilanova Artigas e sua contribuição à arquitetura brasileira. Dissertação de mestrado. Orientadora: Ana Maria de Moraes Belluzzo. São Paulo: FAU-USP, 1997.

${ }^{35}$ CORRÊA, Maria Luiza. Artigas: da idéia ao desenho. Dissertação de mestrado. Orientador: Júlio Roberto Katinsky. São Paulo: FAU-USP, 1998.

${ }^{36}$ GABRIEL, Marcos Faccioli. Vilanova Artigas: uma poética traduzida. Dissertação de mestrado. Orientadora: Cibele Saliba Rizek. São Carlos: EESC-USP, 2003. 
Artigas se focou em recortes de sua obra, seja pelo ensino ${ }^{38}$, por períodos específicos ${ }^{39}$, por programas funcionais ${ }^{40}$, por obras específicas ${ }^{41}$ ou por assuntos específicos. ${ }^{42}$ Ao mesmo tempo, a diversificação das pesquisas em arquitetura e urbanismo trouxe contribuições indiretas sobre a Escola de Vilanova Artigas, tais como trabalhos dedicados à história do ensino de arquitetura ${ }^{43}$ ou sobre a Cidade Universitária. ${ }^{44}$ Trataremos desses assuntos nos segundo e terceiro capítulos.

No que diz respeito à escola artiguista, o assunto se dispersou por diferentes abordagens.

Em seu livro, Arquiteturas no Brasil 1900-1990 45, Hugo Segawa, difere dos principais manuais de história, classificados por movimentos, arquitetos e obras, propondo, em seu lugar, tramas múltiplas, formadas também pelas atividades editoriais, didáticas e políticas dos arquitetos. Segawa destacou o posicionamento de Artigas em relação ao nacionalismo de Demétrio Ribeiro; sua interlocução com Flávio Motta - com quem teria desenvolvido a noção de desígnio -; seu pensamento político; sua proposta para o currículo da FAUUSP e para o ensino do Desenho Industrial. Essa perspectiva, mais descolada das obras, e

${ }^{37}$ THOMAZ, Dalva Elias. Artigas: a liberdade na inversão do olhar; modernidade e arquitetura brasileira. Tese de doutorado em Arquitetura e Urbanismo. Orientador: Júlio Roberto Katinsky. São Paulo: FAU-USP, 2005.

${ }^{38}$ ALBUQUERQUE, Roberto Portugal. Uma escola de arquitetura - FAUUSP: edifícios e ensino. Dissertação de Mestrado. Orientador: Miguel Alves Pereira São Paulo: FAUUSP, 2004; BAROSSI, Antonio Carlos. Ensino de projeto na FAUUSP. Tese de doutorado em Arquitetura e Urbanismo. Orientador: Joaquim Guedes. São Paulo: FAUUSP, 2006; DOMSCHKE, Vera Lúcia. $O$ ensino da arquitetura e a construção da modernidade. Tese de doutorado em Arquitetura e Urbanismo. Orientadora: Marlene Yurgel. São Paulo: FAU-USP, 2007; PEREIRA, Juliano Aparecido. Desenho industrial e arquitetura no ensino da FAU USP (1948-1968). Tese de doutorado. Orientador: Renato L. S. Anelli. São Carlos: EESC-USP, 2009; SODRÉ, João Clark de Abreu. Arquitetura e viagens de formação pelo Brasil (1938-1962). Dissertação de mestrado. Orientador: José Tavares Correia de Lira. São Paulo: FAUUSP, 2010.

39 JUCÁ, Christina B. de Mello. João Batista Vilanova Artigas, arquiteto: a gênese de uma obra (1934-1941). Dissertação de mestrado. Orientador: Jaime de Almeida. Brasília: UNB, 2001; PETROSINO, Maurício Miguel. João Batista Vilanova Artigas: elementos para a compreensão de um caminho da arquitetura brasileira, 1938-1967. Dissertação de mestrado em Arquitetura e Urbanismo. Orientadora: Mônica Junqueira de Camargo. São Paulo: FAU-USP, 2009; CUNHA, Gabriel Rodrigues da. Uma Análise da produção de Vilanova Artigas entre os anos 1967 e 1976. Dissertação de mestrado. Orientador: Miguel A. Buzzar. São Carlos: EESC-USP, 2009.

${ }^{40}$ COTRIM, Marcio. Construir a casa paulista: o discurso e a obra de Vilanova Artigas entre 1967 e 1985. Tese de doutorado. Orientadores: Fernando Alvarez Prozorovich e Abilio Guerra. Barcelona: ETSAB-UPC, 2008; VALENTIM, Fábio Rago. Casas para o ensino: as escolas de Vilanova Artigas. Dissertação de mestrado em Arquitetura e Urbanismo. Orientador: Eduardo Luiz Paulo Riesencampf de Almeida. São Paulo: FAU-USP, 2003; SEIXAS, Alexandre Rodrigues. A arquitetura escolar de Vilanova Artigas e Carlos Cascaldi (1959-1962). Dissertação de mestrado. Orientador: Carlos A. Ferreira Martins. São Carlos: EESCUSP, 2003; FLORIO, Ana Maria. Os projetos residenciais não-construídos de Vilanova Artigas em São Paulo. Tese de doutorado. São Paulo: FAUUSP, 2012.

41 IWAMIZU, Cesar Shundi. A Estação Rodoviária de Jaú e a dimensão urbana da arquitetura. Dissertação de Mestrado. Orientador: Anália Maria Marinho de Carvalho Amorim. São Paulo: FAU-USP, 2008; GIANNECCHINI, Ana Clara. Técnica e estética no concreto armado. Um estudo sobre os edifícios do MASP e da FAUUSP. Dissertação de mestrado em Arquitetura e Urbanismo. Orientadora: Maria Lúcia Bressan Pinheiro. São Paulo: FAU-USP, 2009. OLIVEIRA, Gliceli. A casa Bettega de Vilanova Artigas: desenhos e conceitos. Dissertação de mestrado. São Paulo: FAUUSP, 2009.

42 IRIGOYEN DE TOUCEDA, Adriana Marta. Wright e Artigas: duas viagens. São Paulo: Ateliê Editorial / FAPESP, 2002; SUZUKI, Juliana Harumi. Vilanova Artigas e Carlos Cascaldi: arquitetura em Londrina. São Paulo: Ateliê Editorial, 2003; GRAZZIANO, Raphael. Aspectos do debate entre realismo socialista e concretismo: a obra de Vilanova Artigas. Trabalho final de graduação. Orientador: Luiz Recamán. São Paulo: FAUUSP, 2012.

${ }^{43}$ FICHER, Sylvia. Os arquitetos da Poli: Ensino e profissão em São Paulo. São Paulo: Edusp, 2005.

${ }^{44}$ CABRAL, Neyde A. Joppert. A universidade de São Paulo: modelos e projetos. Tese de doutorado. Orientador: Dácio Ottoni. São Paulo: FAUUSP, 2004.

${ }^{45}$ SEGAWA, Hugo. Arquiteturas no Brasil 1900-1990. São Paulo: Edusp, 1998, p. 148. 
principalmente de seus aspectos formais, permitiu que Segawa enxergasse convergências programáticas entre Artigas e Niemeyer, a assim como Sanovicz e Ohtake. Segawa, porém, foi além e apontou a autocrítica de Niemeyer $(1958)^{46}$ como o ponto de partida para um tipo de arquitetura feita em São Paulo, a "linha paulista".

Alheia à disputa sobre a herança e a condução do legado da arquitetura moderna no Brasil, outra linha de pesquisa vem explorando o contexto político e econômico do surgimento da escola paulista: o Plano de Ação do Governo do Estado (PAGE), que discutiremos em detalhe no terceiro capítulo, sobre e Cidade Universitária. Um dos primeiros trabalhos a destacar o contexto do plano foi o de Maria Alice Junqueira Bastos. ${ }^{47}$ Outro trabalho foi desenvolvido por Ana Paula Koury, interessada nas políticas públicas que sustentaram o pensamento construtivo dos arquitetos nos anos 1960.48 Mais recentemente, o PAGE vem sendo sistematicamente pesquisado por Mônica Junqueira e Miguel Buzzar.

Longe de São Paulo, onde quase todos os trabalhos discutidos até aqui foram elaborados, Ruth Verde Zein, foi desenvolver sua tese de doutorado na Universidade Federal do Rio Grande do Sul${ }^{49}$ - uma escola profundamente ligada ao puro-visibilismo de Hélio Piñon. Para Zein, os estudiosos da arquitetura deveriam se ocupar mais com a linguagem arquitetônica e menos com 0 discurso dos arquitetos sobre temas como 0 subdesenvolvimento ou a industrialização. Para a autora, a semelhança visual entre as diversas manifestações brutalistas deveria ser suficiente para configurar um caso de interesse da arquitetura, justamente pela transposição dos limites regionais e programáticos. Para isso, Zein teve de marcar posição em relação a Reyner Banham ${ }^{50}$, que ao criar o termo brutalismo, havia sugerido um movimento mais ou menos coeso: "ética ou estética"?

Assim, ainda que houvesse diferenças substancias entre os diversos contextos, a recusa dos arquitetos pelo rótulo não deveria impedir uma aproximação entre as obras; ${ }^{51}$ uma aproximação, ou "conexão brutalista", que Bruand já havia destacado como relativa:

\footnotetext{
${ }^{46}$ NIEMEYER, Oscar. "Depoimento". Módulo, Rio de Janeiro, n.9, pp. 3-6, fev.1958. Republicado em XAVIER, Alberto (org.). Depoimento de uma geração - arquitetura moderna brasileira. São Paulo: Cosac \& Naify, 2003. Por mais que a prática de Niemeyer não tenha acompanhado sua autocrítica, está lá que seus edifícios "não mais se exprimam por seus elementos secundários, mas pela própria estrutura, devidamente integrada na concepção plástica original”.

${ }^{47}$ BASTOS, Maria Alice Junqueira. Pós-Brasília: rumos da arquitetura brasileira. São Paulo: Perspectiva, 2003.

${ }^{48}$ KOURY, Ana Paula. Arquitetura construtiva: proposições para a produção material da arquitetura contemporânea no Brasil. Tese de doutorado em Arquitetura e Urbanismo. Orientador: Nestor G. Reis Filho. São Paulo: FAU-USP, 2005.

49 ZEIN, Ruth Verde. A arquitetura da escola paulista brutalista 1953-1973. Tese de doutorado. Orientador: Carlos Eduardo Dias Comas. Porto Alegre: FAU-UFRGS, 2005.

50 ZEIN, Ruth Verde. "Brutalismo, sobre sua definição (ou, de como um rótulo superficial é, por isso mesmo, adequado)". Arquitextos, São Paulo, ano 07, n. 084.00, Vitruvius, maio 2007 disponível em <www.vitruvius.com.br/revistas/read/arquitextos/07.084/243>.

${ }^{51}$ ZEIN, Ruth Verde. "Brutalismo, escola paulista: entre o ser e o não ser". Revista Arquitexto n. 2, UFRGS, 2002 , p. 6-31.
} 
"Plasticamente, esse brutalismo deve muito ao de Le Corbusier [...]. Mas o brutalismo de Artigas vai bem mais além por suas implicações teóricas e seu radicalismo; visto sob esse ângulo, aproxima-se mais de seu homônimo britânico, embora não tendo qualquer vínculo com ele no plano formal. Assim, é uma concepção nova que nasceu do espírito e do lápis de Artigas, concepção que se traduziu num estilo pessoal que fez escola". ${ }^{52}$

Desse modo, ela se opôs radicalmente à noção de que a escola paulista representava uma continuidade com a arquitetura moderna brasileira, fosse por motivos programáticos ou de identidade nacional. Para Ruth Zein, Artigas e seus discípulos apenas tentaram evitar que a questão do brutalismo levasse a uma formulação do debate em termos formais e estéticos uma visão "oficialesca" e nacionalista que a maior parte dos historiadores da arquitetura teria endossado, ocultado as trocas internacionais. ${ }^{53}$

Numa linha igualmente centrada na autonomia disciplinar da arquitetura, porém menos visibilista, Luiz Espallargas Gimenez estudou a arquitetura paulistana da década de 1960 sob 0 corolário da perspectiva funcionalista. ${ }^{54}$ Suas análises de obra precisas e tecnicamente fundamentadas, o levaram a distinguir as posturas de projeto de arquitetos como Vilanova Artigas, Lina Bo Bardi, Sérgio Ferro, Joaquim Guedes, Paulo Mendes da Rocha, entre outros. Em meio a elas, Espallargas identifica anomalias em relação aos preceitos modernos, que estabeleceriam sistemas para estruturas, implantações, composições de fachadas e volumes, e ainda comprometimento com a prática, os custos e a boa técnica. A obra de Artigas nesse período é caracterizada como resultado da combinação de "desejos estranhos", colecionados ao longo da carreira, que construíram incompatibilidades com a função estrita do projeto arquitetônico. ${ }^{55}$

Para Espallargas, o projeto para a FAU partiria de duas soluções conflitantes: a cobertura horizontal e o esquema split level. Esse conflito visual é notável nos trechos em que as lajes alternadas se aproximam: internamente, na proximidade da escada, onde a empena do Ateliê Interdepartamental toca a laje dos estúdios, por exemplo; e externamente, onde laje dos Departamentos fica abaixo das empenas cegas das fachadas. Espallargas identifica que grande parte das soluções que não encontram explicações funcionais no projeto, é decorrente de dessa escolha inicial. Para contorná-los, Artigas teria criado alinhamentos

\footnotetext{
52 BRUAND, Yves. Op. Cit., p. 300-302.

${ }^{53}$ Dalva Thomaz e Rosa Artigas, por exemplo, foram acusadas de assumir uma posição somente interessada no "viés da oportunidade política", minimizando a abordagem estética. Ver: ZEIN, Ruth Verde. "Brutalismo, escola paulista: entre o ser e o não ser". Arquitexto, n. 2, UFRGS, 2002, p. 6-31.

${ }^{54}$ ESPALLARGAS Gimenez, Luis. Arquitetura paulistana da década de 1960: técnica e forma. Tese de doutorado. Orientado: Ricardo Marques de Azevedo. São Paulo: FAUUSP, 2004.

${ }^{55}$ Idem, p. 189.
} 
horizontais injustificáveis funcionalmente, como a correlação da altura das divisórias dos estúdios com o nível das salas de aula, ou a criação de anteparo que esconde a laje do piso do museu, que ao ser prolongado na parte inferior, sobre a estrutura, impede a percepção visual do esquema desencontrado das lajes. A empena do Ateliê Interdepartamental e o banco do corredor das salas de aula seguem o mesmo princípio, de horizontalizar o conjunto, criar planos avançados e recuados, diluindo o encontro, e criando continuidades no concreto armado (empenas mais laje) com um resultado visual que não condiz com a estrutura.

O quarto capítulo desta tese, apesar de não se inscrever nos limites da autonomia disciplinar, considera os argumentos visuais, projetuais e construtivos levantados por essas análises, para avaliar algumas contradições da Escola de Vilanova Artigas.

Outra linha de pesquisa que vem impactando profundamente o entendimento da Escola de Vilanova Artigas foi o resgate do Grupo Arquitetura Nova, ocorrido na virada dos anos 2000. Entre esses trabalhos, o de Pedro Arantes foi o que mais enfatizou o legado teórico e crítico de Artigas para seus discípulos ${ }^{56}$, apesar do tema ter sido primeiramente sistematizado por Ana Paula Koury. ${ }^{57}$ Desde então, os motivos e o contexto da ruptura entre Sérgio Ferro, Rodrigo Lefèvre e Flávio Império com Vilanova Artigas vem sendo discutidos e gradualmente relativizados. Essa perspectiva mais ampla da Escola de Vilanova Artigas é o ponto de partida para os argumentos que apresentaremos no primeiro capítulo desta tese, que buscam reconstituir o pensamento programático do arquiteto antes de 1964.

Mais ou menos ao mesmo tempo, João Masao Kamita revisitou o pensamento e a obra de Vilanova Artigas e se concentrou no debate político dos anos 1950 e 1960 e sua visão crítica do desenvolvimento industrial. ${ }^{58}$ A relação de Artigas com o PCB, já bastante explorada, ganhou uma contribuição importante com o trabalho Raphael Grazziano, que análise a influência que o texto de Nikita Kruschev, de 1955, publicado na revista Fundamentos ${ }^{59}$, teria tido para o realismo socialista de Artigas. ${ }^{60}$

\footnotetext{
${ }^{56}$ ARANTES, Pedro Fiori. Arquitetura Nova: Sérgio Ferro, Flávio império, Rodrigo Lefèvre, de Artigas aos mutirões autogeridos. São Paulo: Editora 34, 2002.

${ }^{57}$ KOURY, Ana Paula. Grupo arquitetura nova. Coleção olhar arquitetônico. São Paulo: Romano Guerra Editora, 2003. Livro editado a partir da dissertação de mestrado: KOURY, Ana Paula. Grupo Arquitetura Nova. Orientador: Carlos Alberto F. Martins. São Carlos: EESC-USP, 1999.

${ }^{58}$ KAMITA, João Masao. Vilanova Artigas. São Paulo: Cosac \& Naify, 2000.

${ }^{59}$ KRUSCHEV, Nikita. "Rumos da arquitetura soviética", Fundamentos, nov. 1955 apud GRAZZIANO, Raphael. Aspectos do debate entre realismo socialista e concretismo: a obra de Vilanova Artigas. Trabalho final de graduação. Orientador: Luiz Recamán. São Paulo: FAUUSP, 2012.

${ }^{60}$ GRAZZIANO, Raphael. Aspectos do debate entre realismo socialista e concretismo: a obra de Vilanova Artigas. Trabalho final de graduação. Orientador: Luiz Recamán. São Paulo: FAUUSP, 2012.
} 
Em uma rara retomada da perspectiva panorâmica da arquitetura moderna brasileira, Renato Anelli ${ }^{61}$ representou uma linha historiográfica mais independente em relação à Escola de Vilanova Artigas, que trouxe a incômoda questão da incorporação da linguagem da "linha paulista" pelo regime militar. ${ }^{62}$

"Desde o início o regime militar procurou expressar que poderia atingir índices de desenvolvimento econômico superiores aos governos democráticos. Para isso escolhiam os projetos mais ousados para representar seus edifícios públicos. Vão livres e balanços deveriam ser os maiores e os arquitetos sempre encontraram formas espetaculares para isso. Mesmo involuntariamente, o concreto aparente e as grandes estruturas que nos anos cinquenta expressavam uma postura social de raiz ética e transformadora, adquiriam então um novo significado: representavam o regime militar e suas instituições". 63

Concordando com Katinsky, segundo o qual a noção de "escola paulista" era resultado da diluição da perspectiva nacional e ocultava a posição programática de suas lideranças, Anelli identificou na escola artiguista uma posição estética-política de esquerda surgida em resposta à retórica nacional-desenvolvimentista de Brasília.

"Artigas define na continuidade do espaço e na explicitação do processo construtivo a equivalência arquitetônica de sua posição política. O piso do solo se desdobra para os níveis superiores e inferiores através de rampas, em uma promenade ininterrupta. $\mathrm{O}$ concreto armado aparente, com superfícies rugosas mal-acabadas traduz uma posição ética que pretende revelar a condição precária de trabalho manufaturado da sua produção". ${ }^{4}$

A ideia de que Artigas teria a intenção de revelar a condição precária de trabalho manufaturado é interessante, ainda que não encontre respaldo em seus depoimentos. Afinal, ela aponta para uma concepção mais alinhada com os discípulos do grupo Arquitetura Nova, que reivindicavam esse legado da Escola de Vilanova Artigas antes do golpe militar, quando o edifício foi projetado.

\footnotetext{
${ }^{61}$ ANELLI, Renato. Architettura Contemporanea: Brasile. Milão, 24 Ore Motta Cultura, 2008 [versão francesa: Architectures contemporaines: Brésil. Paris, Actes Sud, 2009].

${ }^{62}$ Apesar de seu afastamento da USP provocado pelo Al-5, o período em que Artigas mais projetou obras públicas foi durante a década de 1970, inclusive um Quartel do Exército em Macapá (1971).

${ }^{63}$ ANELLI, Renato. Op. Cit., p. 10.

${ }^{64}$ Idem, p. 6. Interessante notar que enquanto Anelli enxergou "superfícies rugosas mal acabadas", Bruand havia descrito "paredes de cimento cujas fôrmas foram tão cuidadas que de longe parecem mármore".
} 
Este ponto remete às primeiras críticas que a Escola de Vilanova Artigas recebeu, ainda durante a construção do edifício da FAU. Entre elas, a mais contundente foi a de seu discípulo Sérgio Ferro, em 1967, que criticou o surgimento de uma espécie cabocla de brutalismo no seio da nova geração de arquitetos de "orientação racional em São Paulo". ${ }^{65}$ "Caboclo" não era uma ofensa, como muitos entenderam. Mas como Artigas bem sabia, a caracterização de um estilo - ainda mais importado - era.

Em resumo, para Ferro, as propostas experimentais e progressistas que os arquitetos modernos brasileiros preparavam às vésperas do golpe para um desenvolvimento suposto provável, mantinham um "equilíbrio entre o ser e o dever ser" de cada obra. Ou seja, entre as expectativas de futuro e as condições concretas e limitadas do subdesenvolvimento. Já a nova arquitetura, nascida daquela e transformada em estilo após o golpe, teria perdido esse equilíbrio, passando a não corresponder suas propostas experimentais com suas condições concretas. Surgiam propostas cada vez mais radicais de estruturas de concreto armado, unidades mínimas, ausência de acabamento, símbolos e metáforas, em projetos incompatíveis, como residências de alto padrão.

Ainda que Ferro tenha criticado a noção de que os arquitetos podiam resolver os problemas sociais através de sua técnica, os textos e depoimentos da época confirmam que essa ideologia predominava entre os arquitetos progressistas.

"Meu artigo sobre Arquitetura nova tem a marca da ditadura. Texto de combate, enfeita demais o que foi interrompido pelo golpe. Diz: os arquitetos estavam prontos para um outro tempo imaginado próximo. A ditadura não os deixou fazer o que sabiam. Sob o protesto, passa a velha pretensão: os técnicos têm as soluções para as necessidades sociais. Simplificando, esta era a posição do Partido Comunista. Mas também a dos golpistas". 66

O distanciamento definitivo das expectativas de transformação do país convertia as propostas cada vez mais radicais dos arquitetos em "compensações para a frustração crescente". O resultado seriam obras isoladas que fingiriam concretizar o desenvolvimento esperado com uma linguagem tanto mais exagerada, quanto mais vazia e auto referenciada. ${ }^{67}$ Para Ferro, a linguagem desenvolvida em função da racionalidade das técnicas construtivas e da redução de custos, passava a ser empregada

\footnotetext{
${ }^{65}$ FERRO, Sérgio. "Arquitetura Nova” [1967], In: Arquitetura e trabalho livre. São Paulo: Cosac \& Naify, 2006.

${ }^{66}$ FERRO, Sérgio. "As visões de Sérgio Ferro sobre a posição da arquitetura brasileira - e dos arquitetos - com a chegada do golpe militar de 1964, e seu trabalho como arquiteto e pinto". Entrevista a Rafael Urano Frajndlich. AU, n. 241, abril 2014.

${ }^{67}$ Esta hipótese de Ferro se tornou um paradigma para o entendimento da hegemonia cultura da esquerda durante o regime de militar (Ver: SCHWARZ, Roberto. "Cultura e política, 1964-1969" [1978], In: O pai de família e outros estudos. São Paulo: Companhia das Letras, 2008). A aparente contradição se explica pelo isolamento social dessa cultura, rompidos os laços concretos com o operariado, e sua inclusão na lógica da indústria cultural.
} 
indiscriminadamente em programas insignificantes, atestando o consumo privado de uma pesquisa voltada ao interesse público.

Ferro argumentou que a busca por uma economia espacial, justificável num país subdesenvolvido, invadia toda e qualquer obra, inclusive edifícios de luxo, da mesma maneira que a ênfase nos espaços coletivos, em comparação com o mínimo para a vida individual, se tornava mais radical em programas que não justificam esta austeridade. Segundo ele, as exageradas estruturas aparentes desses projetos insistiam em novos desenhos das poucas fórmulas estruturais compatíveis com as possibilidades disponíveis, representando riscos e custos desnecessários em nome de um simbolismo impróprio à maioria dos programas de reduzidas dimensões. ${ }^{68}$ Além disso, a grande quantidade de pormenores irrelevantes representaria uma caricatura de complexidade, presente em detalhes rebuscados, painéis de concreto que exibiam artificiosamente as marcas de seu processo de produção (tábuas e chapas desenhadas uma a uma), texturas mais violentas, retalhamento das superfícies contínuas, etc. ${ }^{69}$ Por fim, o desenho típico de peças industrializadas insinuaria um processo de produção não condizente com sua realidade artesanal e manufatureira.

Em resumo, para Ferro, a busca pela racionalidade substantiva na arquitetura agora se limitava ao "conforto de uma 'racionalidade' sem perigo e sem muita exigência"70, uma racionalidade parcial, adjetiva, "evolução de uma técnica autossuficiente, esvaziada de sentido histórico" ${ }^{71}$

Tais críticas não se dirigiam pessoalmente à Artigas, mas principalmente à sua escola, da qual o próprio autor era também um discípulo. A concepção de Ferro, para quem "a arquitetura só abriga uma dimensão estética quando a coerência responsável do projeto está profundamente ancorada num comprometimento prático"72, continuava profundamente artiguista. Essa espécie de autocrítica da escola de Artigas produziu resultados, sobretudo na geração ainda mais jovem, que acompanhava na FAU, até então sediada na Vila Penteado, o debate entre os professores, buscando um modelo a ser seguido na arquitetura e na política.

\footnotetext{
68 'Sublinhadas artificialmente para evidenciar sua presença, deturpadas para figurar mais 'lógica' do que realmente contêm, estas estruturas escondem várias deformações. Comparadas às anteriores, imediatamente revelam seu absurdo: a simplicidade e a eficácia esquecidas pelo prazer do virtuosismo individual. [...]. Sem dúvida são mais agressivas que as anteriores e respondem parcialmente à renovação forçada de linguagem: mas a didatização de sua razão de ser (isto é, da racionalidade construtiva) passa a ser sua quase única razão de ser". FERRO, Sérgio. Op. Cit., pp. 52-53.

69 Idem, p. 55.

${ }^{70}$ Idem, pp. 51-52.

${ }^{71}$ Idem, p. 51.

${ }^{72}$ Idem, p. 54.
} 
Isso é particularmente importante, porque quando o edifício da FAU - obra prima e síntese da contribuição de Artigas à arquitetura brasileira - foi inaugurado, em 1969, o debate e os critérios de juízo eram substancialmente diferentes de quando o projeto havia sido concebido. Isso produziu resultados importantes na interpretação posterior da escola de Vilanova Artigas.

A princípio, a FAU contém todos os elementos de uma "estética verdadeira", se analisada a partir dos elementos conceituais de Ferro, pois seus símbolos estão em equilíbrio com sua função e sua realidade. ${ }^{73} \mathrm{~A}$ didatização dos procedimentos construtivos e a exploração plástica do funcionamento estrutural são adequadas aos objetivos de uma escola de arquitetura, sem se reduzir a uma dimensão funcional. Sua arquitetura sóbria e direta é compatível com uma obra pública, parte de um plano de Estado. Sua monumentalidade é expressão autêntica da luta pela renovação do ensino da arquitetura no país, ou mais amplamente, da afirmação da própria arquitetura. E tudo isso parece estar de acordo com as condições excepcionais da Cidade Universitária durante o Plano de Ação do governo Carvalho Pinto.

Por outro lado, como detalharemos ao longo desta tese, o projeto da FAU contém também, ao menos em germe, elementos que apontam para certo maneirismo. Apenas para citar alguns exemplos, 1) a didatização dos processos construtivos do edifício é relativa, pois há aspectos da estrutura de concreto armado apenas com função visual que não correspondem ao modo de construção. 2) A inserção do edifício na Cidade Universitária explicita a falência dos planos de integração entre as unidades da universidade. Ou seja, se a FAU é o maior testemunho do "que poderia ter sido e não foi"74, é também expressão do que foi: um edifício isolado, mais bem-sucedido como monumento do que como articulador do território. 3) por fim, a antecipação hipotética de Artigas sobre o desenvolvimento almejado se alimenta do presente que quer negar, incorporando-o passivamente. Estes e outros aspectos do projeto serão discutidos mais profundamente ao longo desta tese, sem teorizá-los excessivamente, mas trabalhando-os como fatos históricos.

\footnotetext{
${ }^{73}$ Segundo Ferro, símbolos são "formas de participação cuja estrutura se aproxima dos conteúdos simbolizados e ao mesmo tempo representam os conteúdos de forma mediada, como metáforas". A arquitetura nova, ao contrário, não conteria símbolos, mas sinais, que segundo Ferro, seriam produto da adição arbitrária de conteúdo, normalmente extraído das produções industrializadas e dos símbolos anteriores. FERRO, Sérgio. Op. Cit. 2006, p. 56.

${ }^{74}$ GFAU. Corredor das humanas: a poesia que poderia ter sido e que não foi. São Paulo: GFAU, 2009.
} 


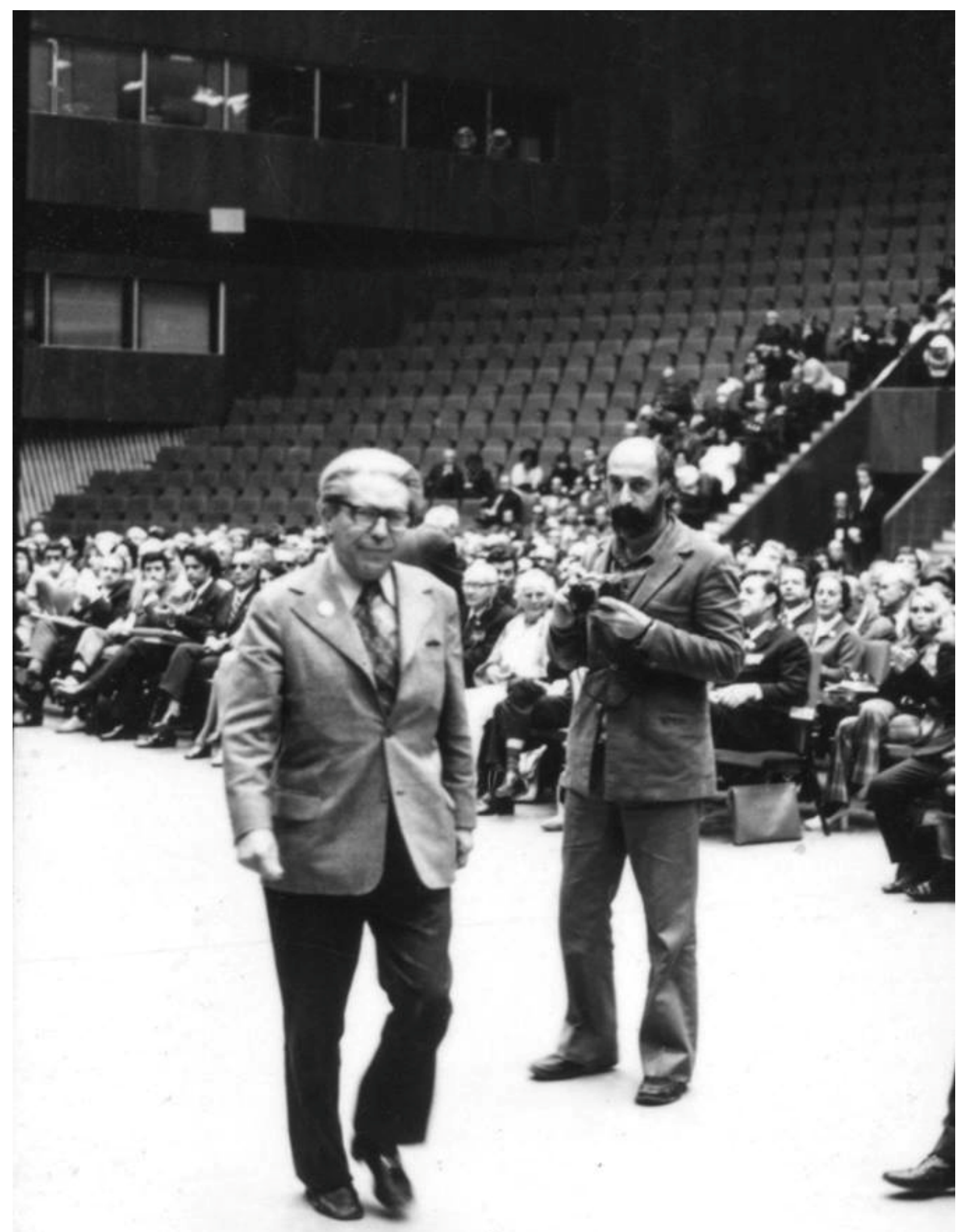

Entrega do Prêmio Jean Tschumi, UIA, Varna, Bulgária, 1972. Arquivo: Vilanova Artigas 

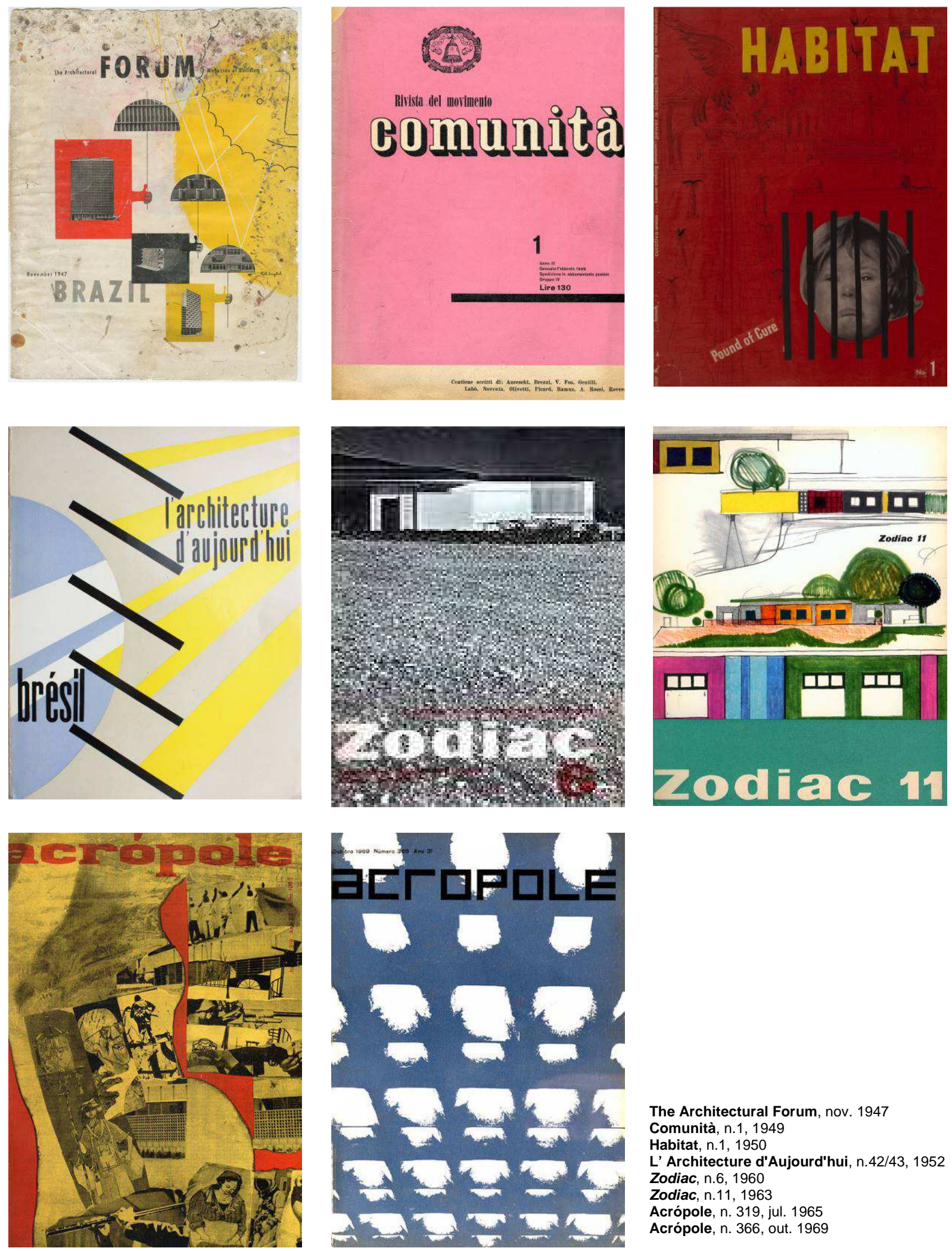

The Architectural Forum, nov. 1947

Comunità, n.1, 1949

Habitat, n.1, 1950

L' Architecture d'Aujourd'hui, n.42/43, 1952

Zodiac, n.6, 1960

Zodiac, n.11, 1963

Acrópole, n. 319, jul. 1965

Acrópole, n. 366, out. 1969 

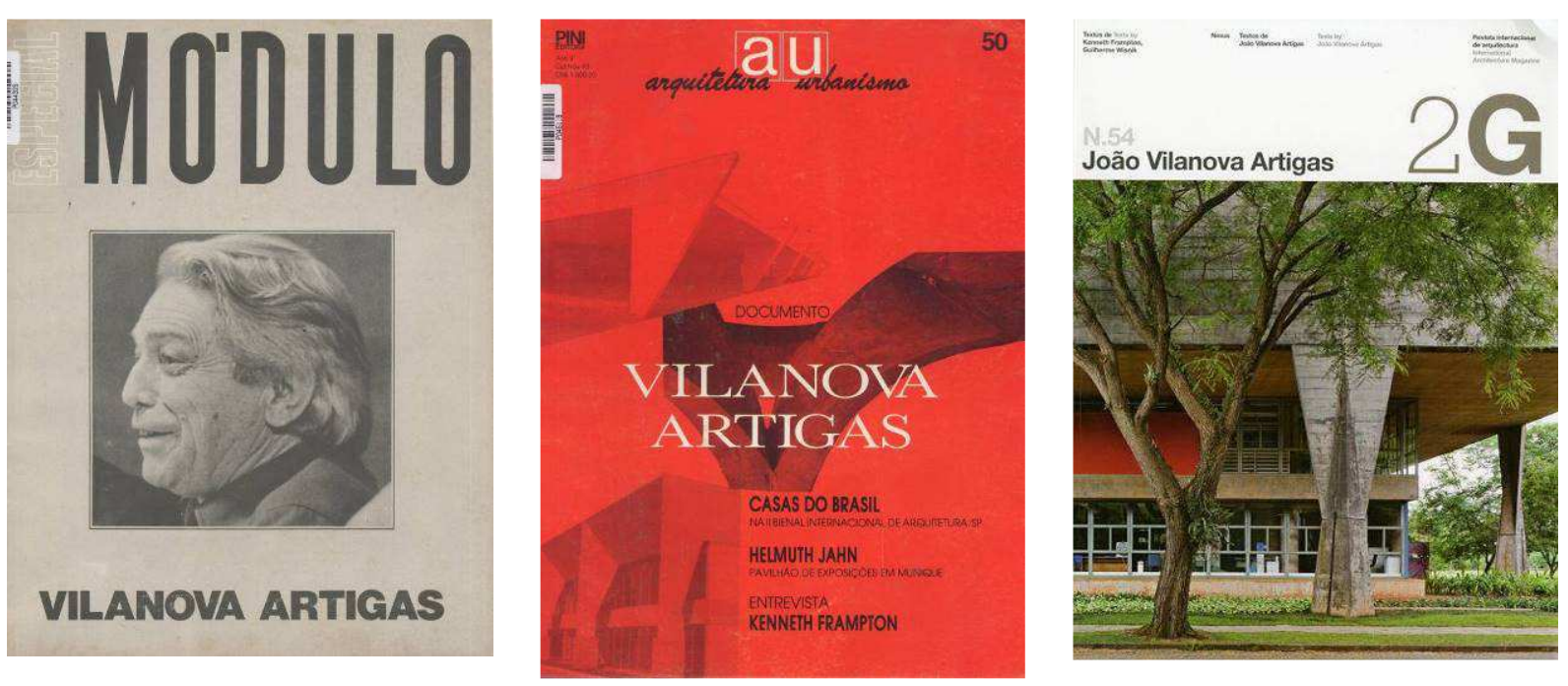

Módulo, 1985

Arquitetura e Urbanismo, n. 50, 1993 2G, n. 54, 2010

70

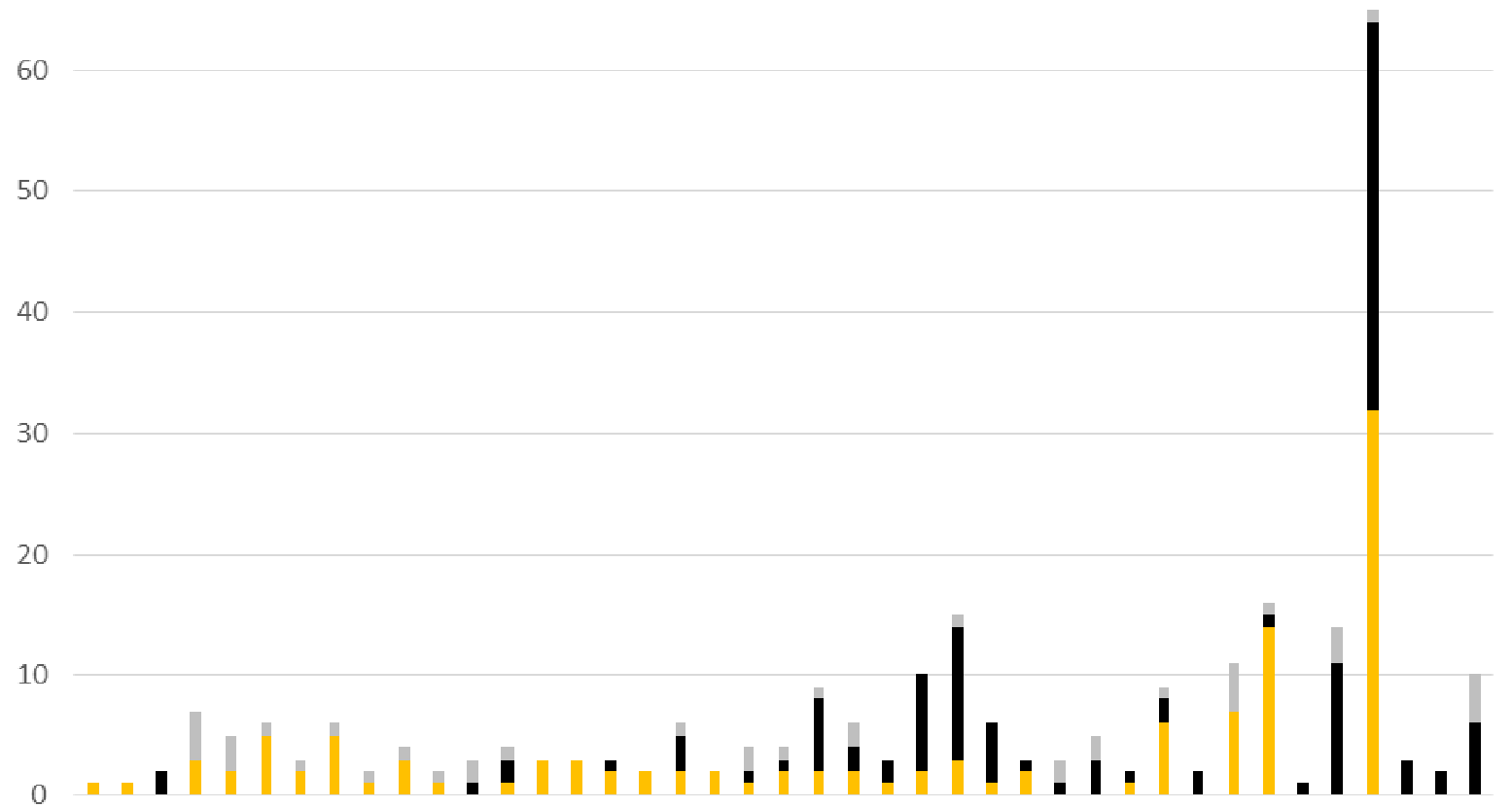

194719501952195419561958196019621964196619681970197219741976197819801982198419861988

- PROJETO $\square$ PASSIVO $\square$ ATIVO

Cronologia da bibliografia ativa e passiva de Vilanova Artigas em periódicos. Tabela elaborada com base em: MARQUES, Eliana de Azevedo. João Batista Vilanova Artigas (1915-1985): bibliografia. Colaboração de Jefferson Lafaiette Keese. São Paulo: FAUUSP, 1996. 



\section{REALISMO E MONUMENTALIDADE NA TRAJETÓRIA DE VILANOVA ARTIGAS}

MORAL CONSTRUTIVA (1937-1943)

Artigas nasceu em Curitiba em 1915 e iniciou seus estudos na Faculdade de Engenharia do Paraná em 1932. Dois anos depois transferiu-se para a Escola Politécnica de São Paulo onde "fez regularmente o curso de engenheiro civil e, como ouvinte, o de engenheiroarquiteto"'. De 1935 a 1937 estagiou na construtora Bratke \& Botti que, conforme seus depoimentos, Ihe serviu de referência profissional por muitos anos. Entre 1936 e 1939, Artigas frequentou no período noturno o curso-livre de desenho da Escola de Belas Artes de São Paulo, recomendado por seu professor, Alexandre Albuquerque. Nesse curso de desenho, em que os participantes se cotizavam para pagar modelos vivos, Artigas conheceu Virgínia Camargo, sua futura esposa, bem como os artistas do grupo Santa Helena, Rebolo Gonzáles, Alfredo Volpi, Clóvis Graciano, Aldo Bonadei, Mário Zanini, entre outros.

Diplomado engenheiro-arquiteto em 1937, Artigas foi procurado por seu colega, o engenheiro civil Duílio Marone (Poli, 1936), que propôs sociedade em uma firma construtora. ${ }^{2}$ Filho de um pequeno industrial e comerciante, dono da perfumaria Fachada, Marone podia oferecer acesso a clientes que Artigas não dispunha. De família modesta e órfão de pai aos seis anos de idade, Artigas não frequentava grupos sociais que the

\footnotetext{
${ }_{1}^{1}$ FICHER, Sylvia. Os arquitetos da Poli: Ensino e profissão em São Paulo. São Paulo: Edusp, 2005, p. 292.

${ }^{2}$ Ver série de 15 entrevistas inéditas com Duílio Marone, realizadas em 1980, disponíveis na pasta de Vilanova Artigas na seção de obras raras da Biblioteca da FAUUSP. Complementarmente, ver: LEMOS, Carlos Alberto. Alvenaria Burguesa. Editora Studio Nobel, 1989; e FICHER, Sylvia. Op. Cit.
} 
proporcionassem boa inserção no mercado paulista. Não era sócio de clubes, não pertencia a colônias de imigrantes, não era religioso, nem convivia com parentes ou amigos de sua família. Na Marone \& Artigas, criada naquele ano e sediada na Rua São Bento, n. 484, 3ํㅜ andar, Marone cuidava da parte comercial: "o trato com os mestres, os pedidos e a compra de materiais, a coleta de preços no mercado, o preparo das contas dos clientes, a escrituração das obras [...]". Segundo Marone: "O Artigas ficava na outra sala projetando e muitas vezes discutindo detalhes com os empreiteiros, encanadores, etc." (MARONE p. 12). Conforme Artigas:

"Eu já tinha uma prática de arquitetura quando fui trabalhar com o Marone em 1937. Eu já sabia fazer tudo direitinho, conhecia os mestres de obra, sabia o nome deles um por um, sabia o trabalho que eles executavam, tinha amizade com eles, tinha um relacionamento com a construção. Eu sabia como executar um desenho simplificado (...) suficiente para a aprovação na Prefeitura, sem precisar colocar todos os detalhes. Fazia o desenho do telhado de modo simplificado, as fundações, colocava a ventilação permanente. Isso tudo eu aprendi e fazia no escritório do Bratke. $\mathrm{Na}$ escola a gente não aprendia nada disso. Ninguém sabia como se fazia uma planta para ser aprovada na Prefeitura". ${ }^{3}$

A análise dos projetos da Marone \& Artigas, recolhido por D. Thomaz ${ }^{4}$ permite afirmarmos que os primeiros projetos se resumiam em poucos desenhos feitos à lápis - normalmente as plantas de arquitetura, sem especificação para execução, fachadas (às vezes apenas as principais), poucos cortes e, em alguns casos, uma perspectiva artística para agradar ou explicar o projeto ao cliente. Aos poucos, e sempre na medida do porte do projeto e da disponibilidade financeira dos clientes, Artigas se dedicava a detalhar "pormenores". Mas de acordo com a prática corrente da época não havia necessidade de maiores detalhes. Os ornamentos podiam ser interpretados pelo responsável a partir de indicações sumárias e reuniões. Os serviços especializados, como escadas e telhados, seguiam soluções padrão, dominadas pelos mestres de ofício e discutidas durante a execução:

"Nós aprendemos, na Escola Politécnica, que a planta de uma casa tinha que ter um vestíbulo [...] e uma coisa que se chamava caixa de escada que deveria ter, mais ou menos 4,50 a $5 \mathrm{~m}$, a fim de poder caber uma escada [...]. E você não faça muito menor porque o pobre do escadeiro não vai saber colocar a escada nesse lugar. A técnica

\footnotetext{
${ }^{3}$ Depoimento de Artigas a José Luiz Teles dos Santos, realizado em 16/07/1980, apud THOMAZ, Dalva. Um olhar sobre Vilanova Artigas e sua contribuição à arquitetura brasileira. Dissertação de mestrado. São Paulo: FAUUSP, 1997, p. 53.

${ }^{4}$ Levantamento realizado por Dalva Thomaz, que recolheu cópias inéditas dos projetos da Marone \& Artigas que estavam prestes a serem descartadas, contabiliza cento e setenta e um projetos. Atualmente, a pesquisadora está catalogando este material.
} 
era distribuída por um grupo de artesãos capaz de realizar a prática da construção da residência: o escadeiro, o telhadeiro, que era o homem que fazia o telhado, via onde pôr as tesouras, o pedreiro, e essa coisa fantástica que é o encanador. E havia ainda, um misteriosíssimo, o fachadista, que era capaz de bordar com cal e areia em uma fachada, todos os desenhos que se pudesse imaginar, volutas. Aqui em São Paulo os homens eram italianos". 5

A Marone \& Artigas começou lentamente e os rumos da empresa ainda eram incertos. Ambos os sócios se dividiam em outras atividades. Marone lecionava matemática e física num ginásio normal enquanto Artigas fez um "estágio desinteressante" na Secretaria de Viação e Obras Públicas, em 1938, também por sugestão de Alexandre Albuquerque. Até julho de 1939, quando o escritório se mudou para um conjunto de duas salas na Rua Marconi, foram realizadas apenas cinco pequenas obras e mais alguns projetos não construídos. A data marcaria uma guinada da construtora, que prosperou no novo endereço, realizando cerca de cento e cinquenta projetos em cinco anos, a maioria de residências.

Naqueles anos iniciais, em meio a projetos de baixo orçamento, a primeira residência "fina" do escritório, construída para o cirurgião Henrique Arouche de Toledo, amigo de Marone, em 1938, representou um passo importante para a consolidação da empresa. O estilo colonial mexicano dessa residência, assim como o estilo da casa para José Morganti e outras, que surgiram depois, foi imposto pelo cliente. Segundo Marone, desde a época de estagiário na Bratke \& Botti, Artigas "já era um arquiteto avançado e repugnava construir em estilo colonial, etc., coisas que os outros faziam indistintamente", mas "no começo a gente precisava ganhar dinheiro" (MARONE p.10). Paradoxalmente, ao invés de representar liberdade, seus melhores clientes limitavam a linguagem arquitetônica às preferências do mercado, no qual predominavam variações ecléticas e historicistas. Gradualmente, Artigas conseguiu realizar projetos menos comprometidos com as ideias estéticas de seus clientes, ainda que muitas vezes bastante simples.

Nessa época, Artigas e Virgínia frequentavam o ateliê alugado por Francisco Rebolo no Palacete Santa Helena, na Praça da Sé. O chamado grupo Santa Helena era constituído por artistas, quase todos autodidatas e italianos. Além de Rebolo (pintor de parede) participavam Clóvis Graciano (ferroviário e ferreiro), Aldo Bonadei (bordador), Mário Zanini (pintor de parede), Alfredo Rizotti (torneiro e alfaiate), Fulvio Pennacchi (dono de açougue), Manuel Martins (aprendiz de ourives), Humberto Rosa e Alfredo Volpi. O círculo era

\footnotetext{
${ }^{5}$ Depoimento de Artigas em: FERRAZ, Marcelo C. (coord.ed.). Vilanova Artigas. São Paulo: Instituto Lina Bo e P.M.Bardi e Fundação Vilanova Artigas, 1997, p. 20.
} 
completo por escritores e intelectuais como Mário de Andrade, Menotti del Pichia e Oswald de Andrade.

Ao lado de membros do grupo Santa Helena, Artigas participou do $2^{\text {a }}$ Salão da Família Artística Paulista, em maio de 1939. A FAP, idealizada pelo pintor e arquiteto Paulo Rossi Osir em 1937, reunia, além do grupo Santa Helena, outros artistas que faziam parte do movimento renovador da arte brasileira, mas que eram contrários à crescente influência das vertentes modernas mais radicais no cenário artístico da cidade, como Anita Malfatti, Bernard Rudofsky, Clovis Graciano, Ernesto de Fiori, entre outros. A posição intelectual e artística que Artigas introduziria em seus projetos nos anos seguintes se revelaria muito coerente os debates deste círculo artístico.

Outro fato que pode explicar a guinada da Marone \& Artigas na virada para a década de 1940 é sua parceria com o arquiteto ucraniano Gregori Warchavchik (formado no Regio Instituto Superiore di Belle Arti de Roma, 1920).

Foi por desenhar bem que, em 1939, Warchavchik teria convidado Artigas e o estudante de engenharia Jacob Ruchti (Mackenzie, 1940) para colaborar no anteprojeto de um parque de recreio no Brás e nos concursos para a remodelação da Praça da República e para o Paço Municipal de São Paulo. Juntos, obtiveram o segundo lugar neste concurso.

Warchavchik nessa altura era uma sumidade por seu pioneirismo manifesto em sua própria residência, de 1927, na rua Santa Cruz, em São Paulo. Porém, mais de dez anos depois de causar estrondo na conservadora sociedade paulistana e de sua marcante passagem pelo Rio de Janeiro a convite de Lucio Costa entre 1930 e 1932, Warchavchik atravessava uma crise criativa que pode revelar nuances até hoje pouco consideradas sobre a parceria com Artigas e Ruchti. Apesar de pontuais, as "casas modernas" de São Paulo, desenvolvidas também por Rino Levi entre 1929 e $1932^{6}$, permitiram experimentar de vãos e balanços em concreto armado e uma linguagem geométrica-abstrata, tida como expressão da racionalidade moderna. Warchavchik era membro do Congrès Internationale d'Architecture Moderne (CIAM) e teve um papel fundamental na divulgação dos princípios da nova arquitetura no Brasil. Em seu manifesto de 1925 ele condenava "as decorações absurdas" e saudava "a construção lógica" e o novo gosto nascido das máquinas projetadas por engenheiros segundo a economia e a funcionalidade. ${ }^{7}$

${ }^{6}$ Ver: ANELLI, Renato; GUERRA, Abilio; KON, Nelson. Rino Levi, arquitetura e cidade. São Paulo: Romano Guerra, 2001, p. 28-29.

${ }^{7}$ WARCHAVCHIK, Gregori. “Acerca da arquitetura moderna” [1925], In: Arte em Revista, n. 4, 1980, pp. 5-6. 
É possível que até este momento Artigas "não soubesse quem era Le Corbusier e nem o que estava acontecendo no Rio de Janeiro"8, como sugere Arantes. Após o contato com Warchavchik, Artigas passou a se interessar abertamente pela nova arquitetura e chegou a imitar a casa modernista da Rua Santa Cruz em duas ocasiões: na casa Ottoni de Arruda Castanho e na casa Giulio Pasquale, ambas de 1939. Apesar disso, o que Artigas registrou dessa experiência foi sua crítica aos recursos de dissimulação que ele teria considerado contraditórios com os princípios defendidos pelo próprio Warchavchik em 1925: tijolos escondidos com reboco rústico de cimento branco, caulim e mica, dando aparência de concreto, uma platibanda que escondia um telhado, sugerindo uma laje e caixilhos de feição industrial que foram realizados artesanalmente. ${ }^{10}$

"O que me irritava, na arquitetura do Warchavchik e de outros, é que as coberturas das casas modernistas deles, tinham um telhado e uma platibanda que escondiam a estrutura, aquele assoalho também, e que davam margem a eles fazerem casas com esse aspecto, mas que não tinham nada a ver com a moral construtiva. Moral construtiva! "11

Esse comentário, publicado primeiramente por Bruand, foi feito no início da década de 1970 . Não se deve, portanto, desconsiderar a intenção ou a ilusão retrospectiva que podem ter influenciado Artigas. O próprio Warchavchik já havia se justificado no 3 CIAM, de 1930, argumentando que "a indústria local ainda não fabrica as peças necessárias, estandardizadas, de bom gosto e de boa qualidade"12. Ainda assim, para Artigas, a casa revelaria o oposto do que pretendia: seu caráter mimético de um estilo importado, em desacordo com as possibilidades locais.

Ainda que Artigas só tenha formalizado essa crítica anos mais tarde, sua obra após 1939 confirma uma busca por soluções alternativas ao concreto armado e à linguagem "modernista" de Warchavchik. A busca por um modelo mais adequado às condições disponíveis (materiais, mão de obra, pluviometria, custos, etc.). Um ponto particularmente importante de sua crítica era o custo do concreto armado, que durante a Segunda Guerra Mundial havia se tornado artigo de luxo:

\footnotetext{
${ }^{8}$ ARANTES, Pedro Fiori. Arquitetura Nova: Sérgio Ferro, Flávio Império, Rodrigo Lefèvre, de Artigas aos mutirões autogeridos. São Paulo: Editora 34, 2002.

9 THOMAZ, Dalva. Op. Cit., p. 87-88.

${ }^{10}$ BRUAND, Yves, Arquitetura Contemporânea no Brasil. São Paulo: Perspectiva, 1981.

${ }^{11}$ Depoimento de Artigas a Sylvia Ficher realizado em 1982, apud THOMAZ, Dalva. Op. Cit., p. 102.

${ }^{12}$ WARCHAVCHIK, Gregori apud SEGAWA, Hugo. Arquiteturas no Brasil 1900-1990. São Paulo: Edusp, 1998.
} 
"A verdade é que para fazer executar as teses corbusianas de construção: concreto armado, pilotis, toit-jardin, para o desenvolvimento tecnológico nosso, isso tinha graus de ridículo. Graus de ridículo! Porque eu não podia oferecer para os meus jovens clientes e intelectuais daquela época fazer um jardim no seu teto, sem fazê-los morrer de rir e tinham muita razão. A verdade é como propor a laje, quando a laje custava cinquenta vezes mais caro do que o chão de vigas de peroba. E essa coisa só poderia servir como forma construtiva para meia dúzia de latifundiários que vinham da Europa e queriam fazer exibição do que tinham". ${ }^{13}$

Naquele momento, Vilanova Artigas recusou a linguagem corbusiana que começava a despontar e seguiu a "tendência da época entre os que buscavam se afastar do ecletismo predominante na cidade"14, indo buscar em Frank Lloyd Wright soluções modernas mais baratas e mais adequadas à realidade local: grandes telhados, caixilhos de madeira e tijolos aparentes. Um "moderno paulista, sem compromisso com escola alguma, com algumas esfregações de Frank Lloyd Wright" ${ }^{15}$, caracterizaria Artigas jocosamente, anos mais tarde.

Mas a importância de Wright para o jovem Artigas não parece ter se limitado à uma questão de estilo. Foi na biblioteca de Warchavchik que Artigas e Ruchti teriam descoberto Wright: "Me intoxiquei com um monte de leitura do Wright, li uma porção de coisas que não compreendi em toda sua profundeza". ${ }^{16}$ Em outro depoimento, menos apressado, Artigas considerou:

"Dentro do marasmo que nos encontrávamos, da situação de ditadura dentro do nosso país [Estado Novo], numa guerra que havia estourado naquele momento, num mundo que ninguém sabia onde ia nos conduzir. A liderança no meio da intelectualidade estava desfeita ou dispersa, é só ler a autocrítica do Mário de Andrade para compreender que nós procurávamos um processo de diversão em vez de enfrentar os problemas que o mundo nos oferecia na ocasião. Em Wright era uma saída escapista [...] de volta ao campo, de procurar uma integração numa residência onde o homem plantasse para si mesmo e descentralizasse a indústria; ele tinha qualquer coisa de descrédito em relação ao mundo em que nós vivíamos. Correspondia mesmo, para mim à uma necessidade de uma solução ou de procura de uma solução. Razão que Wright não era somente no plano estético, é claro, que esse era fácil de encontrar uma

\footnotetext{
${ }^{13}$ Depoimento de Artigas a Sylvia Ficher realizado em 1982, apud THOMAZ, Dalva. Op. Cit., p. 101.

${ }^{14}$ FICHER, Sylvia. Op. Cit., p. 293.

${ }^{15}$ Depoimento de Artigas a Sylvia Ficher realizado em 10/08/1982, apud FICHER, Sylvia. Op. Cit., p. 293.

${ }^{16}$ Depoimento de Artigas em: FERRAZ, Marcelo C. Op. Cit., p. 20.
} 
atração, mas principalmente pelas soluções que ele apresentava para o caos do mundo da época". ${ }^{17}$

No início da década de 1940, Artigas obteve certo prestígio com suas casas wrightianas enquanto sua construtora passou a ter grande demanda de trabalho. A maior parte de seus clientes não dispunha de muito dinheiro e buscava soluções pragmáticas. Associando sua formação politécnica às lições extraídas de Wright, principalmente em relação ao uso dos materiais, Artigas oferecia projetos em conformidade com as condições de seus clientes, sem abrir mão de uma modernidade que rompia com a tradição eclética de São Paulo.

Segundo Dalva Thomaz os projetos de Artigas desse período,

"[...] propõe através de requintados detalhamentos, o emprego de materiais e técnicas de modos diversos dos usuais. Se isso permitia reformular métodos construtivos que impunham determinados padrões de projeto àquela altura já arraigados, tendia também em última instância a redimensionar o rotineiro espaço reservado aos artesãos que participavam da construção residencial". ${ }^{18}$

Artigas foi convidado para ser assistente de Anhaia Mello na Escola Politécnica em 1940. À esta altura, a Marone \& Artigas já contava com desenhistas auxiliares, inclusive Carlos Cascaldi. Com exceção de alguns projetos que foram calculados pelo engenheiro Octacílio Pousa Sene, companheiro de Artigas da época de estudante na Politécnica, Artigas calculou a estrutura da maioria de seus projetos. Um exemplo é o famoso balanço da casa Rio Branco Paranhos, de 1943, declaradamente inspirado em fotografias da obra de Wright (cobertura da casa Robie, de 1909, e volumetria da Falling Water, de 1936) e num teorema de Langendonck publicado na Revista do Instituto de Engenharia. ${ }^{19}$

A intenção de Artigas era "sair da forma só do edifício para querer organizar a vida também". ${ }^{20}$ Talvez por isso se sentisse intelectualmente isolado no campo da arquitetura ${ }^{21}$, apesar da influência wrightiana ter constituído uma tendência estilística em São Paulo no início da década de 1940.

O desejo de extrapolar os limites da profissão para organizar a vida das pessoas viria de encontro com as diretrizes do Partido Comunista Brasileiro, do qual Artigas se tornou

\footnotetext{
17 Depoimento de Artigas a Rodrigo Lefèvre realizado em 1962, apud THOMAZ, Dalva, Op. Cit.

${ }^{18}$ THOMAZ, Dalva. Op. Cit., p. 103.

${ }^{19}$ Cf. depoimento do arquiteto em ARTIGAS, João B. Vilanova, "A função social do arquiteto" [1984]. Caminhos da arquitetura. São Paulo: Cosac Naify, 2004.

${ }^{20}$ Depoimento de Artigas a Rodrigo Lefèvre, realizado em 1962, apud THOMAZ, Dalva, Op. Cit., p. 99.

${ }^{21}$ Idem: "Mas o que me resta como síntese desta época [...] é mesmo uma sensação de isolamento, de homem sozinho, de autodidata, de não ter com quem conversar, de solilóquio, de monólogo, porque é que claro, é um problema para um arquiteto jovem dessa época. Com quem poderia discutir as questões?"
} 
militante em 1945. No mesmo momento que o PCB considerava que o proletariado brasileiro ainda não estava formado, sendo preciso cumprir uma etapa democrático-burguesa, Artigas dedicava-se a redefinir a casa e os hábitos domésticos. Ainda que experimentais e sem perspectivas de serem massificadas, essas casas tinham o sentido de reeducar seus moradores, estabelecendo uma "moral severa" que ensinaria valores humanistas à burguesia através de espaços funcionais, desconstrução das fachadas, dimensões mínimas, adequação à tecnologia nacional e integração das áreas comuns. ${ }^{22}$

Ainda que semelhanças formais com a obra de Wright possam ser facilmente identificadas nesses projetos de Artigas, é fundamental distingui-las em relação aos recursos ornamentais e decorativos usados pelo arquiteto norte-americano. Talvez por isso, Artigas reagisse contra tal identificação: "Nunca fiz coisas 'wrightianas' no Brasil e, se tivesse feito, também não tinha a menor importância". ${ }^{23}$ A aproximação com Wright que Artigas autorizou e até postulou era outra:

"Com Wright, entrei no mundo moderno: ver como é que precisava ser leal e honesto em relação à humanidade no seu conjunto. As lições wrightianas eram meio protestantes. A moral era protestante. Só mais tarde vim a perceber essas coisas. Em todo caso, Wright me deu uma visão do mundo: o respeito à natureza do material, procurar a cor tal como ela é na natureza $[\ldots ..]{ }^{24}$

Artigas atribuía a Wright a sua noção de "moral construtiva". No entanto, parece claro que a "moral construtiva" definida por Artigas como uma "moral tecnológica capaz de fazer com que a arquitetura responda à capacidade de produção das forças de realização técnica dentro da época em que nós estamos vivendo"25, bem como seus equivalentes, conceituar "verdade construtiva" ou "verdade dos materiais" foi mais uma interpretação sua do que um conceito emprestado de Wright em sua totalidade. Não devemos, portanto, subestimar a operação historiográfica dos depoimentos de Artigas, que serviram para dar um sentido a sua obra e, por extensão, à sua escola, dentro da arquitetura moderna brasileira.

Após 1945, da mesma forma que a memória de isolamento contida nos depoimentos posteriores de Vilanova Artigas começa a dar lugar para um sentimento de pertencimento, a "moral construtiva" perde espaço para uma missão civilizadora da arquitetura enquanto cultura.

\footnotetext{
22 Há que se reconhecer que o etapismo do PCB convinha às possibilidades imediatas de atuação dos arquitetos, sobretudo em São Paulo, onde quase não havia grandes obras públicas, e, principalmente, entre os jovens profissionais.

${ }^{23}$ Depoimento de Vilanova Artigas em SANTOS, Lena Coelho. "Fragmentos de um discurso complexo", Projeto, n. 109, São Paulo, abril 1988, p. 94

${ }^{24}$ Idem, p. 24. Destaque nosso.

${ }^{25}$ Depoimento de Artigas a Sylvia Ficher, realizado em 1982, apud THOMAZ, Dalva. Op. Cit., p. 102.
} 


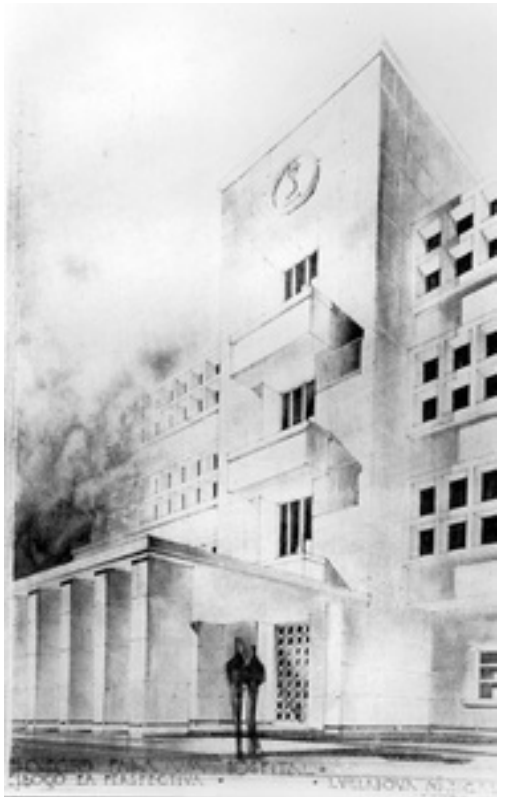

João B. Vilanova Artigas Projeto para um hospital Trabalho escolar publicado em O Politécnico, 1935.

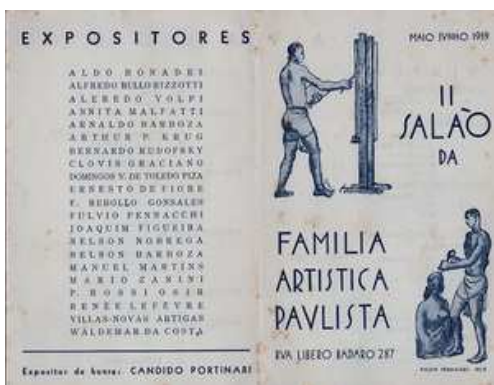

Convite do $2^{\circ}$ Salão da Família Artística Paulista, 1939.

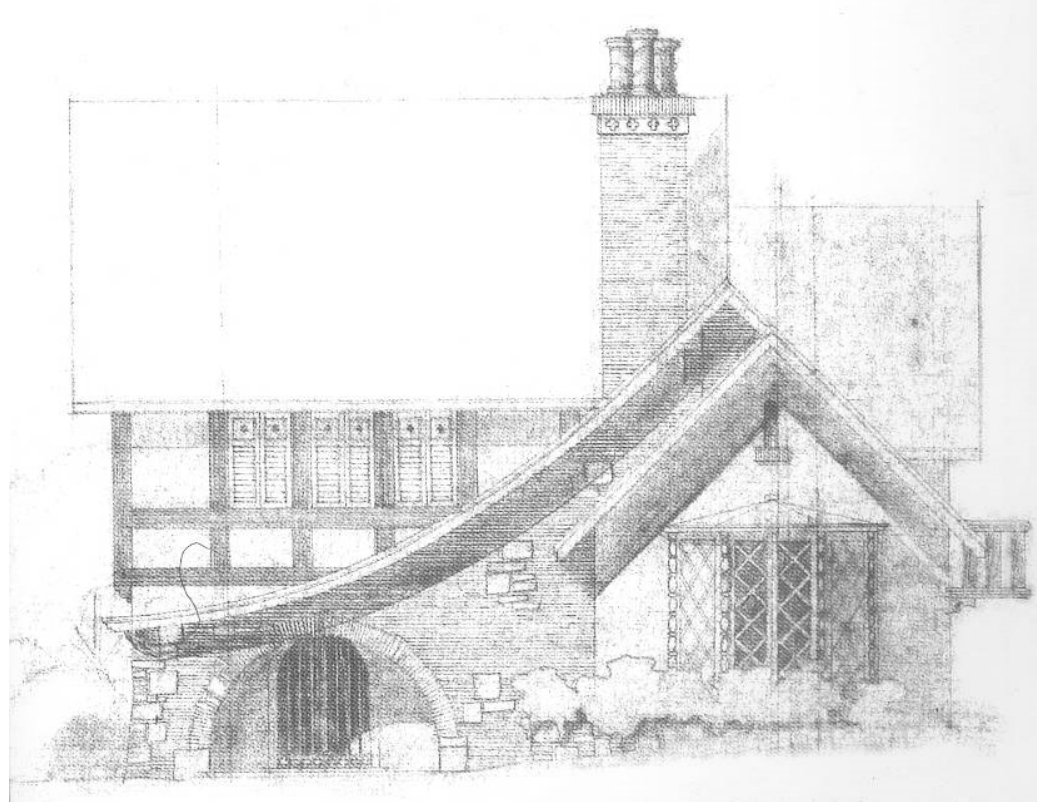

João B. Vilanova Artigas

Residência Henrique Arouche de Toledo, São Paulo, SP, 1938 Arquivo Vilanova Artigas

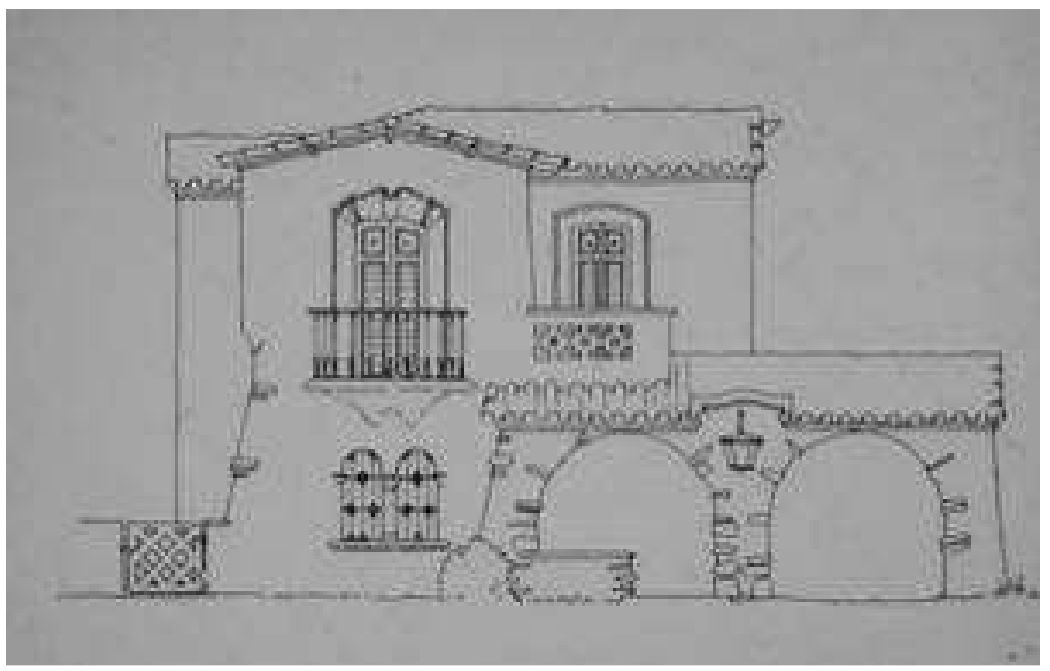

João B. Vilanova Artigas.

Residência Nicolau Scarpa Junior, São Paulo, 1940 Arquivo Vilanova Artigas 


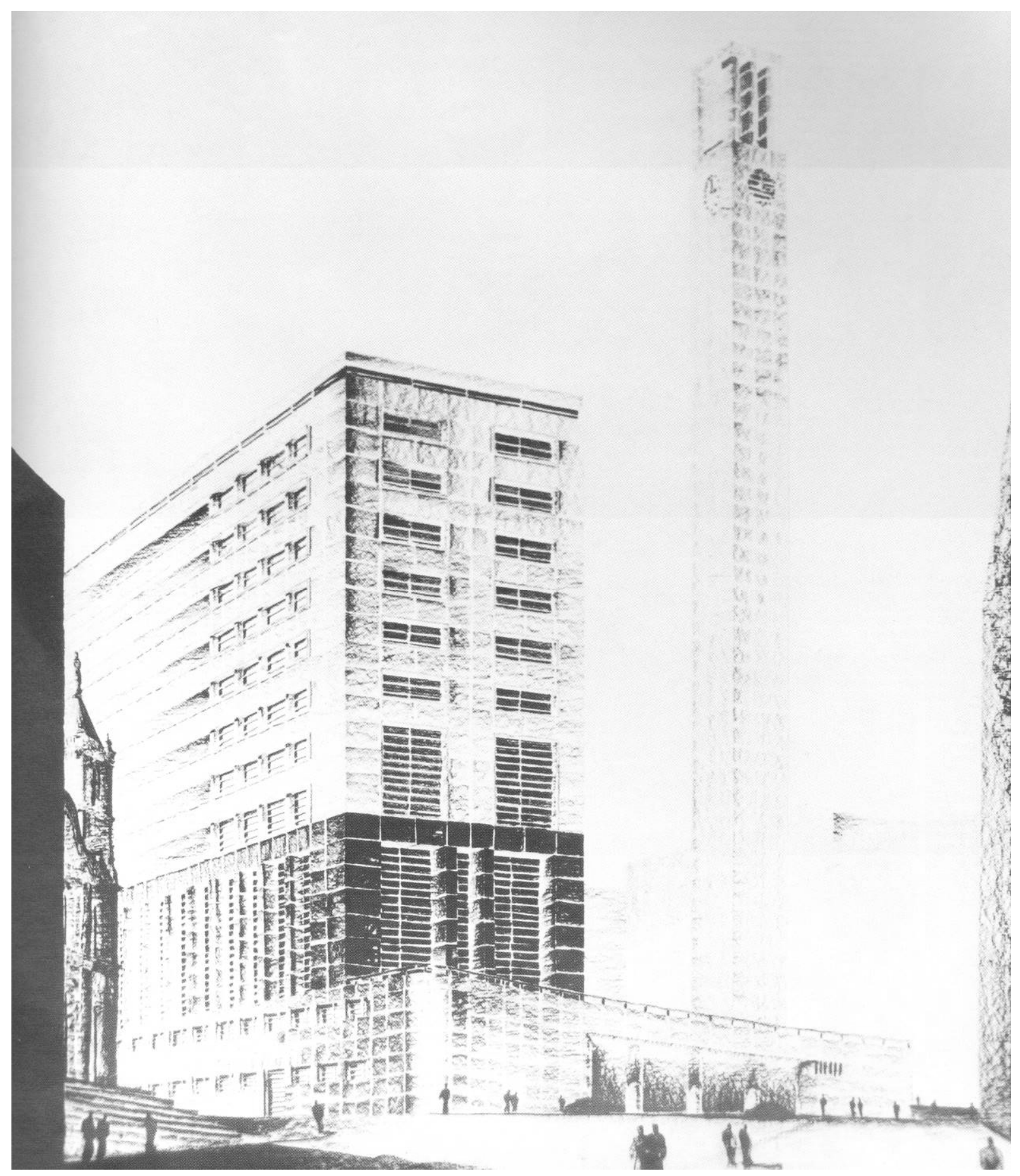

Gregori Warchavchik e equipe formada por João B. Vilanova Artigas e Jacob Ruchti

Concurso para o paço municipal. São Paulo, 1939

Arquivo Vilanova Artigas 

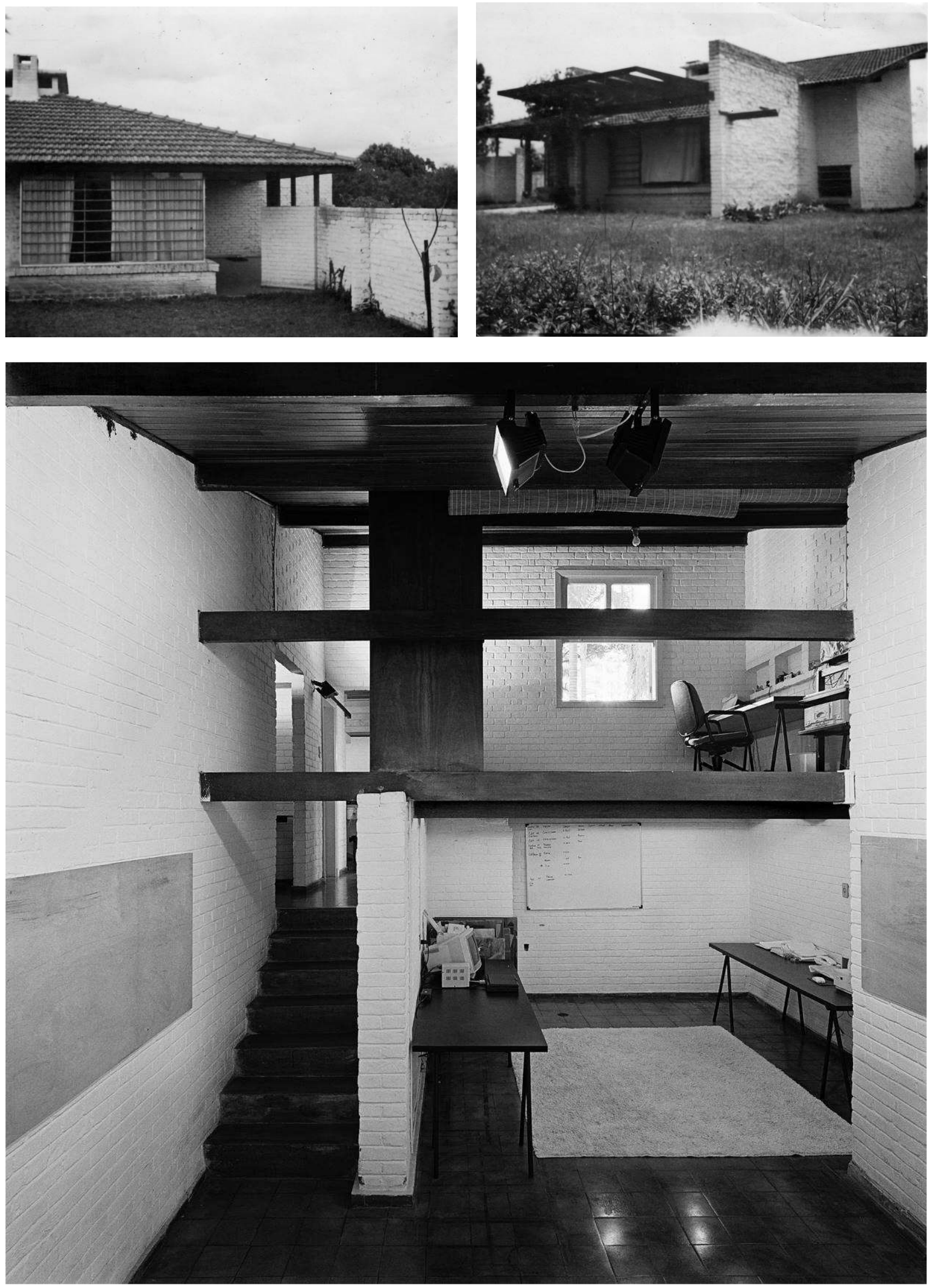

João B. Vilanova Artigas. 1ª Casa do arquiteto, São Paulo, 1942 Arquivo BFAUUSP 

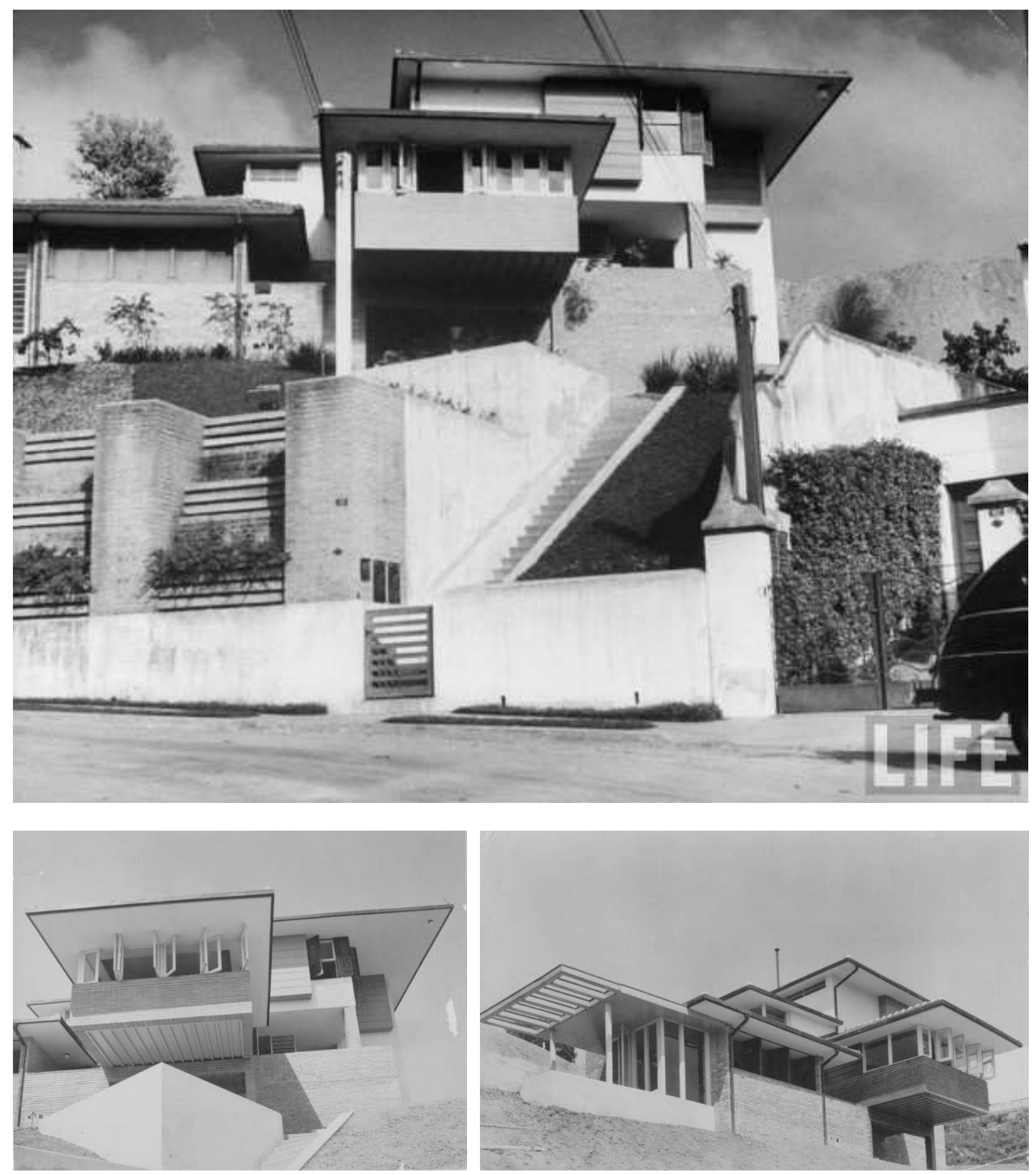

João B. Vilanova Artigas. Casa Rio Branco Paranhos, São Paulo, 1943 Arquivo Life Magazine (acima) / BFAUUSP 

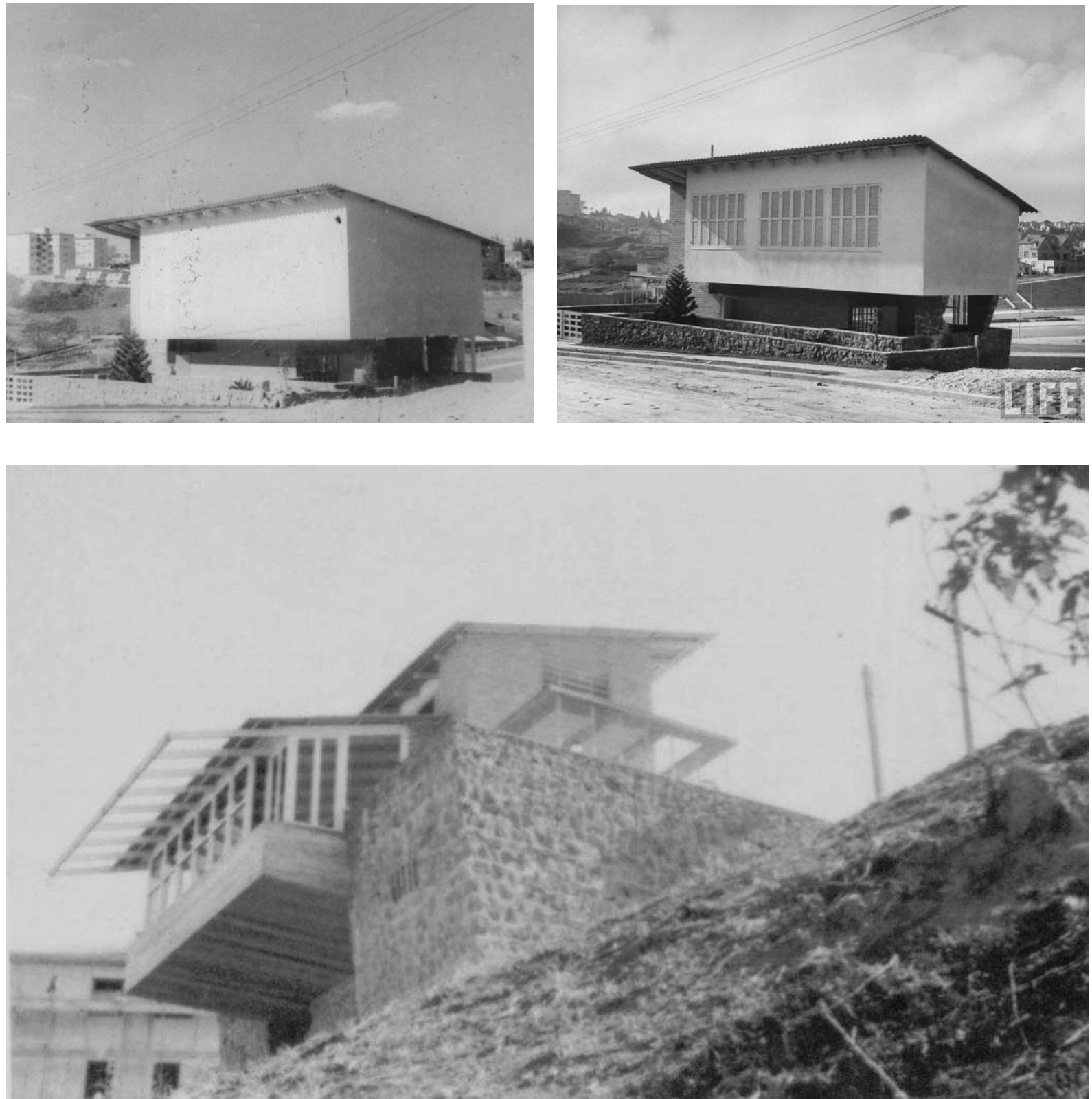

João B. Vilanova Artigas. Casa Luís Antônio Leite Ribeiro, São Paulo, 1943 Notar a empena cega para a rua, que na foto da Life Magazine aparece com janelas.

Arquivo Life Magazine (acima dir.) / Vilanova Artigas 
MONUMENTALIDADE MODERNA (1943-1956)

A partir de meados de 1944, Vilanova Artigas, que até então desenvolvera uma obra relativamente isolada, ou pelo menos mais restrita às tendências arquitetônicas de São Paulo, renovou seu vocabulário, aproximando-se dos arquitetos modernos do Rio de Janeiro. Dalva Thomaz analisou detalhadamente os diversos fatores dessa inflexão, incluindo: escritório, IAB, a repercussão de Brazil Builds, FAU e o engajamento de Artigas no PCB. Apesar desses fatos estarem todos correlacionados, essa convergência com o grupo carioca deve ser primeiramente pensada à luz da repercussão de Brazil Builds, a partir da qual Artigas teria "se dado conta de que enquanto se empenhava por construir isoladamente uma arquitetura de características locais, já despontava ao mundo através dos olhos norte-americanos, uma outra arquitetura reconhecida como brasileira". ${ }^{26}$

Apesar da intensa atividade profissional de João Batista Vilanova Artigas no início da década de 1940, o arquiteto ainda era muito jovem quando começou a se destacar no mercado paulistano com suas "casas wrightianas", e talvez por isso não havia sido mencionado quando surgiu Brazil Builds, ${ }^{27}$ - o mais importante marco do reconhecimento da arquitetura brasileira - ainda que, para Mário de Andrade, o arquiteto "paulista" despontasse como um legítimo intérprete daquele movimento:

"Eu creio que este [Brazil Builds] é um dos gestos de humanidade mais fecundos que os Estados Unidos já praticaram em relação a nós, os brasileiros. Porque ele virá, já veio, regenerar a nossa confiança em nós, e diminuir o desastroso complexo de inferioridade de mestiços que, nos prejudica tanto [...]. O Ministério da Educação e jamais o Ministério da Guerra; o edifício Ester e jamais a Faculdade de Direito; uma moradia de Artigas e jamais uma moradia neocolonial". ${ }^{28}$

Apesar da consideração de Mário de Andrade, seu amigo, a arquitetura de Artigas até aquela data não se adequava ao projeto historiográfico de Philip Goodwin, orientado pela interpretação "racionalista" de Lúcio Costa.

Artigas parece ter encontrado um repouso para suas inquietações intelectuais solitárias em um projeto coletivo que, se antes ele havia rechaçado como superficial, estrangeiro e impraticável, agora seria encarado como necessário, libertador e popular. Nessa altura,

\footnotetext{
${ }^{26}$ THOMAZ, Dalva. Op. Cit., p. 125

${ }_{27}$ GOODWIN, Phillip. Brazil Builds. New York: MoMA, 1943.

${ }^{28}$ ANDRADE, Mário de. "Brazil Builds", O Estado de São Paulo, 1943. Republicado em Depoimentos 1. São Paulo: GFAU, p. 49.
} 
Artigas já se identificava plenamente com o projeto moderno enquanto ponte entre a renovação cultural e a reforma da sociedade ou, dito de outro modo, entre a modernidade e a modernização. Como arquiteto de prancheta, da prática mais que da teoria, Artigas buscou sua referência em Oscar Niemeyer.

O interesse de Artigas pelo racionalismo carioca não se inclui na onda estilística que sucedeu a exposição e o catálogo Brazil. A nova arquitetura brasileira, longe de aparecer como questão restrita à necessidade de identidades nacionais na América Latina, surgia aos olhos internacionais como uma resposta estética-programática à crise da arquitetura moderna num plano internacional.

Em 1943, Sigfried Giedion, Josep Lluís Sert e Fernand Legèr ${ }^{29}$ apresentaram uma nova tese - em Nova York - no mesmo ano e na mesma cidade em que ocorrera a exposição Brazil Builds. Foi uma novidade dentro do grupo dos CIAMs, se opondo à objetividade que predominante na arquitetura moderna de então. Para os autores, o sucesso da arquitetura dos regimes totalitários decorria da sua capacidade de ser identificada afetiva e politicamente por indivíduos de uma nova sociedade cujos elos sociais haviam sido corroídos. A isto foi reconhecida a função monumental da arquitetura. Os nove pontos propostos vislumbravam ocupar esse espaço com uma monumentalidade do cotidiano aberta à diversidade, e associada ao Estado democrático. Cabia à arquitetura moderna uma autocrítica e o desafio de substituir a monumentalidade opressora por uma nova monumentalidade. Para isso seria preciso rever os princípios da Nova Objetividade.

Henry Hitchcock ${ }^{30}$ notou que a monumentalidade das construções incas, maias e astecas foram referências para a construção de identidades nacionais e populares no México, Peru e Chile. Lucio Costa e depois Philip Goodwin encontraram no barroco brasileiro, de feições autóctones, elementos que cumpriam o mesmo papel. ${ }^{31}$ Porém, essas "formas do passado continuavam se reportando à metrópole, e, desse modo, representavam exatamente o que se desejava negar e superar". ${ }^{32}$ Com a ausência de um patrimônio material pré-colonial, o

\footnotetext{
${ }^{29}$ GIEDION, Sigfried; SERT, José Luis; LEGÉR, Fernand. "Nine Points on Monumentality" [1943], In: OCKMAN, Joan (org). Architecture Culture 1943-1968: A Documentary Anthology. New York: Rizzoli, 1984, pp. 29-30.

${ }^{30}$ HITCHCOCK, Henry Russell. Latin American Architecture since 1945. New York: Museum of Modern Art, 1955.

${ }^{31}$ Posição que seria repetida por Hitchcock e por outros autores, inclusive latino-americanos, como o argentino Francisco Bulrich. Cabe lembrar que referência ao barroco não é unânime. Argan, por exemplo, prefere referir-se à monumentalidade romana, "mais grave e maciça" como modo de exprimir a "autoridade e estabilidade das instituições civis". Ver: ARGAN, Giulio Carlo. "Arquitetura moderna no Brasil" [1954], In: XAVIER, Alberto. Op. Cit. pp. 170-175. A conexão da arquitetura moderna com a tradição colonial, eclipsando o ecletismo do século XIX e início do XX, foi constituída por Lúcio Costa e desenvolvida por Goodwin (1943), Mindlin (1956) e Bruand (1981). Ver: MARTINS, Carlos A. F. Arquitetura e Estado no Brasil: Elementos para uma investigação sobre a Constituição do Discurso Modernista no Brasil. Dissertação de mestrado. São Paulo, FFLCH-USP, 1988.

${ }^{32}$ MARTINS, Carlos Alberto F. "Estado, cultura e natureza na origem da arquitetura moderna brasileira: Le Corbusier e Lúcio Costa, 1929-1936", Caramelo, n. 6, 1993, p. 131.
} 
projeto moderno brasileiro privilegiou a construção de uma identidade a partir da paisagem natural e da relação telúrica com ela. ${ }^{33}$

Para Martins, a relação entre o projeto moderno articulado por Lúcio Costa e a matriz corbusiana repousa no interesse mútuo pela "descoberta poética da natureza sulamericana", pelo "espírito profundo" das tradições populares, enraizado nas práticas construtivas adaptadas ao clima, à paisagem e à cultura ao longo de séculos e possivelmente pela coincidência entre o "constante apelo à autoridade" de Le Corbusier e o chamado "pensamento autoritário brasileiro". ${ }^{34}$

Quando Artigas se aproximou desse projeto moderno, pouco antes do final da $2^{\text {a }}$ Guerra, não se tratava mais de uma intenção abstrata de um grupo de artistas, mas de um projeto em andamento nas mais diversas áreas de conhecimento, cujas bases já estavam em grande medida consolidadas. No Brasil, com uma população majoritariamente rural, analfabeta e de cultura ornamental, inúmeros intelectuais, assumiram o papel de demiurgos, com uma missão civilizadora da nação. A tática cultural dessa intelligentsia foi disputar o Estado, tido como agente modernizador por excelência, para transformar ação cultural em política cultural.

A disputa pela representação arquitetônica do Estado havia predominado durante o primeiro governo Vargas (1930-1945)..$^{35}$ O projeto para a sede do Ministério de Educação e Saúde representou a primeira grande vitória do grupo moderno. Os embates políticos haviam sido de tal monta que levaram à não construção do projeto vencedor do concurso promovido em 1935. Com a opção do ministro Gustavo Capanema pelo grupo de vanguarda, Costa foi chamado para elaborar um novo projeto. Ele então constituiu sua famosa equipe composta por ex-alunos e, após a elaboração de um primeiro estudo, recomendou a consultoria de Le Corbusier, que permaneceu no Rio de Janeiro trabalhando com a equipe entre julho e agosto de 1936.

Por fim, a conclusão do Ministério apenas em 1943, provara a viabilidade técnico-construtiva da matriz corbusiana - de modo geral muito menos dependente da industrialização avançada do que a matriz alemã. De fato, o único elemento construtivo "novo" fundamental era o concreto armado, cujo domínio já estava consolidado no país, conforme demonstrado acima. Não por acaso o projeto da estrutura foi desenvolvido por Emilio Baumgart, o mesmo do edifício "A Noite", inaugurado em 1930 como o mais alto da América Latina.

\footnotetext{
${ }^{33}$ Idem, Ibidem

${ }^{34}$ Idem, Ibidem

${ }^{35}$ Entre as principais correntes de arquitetos formados pela Escola Nacional de Belas Artes a mais forte era o movimento nacionalista que propunha a retomada da figuratividade da arquitetura colonial, do qual Lucio Costa participava até 1931.
} 
Em seu conjunto o MES representou também um exercício original de síntese das artes maiores. Além de seguirem as recomendações de Corbusier para a locação das esculturas e transformação de paredes inconvenientes em painéis ${ }^{36}$, Costa e sua equipe introduziram novas experiências no paisagismo de Burle Marx e painéis de azulejos de Candido Portinari, que, junto com o pioneiro uso de brises, acrescentava uma retórica nacional ao projeto essencialmente moderno e internacional.

Foi a partir dessa formulação estética que Oscar Niemeyer passou a desenvolver sua própria poética, primeiro em 1938, no projeto para o Pavilhão Brasileiro na Exposição de Nova York, e em seguida no conjunto da Pampulha, em Belo Horizonte, inaugurado em 1943. Dominando a técnica de projetar com croquis sintéticos, Niemeyer controlava a forma de modo a explorar as imensas potencialidades plásticas do concreto armado, como nos casos da Igreja da Pampulha, com sua sequência inusitada de abóbadas, e da Casa do Baile, com a sinuosa marquise. $\mathrm{O}$ arquiteto remetia suas formas à natureza da paisagem $\mathrm{e}$ da figura humana. O discurso de Oscar Niemeyer lhe autorizava inclusive distorcer as formas estruturais - uma licença incompatível com a moral reivindicada por Vilanova Artigas, mas cujo princípio da figuratividade como forma de comunicação, terá grande importância.

A adoção da nova linguagem por Artigas se deu em um conturbado contexto político, pessoal e profissional, de modo que é difícil atribuir a um ou outro fator apenas a sua aproximação com o grupo carioca. Fato é que a vida cultural de São Paulo estava mudando rapidamente através de novas associações, museus e revistas e, além da chegada de uma nova leva de imigrantes no fim da Guerra, inclusive muitos artistas e arquitetos.

Nesse contexto, a distinção profissional entre engenheiros e arquitetos era um tema latente, com implicações tanto estéticas quanto produtivas. Se por um lado os arquitetos buscaram uma linguagem própria, não mais definida pela construção, por outro buscaram se afirmar como projetistas, desligando-se das atividades comerciais e de construção.

"Raramente o engenheiro vê a arquitetura além do desenho do edifício. Cercar a arquitetura do significado cultural e artístico que ela tem não é tarefa muito fácil. É muito difícil até para os próprios arquitetos que, de vez em quando, degeneraram em construtores. Ter a coragem de assimilar a condição de arquiteto como artista não é uma vaidade, mas necessidade de formação de uma consciência, de uma visão de mundo". ${ }^{37}$

\footnotetext{
${ }^{36}$ LE CORBUSIER. "L’Architettura ed il Rapporto com le Arti Figurative" [1936], Revista do Patrimônio Histórico e Artístico Nacional, n. 19, 1984, pp 53-69.

${ }^{37}$ Depoimento de Vilanova Artigas em: FERRAZ, Marcelo. Op. Cit., p. 26.
} 
Em 1943, procurado por Eduardo Kneese de Mello, Artigas assumiu a co-liderança na criação do departamento paulista do IAB. Era um gesto de alinhamento de São Paulo ao IAB do Rio de Janeiro, que apesar de ser nacional não tinha maior representatividade no resto do país. ${ }^{38}$ Não por acaso o $1^{\circ}$ Congresso Brasileiro de Arquitetos, realizado em São Paulo e coordenado por Artigas, teve em sua pauta a distinção entre as atividades do arquiteto e do engenheiro. As manifestações apresentadas no eixo "função social da arquitetura" revelavam o desejo da nova classe profissional se posicionar em relação aos grandes temas nacionais e internacionais.

Paralelamente a esta série de eventos, Vilanova Artigas encerrou sua sociedade com Duílio Marone para montar um novo escritório, só de projetos, em $1944 .{ }^{39}$ A nova empresa de Artigas, que manteve suas características até aproximadamente 1968, não possuiu sócios, mas contou, durante cerca de vinte anos, com a colaboração do arquiteto Carlos Cascaldi ${ }^{40}$ (1919-2010), que Artigas trouxe da Marone \& Artigas. Em seu novo escritório, desimpedido dos compromissos ordinários com a construção, Artigas passou a ter mais tempo para as atividades didáticas, políticas e artísticas, além de viagens e palestras. Artigas se tornava cada vez mais requisitado, o que Ihe implicava em dificuldade para cumprir com todas as suas obrigações. ${ }^{41} \mathrm{~A}$ maior parte de sua atividade no escritório era dedicada aos estudos preliminares, visitas a obras, reuniões com fornecedores e projetistas, e relacionamento com clientes, restando pouco tempo para o desenvolvimento detalhado dos projetos. Para isso, havia Cascaldi, que era reconhecido por sua qualidade técnica, personalidade retraída e lealdade a Artigas.

Encontramos registros de diversos desenhistas e estagiários que passaram pelo escritório. Sua equipe, porém, sempre foi reduzida ao mínimo, com uma secretária e um ou outro estagiário, além, é claro, de Cascaldi. Assim, seu escritório estava adaptado à intermitência e escassez de projetos. Ao contrário de outros colegas, Artigas não costumava se associar com outros arquitetos para projetos específicos. No entanto, até meados da década de 1960, quando Cascaldi deixou o escritório, a ausência de um sócio bem articulado nos meios sociais e com vocação para os negócios representou um obstáculo para conseguir

\footnotetext{
${ }^{38}$ A criação dos primeiros departamentos regionais do IAB, em Minas Gerais e São Paulo, ocorre durante a gestão presidida por Paulo de Camargo e Almeida (1943 e 1946), o primeiro presidente fora do grupo dos vinte e sete sócios fundadores..

${ }^{39} \mathrm{O}$ escritório de Artigas foi inicialmente instalado na Rua Dom José de Barros, 377, esquina com a Av. São João e transferido em 1951 para o novo edifício do IAB-SP, na Rua Bento Freitas.

${ }^{40}$ Apesar de figurar como coautor em diversos projetos de Artigas, Cascaldi não foi sócio do escritório, como comprova-se no registro da empresa em cartório. Ele próprio respondeu, em depoimentos à pesquisadora Dalva Thomaz, quando perguntado de sua sociedade: "Não, eu não fui... veja bem, sócio mesmo do... sócio nunca fui. Na realidade, nunca fomos sócios no papel nem coisa nenhuma. Comecei trabalhando com ele já quando eu estava na escola, estava no $5^{\circ}$ ano da escola ele me convidou para trabalhar com ele, a desenhar e tudo mais, 44 mais ou menos. Eu me formei em 44 . No começo de 44 já comecei a trabalhar com ele. Mas num escritoriozinho... ainda no escritório de Marone e Artigas". Ver THOMAZ, Dalva. Op. Cit., p. 122.

${ }^{41}$ É notável, por exemplo, que sua ficha funcional na FAU, registre diversos protestos contra suas ausências recorrentes.
} 
novos projetos. Sua clientela, quase sempre esteve restrita aos seus círculos pessoais: gente da universidade, da cena artística e conexões do partido. Daí a grande quantidade de projetos para residências unifamiliares, sede de sindicatos e colônias de férias para trabalhadores. ${ }^{42}$

Apesar da diminuição que seu escritório sofreu por abandonar as atividades de construção, Artigas nesse período recebeu suas primeiras encomendas de maior porte como o Hospital São Lucas (1945); o Edifício Louveira (1946); o Edifício Autolon e o Cine Ouro Verde (1948), a Casa da Criança (1950), a Estação Rodoviária de Londrina (1950); e o Estádio do Morumbi (1952). Paralelamente, projetou dezenas de casas de grande qualidade, que demonstram sua inquietude em redefinir o programa domiciliar.

A residência Rivadávia de Mendonça, de 1944, foi o primeiro projeto publicado de Artigas. ${ }^{43}$ Ele foi incluído no número dedicado ao Brasil da revista Architectural Forum, de Nova York, de 1947 - ano que Artigas passou nos EUA com bolsa de estudos da Fundação Guggenheim.

Dada a escassez de considerações sobre arquitetura moderna no Brasil, a inclusão de obras nacionais em publicações especializadas internacionais era um sinal importante de reconhecimento, principalmente em edições dedicadas à produção brasileira.

Também no exterior, foram publicados projetos seus na Rivista del Movimento Comunitá4 ${ }^{4}$, de Milão, em 1949; na South African Architectural Record, em 1950; e no número especial sobre o Brasil da revista francesa L'Architecture d'Aujourd'hui, de 1952.

Sua obra foi publicada no Brasil, primeiramente no número de estreia da revista Habitat, de 1950. Lina Bo Bardi, responsável pela revista, reuniu projetos recentes de Artigas e introduziu algumas das categorias interpretativas mais persistentes na análise de sua obra:

"Artigas é um temperamento retraído. Trabalha na sombra; o seu nome não aparece nas revistas, e ele não gosta de publicar projetos, ideias, desenhos; para ele Arquitetura é trabalho realizado, acabado, resolvido em cada pormenor. A sua é uma arquitetura humana, ou melhor, doméstica, no sentido mais claro da palavra. Uma casa construída por Artigas não segue as leis ditadas pela vida de rotina

\footnotetext{
${ }^{42}$ Os projetos para Londrina são exceção. Foram contratados durante a gestão do prefeito Hugo Cabral (1947-1951), quando o Secretário de Obras e Viação foi o engenheiro Rubens Cascaldi, irmão de Carlos Cascaldi.

${ }^{43}$ Antes disso, Artigas havia publicado, em 1937, dois trabalhos escolares na revista da Escola Politécnica: uma residência em estilo beaux-arts e um projeto hospitalar em estilo clássico simplificado.

${ }^{44} \mathrm{O}$ movimento Comunità foi fundado e financiado pelo industrial Adriano Olivetti, interessado na relação entre indústria, ciência, política, arte e bem estar social. A revista Comunità, que deu origem à revista Zodiac em 1957, publicou obras de Friedman, Fromm, Le Corbusier e Lippmann, entre muitos outros. A revista buscava articular intelectuais, artistas, arquitetos e designers progressistas em torno da organização das cidades e do território no pós-guerra. Ver: RAGGHIANTI, Carlo. "Adriano Olivetti", Zodiac, n. 6, maio, 1960 apud BRAGA, Juliana. Ver não é só ver: dois estudos a partir de Flavio Motta. Dissertação de mestrado em Arquitetura e Urbanismo. Orientador: José T. C. de Lira. São Paulo: FAU-USP, 2010, p. 84.
} 
do homem, mas lhe impõe uma lei vital, uma moral que é sempre severa, quase puritana. Não é 'vistosa', nem se impõe por uma aparência de modernidade, que já hoje se pode definir num estilismo. As casas de Artigas não se exaurem na única impressão de prazer comunicada por uma boa arquitetura de exteriores; eliminada a sensação de aprazível novidade que sempre suscita uma obra moderna, depois da primeira volta em roda das paredes de fora 0 observador não sofre uma brusca interrupção por ter entrado na casa, mas aí ele tem a percepção exata de que a continuidade do espaço se produz, solidária com o rigor constante que as formas externas denunciavam. Essa harmônica continuidade de espaço é obtida por meios límpidos, claríssimos, sem recorrência a efeitos forçados, da forma livre, que como se pode observar em muita expressão arquitetônica contemporânea, especialmente na norteamericana, descamba para o decorativo. [...]. Cada casa de Artigas quebra todos os espelhos do salão burguês. Nas casas de Artigas que se veem, dentro tudo é aberto, por toda parte o vidro, e os tetos baixos, muitas vezes a cozinha não é separada [...]. As casas de Artigas são espaços abrigados contra as intempéries, o vento a chuva, mas não contra o homem, tornando-se o mais distante da casa fortaleza, a casa fechada, a casa com interior e exterior, denúncia de uma época de ódios mortais. A casa de Artigas, que um observador superficial pode definir como absurda, é a mensagem paciente e corajosa de quem vê os primeiros clarões de uma nova época: a época da solidariedade humana". ${ }^{45}$

Durante a década de 1950, os projetos de Artigas ganharam espaço em revistas como Arquitetura e Decoração, Módulo e, principalmente, na revista Acrópole, que teve um importante papel na divulgação da arquitetura feita em São Paulo. ${ }^{46}$

Nesses projetos, Artigas adotou soluções já dominadas pelos cariocas, como a composição de volumes geométricos puros, ora apoiados diretamente do solo e ora sobre pilotis; as grandes aberturas e os anteparos para produzir sombras; as rampas como elementos de ligação entre planos superpostos; e a estrutura independente de concreto armado. Artigas se aproxima da forma livre de Niemeyer, em projetos como o do MAM mas adota alguns de seus partidos, como o telhado asa de borboleta da residência Kubitschek (1943), em sua própria residência de 1949 .

\footnotetext{
${ }^{45}$ BARDI, Lina. "Casas de Vilanova Artigas". Habitat, n, 1, São Paulo, out-dez 1950, pp. 2-16. Republicado em XAVIER, Alberto (org). Depoimentos de uma geração: arquitetura moderna brasileira. São Paulo: Cosac Naify, 2003, pp. 348-349.

${ }^{46}$ A respeito das revistas especializadas do período, ver: DEDECCA, Paula. Sociabilidade, crítica e posição. O meio arquitetônico, as revistas especializadas e o debate do moderno em São Paulo (1945-1965). Dissertação de mestrado em Arquitetura e Urbanismo. Orientador: José T. C. de Lira. São Paulo: FAUUSP, 2012.
} 
"Mais tarde eu me reconciliei com essas coisas do Corbusier, mas veja você, a partir das coisas que Corbusier fez posteriormente, como a Maison au Chile, e também as obras que o Antoin Raymond - um arquiteto que copiava o Corbusier no Japão. Aí, depois com o Oscar, também começamos a formular hipóteses corbusianas, mas agora a meu modo. O telhado tipo Brasilit, o domínio da forma através do conhecimento perfeito das condições tecnológicas que poderiam determina-la". ${ }^{47}$

De todos os recursos estéticos incorporados por Artigas, o que mais explicita o deslocamento de sua posição crítica anterior talvez seja o revestimento da alvenaria. O que teria acontecido com sua noção de honestidade com a aparência natural dos materiais? 0 tijolo das fachadas passa a figurar revestido enquanto a presença marcante da madeira em janelas, telhados, vigas, pilares e guarda corpos foi minimizada ou substituída por ferro e alvenaria.

Nas obras produzidas nesses anos, a forma do concreto armado pode ser deduzida apenas de modo analítico, pois, assim como na obra de Niemeyer, está encoberto por diversos tipos de revestimentos. Além disso, o recurso a lajes duplas com fôrmas do tipo "caixão perdido" dificulta o entendimento do comportamento estrutural através de uma análise estritamente visual. Apesar de tudo isso, o concreto está presente e desempenha um importante papel no discurso como o fator que permite maiores aberturas, múltiplos pavimentos, plantas livres e, principalmente, inovações formais.

"Aconteceu que toda essa ética [de Wright] me levou a compreender também, pelos cantos, a problemática do povo brasileiro, da nossa condição de subdesenvolvidos ${ }^{48}$. Percebi que a arquitetura estava ligada a uma problemática nacional e popular e que era preciso arranjar uma ética que me reconciliasse com os ideais do povo brasileiro". ${ }^{49}$

Ainda que Artigas seguisse comprometido tecnicamente com a simplicidade do programa e da construção, inclusive calculando a maioria das estruturas de menor porte de suas obras, essa inflexão em sua obra revela o reconhecimento da função comunicativa da arquitetura justamente num momento em que até a imprensa não especializada esteve interessada em arquitetura. Para Artigas, se tratava, antes, de uma questão política: construir uma

\footnotetext{
47 Depoimento de Artigas a Sylvia Ficher, realizado em 1982, apud THOMAZ, Dalva, Op. Cit.

${ }^{48}$ É altamente improvável que Artigas usasse o termo "subdesenvolvimento" antes de 1948, quando a política do Banco Mundial de distinguir países desenvolvidos de países subdesenvolvidos popularizou a expressão.

${ }^{49}$ Depoimento de Vilanova Artigas em: FERRAZ, Marcelo. Op. Cit., p. 24.
} 
identidade popular como o projeto nacional moderno, capaz de criar as condições subjetivas para uma revolução progressista.

Nesse sentindo a "arquitetura moderna brasileira" aparece em sua obra com contornos miméticos assim como os estilos nos quais havia sido treinado. Na medida em que a função comunicativa passou a preceder sua crítica moral à falsidade construtiva, o concreto armado e a engenharia nacional passaram a ser abraçados em nome do progresso..$^{50}$

Saído da ilegalidade por um curto período após o fim da ditadura Vargas, o PCB se tornou rapidamente um partido de massas, muito popular entre intelectuais, artistas e arquitetos. $\mathrm{A}$ entrada de potenciais lideranças intelectuais em suas áreas, como Artigas, implicava em alinhamento às posições centrais, que no contexto da guerra fria significava repelir o imperialismo capitalista. Com base nessa militância, Artigas formulou uma curiosa articulação teórica entre o Realismo Socialista, o desenvolvimento nacional e a "arquitetura moderna brasileira".

No início dos anos 1950, com a efervescência da Guerra Fria, Artigas estava francamente dedicado às atividades cotidianas do Partido Comunista, colocado novamente na ilegalidade como reação ao seu sucesso nas eleições de 1945. Participando do conselho de redação da revista do partido, Fundamentos, Artigas publicou entre 1951 e 1952 seus textos mais polêmicos em defesa do realismo socialista e da arte figurativa. A arte abstrata e a influência de Le Corbusier foram consideradas "imperialista" e as tendências artesanais - incluindo desde o Arts and Crafts até Wright - "reacionárias". ${ }^{51}$ Essas polêmicas lhe custaram caro e implicaram inclusive em seu afastamento temporário da FAU. Contudo, os revezes demoraram para atingir sua convicção na "arquitetura moderna brasileira", segundo à qual ele continuava a projetar.

Foi nesse contexto que se deu a sua inclusão definitiva no panorama da história da arquitetura brasileira em 1956, com o livro de Henrique Mindlin, Arquitetura moderna no Brasil. Mindlin deu grande destaque à obra recente de Artigas $^{52}$, minimizando seu interesse

\footnotetext{
$50 \mathrm{O}$ agravamento da precarização do trabalho provocado pelo concreto armado, somente será reconhecido pelos discípulos de Artigas na década de 1970. Referimo-nos a Sérgio Ferro, Rodrigo Lefèvre e Flávio Império. Ver: KOURY, Ana Paula. Grupo Arquitetura Nova. Dissertação de Mestrado. São Carlos: EESC-USP, 1999; ARANTES, Pedro. Op. Cit.; e CONTIER, Felipe. "História da arquitetura a contrapelo" In: FERRO, Sergio. A história da arquitetura vista do canteiro. São Paulo, GFAU, 2009.

51 Ver: "Le Corbusier e o imperialismo" (1951), "A Bienal é contra os artistas brasileiros" (1951), "Os caminhos da arquitetura moderna" (1952), todos reunidos em ARTIGAS, João B. Vilanova. Op. Cit.

52 Esse destaque pode ser mensurado pelo número de obras selecionada no livro: Oscar Niemeyer (ENBA, 1934), 19 projetos; Affonso Eduardo Reidy (ENBA, 1930) e Henrique Mindlin (EEM, 1932), 9 projetos cada; MMM Roberto, 8 projetos; Rino Levi (Roma, 1926), 6 projetos; Lucio Costa (ENBA, 1924) e Francisco Bolonha (ENBA, 1945), 5 projetos cada; João B. Vilanova Artigas (EPUSP, 1937); Sérgio Bernardes (FNA, 1948); Paulo Antunes Ribeiro (ENBA, 1935); 4 projetos cada; Gregori Warchavchik (Roma, ?); Carlos Frederico Ferreira (ENBA, 1935); Álvaro Vital Brazil (ENA, 1933, EPRJ, 1933); Olavo Redig de Campos (Roma, 1931), 3 projetos cada; Lina Bo Bardi (Roma, 1940); Oswaldo Artur Bratke (EEM, 1931) e Alcides Rocha Miranda (ENBA, 1932), 2 projetos cada; e Plínio Croce e Roberto Aflalo, Ícaro de Castro Mello e Eduardo Kneese de Mello, Hélio Duarte e outros, com apenas um projeto. Entre os paulistas Artigas ficou atrás apenas de Rino Levi e do próprio Mindlin. Os projetos publicados foram: a casa Heitor de Almeida, em Santos; o edifício Louveira e a casa do arquiteto, em São Paulo; e o terminal rodoviário de Londrina.
} 
inicial por Frank Lloyd Wright, do qual o brasileiro teria absorvido apenas um "senso de continuidade espacial". Talvez por conta da agressividade de seus textos do início da década de 1950, Mindlin retratou Artigas como uma personalidade mais afirmativa do que discreta:

"Artigas vê o homem moderno como um dominador e organizador do seu meio ambiente, na busca de um marco adequado a uma sociedade integrada e harmônica. Daí sua preferência por uma expressão clara e honesta dos métodos e técnicas contemporâneos, em vez de submissão à paisagem e uma fusão com a natureza. Se, por um lado, esta preferência pode parecer algo seca e doutrinária, por outro, não deixa de ser uma manifestação de consistente percepção poética" ${ }^{53}$

${ }^{53}$ MINDLIN, Henrique. Arquitetura moderna no Brasil. Rio de Janeiro: Aeroplano, 1999, p. 56, grifo nosso. 


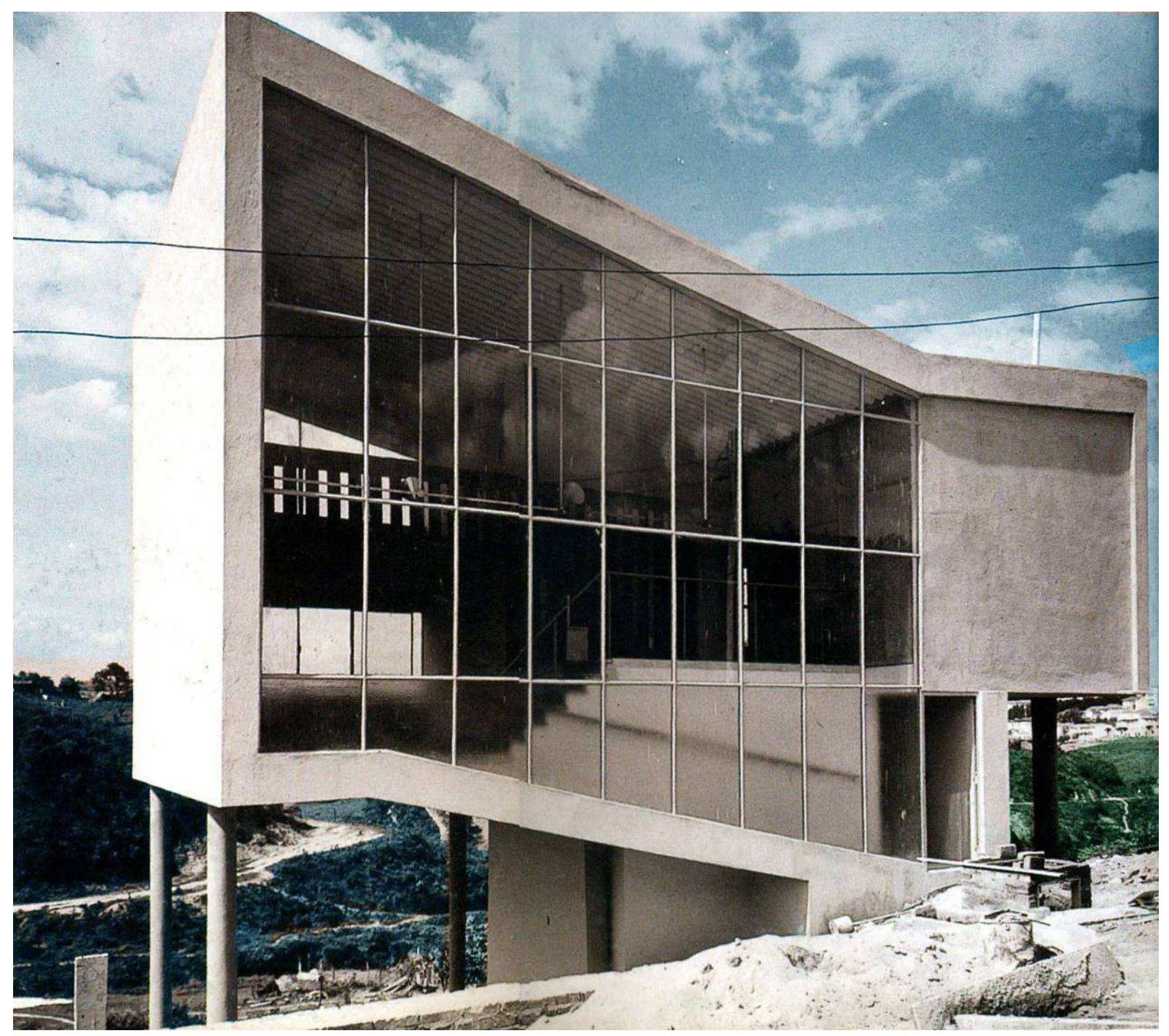

João B. Vilanova Artigas. Casa Czapsky (Alice Brill), São Paulo, 1949. Arquivo Vilanova Artigas 


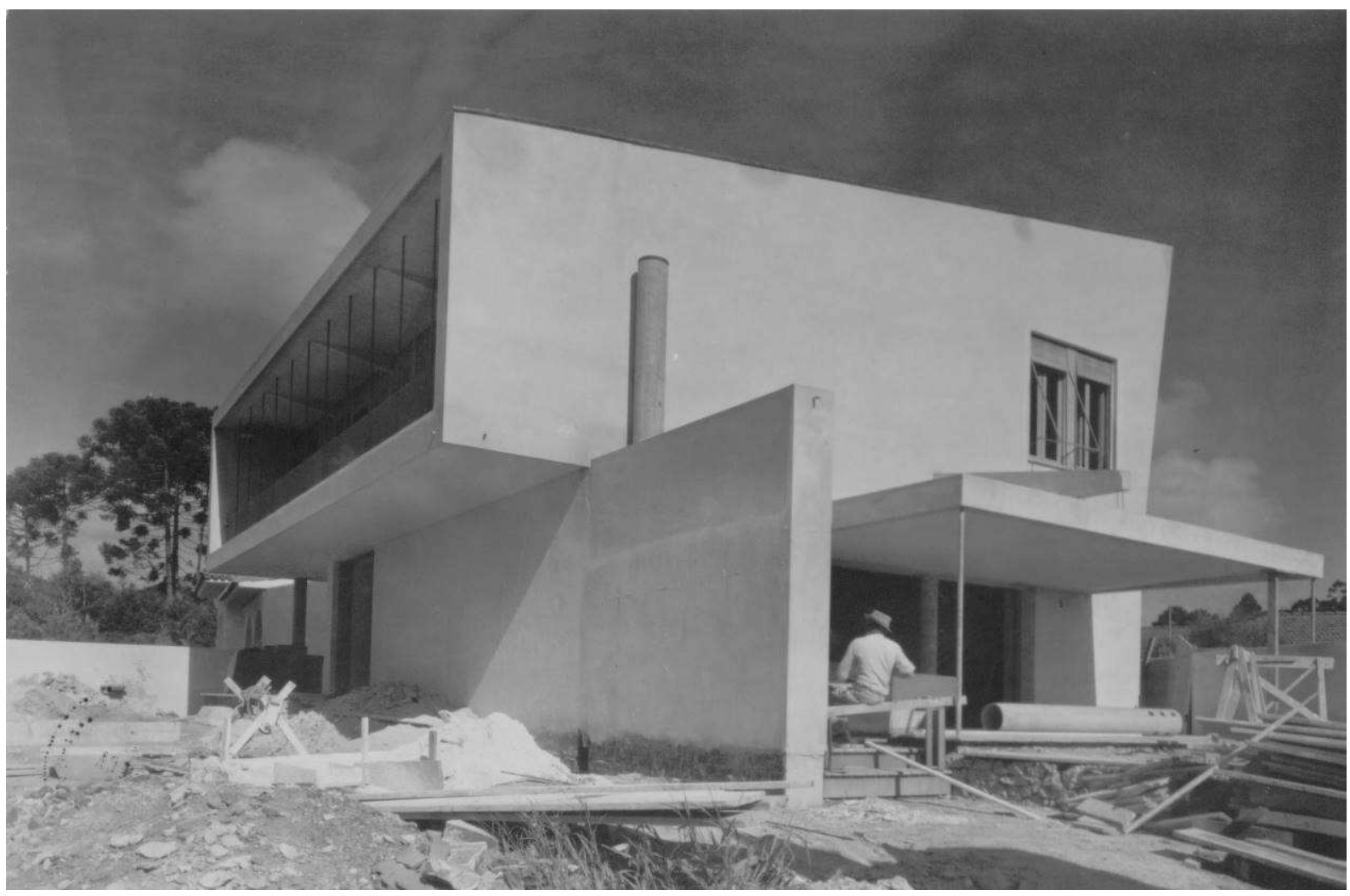

João B. Vilanova Artigas, Casa Benedito Levi. São Paulo, 1944. Arquivo: Vilanova Artigas

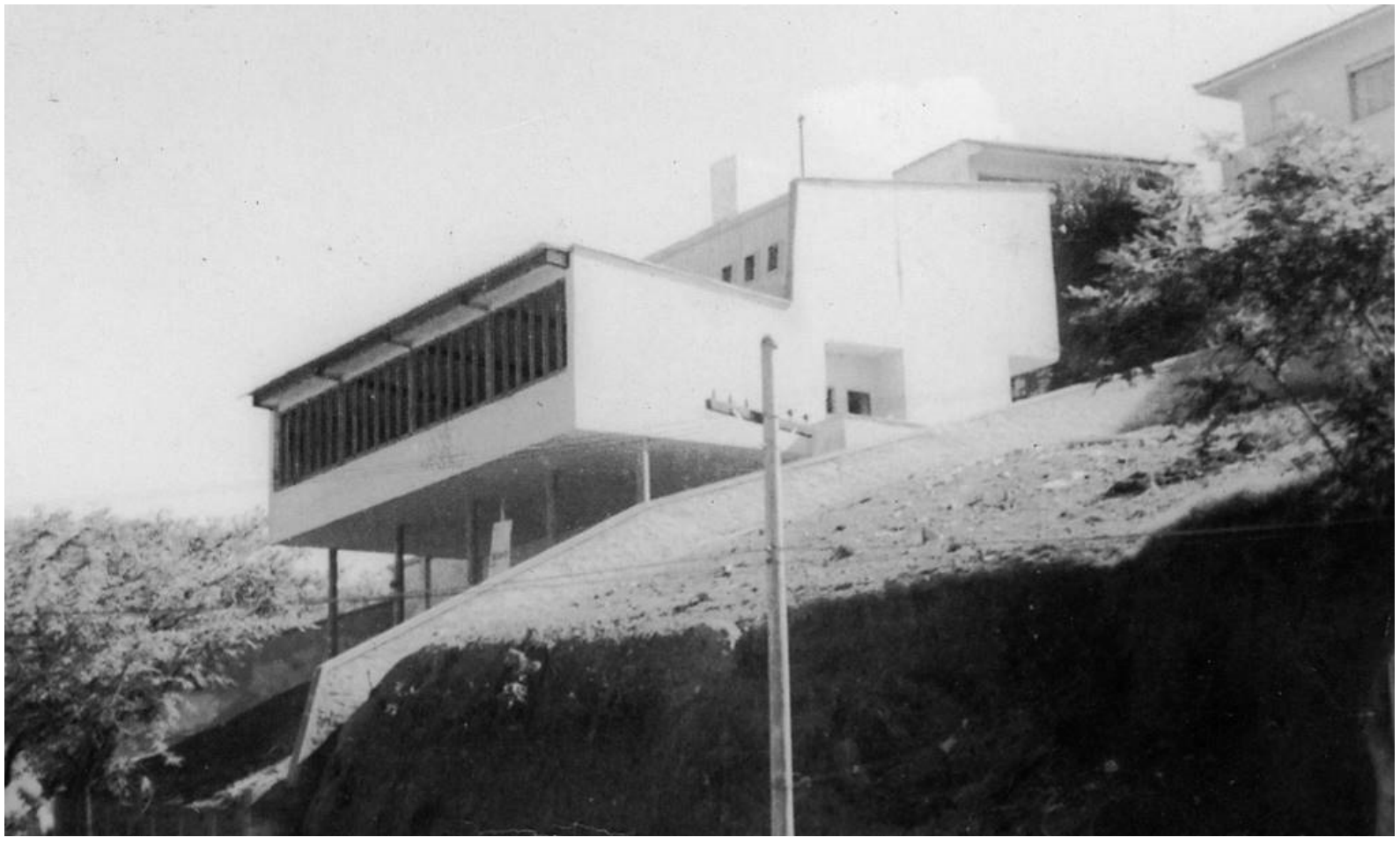

João B. Vilanova Artigas, Casa Rivadavia de Mendonça, São Paulo, 1944. Arquivo: Vilanova Artigas 


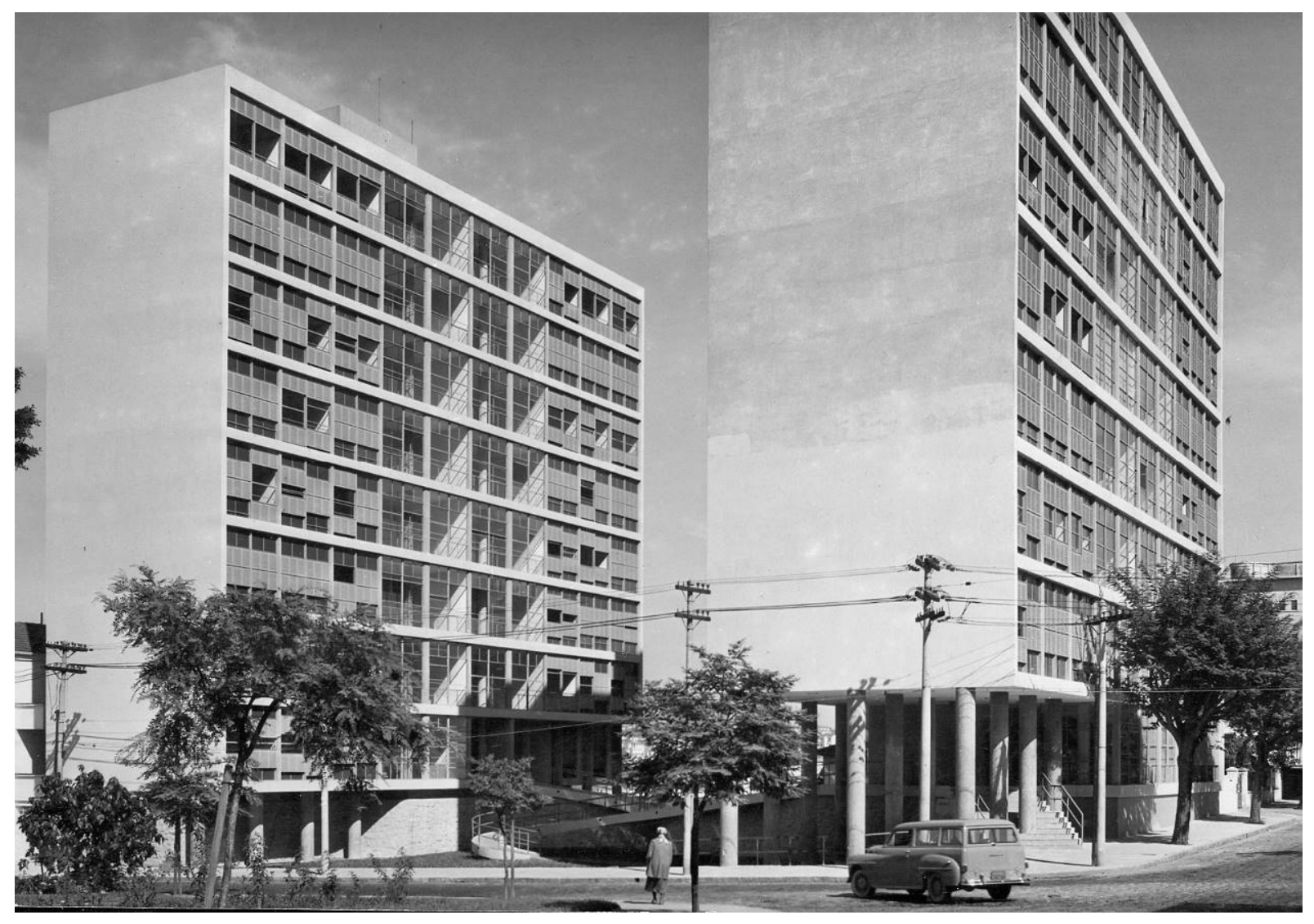

João B. Vilanova Artigas. Edifício Louveira, São Paulo, 1946. Arquivo: Vilanova Artigas

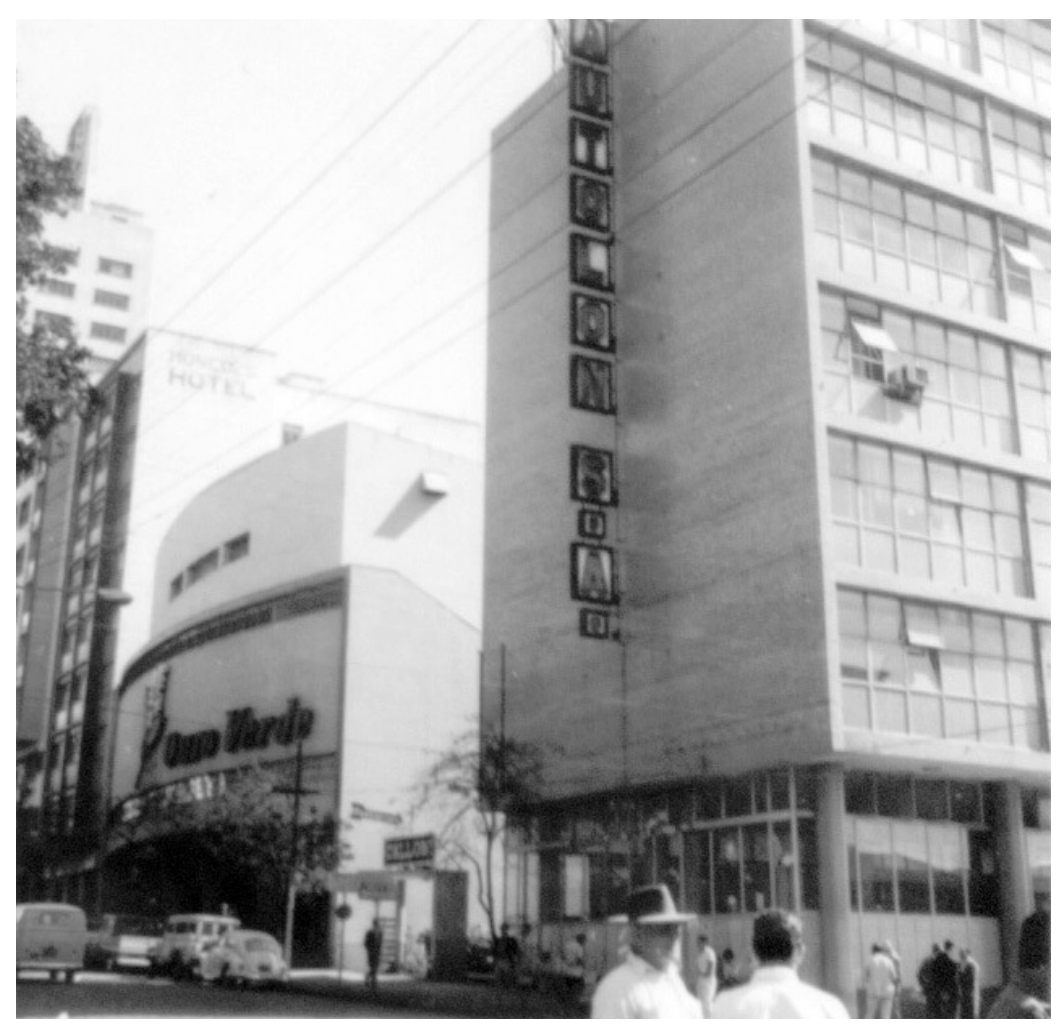

João B. Vilanova Artigas. Edifício da Sociedade Autolon e Cinema Ouro Verde, Londrina, 1948. Arquivo: Vilanova Artigas 


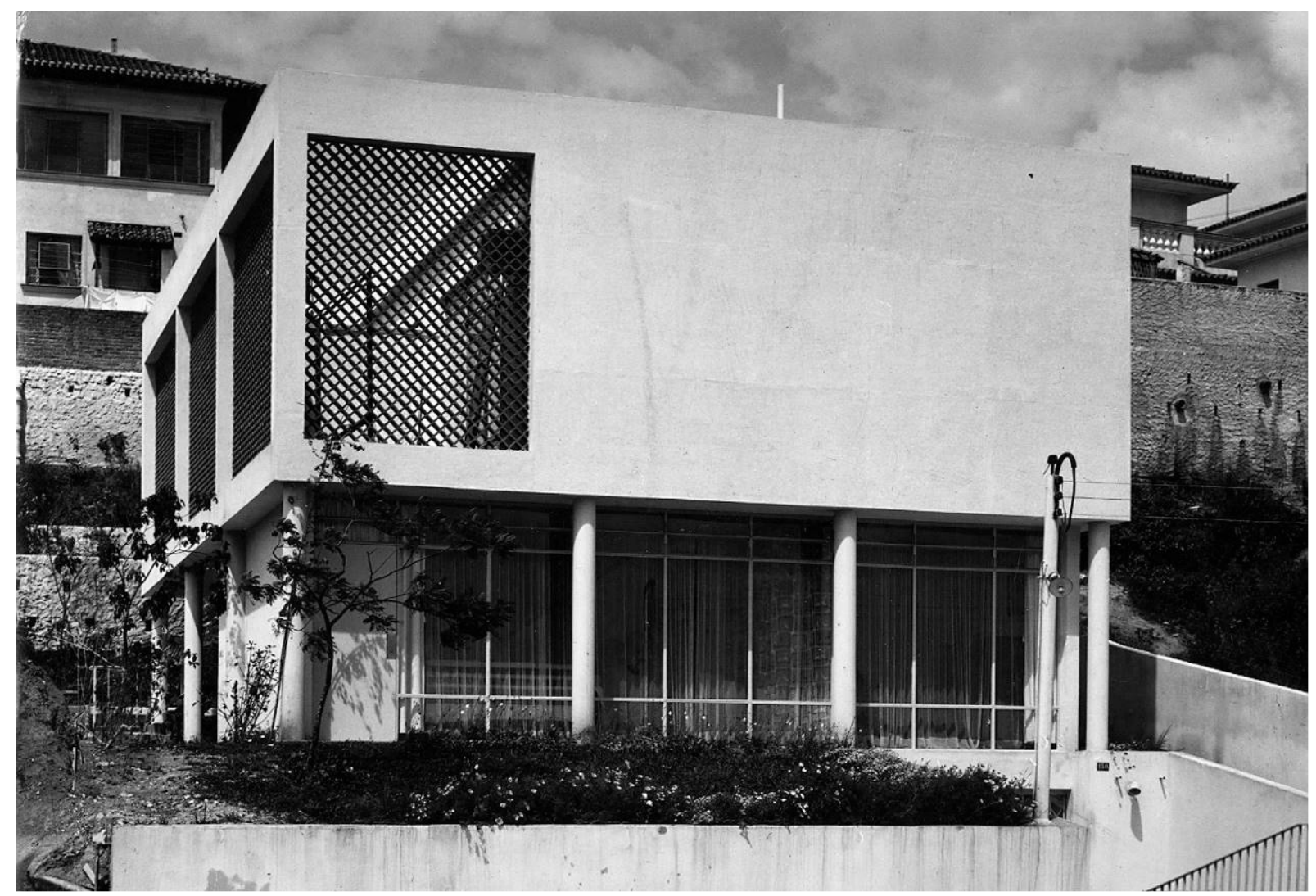

João B. Vilanova Artigas, Casa Hans Victor Trostli, São Paulo, 1948. Arquivo: Vilanova Artigas

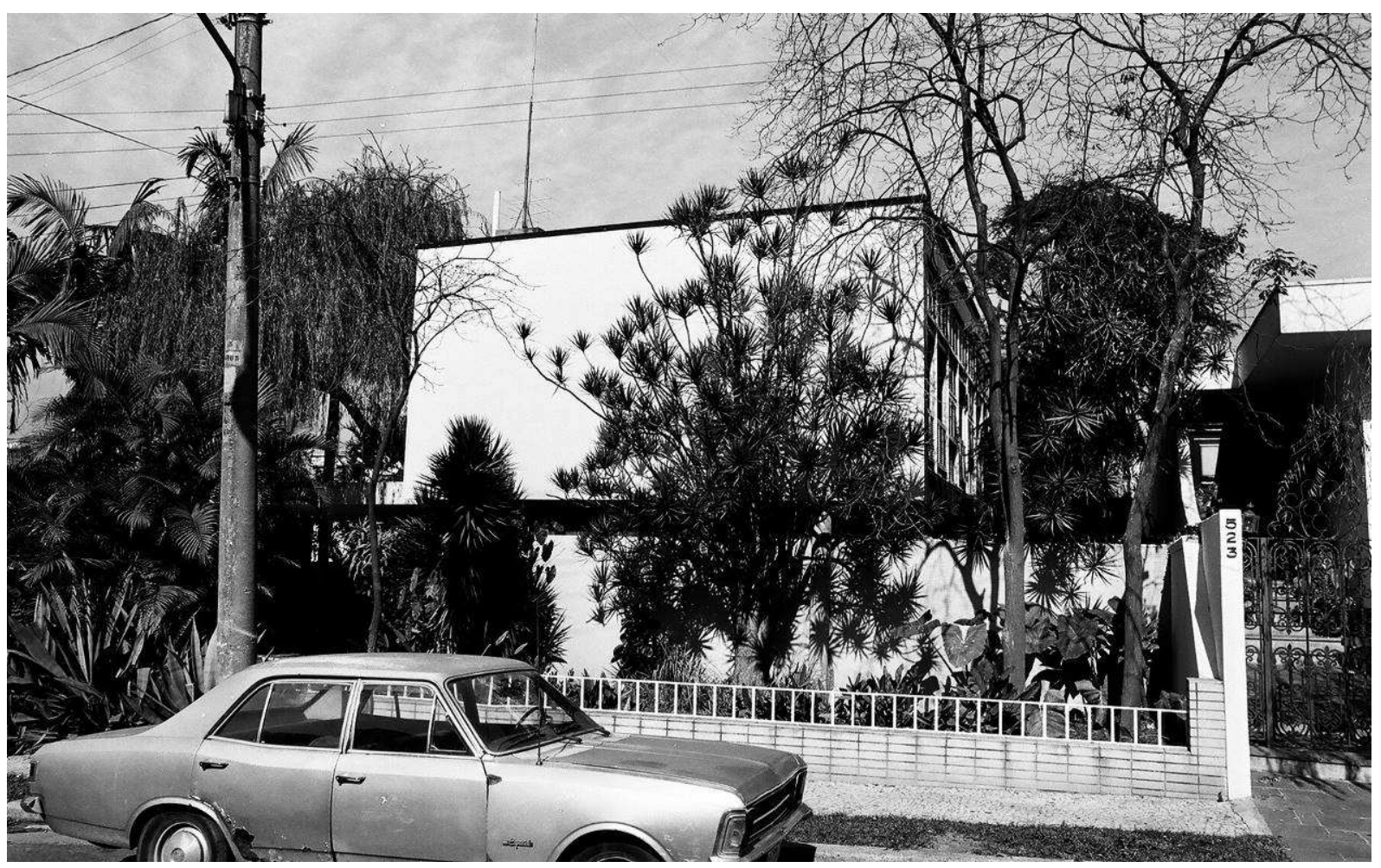

João B. Vilanova Artigas, Casa Elphy Rosenthal, São Paulo, 1950. Arquivo: Vilanova Artigas 


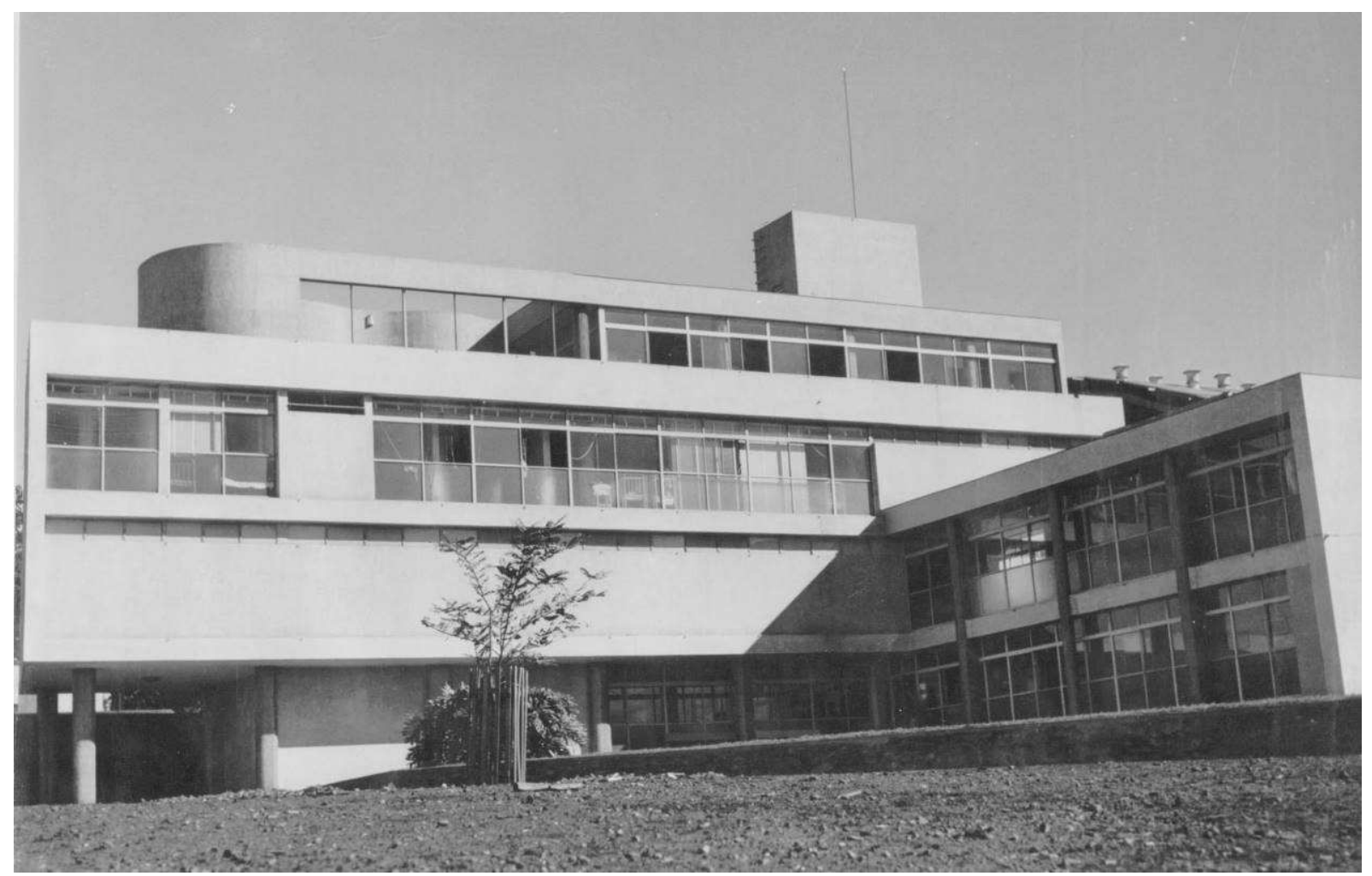

João B. Vilanova Artigas. Casa da Criança, Londrina, PR,1950. Arquivo: Vilanova Artigas

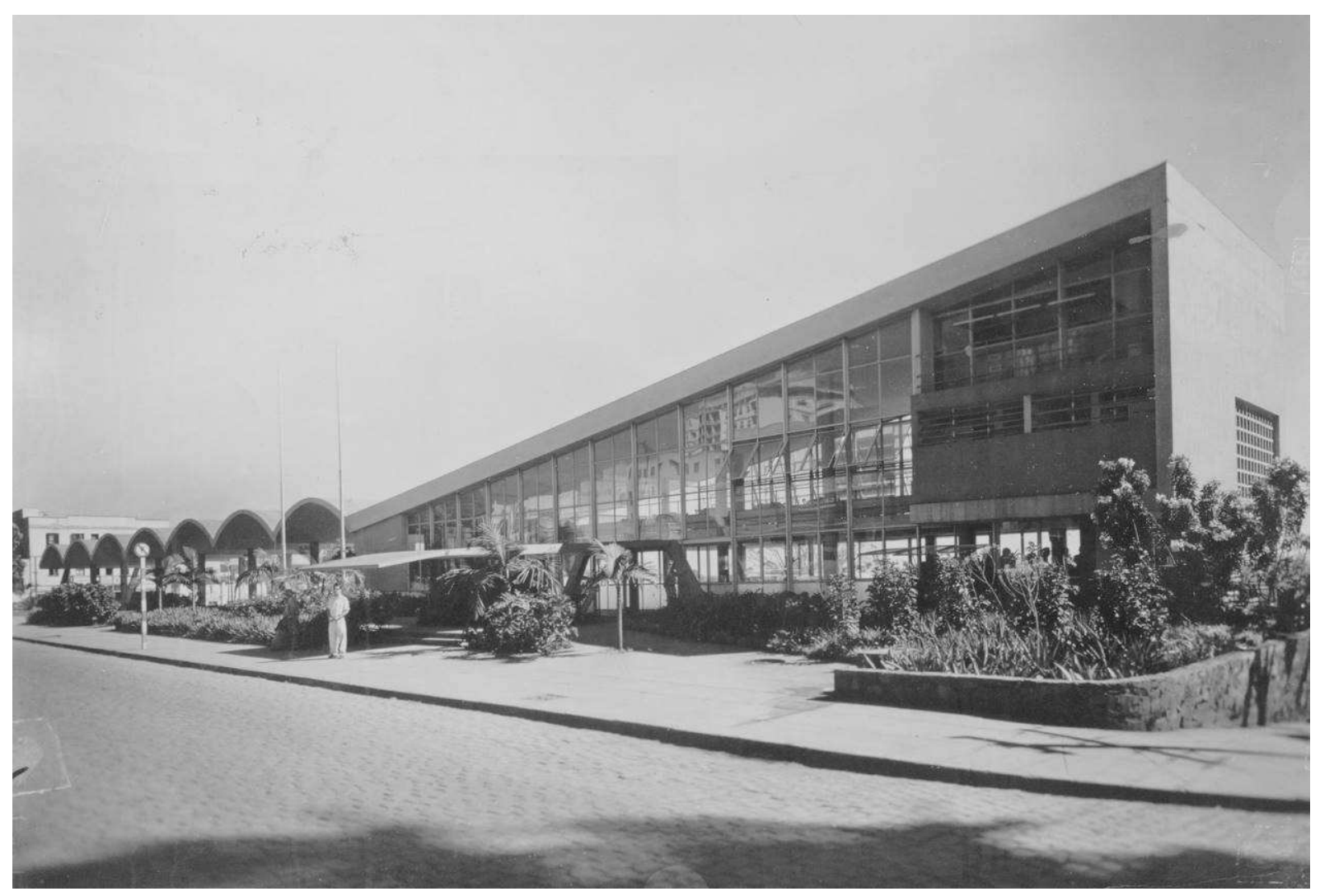

João B. Vilanova Artigas. Rodoviária de Londrina, Londrina, PR, 1950. Arquivo: Vilanova Artigas 


\section{REALISMO CONSTRUTIVO OU BRUTALISMO CABOCLO? (1956-1964)}

De Getúlio Vargas a João Goulart (1961-64), os governos fizeram com que a década de 1950 fosse marcada pela busca do desenvolvimento nacional através da industrialização e da urbanização. Enquanto setores internos e externos mantiveram a democracia constantemente ameaçada por diversas tentativas de golpe de estado para manter o caráter agrário da economia. A esquerda brasileira esteve aliada a esses governos, procurando inserir uma agenda de classe na política nacionalista que conduziria a reformas sociais de base. Neste grupo estavam Oscar Niemeyer, Vilanova Artigas e parte significativa dos arquitetos modernos.

Kubitschek fez o mais bem-sucedido governo na contenção dos opositores e na realização das propostas desenvolvimentistas. Seu Plano de Metas estabeleceu um conjunto de investimentos em setores estratégicos, como energia, transporte e indústria de base. De última hora, foi incluída no Plano a meta de se construir a nova lendária capital, especulada desde os tempos mais remotos do país. Era também uma forma de estimular o setor da construção civil, fundamental por sua capilaridade e emprego de mão de obra, na estratégia desenvolvimentista. Como se sabe, Lúcio Costa venceu o concurso, e o presidente Kubitschek, em pessoa, encarregou Niemeyer de projetar os principais edifícios da nova capital. ${ }^{54}$

Brasília deu forma ao processo de modernização acelerada do país, cujas contradições vêm sendo exploradas por alguns estudos desde então, que destacam as tensões resultantes do contraste entre as formas modernas da arquitetura em concreto armado e as condições de produção extremamente precárias nos canteiros de obras. ${ }^{55}$ Apesar do plano de industrialização que o projeto teoricamente representava, a modernização era sugerida por formas arquitetônicas que não expressavam a reordenação dos meios de produção da construção. Pelo contrário, a construção de uma cidade inteira, em prazo tão curto, reafirmou certas contradições da modernização, como o transporte por avião de estruturas metálicas e uma precariedade ímpar nas condições de vida e trabalho dos candangos. Sob esta perspectiva, Brasília foi retrato de um desenvolvimento incompleto e desigual, no qual preponderaram os avanços formais e técnicos sobre os sociais.

Naquele momento, a arquitetura moderna brasileira, capitaneada por Niemeyer, já era reconhecida como uma perspectiva de futuro ao mundo devastado pela Guerra e tornava-se

\footnotetext{
${ }^{54}$ Kubitschek havia feito o mesmo quando prefeito de Belo Horizonte, entre 1940 e 1945. Sem dúvida, a experiência bem sucedida de Pampulha vinha de encontro aos objetivos estético-políticos do presidente com a nova capital.

${ }^{55}$ Ver: CONTERRÂNEOS velhos de guerra. Direção e Produção: Vladimir Carvalho, 1992. (175 min).
} 
ponto fulcral do debate internacional do período. Tal produção foi rapidamente popularizada no país, sendo adotada pela maioria dos arquitetos durante a década de 1950. Como consequência, surgiram distorções, exageros, repetição, e uma série de vícios gerados pelas modas e estilos. Mas também, surgiu um padrão médio de construções de alta qualidade.

De todos os ataques que a "arquitetura moderna brasileira" sofreu, o mais conhecido foi o proferido pelo arquiteto suíço Max Bill quando em viagem ao Brasil por ocasião da $2^{\text {a }}$ Bienal de São Paulo, em 1953. Em uma entrevista à revista Manchete, o diretor da escola de Ulm criticou o formalismo da arquitetura brasileira como uma atitude leviana, irresponsável e antimoderna. ${ }^{56}$ Em palestra na FAUUSP, realizada em 9 de julho, dias depois das entrevistas aos meios de comunicação, mas antes de sua publicação, Bill procurou amenizar suas críticas, mas manteve o tom contra o que chamou de "espírito acadêmico modernizado". ${ }^{57}$ Essas declarações provocaram tremenda reação dos arquitetos brasileiros de antipatia por Bill e diversas manifestações de apoio a Niemeyer.

Artigas não deixou de expressar sua opinião. Em "Brazilian Experience" (1953), ele avaliou negativamente a experiência brasileira com o "funcionalismo" e criticou o seu caráter antipopular. Propunha em seu lugar símbolos que brotassem da experiência popular ao invés do "cosmopolitismo". 58

Mesmo abalado pelo contato direto com a arquitetura neoclássica praticada na URSS em $1953^{59}$, ele continuava insistindo no argumento de que o realismo socialista deveria reconhecer em Niemeyer "a posição certa, a posição materialista", no sentido de "compreender os anseios populares" dos brasileiros. ${ }^{60}$

As críticas internacionais continuaram nos anos seguintes com Argan denunciando a ausência de planejamento urbano e o predomínio da especulação imobiliária ${ }^{61}$, e Giedion apesar de seu entusiasmo pela nova arquitetura no Brasil - notando uma "certa

\footnotetext{
${ }^{56}$ BILL, Max. "A nossa moderna arquitetura", Manchete. Rio de Janeiro, 13 de julho de 1953, p. 38.

${ }^{57}$ BILL, Max. "O arquiteto, a arquitetura e a sociedade". [1954], In: XAVIER, Alberto. Depoimentos de uma geração. São Paulo: Cosac Naify, 2003, pp. 158-163.

${ }^{58}$ ARTIGAS, João B. Vilanova. "Brazilian Experience", Arkitekten, Arkitektens Forlag, n. 20, ano 4. Kopenhagen, maio 1953, p. 150.

${ }^{59}$ Artigas participou de duas viagens à URSS nos anos de 1952 e 1953, a primeira junto aos arquitetos do IAB a segunda numa delegação de artistas e intelectuais do PCB. Após a segunda viagem, o arquiteto passou por um período de crise e projetou apenas duas residências entre 1954 e 1955. A desilusão de Artigas com a arquitetura do realismo socialista, narrada pelo companheiro de viagem Jacob Gorender, teria sido o principal motivo de sua crise pessoal nos anos seguintes. Ver: THOMAZ, Dalva. Op. Cit., p. 206-208.

${ }^{60}$ ARTIGAS, João B. Vilanova. "Considerações sobre arquitetura brasileira" [1954], In: Caminhos da arquitetura. Op. Cit., pp. 51-55. Nesse texto, Artigas marca posição contrária aos seus colegas do Rio Grande do Sul, Edgar Graeff e Demétrio Ribeiro,
} que defendiam um realismo socialista com viés regionalista.

${ }^{61}$ ARGAN, Giulio Carlo. Op. Cit. 
irracionalidade" na velocidade dessa difusão em todos os programas que acompanhavam o desenvolvimento nacional. ${ }^{62}$ Giedion não deixou de apontar que a "especulação com a terra" na qual a arquitetura estava envolvida era como um "câncer do desenvolvimento do Brasil". ${ }^{63}$

Mas além das críticas especializadas, o Partido Comunista também atravessava uma profunda revisão de seu dogmatismo, com significativas consequências em sua doutrina artística. Em artigo publicado pela revista Fundamentos ${ }^{64}$ em 1955, o novo líder do PC Soviético, Nikita Kruschev, fazia duras críticas à arquitetura da URSS, afirmando que o realismo socialista deveria estar mais comprometido com as dinâmicas econômicas e as necessidades materiais da população do que com a forma - crítica aliás que havia levado à ascensão do realismo socialista sobre o construtivismo na década de $1930 .{ }^{65}$

Para Kruschev, o neoclassicismo praticado implicava numa construção lenta, custosa, sem contrapartidas de comodidade, aumento de área ou qualidade construtiva. Kruschev ia além, e sugeria que uma poética fosse extraída dos elementos da própria edificação, e, a partir desse realismo, se buscasse uma transformação produtiva no sentido da industrialização da arquitetura através de projetos-tipo e pré-fabricados de concreto armado, rápidos e baratos.

Em 1956, Kruschev também deu nova diretriz aos Partidos Comunistas de todo o mundo, para que passassem a respeitar e incentivar a "atividade criadora dos intelectuais", liberando os artistas filiados para suas pesquisas individuais.

Todo esse preâmbulo é fundamental para se entender o contexto no qual Oscar Niemeyer surpreendeu a todos com uma inesperada autocrítica em seu "Depoimento", de 1958. ${ }^{66} \mathrm{O}$ arquiteto declarava ter iniciado em 1956, na ocasião dos projetos para Brasília, uma nova etapa de sua obra, deixando para trás a pressa, a improvisação e a originalidade excessiva, responsáveis pelo desvirtuamento dos últimos anos. Ele afirmava estar agora comprometido com "a simplicidade das construções e o sentido de lógica e economia que muitos

62 GIEDION, Sigfried. "Prefácio" [1956], In: MINDLIN, Henrique. Arquitetura moderna no Brasil. Rio de Janeiro: Aeroplano, 1999.

${ }^{63}$ Alan Colquhoun (2002) propõe que as teses da Nova Monumentalidade buscavam uma ideia ampla de representação em oposição ao caráter estritamente utilitário do edifício. No entanto, tal posição não se destacava dos processos mais amplos de planejamento urbano e territorial. Longe de ser concebida como ação de ordem restrita à estética, a integração proposta no manifesto deveria abranger o "planejador, arquiteto, pintor, escultor, paisagista", constituindo uma ação que se estende das "unidades isoladas para vastas áreas urbanas" e defendendo que "não há fronteiras entre arquitetura e planejamento urbano, como não há fronteira entre cidade e região". A Nova Monumentalidade daria visibilidade concreta e significação social para as ações de planejamento.

${ }^{64}$ KRUSCHEV, Nikita. "Rumos da arquitetura soviética", Fundamentos, nov. 1955 apud GRAZZIANO, Raphael. Aspectos do debate entre realismo socialista e concretismo: a obra de Vilanova Artigas. Trabalho final de graduação. Orientador: Luiz Recamán. São Paulo: FAUUSP, 2012.

${ }^{65}$ A regulamentação dos sindicatos literários e artísticos pelo Partido Comunista da URSS em 1932 encerrou as polêmicas entre construtivistas, produtivistas e outros agrupamentos, para criar uma política centralizada para as artes. Ver. COHEN, Jean Louis. The Future of Architecture since 1889. London, Phaidon, 2012, p. 172.

${ }^{66}$ NIEMEYER, Oscar. “Depoimento” [1958], In: XAVIER, Alberto. Op. Cit. pp. 238-240. 
reclamavam". Niemeyer buscava a depuração da forma plástica, o equilíbrio com os problemas funcionais e construtivos e - o que mais nos interessa aqui - que seus edifícios "não mais se exprimam por seus elementos secundários, mas pela própria estrutura, devidamente integrada na concepção plástica original”. ${ }^{67}$

Os pilares da fachada do Palácio da Alvorada, que se tornariam ícone do estilo bossa-nova de Kubitschek, sintetizam as realizações de Niemeyer. Ao trabalhar a forma desses pilares, o arquiteto buscou conferir "uma leveza tal que eles parecessem quase destacados do solo e apenas pousando na superfície de apoio". ${ }^{68}$ Niemeyer chegou mesmo a cancelar alguns deles, contrariando a lógica evidente, para romper com ritmo constante e acentuar o acesso do edifício. Nervi notou que a concepção formal era independente do desempenho estrutural. ${ }^{69}$ Vasconcelos, o calculista de Oscar Niemeyer, contemporizou, argumentando que esses pilares da fachada tinham função estrutural secundária, sendo os pilares recuados em segundo plano os que suportavam a carga principal. ${ }^{70}$ Para conseguir que os pilares internos fossem esbeltos o suficiente para não se destacarem no segundo plano, Cardozo executou-os com um invólucro externo de aço que funcionou também como fôrma para o concreto.

Com soluções inventivas como essa, Cardozo foi responsável por um novo tipo de concreto armado, que muitas vezes contrariava as normas vigentes. Para o calculista, a correspondência direta entre os princípios construtivos e estruturais e a racionalização e economia na forma arquitetônica constituía um ponto abertamente questionado. Ele argumentava que "não há adaptação perfeita entre a estética dos arquitetos e a estática dos engenheiros" e seria impossível que as formas, mesmo as "mais puras da arquitetura moderna" resultassem "exatamente da estabilidade das construções". ${ }^{71}$ Seria, portanto, um absurdo pensar que a arquitetura moderna se resumisse a um problema de economia de materiais para a cobertura de um determinado vão.

Para Cardozo, Niemeyer tinha uma noção altamente intuitiva do funcionamento estrutural de geometrias não euclidianas, "perfeitamente solucionáveis pelo cálculo moderno". ${ }^{72}$ Uma

\footnotetext{
${ }^{67} \mathrm{Idem}$, ibidem. A nova atitude implicava até na forma de sua contratação, atuando como coordenador de um escritório público, montado especialmente para as obras de Brasília, e não em seu escritório de profissional liberal.

${ }^{68}$ VASCONCELOS, Augusto Carlos de. O concreto no Brasil: recordes, realizações, história. São Paulo: Copiare, 1985.

${ }^{69}$ NERVI, Pier L. "Critica delle strutture", Casabella Continuità, n. 223, 1959, p. 55.

70 VASCONCELOS, Augusto Carlos de. Op. Cit.

${ }^{71}$ CARDOZO, Joaquim. "Forma estática-forma estética", Módulo, n. 10, 1958, p. 3-6. Disponível em $<$ www.joaquimcardozo.com>.

72 CARDOZO, Joaquim apud TELLES, Sofia. "Oscar Niemeyer. Técnica e forma”, Óculum, n. 2, 1992, p. 4-7.
} 
atitude assumida de "desafio e oposição às teorias estabelecidas"73 que, ao contrário das pesquisas mais funcionais, exigia o máximo do cálculo para usufruir de toda a potencialidade do concreto armado.

Enquanto isso, desde a nova orientação do PCB, em 1956, Vilanova Artigas vinha experimentando novas formulações estruturais em concreto armado aparente. Quando Oscar Niemeyer fez sua autocrítica, Artigas o apoiou prontamente. ${ }^{74}$

Contudo, apesar de sintonia no discurso, a sequência de suas obras revela caminhos independentes. Enquanto Oscar Niemeyer projetava os palácios de Brasília, Artigas investigava a relação entre continuidade espacial e unidade de material. O predomínio do concreto aparente em todos os elementos do edifício surgia como reafirmação de critérios éticos e estéticos, tais como baixo custo, legibilidade do espaço, clareza construtiva e eliminação do supérfluo.

Nos projetos desenvolvidos a partir da casa Baeta (1956) e Bittencourt II (1959) Artigas desenvolveu seu novo esquema básico: uma sequência de planos horizontais dispostos em meio nível e conectados por rampas e cobertos por uma única cobertura. Uma volumetria simples abrigando em seu interior complexos espaços criados pelas lajes intercaladas. Apesar da rigidez do volume edificado, encerrado por duas empenas cegas, a circulação era fluida. Esta concepção foi desenvolvida nas casas e, principalmente, nas escolas que Artigas projetou nesses anos, chegando a sua melhor formulação no projeto da Faculdade de Arquitetura e Urbanismo da Universidade de São Paulo (1960-61).

Concordando com a autocrítica de Niemeyer de que a concepção plástica original do edifício deveria se expressar através da estrutura - sua essência -, Artigas se reconciliou com seu passado wrightiano e com sua interpretação da "verdade dos materiais". ${ }^{75}$ Porém, passados mais de 10 anos de sua inflexão racionalista, ele concentrou sua poética na verdade de um único material: o concreto armado. Se a intenção era se expressar através da estrutura da edificação, os pilares representavam o gesto primordial. Assim como nos projetos de Oscar Niemeyer, os inovadores pilares de Artigas também não se limitavam ao estrito desempenho econômico - o que, para ele, representaria uma regressão da arquitetura à engenharia. Mas, ao invés de perseguir uma forma graciosa e elegante, eles buscavam enfatizar o funcionamento estrutural (combinado com a distribuição das águas), ainda que para isso

\footnotetext{
${ }^{73}$ CARDOZO, Joaquim. "Dois episódios na história da arquitetura moderna brasileira", Módulo, n. 4, 1965. Republicado como "O episódio da Pampulha", In: XAVIER, Alberto. Op. Cit.

${ }^{74}$ ARTIGAS, J. B. Vilanova. "Revisão crítica de Niemeyer", Acrópole, n. 237, julho 1958.

${ }^{75}$ A noção de verdade dos materiais aparece como uma contribuição de Frank Lloyd Wright: "os materiais devem ter a sua cor, a sua textura própria, porque seu funcionamento deve ser 'orgânico'”. ARTIGAS, João B. Vilanova, "Os caminhos da arquitetura moderna" [1952], In: Op. Cit., p. 35.
} 
fossem necessários artifícios para tencionar plasticamente os pontos de apoio, tais como superdimensionamento, linhas diagonais dos esforços horizontais, continuidade do sistema pilar-empena-cobertura, rótulas móveis, afinamento das arestas, etc. Artigas remetia sua nova poética a August Perret, que dizia ser necessário "fazer cantar o ponto de apoio".

Essa inflexão suscitou a primeira sugestão do termo 'brutalismo' para caracterizar sua produção, feita pelo editor da revista Zodiac, Bruno Alfieri, ${ }^{76}$ em mais um número de revista estrangeira dedicado à arquitetura brasileira. Após as considerações de Alfieri, a revista italiana apresentou um ensaio de Flávio Motta que contextualizava produção arquitetônica do Brasil a partir da geografia e da história do país. Nessa ocasião, o crítico, historiador e professor da FAU retratou seu colega Vilanova Artigas como um desbravador bandeirista, cujo espírito prático resultou numa linguagem depurada como a dos pioneiros paulistanos:

"Suas casas, projetadas para intelectuais e profissionais liberais, são caracterizadas pela economia de meios de construção, onde, às vezes, o arquiteto se mistura intimamente com a atividade do mestre de obras e do operário. [...]. Aquilo que este arquiteto brasileiro busca é a expressão da energia que penetra na matéria com a força e obstinação daqueles que não impõem limites para o espaço, mas o cavam procurando o vazio para o homem. [...]. Suas realizações revelaram o esforço para chegar a novas formas por meio de processos construtivos independentes da instabilidade da nascente indústria construtiva". ${ }^{77}$

Flávio Motta identificava uma produção local coletiva e alternativa à arquitetura carioca, já duramente criticada. Se até então o arquiteto havia merecido elogios episódicos por sua produção individual, destacando sua correção técnica e sua atenção aos materiais, ele passava agora a ser visto como protagonista de uma "intensa atividade doutrinária", de proporção semelhante à de Lucio Costa, no Rio de Janeiro, de modo que a ideia de escola já estaria presente. ${ }^{78}$

Não por acaso, foi nesse momento que Artigas projetou o edifício da FAU, recebido como "o fruto mais promissor do movimento de renovação do ensino de arquitetura e urbanismo, em discussão desde os anos 1950", e "síntese da experiência paulista".79

\footnotetext{
${ }^{76}$ ALFIERI, Bruno. "João Vilanova Artigas: ricerca brutalista”, Zodiac, n. 6. Milão, 1960. Neste artigo, Bruno Alfieri pondera os sentidos do termo "brutalismo" e menciona as casas Rubens de Mendonça, Olga Baeta, o Ginásio de Itanhaém e o Estádio do Morumbi.

${ }^{77}$ MOTTA, Flávio. "Introduzione al Brasile”, Zodiac, n. 6. Milão, 1960, p. 67. Tradução livre do italiano.

${ }^{78}$ Essa é a interpretação de: DEDECCA, Paula Gorenstein. "A ideia de uma identidade paulista na historiografia de arquitetura brasileira”. Revista Pós, n. 32, São Paulo, dezembro, 2012, p. 90-101.

79 PEREIRA, Miguel. "Sobre o Projeto da Faculdade de Arquitetura e Urbanismo da Universidade de São Paulo" [1960], In: Arquitetura e os caminhos de sua explicação. São Paulo: Projeto Editores Associados, 1984.
} 
Sob a gigantesca cobertura de concreto em grelha da FAU, um jogo de rampas e corredores conduz o visitante em torno de um grande vazio central sempre visível. Sem portas nem interrupção, passa-se da cidade aos estúdios localizados nos níveis superiores.

Apesar dos rumos independentes a partir de 1956, Artigas e Niemeyer se mantiveram conectados pela amizade e pelas teses do PCB, que agora propunham uma a aliança estratégica com a burguesia nacional para promover o desenvolvimento das forças produtivas. Segundo esse marxismo ortodoxo, a industrialização levaria inevitavelmente, e em última instância, à crise do capitalismo e ao fim da exploração do trabalhador.

Com a industrialização da arquitetura longe de ser viável devido, primeiramente, à grande disponibilidade de mão de obra barata (em parte propiciada pelo concreto armado), Niemeyer achava que esse objetivo devia ser perseguido através da militância política, não havendo o que pudesse ser feito em arquitetura para dirigir o desenvolvimento técnico. ${ }^{80}$ Nas palavras de Niemeyer, a arquitetura era apenas uma distração que, na melhor das hipóteses, poderia instigar a curiosidade e a imaginação. Já para Artigas, que enxergava conteúdos morais nas escolhas de técnicas e materiais, essa separação entre militância e profissão era inaceitável. Em suas próprias palavras: "A Arquitetura Moderna, tal como a conhecemos, é uma arma de opressão, arma da classe dominante; uma arma de opressores, contra oprimidos". ${ }^{81}$ Ainda em 1952, Artigas havia formulado claramente o seu dilema:

"Surge afinal a questão: onde ficamos? Ou: que fazer? Esperar por
uma nova sociedade e continuar fazendo o que fazemos, ou
abandonar os misteres de arquiteto, já que eles se orientam numa
direção hostil ao povo, e nos lançarmos na luta revolucionária
completamente?" 82 A solução para seu dilema - "uma atitude crítica em face da realidade" - pode parecer nebulosa. Mas sob a perspectiva de um arquiteto que não pretendia abrir mão de sua condição de autor e que reconhecia a impossibilidade de romper abruptamente com a lógica econômica de construção, tal atitude crítica recaía, inevitavelmente, sobre a linguagem. Segundo o arquiteto:

"Oscar e eu temos as mesmas preocupações e encontramos os mesmos problemas, (...), mas enquanto ele sempre se esforça para resolver as contradições numa síntese harmoniosa, eu as exponho

\footnotetext{
${ }^{80} \mathrm{Na}$ prática, sua liberdade formal forçou inovações da engenharia, mas de forma não planejada.

${ }^{81}$ ARTIGAS, João B. Vilanova. "Os caminhos da arquitetura moderna", Op. Cit., p. 37.

${ }^{82}$ Idem, p. 49.
} 
claramente. Em minha opinião, o papel do arquiteto não consiste numa acomodação; não se deve cobrir com uma máscara elegante as lutas existentes, é preciso revelá-las sem temor". ${ }^{83}$

A radicalidade dessa linguagem reside, ao menos em tese, em sua consciência das "lutas existentes" na própria construção que é suporte da linguagem. Nesse sentido, a nova poética de Artigas, que fez escola, não rompeu com a monumentalidade de Niemeyer ou com seus recursos, mais substituiu o conteúdo da representação.

A FAU, por exemplo, reproduz lições do Palácio da Alvorada. Seu pilar de fachada igualmente icônico, que estreita no ponto em que esforços horizontais parecem se neutralizar, também sustenta apenas uma parte reduzida da carga da empena acima dele (que dá a impressão de ser mais pesada do que de fato é). Artigas também deslocou os pilares das fachadas laterais do alinhamento com os demais pilares para enfatizar o canto livre e o grande vão resultante. Esses e outros "detalhes" demonstram que Artigas nunca esteve disposto a abrir mão de artifícios (ou efeitos) que servem somente para encantar e induzir à reflexão sobre o funcionamento do edifício. Desse modo, o efeito visual predomina sobre produção ainda que a produção seja o conteúdo manifesto. As marcas expostas das fôrmas de concretagem dão pistas de sua produção, mas que narrativa sua aparência (aparência de verdade) sugere? Denúncia de atraso? Sincretismo regionalista? Pragmatismo desenvolvimentista? Monumentalidade da produção? Representação do desenvolvimento truncado? O significado desse concreto é complexo, já que há uma inegável ambiguidade nele. De todo modo, o primeiro ponto para decifrarmos seu significado é reconhecer que as fôrmas, da produção do concreto, indicadas por Artigas em seus desenhos, possuem uma evidente intencionalidade plástica.

O segundo ponto é reconhecer que, em sua trajetória, Artigas sempre se valeu da consciência de que arte e arquitetura estão incondicionalmente inseridas na história e na economia. Foi essa preocupação realista que impulsionou sua "moral construtiva" do início dos anos 1940 e também sua guinada no pós-guerra em direção ao que considerava mais plausível de ser identificado pelo povo como progresso. E foi essa mesma postura que o levou a resgatar o compromisso com a realidade produtiva ou representar a contradição da realidade. Ao contrário de tantas estéticas brutalistas da época, não há figuração de uma industrialização inexistente na obra de Vilanova Artigas. ${ }^{84}$ Mas há uma valorização do engenho técnico-científico do concreto armado.

\footnotetext{
${ }^{83}$ ARTIGAS, João B. Vilanova apud BRUAND, Yves. Op. Cit., p. 302.

${ }^{84} \mathrm{O}$ que pode ser identificado na imagem de uma mão encaixando uma unidade na maquete da Unité d'Habitation, de Le Corbusier, ou na simulação de unidades seriadas da University of Massachusetts, de Paul Rudolph.
} 
$\mathrm{Na}$ discussão sobre arquitetura moderna e subdesenvolvimento, Artigas talvez tenha resumido um sentimento coletivo difuso, atribuindo dignidade à simplicidade e baixa tecnologia do concreto armado, tomado como a opção mais adaptada às condições terceiromundistas que incluíam fatores negativos, como o uso intensivo de mão de obra, uso intensivo de mão de obra, o esquecimento das técnicas tradicionais de construção e fatores positivos, como a especialização da engenharia. Por mais trágica que pudesse ser, o concreto armado já fazia parte do processo de modernização das relações de produção na construção, bem como da história da arquitetura moderna brasileira. A escola de Artigas valeu-se desse material histórico para construir um sentido completamente distinto do brutalismo europeu ou norte-americano, ainda que posteriormente tenha se conciliado com aqueles.

Por fim, o elogio ao low-tech não deve ser confundido como miserabilismo - o que Artigas recusou veementemente na obra de seus discípulos -, mas sim como uma forma positiva de exibir a astúcia diante das adversidades, seja da natureza, seja da sociedade. Assim, maiores vãos e grandes balanços adquiriram um sentido de ousadia e resistência, radicalizadas através da depuração estética com materiais. De fato, um material: o sonho totalitário de Le Corbusier de um canteiro de obras com um único métier, ganhava novo sentido no subdesenvolvimento brasileiro, onde a opção foi fruto de uma "atitude crítica em face da realidade". ${ }^{85}$

${ }^{85}$ ARTIGAS, João B. Vilanova. "Os caminhos da arquitetura moderna", Op. Cit., p. 50. 


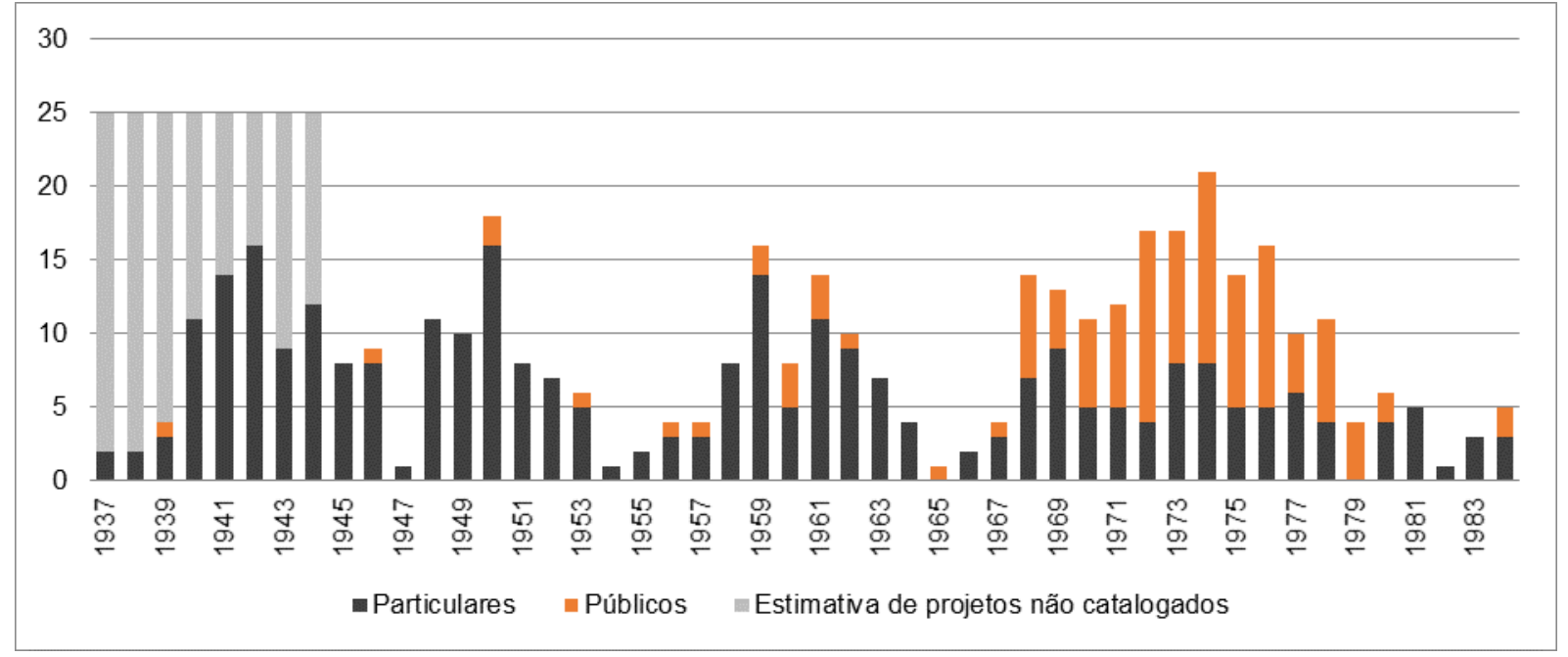

Cronologia dos projetos públicos e privados de Vilanova Artigas.

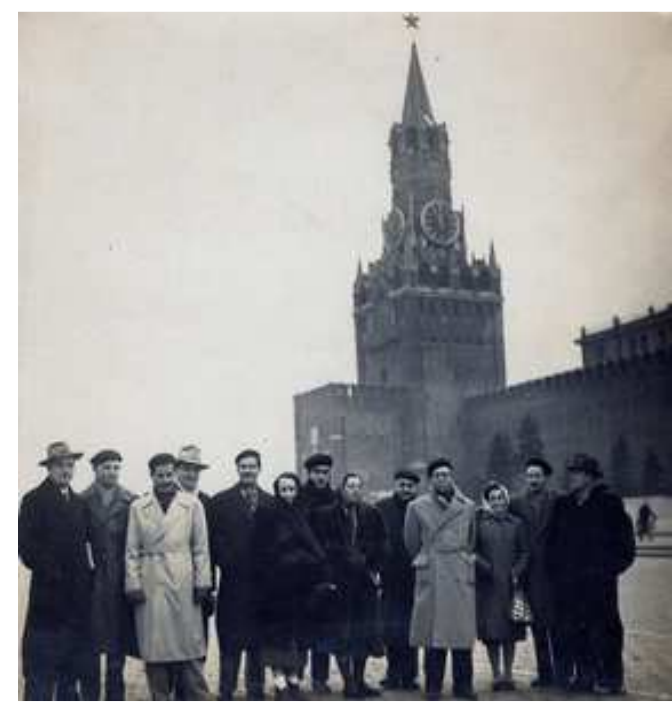

Viagem à URSS com militantes do PCB. 1953. Arquivo Vilanova Artigas

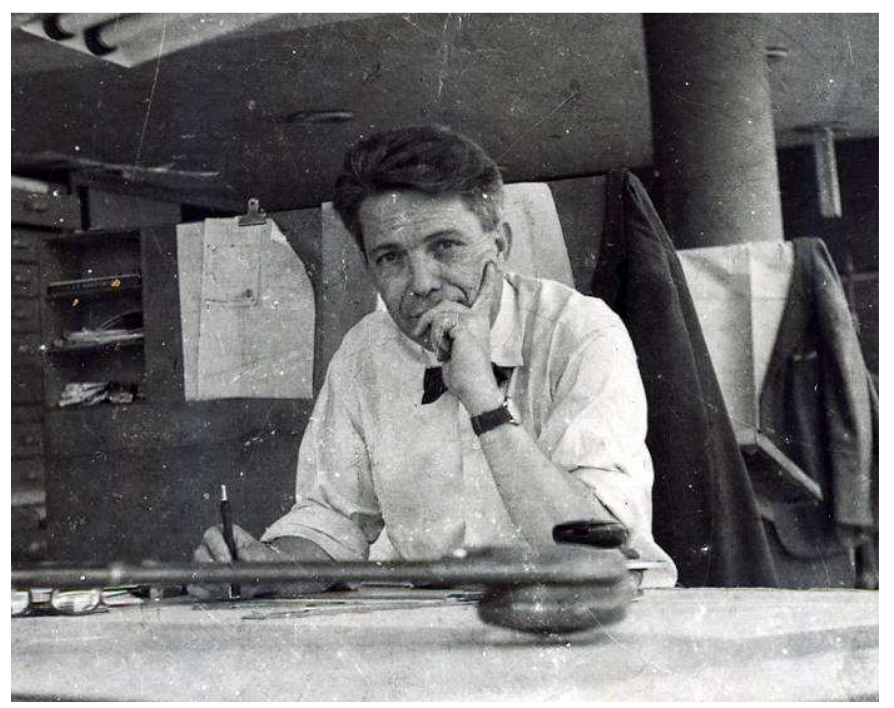

No escritório, 1960. Arquivo Vilanova Artigas 


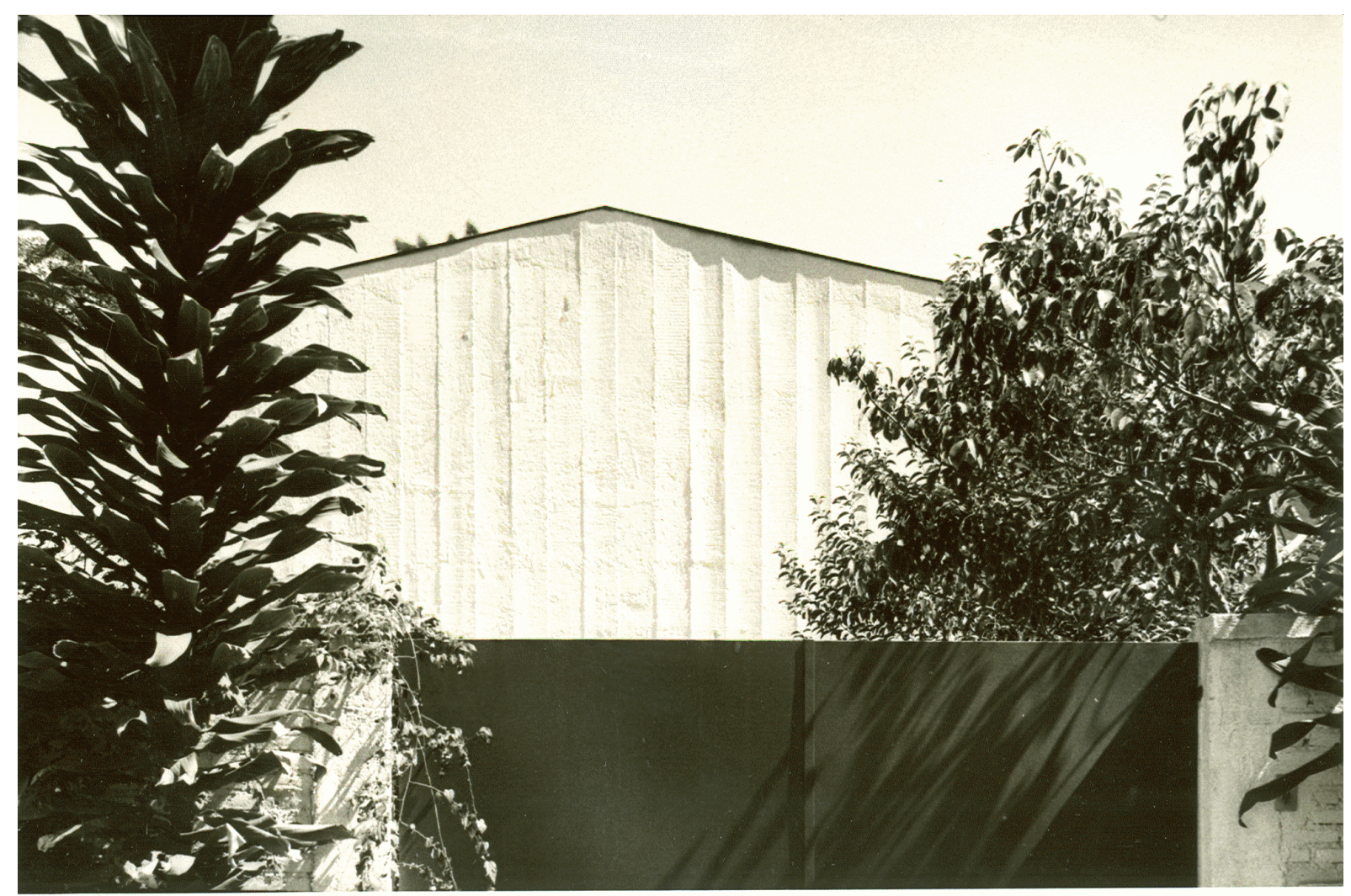

João B. Vilanova Artigas. Casa OIga Baeta, São Paulo, 1956. Arquivo: Vilanova Artigas

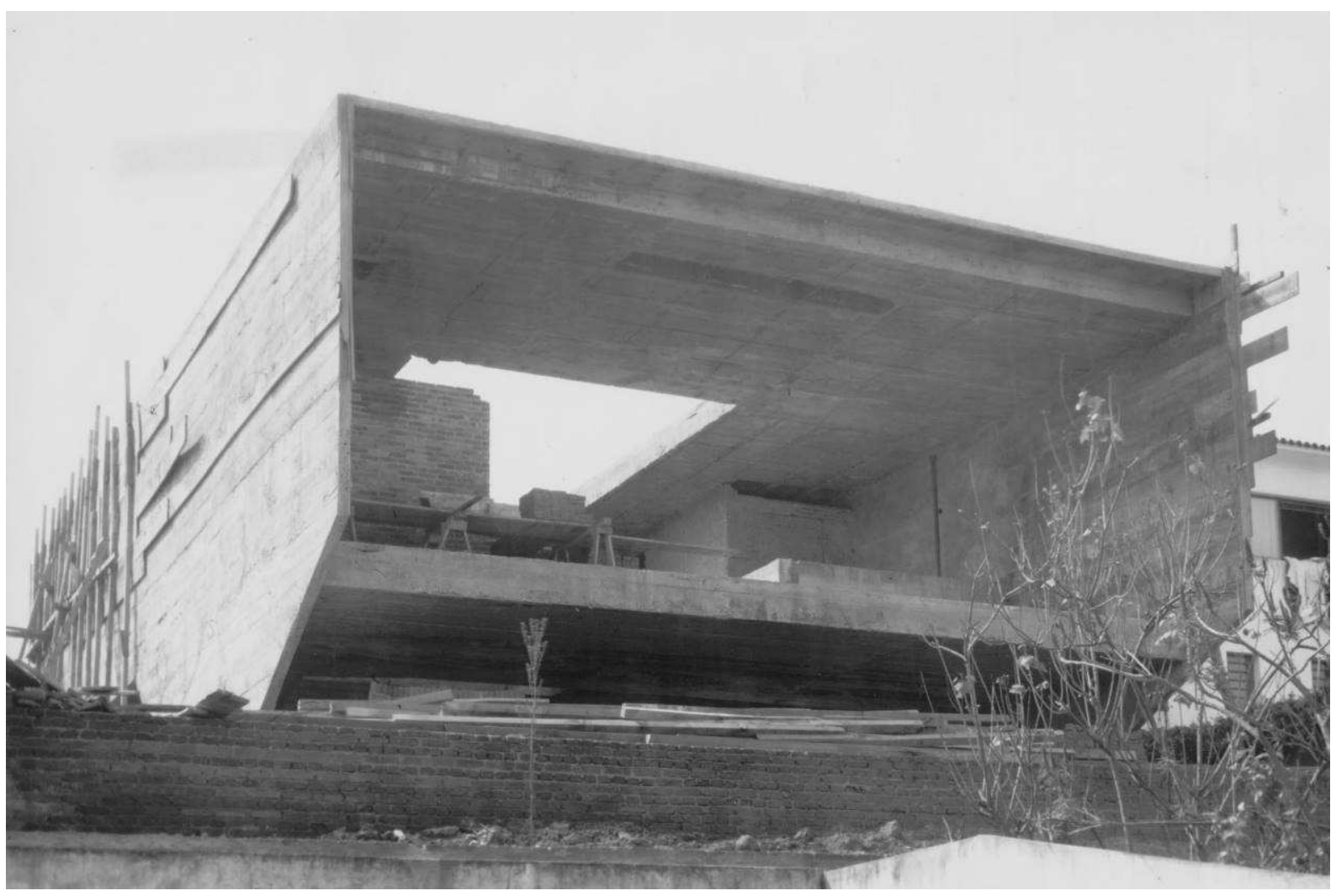

João B. Vilanova Artigas. Casa Mario Taques Bittencourt, São Paulo, 1958. Arquivo: Vilanova Artigas 

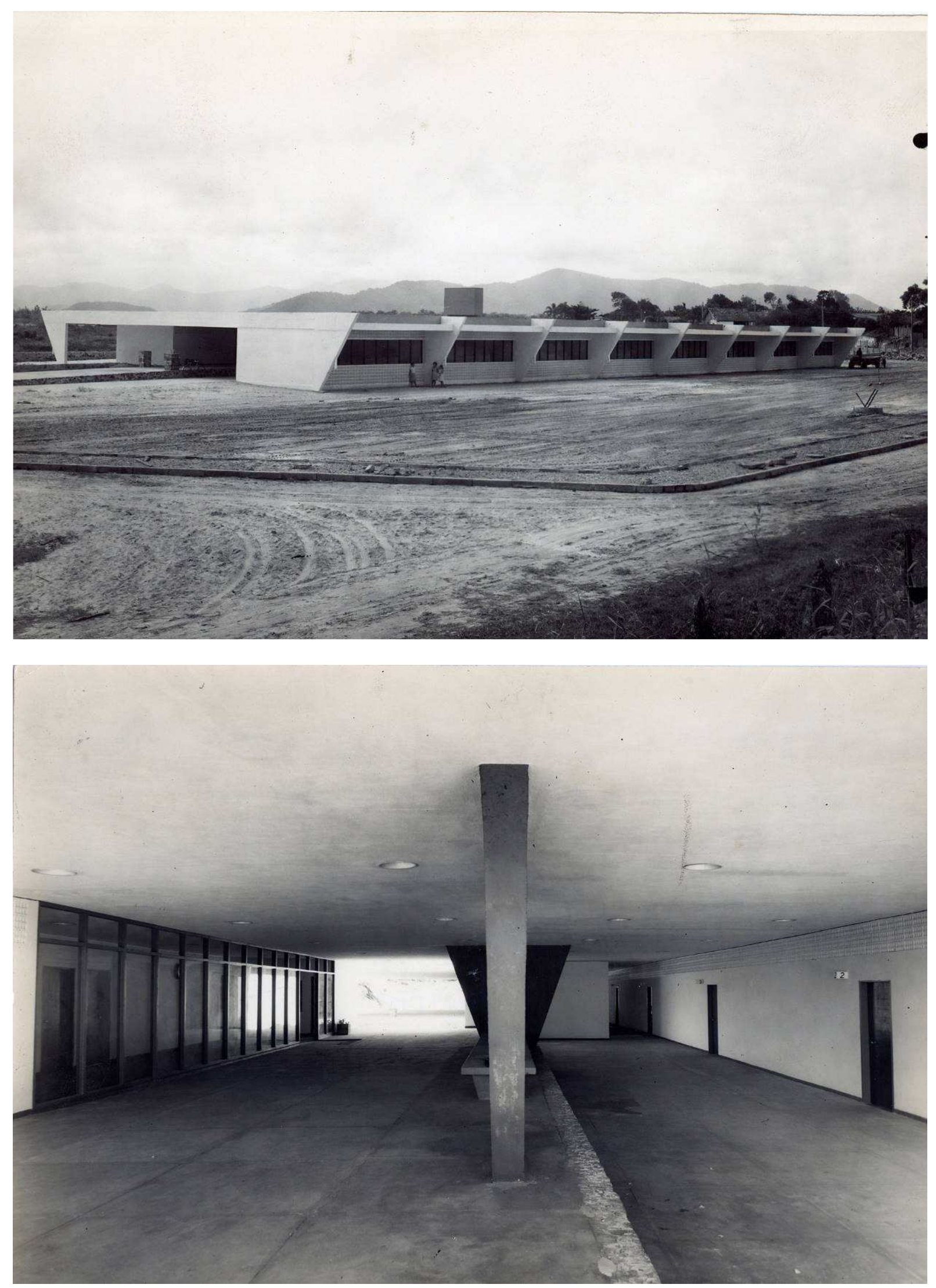

João B. Vilanova Artigas. Ginásio de Itanhaém, Itanhaém, SP, 1959. Arquivo: Vilanova Artigas 

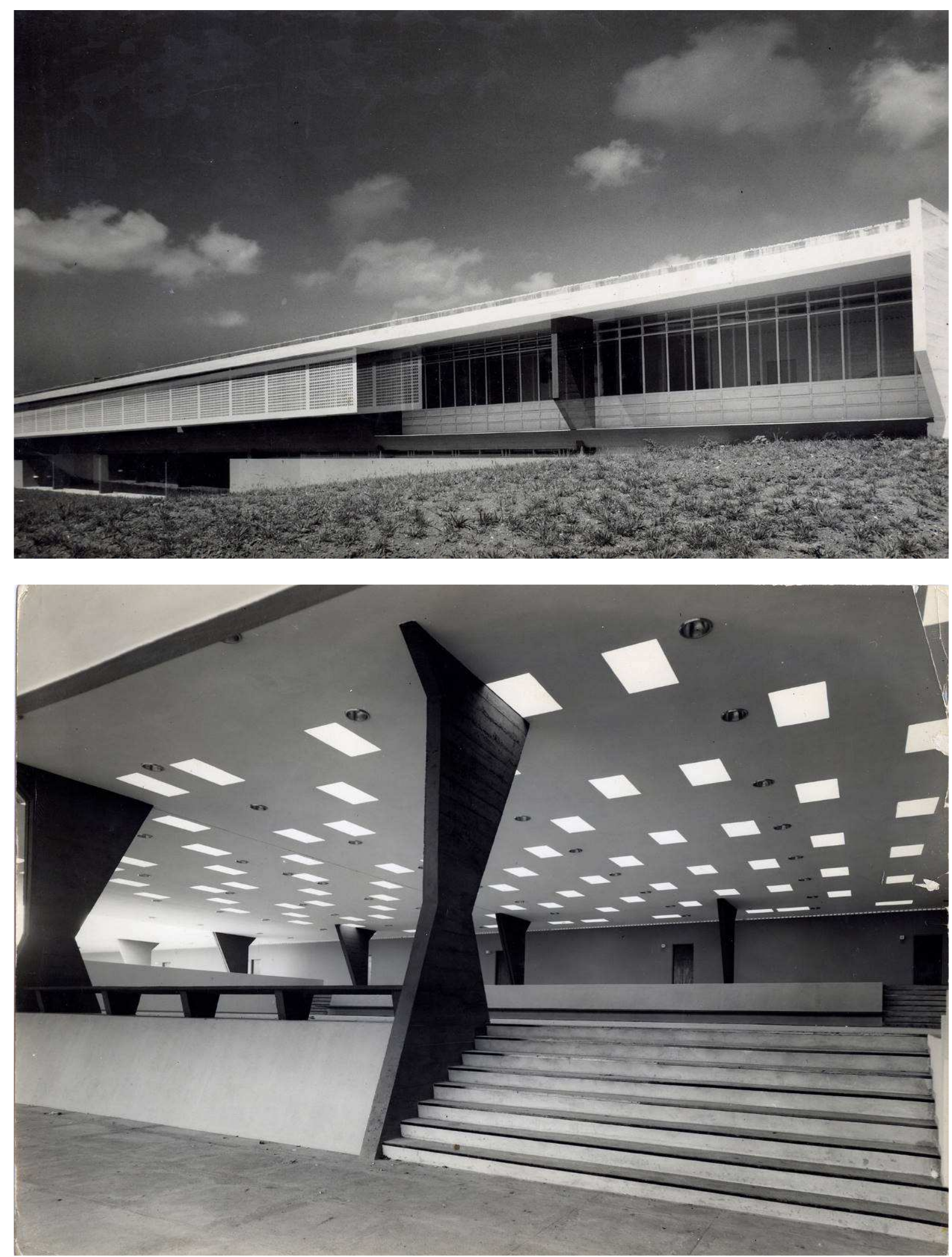

João B. Vilanova Artigas. Ginásio de Guarulhos, Guarulhos, SP, 1960. Arquivo: Vilanova Artigas 

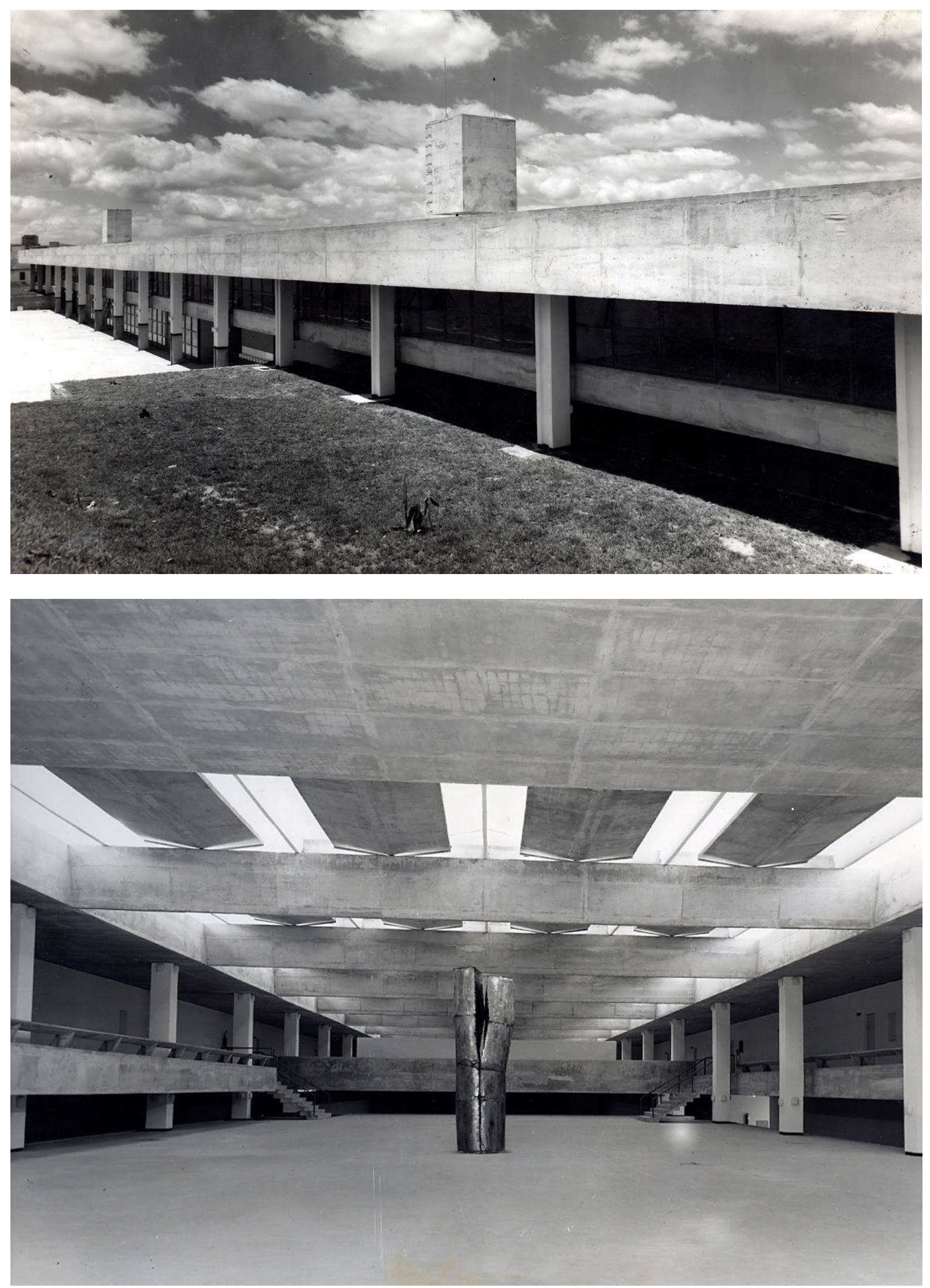

João B. Vilanova Artigas. Ginásio de Utinga, São Paulo, SP, 1962. Arquivo: Vilanova Artigas 

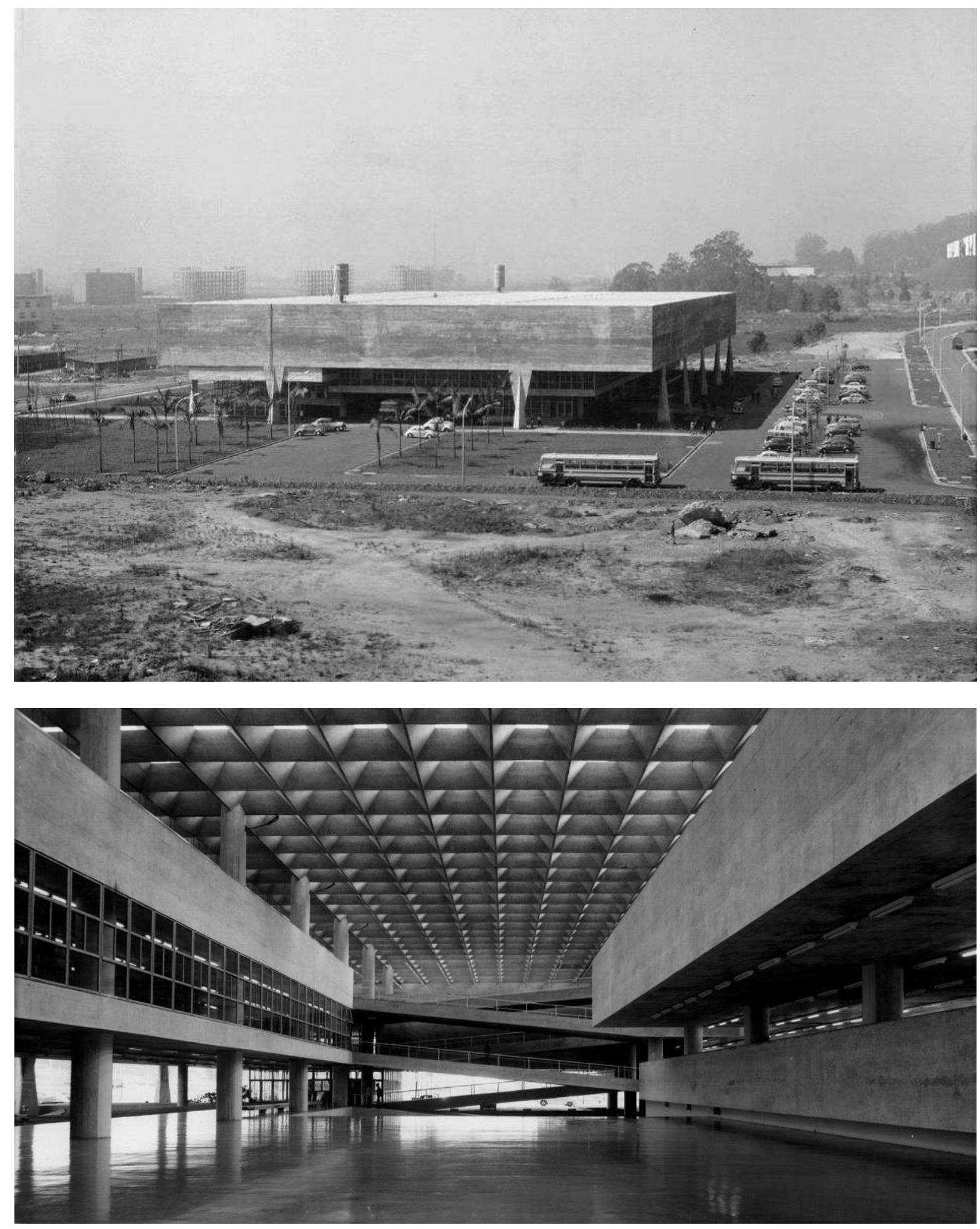

João B. Vilanova Artigas. Faculdade de Arquitetura e Urbanismo. São Paulo, 1960-1969. Foto José Moscardi (?) / Arquivo: BFAUUSP. 


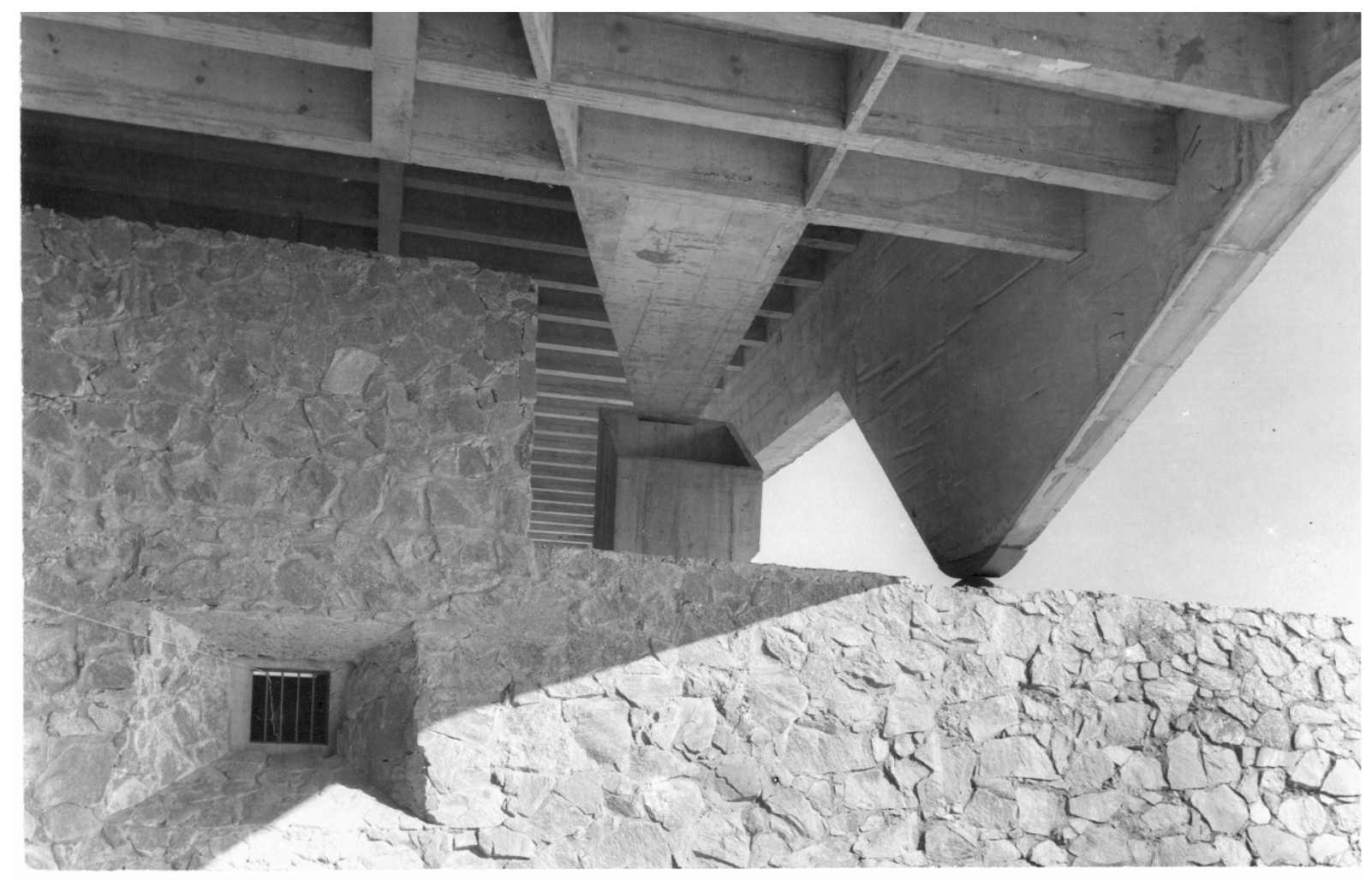

João B. Vilanova Artigas. Garagem de barcos do Clube Santa Paula, São Paulo, 1961. Arquivo: Vilanova Artigas

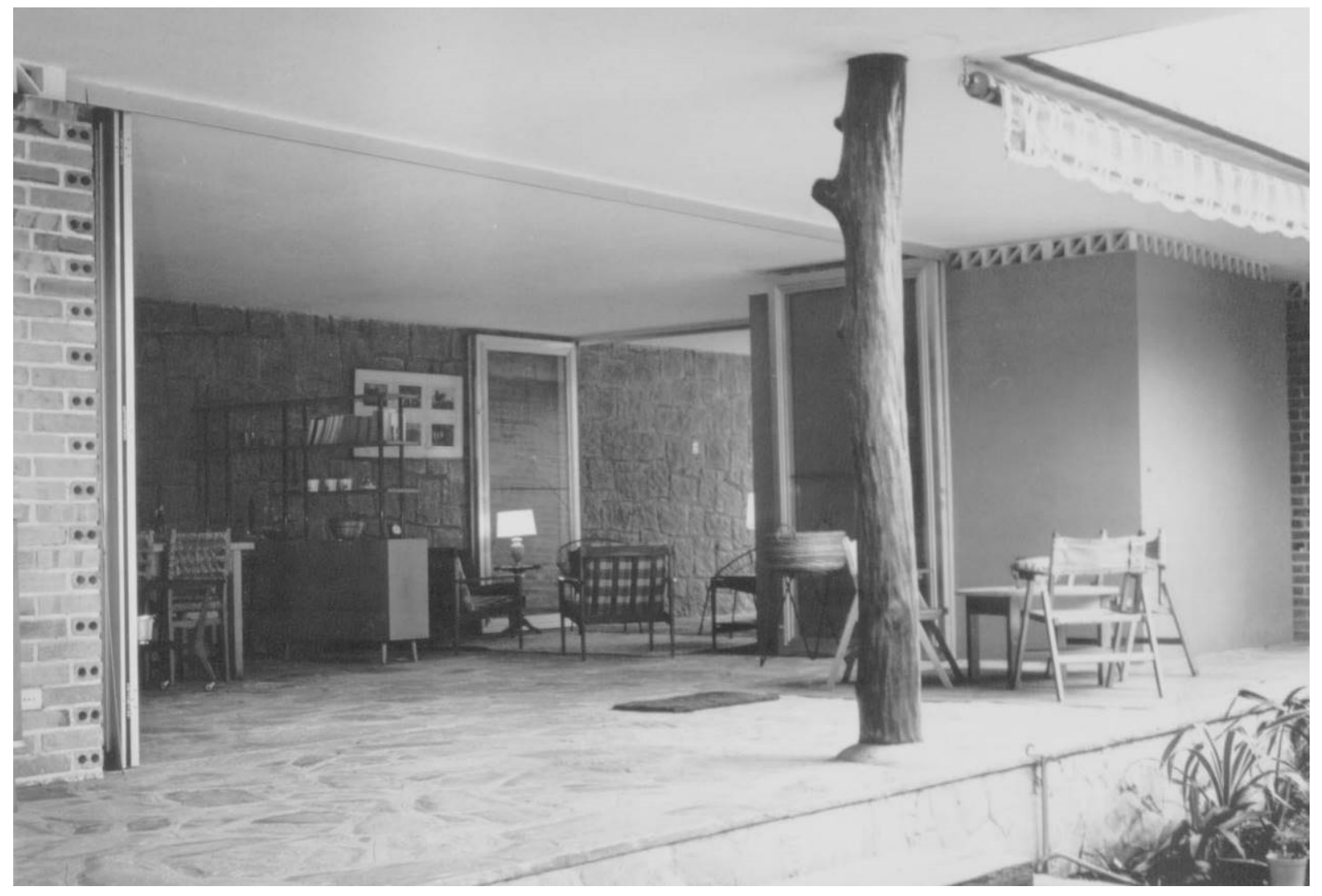

João B. Vilanova Artigas. Casa de praia de Giocondo Vilanova Artigas, Caiobá, PR, 1961. Arquivo: Vilanova Artigas 


\section{A FACULDADE DE ARQUITETURA E URBANISMO}

\section{SOBRE SUAS ORIGENS}

A Escola Politécnica de São Paulo, da qual derivou a Faculdade de Arquitetura e Urbanismo, foi fundada em 1893 e seu curso para formação de engenheiros-arquitetos, o primeiro de São Paulo, foi aberto no ano seguinte, de modo que o ensino de arquitetura nunca foi estranho à Poli, uma escola que, de modo geral, sempre esteve fortemente ligada à construção civil.

Os arquitetos que lá se formavam recebiam o título de "engenheiro-arquiteto". Mas a ênfase dada a esse termo pode causar confusão sugerindo uma formação muito específica ou atribuições profissionais exclusivas. Nada disso é tão claro. Afinal, após a regulamentação profissional de 1933, até mesmo os arquitetos formados na Escola Nacional de Belas Artes do Rio de Janeiro recebiam o título de "engenheiro-arquiteto". A instituição de um padrão federal em 1945 aproximou as matrizes curriculares oriundas da École Polytechnique e da École des Beaux-Arts, que já mostravam convergências, principalmente no ensino artístico. Desse modo, os chamados "vícios de origem" das escolas de arquitetura devem ser relativizados. Ou seja, a origem politécnica não basta para explicar a particularidade da FAU, ainda que seja um componente importante da equação. Um caminho mais produtivo 
pode se revelar através da convergência de trajetórias pessoais, dinâmicas políticas e estatutárias e, principalmente, da relação com os mercados locais. ${ }^{1}$

No início do século XX, com uma presença muito menor do Estado em São Paulo do que na capital federal, o Rio de Janeiro, os arquitetos da Poli estiveram, grosso modo, a serviço de particulares, especialmente de uma clientela burguesa que investiu em construção, tanto para uso próprio quanto para renda. Nesse mercado, liderado pelo gigantesco escritório de Ramos de Azevedo, surgiram pequenas firmas construtoras, que ao lado empresas estrangeiras e alguns órgãos públicos, encerravam as principais possibilidades de emprego para arquitetos. Nas pequenas firmas construtoras, que antecederam os escritórios de arquitetura, os engenheiros-arquitetos concorriam com toda sorte de artesãos, empreiteiros e práticos licenciados. Nelas, o principal produto comercializado não era o projeto, mas o edifício construído. Uma solução mais simples e segura para o cliente, que contratava um, ao invés de dois serviços, e uma forma dos arquitetos custearem a desvalorizada elaboração de projetos através do lucro obtido na construção (onde a mais-valia é muito mais volumosa). Em alguns casos, a atuação das construtoras não se limitava à edificação e incluía operações com os mercados fundiário e imobiliário. O sucesso comercial dependia basicamente da relação custo/benefício da construção e da capacidade dos projetistas em equacionar a construção convencional com inovações técnicas, como verticalização, maiores vãos ou instalações sanitárias mais modernas, e com o gosto predominantemente conservador da clientela. ${ }^{2}$

Nesse cenário o ensino de arquitetura da Poli precisava, por um lado, dotar o futuro profissional de um bom conhecimento da construção que o capacitasse a estimar custos, reduzir prazos e assumir projetos tecnicamente mais complexos (que os práticos não conseguiriam), e por outro lado, reproduzir, com mais ou menos criatividade, o receituário dos estilos de acordo com o gosto da época e a ousadia do cliente.

Em São Paulo, outros cursos de arquitetura surgiram após o da Escola Politécnica, como os cursos da Escola de Engenharia Mackenzie, criado em 1917 a partir do modelo norteamericano, onde estudou seu fundador, Christiano Stockler das Neves ${ }^{3}$; e o breve curso de

\footnotetext{
${ }^{1}$ Os hábitos, práticas e o mercado da arquitetura em São Paulo na primeira metade do século XX foram bem estudados por Sylvia Ficher, Carlos Lemos, Maria Lúcia Gitahy, entre outros. No entanto, existem menos trabalhos equivalentes sobre o pósguerra, quando a arquitetura afirmou sua independência profissional. Um exemplo pode ser visto em: SILVA, Joana Mello de Carvalho e. $O$ arquiteto e a produção da cidade: a experiência de Jacques Pilon em perspectiva (1930-1960). Tese de doutorado. Orientadora: Ana Lucia Duarte Lanna. São Paulo: FAUUSP, 2010.

2 Ver: SCHENKMAN, Raquel. "O edifício da Light: a construção moderna de uma arquitetura tradicional". In: LOPES, João Marcos; LIRA, José T. C. (orgs). Memória, Trabalho e Arquitetura. São Paulo: Edusp, 2013.

3 Stockler das Neves defendia a arquitetura como orientadora e superior à engenharia, e não como um ramo de desdobramento a partir dela. Para ele o arquiteto tinha função como artista antes da função como construtor. Por isso o modelo da escola de arquitetura deveria seguir muito mais as belas artes dos que os institutos de engenharia. FICHER. Sylvia. Os arquitetos da Poli: Ensino e profissão em São Paulo. São Paulo: Edusp, 2005, p. 243.
} 
arquitetura da Academia de Belas Artes de São Paulo4, inaugurado em 1928 por Alexandre Albuquerque (1880-1940), ex-aluno e professor da Escola Politécnica. Cada escola formou, a partir de atuações individuais e coletivas, diferentes posturas profissionais, definindo os rumos da profissão do arquiteto.

Desde seu surgimento até sua incorporação à Universidade de São Paulo, em 1934, a Escola Politécnica já havia trilhado um longo caminho e se consolidado como referência na área tecnológica. Orientada pela matriz alemã, onde estudaram os principais professores da escola $^{5}$, a Poli tornou-se referência nacional no estudo dos materiais, e muito particularmente do concreto armado, cujas pesquisas vinham de encontro com o desejo de superação da defasagem tecnológica em relação à Europa e aos EUA. ${ }^{6}$ Paralelamente aos estudos científicos, os arquitetos da Poli produziram em São Paulo, um ecletismo mais sóbrio e simplificado do que seu equivalente carioca, como ilustra a produção do escritório de Ramos de Azevedo. ${ }^{7}$

Um caso emblemático é o de Hippolyto Gustavo Pujol Jr., recém-diplomado engenheiroarquiteto e engenheiro civil pela Politécnica em 1905, ele publicou o Manual de Resistência dos Materiais, divulgando os resultados das pesquisas realizadas no Gabinete de Resistência dos Materiais. Em 1908, dedicou um artigo para elogiar o caráter pioneiro da estação de Mairinque, projetada por Victor Dubugras, cuja composição arquitetônica teria o mérito de "convencer da possibilidade de fazer bela uma obra de cimento armado os descrentes da estética do novo sistema de construção, os que acreditam que o único meio de tornar atraente uma obra executada com esse material é esconder a natural rigidez geométrica das formas que decorrem da construção mesma". ${ }^{8}$

Porém, ao longo de sua carreira, Pujol Jr. expôs a contradição desse princípio teórico com a prática que Ihe impedia de obter resultados tão radicais quanto os de Dubugras. Em 1912, por exemplo, construiu o edifício Guinle, um dos primeiros arranha-céus com estrutura de

\footnotetext{
${ }^{4}$ A Academia de Belas Artes de São Paulo, criada em 1925 por Pedro Augusto Gomes Cardim, estabeleceu uma identidade a partir da crítica ao domínio da engenharia sobre arte. Em 1931 a nova escola sofreu a suspensão de subvenções estaduais e municipais em consequência de "disposições do Ministério da Educação sobre os institutos livres e da posição adotada pela Secretaria de Educação do Estado de São Paulo e por seu Conselho de Orientação Artística na questão dos gastos públicos com o ensino artístico de nível superior" (FICHER, Sylvia. Op. Cit., p. 176). O curso foi extinto em 1932, formando ainda três turmas remanescentes. A criação da USP, em 1934, incluía uma Escola de Belas Artes, provavelmente fruto da articulação de docentes da ABA que também lecionavam na Escola Politécnica. Esta, porém, nunca saiu do papel.

${ }^{5}$ YURGEL, Marlene. Vila Penteado: Primeira geração de arquitetos formados pela FAUUSP. Coleção Boletim Técnico 1996, n. 6. São Paulo: FAUUSP, 1993, p. 9.

${ }^{6}$ Quase simultaneamente à importação das patentes de concreto armado de Hennebique na década de 1890, se iniciaram pesquisas tecnológicas visando o desenvolvimento de processos nacionais, uma vez que não existia ainda metalurgia no país. Em 1899, quando a nova revista Le Béton Armé ampliou a divulgação do sistema Hennebique, a Escola Politécnica de São Paulo fundou seu Gabinete de Resistência dos Materiais visando ensaios laboratoriais com o concreto armado. Ver: VARGAS, Milton. História da Técnica e da Tecnologia no Brasil. São Paulo: Editora UNESP, 1994.
}

${ }^{7}$ LEMOS, Carlos Alberto. Ramos de Azevedo e seu escritório. São Paulo: Pini, 1993.

8 PUJOL Jr, Hippolyto Gustavo. "Uma Estação Modelo". Revista Politécnica, n. 22. São Paulo, nov. 1908, p. 187, apud FICHER, Sylvia. Op. Cit., p. 122. 
concreto construído em São Paulo, mas cuja ousadia não implicou na eliminação de ornamentos tal qual a estação de Mairinque. Mas assim eram as obras da maioria dos arquitetos da época, que muitas vezes escondiam importantes inovações tecnológicas atrás da aparência tradicional das artes decorativas visível nas fachadas. De todo modo, a precoce atividade teórica que apontava tais contradições não deixa de ser uma característica marcante da Politécnica.

O concreto armado combinado com técnicas de alvenaria, já estava popularizado na década de $1920^{\circ}$ e a possibilidade de adensamento urbano a baixo custo dessa técnica pode ter sido importante para a consolidação das construtoras de engenheiro-arquitetos frente a seus concorrentes, os práticos. Enquanto edifícios e investimentos públicos da Primeira República, tais como vias, pontes, parques, teatros, monumentos, sedes administrativas, estações ferroviárias, portos e sedes de empresas públicas e privadas, entre as quais muitas estrangeiras, significaram oportunidade para altas disputas estéticas na capital Rio de Janeiro, o rápido crescimento de São Paulo - que se tornaria a maior cidade em população do país no final da década de 1950 -, aqueceu principalmente o mercado imobiliário para habitação e renda. ${ }^{10}$

No complexo industrial da construção que se formava, o concreto armado contribuiu para uma nova divisão técnica e social do trabalho ${ }^{11}$ baseada na prescrição do projeto, através da introdução de desenhos cada vez mais detalhados como mediação entre trabalho e trabalhadores. Ao codificar as partes da construção em ordens de serviço possíveis de serem executadas por trabalhadores menos qualificados, essa mediação criou nos canteiros

\footnotetext{
${ }^{9}$ LEMOS, Carlos Alberto. Trilogia do Copan: a história do edifício Copan, v.1. São Paulo: Imprensa Oficial do Estado de São Paulo, 2014, p. 14.

10 Durante a primeira República (1889-1930), grandes empresas e consórcios estrangeiros entraram no mercado brasileiro impactando a indústria da construção e a gestão das cidades. A elas era destinado o papel de modernizar as cidades e as construções, importando seu know-how em troca negócios amplamente favoráveis. Nesse período de grande liberdade para 0 capital estrangeiro, se implantaram no Brasil empresas como a Cia. Light (1899), que criou a primeira fábrica de cimento no Brasil, a Cia. Brasileira de Cimento Portland Perus S.A. de 1924, para contornar os altos custos da importação do cimento para as grandes obras de usinas hidrelétricas; a Cia. City (1912); a Cia. Construtora em Cimento Armado (1913), Do empresário alemão e aluno de Hennebique, L. Riedlinger; a construtora dinamarquesa Christiani \& Nielsen (1922); e a alemã Wayss \& Freytag (1924), instalada como Companhia Construtora Nacional. (Ver: FREITAS, Maria Luiza. Modernidade concreta: as grandes construtoras e o concreto armado no Brasil, 1920 a 1940. Tese de doutorado. São Paulo: FAUUSP, 2011). A Cia. Construtora de Santos, fundada pelo engenheiro brasileiro Roberto Simonsen em 1912, aparece como exceção nesse panorama. Os novos processos e técnicas de construção da Cia., com organização racionalizada do canteiro de obras, pautariam a atuação política de seu proprietário na criação dos primeiros organismos brasileiros de racionalização do trabalho em 1932. (Ver: KOURY, Ana Paula. "Remontando o paradoxo histórico e montando a unidade nacional: os quartéis construídos pela Companhia Construtora de Santos". In: Anais do II ENANPARQ. Natal: 2012.)

${ }^{11}$ Essas mudanças estavam imbricadas no surgimento dos primeiros edifícios verticais em concreto armado construídos em São Paulo e no Rio de Janeiro (ver RABELO, Clévio. Arquitetos na cidade: espaços profissionais em expansão. Tese de Doutorado. São Paulo: FAUUSP, 2011). Em toda a América Latina surgia uma nova geração de grandes edifícios, como o gigantesco Edifício Kavanagh em Buenos Aires, com seus $90.000 \mathrm{~m}^{2}$ construídos em concreto armado entre 1933 e 1936. Liernur atribui a profusão dessas obras à recomendação de substituição dos investimentos financeiros, prejudicados pela crise de 1929, em empreendimentos imobiliários (ver LIERNUR Jorge Francisco. Arquitectura en la Argentina del siglo XX: La construcion de la modernidade. Buenos Aires, Fondo Nacional de las Artes, 2001, p. 202). Após o auge da crise, com grande capital disponível no mercado imobiliário, foi possível estimular a organização racional de projetos e canteiros de obras, resultando no maior rendimento de investimentos. Pioneiro por adotar formas geométricas e pela sua altura de 102 metros, 0 edifício do jornal A Noite, projeto estrutural do engenheiro Emilio Baumgart inaugurado no Rio de Janeiro em 1930, consolidou o domínio brasileiro das estruturas em concreto armado.
} 
de obra condições de trabalho análogas ao trabalho industrial (subsunção real, nos termos de Marx).

\begin{abstract}
"Foi possível, com o concreto, destacar o trabalho qualificado e mental da construção, do elemento puramente manual. As oportunidades oferecidas pelo concreto para tal divisão do trabalho são o que realmente o distingue e o faz único entre todos os outros processos de construção em termos de trabalho. Nenhum outro meio de construção permitiu uma separação tão satisfatória dos elementos mentais e manuais do trabalho". ${ }^{12}$
\end{abstract}

Enquanto ofícios tradicionais ${ }^{13}$ como a serralheria artística e a carpintaria davam lugar a novos (e rebaixados) ofícios, como a carpintaria de fôrmas, um exército de serventes se formava para tarefas braçais como o transporte de materiais, a preparação de armaduras e de massa. Nesta função, destacou-se o papel de migrantes do Nordeste para o Sudeste, atraídos pelas oportunidades da indústria na década de 1930.

Paralelamente aos avanços técnicos, a renovação formal da arquitetura deu seus primeiros passos através da atuação de arquitetos estrangeiros (ou de formação estrangeira). É marcante que dois deles, o ucraniano Gregory Warchavchik e o brasileiro Rino Levi, ambos formados em Roma respectivamente em 1921 e 1926, tenham iniciado suas carreiras na Cia. Construtora de Santos. A introdução do modernismo no ensino de arquitetura no Brasil foi lenta e marginal, sendo o caso mais excepcional o curto período de Lúcio Costa na direção da ENBA entre 1930 e 1931.

\footnotetext{
${ }^{12}$ FORTY, Adrian. Concrete and culture: a material history. London: Reaktion Books, 2012, p. 232. Tradução livre do autor.

${ }^{13}$ No último quartel do Século XIX as técnicas construtivas em alvenaria de tijolo foram introduzidas junto com novos trabalhadores imigrantes, que traziam de seus países de origem o conhecimento necessário para essa forma de construir. Paralelamente, foram criados Liceus de Artes e Ofícios em Salvador (1872), São Paulo (1873) e Recife (1880), revelando estratégias de novas elites locais para formação de mão de obra qualificada em todos os níveis, capazes de atender as demandas da arte e da indústria. Apesar de formados para atender à linguagem acadêmica, os liceus se tornaram prestadores de serviços especializados inclusive para a arquitetura moderna. É notável, por exemplo, que caixilhos de aparência industrializada como os do MASP ou de palácios de Brasília, tenham sido realizados pelo Liceu de São Paulo. Para Lina Bo Bardi, que vinha da Itália, foi difícil aceitar que "velhos artesãos" realizassem o trabalho. Preconceitos a parte, o Liceu de Artes e Ofícios de São Paulo foi financiado pela indústria e o acumulo de conhecimentos técnicos lhes permitiu não apenas produzir objetos de aparência industrial, mas também fornecer produtos, treinamento e inovação tecnológica para indústria. Ver: SCHENKMAN, Raquel. Do vital ao pano de vidro. Dissertação Mestrado. São Paulo, FAUUSP, 2014. Esses fatores contribuíram para formar um corpo de trabalhadores de ofício e oficinas de fundição, carpintaria, vitrais, mosaicos, entalhes e estuques, dotados de qualificação e formação técnica o que Ihes garantia relativa liberdade e boa remuneração em comparação aos operários fabris (GITAHY, Maria Lúcia. "Desmemória das metrópoles: apagando os rastros do trabalho de construir". Ponto, 1998). Muitos eram imigrantes italianos, espanhóis e portugueses que trouxeram consigo conhecimentos de seus ofícios e, não raro, inclinações políticas radicais. Em São Paulo, "na virada do século, três quartos dos pedreiros e a totalidade dos mestres de obra vinham da Itália" (QUEIROZ, A. V. apud ARANTES, Pedro Fiori. Arquitetura Nova: Sérgio Ferro, Flávio Império, Rodrigo Lefèvre, de Artigas aos mutirões autogeridos. São Paulo: Editora 34, 2002, p. 20). Até a Primeira Guerra, eles foram "os principais organizadores do movimento operário" (GITAHY, Maria Lúcia, Op. Cit.). A linguagem arquitetônica tanto dos edifícios oficiais quanto aquela almejada pelas classes abastadas dependia desses profissionais, que por isso gozavam de relativo conforto. Em certos tipos de obras, esses trabalhadores eram encarregados também pela concepção e condução das obras.
} 
O governo Vargas estabeleceu padrões técnicos e científicos ${ }^{14}$ e criou uma indústria de base estatal para induzir a industrialização, para fazer frente à oligarquia cafeeira retirada do poder pela Revolução de 1930. Nesse processo, a criação de uma legislação trabalhista e a regulamentação de sindicatos e profissões garantiu aos engenheiros e arquitetos a exclusividade de projetos e coordenação de obras civis.

No auge da atuação das construtoras paulistas, após a redução da presença estrangeira por conta da crise de 1929 e de medidas nacionalistas do governo Vargas, a nova realidade produtiva do complexo industrial da construção anunciava o esgotamento desse modelo de projeto e construção. Garantido o mercado aos profissionais regulamentados, estabelecido o projeto como instrumento de mediação cada vez mais detalhado nas obras, desorganizado o sistema dos ofícios tradicionais com o qual as construtoras contavam para dividir as responsabilidades sobre as partes da construção, os conflitos entre os próprios arquitetos podiam emergir. Rino Levi, dono de uma típica firma de construções, em 1936 foi o primeiro em São Paulo a abandonar a construção:

"Um dia o Rino me disse que ia abandonar a construção e só fazer projetos. Eu respondi que para isso precisava coragem, porque ele estava tendo muito sucesso e ia largar tudo. Ele disse que ia largar e, de fato, que eu me lembre, o Rino foi o primeiro arquiteto a estabelecer um escritório de arquitetura, pura e simplesmente de arquitetura". ${ }^{15}$

Já no início da década de 1940, paralelamente ao começo do reconhecimento da arquitetura moderna e suas instituições independentes, surgiam as primeiras manifestações a favor da criação de uma escola de arquitetura desvinculada tanto das Belas Artes quando da Escola Politécnica. Como membro do Conselho de Orientação Artística do Estado de São Paulo, o sobrinho do criador da Academia de Belas Artes, Carlos Alberto Gomes Cardim Filho ${ }^{16}$,

"Foi um dos primeiros profissionais a clamar por uma faculdade de arquitetura autônoma em São Paulo, tendo proposto em 1941 a 'criação de uma Escola Superior de Arquitetura, da Universidade sem ligação com a Escola Politécnica, nem com a Escola de Belas

\footnotetext{
${ }^{14}$ Alguns exemplos são a criação da Associação Brasileira de Normas Técnicas (ABNT), Associação Brasileira de Cimento Portland (ABCP), Instituto de Pesquisas Tecnológicas (IPT), e as Universidades de São Paulo (USP) e Porto Alegre (atual UFRGS).

${ }^{15}$ Depoimento de Oswaldo Bratke a Sylvia Ficher [1985] apud FICHER, Sylvia. Op. Cit., p. 244.

${ }^{16}$ Carlos Alberto Gomes Cardim Filho, arquiteto formado pela Escola Politécnica em 1925, participou da fundação da ABA/SP. Assumiu vários cargos na Prefeitura e foi um colaborador próximo do prefeito Prestes Maia (1938-1945). Na década de 1940, defendeu a estética modernista e foi um dos fundadores do IAB/SP. Viria a ser docente da FAU em 1951 (ver: FICHER, Sylvia. Op. Cit., p. 215).
} 
Artes' como solução para a 'falta de concepção artística' nas construções paulistanas". ${ }^{17}$

Durante a década de 1940, a ideia se ampliou, sendo majoritária entre os arquitetos modernistas articulados na recém-criada seção paulista do Instituto de Arquitetos do Brasil. Segundo Artigas, o I Congresso Brasileiro de Arquitetos, realizado em janeiro de 1945 em São Paulo, dedicou-se a incentivar o aperfeiçoamento do ensino da Arquitetura e a fundação de novas faculdades de arquitetura dentro das universidades, separadas das escolas de engenharia. ${ }^{18}$

De fato, a criação da FAU não deve ser vista como um caso isolado. Entre 1945 a 1959 foram fundadas a Faculdade Nacional de Arquitetura (FNA), Rio de Janeiro, 1945; a Faculdade de Arquitetura Mackenzie, em São Paulo, 1947; a Faculdade de Arquitetura do Rio Grande do Sul, em Porto Alegre, 1952; a Faculdade de Arquitetura da Bahia em Salvador, 1959; e a Faculdade de Arquitetura de Pernambuco em Recife, 1959.

O currículo da Faculdade Nacional de Arquitetura da Universidade do Brasil, criada a partir da Escola Nacional de Belas Artes, foi adotado como padrão (designado de padrão federal) para as futuras escolas e imposto, inclusive para a pioneira Escola de Arquitetura de Belo Horizonte, criada em 1930.

Desse modo, a criação da FAU fez parte de um movimento nacional de autoafirmação da arquitetura irradiado a partir do Rio de Janeiro. Em São Paulo, no entanto, a dependência acadêmica e política em relação à Escola Politécnica teve um papel especial.

O plano de criar uma nova escola a partir do curso da Escola Politécnica aparece formalizado em telegrama do Conselho de Orientação Artística, presidido por Gomes Cardim Filho, ao Interventor Federal do Estado de São Paulo, José Carlos de Macedo Soares, com cópia ao Secretário da Educação e ao Diretor da Escola Politécnica da Universidade de São Paulo, em 15 de fevereiro de 1946:

"Os abaixo-assinados, Membros do Conselho de Orientação Artística de São Paulo, vem a presença de Vossa Excelência, solicitar os bons ofícios para ser remodelado o Curso de Arquitetura da Escola Politécnica de S. Paulo nos moldes do padrão Federal, como Faculdade Superior de Arquitetura, com direção autônoma e adatavel [sic] às necessidades atuais dentro da organização Universitária. Oportunidade dessa remodelação está no fato dessa tradicional

\footnotetext{
${ }^{17}$ FICHER, Sylvia. Op. Cit., p. 220.

${ }^{18}$ ARTIGAS, João Batista Vilanova. "Contribuição para o Relatório sobre Ensino de Arquitetura UIA-UNESCO" [1974]. In: ASSOCIAÇÃO BRASILEIRA DE ESCOLAS DE ARQUITETURA. Sobre a história do ensino de arquitetura no Brasil. $1^{\text {a }}$ edição. São Paulo, ABEA, 1978, p. 33.
} 
Escola ter diplomado em 1945 somente um engenheiro-arquiteto ${ }^{19}$. Respeitosamente, Carlos Gomes Cardim Filho, José Marques Campão, Mozart Tavares de Lima, Armando Belardi, José Maria da Silva Neves e Theodoro Braga". ${ }^{20}$

O Conselho de Orientação Artística, criado em 1931 como órgão consultor da Secretaria do Estado da Educação e da Saúde Pública para os assuntos relativos ao ensino e proteção das Belas Artes ${ }^{21}$, atuou a favor da criação da FAU. Importante ressaltar que essa articulação entre arquitetos tinha como intenção dar autonomia para o curso de arquitetura da Escola Politécnica e não criar uma escola do zero. Essa articulação partia do próprio corpo docente do curso de arquitetura da Escola Politécnica, formado pelos professores catedráticos Luiz Ignácio de Anhaia Mello, Bruno Simões Magro, José Maria da Silva Neves, pelo professor Felisberto Ranzini, e pelos assistentes Zenon Lotufo, João Batista Vilanova, Ariosto Mila e Caetano Fraccaroli. O porta-voz desse plano foi Luiz Ignácio de Anhaia Mello, que além de ser o professor mais antigo do curso, tinha legitimidade institucional por sua relevante experiência na vida pública.

Luiz Ignácio Romeiro de Anhaia Mello (1891-1974), já havia sido vereador de São Paulo nos anos 1920, diretor da Escola Politécnica em 1930, interventor federal do município de São Paulo entre 1930 e 1931, diretor da Faculdade de Filosofia Ciências e Letras da USP em 1940 e Secretário de Viação e Obras Públicas do Estado no governo de Fernando Costa (1941-1944). Sua atividade política, seu acesso ao governo do Estado, sua titulação e sua admiração pelo corpo docente da universidade o gabaritavam para essa empreitada. Professor ativo e respeitado, Anhaia havia formado e acolhido a maior parte dos arquitetos modernos da Poli, como os seus assistentes Zenon Lotufo e Vilanova Artigas. Enquanto a arquitetura moderna era ostensivamente rejeitada por Christiano das Neves, no Mackenzie, e pela maioria dos engenheiros da Escola Politécnica, Anhaia seguia uma posição ponderada:

"Embora Anhaia Mello não fizesse esta arquitetura moderna, a forma como a apresentava na época era extremamente avançada, com grande isenção, lucidez e preparação... Ele conhecia aqueles movimentos renovadores da arquitetura, [...] não havia aquele veto violento como no Mackenzie. Evidentemente, havia a obrigação de conhecer todos os estilos, mas quando tínhamos que projetar algo, não era obrigatório fazer um projeto de estilo. Tínhamos liberdade,

\footnotetext{
${ }^{19}$ Os números seriam piores se considerado um período maior. Entre 1943 e 1945 foi diplomado um arquiteto a cada ano. Em 1946, não houve diplomados.

${ }^{20}$ Diário Oficial do dia 15 de fevereiro de 1946, p. 23.

${ }^{21}$ Ver Decreto n. 5.361 de 28 de janeiro de 1932, que reorganiza o Conselho de Orientação Artística e dá outras providências. 
inclusive porque o Anhaia tinha assistentes, como por exemplo o Artigas e o Lotufo, homens de sua confiança... Discutia-se Le Corbusier, Frank Lloyd Wright e os outros modernos com toda a liberdade".22

A liderança de Anhaia Mello nesse processo era respaldada pelo conjunto de arquitetos modernos de São Paulo. Mas isso não o impediu de deixar sua contribuição pessoal. Teria sido dele, por exemplo, a ideia de nomear a nova escola de Faculdade de Arquitetura e Urbanismo $^{23}$, numa visão integrada da arquitetura com a sua disciplina, o urbanismo. Aliás, a nova escola deveria oferecer além do curso de arquitetura, um curso independente de urbanismo, que mais tarde seria transformado na ideia de um curso de pós-graduação e finalmente integrado à FAU como um núcleo de pesquisa, o Centro de Estudos e Pesquisas Urbanísticas (CPEU).

Em 1946, o assistente de Anhaia Mello, Vilanova Artigas, foi contemplado com uma bolsa da John Simon Guggenheim Memorial Foundation ${ }^{24}$ para uma viagem aos EUA que ocorreu entre setembro de 1946 a novembro de 1947. Anhaia apoiou o afastamento do professor sem prejuízo dos vencimentos, ressaltando "a imensa vantagem para nossa escola, nesta emergência de reorganização do Curso de Arquitetura e Urbanismo, aproveitar a ida do arquiteto Artigas aos Estados Unidos" para estudar os cursos de arquitetura de lá, uma vez que "estão hoje ensinando nas escolas de arquitetura norte-americanas os expoentes mundiais da arquitetura: Gropius, Saarinen, Mendelsohn, Behrendt, Frank Lloyd Wright”. ${ }^{25}$

Pouco tempo após sua chegada, Artigas escreveu para Oswaldo Corrêa Gonçalves:

"Cedo descobri que nem sempre, ou quase nunca, os nomes da proa representam conteúdo. E assim, me mandaram para Boston, para que eu visse de perto e 'estudasse' nas duas grandiosíssimas organizações universitárias dos EUA, Harvard e o MIT. [...]. Um mês depois larguei tudo porque eu tinha certeza que a turma não estava completamente certa e alguma coisa de novo deveria existir aqui. As grandes universidades têm colunas por fora e por dentro também. São templos por dentro e por fora. E eu, há anos já, venho mostrando banana para monumentos. [...].

\footnotetext{
22 Depoimento de Roberto Cerqueira Cesar a Sylvia Ficher [1985], apud FICHER, Sylvia. Op. Cit., p. 151.

${ }^{23}$ Depoimento de Oswaldo Corrêa Gonçalves a Sylvia Ficher [1986], apud FICHER, Sylvia. Op. Cit., p. 151.

${ }^{24}$ Tratava-se de uma Fellowship existente desde 1925, destinada a jovens pesquisadores com uma carreira já estabelecida. Outros célebres beneficiados foram Lewis Munford, 1932; Eric Mendelsohn, 1943; e Henry-Russell Hitchcock, 1945. Havia duas modalidades de bolsa, uma para Canadá e EUA e outra para América Latina. Artigas se candidatou e foi contemplado para um projeto nos EUA. A verba podia ser usada livremente. Artigas usou-a para um percorrer todo o país, conhecendo instituições e fazendo contatos.

${ }^{25}$ Correspondência de Anhaia Mello a Paulo de Menezes Mendes da Rocha, diretor da Escola Politécnica, de 22 de agosto de 1946, apud FICHER, Sylvia. Op. Cit., p. 297.
} 
Daqui a alguns dias vou viajar para o sul, para ver umas escolas progressistas que existem por lá, e vou depois a Los Angeles e São Francisco. [...]. Por agora vi as universidades de Boston e de Columbia, aqui em N. York. Mas vi também um grande número de escolas livres, e algumas de grande importância. [...].

Não preste a mínima atenção no programa estabelecido pelo pessoal do Rio. É simplesmente ridículo e superficial. Tremendamente. Quanto mais longe daquilo, nós ficarmos, melhor.

E muito importante. Quando eu estava no Brasil, o Neves me contou que eles estavam procurando levar para a escola de arquitetura os velhos professores que saíram da Politécnica por ocasião da lei de desacumulação. Você sabe: - o Machadão, o Belezinha (Lisandro), etc. Isso não tem importância, eles poderiam até servir. Mas o Neves me disse que eles achavam que, para a escola de arquitetura, qualquer professor serviria - para as cadeiras tipicamente técnicas porque arquiteto não precisa conhecer muito isso. É errado. Exatamente o contrário deve ser o nosso ponto de vista. Para a nova Faculdade, o melhor. Insisto nisso, Oswaldo, porque do tipo de ensino dessas cadeiras básicas, vai depender todo o curso. Mantenha silêncio sobre isso e veja se o nosso pessoal apoia. Mas não critique o pessoal da escola por isso, senão eu vou passar mal depois. Mas o nosso slogan deve ser: para a Escola, o melhor.

[...]. Nós poderíamos copiar a organização da Harvard ou MIT (foram as informações que eu mandei para o Anhaia). Mas eu tenho visto que mesmo elas são bastante criticadas aqui. E além do mais é preciso considerar as condições brasileiras. Uma escola de arquitetura deve estar intimamente ligada com a indústria e o povo e tudo o mais, do país a que serve. [...]. De antemão posso dizer-lhe que o nosso atraso não tem medida com as unidades do tempo que eu conheço. Às vezes, tenho vergonha de responder perguntas por aqui. Mas tenho dito a verdade, muito embora o sangue pretenda escapar pelos cabelos.

Não tenhamos ilusões sobre o apoio que os reacionários brasileiros nos poderão prestar. Eles vão reagir, eu sei. E não será em três meses que a escola começará a funcionar direito. A culpa também não cai sobre os responsáveis imediatos da Escola. O principal responsável pela precariedade do ensino universitário entre nós é o espírito que o criou. As nossas escolas superiores não têm vitalidade, elas não se transformam nunca; não são autônomas, dependem da politicagem e muito. $\mathrm{E}$ depois a coisa bárbara de os professores serem catedráticos e vitalícios. Eles envelhecem e morrem na cátedra; suam velhice nas barbas da gente. Já aqui, uma organização universitária pode mudar a rota da noite para o dia. É só despedir meia dúzia de professores e contratar novos que no mês 
seguinte a escola exibe os mais tentadores programas. E isso não é conversa fiada não. Eu venho de presenciar isso no MIT. Os nomes publicados no catálogo do ano passado já não representam nada hoje. E eram uns nomes pesados, pesadíssimos. Quando eu vi o catálogo em N. York, por ocasião da chegada, estremeci. Mas lá, a revolução estava se processando. A sala de desenho a mão livre e aquarela a cargo de um 'Ranzini' americano qualquer, estava sendo arrasada. E o termo é esse mesmo: arrasada. Eles acabaram de contratar um rapaz de Chicago, que por sinal é o melhor, e quase o único bom elemento no MIT. E não se perde tempo, nem precisa de aquarela. A sala se transformou num laboratório fotográfico (não é bem isso, mas é o melhor termo que eu encontro em português para definir o laboratório) onde se começa agora a estudar cor, 'visual design', composição com elementos abstratos e uma porção de outras coisas. É quase um laboratório de pesquisa sobre cor, forma e espaço.

Um outro ponto em que eu queria tocar, com referência a escolas, é sobre a importância que elas podem ter na vida profissional. [...]. Por intermédio de conferências para os alunos, feitas por arquitetos de fora, eles ficam ao par, até dos defeitos das suas próprias escolas. E as conferências são objetivas e têm a intenção de ajudar. [...]. Aqui o cidadão sobe no estrado e diz o que sabe, brutalmente às vezes, tal é a sinceridade de alguns; e todo mundo se interessa, e as opiniões são diversas, e o país progride. Mas escapei um pouco. Eu queria dizer que, no fundo, as Escolas não são os lugares onde o cidadão tira um diploma; mas são um laboratório de pesquisa sobre o assunto. Sendo assim elas despertam o interesse não só dos alunos, mas também dos profissionais. E o interesse é mútuo. [...]. Por exemplo: o MIT tem uma série de arquitetos que estão estudando pré-fabricação. Eles não ensinam, não são professores: estão numa espécie de laboratório estudando e organizando a experiência que os outros precisam. Quando alguém precisa uma informação, vai à escola para ver se encontra lá. E quando eles podem, publicam o que descobriram também. Que contraste com a nossa universidade, não?" 26

A bolsa obtida por Artigas não exigia um relatório final e toda tentativa de balanço do que ele viu durante a viagem deve ter se limitado às correspondências pessoais, como a transcrita acima. A partir desses escassos documentos, costuma-se afirmar que Artigas se decepcionou com o que encontrou nos EUA, e que não houve consequências diretas para o ensino da FAU. Mas talvez essa questão mereça ser mais bem examinada.

${ }^{26}$ Carta de Vilanova Artigas a Oswaldo Correa Gonçalves, Nova York, 27 de dezembro de 1946. Acervo pessoal Vilanova Artigas. Disponível em <www.dearquiteturas.com>, acesso em 28/04/2015. 
A sequência da viagem de Artigas após esta carta incluiu, ainda, pelo menos três visitas que nos parecem importantes. A primeira foi ao Black Mountain College, famoso por sua proposta experimental e multidisciplinar, que Artigas se refere em outra correspondência como "muito bom e progressista". ${ }^{27}$ Em seguida Artigas visitou o Florida Southern College, que desde aquela época reunia o maior conjunto de obras de Frank Lloyd Wright num mesmo lugar. Por fim, depois de ter atravessado o país, Artigas passou alguns dias na companhia de Wright em sua escola-casa-ateliê, a Taliesin West, no deserto do Arizona. $O$ avançado modelo universitário do Massachussets Institute of Technology e seu laboratório de comunicação visual; o experimentalismo e o vanguardismo do Black Mountain College; o expressionismo estrutural visto na Flórida; e a dinâmica e a espacialidade da Taliesin West (iluminação zenital, integração espacial, informalidade no ensino e papel do professor) são apenas alguns dos elementos que Artigas pode ter tentado trazer para a FAU.

Enquanto Artigas fazia sua viagem pelos EUA, os planos de criação da FAU estavam em andamento. Mas restava conquistar apoio do Governo do Estado, da Assembleia Legislativa, do Reitor da Universidade, do Conselho Universitário e da direção da Escola Politécnica. Não bastasse tudo isso, era preciso uma sede própria já que, por motivos simbólicos, permanecer no conjunto da Escola Politécnica no bairro da Luz estava fora de questão. Os planos para a Cidade Universitária estavam muito atrasados e a Universidade não dispunha de verba para construção ou aquisição de imóveis. Até esse momento, todos os investimentos, fossem no centro ou na Cidade Universitária, dependiam de financiamento direto à unidade. A Fundação Rockfeller, por exemplo, havia financiado obras da Faculdade de Medicina de São Paulo, do departamento de Física da Faculdade de Filosofia, Ciências e Letras e da Faculdade de Medicina de Ribeirão Preto. ${ }^{28}$

A Vila Penteado, que viria a ser sede da FAU entre 1949 e 1968, foi construída em 1902, pelo arquiteto sueco Carlos Ekman, sob a encomenda do conde Antônio Álvares Penteado para residência de sua família. Situado no bairro de Higienópolis, então o mais novo e elegante, o luxuoso palacete em estilo Art Nouveau, ocupava toda a quadra com frente para a Avenida Higienópolis e fundos para a Rua Maranhão.

\footnotetext{
${ }^{27}$ Carta de Vilanova Artigas a Wagley, 13/1/1947 apud IRIGOYEN, Adriana. Wright e Artigas: duas viagens. São Paulo: Ateliê Editorial/FAPESP, 2002, p. 155. O Black Mountain College foi uma escola superior de artes na Carolina do Norte. Artigas visitou sua segunda sede, no lago Eden, inaugurada em 1941. A escola era uma cooperativa de professores e seu edifício foi construído pelos alunos e professores em um terreno isolado de 237 ha. Entre os professores estavam notáveis artistas como Josef e Anni Albers, John Cage, Robert Creeley, Merce Cunningham, Max Dehn, Joseph Fiore, Buckminister Fuller, Edward Lowinsky, Robert Motherwell, Charles Olson, M.C. Richards, e Xanti Schawinsky. A escola foi fechada em 1957, quando muito de seus professores estavam sendo perseguidos pelo macartismo. Ver: HARRIS, Mary Emma. The Arts at Black Mountain College. Cambridge: The MIT Press, 2002.

${ }^{28} \mathrm{Na}$ década de 1950 o Governo Federal custeou as obras do Instituto de Aperfeiçoamento do Professor, ligado à USP, e colônias de imigrantes portugueses, italianos, sírio-libaneses, espanhóis e alemães doaram a construção de outros edifícios na Cidade Universitária em prol do IV Centenário. Ver: CAMPOS, Ernesto de Souza. Cidade Universitária da Universidade de São Paulo: aspectos gerais do planejamento e execução. São Paulo: Comissão da Cidade Universitária da Universidade de São Paulo, 1954.
} 
A Vila foi ocupada como residência dos Álvares Penteado até 1938, ano em que faleceu dona Ana, esposa do conde. Os terrenos a seu redor foram então loteados e postos à venda pelos herdeiros da família, Antonieta, Stella, Maria Helena Prado, Jorge Prado, Silvio e Armando. ${ }^{29}$ Desde então a Vila ficou fechada. Armando e Sílvio Álvares Penteado, que receberam metade do imóvel no inventário de seu pai, adquiriram a outra metade de suas irmãs, Antonieta e Stella.

A doação do palacete à FAU foi articulada por Anhaia Mello, que tinha contato e amizade com os irmãos Silvio e Armando Álvares Penteado, de quem fora colega no colégio São Luiz, em Itu. ${ }^{30}$

${ }^{29}$ Maria Cecília Prado apud BIRKHOLZ; Lauro B.; RONCA, José Luiz C. "Anhaia Mello na Vila Penteado". In: SAMPAIO, Maria Ruth A. Sampaio; MARICATO, Ermínia (Orgs.). Vila Penteado:100 anos. São Paulo: FAUUSP, 2002, p. 87.

${ }^{30}$ BIRKHOLZ; Lauro B.; RONCA, José Luiz C. Op. Cit., p. 87-93. 


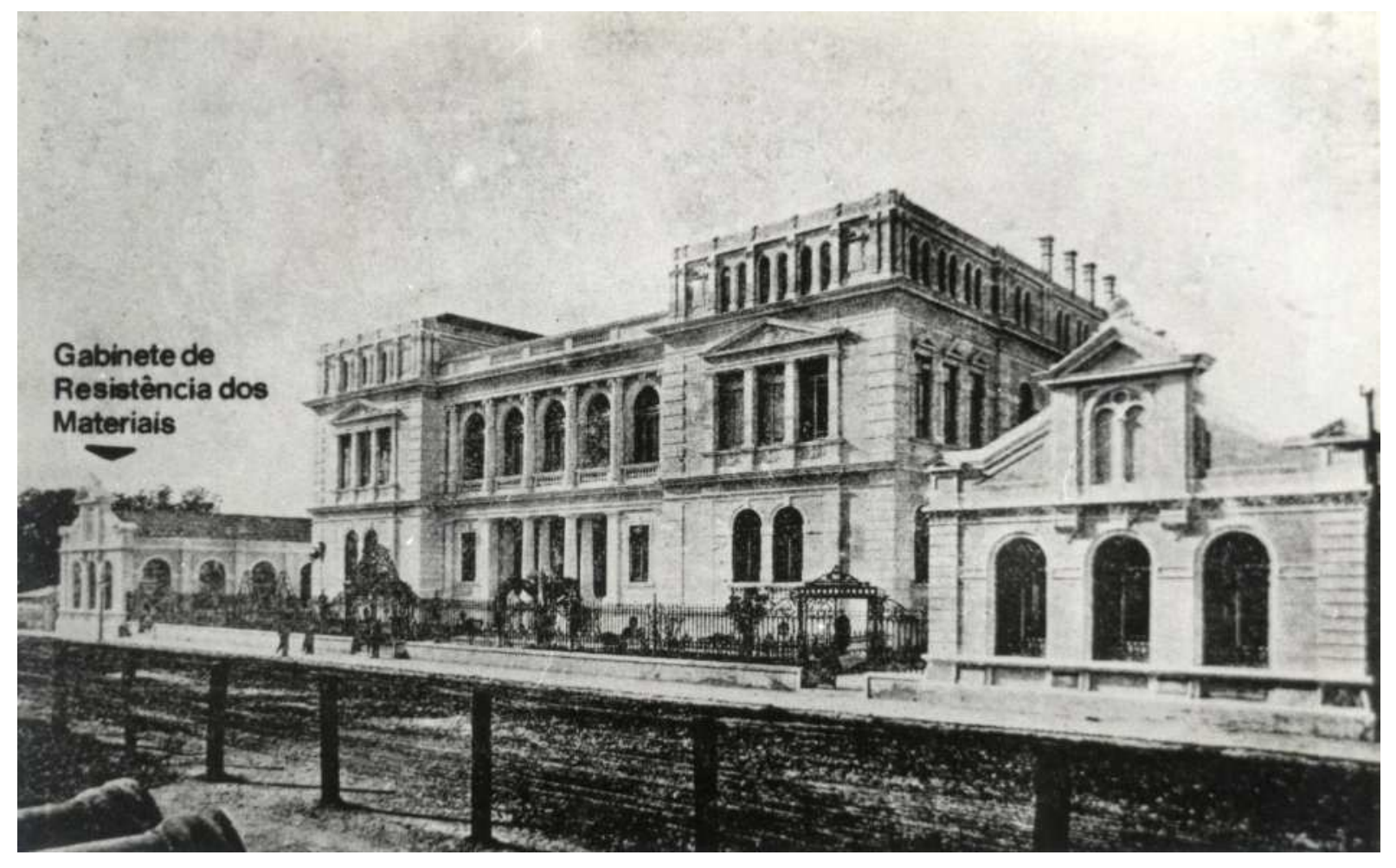

Edifício Paula Souza, no bairro da Luz, onde funcionou a Escola Politécnica até a década de 1940. Em destaque o Gabinete de Resistência dos Materiais, construído em 1899. Arquivo: Escola Politécnica.

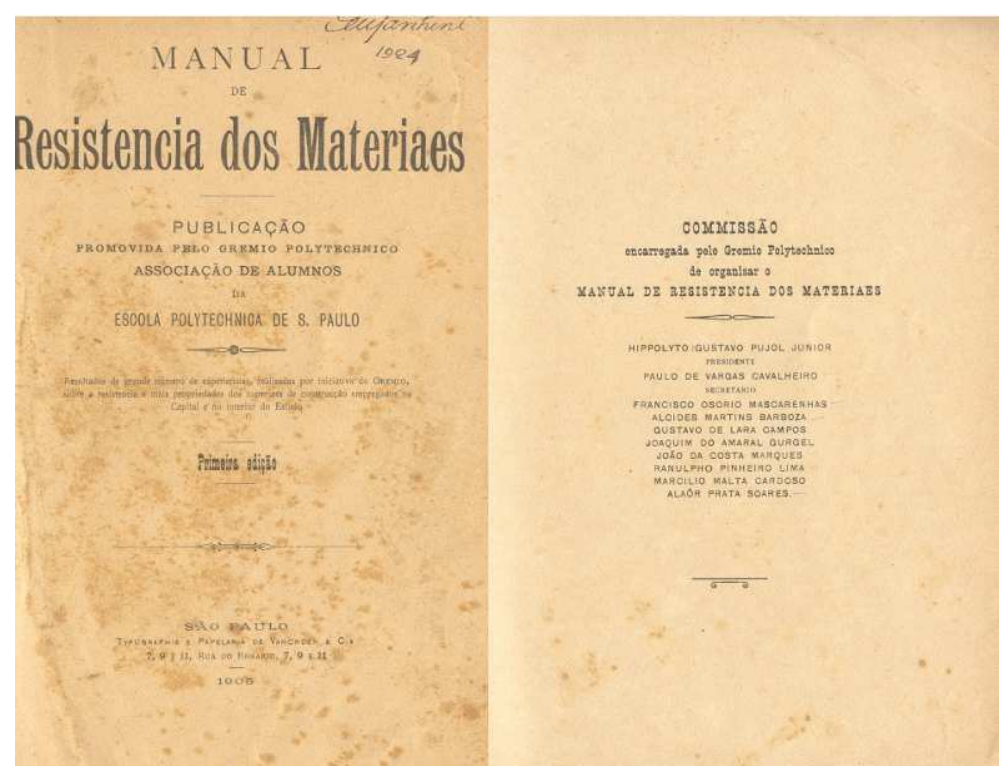

Manual de Resistência dos Materiais, 1904. Arquivo: Escola Politécnica.

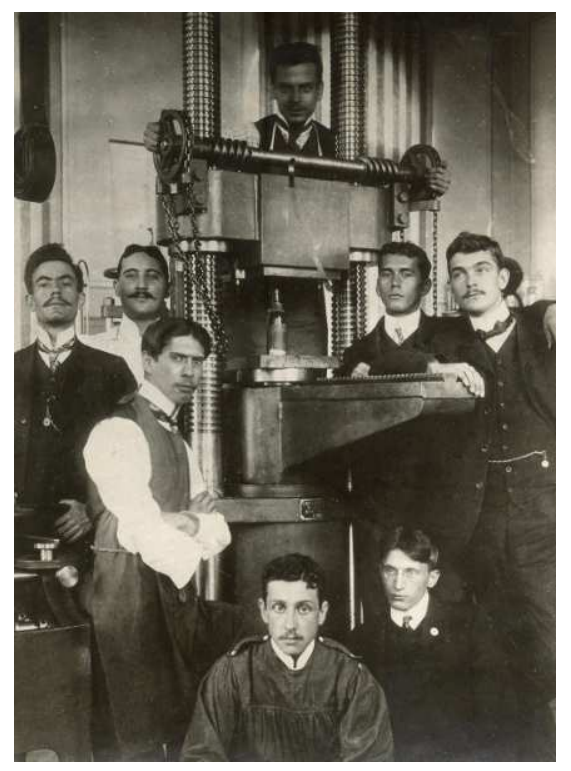

Grupo do "Manual de Resistência dos Materiais" durante ensaio do concreto.

Foto: autor desconhecido, 1904.

Arquivo: Escola Politécnica. 


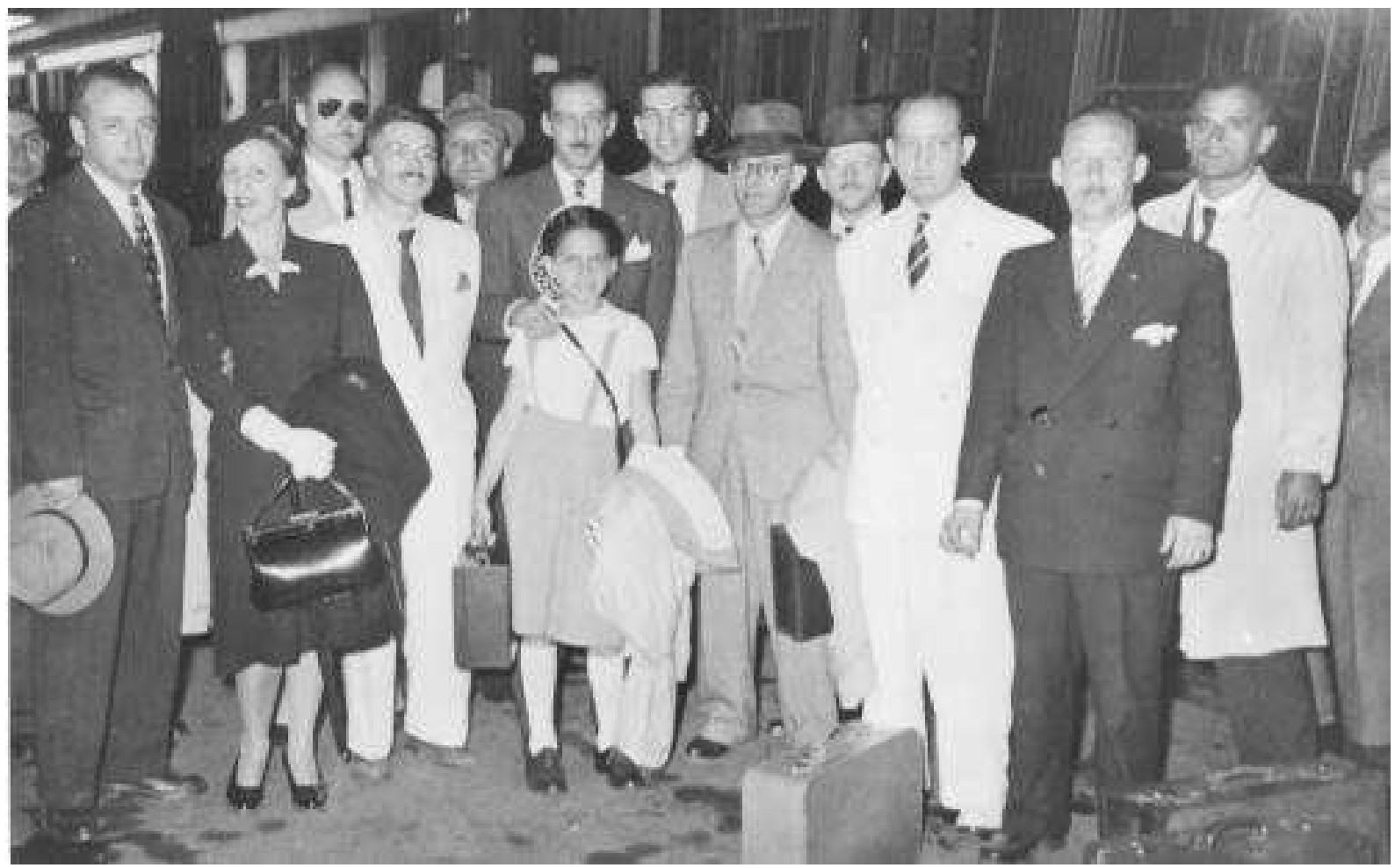

Delegação de arquitetos cariocas vindos para a instalação da seção do IAB em São Paulo, 1943. Estavam presentes os arquitetos Nestor Egydio de Figueiredo, Paulo de Camargo e Almeida, Eduardo Kneese de Mello e Vilanova Artigas, entre outros. Acervo FEBASP - Museu Belas Artes de São Paulo.

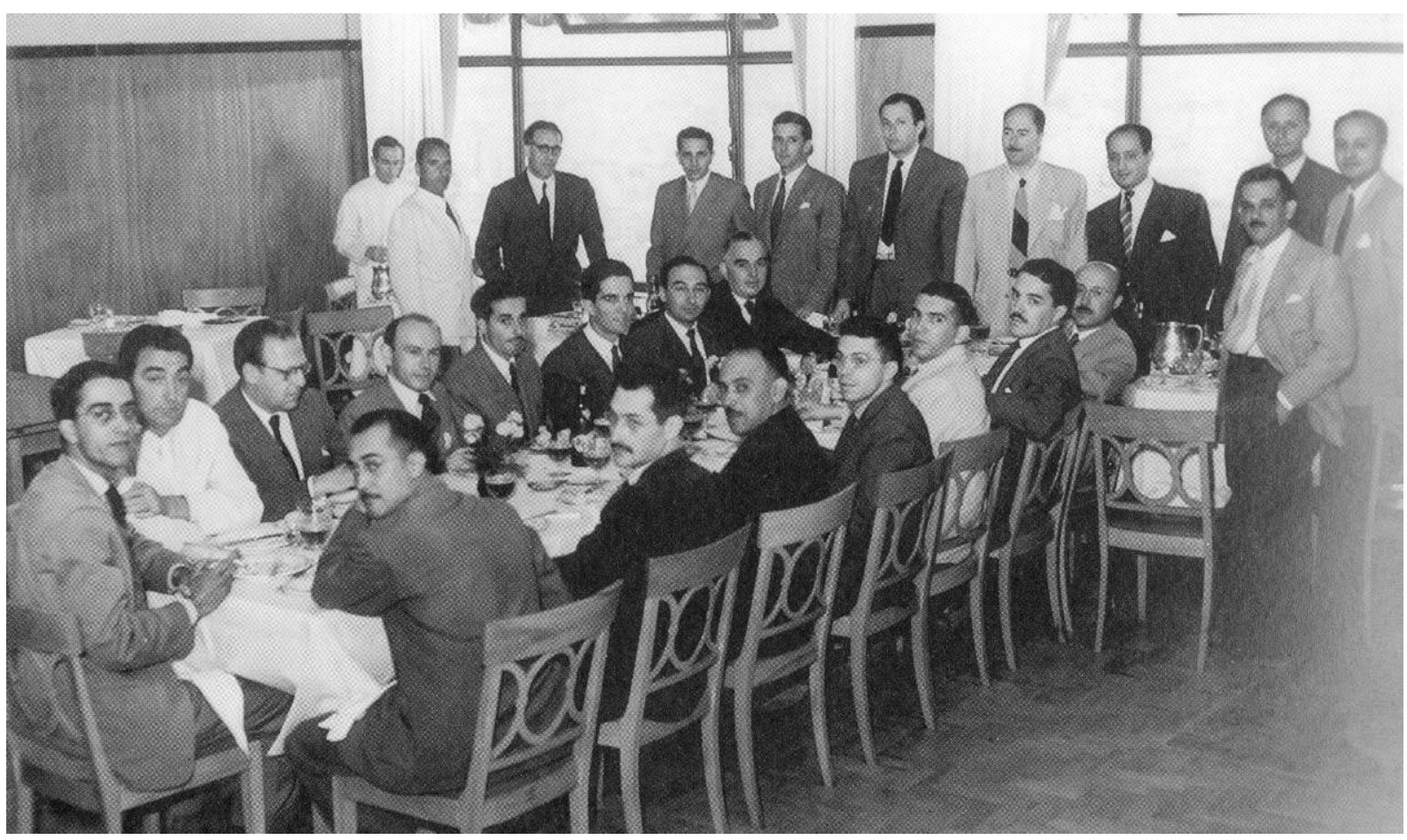

Almoço no Hotel Excelsior pela criação da FAUUSP, São Paulo, 13 de dezembro de 1947.

Com Oswaldo Corrêa Gonçalves, Flavio de Carvalho, Alfredo Ernesto Becker, João Serpa Albuquerque, Gregori Warchavchik, Aníbal Martins Clemente, Carlos da Silva Prado, Plinio Croce, João Batista Vilanova Artigas, Aldo Ferreira, Leo Ribeiro de Moraes, Daniele Calabi, Rino Levi, Alfredo Giglio, Lauro da Costa Lima, lcaro de Castro Mello, Eduardo Kneese de Mello, João Kair, Lucjan Korngold, Hélio Duarte e outros não identificados. Arquivo Oswaldo Corrêa Gonçalves. 


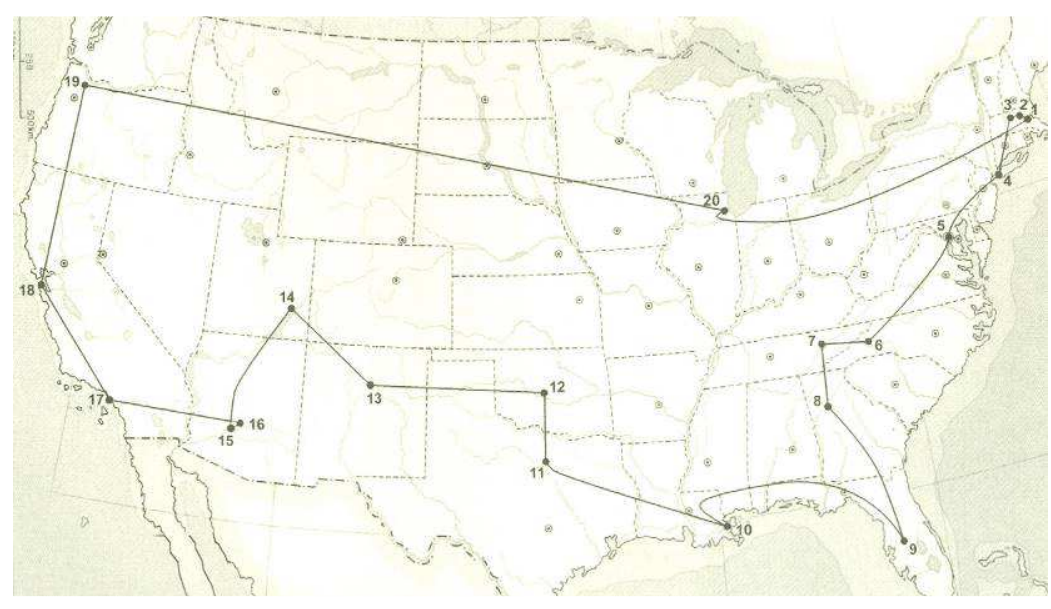

Roteiro de Artigas nos EUA: 1. Boston, 2. Cambridge, 3. Lincon, 4. Nova York,

5. Washington, 6. Black Mountain, 7. Knoxville, 8. Atlanta, 9. Lakeland, 10. Nova Orleans, 11. Dallas-Fort Worth, 12. Oklahoma City, 13. Albuquerque, 14. Grand Canyon,

15. Phoenix, 16. Scottsdale, 17. Los Angeles, 18. San Francisco, 19. Portland, 20. Chicago. Mapa elaborado por Adriana Irigoyen.

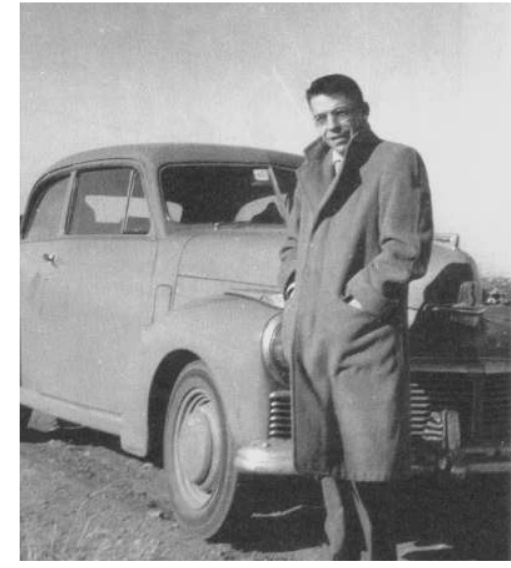

Artigas e o automóvel Studebaker com o qual viajou pelos EUA. Arquivo: Vilanova Artigas.

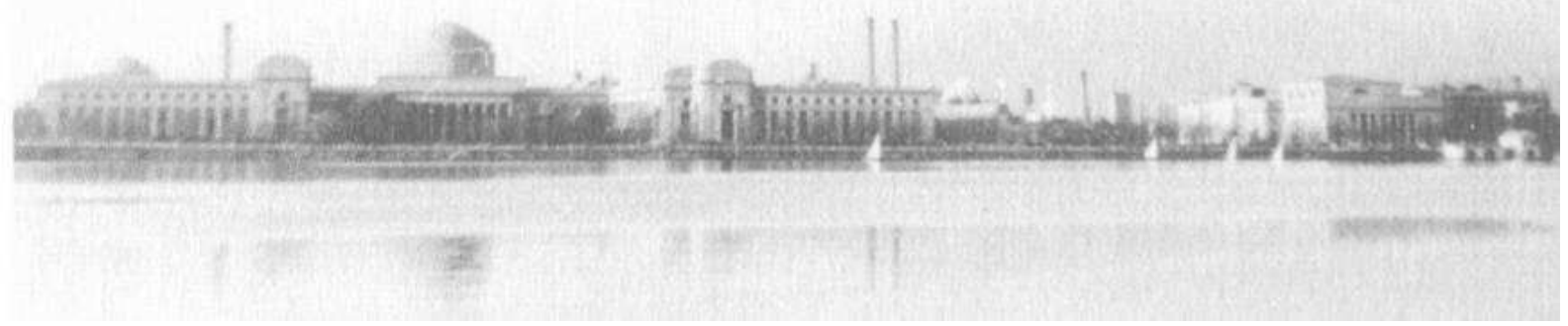

Massachusetts Institute of Technology, EUA.

No centro o big dome, a esquerda o little dome do Rogers Building,

onde funciona a escola de arquitetura. Foto: Vilanova Artigas.

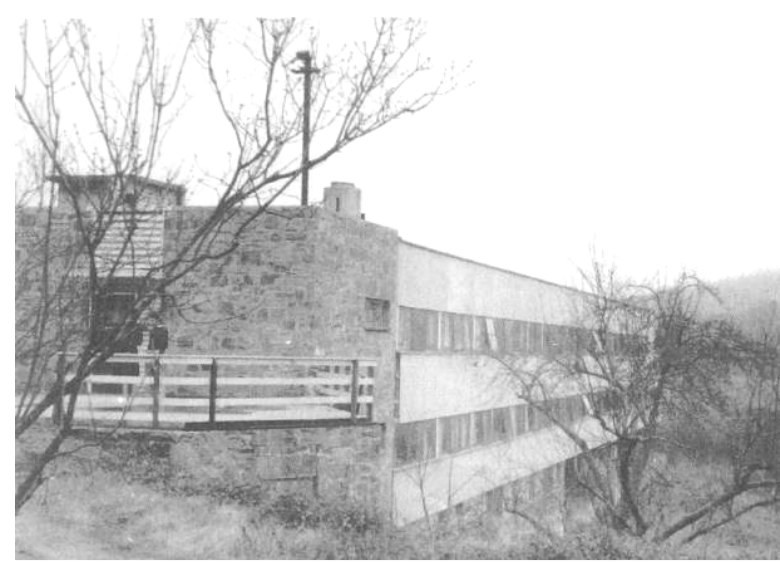

Black Mountain College, Carolina do Norte, EUA. Foto: Vilanova Artigas.

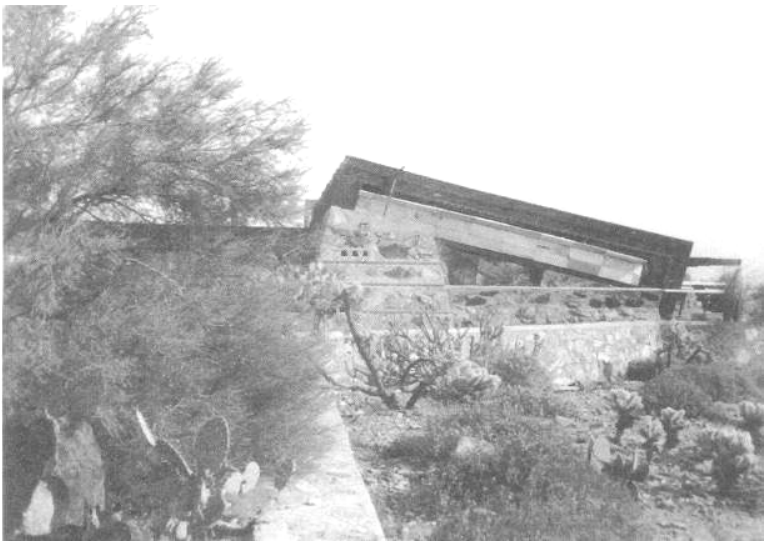

Frank Lloyd Wright. Taliesin West, Arizona, EUA, 1937 Foto: Vilanova Artigas. 

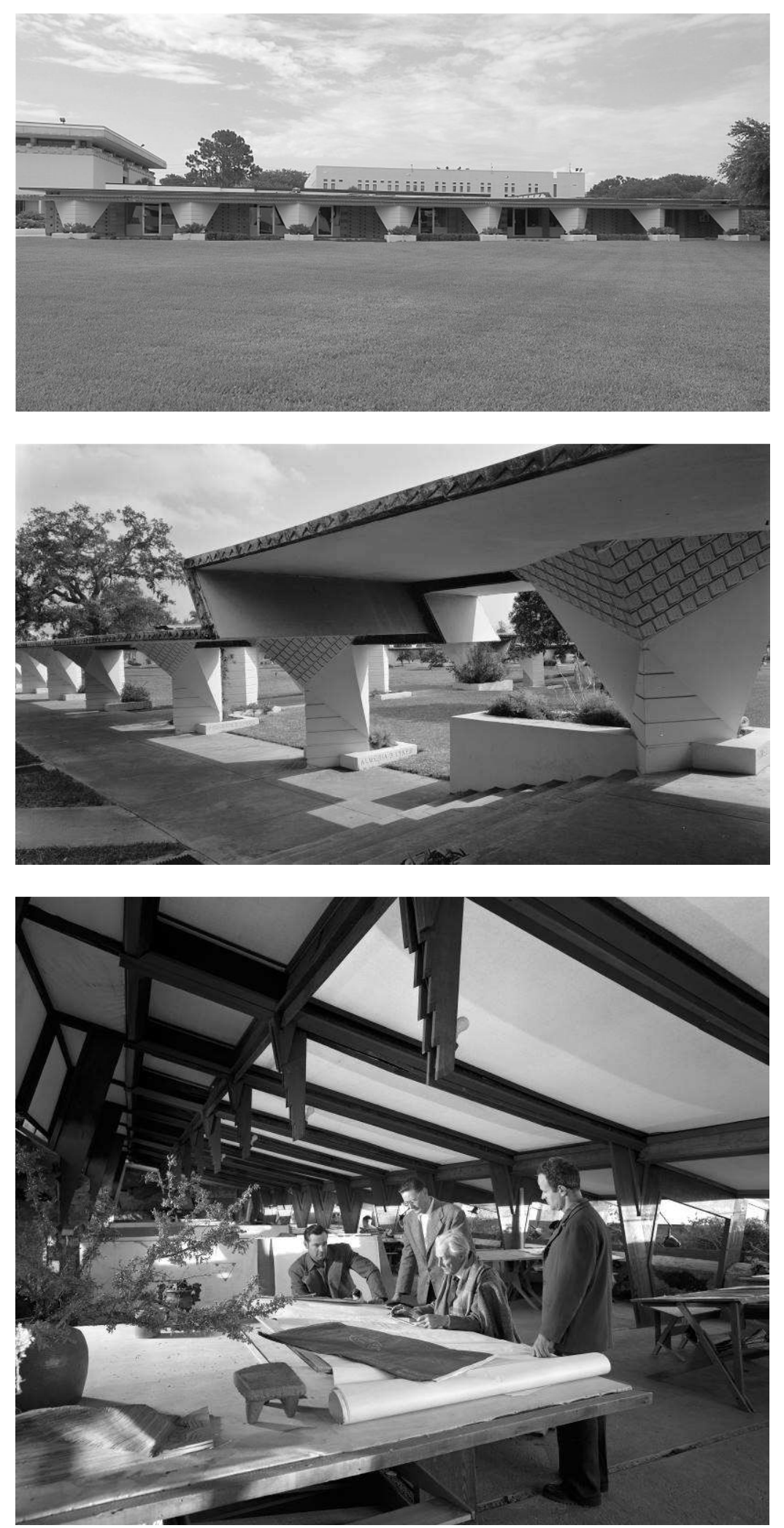

Frank Lloyd Wright Child of Sun, conjunto de edifícios do Florida Southern College (1938-1958). Arquivo: Ebyabe/Wikimedia Commons

Frank Lloyd Wright. Child of Sun, conjunto de edifícios do Florida Southern College

(1938-1958)

As obras concluídas na época da visita de Artigas eram: Annie Pfeiffer Chapel (1941), Seminars (atual Financial Aid and Business Office) (1941), Buckner Building (original Roux Library) (1946) e alguns trechos das marquises, conhecidas como Esplanades. Segundo Irigoyen, Artigas registrou cada ângulo desses edifícios. Arquivo: Library of Congress

Estúdio com luz zenital em Taliesin West Arizona, 1950. Artigas passou alguns dias em companhia de F. L. Wright em 1947. Foto: Ezra Stoller / Esto 


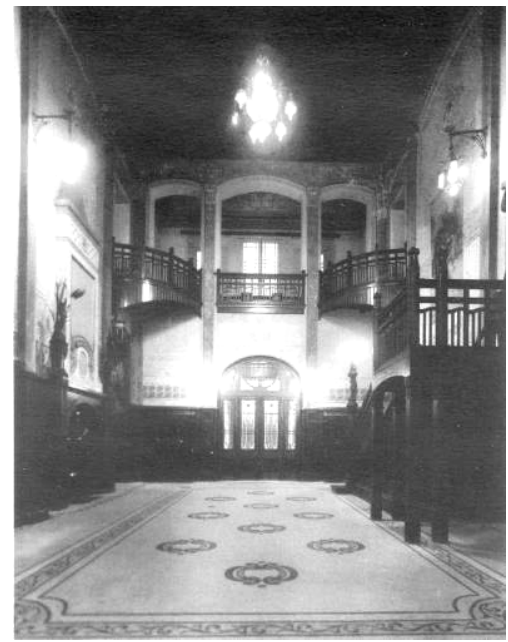

Saguão da Vila Penteado.

Foto: Cristiano Mascaro.

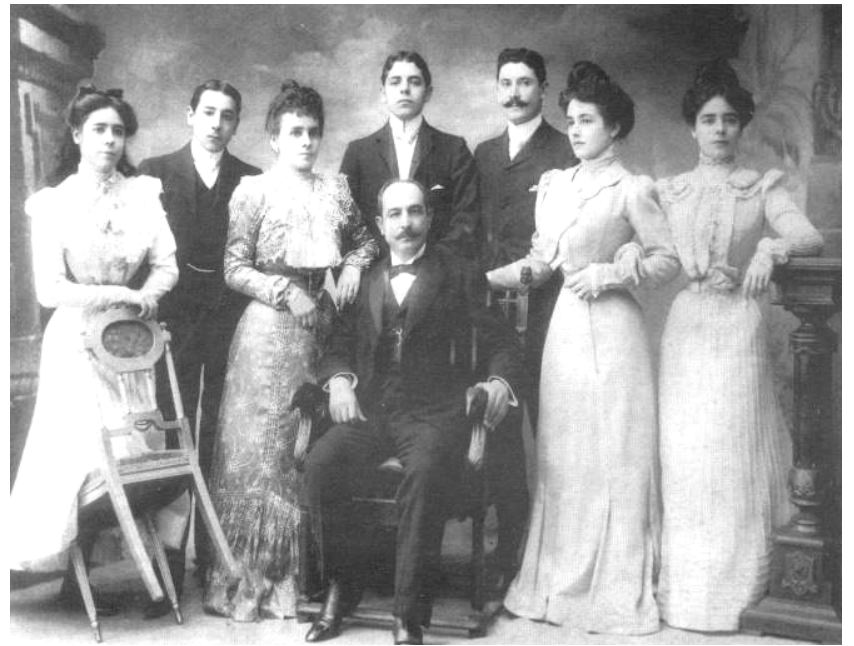

Família Álvares Penteado. Da esquerda para a direita: Stella e Armando

(filhos), dona Ana (esposa), Silvio (filho), Antônio Álvares (sentado), Caio Prado (genro), Antonieta e Eglantina (filhas). Arquivo FAUUSP.

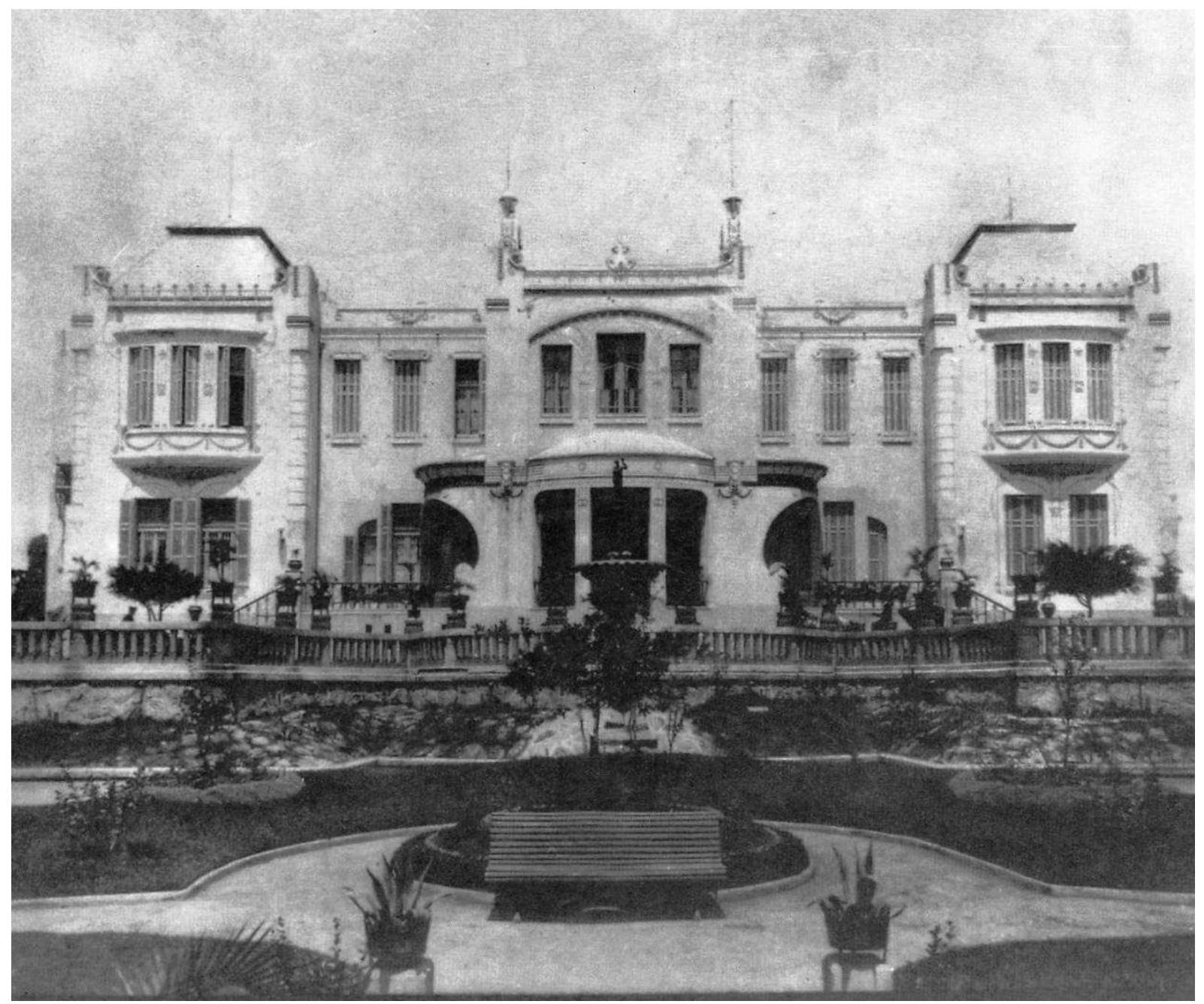

Carlos Ekman, Vila Penteado, São Paulo, 1902. Sede da FAUUSP entre 1948 e 1968. Alçado principal voltado à Avenida Higienópolis. Foto: Guilherme Gaensly, 1928(?). 


\section{A ESCOLA DE ANHAIA MELLO (1948-1952)}

A doação da Vila Penteado à Universidade de São Paulo foi aprovada pelo Conselho Universitário, em 24 de outubro de $1946 .{ }^{31}$ Os proponentes, Silvio e Armando Álvares Penteado, exigiram que a doação fosse condicionada à permanência da FAU no edifício, sendo, caso contrário, revertida aos herdeiros dos doadores. No mesmo dia o processo transitou na Congregação da Escola Politécnica, que aprovou o fechamento do curso de Engenheiro Arquiteto, pois era vedado o funcionamento simultâneo de dois cursos equivalentes na universidade. ${ }^{32}$ Essa ágil articulação deve ser creditada à Anhaia Mello, bem como ao presidente da Congregação e diretor da Poli, Paulo de Menezes Mendes da Rocha. A ata da Congregação registrou a transformação do Curso de Engenheiros Arquitetos da Escola Politécnica na Faculdade de Arquitetura e Urbanismo da Universidade de São Paulo,

"criada nos moldes do padrão federal, representada pela Faculdade Nacional de Arquitetura do Rio de Janeiro (1945): instalação do $1^{\circ}$ ano do curso, em 1947, devendo funcionar, a partir de então, todas as cadeiras especializadas do curso de engenheiro arquitetos na Vila Penteado; criação do curso de Urbanismo a partir do $2^{\circ}$ Semestre de 1947 ou $1948{ }^{33}$

A doação foi efetivada dias depois com a outorga da escritura pública em 31 de outubro de 1946. ${ }^{34}$ Contudo, a doação exigia a formalização da FAU no prazo de dois anos e, para isso, era necessária uma lei que criasse a nova faculdade. ${ }^{35}$ Por motivos desconhecidos, o governador Macedo Soares não fez tramitar o Projeto de Lei, que só foi apresentado após a eleição do governador Adhemar de Barros em 1947. Em 15 de março de 1948 o novo governador enviou à Assembleia Legislativa o Projeto de Lei n. 60, de sua autoria, que dispunha sobre a criação da Faculdade de Arquitetura e Urbanismo na Universidade de São Paulo.

\footnotetext{
${ }^{31}$ Processo n. 9.163/46, da Reitoria da Universidade. Ver: BIRKHOLZ; Lauro B.; RONCA, José Luiz C. Op. Cit., p. 88.

32 O fechamento de um curso não era novidade na Escola Politécnica, que já havia extinto os cursos de engenheiro agrícola e industrial.

${ }^{33}$ Ata da reunião no livro de atas n. 14 da Congregação da Escola Politécnica da Universidade de São Paulo p. 60-61 apud BIRKHOLZ; Lauro B.; RONCA, José Luiz C. Op. Cit., p. 89.

${ }^{34} \mathrm{O}$ documento foi lavrado na residência de Armando Álvares Penteado, na Rua Ceará n. 2, com a presença dos outorgantes doadores, do então reitor da USP, Antônio de Almeida Prado, tendo como testemunhas o diretor da Escola Politécnica, Paulo de Menezes Mendes da Rocha, o professor Luiz Inácio Romeiro de Anhaia Mello, Domício Pacheco e Silva e Ulisses Soares Caiuby.

${ }^{35}$ Até a aprovação do Estatuto da USP de 1962, a criação, exclusão e até mesmo a sequência de disciplinas das cadeiras eram regidas por lei estadual.
} 
Porém, as vésperas de se encerrar o prazo para efetivação da doação da Vila Penteado, o Projeto de Lei ainda não havia sido votado pela Assembleia Legislativa e estava longe de ser prioritário para os deputados. ${ }^{36}$ Mais uma vez a astúcia de Anhaia Mello foi decisiva. Mesmo sem a criação legal da FAU, foi obtida autorização para que a universidade abrisse vagas para seu processo seletivo de 1948, sendo que os candidatos poderiam optar pelo curso de arquitetura da Politécnica, caso a Faculdade não fosse criada. A criação da FAU passou então a contar com a capacidade de mobilização de seus candidatos a estudantes, estimulados a pressionar os deputados pela criação da FAU:

"[...] Nós nos inscrevemos para fazer faculdade de arquitetura condicionalmente, porque a Reitoria não tinha como assegurar que ela fosse fundada naquele ano. E se ela não fosse fundada naquele ano, perderia o direito ao prédio doado pelos irmãos Penteado na rua Maranhão. Então, quero dizer, quando chegou a época do exame de habilitação, fomos comunicados de que a faculdade podia não ser fundada naquele ano e quem quisesse poderia optar por fazer engenharia. Vários colegas que optaram pela arquitetura foram para a engenharia, mas um grupinho permaneceu firme. E um grupo menor, uma meia dúzia de pessoas, do qual eu participava, passou a frequentar a Assembleia Legislativa, pressionando os deputados para aprovarem a lei de criação da Faculdade de Arquitetura e Urbanismo". ${ }^{37}$

Sendo a primeira unidade da Universidade de São Paulo aberta às artes, a FAU encontrava candidatos com um perfil diferenciado, conciliando a intensa atividade editorial, política e cultural dos estudantes da Politécnica. Entre esses futuros alunos estavam, além de Hélio Pasta, José Egreja, Antônio Castro Alves de Carvalho, Marcílio Martins, Plínio Venanzi e Thereza Katinsky.

"[...] fomos procurar o Anhaia, porque ele era a pessoa que estava apontada pelo governador a comandar esse esquema [...]. Nós fomos procura-lo, uns 4 ou 5, entre eles o Marcílio [Martins], o [Antônio Carlos Alves de] Carvalho e eu, e ele nos expôs o plano e nos alertou justamente para isso: que o tempo era curto, porque havia uma doação da família do Conde Penteado daquela casa da rua Maranhão, que era destinada para o curso de arquitetura ou

\footnotetext{
${ }^{36}$ O trâmite da lei foi o seguinte: 15/03/1948: Considerado objeto de deliberação. Parecer 269/48 favorável da C.C.J.; 08/05/1948: $1^{\text {a }}$ discussão, foi adiada a votação por falta de número; 11/05/1948: Aprovado dispensa de interstício requerida pelo Deputado Lino Mattos. Foi apresentada emenda pelo Deputado Nelson Fernandes; 12/05/1948: $2^{\mathrm{a}}$ discussão, foi adiada a votação por requerimento do Deputado Auro Moura Andrade; 14/05/1948: 3ª discussão, aprovado; 15/05/1948: Autógrafo 108/48. Encaminhado a C.C.J., que deu nova redação; 22/05/1948: Mensagem 6268 do Sr. Governador publicada no D.O., com vetos; 17/06/1948: Encaminhado a C.C.J., recebeu o parecer contrário ao veto. Votação adiada a requerimento do Deputado Castro Carvalho; 18/06/1948: Rejeitado o veto do sr. Governador; 21/06/1948: aprovada a Lei $104 / 48$.

${ }^{37}$ Depoimento de Hélio Pasta a João Sodré em 2/2/2009 apud SODRÉ, João. Arquitetura e viagens de formação pelo Brasil (1938-1962). Dissertação de mestrado. Orientador: José Tavares Correia de Lira. São Paulo: FAUUSP, 2010, p. 185.
} 
coisa afim e que o prazo estava se esgotando, porque a doação implicava na constituição das bases da faculdade. Ele então nos incentivou, e a coisa envolvia um pouco de política porque a aprovação dependia de verbas para a reforma e adaptação. $E$ também porque a arquitetura era um negócio que não animava muito a liderança da Assembleia Legislativa do Estado. O pai do [José] Egreja era deputado da UDN e também nos ajudou por diversas razões, mas quem deu realmente um impulso para nós foi um deputado de Santos, de uma família tradicional, e também o Blota Junior que era um diretor da Rádio Record, conhecia o Artigas, e acabou fazendo uns editoriais na Rádio. Tivemos o apoio do jornal $A$ Gazeta, que também publicou artigos nesse sentido". ${ }^{38}$

A estratégia foi bem sucedida e em 21 de junho de 1948 foi aprovada a Lei n. 104, que em dezenove artigos criava a FAU e definia sua finalidade; seus dois cursos (graduação em Arquitetura e Pós Graduação em Urbanismo); suas trinta cátedras; a sequência das disciplinas dos dois cursos; que seu regimento provisório seria baseado no Regulamento da Poli e no Regimento da Faculdade Nacional de Arquitetura, devendo ser apresentado em um ano Anteprojeto de Regulamento próprio; o início do curso com a primeira turma em 1948; o encerramento das matrículas no curso da Escola Politécnica (que teve alunos formados até 1954); a regência preferencial das cátedras por professores de cátedras iguais ou afins da USP; a contratação de servidores não docentes; a quantidade livre de Auxiliares de Ensino; o aproveitamento de instalações e pessoal de cursos afins da USP; e crédito inicial de Cr\$ 2 milhões para a organização da escola.

Criada a FAU, Anhaia Mello foi nomeado seu primeiro diretor. Os exames de ingresso ocorreram em agosto e as aulas foram iniciadas ainda no segundo semestre daquele ano, no antigo prédio da Escola Politécnica, no bairro da Luz, aonde permaneceu até a conclusão da reforma de adequação da Vila Penteado. ${ }^{39}$ Em novembro de 1949 a FAU se mudou para o novo endereço, incorporando-se ao vibrante polo universitário da Vila Buarque, onde se encontravam o Departamento de Filosofia da Faculdade de Filosofia, Letras e Ciências Humanas, a Faculdade de Economia, ambos da USP; a Escola de Sociologia e Política; além da Universidade Presbiteriana Mackenzie. ${ }^{40}$ A proximidade com o centro da cidade, onde se localizavam a maioria dos escritórios de arquitetura, O MASP, O MAM, O IAB e

\footnotetext{
${ }^{38}$ Depoimento de Plínio Venanzi a João Sodré em 10/06/2008 apud SODRÉ, João. Op. Cit., p. 185.

${ }^{39}$ A hipótese mais provável é que o anexo onde funcionou o ateliê tenha sido projetado por Ernest Mange. Contudo não conseguimos resgatar a referência do texto de Geraldo Ferraz, onde encontramos essa informação. Outra possibilidade é que tenha sido projetado por Artigas (cf. Depoimento de Ariosto Mila a Sylvia Ficher [1985] apud FICHER, Sylvia. Op. Cit. p. 207).

40 Nesse período a Santa Casa de Misericórdia não era frequentada por alunos. A Santa Casa havia abrigado o curso de medicina da USP e da Escola Paulista de Medicina anteriormente, mas perdeu essa função na década de 1950, quando foram concluídos o Hospital das Clínicas e o Hospital Paulista. A Faculdade de Ciências Médicas da Santa Casa de São Paulo foi inaugurada em 1963.
} 
escritórios das revistas especializadas, garantia vitalidade à vida estudantil e sintonia com o debate profissional e com a agenda cultural moderna.

O curso de arquitetura da Poli estava organizado pelo 9 regimento da escola, de 1943. Das cerca de dezenove Cadeiras que os alunos da Escola Politécnica deviam cursar para receber o título de engenheiro-arquiteto, apenas quatro eram específicas ou continham disciplinas específicas do curso. Eram elas:

- 'Noções de Arquitetura e Construções Civis. Higiene das Habitações e História da arquitetura I e II'. ${ }^{41}$ Ramos de Azevedo foi seu primeiro catedrático, quando o nome da cadeira era ainda Arquitetura Civil. Ao se afastar em 1928, assumiu Alexandre Albuquerque até seu pedido de exoneração em 1938. Bruno Simões Magro assumiu a cátedra em 1942, tendo como assistentes Ernesto Sampaio de Freitas, até 1945 (interino de 1940 a 1941), Zenon Lotufo, de 1944 a 1945, e Ariosto Mila, de 1946 em diante. ${ }^{42}$

- 'Desenho Arquitetônico'. Foi regida primeiramente por Victor Dubugras até sua aposentadoria, em 1927, quando Prestes Maia, contratado como interino desde 1924, foi efetivado. Devido a proibição de acúmulo de cargos públicos, Prestes Maia optou por seu cargo na Secretaria de Viação e Obras Públicas em 1938, quando se tornou interventor do município de São Paulo. José Maria de Silva Neves defendeu sua tese em 1943 e assumiu a Cátedra no ano seguinte. Affonso lervolino foi o interino nesse meio tempo.

- 'Composição Decorativa. Modelagem'. Substituindo Domiziano Rossi em 1921, Felisberto Ranzini se efetivou professor da cadeira em 1931, tendo como assistente Caetano Fraccaroli a partir de 1944. Ranzini, no entanto, nunca teve o título de catedrático.

- 'Estética. Composição Geral e Urbanismo I e II'. Esta cadeira foi criada em 1926, quando Anhaia Mello, fundador da Escola Politécnica em 1893 e catedrático de 'Mecânica racional', se tornou novamente catedrático. "De 1934 a 1937, seu assistente foi Silva Neves; em 1938, Zenon Lotufo; em 1939, Affonso lervolino; em 1940, Lotufo e João Batista Vilanova Artigas; de 1941 a 1942, Artigas e Ariosto Mila. Em 1943, Artigas assumiu a cátedra interinamente, tendo como assistente Mila; em 1944, Anhaia Mello retornou e Artigas permaneceu até 1946 como seu assistente". 43

\footnotetext{
${ }^{41}$ A parte de história da arquitetura, unificada em 1935, era específica para os arquitetos.

${ }^{42}$ FICHER, Sylvia. Op. Cit., p. 262.

${ }^{43}$ Idem, p. 260. 
Com a viagem de Artigas, Lotufo foi assistente em 1947 e Artigas reassumiu o posto entre 1948 e 1952.

Os oito professores ligados a essas quatro cadeiras ${ }^{44}$ formaram o corpo docente inicial da FAU: os catedráticos Bruno Simões Magro (1882-1956), Luís Inácio de Anhaia Mello (18911974) e José Maria da Silva Neves (1896-1978), o professor Felisberto Ranzini (1881-1976) e os assistentes Zenon Lotufo (1911-1985), João B. Vilanova Artigas (1915-1985), Ariosto Mila (1912-1987) e Caetano Fraccaroli (1911-1987).

O curso da FAU começou com uma turma de 26 alunos de primeiro ano em 1948 e, a cada ano, novos contratos de docência eram feitos à medida que novas disciplinas surgiam na grade, até completar o quadro docente dos cinco anos do curso. Apesar de ter suas próprias cadeiras definidas por lei, a FAU não tinha professores catedráticos, pois a abertura de concursos dependia da FAU ter seu regulamento aprovado em nova lei e de autorização do Conselho Universitário, que por sua vez era composta pelos professores catedráticos da Universidade. Desse modo, todos os professores da FAU entravam na categoria "Professor Contratado", um cargo interino para professores de outras unidades da USP e precário para profissionais externos. A Lei 104 não apenas permitia que professores da Escola Politécnica acumulassem seus cargos com contratos na FAU, mas dava preferência para que suas cadeiras fossem regidas por professores de cátedras equivalentes da universidade. $\mathrm{Na}$ ausência de catedráticos concursados, havia um concurso de títulos dos candidatos ao contrato provisório para regência, avaliado pela Comissão de Ensino e Regimentos do Conselho Universitário. As cadeiras técnicas foram naturalmente ocupadas pelos professores de lá. Para as demais foram contratados novos professores, por meio de concurso de títulos. Daí que a maior renovação se deu nas cadeiras de Composição, Plástica e História, acompanhada de menor experiência docente e titulação. Afinal, seguindo o padrão federal, as cadeiras de composição passaram de três para sete e as de teoria e história, que não existiam, passaram a ser quatro. As de ciências diminuíram de nove para seis e as de construção aumentaram de sete para nove.

Desse modo podemos compreender a afirmação de Artigas:

"[A FAU] organizou-se adaptando-se ao currículo padrão que era o da Escola Nacional de Belas Artes, com suas disciplinas de Plástica, Modelagem, Arquitetura de Interiores, Grandes e Pequenas Composições, etc., mas também conservou o programa de ensino

${ }^{44}$ Ernesto Sampaio de Freitas exonerou-se em 1945 quando foi aberto concurso para preenchimento de sua cátedra após o falecimento de Alexandre Albuquerque; Affonso lervolino se desligou ainda em 1943. 
técnico que caracterizava o curso de Arquitetura da Escola Politécnica". 45

A situação da nova FAU estava longe do ideal de independência almejado pelos arquitetos, mas representava um grande avanço em relação à Politécnica. Acreditava-se que o aprimoramento de um modelo de ensino mais independente se daria quando a faculdade tivesse seu regulamento próprio, o que possibilitaria os concursos para provimento das cátedras e, consequentemente, a formação da Congregação da FAU, que deixaria de se submeter ao Conselho Universitário. Para isso, em maio de 1949, Anhaia Mello nomeou uma comissão para elaborar o anteprojeto desse regulamento, composta por Bruno Simões Magro, José Maria da Silva Neves e por Vilanova Artigas. ${ }^{46}$ Este, porém, só foi enviado à Assembleia Legislativa em 1954 e o número de catedráticos necessários para a formação da Congregação só foi obtido em 1968, um ano antes da Reforma Universitária acabar com o sistema de cátedras.

Apesar das limitações, enquanto diretor da FAU, Anhaia Mello teve grande liberdade para formar o quadro docente, convidando arquitetos e artistas para lecionar as disciplinas que mais tarde viriam a formar os Departamentos de Projeto e de História.

O Grêmio dos alunos da FAU, fundado em 5 de novembro de 1948, também pode ter influenciado na constituição de novos quadros para a escola. Desde o início os alunos foram ativos na definição de todos os rumos da escola, inclusive auxiliando o ensino com a montagem dos materiais didáticos por meio da pequena editora montada pelo Grêmio e mais tarde participando dos seminários de ensino e das reformas curriculares. ${ }^{47}$

Quando a primeira turma de arquitetos da FAU se formou, em 1952, a escola contava com 59 professores, sendo 25 engenheiros, 22 arquitetos e 12 professores com outras formações (matemáticos, sociólogos e principalmente artistas).

Entre os professores contratados ${ }^{48}$ durante as gestões de Anhaia Mello, entre 1948 e 1951, e Bruno Magro, entre 1951 e 1952, os arquitetos podem ser agrupados entre os formados na ENBA do Rio de Janeiro: Abelardo Riedy de Souza (1908-1981/48-78), Hélio de Queiroz Duarte (1906-1944/49-76), Eduardo Corona (1921-2001/49-91), Alcides da Rocha Miranda (1909-2001/50-55) e Elisiário da Cunha Bahiana (1891-1980/51-53); e na Politécnica de São

\footnotetext{
${ }^{45}$ ARTIGAS, João Batista Vilanova. "Contribuição para o Relatório sobre Ensino de Arquitetura UIA-UNESCO", Op. Cit., p. 33.

${ }^{46}$ Cf. depoimento de Ariosto Mila a Sylvia Ficher [1985] apud FICHER, Sylvia. Op. Cit., p. 297. A lei 104 estabelecia que o diretor apresentasse um anteprojeto de regulamento ao Conselho Universitário um ano após a abertura do curso.

${ }^{47}$ Ver: SODRÉ, João. Op. Cit., p. 156.

${ }^{48}$ Sempre que possível, indicaremos a data de nascimento e morte de todos os professores contratados, assim como a escola em que se formou e, em negrito, o ano de início e fim de contrato com a FAU.
} 
Paulo: Ícaro de Castro Mello (1913-1986/50-55), Ernest Robert de Carvalho Mange ${ }^{49}$ (19222005/50-68), Carlos Alberto Gomes Cardim Filho (1899-1990/51-55) e Miguel Badra Júnior (1919/52-54). Completavam o quadro Joaquim Bezerra da Silva (?-?/50-76), José Vicente Vicari (1909-1989/51-53), formado em Roma; Plinio Croce (1921-1984/52-66) e Milton Carlos Ghiraldini (1924-1976/52-76), formados no Mackenzie, e o arquiteto-paisagista Roberto Coelho Cardoso (1923/52-72), formado na Universidade da Califórnia. Observa-se, portanto, um número muito maior de arquitetos, e de formações distintas, do que no curso da Poli, sendo marcante a presença dos cariocas.

Entre os professores que não eram nem arquitetos nem engenheiros, foram contratados os artistas Vera Helena Rossmann Carvalhaes do Amaral (1916-2008, BA Nápoles/49-62), Zanine Caldas (1919-2001/50-52), Antônio Paim Vieira (1895-1988, Escola Normal SP/5153), Alfredo Oliani (1906-1988, ABA SP/51-53), Archimedes Dutra (1908-1983, Escola Normal SP/51-55), Vicente Larocca (1892-1964/52-53), Dante Jorge de Albuquerque (??/52-54) e Bassano Vaccarini (1914-2002, Itália/52-55). Também foram contratados os professores do IME, Nelson da Silveira Leme (?-?/48-70) e Joaquim Dias Tatit (?-?/49-71), e o sociólogo da FFCL, Lourival Gomes Machado (1917-1967/52-53).

Entre os professores engenheiros, estavam os professores catedráticos da Poli, José Octavio Monteiro de Camargo (1901-1963, EP/48-63), João Augusto Breves Filho (19172005/48-69), Henrique Jorge Guedes (1887-1973, EP/49-57) ${ }^{50}$, Ary Frederico Torres (19001976, EP/49-58) ${ }^{51}$, Telêmaco Hippolyto Van Langendonck (1909-1994, EP/50-70), Luiz Cintra do Prado (1904-1984, EP/50-74) ${ }^{52}$, Carlos Alberto Vanzolini (1903-1953, EP/51-53), Lysandro Melo Pereira da Silva (1903-1993/51-57) e Pedro Bento José Gravina (1915, Nápoles/51-67). Completavam a lista, Eurico Cerruti (1911-1976/48-70), Guilherme do Amaral Lyra (?-?/48-70), Pedro Moacyr do Amaral Cruz (?-?/48-70), Jorge Leite Guedes (??, EP/49-51), Vicente Chiaverini (1914-2011, EP/49-56), Raymundo José D`Araujo Costa (??/50-52), Odair Grillo (1911-1996/50-54), Augusto Carlos de Vasconcelos (1922, EP/50-57), Luiz de Queiroz Orsini (1922, EP/50-59), Carlos Pereira de Castro (?-?/50-70), Rui Aguiar da Silva Leme (?-?, EP/51-61), Américo Oswaldo Campiglia (1909-2000/51-62), Sergio Fracarolli (?-?/51-62), Fernando José de Oliveira Escorel (1916-1964, EP/51-64), Alberto Hippolyto de M. Van Langendonck (?-?/51-66), Paulo Sampaio Wilken (1910-1995/51-68),

\footnotetext{
${ }^{49}$ Ernest Mange formou-se em engenharia civil, embora tivesse cursado as disciplinas de arquitetura.

${ }^{50}$ Henrique Jorge Guedes foi diretor da Politécnica entre 1938 e 1941 e novamente entre 1947 e 1950, portanto durante a criação da FAU. Também fora Prefeito de São Paulo, sucedendo Anhaia Melo entre 1931 e 1932.

${ }^{51}$ Ary Torres foi o criador do Laboratório de Ensaio de Materiais (1926) a partir do antigo Gabinete de Resistência de Materiais, mais tarde transformado em IPT (1934).

52 Luiz Cintra do Prado foi diretor da Poli entre 1941 e 1943. Foi também diretor do IPT e da Associação Brasileira de Cimento Portland.
} 
Leopoldino Wilson Paganelli (?-?/52-54) e Victor Froilano Bachmann de Mello (19262009/52-70). A maioria destes já lecionava no curso de arquitetura da Politécnica.

O contrato padrão dos professores era de dois anos, podendo ser renovados indefinidamente. Enquanto muitos professores externos tiveram passagem curta, os professores interinos (de outras unidades da USP), e entre eles os catedráticos da Poli em especial, eram recontratados quase automaticamente. A vantagem para a FAU em ter catedráticos da Escola Politécnica regendo suas cadeiras, além do lema de Artigas "para a FAU, o melhor", equivalia a garantir alguma voz no Conselho Universitário, enquanto para esses professores, lecionar na FAU significava não apenas maiores vencimentos pelo acúmulo de cargos, mas uma ampliação de seu poder na Universidade e o controle da FAU, pois apenas os catedráticos podiam assumir sua direção.

Os documentos encontrados permitem supor que, no início, Anhaia Mello, Vilanova Artigas e boa parte dos arquitetos formados na Escola Politécnica não viam problema na presença dos engenheiros; pelo contrário, julgavam que o forte ensino técnico oferecido pelos catedráticos da Poli seria a base da formação do arquiteto. Por outro lado, Anhaia promoveu uma clara renovação no ensino artístico e arquitetônico, sem precisar consultar os engenheiros. Não por acaso a primeira grande crise institucional da FAU, que fez com que o diretor pedisse afastamento de seu cargo, se deu pelo impedimento da contratação do arquiteto Oscar Niemeyer para lecionar na cadeira n. 17 'Composição de Arquitetura. Grandes Composições II', do 5ํano.

"Eu lembro que por causa do Oscar Niemeyer, nós ficamos seis meses [sic] em greve em 51. Para você ver, o negócio americano, o macarthismo, o que ele gera... A reitoria tinha aprovado o nome dele e sei lá quem buzinou que ele era comunista e voltaram atrás. 0 nome dele estava aprovado". 53

Se durante o governo Adhemar de Barros, Anhaia Mello atingiu o auge de seu prestígio na universidade, conseguindo criar a FAU, sendo nomeado o primeiro vice-reitor da USP e estando à frente da Comissão do Plano e Execução da Cidade Universitária, a eleição do novo governado, o engenheiro e professor catedrático da Poli, Lucas Nogueira Garcez ${ }^{54}$, representou um inesperado revés para o diretor da FAU. O novo reitor, Ernesto de Moraes Leme (Faculdade de Direito), nomeado pelo governador, teria articulado o veto à nomeação de Niemeyer no Conselho Universitário, que meses antes havia sido aprovada. Para a mídia

\footnotetext{
53 Depoimento de Hélio Pasta a João Sodré em 02/02/2009 apud SODRÉ, João. Op. Cit., p. 159.

${ }^{54}$ Lucas Garcez foi eleito pelo Partido Social Progressista com apoio de Adhemar de Barros, vencendo a disputa com Prestes Maia (UDN) para o governo do Estado de São Paulo em 1950. Buscando romper com a polarização entre Jânio Quadro e Adhemar de Barros, Garcez liderou em 1954 uma aliança para eleger Prestes Maia, que ficou em 3ํㅣ lugar.
} 
da época, Garcez estava por trás. ${ }^{55}$ Para outros, era uma ofensiva de Zeferino Vaz, antiga desavença de Anhaia Mello. ${ }^{56}$

A primeira turma de estudantes que havia militado pela criação da FAU perdia, no último ano, e de uma só vez, a possibilidade de ter Niemeyer como professor, bem como a proteção de Anhaia Mello na diretoria da escola. Os estudantes reagiram e entraram em greve reivindicando melhorias mais amplas no ensino da FAU. O presidente do GFAU, Romeu Solferino Neto, sobrinho de Artigas, proferia a posição dos estudantes:

"Nosso movimento é um protesto contra o atraso na indicação de professores, para diversas cadeiras de nossa escola, a demora na aprovação do regulamento da Faculdade, e o julgamento do concurso de títulos para a cadeira Grandes Composições, do 4ํㅜ ano [sic], que foi vencido pelo arquiteto Oscar Niemeyer, de forma alguma se justifica. Além disso, o Conselho Universitário, anulando o seu próprio voto, não mais o aceitou como professor da Faculdade. [...]. Quanto ao caso do arquiteto Oscar Niemeyer, não se compreende porque o Conselho Universitário recusa os serviços de um profissional de capacidade mundialmente reconhecida. Tal atitude, não pode ser ditada pela melhoria do ensino em São Paulo e pelo progresso da arquitetura brasileira, em cuja defesa os estudantes levantam seu protesto" ${ }^{57}$

Os jornais da época acompanharam os quatro meses de greve iniciada em 9 de maio de 1951 e os estudantes recebiam apoio de diretórios acadêmicos e integrantes da classe artística, como Paulo Autran, Tônia Carrero, Hebe Camargo, Carlos Thiré, Osny Silva, entre outros. $^{58} \mathrm{O}$ clima ficou tão acirrado que o Conselho Universitário, finalmente, propôs e aprovou o fechamento da escola e, no dia 28 de junho, o reitor suspendeu as atividades didáticas e culturas da FAU por tempo indeterminado, "considerando o ambiente de indisciplina reinante no corpo discente". ${ }^{59}$

"Era uma forma de repressão, obviamente. [...]. E nós ficamos órfãos de pai e mãe. Então, fecharam a FAU e nós fomos dormir no GFAU

\footnotetext{
55 "Garcez faz o enterro da cultura paulista", Hoje. São Paulo, 10 de maio de 1951, s.p. apud SODRÉ, João. Op. Cit., p. 158. No entanto, isso não impediu que a Comissão para o IV Centenário, constituída pelo governador, contratasse o arquiteto carioca para projetar o conjunto do Ibirapuera.

${ }^{56}$ Essa hipótese é levantada por Nestor Goulart Reis Filho em entrevista a João Sodré apud SODRÉ, João. Op. Cit., p. 158.

57 "Em greve os universitários de urbanismo e arquitetura", Correio Paulistano. São Paulo, 11 de maio de 1951, s.p. Ver também: "Niemeyer impedido de lecionar na Faculdade de Arquitetura e Urbanismo", Jornal de Notícias. São Paulo, 12 de maio de 1951, s.p. apud SODRÉ, João. Op. Cit., p. 160.

58 "Em greve por tempo indeterminado os alunos da Faculdade de Arquitetura e Urbanismo", Folha da Manhã. São Paulo, 8 de junho de 1951 apud SODRÉ, João. Op. Cit., p. 160.

59 "Fechada por tempo indeterminado a Faculdade de Arquitetura e Urbanismo". São Paulo, 29 de junho de 1951 apud SODRÉ, João. Op. Cit., p. 161.
} 
no porão para impedir que o Grêmio fosse invadido, porque era uma sociedade civil, mas o endereço estava registrado lá e não queríamos que fosse fechado". ${ }^{60}$

A greve teria terminado durante o XIV Congresso da UNE, realizado no Rio de Janeiro, após Niemeyer divulgar uma carta abrindo mão do cargo. ${ }^{61}$

Durante esta crise a diretoria da FAU foi assumida interinamente por Bruno Simões Magro. Pressionado por todos os lados, o segundo dos três arquitetos catedráticos da Escola Politécnica, terminou sua gestão sem um acordo.

${ }^{60}$ Depoimento de Nestor Goulart Reis a João Sodré em 28/01/2010 apud SODRÉ, João. Op. Cit., p. 159.

${ }^{61}$ Essa carta é citada no depoimento de Nestor Goulart a João Sodré, já mencionado. 


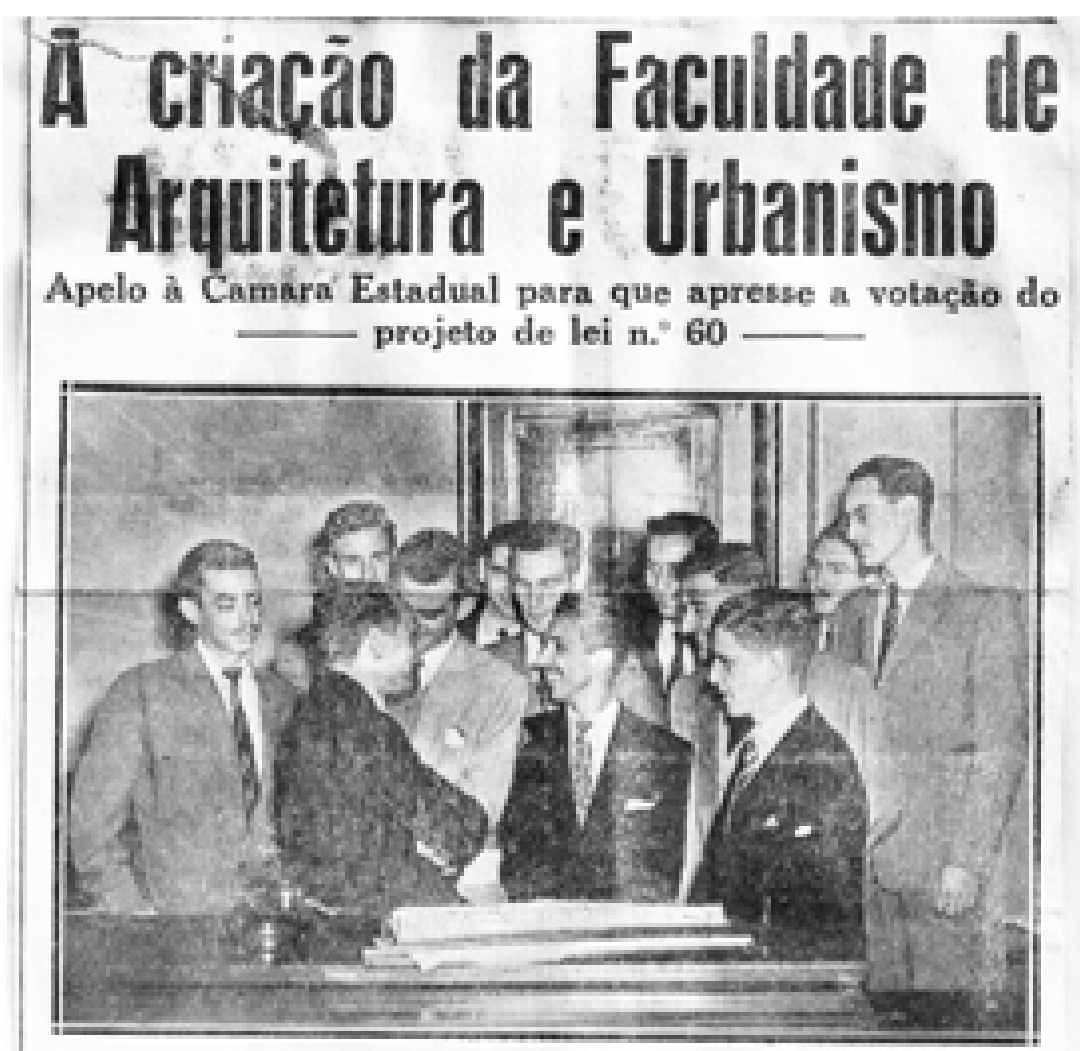

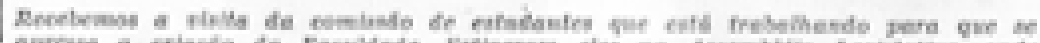

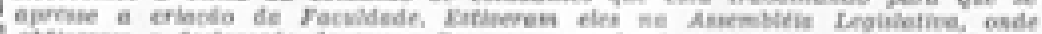

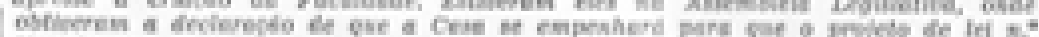

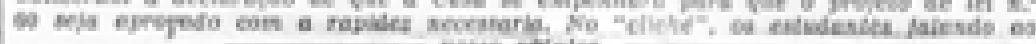

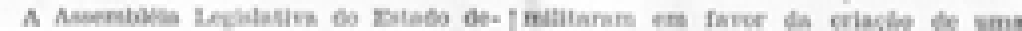

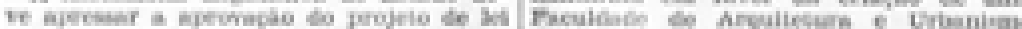

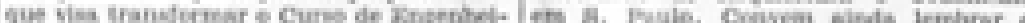

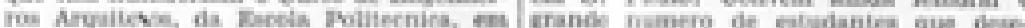

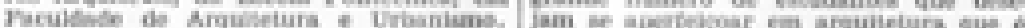

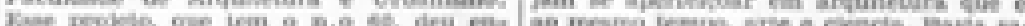

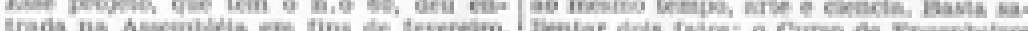

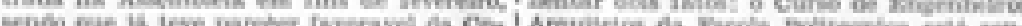

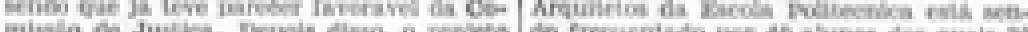

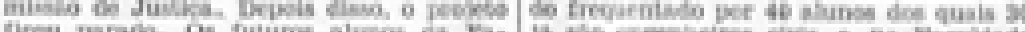

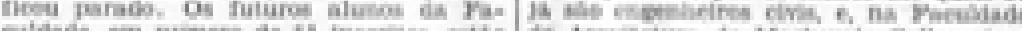

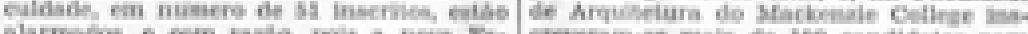

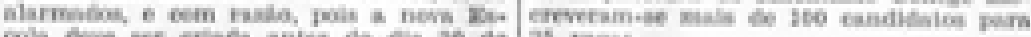

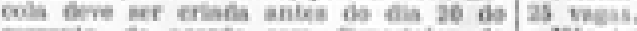

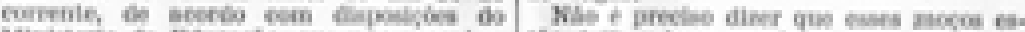

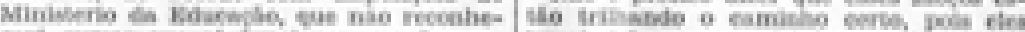

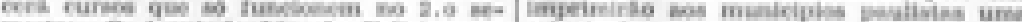

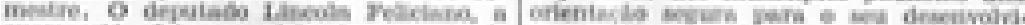

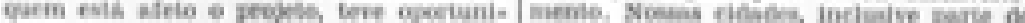

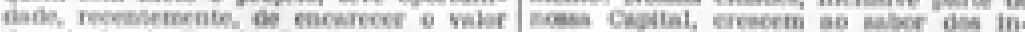

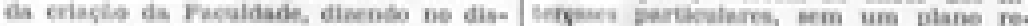

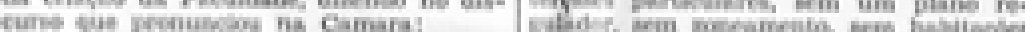

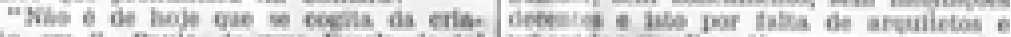

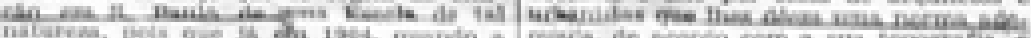

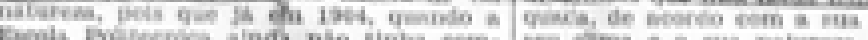

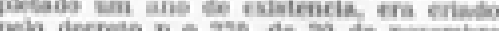

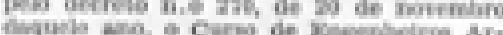
quiletos, Tais fornem is bens Fualiabog

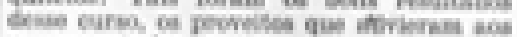

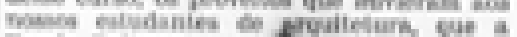

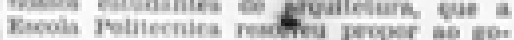

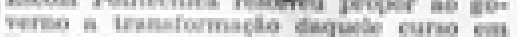

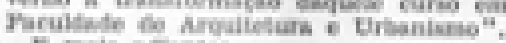
5 mais entarie:

rbiante da coesplexidute da tareta eas

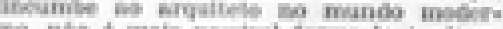

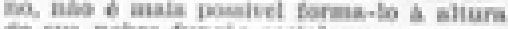

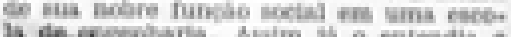

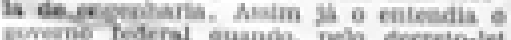

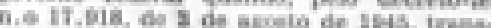

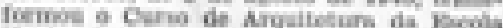

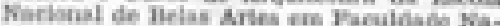
Canal de Areuiletura e Urtepdute?

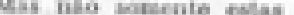

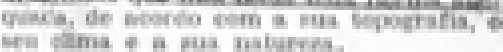
Mina s alinea Xt do eritio 16 ds *Let

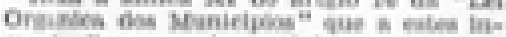

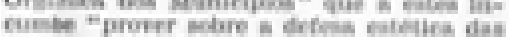
cidudes. reculamenands es ratiles ofe

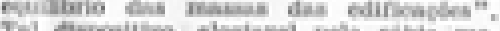

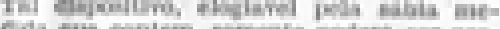

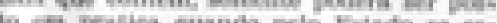

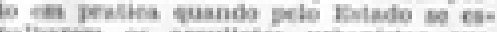

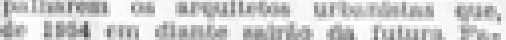

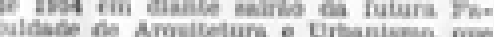

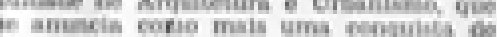

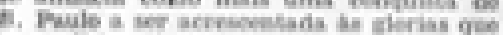

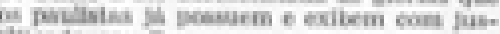
tricude errution.

Chams, peis, para o mesperties peolete

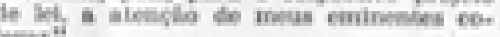
dere ser stendide, Que a Camara aperate necovacte de peojete de att n.e 60.
$\boldsymbol{O}$ apels to drpeitads Inesoln Felictane
"A criação da Faculdade de Arquitetura e Urbanismo". São Paulo, maio 1948. Arquivo Roberto Pinto Monteiro. 

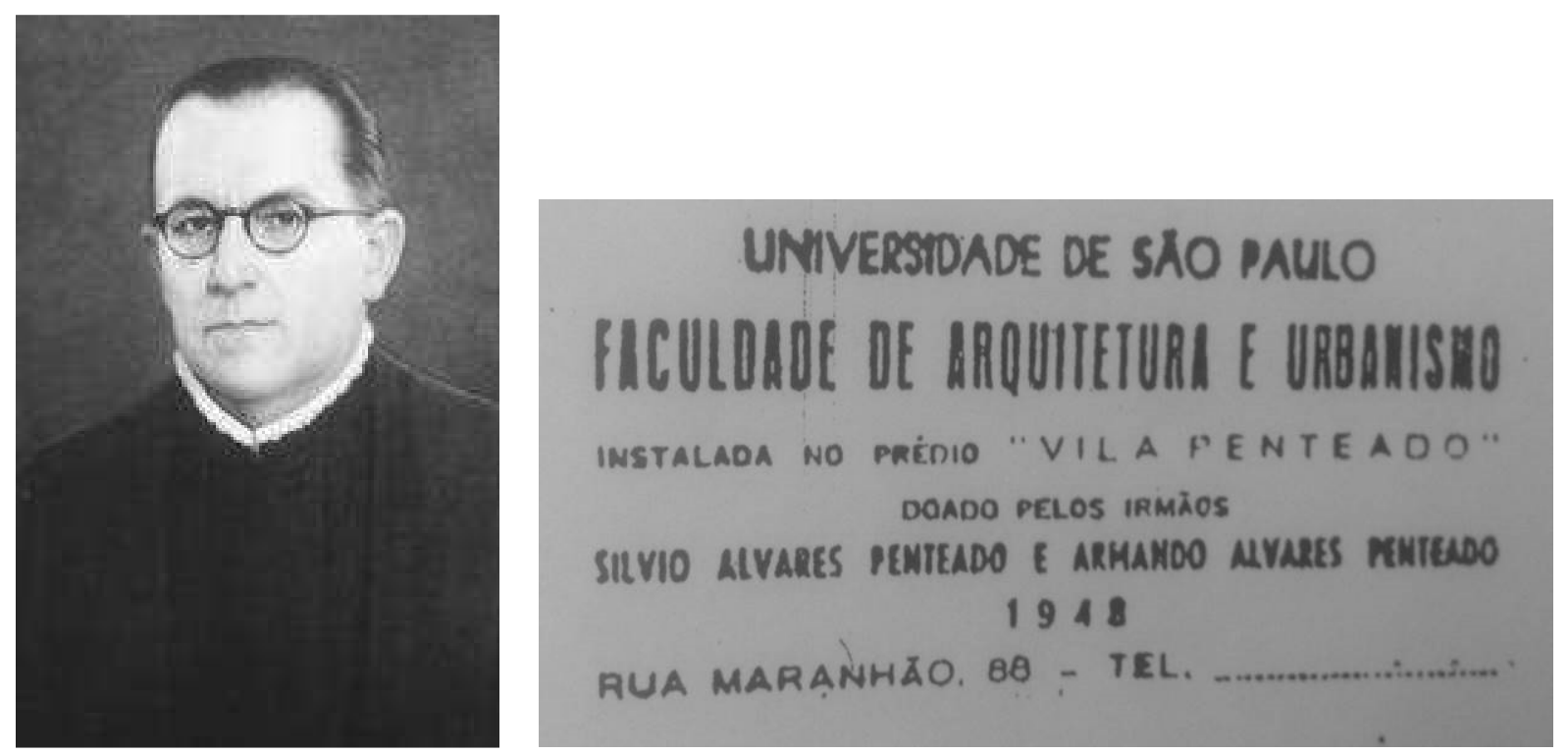

Professor Luiz Ignácio Romeiro de Anhaia Mello.

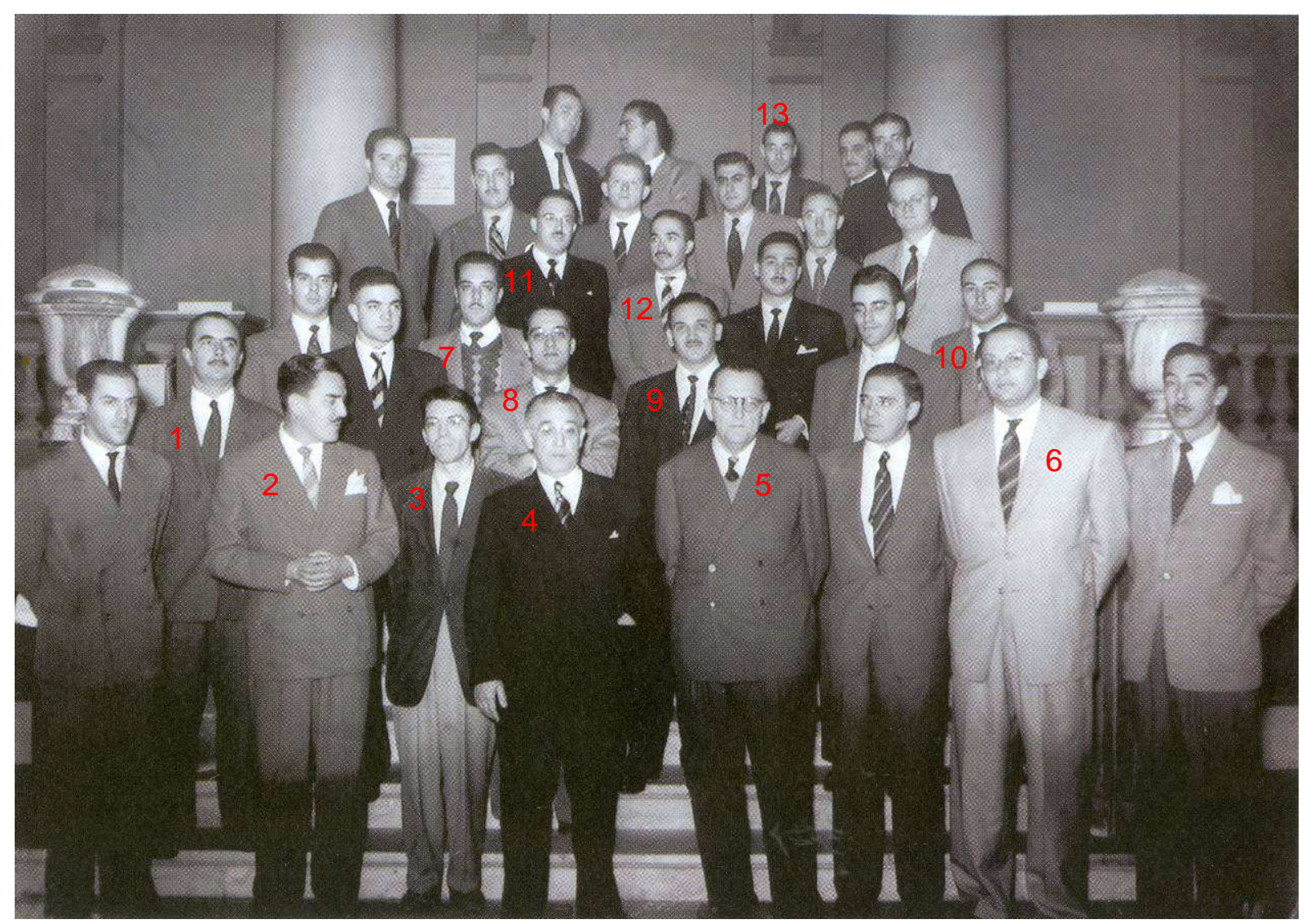

Homenagem a Anhaia Mello pela criação da FAU. São Paulo, agosto de 1948.

Identificados: 1 Abelardo Riedy de Souza, 2 Leo Ribeiro de Moraes, 3 João Batista Vilanova Artigas, 4 Henrique Jorge Guedes, 5 Luiz lgnácio de Anhaia Mello, 6 Ícaro de Castro Mello, 7 Roberto Cerqueira César (?), 8 Oswaldo Corrêa Gonçalves, 9 Zenon Lotufo, 10 Maia Fina, 11 Ariosto Mila, 12 Filho do Henrique Jorge Guedes, 13 Carlos Cascaldi. Arquivo Oswaldo Corrêa Gonçalves. 


\section{Em greve os alunos da Faculdade de Arquitetura e Urbanismo}

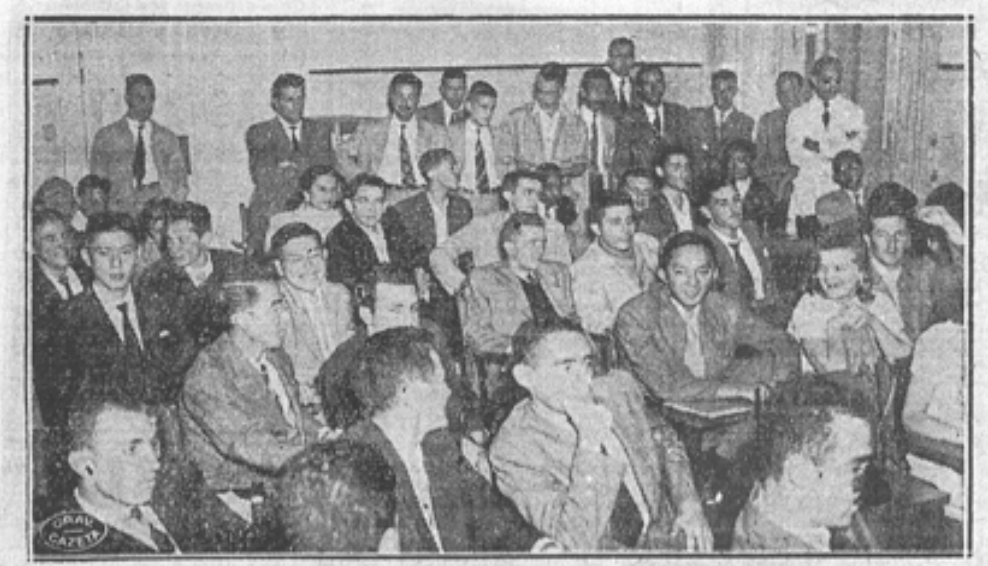

$V_{m}$ aspecto do assembitia perat, reallada ontem, na sede do Gremio daquela eicola.

Os alunos da Faculdade de AF- to do concurso de titulos para a Ribamar. Os estudantes estao des.

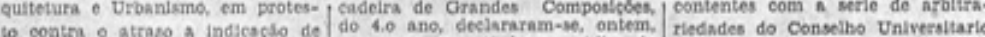

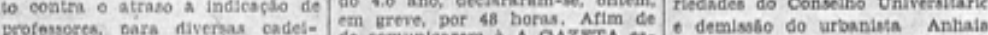

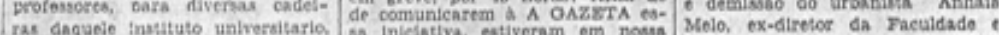

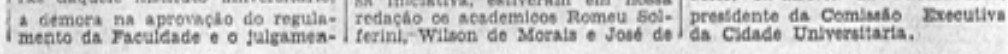

"Em greve os alunos da Faculdade de Arquitetura e Urbanismo". Folha da Manhã. São Paulo, 8 de junho de 1951. Arquivo

Romeu Solferini Neto.

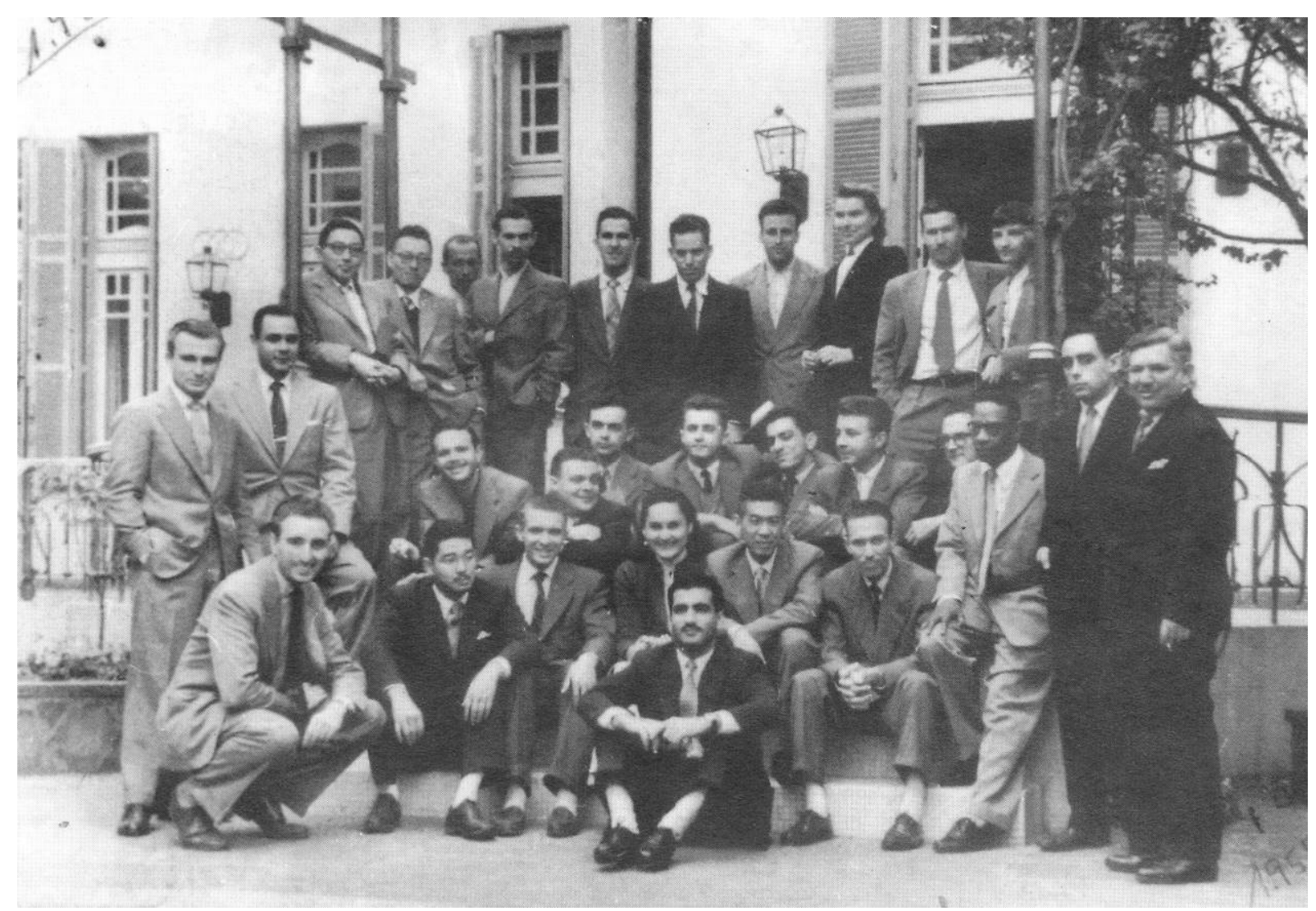

Turma ingressante em 1951. Foto autor desconhecido, 1955. Arquivo Biblioteca da FAUUSP. 


\section{ASCENSÃO DE VILANOVA ARTIGAS (1953-1958)}

A formatura da primeira turma de arquitetos da FAU e da última da Poli, no fim do ano letivo de 1952, marcou o encerramento de um ciclo da escola. Entre 1953 e 1958, as tentativas de reforma do ensino e a consolidação institucional da FAU seriam conduzidas pelos diretores engenheiros Luiz Cintra do Prado (1953-1954), Lysandro Melo Pereira da Silva (1954-1956) e Pedro Bento José Gravina (27/11/1956 a 23/02/1959).

Do lado das tentativas de reforma, um grupo de estudantes foi buscar referências do ensino no exterior ainda durante a greve de $1952 .{ }^{62}$ Jon Maitrejean, aluno da segunda turma, lembra que em julho daquele ano "fomos para o Uruguai e tivemos contato com a Faculdade de Arquitetura de Montevidéu, que era única, enorme". ${ }^{63}$ Ruy Gama completa que os estudantes programaram a viagem para "ver o sistema de ateliês que funcionava lá e que a gente sempre tinha ouvido falar e queria aplicar na FAU". 64

Após a greve de 52, queixas a respeito das heranças da Poli e do currículo imposto pelo padrão federal ainda repercutiam. Os alunos reclamavam do distanciamento dos professores, que apenas passavam para lecionar suas aulas e logo retornavam aos seus escritórios. Mas desde então, a principal reivindicação passou a ser a representação dos arquitetos no quadro docente.

"Nos anos subsequentes instalou-se um antagonismo intelectual entre o 'corpo discente' em torno das diretrizes culturais adequadas a uma Escola que pretendia absorver os mais avançados parâmetros da cultura contemporânea, e um 'corpo docente' que está visto, em grande parte, como indigno de uma Escola Superior". 65

Essas reivindicações acumularam apoios com o passar do tempo, através da participação dos alunos nos primeiros Congressos Nacionais de Estudantes de Arquitetura e Urbanismo, como os de Salvador, em 1952; Recife, em $1953^{66}$ e Porto Alegre, em 1954; e diversas

\footnotetext{
62 Os alunos da FAU mantinham o hábito de viajar em grupo para congressos, viagens de estudo e missões de documentação, muitas vezes acompanhados de professores e com apoio oficial da escola. Inspirados pelo trabalho do SPHAN conduzido por Luiz Saia, Rodrigo Mello Franco e Mário de Andrade, os alunos organizaram a maioria dessas viagens a partir do Centro de Estudos Folclóricos do Grêmio dos estudantes. Através do folclore nacional os alunos estabeleciam um vínculo entre a arquitetura e o povo brasileiro, fosse ela barroca, moderna ou vernacular. O espírito documental que fez parte da formação das primeiras turmas da FAU, os levou a criar aptidões em fotografia, editoração, estudo de paisagens naturais e urbanas, cultura popular, história da arte e da arquitetura, organização de debates e exposições. Ver: SODRÉ, João. Op. Cit.

${ }^{63}$ Depoimento de Jon Maitrejean a João Sodré em 12/12/2008 apud SODRÉ, João. Op. Cit., p. 187.

${ }^{64}$ GAMA, Ruy. Depoimentos, n. 1. São Paulo: FAU-USP, 1992, p. 13 apud SODRÉ, João. Op. Cit., p. 187.

${ }^{65}$ KATINSKY, Júlio. "Primeiro Seminário de Ensino FAUUSP" [2010] In: PRESTES, Lucinda Ferreira (org.). Faculdade de Arquitetura e Urbanismo da USP: documentos históricos. São Paulo: FAU-USP, 2011, p. 44.

${ }^{66}$ Vilanova Artigas foi afastado para acompanhar o Grêmio nessa viagem cf. ofício do diretor Pedro Gravina de 3 de outubro de 1953, reproduzido em ALBUQUERQUE, Roberto Portugal. Uma escola de arquitetura: FAUUSP: edifícios e ensino. Dissertação de Mestrado. Orientador: Miguel Alves Pereira São Paulo: FAUUSP, 2004, p. 163.
} 
atividades culturais do GFAU que expunham a obsolescência do ensino diante de uma nova visão cultural: exposições, palestras, cursos livres, projeção de filmes, publicações independentes, etc.

A primeira resposta dos diretores foi buscar renovar o quadro docente e ampliar a contratação de professores arquitetos, que se tornaram maioria em 1954. Entre 1953 e 1958 a FAU contratou 20 arquitetos, 7 engenheiros e 4 artistas, 2 sociólogos e 1 estatístico.

Os arquitetos, de formação diversificada, incluíram os italianos Rino Levi (1901-1965, Roma/54-59) e Achillina Bo Bardi (1914-1992, Roma/55-56); arquitetos formados no Rio de Janeiro: Enoch da Rocha Lima (?-?/53-60), Manuel da Silva Machado (?-?, FNA/54-57), Roberto José Goulart Tibau (1924-2003, FNA/57-86); e em São Paulo: Eduardo Kneese de Mello (1906-1994, Mack/55-76), Oswaldo Correa Gonçalves (1917-2005, EP/54-55), Roberto Cerqueira César (1917-2003, EP/54-66), Jacob Mauricio Ruchti (1917-1974, Mack/54-61), Carlos Alberto Cerqueira Lemos (1925, Mack/54-95), Luiz Roberto de Carvalho Franco (1926-2001, Mack/58-68); além dos primeiros egressos da FAUUSP, Luiz Gastão de Castro Lima (1927-2003/56-72), Jon Andoni V. Maitrejean (1929/55-69 e 80-87), Nestor Goulart Reis Filho (1931/56-01), Lucio Grinover (1934/58-88), Joaquim Manoel Guedes Sobrinho (1932-2008/58-00) e Dario Imparato (?-?/58-66). Também foram contratados os paisagistas Daisy Ruth Igel Hoffenberg (?-?/54-57) e Rodolpho de Almeida Fernandes (1929, FAU, 57-68); e o urbanista Lauro Bastos Birkholz (1917-2012, EP/57-87).

Entre os engenheiros estavam Klaus Reinach (?-?/53-?), Jorge Polacco (?-?/54-?), Paulo Novack Filho (?-?/54-59), José Carlos de Figueiredo Ferraz (1918-1994, EP/54-70), Carlos Rodrigues Ladeira (?-?/55-?), Paulo Ferraz de Mesquita (?-?/58-72), Paulo Sampaio Goes (?-?/53-66), Victor Manoel de Souza Lima (?-?/58-70) e o ex-governador, Lucas Nogueira Garcez (1913-1982, EP/57-66).

Os artistas eram Olga Elisabeth Nabiling Schoenfeldt (?-?/54-55), Renina Katz Pedreira (1925/56-83), Guelfo Oscar Oswaldo Campiglia (1907-1968/59-62) e Élide Monzeglio (19272006/58-97); os sociólogos, Mario Wagner Vieira da Cunha (1912-2003/54-60) e Juarez Rubens Brandão Lopes (1925-2011/54-75); e o estatístico, Álvaro Marchi (?-?/54-55).

Ao que parece, na virada para o ano letivo de 1954 todos os contratos de docentes da FAU chegaram a ser suspensos pelo diretor em um suposto apoio aos alunos que pediam a renovação do quadro docente. ${ }^{67}$ Nessa ocasião, o Conselho Universitário teria afastado os professores efetivos de outras unidades, mas esse era o caso de poucos professores. $\mathrm{Na}$ verdade, parece só ter afetado Lourival Gomes Machado, professor da FFCL, e Vilanova

${ }^{67}$ BRAGA, Juliana. Ver não é só ver: dois estudos a partir de Flavio Motta. Dissertação de mestrado em Arquitetura e Urbanismo. Orientador: José T. C. de Lira. São Paulo: FAU-USP, 2010, p. 59. 
Artigas, da Poli. Mas é muito provável que o afastamento de Artigas se devesse a razões políticas, por causa de suas viagens à URSS em 1953 e à Polônia em 1952 e de seus textos radicais na revista Fundamentos.

Desde 1948, Artigas regia a cadeira de 'Pequenas Composições de Arquitetura' na FAU. ${ }^{68}$ Sua cadeira tinha uma disciplina no $1^{\circ}$ ano, que a partir de 1949 ficou a cargo de Zenon Lotufo (também auxiliar de Anhaia Mello) e outra no $2^{\circ}$ ano, ministrada por Artigas com o auxílio de Abelardo de Souza. Artigas acumulava o cargo na FAU com o de professor da Politécnica, onde se tornara professor Assistente (estável) em 1950. A situação de Artigas na Poli, contudo, era problemática. Em 1953, havia lecionado 'Estética, Composição Geral e Urbanismo' para um único aluno remanescente do curso de arquitetura. ${ }^{69}$ No ano em que ele foi afastado da FAU os dois últimos arquitetos da Politécnica se formaram. E em 1955, Artigas regeu 'Noções de Arquitetura e Construções Civis. Higiene das Habitações. História da arquitetura' para engenheiros civis. ${ }^{70}$

Apesar de afastado, Artigas permanecia sendo uma referência para os alunos da FAU, que o elegeram paraninfo dos formandos de $1955 .{ }^{71} \mathrm{O}$ respeito dos alunos pode ter sido determinante para que, em agosto de 1956, o reitor Alípio Corrêa Netto decidisse lotar Artigas num dos primeiros cargos de Assistente (estável) da FAU - provavelmente o primeiro. ${ }^{72}$ Zenon Lotufo, que havia assumido a cadeira de 'Pequenas Composições' na ausência de Artigas, o indicou para lecionar novamente no $2^{\circ}$ ano. Nesse meio tempo, seu antigo auxiliar, Abelardo de Souza, havia sido nomeado regente da nova cadeira, 'Pequenas Composições II', para o $3^{\circ}$ ano. Em resumo, Artigas havia perdido seu auxiliar e passava a estar subordinado à Zenon Lotufo, porém, como assistente estável.

Nesse meio tempo, paralelamente à renovação do quadro docente, os diretores engenheiros trabalharam para aprovar o regulamento da FAU e realizar os primeiros concursos para catedráticos. Por razões desconhecidas a comissão responsável pela elaboração do regulamento, instituída por Anhaia Mello em 1949 (composta por Magro, Neves e Artigas) não havia avançado. Desse modo, a FAU se mantinha sob o regulamento da Escola Politécnica e por esta razão estava impedida de realizar os concursos para preenchimento

\footnotetext{
68 Ele havia sido inicialmente contratado por dois anos mediante um concurso de títulos, disputado por outros quatro engenheiros-arquitetos, conforme carta do diretor Anhaia Mello ao reitor Linneu Prestes, de 19 de agosto de 1948 apud ALBUQUERQUE, Roberto Portugal. Op. Cit., pp. 129-130. A escolha de seu nome foi feita pela Comissão de Ensino e Regimentos do Conselho Universitário.

${ }^{69}$ Cf. ofício do diretor da Poli, Pedro Francisco Maffei ao reitor, Ernesto de Moraes leme, de 9/12/1953, apud. ALBUQUERQUE, Roberto Portugal. Op. Cit., pp. 163-164.

${ }^{70}$ FICHER, Sylvia. Op. Cit., p. 297.

71 Ver seu discurso em: ARTIGAS, João Batista Vilanova. "Aos formados da FAUUSP". In AD Arquitetura e Decoração, n. 17. São Paulo: maio-junho, 1956. Republicado em Caminhos da arquitetura. São Paulo: Cosac Naify, 2004.

${ }^{72}$ Portaria n. 53 de 16 de agosto de 1956 apud ALBUQUERQUE, Roberto Portugal. Op. Cit., p. 138.
} 
das cátedras. Em 19 de novembro de 1954, uma portaria do reitor criou a Comissão de Ensino da FAU, órgão consultivo da diretoria que funcionaria enquanto não houvesse catedráticos para formar a Congregação e Conselho Técnico Administrativo da faculdade. ${ }^{73}$ Logo em seguida um projeto de lei foi apresentado à Assembleia Legislativa e, em menos de um ano, a Lei 3.233/55, que regulamentou a FAU, foi aprovada. ${ }^{74}$

O novo regulamento reafirmou, com poucas alterações, as cadeiras e a seriação das disciplinas vigentes desde 1948, e definiu detalhadamente a forma de matricula, o regime didático, a estrutura administrativa e docente, a forma de admissões e concursos, as associações acadêmicas, a organização da biblioteca e das estruturas físicas da escola, a instituição do Centro de Estudos Urbanísticos (CEPEU), seu primeiro centro de pesquisa, entre outros tantos assuntos. Destaca-se o artigo $4^{\circ}$, que previa o agrupamento das cadeiras congêneres em Departamentos; e o artigo 5ำ, que dizia que o ensino de Composição de Arquitetura seria ministrado preferencialmente em ateliês. Essas duas pautas, que adquirirão sentido muito mais amplo nos próximos anos, não implicaram, naquele momento, em medidas concretas para a integração do ensino.

Como mostra a tabela abaixo, além da renumeração das cátedras, a principal mudança foi a incorporação da cadeira de 'Plástica' nas cadeiras de 'Composição de Arquitetura', que passaram de duas para quatro. As cadeiras 'Planologia' permaneceram previstas para o curso de Urbanismo, que nunca foi implementado. A cadeira de 'Matéria Legal Legislação. Ética Profissional', também não foi efetivada. Das vinte e quatro cadeiras, que definiam o curso de arquitetura, sete concentravam as disciplinas práticas e onze eram de ciências aplicadas ou construção, regidas por engenheiros.

Dado o arranjo das cátedras, os arquitetos, que continuavam sendo minoria entre os professores da escola, na melhor das hipóteses chegariam a reger metade delas, considerando as cadeiras de teoria e história da arquitetura e de urbanismo. Desse cálculo dependia o poder na escola e a influência na universidade.

Pelo sistema de cátedras no qual a Universidade de São Paulo estava inscrito, cada cadeira deveria ser regida por um "Professor Catedrático" ou um "Regente de Cátedra" (em caráter interino para professores da USP ou precário para professores externos). Cada cátedra podia reunir uma ou mais disciplinas. Ao "Professor Catedrático" era garantido vitaliciedade e inamovibilidade, além de bons vencimentos e uma equipe composta por auxiliares de ensino. Estes, por sua vez, eram divididos hierarquicamente entre "Professores Adjuntos",

\footnotetext{
${ }^{73} \mathrm{O}$ diretor Lysandro Pereira da Silva indicou o professor Abelardo de Souza para compor a comissão. Ver: ALBUQUERQUE, Roberto Portugal. Op. Cit., p. 75.

${ }^{74}$ O Projeto de Lei n. 1.120 foi apresentado à Assembleia Legislativa em 10/12/1954, dando origem à Lei n. 3.233 , de 27 de outubro de 1955.
} 
"Livre Docentes", "Assistentes", "Professores Contratados" e "Instrutores". O "Assistente" era o primeiro nível estável da carreira, não dependendo da renovação de contratos. Após dois anos como Assistente, o professor seria obrigado a prestar concurso para "Livre Docente" o que não constituiu uma prática na FAU. O "Professor Adjunto" era o mais alto nível entre os "Livre Docentes". Finalmente, ao "Catedrático" cabia indicar seus auxiliares ao órgão colegiado e administrar sua equipe, além de participar da Congregação da unidade e poder ser nomeado para o Conselho Universitário e para cargos de direção.

\begin{tabular}{|c|c|}
\hline \multicolumn{2}{|c|}{ REORGANIZAÇÃO DAS CÁTEDRAS DA FAU EM 1956} \\
\hline Lei 104/48 (Fundação) & Lei 3.233/55 (Regulamento) \\
\hline 1. Matemática Superior & 1. Cálculo. Geometria Analítica. Nomografia \\
\hline 2. Geometria Descritiva & 2. Geometria Descritiva \\
\hline 3. Mecânica Racional & 3. Mecânica \\
\hline 4. Topografia & 4. Física Geral e Aplicada \\
\hline 5. Resistência dos Materiais & 5. Materiais de Construção \\
\hline 6. Materiais de Construção & 6. Resistência dos Materiais. Estabilidade das Construções \\
\hline 7. Hidráulica e Saneamento & $\begin{array}{l}\text { 7. Estruturas Correntes de Madeira, Metálicas e de Concreto } \\
\text { Simples e Armado }\end{array}$ \\
\hline 8. Construções Civis & 8. Grandes Estruturas \\
\hline 9. Concreto Simples e Armado & $\begin{array}{l}\text { 9. Técnica das Construções. Organização dos Trabalhos e } \\
\text { Prática Profissional. Higiene dos Edifícios. Noções de } \\
\text { Mecânica dos Solos. Fundações }\end{array}$ \\
\hline 10. Mecânica dos Solos e Fundações & 10. Hidráulica. Hidráulica Urbana e Saneamento \\
\hline 11. Grandes Estruturas & 11. Topografia, Elementos de Astronomia de Posição \\
\hline 12. Economia Política e Estatística & $\begin{array}{l}\text { 12. Noções de Economia Política. Estatística Aplicada. } \\
\text { Organização Administrativa. Legislação e Contabilidade } \\
\text { Específica }\end{array}$ \\
\hline 13. Física Aplicada & 13. Arquitetura Analítica. \\
\hline 14. Arquitetura Analítica & 14. Teoria da Arquitetura. \\
\hline 15. Teoria da Arquitetura & 15. História da Arte. Estética \\
\hline 16. Pequenas Composições de Arquitetura & $\begin{array}{l}\text { 16. Composição de Arquitetura. Pequenas composições I. } \\
\text { Desenho Arquitetônico. Plástica I }\end{array}$ \\
\hline 17. Grandes Composições de Arquitetura & $\begin{array}{l}\text { 17. Composição de Arquitetura. Pequenas composições II, } \\
\text { Plástica II }\end{array}$ \\
\hline 18. Arquitetura no Brasil & $\begin{array}{l}\text { 18. Composição de Arquitetura. Grandes composições I, } \\
\text { Plástica III }\end{array}$ \\
\hline 19. Urbanismo & 19. Composição de Arquitetura. Grandes composições II \\
\hline 20. Arquitetura Paisagística & 20. Arquitetura no Brasil. \\
\hline 21. História da Arte e Estética & 21. Desenho Artístico \\
\hline 22. Planologia I. A Evolução Urbana * & 22. Composição Decorativa \\
\hline 23. Planologia II. Análise e Sociologia Urbanas * & 23. Urbanismo \\
\hline $\begin{array}{l}\text { 24. Planologia III. Administração Municipal. Serviços de } \\
\text { Utilidade Pública * }\end{array}$ & 24. Planologia I. A Evolução Urbana * \\
\hline 25. Planologia IV. Teoria e Prática dos Planos Reguladores * & 25. Planologia II. Análise e Sociologia Urbanas * \\
\hline 26. Nomografia & 26. Planologia III. Teoria e Prática dos Planos Reguladores * \\
\hline 27. Legislação e Contabilidade & $\begin{array}{l}\text { 27. Planologia IV. Administração Municipal. Serviços de } \\
\text { Utilidade Pública * }\end{array}$ \\
\hline 28. Desenho Artístico & 28. Arquitetura Paisagística \\
\hline 29. Composição Decorativa & 29. Matéria Legal Legislação. Ética Profissional * \\
\hline 30. Plástica & \\
\hline
\end{tabular}

Em verde, as cátedras de história e teoria da arquitetura; em azul, as cátedras "práticas". As cátedras indicadas com * não foram implantadas. 
O título de "Catedrático" só podia ser obtido mediante concurso de títulos e provas prestado perante uma comissão de cinco professores nomeados pela Congregação, ou no caso da FAU, do Conselho Universitário75; o "Adjunto", através de concurso de títulos, aceite da Congregação e nomeação do governador; o "Livre docente", por exame de títulos e provas obrigatório após dois anos como "Assistente"; o "Assistente" e o "Instrutor", por indicação do catedrático e aprovação do diretor, sendo que ao último não competia dar aulas teóricas ou práticas, mas apenas supervisionar os trabalhos dos alunos. ${ }^{76}$

Na FAU, que era uma unidade nova, todos os professores eram "Contratados" e os regentes selecionados pela Comissão de Ensino e Regimentos do Conselho Universitário por prova de títulos. Nessa situação transitória, os regentes ficavam em posição superior aos auxiliares, ainda que provisoriamente e sem os pressupostos do título de "Catedrático".

A abertura de concursos para catedráticos implicava num complexo jogo político, no qual os arquitetos tinham poucas chances de ganhar. Não apenas porque seu conhecimento prático não constituía um campo consolidado do conhecimento acadêmico, mas principalmente pela resistência conservadora do Conselho Universitário, já composto por politécnicos e do qual dependia a abertura de vagas. A ordem de realização dos concursos também importava, pois, os primeiros catedráticos seriam naturalmente os próximos diretores e membros do Conselho Universitário, e determinariam os rumos da escola quando a Congregação se formasse e não dependesse mais da tutela do Conselho Universitário.

Nesses termos, entre 1956 e 1957 foram abertos oito concursos para professor catedrático. ${ }^{77}$ Desses, cinco foram para as áreas de ciências aplicas e construção; dois foram para teoria e história; e um para composição. Por diversos fatores que trataremos a seguir, apenas as cadeiras de ciências aplicas e de construção foram preenchidas.

Telêmaco Hipólito van Langendonck, catedrático pela Poli, foi o único candidato para a cadeira que já regia, de 'Resistência dos Materiais'. O mesmo ocorreu com o diretor Pedro Gravina e a cadeira de 'Grandes Estruturas'. Já Figueiredo Ferraz, que era Livre-Docente pela Poli, se apresentou como único candidato à cadeira de 'Estruturas Correntes', que até 1955 se chamava 'Concreto Armado' e era regida por Fernando José de Oliveira Escorel. Quase um ano depois foi aberto concurso para a cadeira de 'Materiais de Construção', que foi o único disputado por mais de um candidato, sendo vencido justamente pelo professor

\footnotetext{
75 Também eram previstas as possibilidades de transferência de cátedra e aproveitamento de Professor Catedrático em disponibilidade, ainda que tenham sido identificados esses casos na FAU.

${ }^{76}$ Os artigos 164 e 166 da Lei 3.233 foram vetados, sendo impossível saber como funcionava a nomeação do instrutor.

77 Informações extraídas do caderno "Concurso de Professor Catedrático: Inscrições", localizada no Expediente da FAUUSP. O caderno traz apenas informações de inscrições, não mencionando o resultado dos concursos. Outros oito concursos seriam abertos entre 1966 e 1967.
} 
Escorel. Em seguida, Pedro Moacyr do Amaral Cruz foi efetivado como catedrático de 'Geometria Descritiva'. Estes foram os cinco primeiros catedráticos da FAU.

\begin{tabular}{|c|c|c|}
\hline \multicolumn{3}{|c|}{ INSCRIÇÕES EM CONCURSOS PARA PROFESSOR CATEDRÁTICO DA FAU ENTRE 1956-57 } \\
\hline Inscrição & Cadeira & Candidatos \\
\hline 23/03/1956 & $\begin{array}{l}\text { n. } 6 \text {. Resistência dos Materiais. Estabilidade das } \\
\text { Construções }\end{array}$ & Eng. Telêmaco Hipólito de M. van Langendonck \\
\hline $\begin{array}{c}31 / 01 / 1956 \\
a \\
29 / 05 / 1956\end{array}$ & $\begin{array}{l}\text { n. 16. Composição de Arquitetura. Pequenas } \\
\text { Composições I. Desenho Arquitetônico. Plástica I }\end{array}$ & $\begin{array}{l}\text { Arq. Zenon Lotufo } \\
\text { Arq. Mario Russo } \\
\text { Arq. Paulo de Camargo e Almeida } \\
\text { Arq. José Vicente Vicari } \\
\text { Arq. Ernst Robert de Carvalho Mange }\end{array}$ \\
\hline 28/09/1956 & n. 8. Grandes Estruturas & Prof. Dr. Pedro Bento José Gravina \\
\hline $11 / 10 / 1956$ & $\begin{array}{l}\text { n. 7. Estruturas Correntes de Madeira, Metálicas e } \\
\text { de Concreto Simples e Armado }\end{array}$ & Prof. Dr. José Carlos de Figueiredo Ferraz \\
\hline $21 / 06 / 1957$ & n. 5. Materiais de Construção & $\begin{array}{l}\text { Eng. Fernando José de Oliveira Escorel } \\
\text { Eng. Luiz Alfredo Falcão Bauer } \\
\text { Eng. Renato Salmoni }\end{array}$ \\
\hline 19/08/1957 & n. 2. Geometria Descritiva e Aplicações & Eng. Pedro Moacyr do Amaral Cruz \\
\hline $6 / 09 / 1957$ & n. 15. História da Arte e Estética & Flávio Lichtenfels Motta \\
\hline $21 / 09 / 1957$ & n. 14. Teoria da Arquitetura & $\begin{array}{l}\text { Arq. Luiz Saia } \\
\text { Arq. Eduardo Corona } \\
\text { Arq. Miguel Badra Junior } \\
\text { Arq. José Vicente Vicari } \\
\text { Arq. Lina Bo Bardi }\end{array}$ \\
\hline
\end{tabular}

Em verde, as cátedras de história e teoria da arquitetura; em azul, a cátedra "prática".

Fonte: Caderno "Concurso de professor catedrático - Inscrição", localizado na seção de expediente da FAUUSP.

A mesma eficiência não foi verificada nos demais concursos. No polêmico concurso para a cátedra de Pequenas Composições I - cujas inscrições se encerraram três meses antes do retorno de Artigas como Assistente -, além de Zenon Lotufo, que estava regendo a cadeira, se inscreveram: José Vicente Vicari, que havia sido contratado como auxiliar de Elisiário Bahiana na cadeira de Grandes Composições entre 1951 e 1953 e que acabou desistindo do concurso; Ernst Mange, que nesse ano se tornou o primeiro arquiteto livre docente e estava regendo a cadeira de Desenho Artístico; Mario Russo, recém-chegado de Recife, onde havia chefiado o escritório Técnico da Cidade Universitária; e Paulo de Camargo e Almeida, ex-diretor nacional do IAB, recém-chegado do Rio de Janeiro e colaborador de Artigas no concurso para Brasília. Logo voltaremos a esse concurso, realizado em agosto de 1957, em que todos os candidatos foram desclassificados pela banca.

O concurso para a cadeira História da Arte e Estética, aberto cerca de um ano depois, apesar de ter como único candidato o professor Flávio Motta, regente da cadeira, só veio a ser realizado em 1968, onze anos após a inscrição. ${ }^{78}$

Já a cadeira de Teoria da Arquitetura foi disputada pelo regente da cadeira à época, Eduardo Corona; por Luiz Saia, que apesar de não ter sido professor da escola, era muito

${ }^{78}$ Ver: BRAGA, Juliana. Op. Cit., p. 72. 
ligado ao Centro de Estudos Folclóricos do GFAU79; por Miguel Badra, que havia sido contratado para reger essa cadeira entre 1952 e 1954; por José Vicente Vicari, que já havia desistido do concurso para a cadeira de Composição; e por Lina Bo Bardi, que havia lecionado Composição Decorativa entre 1955 e 1956, ao lado de José Maria das Neves. ${ }^{80}$ Não encontramos indícios de que as teses apresentadas ao concurso tenham sido defendidas. Fato é que Corona permaneceu à frente da cadeira e foi professor da escola até 1991, sem se tornar catedrático.

Ainda em 1956, alunos e professores se mostravam apreensivos com o novo regulamento e o início dos concursos de cátedra. Em setembro daquele ano, o estudante Júlio Katinsky divulgou, em nome do Departamento de Ensino do Grêmio da FAU, um texto provocativo que solicitava respostas por escrito de professores e arquitetos para um Seminário de Ensino. ${ }^{81}$ Segundo ele, o rápido desenvolvimento industrial havia tornado obsoleto 0 conhecimento enciclopédico e o universalismo idealista vigentes na FAU, pensados para formar os técnicos multiformes da Escola Politécnica. Contra esse modelo, os estudantes defendiam uma formação baseada na realidade profissional do arquiteto.

São conhecidas as respostas de Mário Wagner Vieira da Cunha, Luiz Saia, Vilanova Artigas e Lina Bo Bardi. ${ }^{82}$

O prof. Mário Wagner, substituindo Américo Campiglia em 1955, havia proposto uma introdução à economia e à sociologia no lugar do ensino de contabilidade. Recebido pelos alunos como um "hausto de ar puro no ambiente algo pesado do leninismo-stalinismo vigente na parte mais dinâmica da FAU"83, a resposta do professor, no entanto, questionou todas as premissas dos estudantes, perguntando se haveria uma realidade consolidada da profissão do arquiteto na qual basear o ensino. Defendendo que a discussão sobre os problemas do ensino era de valor prático muito duvidoso, Mário Wagner argumentou que os problemas levantados eram reflexos do corpo docente. Assim sugeria que os alunos trouxessem para a escola as melhores pessoas que pudessem contribuir com o ensino, fossem estrangeiros ou homens da prática local, que através de cursos paralelos ou

\footnotetext{
79 Dois anos antes, estimulado pelos alunos, Luiz Saia candidatou-se para a vaga na cadeira de Arquitetura no Brasil, quando Gomes Cardim se aposentou em 1955. Segundo Nestor Goulart, que veio a ser assistente de Eduardo Kneese de Mello nessa cadeira, em todas as escolas do Brasil os professores dessa cadeira eram do IPHAN, menos em São Paulo. Depois de negar a vaga a Luiz Saia, o Conselho Universitário suspendeu a resolução que exigia a contratação por provas de título e a direção da FAU convidou Paulo Thedim Barreto e depois José de Souza Reis, do DPHAN do Rio de Janeiro, que por motivos práticos não puderam permanecer no cargo. Somente então foi escolhido Kneese de Mello. Ver: SODRÉ, João. Op. Cit. pp. 190-192.

${ }^{80}$ Lina conseguiu se inscrever em 30/09/1957 a partir de liminar judicial ; a liminar, porém, foi cassada em 22/08/1958, conforme processo USP 14.085/57.

${ }^{81}$ KATINSKY, Júlio. "Carta do Departamento de Ensino do Grêmio da FAU”, 3 de setembro de 1956. In: PRESTES, Lucinda. Op. Cit., pp. 47-52.

82 Ver documentos transcritos em PRESTES, Lucinda. Op. Cit., pp. 43-74.

${ }^{83}$ KATINSKY, Júlio. "Primeiro seminário de ensino FAUUSP" [2010] in PRESTES, Lucinda. Op. Cit., p. 45.
} 
participações temporárias, pudessem dar maior realidade aos concursos em andamento. Wagner defendeu ainda que ex-alunos se tornassem assistentes, sendo fundamental tirar a FAU das mãos de poucos, que, como catedráticos, admitiam assistentes de acordo com suas idiossincrasias pessoais. ${ }^{84}$

Luiz Saia respondeu à provocação dos alunos apontando os vícios de origem do ensino de arquitetura. Reconhecendo como fundamentais os conhecimentos da engenharia, estes, no entanto, deveriam ser transmitidos de modo específico no curso de arquitetura, enfatizandose não o manejo dos meios técnicos, mas o conhecimento de suas capacidades, que deveriam ser ministrados "num plano não menos científico, porém, filosófico" ${ }^{85}$ A mesma tese seria válida aos conhecimentos artísticos. Para Saia, "o arquiteto é um artista plástico de uma arte, cuja gratuidade está reduzida ao mínimo. O caráter experimental, que é possível e necessário no aprendizado das outras artes plásticas não pode acontecer, por motivos óbvios, no ensino da arquitetura". ${ }^{86}$ Saia, porém, achava que o exercício absorvente na prancheta, ainda que fosse um fundamento sine qua non da formação do arquiteto, também poderia levar a uma perigosa desvinculação dos problemas contemporâneos. Por fim, a conclusão de Saia deve ter frustrado os alunos interessados em reformar a FAU:

"consideradas realisticamente, as atuais condições de ensino da arquitetura, resta aos alunos, num esforço pessoal de complementação, a escolha daqueles contatos pessoais e daqueles caminhos que lhes pareçam mais consentâneos e mais logicamente relacionados com a atual realidade político social e econômica. Coletivamente, esta solução corresponde à realização de um curso paralelo, o que só é possível em pouquíssimos setores da obrigação escolar". 87

Já Lina Bo Bardi argumentou que a angústia dos estudantes era semelhante à dos profissionais, carentes de um meio para resolver os problemas reais humanos. Os problemas do ensino, levantados dispersivamente pelos alunos, seguiriam confusos e insolúveis enquanto a escola permanecesse acadêmica e diversa à vida. Para Lina, a escola precisava abdicar da pseudocultura e da teoria estéril e começar a falar a linguagem da vida real. Sem apontar soluções práticas, no entanto, mas mencionando os concursos em

\footnotetext{
${ }^{84}$ CUNHA, Mario Wagner V. da. "Intervenção do professor Mário Wagner Vieira da Cunha", In: PRESTES, Lucinda. Op. Cit., pp. 53-58.

${ }^{85}$ SAIA, Luís. "Intervenção do professor Luís Saia”, In: PRESTES, Lucinda. Op. Cit., p. 61.

${ }^{86}$ Idem, p. 62.

${ }^{87}$ Idem, p. 65.
} 
andamento, a arquiteta apelava à consciência dos professores na comunicação de um método eficiente e aos alunos na capacidade de desenvolver o método dos professores. ${ }^{88}$

Vilanova Artigas, que acabara de regressar à FAU na condição de assistente, após dois anos de ostracismo na Poli, respondeu por uma linha completamente diferente. Para Artigas, a polêmica levantada pelos estudantes revelava a vitalidade dos meios artísticos, particularmente do movimento moderno, em grande medida responsável pela mudança no panorama do ensino de arquitetura através da fundação das novas faculdades de arquitetura, desligadas dos cursos de engenharia..$^{89}$

Ainda segundo o professor, os arquitetos encontravam-se fragilizados como profissionais, fosse nos órgãos de governo, fosse na construção privada, sendo as grandes conquistas da arquitetura sempre excepcionais e quantitativamente insignificantes. Esse antigo conflito da profissão, no entanto, seria mais sensível aos jovens arquitetos, na medida em que as oportunidades públicas e privadas não valorizavam a liberdade criativa e a solução de grandes problemas para as quais as novas escolas os preparavam, ainda que de modo imperfeito.

Seguindo este raciocínio, Artigas neutralizou, uma a uma, todas as teses de seus colegas: a tese do divórcio entre a escola e a vida, a tese do vício de origem e a tese do vício do regime docente. "A tendência mais natural é voltar os olhos para trás e responsabilizar o ensino por estes contrastes, responsabilizar as escolas que a custo têm surgido". Apesar de reconhecer a validade dos argumentos, Artigas julgava exagerado ver neles a causa de todos os males. Os professores, afinal, estariam sujeitos às mesmas limitações que oprimiam os jovens. A escola seria, igualmente, vítima. As correções sugeridas pelos outros professores, ainda que oportunas, "não modificariam em quase nada o processo que estamos vivendo". 90

Alinhado com pauta do IAB, Artigas mencionava, por exemplo, o Decreto 23.569/33, que regulamentava a profissão, e as leis municipais de construção, como responsáveis por moldar a prática e o ensino da arquitetura pelo caminho do atraso. Paralelamente, cobrava uma visão cultural mais ampla do estado paulista e denunciava a subjugação da arquitetura às manobras comerciais no setor imobiliário.

"O que é o desajuste entre a escola e a realidade, senão o choque entre uma consciência profissional que vem sendo formada e se

\footnotetext{
${ }^{88}$ BO BARDI, Lina. “Intervenção da professora Lina Bo Bardi”, In: PRESTES, Lucinda. Op. Cit., p. 73.

${ }^{89}$ ARTIGAS, João B. Vilanova. "Intervenção do professor João Vilanova Artigas" in PRESTES, Lucinda Ferreira. Op. Cit., pp. 66-72. Republicado em ARTIGAS, João Batista Vilanova. "Rumos para o ensino da arquitetura", Caminhos da arquitetura. São Paulo: Cosac Naify, 2004.

90 Idem.
} 
fortalecendo em séculos e uma estrutura 'prática' limitada por um sem número de reminiscências coloniais"?

Por essa razão, Artigas achava que a escola não deveria se subjugar a essa noção desvirtuada de pratica profissional, sendo preferível elevar cada vez mais o nível teórico e cultural, insistindo num conhecimento mais profundo da arte brasileira, da sua história e das causas que freavam o desenvolvimento da técnica e da cultura.

Sem bater de frente com regulamento da FAU ou com seu quadro docente, Artigas propunha focar o ensino no exercício da profissão, com o intuito de estudá-lo e modificá-lo, e não de reproduzi-lo. No contexto da revisão doutrinária promovida pelo relatório Kruschev, divulgado naquele semestre, Artigas defendia, acima de tudo, manter "um clima de liberdade para a livre pesquisa, para a livre criação, contra tudo o que limita a livre expressão do pensamento, o livre acesso ao conhecimento". ${ }^{91}$

Esse, nos parece, foi o momento em que Artigas se credenciou perante alunos e professores como referência sobre o ensino de arquitetura. As manifestações desse Seminário de Ensino se limitavam ao discurso, mas fortaleceram as reivindicações por uma reforma do ensino. Para dar uma resposta à insatisfação com o modelo de ensino da FAU, o diretor Gravina nomeou, em 1957, uma comissão composta por Rino Levi, Vilanova Artigas, Abelardo de Souza e Hélio Duarte, para examinar e propor medidas concretas. O relatório apresentado em julho de 1957, dez meses depois do Seminário de Ensino promovido pelo GFAU, foi o seguinte:

"O ensino da arquitetura constitui um problema de certa complexidade no mundo contemporâneo. Um exame superficial dos debates em curso nas principais organizações universitárias em torno dos critérios dentro dos quais formar arquitetos evidencia nitidamente que há um sério desajuste entre os 'curricula' universitários e a vida profissional do arquiteto. As causas fundamentais desse desajuste, em nossa opinião, não repousam inteiramente no processo de instruir os profissionais. Elas terão suas raízes mais além, dentro da própria organização da sociedade e dos conflitos entre a técnica e a arte contemporâneas. Entretanto é inegável que na procura da integração do arquiteto à sua missão social, um papel preponderante cabe às organizações de ensino e preparação de profissionais.

No Brasil temos pouca experiência de ensino da arquitetura; pouco temos feito para a criação de métodos mais consentâneos com o nosso desenvolvimento. Agora, com a necessidade de enfrentarmos

\footnotetext{
${ }^{91}$ Idem.
} 
um progresso emancipador, aparece o arquiteto brasileiro como fator indispensável no conjunto social que se modifica rapidamente. Os sucessos da arquitetura brasileira, de outro lado, despertaram a atenção do mundo civilizado para o nosso país, o que implica em maior responsabilidade no sentido de manter o prestígio que desfrutamos.

Se temos pouca experiência e pouca tradição no ensino da arquitetura, em compensação estamos menos comprometidos com métodos hoje mundialmente considerados antiquados e contraproducentes. Convém frisar que temos todas as condições para iniciar um novo ciclo de experiências em torno do ensino dentro de um espírito mais evoluído, longe das limitações características de um tradicionalismo que só à primeira vista é difícil de romper.

É chegado o momento de fazer desaparecer a confusão que ainda existe entre as carreiras do engenheiro e do arquiteto. Este vício de origem tem raízes profundas. Para não irmos muito longe, basta uma vista de olhos no decreto 23569 que regulamenta o exercício das duas profissões. No ensino da arquitetura esse espírito se reflete no vezo de adaptar os curricula das escolas de engenharia ao invés de criarmos métodos próprios e originais explorando o rico repositório de informações que a experiência universal nos oferece.

Para a formação do arquiteto as disciplinas de caráter técnico servem para informação tanto quanto as disciplinas históricofilosóficas. A missão do arquiteto, no entanto, é mais complexa. Dele se exige algo mais, isto é, uma síntese, uma visão unitária do mundo contemporâneo e da sociedade em que vive, que envolva e dê expressão às estruturas de toda a sorte.

Do arquiteto se exige uma soma de conhecimentos que tanto quanto possível possa lhe fornecer os meios para desempenhar com segurança sua missão exprimindo o grau de desenvolvimento cultural da sociedade em que vive. Não é por outra razão que se encontra nas programações das escolas estrangeiras mais progressistas uma insistência sobre a expressão "arquiteto integral", particularizando para ele uma visão universal e única do mundo que o envolve.

Walter Gropius, que dos grandes arquitetos contemporâneos é talvez o que maior contribuição tem dado para o esclarecimento desses conceitos assim se exprime: "o arquiteto é um coordenador cuja missão é unificar os numerosos problemas sociais, técnicos, econômicos e plásticos inerentes à construção". E sobre o ensino em particular: "o campo de ação do aluno deve ser universal e não fragmentário, compreendendo todos os conhecimentos e a experiência real". 
A nossa escola tem todas as condições para aproximar-se dessas aspirações conservando mesmo o conjunto de disciplinas que constam do curso atual, sem maiores mudanças que se afastem da atual estrutura federal de ensino. O próprio quadro de professores da escola, a nosso ver, não precisa de modificações, a não ser em número, que os que temos são poucos, principalmente no atelier de composição, para atender as suas variadas exigências. O quadro de professores que dispomos é composto de elementos experimentados, habilitados técnica e culturalmente para 0 desempenho do ensino da arquitetura. O que mais nos falta, talvez é uma maior integração de todos os valores em uma equipe harmônica e convicta das possibilidades que realmente temos de dar um passo à frente na solução da missão que assumimos. O espírito de colaboração existe em alto grau. Esta é uma convicção que se firmou em anos de convívio e que se reforçou nos frequentes contatos que tivemos com a totalidade dos professores que conosco discutiram o programa de ensino que hora apresentamos. Este programa, portanto, não representa opiniões individuais ou de um pequeno grupo, mas o produto de laborioso estudo para o qual todos contribuíram.

O programa proposto define a orientação que se pretende dar ao ensino da arquitetura na nossa escola. Achamos oportuno dar à Composição a importância que a mesma tem no exercício da profissão. Assim, nos parece acertado colocar o atelier em posição de destaque e fazer convergir para ele todas as disciplinas do currículo.

Algumas disciplinas que figuram no atual programa da escola e que não foram incluídas do programa proposto seriam enquadradas no atelier.

A organização e o funcionamento do atelier, em nossa opinião, deverão apresentar estrutura flexível, adaptando-se cada vez mais às necessidades dos trabalhos programados pelos professores". 92

Tal relatório era acompanhado de um esquema de reestruturação do ensino que enfatizava os exercícios de composição, reunindo e organizando as cadeiras existentes, estabelecendo distinções de natureza e função educativa de cada matéria e propondo grupos de matérias de formação científica, de cultura apropriada e de atelier. Sem modificar as cadeiras existentes, a comissão propôs apenas uma nova seriação das matérias, concentrando nos primeiros anos as cadeiras técnicas e nos últimos as de cultura apropriada. Os exercícios de ateliê seriam constantes em todos os anos, sendo que, nos primeiros, seriam fornecidos

\footnotetext{
92 Relatório da comissão composta pelos professores João Vilanova Artigas, Rino Levi, Abelardo de Souza, Hélio Duarte. Acervo pessoal Vilanova Artigas. Disponível em <www.dearquiteturas.com>, acesso em 28/04/2015.
} 
subsídios de linguagem e representação para os exercícios de projeto realizados a partir do $3^{\circ}$ ano.

Como analisou Carlos Millan, dada a necessidade de manter o ensino inscrito no quadro vigente da legislação federal, seus autores abriram mão de propostas mais ambiciosas, conseguindo, entretanto, apresentar um "esquema de reestruturação inteligente e versátil". 93 Mas apesar do pragmatismo das propostas, elas não foram implementadas. Pelo menos não naquele momento.

Enquanto isso, os concursos continuavam ocorrendo na FAU. A banca para professor catedrático de 'Pequenas Composições l' foi realizada entre os dias 9 e 19 de agosto de 1957. ${ }^{94}$ Ernest Mange teve a maior média $(7,00)$, seguido por Paulo de Camargo e Almeida $(6,80)$, Zenon Lotufo $(6,74)$ e Mario Russo $(6,06)$. Mas a banca examinadora, composta pelos professores Demétrio Ribeiro (FA-URGS), Sylvio de Vasconcelos (FA-UMG), Lourival Gomes Machado (FFCL-USP), Diógenes Rebouças (EBA-UB) e presidida por José Benedito de Camargo (ESALQ-USP), considerou que nenhum dos candidatos estava à altura do cargo e decidiu reprovar todos. A contestação judicial durou sete anos, mas a decisão não foi revertida.

\begin{abstract}
"Claro que a questão política contava muito naquela época. Os grupos se dividiam nitidamente em direita, esquerda e centro. A postura de Zenon nunca foi muito clara, não se posicionava claramente. A posição de nós, alunos, sempre foi desfavorável à Cátedra e ao concurso. Não era nada pessoal, contra o Zenon ou o Mange, por exemplo. Por isso, nossas vaias e a comemoração no fim do concurso". ${ }^{95}$
\end{abstract}

Para Lotufo, que esperava se efetivar no posto, tornando-se o primeiro arquiteto catedrático da FAU, o concurso foi "eivado de sérias irregularidades, desde a insuficiência de formalidades legais, até a mais completa irresponsabilidade de certos membros da banca examinadora (dois deles cassados e com direitos políticos suspensos por 10 anos)". ${ }^{96}$ Mas Lotufo deve ter suspeitado que, direta ou indiretamente, Artigas e seus apoiadores foram responsáveis pelo resultado, pois no dia seguinte dispensou seu assistente:

\footnotetext{
${ }^{93}$ MILLAN, Carlos B. "O ateliê na formação do arquiteto". Relatório apresentado pelo professor Carlos Barjas Millan, coordenador do grupo de estudo do Ateliê. São Paulo: FAUUSP, 1962, p. 35. Republicado na Revista Sinopses, da FAUUSP, número especial de 1993.

94 Ver: MODENESE FILHO, Eduardo. Entre linhas e curvas: a teoria e a prática na obra de Zenon Lotufo. Dissertação de mestrado. Orientador: Lúcio Gomes Machado. São Paulo: FAUUSP, 2008, p. 124.

${ }^{95}$ Depoimento de Jon Maitrejean a Eduardo Modenese Filho, em 30/10/2007 apud MODENESE FILHO, Eduardo. Op. Cit., p. 124.

${ }^{96}$ Atribuído a Zenon Lotufo [1957], sem ref. apud MODENESE FILHO, Eduardo. Op. Cit., p. 125.
} 
"Não merecendo mais minha confiança, o sr. J. B. Vilanova Artigas, meu assistente no $2^{\circ}$ ano da Cadeira $n^{\circ}$ 16, Composição de Arquitetura, solicito o seu imediato afastamento". .7

Três dias depois de dispensar Artigas, Lotufo solicitou licença médica e acabou desligandose definitivamente da FAU no final de outubro daquele ano. Já Artigas, que possuía estabilidade, foi colocado à disposição para aproveitamento em outra cátedra. Manifestaram interesse em tê-lo como assistente os regentes, Mário Wagner Vieira da Cunha, da cadeira de 'Noções de Economia Política' - muito embora ressaltando que o arquiteto seria mais bem aproveitado numa cadeira de Composição -, Abelardo de Souza, de 'Pequenas Composições Il', e Rino Levi, de 'Grandes Composições II'. ${ }^{98}$ A Comissão de Ensino indicou Artigas para auxiliar Rino Levi na cadeira do $5^{\circ}$ ano.

Como vimos até aqui, o retorno de Artigas à FAU coincidiu com o amadurecimento das ideias sobre a reforma do ensino. Em sintonia com as mudanças políticas no PCB, Artigas saia da retaguarda para liderar uma campanha institucional ofensiva e pragmática. Nesse sentido montou uma equipe para o concurso de Brasília, integrou em 1957 o Conselho Superior do IAB e orientou o projeto vencedor no concurso de internacional de estudantes na IV Bienal. ${ }^{99}$ A própria renovação formal assistida em sua obra pode ser relacionada a uma visão programática renovada da profissão e refletida no ensino.

O ensino de arquitetura e urbanismo continuou sendo discutido dentro e fora da FAU. Em 1958 foi realizado o 1 Seminário Nacional de Ensino de Arquitetura e Urbanismo, dentro do $1^{\circ}$ Encontro Nacional de Estudantes de Arquitetura, ocorrido em São Paulo com apoio da seção regional do IAB. Suas resoluções incorporaram em grande medida as propostas do Seminário de Ensino e da Comissão para reforma do ensino da FAU, como a instituição do ateliê como linha central do ensino, com aumento da carga horária para os trabalhos de composição a seriação decrescente de matérias técnicas e crescente de matérias culturais. Também se falava na necessidade de departamentos ou estruturas equivalentes - que estavam previstos no Regulamento da FAU - para coordenar as matérias visando a unidade do curso. ${ }^{100}$

\footnotetext{
${ }^{97}$ Carta de Zenon Lotufo ao diretor Pedro Gravina, 20/8/1957, apud ALBUQUERQUE, Roberto Portugal. Op. Cit., p. 145.

${ }^{98}$ Cf. ALBUQUERQUE, Roberto Portugal. Op. Cit., pp. 140-142.

${ }^{99}$ A equipe foi formada pelos alunos do $4^{\circ}$ ano, Abrahão Sanovicz, Heberto Lira F. S, Hélio Penteado, José Caetano de Mello, e do $5^{\circ}$ ano, Jaguanhara Ramos, Jerônimo Bonilha, João Rodolfo Stroeter, Júlio Katinsky e Lúcio Grinover (do $5^{\circ}$ ano). Colaboraram os professores Mário Wagner Vieira da Cunha, Hélio Duarte, Roberto Coelho Cardozo. Ver ofícios reproduzidos em ALBUQUERQUE, Roberto Portugal. Op. Cit., pp. 165-168.

${ }^{100}$ CERQUEIRA CÉSAR, Roberto de. "O ensino da arquitetura e do urbanismo". Relatório de 1960, reproduzido em MILLAN, Carlos B. Op. Cit.
} 
As resoluções daquele seminário iam além e defendiam que o ensino fosse ligado à prática da construção através de oficinas experimentais e canteiros de obra. Pesquisas sobre técnicas construtivas e sobre a realidade brasileira deveriam ser incentivadas com a criação de bolsas de estudo e prêmios, compreendendo viagens de estudo e estágios de pósgraduação remunerados. Para os participantes daquele evento, a remuneração do corpo docente também deveria melhorar para atrair os profissionais mais habilitados para o ensino. Como muitas dessas propostas eram incompatíveis com a legislação vigente, mantinha-se a ideia de que algumas delas fossem aplicadas por meio de cursos paralelos, e atividades informais - o que, em parte, já acontecia na FAU, não só através do GFAU, mas também por iniciativa dos professores, que, por exemplo, levavam os alunos para visitar seus canteiros de obra. ${ }^{101}$

Todas essas ideias sobre o ensino eram acompanhadas de uma mobilização pela revisão do Decreto 23.569/33, que pretendia dar ao arquiteto a exclusividade no exercício da arquitetura. Essa batalha do IAB - sempre lembrada por Artigas como exemplo do atraso cultural do país e apontada como questão estrutural da reforma do ensino - culminou em um projeto de lei de nova regulamentação profissional, apresentado naquele mesmo ano ao presidente Kubitschek.

Enquanto a ideia de reforma do ensino e da regulamentação profissional avançavam para um consenso teórico entre os arquitetos na FAU, a posse dos catedráticos e a prática do ensino apontavam para um sentido contrário, de consolidação do modelo que se queria rejeitar. Somente um diretor com prestígio e autoridade poderia levar uma reforma adiante e interromper os concursos. O nome defendido foi o de Anhaia Mello e a eleição do governador Carvalho Pinto e a nomeação do reitor Ulhôa Cintra em 1959 - ambos mais sensíveis às pautas dos arquitetos - criou as condições para que isso acontecesse. Anhaia foi reconduzido à diretoria da FAU em 1959 faltando menos de três anos para se aposentar compulsoriamente.

${ }^{101}$ Depoimento de Sérgio Ferro ao autor, realizado em 18 de fevereiro de 2011. 


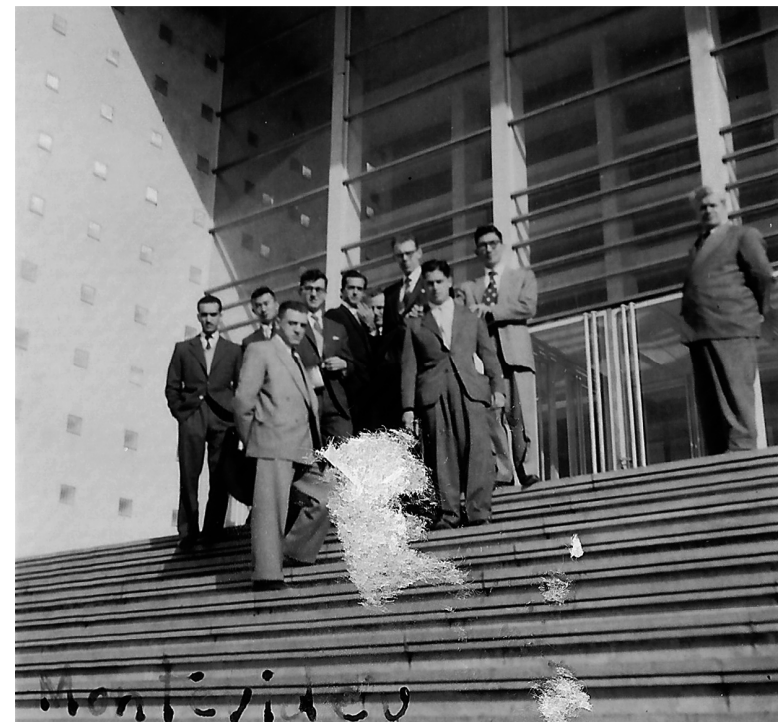

Visita dos alunos da segunda turma FAU à Faculdade de Arquitetura de Montevideo, Uruguai, julho de 1952. Arquivo Domingos Theodoro de Azevedo Netto

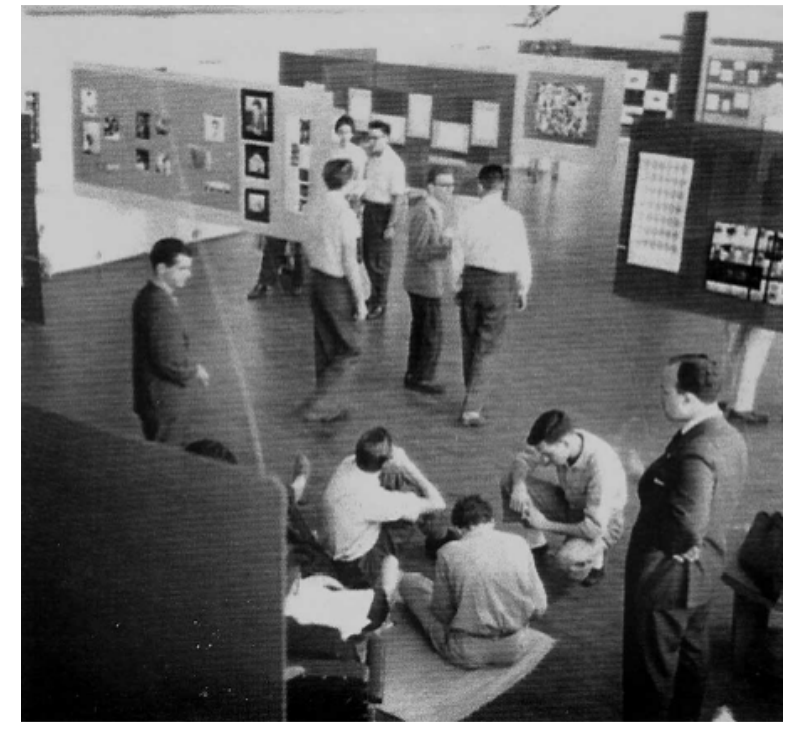

Exposição “Artistas de Domingo”, na Vila Penteado, 1956. Arquivo João Baptista Xavier

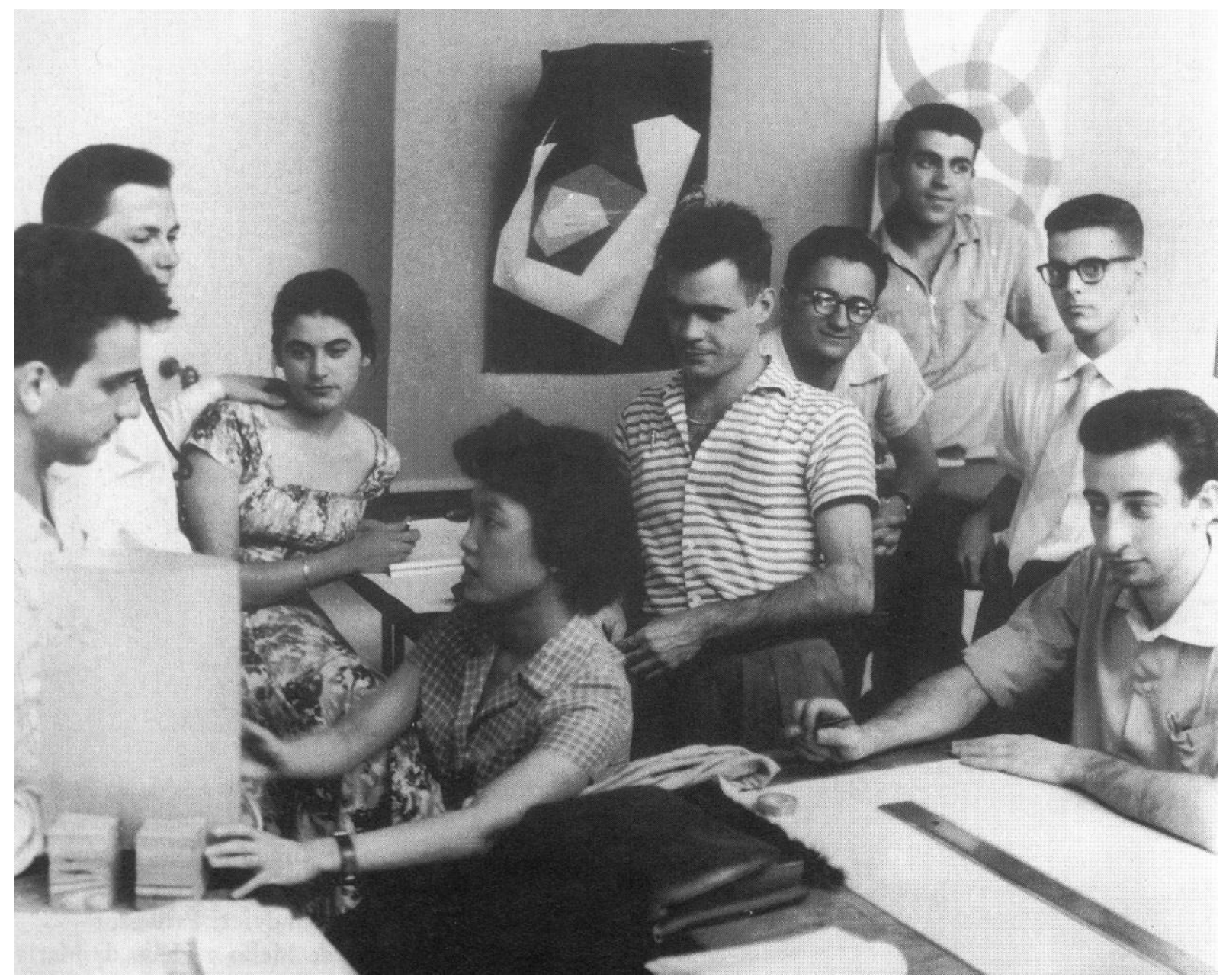

Vida no ateliê. Da esquerda para direita: Sérgio Dompieri, Ubertelo Bulgarini, Elza Emília Gaeta, Mayumi Watanabe, Luiz Nogueira, Ayrton Laragnoit, Antônio Augusto Antunes Neto, Rufino Reis Soares e Sérgio Zaratin. Foto B. L. Toledo, 1957 


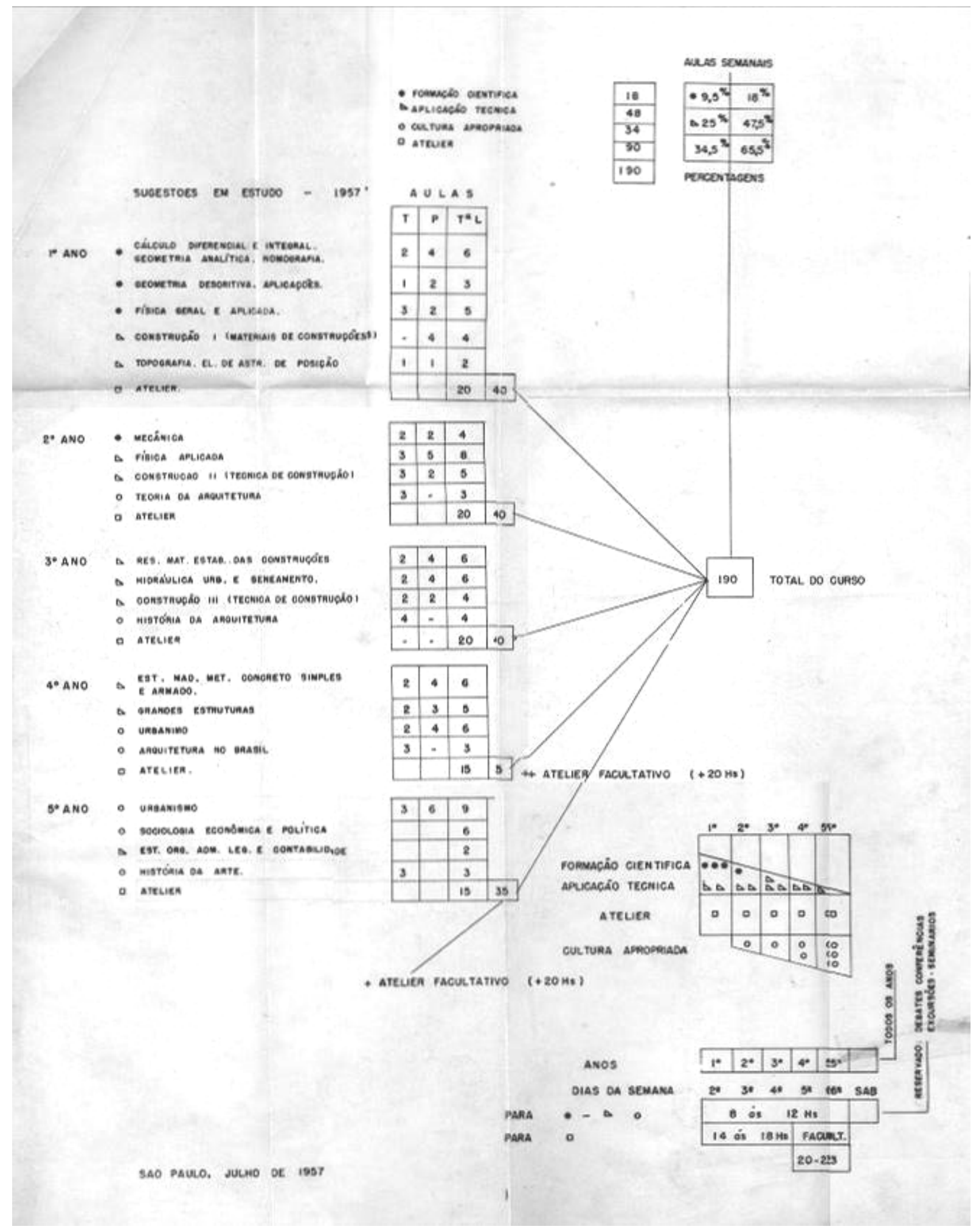

Relatório esquemático da Comissão de Ensino, 1957 
REFORMA DO ENSINO (1959-1963)

A segunda direção de Anhaia Mello (28/02/1959 a 28/08/1961) foi marcada pela interrupção dos concursos de cátedra e pela contratação de jovens arquitetos como auxiliares de ensino, entre eles: Carlos Barjas Millan (1927-1964, Mack/59-64), Leo Quanji Nishikawa (??, FAU/59-67), Ariaki Kato (1931, FAU/59-68), Jose Ribamar da Silva (?-?, FAU/59-69), Paulo Mendes da Rocha (1928, Mack/60-69 e 80-98), Miranda Maria Esmeralda Martinelli Magnoli (1932, FAU/60-88), Gian Carlo Gasperini (1926, ENBA/60-96). Também foram contratados o engenheiro de produção Max Barcellos Correa (1928, EP/60-63) ${ }^{102}$ e o engenheiro inglês John Manoel de Souza (1930/60-70), que atuava próximo aos arquitetos modernos. ${ }^{103}$

Em maio de 1959, Rino Levi se afastou para lecionar como professor convidado na Faculdade de Arquitetura da Universidade Central da Venezuela, de onde surgiu a oportunidade de projetar hospitais na Venezuela. Nessa ocasião, já sob a direção de Anhaia Mello, Artigas assumiu interinamente a cadeira. No início do ano letivo de 1960, Rino Levi se afastou definitivamente da escola e Artigas foi designado para substituí-lo, tornando-se o regente da cátedra mais prestigiada da escola - a mesma que Anhaia Mello havia oferecido para Oscar Niemeyer oito anos antes.

Apesar de não haver documentos que comprovem, três indícios permitem supor que foi nesse momento, entre o segundo semestre de 1959 e o início de 1960, que Artigas começou a projetar o novo edifício da FAU. O primeiro deles é um artigo de Miguel Pereira, de 1960, que traz o primeiro registro textual encontrado do projeto. ${ }^{104} \mathrm{~A}$ nota da republicação deste artigo traz a informação que naquele ano o projeto de Artigas havia sido exposto no hall de exposições da FAU-UFRS e objeto de um "seminário". É muito provável que tal seminário tenha ocorrido no $2^{\circ}$ Encontro Arquitetos, Professores e Estudantes de Arquitetura, mencionado no texto, e realizado em Porto Alegre, em abril de 1960, sob patrocínio do IAB-RS.

Naquele encontro, ainda pautado pela campanha nacional por uma nova legislação profissional, a reforma do ensino de arquitetura foi novamente tema central. Pela primeira

\footnotetext{
102 Assim como Américo Oswaldo Campiglia, Max Correa era assistente da cátedra 19 'Economia Política, Estatística Aplicada e Organizações Administrativas' da Escola Politécnica, regida por Ruy Leme, da qual resultou o curso de engenharia de produção em 1959.

${ }^{103}$ A partir de 1962, John de Souza foi sócio da empresa de móveis Mobilinea. Ver: HUGERTH, Mina Warchavchik. Mobilinea design de um estilo de vida (1959-1975). Dissertação de mestrado. Orientador: José Tavares Correia de Lira. São Paulo: FAUUSP, 2015.

104 PEREIRA, Miguel. "Sobre o Projeto da Faculdade de Arquitetura e Urbanismo da Universidade de São Paulo", Cadernos de Estudos. FA-UFRS, 1960. Republicado em: Arquitetura e os caminhos de sua explicação. São Paulo: Projeto Editores Associados, 1984.
} 
vez nesse tipo de evento, os participantes enfatizaram que além do currículo oficial, que representava uma razão particular para as deficiências do ensino de arquitetura, havia também uma razão geral, que afetava todo ensino superior, que era a centralização e a rigidez da estrutura da universidade, bem como a insuficiência de recursos. ${ }^{105}$ Desse modo a campanha pela reforma do ensino da arquitetura passava a combater com maior ênfase o caráter permanente e estanque das cátedras e a falta de autonomia das faculdades. ${ }^{106}$

Para Miguel Pereira, o projeto da FAU despontava como o fruto mais promissor daquele movimento de renovação do ensino de arquitetura e urbanismo, em discussão desde os anos 1950. A grande contribuição de Vilanova Artigas teria sido materializar as propostas de reforma do ensino da FAUUSP em um projeto de arquitetura dentro e apesar da estrutura vigente do ensino, invertendo a expectativa de se passar à prática apenas depois de uma improvável vitória legal.

"Em todas as conversas que mantivemos com o arquiteto Artigas sobre esse trabalho, vimos bastante claro o propósito do arquiteto em utilizar a oportunidade no sentido de levar à prática as nossas, já bastante conhecidas, reivindicações no plano do ensino. [...] $\mathrm{E}$ a propôs através de um projeto, de uma formulação espacial, de uma organização do espaço, onde passará a viver a massa do estudantado e seus mestres. Cabe, desde já, advertir aos mais exigentes, que não pertence à estrutura cultural de Vilanova Artigas esse propósito de descobrir qualidades mágicas no campo da Arquitetura, a ponto de acreditar que um projeto, uma organização espacial, possa resolver os graves problemas que envolvem o ensino de arquitetura, e em geral o ensino superior no Brasil. [...]. É fácil compreender-se que o simples fato desta Faculdade ter sido construída para abrigar um novo estilo de vida universitária venha a constituir-se num elemento catalisador de grande importância na preparação do elemento humano. De nada nos valerá o texto frio da lei, preceituando uma reforma adequada, se não dispusermos do campo preparado - o elemento humano, preparado e consciente". ${ }^{107}$

Ainda de acordo com Miguel Pereira, a "experiência paulista", que se realizaria com a construção da nova FAU dentro de dois anos, constituiria um campo fértil e dinâmico, capaz

\footnotetext{
${ }^{105}$ Entre as resoluções do encontro, destacamos: 1) repudiar o projeto de lei do Conselho Federal de Engenharia e Agronomia (CONFEA), que subordinava as atividades profissionais a entidades comerciais e negava a paridade no órgão incumbido de delimitar os campos profissionais; 2) manifestar que a obsolescência do ensino de arquitetura tornou-se incompatível com as necessidades de desenvolvimento cultural do país; 3 ) indicar a necessidade de substituição da legislação do ensino superior vigente por formas mais flexíveis; 4) reafirmar que o desenho industrial, a decoração, o paisagismo e o planejamento fazem parte do campo da arquitetura, devendo ser incorporados em sua formação; 5) e manifestar-se contrariamente aos cursos de pós-graduação, por desmembrarem o campo profissional da arquitetura. CERQUEIRA CÉSAR, Roberto de. Op. Cit

${ }^{106}$ PEREIRA, Miguel. Op. Cit., p. 82.

107 Idem, p. 81.
} 
de dar sentido prático à reforma teórica do ensino. Essa seria a "única medida em condições de salvar do descrédito esta campanha pela reforma do ensino da arquitetura, que há tantos anos vem ocupando nossas preocupações". ${ }^{108}$ Além do programa funcional do edifício, cujos ateliês, departamentos ${ }^{109}$, oficinas e museu constituiriam os pontos fundamentais da proposta de ensino, o projeto de Artigas se destacava como um manifesto dos novos caminhos da arquitetura moderna.

O segundo indício de que o projeto já podia estar pronto em 1960, encontra-se no Relatório das Atividades do Fundo para a Construção da Cidade Universitária, de agosto daquele ano, que trazia uma relação dos projetos a serem desenvolvidos e a informação de que o anteprojeto da FAU se encontrava "em estudo entre os próprios alunos do $4^{\circ}$ ano daquela Faculdade". ${ }^{110} \mathrm{Na}$ verdade, deve ter havido um erro nessa informação, sendo mais provável a disciplina do $5^{\circ}$ ano. ${ }^{111}$ Por fim, o terceiro indício, que comprovaria tal erro, vem do depoimento de Sérgio Ferro (aluno do 5o ano em 1961), segundo quem Artigas teria dado dois temas de projeto aos alunos daquele ano: a embaixada do Brasil em Cuba e o projeto de uma faculdade de arquitetura. ${ }^{112}$

Assim, é muito provável que Artigas tenha proposto o tema da escola de arquitetura como exercício aos alunos em 1960 e repetido o exercício em 1961, enquanto trabalhava no projeto da FAU. De tudo isso, resulta uma interessante relação entre o projeto, o debate sobre o ensino e a docência de Artigas em 'composição de arquitetura'.

O que, no entanto, chama a atenção é a ausência de outras menções ao projeto de Artigas nos debates sobre o ensino que sucederam, como o I Encontro de Diretores, Professores e Alunos das Escolas e Faculdades de Arquitetura, realizado em agosto de 1960, em Belo Horizonte, cujas resoluções seguiam a mesma direção dos eventos anteriores. ${ }^{113}$ Ou então o Encontro Regional de Educadores Brasileiros, promovido pelo Serviço Social da Indústria (Sesi) e pelo Ministério da Educação, em São Paulo, no mesmo ano, cuja Comissão de Arquitetura e Urbanismo foi composta basicamente por professores da FAU. ${ }^{114}$ Desse

\footnotetext{
108 Idem, p. 82.

${ }^{109}$ Segundo Pereira, os departamentos propostos por Artigas seriam: Departamento de Matemáticas; Departamento de História e Arte; Departamento de Urbanismo; Departamento de Construções.

${ }^{110}$ ALMEIDA. Paulo de Camargo. "Relatório de atividades do Fundo para a Construção da Cidade Universitária Armando Salles de Oliveira", de 10 de agosto de 1960. Ver: Processo USP n. 60.1.19244.1.2, fls. 4-6.

${ }^{111}$ A cadeira de composição do 4ํano era a de número 18, 'Grandes Composições I e Plástica III', regida naquela ocasião por Roberto Cerqueira César. Considerando que havia quatro cadeiras de composição, nos cinco anos de curso e que a primeira era dada em duas partes, no $1^{\circ}$ e $2^{\circ}$ ano, é provável que o relatório se referisse, na verdade, à quarta cadeira, de número 19 , 'Grandes Composições II', assumida por Artigas no ano anterior.

112 Depoimento de Sérgio Ferro ao autor, realizado em 18 de fevereiro de 2011.

${ }^{113}$ Ver: CERQUEIRA CÉSAR, Roberto de. Op. Cit.

${ }^{114}$ A Comissão foi composta por Vilanova Artigas, Roberto Cerqueira César, Hélio Duarte, Joaquim Guedes, Carlos Millan, Lúcio Grinover, Roberto Coelho Cardoso, Luiz Roberto de Carvalho Franco, Miranda Magnoli, Roberto Cerqueira César e 136
} 
encontro, aliás, resultou o relatório de Cerqueira César intitulado "O ensino da arquitetura e do urbanismo", citado até aqui. Encomendado por Anhaia Mello, o célebre relatório sintetizava os debates e resoluções aprovadas nesse e noutros encontros anteriores, sem qualquer menção ao projeto de Artigas.

Nessa ocasião, Cerqueira César notou um consenso em relação à revisão da regulamentação profissional; à crítica ao sistema de cátedras - responsável por um ensino atomizado, de alto padrão teórico, mas exclusivamente analítico; à defesa do ateliê como forma de integrar as cadeiras técnicas nos trabalhos de projeto; ou em relação à concentração da formação técnica nos anos iniciais. Para Cerqueira César algumas propostas poderiam ser implantadas imediatamente, como a de que todo o ensino fosse ministrado ou orientado por um arquiteto. Mesmo as cadeiras técnicas poderiam ter arquitetos como assistentes, o que favoreceria uma feição aplicada às matérias teóricas. Nas cadeiras de composição, contudo, dever-se-ia evitar o contrato em tempo integral, sendo desejável que o professor mantivesse sua experiência profissional.

Mas a principal contribuição pessoal de Cerqueira César dizia respeito ao planejamento, o que pode ser um reflexo do impacto do Plano de Metas e do Plano de Ação do Governo Carvalho Pinto.

"Hoje, em todos os campos de atividades humana qualquer ação ou esforço criador, tanto do poder público como da iniciativa privada, está estreitamente ligado ao planejamento. Só o planejamento prévio permite a ação coordenada, lógica e consequente". 115

Citando o diretor do Departamento de Planejamento Regional e Urbano da Universidade da Califórnia, o professor Violich, Cerqueira César lamentava que no Brasil apenas o urbanismo fosse ensinado, no último ano, e como uma matéria formal, pouco ligada com os problemas urbanos, enquanto na Colômbia, Chile, Peru e Uruguai o planejamento estaria na base do ensino de arquitetura. Nesse sentido, o formalismo acadêmico e a supervalorização da técnica seriam vícios de origem do ensino de arquitetura no Brasil, enquanto o planejamento representaria o lado humano e social da arquitetura.

Apesar de todo o avanço e consenso nos debates, a reforma do ensino continuava teórica e sem base regimental. É nesse contexto que devemos situar a atuação decisiva de Anhaia Mello junto ao Fundo para Construção da Cidade Universitária para que o projeto da FAU fosse confiado a Artigas. Os documentos encontrados não dão conta de explicar de onde

Rubens Meister (1922-2009), fundador do curso de arquitetura e urbanismo da Universidade Federal do Paraná. Todos demais eram professores da FAU.

${ }^{115}$ CERQUEIRA CÉSAR, Roberto de. Op. Cit., p. 10. 
partiu a iniciativa do projeto - foi uma iniciativa pessoal do arquiteto, um encargo de Anhaia Mello ou fruto de negociações extraoficiais centralizadas no FCCUASO? De todo modo, se a data de abril de 1960 estiver correta, a iniciativa foi anterior aos processos institucionais que a ratificaram. Mais do que isso, parece claro que a iniciativa estava relacionada com uma convergência entre Anhaia Mello e Vilanova Artigas sobre como se poderia precipitar a reforma do ensino dentro e apesar da estrutura vigente.

Por isso, a sucessão de Anhaia Mello, aposentado compulsoriamente pelos 70 anos de idade completos em 23 de agosto de 1961, representou um grande impasse. Os arquitetos mais altos na hierarquia acadêmica eram os Livre-docentes Ernst Mange (1956), Hélio Duarte (1957) e Ariosto Mila (1961), mas sendo necessário um professor catedrático, nenhum deles poderia assumir a direção. Foi então que Vilanova Artigas assumiu novamente a liderança e redigiu uma carta ao reitor Ulhôa Cintra, assinada por um grupo de arquitetos da FAU, solicitando a reformulação do ensino no contexto da escolha do novo diretor. $^{116} \mathrm{O}$ manifesto mencionava as resoluções dos principais eventos dedicados ao assunto e concluía que o currículo da FAU era "como um agregado de informações sem a coordenação que a nossa experiência dentro da própria Faculdade já permite corrigir". Por esse motivo, os professores arquitetos solicitavam que a indicação de um novo diretor levasse em consideração o processo de reformulação do ensino que estava em andamento. Mais especificamente, apelavam para que o reitor procurasse "um meio prático de fazer contribuírem os professores arquitetos com sua experiência, na direção dos destinos do Instituto". Usando o Artigo 212 da Lei 3.233/55, que regulamentava a FAU, os requerentes sugeriam "dar à Comissão de Ensino estrutura e atribuições para que pudesse substituí-lo no que achar de direito dando-Ihe força para opinar em matéria de orientações e aprimoramento do ensino".

A estratégia de Artigas era permitir que um engenheiro assumisse a direção da escola supostamente Escorel, que era catedrático de 'Materiais de Construção' de quem Joaquim Guedes era assistente -, assegurando o controle do processo de reforma do ensino aos arquitetos através da Comissão de Ensino. Tal estratégia, no entanto, já não satisfazia uma parte dos docentes, principalmente os mais jovens, que ambicionavam rupturas mais rápidas e mais profundas com os engenheiros. Foi assim que um grupo ligado à FFCL,

\footnotetext{
116 Abaixo Assinado enviado ao reitor em 11 de setembro de 1961. Republicado em PRESTES, Lucinda Ferreira (org.). Op. Cit., pp. 75-80. Assinaram o documento 25 dos 34 professores arquitetos: Hélio Duarte, Lucio Grinover, Plinio Croce, Gian Carlo Gasperini, Abelardo de Souza, Jon Maitrejean, José Ribamar, Joaquim Guedes, José Maria das Neves, Jacob Ruchti, Roberto Cerqueira César, Carlos Millan, Roberto Carvalho Franco, Dario Imparato, João Vilanova Artigas, Paulo Mendes da Rocha, Nestor Goulart Reis Filho, Rodolfo Almeida Fernandes, Miranda Martinelli Magnoli, Eduardo Corona, Carlos Lemos e Lauro Birkholz. O manuscrito original consta no arquivo pessoal de Vilanova Artigas e trazia ainda os nomes de Roberto Tibau, Eduardo Kneese de Mello, Leo Nishikawa, Ariosto Milla, Luis Gastão Castro Lima e Ariaki Kato para terem suas assinaturas colhidas. Em nenhuma das versões foram localizados os nomes de Caetano Fraccaroli, Ernest Mange, Joaquim Bezerra da Silva, Roberto Coelho Cardoso e Milton Ghiraldini.
} 
liderado por Nestor Goulart Reis Filho ${ }^{117}$, conquistou apoio de estudantes e decidiu buscar outra solução.

\begin{abstract}
"Discutimos qual seria o futuro da FAU, porque estávamos sempre sendo dirigidos por engenheiros civis. Desejávamos autonomia e um diretor da própria escola. Como fazer isso? Estudamos o estatuto e descobrimos que o catedrático que vinha nos dirigir não precisava ser da Escola Politécnica. Fomos conversar com Lourival Gomes Machado, nosso ex-professor, catedrático de Ciência Política da Faculdade de Filosofia, onde eu já estava estudando. Contei os problemas, falei que não havia departamentos, nem recrutamento de jovens, pesquisa, publicações etc. E ele aceitou ser candidato, com o apoio de muita gente desde o palácio do governo, como Hélio Bicudo, que era promotor público e chefe da Casa Civil. A universidade não era autônoma e o governador nomeava os diretores. Lourival foi nomeado por Carvalho Pinto e aí começou a reforma da FAU". 118
\end{abstract}

Vilanova Artigas teria ficado muito contrariado e com a ajuda de Joaquim Guedes - que havia entrado no Partido Comunista - e de seu sócio, Carlos Millan, teria tentado persuadir o grupo de Nestor, formado basicamente por alunos do $5^{\circ}$ ano (Sérgio Ferro, Rodrigo Lefèvre, Flávio Império, Júlio Barone e Benedito de Toledo) a retirar a indicação de Lourival. Não houve acordo. A esta altura, o presidente do grêmio, Benedito de Toledo, já havia lançado o nome de Lourival ao grupo católico progressista do governo Carvalho Pinto, do qual era próximo. Ainda segundo Reis Filho, para ter maioria no Conselho Universitário o reitor precisava que a FAU votasse independentemente da Poli e a nomeação de Lourival foi acordada nesse sentido. Em contrapartida, o reitor teria dado seu apoio incondicional à FAU. ${ }^{119}$

A frustração inicial de Artigas revela mais do que seu compromisso e alta estima pelos politécnicos. Afinal, surgia uma nova força dentro da FAU que refletia um alargamento da profissão para as ciências humanas e que era capaz de dividir o apoio dos alunos. Com uma visão mais ampla do que deveria ser o ensino superior, Nestor e seu grupo avaliavam

\footnotetext{
117 Nestor Goulart Reis Filho (1931) se formou na FAU em 1955 e iniciou sua carreira docente no ano seguinte, como assistente de Kneese de Mello, na cadeira de 'História da Arquitetura'. Com a reforma de 1962, ano que se formou também em Ciências Sociais, passou a reger a cadeira História da Arquitetura II, tendo como assistentes Rodrigo Lefèvre e Benedito de Toledo. Em 1963 era o único pesquisador em tempo integral da escola e contratou o arquiteto Paulo Bruna e as sociólogas Maria Ruth Amaral de Sampaio e Maria Irene Szmrecsanyi. Em 1964 tornou-se o quarto livre-docente da escola, com apenas 33 anos. Em 1967 defendeu seu doutorado tornou-se o primeiro arquiteto catedrático. Foi diretor da FAU entre 1972 e 1975.

${ }^{118}$ Entrevista publicada em MOURA, Mariluce. "Nestor Goulart Reis Filho: do prédio à cidade para interpretar a evolução urbana" Pesquisa Fapesp, n. 226. São Paulo: Fapesp, dez 2014. Disponível em

<http://revistapesquisa.fapesp.br/2014/12/29/nestor-goulart-reis-filho-do-predio-a-cidade-para-interpretar-a-evolucao-urbana/>

119 Entrevista inédita de Nestor Reis Filho à Ana Paula Koury. Ver Anexo do relatório científico da pesquisa "Arquitetura moderna e a tecnologia como meio para uma revolução latino-americana: a contribuição de Rodrigo Lefèvre (1938-1984)", apresentado em 26 de novembro de 2012. Processo Fapesp: 2011/16061-3.
} 
que os arquitetos formados na politécnica não tinham condições nem interesse em promover uma reforma profunda do ensino, abrindo-se para a pesquisa e para a renovação do quadro docente.

Para Nestor, Anhaia Mello e os engenheiros da Poli haviam sido responsáveis por impedir que a geração de Kneese de Mello, Vilanova Artigas, Hélio Duarte, Eduardo Corona e outros arquitetos, se titulasse, mantendo-se como único catedrático sem deixar sucessores.

Lourival Gomes machado assumiu a direção em 11 de outubro de 1961 e logo tratou de sinalizar a continuidade com a gestão de Anhaia Mello, solicitando a colaboração de todos os professores e organizando grupos para estudar a reestruturação do curso de arquitetura. A Comissão de Estudo do Ateliê, que deveria propor uma estrutura preliminar do ateliê, foi entregue a Carlos Millan, Jon Maitrejean, Giancarlo Gasperini e Lucio Grinover.

O relatório de Millan, intitulado "O ateliê na formação do arquiteto", foi apresentado em janeiro de 1962. ${ }^{120}$ Além de reproduzir na íntegra o relatório de Cerqueira César, o novo documento propunha que se partisse da proposta de 1957, que organizava o ensino pela prática em ateliê com ênfase em Composição.

A estrutura proposta por Millan, na verdade, não aprofundou muito a proposta de 1957. Tratava-se da mesma seriação de disciplinas. Durante o período da manhã as matérias "técnicas" seriam progressivamente substituídas por matérias de "cultura apropriada", enquanto no período da tarde as aulas seriam no ateliê, enfatizando o "aprendizado gráfico e plástico-construtivo" nos dois primeiros anos e a "mentalidade de construtor", com urbanismo e composições a partir do $3^{\circ}$ ano. Os termos não eram os mesmos que seriam adotados pela chamada Reforma de 1962. O desenho industrial ganhava o status de uma matéria específica, mas não de uma disciplina. Do mesmo modo, ainda se mantinham os termos "Composição" e "Plástica" ao invés de "Projeto", "Desenho Artístico" ao invés de "Comunicação Visual" e "Urbanismo" e "Paisagismo" ao invés de "Planejamento". A principal novidade foi o detalhamento de duas etapas nos ateliês. A primeira, horizontal, coordenaria as disciplinas do mesmo ano. A segunda, vertical, seria constituída de trabalhos de Urbanismo, entendido como "a prática da coordenação, integração e equipamento do espaço exterior". Imaginava-se um grande espírito de colaboração entre os alunos e entre os professores de todas as disciplinas.

Curiosamente, o relatório de Millan, mais uma vez, deixava de fazer qualquer referência ao projeto de Artigas, que já havia sido entregue ao Fundo para Construção em junho de 1961. De fato, é difícil explicar como o projeto da FAU foi - e continuaria a ser - desconsiderado

${ }^{120}$ MILLAN, Carlos B. Op. Cit. 
em tantos debates sobre o ensino de arquitetura. Ainda mais nesse caso, de uma comissão da própria FAU, cujos membros eram próximos de Artigas, e que tratava da função do ateliê, proposto por ele em 1957.

De todo modo, o projeto do edifício representava uma ação paralela da reforma do ensino e independente de mudanças na lei. Mas a possibilidade de uma reforma completa se tornou concreta quando o governo de João Goulart sancionou a Lei n. 4.024, de 20 de dezembro de 1961, que fixou as Diretrizes e Bases da Educação, conferindo autonomia didática, administrativa, financeira e disciplinar aos órgãos de ensino - incluindo as universidades estaduais. Como resultado, a USP criou seu Estatuto, aprovado em 7 de julho de 1962, através do Decreto n. 40.346 do governador Carvalho Pinto.

O Estatuto da USP manteve o regime vitalício das cátedras, mas agora as unidades indicariam em seus Regulamentos as disciplinas através das quais o ensino seria ministrado, podendo ser integrantes de cátedras, subordinadas a elas, ou autônomas. As disciplinas podiam ser criadas, ampliadas, reduzidas ou suprimidas pelo Conselho Universitário, mediante proposta da Congregação - no caso da FAU, a Comissão de Ensino. Com apoio do reitor, a FAU iniciou a chamada "Reforma de 1962", que implantou os departamentos. As cátedras continuavam existindo, mas a metodologia e a coordenação das matérias seriam feitas por quatro departamentos: Departamento de Ciências Aplicadas, Departamento de Construção, Departamento de História e Departamento de Projeto. ${ }^{121}$ Ao que tudo indica as mudanças começaram no segundo semestre, quando a nova grade curricular foi implementada e novos instrutores de ensino foram contratados. ${ }^{122}$

Vilanova Artigas logo assumiu a liderança na criação do Departamento de Projeto, juntamente com os demais regentes de 'composição de arquitetura', Hélio Duarte, Abelardo de Souza e Roberto Cerqueira César. "Projeto" passou a ter uma dimensão mais ampla, abrangendo edificação, cidade, produção industrial e linguagem. Dai as sequências de Planejamento, Edificações, Desenho Industrial e Comunicação Visual, com suas cadeiras e disciplinas autônomas, que deram início aos ateliês.

Para atender à ampliação do escopo, foram contratados novos professores, quase todos recém-formados pela FAU. Na sequencia de Comunicação Visual, Flávio Império (19351985, FAU, 1961/61-77), Abrahão Velvu Sanovicz (1933-1999, FAU, 1958/62-99), João

\footnotetext{
${ }^{121}$ Ver: PONTES, Ana Paula et al. "Fórum: o percurso do ensino na FAU”, Editorial da Revista Caramelo, n. 6, FAUUSP, 1993.

${ }^{122} \mathrm{~A}$ adaptação curricular dos alunos dos diferentes anos à nova grade parece ter sido complexa. Foram consultados boletins de alunos formados entre 1963 e 1973. Os boletins dos formados em 1963 traziam a grade antiga. Os dos formados em 1964 também trazem a grade antiga, porém com anotações que indicam que os alunos cursaram as matérias em anos diferentes da grade prevista. Os boletins dos formados a partir de 1965 já traziam a grade nova. Desse modo não possível confirmar se a mudança foi gradual, a partir dos ingressantes em 1963. Parece mais provável que a mudança tenha sido imediata para todos os alunos, com exceção dos que se formaram em 1962.
} 
Baptista Alves Xavier (?-?, FAU, 1958/62-74) e José Fernandes de Lemos (1926, EAD Portugal, 1943/62-64); na sequência de Desenho Industrial, João Carlos Rodolpho Stroeter (?-?, FAU, 1957/62-64), Marlene Picarelli (1932, FAU, 1958/62-97) e João Carlos Cauduro (1935, FAU, 1960/64-97); na sequência de Projeto de edifícios, Pedro Paulo de Mello Saraiva (1933, Mack, 1955/62-75) e Ludovico Antônio Martino (1933-2011, FAU, 1962/6478); e na sequência de Planejamento (reunindo paisagismo e urbanismo), José Claudio Gomes (?-?, FAU/61-92); Antônio Augusto Antunes Netto (1936-1982, FAU, 1961/62-69) e Brenno Cyrino Nogueira (?-?, FAU, 1957/62-96).

O departamento de história, inicialmente formado por quatro regentes e dois assistentes, respectivamente, Eduardo Corona, Joaquim Bezerra da Silva, Flavio Mota, Eduardo Kneese de Mello, Carlos Lemos e Nestor Reis Filho, também foi ampliado, incorporando a cadeira de 'Estudo Sociais e Econômicos', que ganhava nova orientação. A proposta do departamento, que acabaria sendo redigida por Nestor Reis Filho, era abrigar a pesquisa em arquitetura e assumir um foco mais operativo, vinculando-se com o Departamento de Projeto através da análise da produção contemporânea.

Para isso, foram contratados a maior parte dos alunos que apoiaram Lourival Gomes Machado em 1961, entre eles, Rodrigo Brotero Lefèvre (1938-1984, FAU, 1961/62-84), Benedito Lima de Toledo (?-?, FAU, 1961/62-?) e Sérgio Ferro Pereira (1938, FAU, 1961/ 62-73). Além deles, Hélio de Maria Penteado (1930, FAU, 1958/62-76), Júlio Roberto Katinsky (1932, FAU, 1957/62-02), Cândido Malta Campos Filho (1936, FAU, 1959/62-06) e Dacio Araujo Benedicto Ottoni (1936, FAU, 1960/62-04), além do sociólogo Gabriel Bolaffi (1934-2011, FFCL/61-93) também teriam sido escolhidos por Nestor. No ano seguinte João Walter Toscano (1933-2011, FAU, 1956/64-?) completaria o quadro docente. Paralelamente, Nestor Reis Filho conseguiu contratar como pesquisadores o arquiteto Paulo Júlio V. Bruna (1941, FAU, 1963/63-11) e as sociólogas Maria Irene Szmrecsanyi (?, FFCL, 1963/ 63-08) e Maria Ruth Amaral de Sampaio (?, FFCL, 1956/63-03).

No Departamento de Ciências Aplicadas, quase não houve mudanças, mantendo-se o modelo politécnico. No Departamento de Construções as mudanças foram um pouco maiores, sobretudo nas cadeiras de 'Construção'. No mais, a seriação do ensino foi alterada, conforme proposta de 1957, concentrando as matérias desses dois departamentos nos primeiros anos. ${ }^{123}$

Os professores contratados foram os engenheiros Ualfrido del Carlo (?-?, EP, 1963/64-93), José Fonseca (1915-1985, Mackenzie, 1941/62-85) e Aluízio Fontana Margarido (1938-

\footnotetext{
${ }^{123}$ Os dois departamentos foram depois reunidos no Departamento de Tecnologia da Arquitetura. Ver: ONO, Rosaria; et al. "Celebrando os 50 anos do AUT: uma reflexão sobre a formação do Departamento de Tecnologia da FAUUSP". Pós, n. 35. São Paulo: FAUUSP, junho 2014.
} 
2012, EP, 1960/64-70), o matemático Domingos Pizanelli (1922-1987/63-81), em substituição do catedrático Camargo, que havia falecido em 1963, e o arquiteto Rufino Reis Soares (1937, FAU, 1960/62-70), como instrutor de 'Hidráulica'.

Além dos departamentos, a Reforma de 62 criou o Museu da FAU, que seria o "órgão encarregado de coordenar as atividades de todos os departamentos, divulgando a produção da Escola através de exposições, debates e publicações". ${ }^{124}$ Dirigido pelo artista plástico Fernando Lemos, com a participação do GFAU e de representantes de cada departamento, o museu seria uma forma de democrática de mediar os departamentos.

Os departamentos e o museu estavam previstos no regulamento da faculdade, de 1955. Mas apesar da lei federal e o Estatuto da USP atribuírem autonomia para as unidades, a Reforma de 62 não estava de acordo com o Regulamento da escola, que definia rigidamente as cadeiras e sua sequência. Para legitimá-la, foi usado um expediente heterodoxo. O Estatuto da USP instituiu um instrumento vago de congregação do corpo docente, discente e de ex-alunos, cuja estrutura e funcionamento seriam estabelecidos pelo Conselho Universitário: o Fórum universitário. O 1ํFórum da USP ocorreu nos dias 10 e 11 de maio de 1963, onde se discutiram dois grandes temas: "A integração universitária na Cidade Universitária" e "Plano de Assistência ao universitário". Estes debates tinham como objetivo a investigação da situação econômica dos estudantes e seus problemas de ajustamento à vida acadêmica. ${ }^{125}$ Uma de suas resoluções, recomendou que cada unidade realizasse seu próprio Fórum. Assim surgiu o Fórum da FAU, promovido como um evento comemorativo do $15^{\circ}$ aniversário da escola.

Contando com a participação de alunos e professores, as conclusões do Fórum da FAU incluíram pautas como a urgência em se transferir a escola para o novo prédio na Cidade Universitária (cujas obras não haviam iniciado) e o apelo pela aprovação da regulamentação profissional pelo Congresso Nacional. Mas acima de tudo, foi entendido que o Fórum da FAU "ratificou e deu corpo à Reforma de 62". ${ }^{126}$ Por fim, foi aprovado um novo Fórum para 1964. Em sintonia com as reformas de base de João Goulart, a Fórum da FAU pretendia se afirmar como uma instância democrática e soberana. Mas então veio o Golpe de 1964 e não houve Fórum naquele ano.

\footnotetext{
${ }^{124}$ PONTES, Ana Paula et al. Op. Cit. p. 11.

125 PREFEITURA DA CIDADE UNIVERSITÁRIA ASO. O espaço da USP: presente e futuro. São Paulo: 1985, p. 50.

${ }^{126}$ PONTES, Ana Paula et al. Op. Cit. p. 11.
} 


\section{REORGANIZAÇÃO DAS CÁTEDRAS DA FAU EM 1962}

\begin{tabular}{|c|c|}
\hline Lei 3.233/55 (Regulamento) & Reforma de 1962 \\
\hline 1. Cálculo. Geometria Analítica. Nomografia & 1. Cálculo Diferencial e Integral. Geometria analítica \\
\hline 2. Geometria Descritiva & 2. Geometria Descritiva \\
\hline 3. Mecânica & 3. Mecânica \\
\hline 4. Física Geral e Aplicada & 4. Topografia, elementos de astronomia de posição \\
\hline 5. Materiais de Construção & 5. Física Geral e Aplicada \\
\hline 6. Resistência dos Materiais. Estabilidade das Construções & 6. Construção I \\
\hline $\begin{array}{l}\text { 7. Estruturas Correntes de Madeira, Metálicas e de Concreto } \\
\text { Simples e Armado }\end{array}$ & 7. Resistencia dos materiais e estabilidade das construções \\
\hline 8. Grandes Estruturas & 8. Hidráulica e saneamento \\
\hline $\begin{array}{l}\text { 9. Técnica das Construções. Organização dos Trabalhos e } \\
\text { Prática Profissional. Higiene dos Edifícios. Noções de } \\
\text { Mecânica dos Solos. Fundações }\end{array}$ & 9. Construção II \\
\hline 10. Hidráulica. Hidráulica Urbana e Saneamento & $\begin{array}{l}\text { 10. Estruturas Correntes de madeira, metálicas e de concreto } \\
\text { simples e armado }\end{array}$ \\
\hline 11. Topografia, Elementos de Astronomia de Posição & 11. Grandes Estruturas \\
\hline $\begin{array}{l}\text { 12. Noções de Economia Política. Estatística Aplicada. } \\
\text { Organização Administrativa. Legislação e Contabilidade } \\
\text { Específica }\end{array}$ & 12. Comunicação Visual I \\
\hline 13. Arquitetura Analítica. & 13. Desenho Industrial III \\
\hline 14. Teoria da Arquitetura. & 14. Projeto I (Parte I / Parte II) \\
\hline 15. História da Arte. Estética & 15. Projeto II \\
\hline $\begin{array}{l}\text { 16. Composição de Arquitetura. Pequenas composições I. } \\
\text { Desenho Arquitetônico. Plástica I }\end{array}$ & 16. Projeto III \\
\hline $\begin{array}{l}\text { 17. Composição de Arquitetura. Pequenas composições II, } \\
\text { Plástica II }\end{array}$ & 17. Projeto IV \\
\hline $\begin{array}{l}\text { 18. Composição de Arquitetura. Grandes composições I, } \\
\text { Plástica III }\end{array}$ & 18. Planejamento I \\
\hline 19. Composição de Arquitetura. Grandes composições II & 19. Planejamento II (Parte I / Parte II) \\
\hline 20. Arquitetura no Brasil. & 20. História da Arte. Estética \\
\hline 21. Desenho Artístico & 21. História da Arquitetura I \\
\hline 22. Composição Decorativa & 22. História da Arquitetura II \\
\hline 23. Urbanismo & 23. História da Arquitetura III \\
\hline 28. Arquitetura Paisagística & 24. História da Arquitetura IV \\
\hline \multirow{2}{*}{ 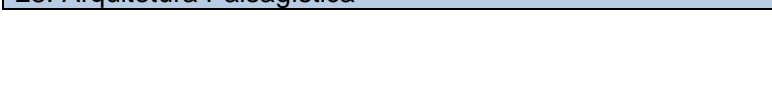 } & 25. Estudos Sociais e Econômicos \\
\hline & 26. Mecânica dos Solos. Fundações \\
\hline
\end{tabular}

Em verde, as cátedras de História; em azul, as cátedras Projeto, em laranja claro as cátedras de Ciências Aplicadas; e em laranja escuro as cátedras de Construção 


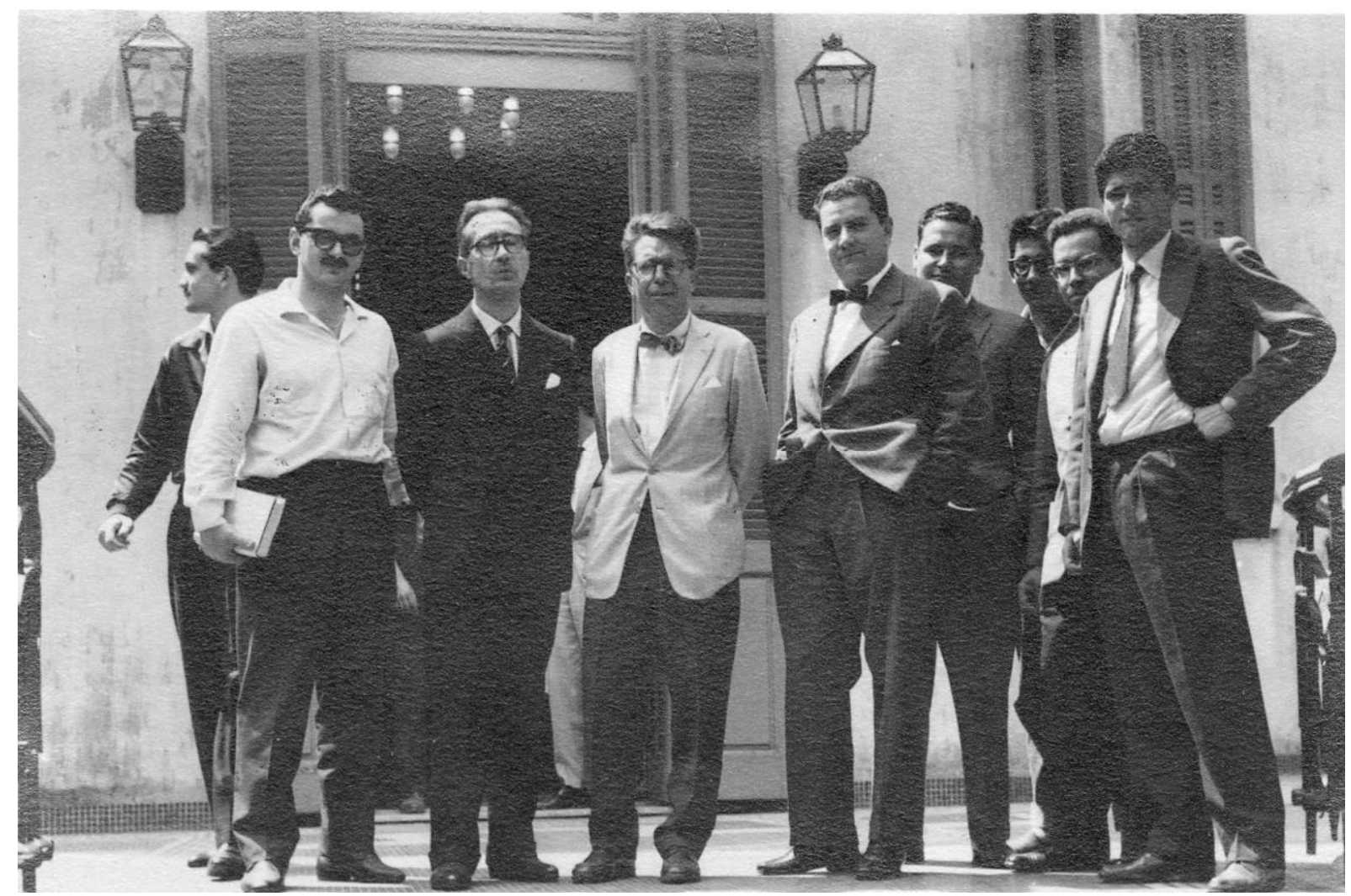

Vilanova Artigas recebe críticos estrangeiros na Vila Penteado, setembro de 1959

Durante o Congresso de Críticos de Arte. Artigas (de paletó claro) no centro entre Giulio Carlo Argan à esquerda e Bruno Zevi à direita. Com a mão na cintura, Renato Nunes. Foto: Benedito Lima de Toledo

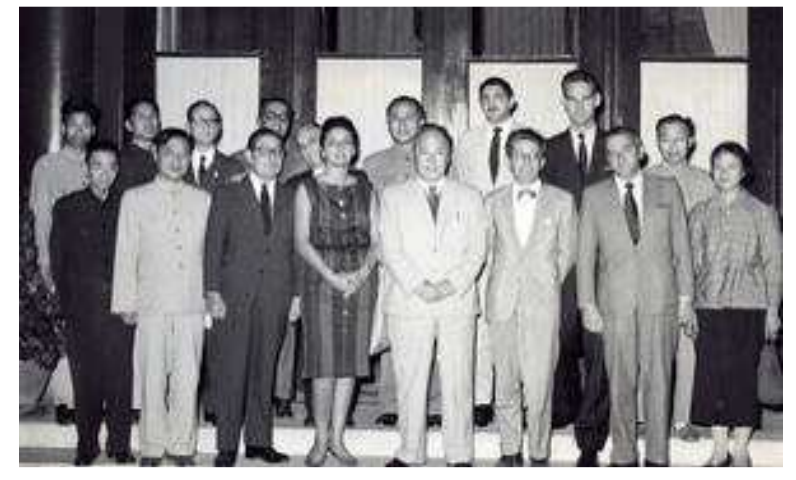

Artigas viaja à china com arquitetos brasileiros, 1961. Arquivo Vilanova Artigas

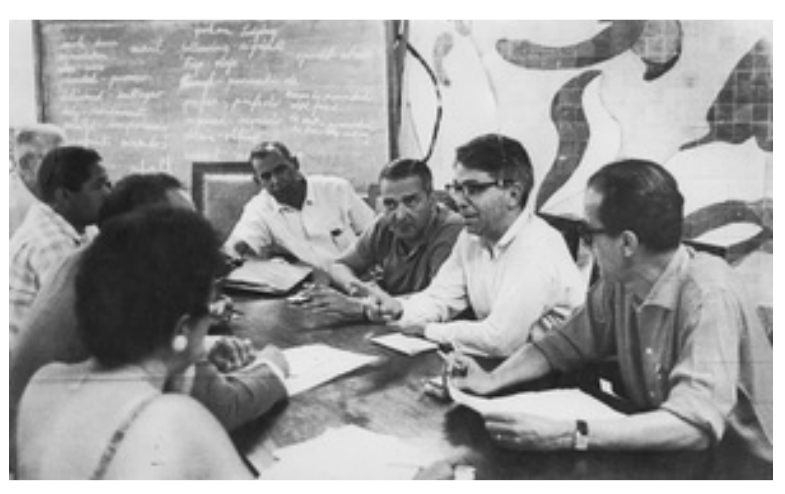

Artigas é relator para a América Latina do VII Congresso da União Internacional dos Arquitetos, realizada em Havana, Cuba, 1963. Arquivo Vilanova Artigas 

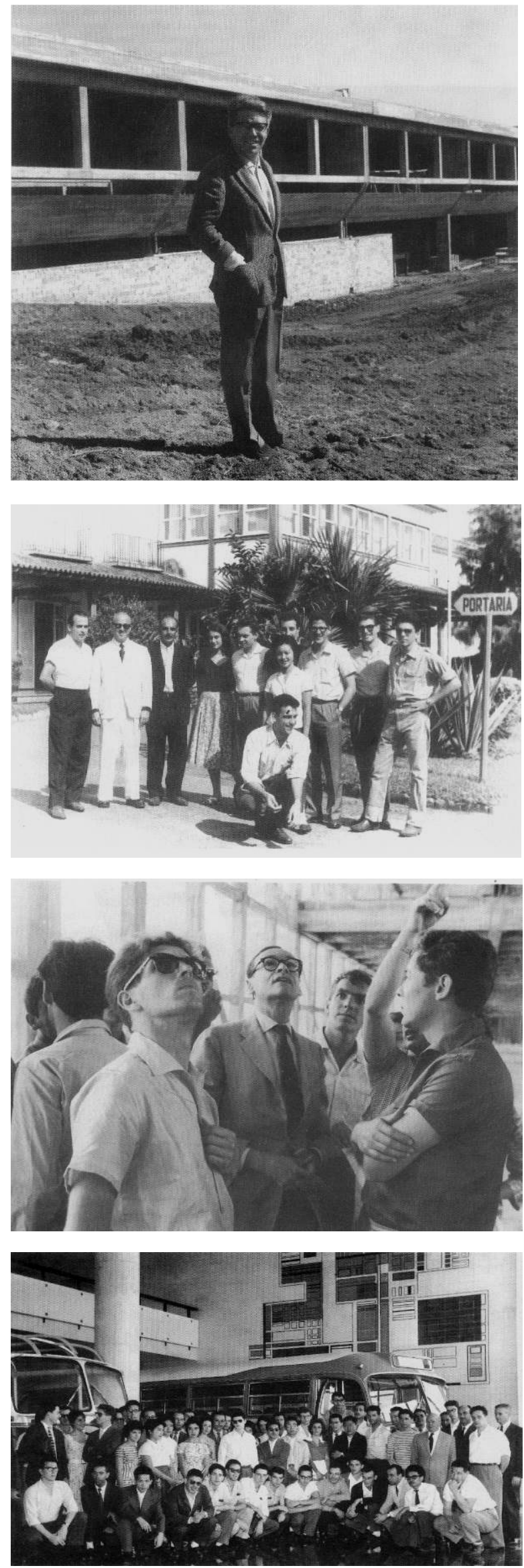

Vilanova Artigas em visita a obra na companhia de alunos. Foto: B. L. Toledo, 1959

Visita a Volta Redonda na companhia do professor Fernando Escorel (o segundo à esquerda).

Arquivo B. L. Toledo

Visita ao Museu de Arte Moderna, Rio de Janeiro. Afonso Eduardo Reidy, ao centro.

Arquivo B. L. Toledo

Visita à Indústria Mercedes Benz, São Bernardo do Campo, 1959. Arquivo B. L. Toledo 


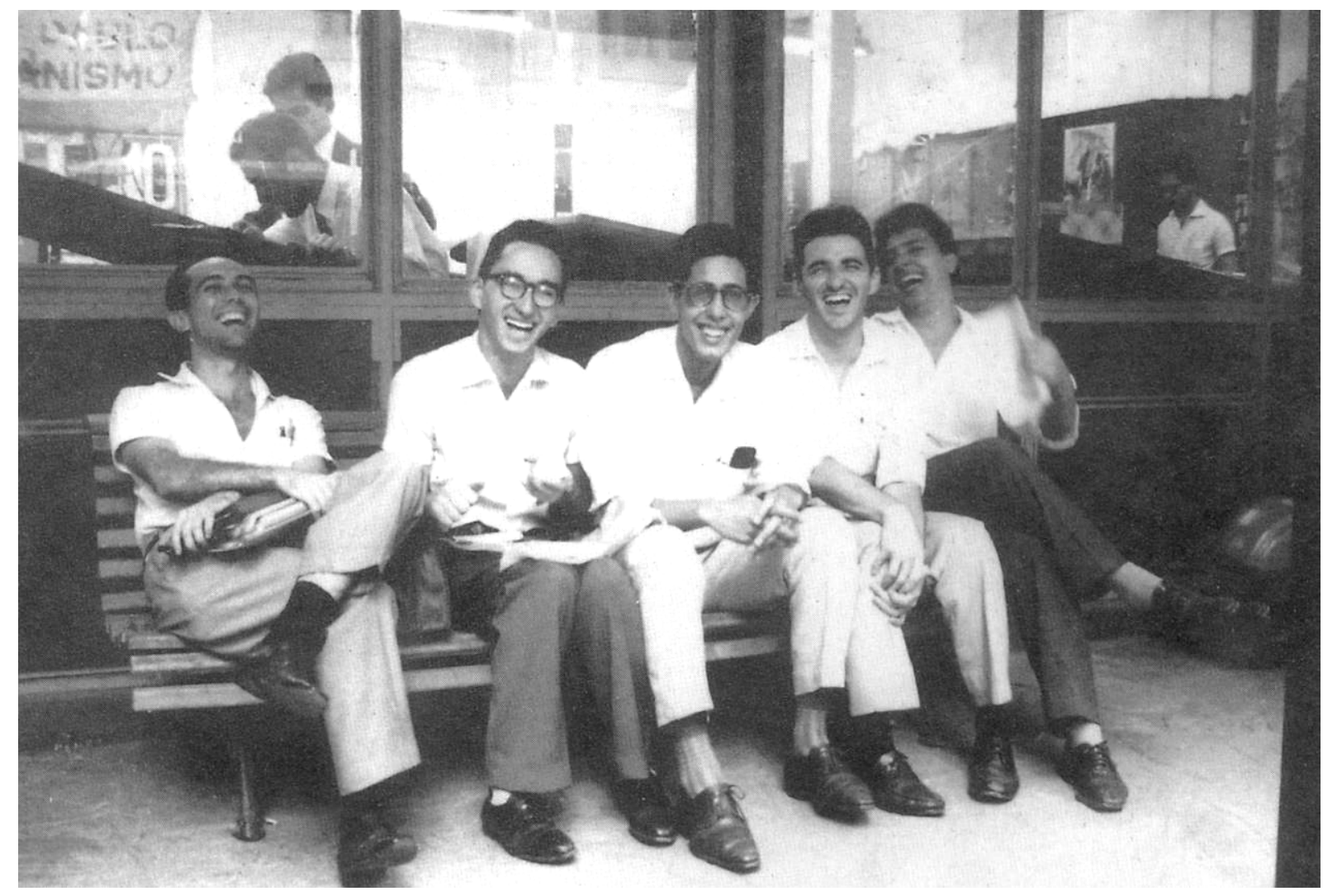

Descontração em frente ao ateliê. Da esquerda para direita: Nélio Rodrigues, Edmundo Lúcio Giordano, Nelson de Andrade, René Pierre e Arnaldo Martino. Foto: B. L. Toledo, 1961

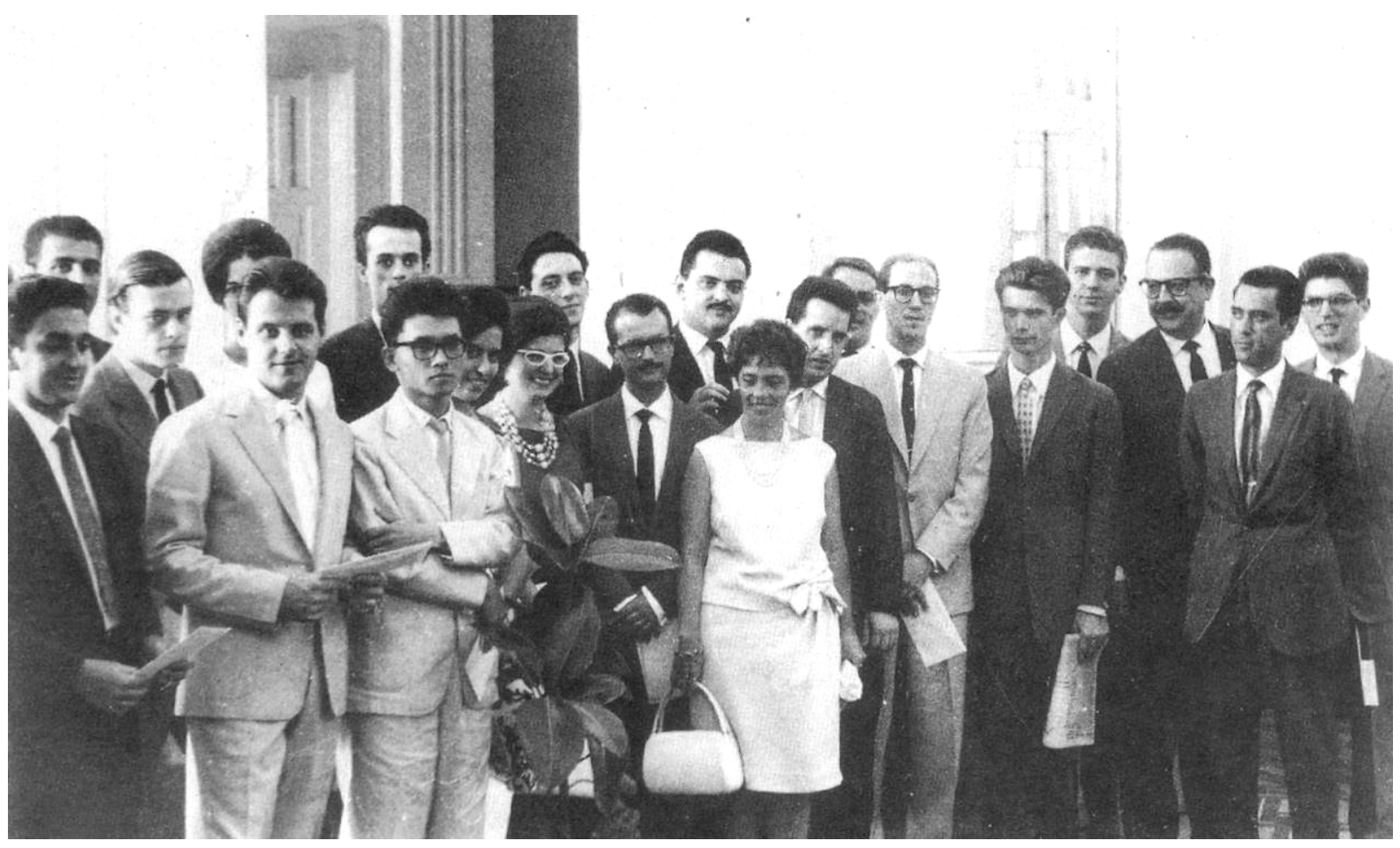

Formatura da turma de 1961. Da esquerda para direita: Raymond Trad, Antônio Augusto Antunes Neto, Sérgio Ferro, Ana Terezinha Freato, Heládio Mancebo, Júlio Barone, Teru Tamaki, Helena, Carmencita, Rinaldi, Geraldo Gomes Serra, Luiz Kupfer, Vera Catunda, Sérgio Leite Monteiro, Carlos Giovanni Bianchi, Rodrigo Lefèvre, Lourival Gomes Machado, Rui Gomes Pinto, Benedito Lima de Toledo.

Foto: Professor Tharcillo Toledo, 1961 


\section{A ESCOLA FRATURADA (1964-1969)}

Antes mesmo do golpe militar, as forças de oposição às reformas do governo de João Goulart obtiveram uma vitória importante nas eleições de 1962. Ambicionando a presidência da república, os governadores eleitos Adhemar de Barros, de São Paulo, Magalhães Pinto, de Minas Gerais, e Carlos Lacerda, do estado da Guanabara, tornaram-se articuladores decisivos do golpe. Assumindo o Estado de São Paulo em 1963, o rival de Jânio Quadros e Carvalho Pinto nomeou para reitor da USP, o jurista ultraconservador Luís Antônio da Gama e Silva. ${ }^{127} \mathrm{O}$ autor do Al-5 foi assim nomeado reitor da Universidade de São Paulo ainda no período democrático.

Lourival Gomes Machado cumpriu seu mandato até o fim, em outubro de 1964. Para substituí-lo, porém, o reitor Gama e Silva escolheu o candidato menos votado da lista tríplice, o engenheiro elétrico e catedrático de 'Geometria Descritiva', Pedro Moacyr do Amaral Cruz, conhecido como Cabrão. Ele próprio parece ter se surpreendido com sua indicação e disse ter sido convencido pelo reitor a assumir o cargo, ao que aceitou estabelecendo três prioridades para sua gestão: a construção do prédio na cidade universitária, um novo regulamento para escola e a instauração da congregação. ${ }^{128}$

Cabrão assumiu a diretoria em janeiro de 1965 e logo fechou o laboratório fotográfico, o Museu, o Centro de Estudos Brasileiros do GFAU e mudou o regime de frequência, o que implicou na reprovação de 25 a 30\% dos alunos. ${ }^{129}$ Apesar de tentar intervir no projeto de Artigas, e até cogitar substituí-lo, o diretor defendeu o início urgente das obras na Cidade Universitária com o objetivo declarado de aumentar as admissões e disciplinar os corpos discente, docente e administrativo. ${ }^{130}$ Seu encaminhamento de um novo regulamento ainda que justificável pela adequação à nova lei federal e ao Estatuto da universidade -, foi interpretado como um questionamento da legitimidade da Reforma de 62 e do Fórum de 63. De fato, para os alunos, sua gestão se caracterizou por "uma constante luta de alunos e arquitetos defendendo as teses de 62 contra a tentativa de voltar aos padrões de ensino da velha Poli". ${ }^{131}$ Por fim, a formação da Congregação exigia que pelo menos um terço das 26

\footnotetext{
127 Professor da Faculdade de Direito, Gama e Silva foi Ministro da Educação de Castelo Branco em 1964 e Ministro da Justiça de Artur da Costa e Silva em 1967. Ficou conhecido por ser o autor do Ato Institucional n. 5. Nomeado reitor no período democrático, Gama e Silva permaneceu no cargo até 1968, acumulando-o com os ministérios. Durante sua ausência a USP foi dirigida por interinos. Um deles, o vice-reitor Hélio Lourenço de Oliveira, foi aposentado compulsoriamente juntamente com dezenas de professores em 1969 por questionar a lista.

${ }^{128}$ Carta de Pedro Moacyr do Amaral Cruz ao reitor Gama e Silva, de 27 de julho de 1966. Processo USP: 66.1.20458.1.8, s/p.

${ }^{129} \mathrm{O}$ Centro de Estudos Folclóricos foi transformado em Centro de Estudos Brasileiros por volta de 1961, quando o presidente do GFAU erai Benedito Lima de Toledo.

${ }^{130}$ Carta de Pedro Moacyr do Amaral Cruz ao reitor Gama e Silva, de 7 de dezembro de 1966. Processo USP: 65.1.3988.51.8, p. 85.

131 "Histórico da FAUUSP”, Desenho, n. 1. São Paulo: GFAU, julho 1970 apud PONTES, Ana Paula et al. Op. Cit. p. 11. 148
} 
cadeiras (ou seja, 9 cadeiras) estivessem preenchidas. Para isso, Cruz retomou os concursos de cátedras interrompidos desde 1957.

Para Vilanova Artigas o golpe militar teve consequências quase imediatas. Segundo Paulo Mendes da Rocha:

"A FAU estava em plena aula, no ateliê, na Rua Maranhão, quando as tropas saíram para a rua. Os rádios anunciaram o golpe militar, e, por coincidência, nós estávamos em aula com o Artigas recebendo três arquitetos cubanos. Quando os rádios começaram a anunciar, o Artigas pegou os arquitetos cubanos e sumiu". 132

Artigas foi perseguido em dois momentos. O primeiro foi no caso do Inquérito da Polícia Militar na USP, endossado por relatório de uma Comissão nomeada pelo Reitor, que destacava a "infiltração marxista na universidade, seus doutrinadores e agentes da subversão"133. Foram indiciados os professores Mário Schenberg, Caio Prado, Florestan Fernandes, Fernando Henrique Cardoso, João da Cruz Costa e Vilanova Artigas, entre outros. O arquiteto foi levado sob custódia de uma sala de aula da Vila Penteado, o que causou comoção e terror na escola. Segundo sua filha, Rosa Artigas, "ele ficou um mês preso, mas 21 dias incomunicável". ${ }^{134}$ Isso ocorreu entre agosto e setembro. Quando voltou à liberdade, os alunos da FAU o homenagearam com uma exposição de seus trabalhos.

Cerca de um mês depois, Artigas foi indiciado em um novo processo por causa das cadernetas apreendidas de Carlos Prestes onde seu nome aparecia. ${ }^{135}$ Temendo nova prisão, Artigas fugiu para o Uruguai, como fizeram muitos que tiveram os direitos políticos cassados pelo Ato Institucional n. 1, de abril 1964 e o Ato Institucional n. 2, de outubro de 1965. ${ }^{136}$ Artigas partiu em outubro de 1964, deixando a família em São Paulo. No fim do ano letivo, sua família foi visita-lo.

"Ficamos até o início do ano letivo seguinte, até março. [...]. Ele ficou mais tempo. Dali muita gente foi para a Alemanha e para União Soviética. Para ele, havia duas propostas: ou ele ficava dando aula

\footnotetext{
132 Depoimento de Paulo Mendes da Rocha ao autor, realizado em 16 de julho de 2014. A menção aos arquitetos cubanos pode estar relacionada à participação de Artigas no VII Congresso da UIA, realizado em Havana no ano anterior.

${ }^{133}$ CARVALHO. Claudia Paiva. Intelectuais, cultura e repressão política na ditadura brasileira (1964-1967): Relações entre direito e autoritarismo. Dissertação de mestrado em Direito. Orientador: Cristiano Paixão. Brasília: Universidade de Brasília, 2013.

${ }^{134}$ Depoimento de Rosa Artigas ao autor, realizado em 14/03/2011.

135 "Foi uma coisa surrealista: ele era o fiador da casa que o Prestes morava na Vila Clementina, mas ele se safou porque o proprietário da casa, que sabia que alugava para o Prestes, não era comunista, e o cara da imobiliária ficou com tanto medo que a casa ficasse fechada pela polícia durante cinco anos que sumiu com os papeis todos. Sem querer, ele salvou a pele de muita gente". Entrevista de Rosa Artigas ao autor, realizada em 14 de março de 2011.

${ }^{136}$ Entre os que tiveram seus direitos cassados no Al-1 e Al-2 estavam João Goulart, Jânio Quadros, Luís Carlos Prestes, Miguel Arraes, Leonel Brizola, Celso Furtado, Plínio Arruda Sampaio, Darcy Ribeiro, entre outros.
} 
na Universidade de Montevidéu, ou ia para Argel porque o Niemeyer estava fazendo o projeto da Universidade de Constantine. O meu pai entra em uma profunda depressão e disse que não ia para Argel, não queria dar aula no Uruguai, queria voltar para cá. [...] Ele já estava decidido que ia voltar clandestino". ${ }^{137}$

Paulo Mendes da Rocha complementa:

"Houve um episódio em que o Ícaro de Castro Mello, de direita, mas era amigo muito fraternal do Artigas, foi ao Uruguai (ou a Buenos Aires, não sei) para um evento da União Pan-americana dos Arquitetos e resolveu ver como ele estava. Foi ao Uruguai e se informou até achar o Artigas. [...]. O Ícaro tinha consciência do que estava fazendo. Não era do Partido Comunista, mas sabia muito bem como agir. Foi falar com a Virgínia, mulher do Artigas, e disse: 'Precisamos tirá-lo de lá, porque ele vai se matar'. Porque ele estava num tugúrio lá, numa pensão que tinha gente como ele, uruguaios, paraguaios, todos fugidos, sem dinheiro, alcoólatras, e no fim da linha; sem comida, comendo mal, cheirando mal, podres. [...]. Arranjaram um Fusquinha muito bem arrumado pelos mecânicos e o Alfredo Paesani, colega nosso - que foi presidente do Sindicato -, e a própria Virgínia foram nesse Fusca, com o itinerário estudado. Saíram lá para baixo, se enfiaram numas vielas, atravessaram numa balsa o rio Paraná, onde atravessa boi, gado e por esses meandros foram até o Uruguai. Ficaram hospedados em Montevidéu, onde o Artigas estava. Se hospedaram num hotel e o Paesani foi fazer contato para preparar o Artigas e não assustá-lo; [...]. Encontraramno, enfiaram-no no fusca e trouxeram-no para cá, para ele ficar escondido na casa de uma senhora do Partido; que não era outra pessoa senão a irmã do Ministro da Agricultura. Essas contradições de família, ela comunista e o irmão, Ministro da Agricultura do regime militar. Ela era Sofia Tassinari (se não me engano), irmã do Pedro Tassinari". ${ }^{138}$

Esse retorno, segundo Rosa Artigas, teria ocorrido em junho de 1965, um pouco antes do aniversário dele. Foram, portanto, cerca de dez meses no Uruguai. Mas mesmo em São Paulo, Artigas passou alguns meses na clandestinidade. Segundo Paulo Mendes da Rocha:

"O Partido Comunista montou um esquema para o Artigas não ficar tão isolado e principalmente para ter contato com a mulher e os filhos. E armaram o seguinte esquema: fulanos escolhidos por revezamento pegavam sua família, mandavam para a casa do sogro,

\footnotetext{
${ }^{137}$ Depoimento de Rosa Artigas ao autor, realizado em 14/03/2011.

${ }^{138}$ Depoimento de Paulo Mendes da Rocha ao autor, realizado em 16 de julho de 2014.
} 
tratavam de fazer o melhor possível com a sua geladeira e, às $9 \mathrm{~h}$ da noite, teriam que sair com o seu automóvel. A sua casa ficava vazia. la encontrar o Artigas, que iam dizer onde estava: '- $\mathrm{Na}$ esquina da rua tal com rua tal e você vai ver. Você encosta que é o Artigas, ele embarca no seu carro, você o leva para sua casa, põe o carro na garagem, sobe no elevador, põe ele no seu apartamento, que já não vai estar vazio. A Virgínia vai de taxi com os filhos como quem vai te visitar. Só que o apartamento estará vazio'. Dava a chave. Ela abre o apartamento, se instala (tem tudo na geladeira), liga uma música e espera o Artigas. E ficam lá das 21:30 até as 3:00. '- Às 4:00 da manhã, você vai buscar o Artigas. A família já não está mais lá, só o Artigas. Você põe ele no carro e solta ele na esquina da rua tal com a rua tal'. Você não sabia nem onde ele estava hospedado. Eu fiz duas vezes isso. Sei que o Pedro Paulo Saraiva fez no mínimo uma vez também no apartamento dele, e talvez ninguém mais tenha feito [...], e isso uma vez por mês". ${ }^{139}$

Artigas retornou à FAU e à legalidade no segundo semestre de 1965, quando o IPM da Universidade acabou. A partir daí um habeas corpus preventivo lhe permitiu responder em liberdade o processo da Lei de Segurança Nacional das cadernetas de Prestes, tendo que se apresentar periodicamente, até o final de 1967. Nesse período, Artigas foi homenageado na 8 ${ }^{\text {a }}$ Bienal de São Paulo (set. -nov. 1965) com uma sala hors concours, onde apresentou uma maquete da FAU. ${ }^{140}$

Apesar do terror que viveu - e talvez justamente por causa dele - Artigas evitou qualquer confronto direto com o regime, o que levaria a uma violência desproporcional e desnecessária, segundo acreditavam os membros do PCB. Foi bem no momento de seu retorno ao Brasil, em julho de 1965, que a revista Acrópole dedicou uma edição à obra de seus discípulos, Sérgio Ferro, Rodrigo Lefèvre e Flávio Império - já não tão obedientes ao seu professor, como o episódio do apoio a Lourival havia demonstrado. ${ }^{141}$ Os jovens, ainda ligados ao PCB, mas prevendo "tempos de guerra", denunciavam o corte abrupto das perspectivas políticas, econômicas e sociais que haviam impulsionado a arquitetura moderna até então. ${ }^{142}$ Artigas, atento ao apelo que as ideias dos jovens professores podiam ter entre os alunos, conseguiu inserir um texto seu na mesma edição da revista. Sob o título de "Uma falsa crise", Artigas argumentava (sempre de modo cifrado), que apesar do regime

\footnotetext{
${ }^{139}$ Idem.

${ }^{140}$ Acrópole, n. 322, outubro 1965, p. 25

141 Sérgio Ferro e Rodrigo Lefèvre também haviam escrito "Proposta inicial para um debate: possibilidades de atuação", publicado pelo GFAU em 1963. Nesse texto, os jovens professores lançaram as bases da "poética da economia", questionando a definição de seus caminhos teóricos na arquitetura.

${ }^{142}$ FERRO, Sérgio, LEFÈVRE, Rodrigo. IMPÉRIO, Flávio. "Notas sobre arquitetura", Acrópole, n. 319. São Paulo, julho 1965. Republicado em FERRO, Sérgio. Arquitetura e trabalho livre. São Paulo: Cosac Naify, 2006.
} 
militar o país continuava no caminho de se tornar uma nação moderna e que a industrialização era positiva, devendo beneficiar os trabalhadores posteriormente. Nessas condições, a essência da arquitetura moderna não estaria em crise, havendo apenas "a superação de uma fase". ${ }^{143}$

Na FAU, as metas de Pedro Cruz estavam sendo cumpridas, apesar da oposição de alunos e professores. Ele enviou o substitutivo do Regulamento, que foi apreciado pelo Conselho Departamental em 1966, iniciou as obras do prédio na Cidade Universitária - naquela altura com modificações - e abriu oito concursos de cátedra, conforme a tabela abaixo.

\begin{tabular}{|l|l|l|}
\hline \multicolumn{3}{|c|}{ INSCRIÇÕES EM CONCURSOS PARA PROFESSOR CATEDRÁTICO DA FAU ENTRE 1966-67 } \\
\hline Inscrição & Cadeira & Candidatos \\
\hline $19 / 03 / 1966$ & n. 1 "Cálculo Diferencial e Integral. Geometria Analítica” & Domingos Pizanelli \\
\hline $19 / 03 / 1966$ & n. 9 "Construção II" & Eng. Renato Salmoni \\
\hline $28 / 03 / 1967$ & n. 3 "Mecânica" & Prof. Dr. João Augusto Breves Filho \\
\hline $28 / 03 / 1967$ & n. 4 "Topografia. Elementos de Astronomia de Posição" & $\begin{array}{l}\text { Paulo Ferraz de Mesquita } \\
\text { Fernando Fraga de Toledo Arruda }\end{array}$ \\
\hline $28 / 03 / 1967$ & n. 6 "Construção l” & Ariosto Mila \\
\hline $28 / 03 / 1967$ & n. 19 "Planejamento II" (parte 1 e 2) & Lauro Bastos Birkholz \\
\hline $28 / 04 / 1967$ & n. 26 "Mecânica dos Solos. Fundações" & Victor F. Bachmann de Mello \\
\hline $28 / 04 / 1967$ & n. 22 "História da Arquitetura Il” & Livre docente Nestor Goulart Reis Filho \\
\hline
\end{tabular}

Fonte: Caderno "Concurso de professor catedrático - Inscrição", localizado na seção de expediente da FAUUSP.

Desta vez, todas as vagas foram preenchidas. A única vaga disputa por mais de um candidato foi para a cadeira de 'Topografia', vencida por Paulo de Mesquita. Aos cinco catedráticos da FAU desde 1957, somaram-se mais nove, pois Flávio Motta, finalmente teve sua tese defendida onze anos após a inscrição no concurso. Desse total, apenas três eram arquitetos: Ariosto Mila (formado na Poli) no Departamento de Tecnologia, Nestor Reis Filho no Departamento de História e Lauro Birkholz ${ }^{144}$ no Departamento de Projeto. Os demais, engenheiros, se acumulavam nos departamentos de tecnologia, onde a estrutura de cátedras continuava precedendo ao departamento.

Após o grande volume de contratações em 1962, as contratações durante a gestão de Pedro Cruz foram pontuais. Nelas, ingressaram os engenheiros Renato Salmoni (?-?/65-69), Paulus Aulus Pompéia (1911-1993, Física, 1939, EP, 1962/66-70), Mitsuo Yada (?-?/66-71), Décio Leal de Zagottis (?-?, EP, 1962/67-70), que, de modo geral, permaneceram pouco tempo na escola.

Em edificações, foram contratados os arquitetos Roger Zmekhol (1928-1976, FAU, 1952/6576) e Siegbert Zanettini (1934, FAU, 1959/67-04). Em Desenho Industrial, Manoel

\footnotetext{
${ }^{143}$ ARTIGAS, João B. Vilanova. "Uma falsa crise". Acrópole, n. 319. São Paulo, julho 1965. Republicado em: Caminhos da arquitetura. São Paulo, Cosac Naify, 2004.

${ }^{144}$ Lauro Birkholz era assistente de Anhaia Mello e foi pesquisador do CEPEU.
} 
Kosciuszko Pereira da Silva Corrêa (1935-1967, FAU, 1959/67-?), que faleceu no mesmo ano, e Eduardo Luiz Paulo Riesencampf de Almeida (1933, FAU, 1960/67-97). Uma equipe de sociólogos e economistas também foi contratada, por um breve período, podendo indicar um contrato de pesquisa. São eles: Dorival Teixeira de Vieira (1916-2012, FFCL/66-67), Paulo Sandroni, (FEA, 1964/66-67) e Maria José Villaça, (1946, FFCL/67-?).

Todas as contratações relatadas até aqui, apontam para um movimento consistente de aumento da proporção de professores arquitetos e para uma diminuição gradual dos professores engenheiros, após 1954, quando eram maioria. Mais discreto, porém não menos significativo é a perda de espaço dos artistas e o aumento do número de professores com formações diversas, com destaque para sociólogos e economistas - também seria interessante notar alguns engenheiros de produção, cuja formação na politécnica começou em 195x. Esse movimento na FAU pode ser acompanhado no gráfico abaixo.

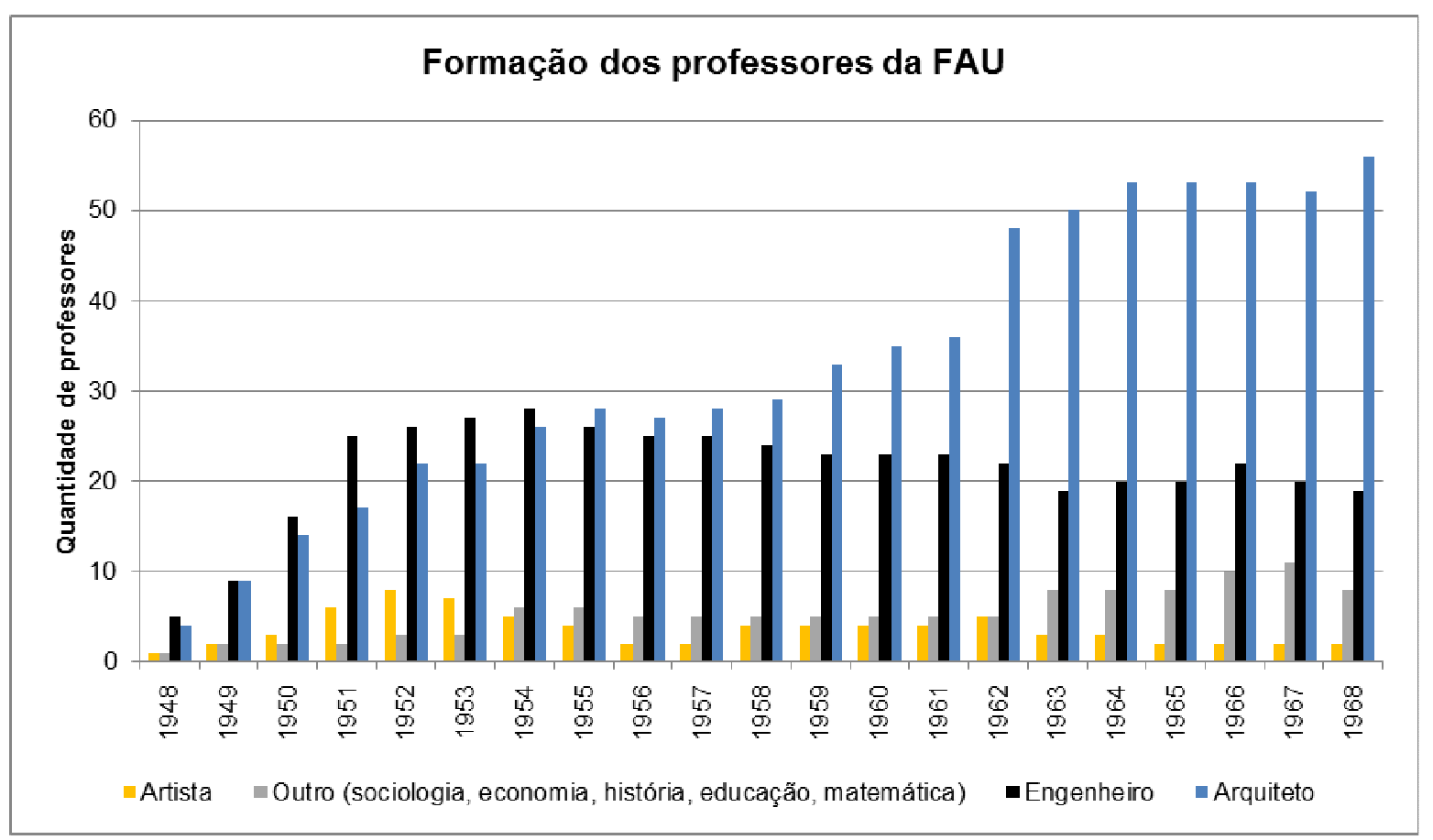

No início de 1967, após atritos causados pela intervenção do diretor no projeto do novo edifício da faculdade, Pedro Cruz o convidou para proferir a aula inaugural sinalizando o reconhecimento da importância de Artigas para a FAU. Na célebre aula "O desenho"145, Artigas mostrou-se otimista em relação ao futuro da arquitetura moderna e do desenvolvimento econômico e tecnológico do país, mas optou por abordar a arquitetura como um gesto poético de domínio da natureza ao invés de se manifestar sobre a conjuntura política e social. Refletindo sobre essa ocasião, o arquiteto ponderou:

${ }^{145}$ ARTIGAS, João Batista Vilanova. "O desenho" [1967], In: Caminhos da arquitetura. São Paulo, Cosac Naify, 2004. 
"Em 1962 não era tão claro como eu estou colocando agora o tema da linguagem. Foi em 67, na aula inaugural com aquele tema do 'Desenho' que alguém conhece por aí. Vejam que coisa interessante que, no momento em que eu fiz essa aula inaugural foi diante de um diretor, o Cabrão, o diretor do momento que foi um miserável, um monstro, professor de geometria descritiva inevitavelmente. Foi nebuloso. Eu tive que fazer a aula na frente dele. Ele havia me convidado quatro dias antes e eu compreendi que ele temia que eu chegasse, na frente dos professores, e dissesse que a democracia é a luta justa por tal e tal coisa. Eu tinha essa tese do desenho, realmente construtiva, ilustre! $\mathrm{E}$ eu li a tese. Tinha um professor da economia que foi mandado pelo reitor e era conhecido como um tremendo reacionário se levantou e disse: '- O senhor é um poeta, o senhor não passa de um poeta!'. Eu pensei: '- Realmente sou poeta, mas não sou burro!'.

Mas meus alunos também não compreenderam essa aula muito bem. Acharam que era hora de dar uma de 1968 e dizer o que eles estavam esperando, com o esquerdismo deles". ${ }^{146}$

A resposta que tais alunos talvez esperassem foi dada por Sérgio Ferro após seu rompimento com o PCB, junto com Rodrigo Lefèvre e Carlos Marighela. Seguindo um raciocínio muito próximo ao que havia consagrado Artigas como uma referência moral para os estudantes, o artigo "Arquitetura Nova", criticava justamente o recuo político dos arquitetos de orientação racional em São Paulo simultâneo à radicalização de suas propostas arquitetônicas. Para Ferro, tanto a poesia quanto a técnica da escola artiguista pareciam se dissociar das condições sociais e produtivas em que estavam inseridas, esvaziando-se politicamente. ${ }^{147}$

O rompimento da "geração da ruptura" 148 com a escola artiguista foi impactante, mas não era a única coisa que cindia a escola, dividida por diferentes vieses artísticos e profissionais, disputada por uma série de tendências políticas, antagonizada por engenheiros, arquitetos, artistas e sociólogos. Nesse amálgama de conflitos, somente a rejeição ao diretor unia a escola. A gota d'água teria sido o boicote da diretoria ao processo de admissão dos excedentes no vestibular, contrariando uma orientação do Ministério da Educação, o que

\footnotetext{
146 Transcrição do depoimento de Vilanova Artigas no Rio Grande do Sul na década de 1980. Acervo pessoal Vilanova Artigas. Disponível em <www.dearquiteturas.com>, acesso em 28/04/2015.

${ }^{147}$ FERRO, Sérgio. "Arquitetura Nova”, [1967], pp. 3-15. Republicado em FERRO, Sérgio. Arquitetura e trabalho livre, Cosac Naify, 2006.

${ }^{148}$ Expressão utilizada por José Wolf em entrevista com Sérgio Ferro. "A geração da ruptura". Arquitetura e Urbanismo, n. 3, São Paulo, 1985.
} 
desencadeou uma greve dos alunos em solidariedade aos vestibulandos. ${ }^{149} \mathrm{O}$ GFAU então apresentou à reitora um dossiê sobre a gestão de Pedro Cruz e o diretor se afastou alegando motivo de saúde, deixando o cargo para seu vice, o historiador Eurípides Simões de Paula da FFCL.

Finalmente, a Congregação da FAU foi instaurada em 15 de fevereiro de 1968, quando a estrutura de concreto armado do novo edifício estava sendo concluída. A partir de então é possível acompanhar a história da faculdade através das atas da Congregação. Além dos catedráticos e livre-docentes, a Congregação também foi composta por Vilanova Artigas, representante dos professores contratados (suplente: Eduardo Corona), Guilherme do Amaral Lyra, representante dos livre-docentes (suplente: Carlos Pereira de Castro), Jon Maitrejean, representante dos demais docentes (suplente: Sérgio Ferro) e por representante dos alunos.

O primeiro ato da Congregação foi indicar os candidatos a diretor da escola. Ariosto Mila foi o mais votado e encabeçou a lista tríplice, formada por Nestor Reis Filho e Domingos Pizanelli, tornando-se o diretor da FAU em 22 de fevereiro de 1968 (até 20/07/1972).

$\mathrm{Na}$ segunda sessão da Congregação elegeram-se os chefes dos departamentos de Construção, Figueiredo Ferraz, e de Ciências Aplicadas, Domingos Pizanelli. Para os departamentos de História e de Projeto não houve votação, pois, os únicos catedráticos eram, respectivamente, Nestor Reis Filho e Lauro Birkholz. Também na segunda sessão foram eleitos os representantes da Congregação no Conselho Universitário, Domingos Pizanelli e o suplente Victor de Mello.

No Conselho Universitário estava sendo discutida a Reforma Universitária. Na oitava sessão da Congregação, de 8 de outubro de 1968, Jon Maitrejean, que era auxiliar de ensino, foi indicado pelo representante dos alunos, Edgar Dente, para substituir Victor de Mello e assumiu como suplente a representação da FAU, participando da maioria das reuniões do Conselho ao lado do diretor Ariosto Mila.

"Para minha surpresa fui eleito; muito contra minha vontade. Eu não gosto, pessoalmente, dessas posições de mando. É muita responsabilidade. E eu era moleque, uma formação ainda muito crua, especialmente política. Isso significou no Conselho uma enorme reviravolta; era a demonstração de que a maioria das minorias ia começar a tomar conta da Faculdade [...]. Naquele tempo os

\footnotetext{
${ }^{149}$ Ver: Folha de S. Paulo. "Alunos dispostos a retomar a FAU", segunda-feira, 22 de maio de 1967. Disponível do acervo online do jornal.
} 
catedráticos eram representantes das Escolas, mas pelo Estatuto da Universidade, qualquer um podia ser". ${ }^{150}$

Ainda segundo depoimento de Maitrejean, o Conselho Universitário ficou dividido entre um grupo mais à esquerda e uma corrente liderada pelo vice-reitor em exercício, Hélio Lourenço.

"Para mim era muito desagradável, porque o Mila era a favor da revolução e eu era contra. Então as nossas votações eram absolutamente antagônicas [...]. A não ser alguma coisa que fosse de consenso, mas a maior parte das coisas nós votávamos diferente. Isso no Conselho era uma coisa terrível. Mas era uma época de radicalizações, e foi assim durante o tempo todo". 151

O principal assunto da Congregação naquele momento era a Reforma Universitária, que vinha sendo discutida desde o acordo MEC-USAID, em meados de 1965. Nesse contexto, com a iminência da Reforma Universitária, Ariosto Mila promoveu o $2^{\circ}$ Fórum da FAU, realizado entre maio e julho de 1968 - quando a mudança para o novo edifício já era tida como certa. Na verdade, segundo Fernando Cabral, o Fórum de 1968 teria sido desencadeado antes, por uma revolta dos alunos, que encontraram o ateliê segmentado com divisórias ao retornar das férias, e desmontaram as divisórias.

De todo modo, o segundo Fórum foi organizado por comissões e subcomissões que prepararam a pauta, envolvendo todos os departamentos. A intenção era adequar o ensino às necessidades do país. Mas o diagnóstico sobre o que o país precisava dividia os grupos mais politizados. Segundo Ferro, o grupo de Artigas buscava prioritariamente o desenvolvimento das forças produtivas, enquanto ele e seus colegas criticavam as relações de produção e exploração. ${ }^{152}$ Segundo Artigas, a sua opção era partir da "proposta brasileira de desenvolvimento, revolucionário, claro". Mas haveria outras opções. De um lado a proposta da própria burguesia nacional, segundo a qual os edifícios deveriam ser baratos "porque somos um país pobre", o que, no entanto, penalizaria apenas o povo e não responsabilizaria a burguesia pela transferência da riqueza para as metrópoles imperialistas. ${ }^{153}$ De outro, a opção de "fazer uma revolução mais rápida", sendo que, para

\footnotetext{
${ }^{150}$ Depoimento de Jon Maitrejean ao autor, realizado em 30/07/2014.

151 Idem.

${ }^{152}$ FERRO, Sérgio. "Depoimento", em SANTOS, Maria Cecilia Loschiavo dos. (org.). Maria Antonia: uma rua na contramão. São Paulo: Nobel, 1988, p. 272.

153 Depoimento de João Vilanova Artigas em 11 de outubro de 1968 apud THOMAZ, Dalva. Um olhar sobre Vilanova Artigas e sua contribuição à arquitetura brasileira. Dissertação de mestrado em Arquitetura e Urbanismo. Orientadora: Ana Maria de Moraes Belluzzo. São Paulo: FAU-USP, 1997, p. 335. Tal fala ocorreu na Unidade de ensino básica do 5ำ ano, sob orientação de Júlio Katinsky, Gabriel Bolaffi e Hélio Penteado. Como debatedores nessa ocasião foram também convidados os professores Flávio Motta, Juarez Soares Brandão, Rodrigo Lefèvre, Paulo Mendes da Rocha e Fábio Penteado.
} 
Artigas, a arquitetura não era uma "forma de conhecimento capaz de influir diretamente no processo". Vinha daí a visão simplificada e persistente de que a crítica das relações de produção não tinha relação com a arquitetura e sua única consequência possível era a luta armada:

"Temos colegas numerosamente classificados que elaboram essa tese e não aceitam que se entre na Faculdade de Arquitetura para fazer um curso de Arquitetura, mas aprender a ser guerrilheiro. Como pode ser isso? No fim não sai nem guerrilheiros nem arquiteto. A revolução que nós vamos fazer prescindirá de conhecimento técnico e de uma visão artística do mundo? Se ela puder prescindir, então vamos fechar todas as escolas". ${ }^{154}$

Apesar da tensão nos bastidores, o Fórum ocorreu normalmente, com uma pauta extensa de assuntos e membros dos dois grupos nas relatorias das comissões. Tratou-se da pósgraduação, da finalidade da Vila Penteado após a mudança para a Cidade Universitária, de novos currículos mais estruturados e proporcionais entre os departamentos, da incorporação e sistematização da pesquisa em todos os departamentos, do funcionamento do ateliê (agora rebatizado de estúdio), da disponibilidade de disciplinas alternativas (optativas), de novas disciplinas, como a de história da técnica, entre outros tantos assuntos.

No entanto, as resoluções mais estruturais foram a reativação e reorganização do museu e a institucionalização do Ateliê Interdisciplinar e do Fórum. O Fórum, como uma assembleia de toda a comunidade, realizaria um balanço anual das atividades da faculdade e discutiria o ideário de ensino e pesquisa, estabelecendo a temática do ano seguinte - naquele ano foi definido como problemática básica "Arquitetura na sociedade de consumo". O Museu coordenaria e divulgaria as atividades curriculares e extracurriculares da graduação e pósgraduação, conforme a problemática adotada pelo Fórum. Por fim, o Ateliê Interdepartamental faria pesquisas em arquitetura de caráter transversal, envolvendo todos os departamentos, de acordo com a programação do Museu.

Para efetivar suas resoluções o Fórum propôs a modificação da Portaria 397/67, cuja redação final foi aprovada pela Congregação em 22 de julho de 1968 e sancionada pelo vice-reitor em exercício, Hélio Lourenço.

A Reforma Universitária foi finalmente regulamentada pela Lei n. 5.540, de 28 de novembro de 1968 e complementada pelo Decreto-Lei n. 464 de 11 de fevereiro de 1969. Sua natureza contraditória foi fruto, por um lado, da modernização e expansão do ensino superior, reivindicadas por universitários de todo o país, e por outro, das políticas federais 
de controle ideológico e privatização do ensino superior. Com apoio de especialistas norteamericanos, foi posto um fim ao regime vitalício de cátedras. O ingresso e a progressão docente passavam a ser vinculados à titulação. ${ }^{155}$

O edifício da FAU foi inaugurado em 25 de fevereiro de 1969, quando Artigas, ao lado do diretor Ariosto Mila e do vice-reitor em exercício Hélio Lourenço, supervisionou o vestibular, a primeira atividade ocorrida no prédio novo. Artigas, porém, não teve oportunidade de lecionar em sua obra por muito tempo. Em abril de 1969 seu nome foi incluído na primeira lista com 42 professores aposentados compulsoriamente por Gama e Silva, reitor-licenciado, Ministro da Justiça e autor do Al-5. ${ }^{156}$ Dias depois, uma segunda lista com mais 24 professores foi publicada no Diário Oficial. Entre estes estavam os professores da FAU que haviam se oposto a Gama e Silva no Conselho Universitário, Paulo Mendes da Rocha e Jon Maitrejean, além do vice-reitor Hélio Lourenço, que teve seus atos revogados, entre eles os relativos à reforma curricular da $\mathrm{FAU} .{ }^{157} \mathrm{~A}$ escola entrou em luto. Em solidariedade aos professores afastados, Oscar Niemeyer recusou o convite de Ariosto Mila para proferir a aula magna daquele ano.

"Na minha opinião, ela [a aposentadoria] não tinha um caráter político partidário. Como não teria a do Paulo Mendes da Rocha, que não tinha uma filiação partidária. Éramos homens de esquerda, éramos mais favoráveis para um lado do que para o outro. Mas não tínhamos nenhuma ação [...]. Daí nós fomos aposentados, na minha opinião, muito por uma razão de circunstâncias. Se eu não tivesse entrado no Conselho, não teria acontecido nada comigo. [...]. Sérgio Ferro, Lefèvre, todo um grupo de esquerda, perfeitamente caracterizado, eles não foram tocados. Acho que faltava a eles um certo aspecto de liderança. Eu, pessoalmente, não tinha, mas dava toda a impressão que tivesse". ${ }^{158}$

A FAU iniciou o ano letivo de 1969 com nova grade curricular e disciplinas optativas. No entanto, apesar da lei federal, o regulamento vigente da USP ainda era o de 1962, baseado no sistema de cátedras. O novo Estatuto da USP - "o primeiro ato da Reforma Universitária do Estado" - foi assinado pelo governador Abreu Sodré em dezembro de 1969, "enquanto o coral da universidade cantava Aleluia, de Handel". 159 Participaram dessa cerimônia

\footnotetext{
${ }^{155}$ MARTINS, Carlos Benedito. "A reforma universitária de 1968 e a abertura para o ensino superior privado no Brasil". In: Educação \& Sociedade, n. 106. Campinas: Cedes, jan-abr, 2009. Disponível em <www.scielo.br/pdf/es/v30n106/v30n106a02>

${ }^{156}$ ASSOCIAÇÃO DOS DOCENTES DA UNIVERSIDADE DE SÃO PAULO [1978]. O controle Ideológico na USP: 1964-1978. São Paulo: Adusp, 2004.

${ }^{157}$ PONTES, Ana Paula et al. Op. Cit., p. 13.

${ }^{158}$ Entrevista de Jon Maitrejean ao autor, realizada em 30 de julho de 2014.

${ }^{159}$ Ver: "Abreu Sodré assina o Estatuto da USP", O Estado de São Paulo, 17 de dezembro de 1969.
} 
autoridades civis e militares, como o vice-presidente da República, almirante Augusto Rademaker, o ministro da Educação, Jarbas Passarinho, o ministro da Justiça, Alfredo Buzaid, o reitor Miguel Reale, o senador Carvalho Pinto, o presidente do Tribunal de Justiça do Estado, Marcio Martins Ferreira, o prefeito, Paulo Salim Maluf, o secretário da Educação, Ulhôa Cintra, o almirante Hélio Ramos Azevedo Leite, o brigadeiro José Vaz da Silva, o general Dale Coutinho, o general Aloisio Guedes Pereira, o presidente do Tribunal de Contas do Estado, Anhaia Mello, o presidente do Conselho Estadual de Educação Carlos Pasquale, o diretor da FAU, Ariosto Mila e o presidente da CESP, Lucas Nogueira Garcez. O local escolhido, para tal cerimônia foi a Faculdade de Arquitetura e Urbanismo na Cidade Universitária.

Artigas só voltaria à FAUUSP nos últimos anos de sua vida, quando a lei de anistia, de 1979, permitiu que ele reassumisse sua vaga. ${ }^{160}$ Contudo, Artigas foi readmitido em 1980 na condição de auxiliar de ensino, equivalente à sua posição antes do afastamento compulsório, enquanto muitos de seus alunos já eram doutores (por conta de uma disposição transitória que regulamentou a nova carreira ${ }^{161}$ ), livre docentes ou titulares. Mais aviltante que isso, Artigas foi designado para lecionar uma disciplina de "moral e cívica" introduzida pelo regime militar, que ele transformou num seminário de estudo dos problemas brasileiros. Artigas, que se aposentaria compulsoriamente por completar 70 anos de idade em 1985, ainda apelou para que a Congregação lhe concedesse o cargo de professor titular, já que era regente de cátedra quando foi afastado. Apesar do apoio de personalidades e instituições, em 1983 a Congregação recusou. Para aposentar-se como professor titular da escola que ajudou a criar, Artigas prestou concurso e apresentou seu memorial no qual foram recolhidos seus textos, projetos e depoimentos. O concurso ocorreu em 1984, tendo a banca composta por Carlos Guilherme Motta, Flávio Motta, Ruy Gama, José Arthur Gianotti, Eduardo Kneese de Mello. ${ }^{162}$ Artigas faleceu no ano seguinte.

\footnotetext{
160 Ver: GFAU; KEESE, Jefferson Lafaiette (ed). Anistia na FAUUSP: A reintegração dos professores cassados pelo Al-5. São Paulo: FAU-USP, 1998.

161 PONTES, Ana Paula et al. Op. Cit., p. 16. Segundo os autores, essa disposição permitiu que dezenas de professores da FAU obtivessem o título em 1972 apresentando como teses alguns "trabalhos improvisados".

${ }^{162}$ As arguições estão disponíveis: ARTIGAS, João B. Vilanova. Caminhos da arquitetura. São Paulo, Cosac Naify, 2004.
} 

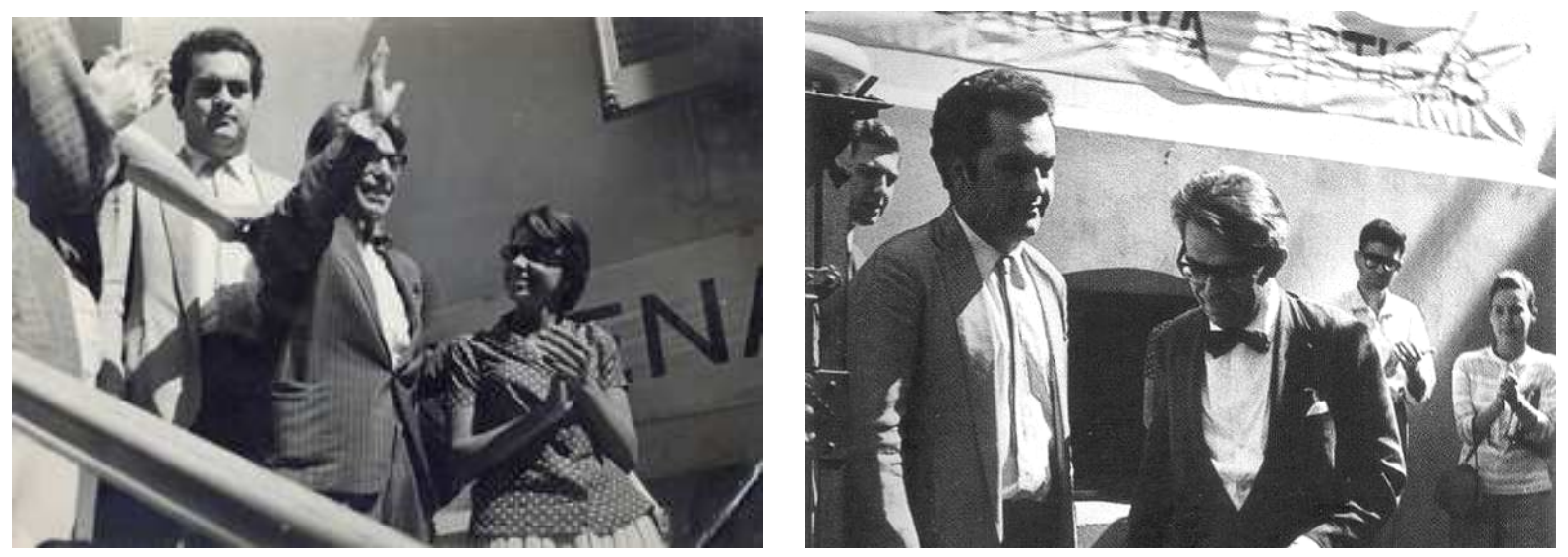

Recepção à Artigas realizada pelos alunos da FAUUSP em 1964 após prisão. Edgar Dente à esquerda de Artigas. Arquivo Vilanova Artigas
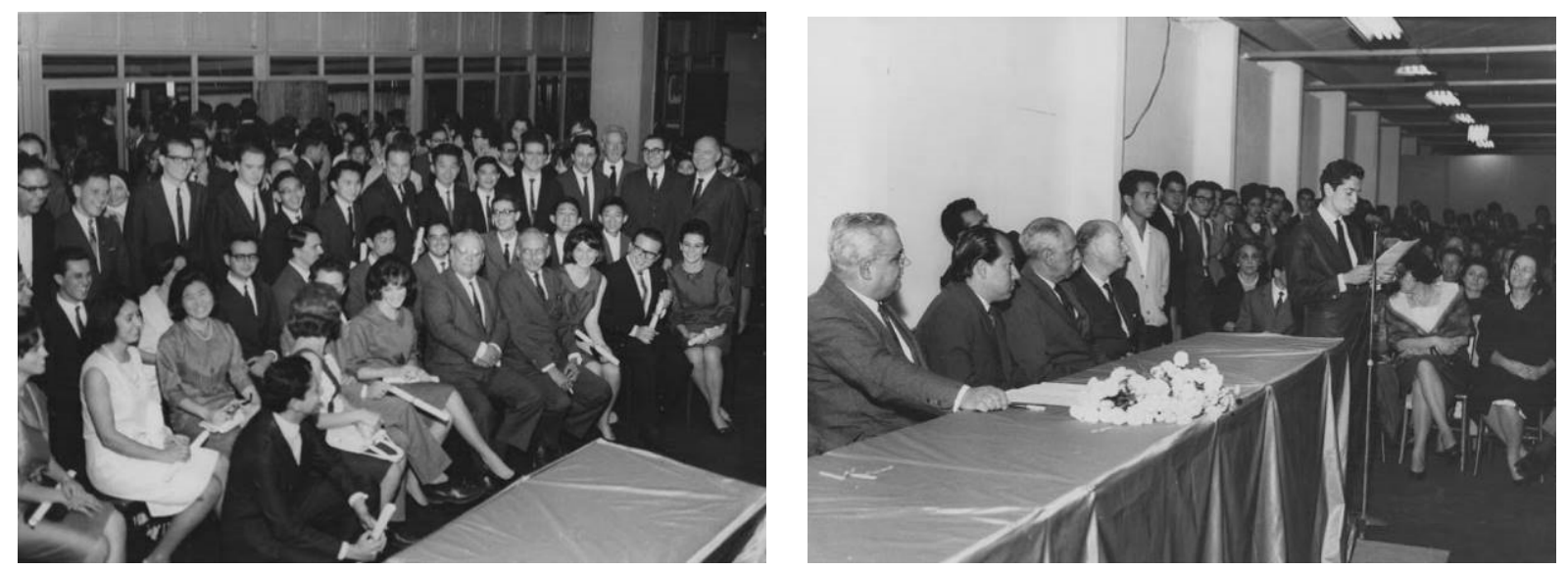

Formatura dos alunos em 1964, realizada no ateliê da Vila Penteado. FAU durante IPM comandado pelo General Chagas. Artigas foi escolhido paraninfo apesar de estar no exilado. Orador Vicente Bicudo. Arquivo Vicente Bicudo
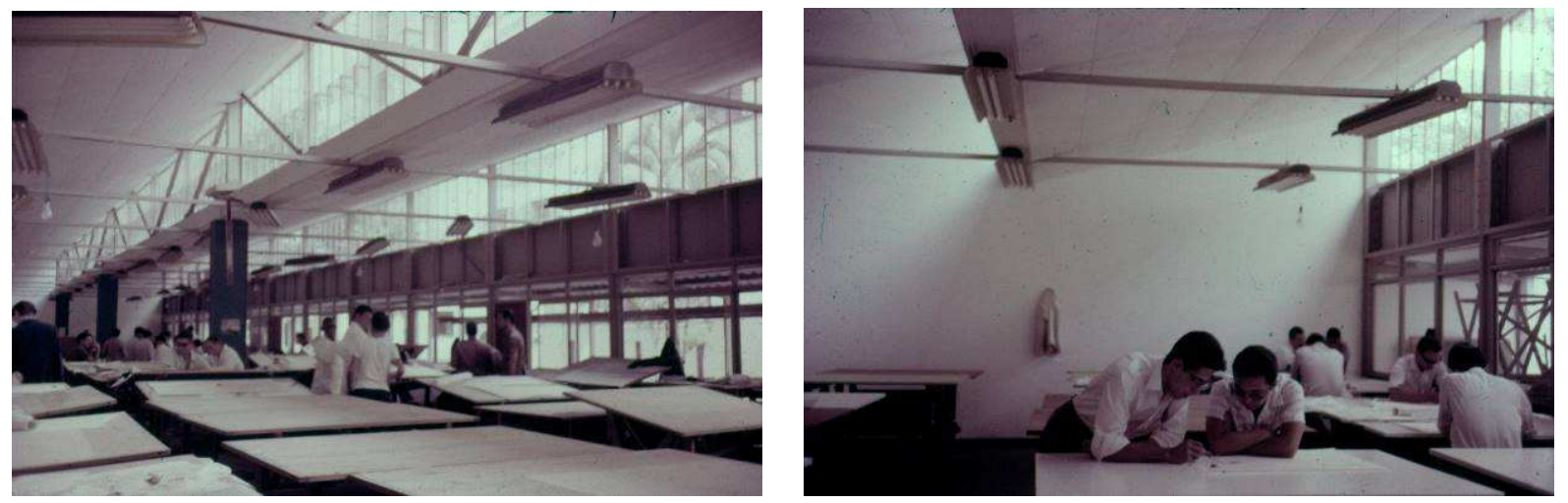

Aspectos do ateliê na Vila Penteado, década de 1960. Arquivo Vilanova Artigas 

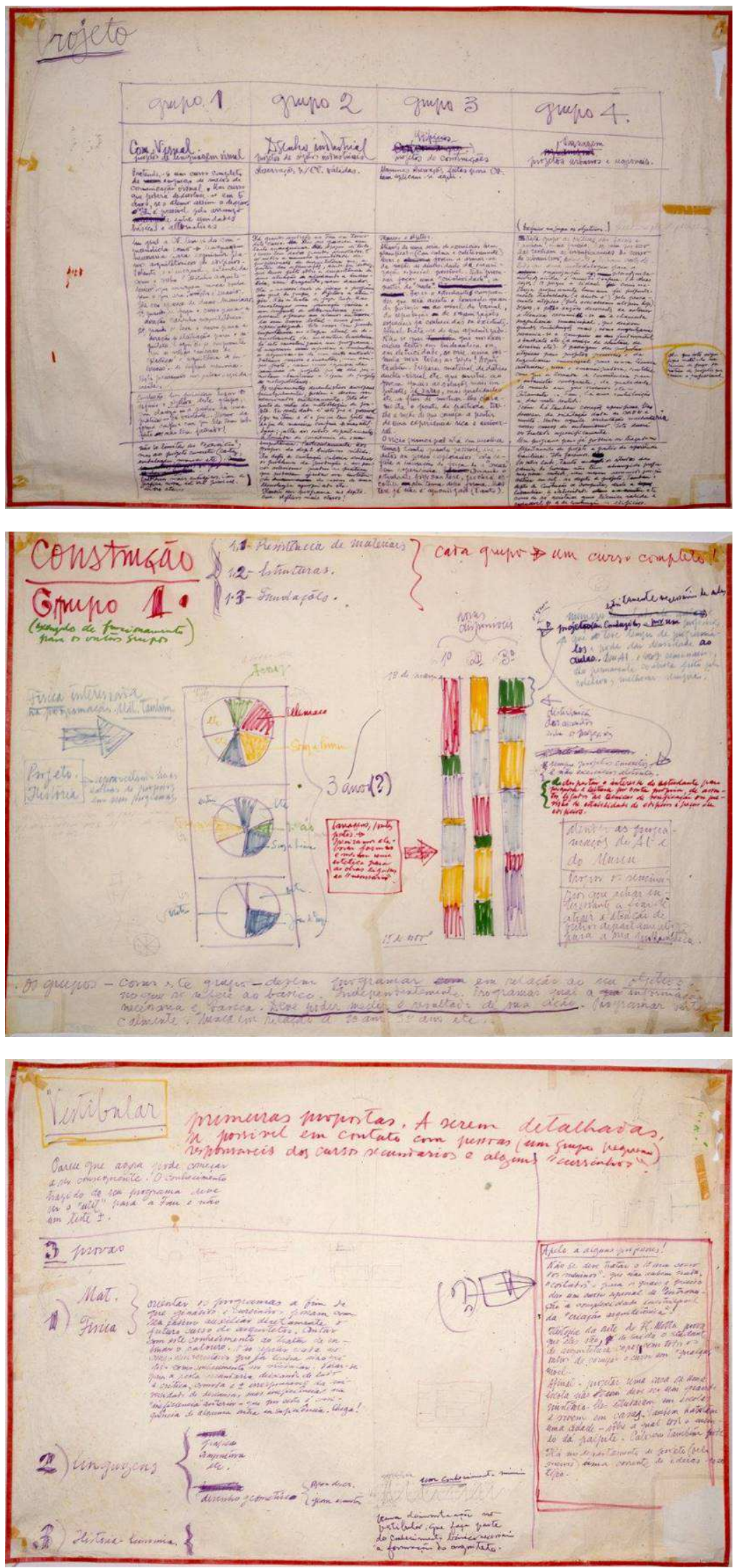

Pranchas para o Fórum de 1968. Arquivo Vilanova Artigas 


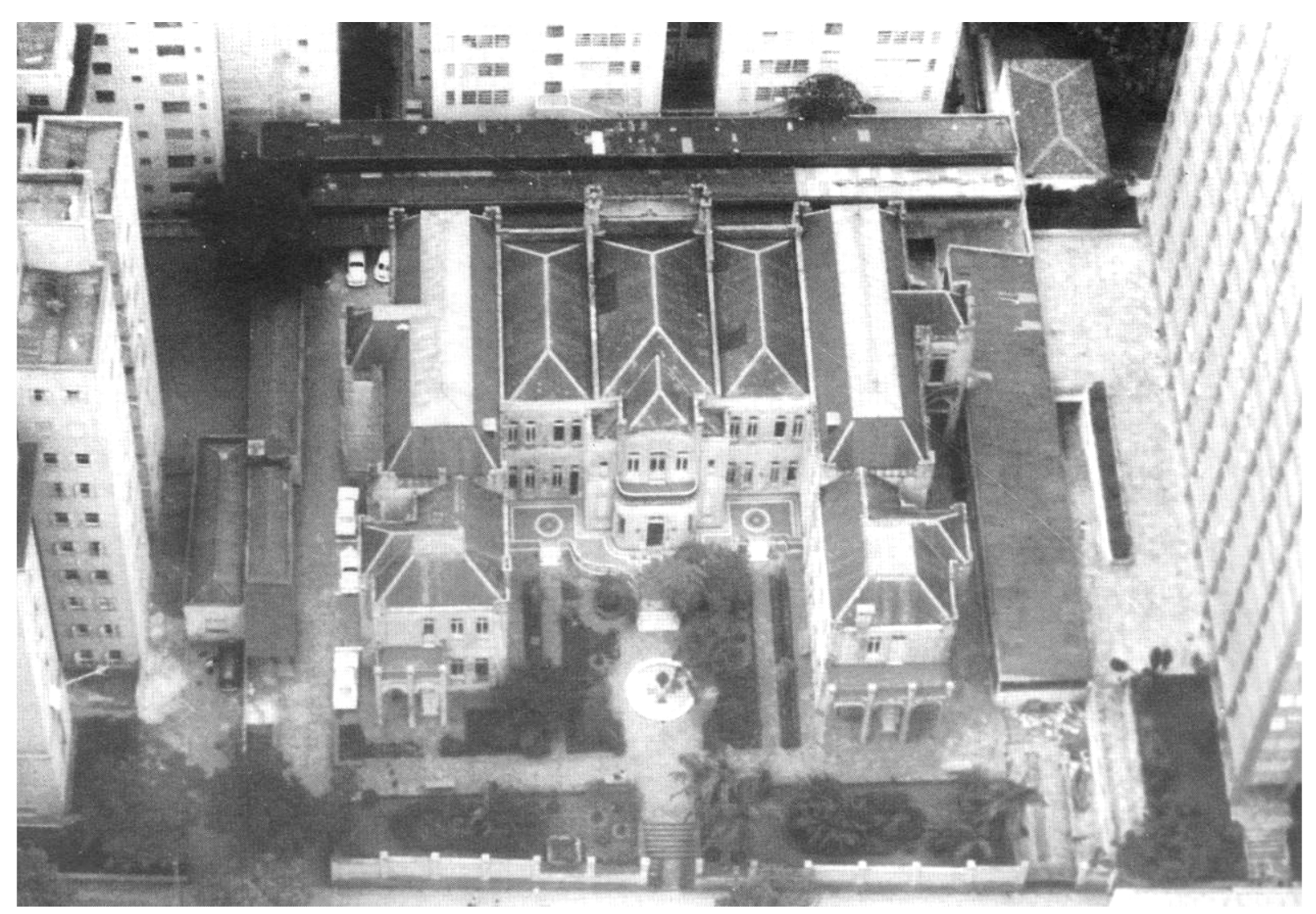

Vila Penteado. Notar anexos construídos na área envoltória, onde funcionaram ateliês e salas de aula. Foto: Benedito Lima de Toledo, 1975

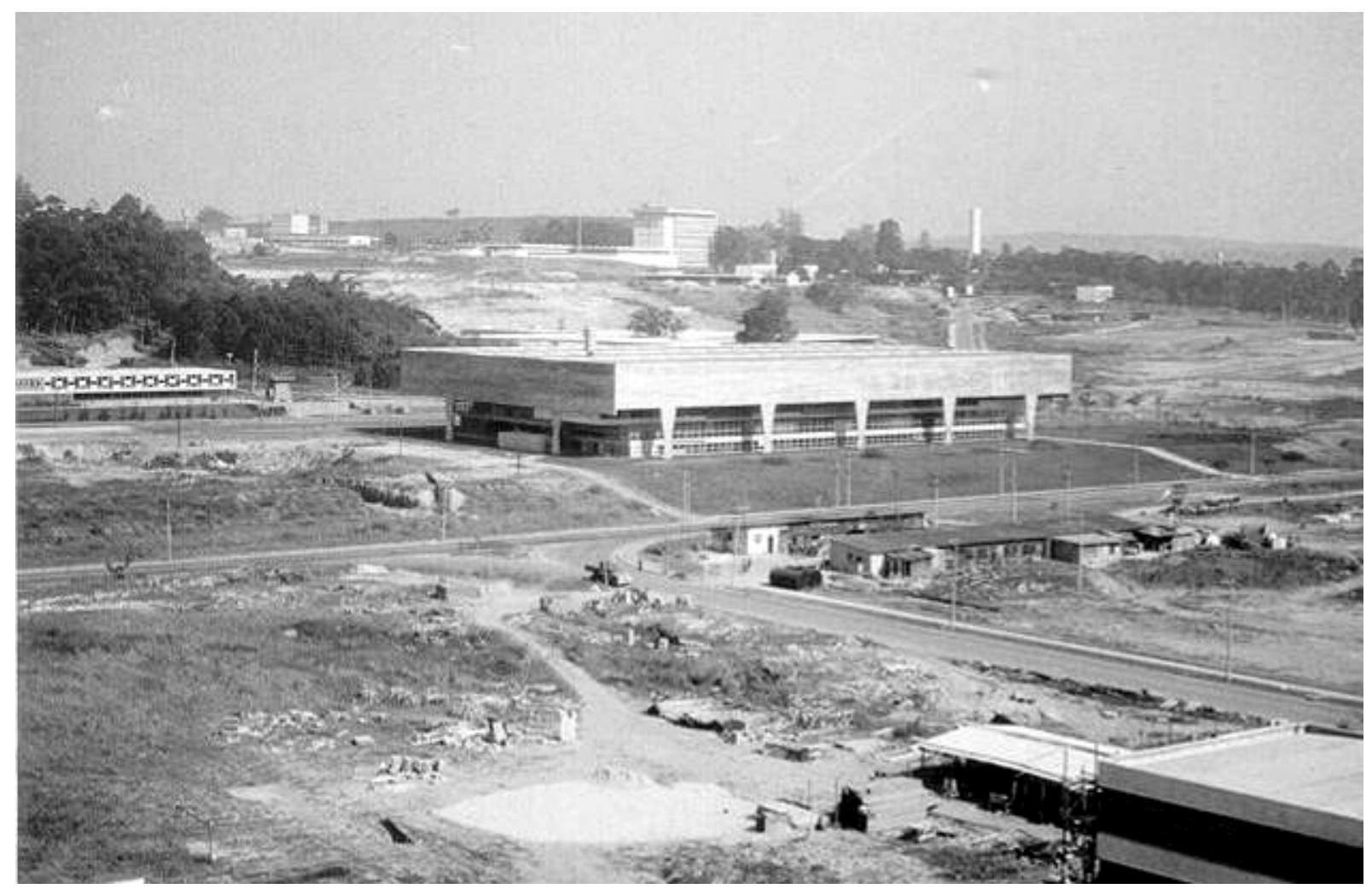

FAUUSP na Cidade Universitária, 1969. Arquivo SEF-USP 

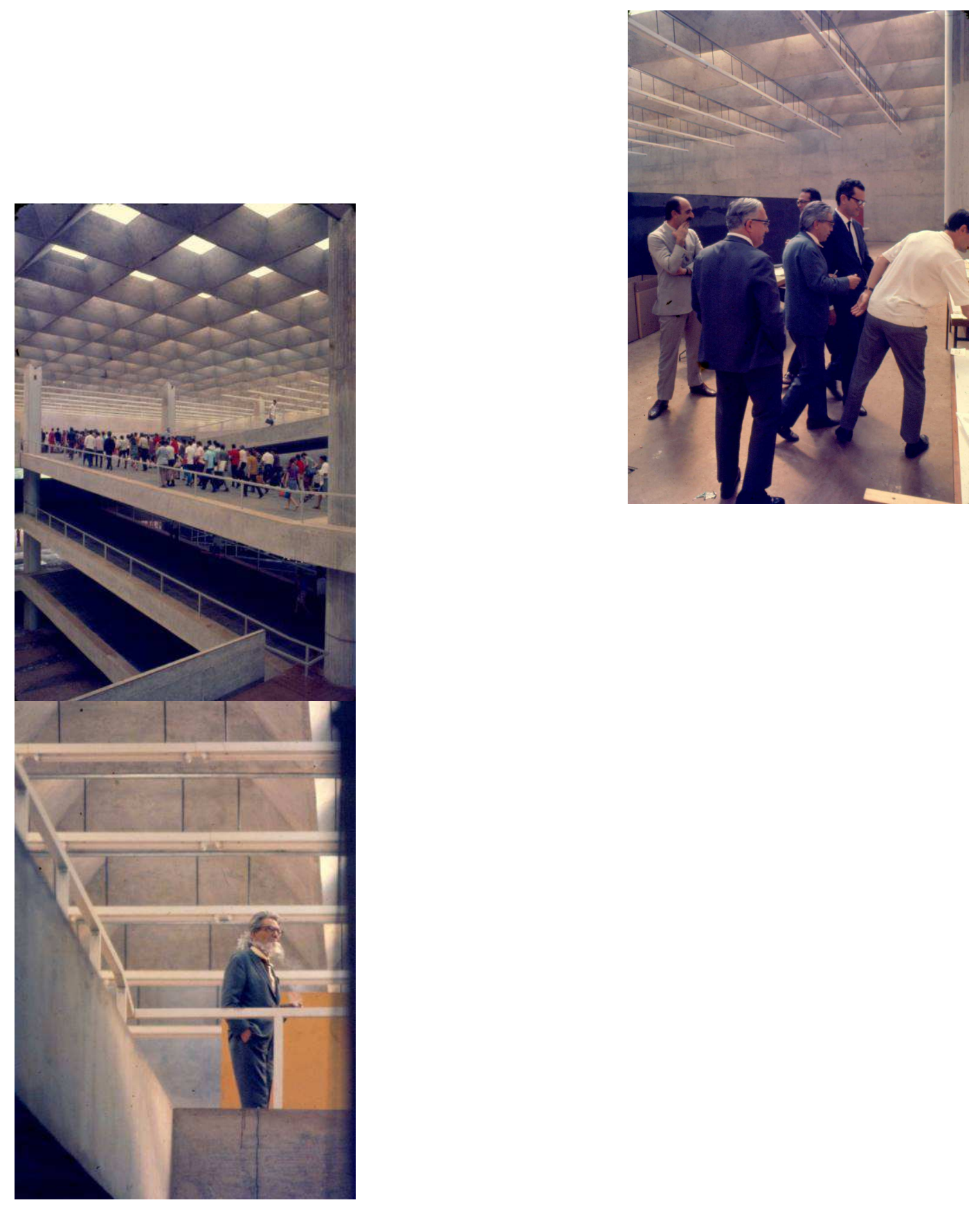

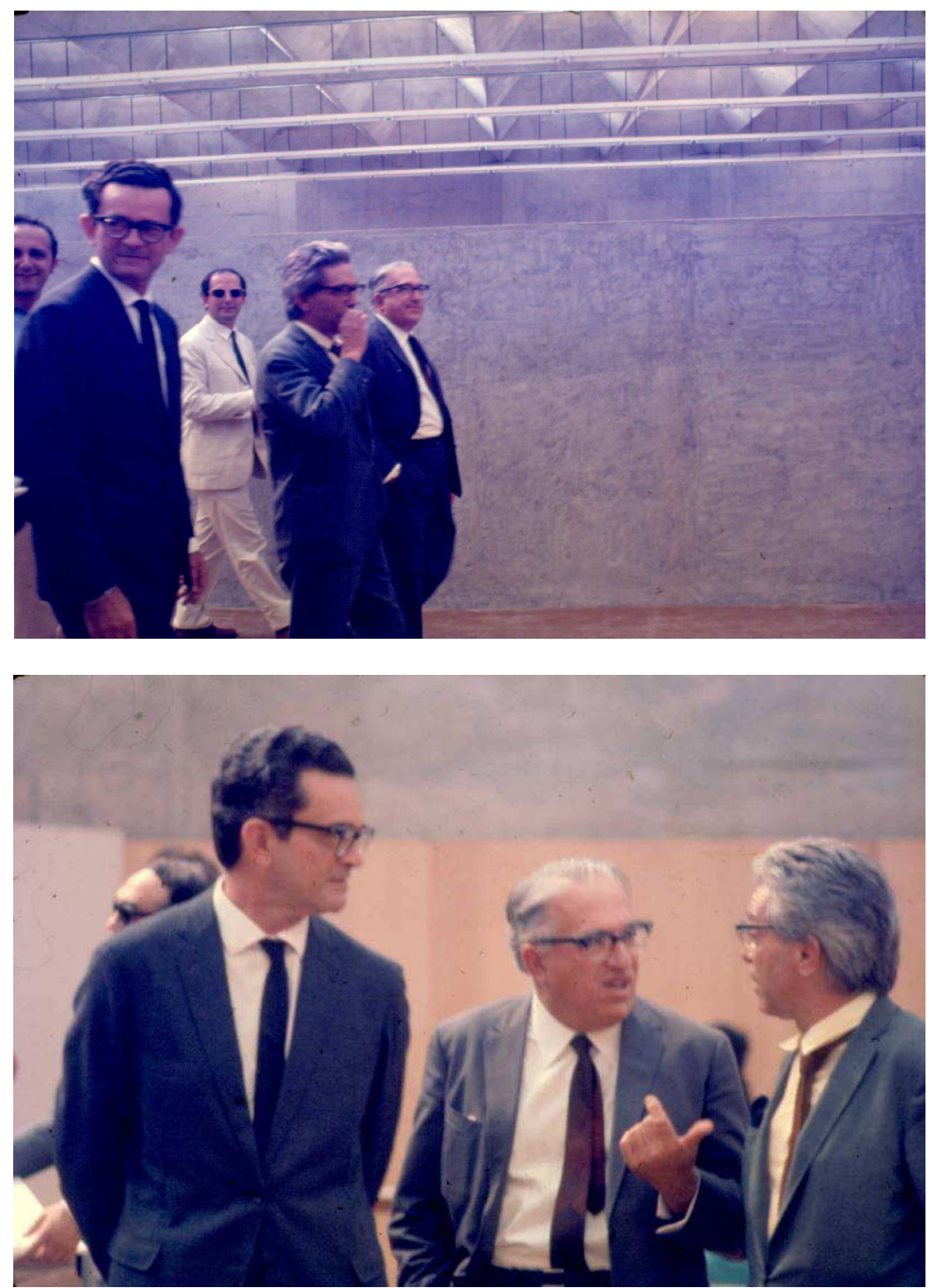

Aspectos do vestibular de 1969,

Arquivo Vilanova Artigas

Na imagem ao lado, reitor em exercício Hélio Lourenço, Ariosto Milla e Vilanova Artigas. 

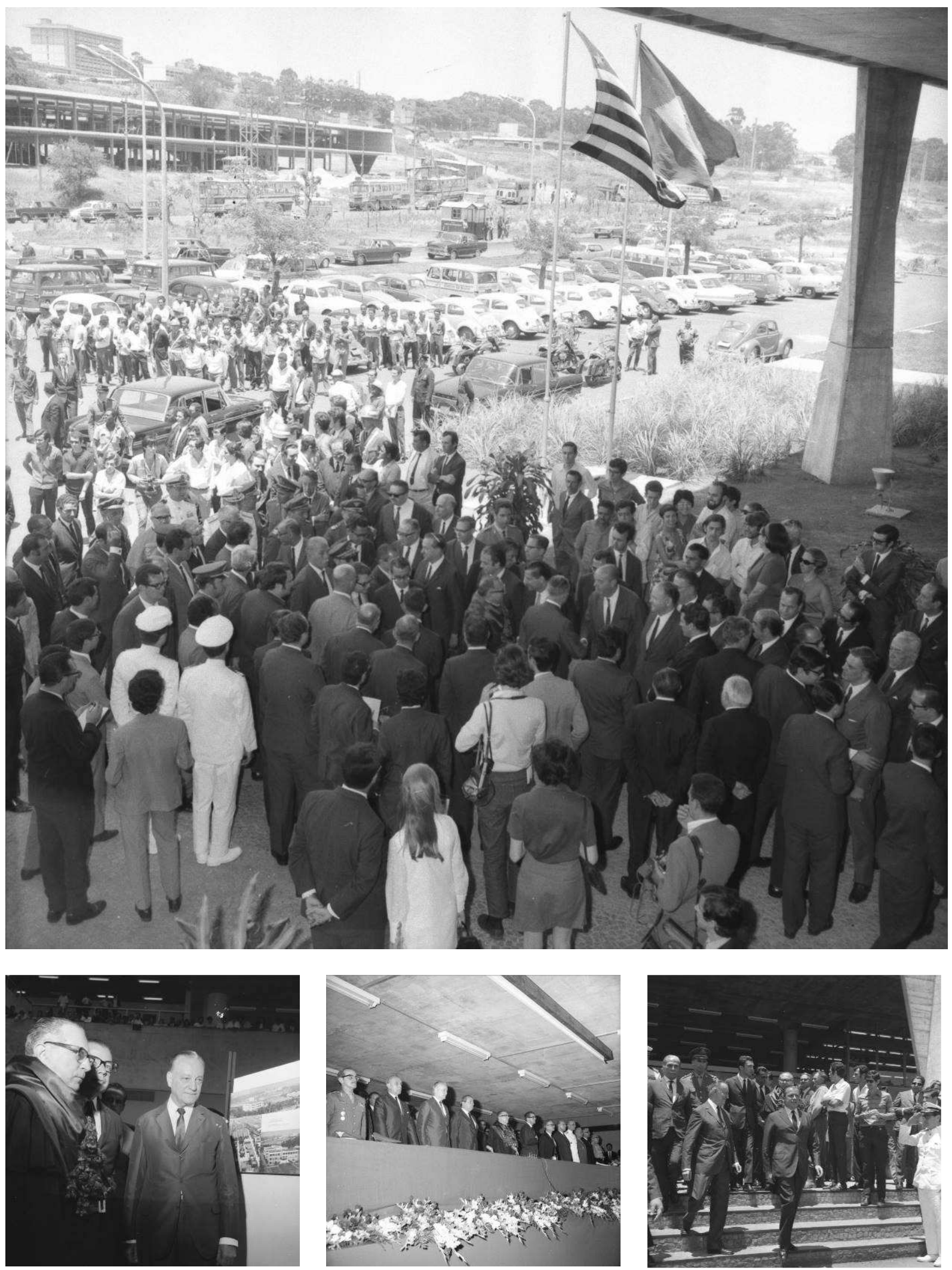

Cerimônia de assinatura do Estatuto da USP, dezembro 1969.

Com presença do governador Roberto Abreu Sodré, do reitor Miguel Reale e do vice-presidente da República, Augusto Rademaker e de autoridades civis e militares. Arquivo Público do Estado de São Paulo 

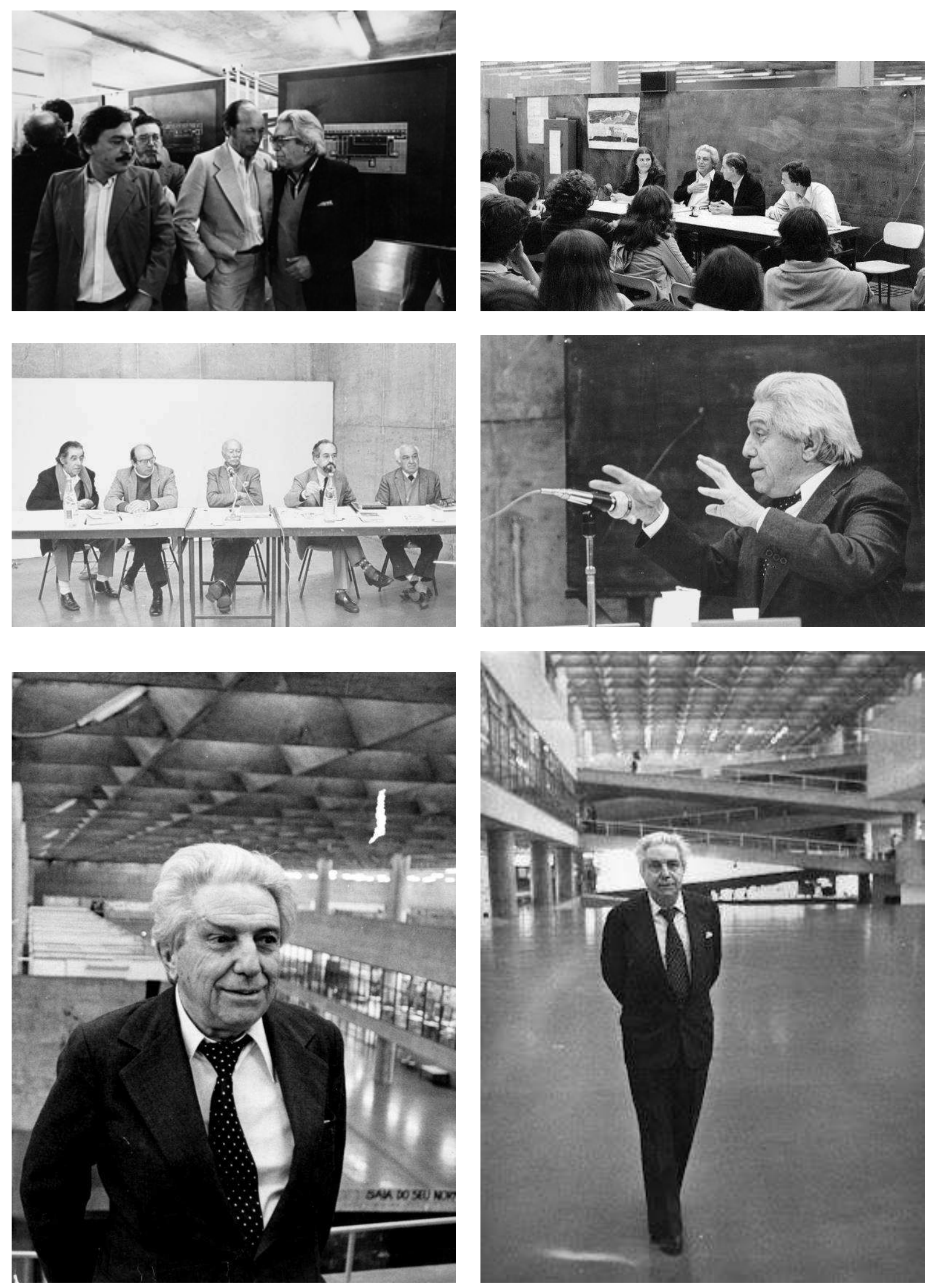

1. Exposição dos riscos originais da FAU em ato pela reintegração dos professores afastados da FAU, 1979. 2. Aula de Artigas, c. 1980. 3. Banca de concurso de professor titular. 4, 5 e 6 . Artigas durante arguição no concurso para professor titular. Arquivo. Vilanova Artigas. 


\section{CIDADE UNIVERSITÁRIA}

\section{A NOÇÃO DE CIDADE UNIVERSITÁRIA (1826-1940)}

Apesar do tema das cidades universitárias possuir relação com o chamado modelo universitário norte-americano e de sua denominação vir de precedentes europeus, como os de Paris (1923) e Madri (1928), as cidades universitárias adquiriram um sentido próprio na América Latina. Planejadas em diversos países a partir da década de 1920, as cidades universitárias começaram a se tornar realidade na América Latina após a $2^{a}$ Guerra Mundial, em meio a uma série de eventos que marcariam suas concepções estéticas e urbanísticas. Nesse contexto, as cidades universitárias foram campos privilegiados de experimentação dos paradigmas da monumentalidade moderna e dos esforços da arquitetura e do urbanismo de adequação ao clima, integração à paisagem e síntese das artes.

Como obras públicas de dimensões urbanas, as cidades universitárias exigiram novas estruturas de planejamento e foram laboratórios de urbanismo moderno, permitindo exercícios de zoneamento setorial, sistema viário funcional, novas tecnologias de infraestrutura urbana (iluminação, sistemas hidráulicos e elétricos) e, principalmente, de desenho urbano integrado com a arquitetura.

A chegada e transmutação da ideia de cidade universitária na América Latina remonta ao papel que as universidades tiveram na modernização de seus países, durante a formação das Repúblicas nacionais, quando novas instituições foram criadas e as mais antigas universidades, como as do México (1551), Peru (1551), Equador (1586), Argentina (Córdoba, 1613), Guatemala (1676), Venezuela (1721), foram refundadas, desligando-se da igreja, ampliando suas vagas e abrindo novos cursos num esforço para atender as 
necessidades do Estado e da sociedade civil por quadros técnicos e políticos. Ainda que o modelo largamente adotado seja caracterizado pelo que Darcy Ribeiro chamou de "modernização reflexa", baseado na reprodução de métodos e tecnologias estrangeiras ${ }^{1}$, e mesmo com números muito deficitários em relação às sociedades ditas desenvolvidas, a renovação e multiplicação das universidades representou um grande esforço. Nesse cenário, não é difícil demonstrar que o Brasil se manteve atrasado qualitativa e quantitativamente, mesmo em comparação com a modernização tardia do ensino superior na América Latina. ${ }^{2}$

A primeira universidade brasileira, a Escola Universitária Livre de Manáos (1909), pagou o preço de se pioneirismo, fragmentando-se em unidades independentes no fim do ciclo da borracha. ${ }^{3}$ A reforma Rivadário Corrêa, de 1911, buscou ampliar as vagas no ensino superior permitindo a existência temporária da Universidade do Paraná ${ }^{4}$ entre 1912 e 1915 e da primeira universidade privada do país, chamada de Universidade de São Paulo ${ }^{5}$, entre 1911 e 1917.

A criação da Universidade do Rio de Janeiro 6 a partir da reunião da Faculdade de Medicina, da Escola Politécnica e da Faculdade de Direito, em 1920, iniciou um intenso debate sobre modelo universitário que deveria ser adotado no país. Esse debate, que atravessou toda a década de 1920, resultaria no Estatuto das Universidades Brasileiras, de 1931, e na criação de universidades estaduais, como a Universidade de São Paulo, em 1934.

\footnotetext{
${ }^{1}$ Ver: RIBEIRO, Darcy. A universidade necessária. Rio de Janeiro: Paz e Terra, 1969.

${ }^{2} \mathrm{O}$ ensino superior no Brasil foi deliberadamente evitado durante o período colonial brasileiro. Além a inexistência de iniciativas oficiais, iniciativas privadas eram proibidas. Em contrapartida, a elite colonial podia receber bolsas da coroa ou pagar altos valores para estudar teologia, direito, medicina ou filosofia em Portugal. A Espanha, ao contrário, logo instalou oito grandes universidades e diversos centros de ensino superior por toda a América Espanhola, permitindo inclusive a imprensa de livros e jornais. O tímido avanço no Brasil se deve ao período em que os jesuítas tiveram autorização da coroa para fundar centros de formação leigos e religiosos para lecionar em seus dezessete colégios (1549-1760), que ofereciam cursos de Artes, Teologia, Ciências Naturais e Filosofia. Apenas com a vinda da família real, em 1808, o ensino superior ressurgiria, impulsionado pela imigração da alta burocracia civil, militar e eclesiástica e da nobreza lusitana, pela importação da Biblioteca Nacional e pela abertura dos portos (1817) que possibilitou a circulação de livros. Com a independência do Brasil, D. Pedro I fundou Faculdades Jurídicas em São Paulo e Olinda em 1827. Ver: RAMOS, Fábio Pestana. "História e política do ensino superior no Brasil: algumas considerações sobre o fomento, normas e legislação". Para entender a história... Ano 2, série 14/03, março 2011, pp. 1-7.

${ }^{3}$ A Universidade de Manáos reunia os cursos de Engenharia, Direito, Medicina, Farmácia, Odontologia e a formação de oficiais da Guarda Nacional. Universidade foi fechada em 1926, sendo diluída e restringida a faculdades independentes, posteriormente incorporadas à Universidade Federal do Amazonas em 1962. RAMOS, Fábio Pestana, Op. Cit.

${ }^{4}$ A Universidade do Paraná foi desmembrada em faculdades isoladas em 1915 por não atender ao Decreto 11.530 - a chamada Reforma Carlos Maximiliano - que entre outras medidas restritivas não mais permitiu universidades em cidades com menos de 100 mil habitantes. RAMOS, Fábio Pestana, Op. Cit.

${ }^{5}$ Criada por um empresário que esperava recuperar o investimento através da cobrança de taxas, essa Universidade de São Paulo chegou a formar alunos em Medicina, Odontologia, Farmácia, Comércio, Direito e Belas Artes. Entretanto, com a criação da Faculdade de Medicina e Cirurgia de São Paulo, do governo do Estado, a universidade privada teria se tornado financeiramente inviável, sendo extinta em 1917. RAMOS, Fábio Pestana, Op. Cit.

${ }^{6}$ Posteriormente denominada Universidade do Brasil (1937) e Universidade Federal do Rio de Janeiro (1965).
} 
Em São Paulo esse debate foi protagonizado pelo chamado "Grupo do Estado", organizado em torno do jornal O Estado de São Paulo ${ }^{7}$ sob o comando de Fernando Azevedo, o jornal promoveu um inquérito sobre a instrução pública em 1926. Conferências nacionais e outro inquérito sobre educação foram realizados no Rio de Janeiro, em 1927, pela Associação Brasileira de Educação (ABE), formada naquele mesmo ano como um braço do Movimento Renovador da Educação, liderado por Fernando de Azevedo, Anísio Teixeira e Lourenço Filho. Quando Getúlio Vargas chegou ao poder, em 1930, foi esse grupo que propôs a criação do Ministério da Educação e Saúde.

Os inquéritos sobre o ensino superior da década de 1920 explicitam visões divergentes sobre a universidade. Havia os que defendiam a adoção do modelo Alemão, como Alcides Bezerra; a experiência Argentina, constituída a partir de institutos já existentes, como Azevedo Sodré; o modelo norte americano, descrito por seus generosos campi, por seu cunho profissional e científico, pela ação ampla e receptora de todo progresso, como Alcides Bezerra, Raul Briquet, Luiz Frederico Carpenter e Hélio Lobo; e até mesmo os que defendiam um modelo próprio, adaptado aos nossos recursos e nossas necessidades, como Ferdinando Laboriau. ${ }^{8}$ Raul Briquet defendia o papel central da Faculdade de Filosofia, Ciências e Letras, em torno da qual orbitariam as escolas profissionais. Outras ideias recorrentes eram as de que as universidades brasileiras deveriam incluir museus, bibliotecas, jardim botânico, jardim zoológico, e uma série de outras instituições especializadas de pesquisa, lazer, cultura e esportes.

O que parecia unânime para aqueles debatedores é que a universidade brasileira deveria ter um papel ativo na formação e desenvolvimento da cultura nacional, promovendo um "sadio nacionalismo" e servindo de núcleo para ações sociais e políticas. Para isso, muito se falava na necessidade de um "espírito universitário", formado pela convivência e pela colaboração. Tal objetivo deveria ser atingido através de um espaço adequado, amplo o suficiente para permitir a ampliação da universidade, concentrado para aproximar os cursos e facilitar a troca de conhecimentos, e ainda dotado dos mais diversos equipamentos, como teatros,

\footnotetext{
${ }^{7}$ Grupo de intelectuais e políticos liderado pelo diretor do jornal O Estado de São Paulo, Júlio de Mesquita Filho, e por Fernando de Azevedo, da Associação Brasileira de Educação. Durante a década de 1920 o grupo promoveu em São Paulo conferências e inquéritos sobre o problema universitário brasileiro. Ver, por exemplo: MESQUITA FILHO, Júlio de. "A crise nacional", O Estado de São Paulo, 15 de novembro de 1925 . Artigo publicado no dia da Proclamação da República que propunha explicitamente a criação da universidade como "organismo concatenador da mentalidade nacional", capaz de lançar um movimento de resistência às oligarquias da República Velha.

${ }^{8}$ Estou seguindo a organização de CAMPOS, Ernesto de Souza. Educação Superior no Brasil. Rio de Janeiro: Ministério da Educação, 1940, p. 258-266 apud CABRAL, Neyde. A universidade de São Paulo: modelos e projetos. Tese de doutorado. Orientador: Dácio Ottoni. São Paulo: FAUUSP, 2004. p. 37-40. Curiosamente, pouco se falou do modelo centralizador e nacionalista da universidade francesa estabelecida por Bonaparte, que acabou tendo grande importância no Brasil.
} 
clubes, restaurantes e alojamento de estudantes e professores. Tudo dentro dos princípios da economia, da salubridade e da modernidade. ${ }^{9}$

Tanto a discussão sobre o ensino universitário quanto a busca por modelos de campus, contêm expressões análogas em diversos países da América Latina onde a criação e a reforma de diversas universidades haviam criado o desejo e a necessidade de unificar seus territórios, geralmente compostos por edifícios pré-existentes, isolados e concebidos para outros fins. Leis foram formuladas, terrenos foram adquiridos e planos urbanísticos foram apresentados em diversas cidades, como Córdoba (1909) ${ }^{10}$, San Juan (1924), Concepción $(1925)^{11}$ e Cidade do México $(1928)^{12}$ no sentido de definir um território universitário. No entanto, a maioria desses planos não prosperou naquele momento. Dependendo de grandes investimentos do Estado, teriam melhor sorte após a crise de 1929 e, principalmente, após a $2^{\mathrm{a}}$ Guerra Mundial.

No Brasil, enquanto o debate era promovido nos jornais e institutos especializados, o prefeito do Rio de Janeiro, Antônio Prado Junior (1926-1930), convidou o urbanista francês Alfred Agache, secretário geral da Societé Française des Urbanistes, para elaborar um plano de remodelação urbana da cidade. Agache contribuiu para a discussão dos modelos universitários ao incluir em seu plano de "Remodelação, Extensão e Embellezamento" do Rio de Janeiro (1930) um centro universitário para a Universidade do Rio de Janeiro na Praia Vermelha. Sua proposta, chamada de Cité Universitaire, baseava-se no fácil acesso a partir do centro, no aproveitamento dos edifícios que já sediavam as faculdades da universidade - todos a cerca de $4 \mathrm{~km}$ da Praia Vermelha -, e de uma "situação pitoresca maravilhosa ao pé do Pão de Açúcar". ${ }^{13}$ O Plano Agache foi o primeiro a empregar o termo "cidade universitária" no Brasil, em provável referência à Cité Internationale Universitaire de Paris, fruto de um convênio entre a universidade e a prefeitura de Paris, precipitado pela

\footnotetext{
${ }^{9} \mathrm{O}$ tema do culto à saúde física e ao corpo na universidade é recorrente e destacado em toda a bibliografia sobre campus. Ele aparece no início do século XX como uma questão de saúde e chega a ser mencionado como estratégia decisiva para a vitória norte-americana na $2^{\underline{a}}$ Guerra. Ver: CAMPOS, Ernesto de Souza. Cidade Universitária da Universidade de São Paulo: aspectos gerais do planejamento e execução. São Paulo: Comissão da Cidade Universitária da Universidade de São Paulo, 1954.

${ }^{10}$ Refiro-me ao estudo do arquiteto Juan Kronfuss.

${ }^{11}$ Refiro-me ao concurso público vencido pelos arquitetos Eguigurren, Arrau e Almozara, do qual nada se realizou. Em seguida um Plano Geral foi desenvolvido pelo arquiteto Carlos Miranda Morales entre 1927 e 1928. Ver: SAAVEDRA, Verónica Esparza. O plano da cidade Universitária de Concepción de Emilio Duhart. A visão integrada do urbanismo moderno. Arquitextos, São Paulo, ano 09, n. 108.02, Vitruvius, maio 2009 <www.vitruvius.com.br/revistas/read/arquitextos/09.108/53>.

12 Refiro-me à tese de licenciatura em arquitetura de Mauricio de María y Campos e Marcial Gutiérrez Camarena, que introduziu o tema da cidade universitária no México. O terreno só foi escolhido em 1943 e a lei federal aprovada em 1945. Ver: $<w w w . p a t r i m o n i o m u n d i a l . u n a m . m x / p a g i n a / e s / 62 / c r e a c i o n-d e-c i u d a d-u n i v e r s i t a r i a>$.

${ }^{13}$ AGACHE, Donat Alfred. Cidade do Rio de Janeiro: extensão, remodelação, embellezamento. Paris: Foyer, 1930 p. 194 apud CABRAL, Neyde. Op. Cit. p. 52.
} 
doação de 10 milhões de francos feitos por Émile Deutsch de la Meurthe em 1921, sendo que seu primeiro edifícios foi inaugurado em $1925 .^{14}$

A cidade universitária do Rio de Janeiro, concebida por Agache, seria constituída por edifícios da administração, edifícios de ensino, uma biblioteca, um museu, um auditorium, e dotada de equipamentos socais e esportivos (inclusive náuticos), além de moradia, que cada estado do país construiria para abrigar alunos e professores, de forma análoga ao que se fez em Paris. ${ }^{15}$ Tudo isso num terreno de aproximadamente 45 ha, que segundo Agache, deveria ser preparado de modo a garantir comunicação fácil entre todos os grupos e contribuir para o aspecto grandioso do conjunto. ${ }^{16}$

Enquanto isso, o mesmo movimento que deu origem ao Ministério da Educação, promoveu o Estatuto das Universidades Brasileiras, promulgado pelos Decretos Federais 19.851 e 19.852, de 1931, que estabeleceram, respectivamente, as condições legais para a criação de universidades estaduais - como a USP (1934), a Universidade de Porto Alegre (1934) e a Universidade do Distrito Federal $(1935)^{17}$, além da inclusão da Universidade de Minas Gerais (1927) no sistema federal - e a reorganização da Universidade do Rio de Janeiro. Tais instituições deveriam contar com uma administração universitária, composta por reitoria, conselho universitário, diretoria de unidades, congregações, e outras instâncias, e possuir pelo menos três faculdades dentre as de Direito, Medicina, Engenharia e Educação, Ciências e Letras. ${ }^{18}$ Estes decretos, também regulamentaram a autonomia administrativa, didática e disciplinar e a manutenção do regime de cátedras.

Foi neste contexto, e sob esta base jurídica, que a USP foi criada em 1934, durante o governo de Armando Salles de Oliveira (1933-1935), sócio do jornal o Estado de S. Paulo e cunhado de seu diretor, Júlio de Mesquita Filho. A nomeação de Salles de Oliveira como interventor federal do Estado de São Paulo foi uma estratégia bem-sucedida de Vargas para

\footnotetext{
${ }^{14}$ A Cité Internationale Universitaire de Paris é uma fundação privada que reúne um conjunto pavilhões de moradia para estudantes estrangeiros, financiados por mecenas ou governos estrangeiros. Ver: BLANC, Brigitte. "La constitution du domaine de la Cité internationale universitaire de Paris", In Situ, reveu des patrimoines, n. 17, 2011. Disponível em $<$ http://insitu.revues.org/855>.

${ }^{15}$ AGACHE, Alfred apud CABRAL, Neyde., Op. Cit. p. 52.

${ }^{16}$ Idem.

${ }^{17}$ A Universidade do Distrito Federal, funcionou no Rio de Janeiro entre 1935 e 1939, liderada por Anísio Teixeira, diretor do Departamento de Educação do Distrito Federal. A proposta da UDF era pioneira por manter desde o início cursos de graduação e pós-graduação em cinco escolas não tradicionais: Escola de Ciências, Faculdade de Economia e Direto, Faculdade de Filosofia e Letras, Instituto de Artes e Instituto de Educação. Lecionaram na UDF importantes intelectuais e artistas, como Mario de Andrade, Cândido Portinari, Jorge de Lima, Gilberto Freyre, Sérgio Buarque de Holanda, Villa-Lobos, entre outros. Após a Intentona Comunista de 1935, Anísio Teixeira e vários professores foram demitidos. O restante do quadro docente foi incorporado ao da Faculdade Nacional de Filosofia da Universidade do Brasil.

${ }^{18}$ A Faculdade de Educação Ciências e Letras abrigaria estudos culturais e de ciências puras, além da formação profissional de professores.
} 
neutralizar sua oposição em São Paulo. ${ }^{19}$ Por causa da relação conflituosa do Grupo do Estado com o governo de Vargas a origem federal da USP muitas vezes foi ofuscada.

"Vencidos pelas armas, sabíamos perfeitamente que só pela ciência e pela perseverança no esforço voltaríamos a exercer a hegemonia que durante longas décadas desfrutáramos no seio da federação. Paulistas até a medula, herdáramos da nossa ascendência bandeirante o gosto pelos planos arrojados e a paciência necessária à execução dos grandes empreendimentos. Ora, que maior monumento poderíamos erguer aos que haviam consentido no sacrifício supremo para preservar contra o vandalismo que acabava de aviltar a obra de nossos maiores, das Bandeiras à Independência e da Regência à República, do que a Universidade?" 20

O Decreto Estadual 6.283, de 1934, amparado no regime universitário federal, reuniu praticamente todas as instituições de ensino superior e pesquisa do Estado de São Paulo, incluindo a Faculdade de Direito, federal, e alguns institutos independentes, para criar a USP. Além das unidades existentes, o decreto criou a Faculdade de Filosofia Ciências e Letras (FFCL), o Instituto de Ciências Econômicas e Comerciais, implantado em 1946, e a Escola de Belas Artes, que nunca saiu do papel.

"A originalidade desse sistema criado em 25 de janeiro de 1934, de acordo com o decreto federal, que então entrou realmente em execução, foi não somente a incorporação, no organismo universitário de uma Faculdade de Filosofia Ciências e Letras, que passou a constituir a medula do sistema, como também a preocupação dominante da pesquisa científica e dos estudos desinteressados, dentro aliás do espírito da lei federal que regulou as universidades brasileiras. O Governo Provisório da República instituiu em 1931 o regime universitário, mas foi São Paulo que tomou em 1934 a iniciativa de executá-lo em sua plenitude". ${ }^{21}$

Nutridos pelo positivismo, os idealizadores da USP acreditavam que a reunião dos institutos sob uma administração centralizada permitiria eliminar cadeiras duplicadas e bibliotecas redundantes, resultando em economia e eficiência. A FFCL faria a integração entre as

\footnotetext{
${ }^{19}$ Engenheiro politécnico de formação, o governador de São Paulo era do Partido Democrático, uma dissidência do Partido Republicano Paulista, que apoio Getúlio Vargas na Aliança Liberal. Após a Revolução de Outubro e o desencanto com Vargas, o PD se reaproximou do PRP, constituindo a "frente única por São Paulo" que defendia a Revolução Constitucionalista de 1932. Após ter vários membros presos e exilados a agremiação se reorganizou em 1933 tornando-se hegemônica no Estado de São Paulo.

${ }^{20}$ MESQUITA FILHO, Júlio. Universidade, realização da revolução democrática. Discurso de paraninfo da primeira turma da FFCL da USP, 25 de janeiro de 1937 apud UNIVERSIDADE DE SÃO PAULO. O espaço da USP: presente e futuro. São Paulo, 1985.

${ }^{21}$ AZEVEDO, Fernando de. História da minha vida. Rio de Janeiro: José Olympio, 1971, p. 119-120, apud UNIVERSIDADE DE SÃO PAULO. Op. Cit.
} 
escolas profissionais e os institutos especializados, oferecendo cursos de literatura, filosofia, sociologia e também de física, química, matemática e outras ciências puras, com o intuito de propiciar a todos os alunos da universidade, uma formação científica e humanista.

A ideia de um espaço próprio, que reunisse todas as unidades dispersas da universidade, reunidas por decreto, se propagou desde cedo. A situação da FFCL, central na proposta da universidade, representava concretamente a fragmentação da universidade, ficando cada uma de suas cadeiras (Química, Matemática, Física, Filosofia, Letras) alojadas num dos edifícios das outras escolas. Mas, para além da racionalidade administrativa ou da questão do ensino, um campus integrado deveria contribuir para a formação do "espírito universitário", definido no decreto da fundação da USP como:

"A aproximação e o convívio dos professores e alunos das diversas Faculdades, Escolas ou Institutos serão promovidos especialmente: a) Pela proximidade dos edifícios e construções de vilas universitárias; b) Pela centralização administrativa da universidade, em tudo que respeite ao interesse comum; c) Pela criação de cursos comuns, que atendam às necessidades de alunos de diferentes Faculdades, Escolas ou Institutos; d) Pelo regime de seminários, centros de debate e trabalho em cooperação; e) Pela prática de atividades sociais em comum, pelos alunos das diferentes Faculdades, Escolas ou Institutos; f) Pela organização de sociedade e clubes universitários, de estudo, de jogos e de recreação; e) Pela prática habitual de esportes, jogos atléticos e competições de que participem universitários das diferentes Faculdades, Escolas ou Institutos". ${ }^{22}$

Ainda em 1934, o presidente do Grêmio Politécnico, José Luiz de Almeida Junqueira convocou os demais centros acadêmicos e lançou a ideia da criação de um 'bairro universitário', que foi apresentada, afinal, como reivindicação dos estudantes ao Governo do Estado, dando origem à ideia de uma cidade universitária. ${ }^{23}$

Em junho de 1935, o governador Armando Salles de Oliveira nomeou uma Comissão encarregada de estudar a localização da já intitulada Cidade Universitária - presidida pelo reitor Reynaldo Porchat e composta por Ernesto Leme (Direito), Alexandre Albuquerque (Politécnica), Ernesto de Souza Campos (Medicina), Fernando Azevedo (Educação), Afrânio do Amaral (Butantã) e Mário de Andrade (Departamento de Cultura). Durante três meses, diversas opções foram consideradas e disputas foram travadas entre escolas tradicionais, que resistiam a sair de suas instalações. A comissão concluiu por recomendar a localização

\footnotetext{
22 Decreto 6.283/34, Título VII, Artigo 47, Parágrafo único.

${ }^{23}$ FICHER. Sylvia. Os arquitetos da Poli: Ensino e profissão em São Paulo. São Paulo: Edusp, 2005, p. 320.
} 
da Cidade Universitária no vasto setor da cidade compreendido entre a Faculdade de Medicina e o Instituto Butantã, justificando a decisão pelo aproveitamento das instalações já existentes. ${ }^{24}$ Naquela ocasião, o perímetro ou o custo das desapropriações não foram focos de discussões. A comissão apenas mencionava que a área da cidade tinha ocupação rarefeita e a maior parte dos terrenos pertencia ao Estado, à Prefeitura ou à Cia City.

Nesse mesmo momento, sob a retórica nacionalista, a noção de cidade universitária ganhava novos contornos na Europa. O primeiro caso foi o do plano para a Cidade Universitária de Madri (1928), elaborado por Modesto López-Otero, diretor da faculdade de arquitetura, por incumbência do rei Afonso XIII. A construção do empreendimento de 360 ha, localizado nos arredores da capital espanhola, ganhou força em 1931, durante a Segunda República, quando foi criada a Junta Construtora da Cidade Universitária de Madri. ${ }^{25} \mathrm{O}$ conjunto, marcado por uma racionalidade austera, serviu como exemplo de monumentalidade fascista para a revista italiana Architettura, do Sindicato Nacional Fascista de Arquitetos. ${ }^{26}$

O segundo caso, inaugurado logo em seguida, em 1935, foi o da Cidade Universitária de Roma, que obteve um resultado estético ainda mais contundente que o espanhol e consolidou uma concepção monumental de cidade universitária. Localizada em um terreno de apenas 44 ha e relativamente central, a menos de $4 \mathrm{~km}$ do Panteão, essa cidade universitária planejada por Marcelo Piacentini, arquiteto de confiança de Mussolini, se caracterizou pelo rigor geométrico do conjunto, pelas colunatas retas do portal de entrada e do edifício da reitoria e pelo controle da perspectiva feito a partir do cruzamento de dois eixos de circulação perpendiculares, onde se encontra a figura de Minerva em frente ao palácio da reitoria. O plano de 1932 contou ainda com a colaboração de diversos arquitetos racionalistas, como Gio Ponti, que projetou o edifício da Matemática. ${ }^{27}$

Na América Latina, o plano do arquiteto austríaco Karl Brunner (1887-1960) para o Bairro Universitário de Concepción, no Chile, de 1931, foi provavelmente o primeiro a sair do papel. A Universidade de Concepción foi excepcional em muitos aspectos. Privada e localizada na província, seu campus foi implantado nos arredores da cidade, privilegiando grandes terrenos menos valorizados. Essa escolha foi defendida pelo fundador da universidade, o

\footnotetext{
${ }^{24}$ À época, a Faculdade de Medicina estava localizada no limite da cidade, a cerca de $5 \mathrm{Km}$ na direção sudoeste.

${ }^{25}$ Composta por cerca de 40 membros, incluindo o Presidente da República, o Primeiro Ministro e o Ministro de Instrução Pública.

${ }^{26}$ GUIDI, Francesco. "La Città universitária di Mardid", Architettura, ano 12, fascículo 10, outubro 1934. A Cidade Universitária foi parcialmente inaugurada em 1936 e destruída durante a guerra civil espanhola. Posteriormente seria reconstruída em 1943, quando passou a abrigar a Universidad Complutense de Madrid.

${ }^{27}$ Ver: Architettura, ano 14, número especial “La Città Universitaria di Roma”, 1935.
} 
reitor Enrique Molina Garmendia (1861-1964), que dizia basear-se no modelo universitário norte-americano, sobre o qual publicou um livro. ${ }^{28} \mathrm{O}$ plano chileno seguia rigorosamente a concepção Beaux-Arts do arquiteto francês Henri Jean Émile Bérnard, vencedor do concurso para o campus de Berkeley em 1899. Em Berkeley, como em Concepción, a tradição americana da vila acadêmica de Thomas Jefferson, foi integrada numa situação suburbana com edifícios de arquitetura eclética. Os campanários foram elementos centrais das composições e tornaram-se símbolos de ambas as universidades. O campus da Universidade de Concepción passou a ser denominado cidade universitária em $1938^{29}$, ao mesmo tempo que os casos de Roma e Madri ganhavam repercussão e a América Latina flertava com o nazi-fascismo. De fato, podemos observar que algumas estratégias monumentais de Piacentini seriam incorporadas posteriormente em Concepción, como o edifício-portal conhecido como arco da medicina, projetado em 1948.

Em Bogotá, o arquiteto judeu alemão Leopoldo Rother (1894-1978), funcionário do Ministério de Obras Públicas, foi responsável pelo plano de 1937 para a Cidade Universitária, apelidada de Ciudad Blanca. Com 116 ha e um traçado simétrico em estilo cidade-jardim, os edifícios foram dispostos ao redor de uma grande praça elíptica que articulava o conjunto. ${ }^{30}$ Os edifícios projetados por Rother e outros arquitetos no início da década de 1940 inauguraram uma nova concepção estética de cidade universitária, alinhada à nova objetividade alemã.

No Brasil, Ernesto de Souza Campos (1882-1970), foi o personagem central dos rumos que as cidades universitárias tomariam. ${ }^{31}$ Professor da Faculdade de Medicina, tornou-se um especialista em campi universitário após integrar uma missão do Governo de São Paulo, financiada pela Fundação Rockfeller, para estudar organizações universitárias nos Estados Unidos, Canadá e Europa. Essa missão teria visitado cerca de duzentos institutos de ensino médico no início da década de $1920 .^{32}$ Em 1930, Souza Campos assumiu a direção da

\footnotetext{
${ }^{28}$ MOLINA GARMENDIA, Enrique. De California a Harvard: estudio sobre las universidades norteamericanas y algunos problemas nuestros. Santiago de Chile: Ediciones Universo, 1921.

${ }^{29}$ Até então, predominava no Chile a noção de "grupos universitários". Ver: SAAVEDRA, Verónica Esparza. Op. Cit. Informações mais detalhadas podem ser encontradas em: GARCIA MOLINA, Jaime. El Campus de la Universidad de
} Concepción. Su desarrollo Urbanístico y Arquitectónico. Ediciones Universidad de Concepción, 1994.

${ }^{30}$ Ver: CORTÉS, Rodrigo. Ciudad aparte: proyecto y realidad en la Ciudad Universitaria de Bogotá. Bogotá: Universidad Nacional de Colombia, 2006.

${ }^{31}$ Formado em Engenharia-agrônoma pela Escola Politécnica de São Paulo em 1906 e médico pela Faculdade de Medicina e Cirurgia de São Paulo, em 1918. Foi assistente do Instituto Oswaldo Cruz em Manguinhos, Rio de Janeiro, e em seguida permaneceu dois anos e meio vinculado à universidade Johns Hopkins nos EUA. Tornou-se catedrático da Faculdade de Medicina de São Paulo em 1925, da qual foi diretor em 1930. Já integrada à USP, dirigiu a Faculdade de Filosofia, Ciências e Letras em 1937. Foi diretor do Escritório de Obras para elaboração dos projetos e execução do edifício de laboratórios e do Hospital das Clínicas e o principal articulador com a Fundação Rockefeller que financiou as obras. Em 1946 chegaria a ser Ministro da Educação e Saúde no governo de Eurico Gaspar Dutra.

${ }^{32}$ CAMPOS 1954 p. 364-366 apud CABRAL, Neyde. Op. Cit., p. 55. Segundo Simões, ele voltou dos EUA em 1923. SIMÕES, João Roberto Leme. Arquitetura na Cidade Universitária 'Armando Sales de Oliveira' - o espaço construído. Dissertação de mestrado em Arquitetura e Urbanismo. Orientador: Ariosto Mila. São Paulo: FAU-USP, 1984, p. 11. 
Faculdade e chefiou as obras do Edifício de Laboratórios e do Hospital das Clínicas, projetados pelo escritório de Ramos de Azevedo. As obras das clínicas renderam notoriedade a Souza Campos, principalmente pela articulação bem-sucedida com a Fundação Rockefeller, que as financiou. No ano da criação da USP, em que defendeu a integração da Faculdade de Medicina no sistema universitário com a implantação de um centro universitário de acordo com o modelo norte-americano, ele visitou outras universidades no sul e no oeste dos EUA, no Japão e na África do Sul.

As origens do modelo americano perseguido por Souza Campos, no Brasil, bem como por Molina Garmendia, no Chile $^{33}$, remontam ao período colonial dos EUA, quando diversas universidades haviam sido criadas. Para o imaginário utópico iluminista a ampla disponibilidade de terras e a inexistência dos vícios das instituições centenárias da Europa representavam a possibilidade de um modelo racional e integrado de universidade, privilegiado por benefícios morais da paisagem campestre. O plano de Thomas Jefferson para a Universidade de Virginia (1820), com sua organização axial e seus edifícios em estilo neoclássico, logo se tornou paradigmático. Esse modelo provinciano que remetia às tradicionais aldeias rurais conhecidas como Village Greens, ofereceria todo o suporte à vida acadêmica em um ambiente isolado da cidade, com moradia, refeitórios e bibliotecas erguidos em ampla área verde.

O modelo americano não apenas mimetizava as prestigiosas universidades colegiadas da Inglaterra, como Cambridge ou Oxford - que também surgiram no campo -, mas inovavam ao integrar, planejar e padronizar o seu território, enquanto os agrupamentos medievais europeus baseavam-se nos colleges, que funcionam como condomínios privados confederados, onde viviam os universitários, cada qual com sua orientação religiosa ou social.

A notoriedade de Souza Campos era tanta que, em julho de 1935 - portanto um mês após a nomeação da Comissão de São Paulo - o ministro Gustavo Capanema Ihe convidou para integrar também a comissão de organização da Universidade do Rio de Janeiro.

"Imaginando dever a universidade de congregar todos os setores da cultura e da técnica, havia chamado para o setor da Medicina o professor Rocha Vaz, uma das maiores figuras da medicina brasileira e o prof. Souza Campos, de São Paulo, nome que se tornou conhecido no Brasil inteiro pela sua capacidade em matéria de

\footnotetext{
33 Apesar de a denominação sugerir o contrário, as centenárias universidades norte-americanas possuem estruturas administrativas tão distintas quanto suas estruturas físicas. A própria noção de campus, que serve para designar tanto os edifícios quanto os territórios de uma universidade, é abstrata em relação à sua dimensão, unidade territorial, tipologia, forma, complexidade programática, inserção urbana, e etc. De todo modo, a expressão "American campus" refere-se habitualmente a grandes territórios universitários que reúnem moradia de professores e estudantes, edifícios de ensino e equipamentos de pesquisa - normalmente padronizados por um único estilo arquitetônico.
} 
construção de escolas de medicina, pelo trabalho que realizou nesse sentido em São Paulo e pelos estudos preciosíssimos que fez nesse sentido". ${ }^{34}$

Seu papel foi decisivo na definição dos locais, dimensionamento das glebas e escolhas dos projetos de arquitetura tanto em São Paulo como no Rio de Janeiro. Souza Campos defendia que a área da universidade não deveria ser inferior a 200 alqueires paulistas (484 ha) $)^{35}$, com uma área de parque dez vezes maior do que a área ocupada por edificações, visando uma universidade bem delineada e arborizada, formando assim um centro atraente e convidativo a uma permanência mais prolongada, o que constituía elemento de valor inestimável para a formação do "espírito universitário". ${ }^{36}$ A proximidade dos edifícios seria obtida pela concentração dos mesmos no terreno, deixando áreas livres para o lazer e a expansão futura. Com este imaginário do "modelo americano", Souza Campos influiu na definição pela gleba Butantã em São Paulo e pela gleba Quinta da Boa Vista, no Rio de Janeiro, onde os terrenos tinham um custo de desapropriação menor, encerrando definitivamente uma possível implantação do plano central de Agache.

Souza Campos também exerceu um papel decisivo na concepção arquitetônica de ambas as universidades. No Rio foi relator das comissões que rejeitaram os projetos de Le Corbusier (1936) $)^{37}$ e da equipe chefiada por Lúcio Costa $(1936)^{38}$ e articulou o convite ao arquiteto Marcello Piacentini, que indicou seu colaborador, Vittorio Morpurgo, para elaborar um novo plano em 1937. ${ }^{39}$ Em São Paulo, Souza Campos defendeu constantemente o

\footnotetext{
${ }^{34}$ Gustavo Capanema em ata da sessão inaugural da comissão encarregada de estudar a organização da Universidade do Rio de Janeiro, em 22 de julho de 1935 apud CAMPOS, Ernesto Souza. Estudos sobre o problema universitário. São Paulo: Revista dos Tribunais, 1938, p. 307 apud CABRAL, Neyde., Op. Cit. p. 54.

${ }^{35}$ Segundo Campos, "na América, com a largueza dos nossos territórios, teríamos de preferir o exemplo americano, de universidade parque". A afirmação era acompanhada de uma tabela com a área das universidades de Stanford, 3.500ha; Michigan, 1.900ha; Louisiana, 1.300ha; Illinois, 900ha; Cornell, 600ha; Madrid, 360ha; e lowa, 150ha. Ver: CAMPOS, Ernesto
} de Souza. Educação Superior no Brasil. Rio de Janeiro, 1940, p. 393 apud CABRAL, Neyde. Op. Cit. p. 57.

${ }^{36}$ CAMPOS, Ernesto de Souza. "História da Universidade de São Paulo", 1954, p. 28, apud UNIVERSIDADE DE SÃO PAULO, Op. Cit., p. 21.

${ }^{37}$ A comissão designada pelo ministro Capanema e composta por Souza Campos e Ignácio Azevedo do Amaral apresentou seu relatório sobre o projeto de Le Corbusier no dia 10 de agosto de 1936. Segundo ele a implantação seria caríssima, a manutenção complicada porque os prédios eram diferentes entre si, a orientação prejudicada pela insolação, a circulação livre no solo seria inconveniente para certas zonas, como a zona médica, a verticalização exigiria um transporte vertical de massa dispendioso, a separação da circulação de pedestres e automóveis seria redundante. Para Lúcio Costa, o fator estético prevalecia: "eles recusaram o projeto porque deixava bastante vazia a parte mais plana e jogava a composição toda para 0 entorno; esse foi um pretexto porque eles eram contra a arquitetura contemporânea, os dois: o Amaral e o Souza Campos". Ver: entrevista de Lucio Costa a Matheus Gorovitz em GOROVITZ, Matheus. 1989, anexo p. 57 apud CABRAL, Neyde. Op. Cit., p. 77.

${ }^{38} \mathrm{O}$ projeto de Costa tentou responder à crítica ao projeto de Le Corbusier ocupando a planície central do terreno. $\mathrm{O}$ depoimento do arquiteto é revelador dos modelos que se tinham: "não procuramos imitar a aparência exterior das universidades americanas, vestidas à Tudor, ao jeito das missões ou à florentina - ridículo contra o qual a nova geração em boa hora reage; nem tampouco as universidades europeias, instituições seculares que se formam completando com o tempo e, quando modernas - enfáticas como a de Roma, ou desarticuladas como a de Madrid - não nos podiam servir de modelo" (Costa 1995 pp. 183-156 apud CABRAL, Neyde. Op. Cit.)

39 O plano de Mopurgo, embora muito mais compacto do que os anteriores, foi cancelado em 1941, supostamente devido ao custo de desapropriação dos terrenos da Quinta da Boa Vista. Na realidade, com a iminência do alinhamento do Brasil na $2^{\text {a }}$ Guerra, a colaboração dos arquitetos fascistas tornou-se menos oportuna para o governo Vargas. Souza Campos teria então 
arquiteto Hippolyto Gustavo Pujol Júnior, seu contemporâneo na Escola Politécnica. Contraditório, usava os exemplos de Madri e Roma como referência para o julgamento das propostas, embora a implantação compacta de Roma fosse oposta ao "modelo americano.

Após a definição da localização da Cidade Universitária de São Paulo, o governo constituiu um Escritório Técnico cujo direção foi confiada a Ernesto de Souza Campos. Esse escritório, chefiado por Pujol Júnior, e tendo em seus quadros os arquitetos Ernesto Sampaio de Freitas e João Serato e o engenheiro civil Guilherme Lyra, produziu em 1936 uma série de estudos de implantação da universidade na grande área, alguns propondo uma ocupação dispersa, outros, núcleos isolados.

A mesma equipe formulou, no ano seguinte, Planos Gerais da Cidade Universitária, entre os quais foi eleita a 'Solução Butantan', com uma urbanização em estilo cidade-jardim centralizada na Fazenda Butantã. Esta proposta, com cerca de 240 ha, incluía um setor residencial (36 ha), um Jardim Botânico (70 ha), um Zoológico (100 ha), a Faculdade de Veterinária (27,5 ha) e uma zona esportiva localizada nas duas margens do Rio Pinheiros.

A noção de cidade universitária transcendia as funções acadêmicas e as necessidades objetivas das unidades, refletindo um exercício de imaginação da modernidade. Ao mesmo tempo, servia também de exercício para pensar a reorganização administrativa da universidade. Daí que na maioria desses planos persistiam diagramas espaciais que estabeleciam hierarquias e agrupamentos de escolas e também propunham a criação, a fusão ou a extinção de unidades existentes.

Nesse sentido, os planos espaciais sempre estiveram relacionados à estrutura da própria universidade e ao planejamento de cada unidade, como por exemplo a quantidade de alunos e professores, as necessidades funcionais e de futuras ampliações. Ernesto de Souza Campos defendia um programa padrão para todas as unidades, cada qual, porém, dotada de símbolos e de uma concepção artística e individualizada.

A proposta 'Butantan' chegou a ser apresentada à Assembleia Legislativa. ${ }^{40}$ Porém uma disputa judicial com a Cia. City, que reivindicava a propriedade dos terrenos, atrasou o trâmite. O golpe do Estado Novo, ao dissolver as Assembleias estaduais em novembro de 1937, enterrou o projeto definitivamente. O Escritório Técnico interrompeu seu trabalho e sua equipe foi deslocada para as obras do Centro Médico Araçá. Nesse intervalo, foram retomados projetos dispersos pela cidade, como o projeto de Mario Whately para a FFCL.

convidado Pujol Junior para elaborar um novo plano, demonstrando a possibilidade de a universidade ocupar apenas a área do Derby Clube, cuja compra já estava resolvida, o que se mostrou inútil, uma vez que a discussão sobre o local foi reaberta. Ver CABRAL, Neyde. Op. Cit., p. 59-61

${ }^{40}$ Projeto de Lei n. 238, de dezembro de 1936. 


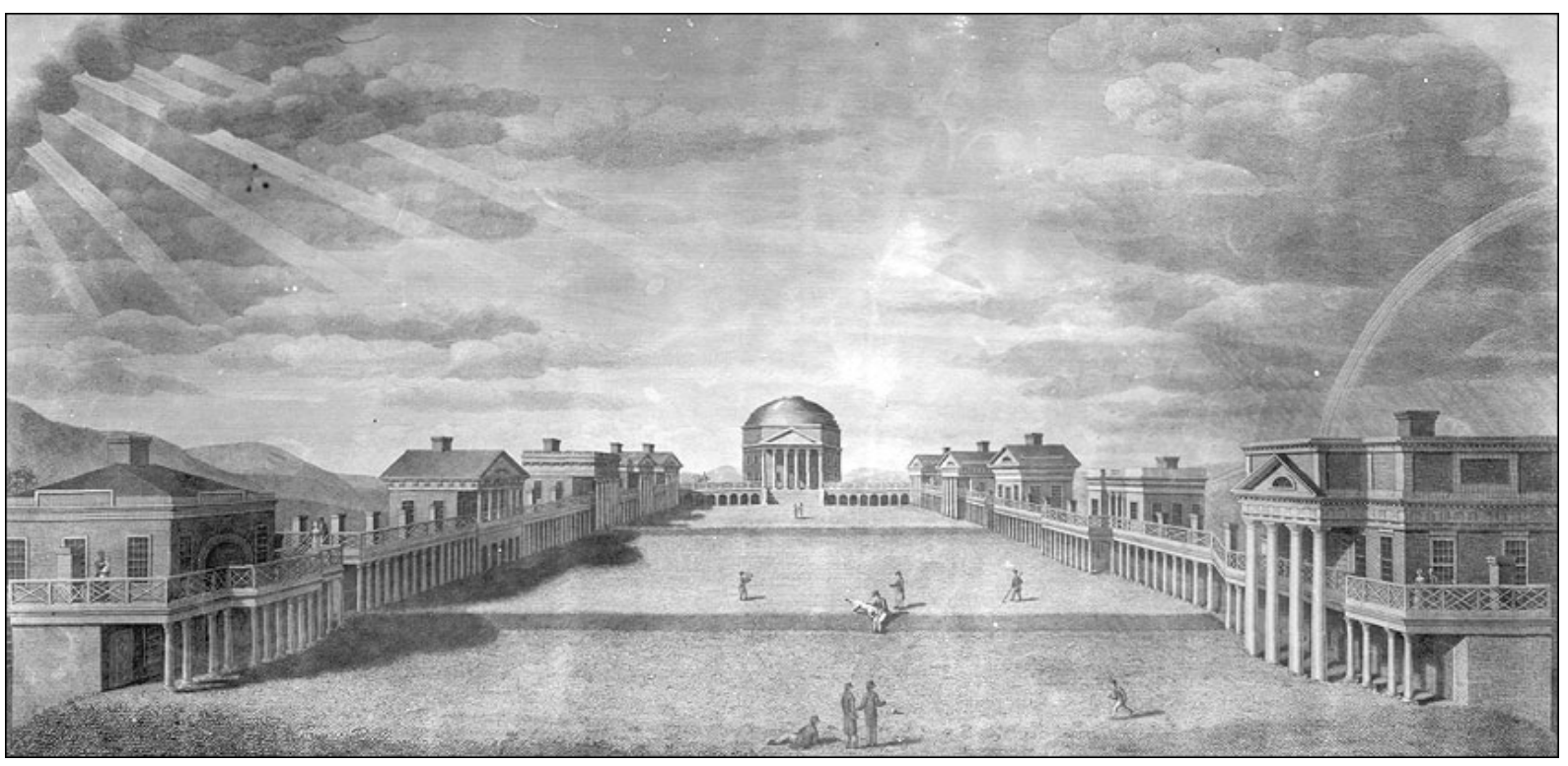

Thomas Jefferson, Academical Village, Universidade da Virginia, Charlottesville, EUA, 1826. University of Virginia Library.

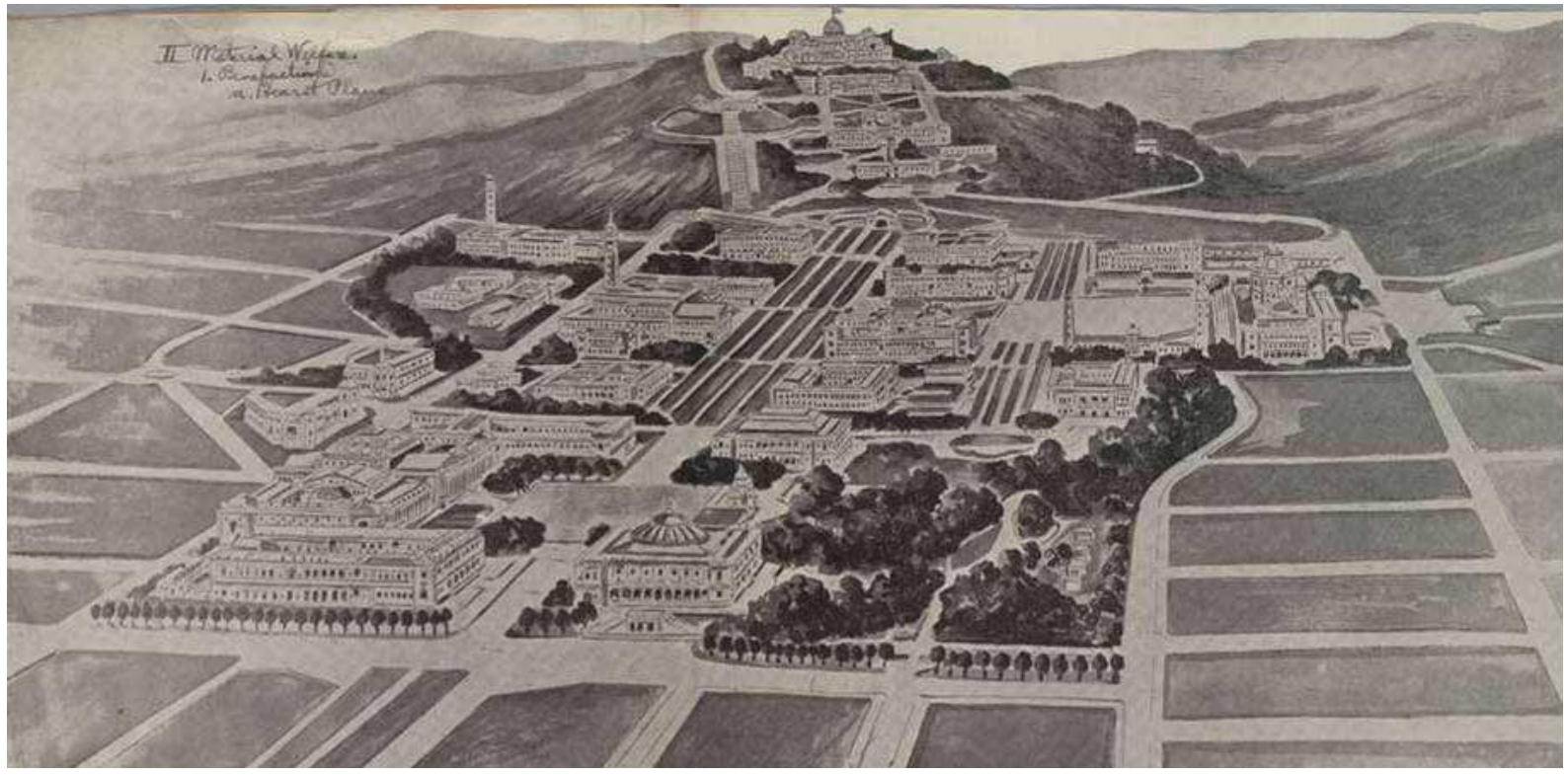

Émile Bernard, General View of the University of California, Berckeley,1899. The Bancroft Library. 


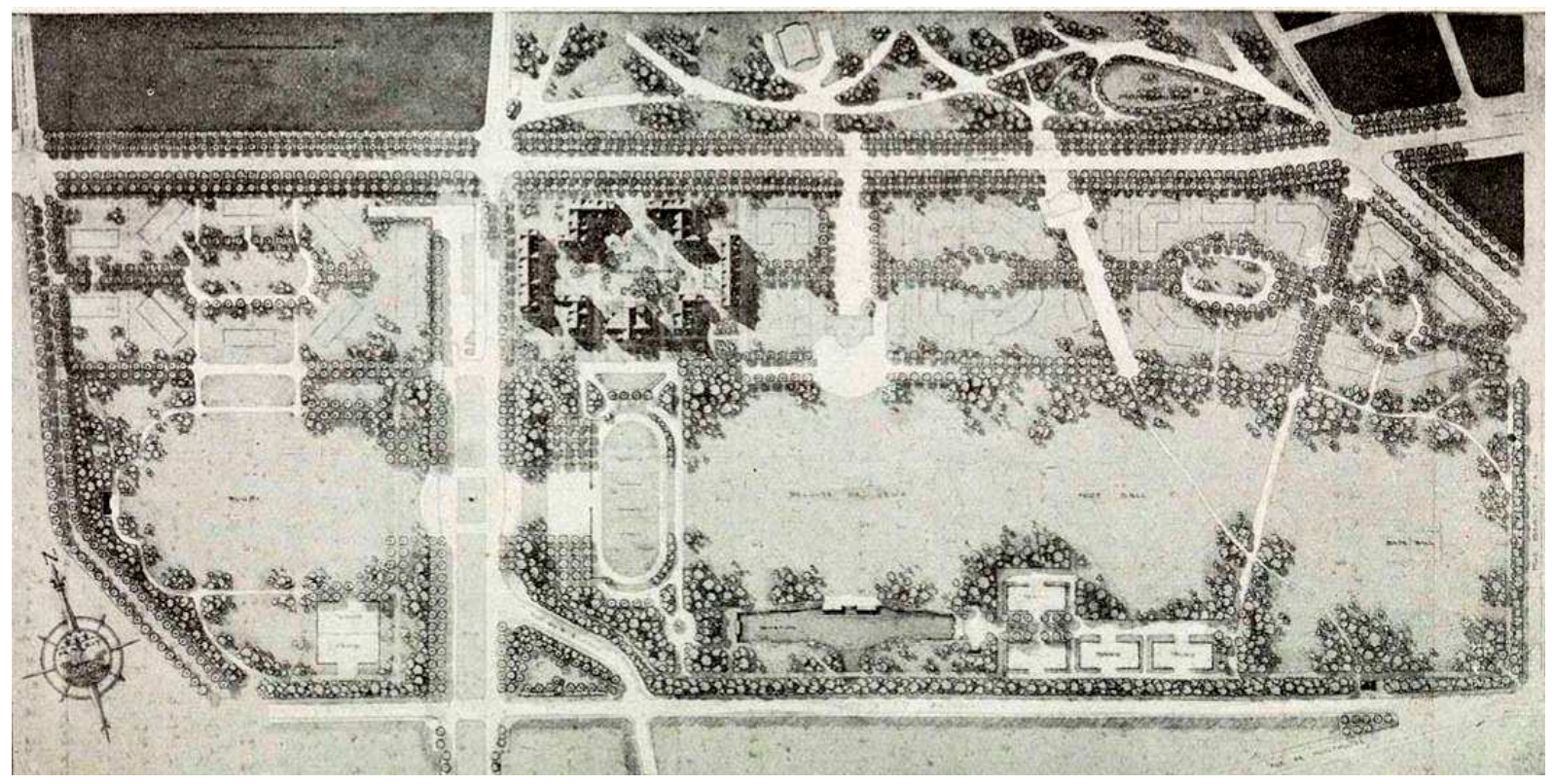

Lucien Bechmann, Plano inicial da Cité Universitaire de Paris, 1923, com o edifício da Fundação Deutsch de la Meurthe. Arquivo: Conseil régional d'île-de-France, Service Patrimoines et Inventaire

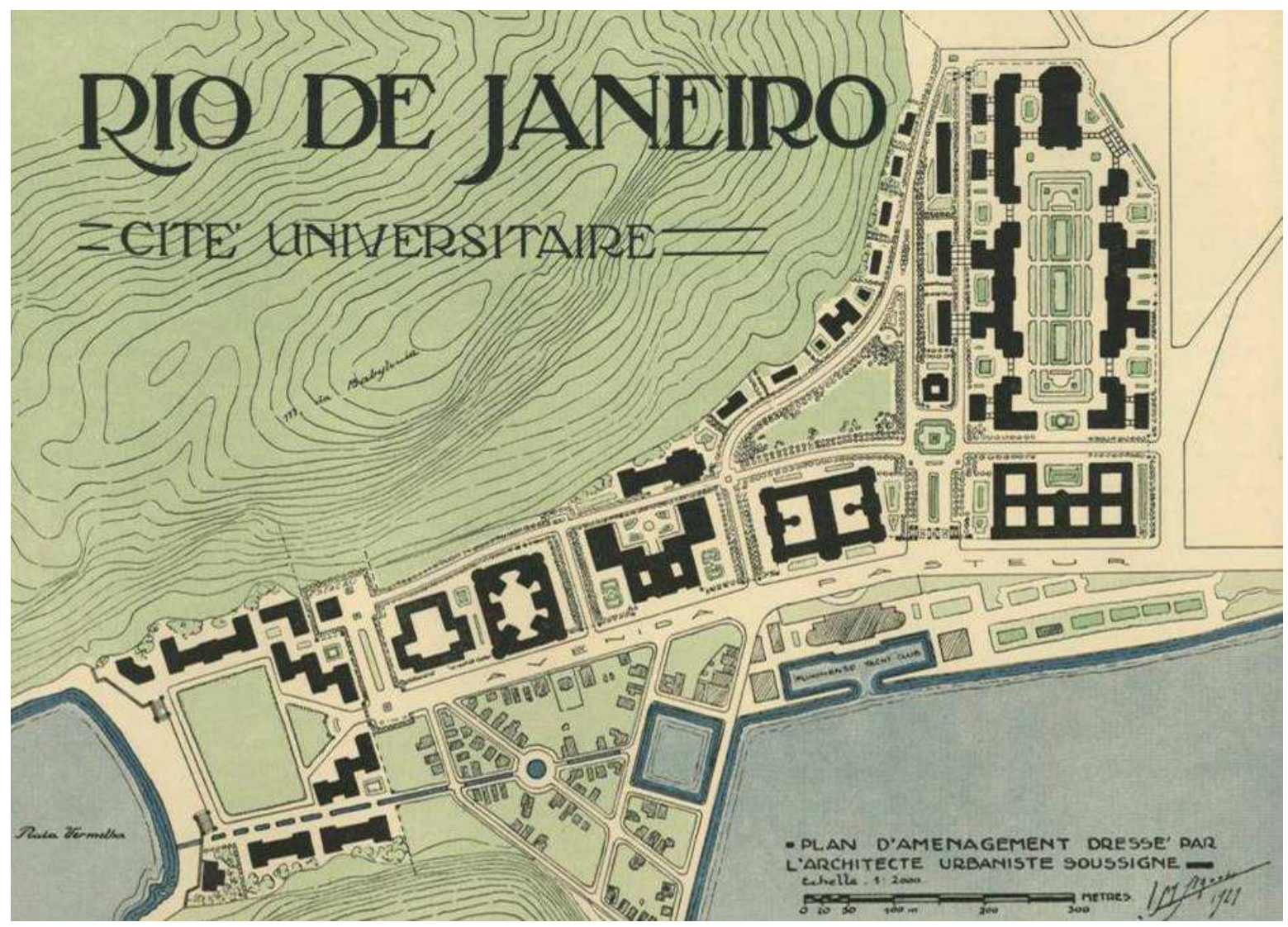

Alfred Agache. Cidade Universitária da Universidade do Rio de Janeiro, 1930

Publicado em AGACHE, Alfred. Cidade do Rio de Janeiro: Remodelação, Extensão e Embellezamento, 1926-1930. Paris: Foyer Brésilien, 1930 

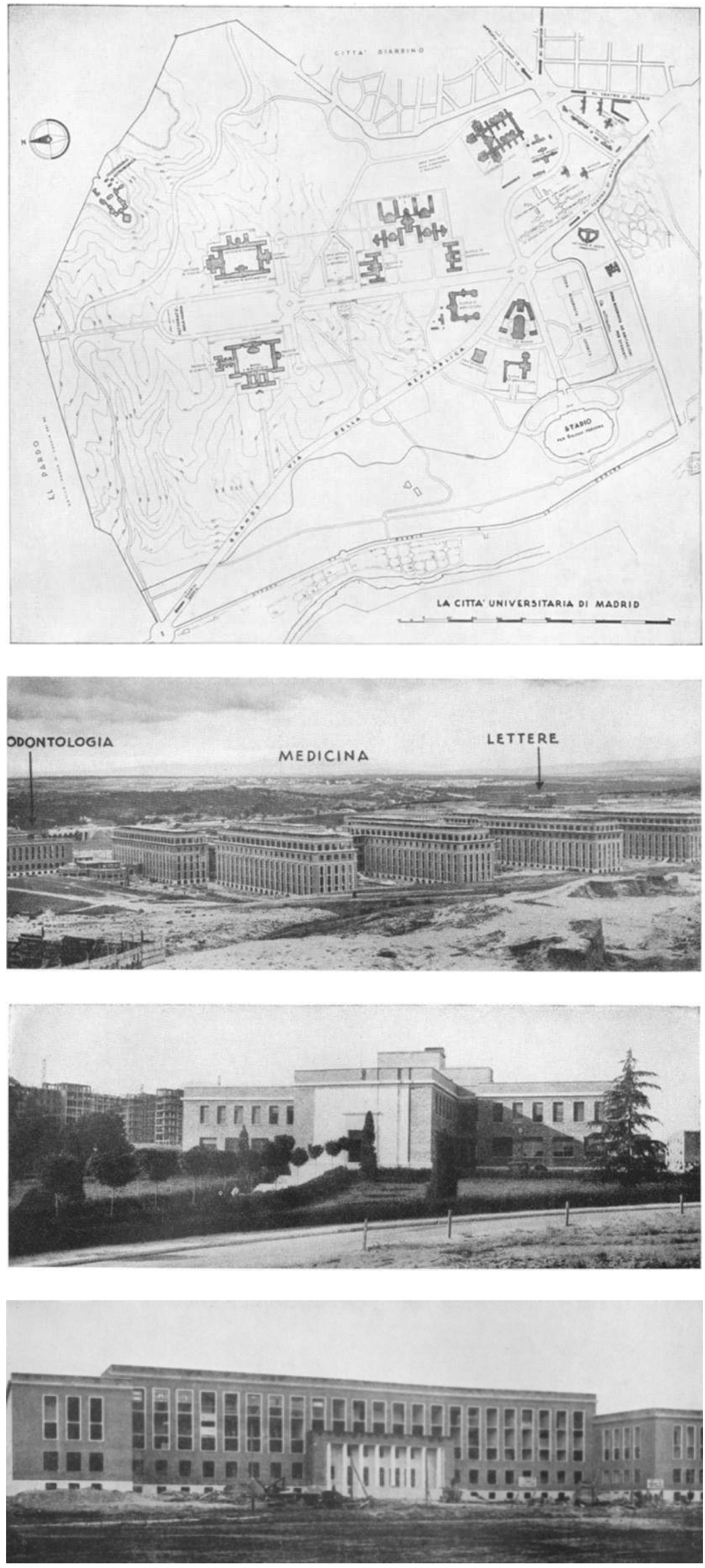

Modesto Lopez-Otero. Plano da Cidade Universitária de Madri, Espanha, 1928

Publicado na revista Architettura, outubro 1934

\section{Faculdade de Medicina}

Escritório Técnico para Construção da Cidade Universitária.

Faculdade de Farmácia 


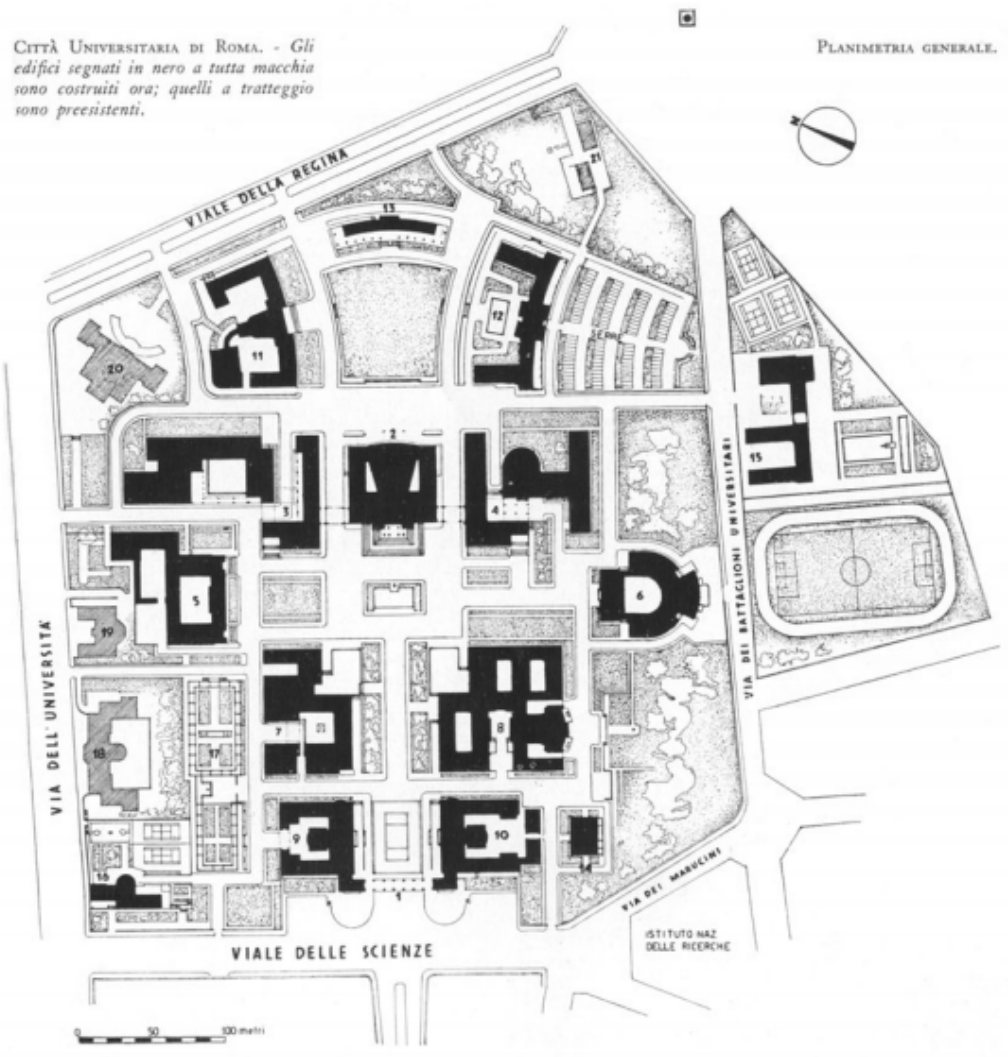

Marcello Piacentini. Plano da Cidade Universitária de Roma, Itália, 1932.

Publicado na revista Architettura, 1935

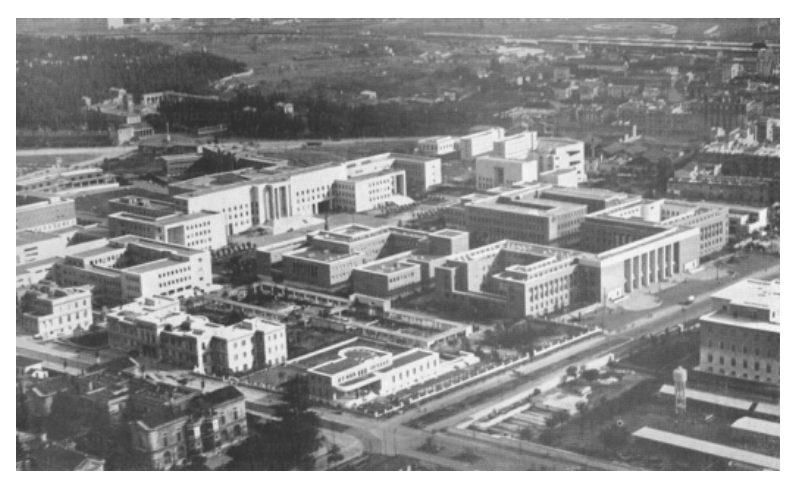

Vista aérea

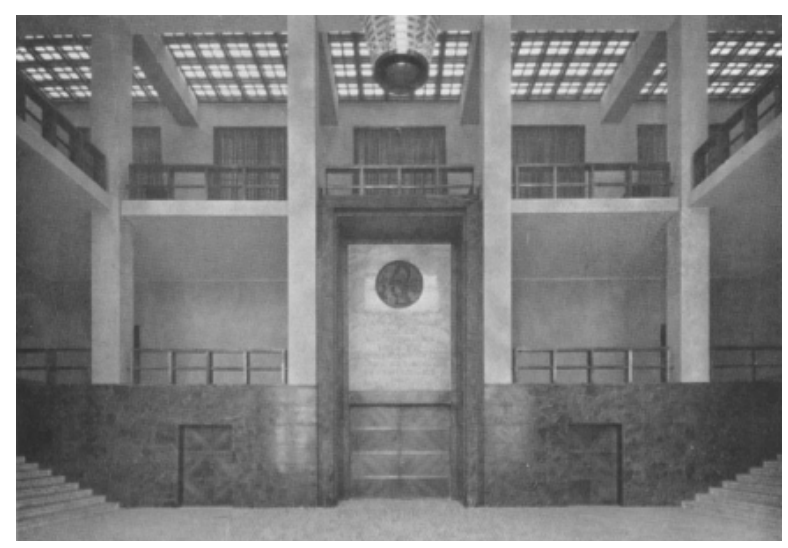

Vestíbulo do Edifício da reitoria

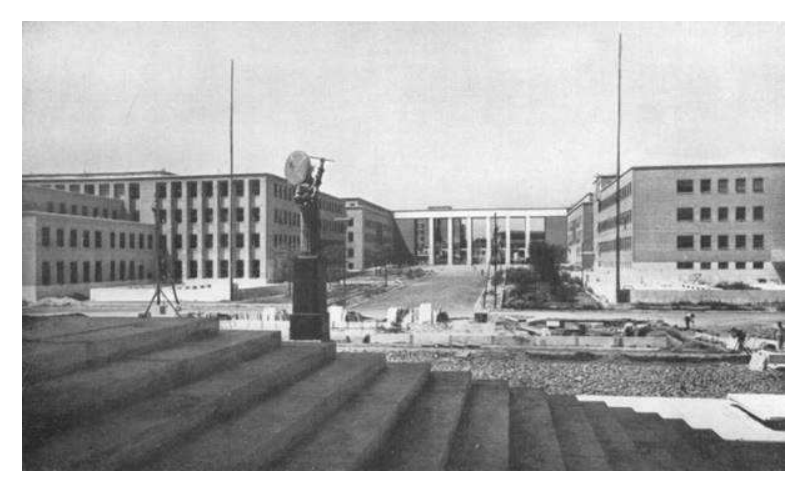

Vista interna

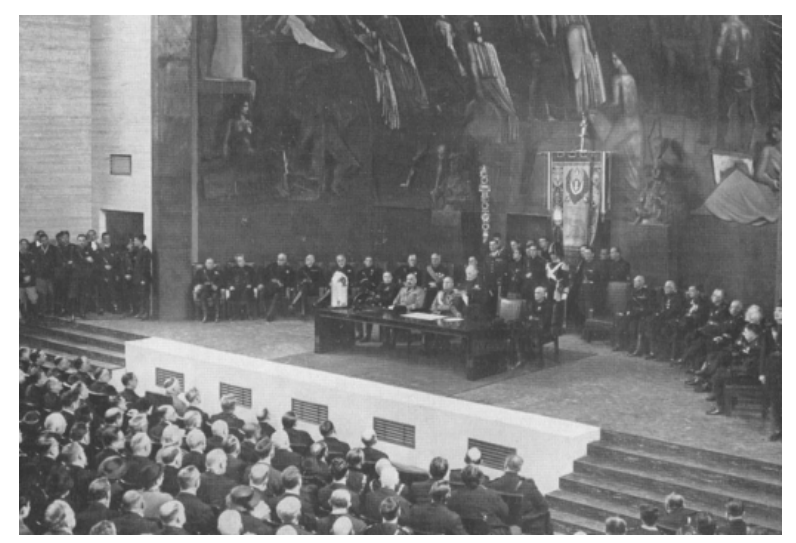

Aula Magna durante a inauguração da Cidade universitária 

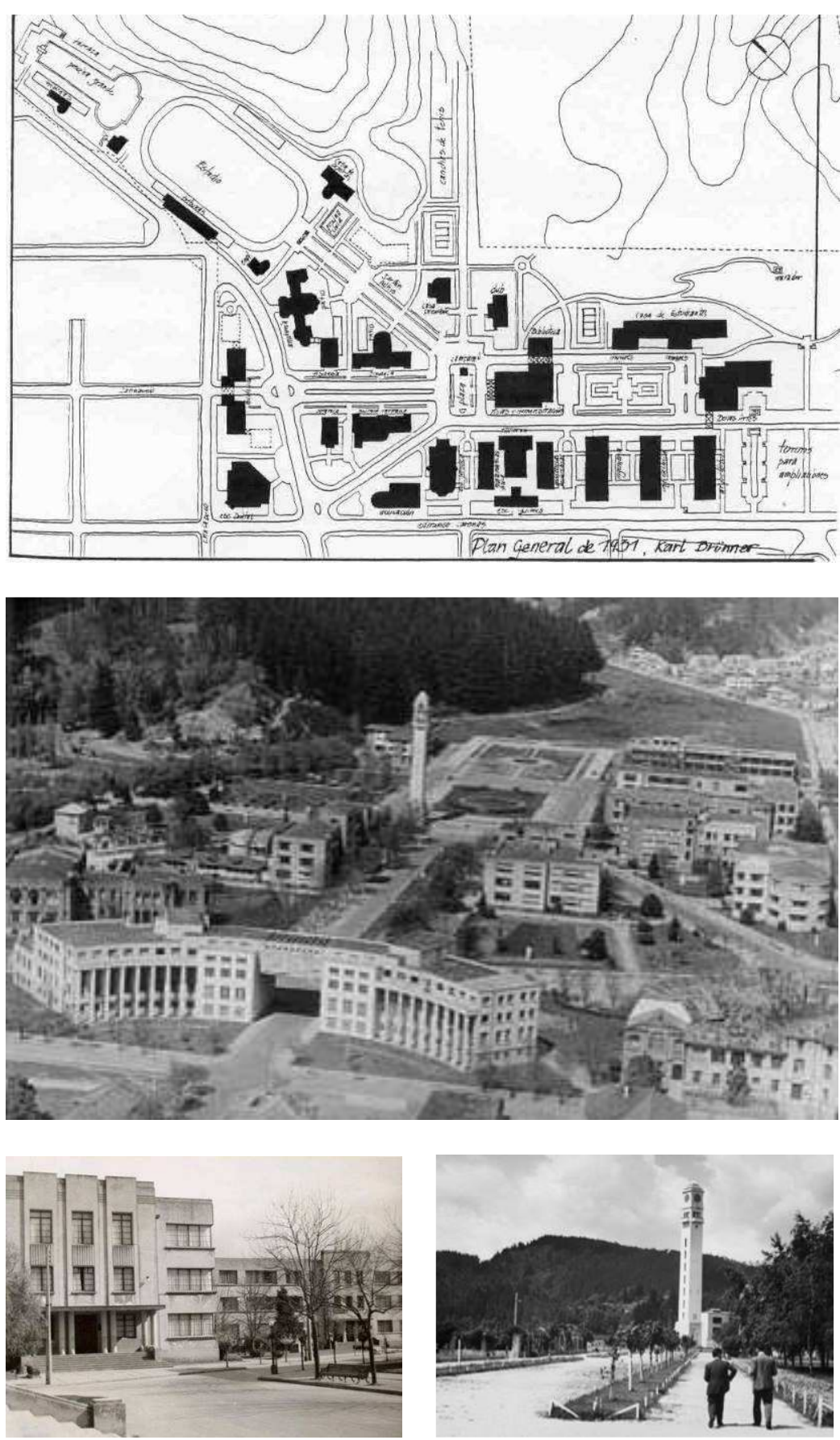

Enrique San Martín, Faculdade de direito 1934-1937. Archivo Fotográfico de la UdeC

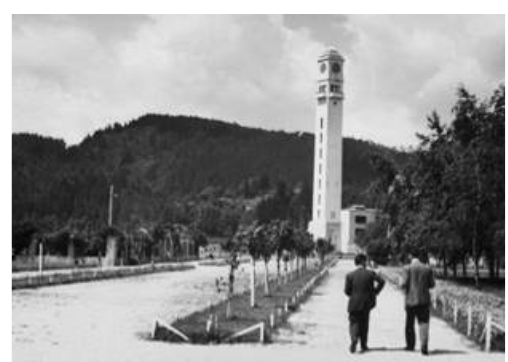

Julio Rios, Campanário, 1941. Inaugurado em 1944. Archivo Fotográfico de la UdeC
Karl Brunner, Plano do Bairro Universitário de Concepción, Chile, 1931.

\section{Vista do Bairro Universitário.}

Foto: Juan Salazar Torres. Colección: Museo Histórico Nacional

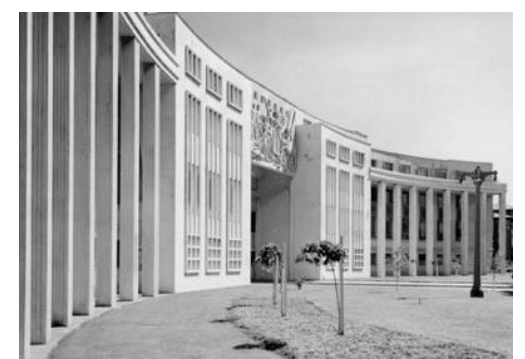

Edmundo Buddenberg e Gabriela González, Arco de Medicina, 1948-1954. Archivo Fotográfico de la UdeC 


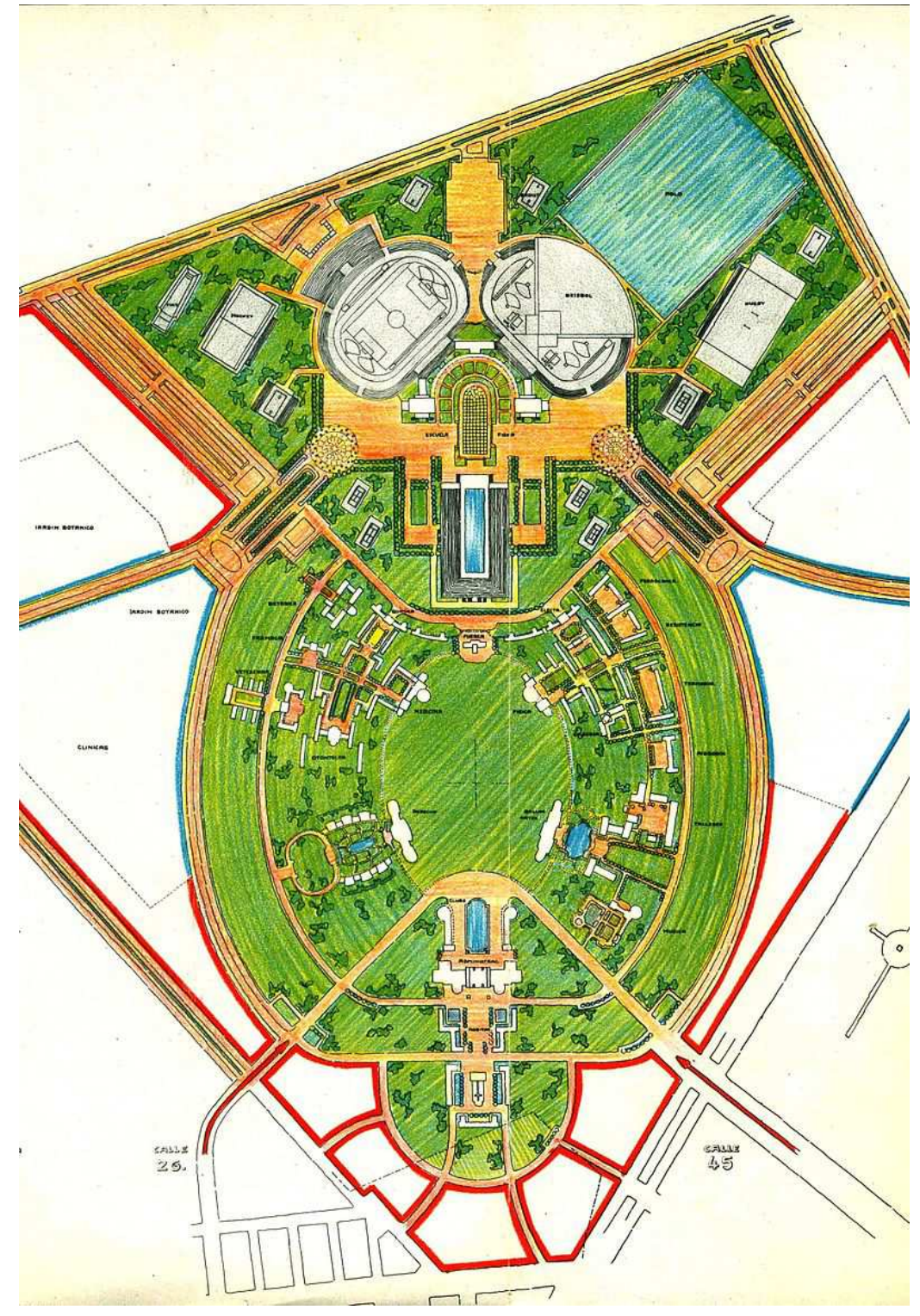

Leopoldo Rother e Erich Lange, Plano da Cidade Universitária de Bogotá, Colômbia, 1937. Arquivo General de la Nación de Colombia.
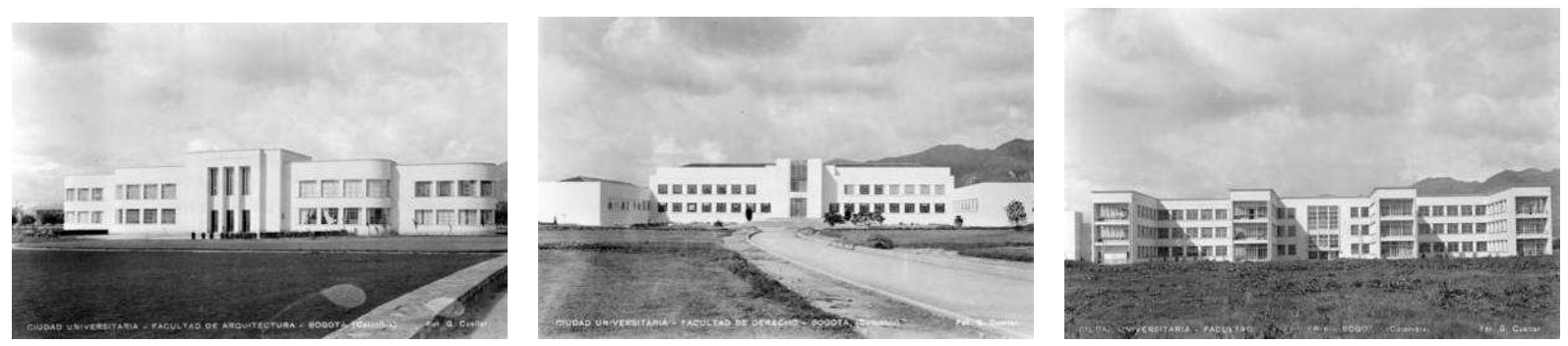

Leopoldo Rother e Bruno Violi. Faculdades de arquitetura, direito e engenharia, c.1940 Fotos: Gumersindo Cuéllar. Arquivo Banco de la República 

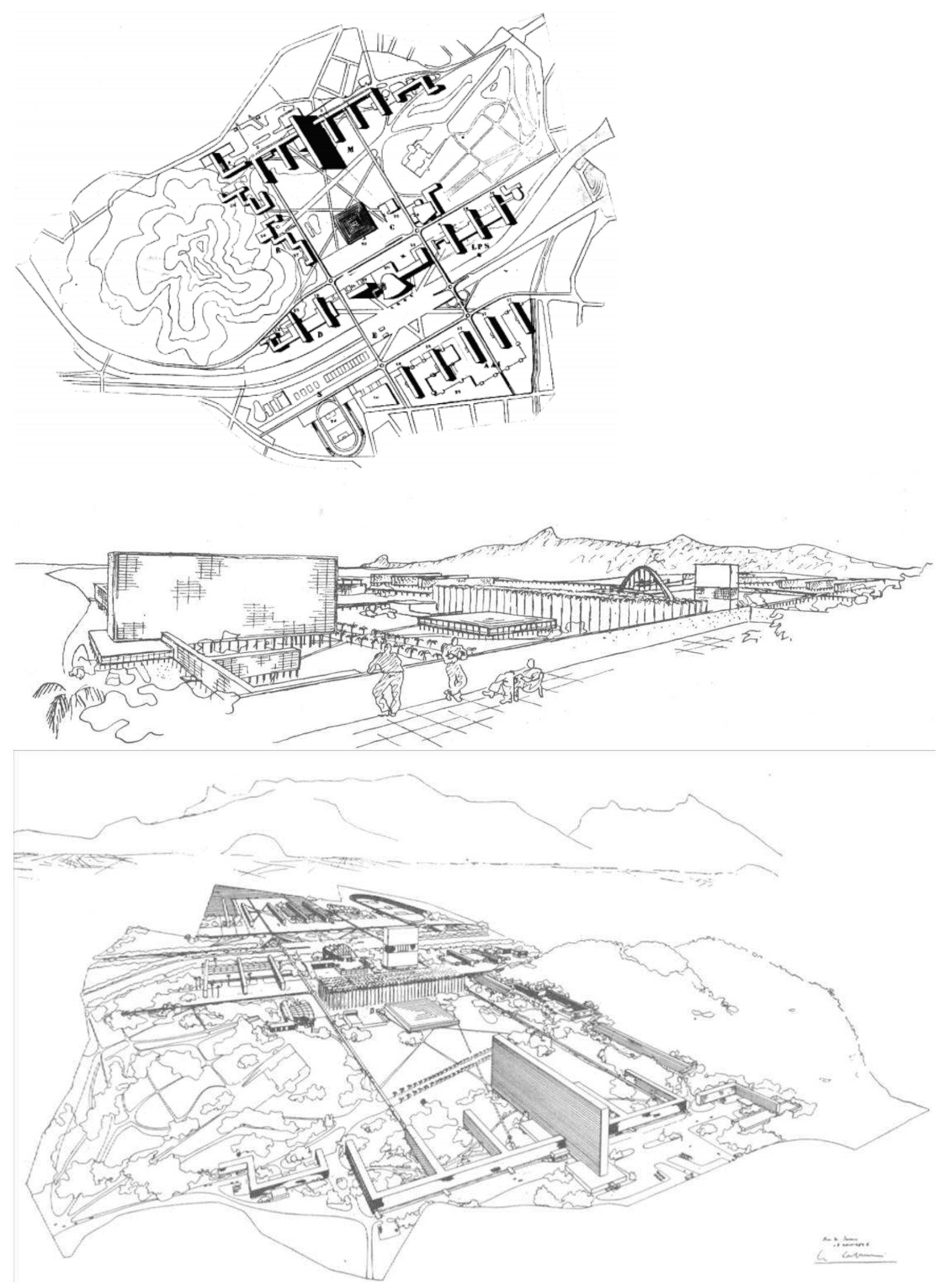

Le Corbusier, Plano para Cidade Universitária da Universidade do Brasil. Quinta da Boa Vista, Rio de Janeiro, 1936. Arquivo: Foundation Le Corbusier 

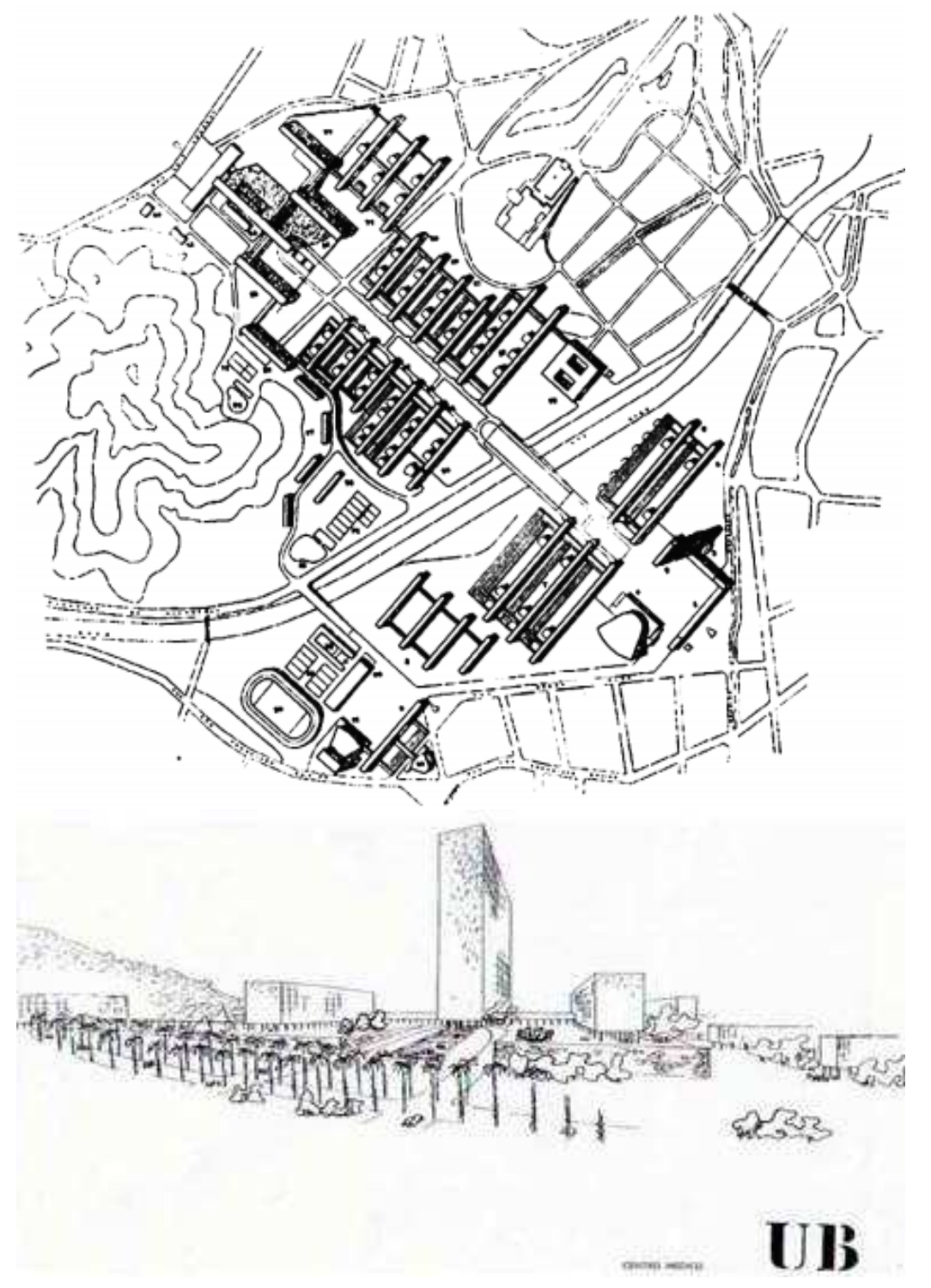

Lucio Costa e equipe. Plano para Cidade Universitária da Universidade do Brasil. Quinta da Boa Vista, Rio de Janeiro, 1936.
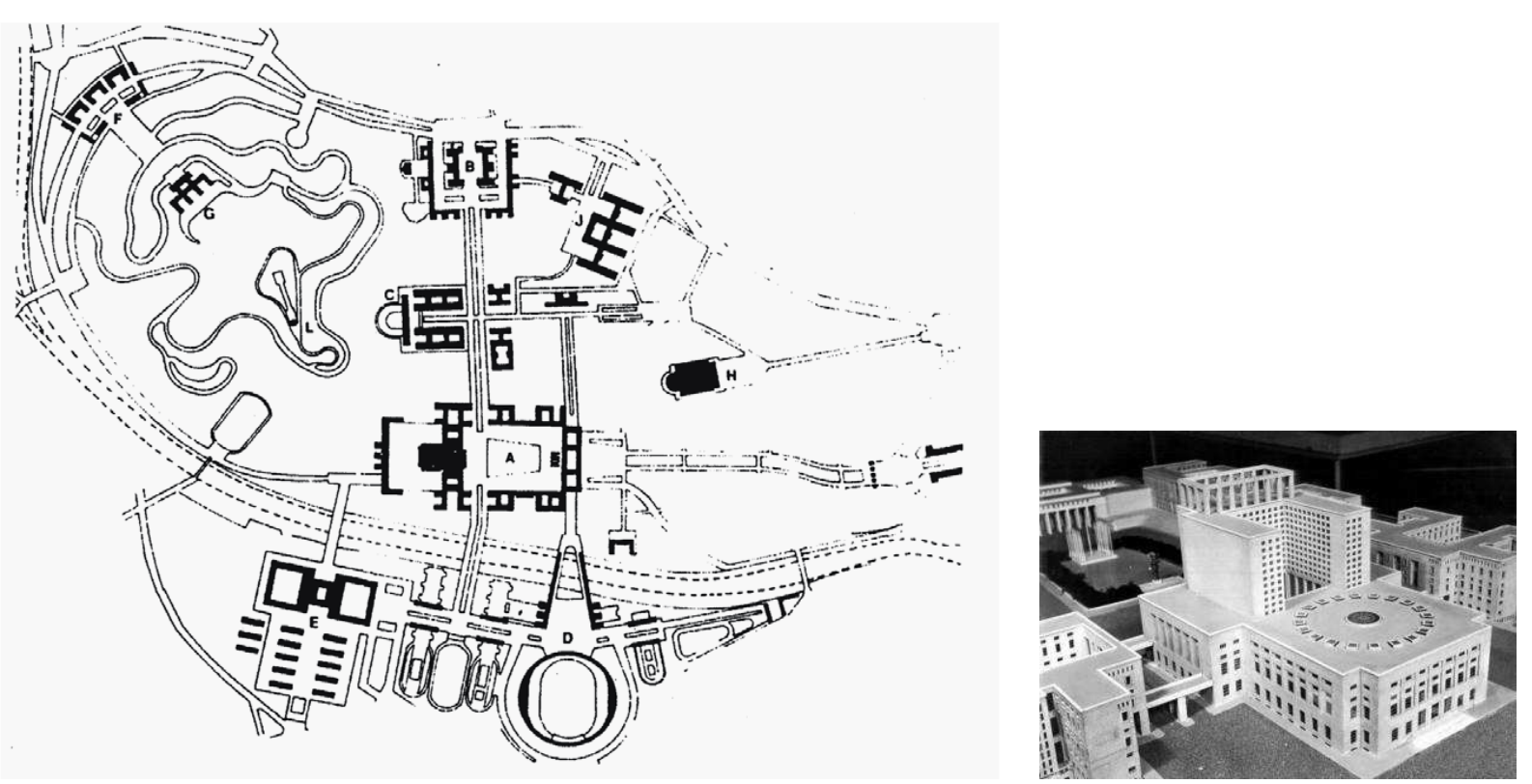

Vittorio Morpurgo e Marcello Piacentini. Plano para Cidade Universitária da Universidade do Brasil. Quinta da Boa Vista, Rio de Janeiro, 1938 


\section{EDIFÍCIOS DAS UNIDADES INCORPORADAS NA USP NA CIDADE DE SÃO PAULO}

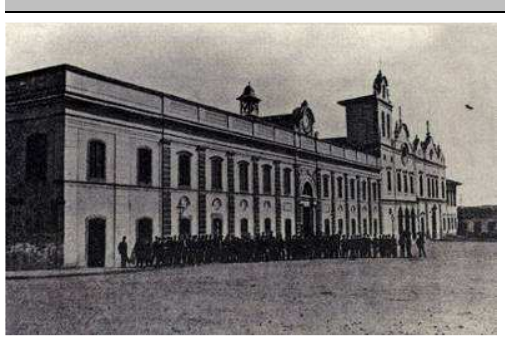

Faculdade de Direito (governo federal), Largo São Francisco, 1827.

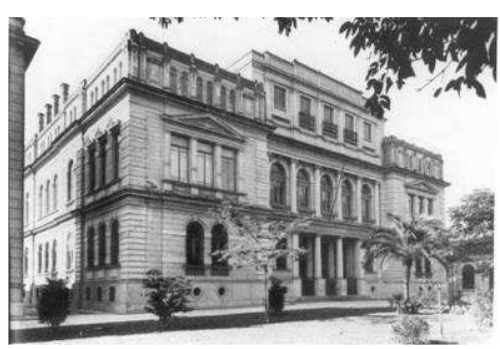

Escola Politécnica, 1893

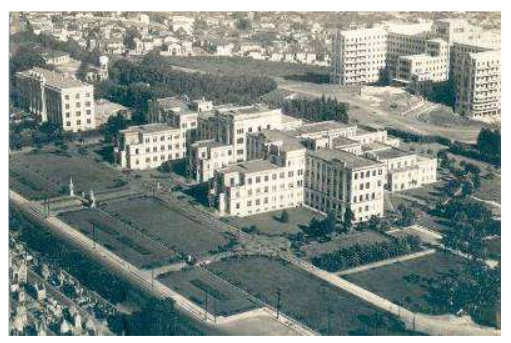

Faculdade de Medicina, 1913

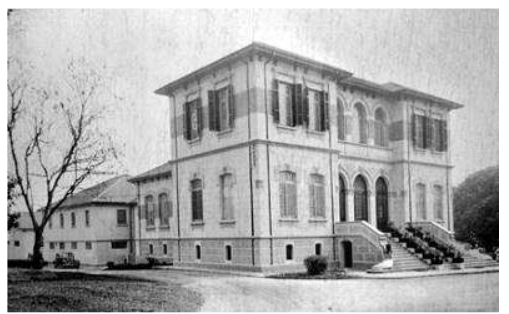

Instituto de Veterinária, 1919

R. Pires da Mota
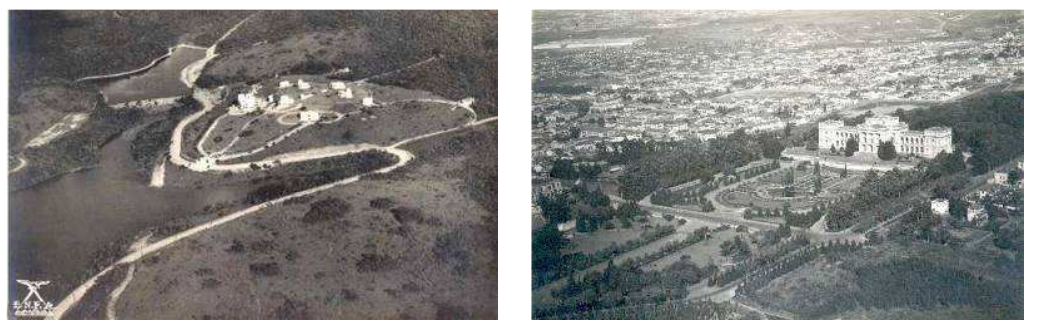

Observatório Instituto Astronômico e

Geofísico, 1886.

Arquivo Instituto Geográfico e Cartográfico

Museu de Arqueologia, História e Etnografia (Museu Paulista), 1892.

Arquivo Instituto Geográfico e Cartográfico
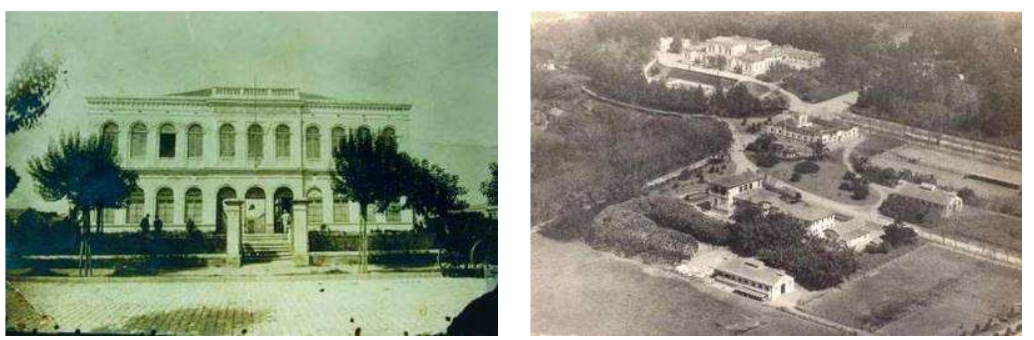

Faculdade de Farmácia e Odontologia, 1899 R. Três Rios

Instituto Butantã, 1901

Arquivo Instituto Geográfico e Cartográfico

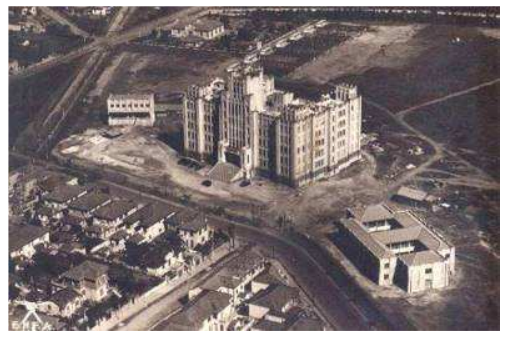

Instituto Biológico, 1927

Arquivo Instituto Geográfico e Cartográfico

Instituto de Educação / Instituto Caetano de Campos (governo federal), 1933 

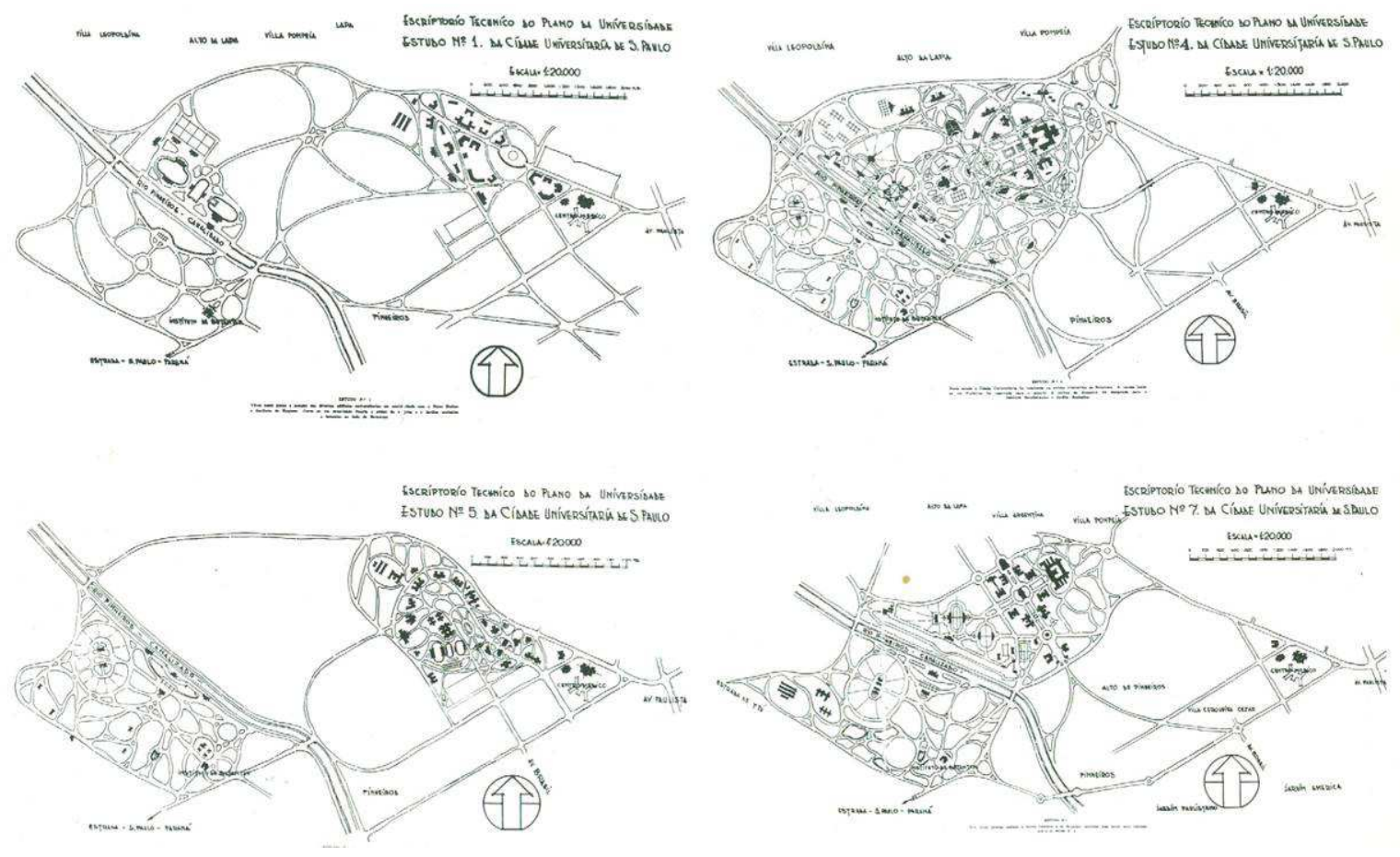

Escritório Técnico do Plano da Cidade da Universidade. Estudos n. 1, n. 4, n. 5 e n. 7 da Cidade Universitária de São Paulo, 1936.

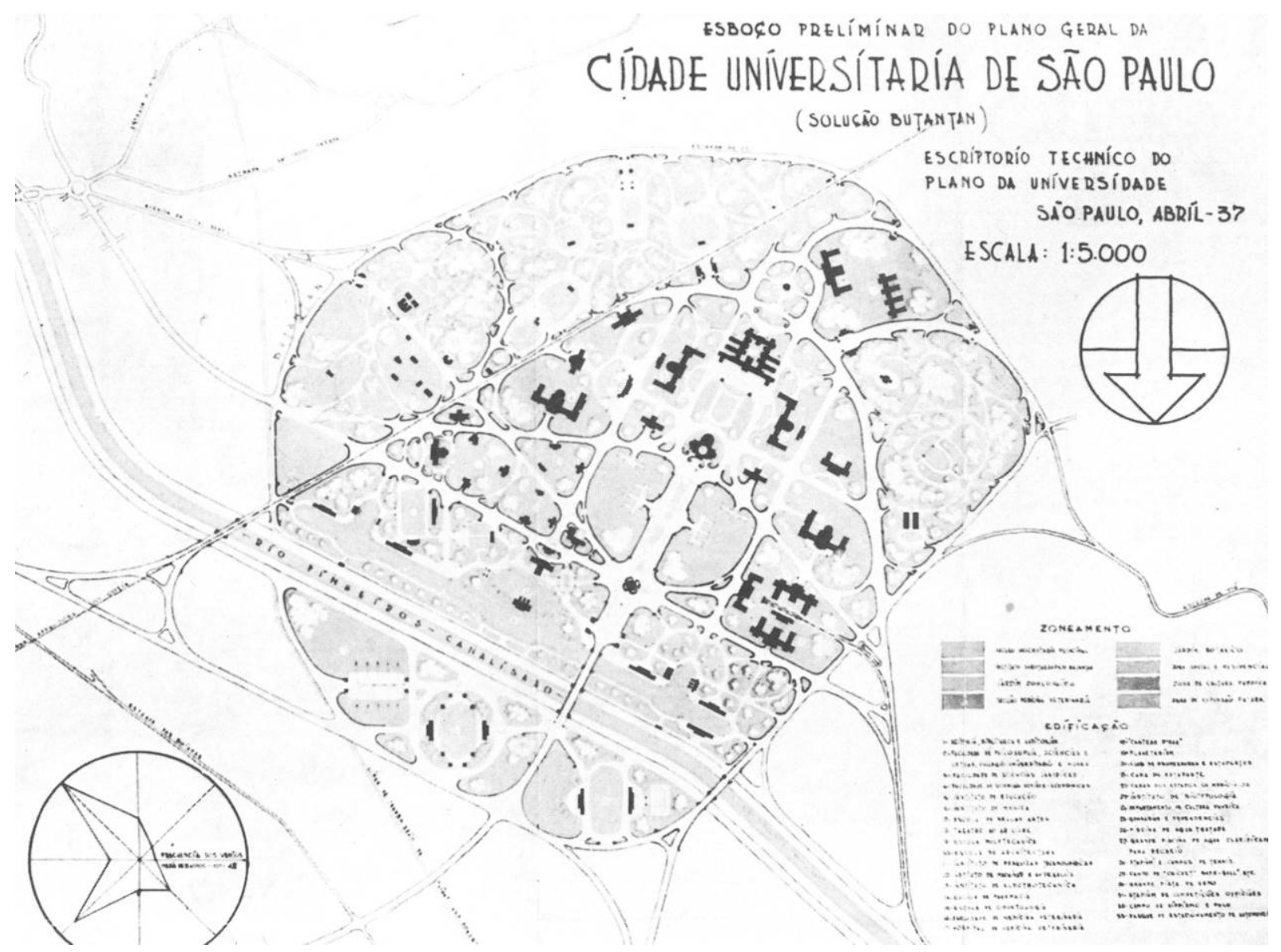

Hippolyto Gustavo Pujol Jr. e Escritório Técnico. Plano da cidade Universitária de São Paulo (Solução Butantan), 1937. 


\section{CONSTRUÇÃO DA CIDADE UNIVERSITÁRIA DA USP (1941-1958)}

\section{Modelos incertos (1941-1947)}

A ideia de uma cidade universitária da USP foi retomada em 1941, quando o presidente Getúlio Vargas nomeou seu ministro da Agricultura, Fernando Costa - engenheiroagrônomo pela Escola Politécnica -, para governar o Estado de São Paulo. O interventor federal, por sua vez, nomeou Jorge Americano, da Faculdade de Direito, como reitor da USP e Anhaia Mello, da Escola Politécnica, como secretário de Viação e Obras Públicas. Nos quatro anos que seguiram foram realizados pelo menos quatro diferentes planos para a cidade universitária: o "Plano Whately", de 1942, encomendado pelo reitor à firma do professor de Mário Whately, da cadeira de pontes e grandes estruturas da Escola Politécnica ${ }^{41}$; um plano realizado pela Secretaria de Viação e Obras Públicas em 1943; o plano vencedor de um concurso realizado entre julho e setembro de 1945; e o plano desenvolvido pelo Escritório Técnico da Cidade Universitária, criado por pelo reitor em maio de 1945. Portanto, nesse curto espaço de tempo, houve não apenas quatro planos urbanísticos - com semelhanças e diferenças que não discutiremos aqui - mas também quatro formas de gestão do plano: por contrato direto, por órgão do Estado, por concurso de projeto e por Escritório Técnico da própria universidade.

Entre um plano e outro, Fernando Costa lançou o decreto n.124, de 16 de dezembro de 1941, destinando uma área de 411,4 ha da Fazenda Butantã para a instalação da universidade em 1941. Em fevereiro de 1944, transformou a USP numa autarquia, conferindo autônoma administrativa em relação ao Governo do Estado (embora continuasse financeiramente dependente). No mesmo instante, o governador lançou a pedra fundamental da Cidade Universitária em cerimônia oficial do início das obras do Instituto de Pesquisas Tecnológicas (IPT) ${ }^{42}$ em uma gleba voltada para o loteamento industrial da Sociedade Imobiliária Jaguaré. ${ }^{43}$ Por fim, em setembro de 1944, o governador ampliou a área da universidade, decretando a utilidade pública de um terreno de 180 ha entre a nova e a velha estrada de Itu (atual Av. Corifeu de Azevedo Marques).

\footnotetext{
${ }^{41}$ Tratava-se, a princípio, de projetos para a Escola Politécnica, o Instituto de Eletrotécnica e a Faculdade de Filosofia, Ciências e Letras. Segundo Neyde Cabral, teria partido de Whately a necessidade de um plano geral. Ver: CABRAL, Neyde. Op. Cit. Como mencionado anteriormente, o engenheiro realizara um projeto para a FFCL em 1939.

42 O IPT, criado a partir do Gabinete de Resistência dos Materiais da Poli, havia se tornado uma autarquia independente da USP, dotada de recursos próprios.

${ }^{43}$ Entre 1937 e 1941, quando o terreno Butantã já estava indicado para abrigar a Cidade universitária, a Sociedade Imobiliária do Jaguaré, de Henrique Dumont Villares, lançou o Centro Industrial Jaguaré em terreno contíguo. O loteamento industrial de 363 ha, "cientificamente planejado", tinha área equivalente à da USP. A propaganda do empreendimento anunciava suas vantagens: vizinhança das áreas industriais já consolidadas, ônibus e trens de passageiros, proximidade com o centro (12 km), conexão ferroviária em bitola larga e estreita, conexão com as mais importantes rodovias do estado, água, eletricidade e serviço telefônico. A canalização do rio e a nova ponte do Jaguaré inauguradas em 1944, permitiriam ainda a navegação e um porto fluvial. Em 1939 alguns lotes já estavam ocupados pela Cia. Standard Oil, pelas pela siderúrgica Matarazzo.
} 
Se as medidas para execução da Cidade Universitária revelavam certa independência em relação aos planos gerais é porque o debate de sobre o modelo a ser seguido ainda era incerto. Para definir esse modelo foi realizada, em outubro de 1944, a Semana da Cidade Universitária, uma iniciativa do reitor sob os auspícios do interventor federal, do prefeito municipal e presidente do Conselho Administrativo do Estado. ${ }^{44}$ Segundo o arquiteto Eduardo Kneese de Mello, que participou do evento, o objetivo era definir o estilo arquitetônico da Cidade Universitária. ${ }^{45}$ Nesse período em que a arquitetura começava a afirmar sua autonomia, a possibilidade de uma arquitetura moderna, já adotada no centro médico do Araçá ${ }^{46}$, não foi sequer considerada. A principal disputa se deu entre o ecletismo sofisticado de Pujol Jr., defendido por Souza Campos, e um "neoclássico avançado", defendido pelo reitor. ${ }^{47}$

Entre julho e setembro de 1945, quase um ano depois da Semana da Cidade Universitária, foi realizado um concurso público, cujo júri foi composto por Ernesto de Souza Campos, pelo prefeito Prestes Maia e presidido pelo reitor Jorge Americano. A proposta vencedora foi o plano 'Accuratus', dos arquitetos Hippolyto Pujol Jr. e Oscar Defilipi. O Escritório Técnico da Cidade Universitária, criado pouco antes, em maio de 1945, ficou responsável por desenvolver e executar o plano até $1947 .{ }^{48}$

Para acomodar visões tão distintas sobre a Cidade Universitária e sobre o método adequado para contratação de planos e projetos arquitetônicos, de modo a atender as complexas demandas políticas, programáticas, institucionais e artísticas que o empreendimento envolvia, prevaleceu o Escritório Técnico, composto pelo engenheiro-chefe José de Freitas Valle Filho ${ }^{49}$, pelo arquiteto Djalma Lepage, por dois desenhistas, um auxiliar de desenhista, um topógrafo, uma secretária, um contínuo, um servente e seis operários. Mas esse modelo também não durou muito tempo.

\footnotetext{
${ }^{44}$ Realizada na Galeria Prestes Maia. As conferências foram feitas por Jorge Americano, Luiz de Anhaia Mello, André Dreyfus, Raul Briquet, Ernesto de Souza Campos, entre outros. Foram expostos planos universitários de diversos países, inclusive, os estudos feitos para São Paulo e o projeto Piacentini-Morpurgo para o Rio de Janeiro. Ver: CABRAL, Neyde. Op. Cit., p. 98.

${ }^{45}$ MELLO, Eduardo Kneese de. "Porque Arquitetura Contemporânea". Palestra realizada na Biblioteca Municipal de São Paulo em 22 de agosto de 1946 apud CABRAL, Neyde., Op. Cit., p. 98.

${ }^{46}$ A moderna Maternidade Universitária, no conjunto do Araçá, foi objeto de um concurso fechado organizado por Kneese de Mello, em 1944. Rino Levi ficou em primeiro lugar e Hélio Duarte em segundo. Também apresentaram projetos, Oscar Niemeyer, José Maria da Neves, Jacques Pillon e Jayme Fonseca Rodrigues. Ver: SEGAWA, Hugo. "Hélio Duarte: moderno, peregrino, educador" In: DUARTE, Hélio. Escolas-classe, escola-parque. Organização: André Takiya. 2ª ed. ampliada. São Paulo: FAUUSP, 2009, p. 45.

${ }^{47}$ AMERICANO, Oscar. 1947, pp. 283-187 apud CABRAL, Neyde. Op. Cit., p. 99.

${ }^{48}$ Este plano mantinha características fundamentais dos anteriores, como a distribuição do programa em círculos concêntricos e um sistema viário simétrico ao longo de um eixo principal. Com a perda da outra margem do rio, contudo, optava-se pelo acesso atual, paralelo ao rio, chegando pela ponte da Cidade Universitária. CABRAL, Neyde., Op. Cit., p. 101.

${ }^{49} \mathrm{O}$ chefe do escritório, José de Freitas Valle Filho, formado em 1927 na Politécnica, trabalhava na Secretaria da Fazenda quando foi contratado pelo Reitor, em fevereiro de 1945. Nesse período, Freitas Valle acompanhou o Reitor em viagem para os EUA e Canadá para visitar campus universitários.
} 


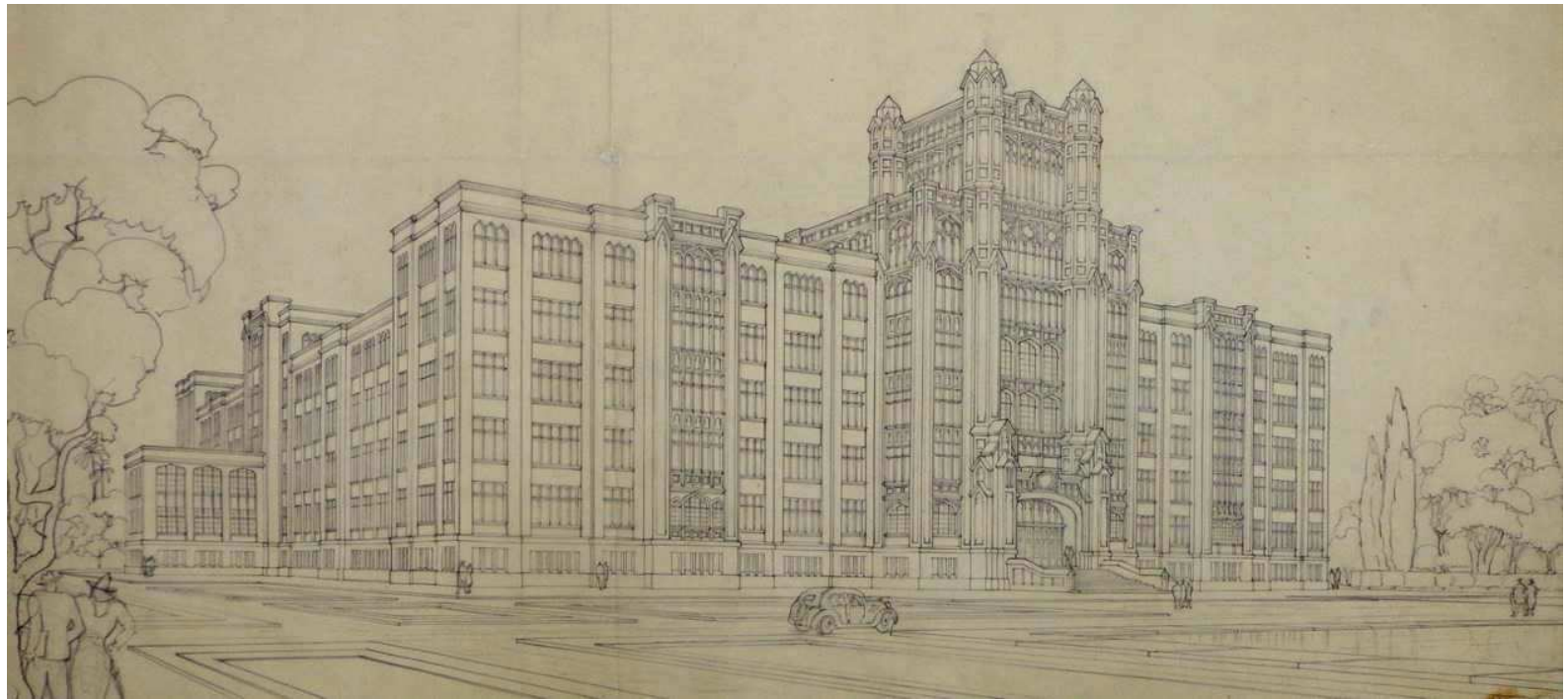

Mario Whately. Projeto para Faculdade de Filosofia, Ciências e Letras, Centro de São Paulo, novembro de 1939. Arquivo do Estado de São Paulo. Cortesia: Mônica Junqueira.

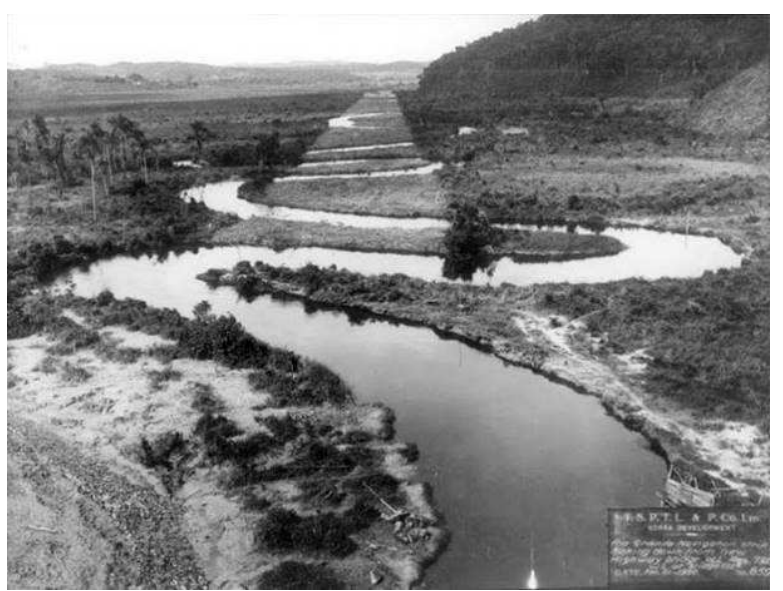

Retificação do Rio Pinheiros, década 1930. Arquivo: Fundação Energia e Saneamento

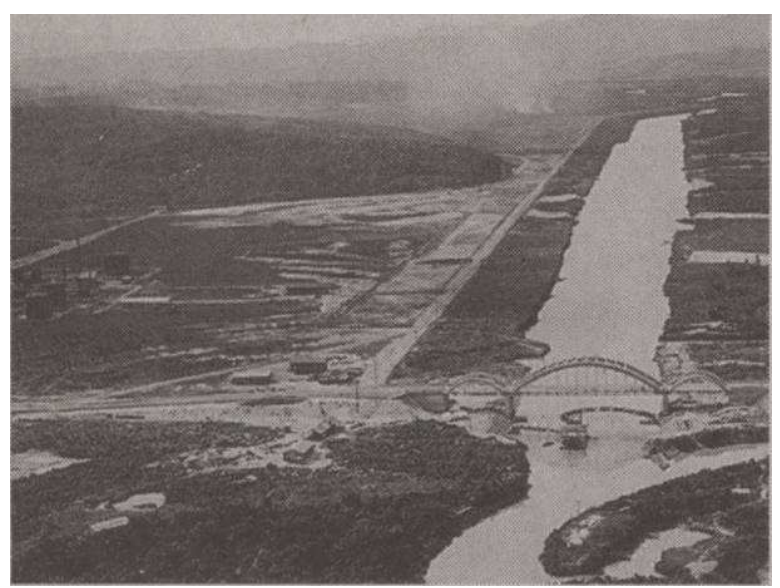

Ponte do Jaguaré. Ocupação inicial do parque industrial do Jaguaré, década 1940. Arquivo: Fundação Energia e Saneamento

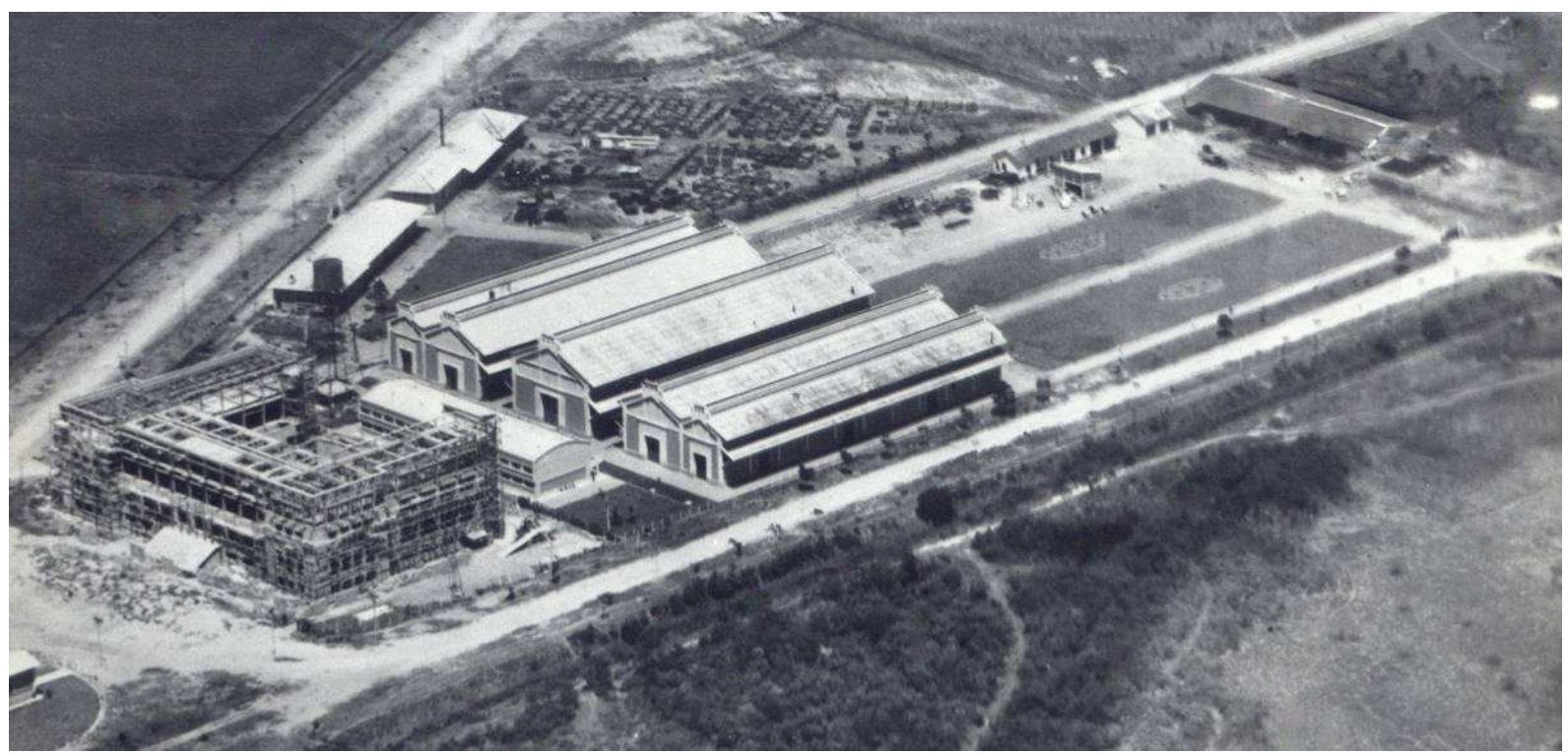

Vista aérea das instalações do IPT no Butantã, 1949. Arquivo: IPT (Flickr) 


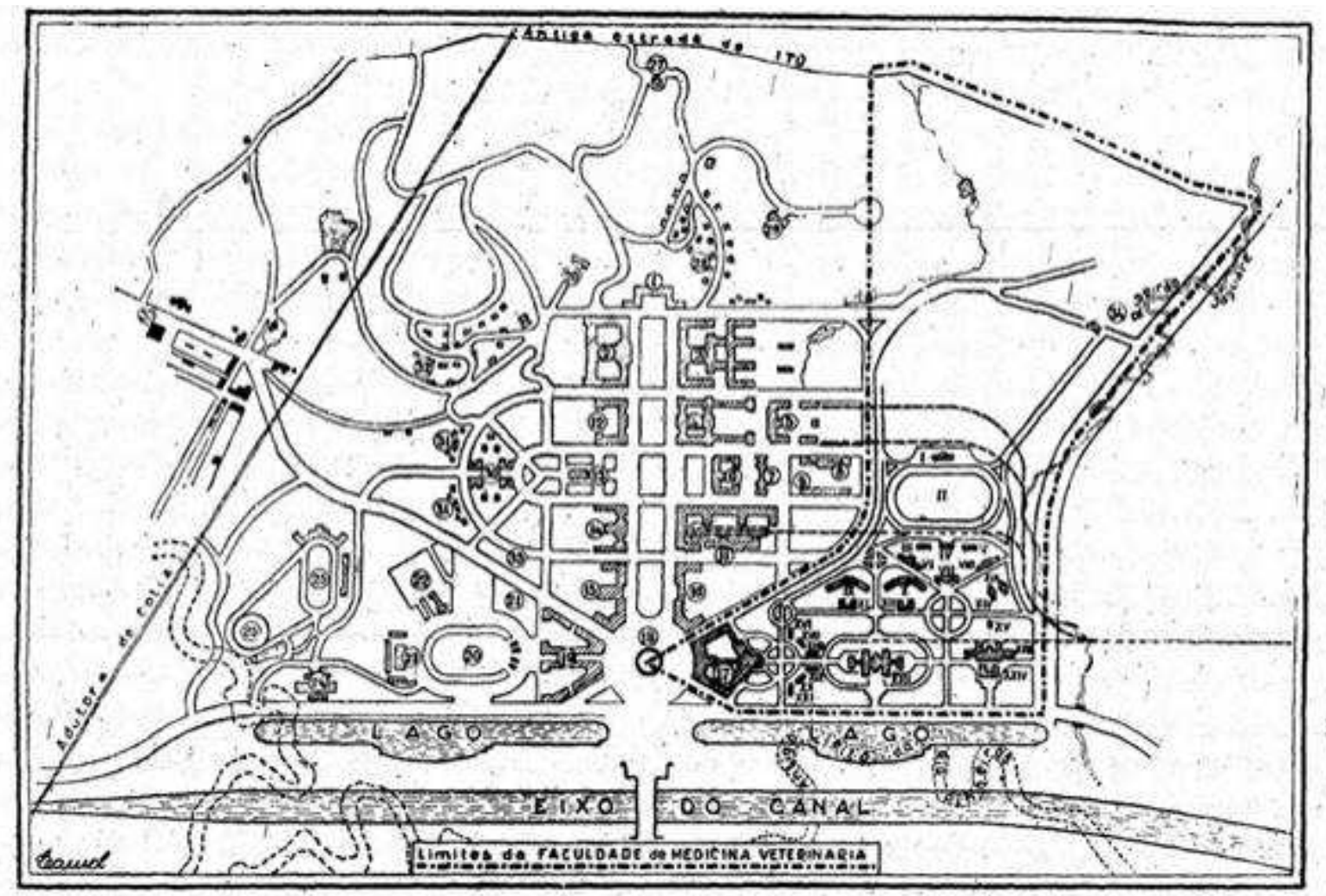

Secretaria de Viação e Obras Públicas. Plano geral da Cidade Universitária de São Paulo, 1943. Publicado em O Estado de São Paulo, 20 de novembro de 1943.

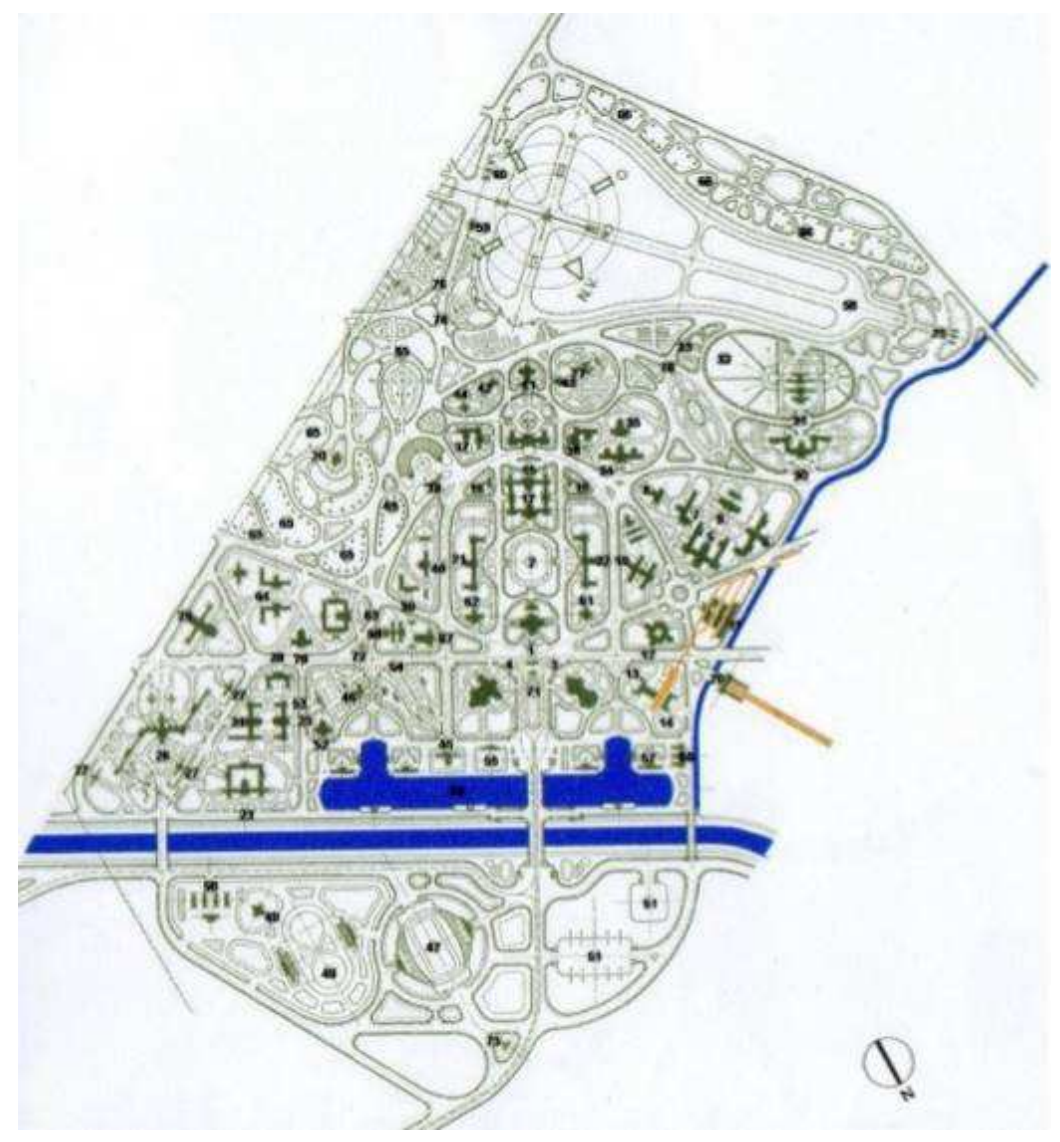

Hippolyto Gustavo Pujol Junior e Oscar Defilipi. Plano Accuratus, setembro 1945 Desenho Neyde Cabral, 2010 


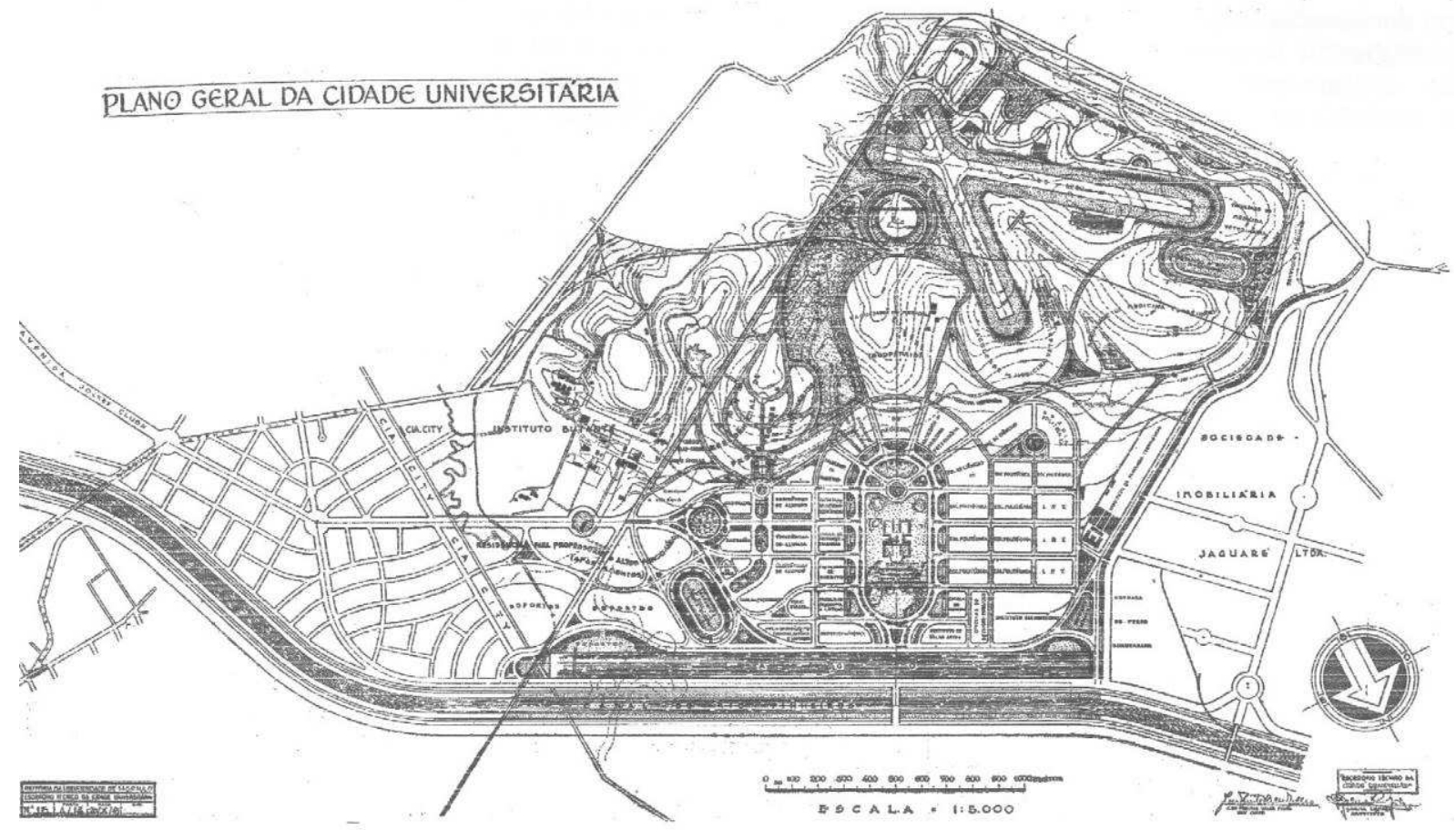

José de Freitas Valle Filho e Djalma Lepage. Plano Geral da Cidade Universitária, outubro 1945.

Fonte AMERICANO, Jorge. "A universidade de São Paulo: dados, problemas e planos". Revista dos Tribunais, 1947, p. 241.

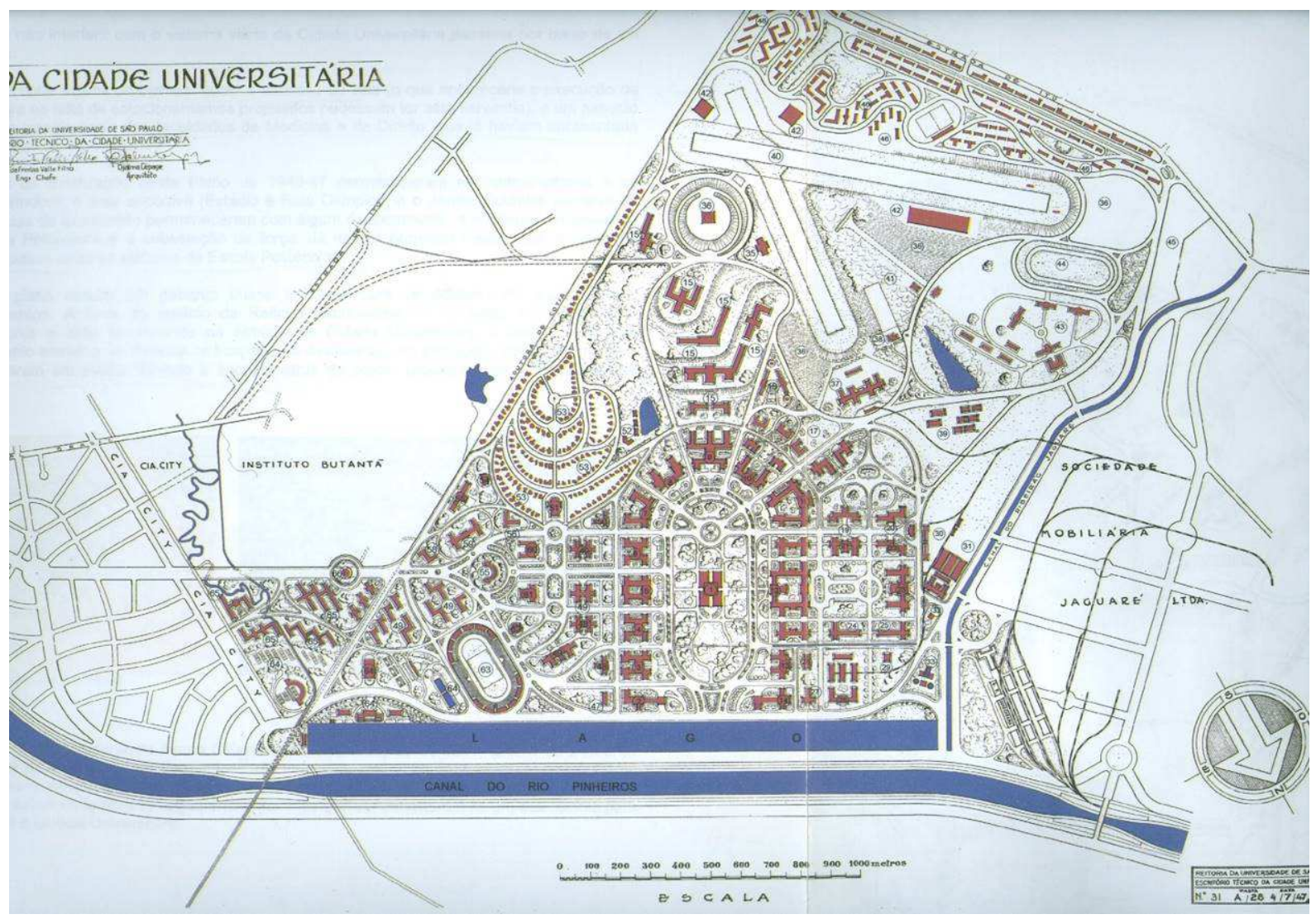

José de Freitas Valle Filho e Djalma Lepage. Plano Geral da Cidade Universitária, julho 1947 Desenho Neyde Cabral, 2010, p. 105 


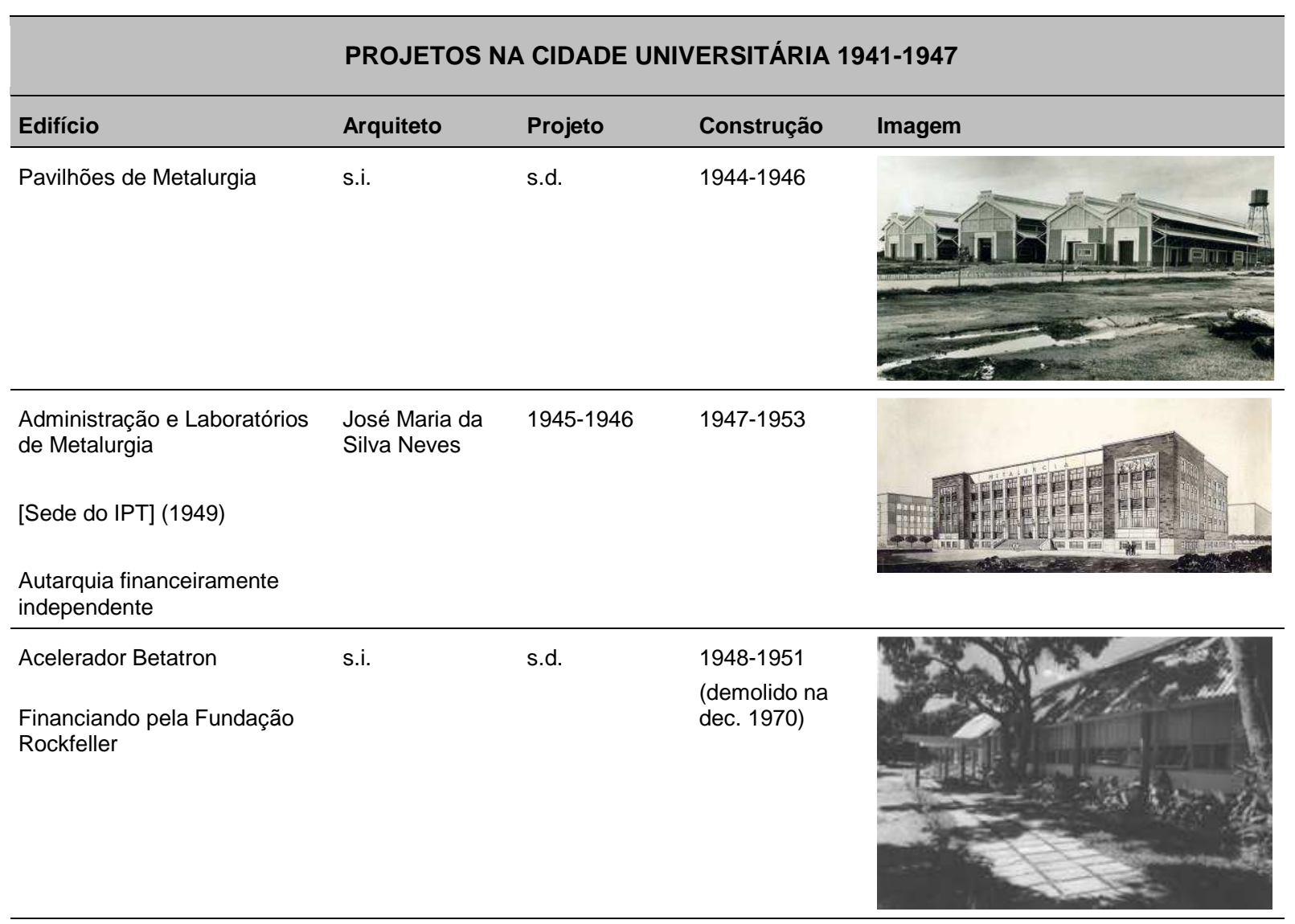

Essa tabela foi elaborada a partir da sistematização de dados dispersos na bibliografia. Algumas informações podem ser contraditórias.Imagens: América Magazine, n. 2, ano 7. São Paulo: Varta, 1962, e outros. 


\section{Primeiros planos modernos (1947-1954)}

Com o fim do governo Vargas, em outubro de 1945, o novo governador, José Carlos de Macedo Soares (1945-1947), nomeou Antônio Almeida Prado, professor da Faculdade de Medicina e presidente da comissão de 1935, como reitor da universidade. O Escritório Técnico continuou gerindo as obras da Cidade Universitária e desenvolvendo o Plano Geral, que foi reapresentado em julho de 1947. Paralelamente, o reitor Almeida Prado nomeou uma comissão de engenheiros e arquitetos, a Comissão da Cidade Universitária (CCU), que, no entanto, só foi instalada (e ampliada) por seu sucessor, o reitor Lineu Prestes ${ }^{50}$ (1947-1949), da Faculdade de Farmácia e Odontologia, indicado pelo governador eleito, Adhemar de Barros (1947-1950).

A criação da CCU pode ser vista como uma resposta à reivindicação dos arquitetos de maior protagonismo nos planos para a Cidade Universitária. Entre abril de 1947 e setembro de 1948 - período que abrange a fundação das escolas de arquitetura da Universidade Mackenzie e da USP -, a CCU foi composta por Luiz Ignácio de Anhaia Mello (presidente), Henrique Jorge Guedes e José Maria da Silva Neves, todos professores catedráticos da Poli e parte do primeiro corpo docente da FAU. Foram também incluídos quadros externos à USP, como os arquitetos Christiano Stockler das Neves (fundador da Faculdade de Arquitetura da Universidade Mackenzie e Prefeito da cidade de São Paulo entre março e agosto de 1947); Eduardo Kneese de Mello, Elisiário da Cunha Bahiana e os engenheiros Francisco Teixeira da Silva Telles e Frederico Brotero, além do chefe do Escritório Técnico, Freitas Valle.

Sem Souza Campos para defender o projeto de Pujol Jr. e Defilipi, o único obstáculo para um plano arquitetônico e urbanístico moderno, alinhado às últimas tendências internacionais, era Stockler das Neves. No entanto, sem autoridade para elaborar um novo plano, essa Comissão apenas se manifestou favorável a um novo plano, e tendo deliberado sobre o assunto para o qual fora constituída, a comissão foi dissolvida.

Para resolver o impasse, o governador Adhemar de Barros constituiu por decreto uma nova $\mathrm{CCU}$, de tamanho reduzido e diretamente responsável pelo plano geral, bem como pelo desenvolvimento de programas para os setores, projetos de edifícios e convênios com outros órgãos. Nessa reformulação os quadros do Escritório Técnico foram mantidos, mas passaram a servir a CCU. Os membros da nova CCU, a quem caberia a autoria do plano,

\footnotetext{
${ }^{50}$ Lineu Prestes já havia sido diretor da Faculdade de Farmácia e Odontologia durante o primeiro governo de Adhemar de Barros (1938-1941). Em sua gestão na reitoria criou novo regimento da universidade, a Faculdade de Ciências Econômicas e Administrativas e a Faculdade de Arquitetura e Urbanismo. Em 1949 foi nomeado secretário da Fazenda do Estado de São Paulo, e no ano seguinte assumiu o cargo de prefeito do município de São Paulo. Em 1950, elegeu-se suplente de senador pelo Partido Social Progressista, assumindo as funções em fevereiro de 1957.
} 
foram nomeados em novembro de 1948. Eram eles: Anhaia Mello, Adriano José Marchini ${ }^{51}$, José Maria da Silva Neves, Christiano Stockler das Neves ${ }^{52}$ e Ernesto Souza Campos, escolhido presidente por indicação dos demais. Àquela altura, Souza Campos já se mostrava aberto a incorporar as novas ideias estéticas e urbanísticas, dada a repercussão positiva da arquitetura moderna brasileira.

O projeto de zoneamento e sistema viário desta comissão foi aprovado pelo Conselho Universitário em 12 de maio de 1949 e continuou sendo desenvolvido nos mesmos moldes até 1954. Com menção ao urbanismo moderno do CIAM em seu memorial, o novo plano definia setores funcionais ao invés da disposição concêntrica dos edifícios. A inversão do eixo da composição, originalmente perpendicular e voltado para o Rio Pinheiros e agora alinhado à via de acesso, definida em 1947, fez o rio - já poluído - um elemento secundário e uma barreira. Essa inversão somada às glebas independentes do IPT e do Instituto Butantã fazia com que a Cidade Universitária se configurasse em um território segregado da cidade - o que se agravaria com as propostas de cessão de novas glebas ao Departamento de Estradas de Rodagem $(D E R)^{53}$, ao Instituto de Pesquisas Energéticas e Nucleares (IPEN) e à Marinha do Brasil. A ligação com a cidade se faria por um parkway monumental, com 100 metros de largura, arborizado com palmeiras imperiais ${ }^{54}$, dando acesso frontal à praça magna, formada por um campanário, pelos edifícios cívicos e culturais da universidade e pela reitoria.

Durante a gestão do reitor Luciano Gualberto (1950-1951), da Faculdade de Medicina, a CCU foi renomeada de "Comissão do Plano e Execução da Cidade Universitária" e no lugar de Souza Campos e da vaga deixada por Stockler das Neves, foram nomeados Bruno Simões Magro e Zeferino Vaz. A presidência foi atribuída a Anhaia Mello, que além de dirigir a FAU foi nomeado vice-reitor da universidade. Com a indicação de Simões Magro, os três arquitetos catedráticos da FAU (sendo os outros dois Anhaia Melo e José Maria das Neves) passavam a estar representados na Comissão. Já a indicação do médico Zeferino Vaz, diretor da Faculdade de Medicina de Ribeirão Preto, deve ter levado em consideração a construção do campus de Ribeirão Preto (inaugurado em 1952) ${ }^{55}$ Afinal, além da criação da

\footnotetext{
${ }^{51}$ Engenheiro ligado ao Laboratório de Ensaios de Materiais da Escola Politécnica.

52 Stockler das Neves solicitou dispensa em 21 de abril de 1950, sendo substituído pelo arquiteto Mario Henrique Pucci, também dispensado a pedido em 26 de junho de 1950.

${ }^{53}$ A CCU elaborou um convênio com o DER para a instalação da autarquia na Cidade Universitária, com a intenção de receber investimentos em contrapartida. Esta cessão foi objeto do decreto 19.449 de 30 de maio de 1950. No entanto, o DER nunca ocupou a área, que mais tarde foi cedida informalmente para a construção do 16을 Batalhão de Polícia Militar.

${ }^{54}$ Esse parkway era defendido por Anhaia Mello, enquanto Stockler das Neves defendia a diminuição da largura para 60 metros, que prevaleceu mais tarde.

55 Segundo depoimento de Nestor Goulart, Zeferino Vaz seria uma desavença de Anhaia Mello e o responsável pelo veto de Niemeyer e da filha de Pujol, Colete Pujol, para lecionarem na FAU em 1951. Ver: SODRÉ, João. Arquitetura e viagens de formação pelo Brasil: 1938-1962. Dissertação de mestrado. São Paulo: FAUUSP, 2010, p. 158.
} 
FAU e a incorporação do Instituto Oceanográfico (1951), a lei 161/48 impôs novos desafios ao planejamento da USP, criando a EESC, a FMRP e a Faculdade de Odontologia de Bauru no interior do Estado de São Paulo.

Nesse momento, a Cidade Universitária foi considerada como uma opção para abrigar a Exposição Internacional do IV Centenário da cidade de São Paulo. ${ }^{56} \mathrm{O}$ atraso das obras de urbanismo e a distância em relação ao centro da cidade, no entanto, levaram ao descarte dessa possibilidade. Esse breve episódio, no entanto, evidenciou a necessidade de maior empenho do Estado, que passou a dispensar mais verbas para a construção da Cidade Universitária. Com isso, foi realizada concorrência para a terraplanagem e, em fevereiro de 1951, foi iniciada a construção do edifício da reitoria, projetado por José Maria da Silva Neves. O Instituto de Aperfeiçoamento do Professor, órgão federal ligado à universidade, recebeu um projeto de arquitetura de Alcides Rocha Miranda (professor contratado da FAU) e José de Souza Reis, em 1951.

Com mais recursos provenientes do Governo do Estado, o Escritório Técnico, agora dirigido pelo arquiteto Djalma Lepage, foi ampliado com um setor administrativo, um setor de engenharia e um de arquitetura, formado por Oscar Gutierrez, Cássio P. Gonçalves, Vicente de Paula Collet e Silva e Tácito Brito de Macedo, além de contar com mais vinte auxiliares. O escritório foi responsável pelos projetos do Pavilhão de Alta Tensão e dos edifícios de Zoologia, de Botânica e de Física Experimental, todos de FFCL. Porém, mesmo ampliado, o Escritório Técnico era insuficiente para projetar todos os edifícios e os planos setoriais da Cidade Universitária, além dos projetos de adaptação do prédio da reitoria na Rua Helvetia, da FFCL na Rua Maria Antônia, da ampliação da Faculdade de Medicina Veterinária na Rua Pires da Mota, e do centro médico do Araçá. Não bastasse a grande demanda de projetos as obras de urbanização e infraestrutura, incluindo uma dispendiosa movimentação de terra (pois os planos foram pouco adaptados à topografia), consumiam a maior parte dos recursos.

Em meados de 1951, Anhaia Mello e Zeferino Vaz se afastaram da Comissão. Para substituí-los, o então reitor Ernesto de Morais Leme, da Faculdade de Direito, trouxe de volta o professor Ernesto de Souza Campos, que, por sua vez, conseguiu contratar a consultoria de Hippolyto Pujol Junior para elaborar estudos para o Setor de Engenharia. Em novembro de 1951, Pujol apresentou sua proposta, uma composição urbana acadêmica com arquitetura eclética. No ano seguinte, o arquiteto faleceu e o professor Souza Campos e o engenheiro Freitas Valle se aposentaram. O Setor de Engenharia recebeu novo estudo

${ }^{56}$ As outras opções eram o Parque D. Pedro II e o Parque do Ibirapuera. Christiano Stockler das Neves, presidente da Comissão Municipal de Obras e Urbanismo da Comissão Municipal dos Festejos do IV Centenário, teria indicado em janeiro de 1950 a Cidade Universitária, mas em 1951 o Parque do Ibirapuera fora escolhido. MEYER, Regina Maria P. Metrópole e urbanismo: São Paulo: Anos 50. Tese de doutorado. São Paulo: FAUUSP, 1991, p. 55, apud CABRAL, Neyde. Op. Cit., p. 109. 
de José Maria das Neves, que projetou um conjunto composto por blocos isolados e eixos ortogonais, aprovado pela Congregação da Escola Politécnica em outubro de 1952.

Apesar do empenho de Souza Campos, nenhum projeto de Pujol foi realizado na Cidade Universitária. De todo modo, a decisão de contar com projetistas externos pode ter dado início a uma mudança na política de projetos para a Cidade Universitária. A partir de 1952, a CCU passou a contratar projetos junto a escritórios particulares. Ariosto Mila projetou o edifício do Laboratório de Hidráulica; Ícaro de Castro Mello assinou um grandioso setor esportivo; Plínio Croce, Carlos Millan, Roberto Aflalo e Galiano Ciampaglia projetaram o conjunto da Faculdade de Filosofia, Ciências e Letras (1953) e fizeram o replanejamento do Instituto de Pesquisas Tecnológicas (1954); Gio Ponti projeta a Faculdade de Física Nuclear (1953); Rino Levi e Roberto Cerqueira César projetaram o Centro Cívico (1952-1953), com paisagismo de Roberto Burle Marx, e um conjunto residencial para dois mil estudantes, com restaurante, clube, salão de festas e bar. ${ }^{57}$

Esses e outros projetos foram incorporados aos planos gerais, atualizados em 1952 e 1954 . Contudo, como as obras superavam em muito a capacidade de investimento do Estado, apenas a primeira parte do Laboratório de Hidráulica começou a ser construída. Em meados de 1954, acompanhando o clima de incerteza causado pelo suicídio de Getúlio Vargas, todas as obras foram paralisadas.

\footnotetext{
${ }^{57}$ A maioria desses arquitetos ainda não eram professores da FAU (ver capítulo anterior e anexos). Sobre o projeto do Centro Cívico, ver: Habitat n.11, São Paulo, 1953. A torre do Centro Cívico chegou a ser estaqueada na década de 1950, mas só foi construída quase duas décadas depois, em local e contexto diferentes.
} 


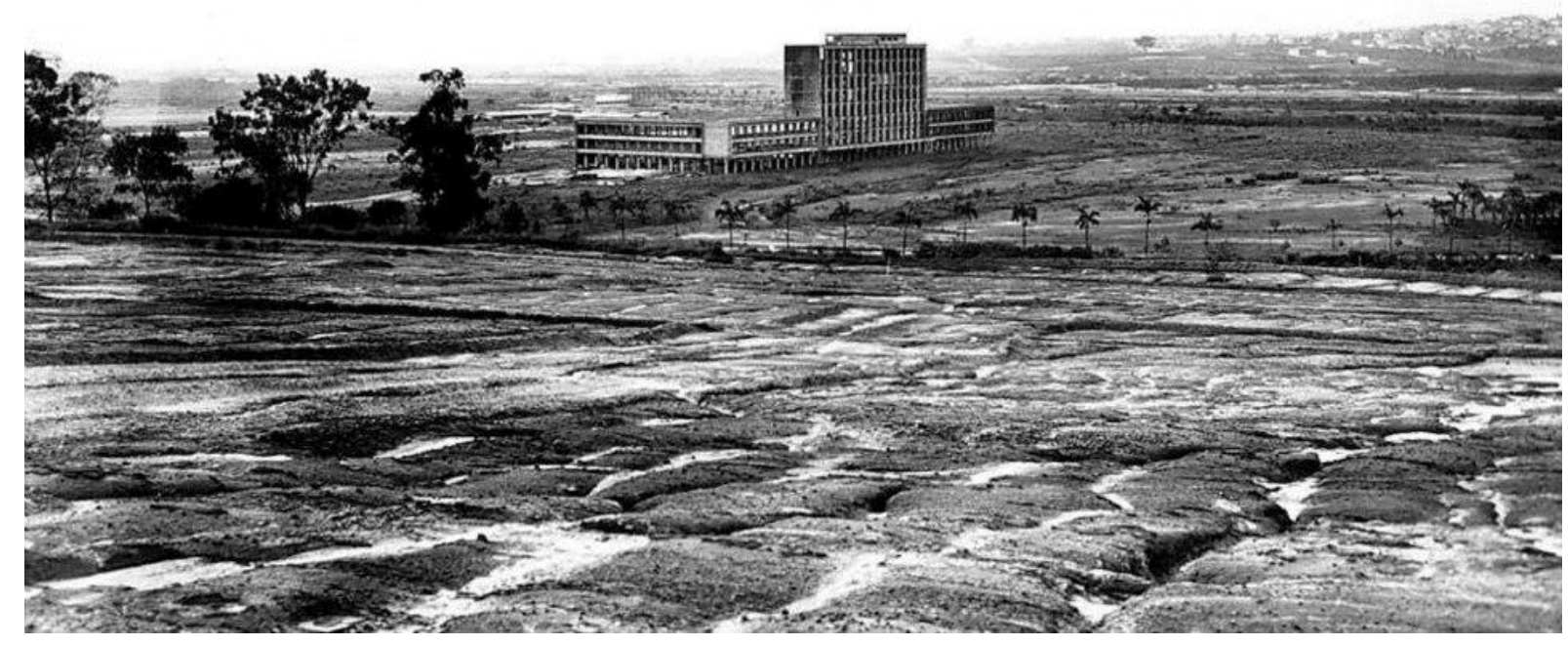

Aspecto da Cidade Universitária no início da década de 1950. 


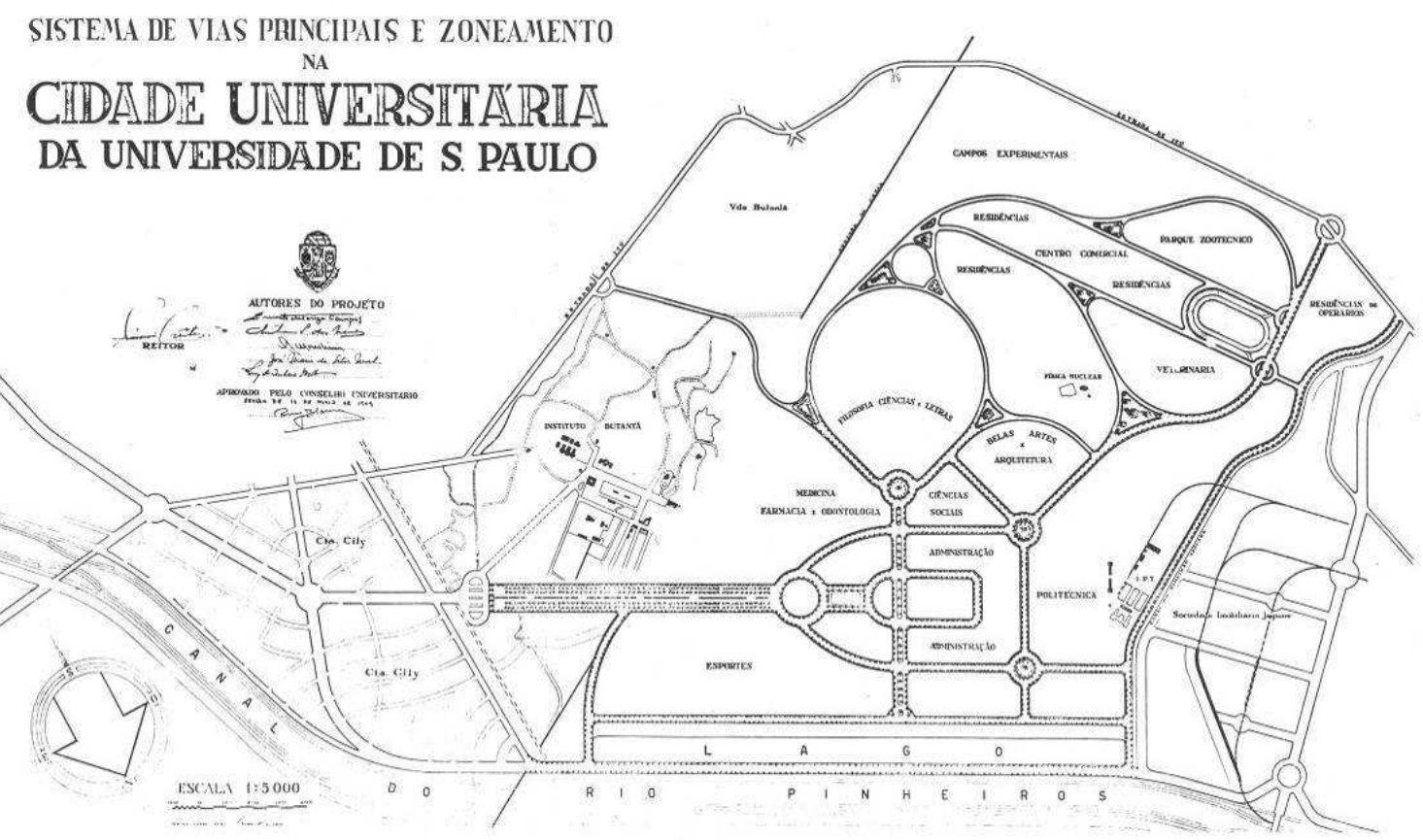

Cristiano Stockler da Neves, Ernesto de Souza Campos, José Maria da Silva Neves e Luiz de Anhaia Mello, Systema de vias principais e zoneamento da Cidade Universitária, maio 1949.

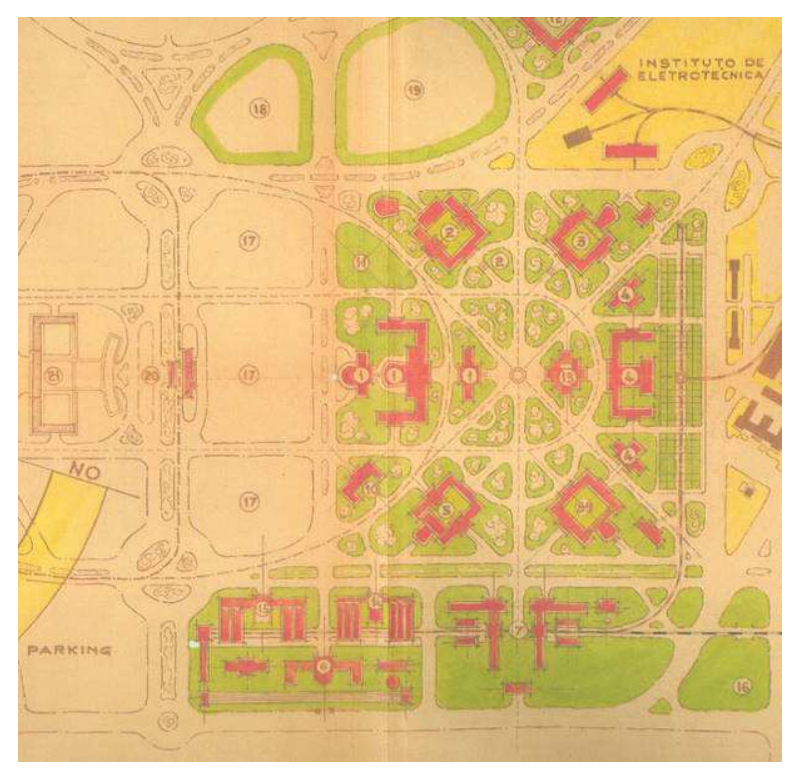

Hippolyto Gustavo Pujol Junior

Setor de Engenharia, novembro 1951

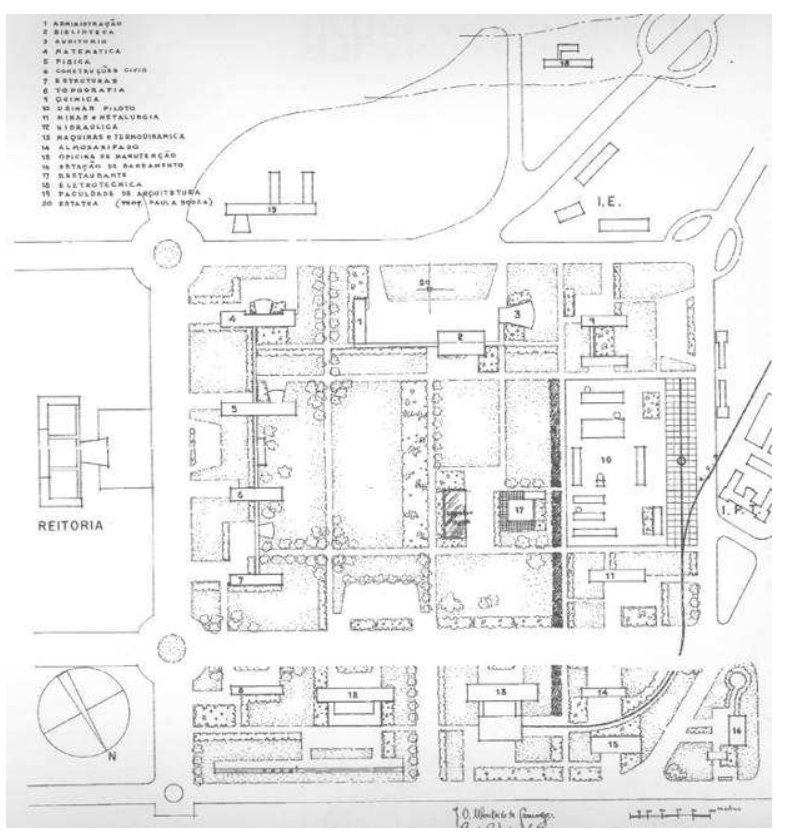

José Maria da Silva Neves

Setor de Engenharia, outubro 1952 


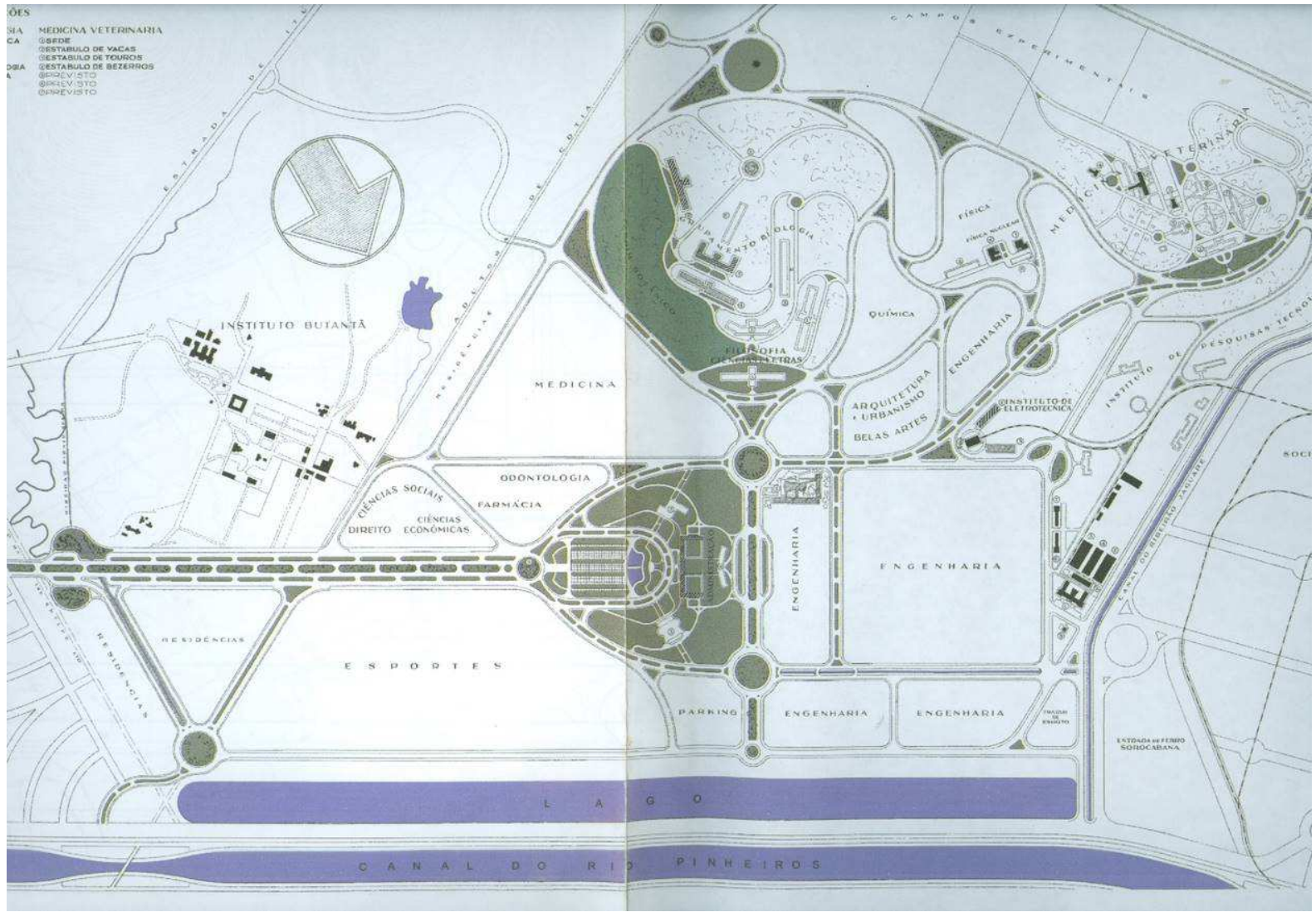

Escritório Técnico. Plano da Cidade Universitária, 1952. Desenho Neyde Cabra, 2010.

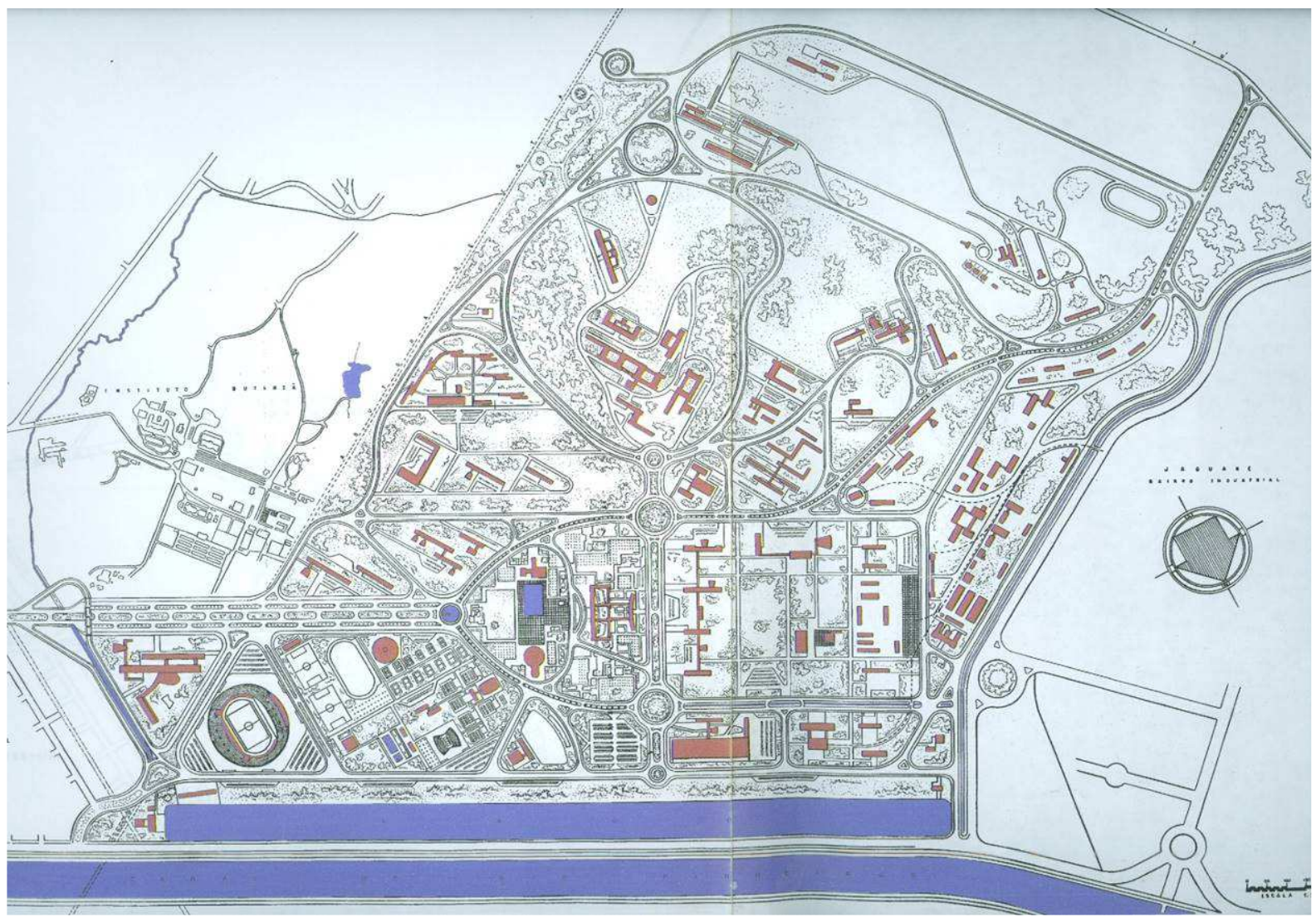

Escritório Técnico. Plano da Cidade Universitária, 1954. Desenho Neyde Cabra, 2010. 


\begin{tabular}{|c|c|c|c|c|}
\hline \multicolumn{5}{|c|}{ PROJETOS NA CIDADE UNIVERSITÁRIA 1947-1954 } \\
\hline Edifício & Arquiteto & Projeto & Construção & Imagem \\
\hline Pavilhão de Alta Tensão & $\begin{array}{l}\text { Djalma Lepage } \\
\text { Escritório Técnico }\end{array}$ & $1949(?)$ & 1951 & \\
\hline
\end{tabular}

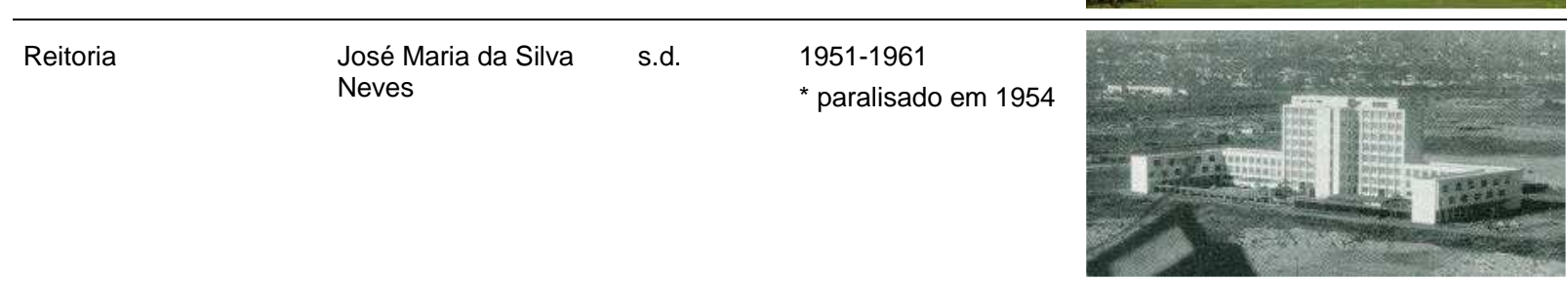

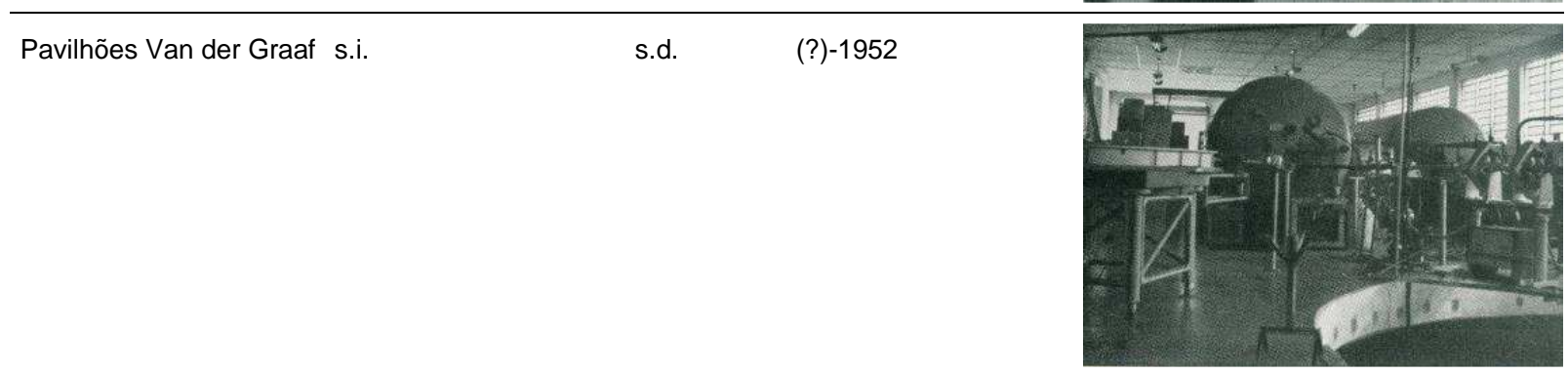

\begin{tabular}{|c|c|c|}
\hline Setor Pedagógico & $\begin{array}{l}\text { Alcides Rocha Miranda } 1951 \\
\text { José de Souza Reis }\end{array}$ & $\begin{array}{l}\text { 1954- } \\
1956 \text { (Bloco B), }\end{array}$ \\
\hline $\begin{array}{l}\text { Instituto de } \\
\text { Aperfeiçoamento do } \\
\text { Professor }\end{array}$ & & $\begin{array}{l}1961 \text { (Bloco A), } \\
1963 \text { (Bloco C). }\end{array}$ \\
\hline
\end{tabular}

Recursos do governo federal

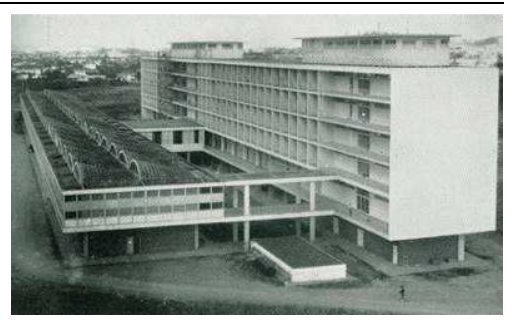

\begin{tabular}{|c|c|c|c|c|}
\hline Edifício da Zoologia & Escritório Técnico (?) & $1951-1953$ & $1954-1955$ & \\
\hline Edifício da Botânica & $\begin{array}{l}\text { Djalma Lepage } \\
\text { Escritório Técnico }\end{array}$ & s.d. & $\begin{array}{l}\text { 1954-1958 } \\
\text { * paralisado em } 1954\end{array}$ & \\
\hline
\end{tabular}




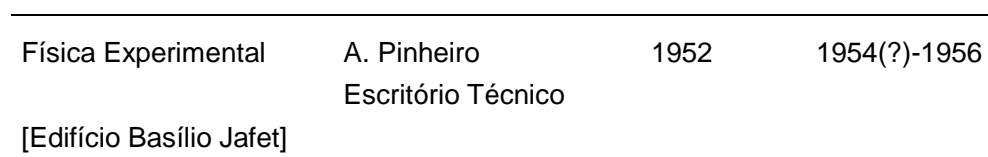

[Edifício Basílio Jafet]
A. Pinheiro

\section{6}

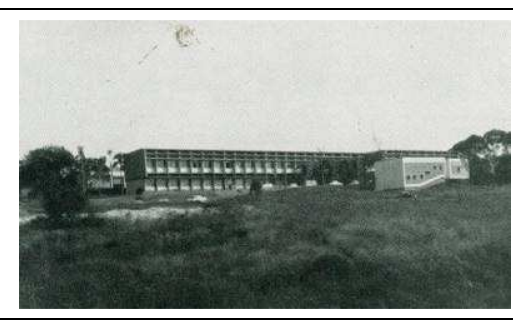

Laboratório de Hidráulica Ariosto Mila 1952
João Cacciola
$\begin{aligned} & \text { J. C. Figueiredo Ferraz } \\ & \text { (cálculo estrutural) }\end{aligned}$

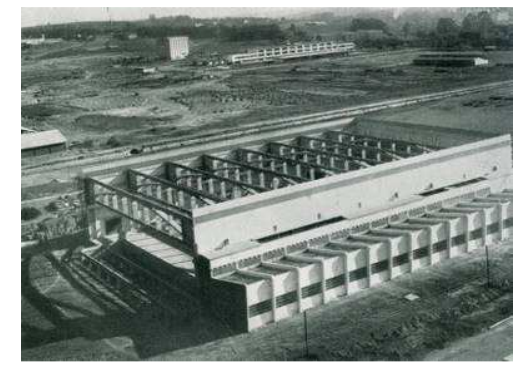

\begin{tabular}{ll}
\hline Residência de & Rino Leve \\
Estudantes & Roberto Cerqueira \\
& César
\end{tabular}

$1952-1953$

César

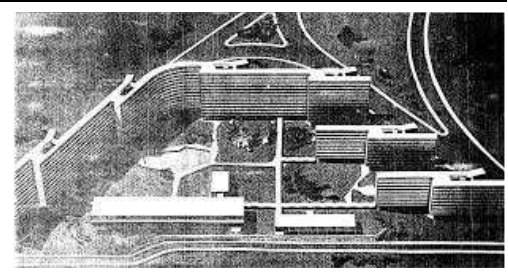

Faculdade de Física $\quad$ Gio Ponti $1953 \quad$ 1954-inacabada
Nuclear

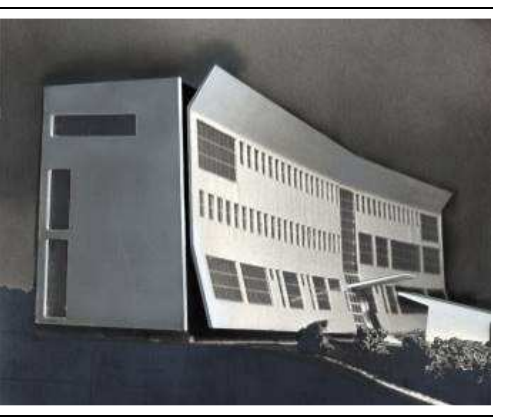

\begin{tabular}{|c|c|c|c|}
\hline $\begin{array}{l}\text { Projeto não identificado } \\
\text { para IPT }\end{array}$ & $\begin{array}{l}\text { Plínio Croce } \\
\text { Carlos Millan } \\
\text { Roberto Aflalo }\end{array}$ & 1954 & --- \\
\hline $\begin{array}{l}\text { Faculdade de Filosofia, } \\
\text { Ciências e Letras }\end{array}$ & $\begin{array}{l}\text { Carlos Millan } \\
\text { Plínio Croce } \\
\text { Roberto Aflalo (?) } \\
\text { Galiano Ciampaglia (?) }\end{array}$ & $1953(?)$ & --- \\
\hline Centro Cívico & $\begin{array}{l}\text { Rino Levi } \\
\text { Roberto Cerqueira } \\
\text { César }\end{array}$ & $1952-1953$ & --- \\
\hline Setor de Esportes & Ícaro de Castro Mello & $1952(?)$ & --- \\
\hline Pavilhão de máquina IEE & s.i. & s.d. & $\begin{array}{l}\text { 1954(?) } \\
\text { * paralisado em } 1954\end{array}$ \\
\hline Reservatório de água & s.i. & s.d. & $1954(?)$ \\
\hline Sede veterinária & s.i. & s.d. & s.d. \\
\hline Pavilhões de bovinos (3) & s.i. & s.d. & s.d. \\
\hline Centro de Saúde & s.i. & s.d. & s.d. \\
\hline
\end{tabular}

Tabela elaborada a partir da sistematização de dados dispersos na bibliografia. Algumas informações podem ser contraditórias.Imagens: América Magazine, n. 2, ano 7. São Paulo: Varta, 1962, e outros. 


\section{Novas referências}

Em meados da década de 1950, a USP não tinha uma estrutura de planejamento capaz de organizar todas as suas necessidades físicas e nem contava com um cronograma financeiro das obras, sempre dependentes de recursos inconstantes. Enquanto os planos de sua Cidade Universitária ainda eram incertos, outras cidades universitárias começavam a ser inauguradas pela América Latina ganhavam projeção internacional, em sintonia com a noção de coração da cidade, tema do VIII CIAM, em 1951.

O primeiro caso emblemático foi o da Cidade Universitária de Caracas, da Universidade Central da Venezuela (UCV), posteriormente reconhecida como patrimônio mundial pela UNESCO. Impulsionada pelos recursos obtidos com o petróleo, a Cidade Universitária pôde passar rapidamente do plano à construção da maioria de seus edifícios. Os trabalhos haviam sido iniciados ainda em 1943 com as obras da faculdade de medicina, inspirada na arquitetura da costa oeste norte-americana. O arquiteto Carlos Raul Villanueva ficou responsável pelos projetos de todos os edifícios, o que corroborou para a coerência do conjunto. Na virada para a década de 1950, as obras ocuparam todo o terreno de aproximadamente 200 ha. Com grande liberdade, o arquiteto priorizou a diversidade de formas e espaços, cuja singularidade foi reforçada através de obras de arte encomendadas a diversos artistas venezuelanos e estrangeiros. ${ }^{58} \mathrm{~A}$ UCV tornou-se um caso paradigmático de integração das artes e também de adaptação ao clima tropical, feita através elementos vazados, pátios, varandas e marquises. ${ }^{59}$

Outro caso notório foi o da Cidade Universitária da Universidad Nacional Autónoma de México (UNAM) - também Patrimônio Cultural da Humanidade. Seu plano, ao contrário do venezuelano, foi resultado de um concurso de projetos realizado em $1946 .{ }^{60}$ As obras foram iniciadas em 1948 e os primeiros edifícios inaugurados em 1952. A enorme área de 730 ha, localizada a cerca de $15 \mathrm{~km}$ do centro da Cidade do México, foi dividida em quatro setores escolares (humanidades, ciências, artes e ciências biológicas), um setor esportivo e o setor do Estádio Universitário ${ }^{61}$, além um generoso parque público, que ainda hoje comporta a ampliação planejada da universidade.

\footnotetext{
${ }^{58}$ Os murais, esculturas, vitrais, outros tipos de intervenção foram encarregados a importantes artistas como Fernand Léger, Henri Laurens, Victor Vasarély, Antoine Pevsner, Baltazar Lobo, Alexander Calder, Oswaldo Vigas, Mateo Manaure, Jean Arp, entre outros.

${ }^{59}$ Ver: VILLANUEVA, Paulina. Carlos Raúl Villanueva. Basel: Birkhäuser, 2000.

$60 \mathrm{O}$ concurso foi realizado entre os membros da Escola Nacional de Arquitetura, da Sociedade de Arquitetos Mexicanos e do Colégio Nacional de Arquitetos do México. A escola de arquitetura realizou um concurso interno entre os professores de composição, no qual se destacaram os projetos de Mario Pani e de Enrique del Moral, que foram combinados em uma única proposta, escolhida pela comissão. Ver: ARTIGAS, Juan B. Unam México: guia de sítios y espacios. Ciudad Universitária: Universidad Autónoma de México, 2006. Ver também: www.patrimoniomundial.unam.mx

${ }^{61}$ Em 1968, o Estádio Universitário abrigou os jogos olímpicos. A Cidade Universitária de São Paulo também teve suas instalações usadas para os Jogos Panamericanos de 1963.
} 
Mas a Cidade Universitária do México destacou-se, sobretudo, pela integração entre o urbanismo, a arquitetura dos edifícios e a arte aplicada. Esse conjunto foi constituído de projetos arquitetônicos heterogêneos de diversos arquitetos modernos, como Armando Franco Rovira, Ernesto Gómez Gallardo Argüelles, Augusto Pérez Palacio, Raúl Salinas Moro, Félix Candela, Mario Pani, Alberto Arai, Luis Barragán, Carlos Lazo, entre outros. Assim como na Venezuela, diversos artistas foram convidados a trabalhar diretamente com os arquitetos, entre os quais, Juan O'Gorman, David Alfaro Siqueiros, Francisco Eppens e Diego Rivera. O destaque do conjunto era a praça central, com extraordinário equilíbrio entre a arquitetura moderna e referências à arte pré-hispânica.

Após esses casos pioneiros, houve uma multiplicação de cidades universitárias por toda a América Latina com a predominância de planos modernos e certa convergência estética e programática. Assim como a de São Paulo, a maioria delas foi construída em etapas e passou por sucessivas alterações - quase sempre no sentido de ampliar a universidade e reduzir os custos. Os planos para as cidades universitárias do Panamá (1947), Tucumán (1947) Recife $(1947)^{62}$, Porto Rico $(1948)^{63}$, Rio de Janeiro (1950), Rosário (1952) $)^{64}$, Florianópolis, (1955) e Belém (1957), não foram realizados integralmente. Entre outros motivos, é possível que a ousadia dos planos tenha sido responsável pelas dificuldades enfrentadas.

O plano para a Cidade Universitária de Tucumán, por exemplo, conduzido por Eduardo Sacriste ${ }^{65}$, em 1947, ligava um pequeno terreno de 25 ha, no pé da serra, a um grande território universitário no alto, conectados por um funicular. Apesar de iniciadas as obras em 1949, o projeto foi abandonado em 1951. O isolamento dessa cidade universitária, localizada a cerca de $10 \mathrm{~km}$ de distância da pequena San Miguel de Tucumán demonstra a dependência que as cidades universitárias latino-americanas teriam em relação aos grandes centros urbanos, onde se concentravam os recursos materiais e humanos de tais universidades.

No Rio de Janeiro, a ideia de uma cidade universitária também havia sido retomada. Com a indisponibilidade de grandes terrenos, porém, foi decidido construir artificialmente a ilha do Fundão com 590 ha, a partir de um arquipélago. Para tanto, foi criado o Escritório Técnico

\footnotetext{
62 Projeto do arquiteto italiano Mário Russo.

${ }^{63}$ Em Porto Rico, o reitor do Recinto Rio Piedras, entrou em contato em 1948 com o escritório de Frank Lloyd Wright, que escalou o arquiteto Henry Klumb para elaborar um plano de remodelamento do campus de 110 ha, que não foi totalmente implementado devido ao protesto de arquitetos locais. De todo modo, Klumb teve a oportunidade de projetar algumas obras que foram efetivamente construídas, entre elas o Centro de Estudantes.

64 Inaugurada apenas em 1974.

65 Eduardo Sacriste era discípulo de Ernst Nathan Rogers e foi diretor da escola de arquitetura da Universidad National Tucumán entre 1945-1960.
} 
da Universidade do Brasil (ETUB), sob direção do arquiteto Jorge Moreira. As obras de infraestrutura consumiram a maior parte dos recursos e apenas cinco de seus edifícios originais foram construídos de acordo com o plano.

De todo modo, projetos não modernos não eram mais aceitos. Em Belo Horizonte, o plano do escritório carioca Eduardo Pederneiras foi criticado pela seção local do IAB em 1951, resultando na intervenção de uma comissão de peritos do Rio de Janeiro - Adolfo Morales de Los Rios, Paulo Santos e Álvaro Vital Brasil - que o considerou inadequado. Como consequência, foi criado o Escritório Técnico da Cidade Universitária para desenvolver um novo plano, chefiado pelo arquiteto Eduardo Mendes Guimarães Junior. ${ }^{66}$

Nas cidades universitárias que já estavam em construção, como em São Paulo, a tendência foi reformular os planos, num sentido de aproximá-los dos cânones mais atuais. Em Paris, um novo plano geral foi elaborado em 1950, que incluiu alguns projetos de arquitetura moderna, como os de Lúcio Costa e Le Corbusier. Em Concepción, o plano de Karl Brunner foi expandido e modificado em 1958, pelo arquiteto Emilio Duhart, formado em Harvard, onde Josep Lluís Sert também conduzia um plano para a universidade americana. Em Concepción, Duhart criou um eixo transversal ao eixo original, definindo novas zonas, cada qual dotada de um polo de atração, como uma rede. Nem tudo foi construído, mas seu maior feito foi o Fórum Aberto, que converteu a praça do campanário em uma praça cívica para quatro mil pessoas.

${ }^{66}$ LEME, 1999, pp. 334-336 apud CABRAL, Neyde. Op. Cit., p. 152. 


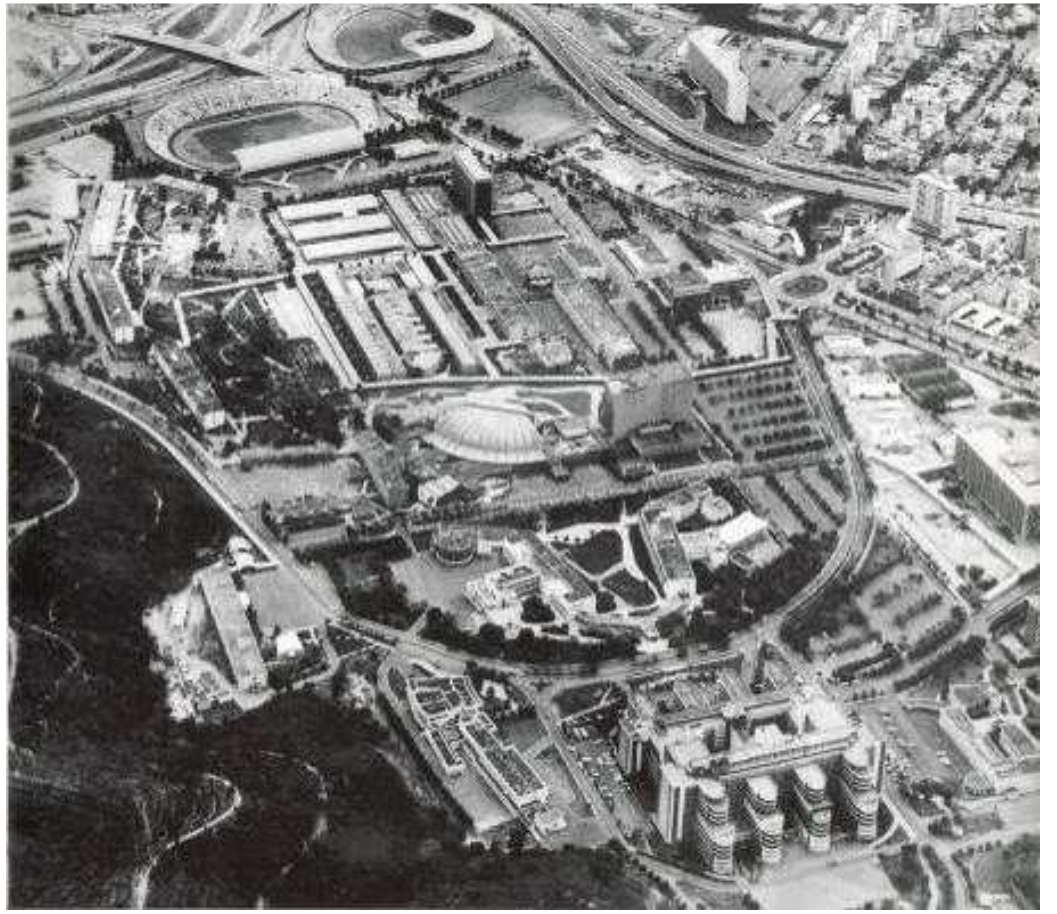

Carlos Raúl Villanueva

Cidade universitária de Caracas,
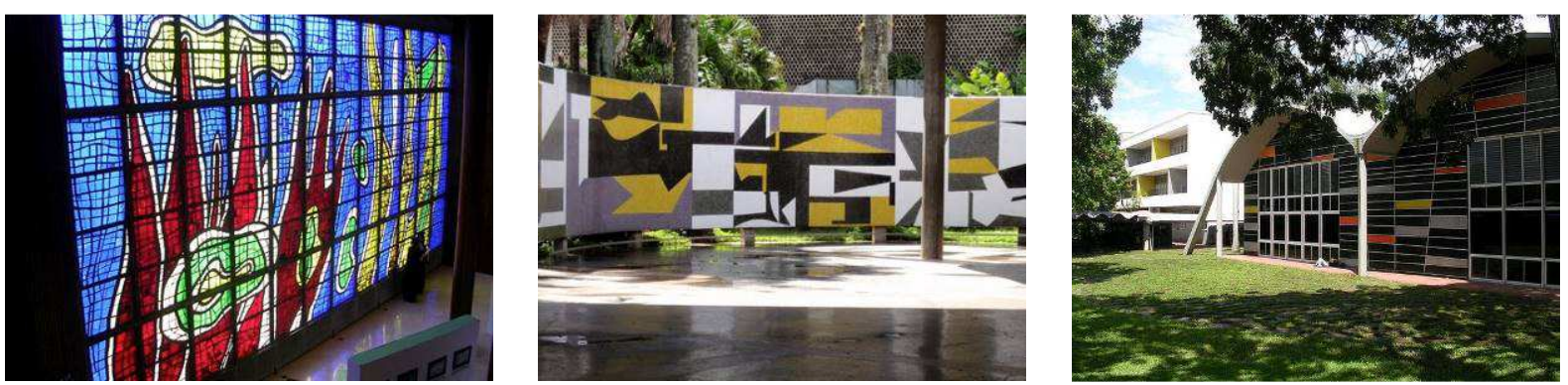

Vitral de Fernand Legèr.

Mural de Pascual Navarro.

Mural de Alejandro Otero.

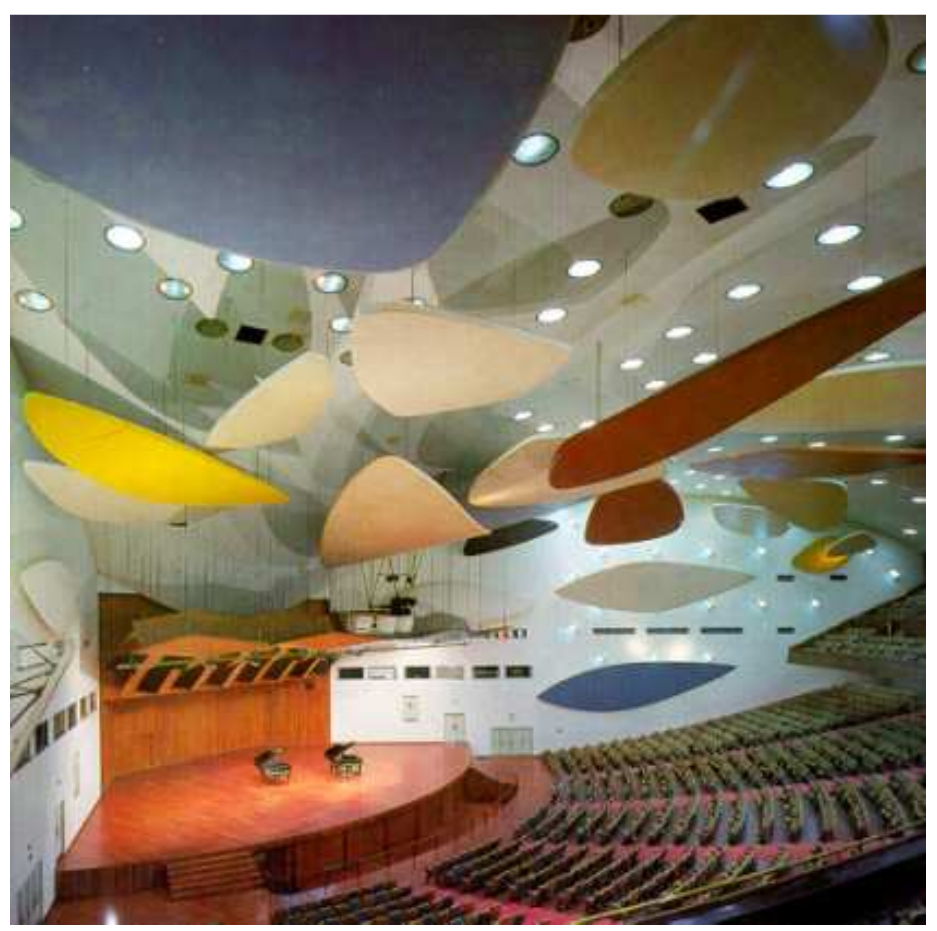

Carlos Raúl Villanueva e Alexander Calder. Aula Magna, UCV, 1952. 


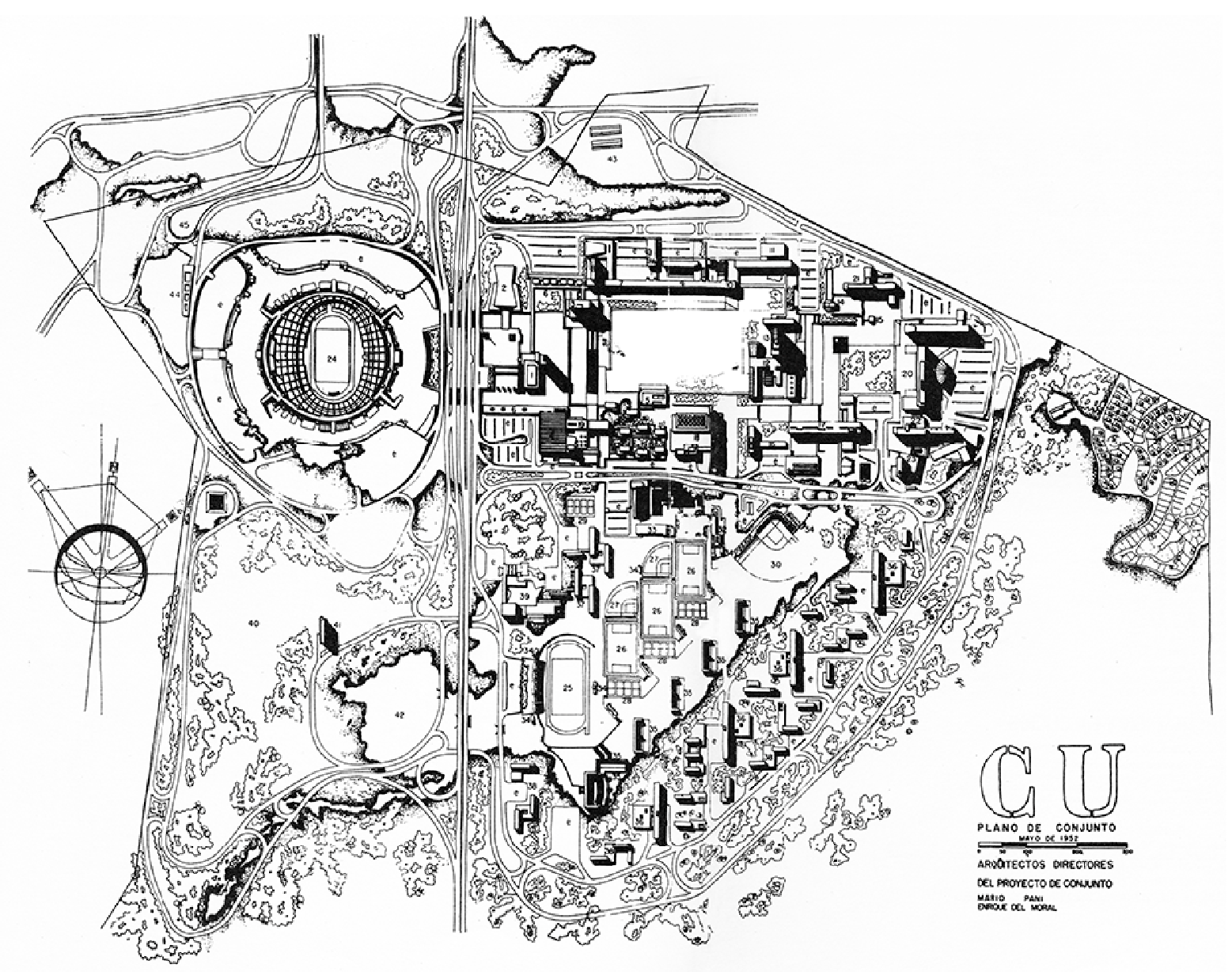

Mario Pani e Enrique del Moral. Plano da Cidade Universitária da UNAM, México, 1952. Archivo Histórico de la UNAM

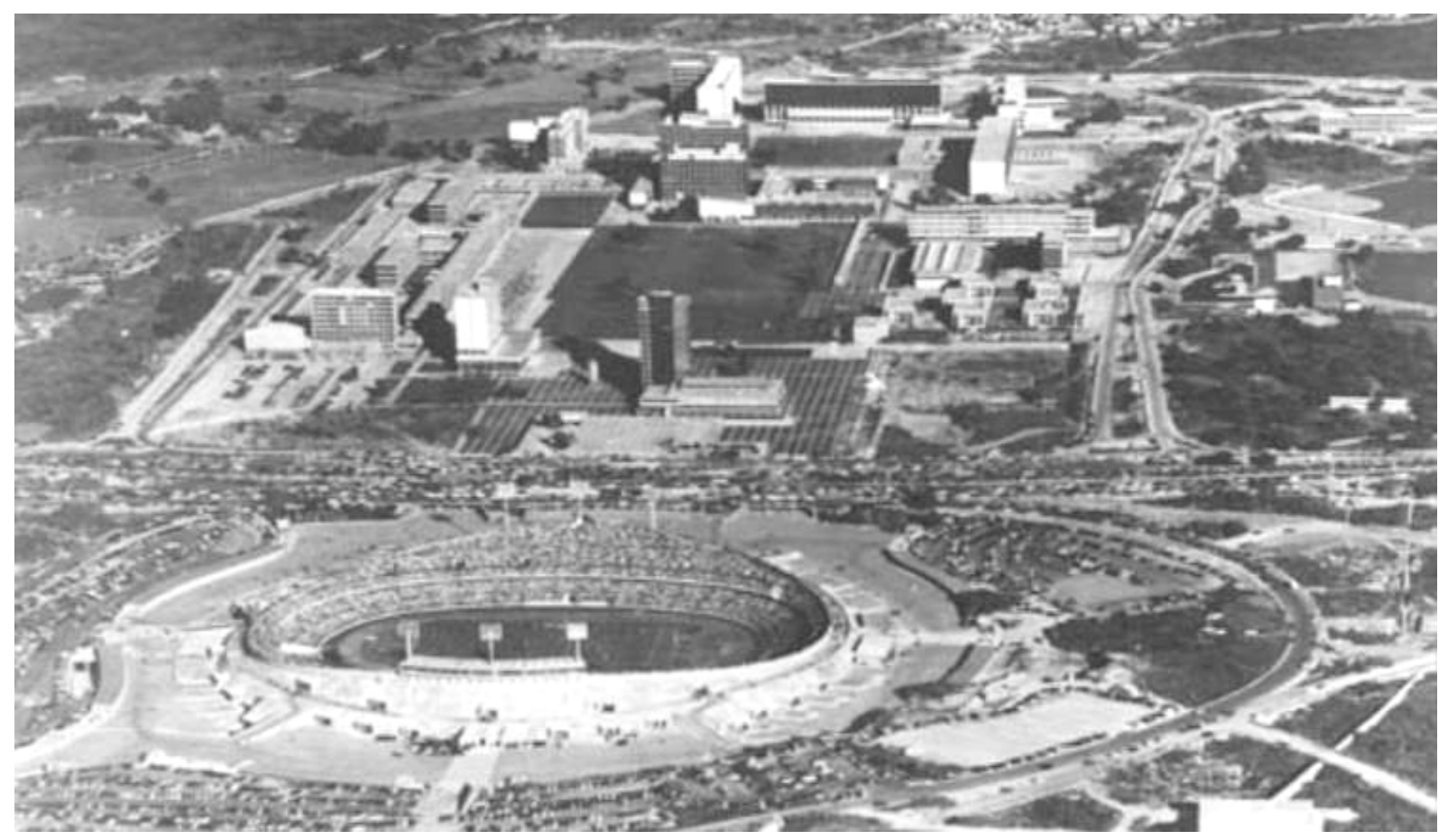

Vista geral da Cidade Universitária, 1954. Archivo Histórico de la UNAM 

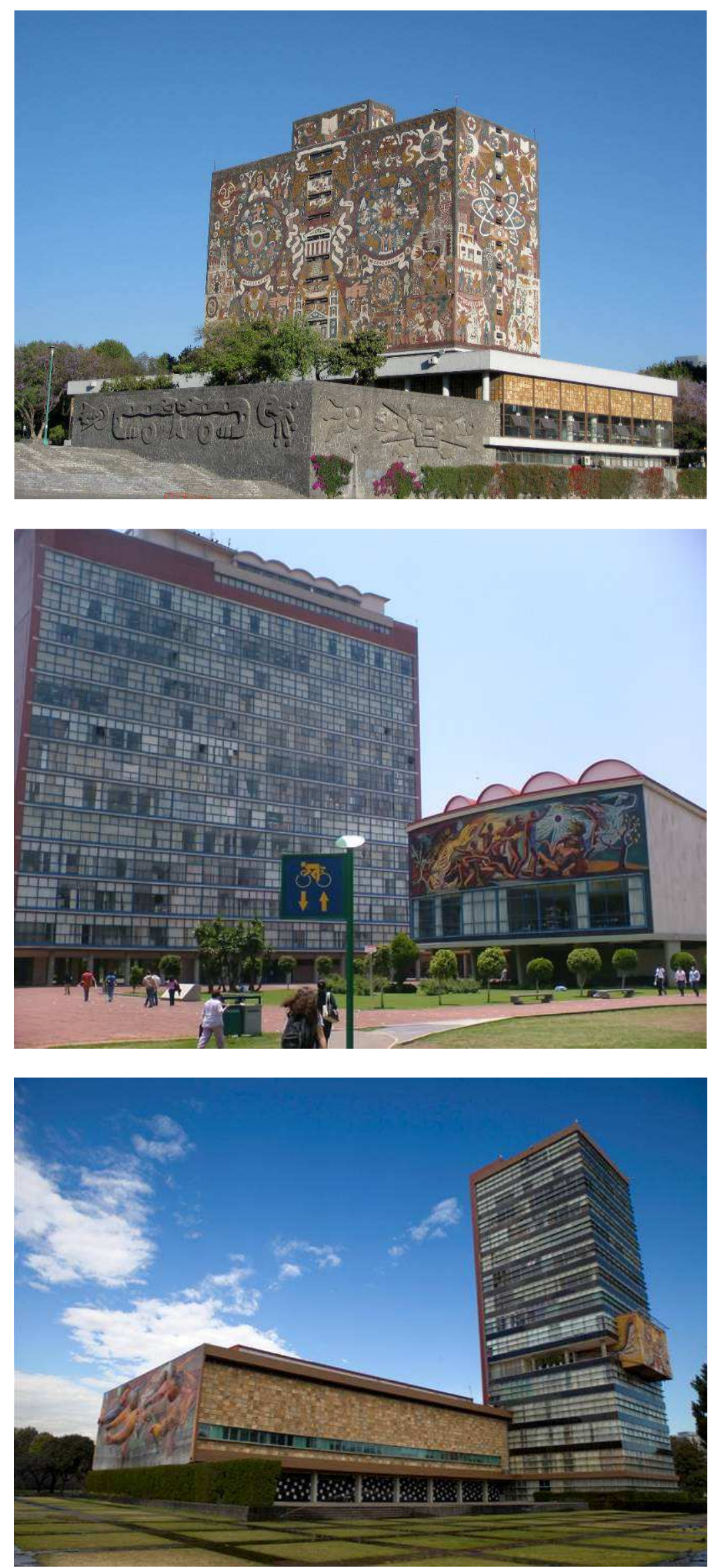

Juan O'Gorman, Gustavo Saavedra e Juan Martínez de Velasco. Biblioteca Central, 1953.

Enrique del Moral, Enrique Landa e Manuel de la Colina. Faculdade de Filosofia e Letras e Institutos de Humanidades, 1953

Mario Pani, Enrique del Moral e Salvador Ortega Flores. Reitoria, 1952. Foto: Paola García e Gilberto Marquina. 


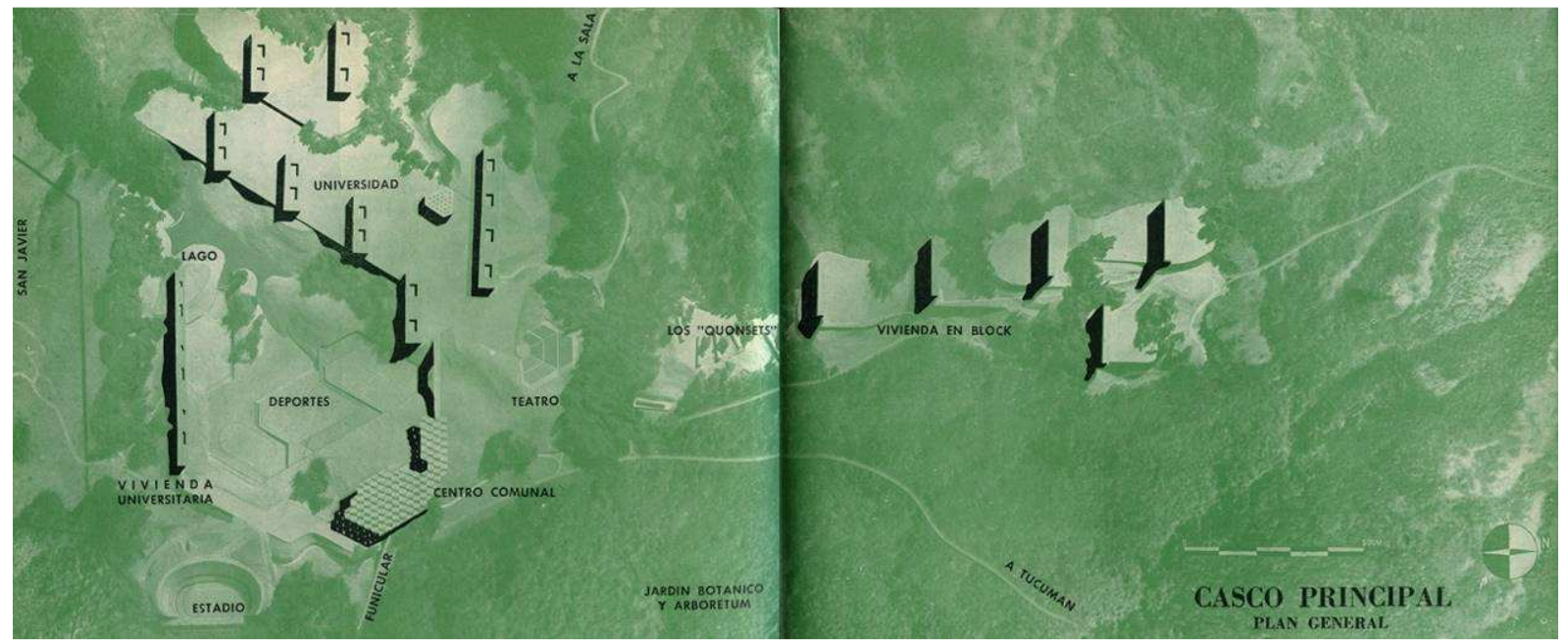

Horacio Caminos, Eduardo Catalano, Luis Felipe Vivanco, Enrico Tedeschi, Eduardo Sacriste. Ciudad Universitaria de Tucumán, 1947-1950.
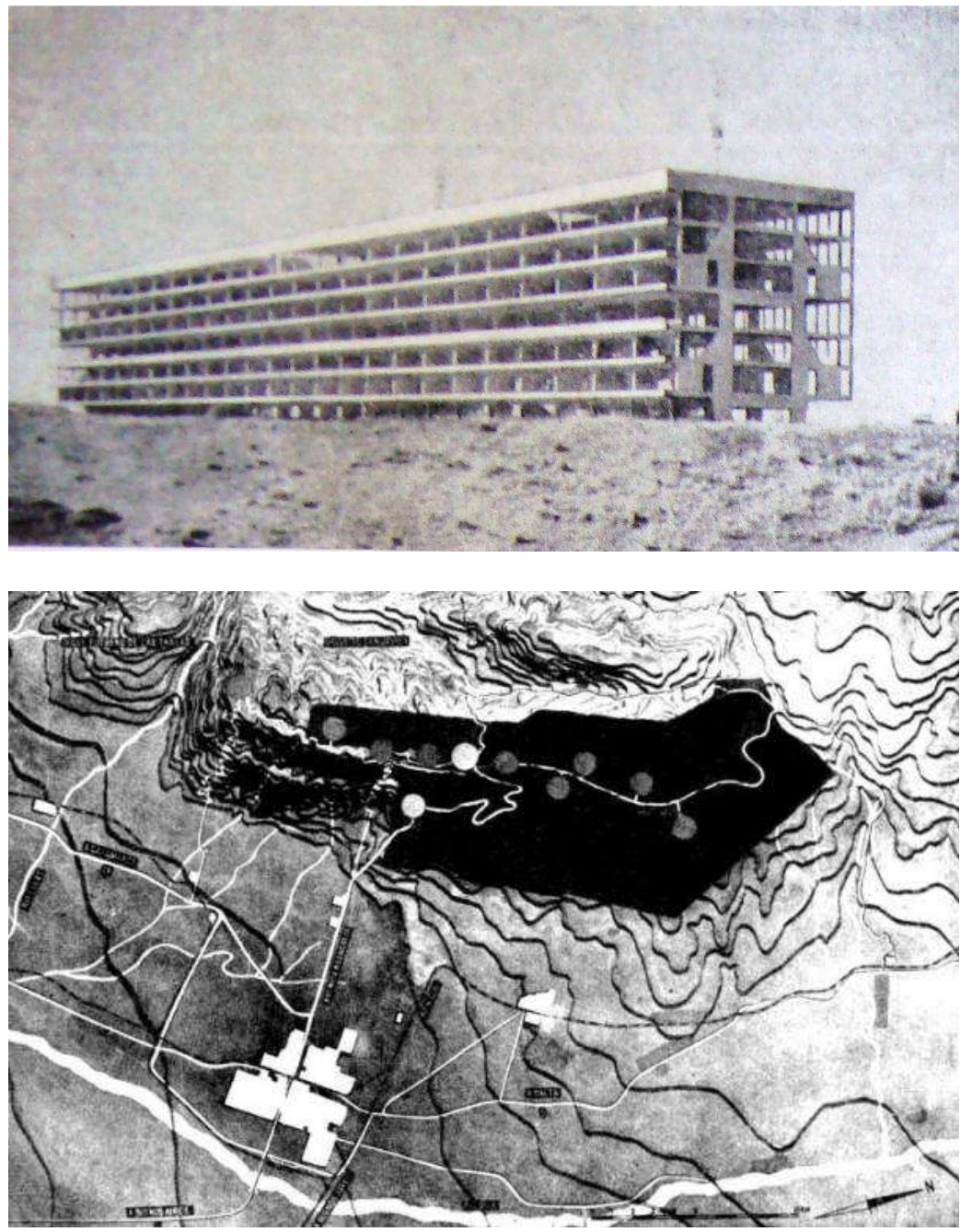


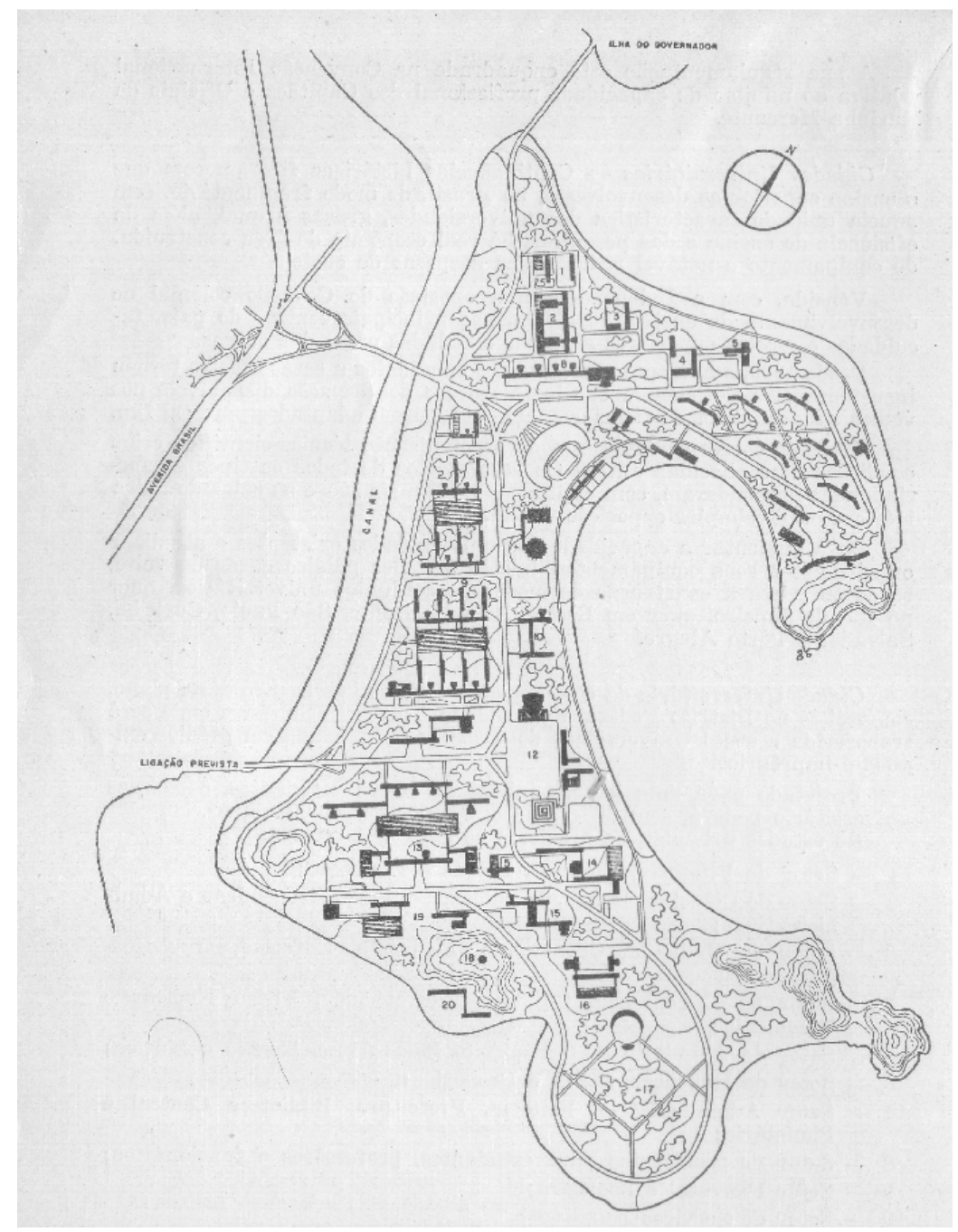

ETUB, Jorge Machado Moreira. Cidade Universitária, Rio de Janeiro, 1954.
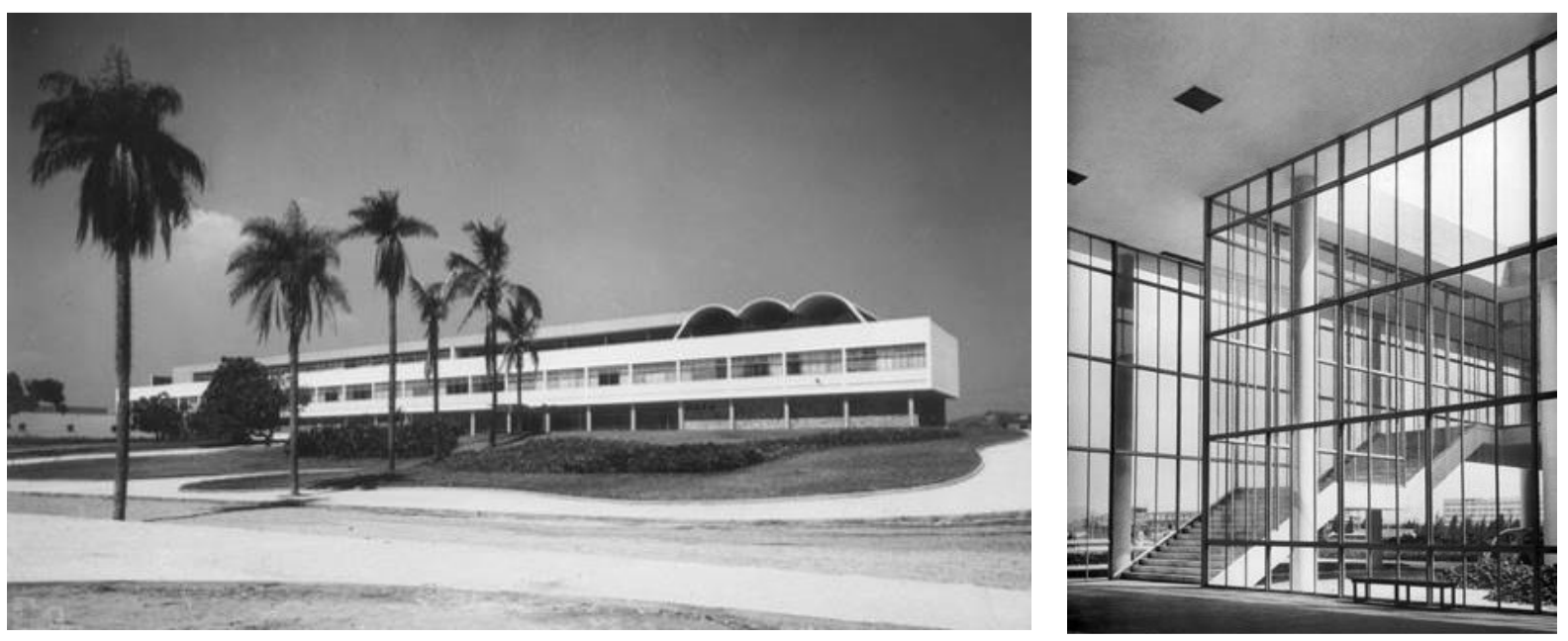

ETUB, Jorge Machado Moreira

Instituto de Puericultura, Rio de Janeiro, 1954

ETUB, Jorge Machado Moreira

Faculdade de Arquitetura, Rio de Janeiro, 1954 


\section{Replanejamento (1955-1958)}

A eleição de Jânio Quadros ${ }^{67}$ para o governo do Estado (1955-1958), sob a retórica da austeridade - após os gastos com a comemoração do IV centenário -, implicou em grandes mudanças na Cidade Universitária de São Paulo. Segundo Geraldo Ferraz, as verbas anuais passaram de $\operatorname{Cr} \$ 80$ milhões para $\mathrm{Cr} \$ 14$ milhões, incluídos os recursos federais. ${ }^{68}$ Jânio, que havia assumido a Prefeitura de São Paulo em 1953, trazia de seu secretariado municipal o engenheiro Carvalho Pinto para a Secretaria da Fazenda, que iniciou o chamado saneamento nas contas do Estado, introduzindo o planejamento orçamentário.

A Comissão da Cidade Universitária foi então totalmente recomposta, passando a ser presidida pelo professor Francisco Degni, da Faculdade de Farmácia e Odontologia. A CCU voltava a ser um órgão mais político do que técnico, composto por Paulo Ribeiro de Arruda (Escola Politécnica), Paulo Sawaya (Faculdade de Filosofia, Ciências e Letras), João Soares Veiga (Faculdade de Medicina Veterinária) e José Maria da Silva Neves. Por outro lado, o Escritório Técnico ganhava mais autonomia e a missão de "replanejar" a Cidade Universitária - que a partir de decreto de 1955, passava a se chamar Armando Salles de Oliveira (CUASO). Hélio de Queirós Duarte ${ }^{69}$ foi contratado para chefiar o Escritório Técnico.

Naquele momento a arquitetura moderna já estava presente em obras públicas da cidade de São Paulo, entre as quais se destacavam as escolas do Convênio Escolar e o conjunto do Ibirapuera. Mas se os projetos para o Ibirapuera, chefiados por Oscar Niemeyer, representavam a suntuosidade e o personalismo do governo anterior, as escolas do Convênio Escolar representavam uma alternativa mais sistemática e coletiva.

Hélio Duarte era o nome perfeito para o governo. Ele não apenas havia coordenado o Escritório Técnico da Comissão Executiva do Convênio Escolar de São Paulo desde sua criação, em 1948, mas também havia se desligado do programa em 1952, depois que parte

\footnotetext{
67 Jânio Quadros (1917-1992) formou-se em direito pela Universidade de São Paulo em 1943 e iniciou o magistério. Foi vereador de São Paulo entre 1948 e 1950 e o deputado estadual mais votado em 1951. Em seguida elegeu-se prefeito de São Paulo em 1953 e governador em 1955, derrotando Adhemar de Barros. Tornar-se-ia presidente da república em 1961.

68 FERRAZ, Geraldo. "Cidade Universitária de São Paulo: uma constatação polêmica dos resultados do plano e da execução das obras no Butantã”. Habitat, São Paulo, n. 27, fev. 1956.

${ }^{69}$ Hélio Duarte nasceu no Rio de Janeiro e se formou arquiteto pela Escola Nacional de Belas Artes em 1931. Atuou em Recife, João Pessoa, Cabedelo e Salvador antes de se fixar em São Paulo, em 1944. Naquele momento já havia realizado importantes obras para Cia. Brasileira Imobiliária - alguma de feições modernas -, e lecionado na Escola de Belas Artes de Salvador, onde, desde 1936, divulgava as ideias de Le Corbusier e André Lurçat. Em São Paulo foi recebido por Eduardo Kneese de Mello e Vilanova Artigas e um dos primeiros trabalhos que realizou foi o projeto para a Maternidade Universitária da USP, concurso organizado por Kneese de Mello. Em 1945 participou do 1ํ Congresso Brasileiro de Arquitetos e foi aceito como membro do CIAM. Nos três anos seguintes foi o $1^{\circ}$ Secretário do IAB/SP. Em 1949 integrou o corpo docente da FAU e, entre 1953 e 1955, lecionou também na EESC. Durante toda sua carreira, sempre trabalhou associado a outros colegas. Seus parceiros mais constantes foram Zenon Lotufo e Abelardo de Souza entre 1945 e 1947, Ernest Mange entre 1950 e 1955 e Roberto Tibau, Lucio Grinover e Marlene Picarelli entre 1961-1966. Ver: SEGAWA, Hugo. Op. Cit.
} 
da verba do Convênio foi realocada para a construção do Parque do Ibirapuera. ${ }^{70}$ Além disso, Duarte havia projetado com Ernest Mange o campus da EESC em São Carlos, um projeto que propunha a 'coordenação modular' em um momento no qual esse conceito começava a ser discutido no Brasil. ${ }^{71}$

Sua experiência à frente do Convênio Escolar, por sua vez, era tributária de outro programa paradigmático: o "Escolas-classe e Escola-parque", concebido na Bahia entre 1947 e 1951, quando o educador Anísio Teixeira (1900-1971) foi Secretário da Educação e Saúde. ${ }^{72}$ Tratava-se de um modelo de rede escolar infantil formado por uma escola-parque para cada quatro escolas-classe, que Duarte se referia como uma "pequenina-quase-universidade infantil". ${ }^{73} \mathrm{~A}$ escola-parque, localizada num raio entre 1 e $2 \mathrm{~km}$ das escolas-classe, seria frequentada em meio período por todos os alunos, oferecendo atividades artísticas, culturais, de aprendizagem profissional (artes industriais) e educação física. Anísio Teixeira planejava instalar sete desses centros em Salvador, mas apenas um chegou a ser inaugurado, em 1950 - o Centro Educacional Carneiro Ribeiro -, planejado por Hélio Duarte e desenvolvido pelo arquiteto Diógenes Rebouças, então envolvido no Escritório de Planejamento Urbano da Cidade de Salvador (EPUCS).

O chamado Convênio Escolar, por sua vez, havia sido uma parceria entre a Prefeitura de São Paulo e o Governo do Estado de São Paulo, entre 1948 e1959, no qual o Estado ficava encarregado pelo ensino e a prefeitura pela da oferta de terreno e construção das escolas. ${ }^{74}$ Esta foi uma iniciativa experimental que teria partido da Secretaria da Educação, interessada nas propostas da nova educação. Para que tais ideias fossem implementadas, julgou-se necessário uma alternativa aos chamados 'projetos padrão' produzidos pela Diretoria de Obras Públicas (DOP), da Secretaria de Viação e Obras Públicas do governo do Estado. O Convênio permitiu que a Prefeitura passasse a contratar arquitetos externos ao invés dos expedientes e quadros do serviço público. ${ }^{75}$ Durante os cinco primeiros anos em

\footnotetext{
70 A partir de 1950, Hélio Duarte presidiu também a subcomissão de Planejamento Escolar. Sobre seu desligamento do programa, ver: BUFFA, Ester; PINTO, Gelson de Almeida. Arquitetura e Educação: organização do espaço e propostas pedagógicas dos Grupos Escolares paulistas (1873-1971). São Carlos: Edufscar / Brasília: Inep, 2002.

${ }^{71}$ A coordenação modular, a industrialização e a racionalização da construção a partir seriam temas de sua tese de livredocência apresentada à Faculdade Nacional de Arquitetura da Universidade do Brasil, no Rio de Janeiro, em 1957, com o título Espaços flexíveis, uma tendência em arquitetura". Sobre o projeto, ver: NOBRE, Ana Luiza. "Módulo Só: O Edifício E1 para a EESC em São Carlos, de Ernest Mange e Hélio Duarte". Revista Risco, n. 5, São Carlos, 2007. Disponível online.

72 DUARTE, Hélio. "O problema escolar e a arquitetura", Habitat, n. 4, 1951, (edição dedicada às escolas do Convênio Escolar).

${ }^{73}$ DUARTE, Hélio. "Escolas classe Escola parque" [1973]. Republicado em: DUARTE, Hélio. Op. Cit., p. 110.

74 O governador era Adhemar de Barros (1947-1950) e os prefeitos, até 1953, eram interventores nomeados pelo governador. Ver: ABREU, Ivanir Reis Neves. Convênio Escolar: utopia construída. Dissertação de mestrado. São Paulo: FAUUSP, 2007. Ver também Decreto municipal n. 1.145, de 30 de maio de 1950.

${ }^{75}$ Não encontramos indícios de que tenham havido concursos. Em conversa com servidores aposentados da Prefeitura Municipal, concluímos que os projetistas podem ter sido contratados como servidores temporários. Seria interessante para futuras pesquisas verificar o vínculo exato desses projetistas, já que este parece ter sido um dos primeiros programas públicos de São Paulo a empregar projetistas externos.
} 
que o programa foi coordenado por Duarte, cerca de 70 escolas foram construídas com projetos de Eduardo Corona, Roberto Tibau, Oswaldo Corrêa Gonçalves e Ernest Mange, entre outros, além do próprio Hélio Duarte. ${ }^{76}$ Com isso, a prefeitura teve um papel importante na introdução da arquitetura moderna (de matriz carioca) nas obras públicas de São Paulo.

Essa experiência paulista foi muito celebrada tanto no campo educacional como no campo da arquitetura. Chegou mesmo a ser recebida como a substituição da "escola-monumento, da escola majestosa e austera" pela "escola alegre, horizontal, no meio dos jardins [...], espaçosas, abertas, simples e bem planejadas". ${ }^{77}$ Jânio Quadros, que vinha do magistério e da política municipal, certamente conhecia o programa.

A tarefa de Hélio Duarte arquiteto na Cidade Universitária consistia em refazer o Plano geral, dentro de uma estrutura de planejamento capaz de reduzir os custos e garantir os prazos de entrega. O novo plano deveria considerar melhor a topografia, evitando o excesso de terraplanagem; aproximar os edifícios e organizá-los por setores que promovessem trocas mais efetivas; e firmar um novo convênio com o Departamento de Estradas de Rodagem para transferir a responsabilidade pela pavimentação das vias, que também deveriam ter a largura reduzida e o traçado simplificado. Em resumo, dever-se-ia reduzir as expectativas:

"Recuemos para linhas objetivas, façamos modestos os nossos sonhos, busquemos realiza-los com urgência para que 0 investimento dos recursos venha a render o mais depressa possível, mas encaremos como um dever dos responsáveis, o governador Jânio Quadros, o reitor Alípio Correia Neto, o presidente da Comissão da Cidade universitária, professor Francisco Degni, o diretor técnico de sua arquitetura, prof. Hélio Queiroz, levar avante essa iniciativa, aparelhando com o que for possível as necessidades da Universidade de São Paulo". ${ }^{78}$

O "Roteiro do Replanejamento" da Cidade Universitária, um livreto com vinte e uma pranchas elaboradas pelo Escritório Técnico, foi aprovado pela CCU e pelo Conselho Universitário em novembro de $1956 .{ }^{79}$ As primeiras pranchas traziam um balanço da universidade e da cidade universitária, com seus órgãos, unidades, projeção de crescimento

\footnotetext{
${ }^{76}$ Ver: FERREIRA, Avany de Francisco; MELLO, Mirela Geiger de. Arquitetura escolar paulista: anos 1950 e 1960. São Paulo: FDE / DOS, 2006, p. 16.

77 Revista Habitat, n. 4, São Paulo, 1951, p. 29, apud SEGAWA, Hugo. Op. Cit. p. 52.

${ }^{78}$ FERRAZ, Geraldo. "Cidade Universitária da Universidade de São Paulo. Uma polêmica dos resultados dos planos e da execução das obras no Butantã". Habitat, n. 27, fevereiro, 1956, p. 5-10.

${ }^{79}$ DUARTE, Hélio. Roteiro de replanejamento da CUASO. São Paulo, 1956.
} 
de sua população ${ }^{80}$, localização na cidade de São Paulo, incidências físico-naturais, zoneamento e sistema viário vigentes e os gastos realizados até então.

As pranchas seguintes traziam propostas de um novo zoneamento e um sistema viário simplificado, concentrando a moradia dos estudantes, professores e funcionários no trecho mais próximo da cidade, entre o acesso da universidade e o core, liberando, desse modo, o núcleo da Cidade Universitária para os institutos, sem, no entanto, defini-los. Para o core e suas adjacências, incluindo o setor esportivo e os setores de moradia de professores, funcionários e estudantes, foram apresentados estudos preliminares e alguns detalhes. A nova centralidade não era mais concebida como Centro Cívico projetado por Rino Levi, composto de uma biblioteca central, um teatro e uma praça cívica. Seu novo programa, mais amplo, abrangia cinema, hotel, comércio, galeria, restaurante, salão de baile, além dos elementos anteriores, como a torre, a reitoria, a biblioteca e a prefeitura. Hélio Duarte fez questão de incluir uma citação do VIII CIAM, de 1951, cujo tema foi The Heart of the City:

"The expression of the core must interpret the human activities that take place: both the relations of individuals with one another, and the relations of individuals with the community, only full development of both these relationships can safeguard the dignity of individual life"81

Diferentemente dos planos anteriores, o Replanejamento não definia as unidades de ensino e pesquisa, apenas um macrozoneamento. A definição dos institutos a serem transferidos para a Cidade Universitária da ordem de prioridade e das necessidades de cada instituto (currículo, metodologia, previsão de crescimento nos próximos 50 anos) deviam ser aprovados pelo Conselho Universitário.

Ao mesmo tempo, o Roteiro de Replanejamento propunha uma reforma profunda do sistema universitário, que passaria a ser formado por institutos básicos e institutos profissionais, nos quais os alunos poderiam montar seu currículo de modo flexível. ${ }^{82}$ Essas e outras mudanças deveriam ser debatidas em consultas às várias instâncias e unidades da universidade, o que representava a introdução de princípios democráticos no planejamento da universidade.

A proposta de Duarte trazia ainda uma nova visão do problema financeiro, que exigiria o planejamento das obras em longo prazo, a fim de garantir sua continuidade. Para isso prazos deveriam ser estabelecidos e os projetos deveriam buscar construções mais baratas e programas mais flexíveis. Por fim, a própria CCU deveria ser reorganizada como uma

\footnotetext{
80 Um gráfico comparava a relação população/área das cidades universitárias de Roma, Columbia, Moscou, Boston, Rio de Janeiro e México. A população máxima estipulada seria de 25 mil alunos.

${ }^{81}$ Apud DUARTE, Hélio. Roteiro de replanejamento da CUASO. São Paulo, 1956.

${ }^{82}$ Essa concepção foi considerada no estatuto de 1962.
} 
estrutura administrativa e financeira mais perene, que garantisse a continuidade da execução do plano e das medidas financeiras para assegurar as obras em um quinquênio.

Com a aprovação do Replanejamento, o Escritório Técnico foi reestruturado. O engenheiro Savério Orlandi ${ }^{83}$ e o arquiteto Paulo de Camargo ${ }^{84}$ e Almeida foram contratados, sendo que o segundo foi indicado para chefiar a nova seção de projetos. Os projetos desenvolvidos pelo Escritório Técnico nos anos seguintes foram de edifícios da FFCL (Física, Biologia) e a da Escola Politécnica (Biênio), que já dispunham de instalações na Cidade Universitária.

Também foram iniciadas as obras do Reator Nuclear de Pesquisa IEA-R1, resultado de uma parceria entre o governo do Estado, o governo federal e o governo norte-americano em 1955. Sua área de isolamento com raio de 300 metros criaria mais uma barreira no centro da Cidade Universitária. Mas com exceção de tal obra, foram priorizadas as obras que já estavam em andamento e todos os demais projetos que não haviam sido iniciados foram cancelados. Em 1956 foram concluídos os edifícios da Zoologia, da Física Experimental e Superior, o primeiro prédio do Instituto do Professor Primário e continuadas as obras do Laboratório de Hidráulica.

\footnotetext{
${ }^{83}$ Savério Orlandi (1931) formou-se engenheiro civil pela Escola Politécnica e urbanista pela Faculdade Nacional de Arquitetura da Universidade do Brasil.

${ }^{84}$ Paulo de Camargo e Almeida nasceu no Rio de Janeiro e se formou na ENBA em 1930, um ano antes de Hélio Duarte. É certo que ambos se conheciam e é provável que tivessem uma relação próxima, pois Paulo de Camargo foi presidente do IAB, quando Duarte participou da criação da sessão paulista do órgão. Paulo de Camargo se mudou para São Paulo em 1956, quando compôs equipe com Artigas para o concurso de Brasília, e foi contratado pelo Escritório Técnico da Cidade Universitária em julho de 1957. A partir de 1958, lecionou na Escola de Engenharia de São Carlos, possivelmente por indicação de Duarte, que havia lecionado lá entre 1953 e 1955.
} 


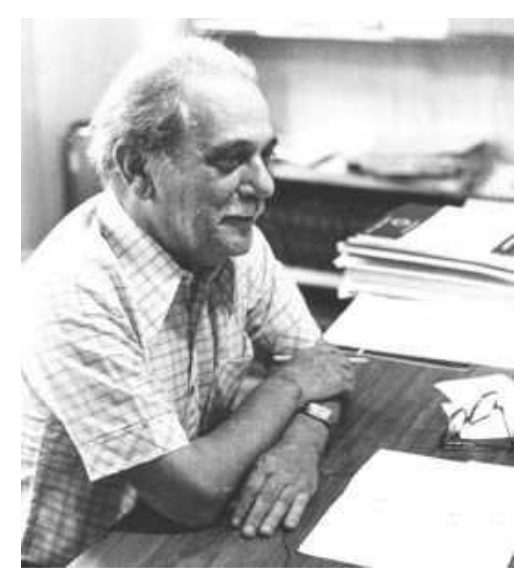

Hélio Duarte.

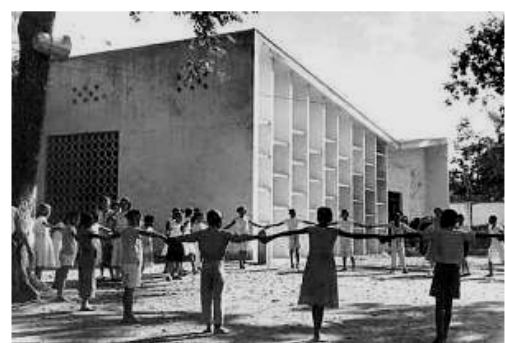

Diógenes Rebouças. Centro Educacional Carneiro Ribeiro. Salvador, 1950.

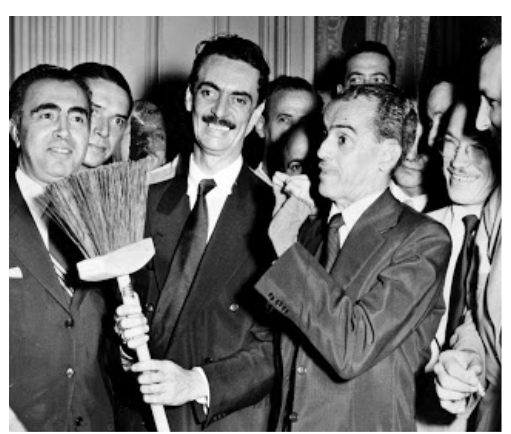

Governador Jânio Quadros (1955-1958)

Ernst Mange, Hélio Duarte, Ariaki Kato e Léo Quanji Nishikawa. Plano da EESC, 1953-54.

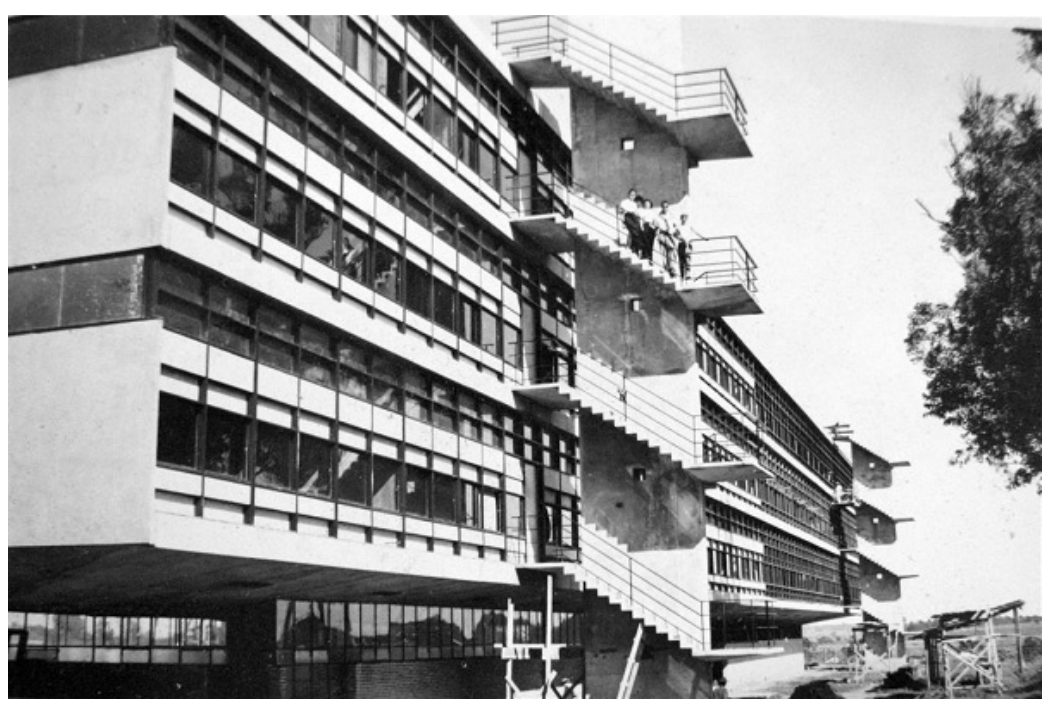

Ernst Mange e Hélio Duarte. Edifício E1, São Carlos, 1954-1956. 

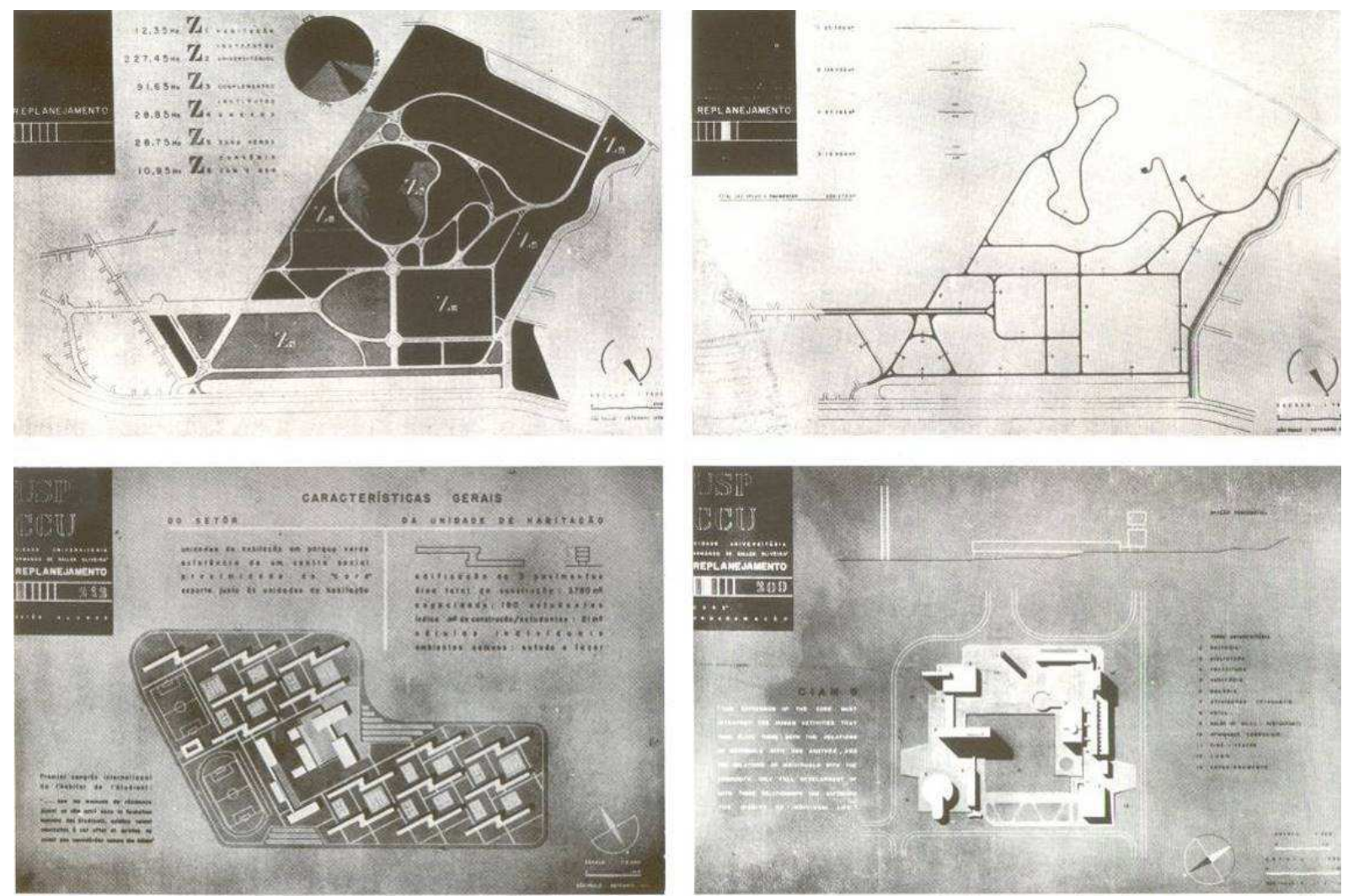

Hélio Duarte e Escritório Técnico da Cidade Universitária,

Roteiro de Replanejamento da CUASO, 1956.

Zoneamento, Sistema viário, Habitação estudantil e Core.

\begin{tabular}{|c|c|c|c|c|}
\hline \multicolumn{5}{|c|}{ PROJETOS NA CIDADE UNIVERSITÁRIA 1955-1958 } \\
\hline Edifício & Arquiteto & Projeto & Construção & Imagem \\
\hline $\begin{array}{l}\text { Reator Nuclear de } \\
\text { Pesquisa IEA-R1 }\end{array}$ & Babcox \& Wilcox (EUA) & $1955(?)$ & $1956-1957$ & \\
\hline \multicolumn{5}{|l|}{$\begin{array}{l}\text { Financiado pelo } \\
\text { Governo federal }\end{array}$} \\
\hline \multirow[t]{2}{*}{$\begin{array}{l}\text { Programa "Atoms for } \\
\text { Peace }\end{array}$} & & & & \\
\hline & & & & 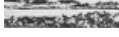 \\
\hline \multirow{2}{*}{$\begin{array}{l}\text { Instituto de Energia } \\
\text { Atômica }\end{array}$} & s.i. & 1956 (?) & s.d. & \\
\hline & Construção ANR & & & \\
\hline \multirow[t]{2}{*}{ Anfiteatro da Física } & A. Pinheiro & $1957(?)$ & 1959 & \\
\hline & Paulo de Camargo e Almeida & & & \\
\hline \multirow[t]{2}{*}{ [Adma Jafet] } & Escritório Técnico & & & \\
\hline & Construção ANR & & & \\
\hline
\end{tabular}




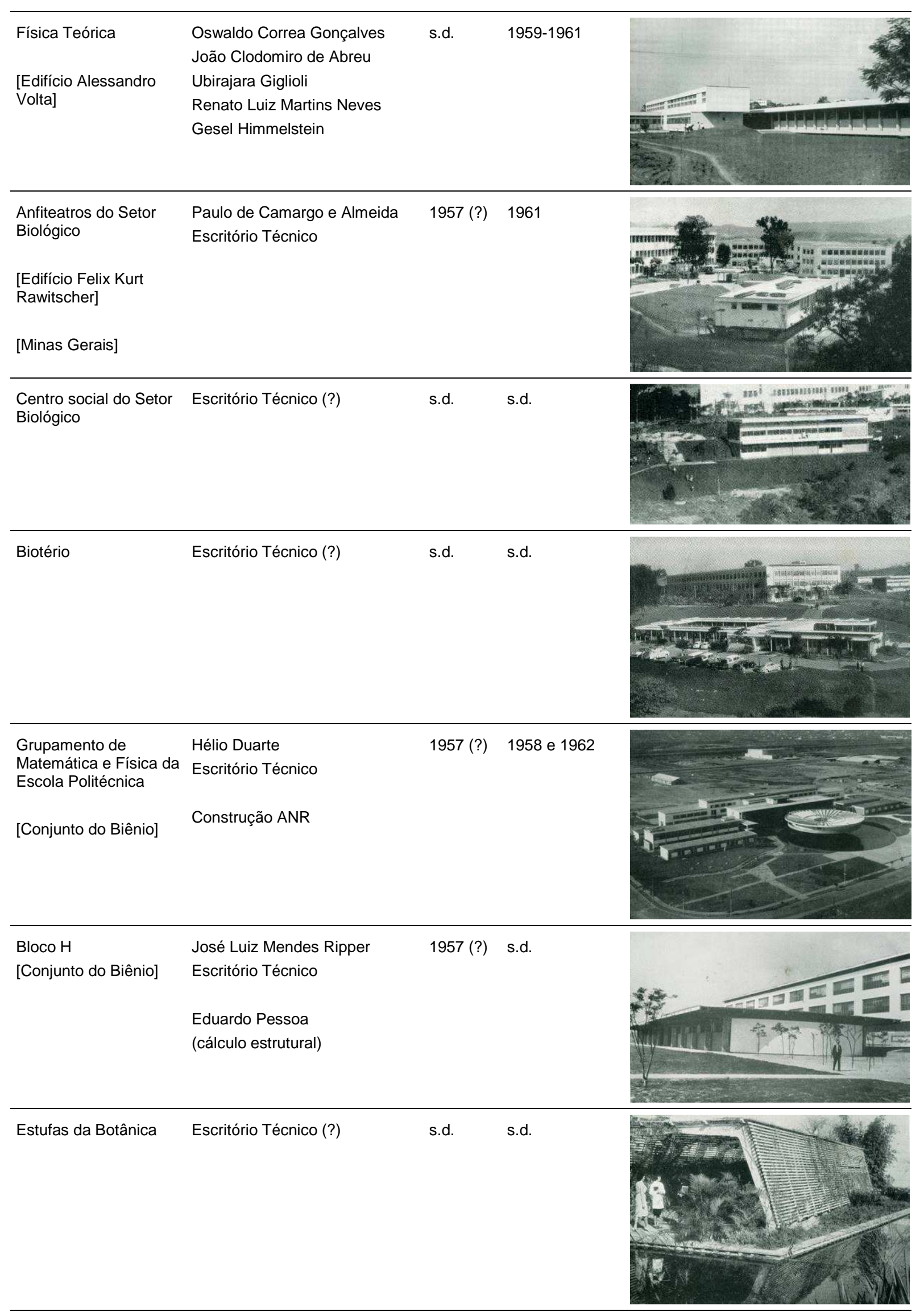

Tabela elaborada a partir da sistematização de dados dispersos na bibliografia. Algumas informações podem ser contraditórias.Imagens: América Magazine, n. 2, ano 7. São Paulo: Varta, 1962, e outros. 


\section{ARQUITETURA E PLANEJAMENTO DE OBRAS PÚBLICAS (1959-1969)}

O planejamento de Hélio Duarte para a Cidade Universitária pode não ter atingido os resultados concretos que outras cidades universitárias já exibiam, mas ao menos evidenciou a necessidade de novos instrumentos de planejamento de obras públicas. Se a Cidade Universitária não podia ser tratada como uma obra pública ordinária, fosse por sua dimensão, fosse por sua especificidade técnica e programática, fosse ainda pelo envolvimento de quadros técnicos e políticos da universidade com relativa autonomia do Estado, sua excepcionalidade fez dela um paradigma de administração direta de obras públicas.

Até então, o principal órgão responsável pelas obras públicas do Estado de São Paulo era a Diretoria de Obras Públicas (DOP) da Secretaria da Agricultura, Comércio e Obras Públicas. ${ }^{85}$ Neste órgão, engenheiros e arquitetos realizavam reformas e administravam projetos de novos edifícios do Estado

Órgãos municipais também tinham departamentos para projetar e gerenciar obras públicas, como a Diretoria de Obras e Viação da Prefeitura Municipal de São Paulo principalmente responsável por pontes, vias e escolas municipais. ${ }^{86}$ Mas com a maior parte do serviço municipal tomado pela fiscalização de obras particulares, a DOP se destacava como órgão público de projetos.

De modo geral, a execução de projetos por órgãos públicos sempre foi evitada. Obras extraordinárias foram quase sempre objeto de concursos de projeto, ainda que isso implicasse em um processo mais demorado. Contudo, edifícios ordinários (como escolas, cadeias e fóruns), logo tiveram que ser produzidos de maneira mais ágil para acompanhar o rápido crescimento das cidades. A DOP passou então a desenvolver projetos padronizados para esses edifícios almejando, além da velocidade, padrões estéticos e orçamentos que garantissem equidade para diferentes regiões - o que também se observa na rede ferroviária e nas agências de correios e telégrafos. Acima de tudo, os projetos padrão eram uma solução para a falta de quadros e para a dispersão de edifícios pelo território.

A rede escolar, mais ampla que as demais, exigiu um destacamento exclusivo do DOP. Contudo, o modelo da escola monumental republicana, ainda que feita com projeto-padrão,

\footnotetext{
85 Primeiramente chamada Secretaria da Agricultura, Commercio e Obras Publicas, pelo Decreto n. 28, de 01 de março de 1892. Depois reorganizada como Secretaria de Viação e Obras Publicas, pelo Decreto 4.283, de 16 de setembro de 1927. Posteriormente desdobrada na Secretaria de Serviços e Obras Públicas pela Lei 7.833, de 19 de fevereiro de 1963.

${ }^{86}$ Ainda que o organograma tenha variado ao longo do tempo, a Diretoria de Obras e Viação, teve na maior parte do tempo uma Divisão de Urbanismo e uma Divisão de Arquitetura e seções de Fiscalização de Obras Públicas e Particulares, Execução e Reforma de Calçamento, Aprovação de Plantas, Serviços de Patrimônio, Cadastro, Limpeza Pública e Projetos Urbanos, segundo informações reunidas a partir das biografias dos engenheiros-arquitetos elaboradas por FICHER. Sylvia. Op. Cit.
} 
era de construção relativamente onerosa e lenta, o que agravava o déficit escolar. ${ }^{87} \mathrm{Da}$ busca por soluções alternativas surgiu, por exemplo, a Comissão Permanente de Prédios Escolares, organizada dentro do Serviço de Prédios Escolares da Diretoria de Ensino da Secretaria de Educação e Saúde, entre 1935 e $1937 .{ }^{88}$ Mais tarde, com a emergência de novos modelos pedagógicos, o Convênio Escolar, buscou substituir a DOP.

Até então, as comissões constituíam a principal forma dos governantes indicarem uma equipe, evitando os concursos e os "projetos padrões". Como na Cidade Universitária, comissões podiam ser criadas por decreto para diversas finalidades, por diferentes prazos, e podiam e incluir pessoal de diferentes órgãos ou mesmo de fora do funcionalismo público. Por isso, essa foi uma forma recorrente de legitimar contratos diretos, julgar propostas ou propor novas diretrizes e metodologias de planejamento. O modelo das comissões permitia o controle pelo executivo através da nomeação de seus membros e era muito usado em obras públicas especiais, como por exemplo, a Comissão do Tietê (1934, municipal); a Comissão de Prédios Escolares (1935-1937, mista); a Comissão Especial de Obras Públicas (1938, estado); a Comissão Executiva do Convênio Escolar (1948-1959, mista); a Comissão Orientadora do Plano da Cidade (1949-1955, municipal); a Comissão encarregada do Paço Municipal (1952-53, municipal); a Comissão do IV Centenário, etc.

Em 1957, o governo Jânio Quadros transferiu para o Instituto de Previdência do Estado de São Paulo (Ipesp) a função de construir a maior parte dos edifícios públicos estaduais. Foi uma alternativa para a falta de recursos, uma vez que o fundo de previdência, por ser recém-criado (1939), dispunha de capital para investimento. O acordo com o Ipesp definia que as obras do Estado, não apenas escolas, mas também fóruns, postos de saúde, delegacias de polícia e presídios, seriam construídas e mantidas pelo Ipesp, que em contrapartida receberia uma espécie de aluguel ao fundo de pensão. ${ }^{89}$ Mas o Ipesp também não tinha quadros suficientes para atender a grande quantidade de projetos e obras e por isso passou a adotar procedimentos semelhantes aos da DOP, entre os quais, a utilização de projetos padronizados. De todo modo, essa terceirização para o IPESP abriu a possibilidade de se contratar projetos fora do serviço público.

\footnotetext{
${ }^{87}$ FERREIRA, Avany de Francisco; MELLO, Mirela Geiger de. Op. Cit.

${ }^{88} \mathrm{O}$ arquiteto José Maria da Silva Neves, funcionário da DOP, foi o presidente da comissão, composta também por Prestes Maia (responsável pela orientação dos prédios), Carlos Alberto Gomes Cardim Filho, funcionário da PMSP e Hernani do Val Penteado. Apesar dessa experiência romper com o rígido modelo escolar do DOP, a inovação técnico-administrativa não foi além do que já era conhecido: comissionar servidores públicos para um projeto especial.

${ }^{89}$ Entrevista de Celso Lamparelli ao autor, realizada em 23/07/2014.
} 


\section{O Plano de Ação do Governo de Estado (1959-1962)}

Em 1959, o Secretário de Finanças de Jânio Quadros, Carlos Alberto de Carvalho Pinto ${ }^{90}$, foi eleito governador do Estado de São Paulo. A marca de seu governo foi o Plano de Ação do Governo do Estado (PAGE), responsável por uma série de investimentos em obras públicas e infraestrutura. Elaborado por um grupo da "esquerda católica", o PAGE foi a primeira experiência de planejamento e orçamento plurianual no Brasil. ${ }^{91}$ Coordenado pelo jovem Plínio de Arruda Sampaio e com uma equipe política multidisciplinar ${ }^{92}$, o PAGE foi elaborado e aprovado em cerca de seis meses. A equipe técnica do Plano era composta basicamente por técnicos da Sociedade para Análise Gráfica e Mecanográfica Aplicada aos Complexos Sociais (SAGMACS) ${ }^{93}$, criada pelo dominicano francês Louis-Joseph Lebret, fundador do movimento Economia e Humanismo.

Aprovado pela Assembleia Legislativa em junho de 1959, o PAGE visava recuperar o crescimento econômico do Estado através de investimentos públicos, mais especificamente através da geração de empregos promovida pela construção civil. ${ }^{94}$ Segundo Celso Lamparelli:

"Era nitidamente uma opção pelo princípio keynesiano de intervenção do Estado para retomar a dinâmica da economia. E pegava todos os setores. Era da base da filosofia do Lebret levantar as necessidades e possibilidades [...]. Então as necessidades eram imediatamente discutidas e anotadas como uma lista". ${ }^{95}$

Para atingir metas ambiciosas, como a eliminação do déficit de salas de aula, o governo precisou aprovar seu Plano na Assembleia Legislativa, que liberou um crédito de CR \$100 bilhões em recursos do Estado de São Paulo ${ }^{96}$ para livre uso do executivo em um prazo de

\footnotetext{
${ }_{90}$ Nascido em 1910, formou-se pela Faculdade de Direito do Largo de São Francisco em 1931. Carvalho Pinto se especializou em finanças, atuando como assessor dos prefeitos Prestes Maia e Abraão Ribeiro (1938-1945). Foi Secretário das Finanças do Município de São Paulo em 1953 e Secretário da Fazenda do Estado de São Paulo em 1955, durante as gestões de Jânio Quadros. Devido ao seu bom desempenho na pasta foi candidato do Partido Democrático Cristão para enfrentar Adhemar de Barros no pleito de 1958.

${ }^{91}$ Entrevista de Celso Lamparelli ao autor, realizada em 23/07/2014.

92 Seu Grupo de Planejamento (GP) era integrado pelo economista Diogo Adholpho Nunes de Gaspar (secretário executivo); Celeste Ângela de Sousa Andrade (diretora do Departamento de Estatística do Estado); os professores Paulo Menezes Mendes da Rocha e Ruy Aguiar da Silva Leme (catedráticos da Escola Politécnica); Antônio Delfim Neto (assistente da Faculdade de Economia, Administração e Contabilidade); Sebastião Advíncula da Cunha (Departamento Econômico do BNDE); Orestes Gonçalves (chefe do Gabinete de Estudos Econômicos e Financeiros da Secretaria da Fazenda); Ruy Miller de Paiva (engenheiro agrônomo do Departamento da Produção Vegetal da Secretaria da Agricultura).

${ }^{93}$ Mario Laranjeira de Mendonça (eng. civil); os arquitetos Celso Lamparelli, Francisco Whitaker Ferreira e Domingos Theodoro de Azevedo Netto; Henrique Amílcar de Oliveira Lima (técnico de administração do DEA); o contador José Reinaldo Gomes, e Pedro Penteado Nogueira.

${ }^{94}$ SAMPAIO, Plínio de Arruda. "Depoimento: o plano de Ação do Governo Carvalho Pinto: planejamento e política no Estado de São Paulo em 1959", Espaço \& Debates, n. 4, ano 1, dez, 1981, p. 127.

${ }^{95}$ Entrevista de Celso Lamparelli ao autor, realizada em 23/07/2014.

96 Para fins corporativos, o Plano de Metas, do governo federal de Juscelino Kubitschek teve um orçamento de aproximadamente $\mathrm{Cr} \$ 420$ bilhões, aplicados entre 1956 e 1961 e divididos em cinco setores: energia (metas de 1 a 5), 222
} 
quatro anos, o que significava "um plano que não dependia de aprovações no varejo". ${ }^{97} \mathrm{~A}$ ideia era que a equipe técnica ligada diretamente ao governador (portanto transversal), mapeasse todas as obras necessárias junto aos diversos órgãos do Estado e Secretarias, sem precisar responder às demandas políticas de deputados e prefeitos.

O Plano de Ação capilarizou a presença do Estado no interior paulista, ampliando significativamente a rede escolar, de saúde, justiça, abastecimento, rodovias e energia, além de induzir o desenvolvimento agropecuário e industrial. Segundo o terceiro relatório do PAGE à América Latina, apresentado em 14 de março de 1962, o governo havia contratado 646 obras de prédios públicos entre grupos escolares, unidades sanitárias, fóruns, casa de lavoura, chefias de extensão agrícola, delegacias agrícolas regionais e oito usinas hidrelétricas. Foram construídas cerca de 7.000 salas de aula de ensino primário, 1.100 de ensino secundário, 113 cadeias e delegacias de polícia, 57 fóruns, 100 postos de assistência médica sanitária, 308 casas de lavoura, etc.

Para execução desses recursos, foram criados o Fundo Estadual de Construções Escolares (FECE), o Fundo de Construção da Cidade Universitária Armando Salles de Oliveira (FCCUASO), o Fundo de Expansão Agropecuária, o Fundo de Financiamento da Indústria de Bens de Produção, o Fundo de Expansão da Indústria de Base, além de uma sociedade por ações, denominada Centro Estadual de Abastecimento S.A. (CEASA). ${ }^{98}$

A ideia por trás desses fundos era evitar qualquer reforma administrativa que pudesse comprometer o Plano por desgastes políticos. Controlados por seus conselhos, a função desses novos órgãos ia desde o planejamento de obras (programa, orçamento, gerenciamento de contratos, compras, etc.) até a execução ou fiscalização das obras. Para isso os fundos tinham acesso direto aos recursos do PAGE, ao contrário das Secretarias e Autarquias as quais as obras eram destinadas. O FECE, em particular, aproveitou a estrutura do IPESP para contratar arquitetos em parceria com o IAB.

Por seu impacto nas obras públicas, muito foi falado sobre a promoção que o Plano fez da arquitetura moderna paulista. Abrahão Sanovicz, dentre outros, comparou o PAGE à construção de Brasília:

"Carvalho Pinto já tinha ido à Brasília, onde se encontrou com Juscelino Kubitschek, que Ihe mostrou o trabalho dos arquitetos. Ele

transporte (6 a 12), alimentação (13 a 18), indústria de base (19 a 29) e educação (30). Considerando a inflação no período, o plano paulista equivale a quase $1 / 3$ do investimento federal.

${ }^{97}$ Entrevista de Celso Lamparelli ao autor, realizada em 23/07/2014.

${ }^{98}$ O governador Carvalho Pinto ainda criou a FAPESP (Lei Orgânica 5.918 de 18 de outubro de 1960, começando a funcionar em 1962, com o Decreto de n. 40.132 de 23.5.1962) e a Universidade Estadual de Campinas (Unicamp) lei Estadual n. 7.655 em 28.12.1962, instalada em 1966. 
entendeu esse fenômeno (da identidade da administração com os edifícios que produz). Se quisesse ter o mesmo resultado, seria necessário usar os quadros que tinha em São Paulo". 99

Mas no que diz respeito à mobilização de arquitetos, a comparação não é muito adequada, pois a contratação dos arquitetos em Brasília se deu através da Companhia Urbanizadora da Nova Capital do Brasil (Novacap), que funcionou como um escritório público. Já o PAGE terceirizou os projetos de arquitetos através de seus Fundos. O novo modelo, que exigiu a mudança do arcabouço jurídico-institucional em nome de um processo de tomada de decisões mais rápido e eficiente ${ }^{100}$, veio atender reinvindicações dos arquitetos em troca de apoio político e menores custos:

"Nesse momento, Vilanova Artigas e outros arquitetos propõem à coordenação do Plano de Ação que sejam feitos projetos específicos a cada edifício público a ser construído, com a participação dos arquitetos nessa tarefa. Argumentam que o uso dos projetos padronizados provoca gastos desnecessários, pois desconsidera a topografia do terreno, obrigando a execução de obras de infraestrutura, terraplanagem e arrimos onerosos, além das questões de insolação e de acesso que não podem ser definidas de forma correta, resultando eu um edifício com várias questões mal resolvidas. Segundo Plínio de Arruda Sampaio, nesse encontro se discutiu a necessidade de diminuir os honorários profissionais dos arquitetos para que fosse possível contratá-los, viabilizando os projetos.

A participação dos arquitetos é discutida em Assembleia do Instituto de Arquitetos do Brasil ${ }^{101}$, em 8 de setembro de 1959. Na ata dessa Assembleia Artigas, representando a diretoria da entidade, considera que 'As últimas administrações do governo desorganizaram seus quadros técnicos, ficando os mesmos impossibilidades de dar continuidade ao planejamento de suas obras e que o convite feito recentemente pelo Ipesp a diversos arquitetos paulistas, na base de honorários injustos, ainda significa um passo à frente no processo de reconhecimento do arquitetos como profissional, devendo o IAB

\footnotetext{
${ }^{99}$ SANOVICZ, Abrahão. Depoimentos, AU: Arquitetura e Urbanismo, n. 17, São Paulo, 1988, p. 56 apud FERREIRA, Avany; MELLO, Mirela. Op. Cit., p. 18.

100 Janice Theodoro da Silva. Arquitetura escolar. p. 55. No início do PAGE a função do FECE foi restrita ao planejamento, cabendo ainda ao Ipesp as funções de contratar os arquitetos e executar as construções escolares. Em 1966 o FECE passou a centralizar todas as atividades relativas à construção escolar. A terceirização dos projetos foi mantida pelos órgãos que sucederam o Fece, isto é, a Companhia de Construções Escolares do Estado de São Paulo (Conesp, 1976) e a Fundação para o Desenvolvimento Escolar (FDE, 1987).

${ }^{101}$ N. A. A diretoria do IAB, gestão 1959-61 era: Ícaro de Castro Mello (presidente), João Vilanova Artigas (vice-presidente), Alfredo Paesani (1ำ secretário), Joaquim Guedes ( $2^{\circ}$ secretário), Victor Reif (1ำ tesoureiro), Fábio Penteado ( $2^{\circ}$ tesoureiro), Carlos Millan, Luiz Roberto de Carvalho Franco, Oswaldo Correa Gonçalves, Pedro Paulo Saraiva e Rosa Klias (diretores), Lauro da Costa Lima, Francisco Beck, Eduardo Kneese de Mello (conselho fiscal).
} 
adotar, nessa oportunidade, atitude tática, adequando a uma evolução desse processo no sentido do interesse da classe.'

E na mesma Assembleia

'Autoriza a diretoria do IAB a promover junto aos órgãos do governo os entendimentos necessários para ampliar cada vez mais as medidas que vêm sendo tomadas no sentido de empregar o esforço criador dos arquitetos paulistas nas obras públicas, comunicar-Ihes 0 significado cultural da arquitetura"' brasileira e encarecer a necessidade do governo de se aparelhar de uma equipe de técnicos capazes de levar a bom termo o planejamento de suas obras". ${ }^{102}$

De fato, o volume de obras ${ }^{103}$ mobilizou grande parte dos arquitetos paulistas, que haviam tido pouca participação nas obras de Brasília, e principalmente os mais jovens, dada a sua baixa condição de remuneração. Isso Ihes permitiu marcar posições em relação aos arquitetos mais velhos. Toda essa atividade voltada para o Estado e discutida em órgãos de classe e escolas de arquitetura fez amadurecer uma cultura e um debate específicos, que talvez tenham convergido para uma linguagem próxima. Mais do que isso, alguns críticos enxergaram também uma convergência programática:

"O excessivo gosto pelo desenho e pelo formalismo acabou sendo conduzido para uma mentalidade de coordenação metodológica, em que o construtivo, nas camadas responsáveis de nossa arquitetura em São Paulo, exemplifiquemos bem - parece-nos predominar. Não se toma conhecimento do debate entre o formalismo plástico e o funcionalismo, mas há uma ardente procura, e da parte dos jovens mesmo uma crítica e uma autocrítica que devemos acentuar, para que não se percam possibilidades que a metodologia coordenadora oferece. Se em Brasília, houve uma certa displicência programática em benefício de uma arquitetura de volumes monumentais, até em edifícios sem maior significação, como no caso dos Ministérios, em São Paulo isto não se dá - predominam aqui as questões que os problemas suscitam e levantam-se em torno dos projetos as respostas que técnicas e disciplinas concomitantes à arquitetura despertam". 104

Se essa convergência ocorreu, foi devido à atuação dos próprios arquitetos, pois não há evidências de que os planejadores do governo Carvalho Pinto entrassem no mérito da qualidade dos projetos:

\footnotetext{
102 FERREIRA, Avany; MELLO, Mirela. Op. Cit., p. 18.

${ }^{103} \mathrm{O}$ Ipesp construiu cerca de 600 escolas, com aproximadamente 180 projetos realizados entre 1959 e 1962.

${ }^{104}$ FERRAZ, Geraldo. “Uma cidade universitária no Brasil”, Zodiac, n. 11. Milão: Edizioni di Comunità, 1963, p. 59.
} 
"No fundo, nós estávamos vivendo um período em que o gargalo era quantitativo. Qualquer escola que saísse das mãos de um arquiteto seria melhor que os barracos que haviam por aí, caindo aos pedaços, nojentos". ${ }^{105}$

Se o FECE, por sua natureza, levou a arquitetura moderna feita por jovens arquitetos às mais diversas regiões do Estado, mudou profundamente o quadro de déficit e a construção da Cidade Universitária concentrou, num mesmo plano urbanístico, um expressivo conjunto de projetos, cuja função simbólica, como vimos, devia contemplar as altas expectativas depositadas na universidade. A excepcionalidade do programa e o tamanho do empreendimento da Cidade Universitária serviam de vitrine aos arquitetos, que tomaram essa oportunidade para colocar em prática suas hipóteses arquitetônicas mais radicais.

Mesmo que a Cidade Universitária representasse apenas $1,5 \%$ do orçamento do PAGE, esse montante era mais de sete vezes maior que o destinado na gestão de Jânio Quadros (210 milhões). E na prática valor pode ter sido pelo menos o dobro do estimado, como demonstra o levantamento de créditos liberados pela Assembleia Legislativa.

\section{DISTRIBUIÇÃO DE RECURSOS DO PAGE (CR\$)}

I- Melhoria das condições do homem - 30,7\%

30.725 .000 .000

A-Educação, Cultura e Pesquisa - 14,7\%

10.326.000.000

1. Ensino Primário

4.155.000.000

2. Ensino Secundário e Normal

2.429 .000 .000

3. Ensino Profissional

952.000 .000

4. Cidade universitária

1.500 .000 .000

5. Outros Institutos e Faculdades da USP

550.000 .000

6. Faculdades Isoladas

640.000 .000

7. Estímulo à Cultura

100.000 .000

8. s.i.

4.374 .000 .000

B- Justiça e Segurança Pública - 5,3\%

C- Saúde Pública e Assistência Social - 9,5\%

D- Sistema de Água e Esgoto - 1,2\%

II- Infraestrutura - 42,0\%

41.954.000.000

III- Expansão Agrícola e industrial - 27,2\%

27.221 .000 .000

Total

100.000.000.000

${ }^{105}$ Entrevista de Celso Lamparelli ao autor, realizada em 23/07/2014. 


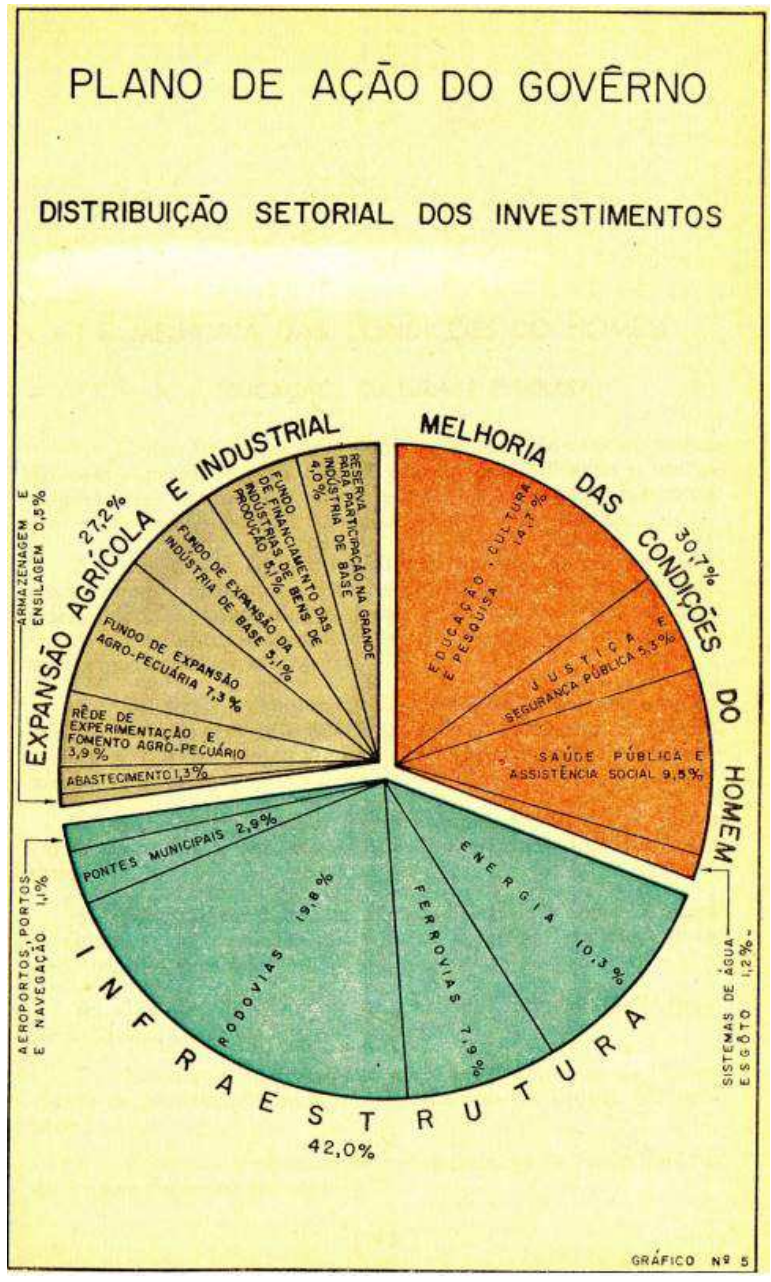

Gráfico das realizações dos objetivos setoriais (PAGE, 3ำ relatório, p. 35)

\begin{tabular}{llr|llr}
\hline \multicolumn{2}{c|}{ CRÉDITOS LIBERADOS FCCUASO (CR\$) } & \multicolumn{2}{c}{ CRÉDITOS LIBERADOS FECE (CR\$) } \\
\hline $08 / 07 / 1960$ & Crédito especial (IPT) & $25.000 .000,00$ & $09 / 09 / 1960$ & Crédito & $112.000 .000,00$ \\
$08 / 07 / 1960$ & Crédito especial & $375.000 .000,00$ & $04 / 05 / 1961$ & Crédito especial & $2.000 .000 .000,00$ \\
$19 / 08 / 1961$ & Crédito especial & $600.000 .000,00$ & $18 / 08 / 1961$ & Crédito especial & $3.000 .000 .000,00$ \\
$24 / 03 / 1962$ & Crédito especial (IPT) & $40.000 .000,00$ & $25 / 05 / 1962$ & Crédito especial & $1.100 .000 .000,00$ \\
$28 / 05 / 1962$ & Crédito especial & $1.200 .000 .000,00$ & $12 / 06 / 1962$ & Crédito especial & 400.00 '0.000,00 \\
$11 / 08 / 1962$ & Crédito especial & $418.625 .000,00$ & & & \\
& (Instituto Butantã) & & & & \\
$27 / 11 / 1962$ & Crédito especial & $450.000 .000,00$ & & & \\
$24 / 12 / 1962$ & Crédito especial & $10.000 .000,00$ & & & \\
& (Instituto de & & & & \\
\hline Total & & & & \\
\hline
\end{tabular}

Tabelas elaboradas com base em pesquisa nas leis de liberação de crédito, consultadas no site da Assembleia Legislativa do Estado de São Paulo.

INVESTIMENTOS NA CIDADE UNIVERSITÁRIA ATRAVES DO PLANO DE ACÄO DO GOVERNO CARVALHO PINTO

(Em milhares de cruzeiros)

\begin{tabular}{|c|c|c|c|c|c|c|c|}
\hline Anos & 1959 & 1960 & 1961 & 1962 & Totais & $\begin{array}{c}\text { Execuçāon } \\
\text { Previsão }\end{array}$ \\
\hline Previsāo & 150.000 & 400.000 & $\frac{450.000}{n n n n n n n}$ & & 500.000 & 1.500 .000 & $100 \%$ \\
\hline Execução & 97.800 & 375.000 & 1.050 .000 & 1.650 .000 & 3.172 .800 & $212 \%$ \\
\hline
\end{tabular}

Fonte: América Magazine, n. 2, ano 7. São Paulo: Varta, 1962: 


\section{O Fundo para Construção da Cidade Universitária}

Quando assumiu o governo do estado, em 1959, Carvalho Pinto nomeou o professor Antônio Barros de Ulhôa Cintra, da Faculdade de Medicina, como reitor da USP. Com o PAGE aprovado em junho daquele ano, começou a ser montado o FCCUASO, para planejar as despesas com a construção, instalação e equipamento da Cidade Universitária.

"Quando fomos montar o Fundo de Construção para substituir a Comissão, eu e o Plínio [Arruda Sampaio] fomos visitar o Hélio Duarte e convidá-lo para ser presidente do Fundo. Passamos uma tarde naquele prédio da reitoria, onde estava montado o escritório da CCU. Ele era o cara para assumir, mas não aceitou. Disse que não era a vocação dele, que ele era arquiteto. Pedimos para ele indicar alguém e ele indicou o Paulo de Camargo. Ele era um dos arquitetos que trabalhavam com o Hélio Duarte na Cidade Universitária [...]. Não tínhamos a menor ideia [de quem era o Paulo de Camargo]. Foi indicação do Hélio e nós fomos na confiança do Hélio. Conversamos com o Paulo de Camargo e gostamos da conversa [...]. Ele aceitou, assumiu a presidência e montou a equipe dele [...]. Estávamos eu, o Plínio e o Anhaia Mello, que era o diretor da escola. A conversa era para não fazer os projetos no escritório central, que não tinha estrutura para isso. Esse Fundo não tem que fazer projetos, esse Fundo tem que construir tudo simultaneamente. Porque a norma do PAGE era cumprir o cronograma para ter dinheiro. Então tinha que ser tudo rápido e barato porque as indústrias médias da construção estavam sem serviço e o Carvalho Pinto negociava até o último centavo nos orçamentos". ${ }^{106}$

O FCCUASO foi criado pelo decreto n. 36.699, de 3 junho de 1960, ligado à Reitoria da universidade e administrado por um Conselho Administrativo. ${ }^{107}$ Em 18 de julho de 1960 o reitor Ulhôa Cintra, presidente do Conselho de Administração do Fundo, nomeou Paulo de Camargo e Almeida ${ }^{108}$ como Diretor Executivo do Fundo. À frente do Escritório Técnico, Paulo de Camargo e Almeida contratou novos técnicos, entre os quais alunos seus da

\footnotetext{
106 Idem.

107 O Conselho de Administração era constituído pelos diretores da Escola Politécnica, Faculdade de Filosofia Ciências e Letras, Faculdade de Farmácia e Odontologia, Faculdade de Medicina Veterinária, Faculdade de Ciências Econômicas e Administrativas, FAU e IPT, o Diretor Executivo do Fundo, o presidente da CCU, um membro do Grupo de Planejamento do PAGE, e o reitor, que presida o Conselho.

108 Paulo de Camargo e Almeida (1906-1973) formou-se na ENBA, no Rio de Janeiro, em 1925, e teve uma trajetória marcada pela pesquisa sobre industrialização da construção. Presidente do IAB entre 1943 e 1946, participou do concurso de Brasília em equipe com Vilanova Artigas, obtendo o $5^{\circ}$ lugar. Em meados da década seguinte erradicou-se em São Paulo e, em 1960 , assumiu a direção do FCCUASO enquanto lecionava arquitetura na EESC-USP, onde, em 1970, fundaria o departamento de arquitetura com mestrado em Industrialização das Construções. Permaneceu à frente do Fundo até 1966, quando os conflitos político com o reitor Gama e Silva inviabilizaram sua gestão. Ver: CERÁVOLO, Ana Lúcia. Paulo de Camargo e Almeida: arquitetura total na trajetória de um arquiteto brasileiro. Dissertação de mestrado. São Carlos, EESC-USP, 2000, p. 172.
} 
EESC, como Vladimir Brega ${ }^{109}$, e jovens arquitetos do Rio de Janeiro, como José Luiz Mendes Ripper e Alberto Daniel. ${ }^{110}$

Com a atribuição de planejar e executar as novas obras da CUASO por administração direta, desde a infraestrutura urbana até o mobiliário dos edifícios. O FCCUASO contratava projetistas, empresas de serviços especializados e trabalhadores de obra ${ }^{111}$; adquiria maquinário, materiais de construção e equipamentos (inclusive mobiliário e equipamento científico); elaborava planos gerais e setoriais; planejava obras (orçamento, cronograma); compatibilizava e detalhava projetos; fiscalizava, acompanhava e executava obras. Poucos meses após a lei 36.699/60, o Fundo contava com uma estrutura muito maior que o do antigo Escritório Técnico, com centenas de funcionários, veículos, tratores e caminhões, uma bomba de gasolina e até uma draga.

"O Fundo funcionava no antigo Biotério do Instituto de Biociências. Lá trabalhavam cerca de 130 pessoas. Era dividido em uma Diretoria Executiva, um Setor Administrativo (com um chefe) e um outro Setor Técnico (com um chefe). Este Setor Técnico se dividia em uma Divisão de Projetos com arquitetos, engenheiros de estruturas, elétricos, hidráulicos, professores Consultores da Poli e da FAU e desenhistas; e outra de Execução, com engenheiros fiscais das obras". ${ }^{112}$

Do lado de fora, nos canteiros de obra, a maioria dos trabalhadores eram imigrantes nordestinos que se instalaram na região de Osasco, Rio Pequeno, Jaguaré e Vila Indiana, ao redor da Cidade Universitária, e conseguiam trabalho a partir de laços comunitários com quem já estava empregado nas obras. ${ }^{113} \mathrm{O}$ agenciamento ou indicação era feito a partir de elos comunitários.

Desde essa época, os moradores dos bairros vizinhos frequentavam a Cidade Universitária por trabalho e também por lazer, mantendo uma relação cotidiana com as obras. O caso de Abdias Nogueira da Silva é, até certo ponto, ilustrativo ${ }^{114}$. Conforme seu depoimento:

\footnotetext{
${ }^{109}$ Depoimento de Vladimir Brega ao auto, realizado em 23 de fevereiro de 2011.

110 Depoimento de José Luiz Mendes Ripper ao autor, realizado em 2013, no Rio de Janeiro.

111 Os operários do Fundo eram contratados segundo a Consolidação das Leis Trabalhistas (CLT) com carteira de trabalho. Diversas equipes alternavam as tarefas segundo o cronograma geral, realizando desde trabalhos de urbanização e edificação (da fundação aos acabamento). De modo geral, apenas os serviços especializados eram contratados por licitação e todo o restante era executado pelo próprio Fundo.

112 Depoimento de Luciano Bernini ao autor, realizado em 2010 por correspondência eletrônica.

${ }^{113}$ Entrevista de Abdias Nogueira da Silva ao autor, realizada em 06/02/2012.

114 Nascido em Feira Grande, AL, em 1948, filho de agricultores, com 12 irmãos, ele veio para São Paulo em maio de 1961, com 13 anos de idade. Sua família se instalou primeiramente no Jaguaré e, em seguida, no Rio Pequeno. Entre seus irmãos, Severino (Martelo) trabalhou no viveiro da USP; José (Zezé ou Chapéu) era sapateiro e chegou a fazer botinas para trabalhadores da USP; Aniceto (Tiririca) era técnico de nível de médio e foi fiscal no FCCUASO, tendo se tornado mestre de obras na Construtora Marpefe e na Andrade Gutierrez (fazendo a Via Norte em Campinas); Vital trabalhou na obra da FAU; um
} 
"Eu trabalhei vendendo amendoim quando era criança, na [obra da] História e Geografia. Vi o pessoal construindo a História e Geografia da USP. [...]. Eu lembro quando a empresa estava batendo as estacas, lembro muito bem, era moleque [...]. A gente vinha pegar carona naqueles caminhões, aqueles Ford. A gente dava uns amendoinzinhos para os motoristas e eles davam carona para a gente. [...]. A gente vinha lá de onde hoje é o HU, e tinha um caminho que tinha capim por todo lado. Eu não sei como a gente passava em dia de chuva. Vinha numa linha reta, passando no IPEN [...]. Era cheio de mato, era um lamaçal desgraçado". ${ }^{115}$

O ápice dos trabalhos deve ter sido atingido por volta do fim de 1962 (limite da vigência do PAGE), quando, segundo Geraldo Ferraz, a "febril aplicação de recursos" do Governo do Estado de São Paulo teria feito da Cidade Universitária o "maior canteiro de obras existente no país". 116

"Há tratores no movimento de terras; há assentamento de canalizações; há fundações plantadas de que se veem apenas as pontas de ferro no chão; e há trabalho por toda a parte... Entretanto, os estudantes frequentam já numerosos institutos e departamentos. As avenidas são trafegadas por carros de todos os feitios, em meio aos caminhões de materiais. Talvez haja uma excessiva movimentação de terra". ${ }^{117}$

Ao contrário do aconteceu no FECE, onde a indicação dos arquitetos parece ter partido do $\mathrm{IAB} / \mathrm{SP}$, conforme acordo com o governo Carvalho Pinto, a escolha dos nomes teria ficado a cargo do Conselho de Administração do Fundo, liderado pelo reitor Ulhôa Cintra e por Anhaia Mello. Depoimentos de Joaquim Guedes, Paulo Mendes da Rocha e Júlio Katinsky, no entanto, sugerem ter havido conflitos com Paulo de Carvalho e Almeida, sobretudo em defesa de Artigas para o projeto da FAU. ${ }^{118}$

Segundo Joaquim Guedes, na época em que os novos projetos na Cidade Universitária estavam sendo designados, o reitor Ulhôa Cintra iniciou um processo de renovação convidando oito arquitetos, sendo quatro mais experientes - Ícaro de Castro Melo, Rino Levi, Eduardo de Almeida e Oswaldo Bratke -, e quatro mais jovens - Paulo Mendes da

sobrinho e uma sobrinha também trabalharam na FEA. O próprio Abdias trabalhou na USP em quatro ocasiões diferentes entre 1966 e 1984, realizando diferentes serviços. Abdias até hoje mora na mesma casa e é conhecido como Poeta do Rio Pequeno. É catador de recicláveis e coordena a Casa de Cultura do Butantã.

${ }^{115}$ Depoimento de Abdias Nogueira da Silva ao autor, realizado em 6 de fevereiro de 2012.

${ }^{116}$ FERRAZ, Geraldo. “Uma Cidade Universitária no Brasil: CUASO”. Zodiac, n. 11, Milão, 1963, p. 77.

117 Idem.

${ }^{118}$ FAUUSP: 30 anos do projeto do edifício. Transcrição do seminário realizado na FAU, disponível na seção de obras raras da BFAUUSP. s/d, p. 6 . 
Rocha, Pedro Paulo Saraiva, Carlos Millan e ele próprio. Incomodados com a ausência de Artigas, os mais jovens teriam procurado o diretor do Fundo para Construção da Cidade Universitária, e exigido que o projeto da FAU fosse confiado a Artigas.

Paulo Mendes da Rocha diz ter participado de uma reunião para "enfrentar esse Paulo de Camargo e Almeida", na qual o diretor do Fundo que Millan projetasse a FAU e Artigas fizesse uma obra mais vultosa, como o Centro de Práticas Esportivas. A contraproposta teria partido de Millan, que faria a Letras, deixando a FAU para Artigas e o CEPE para Ícaro. "O critério não podia ser esse de projeto de maior contrato ou qualquer coisa do tipo. E, de fato, acho que o Paulo de Camargo concordou na hora. Tenho a impressão que o Artigas deve ter ficado muito satisfeito. Nós ficaríamos muito constrangidos se não fosse assim". ${ }^{119}$

O suposto conflito entre Paulo de Camargo e Artigas foi provavelmente aumentado pelos jovens seguidores de Artigas. Afinal, ambos militavam no mesmo partido, tinham boa relação através do $\mathrm{IAB}^{120}$ e fizeram parte da mesma equipe no concurso de Brasília. ${ }^{121}$

De todo modo, a desconfiança do séquito artiguista refletia o temor de que a "esquerda católica" do governo Carvalho Pinto se opusesse às lideranças do PCB. Segundo Lamparelli, que foi aluno de Artigas entre 1953 e 1954 e membro do Grupo de Planejamento do PAGE:

"Eram adversários políticos. Ele [Artigas] era o mentor da UJC [União da Juventude Comunista] na FAU e nós éramos da JUC [Juventude Universitária Católica]. Ele tinha um enorme desprezo por mim. Eu o contatei muitas vezes, tive dois anos de curso com ele e ele deu duas aulas, mas ele juntava quatro pranchetas e ficava com os compinchas dele, fazendo sei-lá-o-que. Era outro grupo [...]. Claro que tinha uma enorme influência através de uma atividade tipicamente política e ideológica, que era subversiva na época. A JUC não. A JUC era uma organização promovida pela igreja e apoiada pelo Lebret, que nos ajudou enormemente como pensamento, etc."122

Essa oposição, por sua vez, refletia divergências sobre urbanismo:

\footnotetext{
${ }^{119}$ Entrevista de Paulo Mendes da Rocha ao autor, realizada em 16/07/2014.

${ }^{120}$ Paulo de Camargo foi presidente do IAB quando a sessão paulista do instituto foi criada em 1943 em articulação com Kneese de Mello e Vilanova Artigas. Durante a primeira diretoria do IAB/SP Artigas foi o 1ํㅗㄴ.

${ }^{121}$ Os motivos sugeridos para que Paulo de Camargo não atribuísse o projeto da FAU ao Artigas eram: a) algum tipo de desentendimento durante o projeto de Brasília (Guedes e Katinsky); b) o ressentimento de Paulo de Camargo e Almeida pela anulação do concurso para professor catedrático da FAU, disputado por ele em 1956 (Lemos sugere uma atuação direta de Artigas para que não houvesse catedráticos na cadeiras de composição. Ver: CERÁVOLO, Ana Lucia. Op. Cit., p. 162); ou c) Paulo de Camargo considerava o projeto da FAU de pouca visibilidade (Paulo Mendes da Rocha).

${ }^{122}$ Depoimento de Celso Lamparelli ao autor, realizado em 23 de setembro de 2014.
} 
"Eu nunca vi o Artigas falar em planejamento nem urbanismo. Para ele urbanismo era a prolongação da arquitetura. O problema urbano era um problema arquitetônico. Ele dizia: - 'Estou falando de arquitetura, mas vocês entendam que isso também vale para o urbanismo'. Um absurdo tamanho". ${ }^{123}$

E, por fim, divergências sobre arquitetura, tecnologia e planejamento:

As conversas que eu tive com ele na hora de dar projetos do FECE aliás, escolas boas - foram decepcionantes. Ele falava: - 'Eu vou fazer uma escola como a que eu tive quando eu era criança'. Quer dizer, uma falta de visão do geral [...] um estudo mínimo da evolução pedagógica, das necessidades da população, do programa, da tecnologia. Ele não tinha tecnologia. Ele aplicou uma tecnologia inadequada na FAU porque o Brasil não tinha capacidade de produzir aquilo que ele queria, por isso dá problema até hoje. A gente não fala essas coisas porque era um tabu. Agora, era um cara genial". 124

No final do ano de 1960, Paulo de Camargo apresentou um balanço das atividades desenvolvidas nos primeiros meses do Fundo e dos planos para os próximos anos.

"O desenvolvimento dos nossos trabalhos de organograma e de pesquisas de informações relativas aos dados fundamentais, necessários e indispensáveis ao planejamento das Faculdades e Institutos a transferirem-se para o 'Campus' da Cidade Universitária 'Armando Salles de Oliveira' permite-nos, a partir do presente momento, enfrentar a fase de projetá-los [...].

Parece-me assim, aconselhável e possível um ataque geral às obras, procurando-se transferir integralmente as diversas Faculdades para o 'Campus', dentro do período 1961 a 1962. Se mantivermos os princípios que vimos até agora respeitando, de eliminação do supérfluo e de real aproveitamento das disponibilidades de áreas de construção, com a supressão, ou melhor, unificação de muitas obras, as nossas possibilidades financeiras permitirão que alcancemos [...] tornar uma realidade a Cidade Universitária 'Armando Salles de Oliveira'.

Para atingirmos integralmente essa finalidade, torna-se absolutamente indispensável uma unidade de comando e de pensamento entre aqueles a quem forem entregues as tarefas de projetar os diversos Institutos de Ensino, sem o que transformaremos a Cidade Universitária numa colcha de retalhos, constituída de uma

\footnotetext{
${ }^{123}$ Idem.

${ }^{124}$ Idem.
} 
série de edifícios, interessantes talvez para serem contemplados individualmente, mas sem qualquer integração universitária e humana.

O perigo da entrega dos diversos projetos isoladamente a diversos arquitetos reside no fato apontado acima, e a fórmula capaz de integrar a classe dos arquitetos numa colaboração efetiva nesta grande obra seria, a meu ver, que os profissionais escolhidos pelo Conselho de Administração do Fundo aceitassem a tarefa com um profundo sentido de equipe e dentro de uma orientação bem definida em seus conceitos fundamentais e básicos.

Por outro lado, e aqui quero frisar, trata-se de uma opinião toda pessoal, a arquitetura contemporânea sofre internacionalmente, e muito em particular no Brasil, de um formalismo, de uma preocupação de excentricidade, e mesmo, porque não dizer, de tendência à originalidade e à grandeza, afastando-se de seus fundamentos técnicos e de relacionamento humano, indispensável a uma boa arquitetura.

Pensando assim, convoquei pessoalmente diversos arquitetos, para uma conversa preliminar de conceituação geral de nossos problemas e pensamentos, e com grande satisfação verifiquei a existência de uma perfeita identidade de sentir e de positivar as soluções em termos de um trabalho de equipe, sem eliminar o espírito criador dos arquitetos em seus trabalhos individuais, mas conceituando normas básicas do planejamento geral, que bem definam um rumo seguro à arquitetura contemporânea, objetivada de forma precisa na Cidade Universitária de São Paulo". ${ }^{125}$

O relatório sugeria o aproveitamento de profissionais como os engenheiros Augusto Carlos Vasconcellos, Eduardo Pessoa e José de Figueiredo Ferraz e o paisagista Roberto Coelho Cardoso. Seguia com uma relação preliminar de arquitetos a serem contratados. ${ }^{126}$

Para alinhar as estratégias de projetos, Paulo de Camargo propunha que o grupo de arquitetos e engenheiros, inclusive o quadro do Fundo, se reunisse semanalmente na Faculdade de Arquitetura e Urbanismo, com Anhaia Mello, representando o Conselho de Administração.

\footnotetext{
${ }^{125}$ ALMEIDA, Paulo de Camargo. "Relatório de atividades do Fundo para a Construção da Cidade Universitária Armando Salles de Oliveira", de 10 de agosto de 1960. Ver: Processo USP n. 60.1.19244.1.2, fls. 4-6. Publicado na íntegra em "Arquitetos estudam a reorganização da Cidade Universitária da USP", O Estado de São Paulo, 31 de dezembro de 1960 apud CABRAL, Neyde. Op. Cit.

${ }^{126}$ a) Departamento de Mecânica: Ernest de carvalho Mange; b) Letras: Carlos Millan; c) Geologia Paleontologia e Mineralogia: Pedro Paulo Saraiva; d) Sociologia e Antropologia e Economia Política e História das Doutrinas: Paulo Mendes da Rocha; e) Filosofia: Joaquim Guedes*; f) Core: Hélio de Queiros Duarte*; g) Arquitetura e Urbanismo: João Vilanova Artigas; h) Eletrotécnica: Fábio Penteado*; i) Habitação: Eduardo Kneese de Mello; j) Esportes competitivos: Ícaro de Castro Mello; k) Rodoviária: Roberto Cerqueira Cezar*; I) Departamento de Química (EP), Conjunto das Químicas e o Laboratório de Hidráulica: Escritório Técnico do Fundo.
} 
Eduardo Kneese de Mello, que participou dessas reuniões, relatou o seguinte:

"[...] o reitor da Universidade Professor Ulhôa Cintra e o diretor da Faculdade de Arquitetura, professor Luiz de Anhaia Mello convocaram professores desta escola para reestudarem o Plano da Cidade Universitária e projetarem os edifícios que deveriam ser construídos.

A equipe de arquitetos reuniu-se inúmeras vezes sob direção do professor Anhaia Mello, analisou os estudos elaborados por seus antecessores que atuavam sob as ordens do arquiteto Hélio Queirós Duarte e fizeram algumas alterações. Em seguida os projetos das diversas áreas foram atribuídos àqueles arquitetos". ${ }^{127}$

Em outro depoimento, Pedro Paulo Saraiva complementou:

"Houve várias reuniões dos arquitetos envolvidos na revisão do Plano da Cidade universitária (era um grupo menor) no escritório de Carlos Millan. O Plano era extremamente acadêmico, cheio de erros, e a gente fez uma coisa mais de acordo com a topografia [...]. Foi elaborado um plano de massas que foi dado como sugestão para o Paulo de Camargo, e o Paulo colocou aquilo funcionando dentro de uma estrutura que ele tinha lá de planejamento". ${ }^{28}$

Tal plano de massas teria sido incorporado ao Plano Geral para a Cidade Universitária, consolidado pelo Escritório Técnico em agosto de 1962. Já as reuniões com Anhaia Melo serviram para definir as diretrizes de projeto. Foi um período de intensa atividade e muita pressa para se concluir as obras durante a gestão. Para agilizar, os anteprojetos eram desenvolvidos pelo Escritório Técnico, o que gerou críticas pontuais sobre a "interferência indevida e nada ética" em alguns projetos. ${ }^{129}$

O Plano Geral continuou sendo desenvolvido e alterado até 1963. Nesse intervalo, a Lei de Diretrizes e Bases da Educação e o Estatuto da USP foram aprovados, respectivamente em 1961 e 1962. Com esses instrumentos ganhavam força as ideias de autonomia universitária e democracia. As Ciências Humanas, que sempre ficaram em segundo plano na FFCL, ganharam novo impulso com a transformação desta em FFLCH, enquanto as ciências puras ganhavam seus próprios institutos.

No novo modelo, o aluno seria estimulado a buscar a complementação de sua formação especializada em outras unidades principalmente na FFLCH. O resultado disso foi uma nova

\footnotetext{
${ }^{127}$ MELLO, Eduardo Kneese de, apud UNIVESIDADE DE SÃO PAULO, Op. Cit., 1985, p. 57.

${ }^{128}$ SARAIVA, Pedro Paulo de Melo apud CABRAL, Neyde. Op. Cit., p. 177.

${ }^{129}$ CORONA, Eduardo. "A construção da Cidade universitária”, Acrópole, n. 299, setembro, 1963, p. 314.
} 
setorização por áreas do conhecimento. Foram então propostos 18 setores (em 1963 seriam 20) e cada um deles foi imaginado como um conjunto autônomo, com seus próprios centros sociais e sistemas de circulação.

Dois setores teriam um papel estratégico para o funcionamento do conjunto: o Setor 6, "Conjunto de Convivência Geral" (em 1963, "Centro Cívico-Cultural e de Convivência Geral”) e o Setor 3, "Conjunto das Ciências Humanas e Sociais".

O core ganhava um novo sentindo a partir de consultas à comunidade acadêmica, promovidas por Paulo de Camargo e Almeida, nas quais predominavam demandas serviços sociais, moradia estudantil e convívio universitário. No plano do FCCAUSOO o setor de moradia voltava a ser localizado no centro da Cidade Universitária e não mais na fronteira com a cidade. $O$ novo desenho fechava a vista da reitoria desde o acesso principal e formava uma praça rodeada por centro social, restaurante, rodoviária, teatro, etc.; o core. Seu principal edifício, que havia sido imaginado por Paulo de Camargo com o projeto de seu antecessor, Hélio Duarte, foi afinal, confiado pelo grupo de Anhaia Mello à Rino Levi e, por fim, à Oswaldo Bratke.

Ao lado do core estaria o setor das Ciências Humanas que faria a articulação com os setores especializados, dispersos pela Cidade Universitária:

"Acreditamos que na verdadeira integração universitária, deveríamos conceituar os meios de desenvolver, entre todos os estudantes, o respeito aos valores humanos e da noção de solidariedade entre os homens, e em particular, inculcarmos nos estudantes de ciências e de técnica o gosto pelas humanidades e certos conhecimentos nesse domínio e aos que se consagram às humanidades, um certo conhecimento dos problemas e métodos da ciência e da técnica". ${ }^{130}$

Para materializar esse princípio os arquitetos responsáveis por esses edifícios notadamente o grupo mais próximo de Anhaia Mello e de Artigas - definiram um partido comum com térreo livre, a partir do qual os projetos individuais foram desenvolvidos isoladamente.

"Abrigando os cursos de Filosofia, Política e Antropologia, o edifício
se organiza de acordo com o partido geral combinado entre os
arquitetos Eduardo Corona, João Batista Vilanova Artigas e Pedro
Paulo de Mello Saraiva [...]. Haveria jardins, com acesso direto aos
museus, cantinas, auditórios, oficinas e grêmio estudantil,
sucedendo-se como elementos de interligação e confraternização
entre as escolas. As demais construções, em construção leve e de

${ }^{130}$ ALMEIDA, Paulo de Camargo e. Relatório Geral 1959-1962. FCCUASO, 1963 apud CABRAL, Neyde. Op. Cit., p. 170. 
implantação transparente, ficariam nos níveis mais elevados, garantindo visuais e conforto ao conjunto das escolas e ao convívio universitário". ${ }^{131}$

Apesar do discurso sugerir um "corredor das humanas", pelo qual os alunos pudessem transitar entre suas unidades e o core, persistiu a concepção de pavilhões isolados sem a preocupação com padrões de gabarito, volumetria ou alinhamento. Na mesma época Niemeyer e Lelé projetavam o Instituto Central de Ciências da Universidade de Brasília com quase $700 \mathrm{~m}$ de comprimento e técnicas de pré-fabricação.

Apesar das falhas na articulação do conjunto e da interrupção do Plano após 1963 os projetos dos edifícios da Cidade Universitária realizados entre 1960 e 1962 foram os que mais se aproximaram de um padrão adequado à universidade daquele tempo. Neles podese identificar uma preferência por materiais aparentes, acabamentos de baixo custo, continuidade interior/exterior, pátios ou jardins internos, corredores e rampas generosos, iluminação zenital, volumes simples, poucos andares e implantação isolada.

${ }^{131}$ ROCHA, Paulo Mendes da, apud UNIVERSIDADE DE SÃO PAULO, Op. Cit., 1985. 


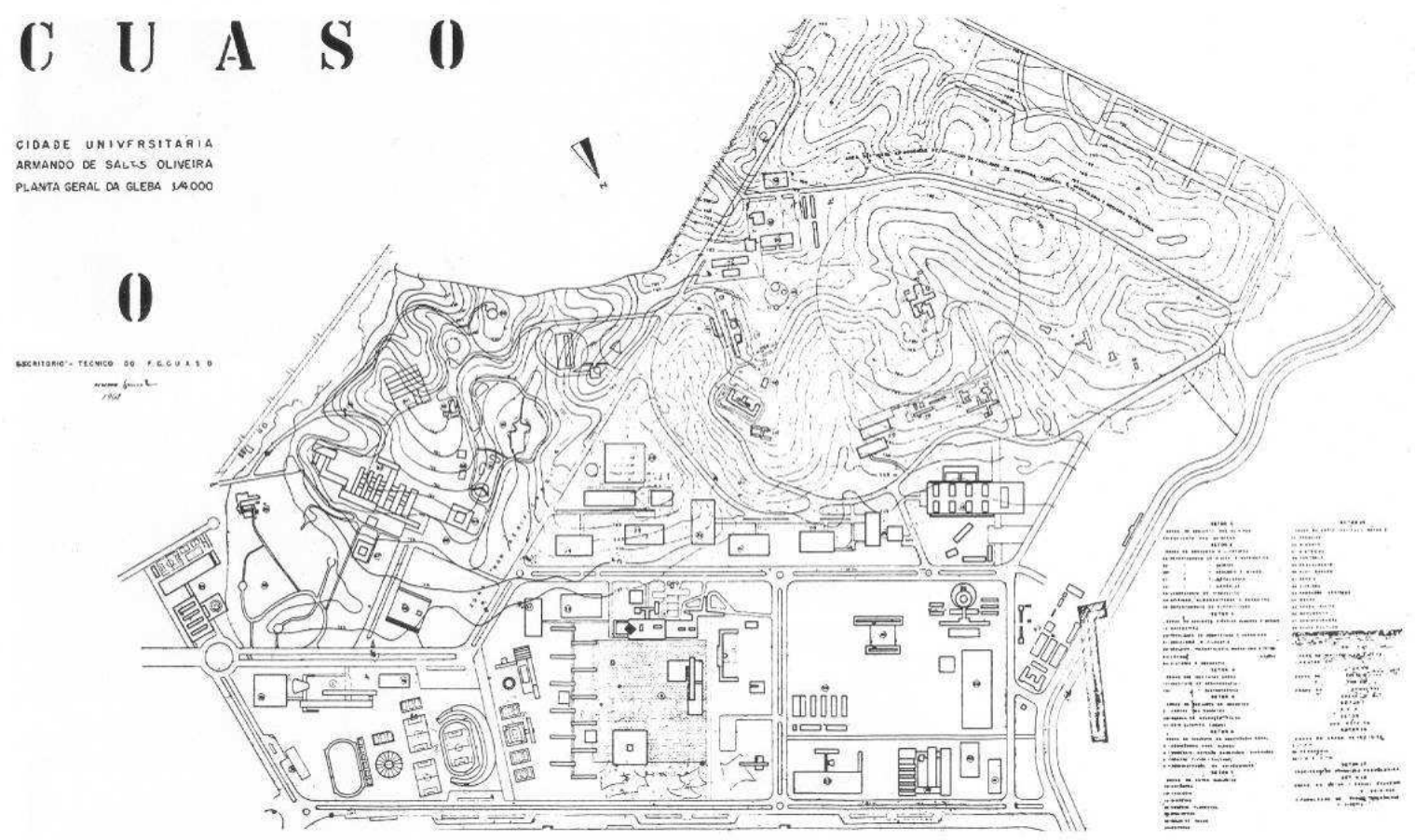

Planta geral da CUASO, projeto do Escritório Técnico do FCCUASO coordenado pelo arquiteto Paulo de Camargo e Almeida, 1962.

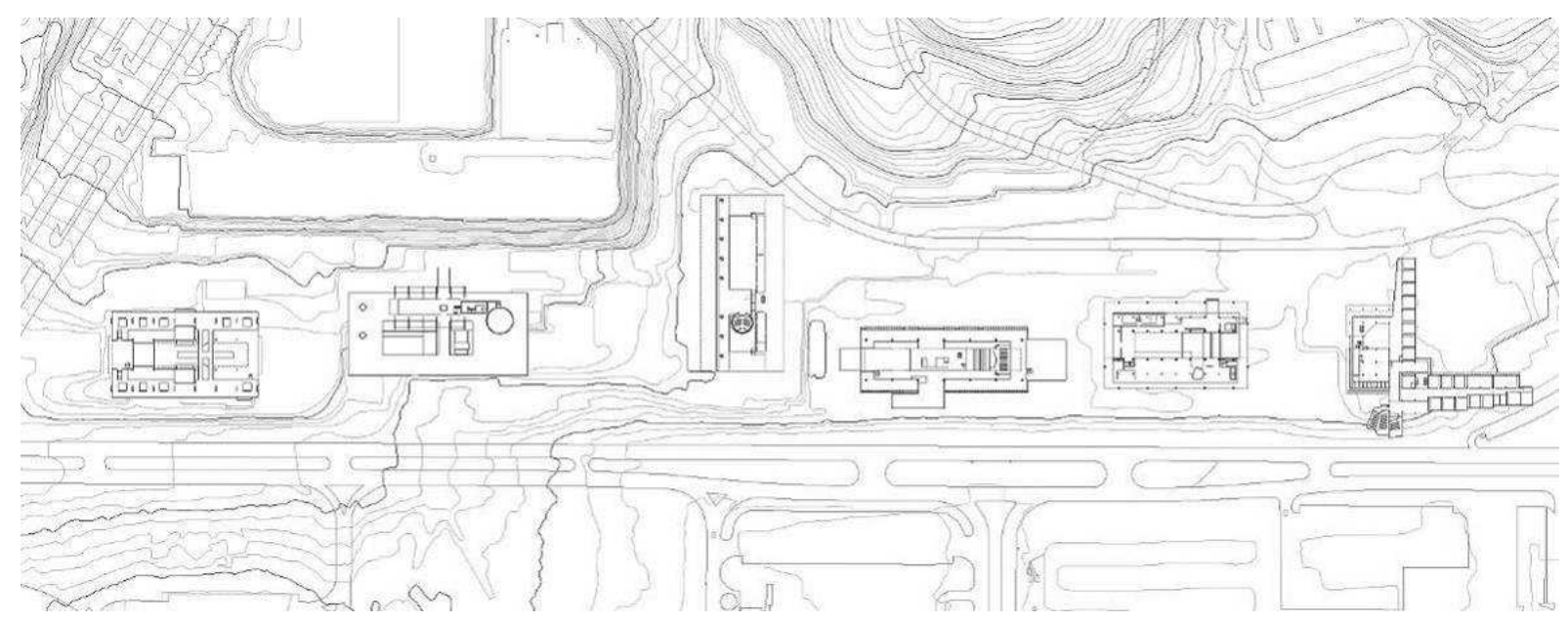

Simulação da implantação do "Corredor das humanas". GFAU, 2010.

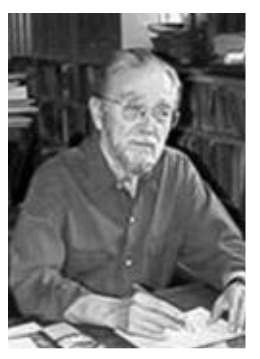

Eduardo Corona

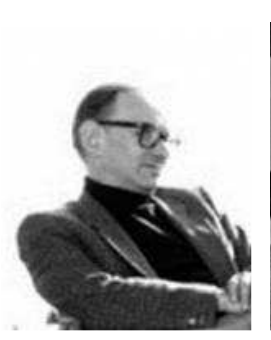

Carlos Millan

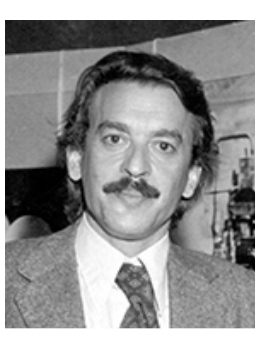

Paulo Mendes da Rocha

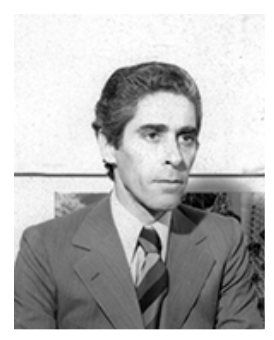

Pedro Paulo Saraiva

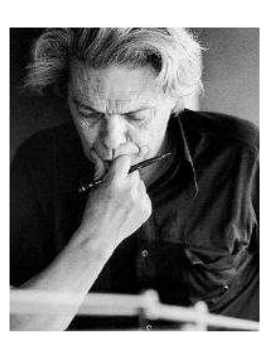

João Batista Vilanova Artigas

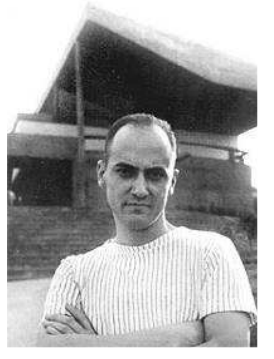

Joaquim Guedes 

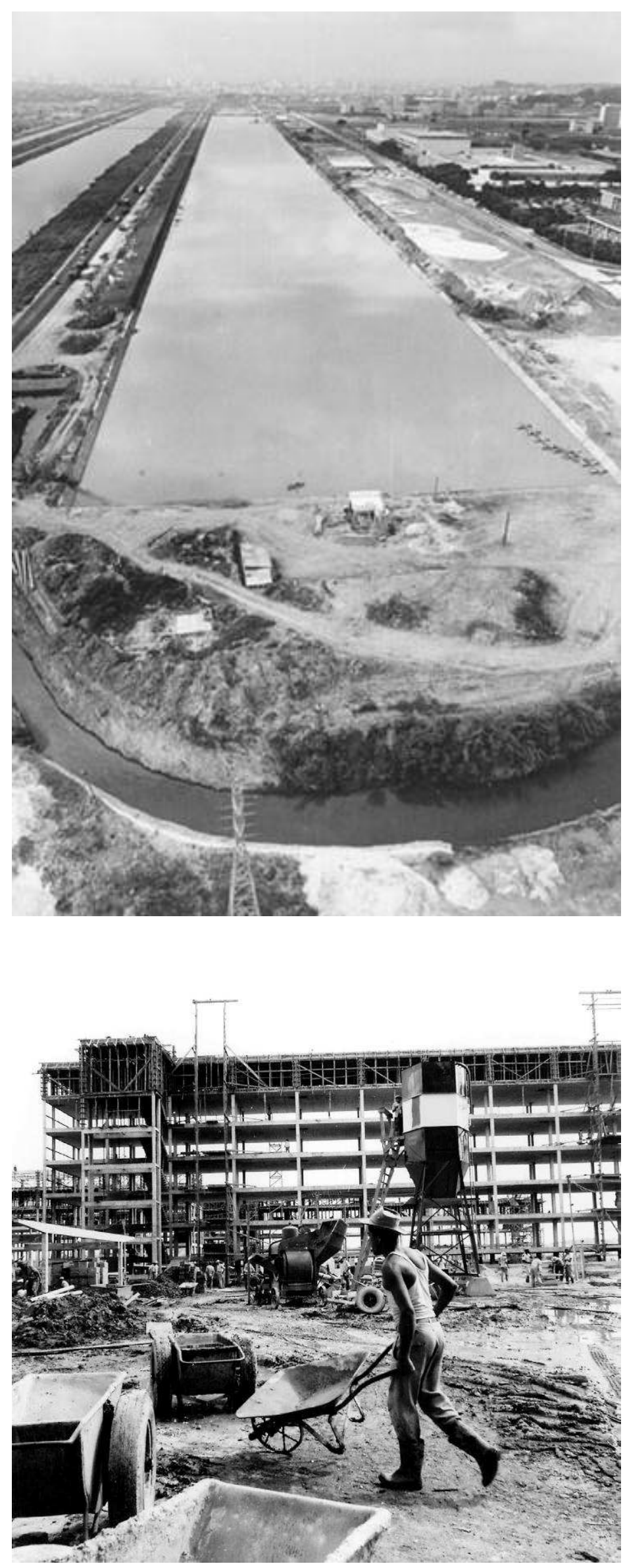

Construção da raia olímpica da USP, da qual foi retirada a areia para parte das obras. Acervo COESF.

Construção do CRUSP. Acervo CCS/Jornal da USP 


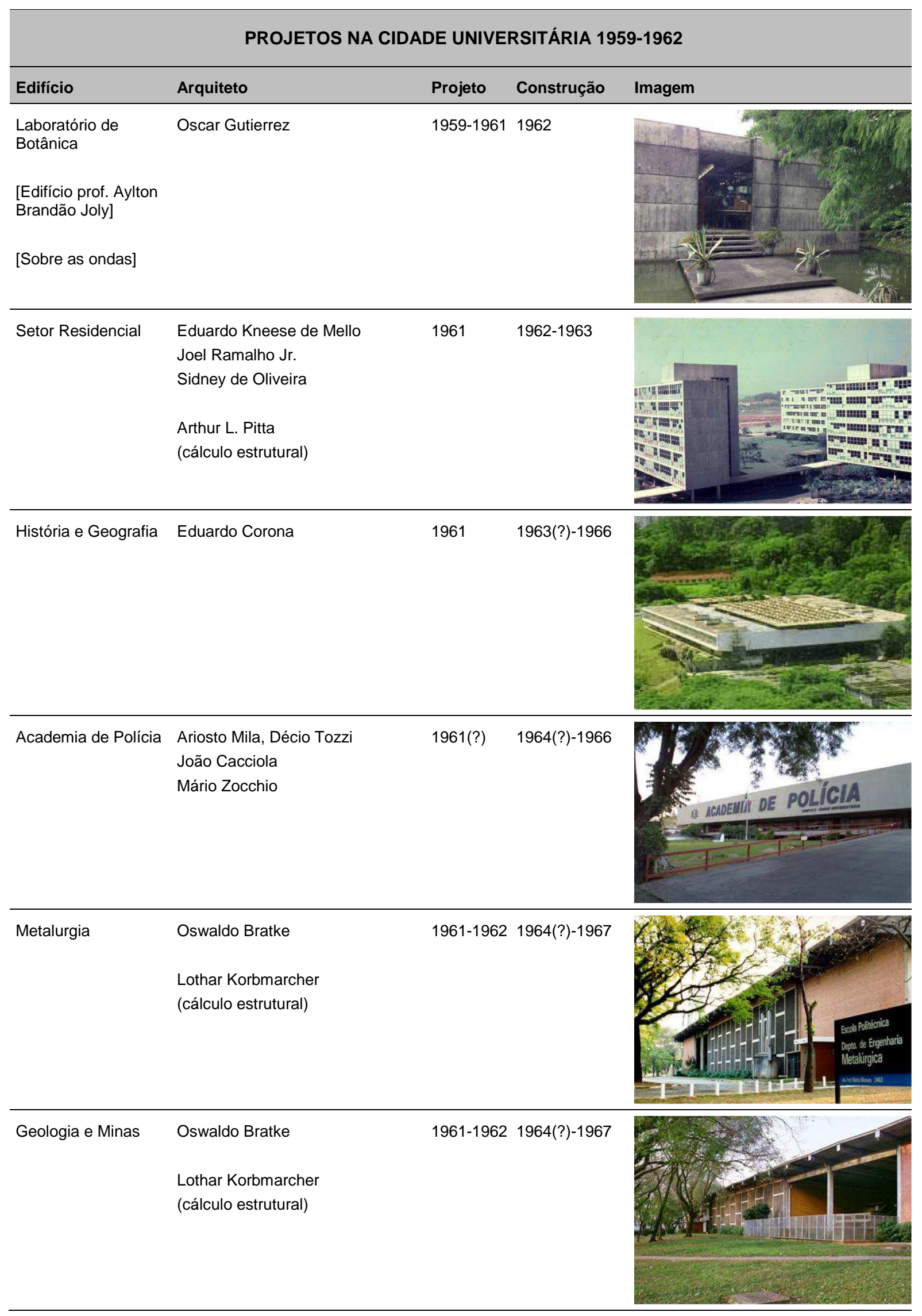




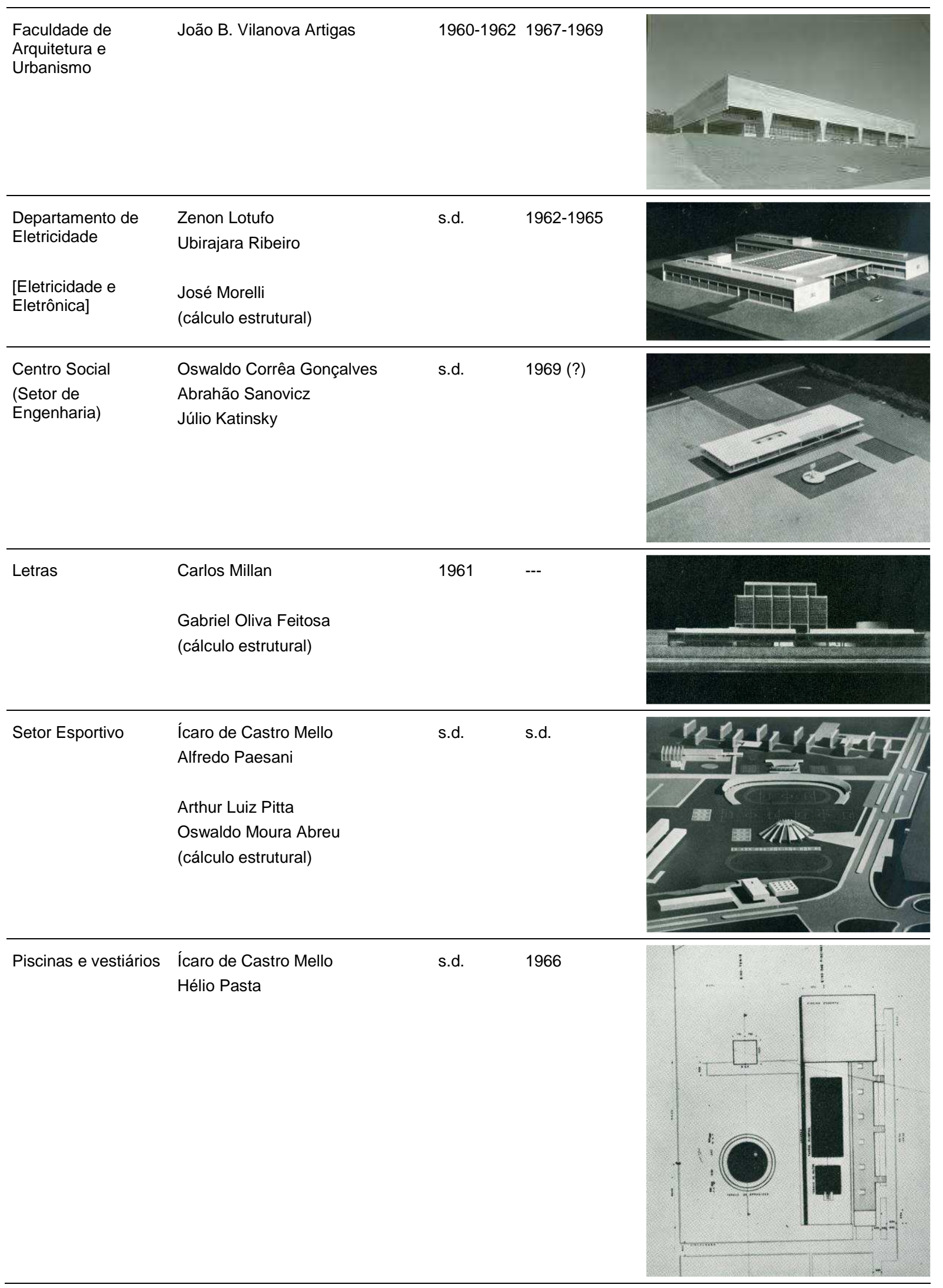




\begin{tabular}{llll}
\hline Estádio Olímpico & Ícaro de Castro Mello \\
Hélio Pasta
\end{tabular}

\section{Ginásio}

Estádio de Tênis

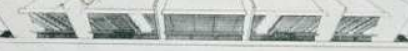

.

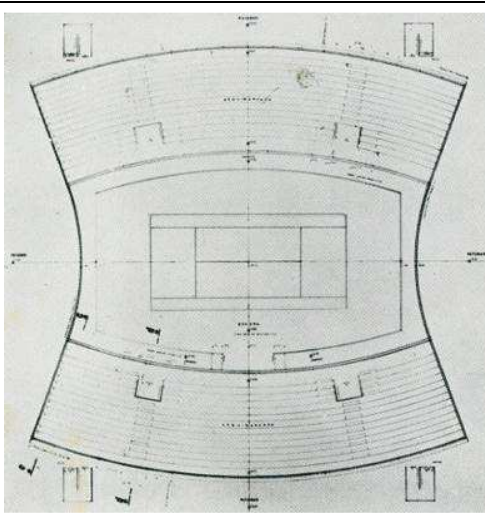

\begin{tabular}{|c|c|c|c|}
\hline Teatro da FFLCH & Carlos Millan & 1962 & --- \\
\hline Filosofia e Sociologia & $\begin{array}{l}\text { Paulo Mendes da Rocha } \\
\text { João Eduardo de Genaro }\end{array}$ & $\begin{array}{l}1961(?)- \\
1962\end{array}$ & --- \\
\hline $\begin{array}{l}\text { Geologia e } \\
\text { Paleontologia }\end{array}$ & Pedro Paulo de Melo Saraiva & $1961(?)$ & --- \\
\hline $\begin{array}{l}\text { Instituto de } \\
\text { Eletrotécnica }\end{array}$ & Fábio Penteado & 1962(?) & --- \\
\hline $\begin{array}{l}\text { Instituto de } \\
\text { Matemática e } \\
\text { Estatística }\end{array}$ & Joaquim Guedes & 1962(?) & --- \\
\hline Centro Social & $\begin{array}{l}\text { Rino Levi } \\
\text { Oswaldo Moura Abreu } \\
\text { (cálculo estrutural) }\end{array}$ & 1961-1962 & --- \\
\hline
\end{tabular}

Ttabela elaborada a partir da sistematização de dados dispersos na bibliografia. Algumas informações podem ser contraditórias. 


\section{Mudança de rumo (1963-1969)}

Com uma grande quantidade de anteprojetos entregues entre 1961-1962 ficava evidente que o Fundo não conseguiria entregar todas as obras até o final daquela gestão. $\mathrm{Na}$ verdade, apenas as obras do Conjunto das Químicas, do Departamentos de Engenharia Elétrica e Eletrônica e de Engenharia Mecânica e Naval da Escola Politécnica, o setor Residencial e possivelmente o edifício da História e Geografia foram iniciadas até o fim de 1962. As demais aguardavam a disponibilidade de equipes enquanto suas fundações eram estaqueadas.

Pelo Decreto 36.699/60, o Fundo para Construção da Cidade Universitária deveria se limitar às obras que pudessem ser "executadas e entregues para pronta utilização até 31 de janeiro de 1963". Às vésperas do encerramento do prazo, a continuidade das obras e a manutenção do órgão que as administrava eram incertas. Paulo de Camargo manifestou sua preocupação com essa questão em novembro de 1962, quando sugeriu que o Reitor solicitasse ao Governador eleito a continuidade do Fundo. ${ }^{132}$

Adhemar de Barros assumiu novamente o Governo do Estado de São Paulo em 1963, opondo-se diametralmente à política de planejamento transversal de Carvalho Pinto. Paulo Camargo de Almeida colocou seu cargo à disposição do Reitor Ulhôa Cintra em janeiro de 1963 tendo em vista o resultado da eleição, porém aceitou permanecer por solicitação do Conselho Universitário. Adhemar criou a Secretaria de Estado dos Negócios de Economia e Planejamento, que centralizou o planejamento financeiro das obras do Estado em uma única pasta. Agora, apesar de mantido o FCCUASO, seu orçamento passava a depender da nova secretaria. A dotação orçamentária para a construção da Cidade Universitária continuou aumentando ano após ano. ${ }^{133}$ No entanto, apenas uma parte desses recursos foi usada para executar o plano elaborado por Camargo e Almeida com a participação de dezenas de arquitetos.

Em meio a conflitos entre o diretor do fundo e o governo do Estado, recursos especiais para a realização dos jogos Pan-Americanos de 1963 foram obtidos para a conclusão dos edifícios de moradia e restaurante do Conjunto Residencial de Estudantes, onde os atletas foram alojados, e parte do complexo esportivo que recebeu algumas das provas.

\footnotetext{
${ }^{132}$ Documento de Paulo de Camargo, Diretor Executivo do FCCUASO, ao Reitor Ulhôa Cintra de 28/12/1962 que sugere encaminhamento da pauta ao governador para que o prazo do decreto original fosse prorrogado. Processo USP $n$. 62.1.660.51.9, p. 22.

${ }^{133}$ Os valores foram: NCR $\$ 375$ mil (1960); NCR $\$ 1,050$ mil (1961); NCR\$ 2.100 mil (1962); NCR\$ 3.600 mil (1963); NCR\$ 8.000 mil (1964); NCR\$ 7.000 mil (1965); NCR $\$ 7.290$ mil (1966); NCR 8.000 mil (1967); NCR\$ 9.400 mil (1968). Houve, portanto, um significativo aumento, mesmo considerando a inflação. Ver: "Separata especial de Anais Científicos", n. 75, 1966; e "Fundo para Construção, USP, 1969" apud CABRAL, Neyde. Op. Cit.
} 
O modo como se deu a realização dos primeiros edifícios do CRUSP representou uma derrota particular a Paulo de Camargo, que havia defendido o emprego de técnicas de préfabricação de peças estruturais de concreto armado, através do qual pretendia demonstrar suas vantagens teóricas de baixo custo e rapidez. Em 1961, o projeto havia sido confiado ao arquiteto Eduardo Kneese de Mello, e seus colaboradores Joel Ramalho Jr. e Sidney de Oliveira, que projetaram um conjunto com doze prédios idênticos, cada um com doze andares. Segundo o engenheiro Augusto Carlos de Vasconcelos, "o pré-moldado em São Paulo era muito pouco conhecido e raramente usado. Em edifício alto, seria o primeiro caso". 134

"As obras nem haviam sido iniciadas e temia-se que não ficassem prontas a tempo [dos Jogos]. Na concorrência, estabeleciam-se multas pesadas para os competidores que não conseguissem entregar as obras no prazo exigido. Um dos participantes foi a firma Ribeiro Franco S.A. de São Paulo, que estudou a fundo o problema e apresentou sua proposta em pré-moldados na obra, incutindo confiança na manutenção dos prazos. Entretanto, desconfiando da novidade, o FUNDUSP decidiu dividir o serviço para duas firmas, uma executando 6 prédios pelo sistema tradicional e a Ribeiro Franco outros 6 prédios pelo sistema de pré-moldados". 135

O resultado "surpreendente" foi que os edifícios construídos pelo método tradicional ficaram prontos a tempo e os pré-fabricados não. Após os Jogos, as obras desses edifícios inacabados foram abandonadas restando, por muitos anos, apenas os esqueletos de sua estrutura pré-fabricada.

Após o golpe, o FCCUASO estava sob nova direção. Paulo de Camargo vinha alertando o reitor Luiz Gama e Silva sobre os problemas advindos do corte orçamentário no Plano de Recursos de 1964. ${ }^{136}$ Em julho de 1964 Paulo de Camargo ainda obteve sucesso na contratação de pessoal, "contrariando a disposição do Governo em cortar gastos e suspender contratações", ao argumentar a "provisoriedade e a facilidade de se encontrar mão-de-obra barata quando necessário". 137 Porém, em meio ao clima de perseguição aos

134 VASCONCELOS, Augusto Carlos de. O concreto no Brasil: pré-fabricação, monumentos, fundações. Vol. 3. São Paulo: Studio Nobel, 2002, p. 17.

135 Idem, Ibidem. Vasconcelos enaltece a escolha dos engenheiros e da firma construtora, e diz que a obra transcorreu sem incidentes: "Apenas os prazos não puderam acompanhar o tirocínio dos construtores hábeis nas construções tradicionais". No entanto afirma também que a construtora Ribeiro Franco e o engenheiro Henrique Herweg não tinham prática em prémoldados e que não havia experiência para confecção de fôrmas com a precisão milimétrica necessária para o encaixe das peças. Vasconcelos destaca ainda dificuldades surgidas com o "calor desenvolvido na solda das armaduras longitudinais". Mas conclui culpando os trabalhadores pelo atraso: "A Ribeiro Franco fez uma obra perfeita, mas teve que resolver inúmeros problemas decorrentes da falta de treinamento dos operários, que nunca haviam trabalhado antes num processo construtivo tão diferente".

${ }^{136}$ Carta de Paulo de Camargo e Almeida ao reitor. 19 de fevereiro de 1964. Processo USP n.64.1.6450.1.1, fl. 4.

${ }^{137}$ Solicitação de Paulo de Camargo e Almeida ao reitor. 2 de julho de 1964. Processo USP n.64.1.17084.1.1, fl. 2-4 
professores "subversivos", Paulo de Camargo, que já vinha acumulando divergências com o novo reitor, deixou o cargo entre o final de 1964 e o início de $1965 .{ }^{138}$ Em julho daquele ano, Adalberto Mendes dos Santos, até então encarregado de Orçamentos do Fundo, foi designado o novo diretor executivo do FCCUASO. No final daquele ano, o reitor Gama e Silva apresentaria uma proposta de reestruturação do Escritório Técnico e Administrativo, regulamentando suas atividades e criando um Conselho Técnico Consultivo. ${ }^{139}$

Entre 1965 e 1966, a nova gestão do Fundo entregou as obras dos edifícios do Plano de 1961-63 que haviam sido iniciadas até dezembro de $1963^{140}$ (Engenharia Mecânica e Naval, Engenharia Elétrica e Eletrônica, História e Geografia, Conjunto das Químicas), juntamente com outras obras, também do Plano 1961-63, iniciadas após 1964, como a Academia de Polícia e parte do complexo esportivo.

O folheto "Subsídios para relatório da Universidade de São Paulo", de maio de 1966, traz um balanço das obras estabelecidas no Plano de 1961-63: 17,2\% dos edifícios haviam sido concluídos, 5,6\% estavam em construção e 77,2\% estavam por construir. ${ }^{141}$ Nesse meio tempo, o Fundo construiu e entregou outras obras, que não faziam parte do Plano, tais como a Escola de aplicação, dois pavilhões de serviços gerais, sete pavilhões no Setor Tecnológico, duas garagens (atual prefeitura da CUASO), e o 16ํㅡㄹataño da Polícia Militar. ${ }^{142}$ Ainda em 1966 estavam com estrutura concluída, os seis blocos pré-fabricados do CRUSP, seis pavilhões no setor Tecnológico, os edifícios dos Departamentos de Minas e de Metalurgia da Poli, o edifício da Radiologia no Setor Energia Atômica.

Em planta da Cidade Universitária datada de fevereiro de 1966 havia a informação de que diversos edifícios se encontravam com as fundações estaqueadas, entre eles o edifício da FAU. ${ }^{143}$ Segundo Sérgio Assumpção, arquiteto ex-diretor do COESF, as fundações de

\footnotetext{
${ }^{138}$ Não é conhecida a data exata do desligamento de Paulo de Camargo e Almeida. Cerávolo sugere que tenha sido após julho de 1966, citando as manifestações do arquiteto e professor da EESC contra a demolição do edifício J do CRUSP. Contudo, a última ocorrência do nome de Paulo de Camargo localizada em um documento oficial foi em setembro de 1964. Adalberto Mendes dos Santos foi indicado para o cargo de Diretor Executivo do Fundo, "enquanto a vaga não fosse provida", em junho de 1965, um dia após a exoneração de Reynaldo Ramos Saldanha Gama, que portanto já estava substituindo Paulo de Camargo. Processo USP n.65.1.32613.1.2, fl. 4.

139 Processo USP n. 65.1.32614.1.9, fl. 2 a 8.

${ }^{140}$ Conforme planta reproduzida por CABRAL, Neyde. Op. Cit., p. 177b.

${ }^{141}$ Idem, p. 213.

142 O Batalhão foi construído pelo Fundo, porém não com verba da CUASO, na área destinada ao Departamento de Estradas de Rodagem, na Av. Corifeu.

${ }^{143}$ Essa planta foi redesenhada por CABRAL, Neyde. Op. Cit., p. 214b. Os edifícios estaqueados eram os da Geologia; Ciências Sociais; Centro Social; $2^{\underline{a}}$ parte do Laboratório de Hidráulica; 2a parte da Mecânica e Naval; Engenharia Civil; Fisiologias (bio-I); Instituto de Eletrotécnica e FAU. É possível que o edifício da FAU já se encontrasse estaqueado por volta de 1963. Narrando a cronologia da obra do novo prédio da FAU, o diretor da FAU, diz que antes de assumir o cargo, em 1965, o projeto definitivo do prédio estava concluído por volta de 1962, "o terreno foi estaqueado" e "houve concorrência que foi anulada". Carta de Pedro do Amaral Cruz ao reitor, de 27 de julho de 1966. Processo USP 66.1.20.458.1.8, fl.2 a 5. Segundo mensagem do FCCUASO encaminhada à Assembleia Legislativa, em 1962, o edifício da Reitoria teria sido concluído em 1961, quando se deu o início da construção do edifício FAU.
} 
edifícios foram executadas pelo próprio Fundo como forma de garantir que as obras fossem executadas de acordo com os projetos contratados. ${ }^{144}$

Se, na prática, o plano de 1961-1963 já estava sendo ignorado, a discussão nesse momento foi desviada pelo ímpeto do reitor em demolir o bloco J do Conjunto Residencial - cuja obra estava parada desde os jogos de 1963 - para construir uma extensão da via de acesso que retomasse a perspectiva central do edifício da reitoria. Com essa mudança, o Centro Social projetado por Rino Levi - que já estava estaqueado - também ficava inviabilizado. $O$ fato provocou intenso confronto entre arquitetos e o reitor, com manifestações públicas dos autores do projeto do Conjunto Residencial, Kneese de Mello, Joel Ramalho Jr. e Sidney de Oliveira ${ }^{145}$, do Instituto dos Arquitetos do Brasil, do membro do Conselho Universitário, Paulo Mendes da Rocha ${ }^{146}$, do sócio de Rino Levi (que falecera no ano anterior) Roberto Cerqueira César ${ }^{147}$ e do editor da revista Acrópole, Eduardo Corona. ${ }^{148} \mathrm{O}$ reitor, respondeu, dizendo que não admitia que um órgão profissional emitisse opinião sobre um assunto que não era de sua alçada e que "às vezes um advogado tem ideias melhores sobre arquitetura que os arquitetos". ${ }^{149}$

O debate se estendeu no Conselho Universitário, órgão máximo da universidade, onde Paulo Mendes da Rocha havia sido eleito representante dos auxiliares de ensino.

"Aqueles prédios do CRUSP, que tinham sido projetados em prémoldado - o primeiro pré-moldado com cura a vapor -, eram um avanço. E eles acharam que aquilo tinha sido feito para fazer uma barreira; e assim foi dito lá, e o Paulo tomou uma defesa brilhantíssima contra essa posição". ${ }^{150}$

Tal defesa, no entanto, não foi suficiente para impedir a demolição do bloco J, cujas peças da estrutura pré-fabricada acabaram sendo reaproveitadas pelo FCCUASO para a construção do edifício da Administração da FFLCH, em 1968. De fato, pouquíssimas obras do plano 1961-63 foram iniciadas após o golpe, como foi o caso da Faculdade de Arquitetura e Urbanismo projetada por Artigas que representou uma excepcional derrota do reitor no Conselho Universitário em novembro de 1966.

\footnotetext{
${ }^{144}$ Entrevista de Sérgio Assumpção ao autor, realizada em 31 de janeiro de 2012.

145 "Arquitetos esclarecem", O Estado de São Paulo, 06 de agosto de 1966.

146 Jornal da Tarde, 1 de novembro de 1966.

147 “O coração da Cidade Universitária”, O Estado de São Paulo, 11 de novembro de 1966.

${ }^{148}$ Acrópole, n. 334, novembro 1966.

149 Jornal da Tarde, 1 de novembro de 1966.

${ }^{150}$ Depoimento de Jon Maitrejean ao autor, realizado em 30 de julho de 2014.
} 
No contexto de endurecimento do regime militar, a Cidade Universitária se tornou um equipamento eficaz de isolamento e controle do corpo discente, docente e administrativo, o que foi implementado pela primeira vez com a imediata transformação do departamento de Filosofia após o atentado sofrido na Rua Maria Antônia. Com um número cada vez maior de estudantes provisoriamente alojados nos pavilhões construídos entre 1965 e 1967, e a tendência de massificação anunciada pela reforma universitária, o Fundo buscou acelerar e baratear as obras ainda mais.

Enquanto na Universidade de Brasília o Instituto Central de Ciências, concebido por Oscar Niemeyer e desenvolvido por João Filgueiras Lima à frente do Escritório Técnico, introduzia um novo paradigma que combinava sistemas pré-fabricados em um único edifício com quase $700 \mathrm{~m}$ de comprimento, germinavam na USP ideias sobre planejamento funcional modulado associado à pré-fabricação.

Em 1969, o governo estadual "orientou" a universidade a reduzir substancialmente as despesas do FCCUASO, iniciando o desmonte do órgão. Em junho o vice-reitor em exercício, Alfredo Buzaid (logo também Ministro da justiça), solicitou a relação nominal dos servidores do Escritório Técnico do Fundo (excluídos os "trabalhadores braçais"), e seus respectivos cargos, salários e funções. Nessa altura eram 9 engenheiros, 8 arquitetos, 13 desenhistas, e um total de 150 funcionários, incluindo, contadores, técnicos administrativos, assistentes, topógrafos, dentistas, um médico, auxiliares de escritório, auxiliares de compras, telefonistas, contínuos, mensageiros, entre outros. Atendendo à solicitação o Diretor Executivo do Fundo, Adalberto dos Santos, respondeu:

"Tendo em vista as expressas recomendações de vossa magnificência sobre a redução substancial das despesas do Fundo, em consonância com a orientação Abreu Sodré, procedemos os necessários estudos e chegamos à conclusão daquela possibilidade, desde que modificada a atual política construtiva deste órgão, mediante substituição do método de 'execução de obras por administração', pelo de 'empreitada'. Aliás, em recentes entendimentos com técnicos da Secretaria de Economia e Planejamento, nós os havíamos auscultado, obtendo informações de que o sistema de 'empreitada' é o que melhor interessa ao Governo Federal, na tendência de estímulo à iniciativa privada, visando a conjugação de seus esforços com a política de planejamento oficial. Em que peses algumas vantagens isoladas do sistema de administração de obras, permitindo atender de pronto certas necessidades surgidas no decorrer das obras e, embora reconhecendo que o Fundo tenha uma organização modelar, está montada para execução de obras de vulto muitas vezes superior 
àquele que vem executando, quando infelizmente, não tem sido possível ao Estado conceder-Ihe recursos condizentes à sua ampla capacidade de produção; melhor será, nesse caso, a adoção do sistema de 'empreitada', reduzindo a organização às necessidades reais e na proporção do montante das dotações que the forem atribuídas.

Com a modificação da política construtiva do Fundo, poder-se-á dispensar grande número de empregados; iniciaremos à dispensa por aqueles de maior salário, obtendo dessa forma, dois proveitos: redução no número de empregados e adoção, para o futuro, da política de salários mais baixos". ${ }^{151}$

Em outro documento a reitoria solicitava saber o custo médio das últimas obras executadas, por metro quadrado. No dia seguinte ao de sua primeira resposta, Adalberto dos Santos assumiu uma postura mais ponderada. Feitas as considerações metodológica de que o "Fundo não se limita apenas a construir os prédios, porém, entrega-os em condições de imediato funcionamento" e de que "tem a seu cargo todas as obras de infraestrutura do campus", o diretor buscou demostrar as vantagens da administração direta:

"Doutro lado, a política de pessoal deste órgão vem proporcionando ótimo sistema de seleção e meios para congregar uma equipe de artífices e operários altamente especializados, cujo rendimento, segundo observações registradas em suas próprias obras, é de 20 a $25 \%$ superior aos dos empreiteiros, permitindo sensível redução no custo do metro quadrado das áreas construídas. É de se considera que a construção da Cidade universitária constitui um empreendimento de envergadura que exige grande mobilidade e desprendimento, tendo o Fundo conseguido criar entre seus servidores a mística de que estão empenhados numa obra grandiosa, que dá sentido às suas vidas e procuram atingir o ideal, não estando apenas, trabalhando pelo salário. Emprega-se nas obras executadas pelo Fundo exclusivamente materiais convencionais, de baixo custo, eliminando tudo quanto implique em requintes ou suntuosidades como mármore, 'ray-ban' e cristais, não obstante, suas construções têm excelente aspecto graças ao aprimoramento da mão de obra". ${ }^{152}$

O relatório de Adalberto Santos era acompanhado de um quadro com os custos totais das obras, incluindo instalações, área $\left(\mathrm{m}^{2}\right)$ e custo por $\mathrm{m}^{2}$.

\footnotetext{
${ }^{151}$ Carta de Adalberto Mendes dos Santos, Diretor Executivo do Fundo ao Vice-Reitor em exercício Alfredo Buzaid, de 30 de junho de 1969. Processo USP n. 69.1.12921.1.7, fls 9-12.

${ }^{152}$ Carta de Adalberto Mendes dos Santos, Diretor Executivo do Fundo ao Vice-Reitor em exercício Alfredo Buzaid, de 1 de julho de 1969. Processo USP n. 69.1.12921.1.7, fls, 14-19.
} 


\begin{tabular}{|c|c|c|c|}
\hline \multicolumn{4}{|c|}{ CUSTO DAS OBRAS EM JUNHO DE 1969} \\
\hline Obras, inclusive instalações & Área $\left(\mathrm{m}^{2}\right)$ & Custo (NCr\$) & Custo / $\mathrm{m}^{2}$ \\
\hline Conjunto residencial bloco $\mathrm{G}$ & $4.884,00$ & $364.276,35$ & $74,59 \quad(1)$ \\
\hline Acelerador Linear "Mark II" & 346,00 & $228.231,25$ & 659,63 \\
\hline Faculdade de Arquitetura e Urbanismo & $18.660,00$ & 4.926.209,01 & $264,00 \quad(2)$ \\
\hline Edifício do Dep. de Minas & $8.243,00$ & $789.060,77$ & 95,72 \\
\hline Lavanderia do Conj. Residencial & 820,00 & $210.384,05$ & 256,57 \\
\hline Ambiente dos Alunos Metalurgia e Caixa d'água & 456,00 & $118.400,66$ & 259,65 \\
\hline Pavilhões para oficinas e Almoxarifado Central & $5.400,00$ & $753.503,03$ & 139,54 \\
\hline Administração da FFCL & $4.370,00$ & $1.126 .250,19$ & 257,72 \\
\hline Computador Digital da Física & 320,00 & $27.140,48$ & 84,81 \\
\hline Semi-Industrial Provisório & 391,00 & $6.528,61$ & 16,70 \\
\hline Pavilhões da Faculdade de Odontologia & $3.600,00$ & $505.644,95$ & 140,46 \\
\hline Ampliação do Edifício de Botânica & 124,00 & $30.791,06$ & 248,32 \\
\hline Pavilhões FMV - FFCL - ECC - FM & $27.450,00$ & $6.729 .914,54$ & 245,17 \\
\hline Botânica Genética & $6.922,80$ & $21.101,70$ & 3,05 \\
\hline E.T.A Fundo & $1.961,40$ & $11.050,27$ & 5,63 \\
\hline Instituto Oceanográfico & $11.752,00$ & $1.042 .811,76$ & 88,73 \\
\hline Conjunto das Químicas & $44.352,00$ & $204.673,61$ & 4,61 \\
\hline Dep. Eng. Mecânica - Laboratórios & $17.200,00$ & $60.778,30$ & 3,53 \\
\hline Laboratório de Hidráulica & $5.730,00$ & 1.032.298,74 & 180,16 \\
\hline Edifício das Fisiologias & $14.368,00$ & $1.068 .994,15$ & 74,40 \\
\hline Edifício das Histologias & $14.696,00$ & $15.426,27$ & 1,05 \\
\hline Biblioteca Dep. Mecânica - Poli & 800,00 & $2.715,07$ & 3,39 \\
\hline Cabine de Alta Tensão - Física & 56,00 & $8.650,86$ & 154,48 \\
\hline 16을atalhão Policial & $2.370,00$ & 342,76 & 0,14 \\
\hline Dep. De Metalurgia & $7.128,00$ & $22.854,50$ & 3,21 \\
\hline Abrigo da Cada da Caldeira - Química & 12,76 & $1.035,22$ & 81,13 \\
\hline Almoxarifado de materiais inflamáveis e explosivos & 70,00 & $15.653,49$ & 223,62 \\
\hline Edifício Laboratório Didáticos da Física & $1.500,00$ & $216.838,38$ & 144,56 \\
\hline Reservatório Geral de Água & $2.500,00$ & $5.684,13$ & 2,27 \\
\hline Cabine Setorial B - FFCL & 44,00 & $63.665,73$ & $1.446,95$ \\
\hline Acelerador Eletrostático Pelletron & $6.964,00$ & $524.022,37$ & 75,25 \\
\hline Cabine n. 3 p/ Pavilhões & 28,00 & $6.974,79$ & 249,10 \\
\hline Reforma restaurante CRUSP & $2.485,00$ & $7.035,45$ & 2,83 \\
\hline Ampliação Barracão Semi-Industrial - FFB & 90,00 & $1.292,53$ & 14,36 \\
\hline \multicolumn{4}{|c|}{$\begin{array}{l}\text { Em cinza, obras em andamento. (1) Computada apenas a despesa de } 1968 / 69 \text {, pois os gastos anteriores estavam } \\
\text { sendo apurados. (2) As divisões efetuadas após a entrega levaram a um acréscimo de } 244,00 \mathrm{NCr} \$ / \mathrm{m}^{2} \text { para } 264,00 \\
\mathrm{NCr} \$ / \mathrm{m}^{2} \text {. Fonte: Processo USP n. } 69.1 .12921 .1 .7 \text {, fls. } 20-21\end{array}$} \\
\hline
\end{tabular}


Em dezembro de 1969 Adalberto Santos foi dispensado do cargo de Diretor Executivo do Fundo pelo novo reitor da USP, Miguel Reale, que designou em seu lugar, o arquiteto Luciano Bernini. O órgão foi reestruturado sob a denominação de Fundusp, sinalizando o foco nas necessidades da universidade em seus diversos campi. A nova administração implantou um sistema modular de planejamento e construção supostamente mais adequado à transitoriedade das funções na universidade, sua expansão e inconstância orçamentária. Ao invés de diminuir o Escritório Técnico aumentou, exportando sua tecnologia de planejamento para outros campi da USP, como o de São Carlos, Bauru, Ribeirão Preto, Piracicaba, e de outras universidades do país, como as Federais de Sergipe e de São Carlos. ${ }^{153}$

\footnotetext{
${ }^{153} \mathrm{O}$ arquiteto Luciano Bernini sistematizou o planejamento de campi universitários em um trabalho que serviu de referência: BERNINI, Luciano. Planejamento Físico de campi Universitários e sua aplicação prática. S.I. Interessante notar que não foi a primeira vez que a USP colaborou no planejamento de outras universidades. Em 1955, o governo do Estado de Santa Catarina contatou a reitoria da USP buscando auxílio para o planejamento da Cidade Universitária da Universidade de Santa Catarina numa área de 92 ha. Hélio Duarte e Ernest Mange foram indicados e contratados em setembro de 1955. O projeto, desenvolvido com os arquitetos Vicente Collet e Silva, Ariaki Kato e Léo Quaji Nishikawa foi entregue em janeiro de 1956 e aprovado em janeiro de 1957, porém apenas o sistema viário e parte do zoneamento foram utilizados. Ver: DUARTE, Hélio de Queirós. Plano da Cidade Universitária de Santa Catarina. Florianópolis: Universidade de Santa Catarina, 1957.
} 


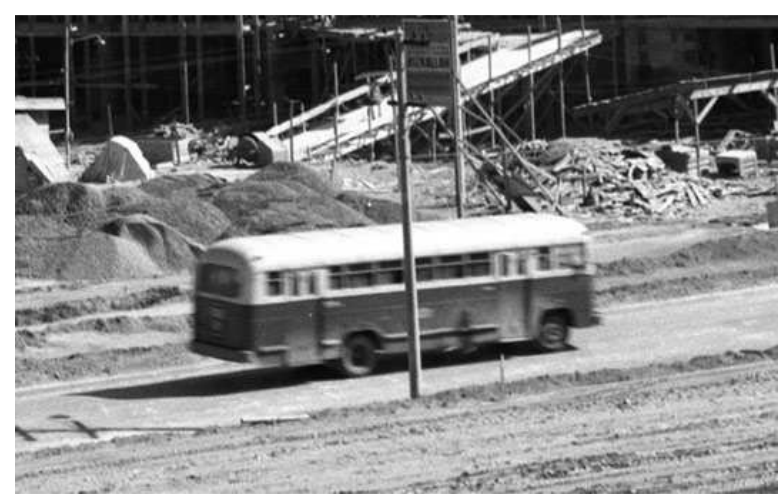

Ônibus circula por trecho em construção da Cidade Universitária, no ano de 1964 (Foto: Acervo CCS/Jornal da USP)

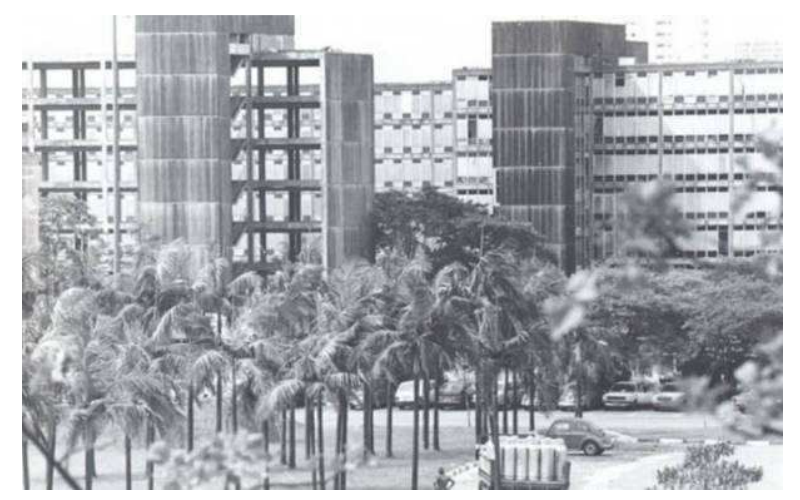

CRUSP. Foto: Rolando de Freitas/Estadão

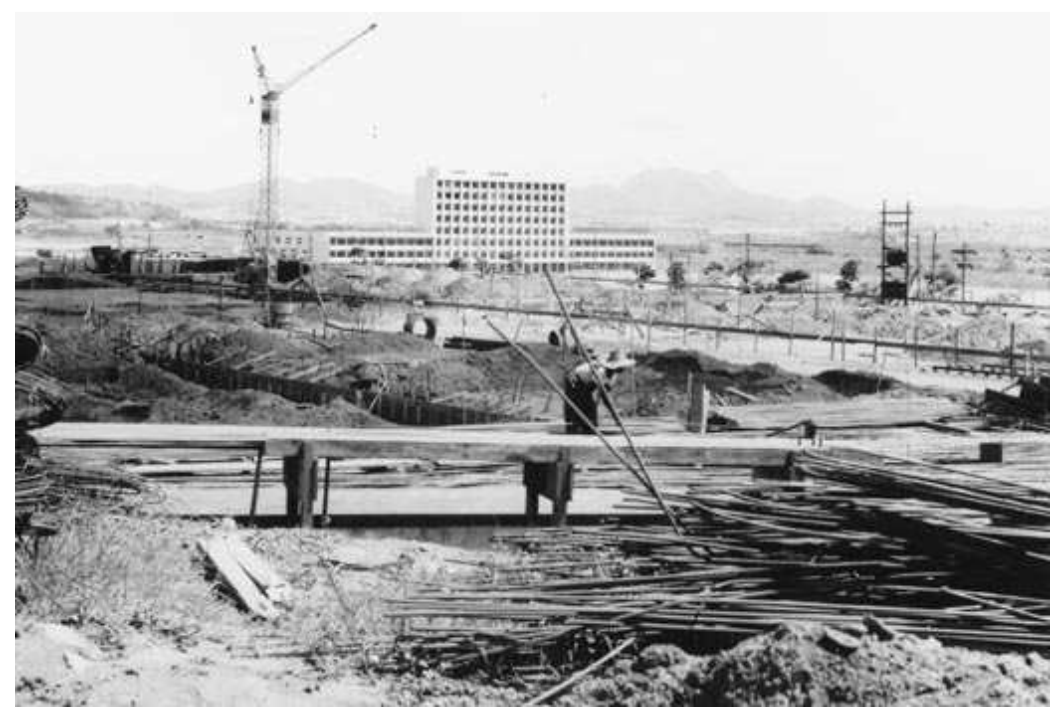

A construção do prédio de geografia e história em 1964. Acervo CCS/Jornal da US

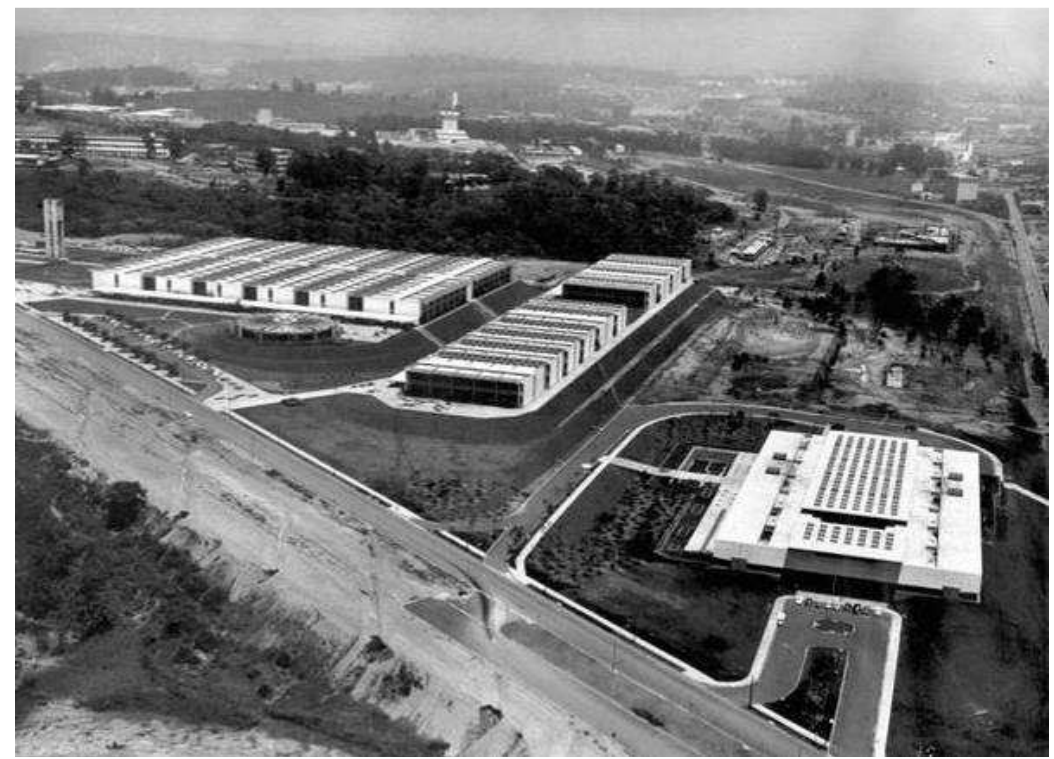

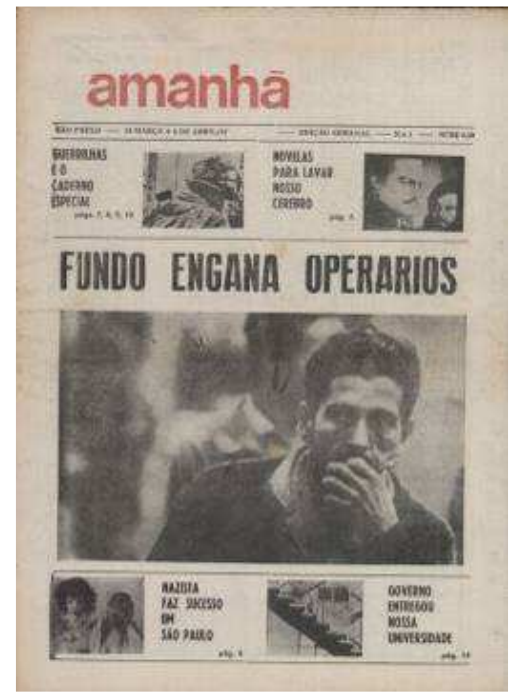

Capa do primeiro número do jornal Amanhã, do Grêmio de estudantes da Faculdade de Filosofia, 1967.

Conjunto das Químicas e Departamento de História e Geografia, c.1967. Arquivo: SEF 


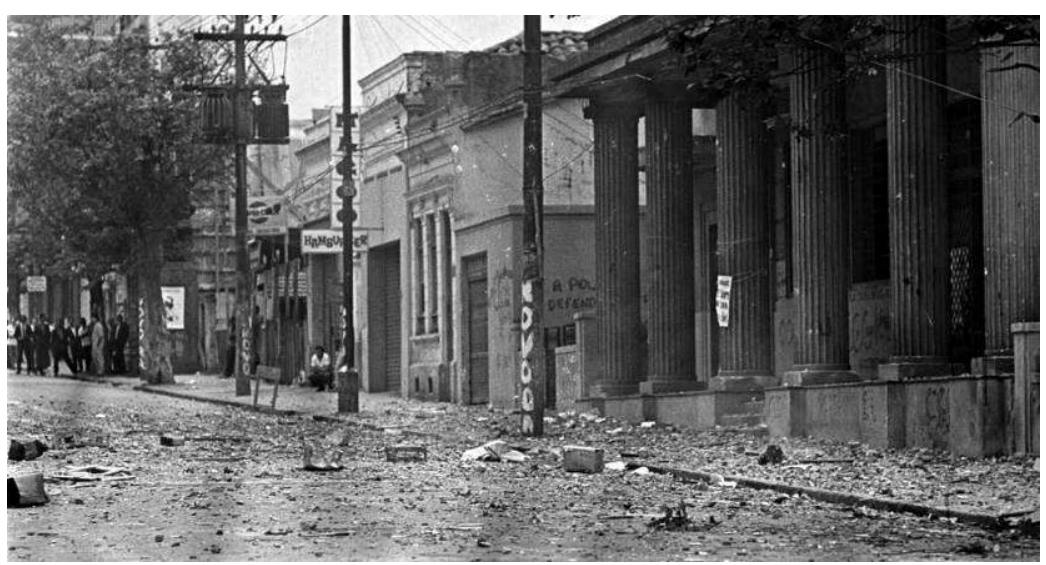

Batalha da Rua Maria Antônia, 1968. Acervo UH/Folhapress

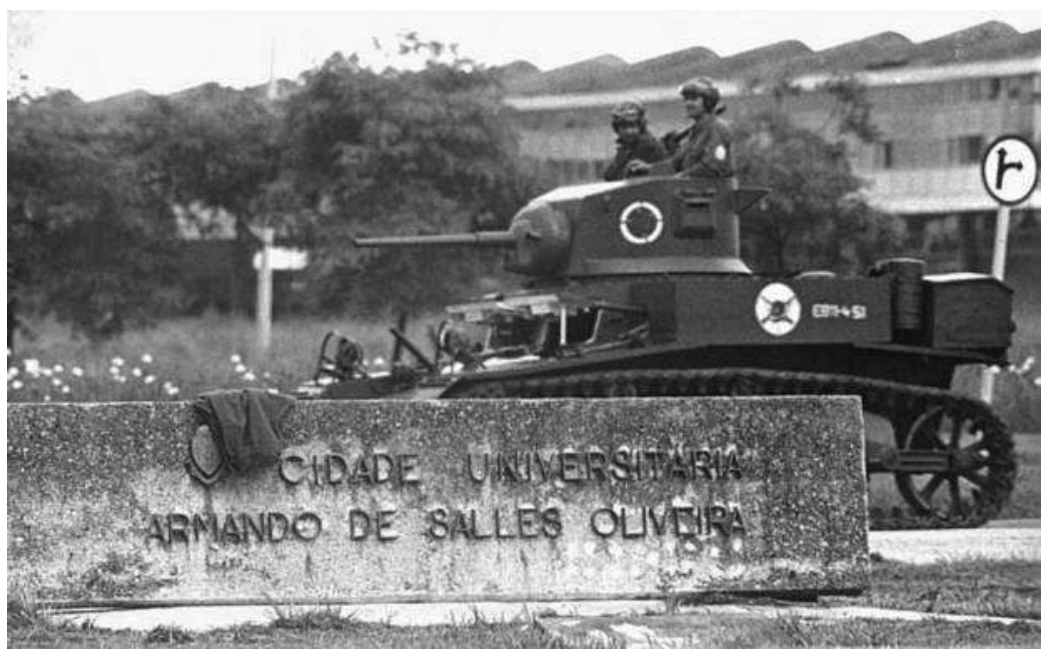

Tanques invadem o campus da USP. Quatro dias após o Al- 5 o Conjunto Residencial dos estudantes da USP foi invadido pelo exército. Arquivo: Estadão

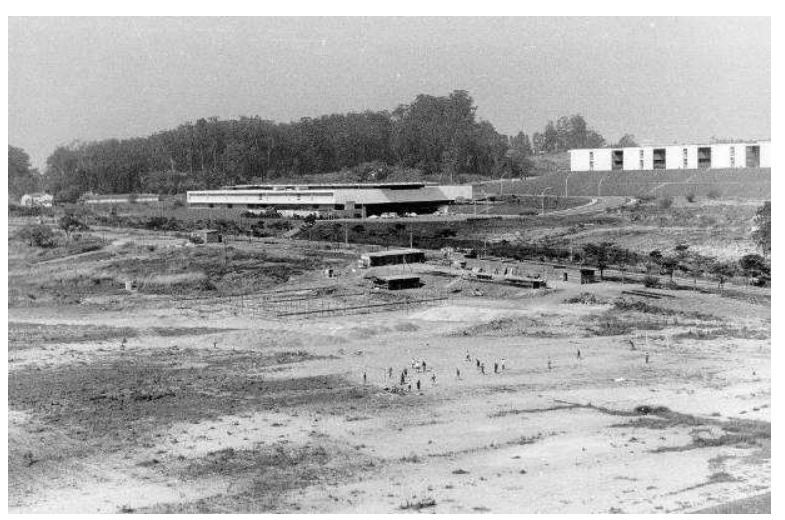

Campo de futebol no canteiro de obras. Acervo SEF

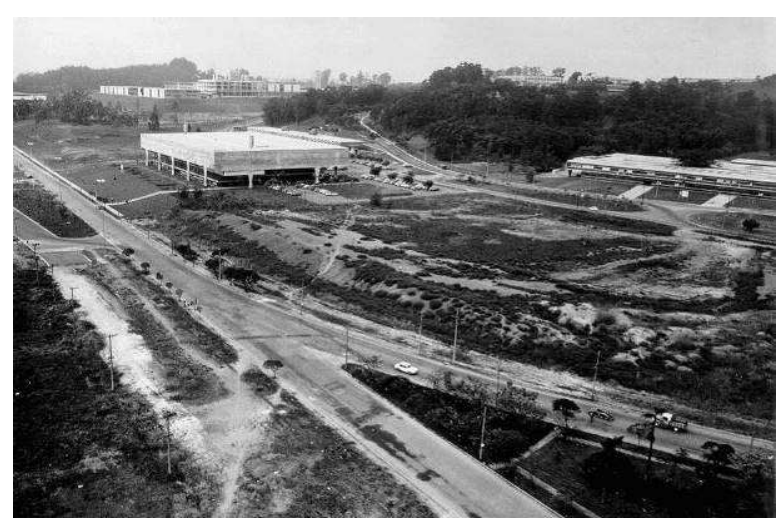

Edifício da Faculdade de Arquitetura e Urbanismo. Acervo SEF 


\section{PROJETOS NA CIDADE UNIVERSITÁRIA 1963-1969}

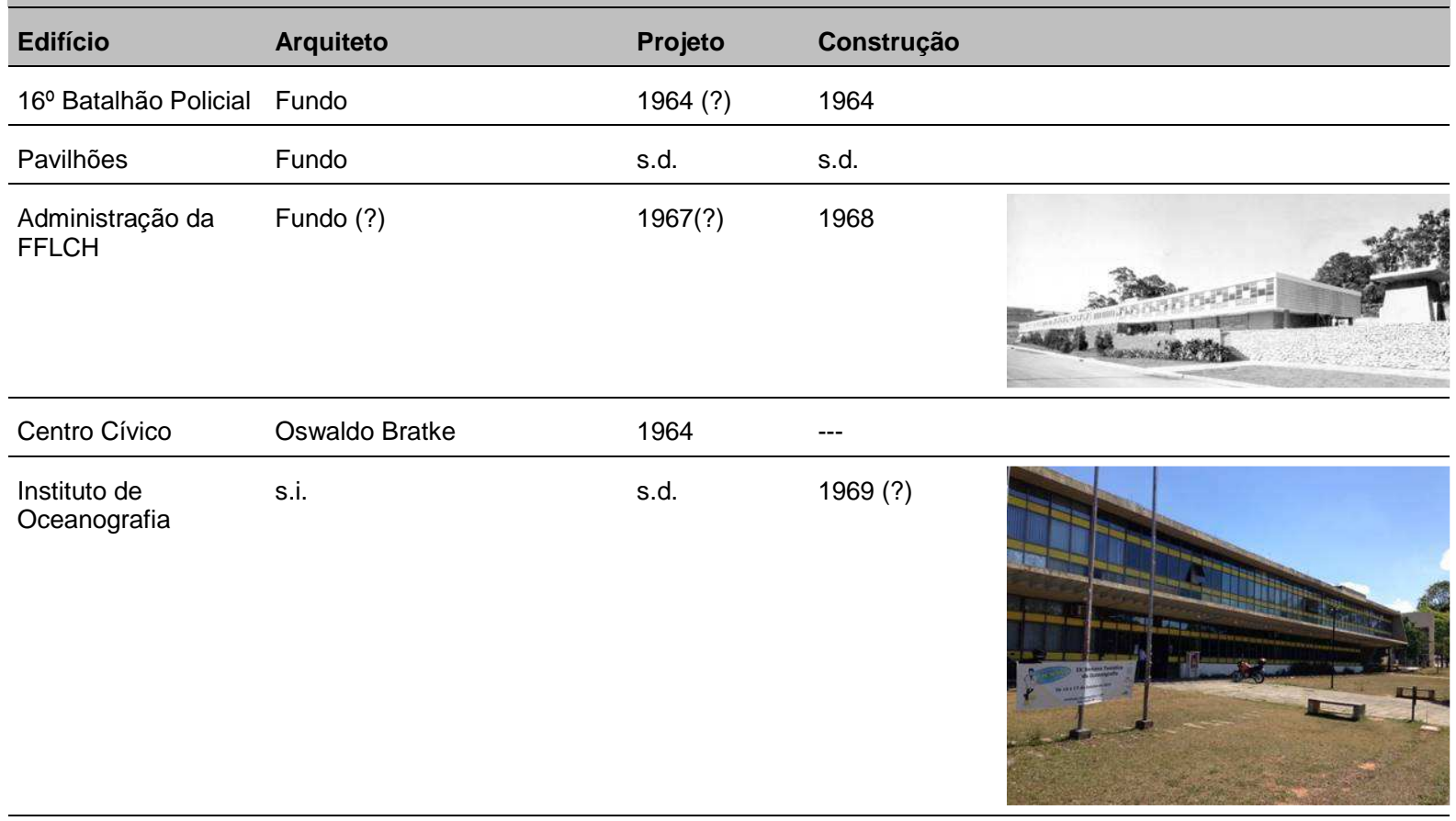

Ttabela elaborada a partir da sistematização de dados dispersos na bibliografia. Algumas informações podem ser contraditórias. 


\section{PROJETO E CONSTRUÇÃO DO EDIFÍCIO DA FAUUSP}

DESENHO (1960-1966)

\section{Encargo, diretrizes e partido}

Como vimos no capítulo anterior, os planos para a Cidade Universitária previam uma área para a Faculdade de Arquitetura e Urbanismo desde antes de sua criação. ${ }^{1}$ Mas os constantes adiamentos, alterações e falta de recursos para a execução dos planos impediam uma perspectiva clara da construção de um novo edifício para a FAU que, no mais, encontrava-se melhor instalada do que outras tantas unidades da USP. Foi apenas durante o Plano de 1961 conduzido por Paulo de Camargo e Almeida à frente do Fundo para Construção da Cidade Universitária e pelo diretor da FAU, Anhaia Mello, à frente do Conselho Administrativo do Fundo que o conjunto de edifícios, na Cidade Universitária, incluindo o da FAU, foram projetados por arquitetos autônomos a partir de um acordo entre O IAB e os planejadores do PAGE.

A instalação da FAU na Vila Penteado, em 1949, não foi provisória, como durante o período em que ficou abrigada na Escola Politécnica, logo após sua criação. Na verdade, até o início da década de 1960 não parecia haver insatisfação com o palacete em Higienópolis. O

\footnotetext{
${ }^{1}$ Desde o Decreto 6.283/34, que criou a USP, até 1943, os planos para a Cidade Universitária previam uma "Escola de Belas Artes". No plano Accuratus, de Gustavo H. Pujol Jr., de 1945, eram previstas uma "Escola de arquitetura" e um "Instituto de Belas Artes". No plano de 1947, havia uma "Faculdade de Arquitetura" e uma "Escola Superior de Artes". No plano de 1949, quando a FAU já havia sido criada, havia apenas uma área destinada para "Belas Artes e Arquitetura". Os estudos de Pujol (1951) e de Neves (1952) para o Setor de engenharia previam uma área para a Faculdade de Arquitetura e Urbanismo do outro lado da avenida, de frente para a Politécnica.
} 
sentimento de inconformidade com a Vila Penteado surgiu gradualmente, paralelamente ao amadurecimento do debate sobre a reforma do ensino de arquitetura e urbanismo. Entre os principais problemas estava a falta de espaço, principalmente no ateliê, divido pelos cinco anos do curso. Mas nem por isso, alunos e professores deixaram de manifestar afeto e admiração pelo edifício da Carlos Ekman. Ao que tudo indica, os corpos discente e docente estavam perfeitamente adaptados à vida universitária no bairro de Higienópolis.

Se por um lado o projeto de um novo edifício para a FAU foi precipitado pelo planejamento da Cidade Universitária, por outro lado, foi também, em grande medida, uma iniciativa de Vilanova Artigas e Anhaia Mello que divergiam da estratégia predominante no movimento nacional de reforma do ensino. A proposta de Artigas pretendia precipitar a reforma do ensino dentro e apesar da estrutura vigente. Nesse sentido, a estratégia de buscar a mudança do ensino através da arquitetura era uma missão de fé na profissão.

A autoridade de Artigas na FAU para liderar tal projeto contava com o apoio do diretor, de alguns professores, sobretudo os mais jovens e principalmente do corpo discente, como atestam as várias vezes em que ele foi escolhido paraninfo. $E$ isso era importante na FAU, onde os estudantes tiveram papel decisivo desde a criação da escola. Entre os professores, Artigas passou a ser mais respeitado após o Seminário de ensino promovido pelo grêmio em 1956, quando defendeu uma solução mínima, mantendo a estrutura de cátedras. No mesmo período, a obra de Artigas ganhou projeção nacional protagonizando uma contribuição "paulista" para os novos rumos da arquitetura moderna brasileira. Como exaluno e ex-professor da Escola Politécnica, Artigas também contava com algum apoio dos engenheiros catedráticos, que apesar das diferenças ideológicas, sempre foram defendidos por Artigas na FAU. Por fim, o arquiteto contava com apoio e admiração dos principais representantes das ciências humanas na escola como Mario Wagner da Cunha e Flávio Motta.

Com tudo isso, é significativo que somente após o projeto de Artigas encontramos manifestações reivindicando a urgência da construção de um novo edifício, que, de um lado, atenderia as necessidades cotidianas da faculdade, e de outro, expressaria a autonomia da profissão e o estado atual da arte. Desse modo, o projeto de Artigas contemplou duas agendas distintas, uma preocupada com a reforma do ensino e a arquitetura contemporânea, outra preocupada com as limitações da Vila Penteado para o funcionamento da escola, o descontrole disciplinar e a necessidade de expansão das vagas. De fato, a reivindicação da ampliação do ensino seria decisiva. Desde que o Estatuto da USP, de 1962, passou a exigir um número fixo de vagas no vestibular, o tema dos excedentes passou a ser seriamente discutido na FAU. Dadas as limitações de espaço, 
foram definidas 30 vagas, que era uma média da quantidade de alunos que a escola vinha formando desde sua criação. Porém, com um número fixo e o debate sobre a Reforma Universitária, que buscava massificar o ensino superior, veio a pressão pela ampliação das vagas, que passaram para 40 em 1967, quando a construção do novo edifício estava autorizada. A recusa do diretor da FAU Pedro Moacyr do Amaral Cruz em absorver os excedentes, contrariando portaria do governo federal, foi decisiva para seu afastamento naquele ano. Em 1968, com a promessa de mudança para o novo endereço no ano seguinte, foram abertas 80 vagas na Vila Penteado. A FAU foi inaugurada na Cidade Universitária, em 1969, com as 100 vagas e, no ano seguinte, a Congregação decidiu ampliar para 150 vagas - número que se manteve até os dias atuais. Ao longo de todo esse tempo, entre 1948 a 1969, a FAU conservou uma proporção baixa e praticamente constante de alunos por professor, variando de 1,8 (em 1951) a 2,99 (em 1969).

No que diz respeito ao ensino da FAU o projeto da Artigas guarda relações ainda não totalmente esclarecidas. Afinal se a Reforma de 1962 e os Fóruns de 1963 e 1968 parecem convergir com o projeto do edifício que continha, por exemplo, uma grande área de exposições, um piso para os departamentos, os ateliês abertos e o chamado Ateliê Interdepartamental, não há registros de menções ao projeto, que já estava concluído, quando estes eventos ocorreram.

Em meados de 1960, Artigas foi encarregado pelo FCCUASO de projetar o edifício da FAU e passou a frequentar as reuniões de coordenação presididas por Anhaia Melo na Vila Penteado. Nessas reuniões foram definidas diretrizes comuns em relação aos padrões de acabamento, distribuição dos programas funcionais e provavelmente outros aspectos, tais como dimensões gerais, sistemas de circulação e acessos, sistemas construtivos e outros. A concepção pavilhonar dos edifícios (plantas retangulares, volumes simples, poucos andares, níveis semienterrados e implantação isolada) para a Cidade Universitária era um reflexo da própria Universidade, composta de unidades independentes e isoladas. ${ }^{2}$

Com exceção de alguns projetos verticais, como a Matemática (Joaquim Guedes) ou o CRUSP (Kneese de Mello), a maioria dos projetos para o Plano de 1961-63 tinha poucos andares, o que pode estar relacionado à posição de Anhaia Melo contra a verticalização. Entre as diretrizes comuns estavam a continuidade interior/exterior; pátios ou jardins internos; corredores e rampas generosos, muitas vezes perimetrais, formando varandas; iluminação zenital e predominância de materiais construtivos aparentes. No setor das humanas, prevaleceu ainda a ideia do térreo livre, com funções coletivas, como lanchonetes

\footnotetext{
${ }^{2}$ Mesmo sem restrição de legislação urbanística ou edilícia, uma solução integrada, como a do Instituto Central de Ciências da UNB (1963), não podia ser concebida. Além do mais, na Cidade Universitária como no PAGE, privilegiou-se a distribuição dos projetos aos escritórios de arquitetura de São Paulo.
} 
e auditórios. A maioria desses itens pode ser notada nos projetos de Eduardo Corona, Pedro Paulo Saraiva e Paulo Mendes da Rocha, mas também no Setor Tecnológico, nos projetos de Fábio Penteado, Ernest Mange, Oswaldo Bratke, e mesmo no Centro Social de Rino Levi ou na Academia de Polícia de Ariosto Mila e equipe.

Ao que tudo indica, Artigas e os demais arquitetos assumiram seus projetos a partir dessas diretrizes e foram responsáveis pela organização dos programas de necessidades. Como afirmou o engenheiro do Fundo, Vladimir Brega, havia uma espécie de competição entre os arquitetos, "cada um querendo ganhar a taça, cada um fazendo uma coisa mais sofisticada, mais bonita que o outro". ${ }^{3}$ Nesse sentido, não apenas Artigas talvez fosse o mais brilhante daquela geração e estivesse no auge de sua carreira, mas era o mais familiarizado as necessidades materiais e simbólicas da faculdade, dispondo, desse modo, de uma condição excepcional fazer do edifício um monumento arquitetônico. Além disso, nenhum outro programa era tão apropriado para uma abordagem monumental quanto a faculdade de arquitetura, em si mesmo um tema autorreferente. Uma arquitetura para representar a própria arquitetura no conjunto da universidade e o ensino da arquitetura que se desejava no conjunto da arquitetura. Eis o prestígio e a responsabilidade envolvidos nesse projeto.

Não é possível afirmar com certeza a data em que Artigas começou a trabalhar no projeto. Os únicos croquis conhecidos são os chamados "riscos originais", pertencentes a um caderno de desenhos que foi publicado numa edição fac-símile. ${ }^{4}$ Contudo, estimamos que estes desenhos sejam do início de 1960, quando Artigas participava das reuniões com Anhaia Melo. As duas primeiras páginas dos croquis da FAU trazem um organograma simples da administração da escola e um quadro das matérias ensinadas ao longo dos anos. Em seguida os desenhos se sucedem alternando entre plantas, cortes, perspectivas e detalhes. Chama a atenção que já os primeiros croquis trazem uma hipótese de projeto bem definida e próxima da versão final, enquanto os croquis seguintes oscilam e se tornam menos claros - isso se as páginas estiverem em ordem cronológica, o que parece ser 0 caso. Entre um desenho e outro, algumas poucas anotações chamam a atenção, como a dúvida sobre "aulas teóricas dentro do atelier?" ou a alusão ao "STALIN TANK" ${ }^{5}$ A implantação não traz elementos significativos do terreno, nem mesmo a indicação do Norte.

\footnotetext{
${ }^{3}$ Depoimento de Vladimir Brega ao autor, realizado em 23 de fevereiro de 2011.

${ }^{4}$ ARTIGAS, João Batista Vilanova. Caderno dos riscos originais: projeto do edifício da FAUUSP. Edição fac-similar. São Paulo: FAUUSP, 1992. Esse caderno possui estudos de outros projetos que podem permitir uma datação mais precisa em futuras pesquisas. O estudo que se segue, por exemplo, é o da garagem de barcos do Clube Santa Paula.

${ }^{5} \mathrm{O}$ Stalin Tank foi um tanque de guerra soviético da $2^{\mathrm{a}}$ Guerra Mundial que se destacou por seu design compacto. Segundo depoimento de Jon Maitrejean ao autor, quando falava de brutalismo, Artigas usava referências militares da guerra fria em suas aulas, como casamatas. Nesse sentido, pode ser interessante observar as maquetes de navios de guerra de sucata que Artigas construía por hobby.
} 
Apenas uma vaga indicação da quadra e uma seta que indica o acesso permite supormos a orientação das plantas.

A análise dos desenhos sugere que Artigas buscava compatibilizar dois partidos que vinham sendo explorados em seus projetos recentes: de um lado, um prisma retangular com empenas cegas, suspenso por pilares; de outro, uma sequência de pórticos destacados na fachada - que a rigor poderia ser estendida ao infinito. Estes dois partidos sintetizavam a evolução de sua obra a partir de 1956: Casa Baeta (1956-57), Casa Rubens Mendonça (1958), Ginásio de Itanhaém (1959), Fórum de Promissão (1959), Casa José Mário Taques Bittencourt II (jun,1959), Ginásio Estadual de Guarulhos (jan,1960), vestiários e piscina do São Paulo Futebol Clube $\left(\right.$ ago, 1960). ${ }^{6}$

A seguir, buscamos analisar os croquis de Artigas para o edifício da FAU, mantendo a numeração das páginas do caderno.

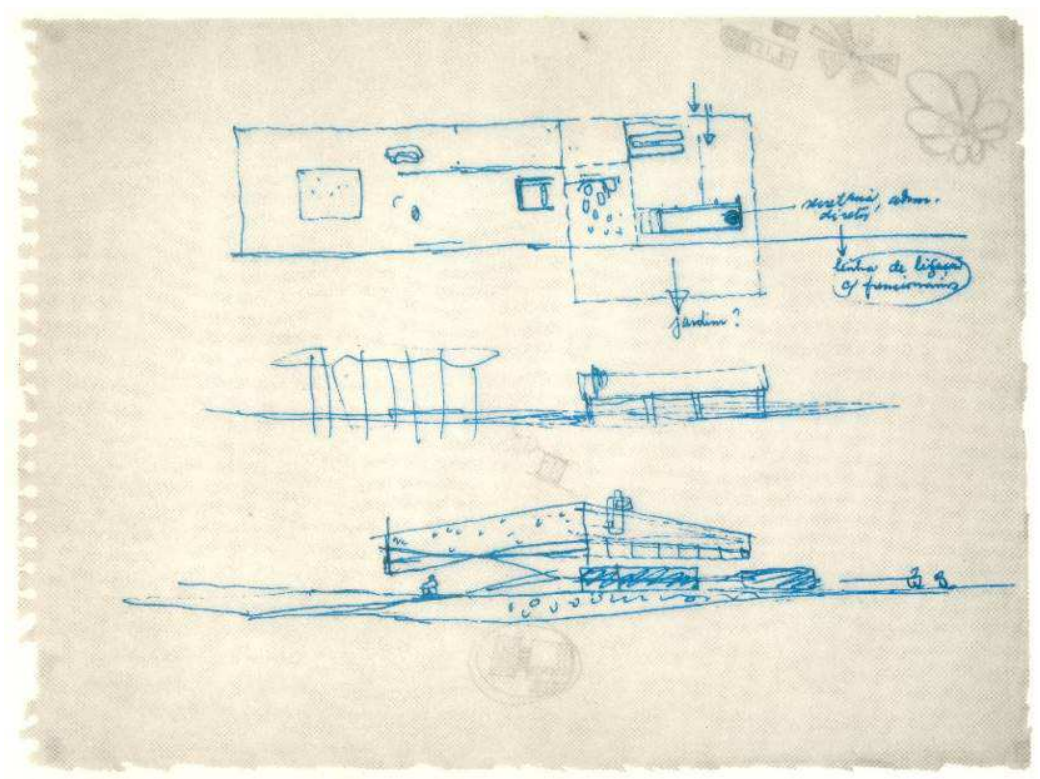

01. Um volume retangular subterrâneo (com um pátio), um térreo livre e um volume quadrado elevado, encerrado por empenas cegas. A posição da implantação corresponderia ao acesso no mesmo lugar de hoje. As rampas seriam inicialmente perpendiculares ao acesso. $O$ térreo abrigaria a secretaria, no subsolo o auditório e as oficinas, e o volume superior, com uma projeção em balanço, abrigaria as funções didáticas.

\footnotetext{
${ }^{6}$ Outros projetos desses anos, que foram executados e, portanto, deviam estar em construção durante a elaboração do projeto da FAU foram: Casa Leo Pereira Lemos Nogueira (jan,1959); Sede do Sindicato dos Trabalhadores nas Indústrias de Fiação e Tecelagem de São Paulo (jan,1959); Pavilhão Industrial da Perfumaria San Dar S.A., de Wolfang Marone, Ary Fachada e João Batista de Almeida (jul,1959); Casa Antônio Galvão Bueno Trigueirinho e reforma de sua peixaria e sua empresa Napesca (dez,1959 a 1960); Reforma do interior do Edifício dos Supervisores (dez,1959) e do Centro Médico e Serviço de Assistência Social (fev,1960), ambos para a Petrobrás, em Cubatão.
} 

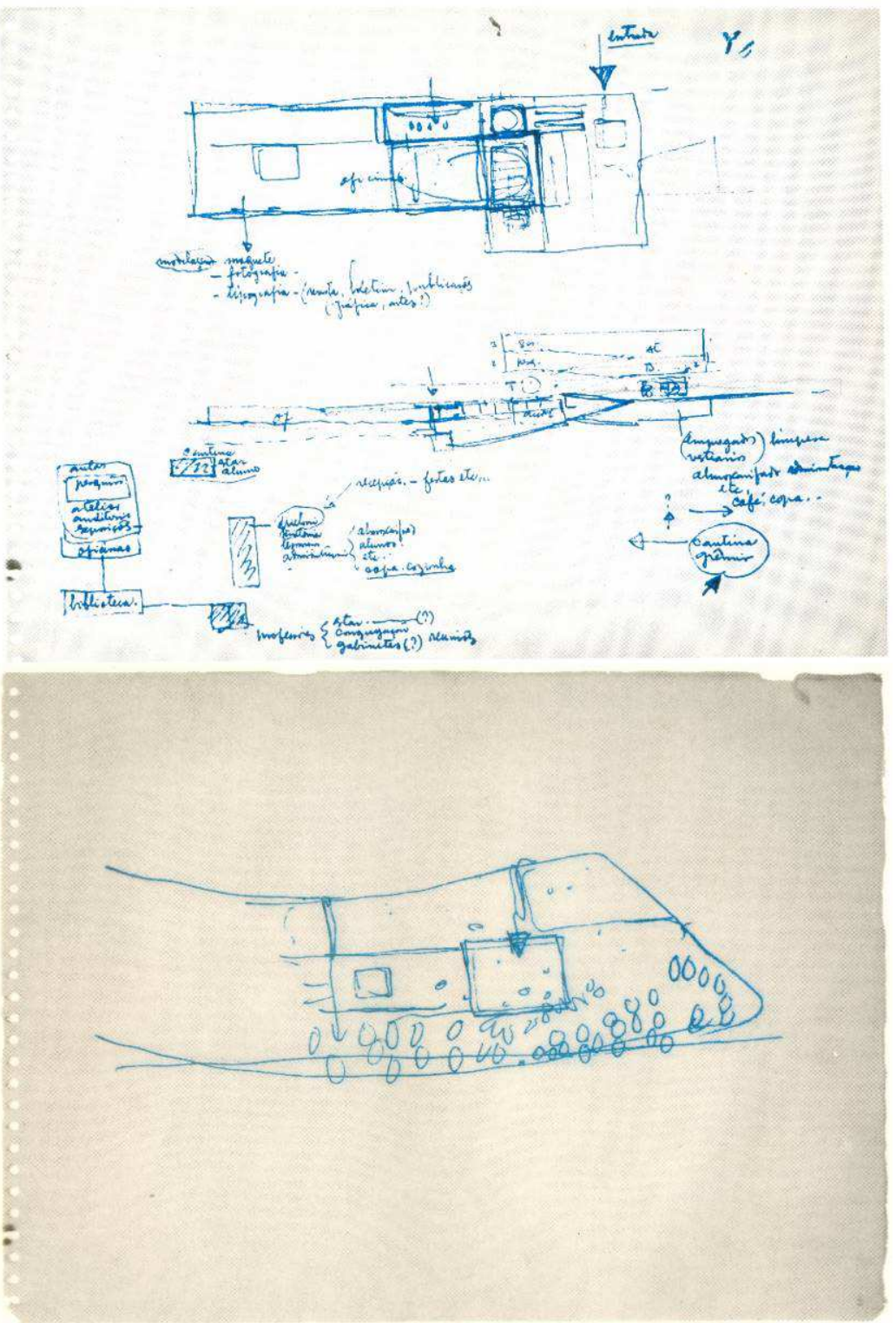

c

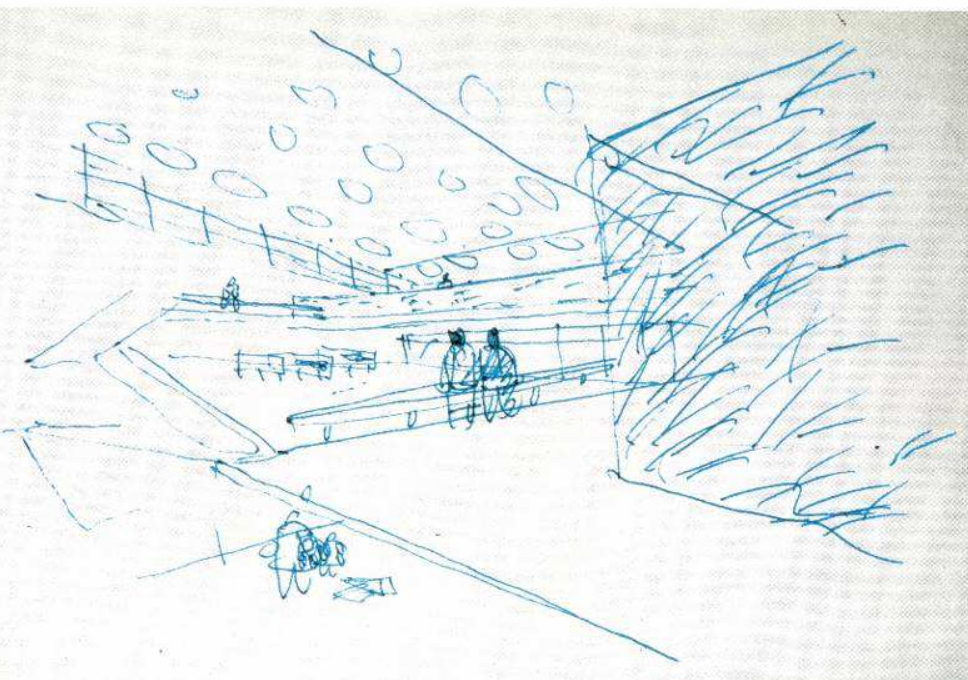

02. Planta do subsolo, com um corte que mostra o auditório a as oficinas. Nessa hipótese inicial, o eixo do desnível seria

perpendicular ao atual. $\mathrm{A}$ distribuição do programa era muito semelhante, nos oito meioníveis: -2 funcionários; -1 oficina e auditório; 0 acesso e

secretaria; 1 cantina e estar; 2 biblioteca; 3 pesquisa; 4 ateliê; 5 aula.

03. Implantação do mesmo estudo, indicando um bosque nos fundos da FAU.

04. Essa perspectiva interna se refere ao mesmo estudo. $O$ observador estaria sobre a lajevaranda da oficina, meio nível acima do nível da rua. O fosso sob a cobertura em grelha seria o foyer do auditório. 


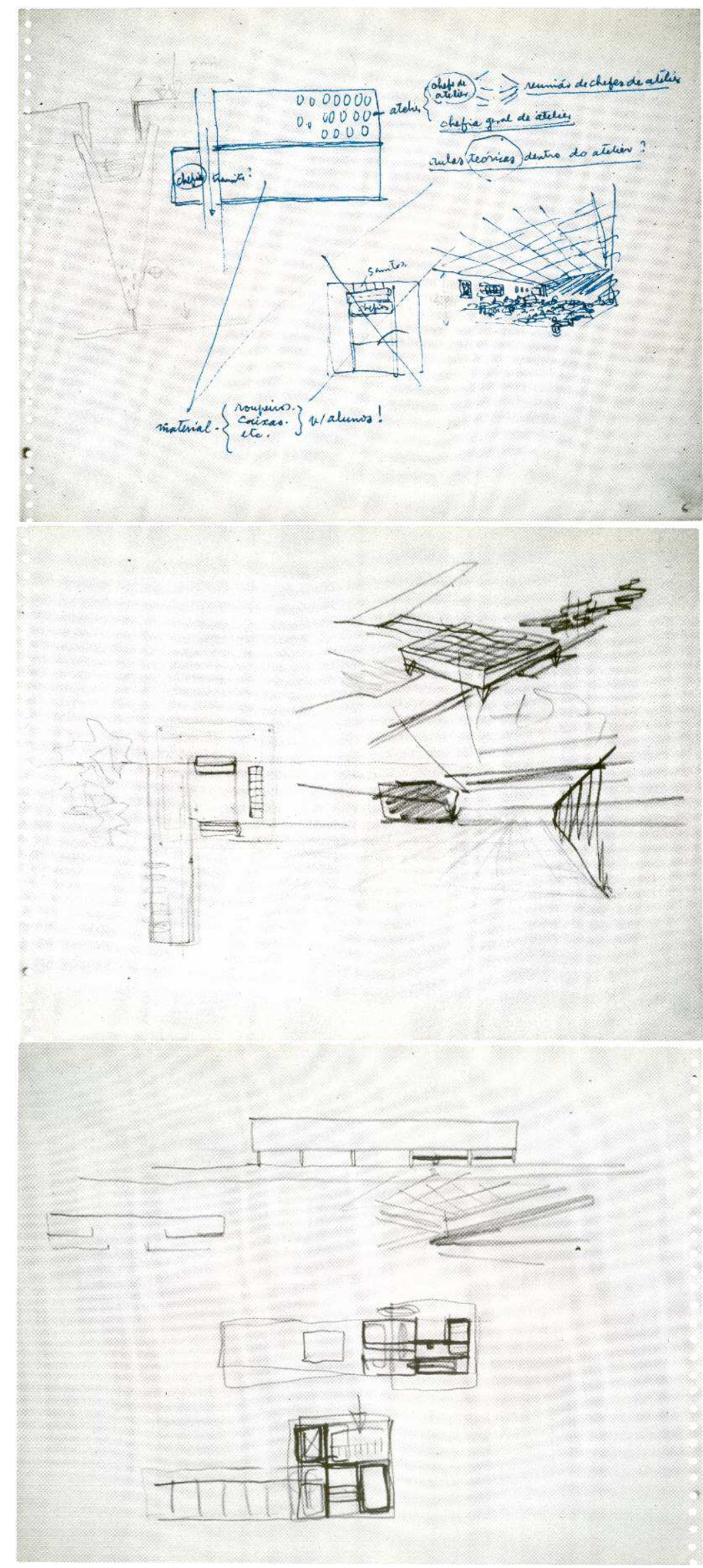

07. Nesse desenho, Artigas estuda o programa dos ateliês, que deveriam ter sala para 0 chefe do ateliê e um ambiente para materiais dos alunos. A perspectiva mostra trabalhos expostos nas paredes.

09. A perspectiva externa revela uma variação no alinhamento do volume elevado em relação ao volume enterrado das oficinas. Aqui aparece pela primeira vez a preocupação com os pilares na fachada. A planta quadrada definida em torno de um vazio central. A administração aparece paralela ao acesso, desobstruindo a continuidade do piso em direção ao jardim.

10. O corte confirma a concepção do vazio central, ainda que sem o desnível de meio nível. A preocupação com a fachada aparece, porém desconexa com os estudos em planta. De alguma forma, Artigas parece querer compatibilizar a ideia da empena cega destacada do solo, mas, ainda se mostra indeciso em como tratar os pilares. 

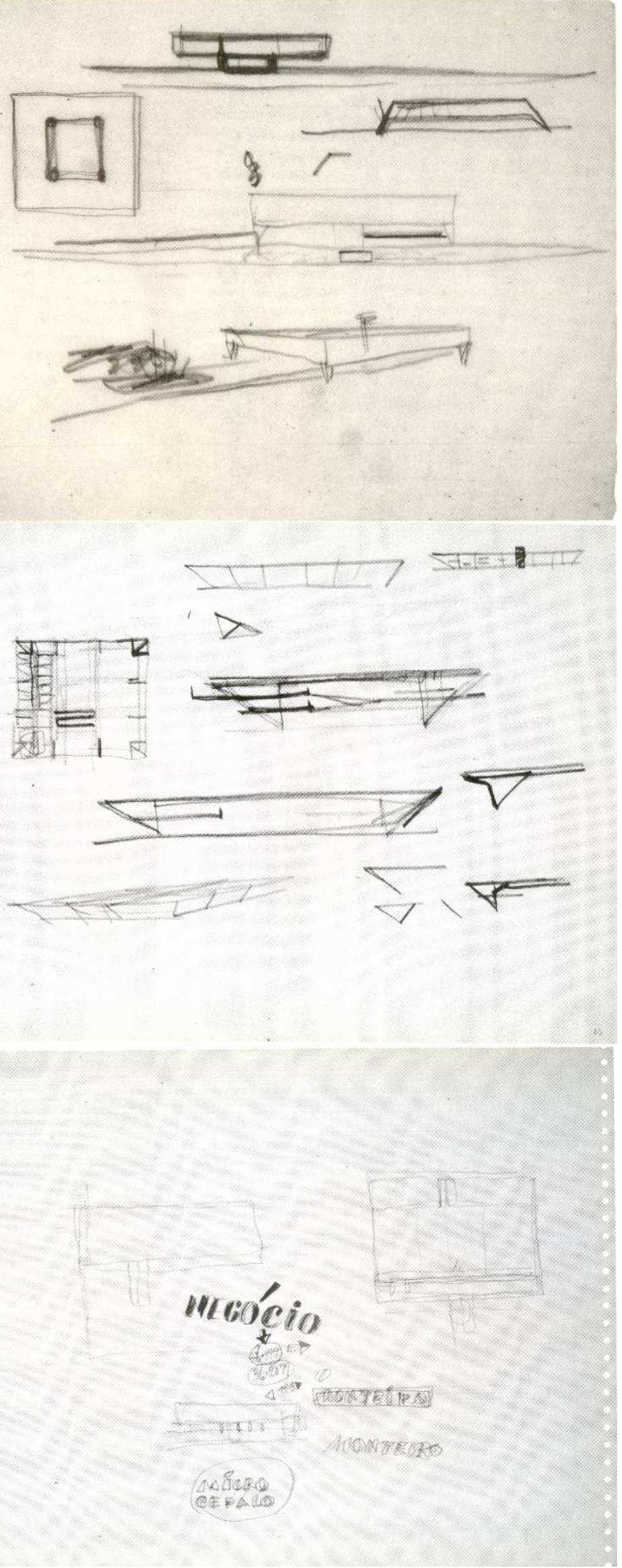

11. Nesses desenhos vemos uma concepção estrutural com pilares nos quatro cantos do prisma elevado, enquanto o corte e a planta especulam a possibilidade de quatro pilares centrais. A série de desenhos que se sucedem, buscando um partido baseado na repetição de pórticos resultará em plantas retangulares e menos pavimentos.

12. Nesses desenhos fica clara a tentativa de compatibilizar a volumetria geral, quadrada, com os pórticos e pilares que Artigas usou em Itanhaém, que, de certo modo, são resultado dos esforços estruturais. Esse estudo lembra o MAM do Rio de Janeiro. Porém Artigas parece incerto em como estabelecer uma volumetria pura e rígida com esse partido, que teria varandas ao invés de uma empena cega para o exterior.

15. Nesse ponto, Artigas parece ter atingido algum tipo de crise com seu partido inicial, e começa a explorar outras variações. Rampa aparece paralela ao eixo de acesso e adjacente ao volume principal. 


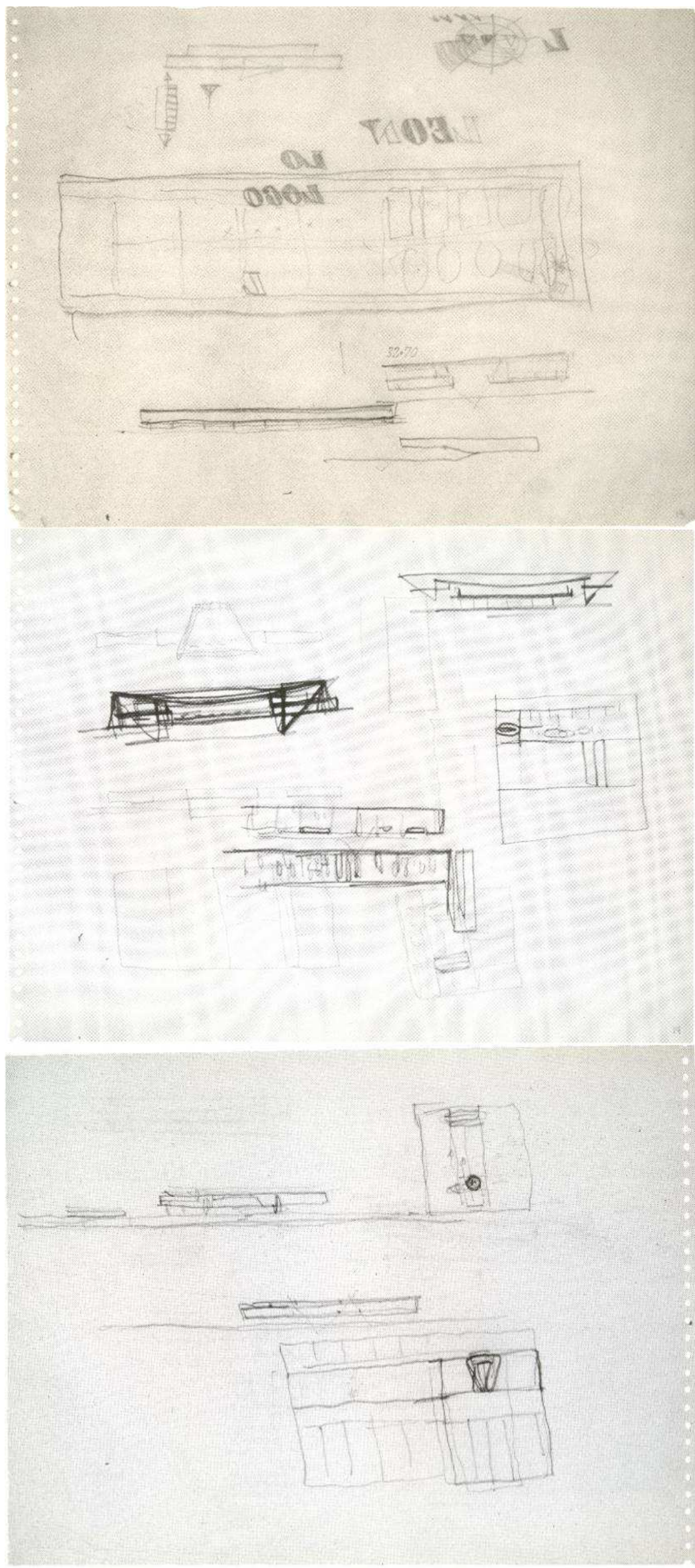

16. Em algum momento, Artigas parece ter abandonado a ideia dos dois volumes e passou a explorar uma solução monolítica. O resultado, no entanto, era muito banal. O corte traz um esquema Split-level na longitudinal, com pilar triangular central. A repetição desse corte, no entanto, prejudicaria o vazio central.

17. Novamente a concepção do pórtico do MAM aparece claramente, agora com o desnível da laje central em relação às lajes perimetrais. $A$ rampa é posicionada paralelamente ao acesso.

18. Nessa elevação, Artigas parece explorar variações na empena cega, como as realizadas no Vestiário do SPFC. O corte retoma o pilar triangular central (e desenha um $V$ e um A). A ideia de uma rampa e uma escada caracol em lados opostos se torna mais clara. 

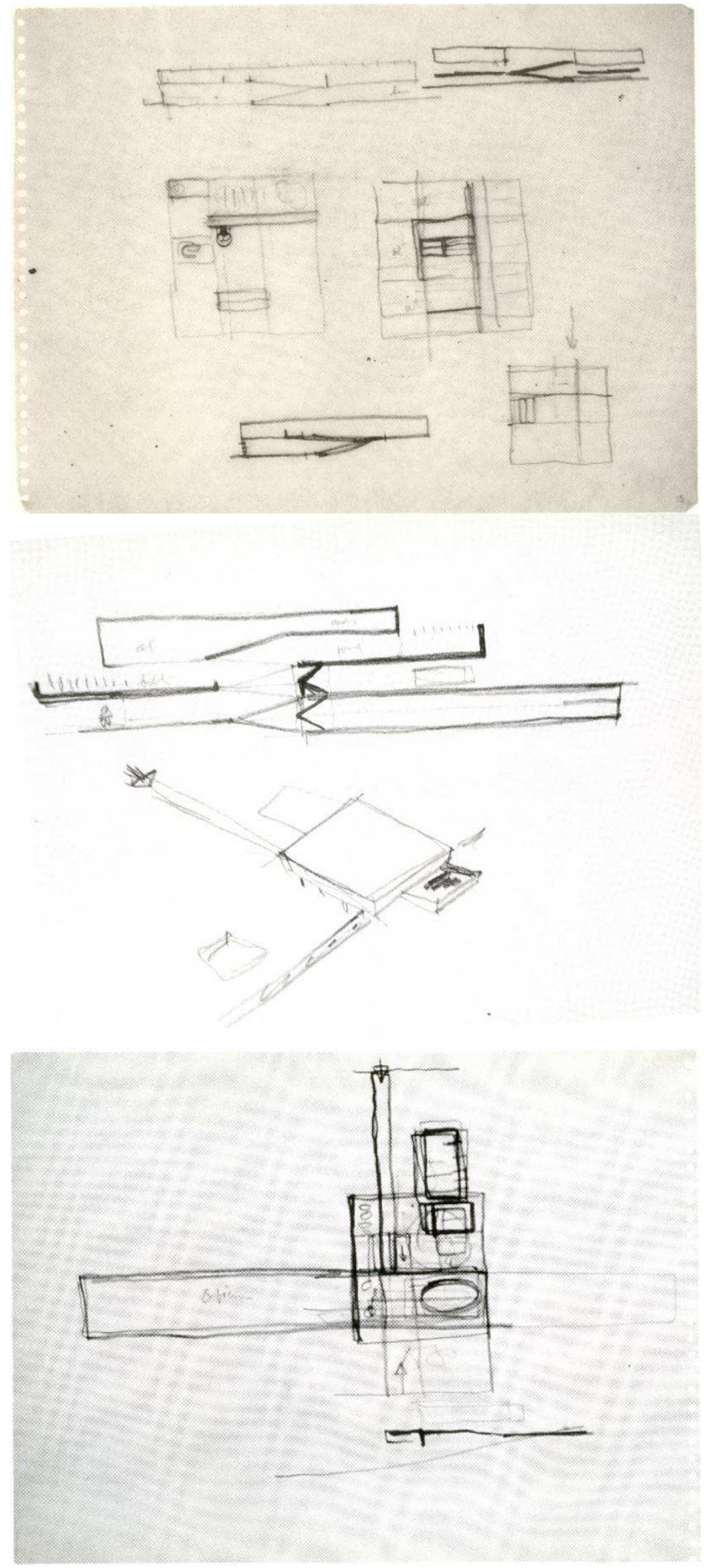

19. Nesse desenho aparece um corte combinando a solução de uma única cobertura, encerrada por empenas cegas, com o splitlevel.

20. Nesses desenhos e nos que se seguem, Artigas parece retomar as hipóteses inicias, sintetizando-as com as varandas que rompem a pureza volumétrica (a função seria iluminar os níveis intermediários). Seriam duas varandas, uma no nível da biblioteca, outra no nível "pesquisa". A questão dos pórticos é deixada de lado, e os pilares aparecem na fachada, porém com os cantos em balanço.

21. Essa seria a planta dos meioníveis térreo e subsolo. Há uma novidade importante: a rampa alinhada ao acesso e a possibilidade de continuidade com outro acesso no nível inferior. Esse é o partido do edifício ponte, desenvolvido, anos mais tarde na Rodoviária de Jaú. 

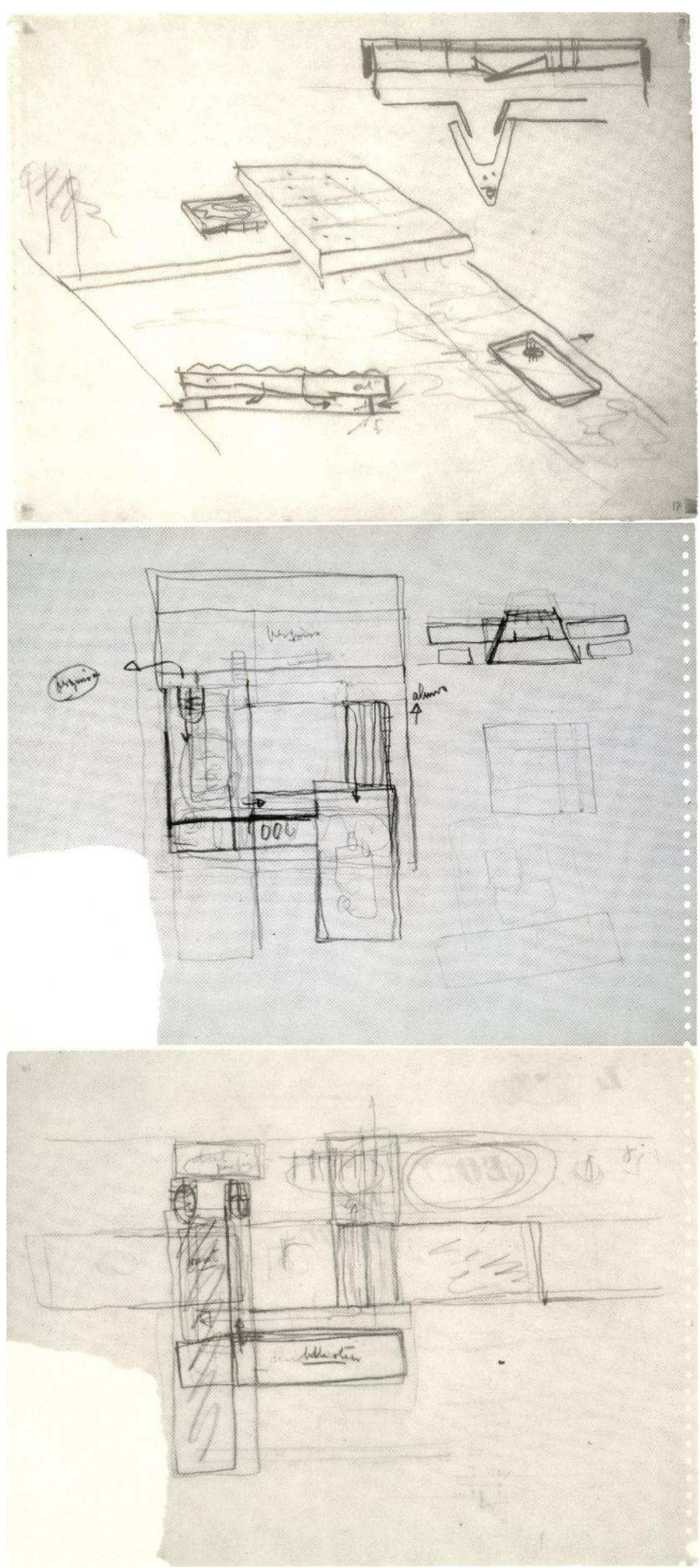

22. Nesse desenho, a pequena seta indica uma continuidade com a ideia anterior de acesso nos dois níveis. Aqui, porém, é enfatizado o eixo de acesso com palmeiras. O corte e o detalhe começam a demonstram o início de soluções para a cobertura contínua, totalmente translúcida. Artigas retoma a viga-calha, esboçada anteriormente.

24. Essa planta refere-se ao piso da "pesquisa". A sequência de plantas nas próximas folhas torna-se confusa, revelando a dificuldade em articular o programa dentro do partido estabelecido (ainda que a separação por pavimentos se mantenha).

25. Essa planta possivelmente se refere ao nível superior. Apenas podemos deduzir que o arquiteto buscava uma composição dos volumes funcionais de cada pavimento compatível com um sistema de circulação vertical. No retângulo horizontal inferior lê-se "laboratório" (?) e no superior "dep. profs." (?). O retângulo vertical está ilegível. 

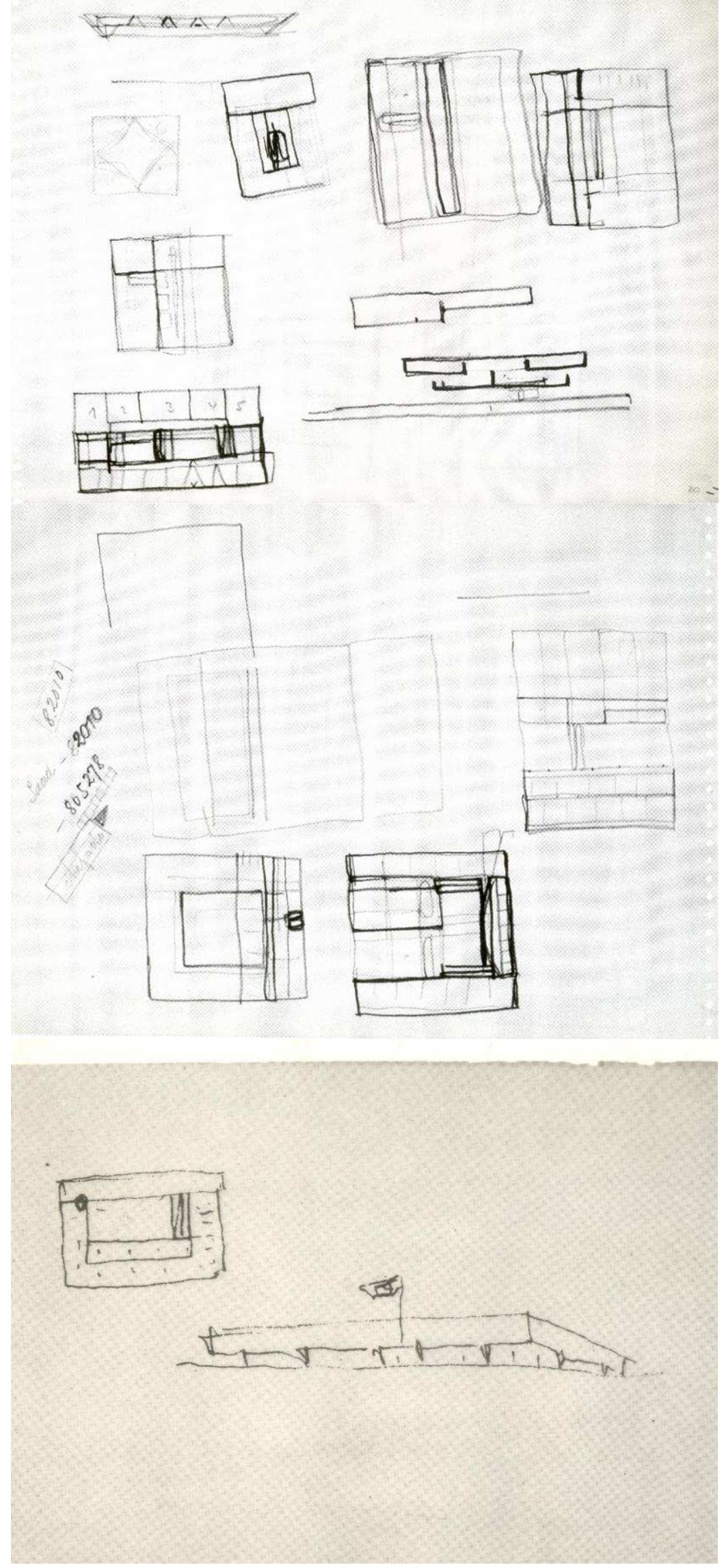

26. Finalmente, no último desses desenhos, no canto inferior esquerdo, a planta do piso dos ateliês e salas de aula aparece em sua estrutura definitiva, ainda que a posição das rampas variasse. Mas nada estava definido. $O$ corte à direita, sem 0 vazio central, revela que ainda havia muitas possiblidades para serem exploradas.

27. Além disso, Artigas continuava insistindo na planta quadrada, sem encontrar uma solução de acordo com a dimensão dos ambientes.

28. Esse croqui encerra a série sobre a FAU no caderno publicado, que traz em seguida croquis de outros projetos, como a Garagem de Barcos do Santa Paula late Clube. A planta retangular parece aceita e, mais importante, Artigas parece ter encontrado uma forma de compatibilizar a empena cega elevada do solo com a inclusão dos pilares na fachada. A planta aparece invertida com as rampas no lado sudeste. 


\section{Estudo Preliminar}

Após os "riscos originais", o primeiro conjunto de desenhos, que podemos chamar de estudo preliminar, traz o volume e as dimensões gerais definitivas do edifício, assim como seus oito pavimentos e sua modulação estrutural de 11 metros. Este estudo, realizado em quatro folhas, cada uma com a planta de um pavimento, não traz carimbo, cotas, detalhes ou anotações. Apenas o texto "FAU", o pavimento a que se refere e a indicação dos ambientes. Tais desenhos não estão datados, mas devem ser anteriores a abril de 1960, quando supomos que a versão seguinte foi concluída. Estes desenhos, contudo, foram nitidamente "passados a limpo" por um desenhista, de modo que, apesar de preliminares, não podem ser considerados desenhos de desenvolvimento do projeto - como devem ter existido outros, que não foram igualmente preservados, impossibilitando acompanharmos a passagem dos croquis ao estudo preliminar.

Apesar das semelhanças gerais, diferenças importantes com o edifício construído se fazem notar. A planta era invertida (espelhada), com as rampas e a entrada principal pelo lado direito da fachada de acesso (é inadequado chamar qualquer fachada de principal ou frontal); os pilares das fachadas laterais seguiam a modulação interna e o padrão das outras fachadas, com um pilar a cada 22 metros; paralelamente aos pilares centrais das fachadas laterais, dois pilares internos, um em cada lado da planta, conformavam um peristilo clássico - como diria Artigas; jardins eram previstos nas áreas correspondentes ao salão caramelo e ao foyer do auditório, como um prolongamento do exterior; e um jogo de volumes que se projetariam sobre a fachada "posterior" aparecia no nível dos departamentos (como reminiscências das varandas esboçadas nos croquis?).

A distribuição do programa também era diferente. A diretoria foi disposta no térreo e o grêmio meio nível acima, opostos diagonalmente. A cantina ficaria semienterrada, abaixo do grêmio, no nível das oficinas, porém aberta ao jardim interno. A biblioteca apresentava repartições internas e sua laje não se estendia ao lado das rampas. Apesar dessas diferenças, já é possível reconhecer praticamente todos os elementos do projeto construído. A ausência de corte ou planta de cobertura não permite compreendermos a solução para a cobertura. 


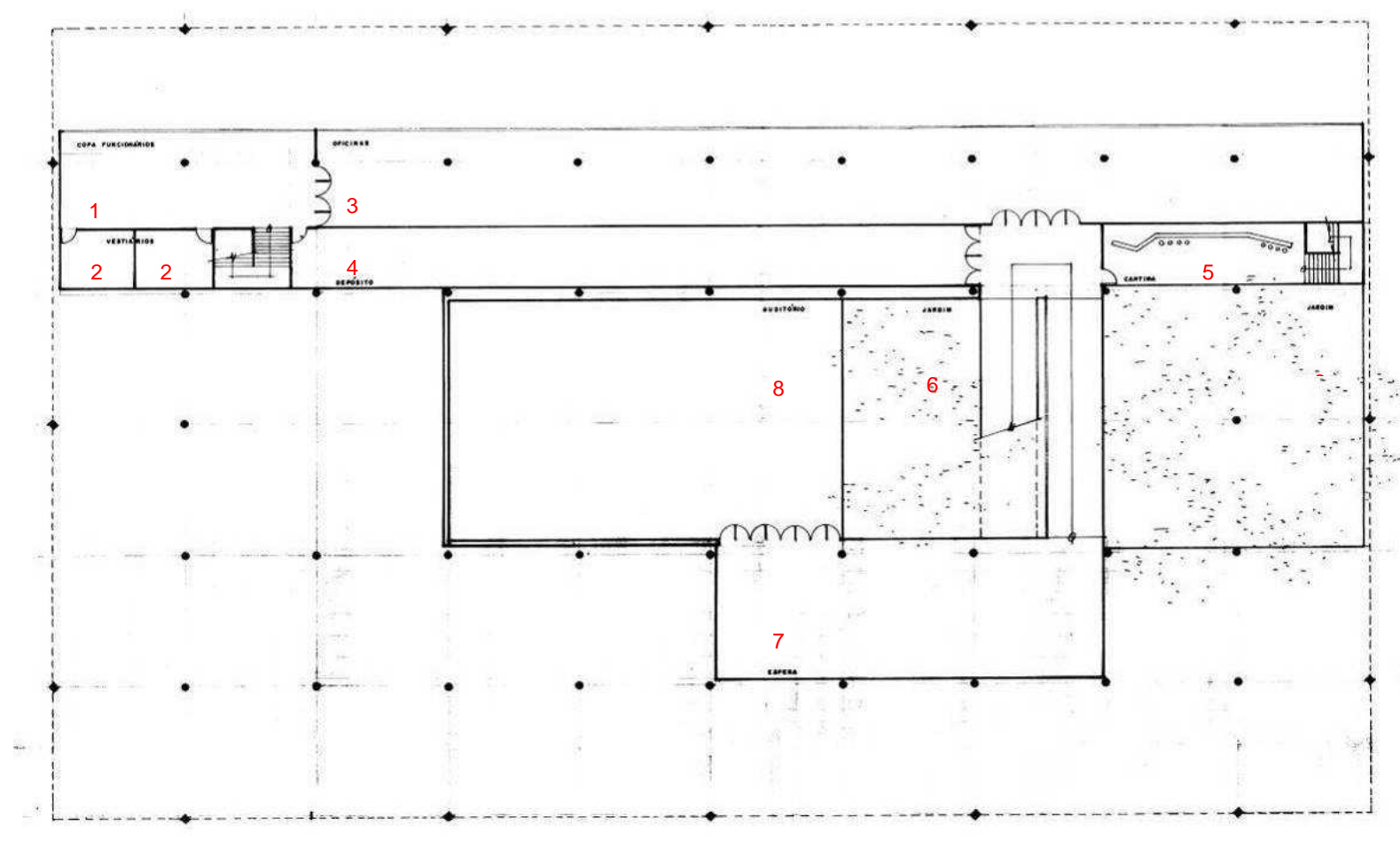

Planta do subsolo

1. Copa funcionários; 2. Vestiários; 3. Oficinas; 4. Depósito; 5. Cantina; 6. Jardim; 7. Espera; 8. Auditório

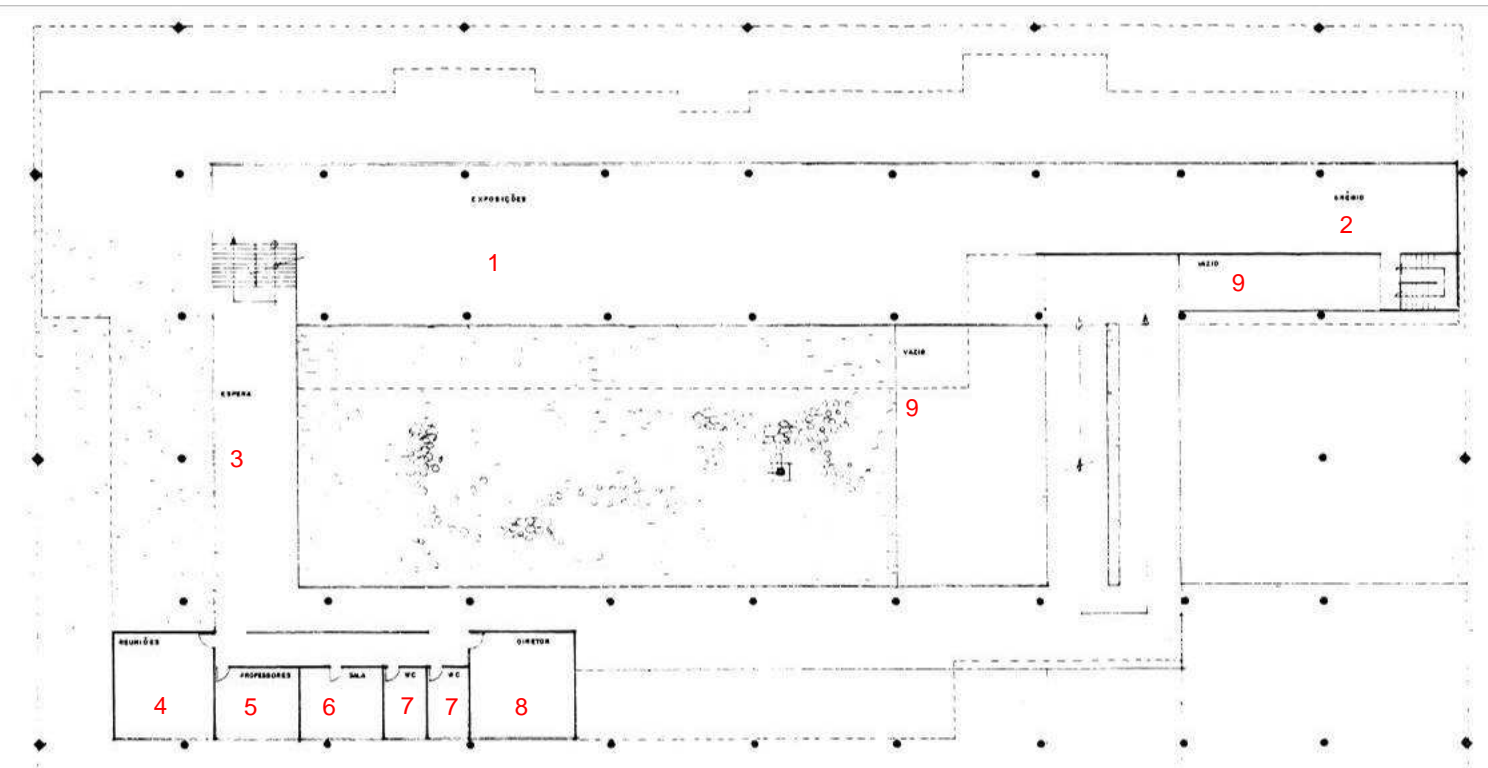




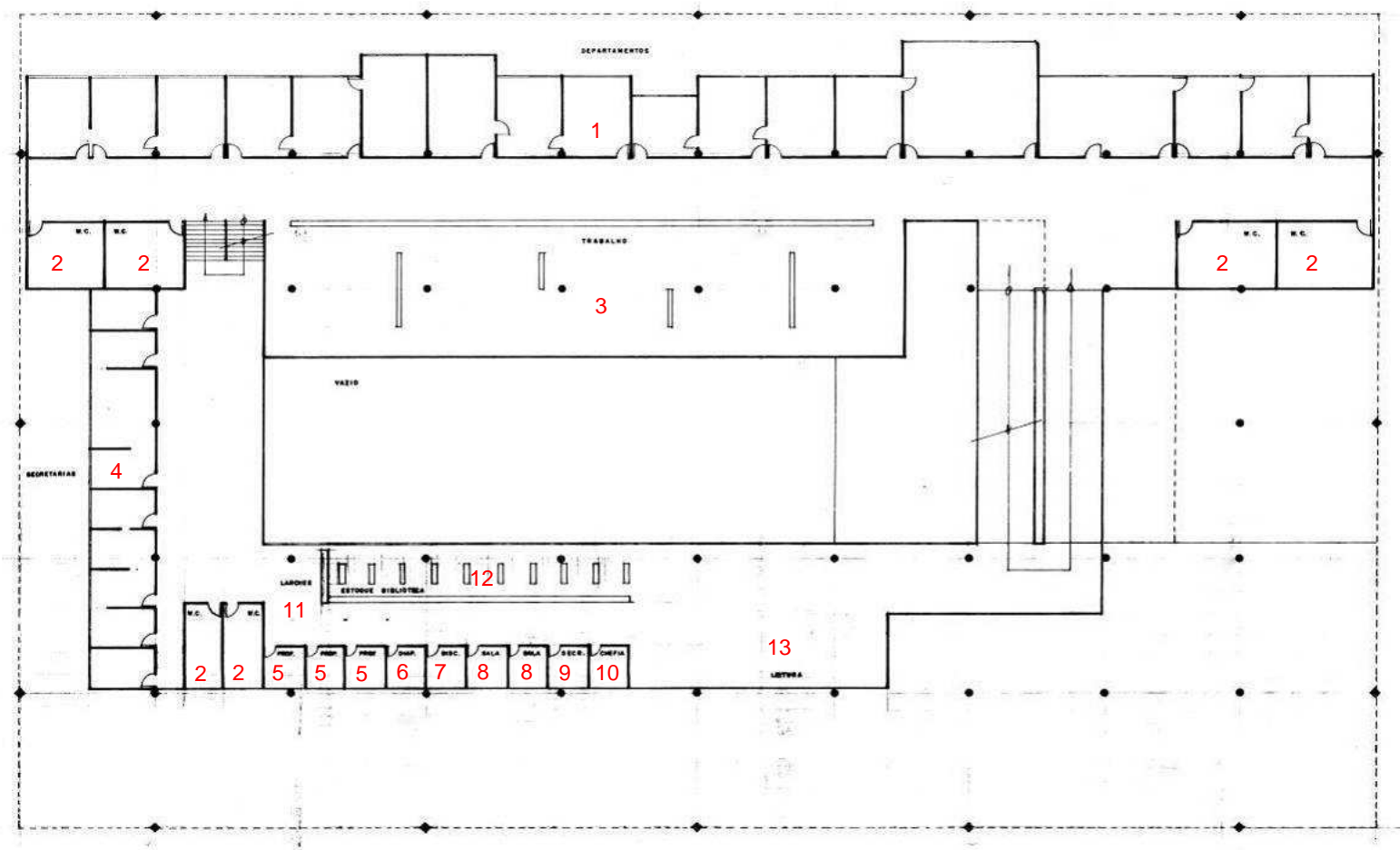

Planta do 20 pavimento

1. Departamentos; 2. WC; 3. Trabalho; 4. Secretarias; 5. Professor; 6. Diapositivo; 7. Discoteca; 8. Sala; 9. Secretária; 10. Chefia; 11. Lanches; 12. Estoque biblioteca; 13. Leitura

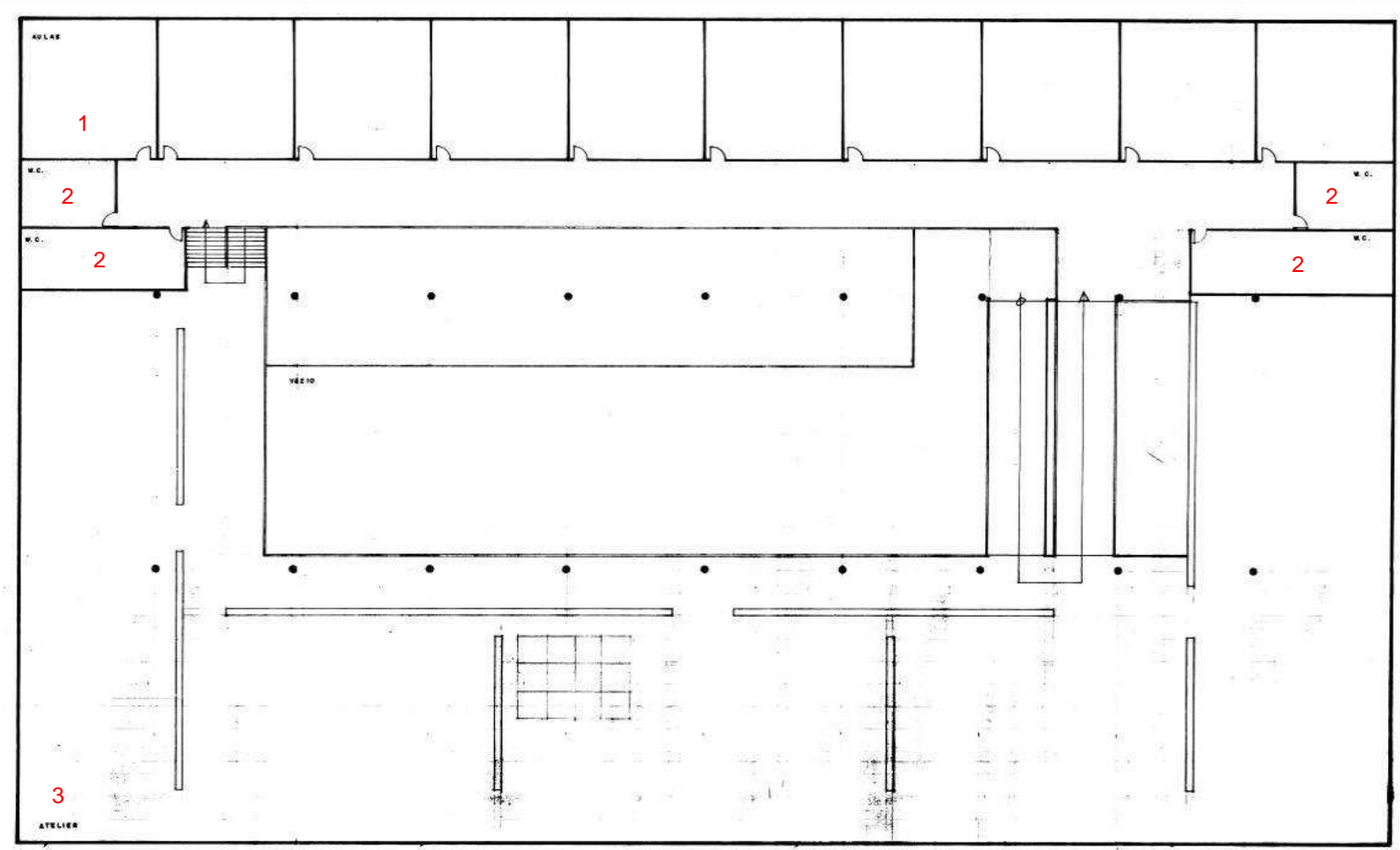

Planta do $3 \circ$ pavimento

1. Aulas; 2. WC; 3. Atelier 


\section{Anteprojeto}

Após o estudo preliminar, surge uma versão que poderíamos chamar de anteprojeto, representada em sete pranchas com desenhos na escala 1:200. Esses desenhos possuem características típicas de desenhos para apresentação, tais como representação de mobiliário e vegetação, escala gráfica, legenda dos ambientes com numeração, título das pranchas e autoria ("Vilanova Artigas arquiteto"). Não trazem informações técnicas como cotas, eixos, nem um carimbo completo do escritório. Esses desenhos também não foram datados, mas supomos que esta foi a versão apresentada no $2^{\circ}$ Encontro Arquitetos, Professores e Estudantes de Arquitetura, realizado em Porto Alegre, em abril de $1960 .{ }^{7}$

Apesar de manter as prerrogativas do estudo preliminar, esse anteprojeto traz uma série de alterações na distribuição do programa, a posição definitiva das rampas e a eliminação dos quatro pilares do eixo longitudinal central, afastando-se da noção clássica de peristilo e aproximando-se da concepção estrutural dos pórticos seriados.

O jardim interno sobre o auditório seria agora separado do exterior por um caixilho, mas com porta de acesso. O grêmio passaria para o subsolo (como na Vila Penteado), integrado com laboratório fotográfico, gráfica e oficinas, enquanto a copa e os vestiários dos funcionários ficariam no fundo do auditório, que foi ampliado. Uma residência para o zelador com dois dormitórios e acesso independente foi incluída no subsolo. Outro acesso lateral com escada permitiria chegar do exterior diretamente no grêmio, meio nível abaixo, ou então na cantina, meio nível acima, que nessa versão aparece fechada. Uma chefia do museu e uma sala de reuniões ocupariam a outra extremidade do piso do museu. No piso dos departamentos, a laje passava a ser alinhada aos pisos inferiores, mantendo duas varandas através do recuo dos caixilhos. Na divisão dos departamentos (que ainda não existiam de fato), Artigas designou um departamento de "matemáticas"; um de "história e arte"; um de "urbanismo"; e um de "construções". ${ }^{8}$ Por fim, nos últimos níveis, os ateliês não teriam divisórias (como na Vila Penteado). Sua organização se faria por três núcleos hidráulicos servidos de pias e um núcleo para os professores e "sala de estudos".

Aparecem pela primeira vez elevações das fachadas com o desenho definitivo de seus pilares, um corte transversal, que não detalhava a estrutura nem o domo da cobertura, e uma implantação consistente com o setor das humanas no plano da CUASO de 1961.

\footnotetext{
7 Mencionada em: PEREIRA, Miguel. "Sobre o Projeto da Faculdade de Arquitetura e Urbanismo da Universidade de São Paulo", Cadernos de Estudos. FA-UFRS, 1960. Republicado em: Arquitetura e os caminhos de sua explicação. São Paulo: Projeto Editores Associados, 1984.

${ }^{8}$ Essa nomenclatura fortalece a hipótese de que essa teria sido a versão apresentada no Rio Grande do Sul, em abril de 1960. Segundo Miguel Pereira, a proposta apresentada por Artigas se baseava em: 1) conhecimento prático no ateliê, e teórico nas salas de aula; 2) Departamentos de Matemática, História da Arte, Urbanismo e Construções, que funcionariam em ateliês próprios e se encarregariam de pesquisas; 3) Síntese composta por museu (com direção e programação próprias), auditório e biblioteca; 4) Plano prático, composto de oficina e laboratórios de fotografia, imprensa, etc. Ver: PEREIRA, Miguel. Op. Cit.
} 


\section{C) U A A S}

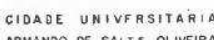

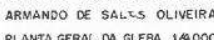
PLANTA GERAL DA GLEBA 19000

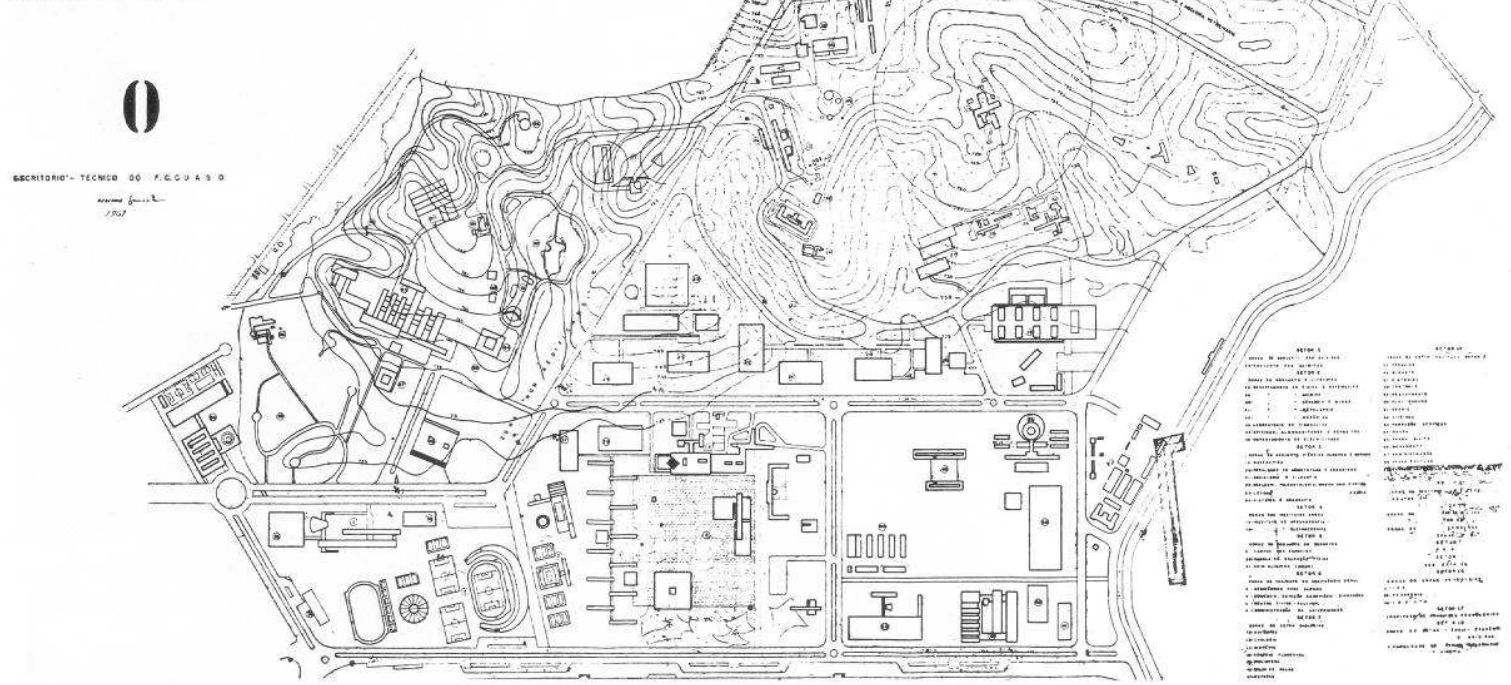

FCCUASO, Plano da Cidade Universitária, 1961

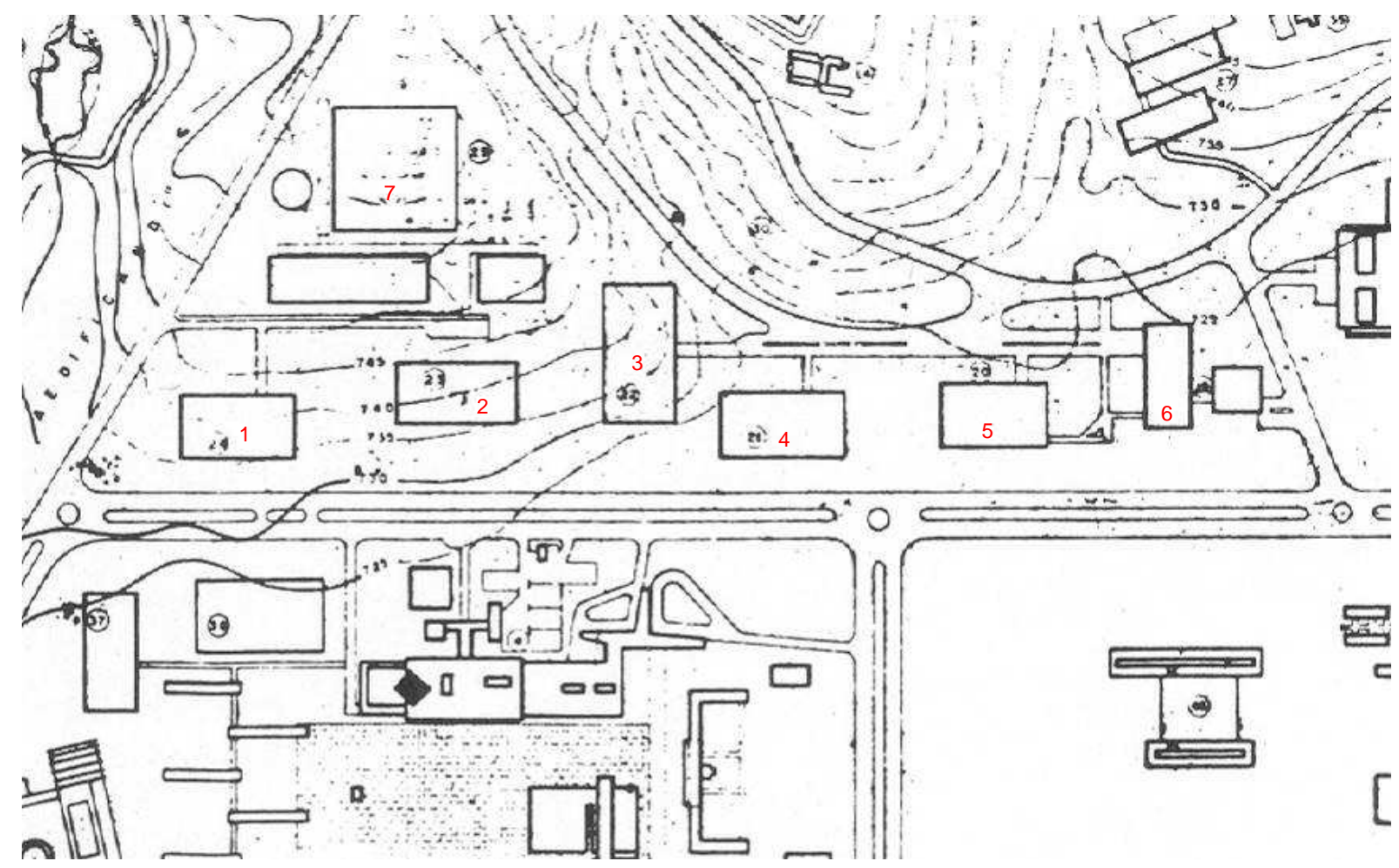

Detalhe do Setor das Humanas

1. História e Geografia, 2. Letras, 3. Geologia, Paleontologia, Mineralogia e Petrografia,

4. Sociologia e Filosofia, 5. Arquitetura e Urbanismo, 6. Matemática, 7. Conjunto das Químicas. 


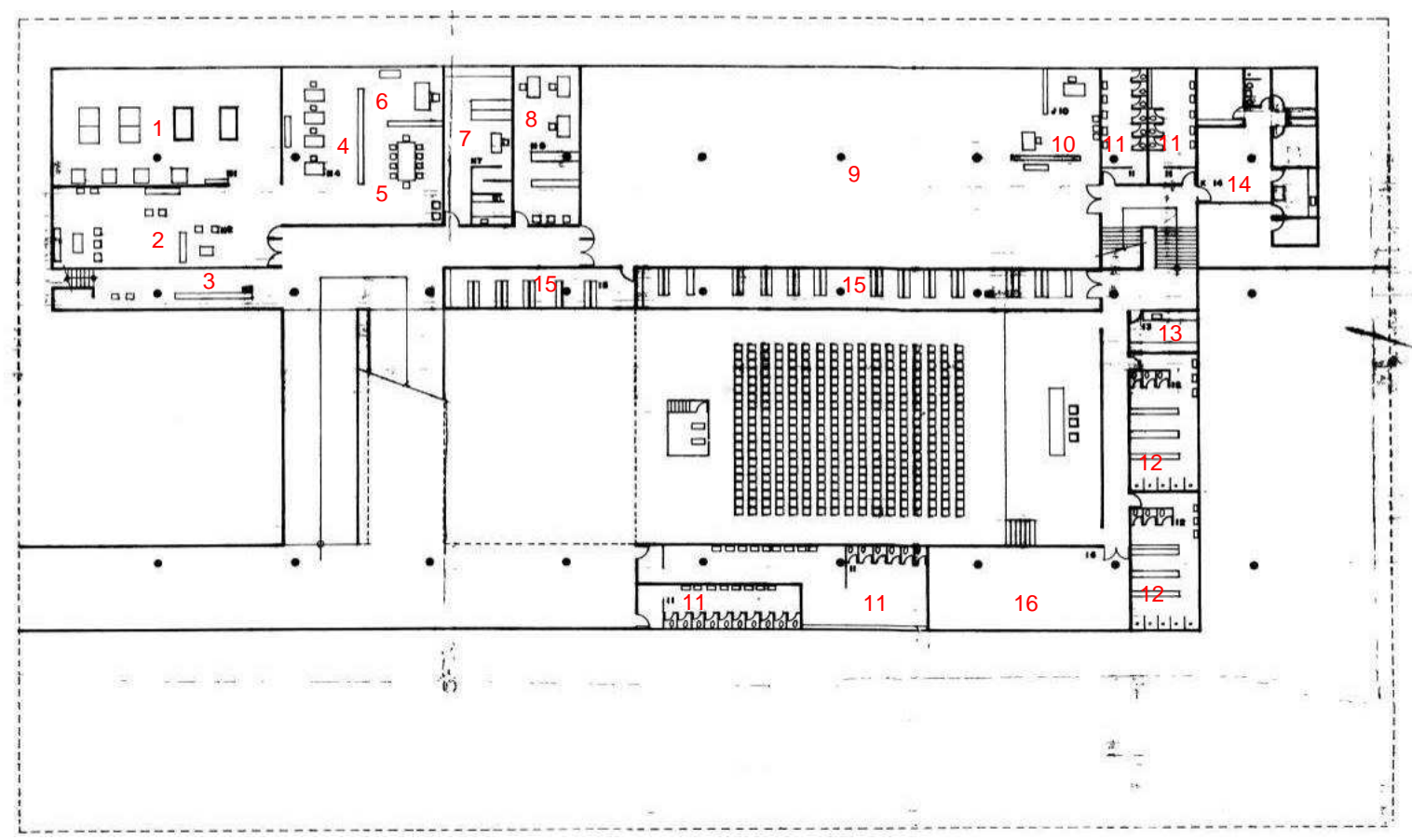

Planta do subsolo

Grêmio: 1. Sala de jogos; 2. Sala de estar; 3. Terraço; 4. Funcionários; 5. Reuniões; 6. Diretoria; 7. Laboratório fotográfico; 8. Publicações; Oficinas: 9. Oficinas; 10. Chefia 11. Sanitários; 12. Vestiário Funcionários; 13. Copa; 14. Residência Zelador; 15. Almoxarifado; 16. Depósito

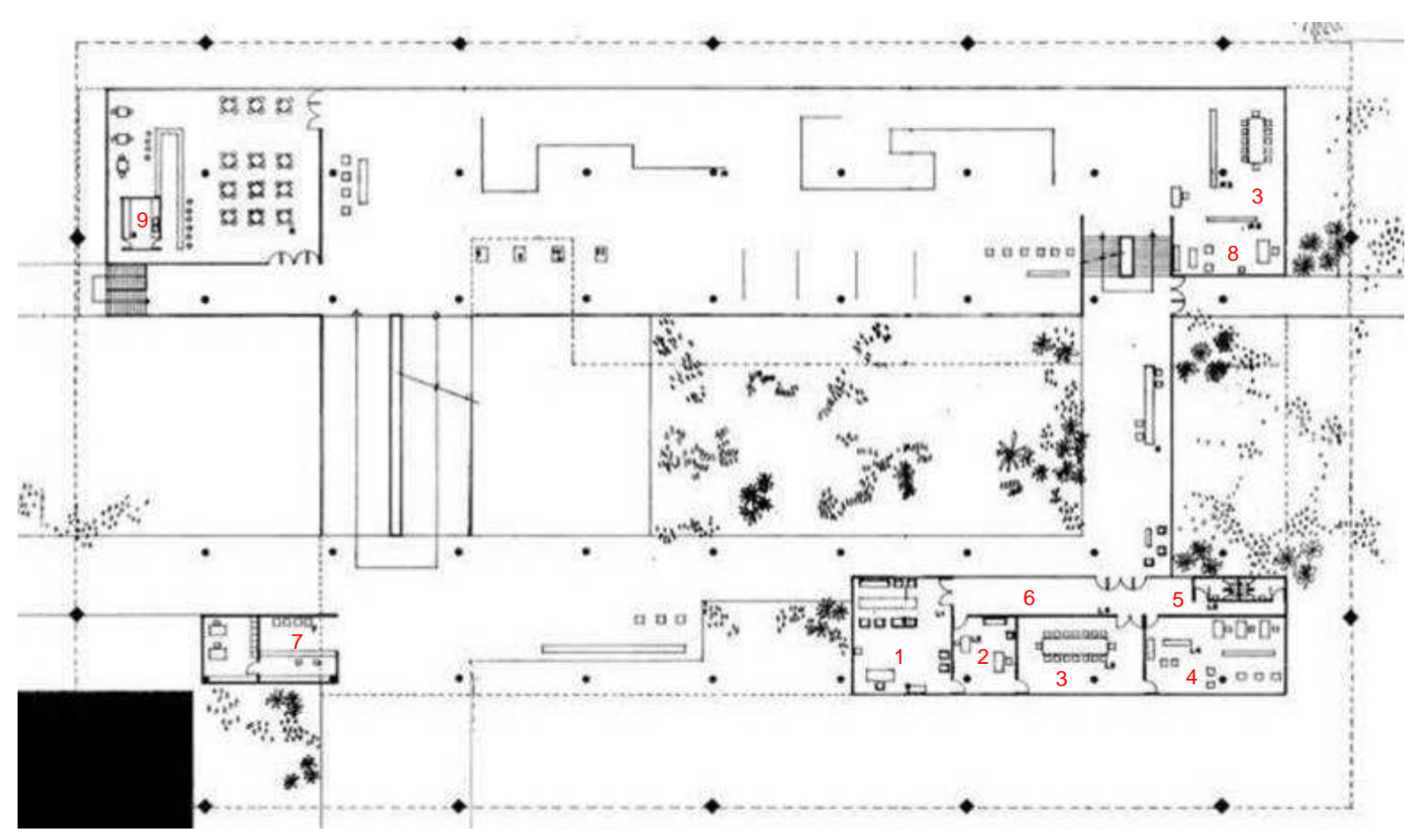

Planta do 1ํ pavimento (térreo)

Diretoria: 1. Diretor; 2. Secretarias; 3. Reuniões; 4. Professores; 5. Sanitários; 6. Sala de espera; 7. Portaria; Museu: 3. Reuniões; 8. Chefia; Cantina: 9. Copa. 


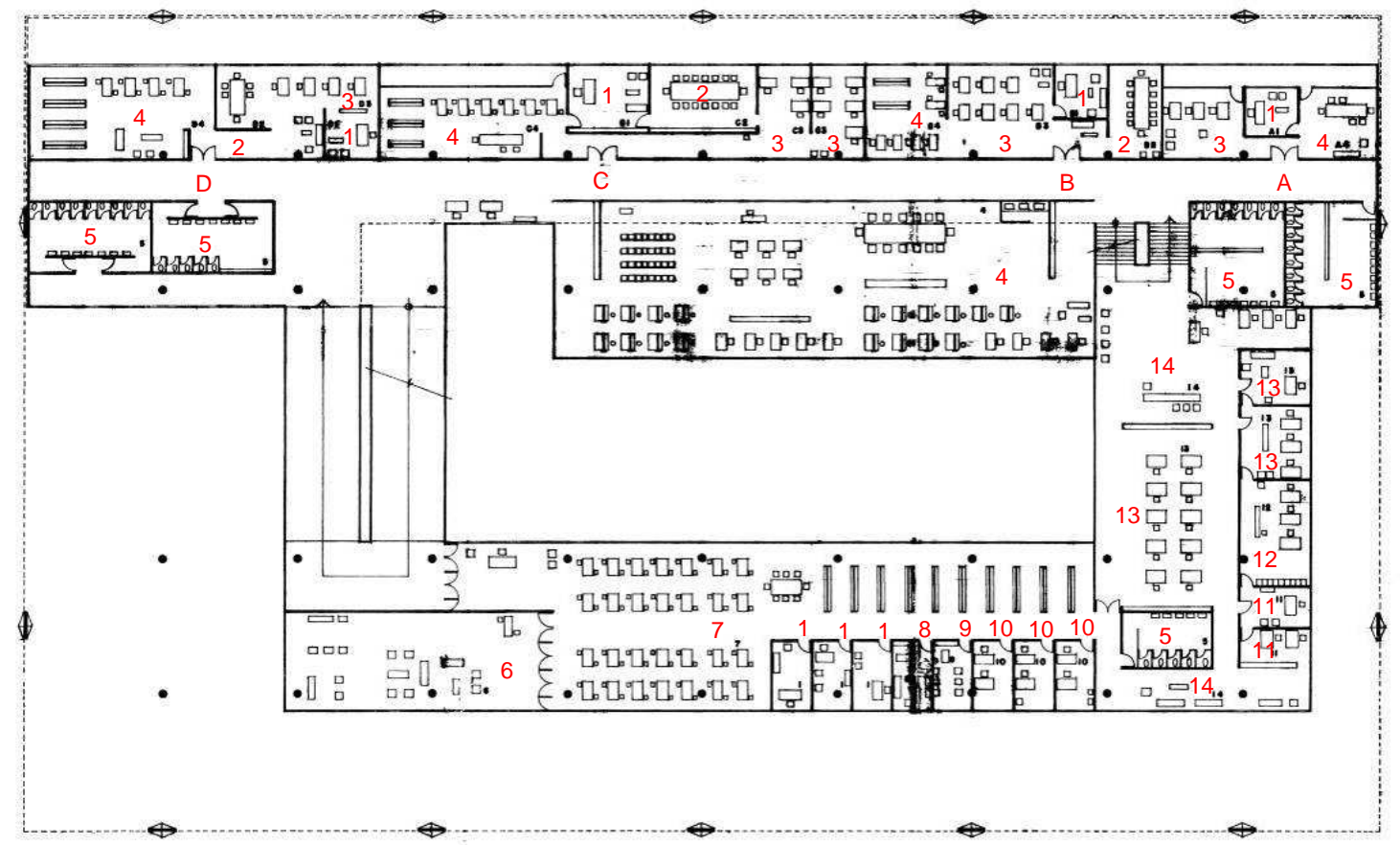

Planta do 20 pavimento

A. Dep. de matemáticas; B. Dep. de História e Arte; C. Dep. de Urbanismo; D. Dep. de Construções; 1. Chefia; 2. Reuniões; 3. Assistentes; 4. Sala de Estudo; 5. Sanitários; 6. Terraço; 7. Biblioteca; 8. Discoteca; 9. Diapositivos; 10. Sala de leitura; 11. Tesouraria; 12. Contabilidade; 13. Secretaria; 14. Sala de espera

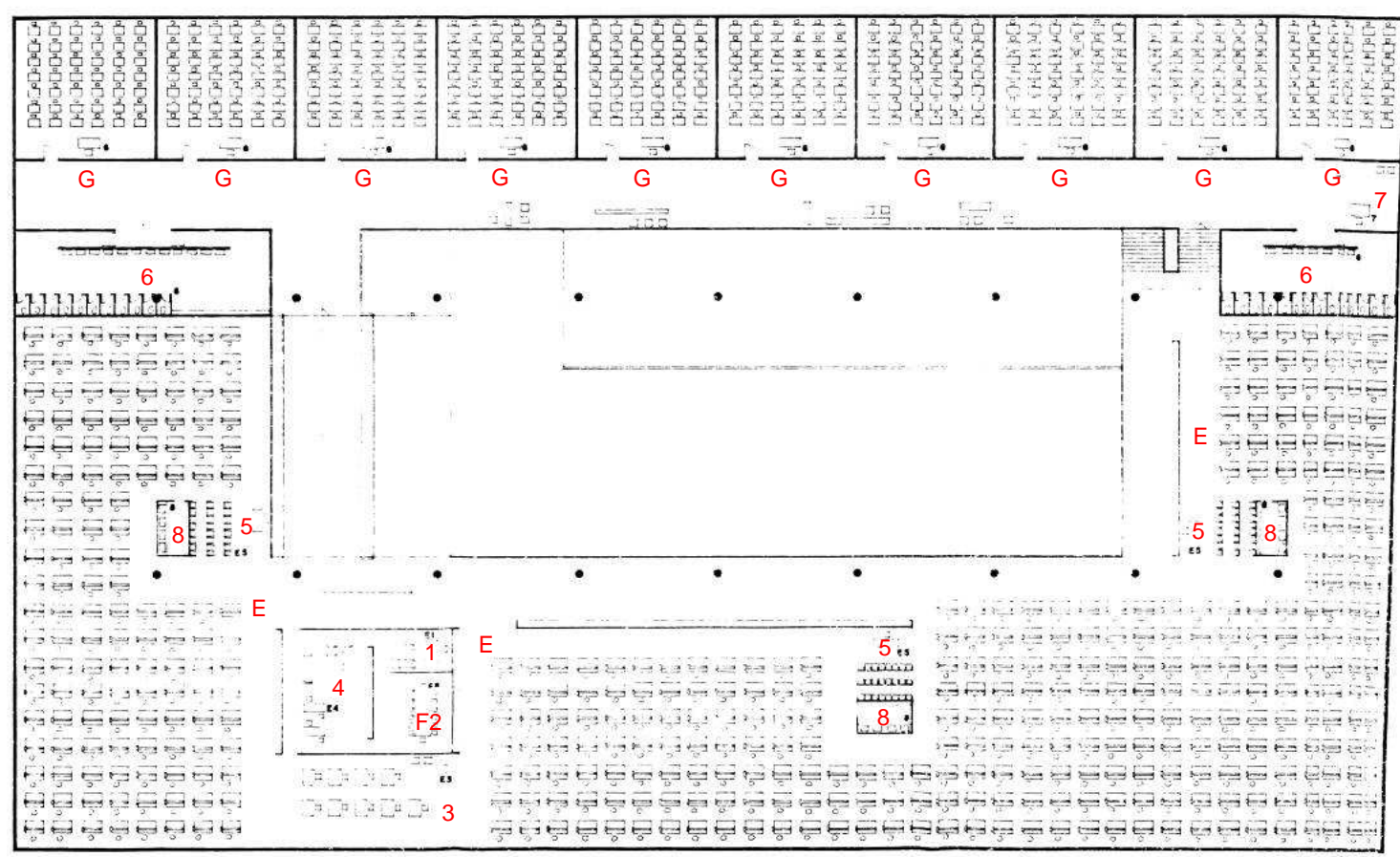

Planta do $3^{\circ}$ pavimento

E. Atelier; F. Chefia do Atelier; G. Salas de aula; 1. Chefia; 2. Reuniões; 3. Assistentes; 4. Sala de estudo; 5. Reunião de equipes; 6. Sanitário; 7. Bedel; 8; Água 

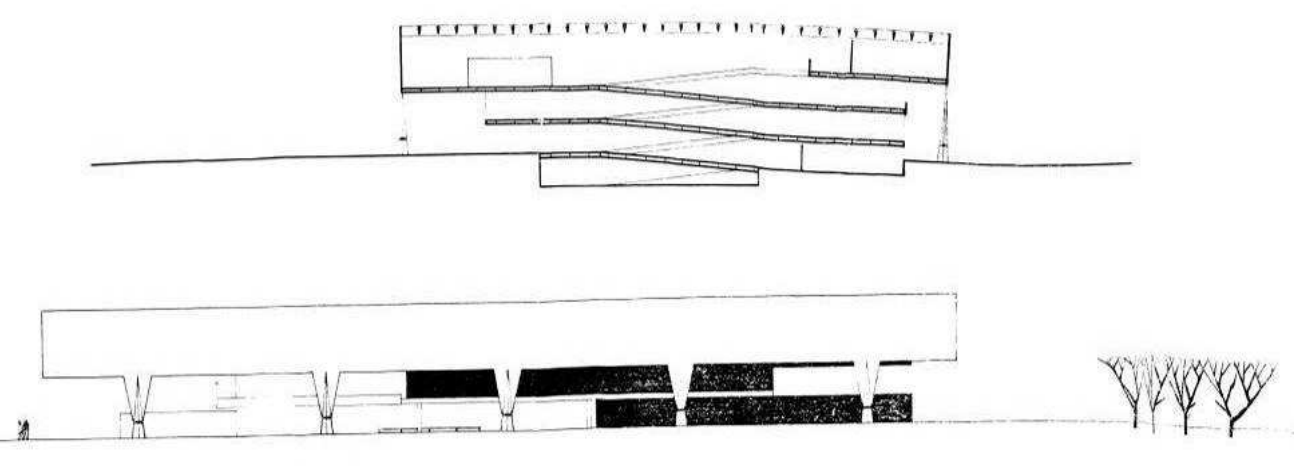

Fachada e corte
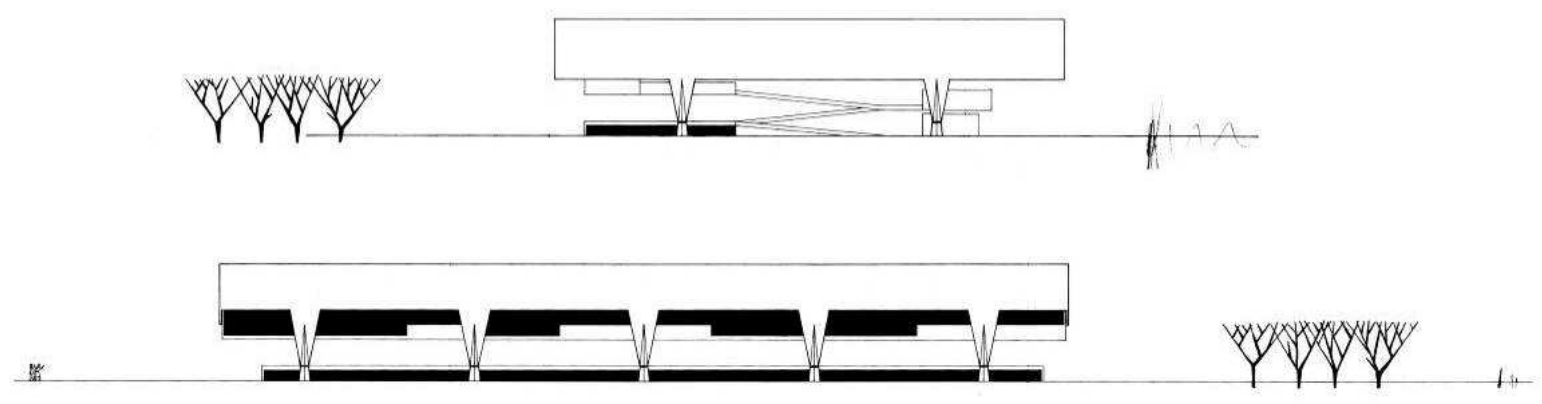

Fachadas

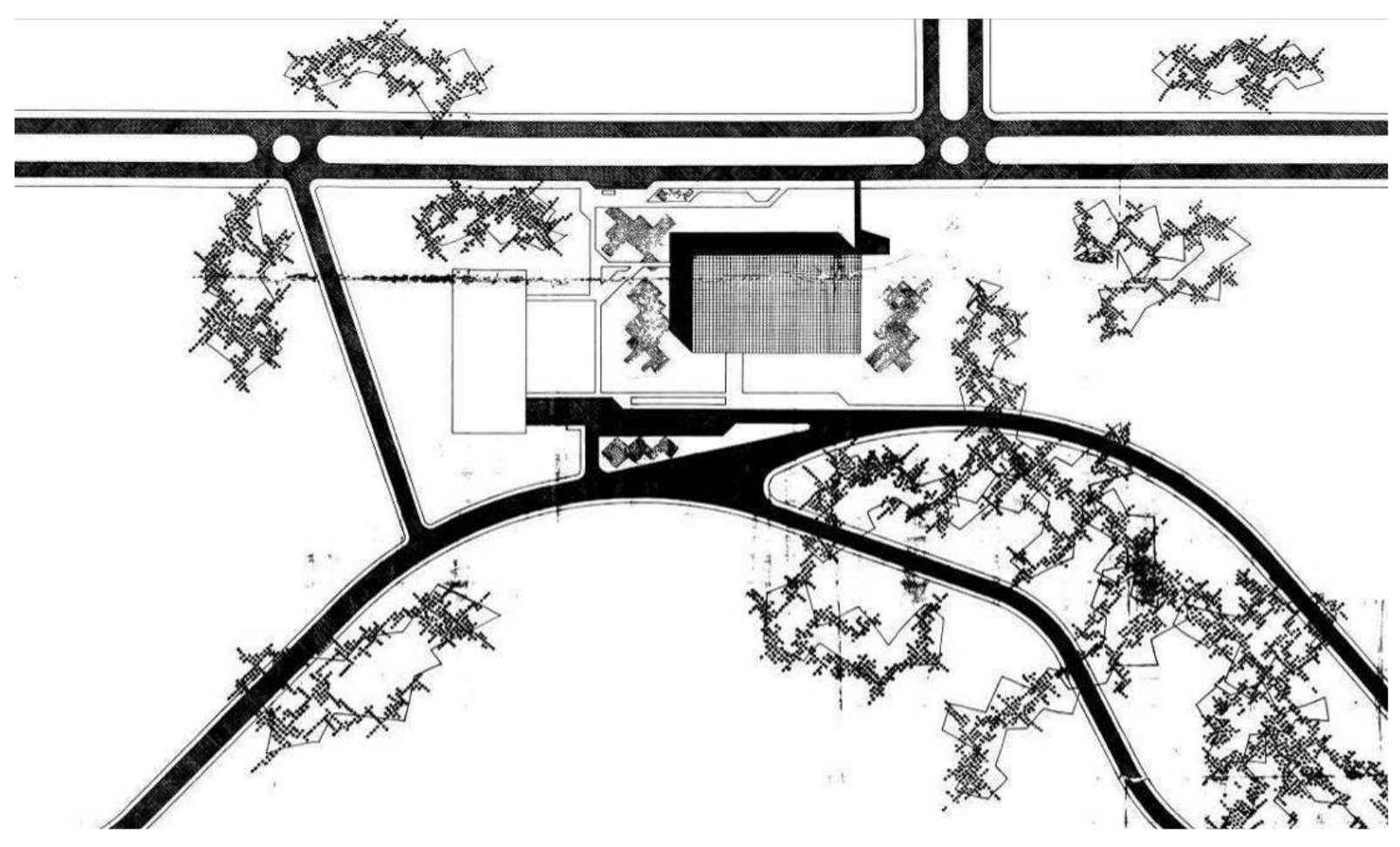

Implantação 


\section{Projeto Básico}

Em fevereiro de 1961, dez meses após a data estimada do anteprojeto, o arquiteto enviou ao Fundo para Construção da CUASO uma carta proposta, cobrando honorários de 2,5\% do preço estimado da construção para elaboração do que hoje chamaríamos de projeto básico - o projeto que serve de base para o orçamento e os projetos complementares. ${ }^{9}$ Ao que parece, essa foi a única entrega contratual do projeto ao Fundo. Cerca de cinco meses depois, em junho de 1961, Artigas entregou sete folhas iniciais, e mais cinco folhas até julho de 1962, formando um conjunto de doze folhas.

A maioria dessas folhas possui desenhos na escala 1:100 e alguns detalhes construtivos em outras escalas. Todas trazem um carimbo padrão do escritório "Vilanova Artigas e Carlos Cascaldi - arquitetos", bem como cotas, eixos, detalhes, quantitativos e indicações de acabamento (p. ex. piso de placas de borracha em todo o edifício ou indicação das fôrmas do concreto nas empenas das fachadas, feitas de tábuas de pinho horizontais com $30 \mathrm{~cm}$ de largura). Esses desenhos serviram para subsidiar os projetos complementares e os detalhes para execução, que foram feitos pelo Escritório Técnico do Fundo durante a obra. Com exceção de pequenos ajustes, como nos sanitários do subsolo ou na compartimentação do piso dos departamentos, o anteprojeto permanecia basicamente o mesmo. É possível notar, por exemplo, uma área entre as escadas, que comportaria um elevador. Os cortes revelaram a totalidade do sistema estrutural, permitindo visualizar as vigas e nervuras, ainda não calculadas, bem como o sistema de cobertura. Detalhes como a seção do pilar central e o domo da cobertura foram apresentados pela primeira vez.

${ }^{9}$ Documento do Encarregado da Divisão de Projetos do FCCUASO, Roberto de Araújo, que menciona a carta proposta original de Artigas (não localizada), de 3 de fevereiro de 1961. Processo USP n. 65.1.3988.51.8, fl.39 
Vilanova Artigas e Carlos Cascaldi.

Projeto Básico da FAU, junho 1961 a julho 1962

Arquivo FAUUSP

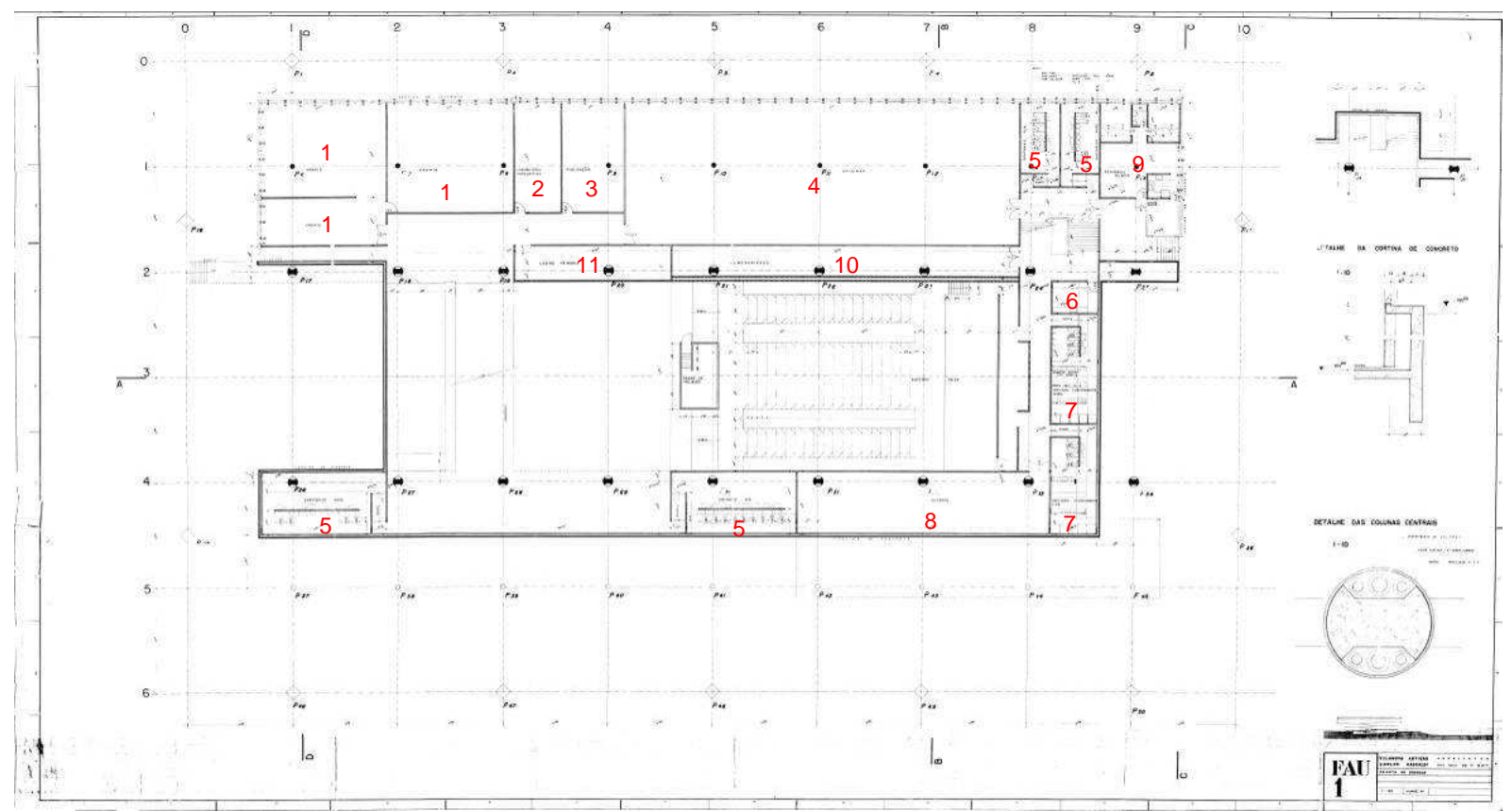

Planta do subsolo, junho 1961

1. Grêmio: 2. Laboratório fotográfico; 3. Publicações; 4. Oficinas; 5. Sanitários; 6. Copa; 7. Vestiário Funcionários; 8. Depósito; 9. Residência Zelador; 10. Almoxarifado; 11. Cabine primária

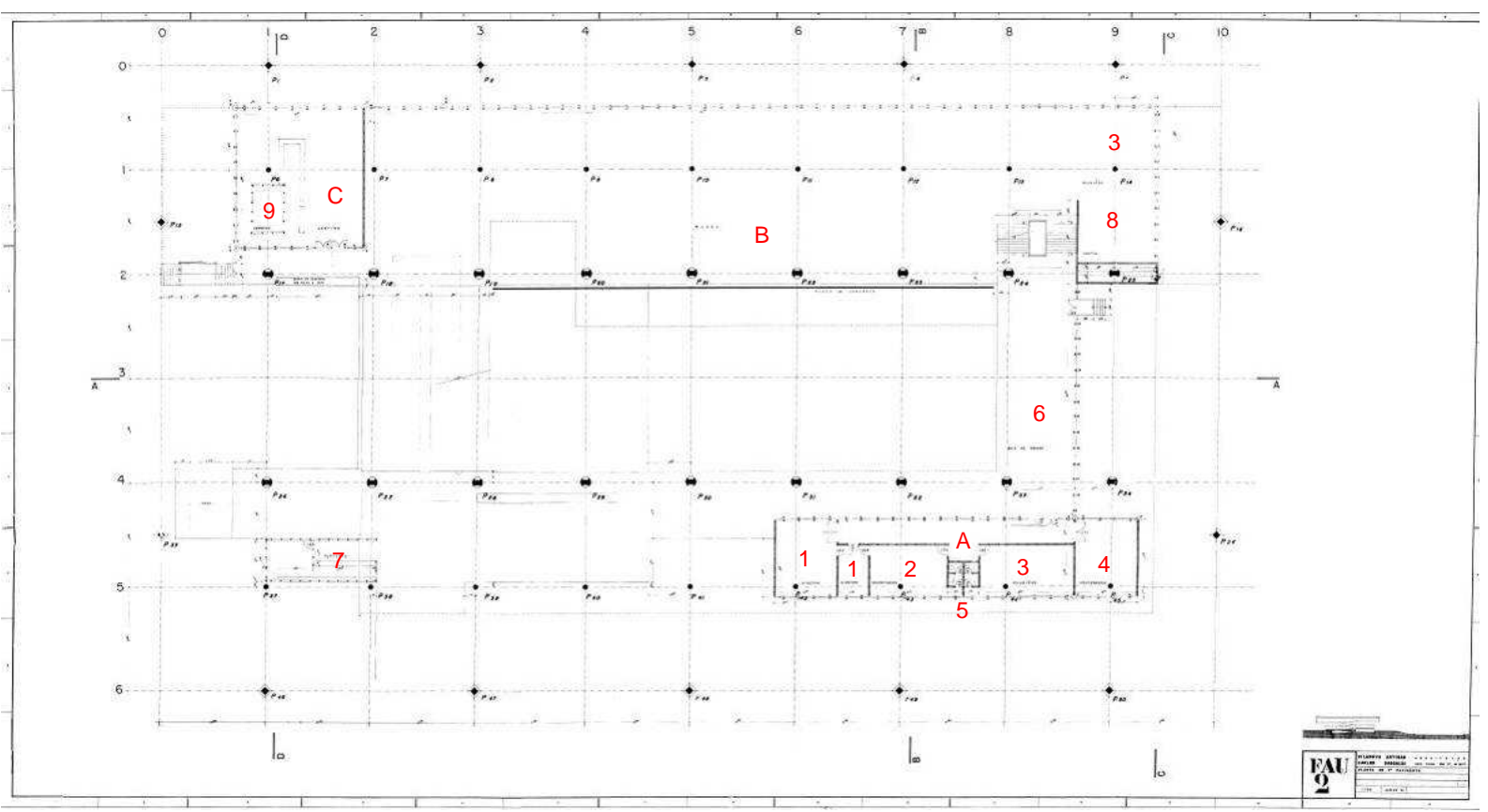

Planta do 1ำ pavimento (térreo), junho 1961

A. Diretoria: 1. Diretor; 2. Secretarias; 3. Reuniões; 4. Professores; 5. Sanitários; 6. Sala de espera; 7. Portaria; B. Museu: 3. Reuniões; 8. Chefia;

C. Cantina: 9. Depósito. Obs. Painéis leves no lugar de alvenarias. 


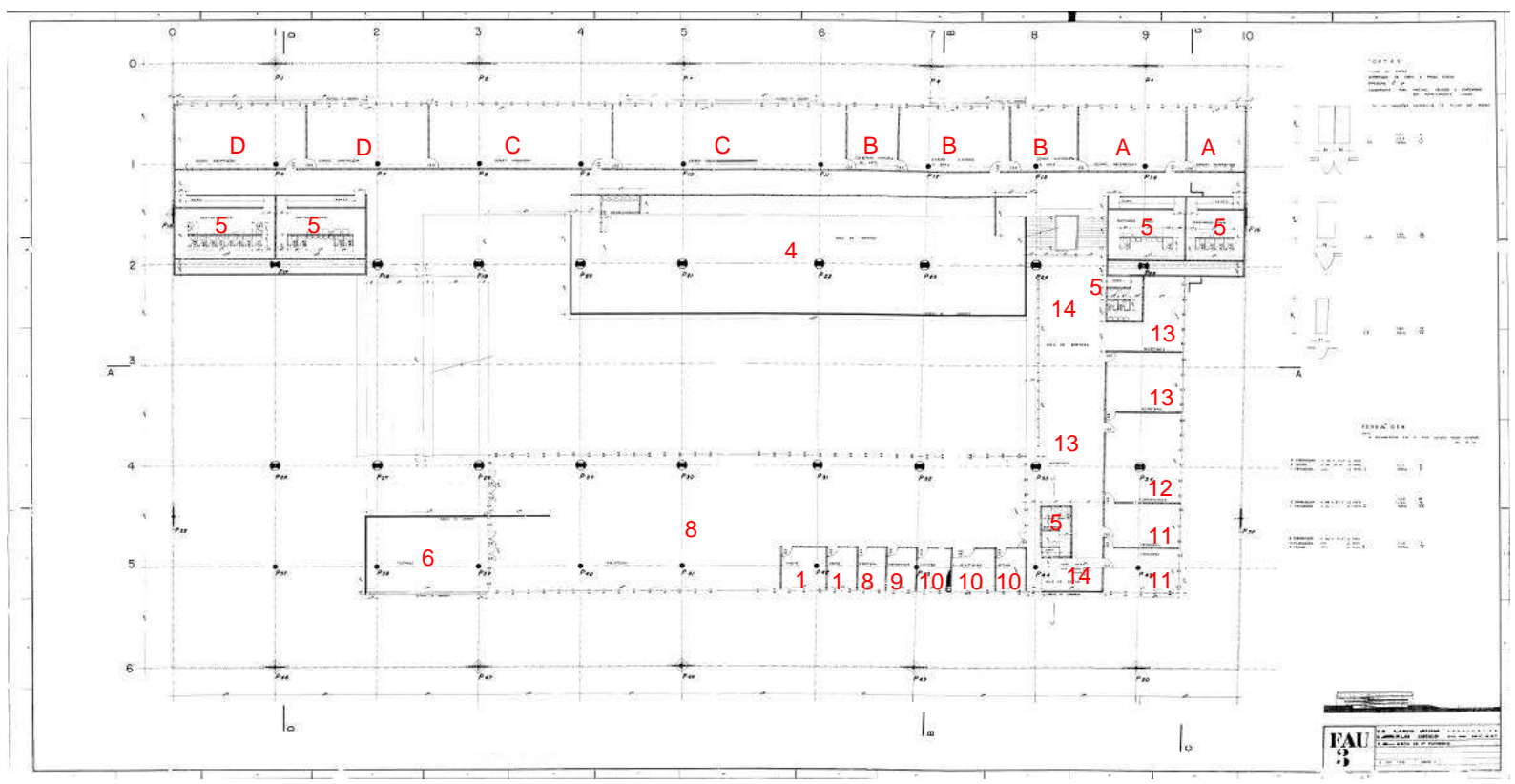

Planta do 20 pavimento, junho 1961

A. Dep. de matemáticas; B. Dep. de História e Arte; C. Dep. de Urbanismo; D. Dep. de Construções; 1. Chefia; 2. Reuniões; 3. Assistentes; 4. Sala de Estudo; 5. Sanitários; 6. Terraço; 7. Biblioteca; 8. Discoteca; 9. Diapositivos; 10. Sala de leitura; 11. Tesouraria; 12. Contabilidade; 13. Secretaria; 14. Sala de espera

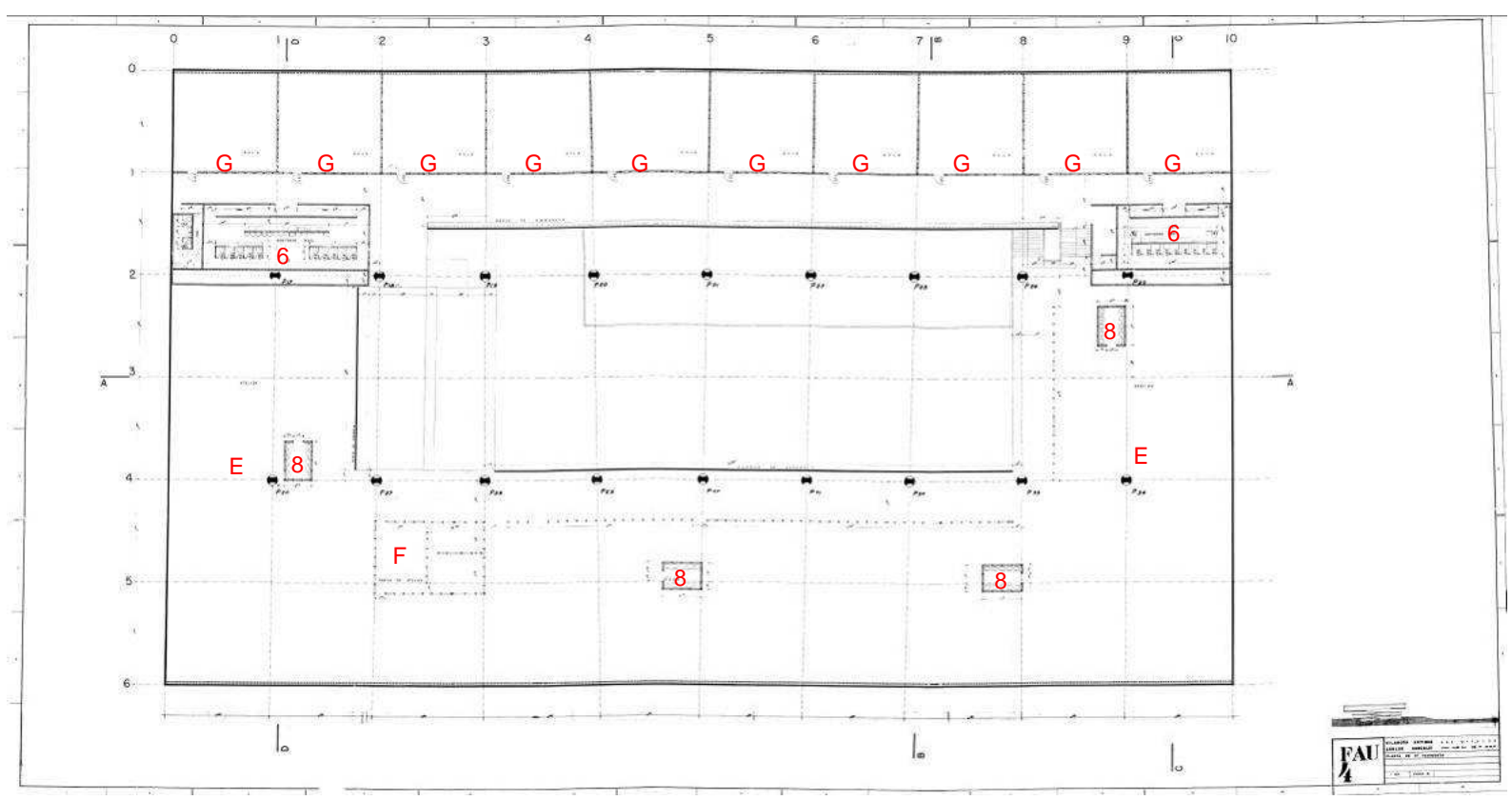

Planta do 3ำ pavimento, junho 1961

E. Atelier; F. Chefia do Atelier; G. Salas de aula; 1. Chefia; 2. Reuniões; 3. Assistentes; 4. Sala de estudo; 5. Reunião de equipes; 6. Sanitário; 7. Bedel; 8; Água. Obs. As paredes divisórias dos ateliês seriam painéis leves. 


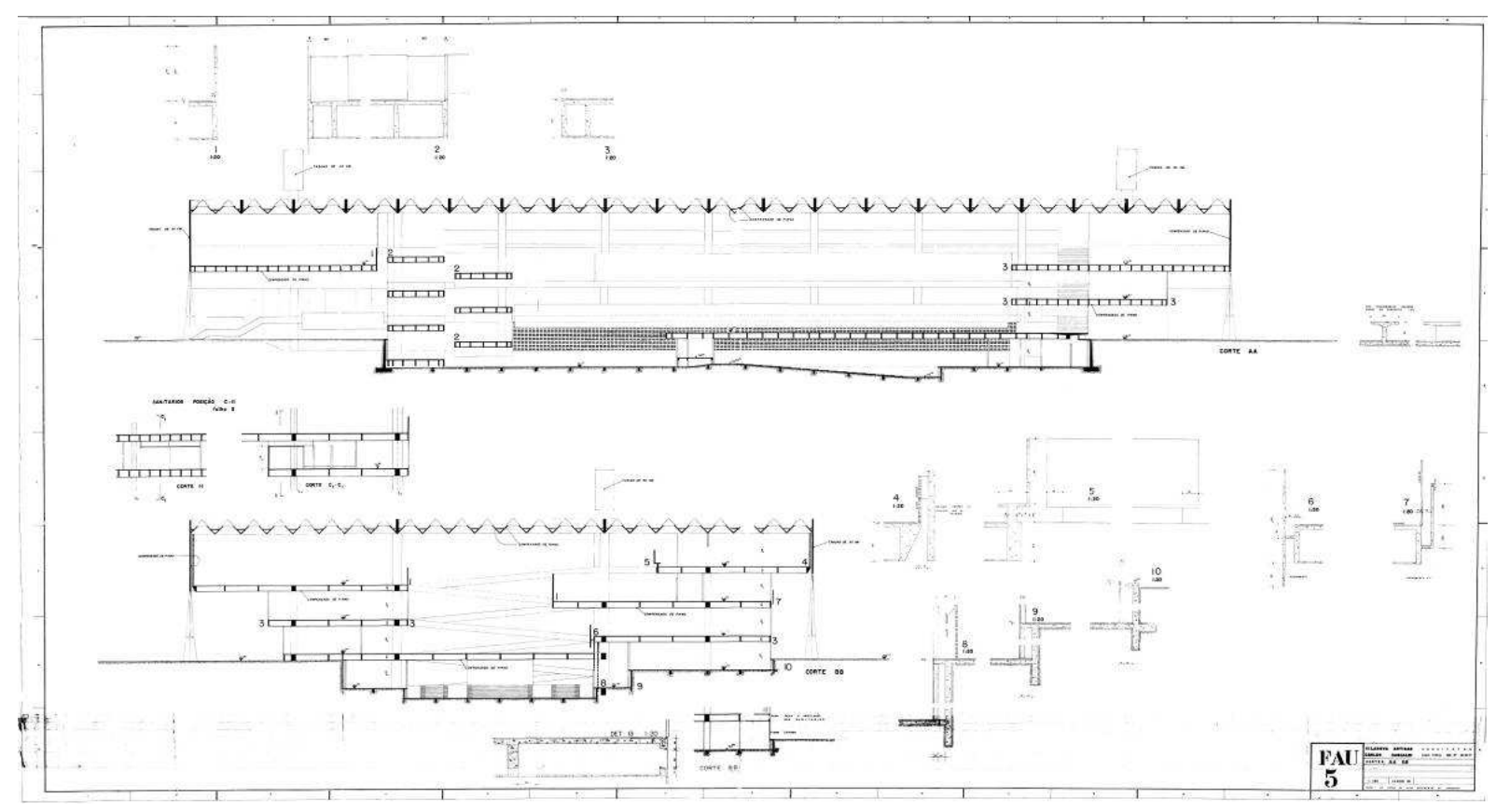

Cortes AA e BB, junho 1961

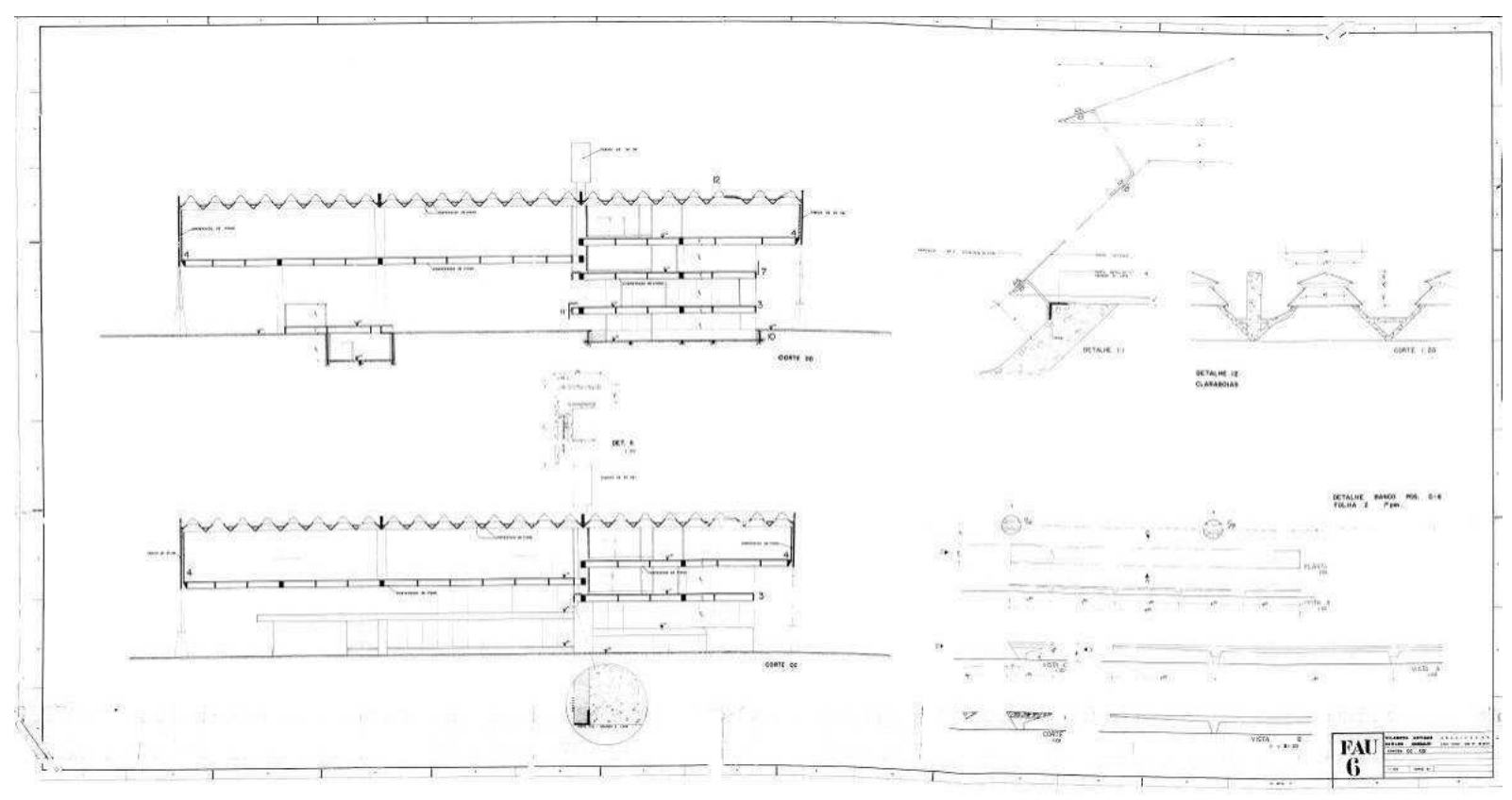

Cortes CC e DD, junho 1961 

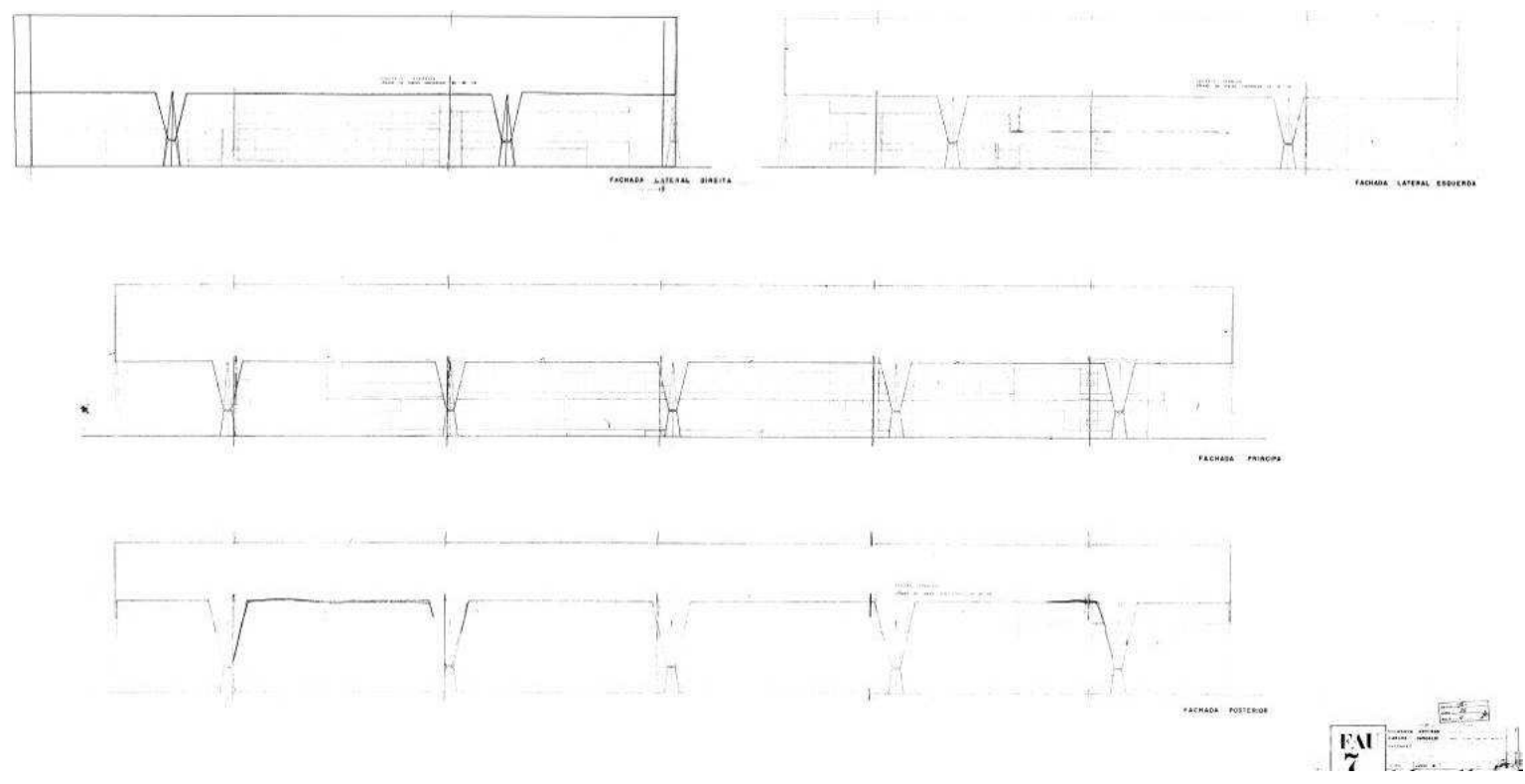

Fachadas, junho 1961

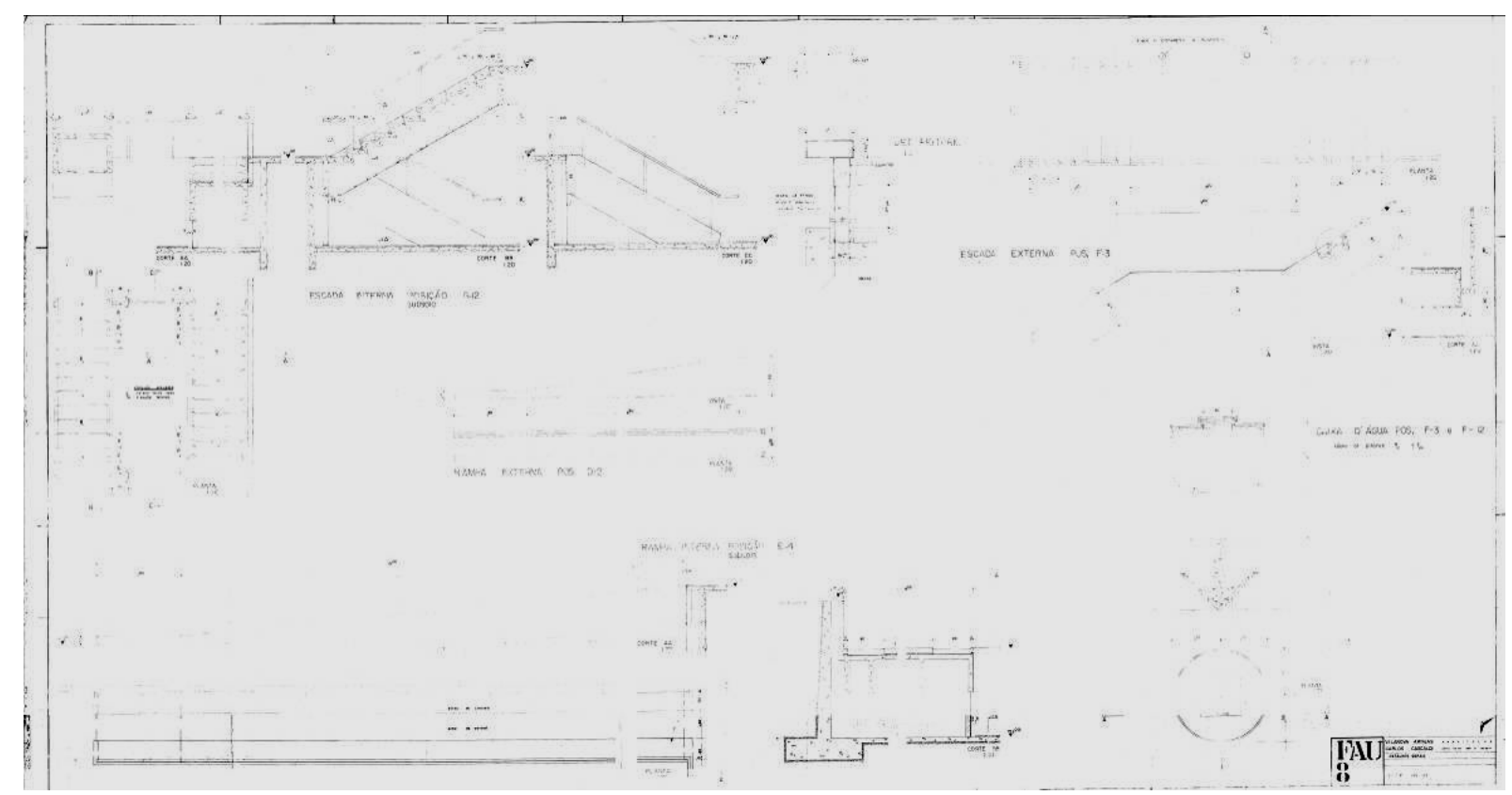

Detalhes Gerais, janeiro 1962 


\section{Projeto de estrutura}

Com o projeto básico de arquitetura, o Fundo para Construção contratou o Escritório Técnico Figueiredo Ferraz para calcular a estrutura de concreto armado do edifício. José Carlos de Figueiredo Ferraz ${ }^{10}$ era um dos calculistas mais renomados de São Paulo e 1960 havia sido apontado por Paulo de Camargo e Almeida como um dos profissionais que deveriam contribuir nas obras da Cidade Universitária. ${ }^{11}$ De fato, além de ter em seu currículo uma série de importantes obras de infraestrutura, ele já havia calculado a "cobertura monumental" do Laboratório de Hidráulica, projetado por Ariosto Mila12, e colaborou no projeto da História e Geografia de Eduardo Corona. ${ }^{13}$

Em 1956, Ferraz começou a lecionar na FAU, tendo sido aprovado na primeira leva de concursos, tornando-se o catedrático da cadeira n. 7, 'Estruturas Correntes de Madeira, Metálicas e de Concreto Simples e Armado'. Esse foi um dos fatores determinantes de seu envolvimento no projeto da FAU e com Artigas, com quem mantinha uma relação de respeito apesar de posições políticas antagônicas. Como catedrático, Ferraz assumiu maiores responsabilidades docentes e cargos políticos, tornando-se secretário de obras do município de São Paulo durante a gestão de Adhemar de Barros (1957-1960). ${ }^{14}$ Com todas essas ocupações, seus ex-alunos João Del Nero e José Lourenço de Almeida Castanho tornaram-se sócios e assumiram a frente de seu escritório. Castanho foi o responsável pelo cálculo do MASP e da FAU, desenvolvidos um na sequência do outro.

O projeto da estrutura de concreto armado da FAU foi iniciado tão logo quanto possível. O Escritório Técnico de Ferraz entregou sua primeira planta na mesma data em que Artigas entregou as setes folhas do projeto básico, em junho de 1961. Era uma planta de fundação com a cota de arrasamento das estacas, possivelmente para permitir o início imediato das obras de terraplanagem e fundação. Ao todo, o projeto estrutural, baseado em 12 folhas de arquitetura, resultou, inicialmente, em 101 folhas. Esse trabalho foi desenvolvido ao longo de 20 meses, entre junho de 1961 e janeiro de 1963.

\footnotetext{
${ }^{10}$ Ferraz se formou na Escola Politécnica em 1940, onde começou a lecionar como assistente de Telêmaco Van Langendonck em 1946.

${ }^{11}$ ALMEIDA, Paulo de Camargo. "Relatório de atividades do Fundo para a Construção da Cidade Universitária Armando Salles de Oliveira", de 10 de agosto de 1960. Ver: Processo USP n. 60.1.19244.1.2, fls. 4-6. Publicado na íntegra em "Arquitetos estudam a reorganização da Cidade Universitária da USP", O Estado de São Paulo, 31 de dezembro de 1960 apud CABRAL, Neyde. Op. Cit.
}

\footnotetext{
12 VASCONCELOS, Augusto Carlos de. O concreto no Brasil: pré-fabricação, monumentos, fundações. Vol. 3. São Paulo: Studio Nobel, 2002, p. 53.

${ }^{13}$ Site www.figueiredoferraz.com.br. Acesso em 22/4/2015. O projeto teria vigas de 60 metros de comprimento

${ }^{14}$ Mais tarde, Figueiredo Ferraz foi também Secretário dos Transportes do Estado em 1967, por seis meses, e Prefeito de São Paulo entre 1971 e agosto de 1973.
} 
No projeto da FAU, a concepção estrutural de Artigas foi mantida sem alterações: o módulo estrutural de 11 metros, as dimensões das lajes nervuradas, a distribuição das vigas, a forma dos pilares, as vigas-calhas da cobertura e uma grande quantidade de detalhes em concreto armado haviam sido definidas pelo arquiteto. Ao escritório de Figueiredo Ferraz coube projetar aquilo que não seria visível: fundação, armaduras, vigas e nervuras ocultas nas lajes além de especificações técnicas de execução. Conforme José Lourenço Castanho, por trás da aparência de obra de infraestrutura, a FAU exigiu um projeto de estrutura minucioso, "como se fosse relojoaria". ${ }^{15}$ Isso se deve em grande medida às variações das lajes, com recuos e avanços, que interrompem as vigas e criam balanços - como no caso da viga do último pavimento na qual a rampa protendida é ancorada, que não chega ao próximo pilar. As empenas cegas e a cobertura em grelha também exigiram soluções extraordinárias, pois fugiam de todos os parâmetros habituais do cálculo de estrutura de concreto armado. No mais,

"A estrutura é hiperestática, com pilares e vigas engastados e funcionando solidariamente. [...]. No subsolo, toda a estrutura é travada por meio de vigas que conectam os pilares em todas as direções, inclusive os pilares externos piramidais, contribuindo para sua estabilidade. As fundações são de tipo tubulão sob os pilares, e estacas em cargas diversas, como no perímetro das fachadas, sob os elevadores e o auditório". ${ }^{16}$

A aparência monolítica das lajes de $80 \mathrm{~cm}$ de espessura é obtida através fôrmas internas, conhecidas como "caixão perdido" - uma solução indissociável da arquitetura moderna. ${ }^{17}$ Os caixões de madeira cuidadosamente dispostos na massa de concreto, formam vigas, nervuras e vazios internos, que aliviam o peso da estrutura. É uma forma de privilegiar a aparência de unidade sobre a economia de material, a funcionalidade e a lógica produtiva. A execução da laje com caixão perdido consiste em definir um plano de compensado, verter o concreto, posicionar os caixões e as armaduras e verter novamente concreto até atingir o nível final. Solução diferente seria estabelecer o plano com cimbramento, posicionar a armadura e os caixões e lançar o concreto, sendo possível retirar as fôrmas por baixo e até reutilizá-las. Desse modo, haveria economia de material e a estrutura ficaria claramente à vista, mas o cálculo seria diferente.

\footnotetext{
${ }^{15}$ Entrevista de José Lourenço de Almeida Castanho ao autor, realizada em janeiro de 2012.

${ }^{16}$ GIANNECCHINI, Ana Clara. Técnica e estética no concreto armado. Um estudo sobre os edifícios do MASP e da FAUUSP. Dissertação de mestrado em Arquitetura e Urbanismo. Orientadora: Maria Lúcia Bressan Pinheiro. São Paulo: FAU-USP, 2009, p. 226.

${ }^{17}$ A origem da laje "sem vigas" seria atribuída à Maillart em 1912. Ver: FRAMPTON, Kenneth. História crítica da arquitetura moderna. São Paulo: Martins Fontes, 2003, p. 37.
} 
Os problemas de infiltração, a dificuldade de manutenção das instalações internas, o custo mais alto e a ocultação da estrutura seriam argumentos contrários à adoção do caixão perdido. Mas como elemento de composição, Artigas tirou proveito dessa linguagem com maestria, fazendo da laje composta uma unidade sobre a qual o projeto versa, avançando e recuando, aparecendo secamente, inclinada nas rampas, fundida com empenas ou ocultada por elementos sobrepostos. Como nas variações de um tema de jazz é fundamental a clareza da unidade, no caso a espessura constante da laje e seu tratamento como bloco, ou um elemento de desenho representado por duas linhas paralelas. Um artifício estético usado para expressar simplicidade e unicidade de critérios.

O sistema em caixão perdido da FAU resulta em duas lajes paralelas com a mesma espessura de $8 \mathrm{~cm}^{18}$, uma para o piso e outra para o forro, solidarizadas pela nervura estrutural. O forro está ausente apenas em espaços menos nobres no subsolo, onde a ventilação é feita através de elementos vazados posicionados entre as nervuras. Com a altura das vigas fixa, o trabalho do calculista consiste em distribuir as cargas com base na armadura, espessura e posição das vigas e nervuras.

Via de regra as lajes da FAU possuem nervuras transversais a cada 1,1 metros, que descarregam nas vigas longitudinais. Para vencer vãos de 22 metros (na cobertura, rampas, e lajes sobre o auditório), o escritório de Ferraz propôs que tais nervuras fossem protendidas com seu sistema patenteado, sem a cobrança de royalties. ${ }^{19}$

Os emblemáticos pilares externos recebem apenas uma pequena parte da carga da cobertura e da última laje - não mais do que 300 toneladas, enquanto os pilares internos recebem até 600 toneladas e os pilares centrais até 950 toneladas. Do ponto de vista estrutural, as empenas cegas de concreto e seus pilares não contribuem significativamente com o conjunto, pois criam uma carga mais relevante do que a carga que transmitem da cobertura. Além disso, exigem uma armadura complexa por causa de sua forma delgada e sua longa extensão. Justamente por causa da independência desta casca exterior, estruturalmente secundária, é possível cancelar um a cada dois pilares e deslocar os pilares da fachada lateral em relação aos eixos das vigas principais.

$\mathrm{O}$ arquiteto conseguiu efeitos surpreendentes, como o pilar que desce direto da cobertura para o Piso do Museu sem tocar na laje do Piso dos Departamentos que o contorna. Mas para isso, o cálculo da estrutura teve de considerar inúmeras variáveis.

\footnotetext{
${ }^{18}$ Embora os desenhos indiquem isso, foi constatado, com ajuda da equipe de manutenção do edifício, que alguns forros no subsolo possuem espessuras muito inferiores.

${ }^{19}$ Sobre o Sistema Ferraz, ver: VASCONCELOS, Augusto Carlos de. O concreto no Brasil: recordes, realizações, história. Vol. 1. São Paulo: Copiare, 1985, pp. 141-143.
} 


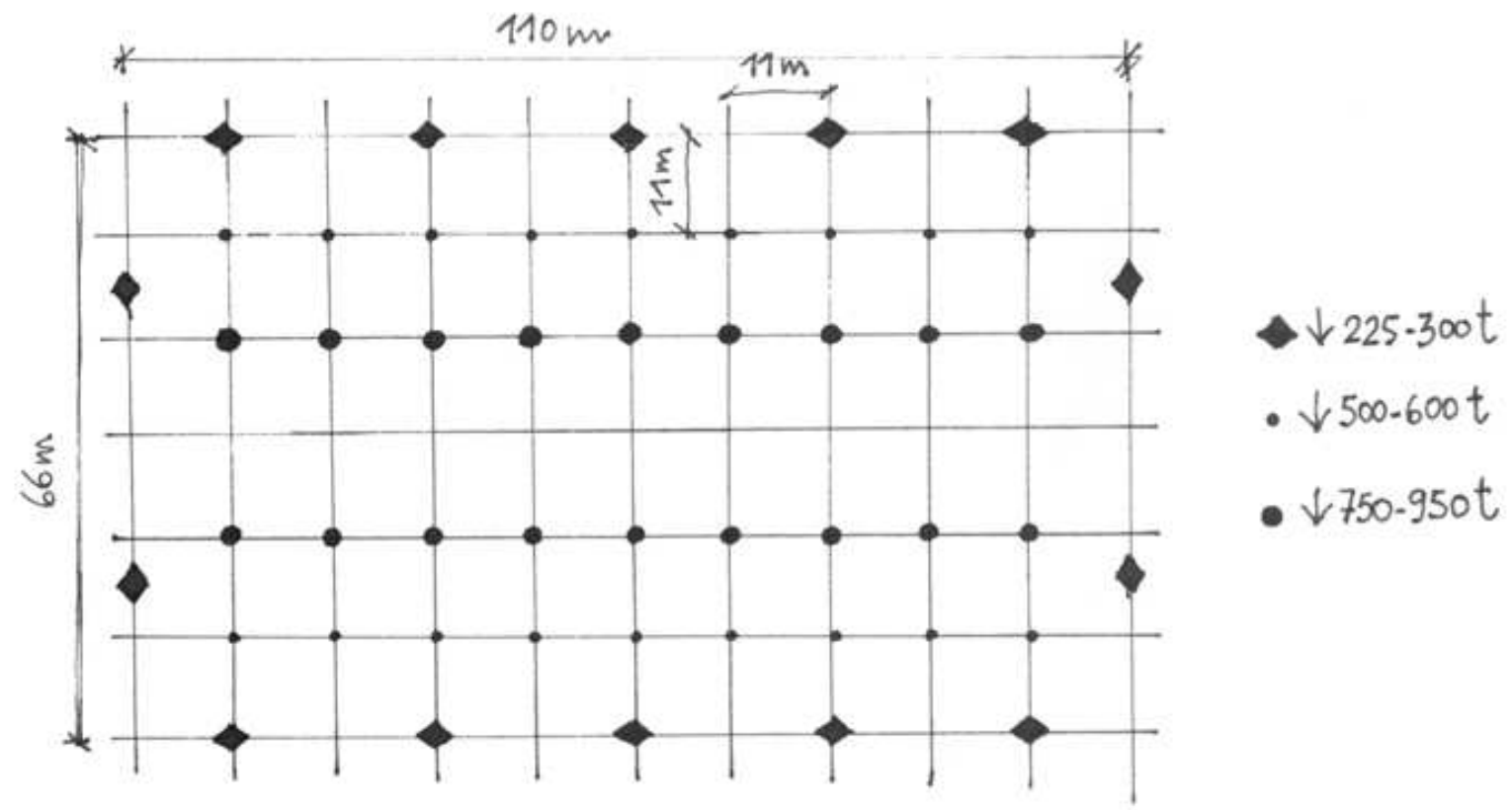

Esquema da malha estrutural.

Desenho Ana Clara Giannecchini

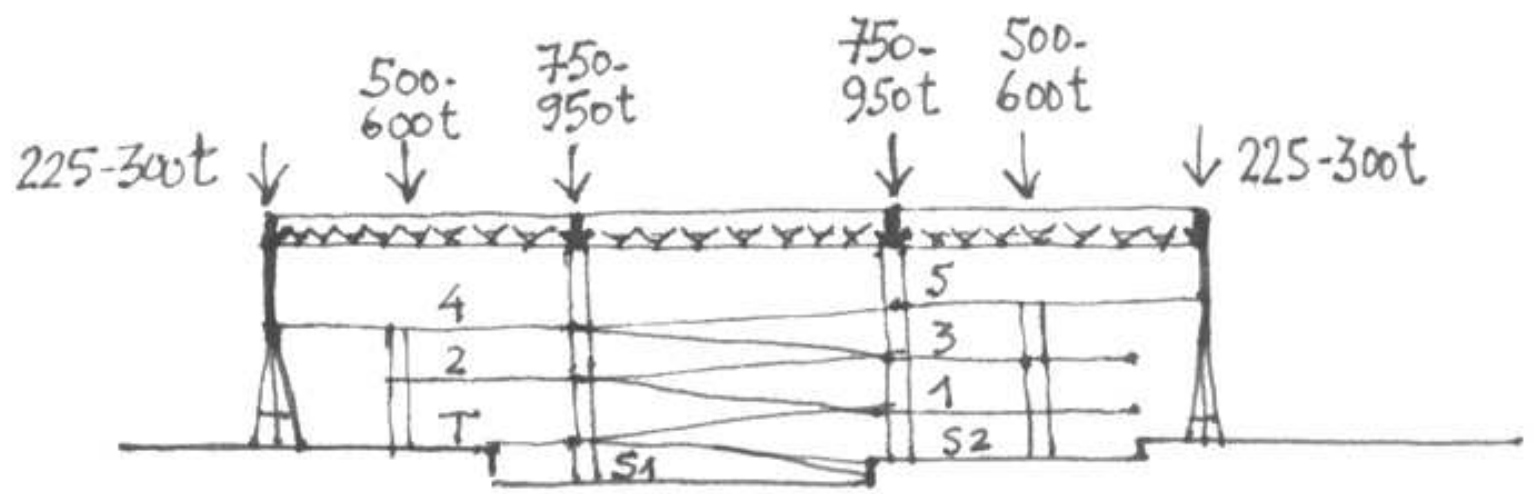

Distribuição das cargas.

Desenho Ana Clara Giannecchini 


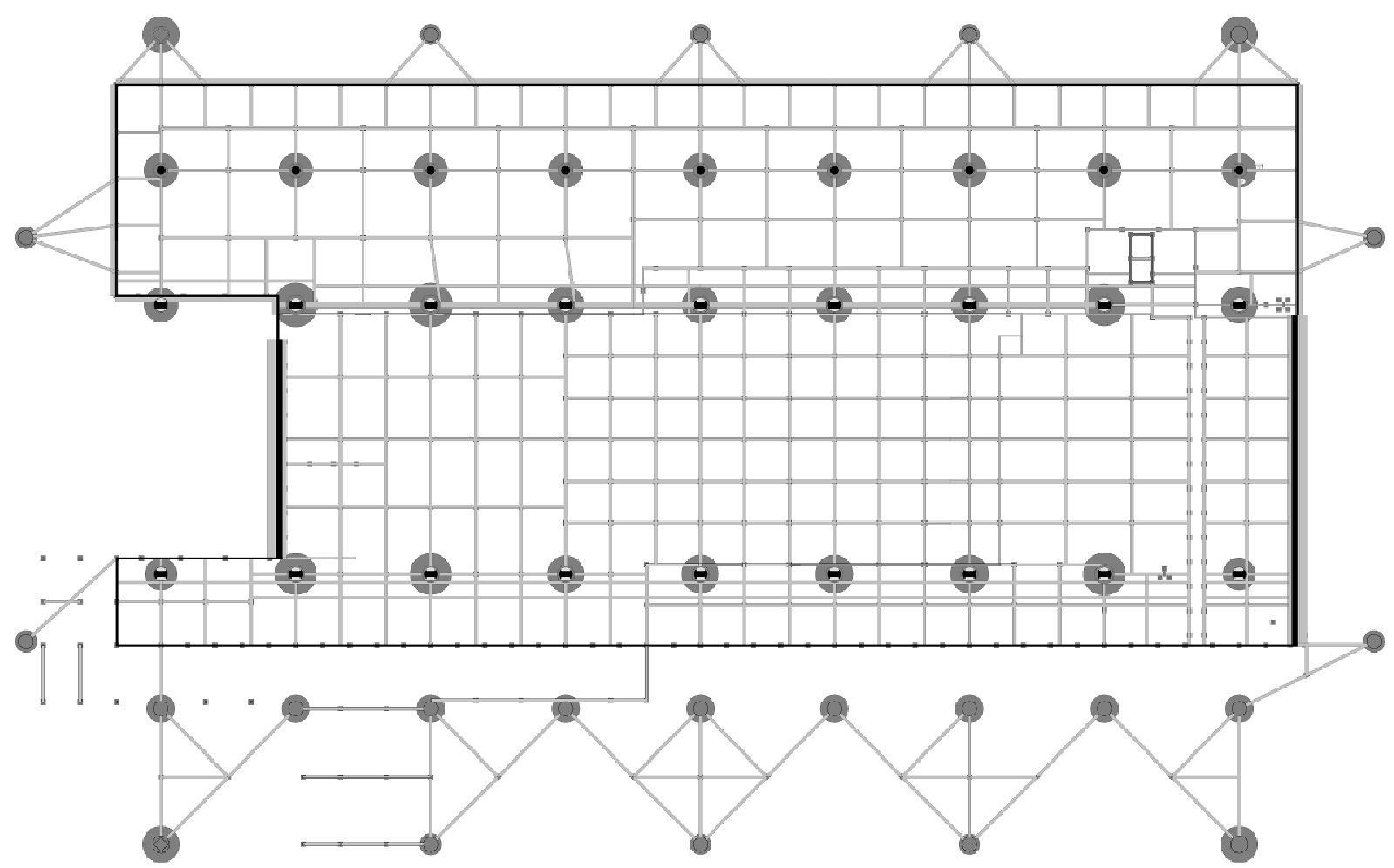

Planta da fundação. Modelo digital conforme projeto.

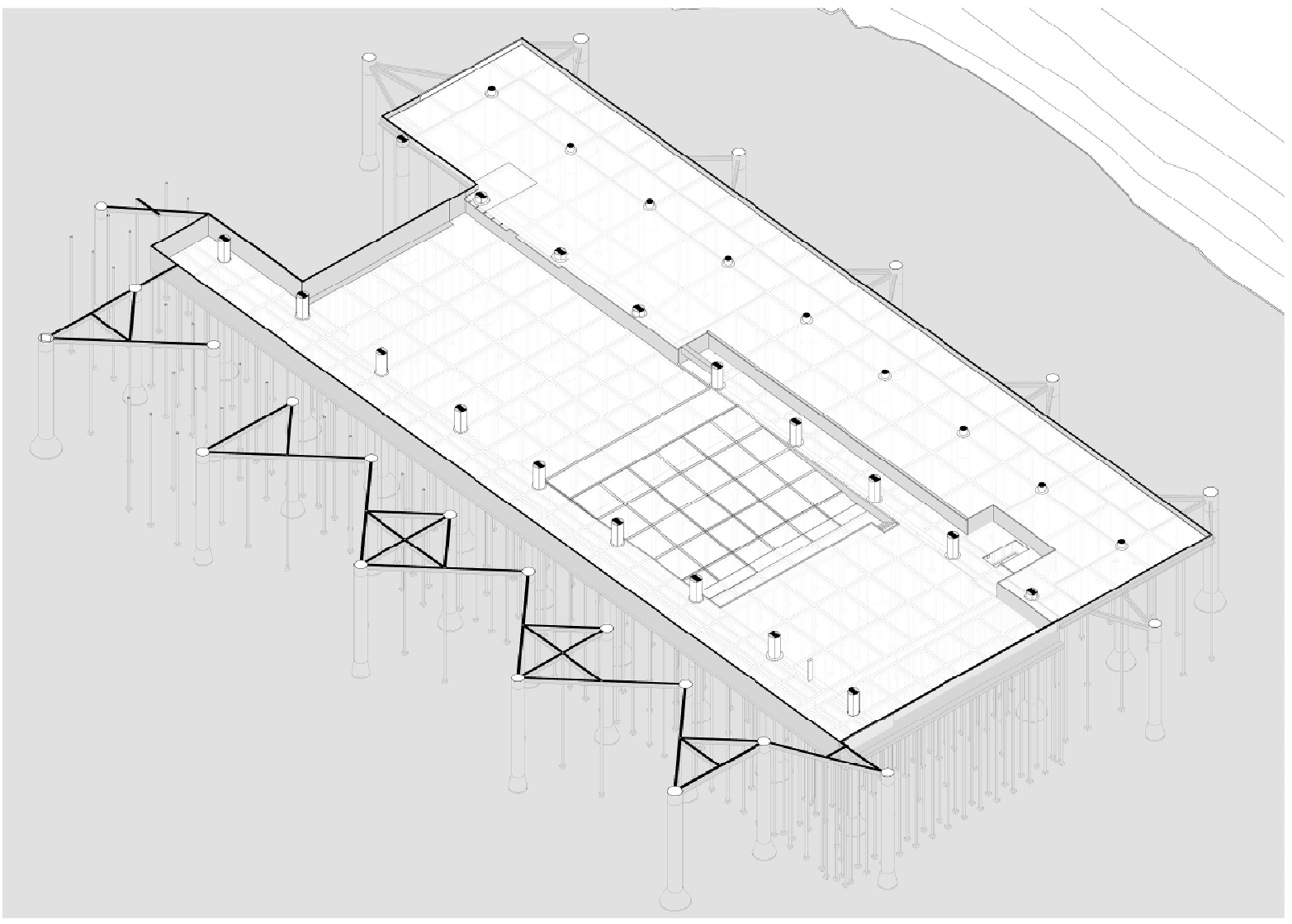

Planta da fundação, Modelo digital conforme projeto. 

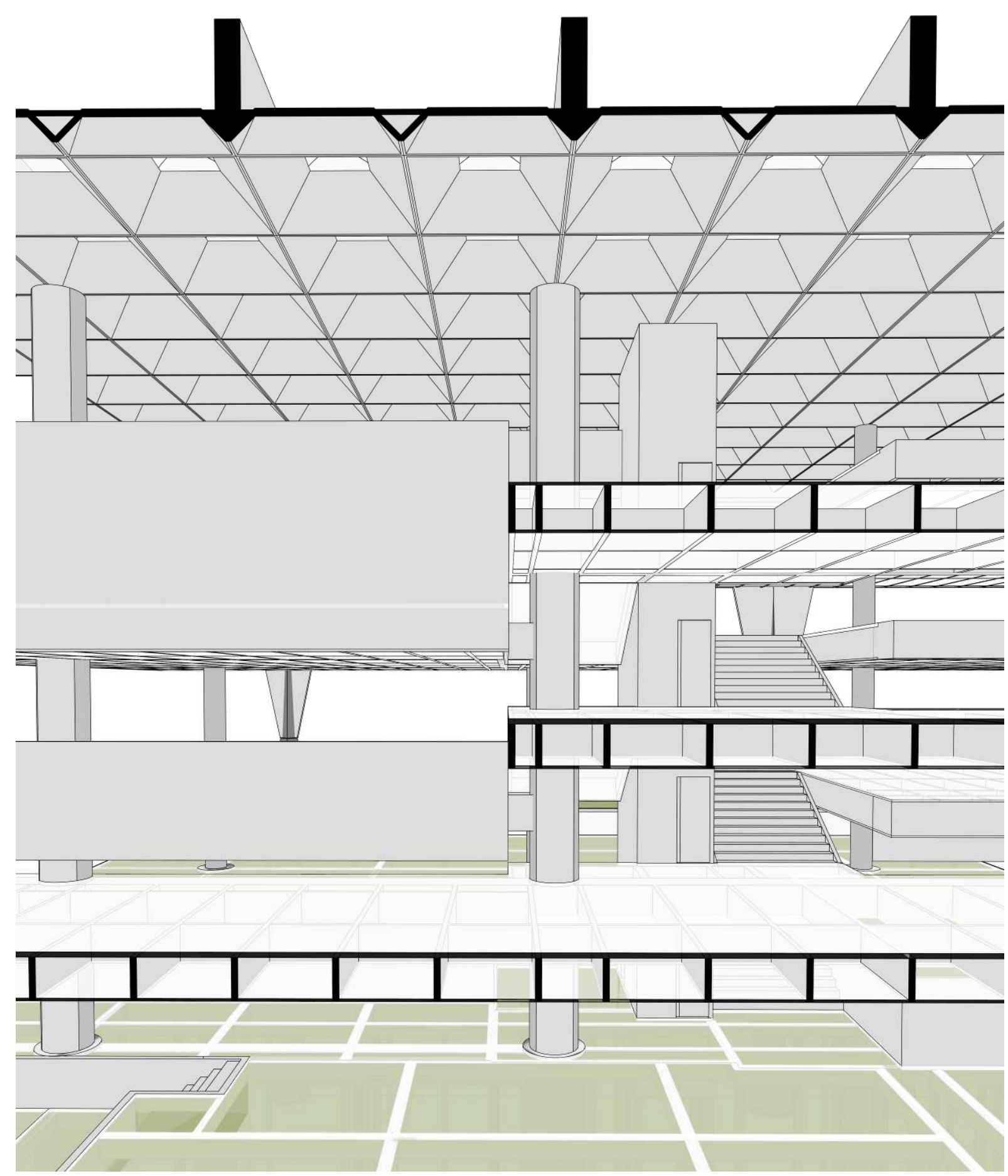

Seção das lajes. Modelo digital conforme projeto. 


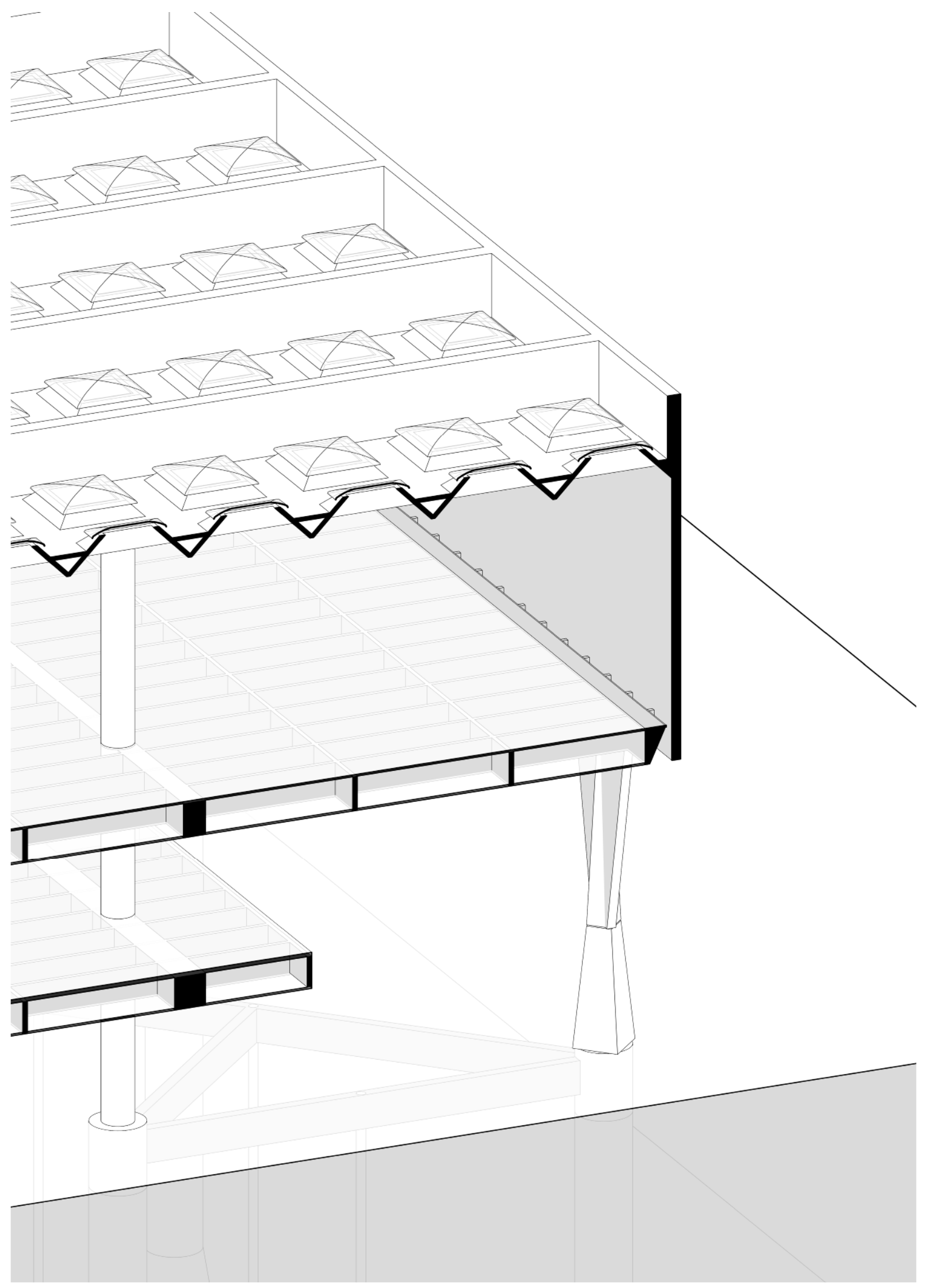

Encontro da empena com a estrutura do edifício. Modelo digital conforme projeto. 


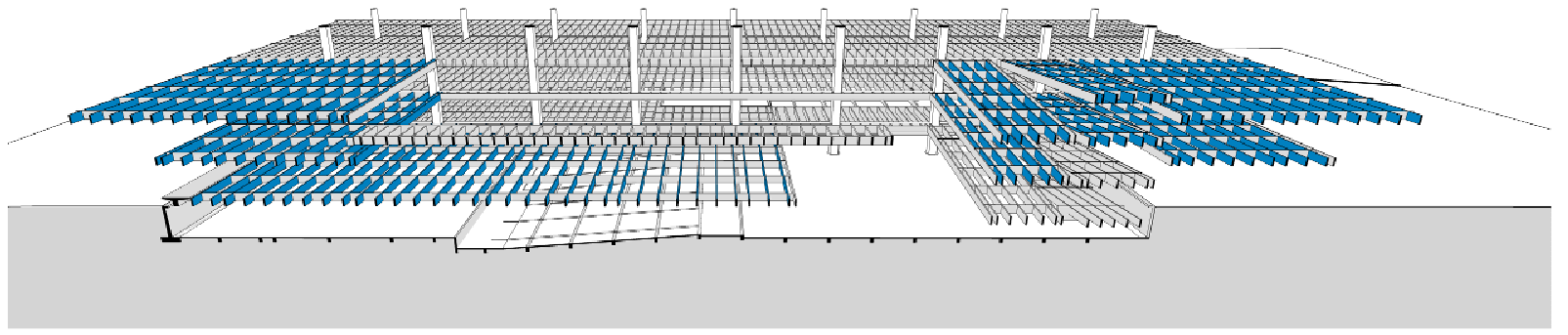

Vigas protendidas. Modelo digital conforme projeto.

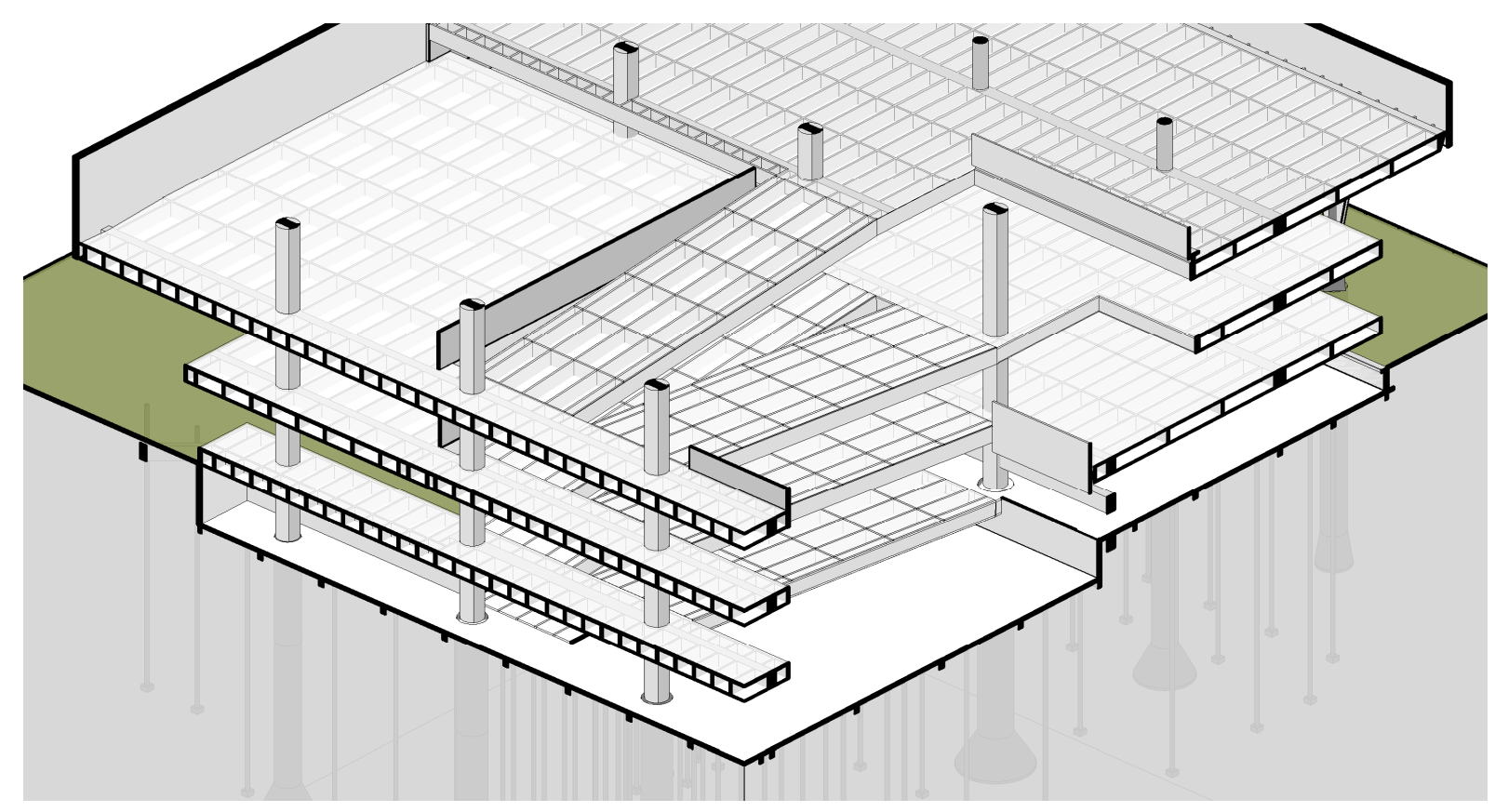

Estrutura das rampas protendidas. Modelo digital conforme projeto.

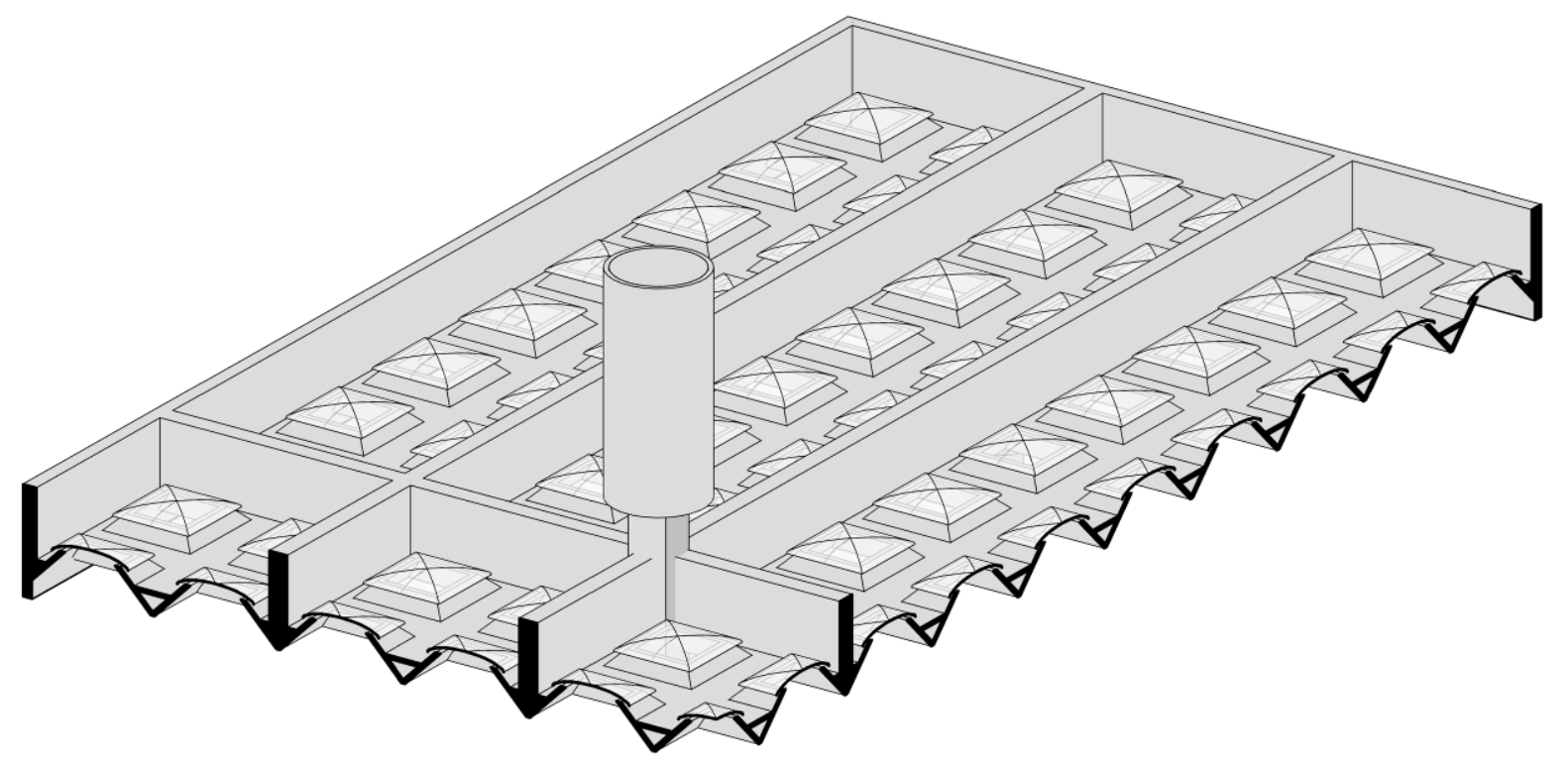

Estrutura da cobertura. Modelo digital conforme projeto. 


\section{Intervenção}

Se no início de 1963 o projeto da FAU estava pronto e o terreno possivelmente estaqueado $^{20}$, as circunstâncias não favoreceram o início da construção. Adhemar de Barros assumiu o governo do Estado de São Paulo e nomeou Luís Antônio da Gama e Silva como reitor. As verbas para a construção da Cidade Universitária, que vinham do Plano de Ação do Governo do Estado, passaram a depender da nova secretaria de Planejamento e apenas obras consideradas prioritárias foram iniciadas ou então as obras ligadas aos jogos PanAmericanos, para as quais foram obtidos recursos extras. No setor das humanas, somente o edifício da História e Geografia foi começado.

O plano para a Cidade Universitária de 1961-63 já estava atrasado, quando o golpe civilmilitar de 1964 e a perseguição a Artigas que o sucedeu tornaram o projeto da FAU ainda mais incerto. Quando Artigas finalmente se reestabeleceu, no segundo semestre de 1965, mais de dois anos depois do projeto ter sido concluído, a realidade era outra. Seu escritório estava abandonado, sem projetos nem funcionários. Até mesmo seu maior colaborador, Carlos Cascaldi, havia conseguido um novo emprego no Departamento de Urbanismo da Secretaria de Obras da prefeitura de São Paulo. ${ }^{21}$

Enquanto a maioria dos projetos do Plano de 1961 foi esquecida a construção do novo edifício da FAU voltou a ser cogitada, paradoxalmente, pelo novo diretor da FAU, Pedro Moacyr do Amaral Cruz, que havia estabelecido a mudança para a Cidade Universitária como uma prioridade de sua gestão por motivos de segurança, controle disciplinar e expansão do ensino. Em julho de 1965 (antes de Artigas ser absolvido e obter um habeas corpus), o diretor da FAU enviou cópias do projeto ao Fundo com alterações feitas por ele. ${ }^{22}$

O professor Anhaia Mello, já aposentado, tentou intervir em agosto de 1965, solicitando que Artigas elaborasse o projeto definitivo de instalação da faculdade na Cidade Universitária. A carta original de Anhaia Mello foi extraviada do processo no qual deveria estar anexada, de

\footnotetext{
${ }^{20}$ Segundo a mensagem encaminhada à Assembleia Legislativa em 1962, o FCCUASO e teria dado início à construção do edifício da FAU após a conclusão da Reitoria, em 1961. "O prédio da Faculdade de Arquitetura e Urbanismo já foi iniciado e deverá estar pronto no início de 1963. Em suas novas instalações, a Faculdade poderá desenvolver seu curso, com maior eficiência, pelo sistema de "atelier", atendendo à diretriz da formação de profissionais por meio do ensino objetivo". PAGE, 1962, p. 59, apud CORDIDO, Maria Tereza R. L. de B.; BUZZAR, Miguel.

${ }^{21}$ Cascaldi permaneceu na Prefeitura por seis meses. De 1966 a 1972 trabalhou na Carvalho Hosken S.A e realizou projetos por conta própria. FICHER. Sylvia. Os arquitetos da Poli: Ensino e profissão em São Paulo. São Paulo: Edusp, 2005, p. 322.

${ }^{22}$ Em carta posterior de Pedro Cruz para o reitor Gama e Silva, o diretor da FAU relembrou a sequência de eventos, afirmando que quando foi nomeado diretor da FAU, havia tentado reunir os professores da FAU para examinar o projeto de Artigas, mas estes se eximiram, de modo que ele próprio assumiu essa tarefa e enviou ao Fundo um conjunto de plantas com críticas e sugestões de alteração, de sua autoria. Carta de Pedro do Amaral Cruz ao reitor, de 27 de julho de 1966. Processo USP 66.1.20.458.1.8, fl.2 a 5 .
} 
modo que só podemos supor o seu teor pelo título do processo e pelos documentos em resposta. $^{23}$

Em resposta a Anhaia Mello, o novo diretor executivo do FCCUASO, Adalberto dos Santos, aparentemente ignorando as alterações propostas pelo diretor da FAU, solicitou autorização ao reitor Gama e Silva para abrir a concorrência para a construção da estrutura do edifício, informando já haver recursos destinados no orçamento do biênio 65-66. A abertura de concorrência foi, a princípio, aprovada pelo reitor, uma vez que a obra estava implicitamente aceita quando o Conselho de Administração do Fundo a incluiu em seu orçamento. Mas, ao tomar conhecimento do andamento do processo, o diretor da FAU, Pedro do Amaral Cruz, protestou alguns dias depois, anunciando que o projeto de Artigas e Ferraz não havia sido aprovado na FAU e que o projeto precisava de alterações:

"O esquisito projeto da Faculdade de Arquitetura e Urbanismo, conduziu a uma estrutura de concreto, totalmente afastada dos cânones usuais, com um volume tremendo de concreto protendido, tendo como consequências: um preço exagerado para a estrutura, e um prazo dilatadíssimo para a sua construção". ${ }^{24}$

Pedro Cruz justificava sua intervenção com base na diretriz do Conselho Universitário que escabeceia que "nenhuma obra deveria ser autorizada sem que se atendesse, primordialmente, os aspectos funcionais e econômicos dentro do fator tempo". 25

A abertura da concorrência foi adiada e, para resolver o impasse de quem deveria fazer as alterações no projeto, o diretor do Fundo sugeriu a criação de uma comissão, que foi nomeada pelo Reitor em 20 de setembro de 1965: fariam parte dela o diretor da FAU, Pedro do Amaral Cruz, o professor Telêmaco Van Langendonck e o engenheiro Oscar Costa. ${ }^{26}$

A Comissão cumpriu um papel meramente formal, apenas ratificando a opinião de Pedro Cruz. Em 11 de outubro de 1965, foi apresentado seu parecer decidindo pela manutenção do projeto de Artigas, uma vez que a substituição completa foi considerada mais custosa e demorada. ${ }^{27}$ No entanto, a comissão condicionava a realização da obra à "revisão da destinação das áreas". O aspecto mais criticado era o baixo aproveitamento de alunos por metro quadrado, sendo necessário conferir "maior funcionalidade interna, o que não havia no projeto primitivo". Assinando o parecer, Pedro do Amaral Cruz conclui que apesar do

\footnotetext{
${ }^{23}$ Processo USP n. 65.1.3988.51.8 - "Professor Anhaia Mello, solicita que o professor João Batista Vilanova Artigas elabore o projeto definitivo de instalação daquela faculdade, na Cidade Universitária".

${ }^{24}$ Carta de Pedro do Amaral Cruz ao reitor, de 30 de agosto de 1965. Processo USP 65.1.3988.51.8, p. 6-8.

${ }^{25}$ Idem.

${ }^{26}$ Ingressou na Escola Politécnica em 1930. Foi presidente do Sinduscon de 1956 a 1971.

${ }^{27}$ Parecer de Pedro Moacyr do Amaral Cruz, de 11 de outubro de1965. Processo USP n. 65.1.3988.51.8, p. 14-17.
} 
"aspecto arquitetônico, excessivamente original, um tanto exótico mesmo", o projeto de Artigas configuraria um "testemunho histórico de uma fase da arquitetura brasileira". No entanto, as "grandes áreas livres" e "jardins cobertos" deveriam ser tratados com "menos poesia e maior realidade".

De fato, a obra de Artigas - nessa altura o arquiteto de maior renome da FAU - parecia ser incompreensível para o diretor da faculdade. Segundo depoimento de Vladimir Brega, engenheiro do Fundo encarregado da obra da FAU, o diretor não se conformava, por exemplo, com a ausência de janelas na fachada. ${ }^{28}$

O Escritório Técnico do Fundo ficou encarregado de desenhar as plantas com as modificações feitas pela diretoria ${ }^{29}$ e enviá-las para que Artigas fizesse os estudos necessários e devolvesse uma versão final para aprovação da Comissão. Os desenhos enviados para Artigas no final do ano de 1965 eram cópias de seu projeto básico, com intervenções sobrepostas aos desenhos originais e as seguintes anotações textuais:

"Estes elementos vasados são condenados pois permitem irrefletidamente incêndio na cabine [primária] por sabotagem externa".

"Vedação necessária [na entrada do auditório] para evitar entrada extemporânea de alunos e funcionários no auditório".

"Verificar a altura do piso [do auditório] com relação ao lençol freático".

"Verificar descarga dos esgotos [nos sanitários]".

"Acessos [do fundo do palco do auditório] a serem bloqueados intermitentemente".

"Estudar nesta vertical a possibilidade para um elevador de passageiros, capacidade reduzida para transporte de professores idosos, excepcionais, livros e material didático, etc.".

"Estudar a possibilidade de instalação sanitária exclusivamente feminina [no sanitário do 1ํ pavimento, ao lado das secretarias]".

De modo geral, as preocupações do diretor da FAU se limitavam a aspectos técnicos, de segurança e hierarquia. Mas para isso ele exigia, por exemplo, que a diretoria ficasse no $2^{\circ}$ pavimento e a biblioteca no térreo. Ou então que o grêmio passasse do subsolo para o piso do museu, permitindo o monitoramento de suas atividades.

\footnotetext{
${ }^{28}$ Depoimento de Vladmir Brega ao autor, realizado em 23 de fevereiro de 2011.

${ }^{29}$ O carimbo das folhas trazia a indicação "Modificada pela diretoria" e a anotação: "Este desenho é cópia fiel do desenho modificado pela diretoria da FAU assinada pelo professor dr. Pedro Moacyr do Amaral Cruz, diretor". Devido ao conturbado processo de aprovação do projeto a placa da obra, instalada pelo Fundo, trouxe o nome Pedro do Amaral Cruz como autor do projeto. Ao perceber o erro, em fevereiro de 1967, o diretor da FAU solicitou a retificação em reconhecimento ao arquiteto Vilanova Artigas.
} 
Em janeiro de 1966, após uma série de cobranças de urgência, o arquiteto enviou sua revisão atendendo as solicitações da Comissão. Artigas acatou as todas as "sugestões" do diretor. O grêmio passaria a ocupar o lugar da cantina, que deixaria de existir (seria uma estratégia para depois apenas mudar a função dos espaços?). A diretoria e a biblioteca passariam para os pisos designados pelo diretor. $02^{\circ}$ pavimento seria estendido ao lado das rampas, para abrigar a Congregação no piso da diretoria. Do mesmo modo a laje do térreo (e do subsolo) se estenderia para acomodar a biblioteca, em $L$ ao redor do salão caramelo, que deixava de ser acessado pelo exterior. No piso dos departamentos, nessa altura já definidos, o Atelier Interdepartamental seria compartimentado para dar espaço ao Gabinete de Comunicação Visual, ao Gabinete de Pesquisas e Estudos de Projetos e Construções e ao Gabinete de Instrumental de Física e Topografia. No último pavimento os estúdios seriam fechados por divisórias e portas e as salas de aula seriam divididas em cinco, uma para cada ano, com capacidade para 80 alunos cada.

No final, a crítica do diretor às áreas vazias e ao baixo aproveitamento de alunos por metro quadrado, não justificava as mudanças. Houve, aliás, acréscimo de área e aumento da circulação. Evidentemente ninguém questionou. Artigas incluiu um elevador no projeto, na área que já estava previsto.

O arquiteto enviou seus honorários referentes às modificações e ao acompanhamento da obra que representavam aproximadamente $15 \%$ do valor que the havia sido pago pelo projeto básico. Esse valor foi contestado e somente pago depois de reduzido. ${ }^{30}$

${ }^{30}$ Processo USP 65.1.3988.51.8, fl 39. 
Vilanova Artigas e Carlos Cascaldi.

Modificações para diretoria, julho 1966

Arquivo FAUUSP

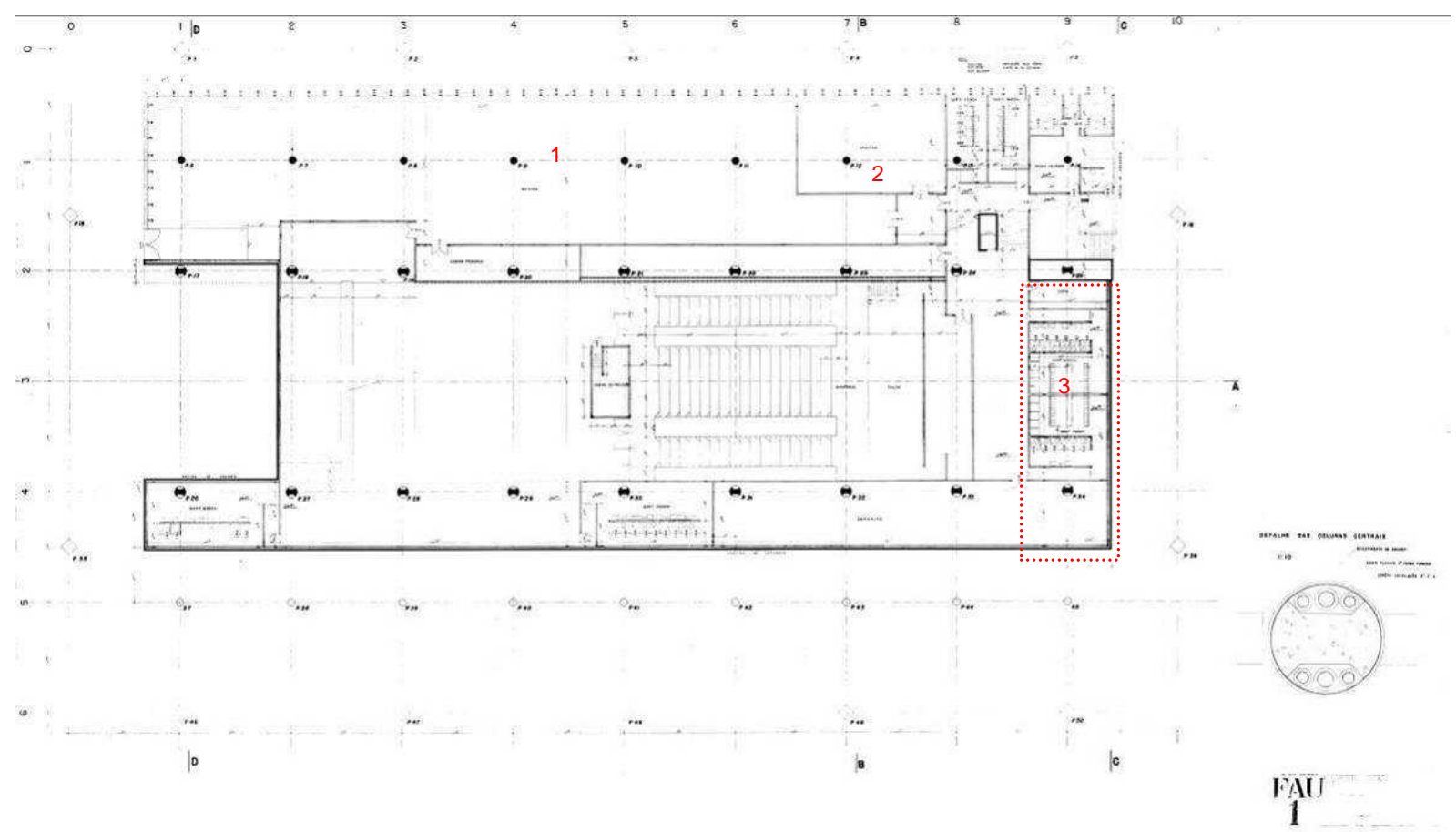

Planta do subsolo, 1:100

Alterações: 1. Oficina (sem o Grêmio) recebe uma rampa de acesso mais larga (ao invés de escada); 2. Gráfica é deslocada; 3. Copa e Vestiário dos funcionários avançam além do eixo 9, aumentando a largura do corredor e a área do depósito.

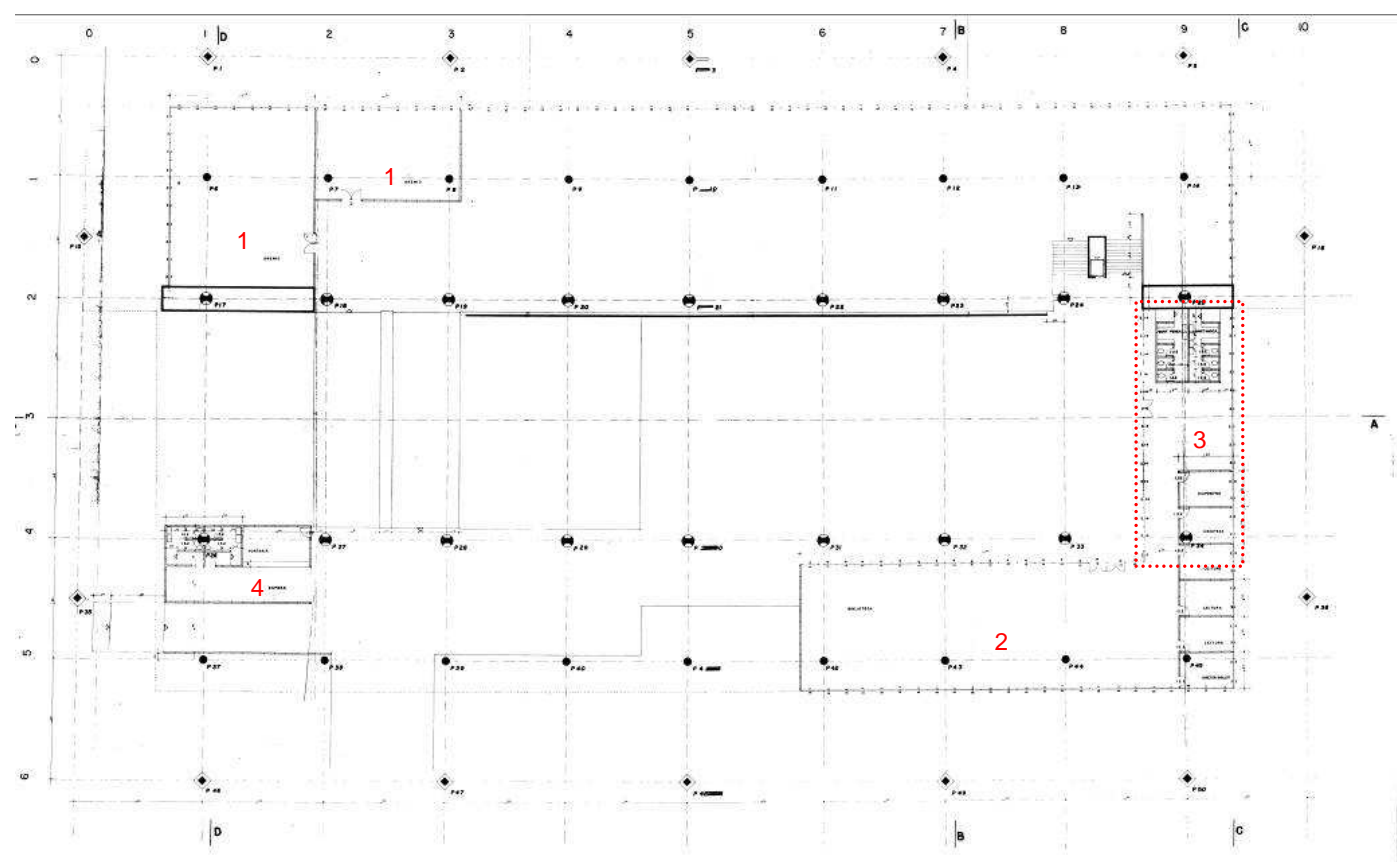

FAU

Planta do $1^{\circ}$ pavimento (térreo), 1:100

Alterações: 1. Grêmio (no lugar da cantina); 2. Biblioteca (no lugar da diretoria); 3. Salas da biblioteca (Diapositivos, Discoteca, Leitura e Diretoria da biblioteca) e um par de sanitários avançam em área que antes era externa; 4 . Ampliação da portaria com sanitário e sala de espera. 


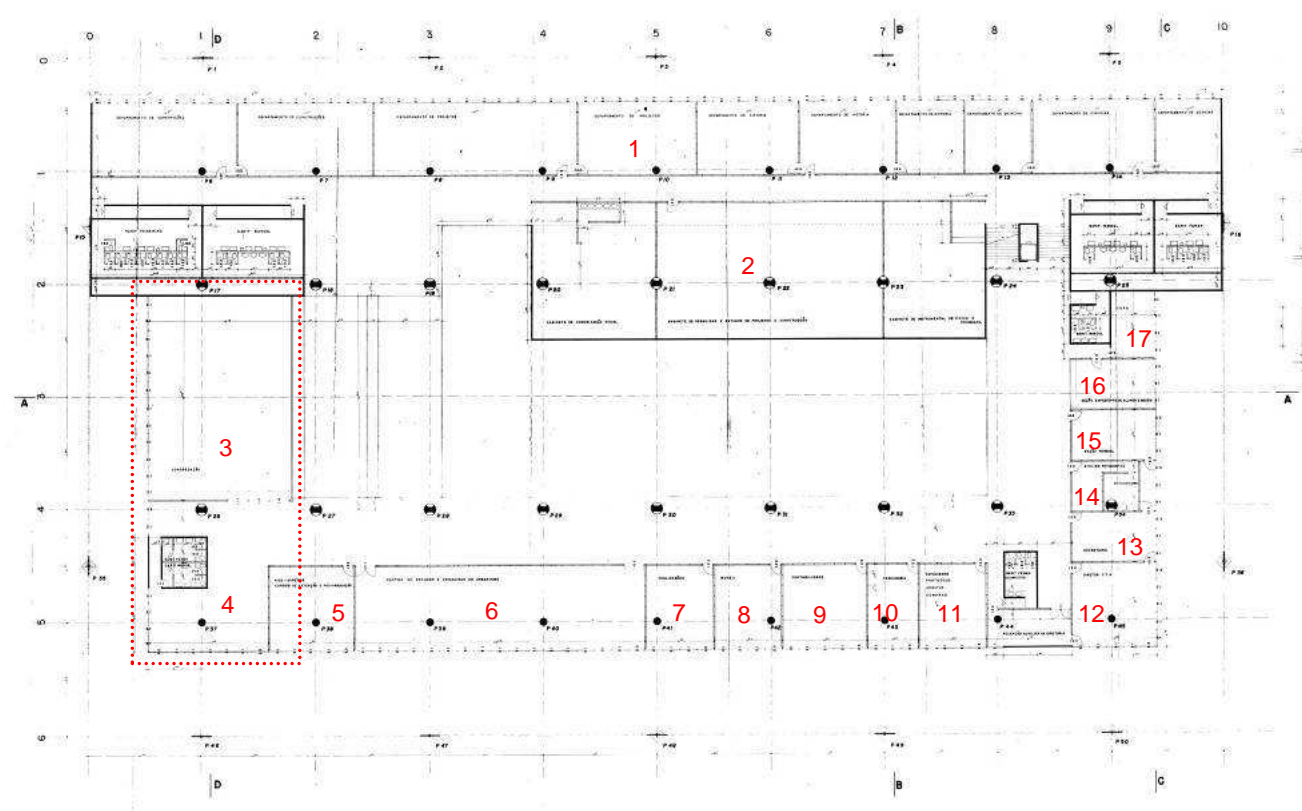

Planta do $2^{\circ}$ pavimento, 1:100

Alterações: 1. Recompartimentação, renomeando os departamentos de Urbanismo para Projetos e de matemáticas para Ciências. Ampliação dos departamentos de História e de Ciências e diminuição do departamento de Projetos; 2. Gabinete de Comunicação Visual; gabinete de Pesquisas e Estudos de Projetos e Construções; e Gabinete de Instrumental de Física e Topografia (com portas e divisórias onde antes não havia); 3. Congregação (acréscimo de área); 4. Sala de espera e sanitários (acréscimo de área); 5. Vice-diretor; 6. CPEU; 7. Publicações; 8. Museu; 9. Contabilidade; 10. Tesouraria; 11. Expediente; 12. Diretor e CTA; 13. Secretaria; 14. Atelier fotográfico; 15. Seção Pessoal; 16. Seção de alunos; 17. Copa.

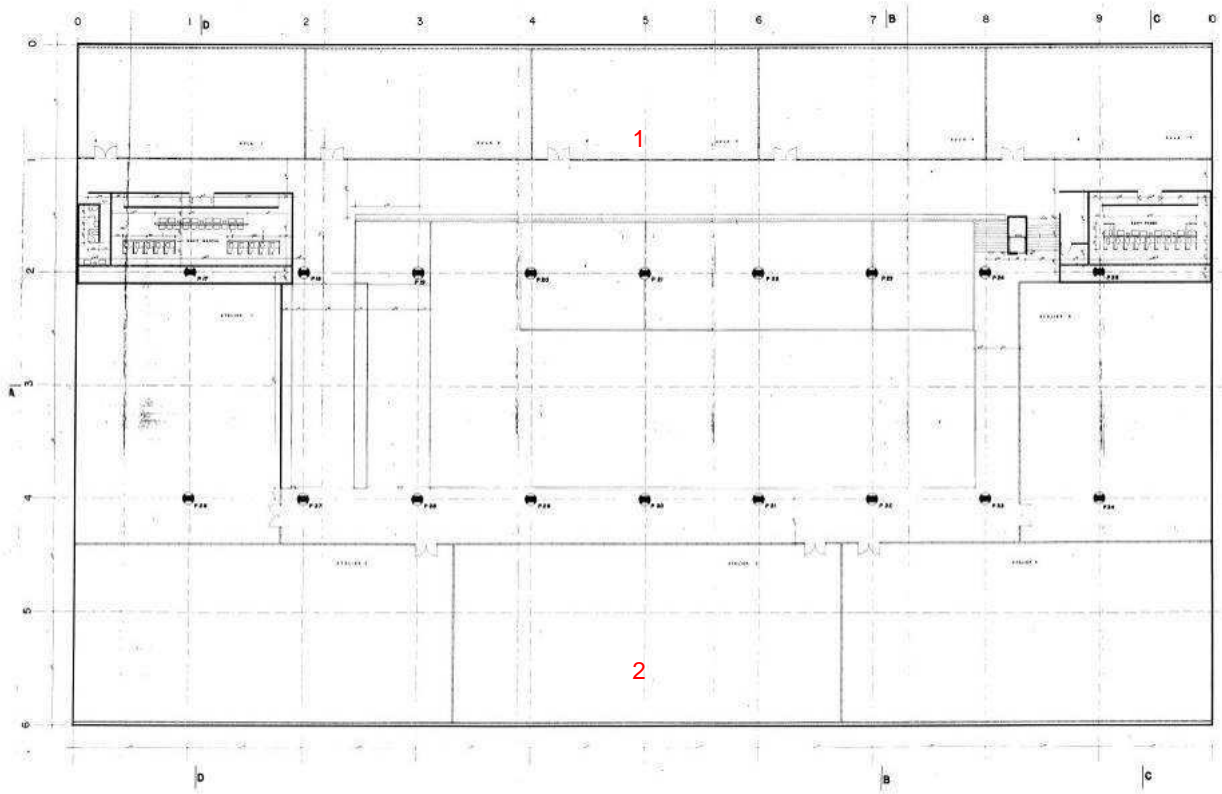

FAU

Planta do 3 pavimento, 1:100

Alterações: 1. Redivisão das salas de aula em 5 (eram 10); 2. Fechamento e portas dividindo os ateliês, eliminação da Chefia dos Ateliês e das cabines com água 


\section{Revisão do projeto de estrutura}

Em de janeiro de 1966, dois dias depois de recebidos os desenhos de Artigas, o diretor do Fundo, Adalberto Mendes dos Santos, informava ao arquiteto que o anteprojeto havia sido integralmente aprovado pelo diretor da FAU e solicitava o reenvio desses desenhos para o escritório de Figueiredo Ferraz proceder a revisão do projeto estrutural por conta das alterações no projeto. Dizia ainda que continuava aguardando sugestões para a simplificação da cobertura.

"Nesta oportunidade, permitimo-nos lembrar que, segundo entendimentos anteriores, a solução encontrada [para a cobertura] deveria ser submetida ao Setor Técnico do 'Fundo' antes de ser apresentada aos engenheiros estruturais, tendo em vista a grande experiência que este órgão possui no campo de coberturas de concreto em grandes vãos". ${ }^{31}$

Artigas inaugurou a solicitação e enviou as plantas diretamente para Ferraz. Os novos desenhos do projeto estrutural começaram a ser entregues em abril de 1966, quando o diretor executivo do Fundo pretendia alocar na obra da FAU os trabalhadores disponíveis. ${ }^{32}$ No entanto, as modificações no projeto exigiram um longo retrabalho no cálculo da estrutura principalmente por conta dos acréscimos de áreas. Do projeto estrutural original, 36 folhas foram modificadas (até novembro de 1966) e 22 folhas completamente reemitidas (até setembro de 1967). Ou seja, a revisão atingiu pelo menos 58 das 101 folhas originais. Além disso, 31 novas folhas que foram emitidas entre maio de 1966 e fevereiro 1968. O projeto estrutura da FAU acabaria sendo um dos mais complexos já realizados por Figueiredo Ferraz, sendo necessários cálculos exaustivos e inúmeros detalhes de fôrmas, armação e fundação. O escritório, que continuou fazendo revisões durante a obra, chegou mesmo a solicitar reconsideração de seus honorários em função do detalhamento "de uma estrutura das mais difíceis dentre as muitas executadas na nossa atividade profissional". ${ }^{33}$

Em 25 de maio de 1966, enfatizando que o resultado final dependeria dos cuidados tomados durante a concretagem, Figueiredo Ferraz enviou orientações para a execução da estrutura, tendo em vista a iminência do edital para execução da estrutura de concreto armado.

\footnotetext{
${ }^{31}$ Carta de Adalberto Mendes dos Santos, Diretor Executivo do FCCUASO, ao arquiteto Vilanova Artigas. 31 de março de 1966 Processo USP n. 65.13988.51, fl. 42.

${ }^{32}$ Carta de Adalberto dos Santos de 17 de fevereiro de 1966, que afirmava o compromisso de iniciar a obra em abril "pela necessidade de dispor de obras para utilizar os operários que ficarem liberados no Prédio da História-Geografia". Processo USP n. 65.1.3988.51.8, fl. 38.

${ }^{33}$ Carta de Figueiredo Ferraz ao diretor do FCCUASO, Adalberto dos Santos. 27 de dezembro de 1967. Processo USP 65.1.3988.51.8, fl. 108.
} 


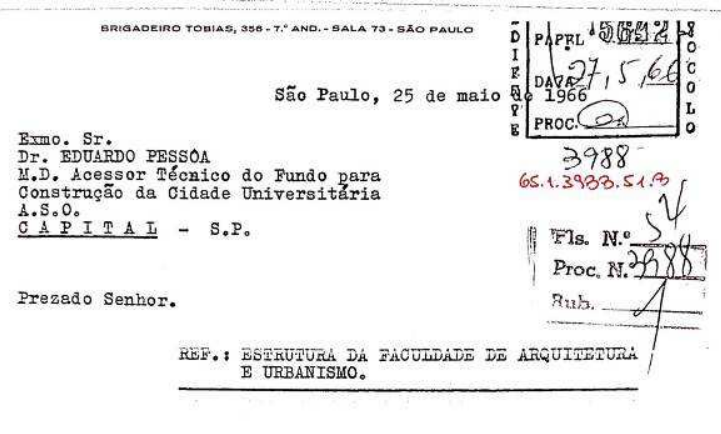

Reportando-nos ao que haviamos prometido quando da nossa última reunião, vimos assinalar certos tópicos que julgamos importantes. Assim :

1. Todo o concreto de fundação, lajes de subsolo, cor tinas e arrimos será de $\sigma_{\mathrm{C}} 28=250 \mathrm{~kg} / \mathrm{cm}^{2}$; tudo $n^{\prime}$ un volume cêrce de $900 \mathrm{~m}^{3}$.

2. Todo o concreto estrutural será de $\sigma_{\mathrm{C}} 28=320 \mathrm{~kg} / \mathrm{cm}^{2}$, $\mathrm{n}^{\prime}$ um volume cêrca de $5.600 \mathrm{~m}^{3}$.

3. o contrôle da qualidade do concreto será rigoroso, nos têrmos da $\mathrm{NB}-1$.

4. As fôrmas serão preparadas de modo a permitir que o concreto aparente apresente-se com aspecto uniforme, sem defeitos.

5. As vigas paredes, da fachada, serão construidas por trechos horizontais, cujas alturas devem ser da ordem de $1,20 \mathrm{~m} \mathrm{a} 1,50 \mathrm{~m}$, com modulação prèviamente estabeleciđa.
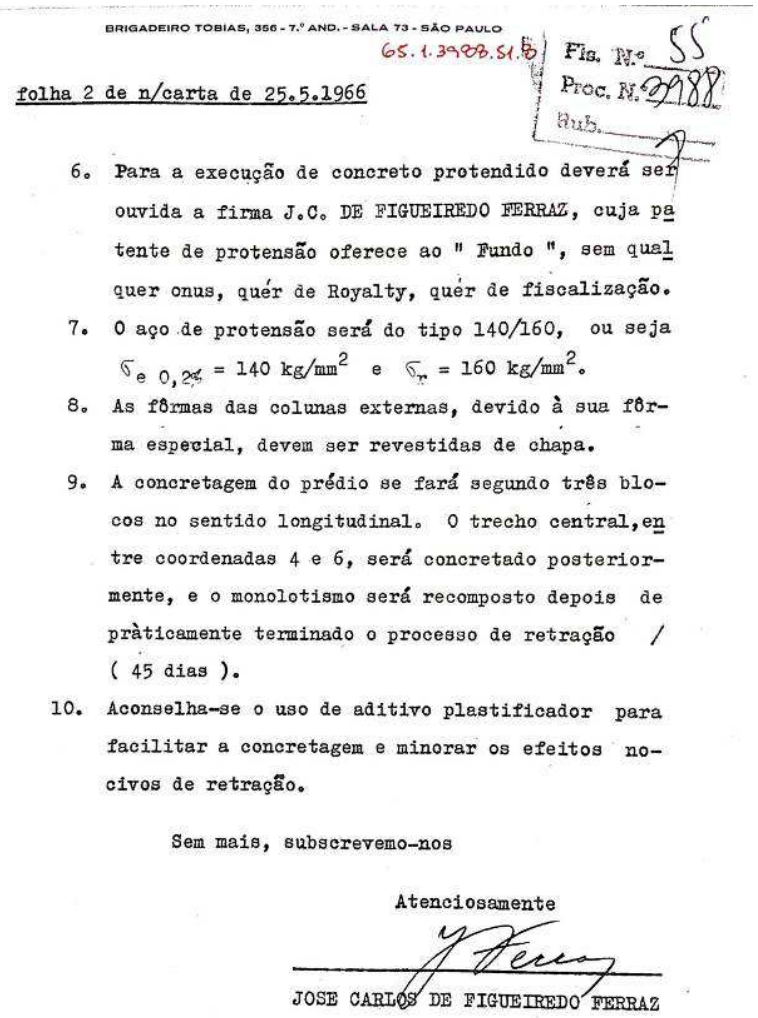

Carta de José Carlos de Figueiredo Ferraz 


\section{Hesitações}

Com a maior parte da revisão do projeto estrutural entregue entre maio e junho de 1966, enquanto uma equipe do Fundo realizava obras de reforço da fundação ${ }^{34}$, o diretor da FAU acreditava ter chegado a hora de contratar uma construtora e cobrou do reitor ações para a liberação de verbas e abertura de concorrência para execução da estrutura de concreto armado. Afinal, mesmo que o projeto não fosse de seu agrado, a construção do edifício era uma de suas prioridades:

"Na minha opinião, longe de evoluir, a Faculdade está em retrocesso, diria mesmo degenerescência; porque: a) inexiste como entidade fechada, administrável, controlável, é casa de todos e de ninguém; b) é difícil, senão impossível, manter o controle disciplinar administrativo, docente e discente; c) não oferece espaços para o funcionamento normal de seus órgãos; d) é impertinente a intromissão de elementos estranhos, perturbadores, no seu território; e) não atinge as suas melhores finalidades porque se desvia a todo momento do campo da construção para o campo da arte e de outras culturas ou semi-culturas paralelas; f) não pode ampliar sua capacidade didática" ${ }^{35}$

Adalberto dos Santos, respondendo pelo FCCUASO, argumentava que a demora no início da obra se devia à falta de recursos.

"O lançamento da concorrência da respectiva estrutura depende do esquema de entrega de recursos por parte da Secretaria da Fazenda, pois, o numerário que vem sendo entregue não tem sido suficiente para fazer frente às despesas das obras em andamento" ${ }^{36}$

Em agosto de 1966, ao informar o reitor da urgência cobrada pelo diretor da FAU, Adalberto Mendes dos Santos propôs executar a estrutura do edifício "diretamente, com os recursos que dispomos, de forma paulatina", estando convicto de "obter sua execução por administração própria, a preço muito mais vantajosos do que aquele estimado". Mais do que vantagens econômicas, o diretor executivo do Fundo enxergava vantagens técnicas em conduzir as obras por administração direta:

"Chegamos à conclusão que as estruturas executadas pelo próprio Fundo demonstram melhor acabamento e muito melhor aparência do que as contratadas. Isso se comprova com aquelas dos edifícios de 'Metalurgia' e de 'Minas' em confronto, como por exemplo, com a do

\footnotetext{
${ }^{34}$ Depoimentos de Vladimir Brega e Abdias Nogueira da Silva ao autor.

${ }^{35}$ Carta de Pedro Moacyr do Amaral Cruz ao reitor. 27 de julho de 1966. Processo USP n. 66.1.20458.1.8, fl. 4.

${ }^{36}$ Carta de Adalberto dos Santos ao direto da FAU. 13 de julho de 1966. Processo USP n. 66.1.20458.1.8, fl.6.
} 
edifício de História e Geografia; nas primeiras o concreto aparente é tão bem-acabado que merece os maiores elogios de todos os que visitam a Cidade universitária, enquanto as do edifício de História e Geografia fomos obrigados a pintá-las a fim de ocultar os defeitos de seu péssimo acabamento". ${ }^{37}$

O diretor do Fundo informava que após os trabalhos de remoção de terra dos blocos de fundações e reforço das fundações, "daremos início a execução da estrutura". A administração direta foi, a princípio, aceita pelo reitor e pelo diretor da FAU que, no entanto, acrescentou uma ressalva exigindo que o concreto protendido fosse executado por uma firma especializada. O diretor do Fundo, no entanto, julgou contraproducente dividir a obra e anunciou que toda a obra seria realizada por inciativa privada.

Em 10 de setembro, dias depois daquela discussão, foi publicado no diário oficial a abertura da concorrência para a execução da estrutura de concreto. Apesar de tudo parecer progredir, o orçamento do Fundo para 1967 foi reduzido pela secretaria de Planejamento. Além disso, o reitor enfrentava uma batalha pública com a classe dos arquitetos por conta de sua decisão de desmontar um edifício do CRUSP quando resolveu questionar o custo estimado do edifício da FAU e o excesso de espaços livres no projeto de arquitetura. A sessão do Conselho Universitário, de 17 de outubro de 1966, reabriu a discussão em torno do plano construção da Cidade Universitária já aprovado pelo Conselho do Fundo. "Após ampla discussão, o Conselho deliberou a não fixação de nenhum prédio no campus, sem que seja resolvido estudo a cargo da Comissão Especial". ${ }^{38} \mathrm{~A}$ ata da reunião do Conselho de Administração do FCCUASO, de 29 de novembro de 1966, traz o posicionamento contrário do reitor, e a defesa do projeto feita por Pedro Moacyr do Amaral Cruz, para quem, mesmo se "exótico", o projeto representaria a arquitetura brasileira de seu tempo. O diretor da FAU teria então, segundo consta em ata, feito "longa exposição do projeto demonstrando sua funcionalidade e o bom aproveitamento obtido nesse trabalho".

O debate se estendeu no Conselho Universitário (CO), órgão máximo da universidade, onde Paulo Mendes da Rocha era representante dos auxiliares de ensino da USP:

"[...] a FAU não tinha voto nenhum, ganhava sempre Medicina, Direito, Politécnica. Estava em votação e a votação era pelo número de representantes dos grêmios [sic]. Então, foi combinado pela

\footnotetext{
${ }^{37}$ Carta de Adalberto dos Santos ao Reitor. 22 de agosto de 1966. Processo USP n. 66.1.20458.1.8, fl.8. A construtora do prédio da História e Geografia foi a ANR (conforme livreto da construtora) e o projeto estrutural foi de Figueiredo Ferraz. Ambos atuaram no edifício da FAU.

${ }^{38}$ RANIERI, Nina Beatriz. (org). Autonomia Universitária na USP: 1934-1969. São Paulo: Edusp, 2005, p. 237.
} 
esquerda justamente que seria eu, e todos votaram em mim, para defender a FAU, para defender a posição da FAU". 39

Ainda que sua atuação estivesse relacionada a um conjunto amplo de posicionamentos em defesa do grupo que representava ${ }^{40}$, Paulo Mendes avalia que seu papel foi mais específico:

"Fiz parte do Conselho Universitário, praticamente só para defender a construção da FAU. Não havia outra razão [...]. A FAU saiu porque eu defendi, inclusive".

E mais adiante, explica como foi feita essa defesa.

"A reunião do Conselho começava de manhã e ia até de noite, com um intervalo de almoço. Quem sentava do meu lado era uma figura nova. [...], era uma senhora, que eu não conhecia [vice-diretora da FMRP]. [...] Depois do almoço, na segunda sessão, ela já me abordou e disse: '- Você é arquiteto? Professor, queria fazer uma pergunta, porque estou um pouco desconfiada' (não lembro qual expressão ela usou). '- Eu fui convidada e fui almoçar na casa do Reitor, entre outras pessoas, e ele falou muito sobre a votação que vai ter sobre a verba da FAU e disse que nós devíamos votar contra. Ele está esperando o nosso voto contra porque o prédio é uma tolice dos arquitetos, é um prédio faraônico, porque tinha inclusive uma piscina olímpica na cobertura. Mas eu achei um pouco estranho. É verdade?'. Aí você imagina o que eu disse a ela. Como o voto era aberto, ela votou a favor da FAU. Então, o Gama e Silva, por essa e outras razões me odeia". 41

Considerando que o edital para contratação de construtora já havia sido publicado, o CO aprovou a verba para o edifício da FAU, ainda que contra a vontade do reitor. Adalberto Mendes dos Santos comunicou ao diretor FAU que havia obtido a autorização para contratação de empresa que construiria a estrutura da FAU e, no dia 15 de dezembro, foi publicado no Diário Oficial o anúncio da contratação da Construtora ANR para a execução da estrutura do edifício da FAU com prazo de 400 dias a partir da autorização de início de serviços, que foi dada no dia 26 daquele mês.

\footnotetext{
${ }^{39}$ Depoimento de Paulo Mendes da Rocha ao autor, realizado em 16/07/2014. Conforme as atas do Conselho, publicadas em RANIERI, Nina Beatriz (org), Op. Cit., Paulo Mendes da Rocha participou das sessões entre 17.10.1966 e 06.11.1967.

${ }^{40}$ Como exemplo, o caso citado em entrevista ao autor: "O nosso professor querido lá do Departamento de História teve que sair, foi pro estrangeiro para um Congresso, e estava marcado o exame para catedrático, em que ele era um candidato na escola dele. Mas ele sabia que o Gama e Silva ia abrir o exame quando ele estivesse fora. Ele não podia adiar a viagem. Então, eu fui encarregado de pedir vistas assim que abrisse o processo... Eu fiz isso três ou quatro vezes".

${ }^{41}$ Depoimento de Paulo Mendes da Rocha ao autor, realizado em 16/07/2014
} 


\section{CANTEIRO (1967-1969)}

\section{A construtora}

A construtora ANR Ltda., fundada em 1951, levava o nome de seu proprietário, Alberto Nagib Rizkallah (1928-1977), engenheiro formado pela Escola de Engenharia da Universidade Mackenzie em 1951, neto do imigrante sírio Rizkallah Jorge, que fez fortuna com a Casa da Boia, fabricante peças de cobre e bronze. ${ }^{42}$

A ANR começou construindo casas por incorporação própria. Na virada para a década de 1960, a empresa cresceu e chegou a figurar entre as maiores de São Paulo, conforme pode ser verificado do indicador mensal da revista Dirigente Construtor. Segundo esse índice, a maior rival da ANR em São Paulo, durante a década de 1960, era a Construtora Adolpho Lindenberg. Nesse período, a ANR saiu do "moderníssimo prédio" na Praça Antônio Prado, n. 33, no qual ocupava "quase um andar", e se mudou para uma casa na Rua Estados Unidos, n. 889, esquina com a Rua Canadá. Se num primeiro momento, segundo o irmão de Alberto, Alfredo Rizkallah ${ }^{43}$, a empresa tinha cerca de 40 funcionários fixos dentre engenheiros residentes e administradores, além de alguns mestres de obras, enquanto os "peões" eram contratados através de empreiteiros; posteriormente, segundo Vera Lucia Rizkallah, a ANR teve quase 500 funcionários, contando os encarregados e mestres de obra, sendo cerca de 200 somente no Escritório Central. ${ }^{44}$ Segundo Vera Lucia Rizkallah, "no dia de cada concorrência, tinha uma reunião em casa com todos os diretores da construtora para eles decidirem que preço que eles colocariam na concorrência". ${ }^{45}$

Nos dez primeiros anos de sua existência, a ANR havia participado da execução de obras para o governo federal de Juscelino Kubitschek, como a Biblioteca da Escola Paulista de Medicina, a Escola Técnica Industrial de São Bernardo, as Faculdades de Direito e Medicina de Niterói; e para o governo do Estado de São Paulo de Carvalho Pinto, muitas das quais na Cidade Universitária, como o Conjunto do Biênio da Escola Politécnica, o Pavilhão de

\footnotetext{
${ }^{42}$ As informações usadas a seguir foram extraídas de entrevista com sua filha, Vera Lucia Rizkallah, realizada em 22 de abril de 2011, de contato telefônico com seu irmão, Alfredo Rizkallah, realizado em 22 de fevereiro de 2011 , do texto aprovado em sua homenagem pela Câmara Municipal de São Paulo, que está disponível no verbete da rua que leva seu nome no dicionário de ruas (http://www.dicionarioderuas.com.br), de um livreto comemorativo dos 10 anos da construtora (1961) e um álbum de fotos, da mesma época, ambos do acervo de Vera Lucia Rizkallah.

${ }^{43}$ Alfredo Rizkallah cursou engenharia na Escola Politécnica e chegou a se associar à ANR. Mais tarde, seguiu sua própria carreira, criando a Novação Engenharia, que existe até hoje. Entre outros cargos, foi presidente da Bolsa de Valores de São Paulo.

${ }^{44}$ Divididos em um Setor Administrativo, com departamentos de "Contabilidade", "Compras" e "Pessoal" e um Setor Técnico, com departamentos de "Arquitetura, Engenharia e Orçamento" e "Apropriação de Custos". Cada departamento tinha um diretor e suas equipes.

${ }^{45}$ Depoimento de Vera Lucia Rizkallah ao autor, realizado em 22 de abril de 2011.
} 
Máquinas do Instituto Eletrotécnico e o Conjunto das Químicas. ${ }^{46}$ Apesar da importância crescente das obras públicas para a ANR, sua atuação principal eram construções para particulares e incorporações próprias, que iam da compra do terreno à comercialização dos imóveis. A habilidade comercial da família sempre esteve presente na atuação de Alberto Rizkallah, que foi também diretor da Associação Comercial de São Paulo e de sua Comissão de Transportes e Comunicação; diretor fundador do Banco da Indústria e Comércio do Brasil; e teve participação em empresas como a Resisthal - Aços de Alta resistência Ltda.; a Itabras - Granitos do Brasil S.A.; a Itamambuca - Empreendimentos Imobiliários S/A; e a Socibel - Administração de Bens S/A. ${ }^{47}$

A atuação social de Alberto Nagib Rizkallah, especialmente na comunidade sírio-libanesa, Ihe rendeu algumas obras, como um edifício do Hospital Sírio Libanês, a sede do Clube Nacional ou do Clube Esporte Sírio, do qual foi presidente. As primeiras obras da construtora na Cidade Universitária, anteriores ao PAGE, foram justamente os edifícios Basílio e Adma Jafet (projeto de Paulo de Camargo para a Física Experimental e seu Auditório), financiados pela família libanesa.

Segundo depoimento de sua filha, Vera Rizkallah, Alberto mantinha um bom relacionamento com prefeituras e governadores, inclusive organizando festas em sua casa.

"Eu me lembro que ele deu uma grande festa para o Adhemar de Barros [...]. O Carvalho Pinto ia em casa, o Juscelino. O Paulo Maluf estudou com o meu tio Alfredo. Eles eram amigos, todos".

Apesar da amplitude do espectro político com o qual Alberto Rizkallah mantinha relações, ele era, segundo sua filha, "um homem de totalmente de direita", que fez de sua casa "um ponto de organização do golpe de 1964".

Tendo vencido a concorrência para execução da estrutura de concreto armado da FAU a ANR designou alguns de seus mestres para supervisionar a obra e subcontratar a mão-deobra através de empreiteiros que não possuíam vínculos formais com a ANR.

\footnotetext{
${ }^{46}$ Informações extraídas do livreto comemorativo da construtora. Segundo Vera Lucia, outras obras foram o prédio da História e Geografia, o Centro Municipal de Cultura Carlos Gomes em Campinas (projeto de Fábio Penteado, 1967-68) e diversos conjuntos para a COHAB na capital e no interior de São Paulo.

47 Nos anos 1970, a ANR continuou crescendo. O volume de obras foi mantido com empreendimentos de habitação de interesse social, promovidos pelo $\mathrm{BNH}$ e $\mathrm{COHAB}$, enquanto suas obras particulares passaram a ter maior porte, o que implicava em maior comprometimento com o sistema financeiro. Ao todo construiu mais de 7500 casas do BNH e mais de 300 obras entre prédios e conjuntos residenciais. Segundo Vera Lucia Rizkallah, nos últimos anos de vida de seu pai, a empresa passava por uma crise financeira, por causa da inflação que afetava os empréstimos bancários dos empreendimentos da construtora. Essa situação chegou a afetar o pagamento dos funcionários e seu patrimônio pessoal. Alberto morreu aos 48 anos de enfarto em 1977. Após sua morte, Alfredo Rizkallah, pediu uma concordata da construtora, mas ele, apesar de ser engenheiro, não podia administrar a concordata porque ele era presidente da bolsa de valores. Quem cuidou do assunto foi a filha de Alberto, recém-formada em Administração. A concordata foi finalizada exatamente dois anos depois de pedida, como regulamenta a lei, e a empresa foi fechada.
} 


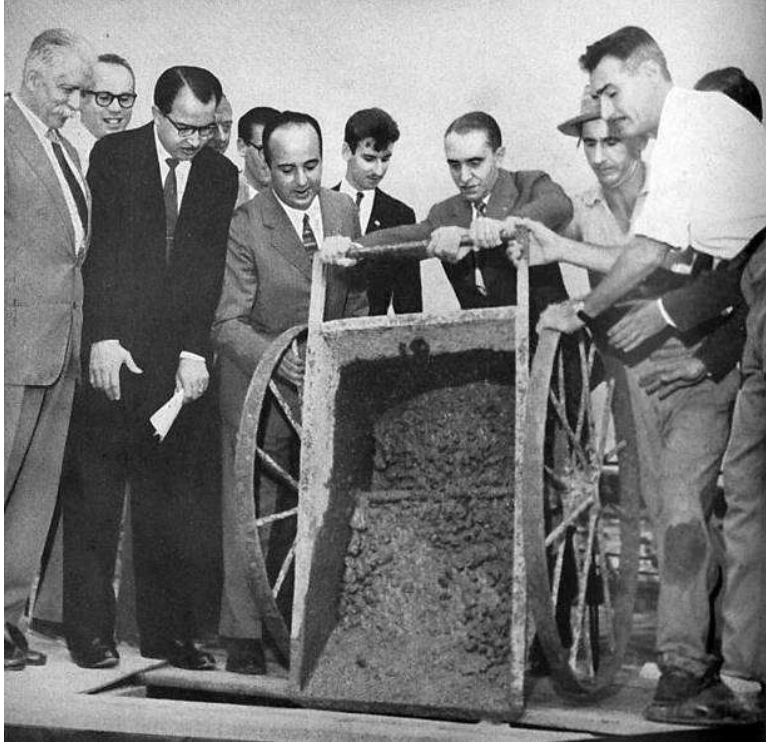

Alberto Nagib Rizkallah ao lado de Carvalho Pinto em obra na Cidade Universitária. Acervo ANR.

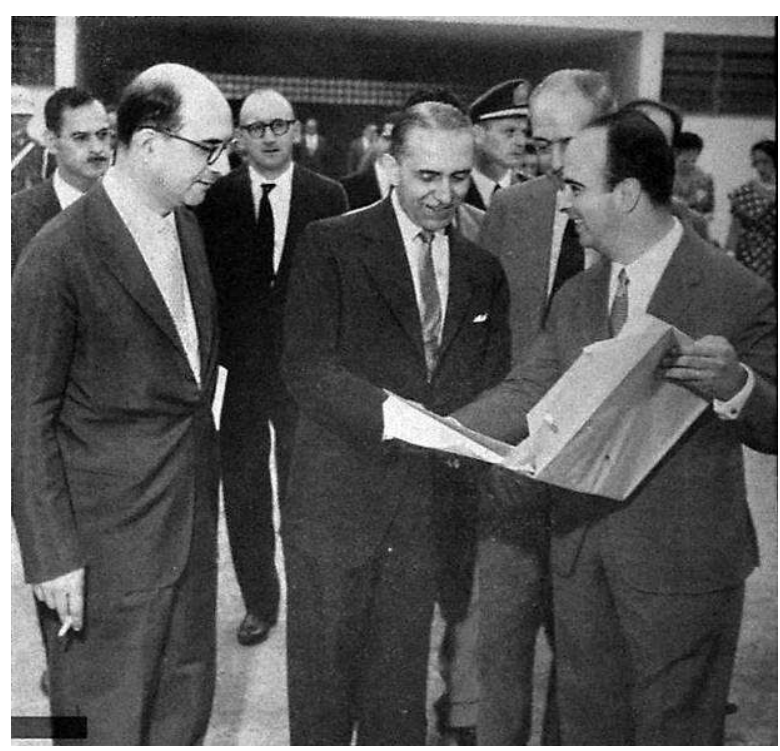

O reitor Ulhôa Cintra, o governador Carvalho Pinto e Alberto Rizkallah em obra na Cidade Universitária. Acervo ANR.

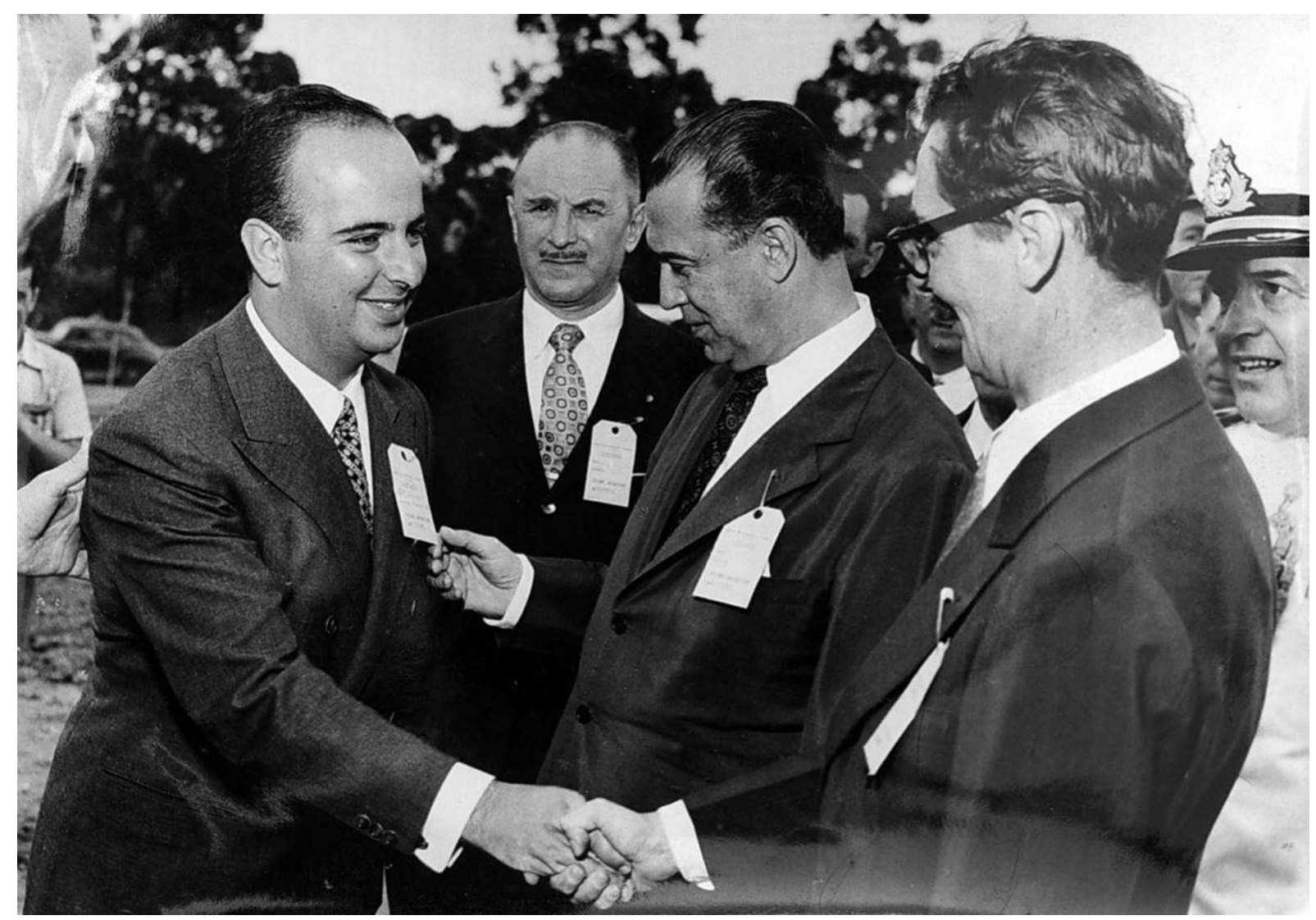

Alberto Nagib Rizkallah com o presidente Juscelino Kubitschek e o governador Jânio Quadros na inauguração do Reator Nuclear. Acervo ANR. 


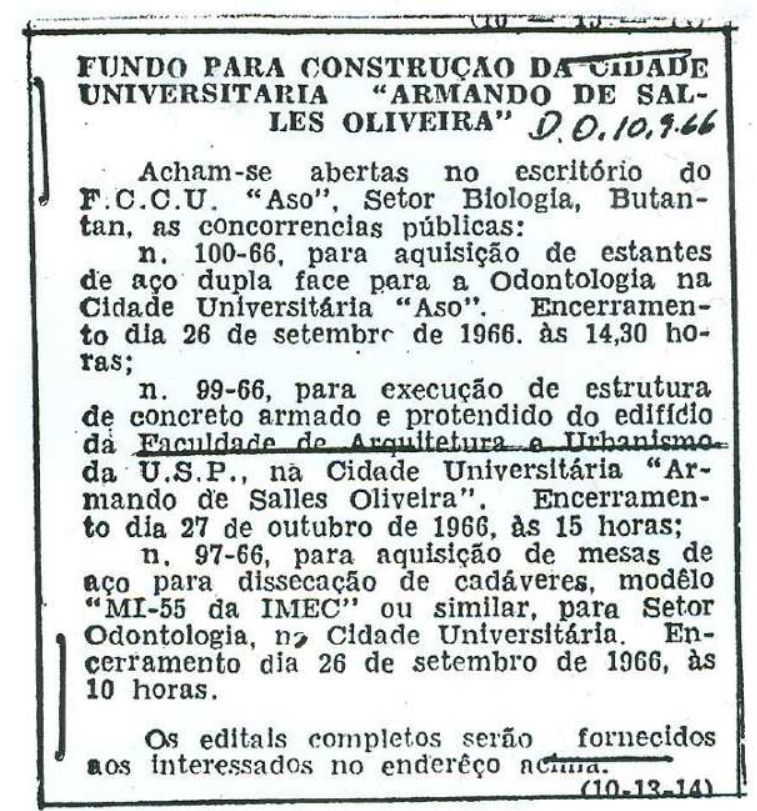

Abertura de concorrência para execução de estrutura de concreto armado e protendido do edifício da FAU.

Diário Oficial, 10/9/1966

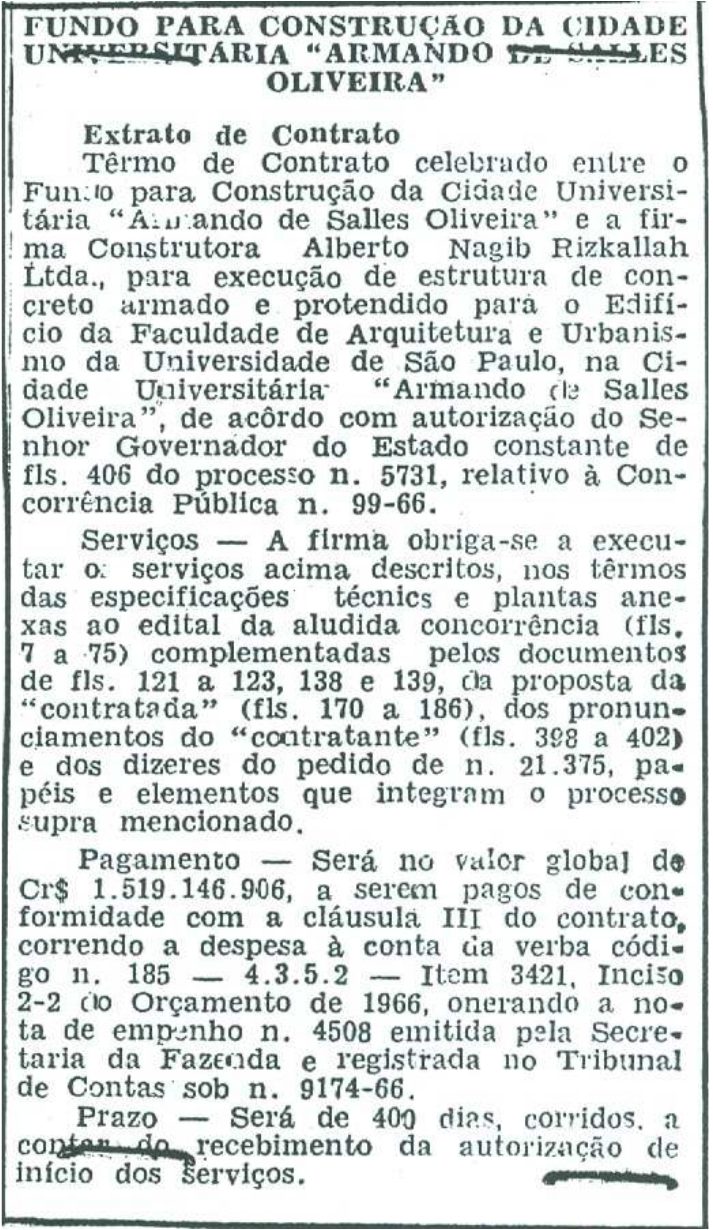

Termo de contrato com a Construtora Alberto Nagib Rizkallah, Diário Oficial, 15/12/1966. 


\section{O primeiro canteiro}

Faltam dados cruciais sobre o canteiro de obras do edifício da FAU, uma vez que o caderno de obra não foi localizado nos arquivos do FCCUASO. Da mesma maneira, restam poucos registros fotográficos conhecidos, a maioria de etapas posteriores à execução da estrutura de concreto armado. Na ausência de tais documentos, buscamos analisar depoimentos orais e vestígios da produção registrados no próprio edifício.

Abdias Nogueira da Silva, por exemplo, foi servente de pedreiro, contratado pelo FCCUASO para trabalhar na obra da FAU antes do contrato da ANR. Morador do entorno da Cidade Universitária, Abdias foi chamado por indicação de seu irmão mais velho, Vital Nogueira, que já trabalhava na obra. Com 18 ou 19 anos, ele não possuía experiência com obras, mas já tinha trabalhado numa firma de encadernação e na seção da borracha de uma fábrica de autopeças. Sua tarefa no canteiro de obras era conduzir as giricas de concreto da betoneira até as frentes de trabalho.

"Tinha um monte de caras fazendo concreto na USP no manual, misturava aquilo, saía rodando e enchia o carrinho de concreto. Eu levava de um lado para o outro [...]. Tinha um encarregado para fazer os caras encherem as carrocinhas de concreto e levar. Eu saí daqui porque eu estava falando para o meu encarregado '- Olha, eu não estou conseguindo levar essas carriolas com esse peso'. Um encarregado decente falaria assim: '- Não, tudo bem, então diminui um pouquinho'. Mas ele: '- Não, não, a carriola vai assim mesmo'. Aí eu me abusei. Cheguei e mandei o cara encher a carrocinha: 'Encha mais, encha mais, encha mais'. Daí eu falei: '- Agora você leva'. Aí ele falou '- Eu vou mandar você embora'". 48

Abdias foi demitido antes de cumprir o prazo de experiência. Seu depoimento, no entanto, revela aspectos cotidianos interessantes como os caminhões que passavam cheios de operários que iam almoçar onde hoje é a Avenida Corifeu de Azevedo Marques. Ou então a suspeita de irregularidades na contabilidade da areia extraída pelo Fundo na raia olímpica. ${ }^{49}$

A ANR assumiu as obras em 26 de dezembro de 1966 para executar a estrutura de concreto armado. Não foi possível confirmar se os cerca de $16.000 \mathrm{~m}^{3}$ de concreto foram preparados in loco, com a areia retirada da escavação da raia olímpica e sacos de cimento Moreira,

\footnotetext{
${ }^{48}$ Depoimento de Abdias Nogueira ao autor, realizado em 06/02/2012.

49 "Tinha uns papos que os caras faziam assim: saíam três caminhões, o cara marcava dois e ficava um para o cara. Dois para o Estado e um para o cara". Depoimento de Abdias Nogueira ao autor, realizado em 06/02/2012.
} 
como nas obras administradas pelo Fundo, ou se foram produzidos em usina e fornecidos pela Holcim do Brasil, como sugere a pesquisadora Ana Clara Giannecchini. ${ }^{50}$

A qualidade do serviço da ANR dependia muito da carpintaria das fôrmas, que foi coordenada por um experiente mestre português que trabalhava para a construtora. $O$ cimbramento das fôrmas de concretagem deve ter constituído uma construção à parte. A complexa estrutura de madeira foi feita com pontaletes de $3 \times 3$ polegadas, e, em alguns casos, teve mais de $15 \mathrm{~m}$ de altura. Por conta da fragilidade do terreno, recentemente aterrado, foram executadas vigas baldrame no perímetro do edifício para que o cimbramento das empenas externas não perdesse o nível. ${ }^{51}$

A maioria das fôrmas do concreto aparente da FAU, cujas marcas são visíveis nas paredes internas, no "forro" das lajes, na grelha da cobertura e nos pilares de seção circular, foi executada com chapas de madeira, conhecidas pelo nome da marca líder, Madeirit. As chapas de Madeirit eram fabricadas na dimensão de 1,10x2,20 metros. Pode ser uma coincidência que a malha estrutural do edifício, cuja dimensão total é de $110 \times 66 \mathrm{~m}$ com vãos de $11 \mathrm{~m}$, siga o módulo da chapa de madeira. Mas não parece coincidência que o perímetro do pilar de seção circular tenha exatos 2,20m: duas pranchas de Madeirit na vertical. Improvável que o cálculo tenha coincidido com essa medida. Mais lógico seria dimensionar o pilar de acordo com a construtibilidade.

As chapas de madeira compensada não eram novidade, porém a Madeirit estava longe dos primeiros laminados de madeira colada. A empresa se consolidou durante a construção de Brasília produzindo industrialmente chapas compensadas resinadas para fôrma ou para tapumes. Seu advento foi um importante passo para a indústria do concreto, reduzindo o preço da fôrma, aumentando a área coberta por cada unidade, facilitando o transporte manual e a estocagem devido aos tamanhos padronizados e a conservação e desforma devido à resina aplicada na fábrica. Não é à toa que a Madeirit se tornou um dos principais anunciantes em revistas de arquitetura. Seu produto, apesar de rudimentar, representava bem o processo de modernização brasileiro.

Mas se praticamente todo o interior da FAU foi moldado com chapas de Madeirit, Artigas especificou exceções em seu projeto básico de 1961. O exterior do edifício deveria ser concretado com tábuas de pinho horizontais de $30 \mathrm{~cm}$ de largura nas empenas e nas caixas d'água, enquanto o triângulo ascendente dos pilares externos seria moldado por tábuas na

\footnotetext{
${ }^{50}$ Essa informação é encontrada em sua dissertação sem as fontes. GIANNECCHINI, Ana Clara. Op. Cit. p. 233. No site da Holcim, encontramos que: "A atividade do grupo suíço Holderbank no Brasil teve início em fevereiro de 1951. Naquele ano, a primeira subsidiária brasileira, denominada Sacomex (Sociedade Extrativa de Calcário Ltda), foi incorporada à companhia. Em 1953, o Grupo Holderbank adquire a fábrica de cimento Ipanema, localizada em Sorocaba (SP)".

${ }^{51}$ Cf. depoimento de Vladimir Brega ao autor, em 23/02/2011. Essas vigas baldrame de concreto armado com $30 \mathrm{~cm}$ de altura que teriam sido desmanchadas após a concretagem.
} 
vertical. Dessa maneira, ao utilizar duas fôrmas na mesma parede, Artigas deixou evidente não se tratar de solução construtiva, mas estética. As tábuas de madeira da fachada gravam a aspereza do material e da técnica dos carpinteiros, enquanto as chapas de compensado, de fatura simplificada e acabamento mais liso e uniforme, lembram a contribuição da indústria. Quando se referiu à empena cega da residência Baeta (1956), Artigas deixou clara sua posição artística:

"Mas a inspiração é da casa paranaense. Aqui ponho as tábuas da empena na vertical, como se fosse a concepção estrutural da casinha de minha infância. Foi a primeira vez que se fez uma empena desse tamanho. Isso me tirava o sono porque, quando nós tiramos a madeira grossa 0 que resultou foi um concreto desesperado. Uma coisa hedionda!" ${ }^{52}$

Outra exceção se encontra no pilar central que abriga a tubulação de águas pluviais e ventilação do esgoto. Como a seção do pilar impedia a execução das fôrmas com chapas de Madeirit, foram utilizadas ripas de $8 \mathrm{~cm}$ de largura posicionadas na vertical. $O$ que chama a atenção nesse caso é que no Projeto Básico de Artigas esse pilar aparecia revestido de "oxicret", o que impossibilitava distinguir a estrutura do enchimento. Apesar da especificação original, o pilar obteve uma nova solução desenhada pelo Fundo em 1968, mais coerente com o princípio da verdade construtiva.

Cerca de sete meses após a ANR assumir a obra, o escritório de Figueiredo Ferraz foi acionado para indicar o plano de concretagem das vigas de concreto protendido no início de agosto de 1967. Ferraz ofereceu sua patente de sistema de protensão como uma contribuição pessoal à Cidade Universitária. Fios rompidos durante a protensão dos cabos da rampa entre a cota $-1,10$ e a cota +80 deixaram a equipe de engenheiros do Fundo preocupada. ${ }^{53}$

Com o prazo de 100 dias para a ANR entregar a obra encerrando no início de fevereiro de 1968 restava ainda o maior desafio: a execução da grelha da cobertura. Nessa altura, Figueiredo Ferraz ainda entregava sua última folha de desenho, referente à armação das vigas da cobertura, que foi enviada à construtora em 23 de fevereiro.

A cobertura foi a última etapa da construção da estrutura. A forma e repetição dos módulos de 2,75 metros de sua grelha sugerem, do interior do edifício, peças pré-fabricadas ou a

\footnotetext{
52 Depoimento de João B. Vilanova Artigas em: FERRAZ, Marcelo Carvalho (coord. ed.). Vilanova Artigas. São Paulo: Instituto Lina Bo e P. M. Bardi e Fundação Vilanova Artigas, 1997, p. 72.

${ }^{53}$ Carta do engenheiro Vladimir Brega de 27 de setembro de 1967, solicitando o pronunciamento do professor Ferraz. Processo USP 65.1.3988.51.8, fl. 91.
} 
reutilização de fôrmas industrializadas. ${ }^{54}$ No entanto, essa aparência não corresponde nem com o modo de produção, nem com a estrutura da cobertura, formada por vigas invertidas transversais a cada 5,5 metros e longitudinais a cada 22 metros.

Apesar de não haver viga entre cada domo, a seção formada por um triângulo invertido (V) mais a laje $(\forall)$ funciona como uma cunha estrutural. $O$ fato de ser oca tem por objetivo aliviar o peso. Tal desenho impôs que a concretagem fosse feita em duas etapas: a primeira até a altura da laje; a segunda até o cume da boca do domo. Isso gerou uma marca visível no interior do edifício que, segundo relatos, Artigas teria lamentado. Para tentar melhorar o aspecto a equipe do Fundo lixou o concreto manualmente, com ajuda de andaimes suspensos, o que não resolveu o problema.

Prospecções recentes para fins de restauração de cobertura evidenciaram uma série de patologias, tais como a infiltração de água, deformação acentuada, descolamento de pedaços de concreto, exposição da armadura. Os caixões perdidos da cobertura, que deveriam aliviar o peso da estrutura, ao ficarem preenchidos de água da chuva, transformaram-se numa carga extra, o que agravou tais problemas. A infiltração ocorreu por vários fatores: escoamento insuficiente das águas pluviais, causado pela inclinação de apenas $0,5 \%$ das lajes e pela instalação de apenas metade dos condutores verticais ${ }^{55}$; manutenção incorreta da impermeabilização com hypalon ${ }^{56}$; e o "esquecimento" dos calculistas em considerar a contraflexa que a viga deveria ter para compensar sua deformação natural. ${ }^{57}$ A concretagem em duas etapas também pode ter contribuído para a infiltração de água. Já a exposição da armadura, outra patologia que atingiu todo o edifício, pode ser atribuída, em grande parte, à precariedade da concretagem, que usava pedras como espaçadores.

\footnotetext{
${ }^{54}$ A Casa Mendes André, de 1966, possui um único domo cujo desenho interno é extremamente semelhante ao da FAU.

55 Essa hipótese, foi lançada quando os pilares foram abertos para restauração e constatou-se a existência de apenas um coletor de águas pluviais de cada lado do pilar. De acordo com o projeto de hidráulica de Homero Lopes, de 1962, deveria haver dois coletores de cada lado.

${ }^{56}$ Durante décadas, foram reaplicadas camadas do produto sem a remoção das camadas anteriores. Quando a restauração foi feita havia cerca de $15 \mathrm{~cm}$ de impermeabilização. Ver: GIANNECCHINI, Ana Clara. Op. Cit., p. 249

${ }^{57}$ Cf. depoimento de José Lourenço de Almeida Castanho ao autor, realizado em janeiro de 2012.
} 


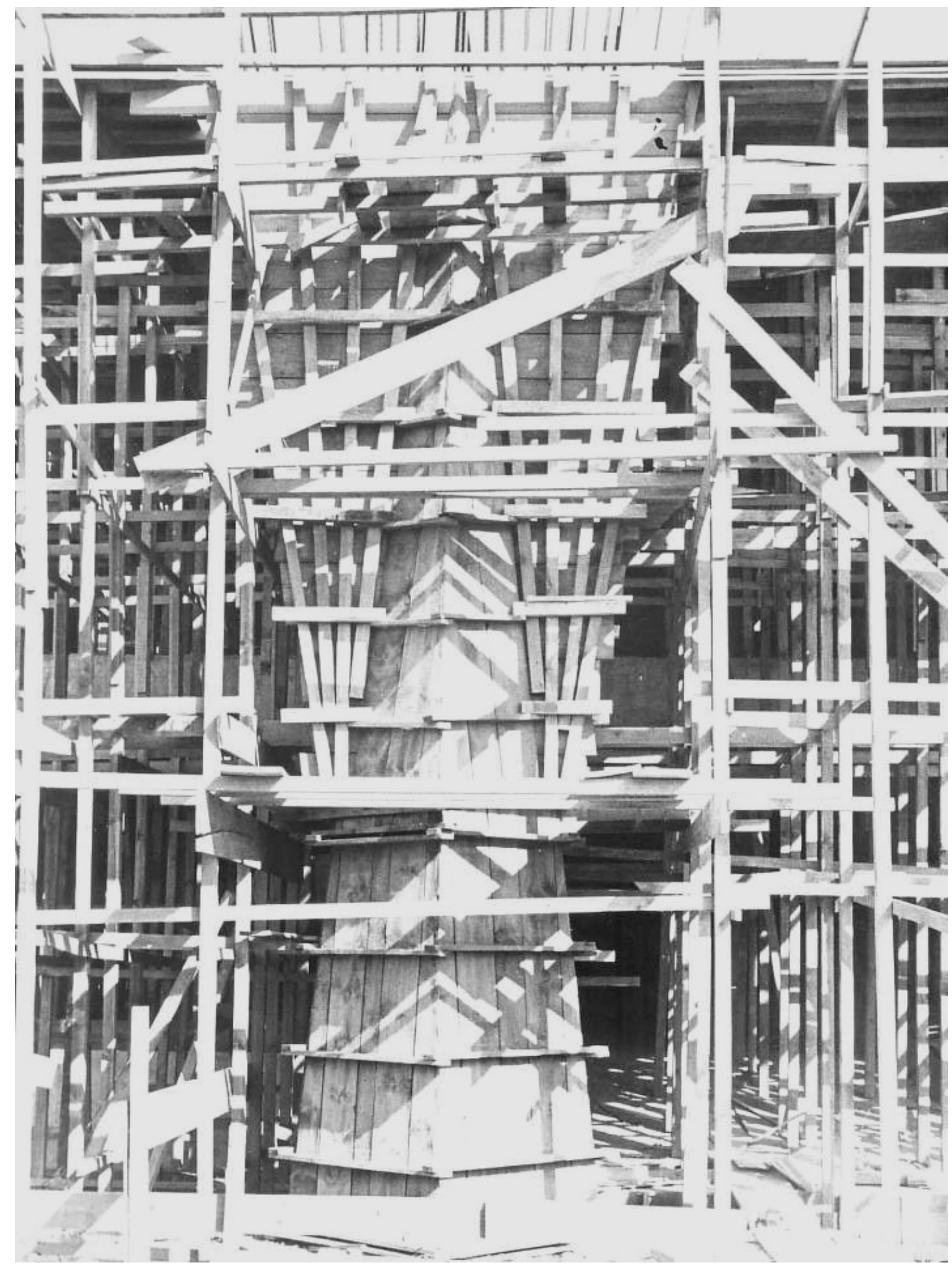

Forma e cimbramento do pilar externo. Visita de alunos de cálculo estrutural à obra com o professor Figueiredo Ferraz, em 1967. Foto: Luciano Fiaschi. 

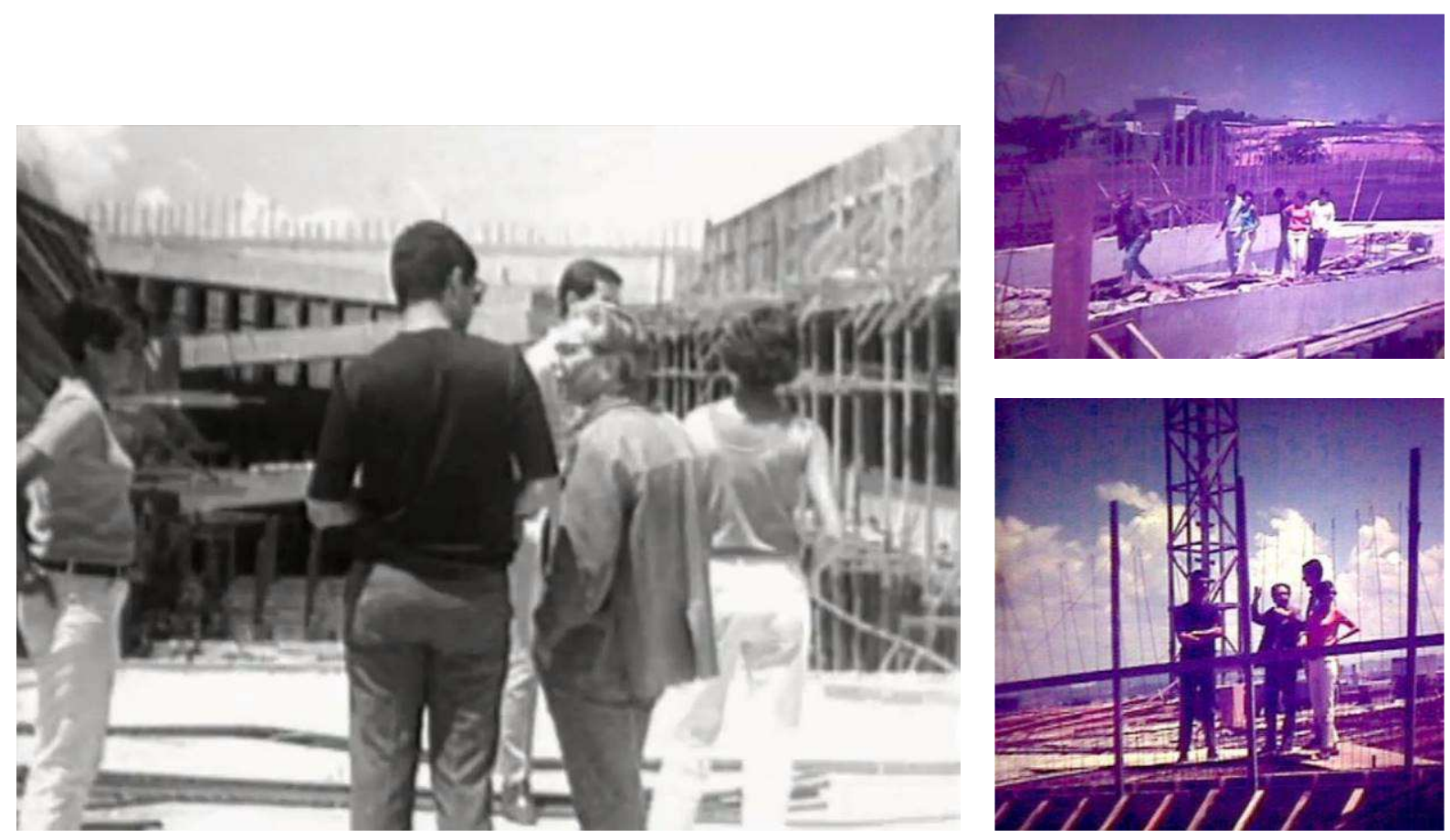

Visita à obra com Vilanova Artigas. Com Edgar Dente, Vera Lucia Domschke (?) e Marlene Yurgel (?). Fotos: Fernando Cabral, 1967

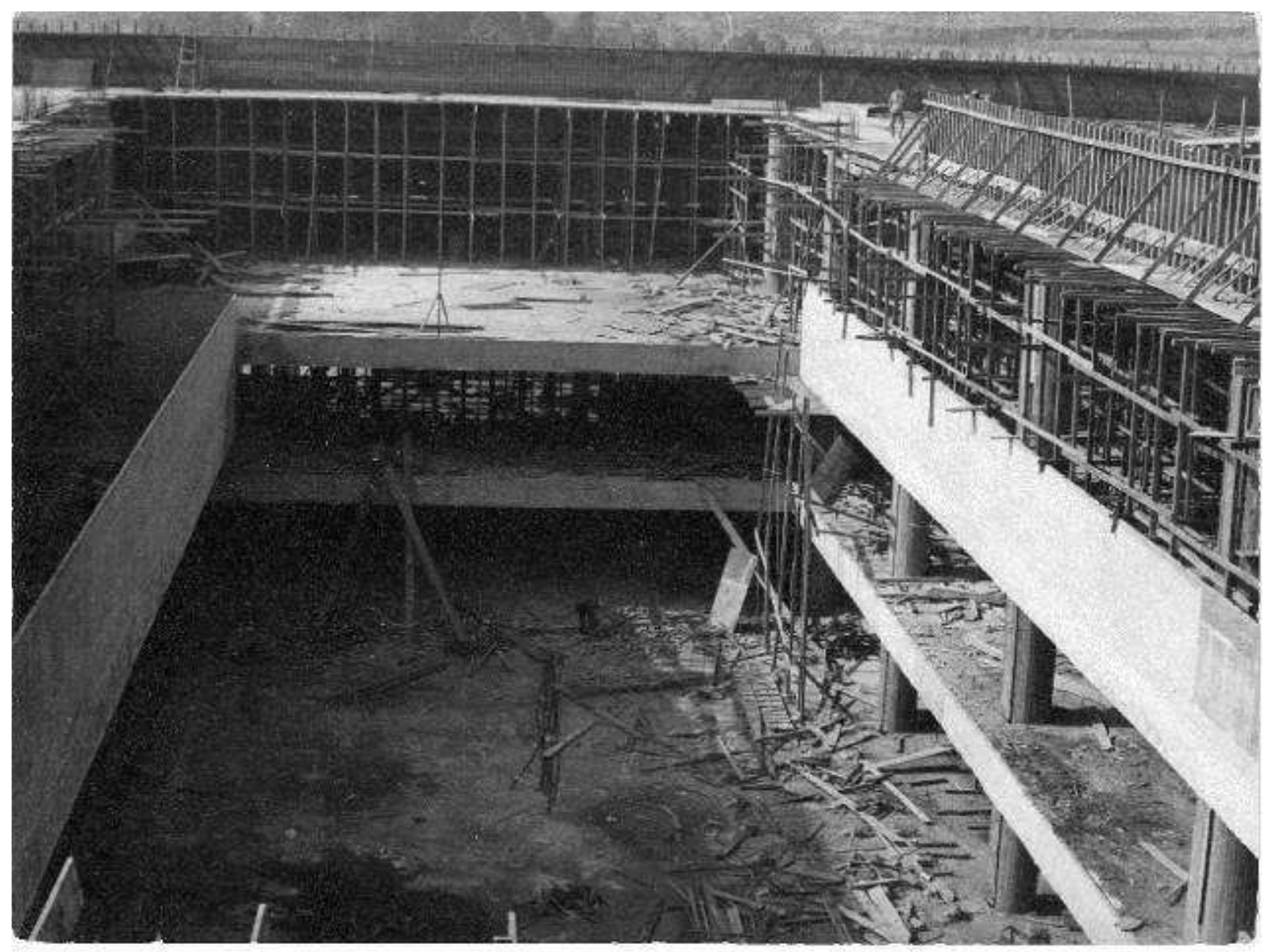

Edifício da FAU em construção. Arquivo BFAUUSP. 

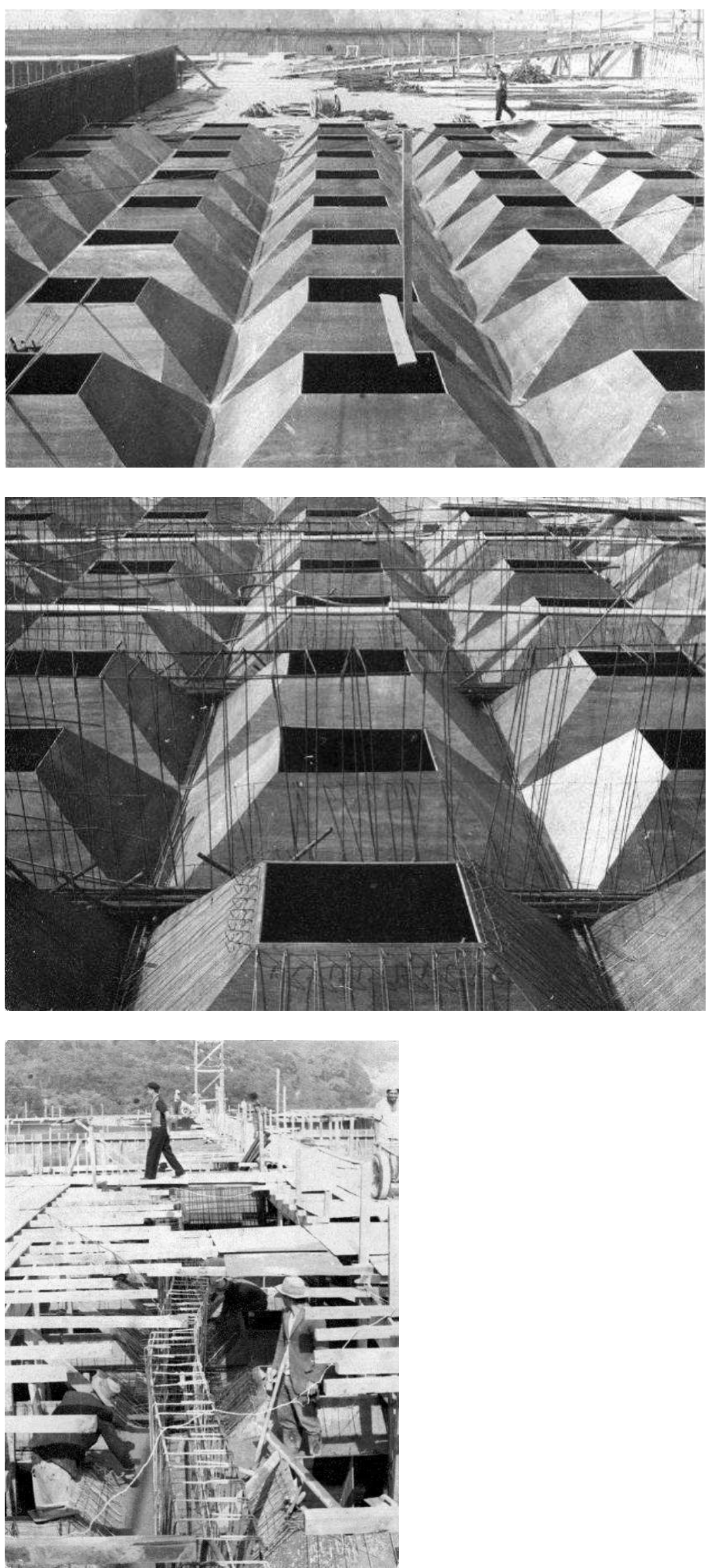


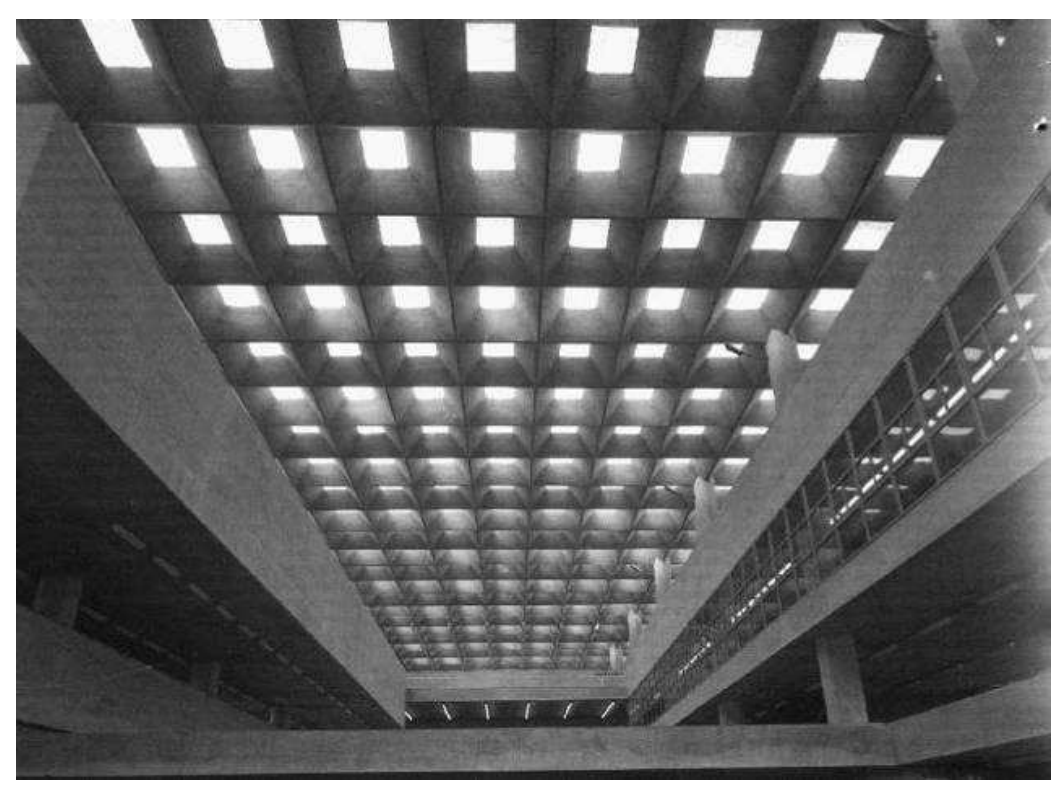

Vista interna da cobertura. Acervo BFAUUSP.

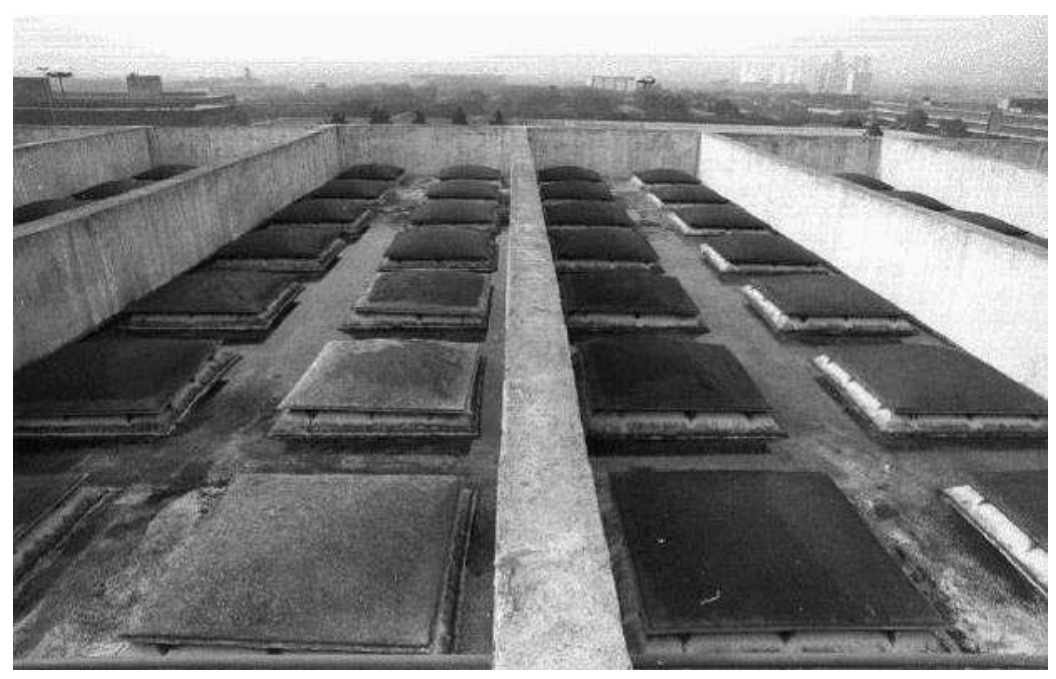

Vista externa da cobertura. Acervo BFAUUSP.
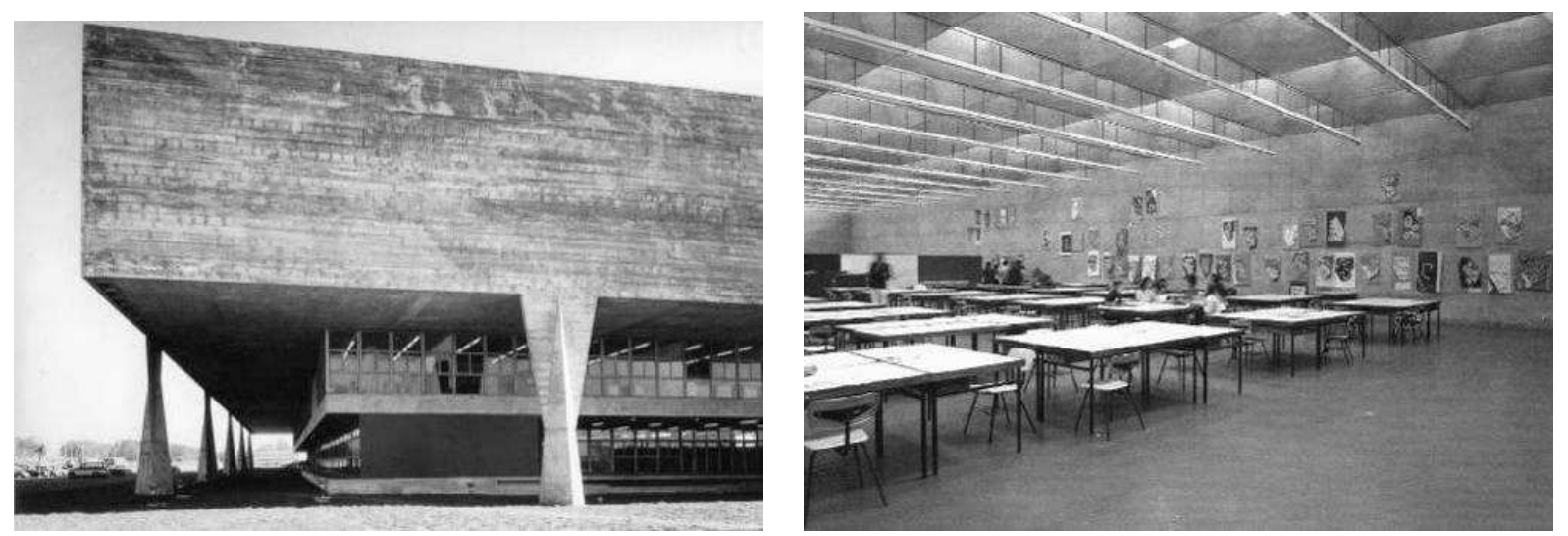

Empena cega com dois tratamentos do concreto aparente, no exterior e no interior do edifício. Acervo BFAUUSP. 


\section{O segundo canteiro}

Em meados de março de 1968, o arquiteto Luciano Bernini anunciava que a construção da estrutura estava sendo concluída, devendo iniciar-se a fase de "acabamentos". 58 Para isso, o Fundo mandava cópia de desenhos para o engenheiro Homero Lopes providenciar a revisão do projeto elétrico, que não havia sido alterado desde a intervenção da diretoria. $A$ nova fase da obra seria executada diretamente por equipe do Fundo e administrada pelo Escritório Técnico. Em 20 de março, um mês depois de assumir a direção da FAU, Ariosto Mila nomeou os professores Vilanova Artigas e Figueiredo Ferraz para acompanharem a obra, argumentando que eles auxiliariam na rapidez de sua construção. ${ }^{59}$

"A Cidade Universitária tinha um grupo de desenhistas e, quando precisava, o arquiteto que estivesse encarregado detalhava o que o Artigas pedia. [...]. Foi o Luciano Bernini, que é um arquiteto muito bom. Eu trabalhei com ele e achei uma pessoa bastante inteligente. Ele fazia essa ligação com o Artigas. [...]. O Artigas vinha segunda, quarta e sexta. Ele chegava as 9 e ia embora às 11. Ele chegava de Karmanguia, fumando que nem um maluco". 60

Entre março e agosto de 1968, o Escritório Técnico do FCCUASO produziu pelo menos 96 folhas de desenhos que podem ser agrupadas em plantas (5), cortes (7) e elevações (3), ampliações de áreas molhadas (39), pisos (5) e detalhes referentes aos painéis (9), caixilhos (4), portas (4), mobiliário (10) e outros (4). O Escritório Técnico do Fundo funcionou como uma extensão do escritório de Artigas, que nessa época, sem Cascaldi, praticamente não existiu. ${ }^{61}$ Como veremos a seguir, essa parceria com um órgão público livre para administrar diretamente as obras resultou em soluções excepcionais do ponto de vista técnico e estético, tanto em relação às demais obras na Cidade Universitária, quanto em relação ao conjunto de obras de Artigas.

Envolvido desde o início da segunda fase da obra, Artigas atuou para reverter as alterações impostas pelo ex-diretor, Pedro do Amaral Cruz. Desde então, temendo que o arquiteto passasse por cima da Administração do Fundo, Adalberto dos Santos alertou que "tratandose de órgão executor das obras programadas e decididas pelo Colendo Conselho de Administração do Fundo, estamos adstritos às decisões daquele colegiado, nenhuma modificação sendo possível sem sua prévia audiência e concordância" e que o projeto

\footnotetext{
58 Processo USP 65.1.3988.51.8, fl. 115 a 121.

${ }^{59}$ Carta de Ariosto Mila ao diretor do FCCUASO. 20 de março de 1968. Processo USP 65.1.3988.51.8, fl. 125.

60 Depoimento de Vladimir Brega ao autor, realizado em 23/02/2011.

${ }^{61}$ Nesse período Artigas fez parcerias com outros arquitetos, como o célebre caso do projeto para o CECAP de Guarulhos (1967), desenvolvido em colaboração com Paulo Mendes da Rocha, Fabio Penteado, entre outros.
} 
aprovado "continuava válido, inclusive a transferência da biblioteca do primeiro andar para o térreo". 62 Para resolver o conflito, Ariosto Mila propôs que a Congregação da FAU pudesse decidir sobre as divergências com o projeto aprovado, autorizando diretamente o Escritório Técnico. Adalberto dos Santos exigiu que tais alterações fossem minuciosamente justificadas.

O impasse só foi resolvido no meio daquele ano. Em carta de 20 de junho de 1968, referendada pela Congregação da FAU, Artigas defendeu a passagem da biblioteca do térreo para o primeiro andar argumentando que tal mudança não implicaria em aumento de área construída, sendo ainda melhor solução do ponto de vista da conservação dos livros. ${ }^{63}$ A carta era acompanhada de plantas desenhadas pelo Escritório Técnico, que apresentavam a nova divisão interna dos espaços. Figueiredo Ferraz ainda respondeu aos questionamentos de Alberto dos Santos, atestando que o pavimento superior suportaria a carga da biblioteca (a previsão de carga não havia sido alterada após a intervenção da diretoria). Com isso, a Congregação da FAU aprovou as mudanças ao que Pedro do Amaral Cruz solicitou que ficasse registrado seu voto contrário.

O diretor do FCCUASO ainda protestou que "deixando o térreo quase que inteiramente vazio" poder-se-ia criar a "falsa pressuposição de que a área não aproveitada é excessiva", justamente num momento em que a universidade estava recebendo críticas incisivas do governo pelo baixo rendimento de alunos $/ \mathrm{m}^{2}{ }^{64}$ Apesar dos protestos, Artigas conseguiu retomar seu projeto original, trazendo a biblioteca de volta para o $2^{\circ}$ pavimento e a diretoria para o térreo.

Enquanto o Escritório Técnico elaborava os desenhos de ampliação de todas as áreas molhadas, os trabalhadores do Fundo devem ter iniciado as instalações hidráulicas principais, concentradas em dois shafts ${ }^{65}$ (cada qual abastecido por uma caixa d'água cilíndrica na cobertura), ao mesmo tempo em que levantavam as paredes de alvenarias, concentradas nos sanitárias e no subsolo. Na concepção de Artigas as demais divisórias deveriam ser feitas com painéis leves, como era o caso das salas de aula, departamentos e entrada do auditório. Preocupados com a flexibilidade do espaço, os projetistas gastaram muito tempo detalhando um sistema de painéis móveis de madeira, que acabou sendo substituído por painéis fixos, mais baratos.

\footnotetext{
${ }^{62}$ Carta de Adalberto dos Santos a Ariosto Mila. 26 de março de 1968. Processo USP n. 66.1.20458.1.8, fls. 126-127.

${ }^{63}$ Carta de Vilanova Artigas ao diretor da FAU. 20 de junho de 1968. Processo USP n. 66.1.20458.1.8, s.n.

${ }^{64}$ Carta de Adalberto dos Santos ao diretor da FAU. 12 de junho de 1968. Processo USP n. 66.1.20458.1.8, s.n.

${ }^{65}$ A concentração das áreas molhadas em torno de prumadas hidráulicas constitui uma estratégia racional, bastante utilizada por Artigas. Apesar do critério estar claramente afirmado desde o Estudo Preliminar, o desenvolvimento do projeto da FAU não manteve esse princípio em todos os casos, como nos vestiários do subsolo e nos sanitários do piso da diretoria e do piso da biblioteca. Tais instalações hidráulicas exigiram obras mais complexas, por conta da estrutura concluída. 
Tanto os painéis de madeira quando as alvenarias tinham a intenção clara de evidenciar a distinção em relação ao concreto aparente da estrutura. Mas as divisórias de concreto dos estúdios e do piso do museu - como o "caracol" que abrigaria a direção do museu - fugiram a esta regra. Tais divisórias, com 1,90 metros de altura, foram solucionadas no canteiro de obras. Segundo o engenheiro Vladimir Brega, que supervisionou a obra da FAU, foi necessário quebrar a laje para engastar os "muros" na estrutura, o que foi feito introduzindo perfis metálicos "U" que haviam sobrado do desmonte de galpões da Veterinária. ${ }^{66}$ Além disso, foi acrescentado argila expandida à massa de concreto para aliviar a carga sobre a estrutura, o que reforça a ideia de que apesar da semelhança visual, o concreto aparente no edifício não corresponde a um único processo de produção.

Entre os três tipos de divisórias internas - painéis de madeira, muros de concreto e paredes de alvenaria - a alvenaria era o único completamente revestido - e não perece coincidência que fosse o material cuja aparência mais expressasse a lógica da manufatura serial. Os blocos cerâmicos que compõe a alvenaria foram rebocados e pintados em cores primárias: azul, vermelho e amarelo. ${ }^{67}$ Cores estas que aparecem com frequência em outras obras de Artigas, bem como nas de tantos outros arquitetos que incorporaram a linguagem neoplasticista. A pintura das paredes produz o efeito de desmaterializá-las, especialmente quando as cores - ou padrões, ou desenhos - integram uma dimensão visual que exige a apreensão do todo ou da parte. Nesse sentido, o efeito da composição cromática, amplificado pelo fundo predominante do concreto, se sobrepõe à constituição material das alvenarias. E não deixa de ser interessante que outros materiais receberam cores mais inusitadas, como o verde oliva dos caixilhos e o caramelo do piso.

O lado interno das paredes dos sanitários foi revestido com folhas de laminado melamínico ${ }^{68}$ brancas, mais leves e de aplicação mais rápida do que os tradicionais revestimentos cerâmicos, que exigem massa, rejunte e grande habilidade manual do aplicador. Segundo Vladimir Brega, Artigas teria gostado tanto do resultado que optou por fazer os quadros de aviso, lousas e áreas de projeção dos estúdios com folhas de fórmica pretas, brancas, vermelhas e amarelas.

\footnotetext{
${ }^{66}$ Depoimento de Vladimir Brega ao autor, realizado em 23/02/2011.

${ }^{67}$ Não localizamos nenhum registro da pintura original da FAU. As tintas acrílicas para paredes surgiram apenas em meados do século XX. Até então era comum o uso de cal com pigmentos, o que produzia cores mais pálidas que desgastavam mais rapidamente.

68 O laminado melamínico, conhecido pelo nome comercial da marca líder Formica, é um revestimento decorativo, muito utilizado na arquitetura e nas artes aplicadas modernas. Desenvolvida em 1912 nos EUA, a resina melamínica é um tipo de plástico termorrígido bastante resistente. Dentre suas características, está a possibilidade de reproduzir diversos padrões, cores e texturas, imitando madeiras, metais, mármores ou mesmo expressar características visuais inexistentes na natureza. Se por um lado a Formica é material híbrido, simulacro industrial de materiais tradicionais, por outro, pode assumir seu caráter industrial com cores sintéticas e homogêneas, como no caso da FAU.
} 
O sistema de fechamento da FAU é formado ainda pela caixilharia que veda, de piso a teto, a maior parte dos espaços do edifício. A folha de "serralheria" do Projeto Básico de Vilanova Artigas, de 1962, trazia um caixilho modulado, composto por três partes horizontais que podiam variar entre vidros fixos, janelas e portas (duplas). No piso das oficinas, semienterrado, o módulo inferior era subtraído. A famosa janela de Artigas, caracterizada por sua "cinemática", como o arquiteto gostava de chamar, ainda não estava presente. Em seu lugar havia duas janelas "maxim ar", abundantes no mercado da época. Como eram duas janelas iguais, consequentemente não havia a divisão vertical na janela intermediária. O projeto de Artigas também não trazia indicação de material e nem espessuras das seções. Relatos sugerem que o alumínio tenha sido considerado. ${ }^{69}$

Durante a construção do edifício, Artigas teria procurado André Mehes, da Serralheria Técnica Industrial (STIL), para rever sua ideia inicial. ${ }^{70} \mathrm{~A}$ STIL fornecia esquadrias para diversos arquitetos modernos, inclusive para obras na Cidade Universitária. Artigas teria chegado com um esboço de sua ideia de abertura e solicitou que Mehes desenvolvesse o projeto. ${ }^{71} \mathrm{Na}$ verdade, o arquiteto já havia executado uma janela com o mesmo funcionamento (os painéis pivotam no eixo central horizontal com uma extremidade fixa a um trilho) no edifício da Sociedade Autolon, em Londrina (projeto de 1948). André Mehes teria detalhado o projeto visando a execução. Contudo, quando o Fundo abriu o edital para execução do caixilho, a STIL perdeu a concorrência para a empresa "Ryval S.A. Esquadrias metálicas", do suíço Charles Ryser e do brasileiro Nathalio Kusminsky.

Conforme documentos localizados na Junta Comercial de São Paulo, a Ryval foi criada em janeiro de 1968 - portanto às vésperas do edital do Fundo - a partir da "Mecânica Ryval", fundada originalmente em 1950 por Ryser em sociedade com Ernesto Vallo. Antes de se especializar em esquadrias, a Ryval se dedicava especialmente a construir e reparar embarcações e estruturas flutuantes. A nova empresa entrou na construção civil tendo em seu portfólio trabalhos em edifícios, galpões, silos, pontes, viadutos, antenas de rádio e televisão e até em plataformas de petróleo.

A produção das peças da caixilharia da FAU não exigia maquinário sofisticado, apesar da grande repetição (mais de quatrocentos módulos). Tudo foi feito a partir de chapas de ferro planas - abundantes no mercado desde a inauguração da Companhia Siderúrgica Nacional,

\footnotetext{
${ }^{69} \mathrm{Em} 1961$ serviços de extrusão de qualquer perfil de alumínio eram anunciados nas revistas de arquitetura. Ver em especial a revista Acrópole n. 267 de 1961, edição especial sobre o alumínio na arquitetura. Segundo depoimento de Vladimir Brega ao autor, as janelas de alumínio do CRUSP, projetado por Eduardo Kneese de Mello, haviam sido sugeridas por Paulo de Camargo e Almeida, mas logo começaram a quebrar. Após esse incidente, professores da FAU teriam exigido que o caixilho da escola fosse de ferro galvanizado, com o que Artigas teria concordado.
}

${ }^{70}$ A STIL possuía uma fábrica no perímetro noroeste da cidade de São Paulo com mais de 80 trabalhadores e uma equipe de projetistas, da qual Mehes fazia parte.

${ }^{71}$ Depoimento de André Mehes ao autor, realizado em setembro de 2010. 
em 1941 - dobradas e aparafusadas umas às outras. A tecnologia mais avançada dos caixilhos estava nos baguetes de Neoprene, que substituíam a massa de vidraceiro; e no "chumbador telescópico" que se acomodava à dilatação do concreto armado. No mais, a produção da estrutura do caixilho, feita em fábrica, era simples. As chapas de ferro, presentes nos montantes verticais e nos quadros das janelas e portas, bem como o perfil da calha de fixação no piso e as réguas dos batentes, precisavam apenas ser cortadas nas medidas certas e dobradas. No canteiro, o trabalho de montagem permitia pequenos ajustes, feitos com ferramentas simples. $O$ acabamento era completado com a pintura, que escondia as imperfeições.

O excesso de material dos caixilhos - se comparado ao que se fazia na época - se devia basicamente às grandes dimensões dos vidros e à opção por meios simples de execução. É o caso das réguas dos batentes das janelas, aparafusadas aos perfis dobrados: se os perfis fossem soldados, dispensariam a dupla espessura das chapas, que no resultado final geraria um desenho mais limpo. Mas o acabamento rústico é coerente com a simplicidade da técnica, com os recursos disponíveis e com a preocupação com a durabilidade.

Os cuidados formais prevalecem em outros aspectos, como a discrição dos puxadores e fechos. O mecanismo de abertura era acessível por um furo no caixilho central, que escondia um fecho Ryval. Mais importante do que isso era a ausência do montante horizontal superior, que faz com que a laje ficasse completamente livre quando a janela era aberta. Curiosamente, esse detalhe não aparecia no projeto da Ryval, aprovado pelo FCCUASO em junho de 1968, devendo ter sido uma solução criada no canteiro de obra. A solução, não projetada, foi colar espumas de Neoprene no topo das janelas para vedar o edifício, o que representa uma solução muito rudimentar.

Se a eloquente simplicidade dos caixilhos e a originalidade da janela da FAU - fruto da dedicação de Artigas aos projetos de esquadria ${ }^{72}$ - são inquestionáveis, o conjunto da esquadria não deixa de revelar alguns estranhamentos. Um deles é causado pela impossibilidade de se abrir duas janelas em esquina, dada a tridimensionalidade da abertura. Aspecto que, se pode ser ignorado no edifício da FAU, não pode ser desconsiderado em uma solução típica. Outro estranhamento se mostra na quantidade de variações e exceções nas dimensões quando o projeto do edifício era, supostamente, modulado. Enquanto o projeto de 1962 contabilizava 5 tipos e 14 variações, com 3 medidas de largura para o tipo principal (com janelas) variando de 825 a 1650 mm, o projeto da Ryval chegou a ter 5 medidas de largura do tipo principal, entre 1330 e $1580 \mathrm{~mm}$.

${ }^{72}$ O exemplo mais lembrado pela crítica é a janela guilhotina do edifício Louveira, de 1946. 
Questões como essa ajudam a explicar porque, apesar dos avanços e da oferta de produtos industrializados, os edifícios mais importantes da arquitetura moderna brasileira quase sempre dependeram de caixilhos manufaturados sob medida. ${ }^{73}$

Juntamente com os caixilhos, foram instalados outros componentes manufaturados. Os guarda corpos de alumínio de seção retangular, por exemplo, eram muito usado na década de 1960, quando a expansão da infraestrutura industrial reduziu o custo da energia elétrica e viabilizou comercialmente a produção de perfis de alumínio. Representava uma solução leve, barata e resistente, além de ser possível deixar o material aparente, sem pintura, com encaixes quase imperceptíveis. A seção quadrada de 5 centímetros, usada nos guarda corpos da FAU, era das mais comuns. A instalação dos guarda corpos consistia em chumbar os postes nas lajes e fixar os corrimãos. O sistema exigia apenas pequenas adaptações no canteiro de obra e ferramentas tão simples quanto serras e furadeiras.

Artigas havia incluído "peitoris" de alumínio para as escadas na folha de Detalhes Gerais de seu Projeto Básico. Mas sua localização nas rampas só aparece nos desenhos feitos pelo FCCUASO, em 1968. Os guarda corpos foram restritos ao mínimo possível. A rampa que desce do térreo para o auditório, por exemplo, permaneceu sem guarda corpos durante anos, assim como permanecem o fosso do auditório e as "varandas" da biblioteca - e as rampas do Congresso Nacional. Essa atitude dos arquitetos revelava uma clara mensagem estético-moral em relação aos riscos que valia a pena correr em nome da beleza. O mais surpreendente é que tal atitude, por mais provocativa que fosse, não era questionada pelas autoridades responsáveis.

Ao mesmo tempo, começavam a ser instalados os componentes elétricos aparentes, como calhas, conduites, luminárias e quadros de luz, que tinham a intenção de evidenciar a "verdade construtiva", evitar o retrabalho de alvenaria na intalação e facilitar a manutenção. A solução, em voga no período, era quase uma decorrência das paredes de concreto e ausência de forros. O projeto de instalações elétricas desenvolvido pelo escritório do engenheiro Homero Lopes, trazia um tronco de distribuição vertical contínguo aos shafts, entre a dupla alvenaria, por onde passavam também intalações telefônicas. No piso, haviam sido deixadas tomadas e caixas de passagem.

O domo da cobertura foi outro componente que amadureceu ao longo do processo. $\mathrm{O}$ projeto de 1961 trazia uma espécie de telhado de vidro com quatro águas. Desde o início, esse detalhe preocupou o Fundo, que cobrou a revisão desta proposta e fez sugestões. Em

\footnotetext{
${ }^{73}$ Em São Paulo, por exemplo, o Liceu de Artes e Ofícios não apenas produziu caixilhos para os principais edifícios da virada do século, com ornamentação eclética em ferro fundido, como também prestou serviços à arquitetura moderna, como os caixilhos do MASP e do Palácio do Itamaraty. Ver: SCHENKMAN, Raquel. Do vital ao pano de vidro. Dissertação Mestrado. Orientador: José Tavares Correia de Lira. São Paulo, FAUUSP, 2014.
} 
1963, a solução de Artigas evoluiu para um domo um pouco mais abaulado que o definitivo, desenhado apenas em 1968. Os domos foram feitos em fibra de vidro, que custava menos, do que o acrílico moldado a quente, que chegou a ser cogitado. A evolução do projeto do domo aponta na direção da industrialização, compatível com a repetição do elemento. É possível que os domos tenham sido comprados e instalados pelo Fundo, mas também é possível que tenham sido produzidos pelo próprio Fundo.

Mas de todos os materiais e soluções técnicas encontrados durante a obra, o que mais chama a atenção por seu impacto no resultado estético é piso. Desde o Projeto Básico de Vilanova Artigas até as plantas de pisos elaboradas pelo FCCUASO em abril de 1968, o piso especificado para todo o edifício da FAU era de placas de borracha vulcanizada lisas e ranhuradas (nas rampas), de $50 \times 50 \mathrm{~cm}$. Amplamente usadas em obras públicas, especialmente em projetos escolares, o piso de borracha era barato, resistente e de fácil substituição - além de ser produto da indústria nacional.

Além das placas de borracha, as plantas de pisos especificavam um mosaico português na transição da área externa para a área interna e no foyer do auditório. As pedras de arenito que compõem o mosaico eram facilmente encontradas no Brasil e representavam uma solução simples e elegante para pisos externos. O desenho do mosaico (não localizado) teria sido trazido por Artigas e entregue diretamente ao pedreiro espanhol, Bartolomeu Gabarron, da equipe do Fundo. ${ }^{74}$

O motivo abstrato do desenho do piso era, provavelmente, uma referência ao córrego que foi canalizado por baixo do edifício. ${ }^{75}$ Por outro lado, o calçamento em mosaico português era também uma homenagem ao trabalho manual e à arte popular. ${ }^{76}$ Mas não deixa de ser interessante que o único material explicitamente artesanal do edifício possuísse uma origem marcada pelo conflito entre arte e trabalho no século XIX. ${ }^{77}$

\footnotetext{
${ }^{74}$ Depoimento de Vladimir Brega ao autor, realizado em 23/02/2011.

75 Sobre a comprovação desse lendário córrego, ver: BONZI, Ramón Stock. "Córregos (e desígnios) ocultos na Cidade Universitária Armando Salles de Oliveira". Revista LABVERDE, n. 8, São Paulo: FAUUSP, junho 2014. Disponível em: www.revistas.usp.br/revistalabverde/article/viewFile/83548/86475

${ }^{76}$ Sobre o entendimento de Artigas de arte popular, ver: ARTIGAS, João B. Vilanova. "Liberdade para Odiléa", Acrópole, n.338, 1967.

77 "A calçada portuguesa, conforme a conhecemos, foi empregada pela primeira vez em Lisboa no ano de 1842. O trabalho foi realizado por presidiários, a mando do Tenente-general Eusébio Pinheiro Furtado". Artigo da Wikipedia que cita como referência os trabalhos: BAIRRADA, Eduardo Martins. Empedrados artísticos de Lisboa: A arte da calçada-mosaico. Lisboa: M. Bairrada, 1986; MATOS, Ernesto. Calçada portuguesa: uma linguagem universal. Lisboa, Câmara Municipal de Lisboa, 2001.
} 
Se o mosaico português se destaca pela memória do trabalho artesanal - na parte mais externa e baixa do edifício, mas combinando com o aspecto do concreto visto do exterior - o piso epóxi chama a atenção pelo oposto: o acabamento liso, colorido, brilhante. ${ }^{78}$

A substituição das placas de borracha pelo epóxi foi feita já na etapa final da obra. O grande empreendedor desta ideia teria sido o engenheiro Odilon da Costa Passos, que convenceu Artigas e os técnicos do Fundo e providenciou a importação do material. ${ }^{79}$ Como funcionário do FCCUASO, Odilon Passos já havia empregado o epóxi em grande quantidade no Conjunto das Químicas, concluído em 1966, projeto dos arquitetos do Fundo, João Roberto Simões Leme e Alberto Daniel.

"A CUASO montou em seu Campus uma central de fabricação desse piso, e de mão de obra direta e própria, sendo que o material foi importado da Shell da Inglaterra com assessoria de técnicos especializados. Adotou-se esse piso após uma pesquisa de desempenho técnico-econômico de aproximadamente 30 pisos existentes na praça de São Paulo". ${ }^{80}$

O epóxi ainda não era produzido e nem facilmente comercializado no Brasil, motivo pelo qual raras obras da arquitetura brasileira haviam usado o material, quase sempre em pequenas áreas, como na residência Antônio D’Elboux (1962), projetada pelo arquiteto Carlos Millan, e na residência do arquiteto Paulo Mendes da Rocha, no Butantã (1964-66).

As principais vantagens do epóxi eram o resultado monolítico, essencialmente arquitetônico, e a suposta facilidade de aplicação. Artigas já havia demonstrado interesse nesse tipo de resultado ao usar materiais com características semelhantes em matéria de cor e brilho, como pisos de cimento queimado (colorido), ladrilhos hidráulicos, lajotas, e pisos de borracha. Contudo, além de constituírem processos de produção totalmente distintos, que exigem contrapisos ou assentamento manual de cada peça, nenhum desses pisos oferecia uma aparência homogênea, contínua e lisa, associada aos padrões industriais de clareza e simplicidade.

Segundo o engenheiro Vladimir Brega, a resina foi importada em tambores de 200 litros, vindos de navio da Inglaterra. Para prepará-la foi montada uma pequena fábrica de tinta entre a FAU e o Instituto de Oceanografia. Lá eram adicionados pigmentos e o catalisador em misturadores com auxílio de pedregulhos. O epóxi era então transportado manualmente

\footnotetext{
${ }^{78} \mathrm{~A}$ resina de poliepóxido é um plástico endurecido com um catalisador químico que teve seu uso comercial desenvolvido no final dos anos 1920, nos EUA e na Suíça, para pisos industriais. Entre suas qualidades estão a alta resistência e a inércia química. Mais tarde se tornou comum em laboratórios e hospitais pela higiene proporcionada pela ausência de juntas.

79 Segundo depoimentos do eng. Vladimir Brega e do arq. Luciano Bernini ao autor.

80 SIMÕES, João Roberto Leme. Arquitetura na Cidade Universitária 'Armando Sales de Oliveira' - o espaço construído. Dissertação de mestrado. São Paulo: FAUUSP, 1984, p. 133.
} 
e aplicado com rolo de pintura. Todo esse trabalho teria sido realizado pelos trabalhadores do Fundo, que adquiriram experiência no Conjunto das Químicas. ${ }^{81}$ Satisfeitos com o resultado, Artigas e a equipe do Escritório Técnico decidiram repetir o acabamento nos bancos dos "bichos" e da varanda da biblioteca, bem como no balcão da lanchonete. Dessa vez, contudo, optaram por testar a aplicação sobre uma superfície lixada, o que teria produzido um resultado superior. ${ }^{82}$

Apesar de Vladimir Brega afirmar que o epóxi teria sido aplicado diretamente sobre as lajes, sem contrapiso ou regularização, esse dado poderia ser melhor investigado. A análise visual de trechos deteriorados do piso sugere a existência de uma fina camada de argamassa entre a pintura e a laje. Sem tal confirmação, permanece a tese da simplicidade da técnica, que a escola artiguista ajudou a divulgar. ${ }^{83}$

\footnotetext{
${ }^{81}$ No final desta pesquisa encontramos uma versão diferente segundo a qual o epóxi teria sido fornecido e executado pela Tintas Âncora, criada em 1963 por Silverio Macchia, Carlo Pega e Pier Luigi Pega, todos italianos. A empresa foi pioneira na fabricação de tintas industriais no Brasil, onde o mercado estava em expansão. A informação veio de Marcelo Macchia, filho de Silverio que se mantém na empresa e que acompanhou a restauração do piso recentemente. Apesar de nossos esforços, a informação não pôde ser verificada, pois seu pai não estava em condições de saúde para conceder uma entrevista. Ainda segundo Marcelo, tanto na FAU como na Biomédicas, foi utilizada uma massa epóxi fluída pigmentada (Duron 3500 massa autonivelante, aplicada manualmente com desempenadeira em piso cimentício nivelado).

$82 \mathrm{Em}$ fotografias que realizei para esta pesquisa é possível identificar marcas de lixa no concreto em trecho onde a pintura descolou do banco da varanda, confirmando a afirmação de Vladimir Brega.

${ }^{83}$ Contudo, mesmo que o epóxi tenha sido aplicado diretamente sobre a laje na maior parte do edifício, nos banheiros o esgoto exigiu a elevação do piso, feita com blocos de alvenaria, entulho e, evidentemente, contrapiso.
} 


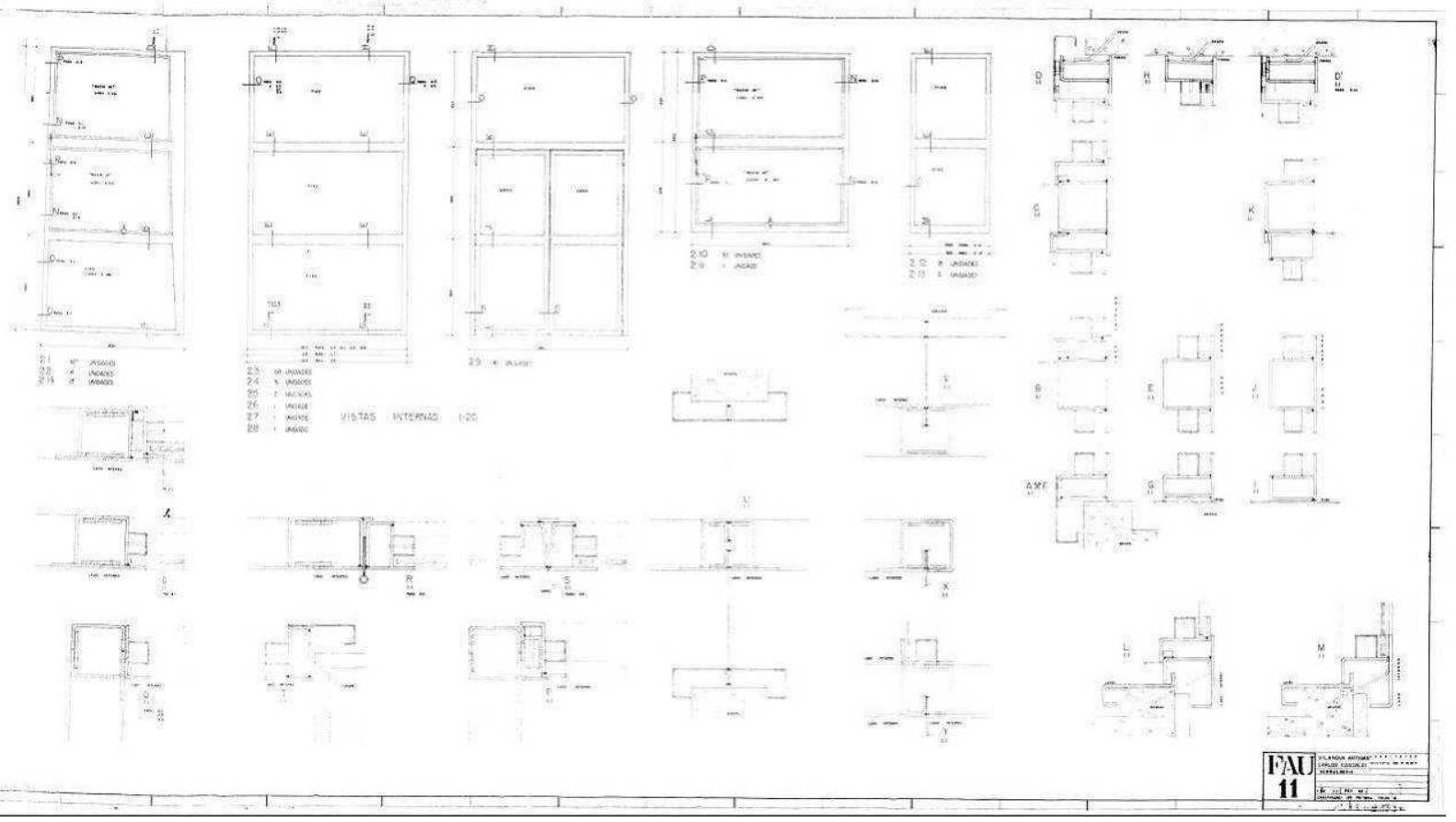

Vilanova Artigas e Carlos Cascaldi. Serralheria, Projeto Básico da FAUUSP, fevereiro de 1962

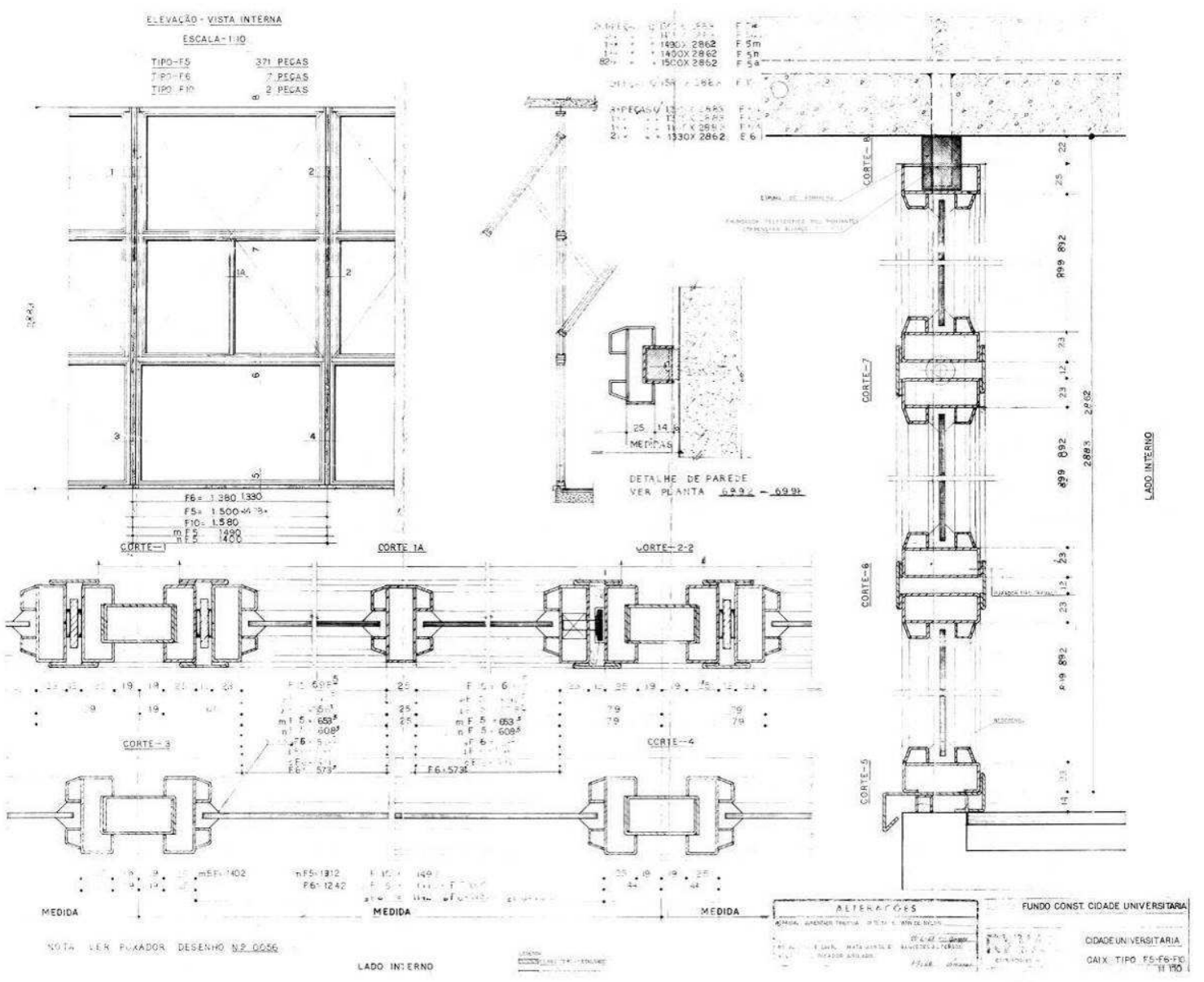

Ryval, Projeto do caixilho da FAU, junho de 1968. Acervo BFAUUSP 


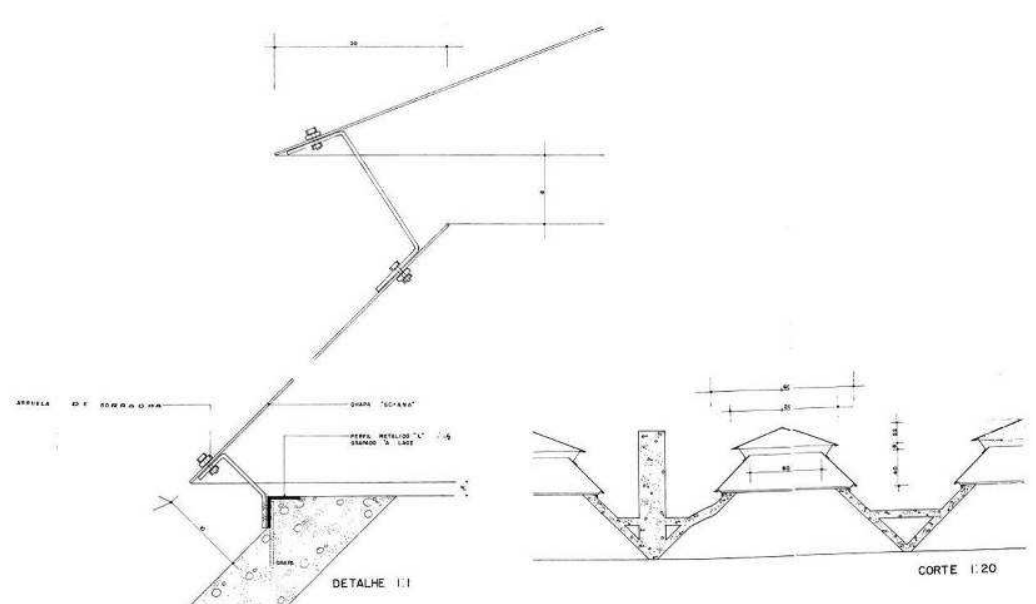

DETALHE 12
CLARABOias

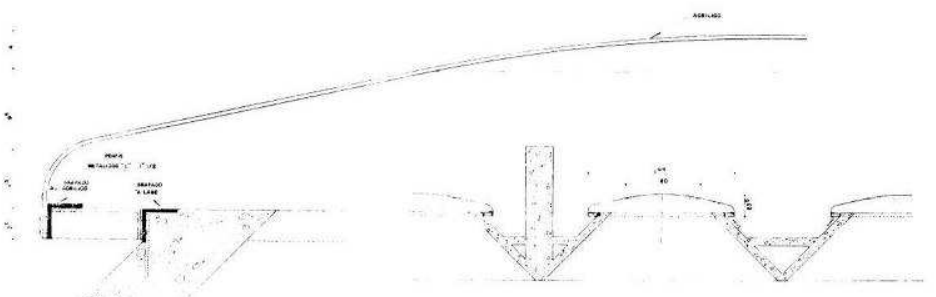

DETALIE : 2

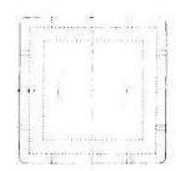

Detalhe da primeira solução para os domos da cobertura com vidros planos anteprojeto de 1961. Acervo BFAUUSP.

Solução para domo, em desenho de 1962. Acervo BFAUUSP.
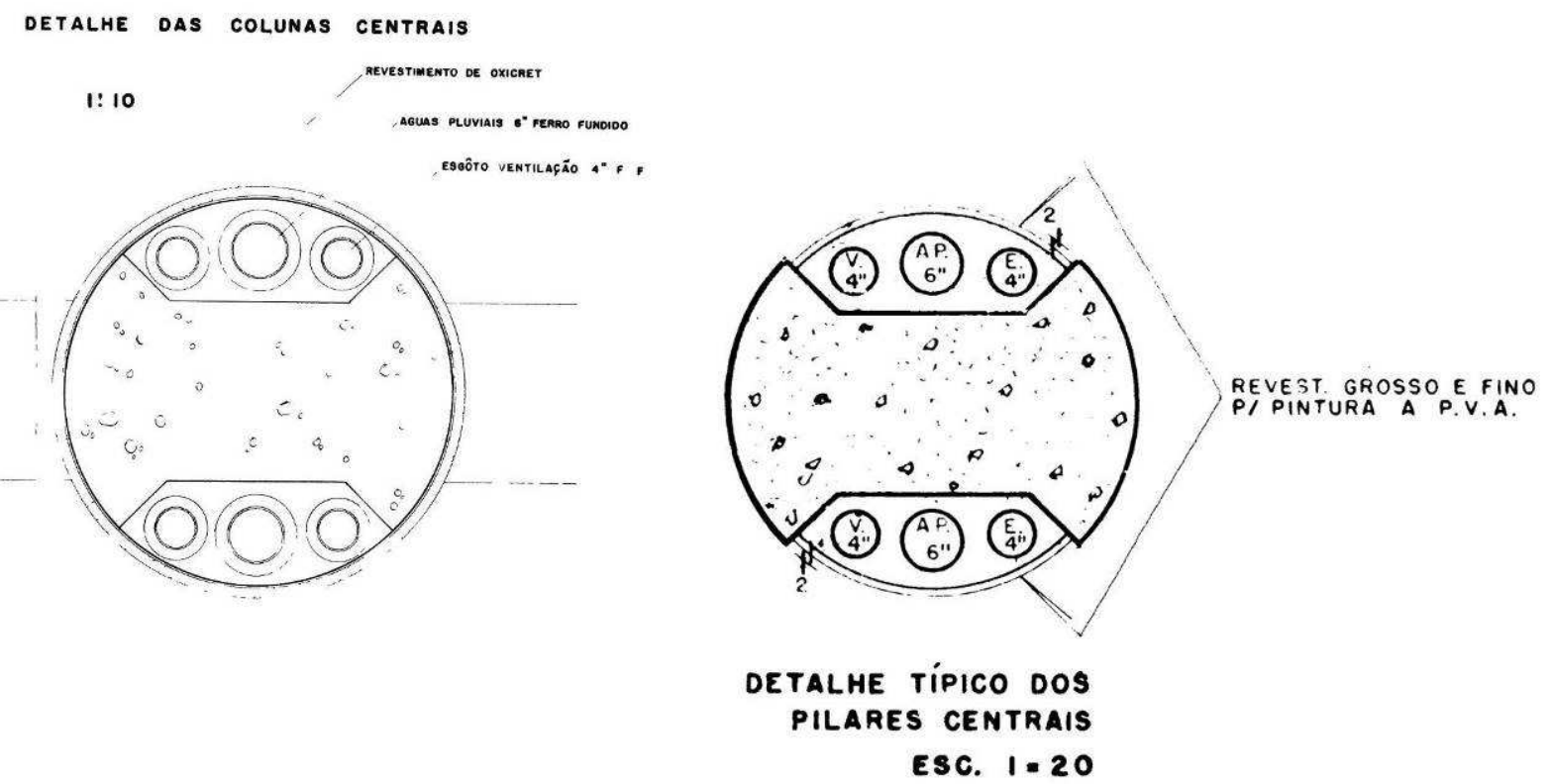

Detalhe do pilar central no Anteprojeto de Artigas, 1961.

Detalhe do pilar central no projeto do FCCUASO, 1968. Acervo BFAUUSP.

Acervo BFAUUSP. 

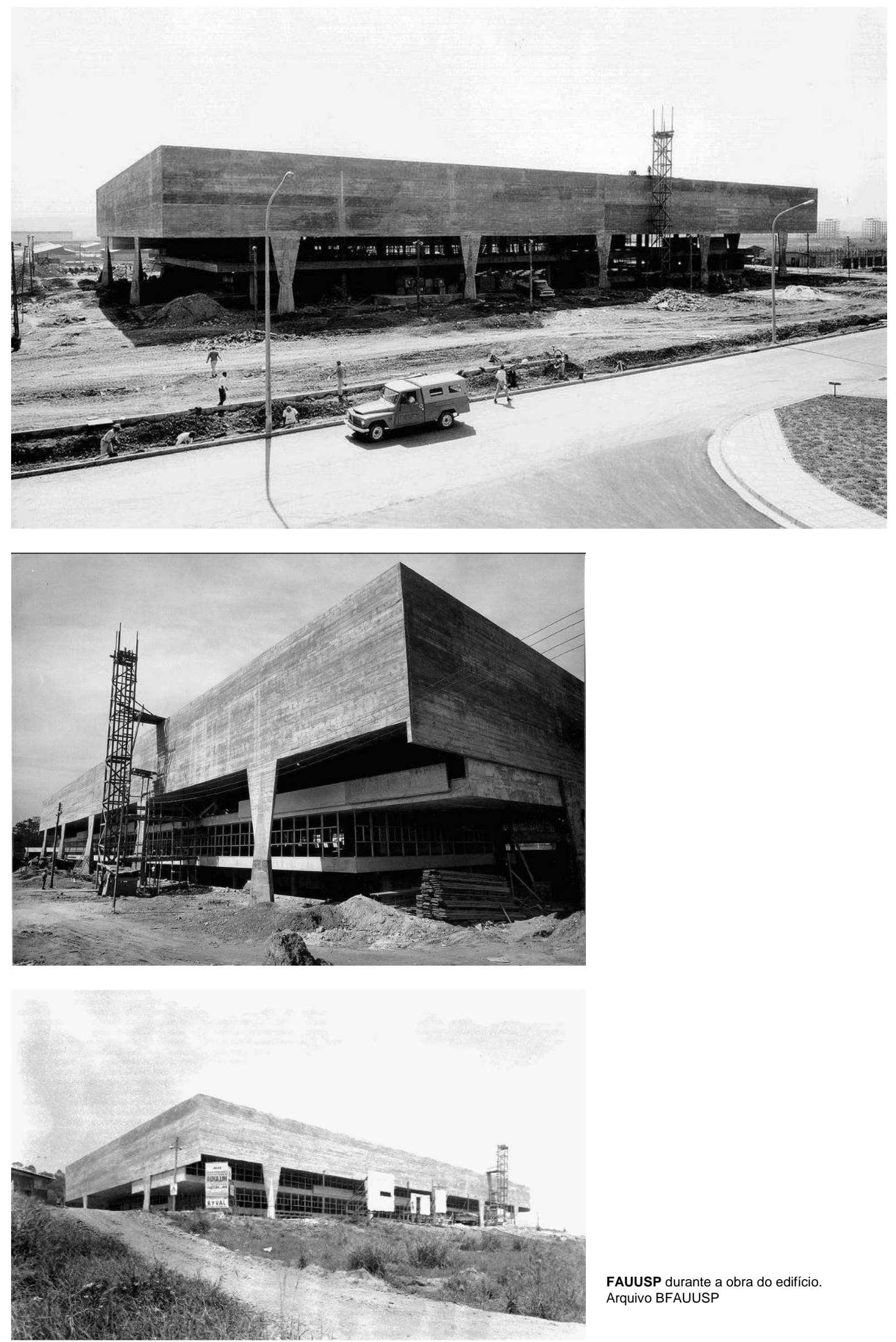

FAUUSP durante a obra do edifício.

Arquivo BFAUUSP 


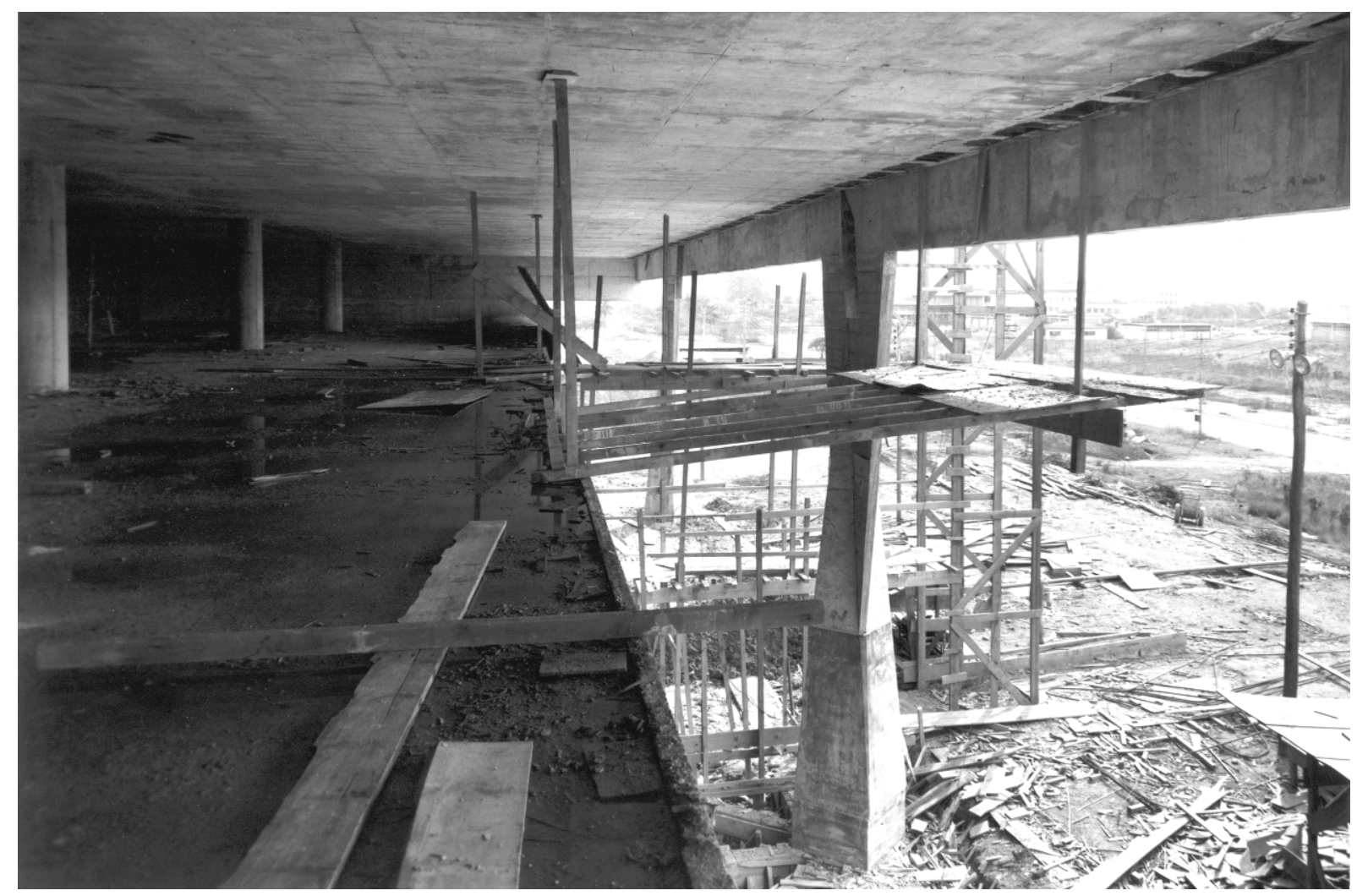

Edifício da FAU em construção.

Foto: José Moscardi

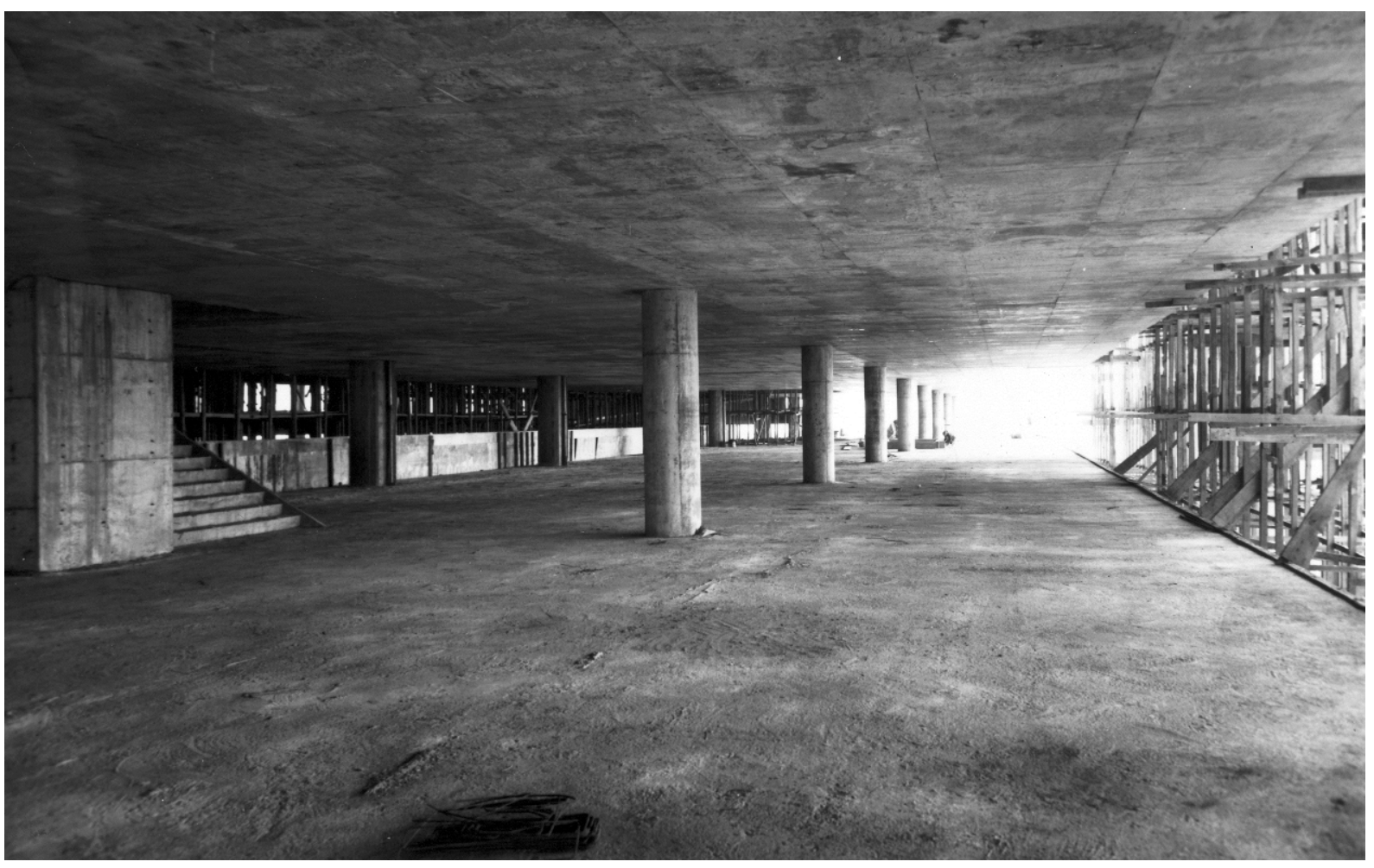

Edifício da FAU em construção.

Foto: José Moscardi (?) 


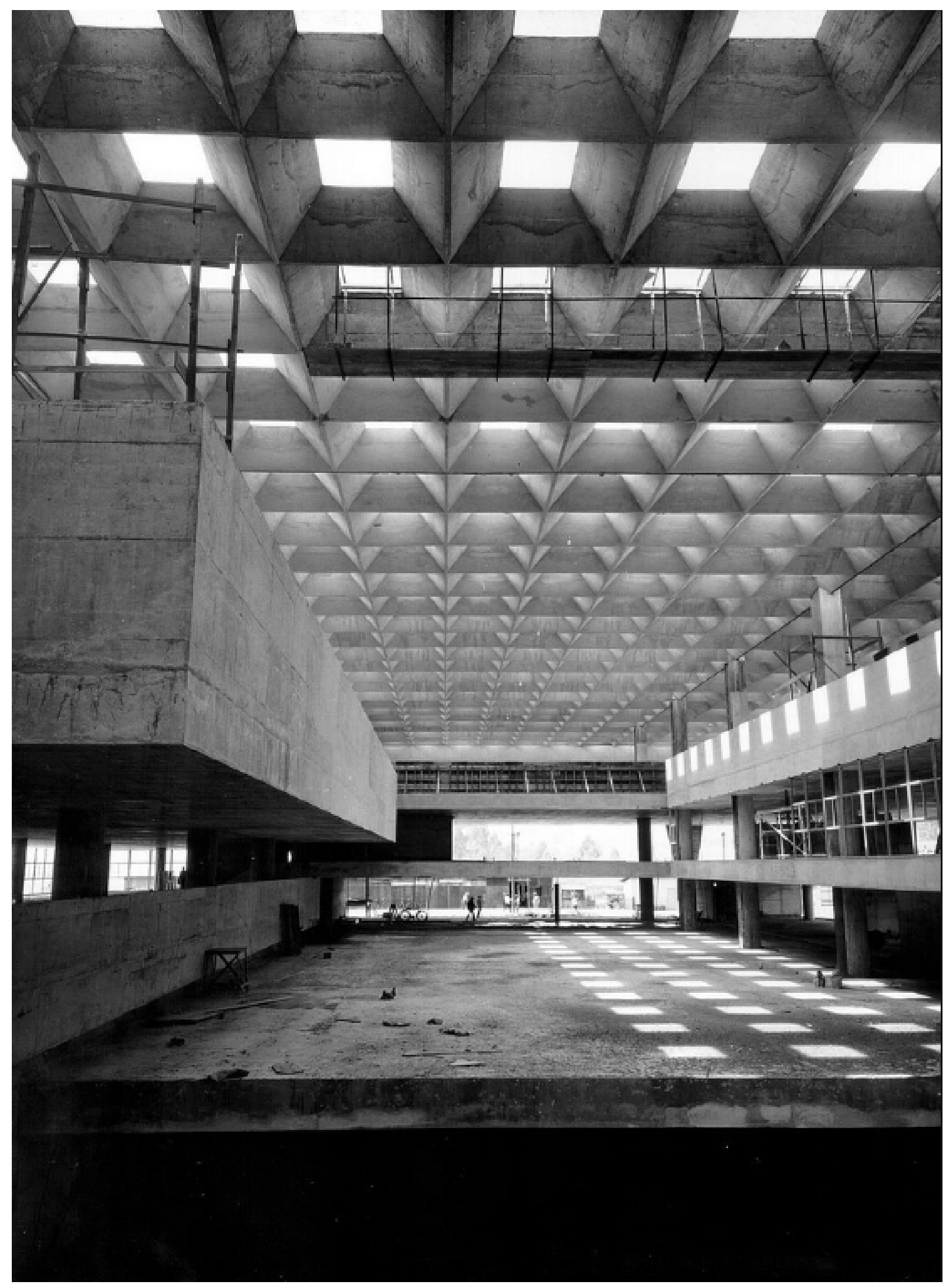

Andaime suspenso para tratamento da junta de concretagem da grelha de cobertura. Notar a concretagem de parede do estúdio ao fundo e a Instalação do caixilho na biblioteca. Acervo BFAUUSP. 

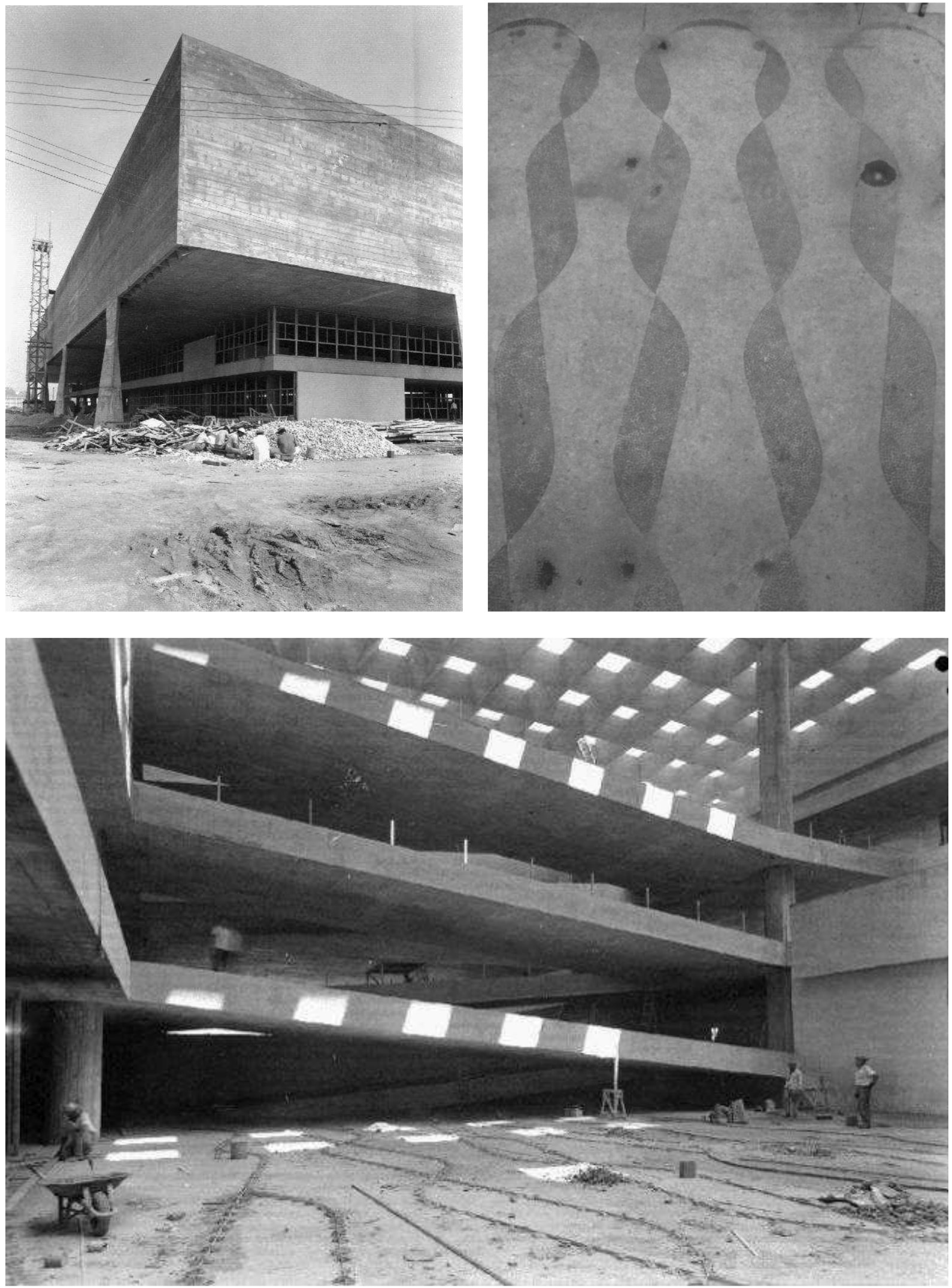

Execução do piso de mosaico do foyer do auditório. Acervo BFAUUSP. Acima à direita, piso de mosaico português. Foto do autor, 2011. 

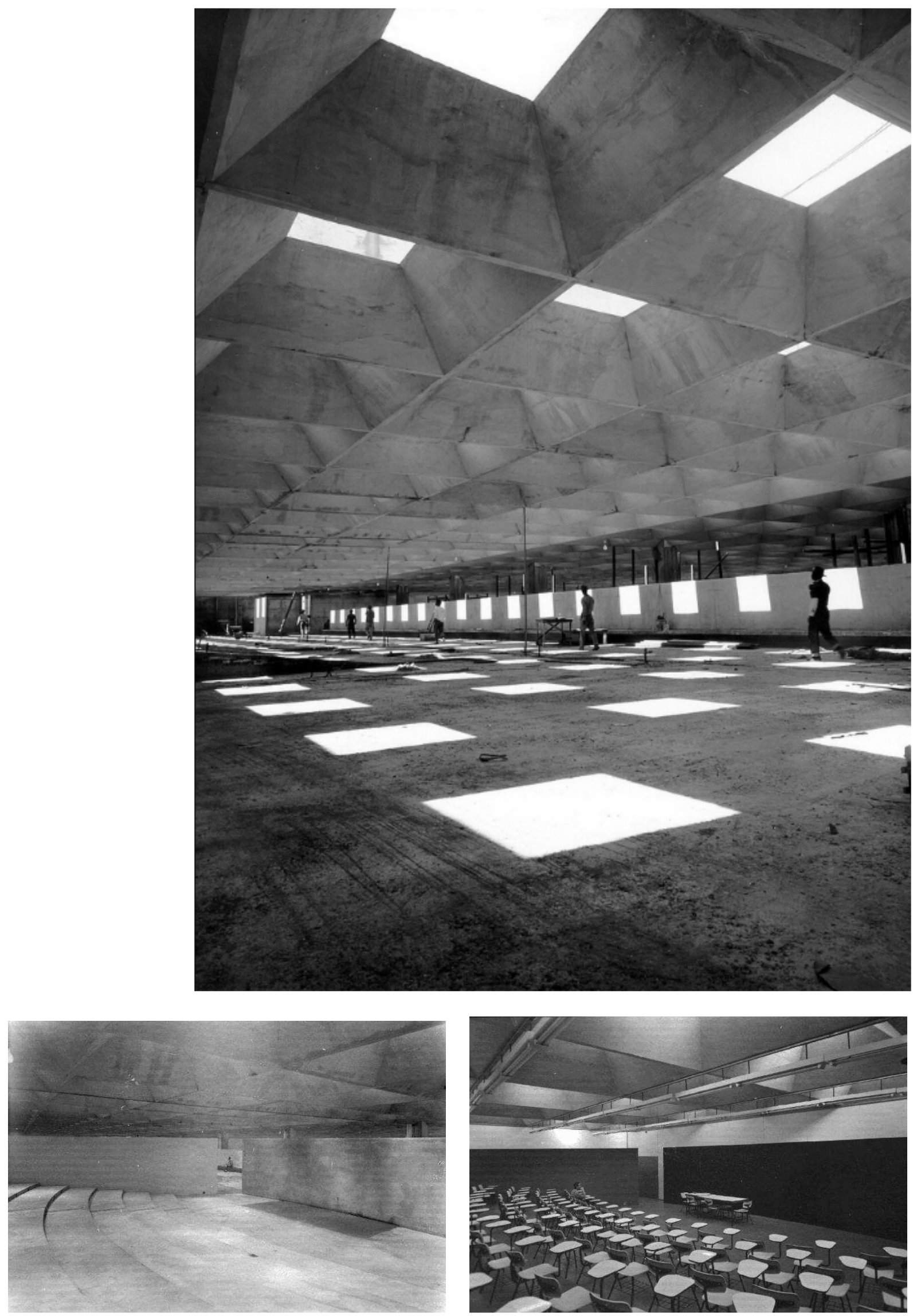

Etapas da obra no piso das salas de aula. Arquivo BFAUUSP 

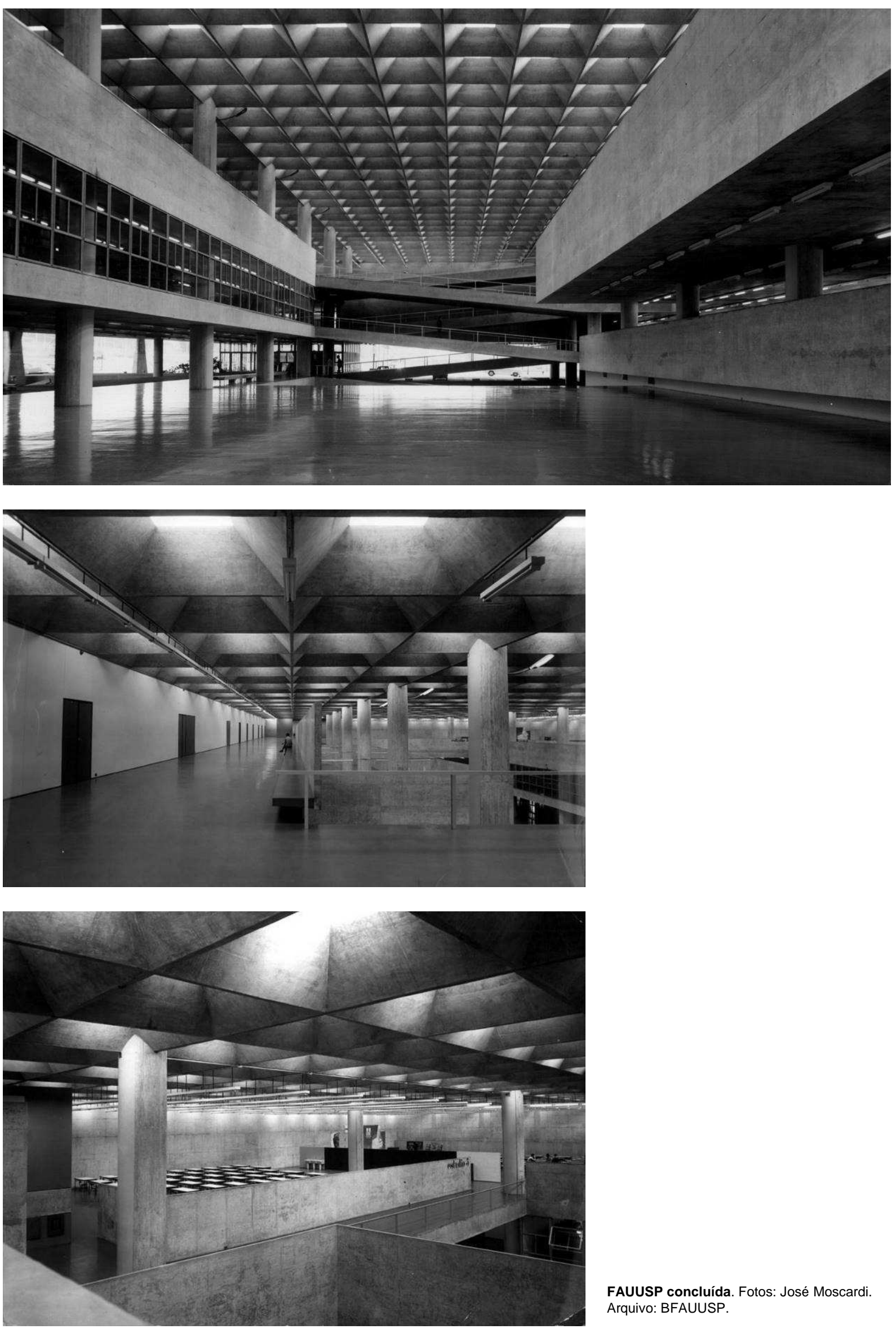

FAUUSP concluída. Fotos: José Moscardi. Arquivo: BFAUUSP. 

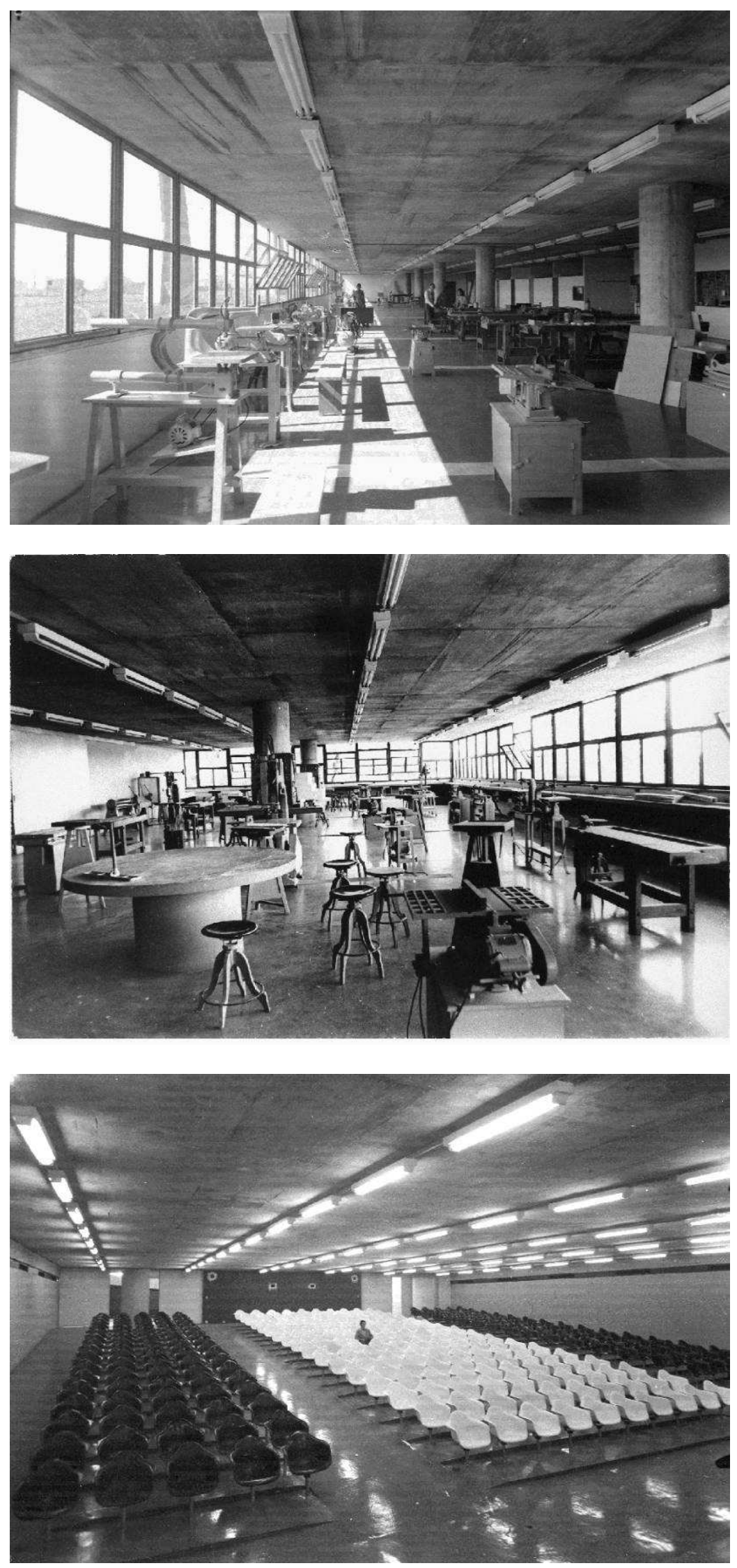

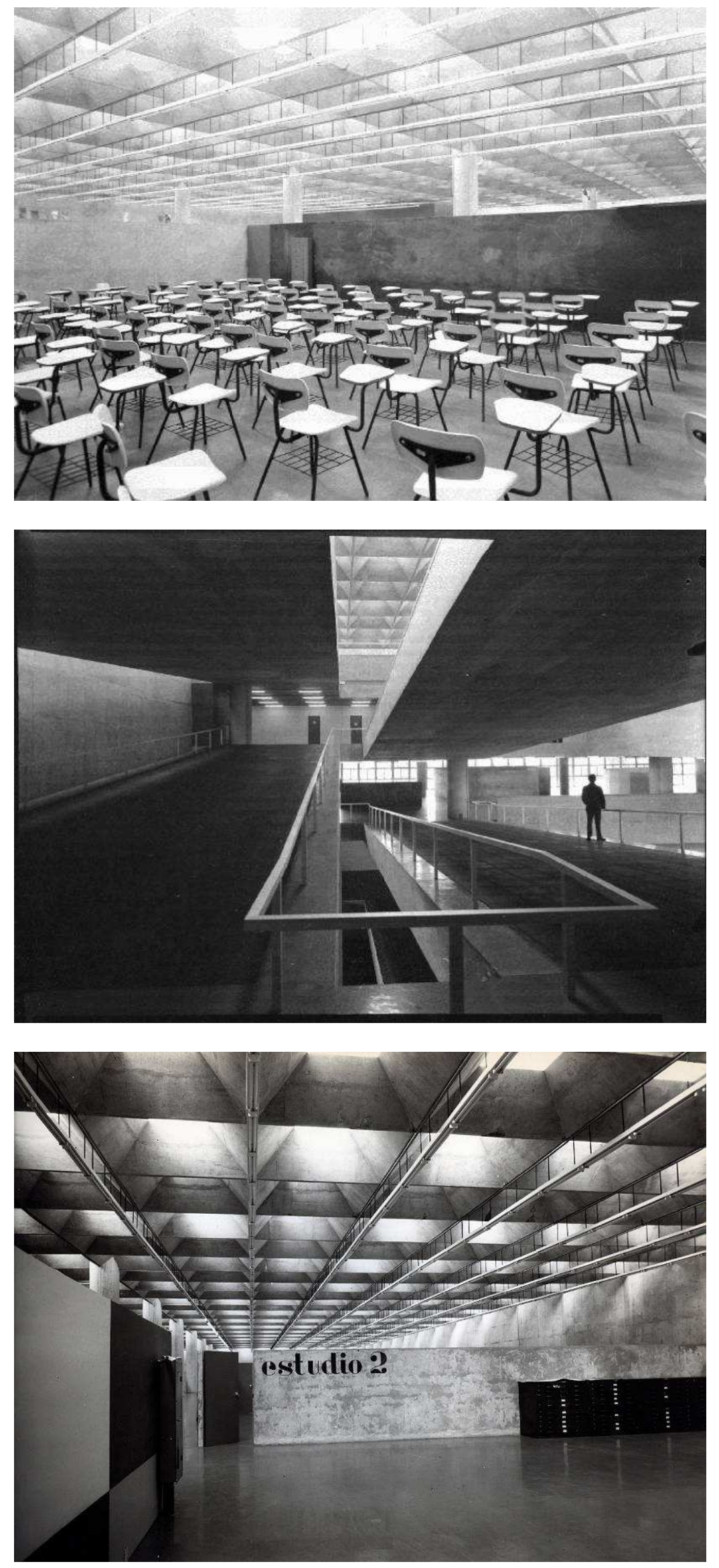


\section{O EDIFÍ́CIO CONSTRUÍDO}

Não é o foco desta tese analisar as possíveis correlações espaciais, formais e construtivas com outras obras, célebres ou não, da história da arquitetura. Mas algumas reflexões, ainda que sumárias, se fazem necessárias.

Em primeiro lugar a cobertura em grelha, além de representar o maior desafio estrutural, trouxe uma solução única para cobertura, integrando iluminação zenital, cobertura e captação de águas pluviais, num sistema relativamente independente da estrutura do edifício. Tal estratégia pode mesmo ser vista como um princípio recorrente na obra de Artigas. ${ }^{84}$ De todo modo, a cobertura única em grelha contínua é encontrada em pouquíssimos projetos, entre os quais o Unity Temple (1904), de Frank Lloyd Wright, em Oak Park, chama muito a atenção. Embora o princípio da iluminação zenital tenha sido amplamente usado por Artigas e estava presente em diversos projetos da Cidade Universitária, a cobertura da FAU é muito inovadora tanto técnica quanto visualmente.

Os estúdios da faculdade - a grande prioridade do programa funcional - foram pensados propositadamente sem aberturas para o exterior, criando um ambiente de imersão. Apesar de inúmeras reações contrárias que tal ideia provocou, a iluminação zenital, além de desejável para a atividade do desenho (como Artigas deve ter notado durante sua estadia na Taliesin West, também de Frank Lloyd Wright), constitui uma solução que oferece as mesmas condições de iluminação para todos os alunos, ao invés uma planta desigual.

Por fora, a empena cega de concreto aparente em todas as fachadas representa uma atitude contra o fetiche formal e a adesão estética imediata. É pensada para provocar, repelir as expectativas superficiais da forma exterior. Mas, ao mesmo tempo, funciona como um entablamento e, sob essa perspectiva, a fachada revela-se rigorosamente clássica. Aliás, é digno de nota que se o entablamento é a área destinada às principais representações figurativas, Artigas nos conduz a observar os vestígios da produção do concreto armado. Como o próprio arquiteto afirmou, "queria como um templo", o que deve tê-lo levado a adotar a planta em peristilo e reinventar a fachada com frontão a colunata. ${ }^{85}$

\footnotetext{
${ }^{84}$ Segundo Luis Espallargas Gimenez. (Arquitetura paulistana da década de 1960: técnica e forma. Tese de doutorado. Orientador: Ricardo Marques de Azevedo. São Paulo: FAUUSP, 2004), o edifício da FAUUSP pode ser visto como o exemplo mais acabado da separação entre cobertura e estrutura, que já aparece no projeto para o posto de gasolina José Mestres Alijostres, de 1949.

85 De certo modo, os palácios de Niemeyer em Brasília, especialmente o Palácio da Alvorada, seguiam a mesma intenção. Uma competente análise comparativa entre o edifício da FAU e o Palácio do Planalto, que confirma essa hipótese, pode ser lida em: BAHIMA. Carlos Fernando S. "Palácio do Planalto versus FAU-USP: continuidades e rupturas entre materialidades e geometrias". Anais do X Seminário Docomomo Brasil. Curitiba: PUC-PR, 2013.
} 
Apesar do modelo clássico, Artigas não parece ter se baseado em nenhum projeto específico e nem mesmo em outra sede de escola de arquitetura ${ }^{86} \mathrm{Em}$ termos de linguagem é notável a sintonia de Artigas com uma série de edifícios de concreto aparente, comuns na época, e particularmente presente nas novas escolas de arquitetura produzidas nos EUA ${ }^{87}$, como o Rudolph Hall (Yale, Paul Rudolph, 1959-1963), mas também na Facultad de Arquitectura, Diseño y Urbanismo (FADU), da Universidade de Buenos Aires, praticamente contemporânea da FAU. ${ }^{88}$ Tal semelhança, no entanto, parece mais estabelecer um meio de comunicação entre os arquitetos do que apontar uma convergência estético-programática, dados os modos antagônicos de produzir e expor o concreto aparente.

A inauguração de La Tourette, em 1959, pode ter influenciado essas e outras vertentes da arquitetura moderna daquele período, definindo um campo de proposições dos arquitetos, especialmente na América Latina, onde a Unité d'Habitation - tida por Banham como precursora do brutalismo - não parece ter tido a repercussão que teve na Europa. Já a partir de La Tourette, podemos identificar algumas obras que, de um modo ou de outro, concentraram uma reflexão sobre o subdesenvolvimento do continente, no qual o concreto aparente, com sua rugosidade e imperfeição características, se afastava da noção de precisão, mas ao mesmo tempo permitia o exercício plástico e a contemplação da estrutura. Dois exemplos de projetos que nitidamente decorrem de La Tourette e guardam semelhanças notáveis com o edifício da FAU são o Urnário Municipal de Montevideo (1959), de Nelson Bayardo, ou o edifício da CEPAL (1960-1966), no Chile, de Emilio Duhart. Isso sem esquecer das obras de Reidy, desde a Escola Brasil-Paraguai até o MAM-RJ, que Artigas acompanhava com grande interesse.

No âmbito do projeto da FAU é também interessante notar possíveis referências à Vila Penteado, primeira sede da escola e patrimônio afetivo daquela comunidade acadêmica. Para muitos que ali estudaram e lecionaram, o novo edifício fazia claras referências ao prédio antigo, como o chafariz, que ficava no fundo da Vila (que virou frente), transformado no "laguinho", igualmente na frente que é fundo do ponto de vista da relação com a Cidade Universitária. O grêmio no subsolo seria outra referência ao porão do palacete, onde os estudantes montaram sua gráfica e produziram boa parte da cultura da escola. Ou mesmo o átrio principal da Vila Penteado, com pé-direito duplo, de onde se vê a movimentação no

\footnotetext{
${ }^{86}$ Artigas certamente procurou se afastar das escolas de arquitetura brasileiras, como a Faculdade Nacional de Arquitetura (Jorge Machado Moreira, 1949-1962) e a Escola de Arquitetura de Belo Horizonte (Shakespeare Gomes e Eduardo Mendes Guimarães Junior, 194?-1954), que já eram alvo de críticas por representarem uma estilização do moderno e representavam o modelo didático que foi imposto à FAU (padrão federal). No âmbito internacional as semelhanças com outros projetos, como o espaço livre dos ateliês do pavilhão S.R. Crown Hall (IIT, Mies van der Rohe, 1956), algumas vezes lembrado, são pouco específicas.

${ }^{87}$ Ver o diagrama com 22 edifícios de escolas de arquitetura brutalistas em: Clog, junho 2013: Brutalism.

${ }^{88}$ Projeto de Eduardo Catalano, Horacio Caminos, Eduardo Sacriste e Carlos Picarel. Concurso realizado em 1960, inaugurado parcialmente 1966 e 1971.
} 
nível superior e que, como o Salão Caramelo, é um vazio em torno do qual orbitam as salas. ${ }^{89}$ Nesse sentido a ideia de alegorias e representações na obra de Artigas ganha força e a comparação pode ser pertinente. Se o átrio da Vila Penteado era decorado com pinturas que representavam as etapas da indústria nacional, desde a cultura indígena até as lavouras de café e a indústria, é possível que Artigas tenha feito sua releitura sobre esse tema no Salão Caramelo, através dos materiais de construção.

O mosaico português e o concreto da fachada externa, como já falamos, trazem a presença do trabalho artesanal, sua rugosidade, imperfeição, beleza e violência. Os materiais de revestimento, especialmente o piso epóxi, remetem ao contrário: o liso, o contínuo, o sofisticado. Também o elevador e seu maquinário aparente. No extremo oposto da planta, em relação ao mosaico, no ponto mais elevado e interno do projeto, a discreta engrenagem do elevador, visível de quase todo o edifício, se mostra integralmente num ponto de destaque vertical do projeto. A operação do elevador implica no movimento da engrenagem, que pode ser testemunhado publicamente. Artigas optou por destacar a mecânica da máquina, que serve ao homem eficientemente, ao invés de ocultá-la, como seria esperado. A engrenagem, parte funcional do edifício, ganha contorno ornamental. É máquina alçada à condição de objeto de admiração, ainda que não receba tratamento monumental. Se o salão caramelo é uma praça, a engrenagem do elevador pode ser comparada aos relógios e sinos das grandes praças públicas. Aliás, essa analogia, apesar de especulativa, parece bastante apropriada à concepção humanista que Artigas fazia da técnica moderna: diferentemente do sino e do relógio, que são aparelhos de controle social, o elevador representaria a subserviência da máquina ao conforto humano.

A oposição mosaico-elevador sugere, como no debate sobre o subdesenvolvimento brasileiro no qual Artigas estava tão envolvido, mesmo que simbolicamente, ao modo como o arquiteto agenciou as técnicas, materiais e componentes da construção. Pode não ter sido uma formulação consciente do arquiteto, mas parece bastante razoável. No entanto, com o início da recepção crítica, o edifício passaria a ter muitos outros sentidos.

Como foi dito, a preocupação com o custo da FAU era constante durante as discussões sobre a realização ou não do projeto e sem qualquer base confiável. Estimada em $1961 \mathrm{em}$ cerca de Cr\$ 1 bilhão (que corrigido pelo índice IPC-SP/FIPE equivaleria a NCr\$ 28.611.156,80 em 1969), a obra aparentemente custou menos de um quinto desse valor e ficou dentro da média das edificações da Cidade Universitária construídas após 1964, perdendo apenas para os pavilhões. ${ }^{90}$ Em março de 1969, o Governo Abreu Sodré produziu

\footnotetext{
${ }^{89}$ Ver essa análise em: BUZZAR, Miguel. João Batista Vilanova Artigas: elementos para a compreensão de um caminho da arquitetura brasileira (1938-1967). Dissertação de mestrado. São Paulo: FAU-USP, 1996.

${ }_{90}$ Processo USP n. 69.1.12921.1.7, fls, 20-21
} 
um folheto comemorativo por ocasião da inauguração do edifício onde o valor anunciado era de $\mathrm{NCr} \$ 244,00 / \mathrm{m}^{2}$, ao longo de 25 meses de obra. Entre março e junho de 1969, houve um acréscimo de $8,5 \%$, supostamente por alterações nas divisórias, que elevou o custo total para NCr\$4.926.209,01. Mesmo assim, com área de $18.660 \mathrm{~m}^{2}$, o edifício da FAU ficou levemente acima demais obras, com um custo de $\mathrm{NCr} \$ 263,99 / \mathrm{m}^{2}$, perdendo apenas - e por razões óbvias - para o Acelerador Linear Mark II, que custou $\mathrm{NCr} \$ 659,62 / \mathrm{m}^{2}{ }^{21}$

Pouco depois promulgar o Al-5 e expulsar os professores da USP, o reitor Gama e Silva se aposentou, ainda em 1969. Com ele, parece ter ido embora a resistência que as autoridades da ditadura demonstravam aos projetos de Artigas e seus colegas. Segundo um esclarecedor depoimento de Júlio Katinsky, durante a festa da desfôrma da estrutura da FAU, Artigas Ihe teria dito:

"Olha, tem uma turma de jovens arquitetos que está fazendo uns barracões pré-fabricados, e estão preocupados com a economia, para chegar a valores muito baixos de construção, como é típico desses moços que querem fazer pré-fabricação. Eles trouxeram 0 Secretário, fulano de tal, para insinuar que isso [o prédio da FAU] era um desperdício, porque não é pré-fabricado, e tudo foi construído in loco [...]. O Secretário olhou, olhou, viu, passeou, depois virou para os meninos, jovens arquitetos, e disse: - vocês precisam continuar fazendo galpão, mas nós precisamos desse tipo de prédio também". 92

Era um prenúncio da apropriação que o regime militar faria da Escola de Vilanova Artigas.

Mas não foi apenas o regime militar que disputou o brutalismo paulista. Logo após a inauguração material do edifício da FAU começou a sua construção imaterial, simbólica e poética, que continua até hoje. Em meio a uma grande quantidade de comentadores, o primeiro grande esforço analítico foi feito por Bruand, que buscou entrelaçar a forma e a técnica do edifício com o pensamento do arquiteto. Ele começa por uma descrição visual e objetiva:

"A obra [...] apresenta-se externamente como um vasto paralelepípedo retangular de faces laterais cegas, todo em concreto bruto, montado em pilares do mesmo material, dos quais só os que ficam no contorno são claramente visíveis - e tão bem parecem sustentar todo o peso dessa enorme massa. O desenho dos pilares em forma de trapézios duplos, mais altos do que largos e opostos

\footnotetext{
91 Idem

${ }^{92}$ Atribuído a Artigas apud KATINSKY, Júlio. In: FAUUSP: 30 anos do projeto do edifício. Transcrição do seminário, s/d., p. 27.
} 
pela base menor, oferece uma síntese das pesquisas originais desenvolvidas em Itanhaém e Guarulhos". ${ }^{93}$

Aos poucos, são introduzidos adjetivos laudatórios:

"O contraste impressionante entre a finura dos pontos de apoio e a pesada carga que repousa sobre eles, apenas esboçada nas realizações precedentes, é bruscamente aumentado além de toda a expectativa como um meio de expressão psicológica essencial. Portanto, a ossatura que assim surge não é só fruto de uma técnica impecável, onde as juntas de dilatação estão ocultas com engenhosidade pelo voo de flechas triangulares que partem do solo, aplicadas dos dois lados da superfície dos pilotis para reforçar-lhe o vigor efetivo e plástico; ela adquire um significado estético que ultrapassa de muito sua simples funcionalidade. [...] O contraste prossegue entre as partes altas, totalmente fechadas por superfícies planas puras, e as partes de baixo abertas ou envidraçadas, cujo recuo mais ou menos acentuado em profundidade deixa perceber discretamente, sem revelar na realidade, o jogo complexo dos espaços internos. Esse jogo constitui um verdadeiro espetáculo de pirotécnica, onde todo o arsenal do arquiteto foi usado ao mesmo tempo e separadamente: grande vazio central com mais de quinze metros de altura indo do subsolo até a cobertura, com variações bruscas de andar para andar, desencontro de níveis produzindo saliências impressionantes (como as do bloco de trabalho em grupo que completa as salas do departamento), alternância da abertura total com fechamentos de vidro ou paredes de cimento cujas formas foram tão cuidadas que de longe parecem mármore, vigorosas oblíquas das rampas destacando-se das horizontais dominantes mas fragmentadas das lajes do pavimentos e das verticais das colunas da estrutura, combinação da iluminação lateral inferior com iluminação de cima na parte superior e mista no centro do prédio, acentuação divergente de algumas curvas (como o caracol do escritório destinado à direção do museu) numa composição ortogonal e retilínea, enfim um ambiente de unidade total, de um espaço às vezes fluido, outras vezes canalizado, cujas divisões jamais constituem uma verdadeira solução de continuidade [...]" ${ }^{94}$

A ocupação perimetral do edifício em torno de seu vazio central sugere, enfim, as primeiras interpretações do ideal social de Artigas:

\footnotetext{
${ }^{93}$ BRUAND, Yves. Arquitetura contemporânea no Brasil. [1973]. São Paulo: Perspectiva, 1981, p. 300-302.

${ }^{94}$ Idem, ibidem.
} 
"Nisso pode-se encontrar o ideal de um modo de vida comunitário, tão apreciado por Artigas, sua preocupação com criar uma arquitetura que facilita os contatos humanos, lutando contra as tendências individuais de fechar-se numa torre de marfim, mas mantendo uma flexibilidade suficiente para não haver uma coação insuportável. Sem dúvida alguma, jamais antes se conseguiu fundir uma rígida geometria disciplinante externa com uma completa liberdade de arranjo interno, lançando-se mão de uma linguagem de violência alternadamente desencadeada e contida. Aqui, o brutalismo é total, material e espiritualmente: ele se manifesta tanto no emprego sistemático dos materiais nus, quanto na evidenciação dos conflitos com que se choca todo artista criador". ${ }^{95}$

Afastado da escola, Artigas havia se tornado uma onipresença ausente e uma ausência onipresente na FAU. Em 1978, um grupo de ex-alunos lhe procurou em seu escritório para registrar seu depoimento em vídeo. Foi o primeiro registro de suas palavras sobre a FAU:

"O português que estava construindo a obra para aquele turco que era o construtor, Rizkallah, disse para mim: - 'Doutor, por dentro é uma maravilha, mas por fora é uma fortaleza! Uma fortaleza!' Você sabe que essa contradição tem seu significado. Eu sabia como era e pensei que aquilo tinha que ser um prédio que não tivesse a menor concessão a nenhum barroquismo; que tivesse insinuações de uma extrema finura, para dizer que partia de um bloco inerme". ${ }^{96}$

Mais adiante:

"O contato com um ponto! Isso lá fora. O resto de uma tremenda simplicidade capaz de ser compreensível para qualquer um. Que não tivesse nenhuma loquacidade necessária. Nenhuma veemência de discurso! Nenhuma concessão barroca! Nada! Uma espécie de quem procura a verdade pura, absolutamente pura! Certo que não consegui. Sabe, que isso aí seria o fim dos tempos [...].

Morria de medo de riscar aquilo tão simples como está colocado. O que eles vão dizer disso? Não chega a ser nada. Não tem porta na entrada. Eu queria que a entrada fosse como ela é: um peristilo clássico, grego, e que não tem porta. Só entram deuses dentro da FAU! Lá não tem frio nem calor". ${ }^{97}$

\footnotetext{
${ }^{95}$ Idem, ibidem.

96 Transcrição do depoimento de Vilanova Artigas gravado em outubro de 1978, no seu escritório em São Paulo, para o filme de Eduardo de Jesus Rodrigues e Fernando Frank Cabral, Vilanova Artigas: espaço e programa para a FAU.

${ }^{97}$ Idem.
} 
Como se pode ver, Artigas era muito hábil poeticamente e suas palavras foram extremamente eficazes em alargar significados e constituir um sentido coletivo e generoso de sua obra. Em seu memorial para o concurso de professor titular da FAU ele deixaria registrada uma visão ainda mais sintética do edifício da FAU, que constitui um ensino para qualquer aluno de sua escola:

"O projeto da FAU, como proposta arquitetônica, defende a tese da continuidade espacial. Seus seis [sic] pavimentos são ligados por rampas suaves e amplas, em desníveis que procuram dar a sensação de um só plano. Há uma interligação física contínua em todo o prédio. O espaço é aberto e as subdivisões e os andares praticamente não o secionam, mas, simplesmente lhe dão função.

É uma escola de acabamento simples, modesto como convém a uma escola de arquitetos, que é também um laboratório de ensaios. A sensação de generosidade espacial que sua estrutura permite, aumenta o grau de convivência, de encontros, de comunicação. Quem der um grito, dentro do prédio, sentirá a responsabilidade de haver interferido em todo o ambiente. Aí, o indivíduo se instrui, se urbaniza, ganha espírito de equipe.

O concreto utilizado não é só uma solução mais econômica, como corresponde à necessidade de se encontrar meios de expressão artística, lançando mão da estrutura do edifício, sua parte mais digna. A estrutura, para o arquiteto, não deve desempenhar o papel humilde de esqueleto, mas exprimir a graça com que os novos materiais permitem dominar as formas cósmicas, com a elegância de vãos maiores, de formas leves.

Este prédio acrisola os santos ideais de então: pensei-o como espacialização da democracia, em espaços dignos, sem portas de entrada, porque o queria como um templo, onde todas as atividades são lícitas". ${ }^{98}$

98 Publicado em: FERRAZ, Marcelo (coord. ed.). Vilanova Artigas. São Paulo: Instituto Lina Bo e P. M. Bardi / Fundação Vilanova Artigas, 1997. 


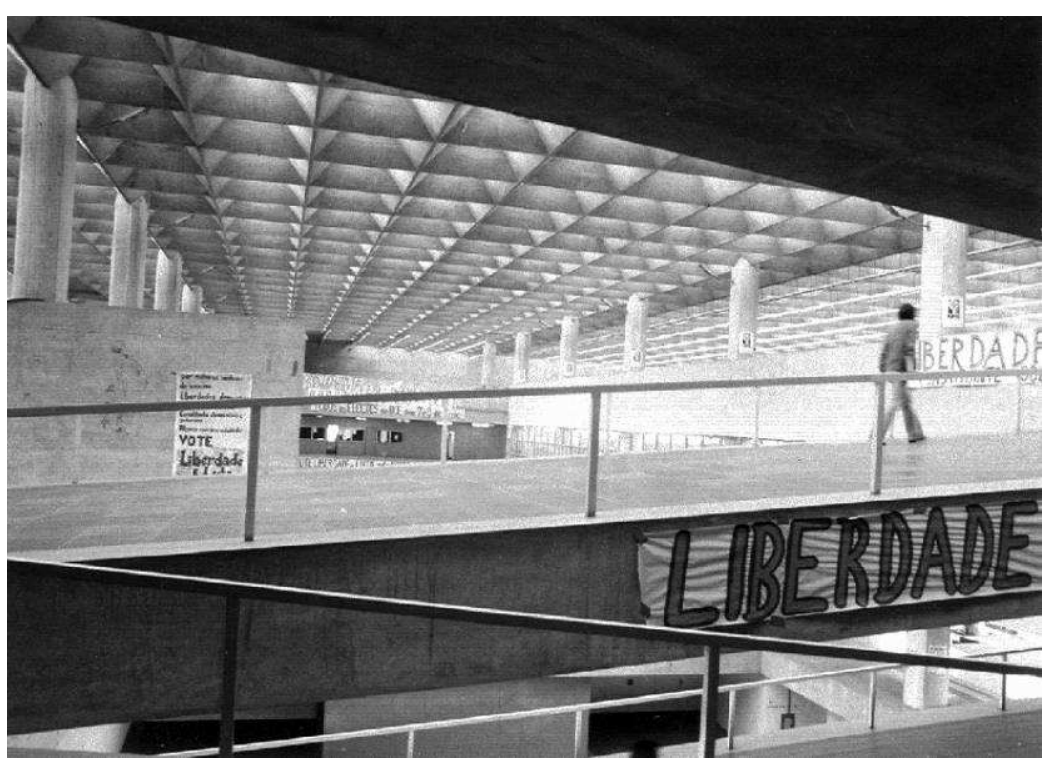

FAUUSP em funcionamento. Arquivo: BFAUUSP.

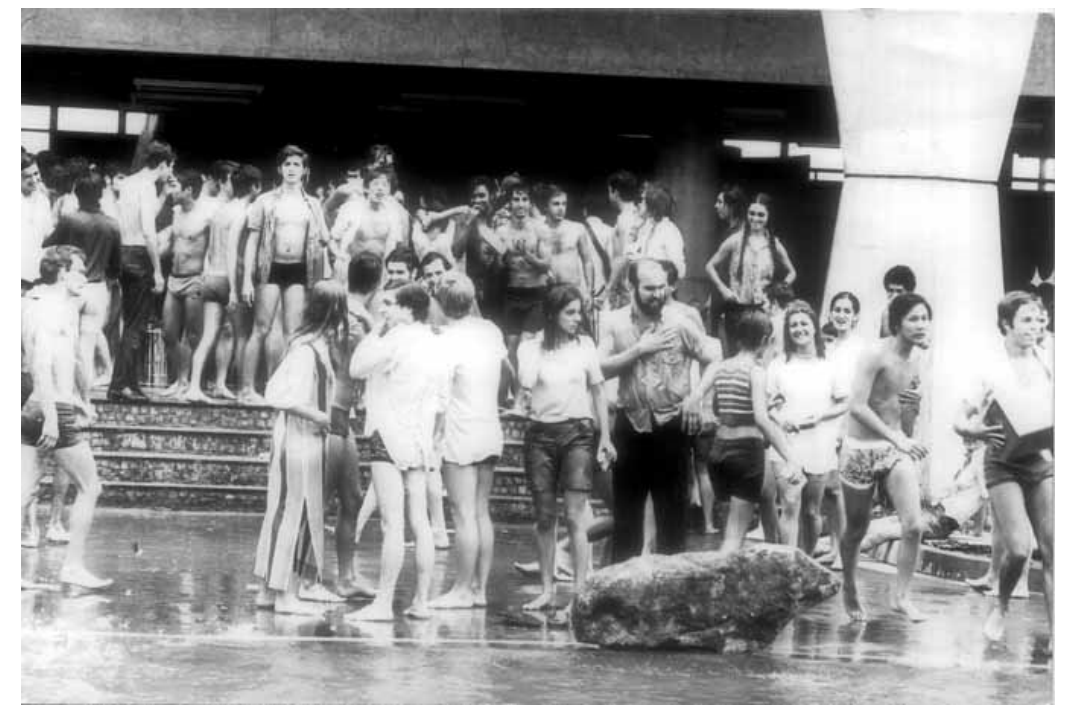

Banho no laguinho no trote de 1969. Arquivo Fernando Stickel
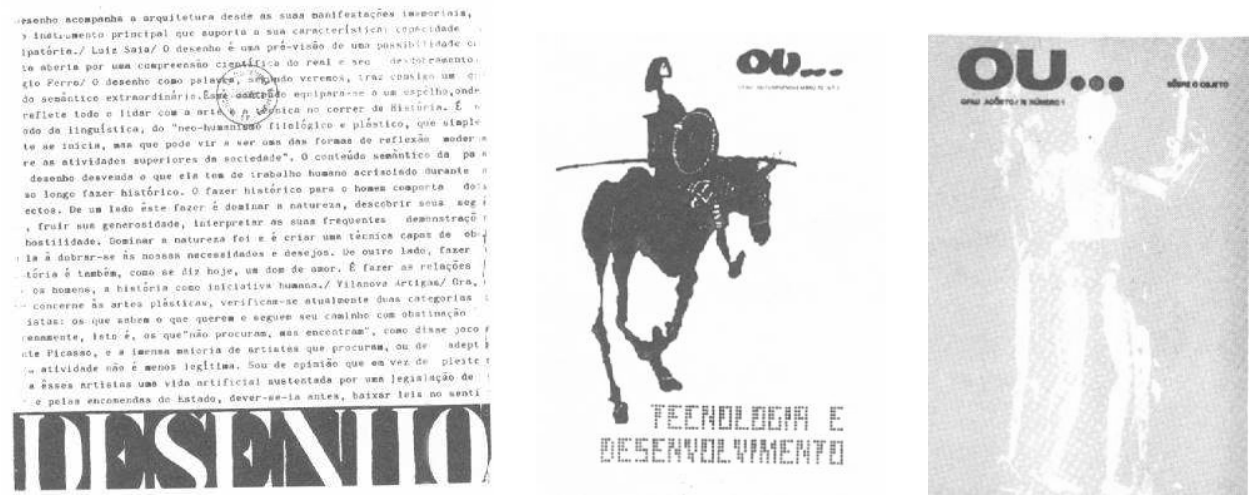

ou...

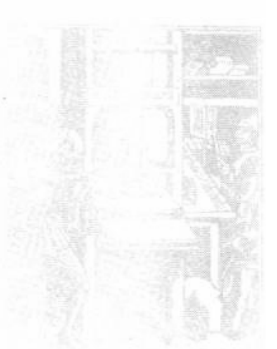

$\mathrm{O}$ autor como produtor

Revistas estudantis de 1970. Revista Desenho n. 1 junho; Revista Ou... n. 1, 2 e 3, de agosto a novembro 

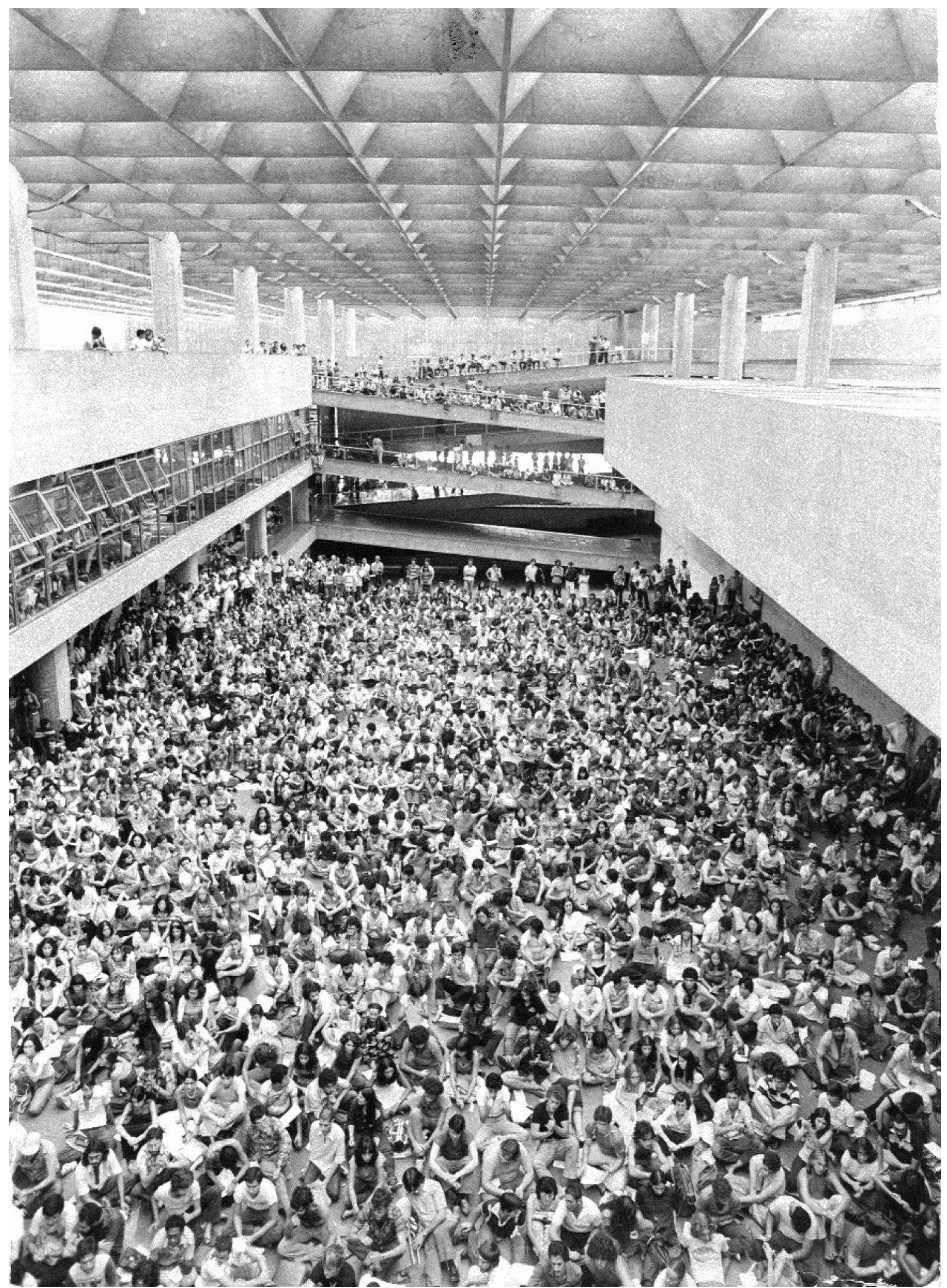

Assembleia dos estudantes da USP, 1970 (?) Foto: Raul Garcês. Arquivo FAUUSP 


\section{CONCLUSÕES}

$\mathrm{Na}$ introdução desta tese enunciamos o interesse em investigar se o projeto do edifício da FAU revelaria as contradições apontadas por Sérgio Ferro no brutalismo caboclo ou, se por tratar de obra anterior à inversão das expectativas de desenvolvimento socioeconômico, a FAU guardaria maior coerência com o discurso de Artigas, que disse tê-la pensado como uma obra sem concessão a nenhum barroquismo.

O primeiro desafio foi identificar precisamente o quanto fosse possível o período da trajetória de Artigas em que ele se dedicou à pesquisa que culminaria na FAU. Vimos que o chamado brutalismo de Artigas não se limitava à uma questão da forma superficial, mas representava uma reflexão crítica sobre a estética e sua relação com a construção através dos significados históricos dos materiais. Nesse sentido, Artigas colocou lições de comunicação da nova monumentalidade a serviço de um pensamento programático, cuja origem foi remetida à moral construtiva de Frank Lloyd Wright.

Em seguida, conduzimos uma sistemática pesquisa a fim de revelar o campo de sociabilidade da FAU, no qual o arquiteto atingiu a distinção máxima, sendo designado para conceber a arquitetura que representaria a escola de arquitetura; e o fez com tal sucesso porque soube formular uma proposta cuja essência correspondeu às expectativas da escola. Esse foi o fator decisivo para projetar Artigas como líder de uma escola estéticoprogramática. Seu afastamento compulsório, ainda que lamentável, contribuiu para amplificar a ascensão do arquiteto sobre seus alunos e discípulos bem como para transformar sua doutrina num cânone, sua estética num estilo.

No terceiro capítulo tivemos que fazer um longo desvio para contextualizar o momento político e econômico do Plano de Ação do Governo do Estado e sua relação com a 
arquitetura das obras públicas, bem como para definir os parâmetros e o sentido de projetar em cidades universitárias. Um esforço necessário para entender os limites do projeto da FAU que não fariam sentido em outros contextos, mas que podem ter sido reproduzidos indiscriminadamente.

Por fim, entramos nas minucias do processo de produção material do edifício da FAU, que mostrou quão delicada era a posição do arquiteto, tanto em relação às autoridades quanto em relação à estrutura de produção do Fundo para Construção da CUASO. Vimos como o processo de projeto e construção foi tumultuado e não linear, incorporando soluções ao sabor das circunstâncias e também como o apoio dos colegas e a adesão dos profissionais do Fundo foram fundamentais para garantir a liberdade do arquiteto. E, ainda, como o sentido da obra foi construído após a recepção por parte da crítica, com contribuições fundamentais de Artigas.

Analisando a execução de cada etapa da obra e os sentidos de cada material, é possível supor que, ao longo do tempo, o significado do edifício se afastou daquelas escolhas materiais e se ampliou em direção ao abstrato.

No contexto de endurecimento do regime militar, a Cidade Universitária deixou de ser vista como uma utopia e o novo senso de realidade revelou sua eficácia na estratégia de isolar a universidade da cidade. A nova realidade acelerou os caminhos que já vinham sendo perseguidos pelo Fundo, de obras ainda mais rápidas e mais baratas. A pré-fabricação defendida por Paulo de Camargo foi então retomada, agora por seus opositores. A justificativa, sempre técnica, incluía uma nova questão: a construção em módulos representaria solução mais adequada à inflação dos preços e a imprevisibilidade de recursos.

Afastado da universidade nesse momento, Artigas dedicou-se completamente ao seu escritório, que expandiu para atender uma demanda crescente por obras públicas. Paradoxalmente, depois de cassado pelo regime militar, Artigas projetou a maior quantidade de obras para o Estado. Aclamado por sua posição intelectual e perseguido por partidários do regime militar, assistiu sua linguagem ser incorporada por seus adversários. Assim, a história do edifício da FAU na Cidade Universitária nos sugere que no arco temporal que abrange sua produção (1960-1969) o significado da realidade pleiteado pela poesia de Artigas foi tragicamente sequestrado pela nova ordem político-cultural.

Talvez possamos agora reformular a ideia de que havia um "equilíbrio entre o ser e o dever ser" na arquitetura de Artigas para um equilíbrio entre a realidade e a representação da realidade. Essa nos parece uma questão central. No início dos anos 1960, Artigas já havia sido identificado pela historiografia com um arquiteto ligado à prática, à construção e à 338 
realidade. Sua trajetória nos permite interpretar que em meio à crise do racionalismo, na segunda metade dos anos 1950, ele formulou suas hipóteses deslocando a monumentalidade da arquitetura moderna brasileira para uma representação da realidade, através da figuratividade da construção. O realismo de Artigas, contudo, mantinha um delicado equilíbrio com a realidade de suas obras, nem se contrapondo, nem se limitando às imposições práticas do "real". É no lugar de poeta, que sempre reivindicou, que ele construiu sua escola e seu realismo.

A crise da escola de Artigas está vinculada ao desenvolvimento de instrumentos técnicos de planejamento que confrontaram os arquitetos com realidades muito mais objetivas. Uma realidade mais real que a realidade representada. Ao ser incluído em um Plano políticoeconômico, desvencilhando-se das pequenas obras experimentais, a arquitetura da escola de Artigas ficou sujeita a interferências de diversas ordens e passou a exigir grande habilidade em equilibrar as decisões de projeto. Nesse sentido, sua crise nasce praticamente junto com ela, quando o arquiteto, representando o IAB-SP, se aliou aos planejadores do PAGE, oferecendo projetos a preços reduzidos que resultaram em uma nova política de obras públicas. Naquele momento, a posição crítica dos católicos progressistas ligados à Lebret em relação à monumentalidade, ao personalismo e às complicações técnicas desnecessárias ${ }^{1}$, representou menos um empecilho do que um desinteresse por parte do governo, que favoreceu a liberdade dos arquitetos. O governo, no entanto, manteve-se focado em suas metas quantitativas para suprir os déficits existentes.

O mesmo já não ocorreu durante a construção do edifício da FAU, quando Artigas e seus colegas foram confrontados de diversas maneiras por um planejamento que requeria "menos poesia e mais realidade". ${ }^{2}$ Não deixa de ser sintomático que com a Reforma Universitária e a mudança no ensino da FAU que sucedeu, as disciplinas de Planejamento foram as que ganharam mais espaço, enquanto Projeto de arquitetura perdeu três dos representantes mais identificados com a escola de Artigas. A escola de Artigas, comprometida com a poesia da realidade, passou a ter que defender a poesia contra a realidade; se descolou do planejamento, ficando restrita à produção de formas.

A inversão das forças sociais e políticas em 1964 completou seu feito na cultura arquitetônica quando, neutralizado o valor estético dessa escola, se apropriou de seus símbolos. Realidade de um lado, poesia de outro.

\footnotetext{
${ }^{1}$ Entrevista de Celso Lamparelli ao autor realizada em São Paulo, 23de julho de 2014.

${ }^{2}$ As palavras foram proferidas pelo diretor da FAU, Pedro Moacyr do Amaral Cruz, quando da interferência no projeto da FAU em 1966, em que julgava necessário janelas nos estúdios, controle de acesso e que a diretoria ficasse no lugar da biblioteca e o grêmio dos alunos fosse para o subsolo. Resistências semelhantes são as preocupações da reitoria da Universidade e do Governo do Estado com relação ao baixo aproveitamento de alunos por metro quadrado construído.
} 



\section{BIBLIOGRAFIA}

\section{Livros}

ACAYABA, Marlene Milan; FICHER, Silvia. Arquitetura moderna brasileira. São Paulo: Projeto, 1982.

ADUSP [1978]. O controle Ideológico na USP: 1964-1978. São Paulo: ADUSP, 2004.

AMARAL, Aracy Abreu (coord.). Projeto construtivo na arte: 1950-1962. Rio de Janeiro: Museu de Arte Moderna/ Pinacoteca do Estado de São Paulo, 1997.

ANDREOLI, Elisabetta; FORTY, Adrian (org.). Arquitetura moderna brasileira. New York: Phaidon, 2004.

ANELLI, Renato. Architettura Contemporanea: Brasile. Milão: 24 Ore Motta Cultura, 2008.

ANELLI, Renato. GUERRA, Abilio; KON, Nelson. Rino Levi: arquitetura e cidade. São Paulo: Romano Guerra, 2001.

ARANTES, Pedro Fiori. Arquitetura na era digital-financeira: Desenho, canteiro e renda da forma. Prefácio: Sérgio Ferro. São Paulo: Editora 34, 2012.

ARANTES, Pedro Fiori. Arquitetura Nova: Sérgio Ferro, Flávio Império, Rodrigo Lefèvre, de Artigas aos mutirões autogeridos. São Paulo: Editora 34, 2002.

ARTIGAS, João Batista Vilanova. Caminhos da arquitetura. São Paulo: Cosac Naify, 2004

ARTIGAS, João Batista Vilanova. Caderno dos riscos originais: projeto do edifício da FAUUSP. Edição fac-similar. São Paulo: FAUUSP, 1992.

ARTIGAS, João Batista Vilanova. Carta a um cliente. São Paulo: Empório Cultural, 1991.

ARTIGAS, João Batista Vilanova. Onze textos e uma entrevista. Almada: Casa da Cerca - Centro de Arte Contemporânea, 2001.

ARTIGAS, Juan B. Unam México: guia de sítios y espacios. Ciudad Universitária: Universidad Autónoma de México, 2006.

ARTIGAS, Rosa. Casas de Artigas. Apresentação Fábio Penteado; introdução Dalva Thomaz. São Paulo: Fundação Vilanova Artigas, 1993.

ASSOCIAÇÃO BRASILEIRA DE ESCOLAS DE ARQUITETURA. Sobre a história do ensino de arquitetura no Brasil. 1를 edição. São Paulo, ABEA, 1978.

AZEVEDO, Fernando de. História da minha vida. Rio de Janeiro: José Olympio, 1971 
BAIRRADA, Eduardo Martins. Empedrados artísticos de Lisboa: A arte da calçada-mosaico. Lisboa: M. Bairrada, 1986

BANHAM, Reyner. Teoria e projeto na primeira era da máquina. São Paulo: Editora Perspectiva, 1975

BANHAM, Reyner. The new brutalism: ethic or aesthetic? London: The Architectural Press, 1966.

BARONE, Ana Cláudia C. Team X: arquitetura como crítica. São Paulo: Annablume / Fapesp, 2002.

BASTOS, Maria Alice Junqueira; ZEIN, Ruth Verde. Brasil: arquiteturas após 1950. São Paulo:

Perspectiva, 2010.

BASTOS, Maria Alice Junqueira. Pós-Brasília: rumos da arquitetura brasileira. São Paulo:

Perspectiva, 2003.

BAXANDALL, Michael. Padrões de intenção: a explicação histórica dos quadros. São Paulo: Cia. das Letras, 2006.

BOURDIEU, Pierre. As regras da arte. São Paulo: Companhia das letras, 1996.

BRAGA, Milton L. A. O concurso de Brasília: sete projetos para uma capital. São Paulo: Cosac \& Naify / Imprensa Oficial do Estado / Museu da Casa Brasileira, 2010.

BRITO, Ronaldo [1985]. Neoconcretismo: Vértice e ruptura do projeto construtivo brasileiro. São Paulo: Cosac \& Naify, 1999.

BRUAND, Yves [1981]. Arquitetura contemporânea no Brasil. São Paulo: Perspectiva, 1999

BRUNA, Paulo. Arquitetura, industrialização e desenvolvimento. São Paulo: Perspectiva, 1976.

BUFFA, Ester; PINTO, Gelson de Almeida. Arquitetura e Educação: organização do espaço e propostas pedagógicas dos Grupos Escolares paulistas (1873-1971). São Carlos: Edufscar / Brasília: Inep, 2002.

BÜRGER, Peter. Teoria da vanguarda. São Paulo: Cosac \& Naify, 2008.

CAMPOS, Cândido Malta; SIMÕES JR, José Geraldo. Palacete Santa Helena: Um pioneiro da modernidade em São Paulo. São Paulo: Senac / Imprensa Oficial do Estado de São Paulo, 2006.

CAMPOS, Ernesto de Souza. Cidade Universitária da Universidade de São Paulo: aspectos gerais do planejamento e execução. São Paulo: Comissão da Cidade Universitária da Universidade de São Paulo, 1954.

CAVALCANTI, Lauro. Moderno e brasileiro: A história de uma nova linguagem na arquitetura (19301960). Rio de Janeiro: Jorge Zahar, 2006.

CHILCOTE, Ronald. Partido Comunista Brasileiro: conflito e integração, 1922-1972. Rio de Janeiro: Edições Graal, 1982.

COHEN, Jean-Louis. The Future of Architecture since 1889. London: Phaidon, 2012

COLQUHOUN, Alan. Modernidade e tradição clássica. São Paulo: Cosac \& Naify, 2004.

CORTÉS, Rodrigo. Ciudad aparte: proyecto y realidad en la Ciudad Universitaria de Bogotá. Bogotá: Universidad Nacional de Colombia, 2006.

CZAJKOWSKI, Jorge. Jorge Machado Moreira. Rio de Janeiro: Centro de Arquitetura e Urbanismo do RJ, 1999.

DEAN, Warren. A Industrialização de São Paulo. São Paulo: DIFEL, 1976.

DRAIBE, Sônia. Rumos e metamorfoses: Um estudo sobre a constituição do Estado e as alternativas da industrialização no Brasil, 1930-1960. Rio de Janeiro: Paz e Terra, 2004.

DUARTE, Hélio de Queirós. Escolas-classe, escola-parque. Organização: André Takiya. $2^{\underline{a}}$ ed.

ampliada. São Paulo: FAUUSP, 2009. 
DURAND, José Carlos. Arte, privilégio e distinção: artes plásticas, arquitetura e classe dirigente no Brasil, 1855/1985. São Paulo: Perspectiva, 2009.

FABRIS, Annateresa (org.). Modernidade e modernismo no Brasil. Porto Alegre: Zouk, 2010.

FARAH, Marta. Processo de trabalho na construção habitacional. Tradição e mudança. São Paulo: Annablume, 1996.

FAUSTO, Boris. História do Brasil. São Paulo: Edusp, 2006.

FERRAZ, Marcelo C. (coord.). Vilanova Artigas. São Paulo: Instituto Lina Bo e P.M. Bardi e Fundação Vilanova Artigas, 1997.

FERREIRA, Avany de Francisco; MELLO, Mirela Geiger de. Arquitetura escolar paulista: anos 1950 e 1960. São Paulo: FDE / DOS, 2006.

FERRO, Sérgio; KEBBAL, Chérif; POTIÉ, Philippe; SIMONNET, Cyrille. Le Couvent de la Tourette. Marseille, Parenthèses, 1987.

FERRO. Sérgio. Michel-Ange: architecte et sculpteur de la chapelle Medicis. Lyon: Plan Fixe Édition, 1998.

FERRO, Sérgio. A história da arquitetura vista do canteiro. São Paulo: GFAU, 2010.

FERRO, Sérgio. Arquitetura e trabalho livre. São Paulo: Cosac \& Naify, 2006.

FICHER. Sylvia. Os arquitetos da Poli: Ensino e profissão em São Paulo. São Paulo: Edusp, 2005.

FORTY, Adrian. Concrete and culture: A material history. London: Reaktion Books, 2012.

FRAMPTON, Kenneth. História crítica da arquitetura moderna. São Paulo: Martins Fontes, 1997

GASPARI, Elio. A Ditadura Envergonhada. Coleção as Ilusões armadas, v. 1. São Paulo: Cia. das Letras, 2002.

GASPARI, Elio. A Ditadura Escancarada. Coleção as llusões armadas, v. 2. São Paulo: Cia. das Letras, 2002.

GFAU; KEESE, Jefferson Lafaiette (ed.). Anistia na FAUUSP: A reintegração dos professores cassados pelo Al-5. São Paulo: FAU-USP, 1998.

GFAU. Corredor das humanas: a poesia que poderia ter sido e que não foi. São Paulo: Gfau, 2009. GOODWIN, Phillip. Brazil Builds. New York: MoMA, 1943.

GORELIK, Adrián. Das vanguardas a Brasília: Cultura Urbana e Arquitetura na América Latina. Belo Horizonte: Editora da UFMG, 2005.

GRAEFF, Edgar. Arte e técnica na formação do arquiteto. São Paulo: Fundação Vilanova Artigas / Studio Nobel, 1995.

GUERRA, Abílio (org.). Textos fundamentais sobre história da arquitetura moderna brasileira. 2 vols. São Paulo: Romano Guerra, 2010.

HARRIS, Mary Emma. The Arts at Black Mountain College. Cambridge: The MIT Press, 2002

HEINICH, Nathalie [2001]. A sociologia da arte. Bauru: Edusc, 2008.

HITCHCOCK, Henri Russel. Latin American Architecture since 1945. New York: Museum of Modern Art, 1955.

HOBSBAWM, Eric [1994]. Era dos extremos: o breve século XX, 1914-1991. São Paulo: Cia. das Letras, 2008.

HUSSEIN, Leila Mahir Saleh. As escolas de J. B. Vilanova Artigas - publicações e depoimentos. São Paulo: 1999. 
IAB. Arquitetura e desenvolvimento nacional: depoimento de arquitetos paulistas. São Paulo: PINI, 1979.

IRIGOYEN DE TOUCEDA, Adriana Marta. Wright e Artigas: duas viagens. São Paulo: Ateliê Ed. / FAPESP, 2002.

JAMESON, Fredric. Marxismo e forma: Teorias dialéticas da literatura no século XX. São Paulo: Hucitec, 1985.

KAMITA, João Masao. Vilanova Artigas. São Paulo: Cosac \& Naify, 2000.

KATINSKY, Júlio Roberto. Vilanova Artigas. Coordenação de Ruy Ohtake e Rosa Artigas. Catálogo da exposição, 12 de setembro a 2 de novembro de 2003. São Paulo: Instituto Tomie Ohtake, 2003.

KOPP, Anatole. Quando o moderno não era um estilo e sim uma causa. São Paulo: Nobel / Edusp, 1990.

KOURY, Ana Paula. Grupo arquitetura nova. Flávio Império, Rodrigo Lefèvre e Sérgio Ferro. Coleção olhar arquitetônico, v. 1. São Paulo: Romano Guerra Editora / Edusp, 2003.

KWASNICKA, Eunice Lacava (coord.). Universidade de São Paulo: Subsídios para uma avaliação. São Paulo: USP, 1985.

LEMOS, Carlos Alberto Cerqueira. Alvenaria Burguesa. São Paulo: Editora Studio Nobel, 1989.

LEMOS, Carlos Alberto Cerqueira. Arquitetura Brasileira. São Paulo: Melhoramentos / Edusp, 1979.

LEMOS, Carlos Alberto Cerqueira. Ramos de Azevedo e seu escritório. São Paulo: Pini, 1993.

LEMOS, Carlos Alberto Cerqueira. Trilogia do Copam: a história do edifício Copam, v.1. São Paulo: Imprensa Oficial do Estado de São Paulo, 2014

LIERNUR, Jorge Francisco. Escritos de arquitectura del siglo XX en América Latina. Madrid: Tanais, 2002

LIRA, José Tavares Correia de. Gregori Warchavchik: fraturas da vanguarda. São Paulo: Cosac \& Naify, 2011.

LOURENÇO, Maria Cecília França; et al. Bens imóveis tombados ou em processo de tombamento da USP. São Paulo: Imprensa Oficial do Estado de São Paulo, 2002.

LOURENÇO, Maria Cecília França. Operários da modernidade. São Paulo: Hucitec / Edusp, 1995.

MARAES, Dênis. A esquerda e o golpe de 64. São Paulo: Expressão Popular, 2011

MATOS, Ernesto. Calçada portuguesa: uma linguagem universal. Lisboa: Câmara Municipal de Lisboa, 2001.

MASCARO, Lucia (org.). Tecnologia e arquitetura. São Paulo: Nobel, 1990, p. 61-86.

MELLO, Eduardo Kneese de et al. Arquitetura e desenvolvimento nacional: depoimento de arquitetos paulistas. São Paulo: IAB/PINI, 19-

MICELI, Sergio. Nacional Estrangeiro: História social e cultural do modernismo artístico em São Paulo. São Paulo: Cia. das Letras, 2003.

MINDLIN, Henrique [1956]. Arquitetura moderna no Brasil. Rio de Janeiro: Aeroplano, 1999.

MOLINA GARMENDIA, Enrique. De California a Harvard: estudio sobre las universidades norteamericanas y algunos problemas nuestros. Santiago de Chile: Ediciones Universo, 1921.

MOTA, Carlos Guilherme; LOPEZ, Adriana. História do Brasil: uma interpretação. São Paulo: Senac, 2008.

MOTA, Carlos Guilherme. Ideologia da cultura brasileira (1933-1974). Pontos de partida para uma revisão histórica. Prefácio: Alfredo Bosi. São Paulo: Editora 34, 2008. 
MOTOYAMA, Shozo (org.). Tecnologia e industrialização no Brasil: uma perspectiva histórica. São Paulo: Unesp, 1994.

NOVAES, Fernando; SILVA, Rogério Forastieri da (org.). Nova história em perspectiva. São Paulo: Cosac \& Naify, 2011.

PAIM, Gilberto. A beleza sob suspeita: o ornamento em Ruskin, Lloyd Wright, Loos, Le Corbusier e outros. Rio de Janeiro: Jorge Zahar, 2000.

PEREIRA, Miguel. Arquitetura: cultura, formação, prática e política profissional. São Paulo: Pini, 2005.

PEREIRA, Paulo César Xavier; GITAHY, Maria Lucia C. (org.). O complexo industrial da construção e a habitação econômica moderna. São Carlos: Rima, 2002.

PEVSNER, Nikolaus. Academias de arte: Passado e presente. São Paulo: Cia. das Letras, 2005.

PEVSNER, Nikolaus. Os Pioneiros do Desenho Moderno: De William Morris a Walter Gropius. São Paulo: Martins Fontes, 2002.

PRESTES, Lucinda Ferreira. Faculdade de Arquitetura e Urbanismo da USP: documentos históricos. São Paulo: FAU-USP, 2011.

RANIERI, Nina Beatriz (org.). Autonomia Universitária na USP: 1934-1969. São Paulo: Edusp, 2005

REIS FILHO, Nestor Goulart (coord.). 100 anos de ensino de arquitetura e urbanismo em São Paulo. São Paulo: FAUUSP, 1996.

RIBEIRO, Ana Isabel et al. (coord.). A cidade é uma casa, a casa é uma cidade: Vilanova Artigas Arquitecto. Catálogo da exposição realizada entre 25/11/2000 e 04/03/2001. Almada: Casa da Cerca / São Paulo: Fundação Vilanova Artigas, 2001.

REIS FILHO, Nestor Goulart. Quadro da arquitetura no Brasil. São Paulo: Perspectiva, 1970.

RIBEIRO, Darcy. A universidade necessária. Rio de Janeiro: Paz e Terra, 1969.

RUBINO, Silvana Barbosa; GRINOVER, Marina (org.). Lina por escrito. Textos escolhidos de Lina Bo Bardi. São Paulo: Cosac \& Naify, 2009.

SÁ, Marcos Moraes de. Ornamento e modernismo: a construção de imagens na arquitetura. Rio de Janeiro: Rocco, 2005.

SEGAWA, Hugo. Arquiteturas no Brasil 1900-1990. São Paulo: Edusp, 1998.

SIMONNET, Cyrille. Le béton: Histoire d'un matériau. Marselha: Parenthèses, 2005.

SKIDMORE, Thomas Elliot [1967]. Brasil: de Getúlio a Castello (1930-64). São Paulo: Cia. das Letras, 2010.

SMITHSON, Alison; SMITHSON, Peter. Without Rhetoric, an architectural, aesthetic 1955-1972. Cambridge: MIT Press, 1974.

STARLING, Heloisa Maria Murgel; DUARTE, Regina Horta (org.). Cidade Universitária da UFMG: História e natureza. Belo Horizonte: UFMG, 2009.

SUZUKI, Juliana Harumi. Vilanova Artigas e Carlos Cascaldi: arquitetura em Londrina. São Paulo: Ateliê Editorial, 2003.

TAFURI, Manfredo. Projecto e utopia: arquitectura e desenvolvimento do capitalismo. Lisboa: Presença, 1985.

TAVARES, André. Novela bufa do ufanismo em concreto: Episódios avulsos das crises conjugais da arquitectura moderna no Brasil (1914-1943). Porto: Dafne, 2009.

TELLES, Pedro Carlos da Silva. História da Engenharia no Brasil - Século XX. Rio de Janeiro: Clube de Engenharia, 1993. 
THOMAS, Katie Lloyd. Material matters: architecture and material practice. Oxford: Routledge / New Ed, 2007.

TOLEDO. Benedito Lima de. Vila Penteado: registros. São Paulo: FAUUSP, 2002.

TRAVASSOS, Renato. Cidade Universitária da Universidade do Brasil. Rio de Janeiro: DASP, 1960.

UNIVERSIDADE DE SÃO PAULO - CENTRO DE PRESERVAÇÃO CULTURAL. Cidades

Universitárias: patrimônio urbanístico e arquitetônico da USP. São Paulo: Edusp / Imprensa Oficial do Estado de São Paulo, 2005.

UNIVERSIDADE DE SÃO PAULO - FAUUSP. Vila Penteado: 100 anos. São Paulo: FAUUSP, 2002.

UNIVERSIDADE DE SÃO PAULO. O espaço da USP: presente e futuro. São Paulo: 1985.

VARGAS, Milton. História da técnica e da tecnologia no Brasil. São Paulo: Unesp, 1995.

VASCONCELOS, Augusto Carlos de. O concreto no Brasil: recordes, realizações, história. Vol. 1. São Paulo: Copiare, 1985.

VASCONCELOS, Augusto Carlos de. O concreto no Brasil: professores, cientistas, técnicos. Vol. 2. São Paulo: Pini, 1992.

VASCONCELOS, Augusto Carlos de. O concreto no Brasil: pré-fabricação, monumentos, fundações. Vol. 3. São Paulo: Studio Nobel, 2002.

VILLANUEVA, Paulina. Carlos Raúl Villanueva. Basel: Birkhäuser, 2000.

WILLIAMS, Richard J. Brazil. Coleção modern architectures in history. Londres: Reaktion, 2009.

XAVIER, Alberto (org.). Depoimentos de uma geração: arquitetura moderna brasileira. São Paulo: Cosac \& Naify, 2003.

XAVIER, Alberto et al. Arquitetura moderna paulistana. São Paulo: Pini, 1983.

YURGEL, Marlene. Vila Penteado: Primeira geração de arquitetos formados pela FAUUSP. Coleção Boletim Técnico 1996, n. 6. São Paulo, FAUUSP, 1993.

\section{Periódicos, Artigos e capítulos de livro}

ADORNO, Theodor. "O funcionalismo hoje". Gávea, n. 15, Rio de Janeiro, junho 1997.

ALFIERI, Bruno. "João Vilanova Artigas: ricerca brutalista". Zodiac, n. 6. Milão, 1960, p. 96-107.

ANAIS CIENTÍFICOS. "Cidade universitária 'Armando Sales de Oliveira' Universidade de São Paulo", Anais Científicos, ano XXII, n. 75, 1966, São Paulo.

ANDERSON, Perry. "Modernidade e revolução". Novos Estudos, n. 14, fevereiro, 1986.

ANELLI, Renato. Luiz Sobral. "Intervenções no Patrimônio: Ceuma, Reitoria Velha, E1". In: LIRA, José Correia Tavares de (org.). Patrimônio construído da USP: Preservação, Gestão e Memória. São Paulo: Edusp, 2014.

ARTIGAS, João Batista Vilanova. "Fragmentos de um discurso complexo". Depoimento de Vilanova Artigas a Lena Coelho Santos. Projeto, n. 109, abril, São Paulo, 1988, p. 94.

ARTIGAS, João Batista Vilanova. "Liberdade para Odiléa”. Acrópole, n. 338, São Paulo, 1967.

ARTIGAS, João Batista Vilanova. “Uma falsa crise”. Acrópole, n. 319, julho, São Paulo, 1965.

ARTIGAS, Rosa Camargo; THOMAZ, Dalva Elias. "Sobre brutalismo, mitos e bares (ou de como se consagrar uma impropriedade)". Arquitetura e Urbanismo, n. 17, abr-maio, São Paulo, 1988, p. 61-63.

BAHIMA. Carlos Fernando S. "Palácio do Planalto versus FAU-USP: continuidades e rupturas entre materialidades e geometrias". In: Anais do X Seminário Docomomo Brasil. Curitiba: PUC-PR, 2013. 
BERNINI, Luciano. "Planejamento físico de campi universitário e sua aplicação prática". S.i., S.n., S.d.

BIRKHOLZ; Lauro B.; RONCA, José Luiz C. "Anhaia Mello na Vila Penteado". In: SAMPAIO, Maria Ruth A. Sampaio; MARICATO, Ermínia (Org.). Vila Penteado:100 anos. São Paulo: FAUUSP, 2002, p. 87-93.

BROADBENT, Geoffrey. "Brazil Still Builds: Vilanova Artigas and Affonso Eduardo Reidy". AA Files, n. 37, Autumn, Londres, 1998, p. 56-62.

CARDOZO, Joaquim. "Dois episódios na história da arquitetura moderna brasileira". Módulo, n. 4, Rio de Janeiro, 1965.

CARDOZO, Joaquim. "Forma estática - forma estética", Módulo, n. 10, Rio de Janeiro, 1958, p. 3-6.

CLARK, Timothy James [1974]. "As condições da criação artística”, In: SALZSTEIN, Sonia.

Modernismos. São Paulo: Cosac \& Naify, 2007.

CORDEIRO, Waldemar. "O concretismo e o problema da organização da cultura". AD Arquitetura e Decoração, n. 22, março, ano 4, São Paulo, 1957.

CORONA, Eduardo. "Faculdade de Arquitetura e Urbanismo da Universidade de São Paulo: análise de Eduardo Corona". AB Arquitetura Brasileira, n. 8, 1973-4, p. 74-81.

COTRIM, Marcio. "Entre protagonistas e esquecidos: a arquitetura dos irmãos Cascaldi". Arquitextos, n. 63, setembro, ano 6, São Paulo, 2005. Disponível em <http://www.vitruvius.com.br/revistas/read/arquitextos/06.063/439>.

DAGUERRE, Mercedes. "João Batista Vilanova Artigas 1915-1985". Casabella, n. 756, junho, Milão, 2007, p. 41.

DE CARLO, Giancarlo. "Università: dall’élite alla massa". Casabella, n. 756, junho, Milão, 2007, p. 3032.

DPH-PMSP. "Tributo a Figueiredo Ferraz". Cidade, n. 2, Ano 2, 1995.

FERNANDES, Fernanda. "Arquitetura e concretismo". Desígnio, n. 2, setembro, São Paulo, 2004, p. 97-104.

FERRAZ, Geraldo. "Cidade Universitária da Universidade de São Paulo. Uma polêmica dos resultados dos planos e da execução das obras no Butantã". Habitat, n. 27, fevereiro, 1956, p. 5-10.

FERRAZ, Geraldo. "Uma Cidade Universitária no Brasil: CUASO”. Zodiac, n. 11, Milão, 1963, p. 5677.

FERRAZ, João Carlos de Figueiredo. "Arquitetura e tecnologia". O Estado de São Paulo, 01 de março de 1970.

FERRAZ, José Carlos de Figueiredo. "O concreto de alta resistência e a estrutura do Museu de Arte de São Paulo Assis Chateaubriand", In: Anais da reunião anual do Ibracon, n. 30, Rio de Janeiro: Ibracon, 1988.

FERRAZ, José Carlos de Figueiredo. "Um novo processo de protensão", In: Anais da jornada sulamericana de engenharia estrutural, n. 11. São Paulo: ABCP / Instituto de Engenharia-SP, 1968.

FERRO, Sérgio. “Arquitetura Nova”, Teoria e prática, São Paulo, n. 1, 1967, pp. 3-15.

FERRO, Sérgio, LEFÈVRE, Rodrigo. IMPÉRIO, Flávio. "Notas sobre arquitetura”, Acrópole, n. 319. São Paulo, julho 1965:

FRAMPTON, Kenneth. "Vilanova Artigas y la escuela de São Paulo". 2G, n. 54. Barcelona, 2010, p. 410.

FUÃO, Fernando Freitas. "Brutalismo: a última trincheira do movimento moderno". Arquitextos, n. 7, Ano 1, 2000, São Paulo. Disponível em <http://www.vitruvius.com.br/revistas/read/arquitextos/01.007/949>. 
GITAHY, Maria Lucia. "Desmemória das metrópoles: apagando os rastros do trabalho de construir". Ponto, 1998.

GITAHY, Maria Lucia. "O papel do Gabinete de Resistência dos Materiais da Escola Politécnica na transferência da tecnologia do concreto para São Paulo, 1899-1925". Pós, n. especial: O estudo da História na formação do Arquiteto. São Paulo,FAU-USP, 1995.

GORELIK, Adrián. "O moderno em debate: cidade, modernidade e modernização". In: MIRANDA, Wander Melo (org.). Narrativas da modernidade. Belo Horizonte: Autêntica, 1999, p.55-80

GUERRA, Abilio. "O brutalismo paulista no contexto paranaense. A arquitetura do escritório Forte Gandolfi", Resenhas Online, n. 106, out, ano 9, São Paulo, 2010. Disponível em <http://www.vitruvius.com.br/revistas/read/resenhasonline/09.106/3792>.

HERNÁNDEZ DE LASALA, Silvia. "Em busca do sublime. Villanueva e a Cidade Universitária de Caracas". Arquitextos, ano 02, n. 016.02, São Paulo, 2001. Disponível em $<$ http://www.vitruvius.com.br/revistas/read/arquitextos/02.016/848/pt>.

JAUA, María Fernanda. "Cidade Universitária de Caracas: a construção de uma utopia moderna". Arquitextos, ano 04, 043.04, dezembro, São Paulo, 2003. Disponível:

<http://www.vitruvius.com.br/revistas/read/arquitextos/04.043/627/pt>.

KATINSKY, Júlio Roberto. "Arquitetura Paulista: uma perigosa montagem ideológica". Arquitetura e Urbanismo, n. 17, abril-maio, São Paulo, 1988, p. 66-71.

LE CORBUSIER [1936], "L'Architettura ed il Rapporto com le Arti Figurative". Revista do Patrimônio Histórico e Artístico Nacional, n. 19, 1984.

LEFÈVRE, Rodrigo Brotero. "O arquiteto assalariado". Módulo, n. 66, setembro, Rio de Janeiro, 1981.

LIERNUR, Jorge Francisco. "Vanguardistas versus expertos". Block, n. 6, março, Buenos Aires: Universidad Torcuato di Tella, 2004.

LIRA, José Tavares Correia de. "Ruskin e o trabalho da arquitetura". Risco, n. 4, dezembro, São Carlos, 2006.

MARQUES, Eliana de Azevedo (org.). "João Batista Vilanova Artigas (1915-1985): bibliografia". Colaboração de Jefferson Lafaiette Keese. São Paulo: FAUUSP, 1996

MARTINS, Carlos A. Ferreira. "Vilanova Artigas e l'architettura moderna in Brasile". Casabella, n. 756, junho, Milão, 2007, p. 33-40.

MOTTA, Flávio [1965]. "João Vilanova Artigas e a escola de São Paulo". Módulo, n. especial Vilanova Artigas, Rio de Janeiro, Avenir, 1985, p. 23.

MOTTA, Flávio. "Introduzione al Brasile". Zodiac, n. 6, Milão, 1960, p. 61-67.

NERVI, Pier Luigi. "Critica delle strutture". Casabella Continuità, n. 223, 1959, p. 55.

NOBRE, Ana Luiza. "Módulo Só: O Edifício E1 em São Carlos, de Ernest Mange e Hélio Duarte". Revista Risco, n. 5, São Carlos, 2007.

OLIVEIRA, Cláudia; SAWAYA, Sylvio; YURGEL, Marlene; et al. "O restauro do moderno: o caso do edifício Vilanova Artigas da FAUUSP". In: Anais do 70 Seminário Docomomo Brasil. Porto Alegre: 2007.

ONO, Rosaria; et al. "Celebrando os 50 anos do AUT: uma reflexão sobre a formação do Departamento de Tecnologia da FAUUSP”. Pós, n. 35. São Paulo: FAUUSP, junho 2014.

PAULA, Maria de Fátima Costa de. "USP e UFRJ: a influência das concepções alemã e francesa em suas fundações". Tempo social, vol.14, n. 2, 2002, pp. 147-161.

PENTEADO, Fábio Moura. "Vilanova Artigas, construtor de escolas". Acrópole, n. 377, setembro, São Paulo, 1970, p. 8-34. 
PEREIRA, Miguel. "Sobre o Projeto da Faculdade de Arquitetura e Urbanismo da Universidade de São Paulo" [1960], In: Arquitetura e os caminhos de sua explicação. São Paulo: Projeto Editores Associados, 1984.

PINHEIRO, Maria Lucia Bressan. "Dilemas na Preservação da Arquitetura Moderna: O Edifício da Faculdade de Arquitetura da USP". In: Anais do 5ํ Seminário Docomomo Brasi. São Carlos: 2003.4

PONTES, Ana Paula et al. "Fórum: o percurso do ensino na FAU", Editorial da Revista Caramelo, n. 6, FAUUSP, 1993.

REALE, Miguel. "Minhas memórias da USP". Estudos avançados, v. 8, n. 22, dezembro, São Paulo, 1994, p. 25-46.

SAAVEDRA, Verónica Esparza. "O plano da cidade Universitária de Concepción de Emilio Duhart. A visão integrada do urbanismo moderno". Arquitextos, ano 09, n. 108.02, maio, São Paulo, 2009.

Disponível em <http://www.vitruvius.com.br/revistas/read/arquitextos/09.108/53>.

SAMPAIO, Plínio de Arruda. "Depoimento: o plano de Ação do Governo Carvalho Pinto: planejamento e política no Estado de São Paulo em 1959". Espaço \& Debates, n. 4, ano 1, dezembro, 1981, p. 127.

SÁNCHEZ SILVA, Isabel. "Villanueva. Modernidade e trópico". Arquitextos, ano 04, n. 043.01, dezembro, São Paulo, 2003. Disponível em

<http://www.vitruvius.com.br/revistas/read/arquitextos/04.043/624/pt>.

SANOVICZ, Abrahão. "Depoimentos". AU Arquitetura e Urbanismo, n. 17, São Paulo, 1988

SCHENKMAN, Raquel. "O edifício da Light: a construção moderna de uma arquitetura tradicional". In: LOPES, João Marcos L.; LIRA, José T. Memória, Trabalho e Arquitetura. São Paulo, Edusp, 2013.

SCHWARZ, Roberto. "Cultura e política, 1964-1969" [1978], In: O pai de família e outros estudos. São Paulo: Companhia das Letras, 2008.

SCHWARZ, Roberto. "Nacional por subtração" [1987], In: Que horas são?. São Paulo: Companhia das Letras, 2006.

GIEDION, Sigfried; SERT, José Luis; LEGÉR, Fernand. "Nine Points on Monumentality" [1943], In: OCKMAN, Joan (org). Architecture Culture 1943-1968: A Documentary Anthology. New York: Rizzoli, 1984, pp. 29-30.

SUMMERSON, John. "What is the history of construction". Journal of the Construction History Society, n. 1,1985 .

TAFURI, Manfredo. "The historical project". Oppositions, n. 17, 1979, p. 55-75.

TELLES, Sophia S. "Oscar Niemeyer. Técnica e forma". Óculum, n. 2, 1992, p. 4-7.

VARGAS, Nilton. "Tendências de mudanças na indústria da construção". Espaço e Debates, n. 36, ano 22, 1992.

WARCHAVCHIK, Gregory. "Acerca da arquitetura moderna" [1925]. Arte em Revista, n. 4, 1980. pp. 5-6.

WISNIK, Guilherme. "Vilanova Artigas y la dialéctica de los esfuerzos". 2G, n. 54, Barcelona, 2010, p. 11-24.

ZEIN, Ruth Verde. "Brutalismo, sobre sua definição". Arquitextos, n. 84, 2007. Disponivel em $<$ http://www.vitruvius.com.br/revistas/read/arquitextos/07.084/243>.

ZEIN, Ruth Verde. "Brutalismo, escola paulista: entre o ser e o não ser". Arquitexto, n. 2, UFRGS, 2002, p. 6-31.

\section{Teses e dissertações}

ABREU, Ivanir Reis Neves. Convênio Escolar: Utopia construída. Dissertação de mestrado.

Orientador: Adilson Costa Macedo. São Paulo: FAUUSP, 2007. 
ALBUQUERQUE, Roberto Portugal. Uma escola de arquitetura - FAUUSP: edifícios e ensino. Dissertação de Mestrado. Orientador: Miguel Alves Pereira São Paulo: FAUUSP, 2004.

ALMEIDA, Paulo de Camargo e. A função social do arquiteto. Tese apresentada para provimento da cadeira $n .16$ na FAUUSP. São Paulo: FAUUSP, 1956.

ALVES, André Augusto de Almeida. Arquitetura e sociedade em São Paulo 1956-1968: projetos de Brasil moderno. Dissertação de mestrado em Arquitetura e Urbanismo. Orientadora: Maria Lúcia Caira Gitahy. São Paulo: FAUUSP, 2003.

ALVES, André Augusto de Almeida. Arquitetura escolar em São Paulo 1959-1962: o PAGE, o IPESP e os arquitetos modernos paulistas. Tese de doutorado em Arquitetura e Urbanismo. Orientadora: Maria Lúcia Caira Gitahy. São Paulo: FAUUSP, 2008.

BAROSSI, Antonio Carlos. Ensino de projeto na FAUUSP. Tese de doutorado em Arquitetura e Urbanismo. Orientador: Joaquim Guedes. São Paulo: FAUUSP, 2006.

BELLUZZO, Ana Maria. Artesanato, Arte e Indústria. Tese de doutorado em Arquitetura e Urbanismo. Orientadora: Aracy Abreu do Amaral. São Paulo: FAUUSP, 1988.

BRAGA, Juliana. Ver não é só ver: dois estudos a partir de Flavio Motta. Dissertação de mestrado em Arquitetura e Urbanismo. Orientador: José T. C. de Lira. São Paulo: FAU-USP, 2010.

BUZZAR, Miguel Antonio. João Batista Vilanova Artigas: elementos para a compreensão de um caminho da arquitetura brasileira (1938-1967). Dissertação de mestrado em Arquitetura e Urbanismo. Orientador: Paulo Bruna. São Paulo: FAU-USP, 1996.

CABRAL, Neyde A. Joppert. A universidade de São Paulo: modelos e projetos. Tese de doutorado. Orientador: Dácio Ottoni. São Paulo: FAUUSP, 2004.

CARVALHO. Claudia Paiva. Intelectuais, cultura e repressão política na ditadura brasileira (19641967): Relações entre direito e autoritarismo. Dissertação de mestrado em Direito. Orientador: Cristiano Paixão. Brasília: Universidade de Brasília, 2013.

CARAM, André Luís Balsante. Arquitetura e educação superior: projetos e realizações dos engenheiros-arquitetos da Poli. Dissertação de mestrado. Orientadora: Maria Lúcia Gitahy. São Paulo: FAUUSP, 2014

CASALADE, Flavio de Lemos. Ensino de projeto de arquitetura: uma visão construtivista. Dissertação de mestrado. Orientadora: Maria Lúcia Malard. Belo Horizonte: UFMG, 1997.

CASTRO, Maria Beatriz de. Vilanova Artigas modernité éthique, tradition esthétique. Tese de doutorado. Paris: 1997.

CERÁVOLO, Ana Lúcia. Paulo de Camargo e Almeida: arquitetura total na trajetória de um arquiteto brasileiro. Dissertação de mestrado. Orientador: Carlos Roberto M. de Andrade. São Carlos: EESCUSP, 2000.

COMITRE, Edvânia Helenice Dantas. Análise gráfica: um olhar para a arquitetura moderna paulistana. Dissertação de mestrado em Arquitetura e Urbanismo. Orientador: Rafael A. C. Perrone. São Paulo: FAUUSP, 2005.

CORDIDO, Maria Tereza R. L. de B. Arquitetura moderna: a rede de fóruns modulares do Estado de São Paulo (1969-1975). Tese de doutorado. Orientador: Miguel Buzzar. São Carlos: IAUUSP, 2012

CORRÊA, Maria Luiza. Artigas: da idéia ao desenho. Dissertação de mestrado em Arquitetura e Urbanismo. Orientador: Júlio Roberto Katinsky. São Paulo: FAU-USP, 1998.

COTRIM, Marcio. Construir a casa paulista: o discurso e a obra de Vilanova Artigas entre 1967 e 1985. Tese de doutorado. Orientadores: Fernando Alvarez Prozorovich e Abilio Guerra. Barcelona: ETSAB-UPC, 2008.

CUNHA, Gabriel Rodrigues da. Uma Análise da produção de Vilanova Artigas entre os anos 1967 e 1976. Dissertação de mestrado. Orientador: Miguel A. Buzzar. São Carlos: EESC-USP, 2009. 
DEDECCA, Paula. Sociabilidade, crítica e posição. O meio arquitetônico, as revistas especializadas e o debate do moderno em São Paulo (1945-1965). Dissertação de mestrado em Arquitetura e Urbanismo. Orientador: José T. C. de Lira. São Paulo: FAUUSP, 2012.

DOMSCHKE, Vera Lúcia. O ensino da arquitetura e a construção da modernidade. Tese de doutorado em Arquitetura e Urbanismo. Orientadora: Marlene Yurgel. São Paulo: FAU-USP, 2007.

DURAND, José Carlos. O arquiteto: estudo introdutório de uma ocupação. Dissertação de mestrado em Sociologia. Orientador: Luiz Pereira. São Paulo: FFLCH-USP, 1972.

ESPALLARGAS Gimenez, Luis. Arquitetura paulistana da década de 1960: técnica e forma. Tese de doutorado. Orientador: Ricardo Marques de Azevedo. São Paulo: FAUUSP, 2004.

FAGGIN, Carlos Augusto Mattei. Carlos Millan: itinerário profissional de um arquiteto paulista. Tese de doutorado em Arquitetura e Urbanismo. Orientadora: Marlene Yurgel. São Paulo: FAU-USP, 1992.

FERRATA, Carlos Augusto. Escolas públicas em São Paulo (1960-1972). Dissertação de mestrado em Arquitetura e Urbanismo. Orientadora: Anália Maria Marinho de Carvalho Amorim. São Paulo: FAU-USP, 2008.

FLORIO, Ana Maria. Os projetos residenciais não-construídos de Vilanova Artigas em São Paulo. Tese de doutorado. São Paulo: FAUUSP, 2012.

FREITAS, Maria Luiza. Modernidade concreta: as grandes construtoras e o concreto armado no Brasil, 1920 a 1940. Tese de Doutorado. São Paulo: FAUUSP, 2011.

FUJIOKA, Paulo Y. Princípios da arquitetura organicista de Frank Lloyd Wright e suas influências na arquitetura moderna paulistana. Tese de doutorado em Arquitetura e Urbanismo. Orientador: Lucio Gomes Machado. São Paulo: FAU-USP, 2004.

GABRIEL, Marcos Faccioli. Vilanova Artigas: uma poética traduzida. Dissertação de mestrado. Orientadora: Cibele Saliba Rizek. São Carlos: EESC-USP, 2003.

GIANNECCHINI, Ana Clara. Técnica e estética no concreto armado. Um estudo sobre os edifícios do MASP e da FAUUSP. Dissertação de mestrado em Arquitetura e Urbanismo. Orientadora: Maria Lúcia Bressan Pinheiro. São Paulo: FAU-USP, 2009.

GRAZZIANO, Raphael. Aspectos do debate entre realismo socialista e concretismo: a obra de Vilanova Artigas. Trabalho final de graduação. Orientador: Luiz Recamán. São Paulo: FAUUSP, 2012.

HADLICH. Flávio. As escolas do Ipesp: projetos de edifícios escolares produzidos para o Instituto de previdência do Estado de São Paulo de 1959 a 1962. Dissertação de mestrado. Orientador: Adilson Costa Macedo. São Paulo: FAUUSP, 2009.

HUGERTH, Mina Warchavchik. Mobilinea design de um estilo de vida (1959-1975). Dissertação de mestrado. Orientador: José Tavares Correia de Lira. São Paulo: FAUUSP, 2015.

IWAMIZU, Cesar Shundi. A Estação Rodoviária de Jaú e a dimensão urbana da arquitetura.

Dissertação de Mestrado. Orientador: Anália Maria Marinho de Carvalho Amorim. São Paulo: FAUUSP, 2008.

JUCÁ, Christina B. de Mello. João Batista Vilanova Artigas, arquiteto: a gênese de uma obra (19341941). Dissertação de mestrado. Orientador: Jaime de Almeida. Brasília: UNB, 2001.

KOURY, Ana Paula. Arquitetura construtiva: proposições para a produção material da arquitetura contemporânea no Brasil. Tese de doutorado em Arquitetura e Urbanismo. Orientador: Nestor G. Reis Filho. São Paulo: FAU-USP, 2005.

LIMA, Camila Venanzi. As escolas implementadas no interior do Estado de São Paulo pelo Plano de Ação do Governo do Estado entre os anos 1959 e 1963. Dissertação de mestrado. Orientador: Gelson Pinto. São Carlos: IAUUSP, 2013.

MACEDO, Adilson Costa. Idéias preliminares para o projeto urbano da Cidade Universitária Armando Sales de Oliveira. Tese de doutorado em Arquitetura e Urbanismo. Orientador: Gustavo Neves da Rocha. São Paulo: FAU-USP, 1987. 
MACHADO, Lúcio Gomes. Rino Levi e a renovação da arquitetura brasileira. Tese de doutorado em Arquitetura e Urbanismo. Orientador: Benedito Lima de Toledo. São Paulo: FAU-USP, 1992.

MARTINS, Carlos A. Ferreira. Arquitetura e Estado no Brasil: elementos para uma investigação sobre a constituição do discurso moderno no Brasil; a obra de Lucio Costa (1924-1952). Dissertação de mestrado. Orientador: Arnaldo Daraya Contier. São Paulo: FFLCH-USP, 1987.

MATERA, Sergio. Carlos Millan: um estudo sobre a produção em arquitetura. Dissertação de mestrado em Arquitetura e Urbanismo. Orientador: José Eduardo de Assis Lefèvre. São Paulo: FAUUSP, 2006.

MIGUEL, Jorge Marão Carnielo. Pensar e fazer arquitetura. Tese de doutorado em Arquitetura e Urbanismo. Orientador: Júlio Roberto Katinsky. São Paulo: FAU-USP, 1999.

MODENESE FILHO, Eduardo. Entre linhas e curvas: a teoria e a prática na obra de Zenon Lotufo. Dissertação de mestrado. Orientador: Lúcio Gomes Machado. São Paulo: FAUUSP, 2008,

MONEGATTO, Karina Benassi. Do artífice ao peão: a constituição e a quebra do reconhecimento do trabalhador da construção civil. Dissertação de mestrado em Arquitetura e Urbanismo. Orientadora: Maria Ruth Amaral de Sampaio. São Paulo: FAU-USP, 2008.

MONTENEGRO FILHO, Roberto Alves de Lima. Pré-fabricação e a obra de Kneese de Mello. Dissertação de mestrado em Arquitetura e Urbanismo. Orientadora: Maria Lúcia Bressan Pinheiro. São Paulo: FAU-USP, 2007.

NASCIMENTO, Mario Fernando P. do. Arquitetura para a educação: a contribuição do espaço para a formação do estudante. Dissertação de mestrado em Arquitetura e Urbanismo. Orientadora: Mônica Junqueira de Camargo. São Paulo: FAUUSP, 2012.

NASCIMENTO, Myrna de Arruda. A tecitura da rede: arquitetura como interlinguagens. Dissertação de mestrado em Arquitetura e Urbanismo. Orientadora: Lucrécia D'Aléssio Ferrara. São Paulo: FAUUSP, 1997.

NOBRE, Ana Luiza. Fios cortantes: Projeto e produto, arquitetura e design no Rio de Janeiro (195070). Tese de doutorado. Orientador: Ronaldo Brito Fernandes. Rio de Janeiro: PUC-RJ, 2008.

OKSMAN, Sílvio. Preservação do patrimônio arquitetônico moderno: a FAU de Vilanova Artigas. Dissertação de mestrado em Arquitetura e Urbanismo. Orientador: Luís Antônio Jorge. São Paulo: FAU-USP, 2011.

OLIVEIRA, Gliceli. A casa Bettega de Vilanova Artigas: desenhos e conceitos. Dissertação de mestrado. São Paulo: FAUUSP, 2009.

PEREIRA, Alessandro Guimarães. Arquitetura escolar: notas comparativas sobre projetos em São Paulo e Brasília. Dissertação de mestrado. Orientador: Antônio Carlos Cabral Carpintero. Brasília: FAU-UNB, 2007.

PEREIRA, Juliano Aparecido. Desenho industrial e arquitetura no ensino da FAU USP (1948-1968). Tese de doutorado. Orientador: Renato L. S. Anelli. São Carlos: EESC-USP, 2009.

PETROSINO, Maurício Miguel. João Batista Vilanova Artigas: elementos para a compreensão de um caminho da arquitetura brasileira, 1938-1967. Dissertação de mestrado em Arquitetura e Urbanismo. Orientadora: Mônica Junqueira de Camargo. São Paulo: FAU-USP, 2009.

RABELO, Clévio. Arquitetos na cidade: espaços profissionais em expansão. Tese de Doutorado. Orientador: José T. C. de Lira. São Paulo: FAUUSP, 2011.

REGINO, Aline Nassarala. Arquitetura moderna paulista e a habitação coletiva. Análise da contribuição do arquiteto Eduardo Kneese de Mello. Dissertação de mestrado. Orientador: Rafael A. C. Perrone. São Paulo: FAU Mackenzie, 2006.

ROSSETTI, Eduardo Pierrotti. Arquitetura em transe. Lucio Costa, Oscar Niemeyer, Vilanova Artigas e Lina Bo Bardi: nexos da arquitetura brasileira pós-Brasília [1960-85]. Tese de Doutorado.

Orientador: Fernanda Fernandes da Silva. São Paulo: FAU-USP, 2007. 
SANVITTO, Maria Luiza Adams. Brutalismo paulista: uma análise compositiva de residências paulistanas entre 1957 e 1972. Dissertação de mestrado em Arquitetura. Orientador: Edson da C. Mahfuz. Porto Alegre: PROPAR-UFRGS, 1997.

SCHENKMAN, Raquel. Do vital ao pano de vidro. Dissertação Mestrado. Orientador: José Tavares Correia de Lira. São Paulo, FAUUSP, 2014.

SEIXAS, Alexandre Rodrigues. A arquitetura escolar de Vilanova Artigas e Carlos Cascaldi (19591962). Dissertação de mestrado. Orientador: Carlos A. Ferreira Martins. São Carlos: EESC-USP, 2003.

SILVA, Helena Aparecida Ayoub. Abrahão Sanovicz: o projeto como pesquisa. Tese de doutorado em Arquitetura e Urbanismo. Orientador: Eduardo Luiz Paulo Riesencampf de Almeida. São Paulo: FAUUSP, 2004.

SILVA, Joana Mello de Carvalho e. O arquiteto e a produção da cidade: a experiência de Jacques Pilon em perspectiva (1930-1960). Tese de doutorado. Orientadora: Ana Lucia Duarte Lanna. São Paulo: FAUUSP, 2010.

SIMÕES, João Roberto Leme. Arquitetura na Cidade Universitária 'Armando Sales de Oliveira' - o espaço construído. Dissertação de mestrado em Arquitetura e Urbanismo. Orientador: Ariosto Mila. São Paulo: FAU-USP, 1984.

SODRÉ, João Clark de Abreu. Arquitetura e viagens de formação pelo Brasil (1938-1962).

Dissertação de mestrado. Orientador: José Tavares Correia de Lira. São Paulo: FAUUSP, 2010.

THOMAZ, Dalva Elias. Artigas: a liberdade na inversão do olhar; modernidade e arquitetura brasileira. Tese de doutorado em Arquitetura e Urbanismo. Orientador: Júlio Roberto Katinsky. São Paulo: FAUUSP, 2005.

THOMAZ, Dalva Elias. Um olhar sobre Vilanova Artigas e sua contribuição à arquitetura brasileira. Dissertação de mestrado em Arquitetura e Urbanismo. Orientadora: Ana Maria de Moraes Belluzzo. São Paulo: FAU-USP, 1997.

VALENTIM, Fábio Rago. Casas para o ensino: as escolas de Vilanova Artigas. Dissertação de mestrado em Arquitetura e Urbanismo. Orientador: Eduardo Luiz Paulo Riesencampf de Almeida. São Paulo: FAU-USP, 2003.

VIANA, Salvador T. Werneck. Desenvolvimento econômico e reformas institucionais no Brasil: Considerações sobre a construção interrompida. Tese de doutorado. Orientadora: Beatriz Azeredo. Rio de Janeiro: IE-UFRJ, 2007.

ZEIN, Ruth Verde. A arquitetura da escola paulista brutalista 1953-1973. Tese de doutorado. Orientador: Carlos Eduardo Dias Comas. Porto Alegre: FAU-UFRGS, 2005.

\section{Relatórios}

DUARTE, Hélio de Queiroz. Comissão da Cidade Universitária 'Armando Sales de Oliveira'. Relatório. São Paulo: 1956.

FAUUSP. Pasta funcional João Batista Vilanova Artigas. São Paulo: FAUUSP, 199-

FAUUSP. FAUUSP: 30 anos do projeto do edifício. Transcrição do seminário, s/d.

FAUUSP. Folheto Publicitário da USP de inauguração do edifício da FAU. São Paulo, Arquivo Biblioteca FAUUSP.

MILLAN, Carlos Barjas. O ateliê na formação do arquiteto. Relatório apresentado pelo professor Carlos Barjas Millan, coordenador do grupo de estudo do Ateliê. São Paulo: FAUUSP, 1962

PEREIRA, Maria Fernanda; BARBOSA, Paulo Eduardo. Edifício Vilanova Artigas. Projeto, especificação de materiais / sistemas e procedimentos para reabilitação do edifício com previsão orçamentária. Relatório técnico com consultoria de Paulo Helene. São Paulo: 2006. 


\section{Processos USP}

60.1.10846.1.0 - Contrato: Bartolomeu Gabarron

60.1.19244.1.2 - Copias de documentos a fim de esclarecer diversos processos do fundo a construção

62.1.660.51.9 - Decreto 36.959, que regulamenta o art. 5ª , item B do Decreto 36.699, Artigo 2, letra A o que estabelece para as pessoas estranhas ao serviço público a serem contratados pelo Fundo.

63.1.3159.1.3 - Sobre exame da situação do fundo para construção, tendo em vista a autonomia da usp, face ao pedido de dispensa do atual diretor executivo

64.1.17084.1.1 - Solicita que esse órgão seja autorizado a proceder admissões e dispensas de servidores indispensáveis ao plano de obras desse fundo

64.1.25745.1.3 - Solicita autorização no sentido de ser doado a escola de engenharia da universidade de juiz de fora, o filme sobre a construção da cidade universitária.

64.1.6450.1.1 - Plano de aplicação para 1964

65.1.17666.1.1 - Proposta orçamentária para o Fundo do exercício de 1966

65.1.32613.1.2 - Preenchimento do cargo de diretor executivo do F.C.C.U "ASO"

65.1.32614.1.9 - Proposta e reestruturação do escritório técnico e administrativo

65.1.3988.51.8 - Professor Anhaia Mello, solicita que o professor João Batista Vilanova Artigas elabore o projeto definitivo de instalação daquela faculdade, na Cidade universitária

66.1.20458.1.8 - Construção do prédio da F.A.U. no "campus" da Cidade Universitária

67.1.5794.1.1 - Programação de obras

69.1.12921.1.7 - Sobre levantamento nominal dos servidores

\section{Entrevistas}

Conversa com Alfredo Rizkallah por telefone dia 22 de fevereiro de 2011.

Entrevista com Abdias Nogueira, realizada em 6 de fevereiro de 2012, no Departamento de História da FAUUSP.

Entrevista com André Mehes, realizada em 17 de setembro de 2010 em seu escritório.

Entrevista com Celso Lamparelli, realizada em 23 de setembro de 2014

Entrevista com Jon Maitrejean, realizada em 30 de julho de 2014, na residência do arquiteto.

Entrevista com José Castanho, realizada em janeiro de 2012 no escritório Contier Arquitetura.

Entrevista com José Luiz Mendes Ripper, realizada em 2013 na PUC do Rio de Janeiro.

Entrevista com Luciano Bernini, realizada por e-mail entre agosto e novembro de 2010.

Entrevista com Paulo Mendes da Rocha, realizada em 16 de julho de 2014, no escritório do arquiteto.

Entrevista com Rosa Artigas, realizada em 14 de março de 2011, em sua residência.

Entrevista com Sérgio Assumpção, realizada em 31 de janeiro de 2012 na sede da COESF.

Entrevista com Sérgio Ferro, realizada em 18 de fevereiro de 2011 por Skype.

Entrevista com Vera Lúcia Rizkallah, realizada em 22 de abril de 2011 em café próximo à Av. Berrini.

Entrevista com Vladimir Brega, realizada em 23 de fevereiro de 2011 em sua residência na cidade de Bauru. 


\section{Leis}

Decreto Federal n.19.851, de 11 de abril de 1931. Dispõe que o ensino superior no Brasil obedecerá, de preferência, ao systema universitário, podendo ainda ser ministrado em institutos isolados, e que a organização technica e administrativa das universidades é instituída no presente Decreto, regendo-se os institutos isolados pelos respectivos regulamentos, observados os dispositivos do seguinte Estatuto das Universidades Brasileiras.

Decreto Estadual n. 5.361, de 28 de janeiro de 1932. Reorganiza o Conselho de Orientação Artística e dá outras providências

Lei Estadual n. 2.521, de 9 de janeiro de 1936. Autoriza o Poder Executivo a adquirir os terrenos necessários à construção da Cidade universitária.

Lei Estadual n. 104, de 21 de junho de 1948. Dispõe sobre a criação, na Universidade de São Paulo, da Faculdade de Arquitetura e Urbanismo.

Decreto Estadual n. 21.705, de 22 de setembro de 1952. Reorganiza os serviços da Diretoria de Obras Públicas da Secretaria da Viação e Obras Públicas.

Lei Estadual n. 2.620, de 20 de janeiro de 1954. Dispõe sobre a admissão de estagiáriosuniversitários aos serviços técnicos das repartições e autarquias da Secretaria da Viação e Obras Públicas, e dá outras providências.

Lei Estadual n. 2.816, de 27 de novembro de 1954. Aprova o Convênio Escolar celebrado entre o Governo do Estado e a Prefeitura do Município da Capital.

Lei Estadual n. 3.233, de 27 de outubro de 1955. Dispõe sobre o regulamento da Faculdade de Arquitetura e Urbanismo, da Universidade de São Paulo, criada pela Lei n. 104, de 21-6-48, e dá outras providências.

Decreto Estadual n. 28.308, de 4 de maio de 1957. Autoriza o Reitor da universidade de São Paulo a celebrar contratos individuais de trabalho com pessoal especializado, para as obras da Cidade Universitária "Armando Salles de Oliveira".

Decreto Estadual n. 34.017, de 21 de novembro de 1958. Introduz o regime de matrícula por Cadeira ou Disciplina subordinada, na Faculdade de Arquitetura e Urbanismo, da Universidade de São Paulo e dá outras providências.

Lei Estadual n. 5.444, de 17 de novembro de 1959. Dispõe sobre medidas de caráter financeiro relativas ao Plano de Ação do Governo, e dá outras providências.

Decreto Estadual n. 35.796, de 20 de novembro de 1959. Plano de Ação - Dispõe sobre a abertura de crédito especial de $\operatorname{Cr} \$ 202.950 .000,000$, destinado a atender despesas com a execução do Plano de Ação, nos termos da Lei n. 5.444, de 17 de novembro de 1959.

Decreto Estadual n. 36.699, de 3 de junho de 1960. Plano de Ação - Cria o Fundo de Construção da Cidade Universitária "Armando Salles de Oliveira" e regulamenta sua aplicação.

Decreto Estadual n. 36.799, de 21 de junho de 1960. Plano de Ação - Regulamenta o Fundo Estadual de Construções Escolares, criado pela Lei n. 5.444, de 17 de novembro de 1959.

Decreto Estadual n. 36.922, de 8 de julho de 1960. Plano de Ação - Dispõe sobre a abertura de crédito especial de $\mathrm{Cr} \$ 375.000 .000,000$, destinado a atender despesas com a execução do Plano de Ação, nos termos da Lei n. 5.444, de 17 de novembro de 1959.

Decreto Estadual n. 36.959, de 13 de julho de 1960. Plano de Ação - Regulamenta o Artigo 5o item do Decreto n. 6.699, de 3 de julho de 1960.

Decreto Estadual n. 37.213, de 9 de setembro de 1960. Plano de Ação - Altera a redação do Artigo 1ำ do Decreto n. 37.138, de 24-8-1960.

Lei Federal 4.024, de 20 de dezembro de 1961. Diretrizes e Bases da Educação Nacional. 
Decreto Estadual n. 40.346, de 7 de julho de 1962. Aprova os Estatutos da Universidade de São Paulo e dá outras providencias.

Lei Estadual n. 7.193, de 19 de outubro de 1962. Dispõe sobre a reorganização da Diretoria de Obras Públicas, da Secretaria de Estado dos Negócios da Viação e dá outras providências.

Lei Federal n. 5.540, de 28 de novembro de 1968. Fixa normas de organização e funcionamento do ensino superior e sua articulação com a escola média, e dá outras providências.

Decreto-Lei federal n. 464, de 11 de fevereiro de 1969. Estabelece normas complementares à Lei oㅡ 5.540 , de 28 de novembro de 1968, e dá outras providências. 


\section{ANEXO I \\ CADEIRAS DA FAU}

Os números que precedem as disciplinas correspondem ao número das respectivas cadeiras. Os nomes sob a disciplina são dos professores regentes e abaixo, mais à direita, dos professores auxiliares, se houver. 



\section{CADEIRAS DO DEPARTAMENTO DE CIÊNCIAS APLICADAS}

\begin{tabular}{|c|c|c|c|}
\hline Poli 1946-1954 & 1948-1955 & $1956-1961$ & 1962-1968 \\
\hline $\begin{array}{l}\text { Cálculo Diferencial e Integral. Cálculo Vetorial. } \\
\text { Nomografia }\end{array}$ & 01. Matemática Superior & 01. Cálculo. Geometria Analítica. Nomografia & 01. Cálculo. Geometria analítica \\
\hline \multirow[t]{3}{*}{ José Octavio Monteiro de Camargo } & José Octavio Monteiro de Camargo & \multirow{3}{*}{$\begin{array}{l}\text { José Octavio Monteiro de Camargo } \\
\text { Eurico Cerruti }\end{array}$} & \multirow{3}{*}{$\begin{array}{r}\text { Domingos Pizanelli } \\
\text { Eurico Cerruti }\end{array}$} \\
\hline & 23. Nomografia & & \\
\hline & Eurico Cerruti & & \\
\hline $\begin{array}{l}\text { Perspectiva. Aplicações Técnicas. Geometria } \\
\text { Projetiva e Noções de Cálculo Gráfico }\end{array}$ & 02. Geometria Descritiva & 02. Geometria Descritiva & 02. Geometria Descritiva \\
\hline Pedro Moacyr do Amaral Cruz & $\begin{array}{l}\text { Pedro Moacyr do Amaral Cruz } \\
\text { Guilherme do Amaral Lyra }\end{array}$ & $\begin{array}{l}\text { Pedro Moacyr do Amaral Cruz } \\
\text { Guilherme do Amaral Lyra }\end{array}$ & $\begin{array}{l}\text { Pedro Moacyr do Amaral Cruz } \\
\text { Guilherme do Amaral Lyra }\end{array}$ \\
\hline Mecânica Racional & 03. Mecânica & 03. Mecânica & 03. Mecânica \\
\hline Paulo Araújo Correia de Brito & João Augusto Breves Filho & João Augusto Breves Filho & João Augusto Breves Filho \\
\hline Topografia & 4. Topografia & 11. Topografia & 4. Topografia \\
\hline Henrique Jorge Guedes & Henrique Jorge Guedes & Paulo Ferraz de Mesquita (1958) & Paulo Ferraz de Mesquita \\
\hline Física I e II & 13. Física Aplicada & 4. Física Geral e Aplicada & 5. Física Geral e Aplicada \\
\hline Luiz Cintra do Prado & Luiz Cintra do Prado & $\begin{array}{l}\text { Luiz Cintra do Prado } \\
\text { Leo Quanji Nishikawa? (1959) }\end{array}$ & $\begin{array}{c}\text { PaulusAulus Pompéia (1966) } \\
\text { Leo Quanji Nishikawa? (-1967) } \\
\text { Ualfrido del Carlo? (1964) }\end{array}$ \\
\hline \multicolumn{4}{|l|}{ Complementos de Geometria Analítica e Projetiva } \\
\hline \multicolumn{4}{|l|}{$\begin{array}{l}\text { GiacomoAlbanese } \\
\text { Pedro Bento de Camargo }\end{array}$} \\
\hline \multicolumn{4}{|l|}{ Química Geral Tecnológica I } \\
\hline \multicolumn{4}{|l|}{ Theoduretto de Arruda Souto } \\
\hline \multicolumn{4}{|l|}{ Desenho Topográfico } \\
\hline \multicolumn{4}{|l|}{$\begin{array}{l}\text { Vicente Azevedo } \\
\text { John Settle Addison }\end{array}$} \\
\hline \multicolumn{4}{|l|}{ Mineralogia, Geologia e Petrografia } \\
\hline $\begin{array}{l}\text { Octavio Barbosa } \\
\text { Fernando F M. de Almeida } \\
\text { José Carlos Rodrigues }\end{array}$ & & & \\
\hline
\end{tabular}





\begin{tabular}{|c|c|c|c|}
\hline \multicolumn{4}{|c|}{ CADEIRAS DO DEPARTAMENTO DE CONSTRUÇÃO } \\
\hline Poli 1946-1954 & 1948-1955 & 1956-1961 & 1962-1968 \\
\hline $\begin{array}{l}\text { Noções de Arquitetura e Construções Civis. Higiene } \\
\text { das Habitaçôes e História da arquitetura I e II }\end{array}$ & 8. Construções Civis & $\begin{array}{l}\text { 9. Técnica das Construçōes, Organização dos Trabalhos e } \\
\text { Prática Profissional, Higiene dos Edifícios, Noçōes de } \\
\text { Mecânica dos Solos, Fundaçôes }\end{array}$ & 6. Construção I \\
\hline $\begin{array}{r}\text { Bruno Simões Magro } \\
\text { Ariosto Mila }\end{array}$ & Ariosto Mila & \multirow[t]{3}{*}{$\begin{array}{l}\text { Ariosto Mila } \\
\text { Victor F. Bachmann de Mello }\end{array}$} & Ariosto Mila \\
\hline Materiais de Construção. Fundações & 10. Fundações & & 26. Mecânica dos Solos e Fundações (1968) \\
\hline \multirow[t]{3}{*}{$\begin{array}{l}\text { Ary Frederico Torres } \\
\text { John Burke Jr. }\end{array}$} & $\begin{array}{l}\text { Odair Grillo } \\
\text { Victor F. Bachmann de Mello }\end{array}$ & & Victor F. Bachmann de Mello \\
\hline & 6. Materiais de Construção & 5. Materiais de Construção & 9. Construções II \\
\hline & Ary Frederico Torres & $\begin{array}{r}\text { Fernando José de O. Escorel (1957) } \\
\text { Joaquim M. Guedes (1958) }\end{array}$ & $\begin{array}{l}\text { Renato Salmoni (1965) } \\
\text { Joaquim M. Guedes(?) } \\
\text { José Fonseca (1962) }\end{array}$ \\
\hline Resistência dos Materiais & 5. Resistência dos Materiais & 6. Resistência dos Materiais & 7. Resistência dos Materiais \\
\hline $\begin{array}{l}\text { Telêmaco H.M. Van Langendonck } \\
\text { Fernando J. de O. Escorel } \\
\text { Jayme Ferreira da Silva Jr. } \\
\text { José Carlos de F. Ferraz }\end{array}$ & $\begin{array}{l}\text { TelêmacoH.M. Van Langendonck } \\
\text { Paulo NovackFilho (1954) }\end{array}$ & $\begin{array}{l}\text { TelêmacoH.M. Van Langendonck } \\
\text { Paulo NovackFilho (-1960) } \\
\text { Victor Maoel de Souza Lima (1958) }\end{array}$ & $\begin{array}{l}\text { Telêmaco H.M. Van Langendonck } \\
\text { Victor Maoel de Souza Lima } \\
\text { Décio L. de Zagottis (1967) }\end{array}$ \\
\hline Hidráulica & 7. Hidráulica & 10. Hidráulica & 8. Hidráulica \\
\hline $\begin{array}{l}\text { Lucas Nogueira Garcez } \\
\text { Octacílio Souza Sene }\end{array}$ & $\begin{array}{l}\text { Lysandro M. Pereira da Silva } \\
\text { Paulo Sampaio Wilken }\end{array}$ & $\begin{array}{l}\text { Lucas Nogueira Garcez (1957) } \\
\text { Paulo Sampaio Wilken }\end{array}$ & $\begin{array}{l}\text { Paulo Sampaio Wilken (1967) } \\
\text { Rufino Reis Soares (1962) }\end{array}$ \\
\hline Concreto Simples e Armado & 9. Concreto Simples e Armado & $\begin{array}{l}\text { 7. Estruturas Correntes de Madeira, Metálicas e de } \\
\text { Concreto Simples e Armado }\end{array}$ & $\begin{array}{l}\text { 10. Estruturas Correntes de madeira, metálicas e } \\
\text { de concreto simples e armado }\end{array}$ \\
\hline \multirow[t]{3}{*}{$\begin{array}{l}\text { Nilo Andrade Amaral } \\
\text { Eduardo C. Rodrigues }\end{array}$} & Fernando José de O. Escorel & José Carlos de F. Ferraz (1956) & José Carlos de F. Ferraz \\
\hline & 11. Grandes Estruturas & 8. Grandes Estruturas & 11. Grandes Estruturas \\
\hline & $\begin{array}{c}\text { Pedro Bento José Gravinha } \\
\text { Sergio Fracarolli }\end{array}$ & $\begin{array}{c}\text { Pedro Bento José Gravinha } \\
\text { Sergio Fracarolli }\end{array}$ & Pedro Bento José Gravinha \\
\hline $\begin{array}{l}\text { Economia Política. Estatística Aplicada. } \\
\text { Organizações Administrativas }\end{array}$ & $\begin{array}{l}\text { 12. Economia Política e Estatística Aplicada. } \\
\text { Organizações Administrativas }\end{array}$ & $\begin{array}{l}\text { 12. Noções de Economia política, Estatística } \\
\text { Aplicada }\end{array}$ & 25. Estudos Sócio Econômicos \\
\hline Carlos Alberto Vanzolini & $\begin{array}{c}\text { Carlos Alberto Vanzolini (1951-53) } \\
\text { Rui A. da S. Leme } \\
\text { Mario Wagner V. da Cunha (1954) } \\
\text { Alvaro Marchi (1954) } \\
\text { Juarez R.B. Lopes (1954) }\end{array}$ & $\begin{array}{l}\text { Mario Wagner Vieira da Cunha } \\
\text { Juarez R. Brandão Lopes } \\
\text { Rui A. da S. Leme } \\
\text { Américo Oswaldo Campiglia(?) }\end{array}$ & $\begin{array}{l}\text { Juarez R. Brandão Lopes } \\
\text { Gabriel Bolaffi }\end{array}$ \\
\hline Contabilidade & 27. Legislação e Contabilidade & & \\
\hline Américo Oswaldo Campilia & Américo Oswaldo Campiglia & & \\
\hline
\end{tabular}



CADEIRAS DO DEPARTAMENTO DE PROJETO

\begin{tabular}{|c|c|c|c|}
\hline Poli 1946-1954 & 1948-1955 & 1956-1961 & 1962-1968 \\
\hline Desenho Arquitetônico & 28. Desenho Artístico & 21. Desenho Artístico & 12. Comunicação Visual \\
\hline José Maria da Silva Neves & $\begin{array}{l}\text { Vera H. R. C. do Amaral } \\
\text { Arquimedes Dutra }\end{array}$ & $\begin{array}{l}\text { Ernest R. de C. Mange } \\
\text { vera H. R. C. do Amaral } \\
\text { Elide Monzeglio (1963) }\end{array}$ & $\begin{array}{l}\text { Ernest R. de C. Mange } \\
\text { Elide Monzeglio } \\
\text { Caetano Fracarolli } \\
\text { Renina Katz } \\
\text { Flávio Império (1961) } \\
\text { João B. Alves Xavier (1963) }\end{array}$ \\
\hline Desenho de Composição Geral. Modelagem & 29. Composição Decorativa & 22. Composição Decorativa & 13. Desenho Industrial \\
\hline \multirow[t]{3}{*}{$\begin{array}{l}\text { Felisberto Ranzini } \\
\text { Caetano Fraccaroli }\end{array}$} & $\begin{array}{l}\text { José Maria da Silva Neves } \\
\text { Antonio Paim Vieira (1951-53) } \\
\text { Jacob MauricioRuchti(1954) } \\
\text { Achilina Bo Bardi (1955) }\end{array}$ & $\begin{array}{l}\text { José Maria da Silva Neves } \\
\text { Jacob Mauuricio Ruchti } \\
\text { Luiz Gastẫo de Castro Lima }\end{array}$ & $\begin{array}{l}\text { José Maria da Silva Neves / Lúcio Grinover (1967) } \\
\text { Luiz Gastão de Castro Lima } \\
\text { Luiz Roberto de C. Franco } \\
\text { Dario Imparato } \\
\text { João C. R. Stroeter (1962) } \\
\text { Marlene Picarelli (1962) } \\
\text { João Carlos Cauduro (1964) } \\
\text { Eduardo de Almeida (1967) } \\
\text { Ronaldo Duschenes (1968) }\end{array}$ \\
\hline & 30. Plástica & \multirow[t]{2}{*}{ Integrada às Cadeiras de Composição } & \\
\hline & $\begin{array}{l}\text { Felisberto Ranzini / Caetano Fracarolli } \\
\text { Zanine Caldas } \\
\text { Alcides Rocha Miranda } \\
\text { Alfredo Oliani } \\
\text { Vicente Laroca } \\
\text { Bassano Vacarini } \\
\text { Plinio Croce } \\
\text { Ernest R. de C. Mange (1954) } \\
\text { Olga E.M. Schoenfeldt(1954) }\end{array}$ & & \\
\hline
\end{tabular}





\section{CADEIRAS DO DEPARTAMENTO DE PROJETO (CONTINUAÇÃO)}

\begin{tabular}{|c|c|c|c|}
\hline Poli 1946-1954 & 1948-1955 & 1956-1961 & 1962-1968 \\
\hline Composição Geral e Estética. Urbanismo & 16. Pequenas Composições & $\begin{array}{l}\text { 16. Pequenas Composições I. Desenho } \\
\text { Arquitetônico. Plástica I }\end{array}$ & 14. Projeto I \\
\hline \multirow[t]{11}{*}{$\begin{array}{l}\text { Luís I. de Anhaia Mello } \\
\text { João B. Vilanova Artigas } \\
\text { Zenon Lotufo }\end{array}$} & \multirow[t]{3}{*}{$\begin{array}{l}\text { João B. Vilanova Artigas / Zenon Lotufo } \\
\text { Abelardo de Souza } \\
\text { Ícaro de C. Mello (1950-53) } \\
\text { Manoel S. Machado (1954) }\end{array}$} & $\begin{array}{l}\text { Zenon Lotufo / Hélio de Queiroz Duarte (1958) } \\
\text { Lúcio Grinover (1958) }\end{array}$ & $\begin{array}{l}\text { Hélio de Queiroz Duarte } \\
\text { Ludovico A. Martino (1964) } \\
\text { Siegbert Zanettini (1967) } \\
\text { Dario Montesano (1968) }\end{array}$ \\
\hline & & 17. Pequenas Composições II. Plástica II & 15. Projeto II \\
\hline & & $\begin{array}{l}\text { Abelardo de Souza } \\
\text { Jon Maitrejean } \\
\text { Renina Katz }\end{array}$ & $\begin{array}{l}\text { Abelardo de Souza } \\
\text { Jon Maitrejean }\end{array}$ \\
\hline & 17. Grandes Composições & 18. Grandes Composições I. Plástica III & 16. Projeto III \\
\hline & \multirow{3}{*}{$\begin{array}{l}\text { Hélio de Queiroz Duarte } \\
\text { Ernest R. C. Mange (1950-53) } \\
\text { Roberto C. César (1954) } \\
\text { Ícaro de C. Mello (1954-55) } \\
\text { José V. Vicari (1951-53) } \\
\text { Elisiário C. Bahiana (1951-53) } \\
\text { Oswaldo C. Gonçalves (1954) } \\
\text { Rino Levi (1954) } \\
\text { Jon A. V. Maitrejean (1955) }\end{array}$} & $\begin{array}{l}\text { Roberto Cerqueira César (1958) } \\
\text { Luiz R. de C. Franco (1958) } \\
\text { Dario Imparato (1958) }\end{array}$ & $\begin{array}{l}\text { Roberto Cerqueira César } \\
\text { Roger Zmekhol (1965) }\end{array}$ \\
\hline & & 19. Grandes Composições II & 17. Projeto IV \\
\hline & & $\begin{array}{l}\text { Rino Levi / João B. Vilanova Artigas } \\
\text { João B. Vilanova Artigas (1958) } \\
\text { Paulo Mendes da Rocha (1960) }\end{array}$ & $\begin{array}{l}\text { João B. Vilanova Artigas } \\
\text { Paulo Mendes da Rocha } \\
\text { Pedro Paulo M. Saraiva }\end{array}$ \\
\hline & 19. Urbanismo & 23. Urbanismo & 19. Planejamento II \\
\hline & $\begin{array}{l}\text { Luís de I. Anhaia Mello } \\
\text { Milton Carlos Ghiraldini }\end{array}$ & $\begin{array}{l}\text { Luís I. de Anhaia Mello } \\
\text { Milton Carlos Ghiraldini } \\
\text { Lauro B. Birkholz (1957) }\end{array}$ & $\begin{array}{l}\text { Lauro Birkholz (1962) } \\
\text { Milton Carlos Ghiraldini } \\
\text { José Claudio Gomes (1961) } \\
\text { Brenno C. Nogueira (1962) }\end{array}$ \\
\hline & 20. Paisagismo & 28. Paisagismo & 18. Planejamento I \\
\hline & $\begin{array}{l}\text { Roberto Coelho Cardoso } \\
\text { Daisy Ruth Igel Hoffemberg }\end{array}$ & $\begin{array}{l}\text { Roberto Coelho Cardoso } \\
\text { Rodolpho de A. Fernandes (1957) }\end{array}$ & $\begin{array}{l}\text { Roberto Coelho Cardoso } \\
\text { Rodolpho de A. Fernandes } \\
\text { Antonio A. Antunes N. (1962) } \\
\text { Marcos de S. Dias (1968) }\end{array}$ \\
\hline
\end{tabular}





\begin{tabular}{|c|c|c|c|}
\hline \multicolumn{4}{|c|}{ CADEIRAS DO DEPARTAMENTO DE HISTORIA } \\
\hline Poli 1946-1954 & 1948-1955 & $1956-1962$ & $1963-1968$ \\
\hline \multirow{2}{*}{$\begin{array}{l}\text { Fazia parte da Cadeira de Composição Geral e } \\
\text { Estética }\end{array}$} & 21. História da Arte. Estética & 15. História da Arte. Estética & 20. História da Arte. Estética \\
\hline & $\begin{array}{l}\text { Lourival Gomes Machado } \\
\text { Flávio Lichtenfels Motta (1954) }\end{array}$ & Flávio Lichtenfels Motta & $\begin{array}{l}\text { Flávio Lichtenfels Motta } \\
\text { Julio Katinsky (1962) } \\
\text { Sérgio Ferro (1962) }\end{array}$ \\
\hline \multirow{6}{*}{$\begin{array}{l}\text { Estava integrada à Cadeira Noções de } \\
\text { Arquitetura e Construções Civis. Higiene das } \\
\text { Habitações e História da arquitetura I e II }\end{array}$} & 14. Arquitetura Analítica & 13. Arquitetura Analítica & 21. História da Arquitetura I \\
\hline & $\begin{array}{l}\text { Bruno Simões Magro } \\
\text { Joaquim Bezerra da Silva }\end{array}$ & $\begin{array}{l}\text { Enoch da Rocha Lima (1957) } \\
\text { Joaquim Bezerra da Silva }\end{array}$ & $\begin{array}{l}\text { Joaquim Bezerra da Silva } \\
\text { Hélio de Maria Penteado (1962) } \\
\text { Dacio A. B. Ottoni (1962) } \\
\text { Cândido M. Campos Filho (1962) }\end{array}$ \\
\hline & 18. Arquitetura no Brasil & 20. Arquitetura no Brasil & 22. História da Arquitetura II \\
\hline & \multirow[t]{3}{*}{ Carlos Alberto Gomes Cardim Filho } & \multirow[t]{3}{*}{$\begin{array}{l}\text { Eduardo Kneese de Mello } \\
\text { Nestor Goulart Reis Filho }\end{array}$} & $\begin{array}{l}\text { Nestor Goulart Reis Filho } \\
\text { Rodrigo B. Lefèvre (1962) }\end{array}$ \\
\hline & & & 23. História da Arquitetura III \\
\hline & & & $\begin{array}{l}\text { Eduardo Kneese de Mello } \\
\text { Benedito L. de Toledo (1962) }\end{array}$ \\
\hline & 15. Teoria da Arquitetura & 14. Teoria da Arquitetura & 24. História da Arquitetura IV \\
\hline & $\begin{array}{l}\text { Eduardo Corona } \\
\text { Miguel Badra Júnior (1952-54) } \\
\text { Leopoldino W. Paganelli (1952-54) } \\
\text { Carlos A. C. Lemos (1954) }\end{array}$ & $\begin{array}{l}\text { Eduardo Corona } \\
\text { Carlos A. C. Lemos }\end{array}$ & $\begin{array}{l}\text { Eduardo Corona } \\
\text { Carlos A. C. Lemos }\end{array}$ \\
\hline
\end{tabular}



ANEXO II PROFESSORES DA FAU 



\begin{tabular}{|c|c|c|c|c|c|c|c|c|c|c|c|c|c|c|c|c|c|c|c|c|c|c|}
\hline Professor & 1948 & 1949 & 1950 & 1951 & 1952 & 1953 & 1954 & 1955 & 1956 & 1957 & 1958 & 1959 & 1960 & 1961 & I 1962 & 1963 & 1964 & 1965 & 1966 & 1967 & $1968 \mid$ & 1969 \\
\hline Felisberto Ranzini $(1881-1976)^{* 2}[\mathrm{Art}]$ & n. 30 & n. 30 & n. 30 & n. 30 & & & & & I & & & & & & 1:5: & & & & & & !1 & ] \\
\hline Bruno Simões Magro $(1882-1956)^{* 2}[$ Arq] & n. 14 & n. 14 & n. 14 & n. 14 & n. 14 & n. 14 & n. 14 & n. 14 & n. 13 & & & & & & I: & & & & & & i & i \\
\hline José Octavio Monteiro de Camargo $(1901-1963)^{\star 1}[\mathrm{Eng}]$ & n. 01 & n. 01 & n. 01 & n. 01 & n. 01 & n. 01 & n. 01 & n. 01 & n. 01 & n. 01 & n. 01 & n. 01 & n. 01 & n. 01 & n. 01 & n. 01 & & & & & & i \\
\hline José Maria da Silva Neves $(1896-1978)^{* 2}[$ Ara] & n. 28 & n. 28 & n. 29 & n. 29 & n. 29 & n. 29 & n. 29 & n. 29 & n. 22 & n. 22 & n. 22 & n. 22 & n. 22 & n. 22 & n. 22 & n. 13 & n. 13 & n. 13 & n. 13 & & & \\
\hline João Augusto Breves Filho $(1917-2005)^{\star_{1}}[$ [Eng] & & n. 03 & n. 03 & n. 03 & n. 03 & n. 03 & n. 03 & n. 03 & n. 03 & n. 03 & n. 03 & n. 03 & n. 03 & n. 03 & n. 03 & n. 03 & n. 03 & n. 03 & n. 03 & n. 03 & n. 03 & ? \\
\hline Eurico Cerruti (1911-1976) [Eng] & n. 26 & n. 26 & n. 26 & n. 26 & n. 26 & n. 26 & n. 26 & n. 26 & n. 01 & n. 01 & n. 01 & n. 01 & n. 01 & n. 01 & n. 01 & n. 01 & n. 01 & n. 01 & n. 01 & n. 01 & n. 01 & $?$ \\
\hline Guilherme do Amaral Lyra [Eng] & n. 02 & n. 02 & n. 02 & n. 02 & n. 02 & n. 02 & n. 02 & n. 02 & n. 02 & n. 02 & n. 02 & n. 02 & n. 02 & n. 02 & n. 02 & n. 02 & n. 02 & n. 02 & n. 02 & n. 02 & n. 02 & ? \\
\hline Nelson da Silveira Leme (IME) [O] & n. 01 & n. 03 & n. 03 & n. 03 & n. 03 & n. 03 & n. 03 & n. 03 & n. 03 & n. 03 & n. 03 & n. 03 & n. 03 & ก. 03 & ก. 03 & n. 03 & n. 03 & n. 03 & n. 03 & n. 03 & ก. 03 & ? \\
\hline Pedro Moacyr do Amaral Cruz [Eng] & n. 02 & n. 02 & n. 02 & n. 02 & n. 02 & n. 02 & n. 02 & n. 02 & n. 02 & n. 02 & n. 02 & n. 02 & n. 02 & n. 02 & n. 02 & n. 02 & n. 02 & n. 02 & n. 02 & n. 02 & n. 021 & $?$ \\
\hline Abelardo Riedy de Souza (1908-1981) [Arq] & n. 16 & ก. 16 & n. 16 & n. 16 & n. 16 & n. 16 & n. 16 & n. 16 & n. 17 & n. 17 & n. 17 & n. 17 & n. 17 & n. 17 & n. 17 & n. 15 & n. 15 & n. 15 & n. 15 & n. 15 & n. 15 & $?$ \\
\hline João Batista Vilanova Artigas $(1915-1985)^{* 2}[$ Arq] & n. 16 & n. 16 & n. 16 & n. 16 & n. 16 & n. 16 & & & n. 16 & ก. 16 & ก. 19 & ก. 19 & n. 19 & ก. 19 & n. 19 & n. 19 & n. 19 & n. 17 & n. 17 & n. 17 & n. 17 । & \\
\hline Jorge Leite Guedes [Eng] & & $?$ & $?$ & $?$ & & & & & I & & & & & & i: & & & & & & $\vdots j$ & \\
\hline Vicente Chiaverini (1914-2011) [Eng] & & $?$ & ? & ? & ? & ? & ? & $?$ & ? & & & & & & i: & & & & & & & \\
\hline Henrique Jorge Guedes $(1887-1973)^{\star 1}[E n g]$ & & n. 04 & n. 04 & n. 04 & n. 04 & n. 04 & n. 04 & n. 04 & n. 11 & n. 11 & & & & & i: & & & & & & & \\
\hline Ary Frederico Torres $(1900-1976)^{\star 1}[$ Eng] & & n. 06 & n. 06 & n. 06 & n. 06 & n. 06 & n. 06 & n. 06 & n. 05 & $?$ & ? & & & & 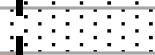 & & & & & & & \\
\hline 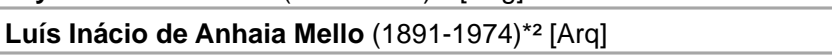 & & n. 15 & n. 15 & n. 15 & n. 19 & n. 19 & n. 19 & n. 19 & n. 23 & n. 23 & n. 23 & n. 23 & n. 23 & n. 23 & & & & & & & & \\
\hline Vera Helena Rossmann Carvalhaes do Amaral (1916-2008) [Art] & & n. 28 & n. 28 & n. 28 & n. 28 & n. 28 & n. 28 & n. 28 & n. 21 & n. 21 & n. 21 & n. 21 & n. 21 & n. 21 & n. 21 & & & & & & & \\
\hline Joaquim Dias Tatit (IME) [O] & & $?$ & $?$ & $?$ & $?$ & $?$ & $?$ & $?$ & ? & $?$ & $?$ & $?$ & $?$ & $?$ & $?$ & $?$ & ? & ? & ? & $?$ & $?$ & ? \\
\hline Hélio de Queiroz Duarte (1906-1989) [Arq] & & ? & n. 17 & n. 17 & n. 17 & n. 17 & n. 17 & n. 17 & n. 18 & n. 18 & n. 16 & n. 16 & n. 16 & n. $16 / 14$ & 4I $n .14$ & n. 14 & n. 14 & n. 14 & n. 14 & n. 14 & n. 14 I & ? \\
\hline Caetano Fraccaroli $(1911-1987)^{* 2}[\mathrm{Arq}]$ & & n. 30 & n. 30 & ก. 30 & n. 30 & n. 30 & n. 30 & n. 30 & n. 16 & n. 16 & ก. 16 & ก. 16 & ก. 16 & n. $16 / 121$ & n. 121 & n. 121 & n. 121 & n. 121 & n. 121 & n. 121 & n. $121 \mathrm{I}$ & ? \\
\hline Zenon Lotufo $(1911-1985)^{*_{2}}[$ Arq] & & n. 16 & n. 16 & n. 16 & n. 16 & n. 16 & n. 16 & n. 16 & n. 16 & n. 16 & & & & & $1: 0$ & $\vdots \vdots$ & $\vdots \vdots \vdots$ & $\vdots \vdots$ & & & & \\
\hline Eduardo Corona (1921-2001) [Arq] & & n. 15 & n. 15 & n. 15 & $?$ & $?$ & $?$ & n. 15 & n. 14 & n. 14 & n. 14 & n. 14 & n. 14 & n. 14 & ? & ? & ? & n. 24 & n. 24 & n. 24 & n. 24 & $?$ \\
\hline Raymundo José D' Araujo Costa [Eng] & & & $?$ & $?$ & $?$ & & & & I & & & & & & i & & & & $\ldots$ & $\ldots$ & 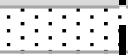 & i \\
\hline Zanine Caldas (1919-2001) [Art] & & & n. 30 & n. 30 & ก. 30 & & & & 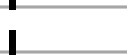 & & & & & & : & & & & & & & \\
\hline Odair Grillo $(1911-1996)^{\star}[$ [Eng] & & & n. 10 & n. 10 & n. 10 & n. 10 & n. 10 & & & & & & & & 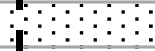 & & & & & & & \\
\hline Ícaro de Castro Mello (1913-1986) [Arq] & & & n. 16 & n. 16 & n. 16 & n. 16 & n. 17 & n. 17 & & & & & & & & & & & & & & \\
\hline Alcides da Rocha Miranda (1909-2001) [Ara] & & & n. 30 & n. 30 & n. 30 & n. 30 & n. 30 & n. $30 / 2$ & & & & & & & & & & & & & & \\
\hline Augusto Carlos de Vasconcelos $(1922)^{* 1}[$ [Eng] & & & $?$ & $?$ & $?$ & $?$ & $?$ & $?$ & ? & ? & & & & & I: & & & & & & & 1 \\
\hline Luiz de Queiroz Orsini $(1922)^{\star}[$ [Eng] & & & $?$ & $?$ & ? & ? & ? & $?$ & I ? & $?$ & $?$ & $?$ & & & 1 & & & & & & & ! \\
\hline Ernest Robert de Carvalho Mange (1922-2005) [Arq] & & & n. 17 & ก. 17 & n. 17 & ก. 17 & ก. 30 & n. 30 & I n. 21 & n. 21 & n. 21 & n. 21 & n. 21 & n. $21 / 12$ & 1 n. 121 & ก. 121 & n. 121 & n. 121 & n. 121 & n. 121 & n. 121 & \\
\hline Carlos Pereira de Castro [Eng] & & & $?$ & $?$ & $?$ & ? & ? & $?$ & I? & $?$ & $?$ & $?$ & $?$ & ? & I? & $?$ & $?$ & $?$ & $?$ & $?$ & ? & $?$ \\
\hline Telêmaco Hippolyto de M. Van Langendonck (1909-1994) ${ }^{\star 1}[E n g]$ & & & n. 05 & n. 05 & n. 05 & n. 05 & n. 05 & n. 05 & n. 06 & n. 06 & n. 06 & n. 06 & n. 06 & n. 06 & n. 06 & n. 07 & n. 07 & n. 07 & n. 07 & n. 07 & n. 07 & $?$ \\
\hline Luiz Cintra do Prado $(1904-1984)^{\star 1}[E n g]$ & & & n. 13 & n. 13 & n. 13 & n. 13 & n. 13 & n. 13 & n. 04 & n. 04 & n. 04 & n. 04 & n. 04 & n. 05 & n. 05 & n. 05 & n. 05 & n. 05 & n. 05 & $?$ & $?$ & $?$ \\
\hline Joaquim Bezerra da Silva [Arq] & & & n. 14 & n. 14 & n. 14 & n. 14 & n. 14 & n. 14 & n. 13 & n. 13 & n. 13 & n. 13 & n. 13 & $?$ & n. 21 & n. 21 & n. 21 & n. 21 & n. 21 & n. 21 & n. 21 & ? \\
\hline Ariosto Mila $(1912-1987)^{* 2}[$ Arq] & & & n. 08 & n. 08 & n. 08 & n. 08 & n. 08 & n. 08 & n. 09 & n. 09 & n. 09 & n. 09 & n. 09 & n. 09 & n. $09 / 06$ & n. 06 & n. 06 & n. 06 & n. 06 & n. 06 & n. 06 & ? \\
\hline Carlos Alberto Vanzolini $(1903-1953)^{*_{1}}[\mathrm{Eng}]$ & & & & n. 12 & n. 12 & n. 12 & & & & & & & & & & & & & & & & \\
\hline Antonio Paim Vieira (1895-1988) [Art] & & & & n. 29 & n. 29 & n. 29 & & & & & & & & & i: & & & & & & & \\
\hline Alfredo Oliani (1906-1988) [Art] & & & & ก. 30 & ก. 30 & ก. 30 & & & 1 & & & & & & i: & & & & & & & i \\
\hline José Vicente Vicari (1909-1989) [Ara] & & & & n. 17 & n. 17 & n. 17 & & & I & & & & & & i: & & & & & & & ! \\
\hline Elisiário da Cunha Bahiana (1891-1980) [Ara] & & & & n. 17 & n. 17 & n. 17 & & & I & & & & & & i: & & & & & & & i \\
\hline Archimedes Dutra (1908-1983) [Art] & & & & n. 28 & n. 28 & n. 28 & ก. 28 & n. 28 & & & & & & & i: & & & & & & & i \\
\hline Carlos Alberto Gomes Cardim Filho (1899-1990) [Ara] & & & & n. 20 & n. 18 & n. 18 & n. 18 & n. 18 & & & & & & & 1 & & & $\because \vdots$ & & & $\vdots !: \vdots$ & 1 \\
\hline
\end{tabular}

*1 Professor da Escola Politécnica (EP)

${ }^{*}$ Professordo curso de Engenheiro-Arquiteto da EP

[Arq] Arquiteto

[Art] Artista

[Eng] Engenheiro

[O] Outro

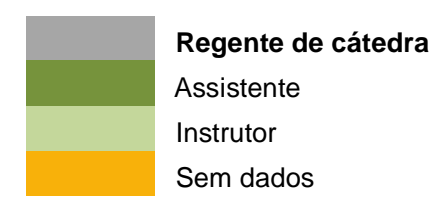

$\begin{array}{ll}\text { i } & \text { i }^{\text {reformas curriculares }} \\ \text { i } & \text { I }\end{array}$ 


\begin{tabular}{|c|c|c|c|c|c|c|c|c|c|c|c|c|c|c|c|c|c|c|c|c|c|c|c|}
\hline Professor & 1948 & 1949 & 1950 & 1951 & 1952 & 1953 & 1954 & 1955 & 1956 & 1957 & 1958 & 1959 & 1960 & 1961 & 1962 & 1963 & 1964 & 1965 & 1966 & 1967 & 1968 & & 1969 \\
\hline Lysandro Melo Pereira da Silva (1903-1993) [Eng] & & & & n. 07 & n. 07 & n. 07 & n. 07 & n. 07 & n. 10 & n. 10 & & & $5:$ & 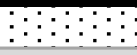 & $1: 1:$ & & $\therefore: \vdots$ & $\vdots \vdots ! \vdots$ & & & & 1 & \\
\hline Rui Aguiar da Silva Leme [Eng] & & & & n. 12 & n. 12 & n. 12 & n. 12 & ก. 12 & n. 12 & ก. 12 & n. 12 & n. 12 & n. 12 & ก. 12 & & & & & & & & 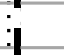 & \\
\hline Américo Oswaldo Campiglia (1909-2000) [Eng] & & & & n. 27 & n. 27 & n. 27 & n. 27 & n. 27 & $?$ & $?$ & $?$ & $?$ & $?$ & $?$ & & & & & & & & + & \\
\hline Sergio Fracarolli (Poli)*1 [Eng] & & & & n. 11 & n. 11 & ก. 11 & n. 11 & ก. 11 & n. 08 & ก. 08 & n. 08 & ก. 08 & ก. 08 & ก. 08 & ก. 08 & & & & & & & & \\
\hline Fernando José de Oliveira Escorel $(1916-1964)^{\star *}[$ [Eng] & & & & n. 09 & n. 09 & n. 09 & n. 09 & n. 09 & n. 05 & n. 05 & n. 05 & n. 05 & n. 05 & n. 05 & n. 05 & n. 09 & n. 09 & & & & & $?$ & \\
\hline Alberto Hipolito de M. van Langendonck [Eng] & & & & $?$ & $?$ & $?$ & $?$ & $?$ & $1 ?$ & $?$ & $?$ & $?$ & $?$ & $?$ & ? & $?$ & $?$ & $?$ & $?$ & & & 1 & \\
\hline Pedro Bento José Gravina $(1915)^{* 1}[$ [Eng] & & & & n. 11 & n. 11 & n. 11 & n. 11 & n. 11 & n. 08 & n. 08 & n. 08 & n. 08 & n. 08 & n. 08 & n. 08 & n. 08 & n. 11 & n. 11 & n. 11 & n. 11 & & ! & \\
\hline Paulo Sampaio Wilken (1910-1995) (F.S.P) [Eng] & & & & n. 07 & n. 07 & n. 07 & n. 07 & n. 07 & I n. 10 & n. 10 & n. 10 & n. 10 & n. 10 & ก. 10 & I n. 10 & n. $10 / 08$ & n. 08 & n. 08 & n. 08 & n. 08 & n. 08 & I & ? \\
\hline Giovanni Ponti (1891-1979) [Ara] & & & & & $?$ & & & & I & & & & & & a: & & & & & & & ! & \\
\hline Vicente Larocca (1892-1964) [Art] & & & & & n. 30 & ก. 30 & & & i & & & & & & i: & & & & & & & 1 & \\
\hline Dante Jorge de Albuquerque [Art] & & & & & $?$ & $?$ & $?$ & & I & & & & & & : & & & & & & & i & \\
\hline Leopoldino Wilson Paganelli [Eng] & & & & & n. 15 & n. 15 & n. 15 & & 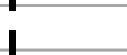 & & & & & & : & & & & & & & 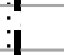 & \\
\hline Miguel Badra Júnior (1919) [Arq] & & & & & n. 15 & n. 15 & n. 15 & & & & & & & & 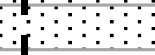 & & & & & & & 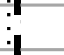 & \\
\hline Bassano Vaccarini (1914-2002) [Art] & & & & & ก. 30 & n. 30 & ก. 30 & ก. 30 & & & & & & & & & & & & & & 1 & \\
\hline Plinio Croce (1921-1984) [Arq] & & & & & ก. 30 & ก. 30 & ก. 30 & ก. 30 & n. 18 & ก. 18 & ก. 18 & n. 18 & ก. 18 & n. 18 & ก. 18 & ก. 18 & ? & ? & ? & & & $?$ & \\
\hline Lourival Gomes Machado (1917-1967) [O] & & & & & n. 21 & n. 21 & & & 1 & & & & 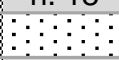 & 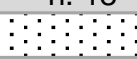 & 1 & & & & & & & 1 & \\
\hline Victor Froilano Bachmann de Mello (1926-2009) [Eng] & & & & & n. 10 & n. 10 & ก. 10 & n. 10 & n. 09 & ก. 09 & ก. 09 & ก. 09 & n. 09 & n. 09 & n. 09 & ก. 061 & ก. 061 & ก. 061 & ก. 061 & n. 26 & ก. 11? & I & ? \\
\hline Roberto Coelho Cardoso (1923) [Ara] & & & & & n. 20 & n. 20 & n. 20 & n. 20 & I n. 28 & n. 28 & n. 28 & n. 28 & n. 28 & n. 28 & n. 28 & n. $28 / 18 \mathrm{n}$ & n. $28 / 18$ & n. 18 & n. 18 & n. 18 & n. 18 & I & ? \\
\hline Milton Carlos Ghiraldini (1924-1976) [Arq] & & & & & n.19 & n.19 & n.19 & ก. 19 & n. 23 & n. 23 & n. 23 & n. 23 & n. 23 & ก. 23 & I n. 23 & n. $23 \mathrm{n}$ & n. $23 / 19$ & n. 19 & n. 19 & n. 19 & ก. 19 & I & ? \\
\hline Klaus Reinach [Eng] & & & & & & $?$ & & & I & & & & (6) & 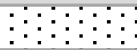 & : & & & $\cdots$ & & & & 1 & \\
\hline Enoch da Rocha Lima [Arq] & & & & & & $?$ & ? & ? & 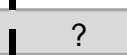 & n. 13 & n. 13 & n. 13 & n. 13 & & i: & & & & & & & i & \\
\hline Paulo Sampaio Goes [Eng] & & & & & & $?$ & $?$ & $?$ & ? & $?$ & $?$ & $?$ & $?$ & $?$ & t & ? & $?$ & $?$ & $?$ & & & 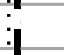 & \\
\hline Jorge Polacco [Eng] & & & & & & & $?$ & & & & & & & & 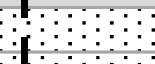 & & & & & & & 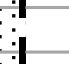 & \\
\hline Alvaro Marchi (Filosofia, dep. Estatística) [O] & & & & & & & n. 12 & ก. 12 & & & & & & & I: & & & & & & & 1 & \\
\hline Olga Elisabeth Magda H. Nobiling Schoenfeldt (1902-1975) [Art] & & & & & & & ก. 30 & ก. 30 & & & & & & & $1:$ & & & & & & & & \\
\hline Oswaldo Correa Gonçalves (1917-2005) [Arq] & & & & & & & n. 17 & ก. 17 & $1 ? ?$ & $?$ & & & & & t: & & & & & & & 1 & \\
\hline Daisy Ruth Igel Hoffemberg [Arq] & & & & & & & n. 20 & ก. 20 & I n. 28 & ก. 28 & & & & & i: & & & & & & & 1 & \\
\hline Manoel da Silva Machado [Arq] & & & & & & & n. 16 & ก. 16 & I n. 16 & ก. 16 & & & & & t: & & & & & & & I & \\
\hline Paulo Novack Filho [Eng] & & & & & & & n. 05 & n. 05 & n. 06 & n. 06 & n. 06 & ก. 06 & & & : & & & & & & & 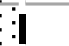 & \\
\hline Rino Levi (1901-1965) [Arq] & & & & & & & n. 17 & n. 17 & n. 19 & n. 19 & n. 19 & n. 19 & & & $i$ & & & & & & & 1 & \\
\hline Mario Wagner Vieira da Cunha $(1912-2003)[0]$ & & & & & & & n. 12 & n. 12 & n. 12 & n. 12 & n. 12 & n. 12 & n. 12 & : & i: & & & & & & & 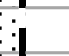 & \\
\hline Jacob Mauricio Ruchti (1917-1974) [Arq] & & & & & & & ก. 29 & ก. 29 & n. 22 & n. 22 & ก. 22 & ก. 22 & n. 22 & ก. 22 & : & & & & & & & & \\
\hline Roberto Cerqueira César (1917-2003) [Arq] & & & & & & & n. 17 & ก. 17 & n. 19 & n. 19 & n. 18 & n. 18 & n. 18 & n. 18 & ก. 18 & ก. 18 & ก. 16 & n. 16 & ก. 16 & $\because \because$ & & 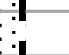 & \\
\hline José Carlos de Figueiredo Ferraz $(1918-1994)^{\star \star}[\mathrm{Eng}]$ & & & & & & & $?$ & $?$ & ก. 07 & n. 07 & n. 07 & n. 07 & n. 07 & n. 07 & n. 07 & n. 07 & n. 10 & n. 10 & n. 10 & n. 10 & n. 10 & & ? \\
\hline Juarez Rubens Brandão Lopes $(1925-2011)[\mathrm{O}]$ & & & & & & & n. 12 & ก. 12 & n. 12 & n. 12 & ก. 12 & n. 12 & n. 12 & n. 12 & n. $12 / 25$ & $5 n .12 / 25 n$ & n. $12 / 25$ & n. 25 & n. 25 & n. 25 & n. 25 & I & $?$ \\
\hline Flávio Lichtenfels Motta (1923) [O] & & & & & & & n. 21 & n. 21 & I n. 15 & n. 15 & n. 15 & n. 15 & n. 15 & n. $15 / 20$ & ${ }_{0} \ln _{\text {n. } 15 / 20}$ & n. $15 / 20$ & n. 20 & n. 20 & n. 20 & n. 20 & n.20 & & $?$ \\
\hline Carlos Alberto Cerqueira Lemos (1925) [Arq] & & & & & & & n. 15 & ก. 15 & n. 14 & n. 14 & ก. 14 & ก. 14 & n. 14 & ก. 14 & $1 ?$ & $?$ & $?$ & ก. 24 & n. 24 & n. 24 & ก. 24 & $\mathrm{~T}$ & ? \\
\hline Carlos Rodrigues Ladeira [Eng] & & & & & & & & $?$ & I & & & & & & t: & & & & & & & I & \\
\hline Achilina Bo Bardi (1914-1992) [Arq] & & & & & & & & ก. 29 & n. 22 & & & & & & : : & & & & & $\cdots$ & & i & \\
\hline Eduardo Kneese de Mello (1906-1994) [Ara] & & & & & & & & n. 18 & n. 20 & n. 20 & n. 20 & n. 20 & ก. 20 & n. 20 & n. 20 & $?$ & n. 23 & n. 23 & n. 23 & n. 23 & n. 23 & & $?$ \\
\hline Jon Andoni V. Maitrejean (1929) [Arq] & & & & & & & & ก. 17 & n. 19 & $?$ & $?$ & $?$ & $?$ & $?$ & ? & ? & $?$ & $?$ & $?$ & $?$ & ? & 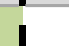 & \\
\hline Luiz Gastão de Castro Lima (1927-2003) [Arq] & & & & & & & & & n. 22 & ก. 22 & ก. 22 & ก. 22 & n. 22 & ก. 22 & ก. 22 & n. 133 & n. 133 & n. 133 & n. 133 & n. 133 & n. 133 & & $?$ \\
\hline & & & Diretor & & & & & & & \multirow{4}{*}{\multicolumn{3}{|c|}{$\begin{array}{l}\text { Regente de cátedra } \\
\text { Assistente } \\
\text { Instrutor } \\
\text { Sem dados }\end{array}$}} & & I & I reformas & Irriculares & & & \multirow[t]{4}{*}{ período } & a produçãã & do edific & cio de & a FAU \\
\hline \multirow[t]{3}{*}{${ }_{2}^{2}$ Professordo curso de Engenheiro-Arquiteto da EP } & & & Profess & catedrátic & & & & & & & & & & I & I & & & & & & & & \\
\hline & & & Livre do & & & & & & & & & & & I & I & & & & & & & & \\
\hline & & & Profess & contratac & (interino & u precáric & & & & & & & & I & I & & & & & & & & \\
\hline
\end{tabular}

(Ar) Arista

[O] Outro 


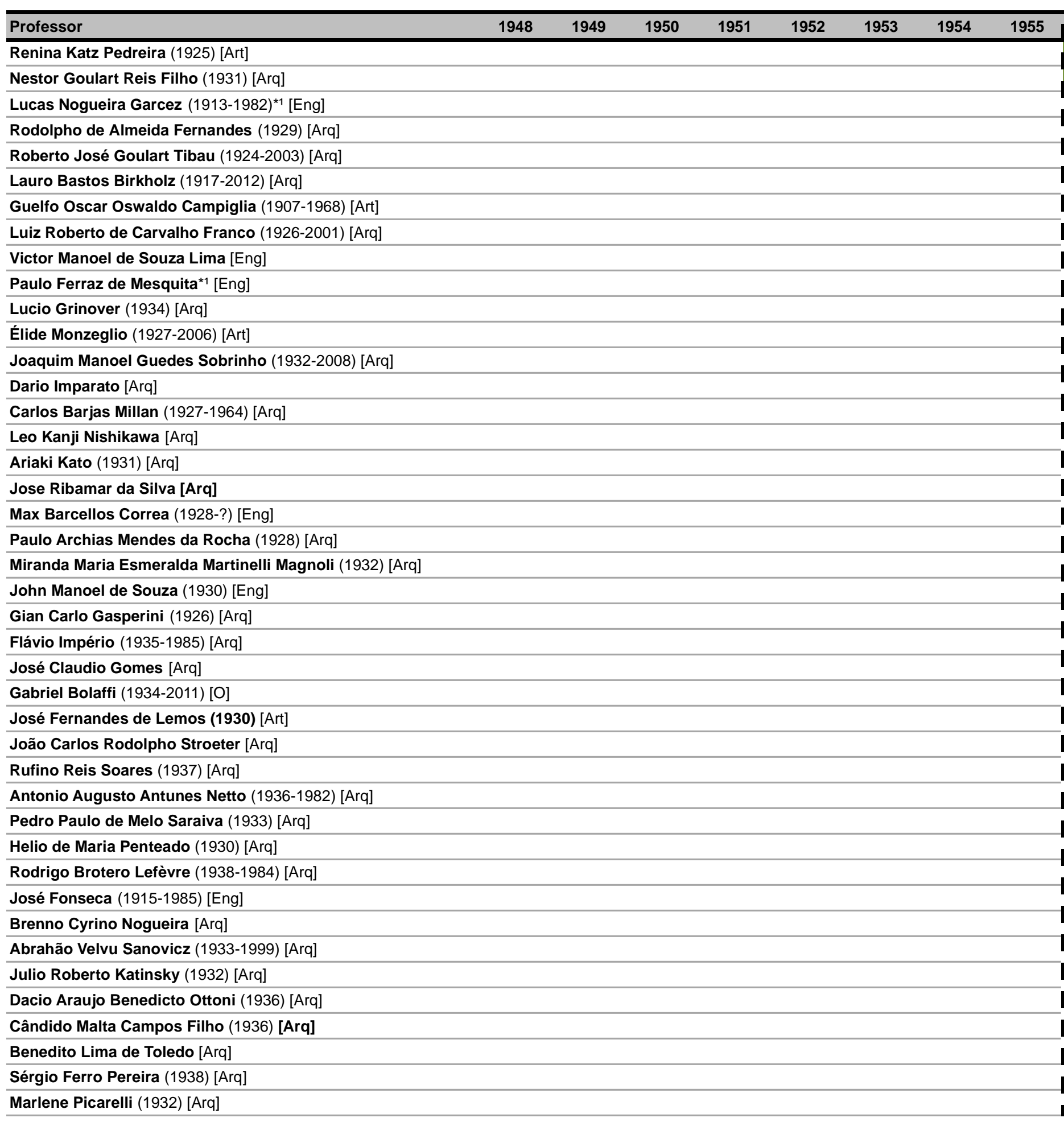

*1 Professor da Escola Politécnica (EP)

*2 Professordo curso de Engenheiro-Arquiteto da EP

[Arq] Arquiteto

[Art] Artista

[Eng] Engenheiro

[O] Outro \begin{tabular}{|llll|lllllllllll|}
\hline 1956 & 1957 & 1958 & 1959 & 1960 & 1961 & 1962 & 1963 & 1964 & 1965 & 1966 & 1967 & 1968 & 1969 \\
\hline
\end{tabular}

\begin{tabular}{cccc|cc|ccccccc|c|}
\hline n. 17 & n. 17 & n. 17 & n. 17 & n. 17 & n. 17 & n. 122 & n. 122 & n. 122 & n. 122 & n. 122 & n. 122 & n. 122 & ? \\
n. 20 & n. 20 & n. 20 & n. 20 & n. 20 & n. 20 & n. 20 & n. 22 & n. 22 & n. 22 & n. 22 & n. 22 & n. 22 & ?
\end{tabular}
\begin{tabular}{llllll|llllll} 
n. 10 & n. 10 & n. 10 & n. 10 & n. 10 & n. 10 & n. $10 / 08$ & n. 08 & n. 08 & n. 08 & $\vdots$ \\
\hline
\end{tabular}

$\begin{array}{llllllllllllll}\text { n. } 28 & \text { n. } 28 & \text { n. } 28 & \text { n. } 28 & \text { n. } 28 & \text { n. } 28 & \text { n. } 28 / 18 & \text { n. } 28 / 18 & \text { n. } 18 & \text { n. } 18 & \text { n. } 18 & \text { n. } 18 & \text { ? }\end{array}$ \begin{tabular}{lll|llllllll} 
n. 23 & n. 23 & n. 23 & n. 23 & n. 23 & n. 23 & n. 23 & n. $23 / 19$ & n. 19 & n. 19 & n.
\end{tabular}

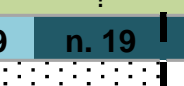

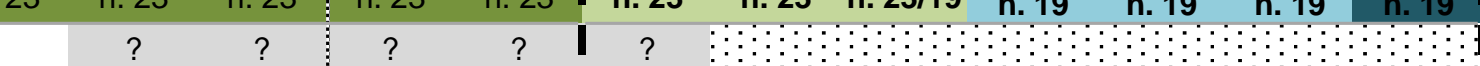
\begin{tabular}{ll|llllllllll|} 
n. 18 & n. 18 & n. 18 & n. 18 & n. 18 & n. 18 & n. 134 & n. 134 & n. 134 & n. 134 & n. 134 \\
\hline
\end{tabular} \begin{tabular}{ccc|ccccccccc|c|c}
\hline n. 11 & n. 11 & n. 06 & n. 06 & n. 06 & n. 07 & n. 07 & n. 07 & n. 07 & n. 07 & n. 07 & ? \\
\hline
\end{tabular}

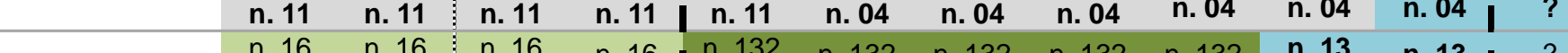
\begin{tabular}{|cc|ccccccccc|} 
n. 21 & n. 21 & n. 21 & n. $21 / 121$ & n. 121 & n. 121 & n. 121 & n. 121 & n. 121 & n. 121 & n. 121 \\
n. 05 & n. 05 & n. 05 & n. 05 & n. 05 & $?$ & $?$ & $?$ & $?$ & $?$
\end{tabular} \begin{tabular}{|llllllllll}
\hline & n. 18 & n. 05 & n. 05 & n. 05 & n. 05 & $?$ & $?$ & $?$ & $?$ \\
\hline
\end{tabular} \begin{tabular}{|c|c|ccccccccccc}
\hline & $?$ & $?$ & $?$ & I & $?$ & $?$ & $?$ & $?$ & $?$ & $?$ & $\vdots$ & l \\
\hline
\end{tabular}

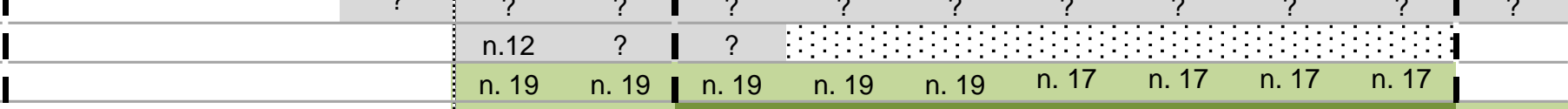

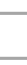

$\begin{array}{ccccccccc}\text { n. } 17 & \text { I. } 122 & \text { n. } 122 & \text { n. } 122 & \text { n. } 122 & \text { n. } 122 & \text { n. } 122 & \text { n. } 122 & \text { ? }\end{array}$ \begin{tabular}{lllllllll} 
n. 23 & n. 23 & n. 23 & n. $23 / 19$ & n. 19 & n. 19 & n. 19 & n. 19 \\
\hline & n. & n. $12 / 25$ & n. 12 & n. $12 / 25$ & n. 25 & n. 25 & n. 25 & n. 25
\end{tabular}

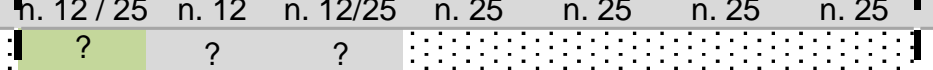
\begin{tabular}{cccccccc|c}
\hline & $?$ & $?$ & n. 134 & n. 134 & n. 134 & n. 134 & n. 134 & ? \\
\hline n. 08 & n. 08 & n. 08 & n. 08 & n. 08 & n. 08 & n. 08 & n. 08
\end{tabular} $\begin{array}{llllllll}\text { n. } 28 & \text { n. } 28 / 18 & \text { n. } 28 / 18 & \text { n. } 18 & \text { n. } 18 & \text { n. } 18 & \text { n. } 18\end{array}$ $\begin{array}{llllllll}\text { n. } 19 & \text { n. } 19 & \text { n. } 19 & \text { n. } 17 & \text { n. } 17 & \text { n. } 17 & \text { n. } 17\end{array}$ $\begin{array}{llllllll}\text { n. } 21 & \text { n. } 21 & \text { n. } 21 & \text { n. } 21 & \text { n. } 21 & \text { n. } 21 & \text { n. } 21 & \text { ? }\end{array}$ \begin{tabular}{llllllll}
\hline & n. 20 & n. 22 & n. 22 & n. 22 & n. 22 & ? ?
\end{tabular} $\begin{array}{llllllllll}1 & \text { n. } 09 & \text { n. } 09 & \text { n. } 09 & \text { n. } 09 & \text { n. } 09 & \text { n. } 09 & \text { n. } 09 & \text { ? }\end{array}$

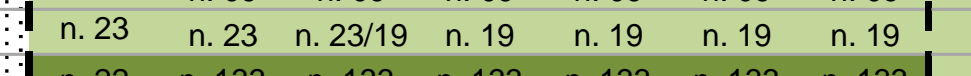

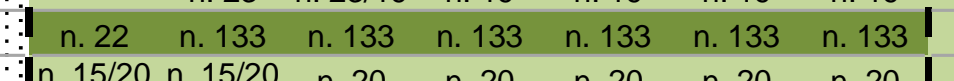

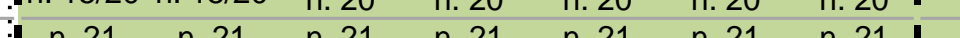

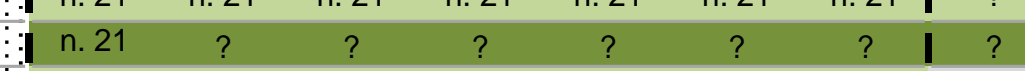

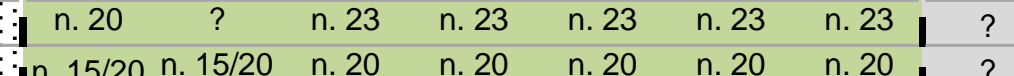
$\begin{array}{lllllllll}\text { n. } 15 / 20 & \text { n. } 15 / 20 & \text { n. } 20 & \text { n. } 20 & \text { n. } 20 & \text { n. } 20 & \text { n. } 20 & \text { ? } \\ \text { n. } 132 & \text { n. } 132 & \text { n. } 132 & \text { n. } 132 & \text { n. } 132 & \text { n. } 132 & \text { n. } 132 & \text { ? }\end{array}$ 
PROFESSORES DA FAU, CADEIRAS E TITULAÇÃO - CRONOLÓGICO

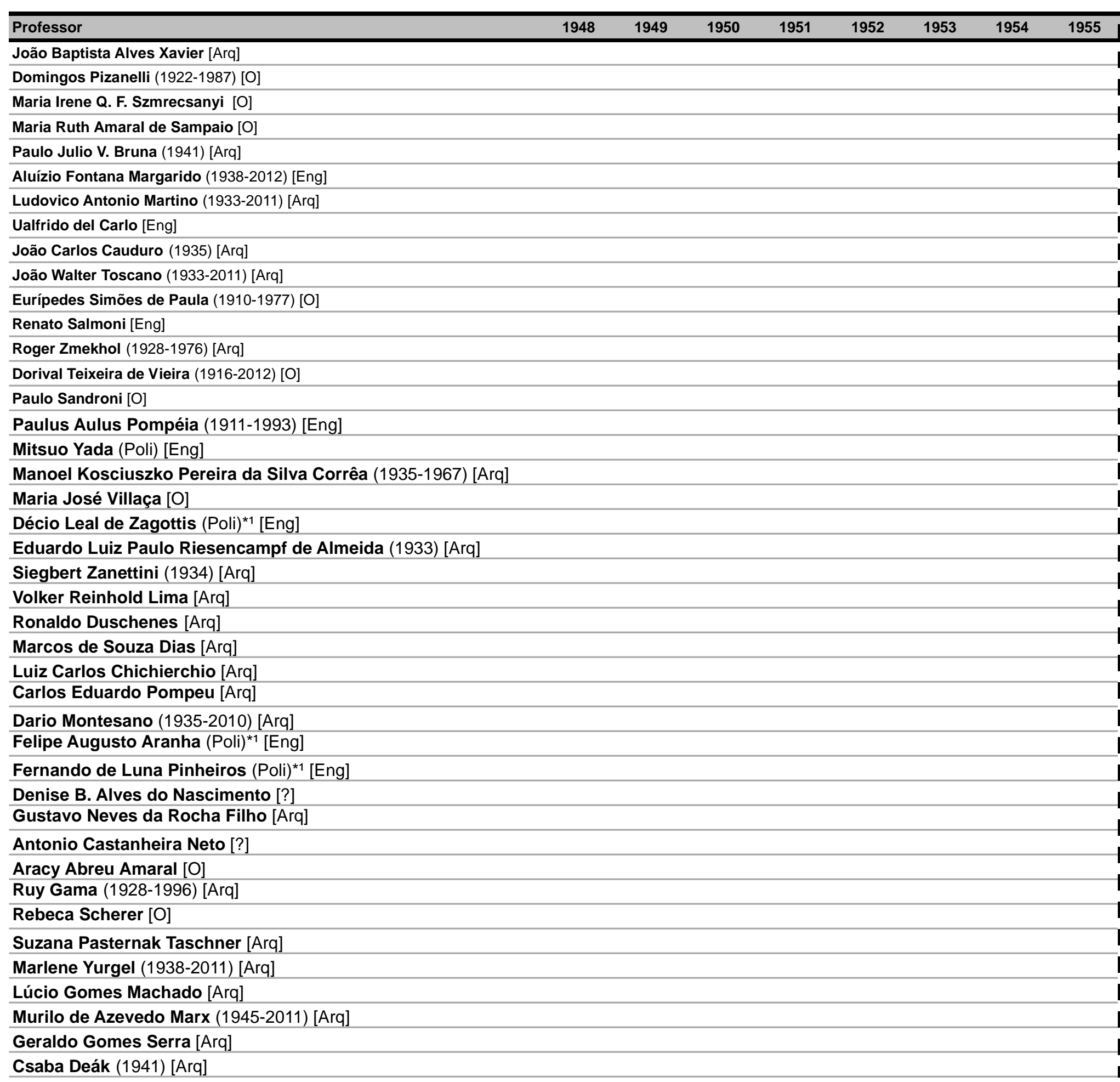

\section{* Professor da Escola Politécnica (EP)}

${ }^{*} 2$ Professordo curso de Engenheiro-Arquiteto da EP

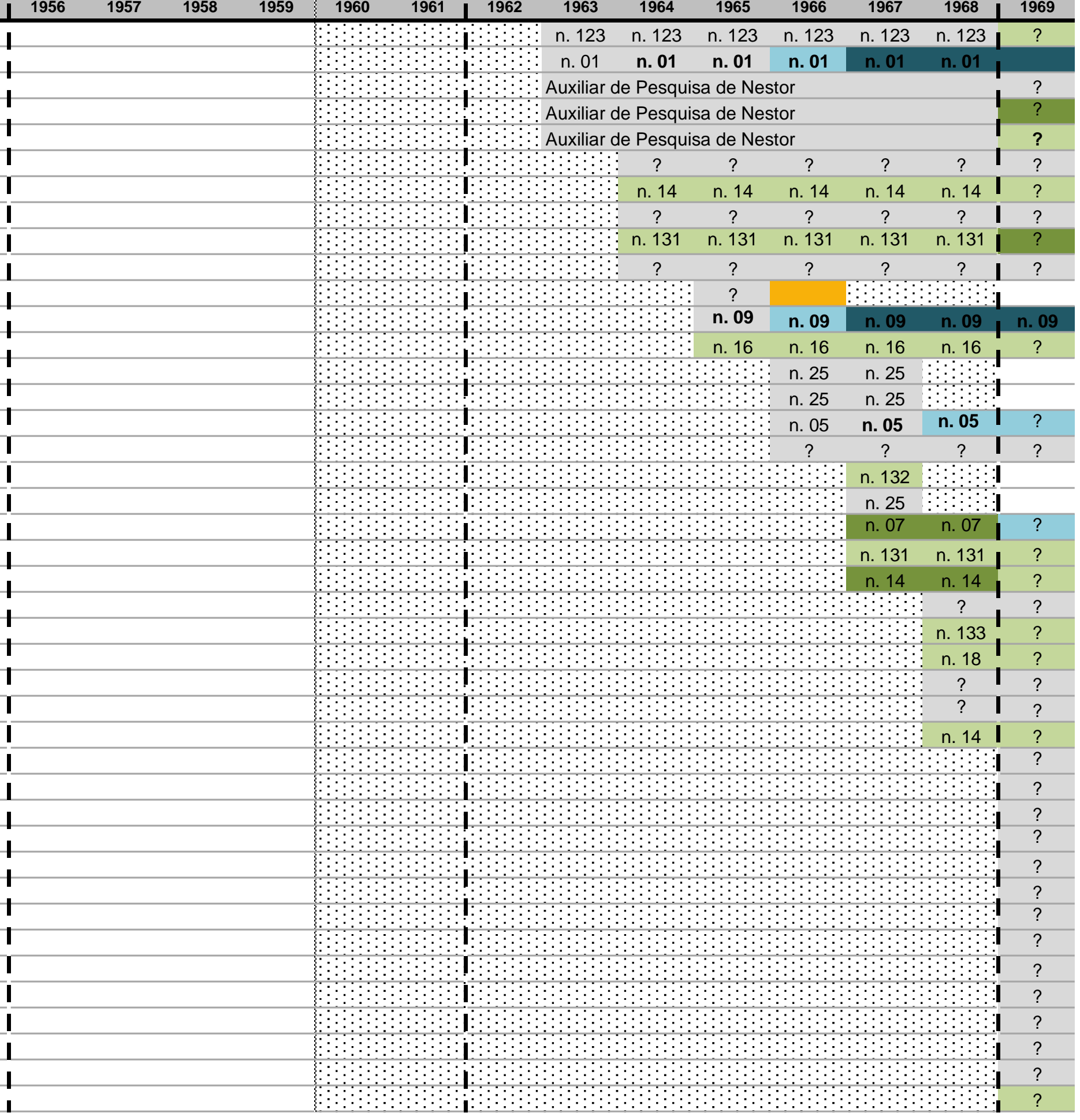

Regente de cátedra Assistente

Instrutor

Sem dados

I I I I I


ANEXO III

GRADE CURRICULAR DA FAU 



\begin{tabular}{|c|c|c|c|c|c|c|c|c|}
\hline & \multicolumn{8}{|c|}{1947} \\
\hline & \multicolumn{8}{|c|}{$1^{\circ}$ ano } \\
\hline Cadeira & \multicolumn{2}{|c|}{$\begin{array}{l}\text { Cálculo Diferencial e Integral. } \\
\text { Cálculo Vetorial }\end{array}$} & $\begin{array}{l}\text { Complementos } \\
\text { de Geometria } \\
\text { Analítica e } \\
\text { Projetiva }\end{array}$ & $\begin{array}{l}\text { Perspect., } \\
\text { Apl. Técn., } \\
\text { Geom. Proj. e } \\
\text { Noções de } \\
\text { Cálculo } \\
\text { Gráfico }\end{array}$ & $\begin{array}{l}\text { Topografia } \\
\text { Geodésica } \\
\text { Elementar e } \\
\text { Astronomia } \\
\text { de Campo }\end{array}$ & Física & $\begin{array}{l}\text { Desenho de } \\
\text { Perspectiva e } \\
\text { de } \\
\text { Arquitetura }\end{array}$ & \\
\hline Regente & \multicolumn{2}{|c|}{ José O. M. de Camargo } & $\begin{array}{l}\text { Giacomo } \\
\text { Albanese }\end{array}$ & $\begin{array}{l}\text { Pedro M. do } \\
\text { Amaral Cruz } \\
\text { (interino de } \\
\text { Alcides M. } \\
\text { Barbosa) }\end{array}$ & $\begin{array}{l}\text { Henrique J. } \\
\text { Guedes }\end{array}$ & $\begin{array}{l}\text { Luiz Cintra do } \\
\text { Prado }\end{array}$ & $\begin{array}{l}\text { José M. S. } \\
\text { Neves }\end{array}$ & \\
\hline Disciplina & $\begin{array}{l}\text { Cálculo } \\
\text { Vetorial I }\end{array}$ & $\begin{array}{l}\text { Cálculo } \\
\text { Gráfico e } \\
\text { Mecânico. } \\
\text { Nomografia I }\end{array}$ & --- & Parte 1 & --- & Física I & $\begin{array}{l}\text { Desenho } \\
\text { Arquitetônico } \\
\text { e Esboço } \\
\text { Natural } \\
\end{array}$ & \\
\hline \multirow[t]{2}{*}{ Prof. } & --- & --- & $\begin{array}{l}\text { Pedro B. de } \\
\text { Camargo }\end{array}$ & --- & --- & --- & --- & \\
\hline & \multicolumn{8}{|c|}{$2^{\circ}$ ano } \\
\hline Cadeira & $\begin{array}{l}\text { Mecânica } \\
\text { Racional }\end{array}$ & Física & $\begin{array}{l}\text { Química Geral } \\
\text { Tecnológica I }\end{array}$ & $\begin{array}{l}\text { Perspect., } \\
\text { Apl. Técn., } \\
\text { Geom. Proj. e } \\
\text { Noções de } \\
\text { Cálculo } \\
\text { Gráfico }\end{array}$ & $\begin{array}{l}\text { Cálculo } \\
\text { Diferencial e } \\
\text { Integral. } \\
\text { Cálculo } \\
\text { Vetorial }\end{array}$ & $\begin{array}{l}\text { Desenho de } \\
\text { Perspectiva e } \\
\text { de } \\
\text { Arquitetura }\end{array}$ & $\begin{array}{l}\text { Desenho } \\
\text { Topográfico }\end{array}$ & \\
\hline Regente & $\begin{array}{l}\text { Paulo A.C. de } \\
\text { Brito }\end{array}$ & $\begin{array}{l}\text { Luiz Cintra do } \\
\text { Prado }\end{array}$ & $\begin{array}{l}\text { Theoduretto de } \\
\text { A. Souto }\end{array}$ & $\begin{array}{l}\text { Pedro M. do } \\
\text { Amaral Cruz } \\
\text { (interino de } \\
\text { Alcides M. } \\
\text { Barbosa) }\end{array}$ & $\begin{array}{l}\text { José O. M. de } \\
\text { Camargo }\end{array}$ & $\begin{array}{l}\text { José M. S. } \\
\text { Neves }\end{array}$ & $\begin{array}{l}\text { Vicente } \\
\text { Azevedo }\end{array}$ & \\
\hline Disciplina & --- & Física II & --- & Parte 2 & $\begin{array}{l}\text { Cálculo } \\
\text { Vetorial II }\end{array}$ & $\begin{array}{l}\text { Desenho de } \\
\text { Perspectiva I }\end{array}$ & --- & \\
\hline \multirow[t]{2}{*}{ Prof. } & --- & --- & --- & --- & $\begin{array}{l}-- \\
\end{array}$ & $\begin{array}{l}-- \\
--\end{array}$ & $\begin{array}{l}\text { John S. } \\
\text { Addison }\end{array}$ & \\
\hline & \multicolumn{8}{|c|}{$3 \circ$ ano } \\
\hline Cadeira & $\begin{array}{l}\text { Resistência } \\
\text { dos Materiais. } \\
\text { Estabilidade } \\
\text { das } \\
\text { Construções }\end{array}$ & $\begin{array}{l}\text { Tecnologia } \\
\text { Civil. Mat. de } \\
\text { Construção. } \\
\text { Fundaçôes }\end{array}$ & $\begin{array}{l}\text { Mineralogia, } \\
\text { Geologia e } \\
\text { Petrografia }\end{array}$ & --- & $\begin{array}{l}\text { Hidráulica. } \\
\text { Hidráulica } \\
\text { Urbana e } \\
\text { Saneamento }\end{array}$ & $\begin{array}{l}\text { Desenho de } \\
\text { Perspectiva e } \\
\text { de } \\
\text { Arquitetura }\end{array}$ & $\begin{array}{l}\text { Composição } \\
\text { Decorativa. } \\
\text { Modelagem }\end{array}$ & \\
\hline Regente & $\begin{array}{l}\text { Telêmaco H. } \\
\text { M. van } \\
\text { Langenlonck }\end{array}$ & Ary F. Torres & $\begin{array}{l}\text { Octavio } \\
\text { Barbosa }\end{array}$ & $\begin{array}{l}\text { Luiz I. R. de } \\
\text { Anhaia Mello }\end{array}$ & $\begin{array}{l}\text { Lucas N. } \\
\text { Garcez }\end{array}$ & $\begin{array}{l}\text { José M. S. } \\
\text { Neves }\end{array}$ & $\begin{array}{l}\text { Felisberto } \\
\text { Ranzini }\end{array}$ & \\
\hline Disciplina & $\begin{array}{l}\text { Resistência e } \\
\text { Estabilidade I }\end{array}$ & $\begin{array}{l}\text { Materiais de } \\
\text { Construção I }\end{array}$ & --- & $\begin{array}{l}\text { Composição } \\
\text { Geral I e } \\
\text { Estética }\end{array}$ & Parte 1 & $\begin{array}{l}\text { Desenho de } \\
\text { Perspectiva II }\end{array}$ & --- & \\
\hline \multirow[t]{2}{*}{ Prof. } & $\begin{array}{l}\text { Fernando J. O. } \\
\text { Escorel / } \\
\text { Jayme F. da } \\
\text { Silva Jr. / José } \\
\text { C. Figueiredo } \\
\text { Ferraz }\end{array}$ & John Burke Jr. & $\begin{array}{l}\text { Fernando F. M. } \\
\text { de Almeida / } \\
\text { José C. } \\
\text { Rodrigues }\end{array}$ & $\begin{array}{l}\text { João B. } \\
\text { Vilanova } \\
\text { Artigas / } \\
\text { Zenon Lotufo }\end{array}$ & $\begin{array}{l}\text { Octacílio S. } \\
\text { Sene }\end{array}$ & --- & $\begin{array}{l}\text { Caetano } \\
\text { Fraccaroli }\end{array}$ & \\
\hline & \multicolumn{8}{|c|}{$4^{\circ}$ ano } \\
\hline Cadeira & $\begin{array}{l}\text { Resistência } \\
\text { dos Materiais, } \\
\text { Estabilidade } \\
\text { das } \\
\text { Construções }\end{array}$ & --- & \multicolumn{2}{|c|}{$\begin{array}{l}\text { Noções de Arquitetura e } \\
\text { Construções Civis. Higiene das } \\
\text { Habitações e História da } \\
\text { Arquitetura I e II }\end{array}$} & $\begin{array}{l}\text { Composição } \\
\text { Decorativa. } \\
\text { Modelagem }\end{array}$ & & & \\
\hline Regente & $\begin{array}{l}\text { Telêmaco H. } \\
\text { M. van } \\
\text { Langenlonck }\end{array}$ & $\begin{array}{l}\text { Luiz I. R. de } \\
\text { Anhaia Mello }\end{array}$ & \multicolumn{2}{|l|}{ Bruno S. Magro } & $\begin{array}{l}\text { Felisberto } \\
\text { Ranzini }\end{array}$ & & & \\
\hline Disciplina & $\begin{array}{l}\text { Resistência e } \\
\text { Estabilidade II }\end{array}$ & $\begin{array}{l}\text { Composição } \\
\text { Geral II e } \\
\text { Estética }\end{array}$ & \multicolumn{2}{|c|}{ História da arquitetura I e II } & --- & & & \\
\hline \multirow[t]{2}{*}{ Prof. } & $\begin{array}{l}\text { Fernando J. O. } \\
\text { Escorel / } \\
\text { Jayme F. da } \\
\text { Silva Jr. / José } \\
\text { C. F. Ferraz }\end{array}$ & $\begin{array}{l}\text { João } \\
\text { B.Vilanova } \\
\text { Artigas / } \\
\text { Zenon Lotufo }\end{array}$ & Ariosto Mila & --- & $\begin{array}{l}\text { Caetano } \\
\text { Fraccaroli }\end{array}$ & & & \\
\hline & \multicolumn{8}{|c|}{$5^{\circ}$ ano } \\
\hline Cadeira & --- & $\begin{array}{l}\text { Concreto } \\
\text { Simples e } \\
\text { Armado }\end{array}$ & $\begin{array}{l}\text { Hidráulica. } \\
\text { Hidráulica } \\
\text { Urbana e } \\
\text { Saneamento }\end{array}$ & $\begin{array}{l}\text { Economia } \\
\text { Política, } \\
\text { Estatística } \\
\text { Apl., Org. } \\
\text { Adm. }\end{array}$ & --- & $\begin{array}{l}\text { Composição } \\
\text { Decorativa. } \\
\text { Modelagem }\end{array}$ & & \\
\hline Regente & $\begin{array}{l}\text { Luiz I. de } \\
\text { Anhaia Mello }\end{array}$ & Nilo A. Amaral & $\begin{array}{l}\text { Lucas N. } \\
\text { Garcez }\end{array}$ & $\begin{array}{l}\text { Carlos A. } \\
\text { Vanzolini }\end{array}$ & $\begin{array}{l}\text { Américo O. } \\
\text { Campilia }\end{array}$ & $\begin{array}{l}\text { Felisberto } \\
\text { Ranzini }\end{array}$ & & \\
\hline Disciplina & $\begin{array}{l}\text { Composição } \\
\text { Geral III e } \\
\text { Urbanismo }\end{array}$ & $--\cdot$ & Parte 2 & --- & Contabilidade & --- & & \\
\hline Prof. & $\begin{array}{l}\text { João B. } \\
\text { Vilanova } \\
\text { Artigas / } \\
\text { Zenon Lotufo }\end{array}$ & $\begin{array}{l}\text { Eduardo C. } \\
\text { Rodrigues }\end{array}$ & $\begin{array}{l}\text { Octacílio S. } \\
\text { Sene }\end{array}$ & --- & --- & $\begin{array}{l}\text { Caetano } \\
\text { Fraccaroli }\end{array}$ & & \\
\hline
\end{tabular}




\begin{tabular}{|l|l|l|l|l|l|l|l|l|}
\hline \multicolumn{2}{|c|}{1948} \\
\hline Cadeira & $\begin{array}{l}\text { 1. Matemática } \\
\text { Superior }\end{array}$ & $\begin{array}{l}\text { 2. Geometria } \\
\text { Descritiva }\end{array}$ & $\begin{array}{l}\text { 14. Arquitetura } \\
\text { Analítica }\end{array}$ & $\begin{array}{l}\text { 16. Pequenas } \\
\text { Composicões } \\
\text { de Arquitetura }\end{array}$ & 26. Nomografia & $\begin{array}{l}\text { 28. Desenho } \\
\text { Artístico }\end{array}$ & 30. Plástica & \\
\hline Regente & $\begin{array}{l}\text { João A. Breves } \\
\text { Filho }\end{array}$ & $\begin{array}{l}\text { Pedro M. do } \\
\text { Amaral Cruz }\end{array}$ & Bruno S. Magro & $\begin{array}{l}\text { João B. Vilanova } \\
\text { Artigas }\end{array}$ & Eurico Cerruti & $\begin{array}{l}\text { José M. S. } \\
\text { Neves }\end{array}$ & $\begin{array}{l}\text { Felisberto } \\
\text { Ranzini }\end{array}$ & \\
\hline Disciplina & --- & ----- & $\begin{array}{l}\text { Pequenas } \\
\text { Composições I }\end{array}$ & --- & $\begin{array}{l}\text { Desenho } \\
\text { Artístico I }\end{array}$ & Plástica I & \\
\hline Prof. & $\begin{array}{l}\text { Nelson da S. } \\
\text { Leme (?) }\end{array}$ & $\begin{array}{l}\text { Guilherme do } \\
\text { A. Lyra }\end{array}$ & Ariosto Mila (?) & $\begin{array}{l}\text { Abelardo R. de } \\
\text { Souza }\end{array}$ & $-\cdots$ & --- & --- & \\
\hline
\end{tabular}




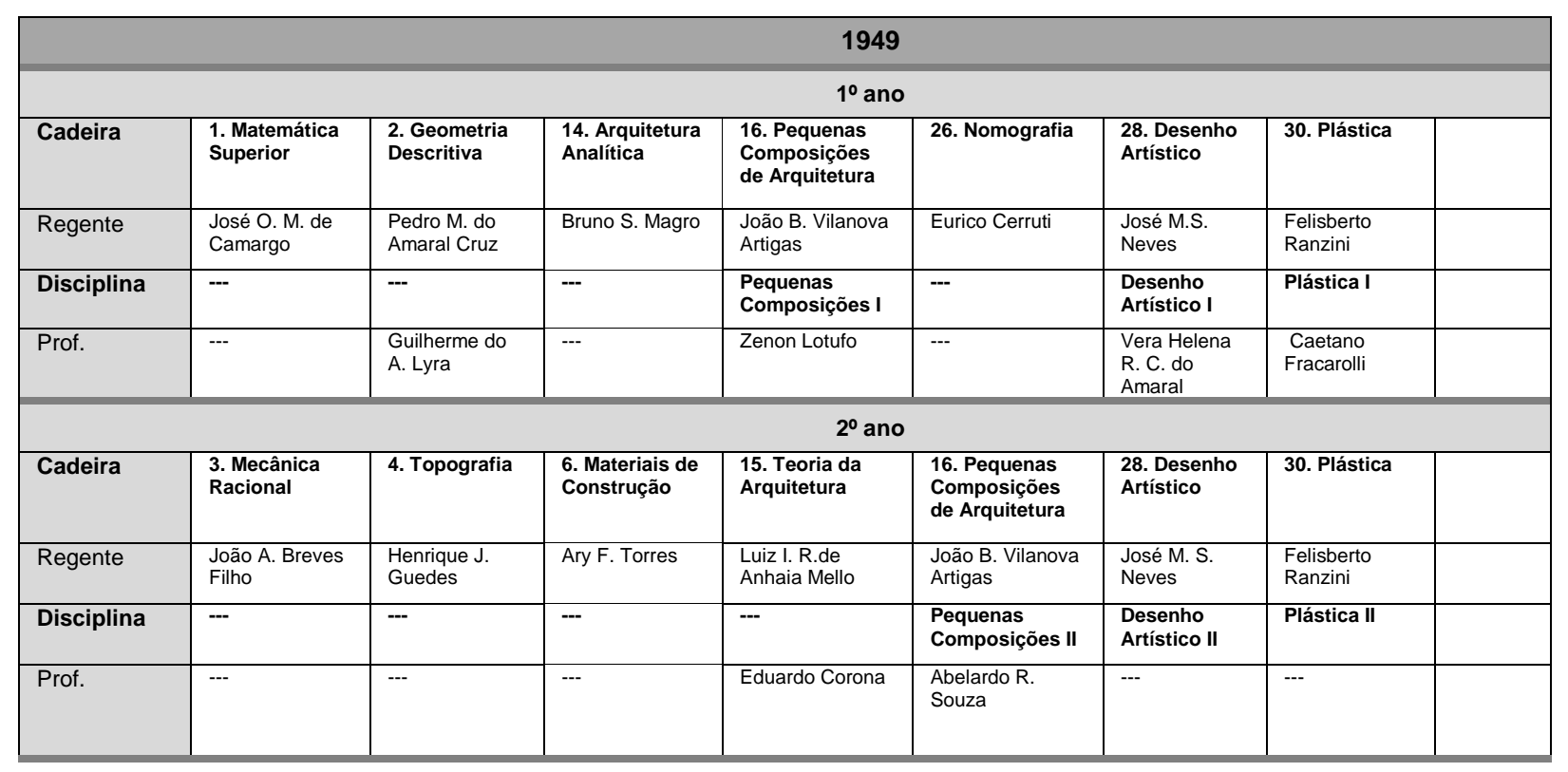




\begin{tabular}{|c|c|c|c|c|c|c|c|c|}
\hline & \multicolumn{8}{|c|}{1950} \\
\hline & \multicolumn{8}{|c|}{$1{ }^{\circ}$ ano } \\
\hline Cadeira & $\begin{array}{l}\text { 1. Matemática } \\
\text { Superior }\end{array}$ & $\begin{array}{l}\text { 2. Geometria } \\
\text { Descritiva }\end{array}$ & $\begin{array}{l}14 . \\
\text { Arquitetura } \\
\text { Analítica }\end{array}$ & $\begin{array}{l}\text { 16. Pequenas } \\
\text { Composições } \\
\text { de Arquitetura }\end{array}$ & 26. Nomografia & $\begin{array}{l}\text { 28. Desenho } \\
\text { Artístico }\end{array}$ & 30. Plástica & \\
\hline Regente & $\begin{array}{l}\text { José O. M. de } \\
\text { Camargo }\end{array}$ & $\begin{array}{l}\text { Pedro M. do } \\
\text { Amaral Cruz }\end{array}$ & $\begin{array}{l}\text { Bruno S. } \\
\text { Magro }\end{array}$ & $\begin{array}{l}\text { João B. Vilanova } \\
\text { Artigas }\end{array}$ & Eurico Cerruti & $\begin{array}{l}\text { Vera Helena R. } \\
\text { C. do Amaral }\end{array}$ & $\begin{array}{l}\text { Caetano } \\
\text { Fracarolli }\end{array}$ & \\
\hline Disciplina & --- & --- & --- & $\begin{array}{l}\text { Pequenas } \\
\text { Composições I }\end{array}$ & --- & $\begin{array}{l}\text { Desenho } \\
\text { Artístico I }\end{array}$ & Plástica I & \\
\hline Prof. & --- & $\begin{array}{l}\text { Guilherme do A. } \\
\text { Lyra }\end{array}$ & $\begin{array}{l}\text { Joaquim B. da } \\
\text { Silva }\end{array}$ & Zenon Lotufo & --- & --- & --- & \\
\hline \multicolumn{9}{|c|}{$2^{\circ}$ ano } \\
\hline Cadeira & $\begin{array}{l}\text { 3. Mecânica } \\
\text { Racional }\end{array}$ & 4. Topografia & $\begin{array}{l}\text { 6. Materiais de } \\
\text { Construção }\end{array}$ & $\begin{array}{l}\text { 15. Teoria da } \\
\text { Arquitetura }\end{array}$ & $\begin{array}{l}\text { 16. Pequenas } \\
\text { Composições } \\
\text { de Arquitetura }\end{array}$ & $\begin{array}{l}\text { 28. Desenho } \\
\text { Artístico }\end{array}$ & 30. Plástica & \\
\hline Regente & $\begin{array}{l}\text { João A. Breves } \\
\text { Filho }\end{array}$ & $\begin{array}{l}\text { Henrique J. } \\
\text { Guedes }\end{array}$ & Ary F. Torres & $\begin{array}{l}\text { Luiz I. R. de } \\
\text { Anhaia Mello }\end{array}$ & $\begin{array}{l}\text { João B. Vilanova } \\
\text { Artigas }\end{array}$ & $\begin{array}{l}\text { Vera Helena R. } \\
\text { C. do Amaral }\end{array}$ & $\begin{array}{l}\text { Felisberto } \\
\text { Ranzini }\end{array}$ & \\
\hline Disciplina & --- & --- & -- & -- & $\begin{array}{l}\text { Pequenas } \\
\text { Composições II }\end{array}$ & $\begin{array}{l}\text { Desenho } \\
\text { Artístico II }\end{array}$ & Plástica II & \\
\hline Prof. & --- & --- & --- & Eduardo Corona & $\begin{array}{l}\text { Abelardo R. de } \\
\text { Souza }\end{array}$ & --- & --- & \\
\hline \multicolumn{9}{|c|}{$3^{\circ}$ ano } \\
\hline Cadeira & $\begin{array}{l}\text { 5. Resistência } \\
\text { dos Materiais }\end{array}$ & $\begin{array}{l}\text { 8. Construções } \\
\text { Civis }\end{array}$ & $\begin{array}{l}\text { 10. Elementos } \\
\text { de Mecânica } \\
\text { dos Solos. } \\
\text { Fundações }\end{array}$ & $\begin{array}{l}\text { 13. Física } \\
\text { Aplicada }\end{array}$ & $\begin{array}{l}\text { 17. Grandes } \\
\text { Composições } \\
\text { de Arquitetura }\end{array}$ & $\begin{array}{l}29 . \\
\text { Composição } \\
\text { Decorativa }\end{array}$ & 30. Plástica & \\
\hline Regente & $\begin{array}{l}\text { Telêmaco H. M. } \\
\text { van } \\
\text { Langenlonck }\end{array}$ & Ariosto Mila & Odair Grillo & $\begin{array}{l}\text { Luiz Cintra do } \\
\text { Prado }\end{array}$ & $\begin{array}{l}\text { Hélio de Q. } \\
\text { Duarte }\end{array}$ & $\begin{array}{l}\text { José M. S. } \\
\text { Neves }\end{array}$ & $\begin{array}{l}\text { Alcides R. } \\
\text { Miranda }\end{array}$ & \\
\hline Disciplina & $\cdots$ & --- & --- & -- & $\begin{array}{l}\text { Grandes } \\
\text { Composições I }\end{array}$ & $\begin{array}{l}\text { Composição } \\
\text { Decorativa I }\end{array}$ & Plástica III & \\
\hline Prof. & --- & --- & --- & --- & $\begin{array}{l}\text { Ícaro de Castro } \\
\text { Mello / Ernest R. } \\
\text { C. Mange }\end{array}$ & --- & Zanine Caldas & \\
\hline
\end{tabular}




\begin{tabular}{|c|c|c|c|c|c|c|c|c|}
\hline & \multicolumn{8}{|c|}{1951} \\
\hline & \multicolumn{8}{|c|}{$1^{\circ}$ ano } \\
\hline Cadeira & $\begin{array}{l}\text { 1. Matemática } \\
\text { Superior }\end{array}$ & $\begin{array}{l}\text { 2. Geometria } \\
\text { Descritiva }\end{array}$ & $\begin{array}{l}\text { 14. Arquitetura } \\
\text { Analítica }\end{array}$ & $\begin{array}{l}\text { 16. Pequenas } \\
\text { Composições } \\
\text { de Arquitetura }\end{array}$ & 26. Nomografia & $\begin{array}{l}\text { 28. Desenho } \\
\text { Artístico }\end{array}$ & 30. Plástica & \\
\hline Regente & $\begin{array}{l}\text { José O. M. de } \\
\text { Camargo }\end{array}$ & $\begin{array}{l}\text { Pedro M. do } \\
\text { Amaral Cruz }\end{array}$ & $\begin{array}{l}\text { Bruno S. } \\
\text { Magro }\end{array}$ & $\begin{array}{l}\text { João B. } \\
\text { Vilanova } \\
\text { Artigas }\end{array}$ & Eurico Cerruti & $\begin{array}{l}\text { Vera Helena R. } \\
\text { C. do Amaral }\end{array}$ & $\begin{array}{l}\text { Caetano } \\
\text { Fracarolli }\end{array}$ & \\
\hline Disciplina & --- & --- & --- & $\begin{array}{l}\text { Pequenas } \\
\text { Composições I }\end{array}$ & --- & $\begin{array}{l}\text { Desenho } \\
\text { Artístico I }\end{array}$ & Plástica I & \\
\hline \multirow[t]{2}{*}{ Prof. } & $\begin{array}{l}-- \\
\end{array}$ & $\begin{array}{l}\text { Guilherme do } \\
\text { A. Lyra }\end{array}$ & $\begin{array}{l}\text { Joaquim B. da } \\
\text { Silva }\end{array}$ & Zenon Lotufo & --- & --- & --- & \\
\hline & \multicolumn{8}{|c|}{$2^{\circ}$ ano } \\
\hline Cadeira & $\begin{array}{l}\text { 3. Mecânica } \\
\text { Racional }\end{array}$ & 4. Topografia & $\begin{array}{l}\text { 6. Materiais } \\
\text { de Construção }\end{array}$ & $\begin{array}{l}\text { 15. Teoria da } \\
\text { Arquitetura }\end{array}$ & $\begin{array}{l}\text { 16. Pequenas } \\
\text { Composições } \\
\text { de Arquitetura }\end{array}$ & $\begin{array}{l}\text { 28. Desenho } \\
\text { Artístico }\end{array}$ & 30. Plástica & \\
\hline Regente & $\begin{array}{l}\text { João A. Breves } \\
\text { Filho }\end{array}$ & $\begin{array}{l}\text { Henrique J. } \\
\text { Guedes }\end{array}$ & Ary F. Torres & $\begin{array}{l}\text { Luiz I. R. de } \\
\text { Anhaia Mello }\end{array}$ & $\begin{array}{l}\text { João B. } \\
\text { Vilanova } \\
\text { Artigas }\end{array}$ & $\begin{array}{l}\text { Vera Helena R. } \\
\text { C. do Amaral }\end{array}$ & $\begin{array}{l}\text { Felisberto } \\
\text { Ranzini }\end{array}$ & \\
\hline Disciplina & --- & --- & --- & $-\cdots$ & $\begin{array}{l}\text { Pequenas } \\
\text { Composições II }\end{array}$ & $\begin{array}{l}\text { Desenho } \\
\text { Artístico II }\end{array}$ & Plástica II & \\
\hline \multirow[t]{2}{*}{ Prof. } & --- & --- & --- & $\begin{array}{l}\text { Eduardo } \\
\text { Corona }\end{array}$ & $\begin{array}{l}\text { Abelardo R. de } \\
\text { Souza }\end{array}$ & $\begin{array}{l}\text { Arquimedes } \\
\text { Dutra }\end{array}$ & --- & \\
\hline & \multicolumn{8}{|c|}{$3 \circ$ ano } \\
\hline Cadeira & $\begin{array}{l}\text { 5. Resistência } \\
\text { dos Materiais }\end{array}$ & $\begin{array}{l}8 . \\
\text { Construções } \\
\text { Civis }\end{array}$ & $\begin{array}{l}10 . \\
\text { Elementos de } \\
\text { Mecânica dos } \\
\text { Solos. } \\
\text { Fundações }\end{array}$ & $\begin{array}{l}\text { 13. Física } \\
\text { Aplicada }\end{array}$ & $\begin{array}{l}\text { 17. Grandes } \\
\text { Composições } \\
\text { de Arquitetura }\end{array}$ & $\begin{array}{l}29 . \\
\text { Composição } \\
\text { Decorativa }\end{array}$ & 30. Plástica & \\
\hline Regente & $\begin{array}{l}\text { Telêmaco H. } \\
\text { M. van } \\
\text { Langenlonck }\end{array}$ & Ariosto Mila & Odair Grillo & $\begin{array}{l}\text { Luiz Cintra do } \\
\text { Prado }\end{array}$ & $\begin{array}{l}\text { Hélio de Q. } \\
\text { Duarte }\end{array}$ & $\begin{array}{l}\text { José M. S. } \\
\text { Neves }\end{array}$ & $\begin{array}{l}\text { Alcides R. } \\
\text { Miranda }\end{array}$ & \\
\hline Disciplina & --- & --- & --- & -- & $\begin{array}{l}\text { Grandes } \\
\text { Composições I }\end{array}$ & $\begin{array}{l}\text { Composição } \\
\text { Decorativa I }\end{array}$ & Plástica III & \\
\hline \multirow[t]{2}{*}{ Prof. } & --- & --- & --- & --- & $\begin{array}{l}\text { Ícaro de Castro } \\
\text { Mello }\end{array}$ & --- & Zanine Caldas & \\
\hline & \multicolumn{8}{|c|}{$4^{\circ}$ ano } \\
\hline Cadeira & $\begin{array}{l}\text { 7. Hidráulica e } \\
\text { Saneamento }\end{array}$ & $\begin{array}{l}\text { 9. Concreto } \\
\text { Simples e } \\
\text { Armado }\end{array}$ & $\begin{array}{l}\text { 11. Grandes } \\
\text { Estruturas }\end{array}$ & $\begin{array}{l}\text { 12. Economia } \\
\text { Política e } \\
\text { Estatística }\end{array}$ & $\begin{array}{l}\text { 17. Grandes } \\
\text { Composições } \\
\text { de Arquitetura }\end{array}$ & $\begin{array}{l}\text { 27. Legislação } \\
\text { e } \\
\text { Contabilidade }\end{array}$ & $\begin{array}{l}\text { 29. Composição } \\
\text { Decorativa }\end{array}$ & 30. Plástica \\
\hline Regente & $\begin{array}{l}\text { Lysandro M. } \\
\text { Pereira da } \\
\text { Silva }\end{array}$ & $\begin{array}{l}\text { Fernando J. O. } \\
\text { Escorel }\end{array}$ & $\begin{array}{l}\text { Pedro B. J. } \\
\text { Gravinha }\end{array}$ & $\begin{array}{l}\text { Carlos A. } \\
\text { Vanzolini }\end{array}$ & $\begin{array}{l}\text { Hélio de Q. } \\
\text { Duarte }\end{array}$ & $\begin{array}{l}\text { Americo O. } \\
\text { Campiglia }\end{array}$ & $\begin{array}{l}\text { José M. S. } \\
\text { Neves }\end{array}$ & $\begin{array}{l}\text { Alfredo } \\
\text { Oliani }\end{array}$ \\
\hline Disciplina & -- & --- & --- & --- & $\begin{array}{l}\text { Grandes } \\
\text { Composições II }\end{array}$ & --- & $\begin{array}{l}\text { Composição } \\
\text { Decorativa II }\end{array}$ & Plástica IV \\
\hline Prof. & $\begin{array}{l}\text { Paulo S. } \\
\text { Wilken (F.S.P) }\end{array}$ & --- & $\begin{array}{l}\text { Sergio } \\
\text { Fracarolli }\end{array}$ & Rui A. S. Leme & $\begin{array}{l}\text { Ernest R. C. } \\
\text { Mange / } \\
\text { Elisiario da C. } \\
\text { Bahiana }\end{array}$ & --- & $\begin{array}{l}\text { Antonio P. } \\
\text { Vieira }\end{array}$ & --- \\
\hline
\end{tabular}




\begin{tabular}{|c|c|c|c|c|c|c|c|c|}
\hline & \multicolumn{8}{|c|}{1952} \\
\hline & \multicolumn{8}{|c|}{$1^{\circ}$ ano } \\
\hline Cadeira & $\begin{array}{l}\text { 1. Matemática } \\
\text { Superior }\end{array}$ & $\begin{array}{l}\text { 2. Geometria } \\
\text { Descritiva }\end{array}$ & $\begin{array}{l}\text { 14. Arquitetura } \\
\text { Analítica }\end{array}$ & $\begin{array}{l}\text { 16. Pequenas } \\
\text { Composições } \\
\text { de Arquitetura }\end{array}$ & 26. Nomografia & $\begin{array}{l}\text { 28. Desenho } \\
\text { Artístico }\end{array}$ & 30. Plástica & \\
\hline Regente & $\begin{array}{l}\text { José O. M. de } \\
\text { Camargo }\end{array}$ & $\begin{array}{l}\text { Pedro M. do } \\
\text { Amaral Cruz }\end{array}$ & $\begin{array}{l}\text { Bruno S. } \\
\text { Magro }\end{array}$ & $\begin{array}{l}\text { João B. } \\
\text { Vilanova } \\
\text { Artigas }\end{array}$ & Eurico Cerruti & $\begin{array}{l}\text { Vera Helena R. } \\
\text { C. do Amaral }\end{array}$ & $\begin{array}{l}\text { Caetano } \\
\text { Fracarolli }\end{array}$ & \\
\hline Disciplina & $--\cdot$ & --- & --- & $\begin{array}{l}\text { Pequenas } \\
\text { Composições I }\end{array}$ & --- & $\begin{array}{l}\text { Desenho } \\
\text { Artístico I }\end{array}$ & Plástica I & \\
\hline \multirow[t]{2}{*}{ Prof. } & --- & $\begin{array}{l}\text { Guilherme do } \\
\text { A. Lyra }\end{array}$ & $\begin{array}{l}\text { Joaquim B. da } \\
\text { Silva }\end{array}$ & Zenon Lotufo & --- & --- & --- & \\
\hline & \multicolumn{8}{|c|}{$2{ }^{\circ}$ ano } \\
\hline Cadeira & $\begin{array}{l}\text { 3. Mecânica } \\
\text { Racional }\end{array}$ & 4. Topografia & $\begin{array}{l}\text { 6. Materiais } \\
\text { de Construção }\end{array}$ & $\begin{array}{l}\text { 15. Teoria da } \\
\text { Arquitetura }\end{array}$ & $\begin{array}{l}\text { 16. Pequenas } \\
\text { Composições } \\
\text { de Arquitetura }\end{array}$ & $\begin{array}{l}\text { 28. Desenho } \\
\text { Artístico }\end{array}$ & 30. Plástica & \\
\hline Regente & $\begin{array}{l}\text { João A. Breves } \\
\text { Filho }\end{array}$ & $\begin{array}{l}\text { Henrique } \mathrm{J} . \\
\text { Guedes }\end{array}$ & Ary F. Torres & $\begin{array}{l}\text { Miguel Badra } \\
\text { Júnior }\end{array}$ & $\begin{array}{l}\text { João B. } \\
\text { Vilanova } \\
\text { Artigas }\end{array}$ & $\begin{array}{l}\text { Vera H. R. C. } \\
\text { do Amaral }\end{array}$ & Vicente Laroca & \\
\hline Disciplina & --- & --- & $--\cdot$ & -- & $\begin{array}{l}\text { Pequenas } \\
\text { Composições II }\end{array}$ & $\begin{array}{l}\text { Desenho } \\
\text { Artístico II }\end{array}$ & Plástica II & \\
\hline \multirow[t]{2}{*}{ Prof. } & --- & --- & --- & $\begin{array}{l}\text { Leopoldino } \\
\text { Paganelli }\end{array}$ & $\begin{array}{l}\text { Abelardo R. de } \\
\text { Souza }\end{array}$ & $\begin{array}{l}\text { Arquimedes } \\
\text { Dutra }\end{array}$ & Plinio Croce & \\
\hline & \multicolumn{8}{|c|}{30 ano } \\
\hline Cadeira & $\begin{array}{l}\text { 5. Resistência } \\
\text { dos Materiais }\end{array}$ & $\begin{array}{l}\text { 8. Construções } \\
\text { Civis }\end{array}$ & $\begin{array}{l}\text { 10. Elementos } \\
\text { de Mecânica } \\
\text { dos Solos. } \\
\text { Fundações }\end{array}$ & $\begin{array}{l}\text { 13. Física } \\
\text { Aplicada }\end{array}$ & $\begin{array}{l}\text { 17. Grandes } \\
\text { Composições } \\
\text { de Arquitetura }\end{array}$ & $\begin{array}{l}\text { 29. Composição } \\
\text { Decorativa }\end{array}$ & 30. Plástica & \\
\hline Regente & $\begin{array}{l}\text { Telêmaco H. M. } \\
\text { van } \\
\text { Langenlonck }\end{array}$ & Ariosto Mila & Odair Grillo & $\begin{array}{l}\text { Luiz Cintra do } \\
\text { Prado }\end{array}$ & $\begin{array}{l}\text { Hélio de Q. } \\
\text { Duarte }\end{array}$ & $\begin{array}{l}\text { José M. S. } \\
\text { Neves }\end{array}$ & $\begin{array}{l}\text { Alcides R. } \\
\text { Miranda }\end{array}$ & \\
\hline Disciplina & -- & --- & --- & --- & $\begin{array}{l}\text { Grandes } \\
\text { Composições I }\end{array}$ & $\begin{array}{l}\text { Composição } \\
\text { Decorativa I }\end{array}$ & Plástica III & \\
\hline \multirow[t]{2}{*}{ Prof. } & --- & --- & $\begin{array}{l}\text { Victor F. B. de } \\
\text { Mello }\end{array}$ & --- & $\begin{array}{l}\text { Ícaro de Castro } \\
\text { Mello }\end{array}$ & --- & Zanine Caldas & \\
\hline & \multicolumn{8}{|c|}{$4^{\circ}$ ano } \\
\hline Cadeira & $\begin{array}{l}\text { 7. Hidráulica e } \\
\text { Saneamento }\end{array}$ & $\begin{array}{l}\text { 9. Concreto } \\
\text { Simples e } \\
\text { Armado }\end{array}$ & $\begin{array}{l}\text { 11. Grandes } \\
\text { Estruturas }\end{array}$ & $\begin{array}{l}\text { 12. Economia } \\
\text { Política e } \\
\text { Estatística }\end{array}$ & $\begin{array}{l}\text { 17. Grandes } \\
\text { Composições } \\
\text { de Arquitetura }\end{array}$ & $\begin{array}{l}\text { 27. Legislação } \\
\text { e } \\
\text { Contabilidade }\end{array}$ & $\begin{array}{l}\text { 29. Composição } \\
\text { Decorativa }\end{array}$ & 30. Plástica \\
\hline Regente & $\begin{array}{l}\text { Lysandro M. } \\
\text { Pereira da Silva }\end{array}$ & $\begin{array}{l}\text { Fernando J. O. } \\
\text { Escorel }\end{array}$ & $\begin{array}{l}\text { Pedro B. J. } \\
\text { Gravinha }\end{array}$ & $\begin{array}{l}\text { Carlos A. } \\
\text { Vanzolini }\end{array}$ & $\begin{array}{l}\text { Hélio de Q. } \\
\text { Duarte }\end{array}$ & $\begin{array}{l}\text { Americo O. } \\
\text { Campiglia }\end{array}$ & $\begin{array}{l}\text { José M. S. } \\
\text { Neves }\end{array}$ & $\begin{array}{l}\text { Alfredo } \\
\text { Oliani }\end{array}$ \\
\hline Disciplina & --- & --- & --- & --- & $\begin{array}{l}\text { Grandes } \\
\text { Composições II }\end{array}$ & --- & $\begin{array}{l}\text { Composição } \\
\text { Decorativa II }\end{array}$ & Plástica IV \\
\hline \multirow[t]{2}{*}{ Prof. } & $\begin{array}{l}\text { Paulo S. Wilken } \\
\text { (F.S.P) }\end{array}$ & --- & $\begin{array}{l}\text { Sergio } \\
\text { Fracarolli }\end{array}$ & Rui A. S. Leme & $\begin{array}{l}\text { Ernest R. C. } \\
\text { Mange / } \\
\text { Elisiario da C. } \\
\text { Bahiana }\end{array}$ & --- & --- & --- \\
\hline & \multicolumn{8}{|c|}{50 ano } \\
\hline Cadeira & $\begin{array}{l}\text { 17. Grandes } \\
\text { Composições } \\
\text { de Arquitetura }\end{array}$ & $\begin{array}{l}\text { 18. Arquitetura } \\
\text { no Brasil }\end{array}$ & 19. Urbanismo & $\begin{array}{l}\text { 20. Arquitetura } \\
\text { Paisagística }\end{array}$ & $\begin{array}{l}\text { 21. História da } \\
\text { Arte e Estética }\end{array}$ & $\begin{array}{l}\text { 29. Composição } \\
\text { Decorativa }\end{array}$ & 30. Plástica & \\
\hline Regente & $\begin{array}{l}\text { Hélio de Q. } \\
\text { Duarte }\end{array}$ & $\begin{array}{l}\text { Carlos A. G. } \\
\text { Cardim Filho }\end{array}$ & $\begin{array}{l}\text { Luiz I. R.de } \\
\text { Anhaia Mello }\end{array}$ & $\begin{array}{l}\text { Roberto C. } \\
\text { Cardoso }\end{array}$ & $\begin{array}{l}\text { Lourival Gomes } \\
\text { Machado }\end{array}$ & $\begin{array}{l}\text { José M. S. } \\
\text { Neves }\end{array}$ & $\begin{array}{l}\text { Bassano } \\
\text { Vacarini }\end{array}$ & \\
\hline Disciplina & $\begin{array}{l}\text { Grandes } \\
\text { Composições III }\end{array}$ & --- & --- & $-\cdot-$ & --- & $\begin{array}{l}\text { Composição } \\
\text { Decorativa III }\end{array}$ & Plástica V & \\
\hline Prof. & $\begin{array}{l}\text { Roberto C. } \\
\text { César / José V. } \\
\text { Vicari }\end{array}$ & --- & $\begin{array}{l}\text { Milton C. } \\
\text { Ghiraldini }\end{array}$ & --- & --- & $\begin{array}{l}\text { Antônio P. } \\
\text { Vieira }\end{array}$ & --- & \\
\hline
\end{tabular}




\begin{tabular}{|c|c|c|c|c|c|c|c|c|}
\hline & \multicolumn{8}{|c|}{1953} \\
\hline & \multicolumn{8}{|c|}{$1^{\circ}$ ano } \\
\hline Cadeira & $\begin{array}{l}\text { 1. Matemática } \\
\text { Superior }\end{array}$ & $\begin{array}{l}\text { 2. Geometria } \\
\text { Descritiva }\end{array}$ & $\begin{array}{l}\text { 14. Arquitetura } \\
\text { Analítica }\end{array}$ & $\begin{array}{l}\text { 16. Pequenas } \\
\text { Composições } \\
\text { de Arquitetura }\end{array}$ & 26. Nomografia & $\begin{array}{l}\text { 28. Desenho } \\
\text { Artístico }\end{array}$ & 30. Plástica & \\
\hline Regente & $\begin{array}{l}\text { José O. M. de } \\
\text { Camargo }\end{array}$ & $\begin{array}{l}\text { Pedro M. do } \\
\text { Amaral Cruz }\end{array}$ & $\begin{array}{l}\text { Bruno S. } \\
\text { Magro }\end{array}$ & $\begin{array}{l}\text { João B. } \\
\text { Vilanova } \\
\text { Artigas }\end{array}$ & Eurico Cerruti & $\begin{array}{l}\text { Vera Helena R. } \\
\text { C. do Amaral }\end{array}$ & $\begin{array}{l}\text { Caetano } \\
\text { Fracarolli }\end{array}$ & \\
\hline Disciplina & --- & --- & --- & $\begin{array}{l}\text { Pequenas } \\
\text { Composições I }\end{array}$ & --- & $\begin{array}{l}\text { Desenho } \\
\text { Artístico I }\end{array}$ & Plástica I & \\
\hline \multirow[t]{2}{*}{ Prof. } & --- & $\begin{array}{l}\text { Guilherme do } \\
\text { A. Lyra }\end{array}$ & $\begin{array}{l}\text { Joaquim B. da } \\
\text { Silva }\end{array}$ & Zenon Lotufo & --- & --- & --- & \\
\hline & \multicolumn{8}{|c|}{$2 \%$ ano } \\
\hline Cadeira & $\begin{array}{l}\text { 3. Mecânica } \\
\text { Racional }\end{array}$ & 4. Topografia & $\begin{array}{l}\text { 6. Materiais } \\
\text { de Construção }\end{array}$ & $\begin{array}{l}\text { 15. Teoria da } \\
\text { Arquitetura }\end{array}$ & $\begin{array}{l}\text { 16. Pequenas } \\
\text { Composições } \\
\text { de Arquitetura }\end{array}$ & $\begin{array}{l}\text { 28. Desenho } \\
\text { Artístico }\end{array}$ & 30. Plástica & \\
\hline Regente & $\begin{array}{l}\text { João A. Breves } \\
\text { Filho }\end{array}$ & $\begin{array}{l}\text { Henrique J. } \\
\text { Guedes }\end{array}$ & Ary F. Torres & $\begin{array}{l}\text { Miguel Badra } \\
\text { Junior }\end{array}$ & $\begin{array}{l}\text { João B. } \\
\text { Vilanova } \\
\text { Artigas }\end{array}$ & $\begin{array}{l}\text { Vera Helena R. } \\
\text { C. do Amaral }\end{array}$ & Vicente Laroca & \\
\hline Disciplina & -- & --- & --- & --- & $\begin{array}{l}\text { Pequenas } \\
\text { Composições II }\end{array}$ & $\begin{array}{l}\text { Desenho } \\
\text { Artístico II }\end{array}$ & Plástica II & \\
\hline \multirow[t]{2}{*}{ Prof. } & --- & --- & --- & $\begin{array}{l}\text { Leopoldino } \\
\text { Paganelli }\end{array}$ & $\begin{array}{l}\text { Abelardo R. de } \\
\text { Souza }\end{array}$ & $\begin{array}{l}\text { Arquimedes } \\
\text { Dutra }\end{array}$ & Plinio Croce & \\
\hline & \multicolumn{8}{|c|}{$3^{\circ}$ ano } \\
\hline Cadeira & $\begin{array}{l}\text { 5. Resistência } \\
\text { dos Materiais }\end{array}$ & $\begin{array}{l}\text { 8. Construções } \\
\text { Civis }\end{array}$ & $\begin{array}{l}\text { 10. Mecânica } \\
\text { dos Solos e } \\
\text { Fundações }\end{array}$ & $\begin{array}{l}\text { 13. Física } \\
\text { Aplicada }\end{array}$ & $\begin{array}{l}\text { 17. Grandes } \\
\text { Composições } \\
\text { de Arquitetura }\end{array}$ & $\begin{array}{l}\text { 29. Composição } \\
\text { Decorativa }\end{array}$ & 30. Plástica & \\
\hline Regente & $\begin{array}{l}\text { Telêmaco H. M. } \\
\text { van } \\
\text { Langenlonck }\end{array}$ & Ariosto Mila & Odair Grillo & $\begin{array}{l}\text { Luiz Cintra do } \\
\text { Prado }\end{array}$ & $\begin{array}{l}\text { Hélio de Q. } \\
\text { Duarte }\end{array}$ & $\begin{array}{l}\text { José M. S. } \\
\text { Neves }\end{array}$ & $\begin{array}{l}\text { Alcides R. } \\
\text { Miranda }\end{array}$ & \\
\hline Disciplina & --- & --- & --- & --- & $\begin{array}{l}\text { Grandes } \\
\text { Composições I }\end{array}$ & $\begin{array}{l}\text { Composição } \\
\text { Decorativa I }\end{array}$ & Plástica III & \\
\hline \multirow[t]{2}{*}{ Prof. } & --- & --- & $\begin{array}{l}\text { Victor F. B. de } \\
\text { Mello }\end{array}$ & --- & $\begin{array}{l}\text { Ícaro de Castro } \\
\text { Mello }\end{array}$ & --- & --- & \\
\hline & \multicolumn{8}{|c|}{$4^{\circ}$ ano } \\
\hline Cadeira & $\begin{array}{l}\text { 7. Hidráulica e } \\
\text { Saneamento }\end{array}$ & $\begin{array}{l}\text { 9. Concreto } \\
\text { Simples e } \\
\text { Armado }\end{array}$ & $\begin{array}{l}\text { 11. Grandes } \\
\text { Estruturas }\end{array}$ & $\begin{array}{l}\text { 12. Economia } \\
\text { Política e } \\
\text { Estatística }\end{array}$ & $\begin{array}{l}\text { 17. Grandes } \\
\text { Composições } \\
\text { de Arquitetura }\end{array}$ & $\begin{array}{l}\text { 27. Legislação } \\
\text { e } \\
\text { Contabilidade }\end{array}$ & $\begin{array}{l}\text { 29. Composição } \\
\text { Decorativa }\end{array}$ & 30. Plástica \\
\hline Regente & $\begin{array}{l}\text { Lysandro M. } \\
\text { Pereira da Silva }\end{array}$ & $\begin{array}{l}\text { Fernando J. O. } \\
\text { Escorel }\end{array}$ & $\begin{array}{l}\text { Pedro B. J. } \\
\text { Gravinha }\end{array}$ & $\begin{array}{l}\text { Carlos A. } \\
\text { Vanzolini }\end{array}$ & $\begin{array}{l}\text { Elisiario da C. } \\
\text { Bahiana }\end{array}$ & $\begin{array}{l}\text { Americo O. } \\
\text { Campiglia }\end{array}$ & $\begin{array}{l}\text { José M. S. } \\
\text { Neves }\end{array}$ & $\begin{array}{l}\text { Alfredo } \\
\text { Oliani }\end{array}$ \\
\hline Disciplina & --- & --- & --- & --- & $\begin{array}{l}\text { Grandes } \\
\text { Composições II }\end{array}$ & -- & $\begin{array}{l}\text { Composição } \\
\text { Decorativa II }\end{array}$ & Plástica IV \\
\hline \multirow[t]{2}{*}{ Prof. } & $\begin{array}{l}\text { Paulo S. Wilken } \\
\text { (F.S.P) }\end{array}$ & --- & $\begin{array}{l}\text { Sergio } \\
\text { Fracarolli }\end{array}$ & Rui A. S. Leme & $\begin{array}{l}\text { Ernest R. C. } \\
\text { Mange / Hélio } \\
\text { de Q. Duarte }\end{array}$ & --- & --- & --- \\
\hline & \multicolumn{8}{|c|}{50 ano } \\
\hline Cadeira & $\begin{array}{l}\text { 17. Grandes } \\
\text { Composições } \\
\text { de Arquitetura }\end{array}$ & $\begin{array}{l}\text { 18. Arquitetura } \\
\text { no Brasil }\end{array}$ & 19. Urbanismo & $\begin{array}{l}\text { 20. Arquitetura } \\
\text { Paisagística }\end{array}$ & $\begin{array}{l}\text { 21. História da } \\
\text { Arte e Estética }\end{array}$ & $\begin{array}{l}\text { 29. Composição } \\
\text { Decorativa }\end{array}$ & 30. Plástica & \\
\hline Regente & José V. Vicari & $\begin{array}{l}\text { Carlos A. G. } \\
\text { Cardim Filho }\end{array}$ & $\begin{array}{l}\text { Luiz I. R. de } \\
\text { Anhaia Mello }\end{array}$ & $\begin{array}{l}\text { Roberto C. } \\
\text { Cardoso }\end{array}$ & $\begin{array}{l}\text { Lourival Gomes } \\
\text { Machado }\end{array}$ & $\begin{array}{l}\text { José M. S. } \\
\text { Neves }\end{array}$ & $\begin{array}{l}\text { Bassano } \\
\text { Vacarini }\end{array}$ & \\
\hline Disciplina & $\begin{array}{l}\text { Grandes } \\
\text { Composições III }\end{array}$ & --- & --- & --- & --- & $\begin{array}{l}\text { Composição } \\
\text { Decorativa III }\end{array}$ & Plástica V & \\
\hline Prof. & $\begin{array}{l}\text { Roberto } \\
\text { Cerqueira } \\
\text { César }\end{array}$ & --- & $\begin{array}{l}\text { Milton C. } \\
\text { Ghiraldini }\end{array}$ & --- & --- & $\begin{array}{l}\text { Antônio P. } \\
\text { Vieira }\end{array}$ & --- & \\
\hline
\end{tabular}




\begin{tabular}{|c|c|c|c|c|c|c|c|c|}
\hline & \multicolumn{8}{|c|}{1954} \\
\hline & \multicolumn{8}{|c|}{$1^{\circ}$ ano } \\
\hline Cadeira & $\begin{array}{l}\text { 1. Matemática } \\
\text { Superior }\end{array}$ & $\begin{array}{l}\text { 2. Geometria } \\
\text { Descritiva }\end{array}$ & $\begin{array}{l}\text { 14. Arquitetura } \\
\text { Analítica }\end{array}$ & $\begin{array}{l}\text { 16. Pequenas } \\
\text { Composições } \\
\text { de Arquitetura }\end{array}$ & 26. Nomografia & $\begin{array}{l}\text { 28. Desenho } \\
\text { Artístico }\end{array}$ & 30. Plástica & \\
\hline Regente & $\begin{array}{l}\text { José O. M. de } \\
\text { Camargo }\end{array}$ & $\begin{array}{l}\text { Pedro M. do } \\
\text { Amaral Cruz }\end{array}$ & $\begin{array}{l}\text { Bruno S. } \\
\text { Magro }\end{array}$ & Zenon Lotufo & Eurico Cerruti & $\begin{array}{l}\text { Vera Helena R. } \\
\text { C. do Amaral }\end{array}$ & $\begin{array}{l}\text { Caetano } \\
\text { Fracarolli }\end{array}$ & \\
\hline Disciplina & --- & --- & --- & $\begin{array}{l}\text { Pequenas } \\
\text { Composições I }\end{array}$ & --- & $\begin{array}{l}\text { Desenho } \\
\text { Artístico I }\end{array}$ & Plástica I & \\
\hline Prof. & --- & $\begin{array}{l}\text { Guilherme do } \\
\text { A. Lyra }\end{array}$ & $\begin{array}{l}\text { Joaquim B. } \\
\text { da Silva }\end{array}$ & $\begin{array}{l}\text { Manoel da S. } \\
\text { Machado (?) }\end{array}$ & --- & --- & --- & \\
\hline \multicolumn{9}{|c|}{$2 \%$ ano } \\
\hline Cadeira & $\begin{array}{l}\text { 3. Mecânica } \\
\text { Racional }\end{array}$ & 4. Topografia & $\begin{array}{l}\text { 6. Materiais } \\
\text { de Construção }\end{array}$ & $\begin{array}{l}\text { 15. Teoria da } \\
\text { Arquitetura }\end{array}$ & $\begin{array}{l}\text { 16. Pequenas } \\
\text { Composições } \\
\text { de Arquitetura }\end{array}$ & $\begin{array}{l}\text { 28. Desenho } \\
\text { Artístico }\end{array}$ & 30. Plástica & \\
\hline Regente & $\begin{array}{l}\text { João A. Breves } \\
\text { Filho }\end{array}$ & $\begin{array}{l}\text { Henrique } \mathrm{J} . \\
\text { Guedes }\end{array}$ & Ary F. Torres & $\begin{array}{l}\text { Miguel Badra } \\
\text { Junior }\end{array}$ & Zenon Lotufo & $\begin{array}{l}\text { Vera Helena R. } \\
\text { C. do Amaral }\end{array}$ & $\begin{array}{l}\text { Olga E. M. H. } \\
\text { N. Schoenfeldt }\end{array}$ & \\
\hline Disciplina & --- & --- & --- & --- & $\begin{array}{l}\text { Pequenas } \\
\text { Composições II }\end{array}$ & $\begin{array}{l}\text { Desenho } \\
\text { Artístico II }\end{array}$ & Plástica II & \\
\hline Prof. & --- & --- & --- & $\begin{array}{l}\text { Leopoldino } \\
\text { Paganelli }\end{array}$ & $\begin{array}{l}\text { Abelardo R. de } \\
\text { Souza }\end{array}$ & $\begin{array}{l}\text { Arquimedes } \\
\text { Dutra }\end{array}$ & Plinio Croce & \\
\hline \multicolumn{9}{|c|}{30 ano } \\
\hline Cadeira & $\begin{array}{l}\text { 5. Resistência } \\
\text { dos Materiais }\end{array}$ & $\begin{array}{l}\text { 8. Construções } \\
\text { Civis }\end{array}$ & $\begin{array}{l}\text { 10. Mecânica } \\
\text { dos Solos e } \\
\text { Fundações }\end{array}$ & $\begin{array}{l}\text { 13. Física } \\
\text { Aplicada }\end{array}$ & $\begin{array}{l}\text { 17. Grandes } \\
\text { Composições } \\
\text { de Arquitetura }\end{array}$ & $\begin{array}{l}\text { 29. Composição } \\
\text { Decorativa }\end{array}$ & 30. Plástica & \\
\hline Regente & $\begin{array}{l}\text { Telêmaco H. } \\
\text { M. van } \\
\text { Langenlonck }\end{array}$ & Ariosto Mila & Odair Grillo & $\begin{array}{l}\text { Luiz Cintra do } \\
\text { Prado }\end{array}$ & $\begin{array}{l}\text { Hélio de Q. } \\
\text { Duarte }\end{array}$ & $\begin{array}{l}\text { José M. S. } \\
\text { Neves }\end{array}$ & $\begin{array}{l}\text { Alcides R. } \\
\text { Miranda }\end{array}$ & \\
\hline Disciplina & --- & --- & --- & --- & $\begin{array}{l}\text { Grandes } \\
\text { Composições I }\end{array}$ & $\begin{array}{l}\text { Composição } \\
\text { Decorativa I }\end{array}$ & Plástica III & \\
\hline Prof. & --- & --- & $\begin{array}{l}\text { Victor F. B. } \\
\text { de Mello }\end{array}$ & --- & $\begin{array}{l}\text { Oswaldo C. } \\
\text { Gonçalves }\end{array}$ & & & \\
\hline \multicolumn{9}{|c|}{$4^{\circ}$ ano } \\
\hline Cadeira & $\begin{array}{l}\text { 7. Hidráulica e } \\
\text { Saneamento }\end{array}$ & $\begin{array}{l}\text { 9. Concreto } \\
\text { Simples e } \\
\text { Armado }\end{array}$ & $\begin{array}{l}\text { 11. Grandes } \\
\text { Estruturas }\end{array}$ & $\begin{array}{l}\text { 12. Economia } \\
\text { Política e } \\
\text { Estatística }\end{array}$ & $\begin{array}{l}\text { 17. Grandes } \\
\text { Composições } \\
\text { de Arquitetura }\end{array}$ & $\begin{array}{l}\text { 27. Legislação } \\
\text { e } \\
\text { Contabilidade }\end{array}$ & $\begin{array}{l}\text { 29. Composição } \\
\text { Decorativa }\end{array}$ & $\begin{array}{l}30 . \\
\text { Plástica }\end{array}$ \\
\hline Regente & $\begin{array}{l}\text { Lysandro M. } \\
\text { Pereria da } \\
\text { Silva }\end{array}$ & $\begin{array}{l}\text { Fernando J. } \\
\text { O. Escorel }\end{array}$ & $\begin{array}{l}\text { Pedro B. J. } \\
\text { Gravinha }\end{array}$ & $\begin{array}{l}\text { Mario W. V. da } \\
\text { Cunha }\end{array}$ & Rino Levi & $\begin{array}{l}\text { Americo O. } \\
\text { Campiglia }\end{array}$ & $\begin{array}{l}\text { José M. S. } \\
\text { Neves }\end{array}$ & --- \\
\hline Disciplina & --- & --- & --- & --- & $\begin{array}{l}\text { Grandes } \\
\text { Composições II }\end{array}$ & --- & $\begin{array}{l}\text { Composição } \\
\text { Decorativa II }\end{array}$ & Plástica IV \\
\hline Prof. & $\begin{array}{l}\text { Paulo S. } \\
\text { Wilken (F.S.P) }\end{array}$ & --- & $\begin{array}{l}\text { Sergio } \\
\text { Fracarolli }\end{array}$ & $\begin{array}{l}\text { Alvaro Marchi / } \\
\text { Rui A. S. Leme } \\
\text { / Juarez R. } \\
\text { Brandão Lopes }\end{array}$ & $\begin{array}{l}\text { Hélio de Q. } \\
\text { Duarte }\end{array}$ & --- & $\begin{array}{l}\text { Jacob M. } \\
\text { Ruchti }\end{array}$ & --- \\
\hline \multicolumn{9}{|c|}{$5^{\circ}$ ano } \\
\hline Cadeira & $\begin{array}{l}\text { 17. Grandes } \\
\text { Composições } \\
\text { de Arquitetura }\end{array}$ & $\begin{array}{l}\text { 18. Arquitetura } \\
\text { no Brasil }\end{array}$ & 19. Urbanismo & $\begin{array}{l}\text { 20. Arquitetura } \\
\text { Paisagística }\end{array}$ & $\begin{array}{l}\text { 21. História da } \\
\text { Arte e Estética }\end{array}$ & $\begin{array}{l}\text { 29. Composição } \\
\text { Decorativa }\end{array}$ & 30. Plástica & \\
\hline Regente & Rino Levi & $\begin{array}{l}\text { Carlos A. G. } \\
\text { Cardim Filho }\end{array}$ & $\begin{array}{l}\text { Luiz I. R. de } \\
\text { Anhaia Mello }\end{array}$ & $\begin{array}{l}\text { Roberto C. } \\
\text { Cardoso }\end{array}$ & Flávio L. Motta & $\begin{array}{l}\text { José M. S. } \\
\text { Neves }\end{array}$ & $\begin{array}{l}\text { Bassano } \\
\text { Vacarini }\end{array}$ & \\
\hline Disciplina & $\begin{array}{l}\text { Grandes } \\
\text { Composições III }\end{array}$ & --- & --- & --- & --- & $\begin{array}{l}\text { Composição } \\
\text { Decorativa III }\end{array}$ & Plástica V & \\
\hline Prof. & $\begin{array}{l}\text { Roberto } \\
\text { Cerqueira } \\
\text { César }\end{array}$ & --- & $\begin{array}{l}\text { Milton C. } \\
\text { Ghiraldini }\end{array}$ & $\begin{array}{l}\text { Daisy R. } \\
\text { I.Hoffemberg / } \\
\text { Elisabeth N. } \\
\text { Schoenfeldt }\end{array}$ & --- & --- & $\begin{array}{l}\text { Ernest R. C. } \\
\text { Mange }\end{array}$ & \\
\hline
\end{tabular}




\begin{tabular}{|c|c|c|c|c|c|c|c|c|}
\hline & \multicolumn{8}{|c|}{1955} \\
\hline & \multicolumn{8}{|c|}{$1^{\circ}$ ano } \\
\hline Cadeira & $\begin{array}{l}\text { 1. Matemática } \\
\text { Superior }\end{array}$ & $\begin{array}{l}\text { 2. Geometria } \\
\text { Descritiva }\end{array}$ & $\begin{array}{l}\text { 14. Arquitetura } \\
\text { Analítica }\end{array}$ & $\begin{array}{l}\text { 16. Pequenas } \\
\text { Composições } \\
\text { de Arquitetura }\end{array}$ & 26. Nomografia & $\begin{array}{l}\text { 28. Desenho } \\
\text { Artístico }\end{array}$ & 30. Plástica & \\
\hline Regente & $\begin{array}{l}\text { José O. M. de } \\
\text { Camargo }\end{array}$ & $\begin{array}{l}\text { Pedro M. do } \\
\text { Amaral Cruz }\end{array}$ & $\begin{array}{l}\text { Bruno S. } \\
\text { Magro }\end{array}$ & Zenon Lotufo & Eurico Cerruti & $\begin{array}{l}\text { Vera Helena R. } \\
\text { C. do Amaral }\end{array}$ & $\begin{array}{l}\text { Caetano } \\
\text { Fracarolli }\end{array}$ & \\
\hline Disciplina & -- & --- & --- & $\begin{array}{l}\text { Pequenas } \\
\text { Composições I }\end{array}$ & -- & $\begin{array}{l}\text { Desenho } \\
\text { Artístico I }\end{array}$ & Plástica I & \\
\hline \multirow[t]{2}{*}{ Prof. } & --- & $\begin{array}{l}\text { Guilherme do } \\
\text { A. Lyra }\end{array}$ & $\begin{array}{l}\text { Joaquim B. da } \\
\text { Silva }\end{array}$ & $\begin{array}{l}\text { Manoel da S. } \\
\text { Machado / Jon } \\
\text { Maitrejean }\end{array}$ & --- & --- & --- & \\
\hline & \multicolumn{8}{|c|}{$2^{\circ}$ ano } \\
\hline Cadeira & $\begin{array}{l}\text { 3. Mecânica } \\
\text { Racional }\end{array}$ & 4. Topografia & $\begin{array}{l}\text { 6. Materiais } \\
\text { de Construção }\end{array}$ & $\begin{array}{l}\text { 15. Teoria da } \\
\text { Arquitetura }\end{array}$ & $\begin{array}{l}\text { 16. Pequenas } \\
\text { Composições } \\
\text { de Arquitetura }\end{array}$ & $\begin{array}{l}\text { 28. Desenho } \\
\text { Artístico }\end{array}$ & 30. Plástica & \\
\hline Regente & $\begin{array}{l}\text { João A. Breves } \\
\text { Filho }\end{array}$ & $\begin{array}{l}\text { Henrique J. } \\
\text { Guedes }\end{array}$ & Ary F. Torres & $\begin{array}{l}\text { Eduardo } \\
\text { Corona }\end{array}$ & Zenon Lotufo & $\begin{array}{l}\text { Vera Helena R. } \\
\text { C. do Amaral }\end{array}$ & $\begin{array}{l}\text { Olga E. M. H. } \\
\text { N. Schoenfeldt }\end{array}$ & \\
\hline Disciplina & --- & --- & --- & --- & $\begin{array}{l}\text { Pequenas } \\
\text { Composições II }\end{array}$ & $\begin{array}{l}\text { Desenho } \\
\text { Artístico II }\end{array}$ & Plástica II & \\
\hline \multirow[t]{2}{*}{ Drof. } & --- & --- & --- & $\begin{array}{l}\text { Carlos A. C. } \\
\text { Lemos }\end{array}$ & $\begin{array}{l}\text { Abelardo R. de } \\
\text { Souza }\end{array}$ & $\begin{array}{l}\text { Arquimedes } \\
\text { Dutra }\end{array}$ & Plinio Croce & \\
\hline & \multicolumn{8}{|c|}{30 ano } \\
\hline Cadeira & $\begin{array}{l}\text { 5. Resistência } \\
\text { dos Materiais }\end{array}$ & $\begin{array}{l}\text { 8. Construções } \\
\text { Civis }\end{array}$ & $\begin{array}{l}\text { 10. Mecânica } \\
\text { dos Solos e } \\
\text { Fundações }\end{array}$ & $\begin{array}{l}\text { 13. Física } \\
\text { Aplicada }\end{array}$ & $\begin{array}{l}\text { 17. Grandes } \\
\text { Composições } \\
\text { de Arquitetura }\end{array}$ & $\begin{array}{l}\text { 29. Composição } \\
\text { Decorativa }\end{array}$ & 30. Plástica & \\
\hline Regente & $\begin{array}{l}\text { Telêmaco H. } \\
\text { M. van } \\
\text { Langenlonck }\end{array}$ & Ariosto Mila & $\begin{array}{l}\text { Victor F. B. de } \\
\text { Mello (?) }\end{array}$ & $\begin{array}{l}\text { Luiz Cintra do } \\
\text { Prado }\end{array}$ & $\begin{array}{l}\text { Hélio de Q. } \\
\text { Duarte }\end{array}$ & $\begin{array}{l}\text { José M. S. } \\
\text { Neves }\end{array}$ & $\begin{array}{l}\text { Alcides R. } \\
\text { Miranda }\end{array}$ & \\
\hline Disciplina & --- & --- & --- & --- & $\begin{array}{l}\text { Grandes } \\
\text { Composições I }\end{array}$ & $\begin{array}{l}\text { Composição } \\
\text { Decorativa I }\end{array}$ & Plástica III & \\
\hline Prof. & --- & --- & --- & --- & $\begin{array}{l}\text { Oswaldo C. } \\
\text { Gonçalves }\end{array}$ & $\begin{array}{l}\text { Achilina Bo } \\
\text { Bardi }\end{array}$ & --- & \\
\hline & \multicolumn{8}{|c|}{$4^{\circ}$ ano } \\
\hline Cadeira & $\begin{array}{l}\text { 7. Hidráulica e } \\
\text { Saneamento }\end{array}$ & $\begin{array}{l}\text { 9. Concreto } \\
\text { Simples e } \\
\text { Armado }\end{array}$ & $\begin{array}{l}\text { 11. Grandes } \\
\text { Estruturas }\end{array}$ & $\begin{array}{l}\text { 12. Economia } \\
\text { Política e } \\
\text { Estatística }\end{array}$ & $\begin{array}{l}\text { 17. Grandes } \\
\text { Composições } \\
\text { de Arquitetura }\end{array}$ & $\begin{array}{l}\text { 27. Legislação } \\
\text { e } \\
\text { Contabilidade }\end{array}$ & $\begin{array}{l}\text { 29. Composição } \\
\text { Decorativa }\end{array}$ & 30. Plástica \\
\hline Regente & $\begin{array}{l}\text { Lysandro M. } \\
\text { Pereira da } \\
\text { Silva }\end{array}$ & $\begin{array}{l}\text { Fernando J. O. } \\
\text { Escorel }\end{array}$ & $\begin{array}{l}\text { Pedro B. J. } \\
\text { Gravinha }\end{array}$ & $\begin{array}{l}\text { Mario W. V. da } \\
\text { Cunha }\end{array}$ & $\begin{array}{l}\text { Hélio de Q. } \\
\text { Duarte }\end{array}$ & $\begin{array}{l}\text { Americo O. } \\
\text { Campiglia }\end{array}$ & $\begin{array}{l}\text { José M. S. } \\
\text { Neves }\end{array}$ & Plinio Croce \\
\hline Disciplina & --- & --- & --- & --- & $\begin{array}{l}\text { Grandes } \\
\text { Composições II }\end{array}$ & --- & $\begin{array}{l}\text { Composição } \\
\text { Decorativa II }\end{array}$ & Plástica IV \\
\hline \multirow[t]{2}{*}{ Drof. } & $\begin{array}{l}\text { Paulo S. } \\
\text { Wilken (F.S.P) }\end{array}$ & --- & $\begin{array}{l}\text { Sergio } \\
\text { Fracarolli }\end{array}$ & $\begin{array}{l}\text { Álvaro Marchi / } \\
\text { Rui A. S. Leme } \\
\text { / Juarez R. } \\
\text { Brandão Lopes }\end{array}$ & $\begin{array}{l}\text { Rino Levi / } \\
\text { Roberto } \\
\text { Cerqueira } \\
\text { César }\end{array}$ & --- & $\begin{array}{l}\text { Jacob M. } \\
\text { Ruchti }\end{array}$ & --- \\
\hline & \multicolumn{8}{|c|}{50 ano } \\
\hline Cadeira & $\begin{array}{l}\text { 17. Grandes } \\
\text { Composições } \\
\text { de Arquitetura }\end{array}$ & $\begin{array}{l}\text { 18. Arquitetura } \\
\text { no Brasil }\end{array}$ & 19. Urbanismo & $\begin{array}{l}\text { 20. Arquitetura } \\
\text { Paisagística }\end{array}$ & $\begin{array}{l}\text { 21. História da } \\
\text { Arte e Estética }\end{array}$ & $\begin{array}{l}\text { 29. Composição } \\
\text { Decorativa }\end{array}$ & 30. Plástica & \\
\hline Regente & Rino Levi & $\begin{array}{l}\text { Carlos A. G. } \\
\text { Cardim Filho }\end{array}$ & $\begin{array}{l}\text { Luiz I. R. de } \\
\text { Anhaia Mello }\end{array}$ & $\begin{array}{l}\text { Roberto C. } \\
\text { Cardoso }\end{array}$ & Flávio L. Motta & $\begin{array}{l}\text { José M. S. } \\
\text { Neves }\end{array}$ & $\begin{array}{l}\text { Bassano } \\
\text { Vacarini }\end{array}$ & \\
\hline Disciplina & $\begin{array}{l}\text { Grandes } \\
\text { Composições III }\end{array}$ & --- & --- & --- & --- & $\begin{array}{l}\text { Composição } \\
\text { Decorativa III }\end{array}$ & Plástica V & \\
\hline Prof. & $\begin{array}{l}\text { Roberto } \\
\text { Cerqueira } \\
\text { César }\end{array}$ & --- & $\begin{array}{l}\text { Milton C. } \\
\text { Ghiraldini }\end{array}$ & $\begin{array}{l}\text { Daisy R. I. } \\
\text { Hoffemberg / } \\
\text { Elisabeth N. } \\
\text { Schoenfeldt }\end{array}$ & --- & $\begin{array}{l}\text { Alcides da R. } \\
\text { Miranda / } \\
\text { Achillina Bo } \\
\text { Bardi }\end{array}$ & $\begin{array}{l}\text { Ernest R. C. } \\
\text { Mange }\end{array}$ & \\
\hline
\end{tabular}




\begin{tabular}{|c|c|c|c|c|c|c|c|}
\hline & \multicolumn{7}{|c|}{1956} \\
\hline & \multicolumn{7}{|c|}{10 ano } \\
\hline Cadeira & $\begin{array}{l}\text { 1. Cálculo, } \\
\text { Geom. Anal., } \\
\text { Nomografia }\end{array}$ & $\begin{array}{l}\text { 2. Geometria } \\
\text { Descritiva }\end{array}$ & $\begin{array}{l}\text { 11. Topog., Elem. } \\
\text { de Astronomia } \\
\text { de Posição }\end{array}$ & $\begin{array}{l}\text { 13. Arquitetura } \\
\text { Analítica }\end{array}$ & \multicolumn{2}{|c|}{$\begin{array}{l}\text { 16. Pequenas Composições de } \\
\text { Arquitetura I }\end{array}$} & $\begin{array}{l}\text { 21. Desenho } \\
\text { Artístico }\end{array}$ \\
\hline Regente & $\begin{array}{l}\text { José O. M. de } \\
\text { Camargo }\end{array}$ & $\begin{array}{l}\text { Pedro M. do } \\
\text { Amaral Cruz }\end{array}$ & $\begin{array}{l}\text { Henrique J. } \\
\text { Guedes }\end{array}$ & Bruno S. Magro & \multicolumn{2}{|l|}{ Zenon Lotufo } & $\begin{array}{l}\text { Ernest R. C. } \\
\text { Mange }\end{array}$ \\
\hline Disciplina & $\begin{array}{l}\text { Nomografia (a } \\
\text { cargo do } \\
\text { assistente) }\end{array}$ & --- & --- & --- & $\begin{array}{l}\text { Pequenas } \\
\text { Composições I. } \\
\text { parte } 1\end{array}$ & $\begin{array}{l}\text { Desenho Arq.(a } \\
\text { cargo do } \\
\text { assistente) }\end{array}$ & Parte 1 \\
\hline Prof. & Eurico Cerruti & $\begin{array}{l}\text { Guilherme do A. } \\
\text { Lyra }\end{array}$ & --- & $\begin{array}{l}\text { Joaquim B. da } \\
\text { Silva }\end{array}$ & --- & $\begin{array}{l}\text { Manoel da S. } \\
\text { Machado }\end{array}$ & $\begin{array}{l}\text { Vera Helena R. } \\
\text { C. do Amaral }\end{array}$ \\
\hline & \multicolumn{7}{|c|}{$2^{\circ}$ ano } \\
\hline Cadeira & $\begin{array}{l}\text { 1. Cálculo, } \\
\text { Geom. Anal., } \\
\text { Nomografia }\end{array}$ & 3. Mecânica & $\begin{array}{l}\text { 4. Física Geral e } \\
\text { Aplicada }\end{array}$ & $\begin{array}{l}\text { 14. Teoria da } \\
\text { Arquitetura }\end{array}$ & \multicolumn{2}{|c|}{$\begin{array}{l}\text { 16. Pequenas Composições de } \\
\text { Arquitetura I }\end{array}$} & $\begin{array}{l}\text { 21. Desenho } \\
\text { Artístico }\end{array}$ \\
\hline Regente & $\begin{array}{l}\text { José O. M. de } \\
\text { Camargo }\end{array}$ & $\begin{array}{l}\text { João A. Breves } \\
\text { Filho }\end{array}$ & $\begin{array}{l}\text { Luiz Cintra do } \\
\text { Prado }\end{array}$ & Eduardo Corona & \multicolumn{2}{|l|}{ Zenon Lotufo } & $\begin{array}{l}\text { Ernest R. } \\
\text { C.Mange }\end{array}$ \\
\hline Disciplina & $--\cdot$ & --- & --- & --- & $\begin{array}{l}\text { Pequenas } \\
\text { Composições I. } \\
\text { parte } 2\end{array}$ & $\begin{array}{l}\text { Plástica I (a } \\
\text { cargo do } \\
\text { assistente) }\end{array}$ & Parte 2 \\
\hline Prof. & Eurico Cerruti & --- & --- & $\begin{array}{l}\text { Carlos A. C. } \\
\text { Lemos }\end{array}$ & $\begin{array}{l}\text { João B. Vilanova } \\
\text { Artigas }\end{array}$ & $\begin{array}{l}\text { Caetano } \\
\text { Fracarolli }\end{array}$ & --- \\
\hline & \multicolumn{7}{|c|}{$3^{\circ}$ ano } \\
\hline Cadeira & $\begin{array}{l}\text { 5. Materiais de } \\
\text { Construção }\end{array}$ & $\begin{array}{l}\text { 6. Resist. dos } \\
\text { Materiais. } \\
\text { Estabilidade das } \\
\text { Const. }\end{array}$ & \multicolumn{2}{|c|}{$\begin{array}{l}\text { 9. Técn. das Const., Org. dos Trab. e } \\
\text { Prática Profiss., Hig. dos Ed., } \\
\text { Noções de Mec. dos Solos, } \\
\text { Fundações }\end{array}$} & \multicolumn{2}{|c|}{$\begin{array}{l}\text { 17. Composição de Arquitetura. } \\
\text { Pequenas composições II: Plástica II }\end{array}$} & $\begin{array}{l}\text { 22. Composição } \\
\text { Decorativa }\end{array}$ \\
\hline Regente & Ary F. Torres & $\begin{array}{l}\text { Telêmaco H. M. } \\
\text { van Langenlonck }\end{array}$ & \multicolumn{2}{|l|}{ Ariosto Mila } & \multicolumn{2}{|c|}{ Abelardo R. de Souza } & José M. S. Neves \\
\hline Disciplina & --- & --- & $\begin{array}{l}\text { Técn. das } \\
\text { Const., Org. dos } \\
\text { Trab. e Prática } \\
\text { Profiss. }\end{array}$ & $\begin{array}{l}\text { Elem. de Mec. } \\
\text { dos Solos. } \\
\text { Fundações (a } \\
\text { cargo do } \\
\text { assistente) }\end{array}$ & $\begin{array}{l}\text { Pequenas } \\
\text { Composições II }\end{array}$ & Plástica II & --- \\
\hline Prof. & $\begin{array}{l}\text { Fernando J. O. } \\
\text { Escorel }\end{array}$ & --- & --- & $\begin{array}{l}\text { Victor F. B. de } \\
\text { Mello }\end{array}$ & Jon Maitrejean & $\begin{array}{l}\text { Renina Katz } \\
\text { Pedreira }\end{array}$ & $\begin{array}{l}\text { Jacob M. Ruchti / } \\
\text { Achillina Bo Bardi } \\
\text { / Luiz G. C. Lima }\end{array}$ \\
\hline & \multicolumn{7}{|c|}{$4^{\circ}$ ano } \\
\hline Cadeira & $\begin{array}{l}\text { 7. Estruturas } \\
\text { Correntes de } \\
\text { Madeira, } \\
\text { Metálicas e de } \\
\text { Concreto } \\
\text { Simples e } \\
\text { Armado }\end{array}$ & $\begin{array}{l}\text { 10. Hidráulica, } \\
\text { Urbana e } \\
\text { Saneamento }\end{array}$ & $\begin{array}{l}\text { 12. Noções de } \\
\text { Econ. Política, } \\
\text { Estatística } \\
\text { Aplicada }\end{array}$ & $\begin{array}{l}\text { 9. Técn. das } \\
\text { Const., Org. dos } \\
\text { Trab. e Prática } \\
\text { Profiss., Hig. } \\
\text { dos Ed., Noções } \\
\text { de Mec. dos } \\
\text { Solos, } \\
\text { Fundações }\end{array}$ & \multicolumn{2}{|c|}{$\begin{array}{l}\text { 18. Comp. de Arquitetura. Grandes } \\
\text { comp. I, Plástica III }\end{array}$} & \\
\hline Regente & $\begin{array}{l}\text { José C. } \\
\text { Figueiredo } \\
\text { Ferraz }\end{array}$ & $\begin{array}{l}\text { Lysandro M. } \\
\text { Pereira da Silva }\end{array}$ & $\begin{array}{l}\text { Mario W. V. da } \\
\text { Cunha }\end{array}$ & Ariosto Mila & \multicolumn{2}{|l|}{ Hélio de Q. Duarte } & \\
\hline Disciplina & --- & $--\cdot$ & $\begin{array}{l}\text { Contabilidade (a } \\
\text { cargo do assist. } \\
\text { lic. pela FCEA) }\end{array}$ & --- & $\begin{array}{l}\text { Grandes } \\
\text { Composições I }\end{array}$ & Plástica III & \\
\hline Prof. & --- & $\begin{array}{l}\text { Paulo S. Wilken } \\
\text { (F.S.P) }\end{array}$ & $\begin{array}{l}\text { Americo O. } \\
\text { Campiglia / Rui A. } \\
\text { S. Leme / Juarez } \\
\text { R. B. Lopes }\end{array}$ & --- & $\begin{array}{l}\text { Oswaldo C. } \\
\text { Gonçalves }\end{array}$ & Plinio Croce & \\
\hline & \multicolumn{7}{|c|}{$5^{\circ}$ ano } \\
\hline Cadeira & $\begin{array}{l}\text { 8. Grandes } \\
\text { Estruturas }\end{array}$ & $\begin{array}{l}\text { 15. História da } \\
\text { Arte e Estética }\end{array}$ & $\begin{array}{l}\text { 19. Comp. de } \\
\text { Arq. Grandes } \\
\text { comp. II }\end{array}$ & $\begin{array}{l}\text { 20. Arquitetura } \\
\text { no Brasil }\end{array}$ & 23. Urbanismo & $\begin{array}{l}\text { 28. Arquitetura } \\
\text { Paisagística }\end{array}$ & \\
\hline Regente & $\begin{array}{l}\text { Pedro B. J. } \\
\text { Gravinha }\end{array}$ & Flávio L. Motta & Rino Levi (?) & $\begin{array}{l}\text { Eduardo Kneese } \\
\text { de Mello }\end{array}$ & $\begin{array}{l}\text { Luiz I. R. de } \\
\text { Anhaia Mello }\end{array}$ & $\begin{array}{l}\text { Roberto C. } \\
\text { Cardoso }\end{array}$ & \\
\hline Disciplina & --- & --- & Grandes Comp. II & --- & --- & --- & \\
\hline Prof. & Sergio Fracarolli & --- & $\begin{array}{l}\text { Roberto Cerqueira } \\
\text { César }\end{array}$ & $\begin{array}{l}\text { Nestor Goulart } \\
\text { Reis Filho }\end{array}$ & $\begin{array}{l}\text { Milton C. } \\
\text { Ghiraldini }\end{array}$ & $\begin{array}{l}\text { Daisy R. I. } \\
\text { Hoffemberg / } \\
\text { Elisabeth N. } \\
\text { Schoenfeldt }\end{array}$ & \\
\hline
\end{tabular}




\begin{tabular}{|c|c|c|c|c|c|c|c|}
\hline & \multicolumn{7}{|c|}{1957} \\
\hline & \multicolumn{7}{|c|}{10 ano } \\
\hline Cadeira & $\begin{array}{l}\text { 1. Cálculo, } \\
\text { Geom. Anal., } \\
\text { Nomografia }\end{array}$ & $\begin{array}{l}\text { 2. Geometria } \\
\text { Descritiva }\end{array}$ & $\begin{array}{l}\text { 11. Topog., } \\
\text { Elem. de } \\
\text { Astronomia de } \\
\text { Posição }\end{array}$ & $\begin{array}{l}\text { 13. Arquitetura } \\
\text { Analítica }\end{array}$ & \multicolumn{2}{|c|}{$\begin{array}{l}\text { 16. Pequenas Composições de } \\
\text { Arquitetura I }\end{array}$} & $\begin{array}{l}\text { 21. Desenho } \\
\text { Artístico }\end{array}$ \\
\hline Regente & $\begin{array}{l}\text { José O. M. de } \\
\text { Camargo }\end{array}$ & $\begin{array}{l}\text { Pedro M. do } \\
\text { Amaral Cruz }\end{array}$ & $\begin{array}{l}\text { Henrique J. } \\
\text { Guedes }\end{array}$ & $\begin{array}{l}\text { Enoch da R. } \\
\text { Lima }\end{array}$ & \multicolumn{2}{|c|}{ Zenon Lotufo / Abelardo R. De Souza } & $\begin{array}{l}\text { Ernest R. C. } \\
\text { Mange }\end{array}$ \\
\hline Disciplina & $\begin{array}{l}\text { Nomografia } \\
\text { (a cargo } \\
\text { assistente) }\end{array}$ & --- & --- & --- & $\begin{array}{l}\text { Pequenas } \\
\text { Composições I. } \\
\text { parte } 1\end{array}$ & $\begin{array}{l}\text { Desenho } \\
\text { Arquitetônico (a } \\
\text { cargo do assist.) }\end{array}$ & Parte 1 \\
\hline Prof. & Eurico Cerruti & $\begin{array}{l}\text { Guilherme do A. } \\
\text { Lyra }\end{array}$ & --- & $\begin{array}{l}\text { Joaquim B. da } \\
\text { Silva }\end{array}$ & --- & $\begin{array}{l}\text { Manoel da S. } \\
\text { Machado }\end{array}$ & $\begin{array}{l}\text { Vera Helena R. } \\
\text { C. do Amaral }\end{array}$ \\
\hline & \multicolumn{7}{|c|}{$2^{\circ}$ ano } \\
\hline Cadeira & $\begin{array}{l}\text { 1. Cálculo, } \\
\text { Geom. Anal., } \\
\text { Nomografia }\end{array}$ & 3. Mecânica & $\begin{array}{l}\text { 4. Física Geral e } \\
\text { Aplicada }\end{array}$ & $\begin{array}{l}\text { 14. Teoria da } \\
\text { Arquitetura }\end{array}$ & \multicolumn{2}{|c|}{$\begin{array}{l}\text { 16. Pequenas Composições de } \\
\text { Arquitetura I }\end{array}$} & $\begin{array}{l}\text { 21. Desenho } \\
\text { Artístico }\end{array}$ \\
\hline Regente & $\begin{array}{l}\text { José O. M. de } \\
\text { Camargo }\end{array}$ & $\begin{array}{l}\text { João A. Breves } \\
\text { Filho }\end{array}$ & $\begin{array}{l}\text { Luiz Cintra do } \\
\text { Prado }\end{array}$ & Eduardo Corona & \multicolumn{2}{|c|}{ Zenon Lotufo / Abelardo R. De Souza } & $\begin{array}{l}\text { Ernest R. C. } \\
\text { Mange }\end{array}$ \\
\hline Disciplina & --- & --- & --- & --- & $\begin{array}{l}\text { Pequenas } \\
\text { Composições I. } \\
\text { parte } 2\end{array}$ & $\begin{array}{l}\text { Plástica I } \\
\text { (a cargo do } \\
\text { assistente) }\end{array}$ & Parte 2 \\
\hline Prof. & Eurico Cerruti & --- & --- & $\begin{array}{l}\text { Carlos A. C. } \\
\text { Lemos }\end{array}$ & $\begin{array}{l}\text { João B. Vilanova } \\
\text { Artigas }\end{array}$ & $\begin{array}{l}\text { Caetano } \\
\text { Fracarolli }\end{array}$ & Élide Monzeglio \\
\hline & \multicolumn{7}{|c|}{$3^{\circ}$ ano } \\
\hline Cadeira & $\begin{array}{l}\text { 5. Materiais de } \\
\text { Construção }\end{array}$ & $\begin{array}{l}\text { 6. Resistência } \\
\text { dos Materiais. } \\
\text { Estabilidade das } \\
\text { Const. }\end{array}$ & \multicolumn{2}{|c|}{$\begin{array}{l}\text { 9. Técn. das Const., Org. dos Trab. e } \\
\text { Prática Profiss., Hig. dos Ed., } \\
\text { Noções de Mec. dos Solos, } \\
\text { Fundações }\end{array}$} & \multicolumn{2}{|c|}{$\begin{array}{l}\text { 17. Composição de Arquitetura. } \\
\text { Pequenas composições II: Plástica II }\end{array}$} & $\begin{array}{l}\text { 22. Composição } \\
\text { Decorativa }\end{array}$ \\
\hline Regente & $\begin{array}{l}\text { Fernando J. O. } \\
\text { Escorel }\end{array}$ & $\begin{array}{l}\text { Telêmaco H. M. } \\
\text { van Langenlonck }\end{array}$ & \multicolumn{2}{|l|}{ Ariosto Mila } & \multicolumn{2}{|c|}{ Abelardo R. de Souza } & José M. S. Neves \\
\hline Disciplina & --- & --- & $\begin{array}{l}\text { Técn. das } \\
\text { Const., Org. dos } \\
\text { Trab. e Prática } \\
\text { Profiss. }\end{array}$ & $\begin{array}{l}\text { Elem. de Mec. } \\
\text { dos Solos. } \\
\text { Fundações } \\
\text { (a cargo do } \\
\text { assistente) }\end{array}$ & $\begin{array}{l}\text { Pequenas } \\
\text { Composições II }\end{array}$ & Plástica II & --- \\
\hline Prof. & --- & --- & --- & $\begin{array}{l}\text { Victor F. B. de } \\
\text { Mello }\end{array}$ & Jon Maitrejean & $\begin{array}{l}\text { Renina Katz } \\
\text { Pedreira }\end{array}$ & $\begin{array}{l}\text { Jacob M. Ruchti / } \\
\text { Luiz G. C. Lima }\end{array}$ \\
\hline & \multicolumn{7}{|c|}{$4^{\circ}$ ano } \\
\hline Cadeira & $\begin{array}{l}\text { 7. Estruturas } \\
\text { Correntes de } \\
\text { Madeira, } \\
\text { Metálicas e de } \\
\text { Concreto } \\
\text { Simples e } \\
\text { Armado }\end{array}$ & $\begin{array}{l}\text { 10. Hidráulica, } \\
\text { Urbana e } \\
\text { Saneamento }\end{array}$ & $\begin{array}{l}\text { 12. Noções de } \\
\text { Econ. Pol., } \\
\text { Estatíst. Apl., } \\
\text { Org. Adm.,, } \\
\text { Legislação }\end{array}$ & $\begin{array}{l}\text { 9. Técn. das } \\
\text { Const., Org. dos } \\
\text { Trab. e Prática } \\
\text { Profiss., Hig. } \\
\text { dos Ed., Noções } \\
\text { de Mec. dos } \\
\text { Solos, } \\
\text { Fundações }\end{array}$ & \multicolumn{2}{|c|}{$\begin{array}{l}\text { 18. Comp. de Arquitetura. Grandes } \\
\text { comp. I, Plástica III }\end{array}$} & \\
\hline Regente & $\begin{array}{l}\text { José C. de } \\
\text { Figueiredo } \\
\text { Ferraz }\end{array}$ & $\begin{array}{l}\text { Lysandro M. P. } \\
\text { da Silva / Lucas } \\
\text { N. Garcez }\end{array}$ & $\begin{array}{l}\text { Mario W. V. da } \\
\text { Cunha }\end{array}$ & Ariosto Mila & \multicolumn{2}{|l|}{ Hélio de Q. Duarte } & \\
\hline Disciplina & --- & --- & $\begin{array}{l}\text { Contabilidade (a } \\
\text { cargo do assist. } \\
\text { lic. pela FCEA) }\end{array}$ & --- & $\begin{array}{l}\text { Grandes } \\
\text { Composições I }\end{array}$ & Plástica III & \\
\hline Prof. & --- & $\begin{array}{l}\text { Paulo S. Wilken } \\
\text { (F.S.P) }\end{array}$ & $\begin{array}{l}\text { Americo O. } \\
\text { Campiglia / Rui A. } \\
\text { S. Leme / Juarez } \\
\text { R. Brandão Lopes }\end{array}$ & --- & $\begin{array}{l}\text { Roberto J. G. } \\
\text { Tibau }\end{array}$ & Plinio Croce & \\
\hline & \multicolumn{7}{|c|}{ 5o ano } \\
\hline Cadeira & $\begin{array}{l}\text { 8. Grandes } \\
\text { Estruturas }\end{array}$ & $\begin{array}{l}\text { 15. História da } \\
\text { Arte e Estética }\end{array}$ & $\begin{array}{l}\text { 19. Comp. de } \\
\text { Arquitetura. } \\
\text { Grandes comp. II }\end{array}$ & $\begin{array}{l}\text { 20. Arquitetura } \\
\text { no Brasil }\end{array}$ & 23. Urbanismo & $\begin{array}{l}\text { 28. Arquitetura } \\
\text { Paisagística }\end{array}$ & \\
\hline Regente & $\begin{array}{l}\text { Pedro B. J. } \\
\text { Gravinha }\end{array}$ & Flávio L. Motta & Rino Levi & $\begin{array}{l}\text { Eduardo Kneese } \\
\text { de Mello }\end{array}$ & $\begin{array}{l}\text { Luiz I. R. de } \\
\text { Anhaia Mello }\end{array}$ & $\begin{array}{l}\text { Roberto C. } \\
\text { Cardoso }\end{array}$ & \\
\hline Disciplina & --- & --- & Grandes Comp. II & --- & --- & --- & \\
\hline Prof. & Sergio Fracarolli & --- & $\begin{array}{l}\text { Roberto } \\
\text { Cerqueira César }\end{array}$ & $\begin{array}{l}\text { Nestor Goulart } \\
\text { Reis Filho }\end{array}$ & $\begin{array}{l}\text { Lauro B. Birkholz } \\
\text { / Milton C. } \\
\text { Ghiraldini }\end{array}$ & $\begin{array}{l}\text { Daisy R. I. } \\
\text { Hoffemberg / } \\
\text { Rodolpho de A. } \\
\text { Fernandes }\end{array}$ & \\
\hline
\end{tabular}




\begin{tabular}{|c|c|c|c|c|c|c|c|}
\hline & \multicolumn{7}{|c|}{1958} \\
\hline & \multicolumn{7}{|c|}{10 ano } \\
\hline Cadeira & $\begin{array}{l}\text { 1. Cálculo, } \\
\text { Geom. Anal., } \\
\text { Nomografia }\end{array}$ & $\begin{array}{l}\text { 2. Geometria } \\
\text { Descritiva }\end{array}$ & $\begin{array}{l}\text { 11. Topog., } \\
\text { Elem. de } \\
\text { Astronomia de } \\
\text { Posição }\end{array}$ & $\begin{array}{l}\text { 13. Arquitetura } \\
\text { Analítica }\end{array}$ & \multicolumn{2}{|c|}{$\begin{array}{l}\text { 16. Pequenas Composições de } \\
\text { Arquitetura I }\end{array}$} & $\begin{array}{l}\text { 21. Desenho } \\
\text { Artístico }\end{array}$ \\
\hline Regente & $\begin{array}{l}\text { José O. M. de } \\
\text { Camargo }\end{array}$ & $\begin{array}{l}\text { Pedro M. do } \\
\text { Amaral Cruz }\end{array}$ & $\begin{array}{l}\text { Paulo F. de } \\
\text { Mesquita }\end{array}$ & $\begin{array}{l}\text { Enoch da R. } \\
\text { Lima }\end{array}$ & \multicolumn{2}{|l|}{ Hélio de Q. Duarte } & $\begin{array}{l}\text { Ernest R. C. } \\
\text { Mange }\end{array}$ \\
\hline Disciplina & $\begin{array}{l}\text { Nomografia (a } \\
\text { cargo } \\
\text { assistente) }\end{array}$ & --- & --- & --- & $\begin{array}{l}\text { Pequenas } \\
\text { Composições I. } \\
\text { parte } 1\end{array}$ & $\begin{array}{l}\text { Desenho } \\
\text { Arquitetônico (a } \\
\text { cargo do } \\
\text { assistente) }\end{array}$ & Parte 1 \\
\hline Prof. & Eurico Cerruti & $\begin{array}{l}\text { Guilherme do A. } \\
\text { Lyra }\end{array}$ & --- & $\begin{array}{l}\text { Joaquim B. da } \\
\text { Silva }\end{array}$ & --- & Lucio Grinover & $\begin{array}{l}\text { Vera Helena R. } \\
\text { C. do Amaral }\end{array}$ \\
\hline & \multicolumn{7}{|c|}{$2^{\circ}$ ano } \\
\hline Cadeira & $\begin{array}{l}\text { 1. Cálculo, } \\
\text { Geom. Anal., } \\
\text { Nomografia }\end{array}$ & 3. Mecânica & $\begin{array}{l}\text { 4. Física Geral e } \\
\text { Aplicada }\end{array}$ & $\begin{array}{l}\text { 14. Teoria da } \\
\text { Arquitetura }\end{array}$ & \multicolumn{2}{|c|}{$\begin{array}{l}\text { 16. Pequenas Composições de } \\
\text { Arquitetura I }\end{array}$} & $\begin{array}{l}\text { 21. Desenho } \\
\text { Artístico }\end{array}$ \\
\hline Regente & $\begin{array}{l}\text { José O. M. de } \\
\text { Camargo }\end{array}$ & João A. B. Filho & $\begin{array}{l}\text { Luiz Cintra do } \\
\text { Prado }\end{array}$ & Eduardo Corona & \multicolumn{2}{|l|}{ Hélio de Q. Duarte } & $\begin{array}{l}\text { Ernest R. C. } \\
\text { Mange }\end{array}$ \\
\hline Disciplina & --- & --- & --- & --- & $\begin{array}{l}\text { Pequenas } \\
\text { Composições I. } \\
\text { parte } 2\end{array}$ & $\begin{array}{l}\text { Plástica I } \\
\text { (a cargo do } \\
\text { assistente) }\end{array}$ & Parte 2 \\
\hline Prof. & Eurico Cerruti & --- & --- & $\begin{array}{l}\text { Carlos A. C. } \\
\text { Lemos }\end{array}$ & --- & $\begin{array}{l}\text { Caetano } \\
\text { Fracarolli }\end{array}$ & Élide Monzeglio \\
\hline & \multicolumn{7}{|c|}{$3^{\circ}$ ano } \\
\hline Cadeira & $\begin{array}{l}\text { 5. Materiais de } \\
\text { Construção }\end{array}$ & $\begin{array}{l}\text { 6. Resistência } \\
\text { dos Materiais. } \\
\text { Estabilidade das } \\
\text { Const. }\end{array}$ & \multicolumn{2}{|c|}{$\begin{array}{l}\text { 9. Técn. das Const., Org. dos Trab.e } \\
\text { Prática Profiss., Hig. dos Ed., Noções } \\
\text { de Mec. dos Solos, Fundações }\end{array}$} & \multicolumn{2}{|c|}{$\begin{array}{l}\text { 17. Composição de Arquitetura. } \\
\text { Pequenas composições II: Plástica II }\end{array}$} & $\begin{array}{l}\text { 22. Composição } \\
\text { Decorativa }\end{array}$ \\
\hline Regente & $\begin{array}{l}\text { Fernando J. O. } \\
\text { Escorel }\end{array}$ & $\begin{array}{l}\text { Telêmaco H. M. } \\
\text { van Langenlonck }\end{array}$ & \multicolumn{2}{|l|}{ Ariosto Mila } & \multicolumn{2}{|c|}{ Abelardo R. de Souza } & José M. S. Neves \\
\hline Disciplina & --- & --- & $\begin{array}{l}\text { Técn. das } \\
\text { Const., Org. dos } \\
\text { Trab. e Prática } \\
\text { Profiss. }\end{array}$ & $\begin{array}{l}\text { Elem. de Mec. } \\
\text { dos Solos. } \\
\text { Fundações } \\
\text { (a cargo do } \\
\text { assistente) }\end{array}$ & $\begin{array}{l}\text { Pequenas } \\
\text { Composições II }\end{array}$ & Plástica II & --- \\
\hline Prof. & $\begin{array}{l}\text { Joaquim M. } \\
\text { Guedes } \\
\text { Sobrinho }\end{array}$ & --- & --- & $\begin{array}{l}\text { Victor F. B. de } \\
\text { Mello }\end{array}$ & Jon Maitrejean & $\begin{array}{l}\text { Renina Katz } \\
\text { Pedreira }\end{array}$ & $\begin{array}{l}\text { Jacob M. Ruchti / } \\
\text { Luiz G. C. Lima }\end{array}$ \\
\hline & \multicolumn{7}{|c|}{$4^{\circ}$ ano } \\
\hline Cadeira & $\begin{array}{l}\text { 7. Estruturas } \\
\text { Correntes de } \\
\text { Madeira, } \\
\text { Metálicas e de } \\
\text { Concreto } \\
\text { Simples e } \\
\text { Armado }\end{array}$ & $\begin{array}{l}\text { 10. Hidráulica, } \\
\text { Urbana e } \\
\text { Saneamento }\end{array}$ & $\begin{array}{l}\text { 12. Noções de } \\
\text { Econ. Pol., } \\
\text { Estatíst. Apl., } \\
\text { Org. Adm., } \\
\text { Legislação }\end{array}$ & $\begin{array}{l}\text { 9. Técn. das } \\
\text { Const., Org. dos } \\
\text { Trab. e Prática } \\
\text { Profiss., Hig. } \\
\text { dos Ed., Noções } \\
\text { de Mec. dos } \\
\text { Solos, } \\
\text { Fundações }\end{array}$ & \multicolumn{2}{|c|}{$\begin{array}{l}\text { 18. Comp. de Arquitetura. Grandes } \\
\text { comp. I, Plástica III }\end{array}$} & \\
\hline Regente & $\begin{array}{l}\text { José C. de } \\
\text { Figueiredo } \\
\text { Ferraz }\end{array}$ & Lucas N. Garcez & $\begin{array}{l}\text { Mario W. V. da } \\
\text { Cunha }\end{array}$ & Ariosto Mila & \multicolumn{2}{|c|}{ Roberto Cerqueira César } & \\
\hline Disciplina & -- & --- & $\begin{array}{l}\text { Contabilidade (a } \\
\text { cargo do } \\
\text { assistente } \\
\text { licenciado pela } \\
\text { FCEA) }\end{array}$ & --- & $\begin{array}{l}\text { Grandes } \\
\text { Composições I }\end{array}$ & Plástica III & \\
\hline Prof. & --- & $\begin{array}{l}\text { Paulo S. Wilken } \\
\text { (F.S.P) }\end{array}$ & $\begin{array}{l}\text { Americo O. } \\
\text { Campiglia / Rui A. } \\
\text { S. Leme / Juarez } \\
\text { R. Brandão Lopes }\end{array}$ & --- & Luiz R. C. Franco & $\begin{array}{l}\text { Plinio Croce / } \\
\text { Dario Imparato }\end{array}$ & \\
\hline & \multicolumn{7}{|c|}{50 ano } \\
\hline Cadeira & $\begin{array}{l}\text { 8. Grandes } \\
\text { Estruturas }\end{array}$ & $\begin{array}{l}\text { 15. História da } \\
\text { Arte e Estética }\end{array}$ & $\begin{array}{l}\text { 19. Comp. de } \\
\text { Arquitetura. } \\
\text { Grandes comp. II }\end{array}$ & $\begin{array}{l}\text { 20. Arquitetura } \\
\text { no Brasil }\end{array}$ & 23. Urbanismo & $\begin{array}{l}\text { 28. Arquitetura } \\
\text { Paisagística }\end{array}$ & \\
\hline Regente & $\begin{array}{l}\text { Pedro B. J. } \\
\text { Gravinha }\end{array}$ & Flávio L. Motta & Rino Levi & $\begin{array}{l}\text { Eduardo Kneese } \\
\text { de Mello }\end{array}$ & $\begin{array}{l}\text { Luiz I. R. de } \\
\text { Anhaia Mello }\end{array}$ & $\begin{array}{l}\text { Roberto C. } \\
\text { Cardoso }\end{array}$ & \\
\hline Disciplina & --- & --- & $\begin{array}{l}\text { Grandes } \\
\text { Composições II }\end{array}$ & --- & --- & --- & \\
\hline Prof. & Sergio Fracarolli & --- & $\begin{array}{l}\text { João B. Vilanova } \\
\text { Artigas }\end{array}$ & $\begin{array}{l}\text { Nestor Goulart } \\
\text { Reis Filho }\end{array}$ & $\begin{array}{l}\text { Lauro B. Birkholz } \\
\text { / Milton C. } \\
\text { Ghiraldini }\end{array}$ & $\begin{array}{l}\text { Rodolpho de A. } \\
\text { Fernandes }\end{array}$ & \\
\hline
\end{tabular}




\begin{tabular}{|c|c|c|c|c|c|c|c|}
\hline & \multicolumn{7}{|c|}{1959} \\
\hline & \multicolumn{7}{|c|}{10 ano } \\
\hline Cadeira & $\begin{array}{l}\text { 1. Cálculo, } \\
\text { Geom. Anal., } \\
\text { Nomografia }\end{array}$ & $\begin{array}{l}\text { 2. Geometria } \\
\text { Descritiva }\end{array}$ & $\begin{array}{l}\text { 11. Topog., } \\
\text { Elem. de } \\
\text { Astronomia de } \\
\text { Posição }\end{array}$ & $\begin{array}{l}\text { 13. Arquitetura } \\
\text { Analítica }\end{array}$ & \multicolumn{2}{|c|}{$\begin{array}{l}\text { 16. Pequenas Composições de } \\
\text { Arquitetura I }\end{array}$} & $\begin{array}{l}\text { 21. Desenho } \\
\text { Artístico }\end{array}$ \\
\hline Regente & $\begin{array}{l}\text { José O. M. de } \\
\text { Camargo }\end{array}$ & $\begin{array}{l}\text { Pedro M. do } \\
\text { Amaral Cruz }\end{array}$ & $\begin{array}{l}\text { Paulo F. de } \\
\text { Mesquita }\end{array}$ & $\begin{array}{l}\text { Enoch da R. } \\
\text { Lima }\end{array}$ & \multicolumn{2}{|l|}{ Hélio de Q. Duarte } & $\begin{array}{l}\text { Ernest R. C. } \\
\text { Mange }\end{array}$ \\
\hline Disciplina & $\begin{array}{l}\text { Nomografia (a } \\
\text { cargo } \\
\text { assistente) }\end{array}$ & --- & --- & --- & $\begin{array}{l}\text { Pequenas } \\
\text { Composições I. } \\
\text { parte } 1\end{array}$ & $\begin{array}{l}\text { Desenho } \\
\text { Arquitetônico (a } \\
\text { cargo do } \\
\text { assistente) }\end{array}$ & Parte 1 \\
\hline Prof. & Eurico Cerruti & $\begin{array}{l}\text { Guilherme do A. } \\
\text { Lyra }\end{array}$ & --- & $\begin{array}{l}\text { Joaquim B. da } \\
\text { Silva }\end{array}$ & --- & Lucio Grinover & $\begin{array}{l}\text { Vera Helena R. } \\
\text { C. do Amaral }\end{array}$ \\
\hline & \multicolumn{7}{|c|}{$2^{\circ}$ ano } \\
\hline Cadeira & $\begin{array}{l}\text { 1. Cálculo, } \\
\text { Geom. Anal., } \\
\text { Nomografia }\end{array}$ & 3. Mecânica & $\begin{array}{l}\text { 4. Física Geral e } \\
\text { Aplicada }\end{array}$ & $\begin{array}{l}\text { 14. Teoria da } \\
\text { Arquitetura }\end{array}$ & \multicolumn{2}{|c|}{$\begin{array}{l}\text { 16. Pequenas Composições de } \\
\text { Arquitetura I }\end{array}$} & $\begin{array}{l}\text { 21. Desenho } \\
\text { Artístico }\end{array}$ \\
\hline Regente & $\begin{array}{l}\text { José O. M. de } \\
\text { Camargo }\end{array}$ & $\begin{array}{l}\text { João A. Breves } \\
\text { Filho }\end{array}$ & $\begin{array}{l}\text { Luiz Cintra do } \\
\text { Prado }\end{array}$ & Eduardo Corona & \multicolumn{2}{|l|}{ Hélio de Q. Duarte } & $\begin{array}{l}\text { Ernest R. C. } \\
\text { Mange }\end{array}$ \\
\hline Disciplina & --- & --- & --- & --- & $\begin{array}{l}\text { Pequenas } \\
\text { Composições I. } \\
\text { parte } 2\end{array}$ & $\begin{array}{l}\text { Plástica I (a } \\
\text { cargo do } \\
\text { assistente) }\end{array}$ & Parte 2 \\
\hline Prof. & Eurico Cerruti & --- & --- & $\begin{array}{l}\text { Carlos A. C. } \\
\text { Lemos }\end{array}$ & --- & $\begin{array}{l}\text { Caetano } \\
\text { Fracarolli }\end{array}$ & Élide Monzeglio \\
\hline & \multicolumn{7}{|c|}{$3^{\circ}$ ano } \\
\hline Cadeira & $\begin{array}{l}\text { 5. Materiais de } \\
\text { Construção }\end{array}$ & $\begin{array}{l}\text { 6. Resistência } \\
\text { dos Materiais. } \\
\text { Estabilidade das } \\
\text { Const. }\end{array}$ & \multicolumn{2}{|c|}{$\begin{array}{l}\text { 9. Técn. das Const., Org. dos Trab. e } \\
\text { Prática Profiss., Hig. dos Ed., Noções } \\
\text { de Mec. dos Solos, Fundações }\end{array}$} & \multicolumn{2}{|c|}{$\begin{array}{l}\text { 17. Composição de Arquitetura. } \\
\text { Pequenas composições II: Plástica II }\end{array}$} & $\begin{array}{l}\text { 22. Composição } \\
\text { Decorativa }\end{array}$ \\
\hline Regente & $\begin{array}{l}\text { Fernando J. O. } \\
\text { Escorel }\end{array}$ & $\begin{array}{l}\text { Telêmaco H. M. } \\
\text { van Langenlonck }\end{array}$ & \multicolumn{2}{|l|}{ Ariosto Mila } & \multicolumn{2}{|c|}{ Abelardo R. de Souza } & José M. S. Neves \\
\hline Disciplina & --- & $--\cdot$ & $\begin{array}{l}\text { Técnica das } \\
\text { Construções. } \\
\text { Organização dos } \\
\text { Trabalhos e } \\
\text { Prática } \\
\text { Profissional }\end{array}$ & $\begin{array}{l}\text { Elementos de } \\
\text { mecânica dos } \\
\text { Solos. } \\
\text { Fundações } \\
\text { (a cargo do } \\
\text { assistente) }\end{array}$ & $\begin{array}{l}\text { Pequenas } \\
\text { Composições II }\end{array}$ & Plástica II & --- \\
\hline Prof. & $\begin{array}{l}\text { Joaquim M. } \\
\text { Guedes } \\
\text { Sobrinho }\end{array}$ & --- & --- & $\begin{array}{l}\text { Victor F. B. de } \\
\text { Mello }\end{array}$ & Jon Maitrejean & $\begin{array}{l}\text { Renina Katz } \\
\text { Pedreira }\end{array}$ & $\begin{array}{l}\text { Jacob M Ruchti / } \\
\text { Luiz G. C. Lima }\end{array}$ \\
\hline & \multicolumn{7}{|c|}{$4^{\circ}$ ano } \\
\hline Cadeira & $\begin{array}{l}\text { 7. Estruturas } \\
\text { Correntes de } \\
\text { Madeira, } \\
\text { Metálicas e de } \\
\text { Concreto } \\
\text { Simples e } \\
\text { Armado }\end{array}$ & $\begin{array}{l}\text { 10. Hidráulica, } \\
\text { Urbana e } \\
\text { Saneamento }\end{array}$ & $\begin{array}{l}\text { 12. Noções de } \\
\text { Econ. Pol., } \\
\text { Estatíst. Apl., } \\
\text { Org. Adm.,, } \\
\text { Legislação }\end{array}$ & $\begin{array}{l}\text { 9. Técn. das } \\
\text { Const., Org. dos } \\
\text { Trab. e Prática } \\
\text { Profiss., Hig. } \\
\text { dos Ed., Noções } \\
\text { de Mec. dos } \\
\text { Solos, } \\
\text { Fundações }\end{array}$ & \multicolumn{2}{|c|}{$\begin{array}{l}\text { 18. Comp. de Arquitetura. Grandes } \\
\text { comp. I, Plástica III }\end{array}$} & \\
\hline Regente & $\begin{array}{l}\text { José C. de } \\
\text { Figueiredo } \\
\text { Ferraz }\end{array}$ & Lucas N. Garcez & $\begin{array}{l}\text { Mario W. V. da } \\
\text { Cunha }\end{array}$ & Ariosto Mila & \multicolumn{2}{|c|}{ Roberto Cerqueira César } & \\
\hline Disciplina & -- & --- & $\begin{array}{l}\text { Contabilidade } \\
\text { (a cargo do } \\
\text { assistente } \\
\text { licenciado pela } \\
\text { FCEA) }\end{array}$ & --- & $\begin{array}{l}\text { Grandes } \\
\text { Composições I }\end{array}$ & Plástica III & \\
\hline Prof. & --- & $\begin{array}{l}\text { Paulo S. Wilken } \\
\text { (F.S.P) }\end{array}$ & $\begin{array}{l}\text { Americo O. } \\
\text { Campiglia / Rui A. } \\
\text { S. Leme / Juarez } \\
\text { R. Brandão Lopes }\end{array}$ & --- & $\begin{array}{l}\text { Luiz R. C. Franco } \\
\text { / Carlos B. Millan }\end{array}$ & $\begin{array}{l}\text { Plinio Croce / } \\
\text { Dario Imparato }\end{array}$ & \\
\hline & \multicolumn{7}{|c|}{$5^{\circ}$ ano } \\
\hline Cadeira & $\begin{array}{l}\text { 8. Grandes } \\
\text { Estruturas }\end{array}$ & $\begin{array}{l}\text { 15. História da } \\
\text { Arte e Estética }\end{array}$ & $\begin{array}{l}\text { 19. Comp. de } \\
\text { Arquitetura. } \\
\text { Grandes comp. II }\end{array}$ & $\begin{array}{l}\text { 20. Arquitetura } \\
\text { no Brasil }\end{array}$ & 23. Urbanismo & $\begin{array}{l}\text { 28. Arquitetura } \\
\text { Paisagística }\end{array}$ & \\
\hline Regente & $\begin{array}{l}\text { Pedro B. J. } \\
\text { Gravinha }\end{array}$ & Flávio L. Motta & Rino Levi & $\begin{array}{l}\text { Eduardo Kneese } \\
\text { de Mello }\end{array}$ & $\begin{array}{l}\text { Luiz I. R. de } \\
\text { Anhaia Mello }\end{array}$ & $\begin{array}{l}\text { Roberto C. } \\
\text { Cardoso }\end{array}$ & \\
\hline Disciplina & --- & --- & $\begin{array}{l}\text { Grandes } \\
\text { Composições II }\end{array}$ & --- & --- & --- & \\
\hline Prof. & Sergio Fracarolli & --- & $\begin{array}{l}\text { João B. Vilanova } \\
\text { Artigas }\end{array}$ & $\begin{array}{l}\text { Nestor Goulart } \\
\text { Reis Filho }\end{array}$ & $\begin{array}{l}\text { Lauro B. Birkholz } \\
\text { / Milton C. } \\
\text { Ghiraldini }\end{array}$ & $\begin{array}{l}\text { Rodolpho de A. } \\
\text { Fernandes }\end{array}$ & \\
\hline
\end{tabular}




\begin{tabular}{|c|c|c|c|c|c|c|c|}
\hline & \multicolumn{7}{|c|}{1960} \\
\hline & \multicolumn{7}{|c|}{10 ano } \\
\hline Cadeira & $\begin{array}{l}\text { 1. Cálculo, } \\
\text { Geom. Anal., } \\
\text { Nomografia }\end{array}$ & $\begin{array}{l}\text { 2. Geometria } \\
\text { Descritiva }\end{array}$ & $\begin{array}{l}\text { 11. Topog., } \\
\text { Elem. de } \\
\text { Astronomia de } \\
\text { Posição }\end{array}$ & $\begin{array}{l}\text { 13. Arquitetura } \\
\text { Analítica }\end{array}$ & \multicolumn{2}{|c|}{$\begin{array}{l}\text { 16. Pequenas Composições de } \\
\text { Arquitetura I }\end{array}$} & $\begin{array}{l}\text { 21. Desenho } \\
\text { Artístico }\end{array}$ \\
\hline Regente & $\begin{array}{l}\text { José O. M. de } \\
\text { Camargo }\end{array}$ & $\begin{array}{l}\text { Pedro M. do } \\
\text { Amaral Cruz }\end{array}$ & $\begin{array}{l}\text { Paulo F. de } \\
\text { Mesquita }\end{array}$ & $\begin{array}{l}\text { Enoch da R. } \\
\text { Lima }\end{array}$ & \multicolumn{2}{|l|}{ Hélio de Q. Duarte } & $\begin{array}{l}\text { Ernest R. C. } \\
\text { Mange }\end{array}$ \\
\hline Disciplina & $\begin{array}{l}\text { Nomog } \\
\text { rafia (a cargo } \\
\text { do assistente) }\end{array}$ & $--\cdot$ & --- & --- & $\begin{array}{l}\text { Pequenas } \\
\text { Composições I. } \\
\text { parte } 1\end{array}$ & $\begin{array}{l}\text { Desenho } \\
\text { Arquitetônico (a } \\
\text { cargo do } \\
\text { assistente) }\end{array}$ & Parte 1 \\
\hline Prof. & Eurico Cerruti & $\begin{array}{l}\text { Guilherme do A. } \\
\text { Lyra }\end{array}$ & --- & $\begin{array}{l}\text { Joaquim B. da } \\
\text { Silva }\end{array}$ & $\begin{array}{l}\text { Gian Carlo } \\
\text { Gasperini }\end{array}$ & Lucio Grinover & $\begin{array}{l}\text { Vera Helena R. } \\
\text { C. do Amaral }\end{array}$ \\
\hline & \multicolumn{7}{|c|}{$2^{\circ}$ ano } \\
\hline Cadeira & $\begin{array}{l}\text { 1. Cálculo, } \\
\text { Geom. Anal., } \\
\text { Nomografia }\end{array}$ & 3. Mecânica & $\begin{array}{l}\text { 4. Física Geral e } \\
\text { Aplicada }\end{array}$ & $\begin{array}{l}\text { 14. Teoria da } \\
\text { Arquitetura }\end{array}$ & \multicolumn{2}{|c|}{$\begin{array}{l}\text { 16. Pequenas Composições de } \\
\text { Arquitetura I }\end{array}$} & $\begin{array}{l}\text { 21. Desenho } \\
\text { Artístico }\end{array}$ \\
\hline Regente & $\begin{array}{l}\text { José O. M. de } \\
\text { Camargo }\end{array}$ & $\begin{array}{l}\text { João A. Breves } \\
\text { Filho }\end{array}$ & $\begin{array}{l}\text { Luiz Cintra do } \\
\text { Prado }\end{array}$ & Eduardo Corona & \multicolumn{2}{|l|}{ Hélio de Q. Duarte } & $\begin{array}{l}\text { Ernest R. C. } \\
\text { Mange }\end{array}$ \\
\hline Disciplina & --- & --- & --- & --- & $\begin{array}{l}\text { Pequenas } \\
\text { Composições I. } \\
\text { parte } 2\end{array}$ & $\begin{array}{l}\text { Plástica I } \\
\text { (a cargo do } \\
\text { assistente) }\end{array}$ & Parte 2 \\
\hline Prof. & Eurico Cerruti & --- & --- & $\begin{array}{l}\text { Carlos A. C. } \\
\text { Lemos }\end{array}$ & $\begin{array}{l}\text { Gian Carlo } \\
\text { Gasperini }\end{array}$ & $\begin{array}{l}\text { Caetano } \\
\text { Fracarolli }\end{array}$ & Élide Monzeglio \\
\hline & \multicolumn{7}{|c|}{$3^{\circ}$ ano } \\
\hline Cadeira & $\begin{array}{l}\text { 5. Materiais de } \\
\text { Construção }\end{array}$ & $\begin{array}{l}\text { 6. Resistência } \\
\text { dos Materiais. } \\
\text { Estabilidade das } \\
\text { Const. }\end{array}$ & \multicolumn{2}{|c|}{$\begin{array}{l}\text { 9. Técn. das Const., Org. dos Trab. e } \\
\text { Prática Profiss., Hig. dos Ed., } \\
\text { Noções de Mec. dos Solos, } \\
\text { Fundações }\end{array}$} & \multicolumn{2}{|c|}{$\begin{array}{l}\text { 17. Composição de Arquitetura. } \\
\text { Pequenas composições II: Plástica II }\end{array}$} & $\begin{array}{l}\text { 22. Composição } \\
\text { Decorativa }\end{array}$ \\
\hline Regente & $\begin{array}{l}\text { Fernando J. O. } \\
\text { Escorel }\end{array}$ & $\begin{array}{l}\text { Telêmaco H. M. } \\
\text { van Langenlonck }\end{array}$ & \multicolumn{2}{|l|}{ Ariosto Mila } & \multicolumn{2}{|c|}{ Abelardo R. de Souza } & José M. S. Neves \\
\hline Disciplina & --- & --- & $\begin{array}{l}\text { Técn. das } \\
\text { Const., Org. dos } \\
\text { Trab. e Prática } \\
\text { Profiss. }\end{array}$ & $\begin{array}{l}\text { Elem. de Mec. } \\
\text { dos Solos. } \\
\text { Fundações (a } \\
\text { cargo do } \\
\text { assistente) }\end{array}$ & $\begin{array}{l}\text { Pequenas } \\
\text { Composições II }\end{array}$ & Plástica II & --- \\
\hline Prof. & $\begin{array}{l}\text { Joaquim M. } \\
\text { Guedes } \\
\text { Sobrinho }\end{array}$ & --- & --- & $\begin{array}{l}\text { Victor F. B. de } \\
\text { Mello }\end{array}$ & $\begin{array}{l}\text { Jon Maitrejean / } \\
\text { Miranda M. E. M. } \\
\text { Magnoli }\end{array}$ & $\begin{array}{l}\text { Renina Katz } \\
\text { Pedreira }\end{array}$ & $\begin{array}{l}\text { Jacob M. Ruchti / } \\
\text { Luiz G. C. Lima }\end{array}$ \\
\hline & \multicolumn{7}{|c|}{$4^{\circ}$ ano } \\
\hline Cadeira & $\begin{array}{l}\text { 7. Estruturas } \\
\text { Correntes de } \\
\text { Madeira, } \\
\text { Metálicas e de } \\
\text { Concreto } \\
\text { Simples e } \\
\text { Armado }\end{array}$ & $\begin{array}{l}\text { 10. Hidráulica, } \\
\text { Urbana e } \\
\text { Saneamento }\end{array}$ & $\begin{array}{l}\text { 12. Noções de } \\
\text { Econ. Pol., } \\
\text { Estatíst. Apl., } \\
\text { Org. Adm.,, } \\
\text { Legislação }\end{array}$ & $\begin{array}{l}\text { 9. Técn. das } \\
\text { Const., Org. } \\
\text { dos Trab. e } \\
\text { Prática } \\
\text { Profiss., Hig. } \\
\text { dos Ed., } \\
\text { Noções de } \\
\text { Mec. dos } \\
\text { Solos, } \\
\text { Fundações }\end{array}$ & \multicolumn{2}{|c|}{$\begin{array}{l}\text { 18. Comp. de Arquitetura. Grandes } \\
\text { comp. I, Plástica III }\end{array}$} & \\
\hline Regente & $\begin{array}{l}\text { José C. de } \\
\text { Figueiredo } \\
\text { Ferraz }\end{array}$ & Lucas N. Garcez & $\begin{array}{l}\text { Mario W. V. da } \\
\text { Cunha }\end{array}$ & Ariosto Mila & \multicolumn{2}{|c|}{ Roberto Cerqueira César } & \\
\hline Disciplina & -- & --- & $\begin{array}{l}\text { Contabilidade } \\
\text { a cargo do } \\
\text { assistente } \\
\text { licenciado pela } \\
\text { FCEA) }\end{array}$ & --- & $\begin{array}{l}\text { Grandes } \\
\text { Composições I }\end{array}$ & Plástica III & \\
\hline Prof. & --- & $\begin{array}{l}\text { Paulo S. Wilken } \\
\text { (F.S.P) }\end{array}$ & $\begin{array}{l}\text { Americo O. } \\
\text { Campiglia / Rui A. } \\
\text { S. Leme / Juarez } \\
\text { R. Brandão Lopes }\end{array}$ & --- & $\begin{array}{l}\text { Luiz R. C. Franco } \\
\text { / Carlos B. Millan }\end{array}$ & Plinio Croce & \\
\hline & \multicolumn{7}{|c|}{$5 \circ$ ano } \\
\hline Cadeira & $\begin{array}{l}\text { 8. Grandes } \\
\text { Estruturas }\end{array}$ & $\begin{array}{l}\text { 15. História da } \\
\text { Arte e Estética }\end{array}$ & $\begin{array}{l}\text { 19. Comp. de } \\
\text { Arquitetura. } \\
\text { Grandes comp. II }\end{array}$ & $\begin{array}{l}\text { 20. Arquitetura } \\
\text { no Brasil }\end{array}$ & 23. Urbanismo & $\begin{array}{l}\text { 28. Arquitetura } \\
\text { Paisagística }\end{array}$ & \\
\hline Regente & $\begin{array}{l}\text { Pedro B. J. } \\
\text { Gravinha }\end{array}$ & Flávio L. Motta & $\begin{array}{l}\text { João B. Vilanova } \\
\text { Artiga }\end{array}$ & $\begin{array}{l}\text { Eduardo Kneese } \\
\text { de Mello }\end{array}$ & $\begin{array}{l}\text { Luiz I. R. de } \\
\text { Anhaia Mello }\end{array}$ & $\begin{array}{l}\text { Roberto C. } \\
\text { Cardoso }\end{array}$ & \\
\hline Disciplina & --- & --- & $\begin{array}{l}\text { Grandes } \\
\text { Composições II }\end{array}$ & --- & --- & --- & \\
\hline Prof. & Sergio Fracarolli & --- & $\begin{array}{l}\text { Paulo A. Mendes } \\
\text { da Rocha }\end{array}$ & $\begin{array}{l}\text { Nestor Goulart } \\
\text { Reis Filho }\end{array}$ & $\begin{array}{l}\text { Lauro B. Birkholz } \\
\text { / Milton C. } \\
\text { Ghiraldini }\end{array}$ & $\begin{array}{l}\text { Rodolpho de A. } \\
\text { Fernandes }\end{array}$ & \\
\hline
\end{tabular}




\begin{tabular}{|c|c|c|c|c|c|c|c|c|}
\hline & \multicolumn{8}{|c|}{1961} \\
\hline & \multicolumn{8}{|c|}{$11^{\circ}$ ano } \\
\hline Cadeira & $\begin{array}{l}\text { 1. Cálculo } \\
\text { Dif. e Int., } \\
\text { Geom. Anal. }\end{array}$ & $\begin{array}{l}\text { 2. Geometria } \\
\text { Descritiva }\end{array}$ & $\begin{array}{l}\text { 4. Topog., } \\
\text { elem. de } \\
\text { astron. de } \\
\text { posição }\end{array}$ & $\begin{array}{l}\text { 5. Física Ger. } \\
\text { e Apl. }\end{array}$ & $\begin{array}{l}12 . \\
\text { Comunicação } \\
\text { Visual I }\end{array}$ & $\begin{array}{l}\text { 14. Projeto I } \\
\text { (Partes I / II) }\end{array}$ & $\begin{array}{l}\text { 20. História da } \\
\text { Arte. Estética }\end{array}$ & $\begin{array}{l}\text { Disciplina } \\
\text { Autônoma }\end{array}$ \\
\hline Regente & $\begin{array}{l}\text { José O. M. de } \\
\text { Camargo }\end{array}$ & $\begin{array}{l}\text { Pedro M. do } \\
\text { Amaral Cruz }\end{array}$ & $\begin{array}{l}\text { Paulo F. de } \\
\text { Mesquita }\end{array}$ & $\begin{array}{l}\text { Luiz Cintra do } \\
\text { Prado }\end{array}$ & $\begin{array}{l}\text { Ernest R. C. } \\
\text { Mange }\end{array}$ & $\begin{array}{l}\text { Hélio de Q. } \\
\text { Duarte }\end{array}$ & Flávio L. Motta & $(?)$ \\
\hline Disciplina & --- & $--\cdot$ & $--\cdot$ & Parte 1 & $\begin{array}{l}121 . \\
\text { Comunicação } \\
\text { Visual I }\end{array}$ & Parte 1 & --- & $\begin{array}{l}131 . \\
\text { Desenho } \\
\text { Industrial I }\end{array}$ \\
\hline \multirow[t]{2}{*}{ Prof. } & Eurico Cerruti & $\begin{array}{l}\text { Guilherme do } \\
\text { A. Lyra }\end{array}$ & --- & --- & $\begin{array}{l}\text { Vera Helena R. } \\
\text { C. do Amaral / } \\
\text { Caetano } \\
\text { Fracarolli }\end{array}$ & --- & --- & --- \\
\hline & \multicolumn{8}{|c|}{$2^{\circ}$ ano } \\
\hline Cadeira & $\begin{array}{l}\text { 1. Cálculo } \\
\text { Diferencial e } \\
\text { Integral, } \\
\text { Geom. Anal. }\end{array}$ & 3. Mecânica & $\begin{array}{l}\text { 4. Física Geral } \\
\text { e Aplicada }\end{array}$ & $\begin{array}{l}\text { 14. Teoria da } \\
\text { Arquitetura }\end{array}$ & \multicolumn{2}{|c|}{$\begin{array}{l}\text { 16. Pequenas Composições de } \\
\text { Arquitetura I }\end{array}$} & $\begin{array}{l}\text { 21. Desenho } \\
\text { Artístico }\end{array}$ & \\
\hline Regente & $\begin{array}{l}\text { José O. M. de } \\
\text { Camargo }\end{array}$ & $\begin{array}{l}\text { João A. Breves } \\
\text { Filho }\end{array}$ & $\begin{array}{l}\text { Luiz Cintra do } \\
\text { Prado }\end{array}$ & $\begin{array}{l}\text { Eduardo } \\
\text { Corona }\end{array}$ & \multicolumn{2}{|l|}{ Hélio de Q. Duarte } & $\begin{array}{l}\text { Ernest R. C. } \\
\text { Mange }\end{array}$ & \\
\hline Disciplina & --- & --- & --- & --- & $\begin{array}{l}\text { Pequenas } \\
\text { Composições } \\
\text { I. parte } 2\end{array}$ & $\begin{array}{l}\text { Plástica I } \\
\text { (a cargo do } \\
\text { assistente) }\end{array}$ & Parte 2 & \\
\hline Prof. & Eurico Cerruti & --- & $\begin{array}{l}--- \\
\end{array}$ & $\begin{array}{l}\text { Carlos A. C. } \\
\text { Lemos }\end{array}$ & --- & $\begin{array}{l}\text { Caetano } \\
\text { Fracarolli }\end{array}$ & $\begin{array}{l}\text { Élide } \\
\text { Monzeglio }\end{array}$ & \\
\hline & \multicolumn{8}{|c|}{30 ano } \\
\hline Cadeira & $\begin{array}{l}\text { 5. Materiais } \\
\text { de } \\
\text { Construção }\end{array}$ & $\begin{array}{l}\text { 6. Resistência } \\
\text { dos Materiais. } \\
\text { Estabilidade } \\
\text { das Const. }\end{array}$ & \multicolumn{2}{|c|}{$\begin{array}{l}\text { 9. Técn. das Const., Org. dos } \\
\text { Trab. e Prática Profiss., Hig. dos } \\
\text { Ed., Noções de Mec. dos Solos, } \\
\text { Fundações }\end{array}$} & \multicolumn{2}{|c|}{$\begin{array}{l}\text { 17. Composição de Arquitetura. } \\
\text { Pequenas composições II: Plástica } \\
\text { II }\end{array}$} & $\begin{array}{l}22 . \\
\text { Composição } \\
\text { Decorativa }\end{array}$ & \\
\hline Regente & $\begin{array}{l}\text { Fernando J. } \\
\text { O. Escorel }\end{array}$ & $\begin{array}{l}\text { Telêmaco H. } \\
\text { M. van } \\
\text { Langenlonck }\end{array}$ & \multicolumn{2}{|l|}{ Ariosto Mila } & \multicolumn{2}{|c|}{ Abelardo R. de Souza } & $\begin{array}{l}\text { José M. S. } \\
\text { Neves }\end{array}$ & \\
\hline Disciplina & --- & -- & $\begin{array}{l}\text { Técn. das } \\
\text { Const., Org. } \\
\text { dos Trab. e } \\
\text { Prática } \\
\text { Profiss. }\end{array}$ & $\begin{array}{l}\text { Elem. de } \\
\text { Mec. dos } \\
\text { Solos. } \\
\text { Fundações } \\
\text { (a cargo do } \\
\text { assistente) }\end{array}$ & $\begin{array}{l}\text { Pequenas } \\
\text { Composições } \\
\text { II }\end{array}$ & Plástica II & --- & \\
\hline \multirow[t]{2}{*}{ Prof. } & $\begin{array}{l}\text { Joaquim M. } \\
\text { Guedes } \\
\text { Sobrinho }\end{array}$ & --- & --- & $\begin{array}{l}\text { Victor F. B. de } \\
\text { Mello }\end{array}$ & $\begin{array}{l}\text { Jon Maitrejean / } \\
\text { Miranda M. E. } \\
\text { M. Magnoli }\end{array}$ & $\begin{array}{l}\text { Renina Katz } \\
\text { Pedreira / } \\
\text { Flávio Império }\end{array}$ & $\begin{array}{l}\text { Jacob M. } \\
\text { Ruchti / Luiz G. } \\
\text { C. Lima }\end{array}$ & \\
\hline & \multicolumn{8}{|c|}{$4^{\circ}$ ano } \\
\hline Cadeira & $\begin{array}{l}\text { 7. Estruturas } \\
\text { Correntes de } \\
\text { Madeira, } \\
\text { Metálicas e } \\
\text { de Concreto } \\
\text { Simples e } \\
\text { Armado }\end{array}$ & $\begin{array}{l}\text { 10. Hidráulica, } \\
\text { Urbana e } \\
\text { Saneamento }\end{array}$ & $\begin{array}{l}\text { 12. Noções de } \\
\text { Econ. Pol., } \\
\text { Estatíst. Apl., } \\
\text { Org. Adm., } \\
\text { Legislação }\end{array}$ & $\begin{array}{l}\text { 9. Técn. das } \\
\text { Const., Org. } \\
\text { dos Trab. e } \\
\text { Prática } \\
\text { Profiss., Hig. } \\
\text { dos Ed., } \\
\text { Noções de } \\
\text { Mec. dos } \\
\text { Solos, } \\
\text { Fundações }\end{array}$ & \multicolumn{2}{|c|}{$\begin{array}{l}\text { 18. Comp. de Arquitetura. } \\
\text { Grandes comp. I, Plástica III }\end{array}$} & & \\
\hline Regente & $\begin{array}{l}\text { José C. de } \\
\text { Figueiredo } \\
\text { Ferraz }\end{array}$ & $\begin{array}{l}\text { Lucas N. } \\
\text { Garcez }\end{array}$ & $\begin{array}{l}\text { Juarez R. } \\
\text { Brandão Lopes }\end{array}$ & Ariosto Mila & \multicolumn{2}{|c|}{ Roberto Cerqueira César } & & \\
\hline Disciplina & --- & --- & $\begin{array}{l}\text { Contabilidade } \\
\text { (a cargo do } \\
\text { assistente } \\
\text { licenciado pela } \\
\text { FCEA) } \\
\end{array}$ & --- & $\begin{array}{l}\text { Grandes } \\
\text { Composições I }\end{array}$ & Plástica III & & \\
\hline \multirow[t]{2}{*}{ Prof. } & --- & $\begin{array}{l}\text { Paulo S. } \\
\text { Wilken (F.S.P) }\end{array}$ & $\begin{array}{l}\text { Americo O. } \\
\text { Campiglia / Rui } \\
\text { A. S. Leme }\end{array}$ & --- & $\begin{array}{l}\text { Luiz R. } \\
\text { C.Franco }\end{array}$ & Plinio Croce & & \\
\hline & \multicolumn{8}{|c|}{$5^{\circ}$ ano } \\
\hline Cadeira & $\begin{array}{l}\text { 8. Grandes } \\
\text { Estruturas }\end{array}$ & $\begin{array}{l}\text { 15. História da } \\
\text { Arte e } \\
\text { Estética }\end{array}$ & $\begin{array}{l}\text { 19. Comp. de } \\
\text { Arquitetura. } \\
\text { Grandes } \\
\text { comp. II }\end{array}$ & $\begin{array}{l}20 . \\
\text { Arquitetura } \\
\text { no Brasil }\end{array}$ & 23. Urbanismo & $\begin{array}{l}28 . \\
\text { Arquitetura } \\
\text { Paisagística }\end{array}$ & & \\
\hline Regente & $\begin{array}{l}\text { Pedro B. J. } \\
\text { Gravinha }\end{array}$ & Flávio L. Motta & $\begin{array}{l}\text { João B. } \\
\text { Vilanova } \\
\text { Artigas }\end{array}$ & $\begin{array}{l}\text { Eduardo } \\
\text { Kneese de } \\
\text { Mello }\end{array}$ & $\begin{array}{l}\text { Luiz I. R. de } \\
\text { Anhaia Mello }\end{array}$ & $\begin{array}{l}\text { Roberto C. } \\
\text { Cardoso }\end{array}$ & & \\
\hline Disciplina & --- & --- & -- & 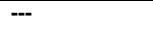 & --- & --- & & \\
\hline Prof. & $\begin{array}{l}\text { Sergio } \\
\text { Fracarolli }\end{array}$ & --- & $\begin{array}{l}\text { Paulo A. } \\
\text { Mendes da } \\
\text { Rocha }\end{array}$ & $\begin{array}{l}\text { Nestor } \\
\text { Goulart Reis } \\
\text { Filho }\end{array}$ & $\begin{array}{l}\text { Lauro B. } \\
\text { Birkholz / Milton } \\
\text { Carlos } \\
\text { Ghiraldini / José } \\
\text { Claudio Gomes }\end{array}$ & $\begin{array}{l}\text { Rodolpho de } \\
\text { A. Fernandes }\end{array}$ & & \\
\hline
\end{tabular}




\begin{tabular}{|c|c|c|c|c|c|c|c|c|}
\hline & \multicolumn{8}{|c|}{1962} \\
\hline & \multicolumn{8}{|c|}{$1^{\circ}$ ano } \\
\hline Cadeira & $\begin{array}{l}\text { 1. Cálculo Dif. } \\
\text { e Int., Geom. } \\
\text { Anal. }\end{array}$ & $\begin{array}{l}\text { 2. Geometria } \\
\text { Descritiva }\end{array}$ & $\begin{array}{l}\text { 4. Topog., } \\
\text { elem. de } \\
\text { astron. de } \\
\text { posição }\end{array}$ & $\begin{array}{l}\text { 5. Física Ger. } \\
\text { e Apl. }\end{array}$ & $\begin{array}{l}12 . \\
\text { Comunicação } \\
\text { Visual I }\end{array}$ & $\begin{array}{l}\text { 14. Projeto I } \\
\text { (Partes I / II) }\end{array}$ & $\begin{array}{l}\text { 20. História da } \\
\text { Arte. Estética }\end{array}$ & $\begin{array}{l}\text { Disciplina } \\
\text { Autônoma }\end{array}$ \\
\hline Regente & $\begin{array}{l}\text { José O. M. de } \\
\text { Camargo }\end{array}$ & $\begin{array}{l}\text { Pedro M. do } \\
\text { Amaral Cruz }\end{array}$ & $\begin{array}{l}\text { Paulo F. de } \\
\text { Mesquita }\end{array}$ & $\begin{array}{l}\text { Luiz Cintra do } \\
\text { Prado }\end{array}$ & $\begin{array}{l}\text { Ernest R. C. } \\
\text { Mange }\end{array}$ & $\begin{array}{l}\text { Hélio de Q. } \\
\text { Duarte }\end{array}$ & Flávio L. Motta & $(?)$ \\
\hline Disciplina & --- & -- & -- & Parte 1 & $\begin{array}{l}\text { 121. Comunic. } \\
\text { Visual I }\end{array}$ & Parte 1 & --- & $\begin{array}{l}131 . \\
\text { Desenho } \\
\text { Industrial I }\end{array}$ \\
\hline \multirow[t]{2}{*}{ Prof. } & Eurico Cerruti & $\begin{array}{l}\text { Guilherme do } \\
\text { A. Lyra }\end{array}$ & $\begin{array}{l}--- \\
\end{array}$ & --- & $\begin{array}{l}\text { Vera Helena R. } \\
\text { C. do Amaral / } \\
\text { Caetano } \\
\text { Fracarolli }\end{array}$ & --- & $\begin{array}{l}\text { Julio R. } \\
\text { Katinsky / } \\
\text { Sérgio Ferro }\end{array}$ & -- \\
\hline & \multicolumn{8}{|c|}{$2^{\circ}$ ano } \\
\hline Cadeira & 3. Mecânica & $\begin{array}{l}\text { 5. Física Ger. } \\
\text { e Apl. }\end{array}$ & $\begin{array}{l}\text { 6. Construção } \\
\text { I }\end{array}$ & $\begin{array}{l}\text { 14. Projeto I } \\
\text { (Partes I / II) }\end{array}$ & $\begin{array}{l}\text { 21. História da } \\
\text { Arq. I }\end{array}$ & $\begin{array}{l}\text { 25. Estudos } \\
\text { Soc. e Econ. }\end{array}$ & $\begin{array}{l}\text { Disciplina } \\
\text { Autônoma }\end{array}$ & $\begin{array}{l}\text { Disciplina } \\
\text { Autônoma }\end{array}$ \\
\hline Regente & $\begin{array}{l}\text { João A. Breves } \\
\text { Filho }\end{array}$ & $\begin{array}{l}\text { Luiz Cintra do } \\
\text { Prado }\end{array}$ & Ariosto Mila & $\begin{array}{l}\text { Hélio de Q. } \\
\text { Duarte }\end{array}$ & $\begin{array}{l}\text { Joaquim B. da } \\
\text { Silva }\end{array}$ & $\begin{array}{l}\text { Juarez R. B. } \\
\text { Lopes }\end{array}$ & $\begin{array}{l}\text { Instrutor } \\
\text { designado por } \\
\text { Lúcio Grinover }\end{array}$ & $\begin{array}{l}\text { Instrutor } \\
\text { designado por } \\
\text { Renina Katz }\end{array}$ \\
\hline Disciplina & --- & Parte 2 & -- & Parte 2 & --- & --- & $\begin{array}{l}\text { 132. Desenho } \\
\text { Industrial II }\end{array}$ & $\begin{array}{l}122 . \\
\text { Comunic. } \\
\text { Visual II }\end{array}$ \\
\hline \multirow[t]{2}{*}{ Prof. } & $\begin{array}{l}-- \\
\end{array}$ & --- & --- & --- & $\begin{array}{l}\text { Dacio A. B. } \\
\text { Ottoni / Hélio } \\
\text { de M. Penteado }\end{array}$ & --- & $\begin{array}{l}\text { Marlene } \\
\text { Picarelli }\end{array}$ & $\begin{array}{l}\text { Flávio } \\
\text { Império }\end{array}$ \\
\hline & \multicolumn{8}{|c|}{30 ano } \\
\hline Cadeira & $\begin{array}{l}\text { 5. Materiais de } \\
\text { Construção }\end{array}$ & $\begin{array}{l}\text { 6. Resistência } \\
\text { dos Materiais. } \\
\text { Estabilidade } \\
\text { das Const. }\end{array}$ & \multicolumn{2}{|c|}{$\begin{array}{l}\text { 9. Técn. das Const., Org. dos } \\
\text { Trab. e Prática Profiss., Hig. } \\
\text { dos Ed., Noções de Mec. dos } \\
\text { Solos, Fundações }\end{array}$} & \multicolumn{2}{|c|}{$\begin{array}{l}\text { 17. Composição de Arquitetura. } \\
\text { Pequenas composições II: } \\
\text { Plástica II }\end{array}$} & $\begin{array}{l}22 . \\
\text { Composição } \\
\text { Decorativa }\end{array}$ & \\
\hline Regente & $\begin{array}{l}\text { Fernando J. O. } \\
\text { Escorel }\end{array}$ & $\begin{array}{l}\text { Telêmaco H. } \\
\text { M. van } \\
\text { Langenlonck }\end{array}$ & \multicolumn{2}{|l|}{ Ariosto Mila } & \multicolumn{2}{|c|}{ Abelardo R. de Souza } & $\begin{array}{l}\text { José M. S. } \\
\text { Neves }\end{array}$ & \\
\hline Disciplina & --- & -- & $\begin{array}{l}\text { Técn. das } \\
\text { Const., Org. } \\
\text { dos Trab. e } \\
\text { Prática } \\
\text { Profiss. }\end{array}$ & $\begin{array}{l}\text { Elem. de Mec. } \\
\text { dos Solos. } \\
\text { Fundações (a } \\
\text { cargo do } \\
\text { assistente) }\end{array}$ & $\begin{array}{l}\text { Pequenas } \\
\text { Composições } \\
\text { II }\end{array}$ & Plástica II & --- & \\
\hline \multirow[t]{2}{*}{ Prof. } & $\begin{array}{l}\text { Joaquim M. } \\
\text { Guedes } \\
\text { Sobrinho }\end{array}$ & --- & --- & $\begin{array}{l}\text { Victor F. B. de } \\
\text { Mello }\end{array}$ & $\begin{array}{l}\text { Jon Maitrejean / } \\
\text { Miranda M. E. } \\
\text { M. Magnoli }\end{array}$ & $\begin{array}{l}\text { Renina Katz } \\
\text { Pedreira }\end{array}$ & $\begin{array}{l}\text { Abrahão V. } \\
\text { Sanovicz / Luiz } \\
\text { G. C. Lima }\end{array}$ & \\
\hline & \multicolumn{8}{|c|}{$4^{\circ}$ ano } \\
\hline Cadeira & $\begin{array}{l}\text { 7. Estruturas } \\
\text { Correntes de } \\
\text { Madeira, } \\
\text { Metálicas e de } \\
\text { Concreto } \\
\text { Simples e } \\
\text { Armado }\end{array}$ & $\begin{array}{l}\text { 8. Grandes } \\
\text { Estruturas }\end{array}$ & $\begin{array}{l}\text { 9. Técn. das } \\
\text { Const., Org. } \\
\text { dos Trab. e } \\
\text { Prática } \\
\text { Profiss., Hig. } \\
\text { dos Ed., } \\
\text { Noções de } \\
\text { Mec. dos } \\
\text { Solos, } \\
\text { Fundações }\end{array}$ & $\begin{array}{l}\text { 10. Hidráulica, } \\
\text { Urbana e } \\
\text { Saneamento }\end{array}$ & \multicolumn{2}{|c|}{$\begin{array}{l}\text { 18. Comp. de Arquitetura. } \\
\text { Grandes comp. I, Plástica III }\end{array}$} & $\begin{array}{l}23 . \\
\text { Urbanismo }\end{array}$ & \\
\hline Regente & $\begin{array}{l}\text { José C. F. } \\
\text { Ferraz }\end{array}$ & $\begin{array}{l}\text { Pedro B. J. } \\
\text { Gravinha }\end{array}$ & Ariosto Mila & $\begin{array}{l}\text { Lucas N. } \\
\text { Garcez }\end{array}$ & \multicolumn{2}{|c|}{ Roberto Cerqueira César } & $\begin{array}{l}\text { Lauro B. } \\
\text { Birkholz }\end{array}$ & \\
\hline Disciplina & --- & --- & --- & --- & $\begin{array}{l}\text { Grandes } \\
\text { Composições I }\end{array}$ & Plástica III & Urbanismo I & \\
\hline \multirow[t]{2}{*}{ Prof. } & --- & $\begin{array}{l}\text { Sergio } \\
\text { Fracarolli }\end{array}$ & --- & $\begin{array}{l}\text { Paulo S. } \\
\text { Wilken (F.S.P) } \\
\text { / Rufino Reis } \\
\text { Soares }\end{array}$ & $\begin{array}{l}\text { Luiz R. C. } \\
\text { Franco }\end{array}$ & Plinio Croce & $\begin{array}{l}\text { Milton C. } \\
\text { Ghiraldini / José } \\
\text { C. Gomes / } \\
\text { Brenno C. } \\
\text { Nogueira }\end{array}$ & \\
\hline & \multicolumn{8}{|c|}{$5^{\circ}$ ano } \\
\hline Cadeira & $\begin{array}{l}\text { 12. Noções de } \\
\text { Econ. Pol., } \\
\text { Estatíst. Apl., } \\
\text { Org. Adm., } \\
\text { Legislação }\end{array}$ & $\begin{array}{l}\text { 15. História da } \\
\text { Arte e } \\
\text { Estética }\end{array}$ & $\begin{array}{l}\text { 19. Comp. de } \\
\text { Arquitetura. } \\
\text { Grandes } \\
\text { comp. II }\end{array}$ & $\begin{array}{l}20 . \\
\text { Arquitetura } \\
\text { no Brasil }\end{array}$ & 23. Urbanismo & $\begin{array}{l}28 . \\
\text { Arquitetura } \\
\text { Paisagística }\end{array}$ & & \\
\hline Regente & $\begin{array}{l}\text { Juarez R. } \\
\text { Brandão Lopes }\end{array}$ & Flávio L. Motta & $\begin{array}{l}\text { João B. } \\
\text { Vilanova } \\
\text { Artigas }\end{array}$ & $\begin{array}{l}\text { Eduardo } \\
\text { Kneese de } \\
\text { Mello }\end{array}$ & $\begin{array}{l}\text { Lauro B. } \\
\text { Birkholz }\end{array}$ & $\begin{array}{l}\text { Roberto C. } \\
\text { Cardoso }\end{array}$ & & \\
\hline Disciplina & $\begin{array}{l}\text { Contabilidade } \\
\text { (a cargo do } \\
\text { assistente } \\
\text { licenciado } \\
\text { pela FCEA) }\end{array}$ & --- & -- & -- & --- & --- & & \\
\hline Prof. & $\begin{array}{l}\text { Americo O. } \\
\text { Campiglia }\end{array}$ & $\begin{array}{l}\text { Julio R. } \\
\text { Katinsky / } \\
\text { Sérgio Ferro }\end{array}$ & $\begin{array}{l}\text { Pedro P. M. } \\
\text { Saraiva / } \\
\text { Paulo A. } \\
\text { Mendes da } \\
\text { Rocha }\end{array}$ & $\begin{array}{l}\text { Nestor Goulart } \\
\text { Reis Filho / } \\
\text { Benedito L. de } \\
\text { Toledo / } \\
\text { Rodrigo B. } \\
\text { Lefèvre }\end{array}$ & $\begin{array}{l}\text { Milton C. } \\
\text { Ghiraldini / } \\
\text { José C. Gomes } \\
\text { / Brenno C. } \\
\text { Nogueira }\end{array}$ & $\begin{array}{l}\text { Rodolpho de } \\
\text { A. Fernandes / } \\
\text { Antonio A. } \\
\text { Antunes Netto }\end{array}$ & & \\
\hline
\end{tabular}




\begin{tabular}{|c|c|c|c|c|c|c|c|c|c|}
\hline & \multicolumn{9}{|c|}{1963} \\
\hline & \multicolumn{9}{|c|}{$1 \%$ ano } \\
\hline Cadeira & $\begin{array}{l}\text { 1. Cálculo } \\
\text { Dif. e Int., } \\
\text { Geom. Anal. }\end{array}$ & $\begin{array}{l}2 . \\
\text { Geometria } \\
\text { Descritiva }\end{array}$ & $\begin{array}{l}\text { 4. Topog., } \\
\text { elem. de } \\
\text { astron. de } \\
\text { posição }\end{array}$ & $\begin{array}{l}\text { 5. Física } \\
\text { Ger. e Apl. }\end{array}$ & $\begin{array}{l}12 . \\
\text { Comunicação } \\
\text { Visual I }\end{array}$ & $\begin{array}{l}\text { 14. Projeto I } \\
\text { (Partes I / II) }\end{array}$ & $\begin{array}{l}20 . \\
\text { História da } \\
\text { Arte. } \\
\text { Estética }\end{array}$ & $\begin{array}{l}\text { Disciplina } \\
\text { Autônoma }\end{array}$ & \\
\hline Regente & $\begin{array}{l}\text { José O. M. } \\
\text { de Camargo }\end{array}$ & $\begin{array}{l}\text { Pedro M. do } \\
\text { Amaral } \\
\text { Cruz }\end{array}$ & $\begin{array}{l}\text { Paulo F. de } \\
\text { Mesquita }\end{array}$ & $\begin{array}{l}\text { Luiz Cintra } \\
\text { do Prado }\end{array}$ & $\begin{array}{l}\text { Ernest R. C. } \\
\text { Mange }\end{array}$ & $\begin{array}{l}\text { Hélio de Q. } \\
\text { Duarte }\end{array}$ & $\begin{array}{l}\text { Flávio L. } \\
\text { Motta }\end{array}$ & (?) & \\
\hline Disciplina & --- & --- & --- & Parte 1 & $\begin{array}{l}\text { 121. Comun. } \\
\text { Visual I }\end{array}$ & Parte 1 & --- & $\begin{array}{l}\text { 131. Desenho } \\
\text { Industrial I }\end{array}$ & \\
\hline \multirow[t]{2}{*}{ Prof. } & $\begin{array}{l}\text { Domingos } \\
\text { Pizanelli / } \\
\text { Eurico Cerruti }\end{array}$ & $\begin{array}{l}\text { Guilherme } \\
\text { do A. Lyra }\end{array}$ & $-\cdots$ & --- & $\begin{array}{l}\text { Élide } \\
\text { Monzeglio / } \\
\text { Caetano } \\
\text { Fracarolli }\end{array}$ & --- & $\begin{array}{l}\text { Julio R. } \\
\text { Katinsky / } \\
\text { Sérgio } \\
\text { Ferro }\end{array}$ & --- & \\
\hline & \multicolumn{9}{|c|}{$2^{\circ}$ ano } \\
\hline Cadeira & 3. Mecânica & $\begin{array}{l}\text { 5. Física } \\
\text { Ger. e Apl. }\end{array}$ & $\begin{array}{l}6 . \\
\text { Construção I }\end{array}$ & $\begin{array}{l}\text { 14. Projeto I } \\
\text { (Partes I / II) }\end{array}$ & $\begin{array}{l}\text { 21. História } \\
\text { da Arq. I }\end{array}$ & $\begin{array}{l}\text { 25. Estudos } \\
\text { Soc. e Econ. }\end{array}$ & $\begin{array}{l}\text { Disciplina } \\
\text { Autônoma }\end{array}$ & $\begin{array}{l}\text { Disciplina } \\
\text { Autônoma }\end{array}$ & \\
\hline Regente & $\begin{array}{l}\text { João A. } \\
\text { Breves Filho }\end{array}$ & $\begin{array}{l}\text { Luiz Cintra } \\
\text { do Prado }\end{array}$ & Ariosto Mila & $\begin{array}{l}\text { Hélio de Q. } \\
\text { Duarte }\end{array}$ & $\begin{array}{l}\text { Joaquim B. da } \\
\text { Silva }\end{array}$ & $\begin{array}{l}\text { Juarez R. B. } \\
\text { Lopes }\end{array}$ & $\begin{array}{l}\text { Instrutor } \\
\text { designado } \\
\text { por Lúcio } \\
\text { Grinover }\end{array}$ & $\begin{array}{l}\text { Instrutor } \\
\text { designado } \\
\text { por Renina } \\
\text { Katz }\end{array}$ & \\
\hline Disciplina & --- & Parte 2 & --- & --- & --- & $-\cdots$ & $\begin{array}{l}132 . \\
\text { Desenho } \\
\text { Industrial II }\end{array}$ & $\begin{array}{l}122 . \\
\text { Comum. } \\
\text { Visual II }\end{array}$ & \\
\hline Prof. & --- & --- & --- & $-\cdots$ & $\begin{array}{l}\text { Dacio A. B. } \\
\text { Ottoni / Hélio } \\
\text { de M. } \\
\text { Penteado }\end{array}$ & --- & $\begin{array}{l}\text { Marlene } \\
\text { Picarelli }\end{array}$ & $\begin{array}{l}\text { Flávio } \\
\text { Império }\end{array}$ & \\
\hline \multicolumn{10}{|c|}{$3^{\circ}$ ano } \\
\hline Cadeira & $\begin{array}{l}\text { 7. Resist. } \\
\text { dos mat. e } \\
\text { estabilidade } \\
\text { das constr. }\end{array}$ & $\begin{array}{l}\text { 8. Hidráulica } \\
\text { e } \\
\text { saneamento }\end{array}$ & $\begin{array}{l}9 . \\
\text { Construção II }\end{array}$ & $\begin{array}{l}\text { 13. Desenho } \\
\text { Industrial III }\end{array}$ & 15. Projeto II & $\begin{array}{l}18 . \\
\text { Planejamento } \\
\text { I }\end{array}$ & $\begin{array}{l}22 . \\
\text { História da } \\
\text { Arq. II }\end{array}$ & $\begin{array}{l}\text { Disciplina } \\
\text { Autônoma } \\
\text { (61. Mec. } \\
\text { dos solos } \\
\text { e fund.?) }\end{array}$ & $\begin{array}{l}\text { Disciplina } \\
\text { Autônoma }\end{array}$ \\
\hline Regente & $\begin{array}{l}\text { Telêmaco } \mathrm{H} \text {. } \\
\text { M. van } \\
\text { Langendonck }\end{array}$ & $\begin{array}{l}\text { Lucas N. } \\
\text { Garcez }\end{array}$ & $\begin{array}{l}\text { Fernando J. } \\
\text { O. Escorel }\end{array}$ & $\begin{array}{l}\text { José M. S. } \\
\text { Neves }\end{array}$ & $\begin{array}{l}\text { Abelardo R. } \\
\text { de Souza }\end{array}$ & $\begin{array}{l}\text { Roberto C. } \\
\text { Cardoso }\end{array}$ & $\begin{array}{l}\text { Nestor } \\
\text { Goulart } \\
\text { Reis Filho }\end{array}$ & $\begin{array}{l}\text { Prof. } \\
\text { Assistente } \\
\text { designado } \\
\text { por Vitor F. } \\
\text { B. de Mello }\end{array}$ & $\begin{array}{l}\text { Instrutor } \\
\text { designado } \\
\text { por João } \\
\text { B. A. } \\
\text { Xavier }\end{array}$ \\
\hline Disciplina & --- & --- & --- & $\begin{array}{l}\text { Desenho } \\
\text { Industrial III }\end{array}$ & --- & --- & --- & Fundações & $\begin{array}{l}123 . \\
\text { Comunic. } \\
\text { Visual III }\end{array}$ \\
\hline Prof. & --- & $\begin{array}{l}\text { Paulo S. } \\
\text { Wilken } \\
\text { (F.S.P) }\end{array}$ & $\begin{array}{l}\text { José } \\
\text { Fonseca }\end{array}$ & $\begin{array}{l}\text { Abrahão V. } \\
\text { Sanovicz / } \\
\text { Luiz G. C. } \\
\text { Lima }\end{array}$ & --- & $\begin{array}{l}\text { Rodolpho A. } \\
\text { Fernandes / } \\
\text { Antonio A. } \\
\text { Antunes Netto }\end{array}$ & $\begin{array}{l}\text { Rodrigo B. } \\
\text { Lefèvre / } \\
\text { Paulo J. V. } \\
\text { Bruna }\end{array}$ & --- & --- \\
\hline \multicolumn{10}{|c|}{$4^{\circ}$ ano } \\
\hline Cadeira & $\begin{array}{l}\text { 7. Estruturas } \\
\text { Correntes } \\
\text { de Madeira, } \\
\text { Metálicas e } \\
\text { de Concreto } \\
\text { Simples e } \\
\text { Armado }\end{array}$ & $\begin{array}{l}\text { 8. Grandes } \\
\text { Estruturas }\end{array}$ & $\begin{array}{l}\text { 9. Técn. das } \\
\text { Const., Org. } \\
\text { dos Trab. e } \\
\text { Prática } \\
\text { Profiss., } \\
\text { Hig. os Ed., } \\
\text { Noções de } \\
\text { Mec. dos } \\
\text { Solos, Fund. }\end{array}$ & $\begin{array}{l}10 . \\
\text { Hidráulica, } \\
\text { Urbana e } \\
\text { Saneamento }\end{array}$ & \multicolumn{2}{|c|}{$\begin{array}{l}\text { 18. Composição de } \\
\text { Arquitetura. Grandes } \\
\text { composições I, Plástica III }\end{array}$} & $\begin{array}{l}23 . \\
\text { Urbanismo }\end{array}$ & & \\
\hline Regente & $\begin{array}{l}\text { José C. F. } \\
\text { Ferraz }\end{array}$ & $\begin{array}{l}\text { Pedro B. J. } \\
\text { Gravinha }\end{array}$ & Ariosto Mila & $\begin{array}{l}\text { Lucas N. } \\
\text { Garcez }\end{array}$ & \multicolumn{2}{|c|}{ Roberto Cerqueira César } & $\begin{array}{l}\text { Lauro B. } \\
\text { Birkholz }\end{array}$ & & \\
\hline Disciplina & --- & --- & --- & --- & $\begin{array}{l}\text { Grandes } \\
\text { Comp. I }\end{array}$ & Plástica III & Urbanismo I & & \\
\hline Prof. & --- & --- & --- & $\begin{array}{l}\text { Paulo S. } \\
\text { Wilken } \\
\text { (F.S.P) / } \\
\text { Rufino Reis } \\
\text { Soares }\end{array}$ & $\begin{array}{l}\text { Luiz R. C. } \\
\text { Franco }\end{array}$ & Plinio Croce & $\begin{array}{l}\text { Milton C. } \\
\text { Ghiraldini / } \\
\text { José C. } \\
\text { Gomes / } \\
\text { Brenno C. } \\
\text { Nogueira }\end{array}$ & & \\
\hline \multicolumn{10}{|c|}{50 ano } \\
\hline Cadeira & $\begin{array}{l}\text { 12. Noções } \\
\text { de Econ. Pol., } \\
\text { Estatíst. Apl., } \\
\text { Org. Adm., } \\
\text { Legislação }\end{array}$ & $\begin{array}{l}\text { 15. História } \\
\text { da Arte e } \\
\text { Estética }\end{array}$ & $\begin{array}{l}19 . \\
\text { Composição } \\
\text { de } \\
\text { Arquitetura. } \\
\text { Grandes } \\
\text { comp. II }\end{array}$ & $\begin{array}{l}20 . \\
\text { Arquitetura } \\
\text { no Brasil }\end{array}$ & $\begin{array}{l}23 . \\
\text { Urbanismo }\end{array}$ & $\begin{array}{l}28 . \\
\text { Arquitetura } \\
\text { Paisagística }\end{array}$ & & & \\
\hline Regente & $\begin{array}{l}\text { Juarez R. B. } \\
\text { Lopes }\end{array}$ & $\begin{array}{l}\text { Flávio L. } \\
\text { Motta }\end{array}$ & $\begin{array}{l}\text { João B. V. } \\
\text { Artigas }\end{array}$ & $\begin{array}{l}\text { Eduardo K. } \\
\text { de Mello }\end{array}$ & $\begin{array}{l}\text { Lauro B. } \\
\text { Birkholz }\end{array}$ & $\begin{array}{l}\text { Roberto C. } \\
\text { Cardoso }\end{array}$ & & & \\
\hline Disciplina & $\begin{array}{l}\text { Contabilidade } \\
\text { (a cargo do } \\
\text { assist. licenc. } \\
\text { pela FCEA) }\end{array}$ & --- & $\begin{array}{l}\text { Grandes } \\
\text { Composições ॥ }\end{array}$ & -- & Urbanismo II & --- & & & \\
\hline Prof. & $\begin{array}{l}\text { Americo O. } \\
\text { Campiglia }\end{array}$ & $\begin{array}{l}\text { Julio R. } \\
\text { Katinsky / } \\
\text { Sérgio } \\
\text { Ferro }\end{array}$ & $\begin{array}{l}\text { Pedro P. M. } \\
\text { Saraiva / } \\
\text { Paulo A. } \\
\text { Mendes da } \\
\text { Rocha }\end{array}$ & $\begin{array}{l}\text { Nestor } \\
\text { Goulart Reis } \\
\text { Filho / } \\
\text { Benedito L. } \\
\text { de Toledo / } \\
\text { Rodrigo B. } \\
\text { Lefèvre }\end{array}$ & $\begin{array}{l}\text { Milton C. } \\
\text { Ghiraldini / } \\
\text { José C. } \\
\text { Gomes / } \\
\text { Brenno C. } \\
\text { Nogueira }\end{array}$ & $\begin{array}{l}\text { Rodolpho de } \\
\text { A. Fernandes } \\
\text { / Antonio A. } \\
\text { Antunes Netto }\end{array}$ & & & \\
\hline
\end{tabular}




\begin{tabular}{|c|c|c|c|c|c|c|c|c|c|}
\hline & \multicolumn{9}{|c|}{1964} \\
\hline & \multicolumn{9}{|c|}{10 ano } \\
\hline Cadeira & $\begin{array}{l}\text { 1. Cálculo } \\
\text { Dif. e Int., } \\
\text { Geom. Anal. }\end{array}$ & $\begin{array}{l}2 . \\
\text { Geometria } \\
\text { Descritiva }\end{array}$ & $\begin{array}{l}\text { 4. Topog., elem. } \\
\text { astron. de posiça }\end{array}$ & $\begin{array}{l}\text { 5. Física } \\
\text { Geral e } \\
\text { Aplicada }\end{array}$ & $\begin{array}{l}12 . \\
\text { Comunicação } \\
\text { Visual I }\end{array}$ & $\begin{array}{l}\text { 14. Projeto I } \\
\text { (Parte I/ } \\
\text { Parte II) }\end{array}$ & $\begin{array}{l}\text { 20. História } \\
\text { da Arte. } \\
\text { Estética }\end{array}$ & $\begin{array}{l}\text { Disciplina } \\
\text { Autônoma }\end{array}$ & \\
\hline Regente & $\begin{array}{l}\text { Domingos } \\
\text { Pizanelli }\end{array}$ & $\begin{array}{l}\text { Pedro M. do } \\
\text { Amaral Cruz }\end{array}$ & $\begin{array}{l}\text { Paulo Ferraz } \\
\text { de Mesquita }\end{array}$ & $\begin{array}{l}\text { Luiz Cintra do } \\
\text { Prado }\end{array}$ & $\begin{array}{l}\text { Ernest R. C. } \\
\text { Mange }\end{array}$ & $\begin{array}{l}\text { Hélio de Q. } \\
\text { Duarte }\end{array}$ & $\begin{array}{l}\text { Flávio L. } \\
\text { Motta }\end{array}$ & $\begin{array}{l}\text { Instrutor } \\
\text { designado } \\
\text { por João } \\
\text { Carlos } \\
\text { Cauduro }\end{array}$ & \\
\hline Disciplina & $--\cdot$ & --- & --- & Parte 1 & $\begin{array}{l}\text { 121. Comum. } \\
\text { Visual I }\end{array}$ & Parte 1 & $--\cdot$ & $\begin{array}{l}\text { 131. Desenho } \\
\text { Industrial I }\end{array}$ & \\
\hline Prof. & $\begin{array}{l}\text { Eurico } \\
\text { Cerruti }\end{array}$ & $\begin{array}{l}\text { Guilherme } \\
\text { do A. Lyra }\end{array}$ & --- & --- & $\begin{array}{l}\text { Élide } \\
\text { Monzeglio / } \\
\text { Caetano } \\
\text { Fracarolli }\end{array}$ & $\begin{array}{l}\text { Ludovico A. } \\
\text { Martino }\end{array}$ & $\begin{array}{l}\text { Julio R. } \\
\text { Katinsky / } \\
\text { Sérgio } \\
\text { Ferro }\end{array}$ & \begin{tabular}{|l|}
--- \\
\end{tabular} & \\
\hline \multicolumn{10}{|c|}{$2^{\circ}$ ano } \\
\hline Cadeira & 3. Mecânica & $\begin{array}{l}\text { 5. Física } \\
\text { Ger. e Apl. }\end{array}$ & 6. Construção I & $\begin{array}{l}\text { 14. Projeto I } \\
\text { (Partes I / II) }\end{array}$ & $\begin{array}{l}\text { 21. História } \\
\text { da Arq. I }\end{array}$ & $\begin{array}{l}\text { 25. Estudos } \\
\text { Soc. e Econ. }\end{array}$ & $\begin{array}{l}\text { Disciplina } \\
\text { Autônoma }\end{array}$ & $\begin{array}{l}\text { Disciplina } \\
\text { Autônoma }\end{array}$ & \\
\hline Regente & $\begin{array}{l}\text { João A. } \\
\text { Breves Filho }\end{array}$ & $\begin{array}{l}\text { Luiz Cintra } \\
\text { do Prado }\end{array}$ & Ariosto Mila & $\begin{array}{l}\text { Hélio de Q. } \\
\text { Duarte }\end{array}$ & $\begin{array}{l}\text { Joaquim B. da } \\
\text { Silva }\end{array}$ & $\begin{array}{l}\text { Juarez R. } \\
\text { Brandão } \\
\text { Lopes }\end{array}$ & $\begin{array}{l}\text { Instrutor } \\
\text { designado } \\
\text { por Lúcio } \\
\text { Grinover }\end{array}$ & $\begin{array}{l}\text { Instrutor } \\
\text { designado } \\
\text { por Renina } \\
\text { Katz }\end{array}$ & \\
\hline Disciplina & --- & Parte 2 & --- & Parte 2 & --- & --- & $\begin{array}{l}132 . \\
\text { Desenho } \\
\text { Industrial II }\end{array}$ & $\begin{array}{l}122 . \\
\text { Comum. } \\
\text { Visual II }\end{array}$ & \\
\hline Prof. & --- & --- & --- & $\begin{array}{l}\text { Ludovico A. } \\
\text { Martino }\end{array}$ & $\begin{array}{l}\text { Dacio A. B. } \\
\text { Ottoni / Hélio } \\
\text { de M. } \\
\text { Penteado }\end{array}$ & --- & $\begin{array}{l}\text { Marlene } \\
\text { Picarelli }\end{array}$ & $\begin{array}{l}\text { Flávio } \\
\text { Império }\end{array}$ & \\
\hline \multicolumn{10}{|c|}{$3^{\circ}$ ano } \\
\hline Cadeira & $\begin{array}{l}\text { 7. Resist. } \\
\text { dos } \\
\text { materiais e } \\
\text { estabilidade } \\
\text { das const. }\end{array}$ & $\begin{array}{l}8 . \\
\text { Hidráulica e } \\
\text { saneamento }\end{array}$ & $\begin{array}{l}9 . \\
\text { Construção II }\end{array}$ & $\begin{array}{l}\text { 13. Desenho } \\
\text { Industrial III }\end{array}$ & 15. Projeto II & $\begin{array}{l}18 . \\
\text { Planejamento } \\
\text { I }\end{array}$ & $\begin{array}{l}\text { 22. História } \\
\text { da } \\
\text { Arquitetura } \\
\text { II }\end{array}$ & $\begin{array}{l}\text { Disciplina } \\
\text { Autônoma (61. } \\
\text { Mec. dos } \\
\text { solos e } \\
\text { fundações?) } \\
\end{array}$ & $\begin{array}{l}\text { Disciplina } \\
\text { Autônoma }\end{array}$ \\
\hline Regente & $\begin{array}{l}\text { Telêmaco } \\
\text { H.M. van } \\
\text { Langendonck }\end{array}$ & $\begin{array}{l}\text { Lucas N. } \\
\text { Garcez }\end{array}$ & $\begin{array}{l}\text { Fernando J. } \\
\text { O. Escorel }\end{array}$ & $\begin{array}{l}\text { José M. Silva } \\
\text { Neves }\end{array}$ & $\begin{array}{l}\text { Abelardo R. } \\
\text { de Souza }\end{array}$ & $\begin{array}{l}\text { Abelardo R. } \\
\text { de Souza }\end{array}$ & $\begin{array}{l}\text { Nestor } \\
\text { Goulart } \\
\text { Reis Filho }\end{array}$ & \begin{tabular}{l|} 
Prof. \\
Assistente \\
designado \\
por Vitor F. \\
B de Mello \\
\end{tabular} & $\begin{array}{l}\text { Instrutor } \\
\text { designado } \\
\text { por João } \\
\text { B. A. } \\
\text { Xavier }\end{array}$ \\
\hline Disciplina & $--\cdot$ & --- & --- & $\begin{array}{l}\text { Desenho } \\
\text { Industrial III }\end{array}$ & --- & --- & --- & Fundações & $\begin{array}{l}123 . \\
\text { Comum. } \\
\text { Visual III }\end{array}$ \\
\hline Prof. & --- & $\begin{array}{l}\text { Paulo S. } \\
\text { Wilken } \\
\text { (F.S.P) / } \\
\text { Rufino Reis } \\
\text { Soares }\end{array}$ & $\begin{array}{l}\text { José } \\
\text { Fonseca }\end{array}$ & $\begin{array}{l}\text { Abrahão V. } \\
\text { Sanovicz / } \\
\text { Luiz G. C. } \\
\text { Lima }\end{array}$ & --- & $\begin{array}{l}\text { Rodolpho de } \\
\text { A. Fernandes } \\
\text { / Antonio A. } \\
\text { Antunes } \\
\text { Netto }\end{array}$ & $\begin{array}{l}\text { Rodrigo B. } \\
\text { Lefèvre / } \\
\text { Paulo J. V. } \\
\text { Bruna }\end{array}$ & --- & --- \\
\hline \multicolumn{10}{|c|}{$4^{\circ}$ ano } \\
\hline Cadeira & $\begin{array}{l}\text { 10. Estrut. } \\
\text { Correntes } \\
\text { de madeira, } \\
\text { metál. e de } \\
\text { concreto } \\
\text { simples e } \\
\text { armado }\end{array}$ & $\begin{array}{l}\text { 11. Grandes } \\
\text { Estruturas }\end{array}$ & 16. Projeto III & $\begin{array}{l}19 . \\
\text { Planejamento } \\
\text { II (Parte I/ } \\
\text { Parte II) }\end{array}$ & $\begin{array}{l}\text { 23. História } \\
\text { da } \\
\text { Arquitetura III }\end{array}$ & $\begin{array}{l}\text { Disciplina } \\
\text { Autônoma }\end{array}$ & & & \\
\hline Regente & $\begin{array}{l}\text { José C. de } \\
\text { Figueiredo } \\
\text { Ferraz }\end{array}$ & $\begin{array}{l}\text { Pedro B. J. } \\
\text { Gravina }\end{array}$ & $\begin{array}{l}\text { Roberto } \\
\text { Cerqueira } \\
\text { César }\end{array}$ & $\begin{array}{l}\text { Lauro B. } \\
\text { Birkholz }\end{array}$ & $\begin{array}{l}\text { Eduardo } \\
\text { Kneese de } \\
\text { Melo }\end{array}$ & $\begin{array}{l}\text { Instrutor } \\
\text { designado } \\
\text { por Luiz } \\
\text { Roberto C. } \\
\text { Franco }\end{array}$ & & & \\
\hline Disciplina & --- & --- & --- & Parte 1 & --- & $\begin{array}{l}\text { 134. Desenho } \\
\text { Industrial IV }\end{array}$ & & & \\
\hline Prof. & --- & --- & --- & $\begin{array}{l}\text { Milton C. } \\
\text { Ghiraldini / } \\
\text { José C. } \\
\text { Gomes / } \\
\text { Brenno C. } \\
\text { Nogueira }\end{array}$ & $\begin{array}{l}\text { Benedito Lima } \\
\text { de Toledo }\end{array}$ & $\begin{array}{l}\text { Dario } \\
\text { Imparato / } \\
\text { João C. R. } \\
\text { Stroeter }\end{array}$ & & & \\
\hline \multicolumn{10}{|c|}{$5^{\circ}$ ano } \\
\hline Cadeira & $\begin{array}{l}\text { 12. Noções } \\
\text { de Econ. Pol., } \\
\text { Estatíst. Apl., } \\
\text { Org. Adm., } \\
\text { Legisl. }\end{array}$ & $\begin{array}{l}\text { 15. História } \\
\text { da Arte e } \\
\text { Estética }\end{array}$ & $\begin{array}{l}19 . \\
\text { Composição } \\
\text { de Arq.. } \\
\text { Grandes } \\
\text { comp. II }\end{array}$ & $\begin{array}{l}20 . \\
\text { Arquitetura } \\
\text { no Brasil }\end{array}$ & $\begin{array}{l}23 . \\
\text { Urbanismo }\end{array}$ & $\begin{array}{l}28 . \\
\text { Arquitetura } \\
\text { Paisagística }\end{array}$ & & & \\
\hline Regente & $\begin{array}{l}\text { Juarez R. } \\
\text { Brandão } \\
\text { Lopes }\end{array}$ & $\begin{array}{l}\text { Flávio L. } \\
\text { Motta }\end{array}$ & $\begin{array}{l}\text { João B. } \\
\text { Vilanova } \\
\text { Artigas }\end{array}$ & $\begin{array}{l}\text { Eduardo } \\
\text { Kneese de } \\
\text { Mello }\end{array}$ & $\begin{array}{l}\text { Lauro B. } \\
\text { Birkholz }\end{array}$ & $\begin{array}{l}\text { Roberto C. } \\
\text { Cardoso }\end{array}$ & & & \\
\hline Disciplina & $\begin{array}{l}\text { Contabilidade } \\
\text { (a cargo do } \\
\text { assist. licenc. } \\
\text { pela FCEA) }\end{array}$ & --- & $\begin{array}{l}\text { Grandes } \\
\text { Composições } \\
\text { II }\end{array}$ & --- & Urbanismo II & --- & & & \\
\hline Prof. & $\begin{array}{l}\text { Americo O. } \\
\text { Campiglia }\end{array}$ & $\begin{array}{l}\text { Julio R. } \\
\text { Katinsky / } \\
\text { Sérgio Ferro }\end{array}$ & $\begin{array}{l}\text { Pedro P. M. } \\
\text { Saraiva / } \\
\text { Paulo A. } \\
\text { Mendes da } \\
\text { Rocha }\end{array}$ & $\begin{array}{l}\text { Nestor } \\
\text { Goulart Reis } \\
\text { Filho / } \\
\text { Benedito L. } \\
\text { Toledo / } \\
\text { Rodrigo B. } \\
\text { Lefèvre }\end{array}$ & $\begin{array}{l}\text { Milton C. } \\
\text { Ghiraldini / } \\
\text { José C. } \\
\text { Gomes / } \\
\text { Brenno C. } \\
\text { Nogueira }\end{array}$ & $\begin{array}{l}\text { Rodolpho de } \\
\text { A. Fernandes } \\
\text { / Antonio A. } \\
\text { Antunes } \\
\text { Netto }\end{array}$ & & & \\
\hline
\end{tabular}




\begin{tabular}{|c|c|c|c|c|c|c|c|c|c|}
\hline & \multicolumn{9}{|c|}{1965} \\
\hline & \multicolumn{9}{|c|}{$1^{\circ}$ ano } \\
\hline Cadeira & $\begin{array}{l}\text { 1. Cálculo } \\
\text { Dif. e Int., } \\
\text { Geom. Anal. }\end{array}$ & $\begin{array}{l}\text { 2. Geometria } \\
\text { Descritiva }\end{array}$ & $\begin{array}{l}\text { 4. Topog., } \\
\text { elem. de } \\
\text { astron. de } \\
\text { posição }\end{array}$ & $\begin{array}{l}\text { 5. Física } \\
\text { Geral e } \\
\text { Aplicada }\end{array}$ & $\begin{array}{l}12 . \\
\text { Comunicação } \\
\text { Visual I }\end{array}$ & $\begin{array}{l}\text { 14. Projeto I } \\
\text { (Parte I/ } \\
\text { Parte II) }\end{array}$ & $\begin{array}{l}20 . \\
\text { História } \\
\text { da Arte. } \\
\text { Estética }\end{array}$ & $\begin{array}{l}\text { Disciplina } \\
\text { Autônoma }\end{array}$ & \\
\hline Regente & $\begin{array}{l}\text { Domingos } \\
\text { Pizanelli }\end{array}$ & $\begin{array}{l}\text { Pedro M. do } \\
\text { Amaral Cruz }\end{array}$ & $\begin{array}{l}\text { Paulo } \\
\text { Ferraz de } \\
\text { Mesquita }\end{array}$ & $\begin{array}{l}\text { Luiz Cintra do } \\
\text { Prado }\end{array}$ & $\begin{array}{l}\text { Ernest R. C. } \\
\text { Mange }\end{array}$ & $\begin{array}{l}\text { Hélio de Q. } \\
\text { Duarte }\end{array}$ & $\begin{array}{l}\text { Flávio L. } \\
\text { Motta }\end{array}$ & $\begin{array}{l}\text { Instrutor } \\
\text { designado por } \\
\text { João Carlos } \\
\text { Cauduro }\end{array}$ & \\
\hline Disciplina & --- & --- & --- & Parte 1 & $\begin{array}{l}121 . \\
\text { Comunicação } \\
\text { Visual I }\end{array}$ & Parte 1 & --- & $\begin{array}{l}\text { 131. Desenho } \\
\text { Industrial I }\end{array}$ & \\
\hline Prof. & $\begin{array}{l}\text { Eurico } \\
\text { Cerruti }\end{array}$ & $\begin{array}{l}\text { Guilherme do } \\
\text { A. Lyra }\end{array}$ & --- & --- & $\begin{array}{l}\text { Élide } \\
\text { Monzeglio / } \\
\text { Caetano } \\
\text { Fracarolli }\end{array}$ & $\begin{array}{l}\text { Ludovico A. } \\
\text { Martino }\end{array}$ & $\begin{array}{l}\text { Julio R. } \\
\text { Katinsky / } \\
\text { Sérgio } \\
\text { Ferro }\end{array}$ & --- & \\
\hline \multicolumn{10}{|c|}{$2^{\circ}$ ano } \\
\hline Cadeira & 3. Mecânica & $\begin{array}{l}\text { 5. Física } \\
\text { Geral e } \\
\text { Aplicada }\end{array}$ & $\begin{array}{l}6 . \\
\text { Construção } \\
\text { I }\end{array}$ & $\begin{array}{l}\text { 14. Projeto I } \\
\text { (Parte I/ } \\
\text { Parte II) }\end{array}$ & $\begin{array}{l}\text { 21. História } \\
\text { da } \\
\text { Arquitetura I }\end{array}$ & $\begin{array}{l}\text { 25. Estudos } \\
\text { Sociais e } \\
\text { Econômicos }\end{array}$ & $\begin{array}{l}\text { Disciplina } \\
\text { Autônoma }\end{array}$ & $\begin{array}{l}\text { Disciplina } \\
\text { Autônoma }\end{array}$ & \\
\hline Regente & $\begin{array}{l}\text { João A. } \\
\text { Breves Filho }\end{array}$ & $\begin{array}{l}\text { Luiz Cintra do } \\
\text { Prado }\end{array}$ & Ariosto Mila & $\begin{array}{l}\text { Hélio de Q. } \\
\text { Duarte }\end{array}$ & $\begin{array}{l}\text { Joaquim B. da } \\
\text { Silva }\end{array}$ & $\begin{array}{l}\text { Juarez R. } \\
\text { Brandão } \\
\text { Lopes }\end{array}$ & $\begin{array}{l}\text { Instrutor } \\
\text { designado } \\
\text { por Lúcio } \\
\text { Grinover }\end{array}$ & $\begin{array}{l}\text { Instrutor } \\
\text { designado por } \\
\text { Renina Katz }\end{array}$ & \\
\hline Disciplina & --- & Parte 2 & --- & Parte 2 & --- & & $\begin{array}{l}132 . \\
\text { Desenho } \\
\text { Industrial } \\
\text { II }\end{array}$ & $\begin{array}{l}122 . \\
\text { Comunicação } \\
\text { Visual II }\end{array}$ & \\
\hline Prof. & --- & --- & --- & $\begin{array}{l}\text { Ludovico A. } \\
\text { Martino }\end{array}$ & $\begin{array}{l}\text { Dacio A. B. } \\
\text { Ottoni / Hélio } \\
\text { de M. } \\
\text { Penteado }\end{array}$ & --- & $\begin{array}{l}\text { Marlene } \\
\text { Picarelli }\end{array}$ & Flávio Império & \\
\hline \multicolumn{10}{|c|}{30 ano } \\
\hline Cadeira & $\begin{array}{l}7 . \\
\text { Resistência } \\
\text { dos } \\
\text { materiais e } \\
\text { estabilidade } \\
\text { das } \\
\text { construções }\end{array}$ & $\begin{array}{l}\text { 8. Hidráulica } \\
\text { e } \\
\text { saneamento }\end{array}$ & $\begin{array}{l}9 . \\
\text { Construção } \\
\text { II }\end{array}$ & $\begin{array}{l}\text { 13. Desenho } \\
\text { Industrial III }\end{array}$ & 15. Projeto II & $\begin{array}{l}18 . \\
\text { Planejamento I }\end{array}$ & $\begin{array}{l}\text { 22. História } \\
\text { da } \\
\text { Arquitetura } \\
\text { II }\end{array}$ & $\begin{array}{l}\text { Disciplina } \\
\text { Autônoma } \\
\text { (61. Mec. dos } \\
\text { solos e } \\
\text { fundações?) }\end{array}$ & $\begin{array}{l}\text { Disciplina } \\
\text { Autônoma }\end{array}$ \\
\hline Regente & $\begin{array}{l}\text { Telêmaco } \\
\text { H.M. van } \\
\text { Langendonck }\end{array}$ & $\begin{array}{l}\text { Lucas N. } \\
\text { Garcez }\end{array}$ & $\begin{array}{l}\text { Renato } \\
\text { Salmoni }\end{array}$ & $\begin{array}{l}\text { José M. S. } \\
\text { Neves }\end{array}$ & $\begin{array}{l}\text { Abelardo R. } \\
\text { de Souza }\end{array}$ & $\begin{array}{l}\text { Abelardo R. } \\
\text { de Souza }\end{array}$ & $\begin{array}{l}\text { Nestor } \\
\text { Goulart } \\
\text { Reis Filho }\end{array}$ & $\begin{array}{l}\text { Prof. } \\
\text { Asssitente } \\
\text { designado por } \\
\text { Vitor F. } \\
\text { Bachmann de } \\
\text { Mello }\end{array}$ & $\begin{array}{l}\text { Instrutor } \\
\text { designado } \\
\text { por João B. } \\
\text { A. Xavier }\end{array}$ \\
\hline Disciplina & --- & --- & --- & $\begin{array}{l}\text { 133. Desenho } \\
\text { Industrial III }\end{array}$ & --- & --- & --- & Fundações & $\begin{array}{l}123 . \\
\text { Comunicação } \\
\text { Visual III }\end{array}$ \\
\hline Prof. & --- & $\begin{array}{l}\text { Paulo S. } \\
\text { Wilken (F.S.P) } \\
\text { / Rufino Reis }\end{array}$ & $\begin{array}{l}\text { José } \\
\text { Fonseca }\end{array}$ & $\begin{array}{l}\text { Abrahão V. } \\
\text { Sanovicz / } \\
\text { Luiz G. C. } \\
\text { Lima }\end{array}$ & --- & $\begin{array}{l}\text { Rodolpho de } \\
\text { A. } \\
\text { Fernandes / } \\
\text { Antonio A. } \\
\text { Antunes } \\
\text { Netto }\end{array}$ & $\begin{array}{l}\text { Rodrigo } \\
\text { B. Lefèvre } \\
\text { / Paulo J. } \\
\text { V. Bruna }\end{array}$ & --- & --- \\
\hline \multicolumn{10}{|c|}{$4^{\circ}$ ano } \\
\hline Cadeira & $\begin{array}{l}\text { 10. Estrut. } \\
\text { correntes de } \\
\text { madeira, } \\
\text { metál. e de } \\
\text { concreto } \\
\text { simples e } \\
\text { armado }\end{array}$ & $\begin{array}{l}\text { 11. Grandes } \\
\text { Estruturas }\end{array}$ & $\begin{array}{l}\text { 16. Projeto } \\
\text { III }\end{array}$ & $\begin{array}{l}19 . \\
\text { Planejamento } \\
\text { II (Partes I / II) }\end{array}$ & $\begin{array}{l}\text { 23. História } \\
\text { da } \\
\text { Arquitetura III }\end{array}$ & $\begin{array}{l}\text { Disciplina } \\
\text { Autônoma }\end{array}$ & & & \\
\hline Regente & $\begin{array}{l}\text { José C. de } \\
\text { Figueiredo } \\
\text { Ferraz }\end{array}$ & $\begin{array}{l}\text { Pedro B. J. } \\
\text { Gravina }\end{array}$ & $\begin{array}{l}\text { Roberto } \\
\text { Cerqueira } \\
\text { César }\end{array}$ & $\begin{array}{l}\text { Lauro B. } \\
\text { Birkholz }\end{array}$ & $\begin{array}{l}\text { Eduardo } \\
\text { Kneese de } \\
\text { Melo }\end{array}$ & $\begin{array}{l}\text { Instrutor } \\
\text { designado } \\
\text { por Luiz R. } \\
\text { C. Franco }\end{array}$ & & & \\
\hline Disciplina & --- & --- & --- & Parte 1 & --- & $\begin{array}{l}134 . \\
\text { Desenho } \\
\text { Industrial IV }\end{array}$ & & & \\
\hline Prof. & --- & --- & $\begin{array}{l}\text { Roger } \\
\text { Zmekhol }\end{array}$ & $\begin{array}{l}\text { Milton Carlos } \\
\text { Ghiraldini / } \\
\text { José Claudio } \\
\text { Gomes / } \\
\text { Brenno Cyrino } \\
\text { Nogueira }\end{array}$ & $\begin{array}{l}\text { Benedito Lima } \\
\text { de Toledo }\end{array}$ & $\begin{array}{l}\text { Dario } \\
\text { Imparato / } \\
\text { João Carlos } \\
\text { Rodolpho } \\
\text { Stroeter }\end{array}$ & & & \\
\hline \multicolumn{10}{|c|}{$5^{\circ}$ ano } \\
\hline Cadeira & $\begin{array}{l}\text { 17. Projeto } \\
\text { IV }\end{array}$ & $\begin{array}{l}19 . \\
\text { Planejamento } \\
\text { II (Partes I / II) }\end{array}$ & $\begin{array}{l}\text { 24. História } \\
\text { da } \\
\text { Arquitetura } \\
\text { IV }\end{array}$ & & & & & & \\
\hline Regente & $\begin{array}{l}\text { João B. V. } \\
\text { Artigas }\end{array}$ & $\begin{array}{l}\text { Lauro B. } \\
\text { Birkholz }\end{array}$ & $\begin{array}{l}\text { Eduardo } \\
\text { Corona }\end{array}$ & & & & & & \\
\hline Disciplina & --- & Parte 2 & +-- & & & & & & \\
\hline Prof. & $\begin{array}{l}\text { Paulo } \\
\text { Archias } \\
\text { Mendes da } \\
\text { Rocha / } \\
\text { Pedro Paulo } \\
\text { de Melo } \\
\text { Saraiva }\end{array}$ & $\begin{array}{l}\text { Milton Carlos } \\
\text { Ghiraldini / } \\
\text { José Claudio } \\
\text { Gomes / } \\
\text { Brenno Cyrino } \\
\text { Nogueira }\end{array}$ & $\begin{array}{l}\text { Carlos } \\
\text { Alberto } \\
\text { Cerqueira } \\
\text { Lemos }\end{array}$ & & & & & & \\
\hline
\end{tabular}




\begin{tabular}{|c|c|c|c|c|c|c|c|c|c|}
\hline & \multicolumn{9}{|c|}{1966} \\
\hline & \multicolumn{9}{|c|}{10 ano } \\
\hline Cadeira & $\begin{array}{l}\text { 1. Cálculo } \\
\text { Dif. e Int., } \\
\text { Geom. Anal. }\end{array}$ & $\begin{array}{l}\text { 2. Geometria } \\
\text { Descritiva }\end{array}$ & $\begin{array}{l}\text { 4. Topog., } \\
\text { elem. de } \\
\text { astronomia } \\
\text { de posição }\end{array}$ & $\begin{array}{l}\text { 5. Física } \\
\text { Geral e } \\
\text { Aplicada }\end{array}$ & $\begin{array}{l}12 . \\
\text { Comunicação } \\
\text { Visual I }\end{array}$ & $\begin{array}{l}\text { 14. Projeto I } \\
\text { (Parte I/ } \\
\text { Parte II) }\end{array}$ & $\begin{array}{l}20 . \\
\text { História } \\
\text { da Arte. } \\
\text { Estética }\end{array}$ & $\begin{array}{l}\text { Disciplina } \\
\text { Autônoma }\end{array}$ & \\
\hline Regente & $\begin{array}{l}\text { Domingos } \\
\text { Pizanelli }\end{array}$ & $\begin{array}{l}\text { Pedro M. do } \\
\text { Amaral Cruz }\end{array}$ & $\begin{array}{l}\text { Paulo } \\
\text { Ferraz de } \\
\text { Mesquita }\end{array}$ & $\begin{array}{l}\text { Luiz Cintra } \\
\text { do Prado }\end{array}$ & $\begin{array}{l}\text { Ernest R. C. } \\
\text { Mange }\end{array}$ & $\begin{array}{l}\text { Hélio de Q. } \\
\text { Duarte }\end{array}$ & $\begin{array}{l}\text { Flávio L. } \\
\text { Motta }\end{array}$ & $\begin{array}{l}\text { Instrutor } \\
\text { designado } \\
\text { por João } \\
\text { Carlos } \\
\text { Cauduro }\end{array}$ & \\
\hline Disciplina & --- & --- & --- & Parte 1 & $\begin{array}{l}\text { 121. Comun. } \\
\text { Visual I }\end{array}$ & Parte 1 & --- & $\begin{array}{l}\text { 131. Desenho } \\
\text { Industrial I }\end{array}$ & \\
\hline Prof. & $\begin{array}{l}\text { Eurico } \\
\text { Cerruti }\end{array}$ & $\begin{array}{l}\text { Guilherme do } \\
\text { A. Lyra }\end{array}$ & --- & $\begin{array}{l}\text { Paulus A. } \\
\text { Pompéia }\end{array}$ & $\begin{array}{l}\text { Élide } \\
\text { Monzeglio / } \\
\text { Caetano } \\
\text { Fracarolli }\end{array}$ & $\begin{array}{l}\text { Ludovico } \\
\text { Antonio } \\
\text { Martino }\end{array}$ & $\begin{array}{l}\text { Sérgio } \\
\text { Ferro / } \\
\text { Julio R. } \\
\text { Katinsky }\end{array}$ & --- & \\
\hline \multicolumn{10}{|c|}{$2^{\circ}$ ano } \\
\hline Cadeira & 3. Mecânica & $\begin{array}{l}\text { 5. Física } \\
\text { Geral e } \\
\text { Aplicada }\end{array}$ & $\begin{array}{l}6 . \\
\text { Construção } \\
\text { I }\end{array}$ & $\begin{array}{l}\text { 14. Projeto I } \\
\text { (Parte I/ } \\
\text { Parte II) }\end{array}$ & $\begin{array}{l}\text { 21. História } \\
\text { da } \\
\text { Arquitetura I }\end{array}$ & $\begin{array}{l}\text { 25. Estudos } \\
\text { Sociais e } \\
\text { Econômicos }\end{array}$ & $\begin{array}{l}\text { Disciplina } \\
\text { Autônoma }\end{array}$ & $\begin{array}{l}\text { Disciplina } \\
\text { Autônoma }\end{array}$ & \\
\hline Regente & $\begin{array}{l}\text { João A. } \\
\text { Breves Filho }\end{array}$ & $\begin{array}{l}\text { Luiz Cintra } \\
\text { do Prado }\end{array}$ & Ariosto Mila & $\begin{array}{l}\text { Hélio de Q. } \\
\text { Duarte }\end{array}$ & $\begin{array}{l}\text { Joaquim B. da } \\
\text { Silva }\end{array}$ & $\begin{array}{l}\text { Juarez R. } \\
\text { Brandão } \\
\text { Lopes }\end{array}$ & $\begin{array}{l}\text { Instrutor } \\
\text { designado } \\
\text { por Lúcio } \\
\text { Grinover }\end{array}$ & $\begin{array}{l}\text { Instrutor } \\
\text { designado } \\
\text { por Renina } \\
\text { Katz } \\
\end{array}$ & \\
\hline Disciplina & --- & Parte 2 & --- & Parte 2 & --- & --- & $\begin{array}{l}132 . \\
\text { Desenho } \\
\text { Industrial II }\end{array}$ & $\begin{array}{l}122 . \\
\text { Comum. } \\
\text { Visual II }\end{array}$ & \\
\hline Prof. & --- & $\begin{array}{l}\text { Paulus A. } \\
\text { Pompéia }\end{array}$ & --- & $\begin{array}{l}\text { Ludovico A. } \\
\text { Martino }\end{array}$ & $\begin{array}{l}\text { Dacio A. } \\
\text { B.Ottoni / } \\
\text { Hélio de M. } \\
\text { Penteado }\end{array}$ & --- & $\begin{array}{l}\text { Marlene } \\
\text { Picarelli }\end{array}$ & $\begin{array}{l}\text { Flávio } \\
\text { Império }\end{array}$ & \\
\hline \multicolumn{10}{|c|}{30 ano } \\
\hline Cadeira & $\begin{array}{l}\text { 7. Resist. } \\
\text { dos } \\
\text { materiais e } \\
\text { estabilidade } \\
\text { das const. }\end{array}$ & $\begin{array}{l}\text { 8. Hidráulica } \\
\text { e } \\
\text { saneamento }\end{array}$ & $\begin{array}{l}9 . \\
\text { Construção } \\
\text { II }\end{array}$ & $\begin{array}{l}\text { 13. Desenho } \\
\text { Industrial III }\end{array}$ & 15. Projeto II & $\begin{array}{l}18 . \\
\text { Planejamento } \\
\text { I }\end{array}$ & $\begin{array}{l}22 . \\
\text { História } \\
\text { da } \\
\text { Arquitetura } \\
\text { II }\end{array}$ & $\begin{array}{l}\text { Disciplina } \\
\text { Autônoma } \\
\text { (61. Mec. } \\
\text { dos solos e } \\
\text { fundações?) }\end{array}$ & $\begin{array}{l}\text { Disciplina } \\
\text { Autônoma }\end{array}$ \\
\hline Regente & $\begin{array}{l}\text { Telêmaco } \\
\text { H.M. van } \\
\text { Langendonc } \\
\text { k }\end{array}$ & $\begin{array}{l}\text { Lucas } \\
\text { Nogueira } \\
\text { Garcez }\end{array}$ & $\begin{array}{l}\text { Renato } \\
\text { Salmoni }\end{array}$ & $\begin{array}{l}\text { José M. } \\
\text { S.Neves }\end{array}$ & $\begin{array}{l}\text { Abelardo R. } \\
\text { de Souza }\end{array}$ & $\begin{array}{l}\text { Abelardo R. } \\
\text { de Souza }\end{array}$ & $\begin{array}{l}\text { Nestor } \\
\text { Goulart } \\
\text { Reis Filho }\end{array}$ & $\begin{array}{l}\text { Prof. } \\
\text { Assistente } \\
\text { designado } \\
\text { por Vitor F. } \\
\text { Bachmann } \\
\text { de Mello }\end{array}$ & $\begin{array}{l}\text { Instrutor } \\
\text { designado } \\
\text { por João } \\
\text { B. A. } \\
\text { Xavier }\end{array}$ \\
\hline Disciplina & -- & --- & --- & $\begin{array}{l}133 . \\
\text { Desenho } \\
\text { Industrial III }\end{array}$ & --- & --- & --- & Fundações & $\begin{array}{l}123 . \\
\text { Comum. } \\
\text { Visual III }\end{array}$ \\
\hline Prof. & --- & $\begin{array}{l}\text { Paulo S. } \\
\text { Wilken } \\
\text { (F.S.P) / } \\
\text { Rufino Reis } \\
\text { Soares }\end{array}$ & $\begin{array}{l}\text { José } \\
\text { Fonseca }\end{array}$ & $\begin{array}{l}\text { Abrahão V. } \\
\text { Sanovicz / } \\
\text { Luiz Gastão } \\
\text { de Castro } \\
\text { Lima }\end{array}$ & --- & $\begin{array}{l}\text { Rodolpho de } \\
\text { A. Fernandes } \\
\text { / Antonio A. } \\
\text { Antunes } \\
\text { Netto }\end{array}$ & $\begin{array}{l}\text { Rodrigo B. } \\
\text { Lefèvre / } \\
\text { Paulo J. V. } \\
\text { Bruna }\end{array}$ & --- & $\begin{array}{l}\text { Ludovico } \\
\text { A. Martino }\end{array}$ \\
\hline \multicolumn{10}{|c|}{$4^{\circ}$ ano } \\
\hline Cadeira & $\begin{array}{l}\text { 10. Estrut. } \\
\text { correntes } \\
\text { de madeira, } \\
\text { metálicas e } \\
\text { de concreto } \\
\text { simples e } \\
\text { armado }\end{array}$ & $\begin{array}{l}\text { 11. Grandes } \\
\text { Estruturas }\end{array}$ & $\begin{array}{l}\text { 16. Projeto } \\
\text { III }\end{array}$ & $\begin{array}{l}19 . \\
\text { Planejament } \\
\text { o II (Parte I / } \\
\text { Parte II) }\end{array}$ & $\begin{array}{l}\text { 23. História } \\
\text { da } \\
\text { Arquitetura III }\end{array}$ & $\begin{array}{l}\text { Disciplina } \\
\text { Autônoma }\end{array}$ & & & \\
\hline Regente & $\begin{array}{l}\text { José C. de } \\
\text { Figueiredo } \\
\text { Ferraz }\end{array}$ & $\begin{array}{l}\text { Pedro B. J. } \\
\text { Gravina }\end{array}$ & $\begin{array}{l}\text { Roberto } \\
\text { Cerqueira } \\
\text { César }\end{array}$ & $\begin{array}{l}\text { Lauro B. } \\
\text { Birkholz }\end{array}$ & $\begin{array}{l}\text { Eduardo } \\
\text { Kneese de } \\
\text { Melo }\end{array}$ & $\begin{array}{l}\text { Instrutor } \\
\text { designado } \\
\text { por Luiz R. C. } \\
\text { Franco } \\
\end{array}$ & & & \\
\hline Disciplina & --- & --- & --- & Parte 1 & --- & $\begin{array}{l}134 . \\
\text { Desenho } \\
\text { Industrial IV }\end{array}$ & & & \\
\hline Prof. & --- & --- & $\begin{array}{l}\text { Roger } \\
\text { Zmekhol }\end{array}$ & --- & $\begin{array}{l}\text { Benedito L. de } \\
\text { Toledo }\end{array}$ & $\begin{array}{l}\text { Dario } \\
\text { Imparato / } \\
\text { João C. R. } \\
\text { Stroeter }\end{array}$ & & & \\
\hline \multicolumn{10}{|c|}{$5^{\circ}$ ano } \\
\hline Cadeira & $\begin{array}{l}\text { 17. Projeto } \\
\text { IV }\end{array}$ & $\begin{array}{l}19 . \\
\text { Planejament } \\
\text { o II (Parte I/ } \\
\text { Parte II) }\end{array}$ & $\begin{array}{l}\text { 24. História } \\
\text { da } \\
\text { Arquitetura } \\
\text { IV }\end{array}$ & & & & & & \\
\hline Regente & $\begin{array}{l}\text { João B. } \\
\text { Vilanova } \\
\text { Artigas }\end{array}$ & $\begin{array}{l}\text { Lauro B. } \\
\text { Birkholz }\end{array}$ & $\begin{array}{l}\text { Eduardo } \\
\text { Corona }\end{array}$ & & & & & & \\
\hline Disciplina & --- & Parte 2 & --- & & & & & & \\
\hline Prof. & $\begin{array}{l}\text { Paulo A. } \\
\text { Mendes da } \\
\text { Rocha / } \\
\text { Pedro P. M. } \\
\text { Saraiva }\end{array}$ & --- & $\begin{array}{l}\text { Carlos A. C. } \\
\text { Lemos }\end{array}$ & & & & & & \\
\hline
\end{tabular}




\begin{tabular}{|c|c|c|c|c|c|c|c|c|c|}
\hline & \multicolumn{9}{|c|}{1967} \\
\hline & \multicolumn{9}{|c|}{$1^{\circ}$ ano } \\
\hline Cadeira & $\begin{array}{l}\text { 1. Cálculo } \\
\text { Dif. e Int., } \\
\text { Geom. Anal. }\end{array}$ & $\begin{array}{l}\text { 2. Geometria } \\
\text { Descritiva }\end{array}$ & $\begin{array}{l}\text { 4. Topog., } \\
\text { elem. de } \\
\text { astron. de } \\
\text { posição }\end{array}$ & $\begin{array}{l}\text { 5. Física } \\
\text { Geral e Apl. }\end{array}$ & $\begin{array}{l}12 . \\
\text { Comunicação } \\
\text { Visual I }\end{array}$ & $\begin{array}{l}\text { 14. Projeto I } \\
\text { (Partes I / II) }\end{array}$ & $\begin{array}{l}20 . \\
\text { História } \\
\text { da Arte. } \\
\text { Estética }\end{array}$ & $\begin{array}{l}\text { Disciplina } \\
\text { Autônoma }\end{array}$ & \\
\hline Regente & $\begin{array}{l}\text { Domingos } \\
\text { Pizanelli }\end{array}$ & $\begin{array}{l}\text { Pedro M. do } \\
\text { Amaral Cruz }\end{array}$ & $\begin{array}{l}\text { Paulo } \\
\text { Ferraz de } \\
\text { Mesquita }\end{array}$ & $\begin{array}{l}\text { Paulus A. } \\
\text { Pompéia }\end{array}$ & $\begin{array}{l}\text { Ernest R. C. } \\
\text { Mange }\end{array}$ & $\begin{array}{l}\text { Hélio de Q. } \\
\text { Duarte }\end{array}$ & $\begin{array}{l}\text { Flávio L. } \\
\text { Motta }\end{array}$ & $\begin{array}{l}\text { Instrutor } \\
\text { designado por } \\
\text { João Carlos } \\
\text { Cauduro }\end{array}$ & \\
\hline Disciplina & --- & --- & --- & Parte 1 & $\begin{array}{l}\text { 121. Comun. } \\
\text { Visual I }\end{array}$ & Parte 1 & --- & $\begin{array}{l}\text { 131. Desenho } \\
\text { Industrial I }\end{array}$ & \\
\hline Prof. & $\begin{array}{l}\text { Eurico } \\
\text { Cerruti }\end{array}$ & $\begin{array}{l}\text { Guilherme do } \\
\text { A. Lyra }\end{array}$ & --- & --- & $\begin{array}{l}\text { Élide } \\
\text { Monzeglio / } \\
\text { Caetano } \\
\text { Fracarolli }\end{array}$ & $\begin{array}{l}\text { Ludovico A. } \\
\text { Martino }\end{array}$ & $\begin{array}{l}\text { Sérgio } \\
\text { Ferro / } \\
\text { Julio R. } \\
\text { Katinsky }\end{array}$ & $\begin{array}{l}\text { Eduardo L. } \\
\text { P. R. de } \\
\text { Almeida }\end{array}$ & \\
\hline \multicolumn{10}{|c|}{$2^{\circ}$ ano } \\
\hline Cadeira & 3. Mecânica & $\begin{array}{l}\text { 5. Física } \\
\text { Geral e } \\
\text { Aplicada }\end{array}$ & $\begin{array}{l}6 . \\
\text { Construção } \\
\text { I }\end{array}$ & $\begin{array}{l}\text { 14. Projeto I } \\
\text { (Parte I/ } \\
\text { Parte II) }\end{array}$ & $\begin{array}{l}\text { 21. História } \\
\text { da } \\
\text { Arquitetura I }\end{array}$ & $\begin{array}{l}\text { 25. Estudos } \\
\text { Sociais e } \\
\text { Econômicos }\end{array}$ & $\begin{array}{l}\text { 26. Mec. } \\
\text { dos Solos } \\
\text { e } \\
\text { Fundações }\end{array}$ & $\begin{array}{l}\text { Disciplina } \\
\text { Autônoma }\end{array}$ & $\begin{array}{l}\text { Disciplina } \\
\text { Autônoma }\end{array}$ \\
\hline Regente & $\begin{array}{l}\text { João } \\
\text { Augusto } \\
\text { Breves Filho }\end{array}$ & $\begin{array}{l}\text { Paulus A. } \\
\text { Pompéia }\end{array}$ & $\begin{array}{l}\text { Ariosto } \\
\text { Mila }\end{array}$ & $\begin{array}{l}\text { Hélio de } \\
\text { Queiróz } \\
\text { Duarte }\end{array}$ & $\begin{array}{l}\text { Joaquim } \\
\text { Bezerra da } \\
\text { Silva }\end{array}$ & $\begin{array}{l}\text { Juarez } \\
\text { Rubens } \\
\text { Brandão } \\
\text { Lopes }\end{array}$ & $\begin{array}{l}\text { Vitor } \\
\text { Froilano } \\
\text { Bachmann } \\
\text { de Mello }\end{array}$ & $\begin{array}{l}\text { Instrutor } \\
\text { Marlene } \\
\text { Picarelli }\end{array}$ & $\begin{array}{l}\text { Instrutor } \\
\text { designado } \\
\text { por Renina } \\
\text { Katz }\end{array}$ \\
\hline Disciplina & --- & Parte 2 & --- & Parte 2 & --- & --- & --- & $\begin{array}{l}132 . \\
\text { Desenho } \\
\text { Industrial II }\end{array}$ & $\begin{array}{l}122 . \\
\text { Comunicação } \\
\text { Visual II }\end{array}$ \\
\hline Prof. & --- & --- & --- & $\begin{array}{l}\text { Siegbert } \\
\text { Zanettini / } \\
\text { Ludovico A. } \\
\text { Martino }\end{array}$ & $\begin{array}{l}\text { Dacio A. B. } \\
\text { Ottoni / Hélio } \\
\text { de M. } \\
\text { Penteado }\end{array}$ & --- & --- & $\begin{array}{l}\text { Instrutor } \\
\text { Manoel K. } \\
\text { P. S. Corrêa }\end{array}$ & $\begin{array}{l}\text { Flávio } \\
\text { Império }\end{array}$ \\
\hline \multicolumn{10}{|c|}{30 ano } \\
\hline Cadeira & $\begin{array}{l}\text { 7. Resist. } \\
\text { dos } \\
\text { materiais e } \\
\text { estabilidade } \\
\text { das const. }\end{array}$ & $\begin{array}{l}\text { 8. Hidráulica } \\
\text { e } \\
\text { saneamento }\end{array}$ & $\begin{array}{l}9 . \\
\text { Construçã } \\
\text { o II }\end{array}$ & $\begin{array}{l}\text { 13. Desenho } \\
\text { Industrial III }\end{array}$ & 15. Projeto II & $\begin{array}{l}18 . \\
\text { Planejament } \\
\text { ol }\end{array}$ & $\begin{array}{l}22 . \\
\text { História } \\
\text { da } \\
\text { Arquitetur } \\
\text { a II }\end{array}$ & $\begin{array}{l}\text { Disciplina } \\
\text { Autônoma } \\
(61 \\
\text { Mecânica } \\
\text { dos solos e } \\
\text { fundações?) }\end{array}$ & $\begin{array}{l}\text { Disciplina } \\
\text { Autônoma }\end{array}$ \\
\hline Regente & $\begin{array}{l}\text { Telêmaco } \\
\text { H.M. van } \\
\text { Langendonc } \\
\text { k }\end{array}$ & $\begin{array}{l}\text { Paulo S. } \\
\text { Wilken }\end{array}$ & $\begin{array}{l}\text { Renato } \\
\text { Salmoni }\end{array}$ & $\begin{array}{l}\text { Lúcio } \\
\text { Grinover }\end{array}$ & $\begin{array}{l}\text { Abelardo R. } \\
\text { de Souza }\end{array}$ & $\begin{array}{l}\text { Abelardo R. } \\
\text { de Souza }\end{array}$ & $\begin{array}{l}\text { Nestor } \\
\text { Goulart } \\
\text { Reis Filho }\end{array}$ & $\begin{array}{l}\text { Vitor F. B. } \\
\text { de Mello }\end{array}$ & $\begin{array}{l}\text { Instrutor } \\
\text { designado } \\
\text { por João B. } \\
\text { A. Xavier }\end{array}$ \\
\hline Disciplina & --- & --- & $--\cdot$ & $\begin{array}{l}133 . \\
\text { Desenho } \\
\text { Industrial III }\end{array}$ & $--\cdot$ & --- & --- & Fundações & $\begin{array}{l}123 . \\
\text { Comunicaçã } \\
\text { o Visual III }\end{array}$ \\
\hline Prof. & $\begin{array}{l}\text { Décio L. de } \\
\text { Zagottis }\end{array}$ & $\begin{array}{l}\text { Rufino Reis } \\
\text { Soares }\end{array}$ & $\begin{array}{l}\text { José } \\
\text { Fonseca }\end{array}$ & $\begin{array}{l}\text { Abrahão V. } \\
\text { Sanovicz / } \\
\text { Luiz G. C. } \\
\text { Lima }\end{array}$ & --- & $\begin{array}{l}\text { Rodolpho de } \\
\text { A. Fernandes } \\
\text { / Antonio A. } \\
\text { Antunes } \\
\text { Netto }\end{array}$ & $\begin{array}{l}\text { Rodrigo B. } \\
\text { Lefèvre / } \\
\text { Paulo J. V. } \\
\text { Bruna }\end{array}$ & --- & $\begin{array}{l}\text { Ludovico A. } \\
\text { Martino }\end{array}$ \\
\hline \multicolumn{10}{|c|}{$4^{\circ}$ ano } \\
\hline Cadeira & $\begin{array}{l}\text { 10. Estrut. } \\
\text { correntes } \\
\text { de madeira, } \\
\text { metál. e de } \\
\text { concreto } \\
\text { simples e } \\
\text { armado }\end{array}$ & $\begin{array}{l}\text { 11. Grandes } \\
\text { Estruturas }\end{array}$ & $\begin{array}{l}\text { 16. Projeto } \\
\text { III }\end{array}$ & $\begin{array}{l}19 . \\
\text { Planejament } \\
\text { o II (Parte I / } \\
\text { Parte II) }\end{array}$ & $\begin{array}{l}\text { 23. História } \\
\text { da } \\
\text { Arquitetura III }\end{array}$ & $\begin{array}{l}\text { Disciplina } \\
\text { Autônoma }\end{array}$ & & & \\
\hline Regente & $\begin{array}{l}\text { José C. de } \\
\text { Figueiredo } \\
\text { Ferraz }\end{array}$ & $\begin{array}{l}\text { Pedro B. J. } \\
\text { Gravina }\end{array}$ & (?) & $\begin{array}{l}\text { Lauro B. } \\
\text { Birkholz }\end{array}$ & $\begin{array}{l}\text { Eduardo } \\
\text { Kneese de } \\
\text { Melo }\end{array}$ & $\begin{array}{l}\text { Instrutor } \\
\text { designado } \\
\text { por Luiz R. C. } \\
\text { Franco }\end{array}$ & & & \\
\hline Disciplina & --- & --- & --- & Parte 1 & --- & $\begin{array}{l}134 . \\
\text { Desenho } \\
\text { Industrial IV } \\
\end{array}$ & & & \\
\hline Prof. & --- & --- & $\begin{array}{l}\text { Roger } \\
\text { Zmekhol }\end{array}$ & --- & $\begin{array}{l}\text { Benedito L. de } \\
\text { Toledo }\end{array}$ & $\begin{array}{l}\text { Dario } \\
\text { Imparato / } \\
\text { João C. R. } \\
\text { Stroeter }\end{array}$ & & & \\
\hline \multicolumn{10}{|c|}{$5^{\circ}$ ano } \\
\hline Cadeira & $\begin{array}{l}\text { 17. Projeto } \\
\text { IV }\end{array}$ & $\begin{array}{l}19 . \\
\text { Planejamento } \\
\text { II (Parte I/ } \\
\text { Parte II) }\end{array}$ & $\begin{array}{l}24 . \\
\text { História } \\
\text { da } \\
\text { Arquitetura } \\
\text { IV }\end{array}$ & & & & & & \\
\hline Regente & $\begin{array}{l}\text { João B. } \\
\text { Vilanova } \\
\text { Artigas }\end{array}$ & $\begin{array}{l}\text { Lauro B. } \\
\text { Birkholz }\end{array}$ & $\begin{array}{l}\text { Eduardo } \\
\text { Corona }\end{array}$ & & & & & & \\
\hline Disciplina & --- & Parte 2 & --- & & & & & & \\
\hline Prof. & $\begin{array}{l}\text { Paulo A. } \\
\text { Mendes da } \\
\text { Rocha / } \\
\text { Pedro P. M. } \\
\text { Saraiva }\end{array}$ & --- & $\begin{array}{l}\text { Carlos A. } \\
\text { C. Lemos }\end{array}$ & & & & & & \\
\hline
\end{tabular}




\begin{tabular}{|c|c|c|c|c|c|c|c|c|c|}
\hline & \multicolumn{9}{|c|}{1968} \\
\hline & \multicolumn{9}{|c|}{$1^{\circ}$ ano } \\
\hline Cadeira & $\begin{array}{l}\text { 1. Cálculo Dif. e } \\
\text { Int., Geom. } \\
\text { Anal. }\end{array}$ & $\begin{array}{l}2 . \\
\text { Geometria } \\
\text { Descritiva }\end{array}$ & $\begin{array}{l}\text { 4. Topog., } \\
\text { elem. de } \\
\text { astron. de } \\
\text { posição }\end{array}$ & $\begin{array}{l}\text { 5. Física } \\
\text { Geral e Apl. }\end{array}$ & $\begin{array}{l}12 . \\
\text { Comunicaç } \\
\text { ão Visual I }\end{array}$ & $\begin{array}{l}\text { 14. Projeto I } \\
\text { (Parte I/ } \\
\text { Parte II) }\end{array}$ & $\begin{array}{l}20 . \\
\text { História da } \\
\text { Arte. } \\
\text { Estética }\end{array}$ & $\begin{array}{l}\text { Disciplina } \\
\text { Autônoma }\end{array}$ & \\
\hline Regente & $\begin{array}{l}\text { Domingos } \\
\text { Pizanelli }\end{array}$ & $\begin{array}{l}\text { Pedro M. do } \\
\text { Amaral Cruz }\end{array}$ & $\begin{array}{l}\text { Paulo F. de } \\
\text { Mesquita }\end{array}$ & $\begin{array}{l}\text { Paulus A. } \\
\text { Pompéia }\end{array}$ & $\begin{array}{l}\text { Ernest R. C. } \\
\text { Mange }\end{array}$ & $\begin{array}{l}\text { Hélio de Q. } \\
\text { Duarte }\end{array}$ & $\begin{array}{l}\text { Flávio L. } \\
\text { Motta }\end{array}$ & $\begin{array}{l}\text { Instrutor } \\
\text { designado } \\
\text { por João } \\
\text { Carlos } \\
\text { Cauduro }\end{array}$ & \\
\hline Disciplina & --- & --- & --- & Parte 1 & $\begin{array}{l}121 . \\
\text { Comunic. } \\
\text { Visual I }\end{array}$ & Parte 1 & --- & $\begin{array}{l}131 . \\
\text { Desenho } \\
\text { Industrial I }\end{array}$ & \\
\hline \multirow[t]{2}{*}{ Prof. } & Eurico Cerruti & $\begin{array}{l}\text { Guilherme } \\
\text { do Amaral } \\
\text { Lyra }\end{array}$ & --- & --- & $\begin{array}{l}\text { Élide } \\
\text { Monzeglio / } \\
\text { Caetano } \\
\text { Fracarolli }\end{array}$ & $\begin{array}{l}\text { Ludovico A. } \\
\text { Martino }\end{array}$ & $\begin{array}{l}\text { Julio R. } \\
\text { Katinsky / } \\
\text { Sérgio } \\
\text { Ferro }\end{array}$ & $\begin{array}{l}\text { Eduardo L. } \\
\text { P. R. de } \\
\text { Almeida }\end{array}$ & \\
\hline & \multicolumn{9}{|c|}{$2^{\circ}$ ano } \\
\hline Cadeira & 3. Mecânica & $\begin{array}{l}\text { 5. Física } \\
\text { Geral e Apl. }\end{array}$ & $\begin{array}{l}6 . \\
\text { Construção } \\
\text { I }\end{array}$ & $\begin{array}{l}\text { 14. Projeto I } \\
\text { (Partes I/ II) }\end{array}$ & $\begin{array}{l}\text { 21. História } \\
\text { da Arq. I }\end{array}$ & $\begin{array}{l}\text { 25. Estudos } \\
\text { Soc. e Econ. }\end{array}$ & $\begin{array}{l}\text { 26. Mec. } \\
\text { dos solos } \\
\text { e fund. }\end{array}$ & $\begin{array}{l}\text { Disciplina } \\
\text { Autônoma }\end{array}$ & $\begin{array}{l}\text { Discipli } \\
\text { na } \\
\text { Autôno } \\
\text { ma }\end{array}$ \\
\hline Regente & $\begin{array}{l}\text { João A. Breves } \\
\text { Filho }\end{array}$ & $\begin{array}{l}\text { Paulus A. } \\
\text { Pompéia }\end{array}$ & Ariosto Mila & $\begin{array}{l}\text { Hélio de Q. } \\
\text { Duarte }\end{array}$ & $\begin{array}{l}\text { Joaquim B. } \\
\text { da Silva }\end{array}$ & $\begin{array}{l}\text { Juarez R. } \\
\text { Brandão } \\
\text { Lopes }\end{array}$ & $\begin{array}{l}\text { Vitor F. B. } \\
\text { de Mello }\end{array}$ & $\begin{array}{l}\text { Instrutor } \\
\text { Marlene } \\
\text { Picarelli }\end{array}$ & $\begin{array}{l}\text { Instrutor } \\
\text { designad } \\
\text { o por } \\
\text { Renina } \\
\text { Katz } \\
\end{array}$ \\
\hline Disciplina & --- & Parte 2 & --- & Parte 2 & --- & --- & --- & $\begin{array}{l}132 . \\
\text { Desenho } \\
\text { Industrial II }\end{array}$ & $\begin{array}{l}122 . \\
\text { Comuni } \\
\text { c. Visual } \\
\text { II }\end{array}$ \\
\hline \multirow[t]{2}{*}{ Prof. } & --- & --- & --- & $\begin{array}{l}\text { Siegbert } \\
\text { Zanettini / } \\
\text { Ludovico A. } \\
\text { Martino / } \\
\text { Dario } \\
\text { Montesano }\end{array}$ & $\begin{array}{l}\text { Dacio A. B. } \\
\text { Ottoni / Hélio } \\
\text { de M. } \\
\text { Penteado }\end{array}$ & --- & $\begin{array}{l}--- \\
\end{array}$ & --- & $\begin{array}{l}\text { Flávio } \\
\text { Império }\end{array}$ \\
\hline & \multicolumn{9}{|c|}{30 ano } \\
\hline Cadeira & $\begin{array}{l}\text { 7. Resist. dos } \\
\text { materiais e } \\
\text { estabilidade } \\
\text { das const. }\end{array}$ & $\begin{array}{l}8 . \\
\text { Hidráulica e } \\
\text { saneamento }\end{array}$ & $\begin{array}{l}9 . \\
\text { Construção } \\
\text { II }\end{array}$ & $\begin{array}{l}13 . \\
\text { Desenho } \\
\text { Industrial III }\end{array}$ & $\begin{array}{l}\text { 15. Projeto } \\
\text { II }\end{array}$ & $\begin{array}{l}18 . \\
\text { Planejament } \\
\text { o I }\end{array}$ & $\begin{array}{l}22 . \\
\text { História da } \\
\text { Arquitetur } \\
\text { a II }\end{array}$ & $\begin{array}{l}\text { Disciplina } \\
\text { Autônoma }\end{array}$ & \\
\hline Regente & $\begin{array}{l}\text { Telêmaco H.M. } \\
\text { van } \\
\text { Langendonck }\end{array}$ & $\begin{array}{l}\text { Paulo S. } \\
\text { Wilken }\end{array}$ & $\begin{array}{l}\text { Renato } \\
\text { Salmoni }\end{array}$ & $\begin{array}{l}\text { Lúcio } \\
\text { Grinover }\end{array}$ & $\begin{array}{l}\text { Abelardo R. } \\
\text { de Souza }\end{array}$ & $\begin{array}{l}\text { Abelardo R. } \\
\text { de Souza }\end{array}$ & $\begin{array}{l}\text { Nestor } \\
\text { Goulart } \\
\text { Reis Filho }\end{array}$ & $\begin{array}{l}\text { Instrutor } \\
\text { designado } \\
\text { por João B. } \\
\text { Alves Xavier }\end{array}$ & \\
\hline Disciplina & --- & --- & --- & $\begin{array}{l}133 . \\
\text { Desenho } \\
\text { Industrial III } \\
\end{array}$ & --- & --- & --- & $\begin{array}{l}123 . \\
\text { Comunic. } \\
\text { Visual III }\end{array}$ & \\
\hline \multirow[t]{2}{*}{ Prof. } & $\begin{array}{l}\text { Décio L. de } \\
\text { Zagottis }\end{array}$ & $\begin{array}{l}\text { Rufino Reis } \\
\text { Soares }\end{array}$ & $\begin{array}{l}\text { José } \\
\text { Fonseca }\end{array}$ & $\begin{array}{l}\text { Abrahão V. } \\
\text { Sanovicz / } \\
\text { Luiz G. C. } \\
\text { Lima / } \\
\text { Ronaldo } \\
\text { Duschenes }\end{array}$ & --- & $\begin{array}{l}\text { Rodolpho de } \\
\text { A. Fernandes } \\
\text { / Antonio A. } \\
\text { Antunes Netto } \\
\text { / Marcos de S. } \\
\text { Dias }\end{array}$ & $\begin{array}{l}\text { Rodrigo B. } \\
\text { Lefèvre / } \\
\text { Paulo J. V. } \\
\text { Bruna }\end{array}$ & $\begin{array}{l}\text { Ludovico A. } \\
\text { Martino }\end{array}$ & \\
\hline & \multicolumn{9}{|c|}{$4^{\circ}$ ano } \\
\hline Cadeira & $\begin{array}{l}\text { 10. Estrut. } \\
\text { correntes de } \\
\text { madeira, metál. } \\
\text { e de concreto } \\
\text { simpl. e armado }\end{array}$ & $\begin{array}{l}\text { 11. Grandes } \\
\text { Estruturas }\end{array}$ & $\begin{array}{l}\text { 16. Projeto } \\
\text { III }\end{array}$ & $\begin{array}{l}19 . \\
\text { Planejamen } \\
\text { to II (Parte I } \\
\text { / Parte II) }\end{array}$ & $\begin{array}{l}\text { 23. História } \\
\text { da } \\
\text { Arquitetura } \\
\text { III }\end{array}$ & $\begin{array}{l}\text { Disciplina } \\
\text { Autônoma }\end{array}$ & & & \\
\hline Regente & $\begin{array}{l}\text { José C. de } \\
\text { Figueiredo } \\
\text { Ferraz }\end{array}$ & (?) & (?) & $\begin{array}{l}\text { Lauro B. } \\
\text { Birkholz }\end{array}$ & $\begin{array}{l}\text { Eduardo } \\
\text { Kneese de } \\
\text { Melo }\end{array}$ & $\begin{array}{l}\text { Instrutor } \\
\text { designado por } \\
\text { Luiz R. C. } \\
\text { Franco }\end{array}$ & & & \\
\hline Disciplina & --- & --- & --- & Parte 1 & --- & $\begin{array}{l}\text { 134. Desenho } \\
\text { Industrial IV }\end{array}$ & & & \\
\hline \multirow[t]{2}{*}{ Prof. } & --- & --- & $\begin{array}{l}\text { Roger } \\
\text { Zmekhol }\end{array}$ & --- & $\begin{array}{l}\text { Benedito L. } \\
\text { de Toledo }\end{array}$ & $\begin{array}{l}\text { Dario } \\
\text { Imparato / } \\
\text { João C. R. } \\
\text { Stroeter }\end{array}$ & & & \\
\hline & \multicolumn{9}{|c|}{$5^{\circ}$ ano } \\
\hline Cadeira & 17. Projeto IV & $\begin{array}{l}19 . \\
\text { Planejamen } \\
\text { to II (Parte I } \\
\text { / Parte II) }\end{array}$ & $\begin{array}{l}\text { 24. História } \\
\text { da } \\
\text { Arquitetura } \\
\text { IV }\end{array}$ & & & & & & \\
\hline Regente & $\begin{array}{l}\text { João B. Vilanova } \\
\text { Artigas }\end{array}$ & $\begin{array}{l}\text { Lauro B. } \\
\text { Birkholz }\end{array}$ & $\begin{array}{l}\text { Eduardo } \\
\text { Corona }\end{array}$ & & & & & & \\
\hline Disciplina & --- & Parte 2 & --- & & & & & & \\
\hline Prof. & $\begin{array}{l}\text { Paulo A. Mendes } \\
\text { da Rocha / } \\
\text { Pedro P. M. } \\
\text { Saraiva }\end{array}$ & --- & $\begin{array}{l}\text { Carlos A. C. } \\
\text { Lemos }\end{array}$ & & & & & & \\
\hline
\end{tabular}




\section{ANEXO IV}

\section{DESENHOS DE PROJETOS DA FAU}

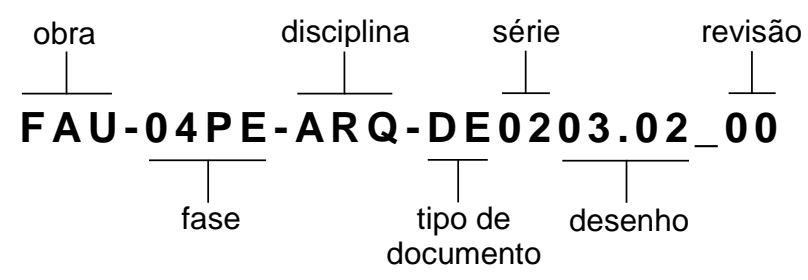

\begin{tabular}{|c|c|c|c|}
\hline fase & disciplina & tipo de documento & revisão \\
\hline 01EP estudo preliminar & ARQ arquitetura & DE desenho & \multirow{5}{*}{$\begin{array}{l}\text { número da revisão } \\
\text { ou } \mathbf{X} \text { (dado faltante) }\end{array}$} \\
\hline 02AP ante projeto & CXO caixilhos & & \\
\hline 03PB projeto básico & ELE elétrica & & \\
\hline \multirow[t]{2}{*}{ 04PE projeto executivo } & EST estrutura & desenho & \\
\hline & HID hidráulica & número do desenho & \\
\hline
\end{tabular}

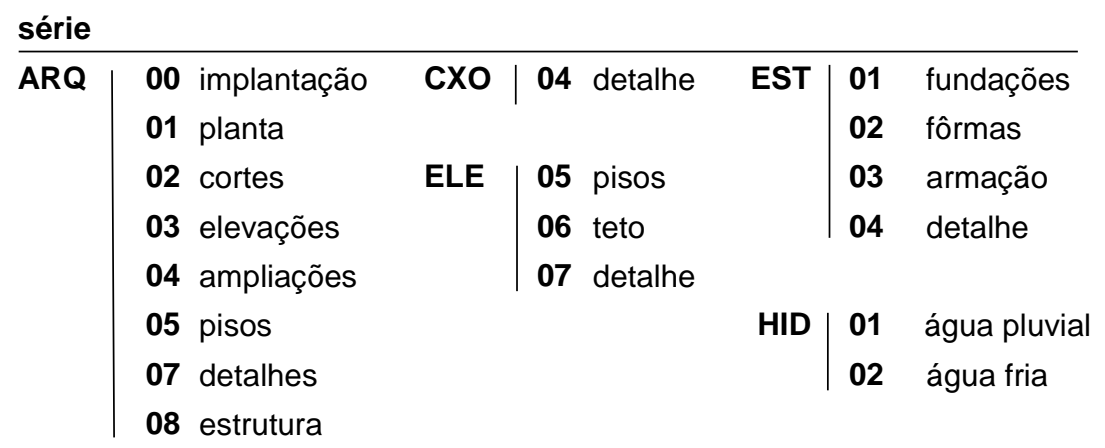





\begin{tabular}{|c|c|c|c|c|c|c|c|c|c|c|c|c|}
\hline \multicolumn{13}{|c|}{ DESENHOS DO PROJETO DA FAU-USP } \\
\hline \multicolumn{6}{|c|}{ Dados do carimbo } & \multicolumn{4}{|c|}{ Sistematização } & \multicolumn{3}{|c|}{$\begin{array}{l}\text { Localização dos Arquivos } \\
\text { Biblioteca FAU }\end{array}$} \\
\hline Data & Modificação & Autor & Folha & Título & Escala & vol. & $\begin{array}{l}\text { Tipo } \\
\text { desenho }\end{array}$ & $\begin{array}{l}\text { Pav./ } \\
\text { Vista }\end{array}$ & Obs. & $\begin{array}{l}\text { Cópias (PE } \\
\text { AR78/727.3) }\end{array}$ & $\begin{array}{l}\text { Originais (P } \\
\text { AR78/727.3) }\end{array}$ & $\operatorname{PDF}(727.3)$ \\
\hline--- & --- & CCUASO & --- & $\begin{array}{l}\text { Locacaão de RN de } \\
\text { edifício F. Arquitetura }\end{array}$ & --- & FAU---DE00_ & --- & --- & --- & --- & --- & F 1962 p.14 \\
\hline--- & -- & --- & --- & $\begin{array}{l}\text { Subsolo: Estudo } \\
\text { preliminar }\end{array}$ & --- & FAU-01EP-ARQ-DE0101.00_00 & Planta & -1 & 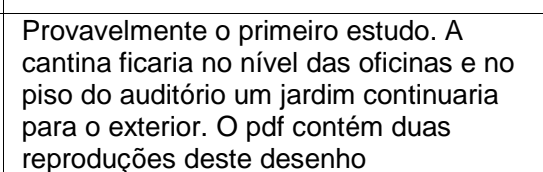 & FEP & $\begin{array}{l}\text { FAC V.1 } \\
(1961)\end{array}$ & $\begin{array}{l}\text { FAC } 1961 \\
\text { p.05/p.06 }\end{array}$ \\
\hline--- & --- & --- & --- & $\begin{array}{l}\text { Térreo: Estudo } \\
\text { preliminar }\end{array}$ & --- & FAU-01EP-ARQ-DE0102.00_00 & Planta & 0 & $\begin{array}{l}\text { Provavelmente o primeiro estudo. } \\
\text { Grêmio na posiçâa atual. Diretoria onde } \\
\text { hoje o o acesso. Rampa invertida. } \\
\text { Jardim sobre a laje do auditortio }\end{array}$ & FEP & $\begin{array}{l}\text { FAC v.1 } \\
(1961)\end{array}$ & $\begin{array}{l}\text { FAC } 1961 \\
\text { p.07 }\end{array}$ \\
\hline--- & -- & --- & --- & $\begin{array}{l}1^{\circ} \text { pav.: Estudo } \\
\text { preliminar }\end{array}$ & --- & FAU-01EP-ARQ-DE0103.00_00 & Planta & 1 & $\begin{array}{l}\text { Departamentos tazem jogo de volume na } \\
\text { fachada. Biblioteca pequena. Secretaria } \\
\text { invertida com a ra ra. Banheiros na } \\
\text { ataual avanand. }\end{array}$ & FEP & $\begin{array}{l}\text { FAC v.1 } \\
(1961)\end{array}$ & $\begin{array}{l}\text { FAC } 1961 \\
\text { p.08/ p.09 }\end{array}$ \\
\hline--- & -- & --- & --- & $\begin{array}{l}2^{\circ} \text { pav: Estudo } \\
\text { preliminar }\end{array}$ & --- & FAU-01EP-ARQ-DE0104.00_00 & Planta & 2 & 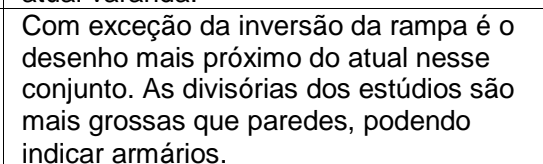 & FEP & $\begin{array}{l}\text { FAC v.1 } \\
(1961)\end{array}$ & $\begin{array}{l}\text { FAC } 1961 \\
\text { p.10/p.11 }\end{array}$ \\
\hline$--/-/ 1961$ & -- & Vilanova Artigas & 1 & Implantação & 1:1000 & FAU-02AP-ARQ-DE0000.00_00 & Implantação & --- & $\begin{array}{l}\text { o único volume que aparece além da } \\
\text { FAU é o atual IME. }\end{array}$ & FAC 1961 & $\begin{array}{l}\text { FAC v.2 } \\
(1961)\end{array}$ & $\begin{array}{l}\text { FAC } 1961 \\
\text { p.16/p.17 }\end{array}$ \\
\hline$--/--/ 1961$ & --- & Vilanova Artigas & 2 & Planta Subsolo & 1:200 & FAU-02AP-ARQ-DE0101.00_00 & Planta & -1 & $-\cdots$ & FAC 1961 & $\begin{array}{l}\text { FAC v.2 } \\
(1961)\end{array}$ & $\begin{array}{l}\text { FAC } 1961 \\
\text { p.18/p.19 }\end{array}$ \\
\hline$--/--/ 1961$ & $-\cdots$ & Vilanova Artigas & 3 & $\begin{array}{l}\text { Anteprojeto: Planta } \\
\text { andar térreo }\end{array}$ & $1: 200$ & FAU-02AP-ARQ-DE0102.00_00 & Planta & 0 & 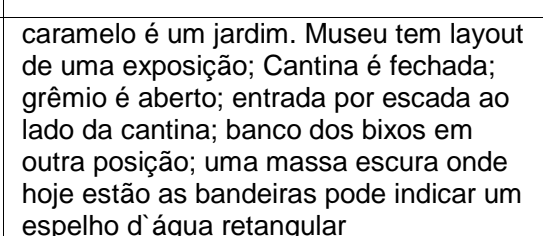 & FAC 1961 & $\begin{array}{l}\text { FAC v.2 } \\
(1961)\end{array}$ & $\begin{array}{l}\text { FAC } 1961 \\
\text { p.20/p.21 }\end{array}$ \\
\hline$--/--/ 1961$ & --- & Vilanova Artigas & 4 & Planta $1^{\circ}$ andar & $1: 200$ & FAU-02AP-ARQ-DE0103.00_00 & Planta & 1 & $\begin{array}{l}\text { nắo existe a parte de projetos da } \\
\text { biblioteca }\end{array}$ & FAC 1961 & $\begin{array}{l}\text { FAC v.3 } \\
(1961)\end{array}$ & $\begin{array}{l}\text { FAC } 1961 \\
\text { p.22/p.23 }\end{array}$ \\
\hline$--/--/ 1961$ & --- & Vilanova Artigas & 5 & Planta $2^{\circ}$ andar & $1: 200$ & FAU-02AP-ARQ-DE0104.00_00 & Planta & 2 & $\begin{array}{l}\text { estúdios sem divisão; aparecem os } \\
\text { núcleos de pias com pequenos espaços } \\
\text { organizados como salas de aula }\end{array}$ & FAC 1961 & $\begin{array}{l}\text { FAC v.3 } \\
(1961)\end{array}$ & $\begin{array}{l}\text { FAC } 1961 \\
\text { p.24/p.25 }\end{array}$ \\
\hline$--/--/ 1961$ & -- & Vilanova Artigas & 6 & Fachada e corte & $1: 200$ & FAU-02AP-ARQ-DE0201.00_00 & Elevação & --- & -- & FAC 1961 & $\begin{array}{l}\text { FAC v.3 } \\
(1961)\end{array}$ & $\begin{array}{l}\text { FAC } 1961 \\
\text { p.26/p.27 }\end{array}$ \\
\hline \multirow[t]{2}{*}{$--/--/ 1961$} & --- & Vilanova Artigas & 7 & Fachadas & 1:200 & FAU-02AP-ARQ-DE0301.00_00 & Elevação & --- & --- & FAC 1961 & $\begin{array}{l}\text { FAC v.3 } \\
(1961)\end{array}$ & $\begin{array}{l}\text { FAC } 1961 \\
\text { p.28/p.29 }\end{array}$ \\
\hline & -- & $\begin{array}{l}\text { Vilanova Artigase } \\
\text { Carlos Cascaldi }\end{array}$ & --- & Locação & 1:500 & FAU-03PB-ARQ-DE0001.00_X & Planta & --- & $\begin{array}{l}\text { Carimbo em branco. Contém a divisão } \\
\text { dos setores ou "blocos" }\end{array}$ & FF e.1 & Fv.1 & Fp.01 \\
\hline$--/$ jun. / 1961 & $\ldots$ & $\begin{array}{l}\text { Vilanova Artigase } \\
\text { Carlos Cascaldi }\end{array}$ & 1 & Planta do subsolo & 1:100 & FAU-03PB-ARQ-DE0101.00_00 & Planta & -1 & $\begin{array}{l}\text { Apresenta acesso externo por escada ao } \\
\text { ladodo do apartamento do zeladore do } \\
\text { outro lado, abaixo da cantina. Grêmio no } \\
\text { subsolo }\end{array}$ & FHI e.2 & $\begin{array}{l}\text { FAC v.5 } \\
(1961) / v .4 / \\
\text { Fv.2 }\end{array}$ & $\begin{array}{l}\text { FAC } 1961 \\
\text { p.31 }\end{array}$ \\
\hline
\end{tabular}




\begin{tabular}{|c|c|c|c|c|c|c|c|c|c|c|c|c|}
\hline \multicolumn{6}{|c|}{ Dados do carimbo } & \multicolumn{4}{|c|}{ Sistematização } & \multicolumn{3}{|c|}{$\begin{array}{l}\text { Localizacãa dos Arquivos } \\
\text { Biblioteca FAU }\end{array}$} \\
\hline Data & Modificação & Autor & Folha & Título & Escala & Vol. & $\begin{array}{l}\text { Tipo } \\
\text { desenho }\end{array}$ & $\begin{array}{l}\text { Pav./I } \\
\text { Vista }\end{array}$ & Obs. & $\begin{array}{l}\text { Cópias (PE } \\
\text { AR78/727.3) }\end{array}$ & $\begin{array}{l}\text { Originais (P } \\
\text { AR78/727.3) }\end{array}$ & PDF (727.3) \\
\hline $06 /$ dec. / 1965 & --- & FCCUASO & 4962 & Planta do subsolo & 1:100 & (n) & Planta & -1 & 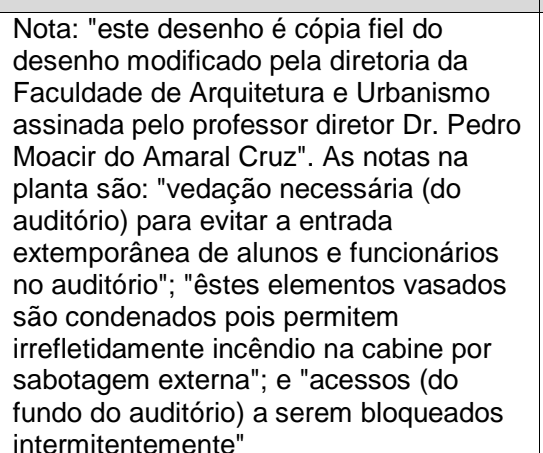 & Fe.2 & F 1965 & F 1965 p.1 \\
\hline-- & -- & $\begin{array}{l}\text { Vilanova Artigas e } \\
\text { Carlos Cascaldi }\end{array}$ & 1 & & 1:100 & FAU-03PB-ARQ-DE0101.00_02 & Planta & -1 & $\begin{array}{l}\text { Este conjunto de desenhos possuio } \\
\text { carimbo Artigas e Cascaldi, mas todos } \\
\text { os campos estão em branco, menos } \\
\text { escala. }\end{array}$ & FLP & Fv.4 & F p.30 \\
\hline 01 / jul. / 1966 & -- & $\begin{array}{l}\text { Vilanova Artigas e } \\
\text { Carlos Cascaldi }\end{array}$ & 1 & Planta do subsolo & $1: 100$ & FAU-03PB-ARQ-DE0101.00_03 & Planta & -1 & $\begin{array}{l}\text { Apartamento do zelador, acesso ao } \\
\text { exterior, banheiro fem. e masc. no fosso. }\end{array}$ & $\mathrm{Fe} .2$ & F $1966 \mathrm{v} .1$ & F 1966 p.1 \\
\hline$--/$ jun. / 1961 & --- & $\begin{array}{l}\text { Vilanova Artigas e } \\
\text { Carlos Cascaldi }\end{array}$ & 2 & Planta $1^{\circ}$ pavimento & $1: 100$ & FAU-03PB-ARQ-DE0102.00_00 & Planta & 0 & $\begin{array}{l}\text { desenho técnico com cotas e número } \\
\text { dos pilares. Desenho diferente da } \\
\text { portaria; cantina seria fechada por } \\
\text { parede e caixilho; Escada e porta de } \\
\text { entrada timida do exterior para o saläo } \\
\text { caramelo. }\end{array}$ & FAC 1961 & $\begin{array}{l}\text { FAC v.5 } \\
(1961) / v .4\end{array}$ & $\begin{array}{l}\text { FAC } 1961 \\
\text { p.32 }\end{array}$ \\
\hline $06 /$ dec. / 1965 & -- & FCCUASO & 4957 & Planta do $1^{\circ}$ pavimento & $1: 100$ & FAU-03PB-ARQ-DE0102.00_01 & Planta & 0 & $\begin{array}{l}\text { Verificar: Essa planta só aparece no pdf } \\
\text { e naóe possivel ler data ou número da } \\
\text { folha. }\end{array}$ & --- & F 1965 & F $1965 \mathrm{p} .2$ \\
\hline--- & --- & --- & --- & -- & --- & FAU-03PB-ARQ-DE0102.00_01X & Planta & 0 & $\begin{array}{l}\text { Não há carimbo. Gfau aparece na } \\
\text { chegada da arampe a a biblioteca no } \\
\text { caramelo. (revisão?) }\end{array}$ & FD & Fv.4 & Fp.28 \\
\hline-- & -- & $\begin{array}{l}\text { Vilanova Artigas e } \\
\text { Carlos Cascaldi }\end{array}$ & 2 & & 1:100 & FAU-03PB-ARQ-DE0102.00_02 & Planta & 0 & $\begin{array}{l}\text { grêmio na chegada da rampa, biblioteca } \\
\text { no caramelo. }\end{array}$ & FLP & Fv.4 & Fp.31 \\
\hline 01 / jul. / 1966 & -- & $\begin{array}{l}\text { Vilanova Artigas e } \\
\text { Carlos Cascaldi }\end{array}$ & 2 & Planta do $1^{\circ}$ pavimento & $1: 100$ & FAU-03PB-ARQ-DE0102.00_03 & Planta & 0 & 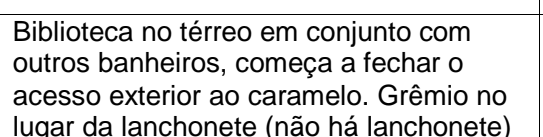 & $\mathrm{Fe} .2$ & F $1966 v .1$ & F $1966 \mathrm{p} .2$ \\
\hline-- & -- & -- & --- & --- & --- & FAU-03PB-ARQ-DE0102.01_01X & Planta & --- & $\begin{array}{l}\text { Ampliação de uma área quevai ido p29 } \\
\text { ao p34. Pode ser a biblioteca ou direşâo. }\end{array}$ & $-\cdots$ & Fv.3 & F p.27 \\
\hline$--/$ jun. / 1961 & -- & $\begin{array}{l}\text { Vilanova Artigas e } \\
\text { Carlos Cascaldi }\end{array}$ & 3 & Planta $2^{\circ}$ pavimento & 1:100 & FAU-03PB-ARQ-DE0103.00_00 & Planta & 1 & 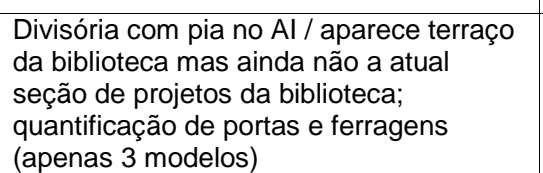 & FHI e.2 & $\begin{array}{l}\text { FAC v.5 } \\
(1961) / v .4\end{array}$ & $\begin{array}{l}\text { FAC } 1961 \\
\text { p. } 33\end{array}$ \\
\hline $07 /$ dec. / 1965 & --- & FCCUASO & 4964 & Planta do $2^{\circ}$ pavimento & $1: 100$ & FAU-03PB-ARQ-DE0103.00_01 & Planta & 1 & $\begin{array}{l}\text { Confirmar diferenchsa com o desenho de } \\
6 / 12 / 1965 \text { na biblioteca }\end{array}$ & $\mathrm{Fe} .2$ & F 1965 & F 1965 p.3 \\
\hline--- & --- & --- & --- & --- & --- & FAU-03PB-ARQ-DE0103.00_01X & Planta & 1 & $\begin{array}{l}\text { Não há carimbo. Já existe sala da } \\
\text { congregacão e o Al está ocupado. } \\
\text { (revisão?) }\end{array}$ & FD & Fv. 4 & Fp.29 \\
\hline--- & --- & $\begin{array}{l}\text { Vilanova Artigas e } \\
\text { Carlos Cascaldi }\end{array}$ & 3 & --- & 1:100 & FAU-03PB-ARQ-DE0103.00_02 & Planta & 1 & $\begin{array}{l}\text { Al ocupado, diretoria no lugar da } \\
\text { bibliteccac com essaço da congregação } \\
\text { (setor de projetos). }\end{array}$ & FLP & Fv.4 & Fp.32 \\
\hline 01 / jul. / 1966 & -- & $\begin{array}{l}\text { Vilanova Artigas e } \\
\text { Carlos Cascaldi }\end{array}$ & 3 & Planta do $2^{\circ}$ pavimento & $1: 100$ & FAU-03PB-ARQ-DE0103.00_03 & Planta & 1 & $\cdots$ & $-\cdots$ & F $1966 v .1$ & F 1966 p.3 \\
\hline$--/$ jun. / 1961 & -- & $\begin{array}{l}\text { Vilanova Artigas e } \\
\text { Carlos Cascaldi }\end{array}$ & 4 & Planta 30 pavimento & 1:100 & FAU-03PB-ARQ-DE0104.00_00 & Planta & 2 & $\begin{array}{l}\text { Não há portas nos ateliers, nem } \\
\text { divisórias entre cada um; Chiqueiro + } 4 \\
\text { nú́cleos de pias nos estúdios }\end{array}$ & FAC 1961 & $\begin{array}{l}\text { FAC v.5 } \\
(1961) / v .4\end{array}$ & $\begin{array}{l}\text { FAC } 1961 \\
\text { p.34 }\end{array}$ \\
\hline
\end{tabular}




\begin{tabular}{|c|c|c|c|c|c|c|c|c|c|c|c|c|}
\hline \multicolumn{6}{|c|}{ Dados do carimbo } & \multicolumn{4}{|c|}{ Sistematização } & \multicolumn{3}{|c|}{$\begin{array}{l}\text { Localização dos Arquivos } \\
\text { Biblioteca FAU }\end{array}$} \\
\hline Data & Modificação & Autor & Folha & Título & Escala & Vol. & $\begin{array}{l}\text { Tipo } \\
\text { desenho }\end{array}$ & $\begin{array}{l}\text { Pav. } / \\
\text { Vista }\end{array}$ & Obs. & $\begin{array}{l}\text { Cópias (PE } \\
\text { AR78/727.3) }\end{array}$ & $\begin{array}{l}\text { Originais }(P \\
A R 78 / 727.3)\end{array}$ & PDF (727.3) \\
\hline 02 / dec. / 1965 & --- & FCCUASO & 4961 & Planta do 30 pavimento & 1:100 & FAU-03PB-ARQ-DE0104.00_01 & Planta & 2 & $\begin{array}{l}\text { Conntirmar diferencencom o desenho de } \\
6 / 1 / 1 / 1965 \text { na biblioteca }\end{array}$ & Fe.2 & F 1965 & F 1965 p.4 \\
\hline-- & --- & $\begin{array}{l}\text { Vilanova Artigas e } \\
\text { Carlos Cascaldi }\end{array}$ & 4 & --- & 1:100 & FAU-03PB-ARQ-DE0104.00_02 & Planta & 2 & Ateliers com portas e sem chiqueiro. & FLP & Fv.4 & F p.33 \\
\hline 01 / jul. / 1966 & --- & $\begin{array}{l}\text { Vilanova Artigas e } \\
\text { Carlos Cascaldi }\end{array}$ & 4 & Planta do 30 pavimento & 1:100 & FAU-03PB-ARQ-DE0104.00_03 & Planta & 2 & Ateliers com portas e sem chiqueiro. & & F $1966 \mathrm{v} .1$ & F 1966 p.4 \\
\hline $01 /$ fev. / 1962 & --- & $\begin{array}{l}\text { Vilanova Artigase } \\
\text { Carlos Cascaldi }\end{array}$ & 10 & Planta da cobertura & 1:100 & FAU-03PB-ARQ-DE0105.00_00 & Planta & Cobertura & --- & FPR 1962 & --- & $-\overline{-}$ \\
\hline 01 / jul. / 1966 & $-\cdots$ & $\begin{array}{l}\text { Vilanova Artigas e } \\
\text { Carlos Cascaldi }\end{array}$ & 10 & Planta de cobertura & $1: 100$ & FAU-03PB-ARQ-DE0105.00_01 & Planta & Cobertura & --- & $\mathrm{Fe} .2$ & F 1966 v.1 & F 1966 p.7 \\
\hline$--/$ jun. / 1961 & --- & $\begin{array}{l}\text { Vilanova Artigas e } \\
\text { Carlos Cascaldi }\end{array}$ & 5 & Cortes AA e BB & 1:100 & FAU-03PB-ARQ-DE0201.00_00 & Corte & $\begin{array}{l}\text { Longitudin } \\
\text { al, } \\
\text { transversal } \\
\text { e detalhes } \\
1: 20\end{array}$ & 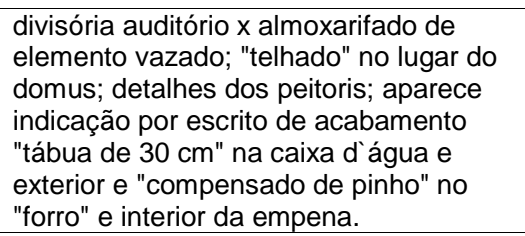 & $\begin{array}{l}\text { FHI e.1/FHI } \\
\text { e.2/FAC } \\
1961\end{array}$ & $\begin{array}{l}\text { FAC v.5 } \\
(1961) / v .4\end{array}$ & $\begin{array}{l}\text { FAC } 1961 \\
\text { p.35 }\end{array}$ \\
\hline 01 / jul. / 1966 & --- & $\begin{array}{l}\text { Vilanova Artigas e } \\
\text { Carlos Cascaldi }\end{array}$ & 5 & Corte AA e BB & 1:100 & FAU-03PB-ARQ-DE0201.00_01 & Corte & --- & $\begin{array}{l}\text { corte transversal; corte longitudinal; } \\
\text { detalhes numerados de } 1 \text { a } 10 \text { das } \\
\text { diferentes solucóces de peitoril e } \\
\text { terminaçons de lajes; persiste solução } \\
\text { de elemento vazado entre auditório e } \\
\text { depósito. }\end{array}$ & $\mathrm{F}$ e.2 & F $1966 v .1$ & F 1966 p.5 \\
\hline$--/$ jun. / 1961 & -- & $\begin{array}{l}\text { Vilanova Artigas e } \\
\text { Carlos Cascaldi }\end{array}$ & 6 & Cortes CC e DD & 1:100 & FAU-03PB-ARQ-DE0202.00_00 & Corte & $\begin{array}{l}\text { Transvers } \\
\text { ais e } \\
\text { detalhes } \\
1: 20\end{array}$ & $\begin{array}{l}\text { Neste conjunto de desenhos, o domos é } \\
\text { uma espécie de telhado }\end{array}$ & $\begin{array}{l}\text { FHI e.1/FHI } \\
\text { e.2/FAC } \\
1961\end{array}$ & $\begin{array}{l}\text { FAC v.5 } \\
(1961) / v .4\end{array}$ & $\begin{array}{l}\text { FAC } 1961 \\
\text { p.36 }\end{array}$ \\
\hline 01 / jul. / 1966 & $\cdots$ & $\begin{array}{l}\text { Vilanova Artigas e } \\
\text { Carlos Cascaldi }\end{array}$ & 6 & Corte CC e DD & $1: 100$ & FAU-03PB-ARQ-DE0202.00_01 & Corte & --- & --- & $\mathrm{Fe} .2$ & --- & --- \\
\hline$--/$ jun. / 1961 & --- & $\begin{array}{l}\text { Vilanova Artigas e } \\
\text { Carlos Cascaldi }\end{array}$ & 7 & Fachadas & 1:100 & FAU-03PB-ARQ-DE0301.00_00 & Elevação & --- & --- & $\begin{array}{l}\text { FHl e.1/FHI } \\
\text { e.2. }\end{array}$ & $\begin{array}{l}\text { FAC v.4 } \\
(1961)\end{array}$ & $\begin{array}{l}\text { FAC } 1961 \\
\text { p.37 }\end{array}$ \\
\hline 01 / jul. / 1966 & --- & $\begin{array}{l}\text { Vilanova Artigas e } \\
\text { Carlos Cascaldi }\end{array}$ & 7 & Fachadas & 1:100 & FAU-03PB-ARQ-DE0301.00_01 & Elevação & & $\begin{array}{l}\text { desenho das } 4 \text { fachadas: as notaçōes } \\
\text { em desenho indicam areas a receber } \\
\text { formas de tábuas de } 30 \mathrm{~cm} \text { e éreas com } \\
\text { Compensado de pinho (no triângulo } \\
\text { ascendente do pilar }\end{array}$ & $\mathrm{Fe} .2$ & F $1966 \mathrm{v} .1$ & F 1966 p.6 \\
\hline 01 / jan. / 1962 & $-\cdots$ & $\begin{array}{l}\text { Vilanova Artigas e } \\
\text { Carlos Cascaldi }\end{array}$ & 9 & Auditorio: detalhes & $\begin{array}{l}1: 50, \\
1: 10\end{array}$ & FAU-03PB-ARQ-DE0400.00_00 & --- & Detalhe & & FPR 1962 & --- & --- \\
\hline-- / set. / 1967 & --- & Vilanova Artigas & $7 \mathrm{~A}$ & Fachada & $\begin{array}{l}1: 100, \\
1: 10,1: 2\end{array}$ & FAU-03PB-ARQ-DE0701.00_00 & $\begin{array}{l}\text { Elevacăo } \\
\text { frontal }\end{array}$ & Detalhe & $\begin{array}{l}\text { Aparece o logo da FAU na tachadac com } \\
\text { detalhes; detalhe da junta de dilataçăã } \\
\text { na empena principal. Há uma cópia no } \\
\text { original }\end{array}$ & FAUR & F 1967 & $\begin{array}{l}\text { F } 1967 \text { p.4/ } \\
\text { p.5 }\end{array}$ \\
\hline 01 / jan. / 1962 & --- & $\begin{array}{l}\text { Vilanova Artigas e } \\
\text { Carlos Cascaldi }\end{array}$ & 8 & Detalhes gerais & $1: 20,1: 2$ & FAU-03PB-ARQ-DE0702.00_00 & --- & Detalhe & Escada; caixa d’água; arrimo; rampa & FPR 1962 & Fv.1 (1962) & F 1962 p.2 \\
\hline $01 /$ jan. / 1962 & -- & $\begin{array}{l}\text { Vilanova Artigas e } \\
\text { Carlos Cascaldi }\end{array}$ & 11 & Serralheria & 1:20, 1:1 & FAU-03PB-ARQ-DE0721.00_00 & -- & Detalhe & $\begin{array}{l}\text { Detalhes de janelas "maxim ar", portas e } \\
\text { caixilhos }\end{array}$ & FPR 1962 & Fv.1 (1962) & F 1962 p.3 \\
\hline 01 / jul. / 1962 & -- & $\begin{array}{l}\text { Vilanova Artigas e } \\
\text { Carlos Cascaldi }\end{array}$ & $6 \mathrm{~A}$ & $\begin{array}{l}\text { Variante do detallhe 12: } \\
\text { claraboias }\end{array}$ & 1:20.1:2 & FAU-03PB-ARQ-DE0771.00_00 & & Detalhe & Material da claraboia é acrílico & $\begin{array}{l}\text { FPR 1962I } \\
\text { FAUR }\end{array}$ & Fv.1 (1962) & F 1962 p.1 \\
\hline-- & -- & $\begin{array}{l}\text { Vilanova Artigas e } \\
\text { Carlos Cascaldi }\end{array}$ & 14 & $\cdots$ & -- & FAU-03PB-ARQ-DE0801.01_00 & Planta & -1 & -- & --- & -- & -- \\
\hline
\end{tabular}




\begin{tabular}{|c|c|c|c|c|c|c|c|c|c|c|c|c|}
\hline \multicolumn{6}{|c|}{ Dados do carimbo } & \multicolumn{4}{|c|}{ Sistematização } & \multicolumn{3}{|c|}{$\begin{array}{l}\text { Localização dos Arquivos } \\
\text { Biblioteca FAU }\end{array}$} \\
\hline Data & Modificação & Autor & Folha & Título & Escala & Vol. & $\begin{array}{l}\text { Tipo } \\
\text { desenho }\end{array}$ & $\begin{array}{l}\text { Pav./ } \\
\text { Vista }\end{array}$ & Obs. & $\begin{array}{l}\text { Cópias (PE } \\
\text { AR78/727.3) }\end{array}$ & $\begin{array}{l}\text { Originais }(P \\
\text { AR78/727.3) }\end{array}$ & PDF (727.3) \\
\hline--- & -- & $\begin{array}{l}\text { Vilanova Artigas e } \\
\text { Carlos Cascaldi }\end{array}$ & 15 & --- & $\cdots$ & FAU-03PB-ARQ-DE0801.02_00 & Planta & -1 & --- & -- & $\cdots$ & --- \\
\hline--- & -- & $\begin{array}{l}\text { Vilanova Artigas e } \\
\text { Carlos Cascaldi }\end{array}$ & 12 & --- & --- & FAU-03PB-ARQ-DE0801.03_00 & Planta & -1 & --- & --- & --- & --- \\
\hline--- & --- & $\begin{array}{l}\text { Vilanova Artigas e } \\
\text { Carlos Cascaldi }\end{array}$ & 13 & --- & --- & FAU-03PB-ARQ-DE0801.04_00 & Planta & -1 & --- & --- & --- & --- \\
\hline--- & --- & $\begin{array}{l}\text { Vilanova Artigas e } \\
\text { Carlos Cascaldi }\end{array}$ & 29 & --- & --- & FAU-03PB-ARQ-DE0801.05_00 & $\begin{array}{l}\text { Planta; } \\
\text { Cortes }\end{array}$ & -1 & Base para Piso auditório - Detalhes & --- & --- & --- \\
\hline--- & $\cdots$ & $\begin{array}{l}\text { Vilanova Artigas e } \\
\text { Carlos Cascaldi }\end{array}$ & 16 & $\cdots$ & $\cdots$ & FAU-03PB-ARQ-DE0802.01_00 & Planta & 0 & --- & --- & --- & --- \\
\hline--- & --- & $\begin{array}{l}\text { Vilanova Artigas e } \\
\text { Carlos Cascaldi }\end{array}$ & 17 & $\cdots$ & $-\cdots$ & FAU-03PB-ARQ-DE0802.02_00 & Planta & 0 & --- & --- & $-\cdots$ & --- \\
\hline-- & -- & $\begin{array}{l}\text { Vilanova Artigas e } \\
\text { Carlos Cascaldi }\end{array}$ & 19 & $\cdots$ & $\cdots$ & FAU-03PB-ARQ-DE0802.03_00 & Planta & 0 & $-\cdots-$ & $-\cdots$ & --- & --- \\
\hline-- & --- & $\begin{array}{l}\text { Vilanova Artigas e } \\
\text { Carlos Cascaldi }\end{array}$ & 18 & --- & $-\cdots$ & FAU-03PB-ARQ-DE0802.04_00 & Planta & 0 & --- & --- & --- & --- \\
\hline--- & --- & $\begin{array}{l}\text { Vilanova Artigas e } \\
\text { Carlos Cascaldi }\end{array}$ & 24 & --- & --- & FAU-03PB-ARQ-DE0803.01_00 & Planta & 1 & --- & --- & --- & --- \\
\hline--- & --- & $\begin{array}{l}\text { Vilanova Artigas e } \\
\text { Carlos Cascaldi }\end{array}$ & 25 & --- & $-\cdots$ & FAU-03PB-ARQ-DE0803.02_00 & Planta & 1 & --- & $-\cdots$ & --- & --- \\
\hline--- & --- & $\begin{array}{l}\text { Vilanova Artigas e } \\
\text { Carlos Cascaldi }\end{array}$ & 20 & --- & $-\cdots$ & FAU-03PB-ARQ-DE0803.03_00 & Planta & 1 & --- & $-\cdots$ & --- & --- \\
\hline--- & --- & $\begin{array}{l}\text { Vilanova Artigas e } \\
\text { Carlos Cascaldi }\end{array}$ & 21 & --- & --- & FAU-03PB-ARQ-DE0803.04_00 & Planta & 1 & --- & --- & --- & --- \\
\hline-- & --- & $\begin{array}{l}\text { Vilanova Artigas e } \\
\text { Carlos Cascaldi }\end{array}$ & 22 & --- & --- & FAU-03PB-ARQ-DE0804.01_00 & Planta & 2 & --- & --- & --- & --- \\
\hline--- & --- & $\begin{array}{l}\text { Vilanova Artigas e } \\
\text { Carlos Cascaldi }\end{array}$ & 23 & --- & $-\cdots$ & FAU-03PB-ARQ-DE0804.02_00 & Planta & 2 & --- & --- & --- & --- \\
\hline--- & --- & $\begin{array}{l}\text { Vilanova Artigas e } \\
\text { Carlos Cascaldi }\end{array}$ & 27 & --- & $\cdots$ & FAU-03PB-ARQ-DE0804.03_00 & Planta & 2 & --- & --- & --- & --- \\
\hline--- & --- & $\begin{array}{l}\text { Vilanova Artigas e } \\
\text { Carlos Cascaldi }\end{array}$ & 26 & --- & --- & FAU-03PB-ARQ-DE0804.04_00 & Planta & 2 & --- & --- & $\cdots$ & --- \\
\hline--- & --- & $\begin{array}{l}\text { Vilanova Artigas e } \\
\text { Carlos Cascaldi }\end{array}$ & 28 & --- & $\ldots$ & FAU-03PB-ARQ-DE0805.00_00 & $\begin{array}{l}\text { Planta; } \\
\text { detalhes }\end{array}$ & Cobertura & -- & --- & --- & --- \\
\hline $31 /$ mai. / 1968 & 19/ set. / 1968 & FCCUASO & 7079 & $\begin{array}{l}\text { Planta dos níveis - } 300,- \\
110\end{array}$ & 1:100 & FAU-04PE-ARQ-DE0101.00_00 & Planta & -1 & $\begin{array}{l}\text { "modificados, gráfica, coop., depósito, } \\
\text { estúdio, laboratório totográfico 19-09- } \\
1968 \text { " }\end{array}$ & F 1968 & F $1968 \mathrm{v} \cdot 3$ & F 1968 p.24 \\
\hline--- & --- & Vilanova Artigas & --- & --- & --- & FAU-04PE-ARQ-DE0101.00_X & Planta & -1 & $\begin{array}{l}\text { Carimbo em branco. Nas oficinas o } \\
\text { desenho tem uma revisãa a mâo, com } \\
\text { mudança de paredes e portas }\end{array}$ & & Fv.1 & F p.08 \\
\hline--- & --- & Vilanova Artigas & --- & --- & --- & FAU-04PE-ARQ-DE0101.01_X & Planta & -1 & $\begin{array}{l}\text { Carimbo em branco. Layout das oficinas. } \\
\text { Ainda aparace um pequeno apartamento } \\
\text { para o zelador. }\end{array}$ & FD & $\mathrm{Fv} .3$ & F p.24 \\
\hline
\end{tabular}




\begin{tabular}{|c|c|c|c|c|c|c|c|c|c|c|c|c|}
\hline \multicolumn{6}{|c|}{ Dados do carimbo } & \multicolumn{4}{|c|}{ Sistematização } & \multicolumn{3}{|c|}{$\begin{array}{l}\text { Localização dos Arquivos } \\
\text { Biblioteca FAU }\end{array}$} \\
\hline Data & Modificação & Autor & Folha & Titulo & Escala & Vol. & $\begin{array}{l}\text { Tipo } \\
\text { desenho }\end{array}$ & Pav. / Vista & Obs. & $\begin{array}{l}\text { Cópias (PE } \\
\text { AR78/727.3) }\end{array}$ & $\begin{array}{l}\text { Originais }(P \\
\text { AR78/727.3) }\end{array}$ & PDF (727.3) \\
\hline 10 / jun. / 1968 & --- & FCCUASO & 7116 & $\begin{array}{l}\text { Planta dos níveis }+80, \\
+270\end{array}$ & 1:100 & FAU-04PE-ARQ-DE0102.00_00 & Planta & 0 & $\begin{array}{l}\text { Na cópia em papel, o carimbo parece } \\
\text { estar rasgado, mas há indicaçoes à } \\
\text { mão; planta mais atual. }\end{array}$ & F 1968 & F $1968 \mathrm{v} .3$ & F 1968 p.27 \\
\hline--- & --- & Vilanova Artigas & --- & --- & $-\cdots$ & FAU-04PE-ARQ-DE0102.00_X & Planta & 0 & $\begin{array}{l}\text { Carimbo em branco. A sétima página } \\
\text { do PDF, porém sem a mancha preta } \\
\text { no centro. }\end{array}$ & --- & Fv.1 & F p.07 \\
\hline 11 / jun. / 1968 & --- & FCCUASO & 7123 & $\begin{array}{l}\text { Administração do } \\
\text { museu: planta e corte. } \\
\text { Nível + } 270 \text {. }\end{array}$ & $\begin{array}{l}1: 20, \\
1: 50\end{array}$ & FAU-04PE-ARQ-DE0102.02_00 & Planta, corte & 0 & Curva do caracol & F 1968 & --- & --- \\
\hline 17 / jun. / 1968 & --- & FCCUASO & 7194 & $\begin{array}{l}\text { Planta dos níveis }+460 \text {, } \\
+650\end{array}$ & 1:100 & FAU-04PE-ARQ-DE0103.00_00 & Planta & 1 & $\begin{array}{l}\text { Final (diferença com o construído na } \\
\text { varanda da biblioteca com pano de } \\
\text { concreto entre a varanda e a seção de } \\
\text { projeto) }\end{array}$ & F 1968 & F 1968 v.4 & F 1968 p.32 \\
\hline$--/$ jan. / 1968 & --- & Vilanova Artigas & --- & Planta do Atelier & 1:100 & FAU-04PE-ARQ-DE0104.00_00 & Planta & 2 & Projeto semelhante ao atual & FD & F $1968 \mathrm{v} .2$ & F 1968 p.17 \\
\hline 18 / jul. / 1968 & --- & FCCUASO & 7285 & $\begin{array}{l}\text { Planta nos niveis }+840, \\
+1030\end{array}$ & 1:100 & FAU-04PE-ARQ-DE0104.00_01 & Planta & 2 & Final & F 1968 & F 1968 v.4 & F 1968 p.33 \\
\hline 20 / jun. / 1968 & --- & FCCUASO & 7124 & Planta da cobertura & 1:100 & FAU-04PE-ARQ-DE0105.00_00 & Planta & Cobertura & --- & F 1968 & F $1968 \mathrm{v} .3$ & F 1968 p.28 \\
\hline--- & --- & FCCUASO & --- & $\begin{array}{l}\text { Cortes longitudinal BB- } \\
\text { AA }\end{array}$ & 1:100 & FAU-04PE-ARQ-DE0201.00_00 & Cortes & $\begin{array}{l}\text { Longitudinai } \\
\mathrm{s}\end{array}$ & $\begin{array}{l}\text { Provavelmente o desenho definitivo } \\
\text { feito pelo fundo em } 1968\end{array}$ & $-\cdots$ & F $1968 \mathrm{v} .2$ & F 1968 p.18 \\
\hline-- & $\cdots$ & FCCUASO & --- & $\begin{array}{l}\text { Cortes transversais CC- } \\
\text { DD }\end{array}$ & 1:100 & FAU-04PE-ARQ-DE0202.00_00 & Cortes & Transversais & --- & --- & F $1968 \mathrm{v} .2$ & F 1968 p.19 \\
\hline 22 / jul. / 1968 & --- & FCCUASO & 7598 & Corte C-C' & $1: 50$ & FAU-04PE-ARQ-DE0202.01_00 & Corte & Transversal & $-\cdots$ & F 1968 & F 1968 v.4 & F 1968 p.36 \\
\hline 23 / jul. / 1968 & --- & FCCUASO & 7599 & Corte D-D' & 1:50 & FAU-04PE-ARQ-DE0202.02_00 & Corte & Transversal & $\cdots$ & F 1968 & F 1968 v.4 & F 1968 p.37 \\
\hline $28 /$ mar. / 1968 & --- & FCCUASO & --- & $\begin{array}{l}\text { Cortes Transversais EE- } \\
\mathrm{FF}\end{array}$ & 1:100 & FAU-04PE-ARQ-DE0203.00_00 & Corte & Transversais & --- & $\cdots$ & F $1968 \mathrm{v} .2$ & F 1968 p.20 \\
\hline 23 / jul. / 1968 & --- & FCCUASO & 7596 & Corte E-E' & 1:50 & FAU-04PE-ARQ-DE0203.01_00 & Corte & Transversal & --- & F 1968 & F $1968 \mathrm{~V} .4$ & F 1968 p.34 \\
\hline 22 / jul. / 1968 & $\cdots$ & FCCUASO & 7597 & Corte F-F' & 1:50 & FAU-04PE-ARQ-DE0203.02_00 & Corte & Transversal & Final & F 1968 & F $1968 \mathrm{v} .4$ & F 1968 p.35 \\
\hline 03 / jul. / 1968 & --- & FCCUASO & 7131 & Fachada Sul & $1: 100$ & FAU-04PE-ARQ-DE0301.01_00 & Elevação & $\begin{array}{l}\text { Longitudinal } \\
\text { Sul }\end{array}$ & $\cdots$ & F 1968 e.1 & F $1968 \mathrm{v} \cdot 3$ & F 1968 p.29 \\
\hline $08 /$ nov. / 1967 & --- & Vilanova Artigas & --- & $\begin{array}{l}\text { Colunas fachada } \\
\text { principal }\end{array}$ & $\cdots$ & FAU-04PE-ARQ-DE0301.02_X & $\begin{array}{l}\text { Elevação } \\
\text { posterior }\end{array}$ & --- & $\begin{array}{l}\text { Data, título e assinatura de Artigas } \\
\text { escritas a lápis. Desenho de fachada } \\
\text { com ampliação do pilar externo. Obs.: } \\
\text { o original encontrado em vegetala } \\
\text { contém cor amarala na aparte ifferior } \\
\text { dos pilares; Há uma cópia no original } \\
\text { (sem cor) }\end{array}$ & FAUR & F 1967 & $\begin{array}{l}\text { F } 1967 \text { p.02/ } \\
\text { p.03/p.07 }\end{array}$ \\
\hline 03 / jul. / 1968 & --- & FCCUASO & 7132 & Fachada Norte & $1: 100$ & FAU-04PE-ARQ-DE0301.02_00 & Elevação & $\begin{array}{l}\text { Longitudinal } \\
\text { Norte }\end{array}$ & & F 1968 e.1 & F $1968 \mathrm{v} .3$ & F 1968 p.30 \\
\hline-- & --- & Vilanova Artigas & --- & --- & --- & FAU-04PE-ARQ-DE0301.02_X & Elevação & -- & 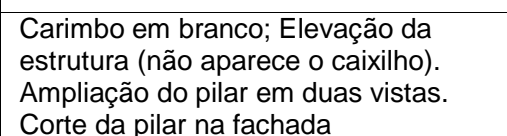 & --- & $\mathrm{Fv} .2$ & Fp.09 \\
\hline 03 / jul. / 1968 & $\cdots$ & FCCUASO & 7133 & $\begin{array}{l}\text { Fachadas "Leste" e } \\
\text { "Oeste" }\end{array}$ & 1:100 & FAU-04PE-ARQ-DE0301.03_00 & Elevação & --- & & F 1968 & F 1968 v.4 & F 1968 p.31 \\
\hline
\end{tabular}




\begin{tabular}{|c|c|c|c|c|c|c|c|c|c|c|c|c|}
\hline \multicolumn{6}{|c|}{ Dados do carimbo } & \multicolumn{4}{|c|}{ Sistematização } & \multicolumn{3}{|c|}{$\begin{array}{l}\text { Localizacãao dos Arquivos } \\
\text { Biblioteca FAU }\end{array}$} \\
\hline Data & Modificação & Autor & Folha & Título & Escala & Vol. & $\begin{array}{l}\text { Tipo } \\
\text { desenho }\end{array}$ & $\begin{array}{l}\text { Pav./ } \\
\text { Vista }\end{array}$ & obs. & $\begin{array}{l}\text { Cópias (PE } \\
\text { AR78/727.3) }\end{array}$ & $\begin{array}{l}\text { Originais }(P \\
A R 78 / 727.3)\end{array}$ & PDF (727.3) \\
\hline 14 / mai. / 1968 & $\cdots$ & FCCUASO & 7082 & $\begin{array}{l}\text { Sanitário e cozinha } \\
\text { zelador. Ampliaçăo. A-1 }\end{array}$ & $\begin{array}{l}1: 20, \\
1: 2,1: 1\end{array}$ & FAU-04PE-ARQ-DE0401.00_00 & $\begin{array}{l}\text { Planta, corte, } \\
\text { elevacăo, } \\
\text { detalhe, }\end{array}$ & $\cdots$ & -- & FA & -- & -- \\
\hline $20 /$ mai. / 1968 & $\cdots$ & FCCUASO & 7083 & Ampliação da copa. A-2 & 1:20 & FAU-04PE-ARQ-DE0402.00_00 & Planta, corte & --- & --- & FA & $-\cdots$ & --- \\
\hline--- & -- & FCCUASO & 7084 & $\begin{array}{l}\text { Ampliação do sanitário } \\
A-3\end{array}$ & 1:20 & FAU-04PE-ARQ-DE0403.00_00 & Planta & --- & --- & FA & --- & --- \\
\hline 05 / jun. / 1968 & $\cdots$ & FCCUASO & 7085 & $\begin{array}{l}\text { Ampliação dos } \\
\text { sanitários A-3. Elevação }\end{array}$ & 1:20 & FAU-04PE-ARQ-DE0403.01_00 & Elevação & --- & --- & FA & --- & --- \\
\hline 22 / mai. / 1968 & --- & FCCUASO & 7086 & $\begin{array}{l}\text { Ampliação do sanitário } \\
\text { A-4. Planta }\end{array}$ & 1:20 & FAU-04PE-ARQ-DE0404.00_00 & Planta & --- & --- & FA & --- & --- \\
\hline 24 / mai. / 1968 & $\cdots$ & FCCUASO & 7087 & $\begin{array}{l}\text { Ampliacão do sanitário } \\
\text { A-4. Elevaçōes }\end{array}$ & 1:20 & FAU-04PE-ARQ-DE0404.01_00 & Elevações & --- & --- & FA & --- & --- \\
\hline 24 / mai. / 1968 & $\cdots$ & FCCUASO & 7088 & $\begin{array}{l}\text { Ampliação do sanitário } \\
\text { A-4 Corte e detalhe } \\
\text { típico dos boxes } p / \\
\text { bacias }\end{array}$ & $1: 20,1: 2$ & FAU-04PE-ARQ-DE0404.02_00 & $\begin{array}{l}\text { Planta, corte, } \\
\text { detalhe, } \\
\text { perspectiva }\end{array}$ & --- & --- & FA & --- & --- \\
\hline 24 / mai. / 1968 & $\cdots$ & FCCUASO & 7089 & $\begin{array}{l}\text { Ampliação do sanitário } \\
\text { A-5 }\end{array}$ & 1:20 & FAU-04PE-ARQ-DE0405.00_00 & & --- & --- & FA & --- & -- \\
\hline 05 / jun. / 1968 & $\cdots$ & FCCUASO & 7090 & $\begin{array}{l}\text { Ampliação do sanitário } \\
A-5\end{array}$ & 1:20 & FAU-04PE-ARQ-DE0405.01_00 & Corte & --- & --- & FA & --- & -- \\
\hline 23 / mai. / 1968 & -- & FCCUASO & 7117 & $\begin{array}{l}\text { Ampliação do sanitário } \\
\text { A-6 }\end{array}$ & $1: 20$ & FAU-04PE-ARQ-DE0406.00_00 & Planta, corte & --- & --- & FA & --- & -- \\
\hline 11 / jun. / 1968 & --- & FCCUASO & 7118 & $\begin{array}{l}\text { Ampliação do sanitário } \\
\text { A-7. Plantas e cortes }\end{array}$ & 1:20 & FAU-04PE-ARQ-DE0407.00_00 & Planta; Corte & -- & --- & FA & -- & -- \\
\hline 16 / ago. / 1968 & --- & FCCUASO & 7316 & $\begin{array}{l}\text { Ampliação do sanitário } \\
\text { A-7. Plantas, cortes e } \\
\text { detallhes }\end{array}$ & $\begin{array}{l}1: 20, \\
1: 10,1: 2\end{array}$ & FAU-04PE-ARQ-DE0407.01_00 & & --- & --- & FA & -- & $\cdots$ \\
\hline 11 / jun. / 1968 & $\cdots$ & FCCUASO & 7119 & $\begin{array}{l}\text { Ampliaçäo da cozinha e } \\
\text { sanitários A-8. Nível } \\
+270 \text { Planta. }\end{array}$ & 1:20 & FAU-04PE-ARQ-DE0408.00_00 & Planta & -- & --- & FA & --- & --- \\
\hline 21 / jun. / 1968 & $\cdots$ & FCCUASO & 7120 & $\begin{array}{l}\text { Ampliacão da cozinha e } \\
\text { sanitários. A-8 Nivel } \\
+2.70 \text {. Cortes AA-BB- } \\
\text { CC }\end{array}$ & 1:20 & FAU-04PE-ARQ-DE0408.01_00 & Cortes & --- & --- & FA & --- & --- \\
\hline 16 / ago. / 1968 & --- & FCCUASO & 7368 & $\begin{array}{l}\text { Ampliação do bar A.9: } \\
\text { Planta }\end{array}$ & --- & FAU-04PE-ARQ-DE0409.00_00 & Planta & --- & --- & F 1968 & -- & -- \\
\hline 21 / ago. / 1968 & -- & FCCUASO & 7369 & $\begin{array}{l}\text { Ampliação do bar A.9: } \\
\text { Cortes }\end{array}$ & 1:20 & FAU-04PE-ARQ-DE0409.01_00 & Cortes & -- & -- & F 1968 & --- & --- \\
\hline 21 / ago. / 1968 & --- & FCCUASO & 7370 & $\begin{array}{l}\text { Ampliação do sanitário } \\
\text { A-9. Cortes e detalhes }\end{array}$ & $\begin{array}{l}\text { 1:20, } \\
1: 5,1: 2, \\
1: 1\end{array}$ & FAU-04PE-ARQ-DE0409.02_00 & --- & --- & --- & FA & -- & $\cdots$ \\
\hline 18 / jun. / 1968 & --- & FCCUASO & 7195 & $\begin{array}{l}\text { Ampliação do sanitário } \\
\text { A-10. Planta }\end{array}$ & 1:20 & FAU-04PE-ARQ-DE0410.00_00 & --- & --- & --- & FA & $-\cdots$ & --- \\
\hline 19 / jun. / 1968 & --- & FCCUASO & 7196 & $\begin{array}{l}\text { Ampliação do sanitário } \\
\text { A-10. Elevaçôes }\end{array}$ & 1:20 & FAU-04PE-ARQ-DE0410.01_00 & Elevação & --- & -- & FA & -- & -- \\
\hline
\end{tabular}




\begin{tabular}{|c|c|c|c|c|c|c|c|c|c|c|c|c|}
\hline \multicolumn{6}{|c|}{ Dados do carimbo } & \multicolumn{4}{|c|}{ Sistematização } & \multicolumn{3}{|c|}{$\begin{array}{l}\text { Localização dos Arquivos } \\
\text { Biblioteca FAU }\end{array}$} \\
\hline Data & Modificação & Autor & Folha & Título & Escala & Vol. & $\begin{array}{l}\text { Tipo } \\
\text { desenho }\end{array}$ & $\begin{array}{l}\text { Pav./ } \\
\text { Vista }\end{array}$ & Obs. & $\begin{array}{l}\text { Cópias (PE } \\
\text { AR78/727.3) }\end{array}$ & $\begin{array}{l}\text { Originais }(P \\
\text { AR78/727.3) }\end{array}$ & PDF (727.3) \\
\hline 24 / jun. / 1968 & $\cdots$ & FCCUASO & 7197 & $\begin{array}{l}\text { Ampliacãa do sanitário } \\
\text { A-10. Elevaçōes e corte }\end{array}$ & 1:50, $1: 5$ & FAU-04PE-ARQ-DE0410.02_00 & -- & -- & --- & FA & -- & --- \\
\hline 26 / jun. / 1968 & --- & FCCUASO & 7198 & $\begin{array}{l}\text { Ampliacão do sanitário } \\
\text { A-11. Planta, corte e } \\
\text { elevaçōoes }\end{array}$ & $1: 20$ & FAU-04PE-ARQ-DE0411.00_00 & $\begin{array}{l}\text { Planta; Corte; } \\
\text { Elevaçâo }\end{array}$ & --- & --- & FA & --- & --- \\
\hline 27 / jun. / 1968 & --- & FCCUASO & 7199 & $\begin{array}{l}\text { Ampliacãao do sanitário } \\
\text { A-12. Planta, corte e } \\
\text { elevaçâo }\end{array}$ & $1: 20$ & FAU-04PE-ARQ-DE0412.00_00 & $\begin{array}{l}\text { Planta; Corte; } \\
\text { Elevaçâo }\end{array}$ & --- & --- & FA & --- & --- \\
\hline 01 / jul. / 1968 & --- & FCCUASO & 7200 & $\begin{array}{l}\text { Ampliação do sanitário } \\
\text { A-13. Planta e detalhes }\end{array}$ & $\begin{array}{l}1: 5,1: 2, \\
1: 1\end{array}$ & FAU-04PE-ARQ-DE0413.00_00 & $\begin{array}{l}\text { Planta; Corte; } \\
\text { Elevaçầo }\end{array}$ & --- & --- & FA & --- & --- \\
\hline 04 / jul. / 1968 & --- & FCCUASO & 7201 & $\begin{array}{l}\text { Ampliação A-13. } \\
\text { Elevaçôes }\end{array}$ & $1: 20$ & FAU-04PE-ARQ-DE0413.01_00 & Elevação & -- & --- & FA & --- & --- \\
\hline 04 / jul. / 1968 & --- & FCCUASO & 7202 & $\begin{array}{l}\text { Ampliação do sanitário } \\
\text { A-13. Corte e detallhes. }\end{array}$ & $\begin{array}{l}1: 20 \\
1: 2,1: 1\end{array}$ & FAU-04PE-ARQ-DE0413.02_00 & Corte; detalhe & --- & --- & FA & --- & --- \\
\hline 05 / jul. / 1968 & --- & FCCUASO & 7203 & $\begin{array}{l}\text { Ampliacãao do sanitário } \\
\text { A-14. Planta }\end{array}$ & $1: 20$ & FAU-04PE-ARQ-DE0414.00_00 & Planta & --- & $\cdots$ & FA & -- & --- \\
\hline 05 / jul. / 1968 & --- & FCCUASO & 7204 & $\begin{array}{l}\text { Ampliação do sanitário } \\
\text { A-14. Elevaç̧oes }\end{array}$ & $1: 20$ & FAU-04PE-ARQ-DE0414.01_00 & Elevação & --- & --- & FA & --- & --- \\
\hline 09 / jul. / 1968 & --- & FCCUASO & 7205 & $\begin{array}{l}\text { Ampliacãão do sanitário } \\
\text { A-14. Elevaçăão e corte }\end{array}$ & $1: 20$ & FAU-04PE-ARQ-DE0414.02_00 & $\begin{array}{l}\text { Elevação; } \\
\text { Corte }\end{array}$ & --- & --- & FA & --- & --- \\
\hline 19 / jul. / 1968 & --- & FCCUASO & 7286 & $\begin{array}{l}\text { Ampliacāoo do sanitário } \\
\text { A-15. Planta }\end{array}$ & $1: 20$ & FAU-04PE-ARQ-DE0415.00_00 & Planta & -- & --- & FA & --- & --- \\
\hline 23 / jul. / 1968 & --- & FCCUASO & 7287 & $\begin{array}{l}\text { Ampliacăoo do sanitárá } \\
\text { A-15. Elevaçăão }\end{array}$ & $1: 20$ & FAU-04PE-ARQ-DE0415.01_00 & Elevação & --- & --- & FA & --- & --- \\
\hline 25 / jul. / 1968 & --- & FCCUASO & 7289 & $\begin{array}{l}\text { Ampliação do sanitário } \\
\text { A-15. Elevaçăâo }\end{array}$ & 1:20 & FAU-04PE-ARQ-DE0415.02_00 & Elevação & --- & --- & FA & --- & --- \\
\hline 24 / jul. / 1968 & --- & FCCUASO & 7288 & $\begin{array}{l}\text { Ampliação do sanitário } \\
\text { A-15. Corte }\end{array}$ & 1:20 & FAU-04PE-ARQ-DE0415.03_00 & Corte & --- & --- & FA & --- & --- \\
\hline 26 / jul. / 1968 & --- & FCCUASO & 7290 & $\begin{array}{l}\text { Ampliacãao do sanitário } \\
\text { A-16. Planta }\end{array}$ & 1:20 & FAU-04PE-ARQ-DE0416.00_00 & Planta & $\cdots$ & --- & FA & --- & --- \\
\hline 29 / jul. / 1968 & $\cdots$ & FCCUASO & 7291 & $\begin{array}{l}\text { Ampliação do sanitário } \\
\text { A-16. Corte }\end{array}$ & $1: 20$ & FAU-04PE-ARQ-DE0416.01_00 & Corte & -- & $\cdots$ & FA & --- & --- \\
\hline 29 / jul. / 1968 & -- & FCCUASO & 7292 & $\begin{array}{l}\text { Ampliacãoo do sanitário } \\
\text { A-1. Planta e } \\
\text { elevaçôes }\end{array}$ & $1: 20$ & FAU-04PE-ARQ-DE0417.00_00 & $\begin{array}{l}\text { Planta, } \\
\text { elevação }\end{array}$ & --- & --- & FA & --- & --- \\
\hline 02 / ago. / 1968 & --- & FCCUASO & 7311 & $\begin{array}{l}\text { Anfiteatro no nível } \\
\text { +1035. Planta e cortes } \\
\text { "A18" }\end{array}$ & 1:50 & FAU-04PE-ARQ-DE0418.00_00 & Planta, corte & --- & --- & FAF & --- & --- \\
\hline $01 /$ jun. / 1968 & --- & FCCUASO & 7080 & Auditório. Planta & 1:50 & FAU-04PE-ARQ-DE0419.00_00 & Planta & -1 & --- & F 1968 & F $1968 \mathrm{v} .3$ & F 1968 p.25 \\
\hline 05 / jun. / 1968 & --- & FCCUASO & 7081 & Auditório. Cortes & 1:50 & FAU-04PE-ARQ-DE0419.01_00 & Corte & $\begin{array}{l}\text { Longitudi- } \\
\text { nal e } \\
\text { transversal }\end{array}$ & $\ldots$ & F 1968 & F $1968 \mathrm{v} .3$ & F 1968 p.26 \\
\hline 07 / mai. / 1968 & --- & FCCUASO & 7012 & $\begin{array}{l}\text { Elevador: planta e } \\
\text { cortes }\end{array}$ & 1:50 & FAU-04PE-ARQ-DE0420.00_00 & Planta, corte & -- & Bloco da escada e elevador & F 1968 & --- & --- \\
\hline
\end{tabular}




\begin{tabular}{|c|c|c|c|c|c|c|c|c|c|c|c|c|}
\hline \multicolumn{6}{|c|}{ Dados do carimbo } & \multicolumn{4}{|c|}{ Sistematização } & \multicolumn{3}{|c|}{$\begin{array}{l}\text { Localizacão dos Arquivos } \\
\text { Biblioteca FAU }\end{array}$} \\
\hline Data & Modificação & Autor & Folha & Título & Escala & Vol. & $\begin{array}{l}\text { Tipo } \\
\text { desenho }\end{array}$ & $\begin{array}{l}\text { Pav./ } \\
\text { Vista }\end{array}$ & Obs. & $\begin{array}{l}\text { Cópias (PE } \\
\text { AR78/727.3) }\end{array}$ & $\begin{array}{l}\text { Originais }(P \\
\text { AR78/727.3) }\end{array}$ & PDF (727.3) \\
\hline $10 /$ abr. / 1968 & --- & FCCUASO & llegivel & $\begin{array}{l}\text { Planta dos pisos: Planta } \\
\text { nos niveisis-300... } \\
\text { (rasgado) }\end{array}$ & 1:100 & FAU-04PE-ARQ-DE0501.00_00 & Planta & -1 & --- & --- & --- & -- \\
\hline 15/ abr. / 1968 & $\cdots$ & FCCUASO & 6984 & $\begin{array}{l}\text { Piso de borracha } \\
\text { vulcanizada e mosaico } \\
\text { português }\end{array}$ & $\begin{array}{l}1: 20,1: 1 \\
0\end{array}$ & FAU-04PE-ARQ-DE0501.01_00 & $\cdots$ & $\cdots$ & --- & FP & $\cdots$ & --- \\
\hline 09/ abr. / 1968 & -- & FCCUASO & 6996 & $\begin{array}{l}\text { Planta dos pisos: Planta } \\
\text { nos níveis }+80,+270\end{array}$ & 1:100 & FAU-04PE-ARQ-DE0502.00_00 & Planta & 0 & $\begin{array}{l}\text { Acabamento do piso seria de borracha } \\
50 \times 50 \text { lisa }\end{array}$ & FP & --- & --- \\
\hline 10/abr. / 1968 & --- & FCCUASO & 6997 & $\begin{array}{l}\text { Planta dos pisos: Planta } \\
\text { nos niveis }+460,+650\end{array}$ & 1:100 & FAU-04PE-ARQ-DE0503.00_00 & Planta & 1 & $\ldots$ & FP & --- & --- \\
\hline 11/abr./ 1968 & --- & FCCUASO & ilegivel & $\begin{array}{l}\text { Planta dos pisos: Planta } \\
\text { nos niveis }+840,+1030\end{array}$ & 1:100 & FAU-04PE-ARQ-DE0504.00_00 & Planta & 2 & --- & --- & --- & --- \\
\hline 31/ mai. / 1968 & $18 /$ nov. / 1968 & FCCUASO & 7020 & $\begin{array}{l}\text { Planta nos níveis -300, - } \\
110\end{array}$ & 1:100 & FAU-04PE-ARQ-DE0710.01_00 & Planta & -1 & $\begin{array}{l}\text { Modificado 18/11/68. Localização dos } \\
\text { painéis divisórios }\end{array}$ & F 1968 & F $1968 \mathrm{v} .2$ & F 1968 p.22 \\
\hline $31 /$ mai. / 1968 & -- & FCCUASO & -- & $\begin{array}{l}\text { Painéis divisórios. } \\
\text { Localização }\end{array}$ & $\cdots$ & FAU-04PE-ARQ-DE0710.02_00 & Planta & 0 & $\begin{array}{l}\text { Planta rasgada. Não da pra ler o numero } \\
\text { da folha nem o titulo. Planta do caramelo } \\
\text { com a diretoria u o gremmio nas suas } \\
\text { posiçoes atuais }\end{array}$ & FP & -- & --- \\
\hline $31 /$ mai. / 1968 & $\cdots$ & FCCUASO & 7021 & $\begin{array}{l}\text { Painéis divisórís: } \\
\text { localizacão. Planta nos } \\
\text { niviseis }+460,650\end{array}$ & 1:100 & FAU-04PE-ARQ-DE0710.03_00 & Planta & 1 & - & FP & $-\cdots$ & --- \\
\hline 12 / jul. / 1968 & --- & FCCUASO & 7266 & $\begin{array}{l}\text { Painéis localização. } \\
\text { Planta dos níveis }+460, \\
+650\end{array}$ & 1:100 & FAU-04PE-ARQ-DE0710.03_01 & Planta & 1 & 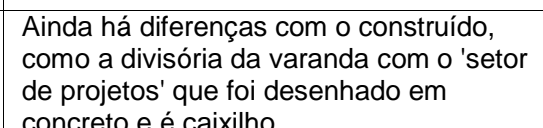 & FP & -- & --- \\
\hline 12 / jul. / 1968 & -- & FCCUASO & 7267 & $\begin{array}{l}\text { Painéis localização. } \\
\text { Planta nos niveis }+840, \\
+1030\end{array}$ & 1:100 & FAU-04PE-ARQ-DE0710.04_00 & Planta & 2 & ---100 & FP & --- & --- \\
\hline $31 /$ mai. / 1968 & --- & FCCUASO & 7025 & $\begin{array}{l}\text { Painéis divisórios. } \\
\text { Detallhes - elevaçôes }\end{array}$ & 1:50 & FAU-04PE-ARQ-DE0711.00_00 & Elevação & --- & --- & FP & --- & --- \\
\hline $31 /$ mai. / 1968 & --- & FCCUASO & 7023 & $\begin{array}{l}\text { Painéis divisórios. } \\
\text { Detalhes }\end{array}$ & $1: 1,1: 2$ & FAU-04PE-ARQ-DE0712.00_00 & Detalhes & --- & $\begin{array}{l}\text { Substituído pelo desenho } 7024 \text { e pelo } \\
7268\end{array}$ & FP & F $1968 \mathrm{v} \cdot 3$ & F 1968 p.23 \\
\hline $31 /$ mai. / 1968 & --- & FCCUASO & 7024 & $\begin{array}{l}\text { Painéis divisiórios. } \\
\text { Detalhes }\end{array}$ & $1: 1$ & FAU-04PE-ARQ-DE0713.00_00 & Detalhes & --- & Substituído pelo desenho 7515 & FP & --- & -- \\
\hline 15 / jul. / 1968 & --- & FCCUASO & 7268 & $\begin{array}{l}\text { Painéis divisórios. } \\
\text { Detalhes }\end{array}$ & $1: 1,1: 2$ & FAU-04PE-ARQ-DE0714.00_00 & Detalhes & --- & Substituído pelo desenho 7024 & FP & --- & --- \\
\hline-- & --- & FCCUASO & 7515 & $\begin{array}{l}\text { Painéis divisórios. } \\
\text { Detalhes para execução }\end{array}$ & $1: 1$ & FAU-04PE-ARQ-DE0715.00_00 & Detalhes & --- & Substitui os desenhos 7024 e 7268 & FP & --- & --- \\
\hline 05 / abr. / 1968 & -- & FCCUASO & ilegivel & $\begin{array}{l}\text { Planta de localizacăo } \\
\text { dos caixilhos. Planta nos } \\
\text { niveis }-300,-110\end{array}$ & 1:100 & FAU-04PE-ARQ-DE0720.01_00 & Planta & -1 & --- & --- & -- & --- \\
\hline 08/abr. / 1968 & --- & FCCUASO & 6991 & $\begin{array}{l}\text { Planta de localizacacão } \\
\text { dos caixihos. Planta nos } \\
\text { níveis }+80,+270\end{array}$ & 1:100 & FAU-04PE-ARQ-DE0720.02_00 & Planta & 0 & --- & FP & --- & --- \\
\hline 09 / abr. / 1968 & --- & FCCUASO & 6992 & $\begin{array}{l}\text { Planta de localizacăa } \\
\text { dos caixihos. Planta nos } \\
\text { níveis }+460,+650\end{array}$ & 1:100 & FAU-04PE-ARQ-DE0720.03_00 & Planta & 1 & --- & FP & --- & -- \\
\hline 16/abr. / 1968 & --- & FCCUASO & 6994 & $\begin{array}{l}\text { Detalhes das esquadrias } \\
\text { de ferro }\end{array}$ & $\begin{array}{l}1: 50, \\
1: 5,1: 2\end{array}$ & FAU-04PE-ARQ-DE0721.00_00 & --- & --- & --- & FP & --- & --- \\
\hline 30 / jul. / 1968 & 10/ ago. / 1968 & FCCUASO & 7293 & $\begin{array}{l}\text { Esquadrias de madeira. } \\
\text { Relação e detalhe das } \\
\text { portas }\end{array}$ & $1: 20,1: 1$ & FAU-04PE-ARQ-DE0731.00_00 & $\begin{array}{l}\text { Elevação, } \\
\text { detalhe }\end{array}$ & --- & $\begin{array}{l}\text { Desenho modificado em 19/8/1968. } \\
\text { Substituído pelo desenho } 7316\end{array}$ & FP & --- & -- \\
\hline
\end{tabular}




\begin{tabular}{|c|c|c|c|c|c|c|c|c|c|c|c|c|}
\hline \multicolumn{6}{|c|}{ Dados do carimbo } & \multicolumn{4}{|c|}{ Sistematização } & \multicolumn{3}{|c|}{$\begin{array}{l}\text { Localização dos Arquivos } \\
\text { Biblioteca FAU }\end{array}$} \\
\hline Data & Modificação & Autor & Folha & Titulo & Escala & Vol. & $\begin{array}{l}\text { Tipo } \\
\text { desenho }\end{array}$ & $\begin{array}{l}\text { Pav./ } \\
\text { Vista }\end{array}$ & Obs. & $\begin{array}{l}\text { Cópias (PE } \\
\text { AR78/727.3) }\end{array}$ & $\begin{array}{l}\text { Originais }(P \\
\text { AR78/727.3) }\end{array}$ & PDF (727.3) \\
\hline 09 / ago. / 1968 & --- & FCCUASO & 7314 & $\begin{array}{l}\text { Anfiteatro Nivel + } 1030 . \\
\text { Detalhe para as portas }\end{array}$ & $1: 10,1: 1$ & FAU-04PE-ARQ-DE0732.00_00 & --- & --- & $\begin{array}{l}\text { Porta já era azul. Teria pivô no centro e } \\
\text { iria atéa a cobertura (sem bandeira) }\end{array}$ & FAF & --- & --- \\
\hline 12 / ago. / 1968 & --- & FCCUASO & 7315 & $\begin{array}{l}\text { Detalhes do batente } \\
\text { para a porta do elevador }\end{array}$ & 1:20, 1:2 & FAU-04PE-ARQ-DE0733.00_00 & --- & --- & --- & FP & --- & --- \\
\hline $21 /$ nov. / 1968 & --- & FCCUASO & 7646 & $\begin{array}{l}\text { Relaçăo de folhas de } \\
\text { portas }\end{array}$ & --- & FAU-04PE-ARQ-DE0734.00_00 & --- & --- & São 9 medidas de portas & FP & --- & --- \\
\hline--- & --- & Vilanova Artigas & --- & --- & --- & FAU-04PE-ARQ-DE0735.00_X & & Detalhe & Carimbo em branco & FAUR & Fv.3 & F p.26 \\
\hline 09 / abr. / 1968 & $\cdots$ & FCCUASO & 6993 & $\begin{array}{l}\text { Planta de localização } \\
\text { dos guarda corpos: } \\
\text { planta nos níveis }+840, \\
+1030\end{array}$ & 1:100 & FAU-04PE-ARQ-DE0740.03_00 & Planta & 3 & $\ldots$ & F 1968 & --- & --- \\
\hline 18 / set. / 1968 & -- & FCCUASO & 7407 & $\begin{array}{l}\text { Mobiliário. Planta dos } \\
\text { níveis }+80,+270\end{array}$ & $1: 100$ & FAU-04PE-ARQ-DE0750.02_00 & Planta & 0 & --- & $-\cdots$ & --- & --- \\
\hline 18 / set. / 1968 & -- & FCCUASO & 7408 & $\begin{array}{l}\text { Mobiliário. Planta dos } \\
\text { niveis }+460,+650\end{array}$ & 1:100 & FAU-04PE-ARQ-DE0750.03_00 & Planta & 1 & Layout da biblioteca & --- & --- & --- \\
\hline ilegivel & -- & FCCUASO & 7409 & $\begin{array}{l}\text { Mobiliário. Planta dos } \\
\text { níveis }+840,+1030\end{array}$ & $1: 100$ & FAU-04PE-ARQ-DE0750.04_00 & Planta & 2 & $\ldots$ & $-\cdots$ & --- & --- \\
\hline 21 / jun. / 1968 & --- & FCCUASO & 7122 & $\begin{array}{l}\text { Detalhe típico dos } \\
\text { armários sob pia }\end{array}$ & $1: 5,1: 1$ & FAU-04PE-ARQ-DE0751.00_00 & --- & --- & --- & FA & --- & --- \\
\hline 26 / jul. / 1968 & --- & FCCUASO & 7284 & $\begin{array}{l}\text { Esquadrias de madeira. } \\
\text { Detalhes dos armários } \\
\text { sob as pias }\end{array}$ & $1: 20$ & FAU-04PE-ARQ-DE0752.00_00 & --- & --- & --- & FP & --- & --- \\
\hline 06 / ago. / 1968 & --- & FCCUASO & 7312 & $\begin{array}{l}\text { Mesa do anfiteatro Nível } \\
+1030\end{array}$ & 1:10,1:2 & FAU-04PE-ARQ-DE0753.00_00 & --- & --- & --- & FAF & --- & --- \\
\hline 07 / ago. / 1968 & --- & FCCUASO & 7313 & $\begin{array}{l}\text { Anfiteatro Nivel }+1030 \text {. } \\
\text { Quadro negro - detalhes }\end{array}$ & indicada & FAU-04PE-ARQ-DE0754.00_00 & --- & --- & --- & FAF & --- & --- \\
\hline 24 / jul. / 1968 & --- & FCCUASO & 7283 & $\begin{array}{l}\text { Detalhes. Canopla e } \\
\text { receptáculo }\end{array}$ & 1:1 & FAU-04PE-ARQ-DE0761.00_00 & Detalhes & & & FA & --- & --- \\
\hline 01 / ago. / 1968 & --- & FCCUASO & 7306 & $\begin{array}{l}\text { Esquadrias de madeira. } \\
\text { Paineise f fixos e portas } \\
\text { dos boxes nos sanitários }\end{array}$ & $\begin{array}{l}1: 20, \\
1: 2,1: 1\end{array}$ & FAU-04PE-ARQ-DE0762.00_00 & --- & --- & --- & FA & --- & --- \\
\hline 08 / ago. / 1968 & --- & FCCUASO & 7307 & $\begin{array}{l}\text { Esquadrias de madeira. } \\
\text { (complemento.) Painéis } \\
\text { fixos e portas dos boxes } \\
\text { nos sanitários }\end{array}$ & $\begin{array}{l}1: 20, \\
1: 2,1: 1\end{array}$ & FAU-04PE-ARQ-DE0763.00_00 & --- & --- & $-\cdots-$ & FA & -- & --- \\
\hline 21 / ago. / 1968 & --- & FCCUASO & 7115 & $\begin{array}{l}\text { Cobertura: detalhes } \\
\text { "Domus" }\end{array}$ & 1:1,1:10 & FAU-04PE-ARQ-DE0771.00_00 & Detalhes & --- & --- & F 1968 & --- & -- \\
\hline--- & --- & Vilanova Artigas & --- & --- & $1: 5$ & FAU-04PE-ARQ-DE0771.01_X & --- & Detalhe & Carimbo em branco (de ponta cabeça) & FAUR & Fv.3 & F p.23 \\
\hline--- & --- & Vilanova Artigas & --- & --- & 1:1 & FAU-04PE-ARQ-DE0771.02_X & --- & Detalhe & Carimbo em branco & FAUR & Fv.3 & F p.25 \\
\hline 22 / ago. / 1968 & --- & FCCUASO & 7304 & Luminária tipo & 1:1 & FAU-04PE-ARQ-DE0781.00_00 & --- & --- & $\begin{array}{l}\text { Desenho de luminíria para lâmpada } \\
\text { fluoresserte.e Notar: naó havia luminárias } \\
\text { no mercado. O desenho é banal. }\end{array}$ & FA e. 1 & --- & --- \\
\hline 21 / jun. / 1968 & --- & FCCUASO & 7121 & $\begin{array}{l}\text { Detalhes do forro do } \\
\text { sanitárin anexo à cozinha - } \\
\text { A8 - nivel +270. Planta, } \\
\text { cortes e etetalhes }\end{array}$ & 1:10,1:2 & FAU-04PE-ARQ-DE0791.00_00 & $\begin{array}{l}\text { Planta, corte, } \\
\text { detalhe }\end{array}$ & --- & --- & FP & --- & --- \\
\hline
\end{tabular}




\begin{tabular}{|c|c|c|c|c|c|c|c|c|c|c|c|c|}
\hline \multicolumn{6}{|c|}{ Dados do carimbo } & \multicolumn{4}{|c|}{ Sistematização } & \multicolumn{3}{|c|}{$\begin{array}{l}\text { Localização dos Arquivos } \\
\text { Biblioteca FAU }\end{array}$} \\
\hline Data & Modificação & Autor & Folha & Titulo & Escala & Vol. & $\begin{array}{l}\text { Tipo } \\
\text { desenho }\end{array}$ & $\begin{array}{l}\text { Pav./ } \\
\text { Vista }\end{array}$ & Obs. & $\begin{array}{l}\text { Cópias (PE } \\
\text { AR78/727.3) }\end{array}$ & $\begin{array}{l}\text { Originais (P } \\
\text { AR78/727.3) }\end{array}$ & PDF (727.3) \\
\hline $28 /$ jan. / 1968 & --- & --- & 7745 & $\begin{array}{l}\text { Detalhes do peitoril e da } \\
\text { escada p/casa das } \\
\text { máquinas }\end{array}$ & $1: 5,1: 50$ & FAU-04PE-ARQ-DE0792.00_00 & --- & $\cdots$ & --- & F 1968 & $\cdots$ & --- \\
\hline--- & --- & Ryval Esquadrias & --- & Caixilho tipo F5, F6, F10 & $1: 10,1: 1$ & FAU-04PE-CXO-DE0401.00_00 & --- & Detalhes & $\cdots$ & --- & F 1968 v.2 & F 1968 p.21 \\
\hline 19/ago. / 1968 & --- & $\begin{array}{l}\text { Eng. Homero V. M. } \\
\text { Lopes (CREA 4333) }\end{array}$ & 5 & $\begin{array}{l}\text { Planta do piso so } \\
\text { subsolo Niveis -300, - } \\
110\end{array}$ & 1:100 & FAU-04PE-ELE-DE0501.00_00 & Planta & -1 & Com base em desenho do Fundo X0037 & $\begin{array}{l}\text { F } 1968 / \text { FA } \\
\text { e.1 }\end{array}$ & F $1968 \mathrm{v} .1$ & F 1968 p.4 \\
\hline 02 / out. / 1968 & --- & FCCUASO & EP-3-702 & $\begin{array}{l}\text { Planta nos niveis -300,- } \\
1110 \text {. Modid. Do piso das } \\
\text { oficinas sanaletas }\end{array}$ & 1:100 & FAU-04PE-ELE-DE0501.00_x & Planta & -1 & $\cdots$ & FA e.1 & $-\cdots-$ & --- \\
\hline 19/ ago. / 1968 & --- & $\begin{array}{l}\text { Eng. Homero V. M. } \\
\text { Lopes (CREA 4333) }\end{array}$ & 6 & $\begin{array}{l}\text { Planta do piso do térreo } \\
\text { Níveis }+80,+270\end{array}$ & 1:100 & FAU-04PE-ELE-DE0502.00_00 & Planta & 0 & Com base em desenho do Fundo X0038 & $\begin{array}{l}\text { F 1968/FA } \\
\text { e.1 }\end{array}$ & F 1968 v.1 & F 1968 p.5 \\
\hline 19/ ago. / 1968 & --- & $\begin{array}{l}\text { Eng. Homero V. M. } \\
\text { Lopes (CREA 4333) }\end{array}$ & 7 & $\begin{array}{l}\text { Planta do piso do } 1^{\circ} \text { pav } \\
\text { Niveis }+460,+650\end{array}$ & 1:100 & FAU-04PE-ELE-DE0503.00_00 & Planta & 1 & Com base em desenho do Fundo X0039 & $\begin{array}{l}\text { F } 1968 / \text { FA } \\
\text { e. } 1\end{array}$ & F $1968 \mathrm{v} .1$ & F 1968 p.6 \\
\hline $05 /$ ago. / 1968 & $\cdots$ & FCCUASO & EP-3-684 & $\begin{array}{l}\text { Planta dos níveis 460, } \\
650 \text {. Modificacão das } \\
\text { instalaçôes elétricas do } \\
\text { piso }\end{array}$ & $s / e$ & FAU-04PE-ELE-DE0503.00_x & Planta & 1 & $\cdots$ & FA e.1 & --- & --- \\
\hline $19 /$ ago. / 1968 & --- & $\begin{array}{l}\text { Eng. Homero V. M. } \\
\text { Lopes (CREA 4333) }\end{array}$ & 8 & $\begin{array}{l}\text { Planta do piso do } 2^{\circ} \text { pav } \\
\text { Niveis }+840,+1030\end{array}$ & 1:100 & FAU-04PE-ELE-DE0504.00_00 & Planta & 2 & Com base em desenho do Fundo X0040 & $\begin{array}{l}\text { F } 1968 / \text { FA } \\
\text { e.1 }\end{array}$ & F $1968 \mathrm{v} .1$ & F 1968 p.7 \\
\hline 12 / ago. / 1968 & --- & FCCUASO & EP-3-686 & $\begin{array}{l}\text { Planta dos níveis } 840, \\
1030 . \text { modificacão das } \\
\text { instalaçōes elétricas do } \\
\text { piso }\end{array}$ & 1:100 & FAU-04PE-ELE-DE0504.00_x & Planta & 2 & $\cdots$ & FA e.1 & $\cdots$ & --- \\
\hline ilegível & --- & $\begin{array}{l}\text { Eng. Homero V. M. } \\
\text { Lopes (CREA 4333) }\end{array}$ & 1 & $\begin{array}{l}\text { Planta do teto do } \\
\text { subsolo Níveis - }-3.00,- \\
1.10\end{array}$ & 1:100 & FAU-04PE-ELE-DE0601.00_00 & Planta & -1 & $\begin{array}{l}\text { Com base em desenhos da FCCUASO } \\
\text { sem numeração }\end{array}$ & $\begin{array}{l}\text { F } 1968 / F A \\
\text { e.1 }\end{array}$ & F $1968 \mathrm{v} .1$ & F 1968 p.1 \\
\hline $19 /$ ago. / 1968 & $-\cdots$ & $\begin{array}{l}\text { Eng. Homero V. M. } \\
\text { Lopes (CREA 4333) }\end{array}$ & 2 & $\begin{array}{l}\text { Planta do teto do térreo } \\
\text { Niveis }+80,+270\end{array}$ & 1:100 & FAU-04PE-ELE-DE0602.00_00 & Planta & 0 & $\begin{array}{l}\text { Com base em desenhos da FCCUASO } \\
\text { sem numeraçăo }\end{array}$ & $\begin{array}{l}\text { F 1968/FA } \\
\text { e.1 }\end{array}$ & F 1968 v.1 & F 1968 p.2 \\
\hline 19 / ago. / 1968 & --- & $\begin{array}{l}\text { Eng. Homero V. M. } \\
\text { Lopes (CREA 4333) }\end{array}$ & 3 & $\begin{array}{l}\text { Planta do teto do } 1^{\circ} \mathrm{pav} \\
\text { Niveis }+460,+650\end{array}$ & 1:100 & FAU-04PE-ELE-DE0603.00_00 & Planta & 1 & $\begin{array}{l}\text { Com base em desenhos da FCCUASO } \\
\text { sem numeraçăo }\end{array}$ & $\begin{array}{l}\text { F } 1968 / F A \\
\text { e. } 1\end{array}$ & F $1968 \mathrm{v} .1$ & F 1968 p.3 \\
\hline 02 / ago. / 1968 & $\cdots$ & FCCUASO & EP-3-683 & $\begin{array}{l}\text { Planta dos níveis 460, } \\
650 \text {. Modificacãá das } \\
\text { instalaçôes elétricas do } \\
\text { forro }\end{array}$ & 1:100 & FAU-04PE-ELE-DE0603.00_x & Planta & 1 & $\cdots$ & FA e.1 & --- & --- \\
\hline--- & --- & $\begin{array}{l}\text { Eng. Homero V. M. } \\
\text { Lopes (CREA 4333) }\end{array}$ & 4 & $\begin{array}{l}\text { Planta do teto do } 2^{\circ} \text { pav } \\
\text { Niveis }+840,+1030\end{array}$ & & FAU-04PE-ELE-DE0604.00_00 & Planta & 2 & --- & --- & --- & --- \\
\hline 12 / ago. / 1968 & $\cdots$ & FCCUASO & EP-3-685 & $\begin{array}{l}\text { Planta dos níveis } 840, \\
1030 . \text { modificacãoo das } \\
\text { instalaçōes elétricas do } \\
\text { forro }\end{array}$ & 1:100 & FAU-04PE-ELE-DE0604.00_x & Planta & 2 & --- & FA e.1 & --- & --- \\
\hline 19/ago. / 1968 & --- & $\begin{array}{l}\text { Eng. Homero V. M. } \\
\text { Lopes (CREA 4333) }\end{array}$ & 9 & $\begin{array}{l}\text { Esquema de } \\
\text { alimentacáa dos } \\
\text { quadros de luz e força }\end{array}$ & $\mathrm{s} / \mathrm{e}$ & FAU-04PE-ELE-DE0701.00_00 & --- & $\cdots$ & -- & $\begin{array}{l}\text { F 1968/FA } \\
\text { e.1 }\end{array}$ & F $1968 v .1$ & F 1968 p.8 \\
\hline 19/ago. / 1968 & --- & $\begin{array}{l}\text { Eng. Homero V. M. } \\
\text { Lopes (CREA 4333) }\end{array}$ & 10 & $\begin{array}{l}\text { Diagrama unifilar dos } \\
\text { quadros e tabelas }\end{array}$ & $\mathrm{s} / \mathrm{e}$ & FAU-04PE-ELE-DE0702.00_00 & --- & --- & -- & $\begin{array}{l}\text { F } 1968 / F A \\
\text { e.1 }\end{array}$ & F $1968 \mathrm{v} .1$ & F 1968 p.9 \\
\hline 19/ago. / 1968 & --- & $\begin{array}{l}\text { Eng. Homero V. M. } \\
\text { Lopes (CREA 4333) }\end{array}$ & 11 & $\begin{array}{l}\text { Diagrama unifilar dos } \\
\text { quadros e tabelas }\end{array}$ & s/e & FAU-04PE-ELE-DE0703.00_00 & $\cdots$ & --- & --- & $\begin{array}{l}\text { F1968/FA } \\
\text { e.1 }\end{array}$ & F $1968 \mathrm{v} .1$ & F 1968 p.10 \\
\hline 19/ago. / 1968 & --- & $\begin{array}{l}\text { Eng. Homero V. M. } \\
\text { Lopes (CREA 4333) }\end{array}$ & 12 & $\begin{array}{l}\text { Diagrama unifiliar dos } \\
\text { quadros e tabelas }\end{array}$ & $\mathrm{s} / \mathrm{e}$ & FAU-04PE-ELE-DE0704.00_00 & 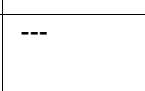 & --- & --- & $\begin{array}{l}\text { F } 1968 / \text { FA } \\
\text { e.1 }\end{array}$ & F $1968 v .1$ & F 1968 p.11 \\
\hline
\end{tabular}




\begin{tabular}{|c|c|c|c|c|c|c|c|c|c|c|c|c|}
\hline \multicolumn{6}{|c|}{ Dados do carimbo } & \multicolumn{4}{|c|}{ Sistematização } & \multicolumn{3}{|c|}{$\begin{array}{l}\text { Localizacão dos Arquivos } \\
\text { Biblioteca FAU }\end{array}$} \\
\hline Data & Modificação & Autor & Folha & Titulo & Escala & Vol. & $\begin{array}{l}\text { Tipo } \\
\text { desenho }\end{array}$ & $\begin{array}{l}\text { Pav./ } \\
\text { Vista }\end{array}$ & Obs. & $\begin{array}{l}\text { Cópias (PE } \\
\text { AR787727.3) }\end{array}$ & $\begin{array}{l}\text { Originais }(P \\
\text { AR787727.3) }\end{array}$ & PDF (727.3) \\
\hline 19/ago. / 1968 & --- & $\begin{array}{l}\text { Eng. Homero V.M. } \\
\text { Lopes (CREA 4333) }\end{array}$ & 13 & $\begin{array}{l}\text { Diagrama unifilar dos } \\
\text { quadros e tabelas }\end{array}$ & $\mathrm{s} / \mathrm{e}$ & FAU-04PE-ELE-DE0705.00_00 & --- & -- & --- & $\begin{array}{l}\text { F 1968 / FA } \\
\text { e.1 }\end{array}$ & F 1968 v.1 & F 1968 p.11 \\
\hline 19/ ago. / 1968 & --- & $\begin{array}{l}\text { Eng. Homero V.M. } \\
\text { Lopes (CREA 4333) }\end{array}$ & 14 & $\begin{array}{l}\text { Prumada dos Alim. dos } \\
\text { quadros de telefone }\end{array}$ & $\mathrm{s} / \mathrm{e}$ & FAU-04PE-ELE-DE0706.00_00 & --- & $-\cdots$ & Com base em desenho do Fundo X0027 & $\begin{array}{l}\text { F } 1968 / F A \\
\text { e. } 1\end{array}$ & F $1968 \mathrm{v} .2$ & F 1968 p.13 \\
\hline 19/ ago. / 1968 & --- & $\begin{array}{l}\text { Eng. Homero V.M. } \\
\text { Lopes (CREA 4333) }\end{array}$ & 15 & $\begin{array}{l}\text { Detalhe da cabine a } \\
\text { tensão e o quadro geral } \\
\text { de baixa tensão }\end{array}$ & $\begin{array}{l}1: 25, \\
1: 20\end{array}$ & FAU-04PE-ELE-DE0707.00_00 & --- & --- & Com base em desenho do Fundo X0044 & $\begin{array}{l}\text { F 1968/FA } \\
\text { e. } 1\end{array}$ & F $1968 \mathrm{v} .2$ & F 1968 p.14 \\
\hline 19/ ago. / 1968 & --- & $\begin{array}{l}\text { Eng. Homero V. M. } \\
\text { Lopes (CREA 4333) }\end{array}$ & 16 & $\begin{array}{l}\text { Inst. Para-raios e } \\
\text { localização do quadro e } \\
\text { cabine }\end{array}$ & $\begin{array}{l}1: 500, \\
1: 100\end{array}$ & FAU-04PE-ELE-DE0708.00_00 & --- & $-\cdots$ & Com base em desenho do Fundo X0043 & $\begin{array}{l}\text { F } 1968 / \text { FA } \\
\text { e. } 1\end{array}$ & F $1968 \mathrm{v} .2$ & F 1968 p.15 \\
\hline $01 /$ nov. / 1968 & --- & FCCUASO & EP-3-719 & $\begin{array}{l}\text { Cabine A.T. 13,2 KV } \\
\text { com transformacăo e } \\
\text { quadro de distribuição } \\
220 \mathrm{~V}-127 \mathrm{~V} 60 \mathrm{~Hz}\end{array}$ & $1: 250$ & FAU-04PE-ELE-DE0708.00_00 & --- & --- & $-\cdots$ & --- & F $1968 \mathrm{v} .2$ & F 1968 p.16 \\
\hline 12 / ago. / 1968 & --- & FCCUASO & EP-3-688 & $\begin{array}{l}\text { Quadros de luz das } \\
\text { salas de aulas }\end{array}$ & 1:25 & FAU-04PE-ELE-DE0709.00_00 & --- & --- & --- & FA e.1 & --- & --- \\
\hline 04 / set. / 1968 & -- & FCCUASO & EP-3-696 & $\begin{array}{l}\text { Desenho orientativo das } \\
\text { formas dos quadros com } \\
\text { interruptores }\end{array}$ & s/e & FAU-04PE-ELE-DE0710.00_00 & --- & --- & -- & FA e.1 & --- & --- \\
\hline $01 /$ dec. / 1968 & --- & FCCUASO & 7669 & $\begin{array}{l}\text { Cabine de Alta Tensão. } \\
\text { Planta, loccaçâo, corte e } \\
\text { elevaçâao. }\end{array}$ & 1:50 & FAU-04PE-ELE-DE0711.00_00 & --- & --- & --- & FA e.1 & --- & --- \\
\hline $06 /$ dec. / 1968 & $-\cdots$ & FCCUASO & EP-3-733 & $\begin{array}{l}\text { Cabine de Altat Tensão. } \\
\text { Planta, Ioccaçâo, corte e } \\
\text { elevaçâa. }\end{array}$ & 1:50 & FAU-04PE-ELE-DE0712.00_00 & $\begin{array}{l}\text { Planta, corte, } \\
\text { elevaçầ }\end{array}$ & & & FA e.1 & $-\cdots$ & --- \\
\hline 23 / jan. / 1969 & --- & FCCUASO & EP-3-760 & $\begin{array}{l}\text { Sub estação } 13200 / \\
2001 \text { 127T Suggestâo } \\
\text { para fundaçăo }\end{array}$ & 1:20 & FAU-04PE-ELE-DE0713.00_00 & --- & --- & --- & FA e.1 & --- & --- \\
\hline 22 / jun. / 1961 & --- & J. C Figueiredo Ferraz & 1 & $\begin{array}{l}\text { Planta de locação dos } \\
\text { pilares e cargas das } \\
\text { fundaçôes }\end{array}$ & 1:100 & FAU-04PE-EST-DE0101.00_00 & Planta & --- & $\begin{array}{l}\text { Anotação de cargas ao lado de cada } \\
\text { pilar }\end{array}$ & FPE e.1/ e.2 & --- & --- \\
\hline 11 / out. / 1961 & 18/ dec./ 1961 & J. C Figueiredo Ferraz & 2 & $\begin{array}{l}\text { planta de } \\
\text { estaqueamento e } \\
\text { localização dos tubulöes }\end{array}$ & 1:100 & FAU-04PE-EST-DE0102.00_00 & Planta & --- & 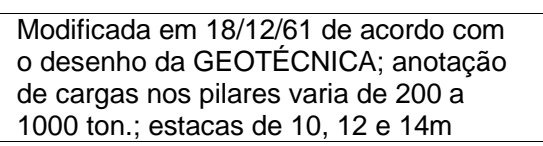 & $\begin{array}{l}\text { FPE e.1/e.2 } \\
\text { / e.3 }\end{array}$ & $\begin{array}{l}\text { FAC v.4 } \\
(1961)\end{array}$ & $\begin{array}{l}\text { FAC } 1961 \\
\text { p.38 }\end{array}$ \\
\hline 10/ mai. / 1966 & --- & J. C Figueiredo Ferraz & $2 \mathrm{~A}$ & $\begin{array}{l}\text { Planta: acréscimoo das } \\
\text { estacas e tubuloes nas } \\
\text { fundaçôs }\end{array}$ & 1:100 & FAU-04PE-EST-DE0102.00_01 & Planta & --- & -- & FPE e.1/ e.2 & -- & --- \\
\hline$--/$ dec. / 1966 & --- & J. C Figueiredo Ferraz & 112 & Reforço nas fundaçōes & $\begin{array}{l}1: 50, \\
1: 25\end{array}$ & FAU-04PE-EST-DE0111.00_00 & --- & --- & --- & --- & -- & --- \\
\hline$--/$ dec. / 1966 & --- & J. C Figueiredo Ferraz & 113 & Reforço nas fundaçōes & $\begin{array}{l}1: 50, \\
1: 20\end{array}$ & FAU-04PE-EST-DE0112.00_00 & --- & --- & --- & --- & --- & --- \\
\hline 12 / abr. / 1967 & --- & J. C Figueiredo Ferraz & 119 & $\begin{array}{l}\text { Alteraçãa bloco P18. } \\
\text { Esquema arranques } \\
\text { P15 }\end{array}$ & $\begin{array}{l}1: 50, \\
1: 25\end{array}$ & FAU-04PE-EST-DE0113.00_00 & $-\cdots$ & -- & --- & --- & -- & -- \\
\hline$--/$ mai. / 1967 & --- & J. C Figueiredo Ferraz & 123 & $\begin{array}{l}\text { Alteração na viga V37 } \\
\text { (fundaçoes) }\end{array}$ & $\begin{array}{l}1: 50, \\
1: 20\end{array}$ & FAU-04PE-EST-DE0114.00_00 & $-\cdots$ & --- & --- & --- & --- & --- \\
\hline--- & --- & J. C Figueiredo Ferraz & 126 & Alter. Vigas fundações & --- & FAU-04PE-EST-DE0115.00_00 & --- & $-\cdots$ & $-\cdots$ & --- & --- & --- \\
\hline--- & --- & J. C Figueiredo Ferraz & 127 & $\begin{array}{l}\text { Variante da armaçãó do } \\
\text { bloco do tubulâa } 25\end{array}$ & 1:25 & FAU-04PE-EST-DE0116.00_00 & --- & --- & --- & $-\cdots$ & --- & -- \\
\hline 05 / abr. / 1967 & --- & J. C Figueiredo Ferraz & $123 \mathrm{~A}$ & Alteração nas fundações & --- & FAU-04PE-EST-DE0117.00_00 & --- & --- & --- & --- & --- & --- \\
\hline
\end{tabular}




\begin{tabular}{|c|c|c|c|c|c|c|c|c|c|c|c|c|}
\hline \multicolumn{6}{|c|}{ Dados do carimbo } & \multicolumn{4}{|c|}{ Sistematização } & \multicolumn{3}{|c|}{$\begin{array}{l}\text { Localização dos Arquivos } \\
\text { Biblioteca FAU }\end{array}$} \\
\hline Data & Modificação & Autor & Folha & Título & Escala & Vol. & $\begin{array}{l}\text { Tipo } \\
\text { desenho }\end{array}$ & $\begin{array}{l}\text { Pav./ } \\
\text { Vista }\end{array}$ & Obs. & $\begin{array}{l}\text { Cópias (PE } \\
\text { AR78/727.3) }\end{array}$ & $\begin{array}{l}\text { Originais (P } \\
\text { AR78/727.3) }\end{array}$ & PDF (727.3) \\
\hline 17 / jan. / 1962 & --- & J. C Figueiredo Ferraz & 6 & $\begin{array}{l}\text { Laje do }{ }^{10} \text { subsolo e do } \\
\text { pavimento térreo }\end{array}$ & 1:50 & FAU-04PE-EST-DE0201.01_00 & Planta & -1 & $-\cdots$ & $\begin{array}{l}\text { FF e.1/e.2 } \\
\text { / e.3/ e.6 }\end{array}$ & $\cdots$ & F 1962 p.16 \\
\hline $26 /$ abr. / 1966 & --- & J. C Figueiredo Ferraz & $6 \mathrm{~A}$ & $\begin{array}{l}\text { Fôrmas: laje do } 1^{\circ} \\
\text { subsolo e do pavimento } \\
\text { térreo }\end{array}$ & 1:50 & FAU-04PE-EST-DE0201.01_01 & Planta & -1 & Modificação do desenho 6. & $\begin{array}{l}\text { FPE e.1/e.2 } \\
\text { / e.3 }\end{array}$ & F 1966 v.2 & F 1966 p.10 \\
\hline--- & --- & --- & --- & --- & --- & FAU-04PE-EST-DE0201.01_X & Planta & -1 & $\begin{array}{l}\text { Referente ao quadrante inferior } \\
\text { esquerdo, com anotaçâo "10 subsolo" }\end{array}$ & --- & Fv.1 & F p.05 \\
\hline $20 /$ dez. / 1961 & --- & J. C Figueiredo Ferraz & 7 & $\begin{array}{l}\text { Fôrmas. Laje do } 1^{\circ} \\
\text { subsolo }\end{array}$ & $1: 50$ & FAU-04PE-EST-DE0201.02_00 & Planta & -1 & $\cdots$ & $\begin{array}{l}\text { FF e.1/e.2 } \\
\text { / e.3/e.7 }\end{array}$ & $\begin{array}{l}\text { FAC v.5 } \\
(1961)\end{array}$ & --- \\
\hline--- & --- & J. C Figueiredo Ferraz & $7 \mathrm{~A}$ & $\begin{array}{l}\text { Fôrmas: modificaçãa e } \\
\text { aumento parte da laje } \\
\text { do } 1^{\circ} \text { subsolo }\end{array}$ & 1:50 & FAU-04PE-EST-DE0201.02_01 & --- & -1 & $\cdots$ & $\begin{array}{l}\text { FPE e. } 1 / \text { e.2 } \\
\text { / e.3 }\end{array}$ & F 1966 v.2 & F 1966 p.11 \\
\hline--- & --- & --- & --- & -- & $\cdots$ & FAU-04PE-EST-DE0201.02_X & Planta & -1 & $\begin{array}{l}\text { Referente ao quadrante inferior direito, } \\
\text { com anotaçâo "10 subsolo" }\end{array}$ & --- & Fv.1 & F p.02 \\
\hline $20 /$ dez. / 1961 & 08 / jun. / 1962 & J. C Figueiredo Ferraz & 4 & $\begin{array}{l}\text { Fôrmas: Laje o } 2^{\circ} \\
\text { subsolo e parte da laje } \\
\text { do } 1^{\circ} \text { subsolo }\end{array}$ & $1: 50$ & FAU-04PE-EST-DE0201.03_00 & Planta & -1 & modificado em 8-6-62. & $\begin{array}{l}\text { FFe.1/ e.2 } \\
\text { / e.3/e.4 }\end{array}$ & \begin{tabular}{|l} 
FAC v.5 \\
$(1961)$
\end{tabular} & --- \\
\hline 20 / abr. / 1966 & $-\cdots$ & J. C Figueiredo Ferraz & $4 \mathrm{~A}$ & $\begin{array}{l}\text { Formas: laje do } 2^{\circ} \\
\text { subsolo e parte da laje } \\
\text { do } 1^{\circ} \text { subsolo }\end{array}$ & 1:50 & FAU-04PE-EST-DE0201.03_01 & Planta, corte & & $\cdots$ & $\begin{array}{l}\text { FPE e.1/e.2 } \\
/ \text { e.3 }\end{array}$ & F 1966 v.2 & F 1966 p.08 \\
\hline-- & -- & -- & --- & --- & --- & FAU-04PE-EST-DE0201.03_X & Planta & -1 & 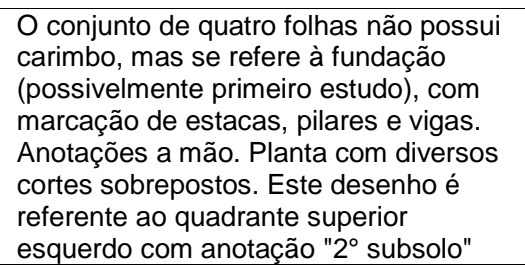 & --- & Fv.1 & F p.04 \\
\hline 03 / jan. / 1962 & $-\cdots$ & J. C Figueiredo Ferraz & 5 & $\begin{array}{l}\text { Fôrmas: Laje o } 2^{\circ} \\
\text { subsolo e parte da laje } \\
\text { do } 1^{\circ} \text { subsolo da }\end{array}$ & $1: 50$ & FAU-04PE-EST-DE0201.04_00 & Planta & -1 & $\begin{array}{l}\text { observação da folha: "deixar tacos na } \\
\text { concretagem para fixacaáo do peitoril"; } \\
\text { "Alvenarias divisórias de Pumex de } 10 \\
\text { cm"; }\end{array}$ & $\begin{array}{l}\text { FFe e.1/e.2 } \\
/ \text { e.3/e.5/ } \\
\text { FPE e.3 }\end{array}$ & Fv.2 (1962) & F 1962 p.15 \\
\hline--- & --- & J. C Figueiredo Ferraz & $5 \mathrm{~A}$ & $\begin{array}{l}\text { Fôrmas: modificaçãa e } \\
\text { aumento parte da laje } \\
\text { do } 1^{\circ} \text { subsolo }\end{array}$ & 1:50 & FAU-04PE-EST-DE0201.04_01 & & -1 & - & $\begin{array}{l}\text { FPE e.1/e.2 } \\
/ \text { e.3 }\end{array}$ & F 1966 v.2 & F 1966 p.09 \\
\hline-- & --- & --- & --- & --- & $-\cdots$ & FAU-04PE-EST-DE0201.04_X & Planta & -1 & $\begin{array}{l}\text { Referente ao quadrante superior direito, } \\
\text { com a anotaçăo "20 subsolo" }\end{array}$ & --- & Fv.1 & F p.03 \\
\hline 24 / abr. / 1962 & --- & J. C Figueiredo Ferraz & 21 & $\begin{array}{l}\text { Fôrmas: Vigas de } \\
\text { concreto protendido } \\
\text { Piso auditório - Detalhes }\end{array}$ & $\begin{array}{l}1: 100, \\
1: 25, \\
1: 10\end{array}$ & FAU-04PE-EST-DE0201.05_00 & $\begin{array}{l}\text { Planta; } \\
\text { Cortes }\end{array}$ & -1 & Fôrmas da caixa d água 11/6/62. & $\begin{array}{l}\text { FFe.1/e.2 } \\
/ \text { e. } 3 / \text { e.21 }\end{array}$ & Fv.3 (1962) & --- \\
\hline 04 / mar. / 1962 & $-\cdots$ & J. C Figueiredo Ferraz & 8 & $\begin{array}{l}\text { Fôrmas: do bloco A no } \\
\text { nivel }+80 \mathrm{e} \text { e }-300 \text { (lado } \\
\text { esquerdo) }\end{array}$ & 1:50 & FAU-04PE-EST-DE0202.01_00 & Planta & 0 & $\cdots$ & $\begin{array}{l}\text { FFe.1/e.2 } \\
/ \text { e.3/e.8 }\end{array}$ & F v.2 (1962) & F 1962 p.17 \\
\hline--- & --- & J. C Figueiredo Ferraz & 8 & $\begin{array}{l}\text { Fôrmas: do bloco A no } \\
\text { nivel (lado esquerdo) }\end{array}$ & 1:50 & FAU-04PE-EST-DE0202.01_X & Planta & 0 & $\begin{array}{l}\text { pequenas diferenças com o desenho } \\
\text { anterior: concreto protendido está com } \\
\text { hachura negra }\end{array}$ & $-\cdots$ & Fv.2 & F p.17 \\
\hline--- & -- & J. C Figueiredo Ferraz & 8 & $\begin{array}{l}\text { Fôrmas: do bloco A no } \\
\text { nivel (lado esquerdo) }\end{array}$ & 1:50 & FAU-04PE-EST-DE0202.01_XX & Planta & 0 & -- & --- & Fv.2 & F p.18 \\
\hline 14/ mar. / 1962 & --- & J. C Figueiredo Ferraz & 9 & $\begin{array}{l}\text { Fôrmas: do bloco A no } \\
\text { nivel +80 (lado direito) }\end{array}$ & 1:50 & FAU-04PE-EST-DE0202.02_00 & Planta & 0 & --- & $\begin{array}{l}\text { FFe.1/e.2 } \\
\text { / e.3/e.9 }\end{array}$ & --- & F 1962 p.18 \\
\hline $28 /$ abr. / 1966 & --- & J. C Figueiredo Ferraz & 9A & $\begin{array}{l}\text { Fôrmas: do bloco A no } \\
\text { nível +80 (lado direito) }\end{array}$ & 1:50 & FAU-04PE-EST-DE0202.02_01 & Planta & 0 & --- & $\begin{array}{l}\text { FPE e. } 1 / \text { e. } 2 \\
\text { / e.3 }\end{array}$ & F 1966 v.2 & F 1966 p.12 \\
\hline--- & --- & J. C Figueiredo Ferraz & 9 & $\begin{array}{l}\text { Fôrmas: do bloco A no } \\
\text { nível (lado direito) }\end{array}$ & 1:50 & FAU-04PE-EST-DE0202.02_X & Planta & 0 & --- & --- & Fv.2 & F p.11 \\
\hline
\end{tabular}




\begin{tabular}{|c|c|c|c|c|c|c|c|c|c|c|c|c|}
\hline \multicolumn{6}{|c|}{ Dados do carimbo } & \multicolumn{4}{|c|}{ Sistematização } & \multicolumn{3}{|c|}{$\begin{array}{l}\text { Localização dos Arquivos } \\
\text { Biblioteca FAU }\end{array}$} \\
\hline Data & Modificação & Autor & Folha & Titulo & Escala & Vol. & $\begin{array}{l}\text { Tipo } \\
\text { desenho }\end{array}$ & $\begin{array}{l}\text { Pav./ } \\
\text { Vista }\end{array}$ & Obs. & $\begin{array}{l}\text { Cópias (PE } \\
\text { AR78/727.3) }\end{array}$ & $\begin{array}{l}\text { Originais }(P \\
\text { AR78/727.3) }\end{array}$ & PDF (727.3) \\
\hline--- & $\cdots$ & J. C Figueiredo Ferraz & 9 & $\begin{array}{l}\text { Fôrmas: do bloco A no } \\
\text { nivel (lado direito) }\end{array}$ & $1: 50$ & FAU-04PE-EST-DE0202.02_XX & Planta & 0 & $\begin{array}{l}\text { pequenas diferenças com o desenho } \\
\text { anterior: concreto protendido está com } \\
\text { hachura negra }\end{array}$ & --- & Fv.2 & F p.10 \\
\hline $14 /$ mar. / 1962 & --- & J. C Figueiredo Ferraz & 11 & $\begin{array}{l}\text { Fôrmas: do bloco B no } \\
\text { nível +270 (lado } \\
\text { esquerdo) }\end{array}$ & 1:50 & FAU-04PE-EST-DE0202.03_00 & Planta & 0 & $\begin{array}{l}\text { Háuma escada que ligava a cantina ao } \\
\text { exterior }\end{array}$ & $\begin{array}{l}\text { FF e.1/e.2 } \\
/ \text { e.3/e.11 }\end{array}$ & Fv.3 (1962) & F 1962 p.20 \\
\hline-- / jun. / 1967 & --- & J. C Figueiredo Ferraz & 124 & $\begin{array}{l}\text { Alteraçăo na tồma e } \\
\text { armacâa. Bloco B - lado } \\
\text { esquerdo - nivel +270 }\end{array}$ & $\begin{array}{l}1: 50, \\
1: 20\end{array}$ & FAU-04PE-EST-DE0202.03_01 & --- & 0 & --- & --- & --- & --- \\
\hline $14 /$ mar. / 1962 & $\cdots$ & J. C Figueiredo Ferraz & 10 & $\begin{array}{l}\text { Fôrmas: do bloco B no } \\
\text { nivel +270 (lado direito) }\end{array}$ & 1:50 & FAU-04PE-EST-DE0202.04_00 & Planta & 0 & --- & $\begin{array}{l}\text { FF e.1/e.2 } \\
\text { / e.3/ e.10 }\end{array}$ & F v.2 (1962) & F 1962 p.19 \\
\hline--- & --- & J. C Figueiredo Ferraz & 10 & $\begin{array}{l}\text { Fôrmas: do bloco B no } \\
\text { nível (lado direito) }\end{array}$ & 1:50 & FAU-04PE-EST-DE0202.04_X & Planta & 0 & --- & --- & Fv.2 & F p.12 \\
\hline $01 /$ mai. / 1966 & --- & J. C Figueiredo Ferraz & $12 \mathrm{~A}$ & $\begin{array}{l}\text { Fôrmas: do bloco C e D } \\
\text { níveis }+460+650\end{array}$ & 1:50 & FAU-04PE-EST-DE0203.00_01 & Planta & 1 & Acréscimo da laje da biblioteca (projeto) & $\begin{array}{l}\text { FPE e.1/e.2 } \\
\text { / e.3 }\end{array}$ & F $1966 \mathrm{v} .2$ & F 1966 p.13 \\
\hline $14 /$ mar. / 1962 & --- & J. C Figueiredo Ferraz & 16 & $\begin{array}{l}\text { Fôrmas: do bloco C no } \\
\text { nível +460 (lado } \\
\text { esquerdo) }\end{array}$ & $1: 50$ & FAU-04PE-EST-DE0203.01_00 & Planta & 1 & --- & $\begin{array}{l}\text { FF e.1/e.2 } \\
\text { / e.3/e.16 }\end{array}$ & Fv.3(1962) & F $1962 p .25$ \\
\hline 28 / abr. / 1966 & --- & J. C Figueiredo Ferraz & $16 \mathrm{~A}$ & $\begin{array}{l}\text { Fôrmas: do bloco C no } \\
\text { nível +460 (lado } \\
\text { esquerdo) }\end{array}$ & $1: 50$ & FAU-04PE-EST-DE0203.01_01 & Planta & 2 & --- & $\begin{array}{l}\text { FPE e.1/ e.2 } \\
\text { / e.3 }\end{array}$ & F $1966 \mathrm{v} .2$ & F 1966 p.14 \\
\hline--- & $\cdots$ & J. C Figueiredo Ferraz & 18 & $\begin{array}{l}\text { Fôrmas: do bloco C no } \\
\text { nível (lado esquerdo) }\end{array}$ & 1:50 & FAU-04PE-EST-DE0203.01_X & Planta & 2 & Carimbo na vertical & --- & $\mathrm{Fv} .3$ & F p.19 \\
\hline $14 /$ mar. / 1962 & --- & J. C Figueiredo Ferraz & 17 & $\begin{array}{l}\text { Fôrmas: do bloco C no } \\
\text { nivel +460 (lado direito) }\end{array}$ & 1:50 & FAU-04PE-EST-DE0203.02_00 & Planta & 1 & --- & $\begin{array}{l}\text { FF e.1/e.2 } \\
\text { / e.3/e.17 }\end{array}$ & Fv.3 (1962) & F 1962 p.26 \\
\hline--- & $\cdots$ & J. C Figueiredo Ferraz & 17 & $\begin{array}{l}\text { Fôrmas: do bloco C no } \\
\text { nível (lado direito) }\end{array}$ & $1: 50$ & FAU-04PE-EST-DE0203.02_X & Planta & & $\cdots$ & --- & Fv.2 & F p.13 \\
\hline $14 /$ mar. / 1962 & -- & J. C Figueiredo Ferraz & 12 & $\begin{array}{l}\text { Fôrmas: do bloco D no } \\
\text { nível +650 (lado } \\
\text { esquerdo) }\end{array}$ & 1:50 & FAU-04PE-EST-DE0203.03_00 & Planta & 1 & --- & $\begin{array}{l}\text { FF e.1/e.2 } \\
\text { / e.3/e.12 }\end{array}$ & Fv.3 (1962) & F 1962 p.21 \\
\hline--- & --- & J. C Figueiredo Ferraz & 12 & $\begin{array}{l}\text { Fôrmas: do bloco D no } \\
\text { nível (lado esquerdo) }\end{array}$ & 1:50 & FAU-04PE-EST-DE0203.03_X & Planta & 1 & --- & --- & $\mathrm{Fv} .3$ & F p.20 \\
\hline $14 /$ mar. / 1962 & --- & J. C Figueiredo Ferraz & 13 & $\begin{array}{l}\text { Fôrmas: : do bloco D no } \\
\text { nivel +650 (lado direito) }\end{array}$ & 1:50 & FAU-04PE-EST-DE0203.04_00 & Planta & 1 & --- & $\begin{array}{l}\text { FF e.1/e.2 } \\
\text { / e.3/e.13 }\end{array}$ & Fv.3(1962) & F 1962 p.22 \\
\hline-- & -- & J. C Figueiredo Ferraz & 13 & $\begin{array}{l}\text { Fôrmas: do bloco D no } \\
\text { nivel (lado direito) }\end{array}$ & 1:50 & FAU-04PE-EST-DE0203.04_X & Planta & 1 & --- & --- & F v.2 & Fp.14 \\
\hline 14 / mar. / 1962 & $\cdots$ & J. C Figueiredo Ferraz & 14 & $\begin{array}{l}\text { Fôrmas: do bloco E no } \\
\text { nivel } 8440 \text { (lado } \\
\text { esquerdo) }\end{array}$ & 1:50 & FAU-04PE-EST-DE0204.01_00 & Planta & 2 & $\cdots$ & $\begin{array}{l}\text { FFe.1/e.2 } \\
\text { / e.3/e.14 }\end{array}$ & $\begin{array}{l}\text { Fv.3(1962)/ } \\
\text { v.2 }\end{array}$ & F 1962 p.23 \\
\hline--- & --- & J. C Figueiredo Ferraz & 14 & -- & $\cdots$ & FAU-04PE-EST-DE0204.01_00 & Planta & 2 & --- & --- & --- & --- \\
\hline--- & $-\cdots$ & J. C Figueiredo Ferraz & 14 & $\begin{array}{l}\text { Fôrmas: do bloco E no } \\
\text { nivel (lado esquerdo) }\end{array}$ & $1: 50$ & FAU-04PE-EST-DE0204.01_XX & Planta & 2 & --- & --- & Fv. 3 & F p.21 \\
\hline$--/-/ 1962$ & $\cdots$ & J. C Figueiredo Ferraz & 15 & $\begin{array}{l}\text { Fôrmas: do bloco E no } \\
\text { nível +840 (lado direito) }\end{array}$ & 1:50 & FAU-04PE-EST-DE0204.02_00 & Planta & 2 & $\cdots$ & $\begin{array}{l}\text { FF e.1/e.2 } \\
\text { / e.3/e.15 }\end{array}$ & Fv.3 (1962) & F 1962 p.24 \\
\hline--- & $-\cdots$ & J. C Figueiredo Ferraz & 15 & $\begin{array}{l}\text { Fôrmas: do bloco E no } \\
\text { nível (lado direito) }\end{array}$ & 1:50 & FAU-04PE-EST-DE0204.02_X & Planta & 2 & --- & --- & Fv.2 & Fp.15 \\
\hline
\end{tabular}




\begin{tabular}{|c|c|c|c|c|c|c|c|c|c|c|c|c|}
\hline \multicolumn{6}{|c|}{ Dados do carimbo } & \multicolumn{4}{|c|}{ Sistematização } & \multicolumn{3}{|c|}{$\begin{array}{l}\text { Localização dos Arquivos } \\
\text { Biblioteca FAU }\end{array}$} \\
\hline Data & Modificação & Autor & Folha & Título & Escala & Vol. & $\begin{array}{l}\text { Tipo } \\
\text { desenho }\end{array}$ & $\begin{array}{l}\text { Pav./ } \\
\text { Vista }\end{array}$ & Obs. & $\begin{array}{l}\text { Cópias (PE } \\
\text { AR78/727.3) }\end{array}$ & $\begin{array}{l}\text { Originais }(P \\
\text { AR78/727.3) }\end{array}$ & PDF (727.3) \\
\hline 14/ mar. / 1962 & --- & J. C Figueiredo Ferraz & 19 & $\begin{array}{l}\text { Fôrmas: do bloco F no } \\
\text { nivel +10.30 (lado } \\
\text { esquerdo) }\end{array}$ & 1:50 & FAU-04PE-EST-DE0204.03_00 & Planta & 2 & $\cdots$ & $\begin{array}{l}\text { FF e.1/e.2 } \\
\text { / e.3/e.19 }\end{array}$ & Fv.3 (1962) & F 1962 p.28 \\
\hline--- & --- & J. C Figueiredo Ferraz & 19 & $\begin{array}{l}\text { Fôrmas: do bloco F no } \\
\text { nível (lado esquerdo) }\end{array}$ & 1:50 & FAU-04PE-EST-DE0204.03_X & Planta & 2 & --- & --- & Fv.3 & F p.22 \\
\hline 14/mar. / 1962 & --- & J. C Figueiredo Ferraz & 18 & $\begin{array}{l}\text { Fôrmas: do bloco F no } \\
\text { nível } 10.30 \text { (lado } \\
\text { direito) }\end{array}$ & 1:50 & FAU-04PE-EST-DE0204.04_00 & Planta & 2 & --- & $\begin{array}{l}\text { FF e.1/e.2 } \\
\text { / e.3/e.18 }\end{array}$ & Fv.3 (1962) & F 1962 p.27 \\
\hline-- & $-\cdots$ & J. C Figueiredo Ferraz & 18 & $\begin{array}{l}\text { Fôrmas: do bloco F no } \\
\text { nível (lado direito) }\end{array}$ & $1: 50$ & FAU-04PE-EST-DE0204.04_X & Planta & 2 & --- & $-\cdots-$ & Fv.2 & F p.16 \\
\hline 14 / mar. / 1962 & 24 / mai. / 1966 & J. C Figueiredo Ferraz & 20 & $\begin{array}{l}\text { Formas: Cobertura } \\
\text { (total) }\end{array}$ & $\begin{array}{l}1: 50, \\
1: 20\end{array}$ & FAU-04PE-EST-DE0205.00_00 & $\begin{array}{l}\text { Planta; } \\
\text { detalhes }\end{array}$ & Cobertura & Modificado em 24/5/1966 & $\begin{array}{l}\text { FF e.1/e.2 } \\
\text { / e.3/ e.20 }\end{array}$ & $\mathrm{Fv} .3(1962)$ & F 1962 p.29 \\
\hline 19 / out. / 1962 & --- & J. C Figueiredo Ferraz & 34 & $\begin{array}{l}\text { Arm. Lajes do } 2^{\circ} \\
\text { subsolo e parte do } 1^{\circ} \\
\text { subsolo }\end{array}$ & 1:50 & FAU-04PE-EST-DE0301.01_00 & Planta & --- & --- & --- & --- & $-\cdots$ \\
\hline 19 / out. / 1962 & 28 / out. / 1966 & J. C Figueiredo Ferraz & 35 & $\begin{array}{l}\text { Arm. Lajes do } 2^{\circ} \\
\text { subsolo e parte do } 1^{\circ} \\
\text { subsolo }\end{array}$ & 1:50 & FAU-04PE-EST-DE0301.02_00 & Planta & --- & Modificada em 28/10/1966 & --- & --- & --- \\
\hline 23 / out. / 1962 & 31/ out. / 1966 & J. C Figueiredo Ferraz & 36 & $\begin{array}{l}\text { Armacão Lajes do }{ }^{\circ} \\
\text { subsolo e do pavimento } \\
\text { térreo }\end{array}$ & 1:50 & FAU-04PE-EST-DE0301.03_00 & Planta & 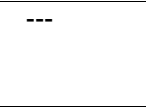 & modificada em 31/10/66 & FPE e.1 & --- & -- \\
\hline 23 / out. / 1962 & $-\cdots$ & J. C Figueiredo Ferraz & 37 & $\begin{array}{l}\text { Armação lajes do } 1^{\circ} \\
\text { subsolo }\end{array}$ & 1:50 & FAU-04PE-EST-DE0301.04_00 & Planta & --- & --- & --- & --- & --- \\
\hline 23 / out. / 1962 & -- / out. / 1966 & J. C Figueiredo Ferraz & 38 & $\begin{array}{l}\text { Bloco A: armação nivel } \\
\text { (lado esquerdo) }\end{array}$ & 1:50 & FAU-04PE-EST-DE0302.01_00 & Planta & --- & modificado out 66 & FPE e.1 & --- & --- \\
\hline 29 / mai. / 1962 & $--/$ out. / 1966 & J. C Figueiredo Ferraz & 39 & $\begin{array}{l}\text { Bloco A: armação nivel } \\
\text { (lado direito) }\end{array}$ & 1:50 & FAU-04PE-EST-DE0302.02_00 & Planta & --- & modificado out 66 & FPE e.1 & --- & -- \\
\hline--- & --- & J. C Figueiredo Ferraz & $39 \mathrm{~A}$ & $\begin{array}{l}\text { Armacăo do aumento } \\
\text { das lajes (bloco } \mathrm{A} \text { nivel } \\
+80 \text { lado direito) }\end{array}$ & $-\cdots-$ & FAU-04PE-EST-DE0302.02_01 & Planta & 0 & & FPE e.1 & $-\cdots$ & -- \\
\hline 29 / mai. / 1962 & -- / out. / 1966 & J. C Figueiredo Ferraz & 40 & $\begin{array}{l}\text { Armação bloco B nível } \\
\text { lado esquerdo }\end{array}$ & $\begin{array}{l}1: 50, \\
1: 20\end{array}$ & FAU-04PE-EST-DE0302.03_00 & Planta & & modificado out 66 & & --- & --- \\
\hline--- & 28 / out. / 1966 & J. C Figueiredo Ferraz & 41 & $\begin{array}{l}\text { Bloco B. Armação nivel. } \\
\text { (lado direito) }\end{array}$ & $-\cdots$ & FAU-04PE-EST-DE0302.04_00 & Planta & & modificado em 28/10/1966 & & --- & --- \\
\hline 31/ mai. / 1962 & --- & J. C Figueiredo Ferraz & 42 & \begin{tabular}{|l|} 
Bloco C nível (lado \\
esquerdo)
\end{tabular} & $\begin{array}{l}1: 50, \\
1: 20\end{array}$ & FAU-04PE-EST-DE0303.01_00 & Planta & & & FPE e.1 & -- & --- \\
\hline--- & $-\cdots$ & J. C Figueiredo Ferraz & $42 \mathrm{~A}$ & $\begin{array}{l}\text { Armaçãoo do aumento } \\
\text { das lajes (bloco C lado } \\
\text { esquerdo) }\end{array}$ & \begin{tabular}{|l}
$1: 50$, \\
$1: 20$
\end{tabular} & FAU-04PE-EST-DE0303.01_01 & Planta & & & FPE e.1 & -- & -- \\
\hline 31 / mai. / 1962 & 01 / mai. / 1966 & J. C Figueiredo Ferraz & 43 & $\begin{array}{l}\text { Armação Bloco C nível } \\
\text { (lado direito) }\end{array}$ & $\begin{array}{l}1: 50, \\
1: 20\end{array}$ & FAU-04PE-EST-DE0303.02_00 & & & modificado maio de 1966 & FPE e.1 & $-\cdots$ & --- \\
\hline 30 / mai. / 1962 & $01 /$ nov. / 1966 & J. C Figueiredo Ferraz & 44 & $\begin{array}{l}\text { Armaçăo do bloco D do do } \\
\text { nivel (lado esquerdo) }\end{array}$ & $\begin{array}{l}\text { 1:50, } \\
1: 20\end{array}$ & FAU-04PE-EST-DE0303.03_00 & Planta & & modificado em 1/11/1966 & & -- & -- \\
\hline-- & $\cdots$ & J. C Figueiredo Ferraz & $44 \mathrm{~A}$ & $\begin{array}{l}\text { Armacăo do aumento } \\
\text { das lajes dob bloco } \mathrm{Ce} \\
\text { D. Niveis }+460,+650\end{array}$ & $\begin{array}{l}1: 50, \\
1: 20\end{array}$ & FAU-04PE-EST-DE0303.03_01 & Planta & 1 & & & --- & --- \\
\hline 30 / mai. / 1962 & 28/ out. / 1966 & J. C Figueiredo Ferraz & 45 & \begin{tabular}{|l|} 
Bloco D Nível. (lado \\
direito)
\end{tabular} & $\begin{array}{l}1: 50, \\
1: 20\end{array}$ & FAU-04PE-EST-DE0303.04_00 & Planta & & modificado em 28/10/1966 & & --- & --- \\
\hline
\end{tabular}




\begin{tabular}{|c|c|c|c|c|c|c|c|c|c|c|c|c|}
\hline \multicolumn{6}{|c|}{ Dados do carimbo } & \multicolumn{4}{|c|}{ Sistematização } & \multicolumn{3}{|c|}{$\begin{array}{l}\text { Localização dos Arquivos } \\
\text { Biblioteca FAU }\end{array}$} \\
\hline Data & Modificação & Autor & Folha & Título & Escala & Vol. & $\begin{array}{l}\text { Tipo } \\
\text { desenho }\end{array}$ & $\begin{array}{l}\text { Pav./ } \\
\text { Vista }\end{array}$ & Obs. & $\begin{array}{l}\text { Cópias (PE } \\
\text { AR78/727.3) }\end{array}$ & $\begin{array}{l}\text { Originais (P } \\
\text { AR78/727.3) }\end{array}$ & PDF (727.3) \\
\hline 29 / mai. / 1962 & 31/ out. / 1966 & J. C Figueiredo Ferraz & 46 & $\begin{array}{l}\text { Armaçăo bloco E nivel } \\
\text { (lado esquerdo) }\end{array}$ & $\begin{array}{l}1: 50, \\
1: 20\end{array}$ & FAU-04PE-EST-DE0304.01_00 & Planta & --- & modificado em 31/10/1966 & --- & -- & --- \\
\hline 29 / mai. / 1962 & 31/ out. / 1966 & J. C Figueiredo Ferraz & 47 & \begin{tabular}{|l} 
Armação bloco E nivel \\
(lado direito)
\end{tabular} & $\begin{array}{l}1: 50, \\
1: 20\end{array}$ & FAU-04PE-EST-DE0304.02_00 & Planta & --- & modificado em 31/10/1966 & --- & --- & --- \\
\hline 29 / mai. / 1962 & 30 / out. / 1966 & J. C Figueiredo Ferraz & 48 & $\begin{array}{l}\text { Armação nivivel. Bloco F } \\
\text { (lado esquerdo) }\end{array}$ & $\begin{array}{l}1: 50, \\
1: 20\end{array}$ & FAU-04PE-EST-DE0304.03_00 & Planta & --- & modificado em 30/10/1966 & --- & --- & --- \\
\hline 29 / mai. / 1962 & $--/$ out. / 1966 & J. C Figueiredo Ferraz & 49 & $\begin{array}{l}\text { Bloco F. Armação. Lado } \\
\text { direito }\end{array}$ & $\begin{array}{l}1: 50, \\
1: 20\end{array}$ & FAU-04PE-EST-DE0304.04_00 & Planta & --- & modificado em outubro de 1966 & --- & --- & -- \\
\hline$--/-/ 1962$ & --- & J. C Figueiredo Ferraz & 22 & $\begin{array}{l}\text { Armaçăo das vigas (48, } \\
55,60,44,51,57,12) \\
\text { da fundaçāo }\end{array}$ & $\begin{array}{l}1: 50, \\
1: 25\end{array}$ & FAU-04PE-EST-DE0311.00_00 & --- & $-\cdots$ & --- & --- & --- & --- \\
\hline$--1-/ 1962$ & --- & J. C Figueiredo Ferraz & 23 & $\begin{array}{l}\text { Armaçăo das vigas (30, } \\
17,19,20,21,16,24, \\
88) \text { da fundaçâo }\end{array}$ & $\begin{array}{l}1: 50, \\
1: 20\end{array}$ & FAU-04PE-EST-DE0312.00_00 & --- & --- & --- & --- & --- & --- \\
\hline 14 / mai. / 1962 & 01 / mai. / 1966 & J. C Figueiredo Ferraz & 24 & $\begin{array}{l}\text { Armação das vigas (v1, } \\
3,5,5,11,2 A, 37,38, \\
43 A, 43,46,50,53,56, \\
58,65,69,74,76,82, \\
85,90,92,39,40) \text {. } \\
\text { Fundação }\end{array}$ & $\begin{array}{l}1: 50, \\
1: 20\end{array}$ & FAU-04PE-EST-DE0313.00_00 & --- & --- & modificado em maio de 1966 & --- & --- & --- \\
\hline$--1-/ 1962$ & --- & J. C Figueiredo Ferraz & 25 & $\begin{array}{l}\text { Armacăão das vigas }\left(1^{*} \text {, }\right. \\
\left.144,9^{*}, 10^{* *}, 6^{*}, 6^{*}\right) \\
\text { da fundaçăo }\end{array}$ & $\begin{array}{l}1: 50, \\
1: 20\end{array}$ & FAU-04PE-EST-DE0314.00_00 & $-\cdots$ & $-\cdots$ & $\ldots$ & --- & --- & --- \\
\hline 15 / out. / 1962 & 19/abr. / 1966 & J. C Figueiredo Ferraz & 26 & 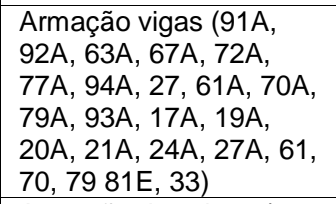 & $\begin{array}{l}1: 50, \\
1: 20\end{array}$ & FAU-04PE-EST-DE0315.00_00 & --- & --- & modificado em 19/4/66 & --- & --- & --- \\
\hline$--/$ dec. / 1962 & 01 / mai. / 1966 & J. C Figueiredo Ferraz & 27 & $\begin{array}{l}\text { Armaçăo das vigas (15, } \\
4,109,122) \text { na } \\
\text { fundação }\end{array}$ & $\begin{array}{l}1: 50, \\
1: 20\end{array}$ & FAU-04PE-EST-DE0316.00_00 & --- & $-\cdots$ & modificado em maio de 1966 & --- & --- & --- \\
\hline 17 / out. / 1962 & 01 / mai. / 1966 & J. C Figueiredo Ferraz & 28 & $\begin{array}{l}\text { Armacão das vigas (54, } \\
101,477,45,97,36 \mathrm{~A}, \\
\text { 112) da fundacăo }\end{array}$ & $\begin{array}{l}1: 50, \\
1: 20\end{array}$ & FAU-04PE-EST-DE0317.00_00 & --- & --- & modificado em maio 1966 & --- & $-\cdots$ & --- \\
\hline 17 / out. / 1962 & --- & J. C Figueiredo Ferraz & 29 & $\begin{array}{l}\text { Armação vigas }(20,105, \\
108,34,35,47 \mathrm{~B}, 54 \mathrm{~A}, \\
36,23,128)\end{array}$ & $\begin{array}{l}1: 50, \\
1: 20\end{array}$ & FAU-04PE-EST-DE0318.00_00 & --- & --- & --- & --- & --- & --- \\
\hline 04 / out. / 1962 & --- & J. C Figueiredo Ferraz & 30 & $\begin{array}{l}\text { Armação das vigas (15, } \\
60 \mathrm{~A}, 64,68,73,78,81, \\
84,86,13,62,80,14,8, \\
188\end{array}$ & $\begin{array}{l}1: 50, \\
1: 20\end{array}$ & FAU-04PE-EST-DE0319.00_00 & ---- & --- & --- & --- & --- & --- \\
\hline--- & --- & J. C Figueiredo Ferraz & 31 & $\begin{array}{l}\text { Armaçãa vigas }(71,93, \\
89,16 \mathrm{~A}, 31,6,113,111, \\
110,35 \mathrm{~A}, 34 \mathrm{~A})\end{array}$ & $\begin{array}{l}1: 50, \\
1: 20\end{array}$ & FAU-04PE-EST-DE0320.00_00 & --- & --- & --- & --- & --- & --- \\
\hline--- & --- & J. C Figueiredo Ferraz & 32 & $\begin{array}{l}\text { Armação vigas }(2,106, \\
107,47,59)\end{array}$ & $\begin{array}{l}1: 50, \\
1: 20\end{array}$ & FAU-04PE-EST-DE0321.00_00 & $\cdots$ & $-\cdots$ & --- & --- & --- & --- \\
\hline$-\cdots$ & --- & J. C Figueiredo Ferraz & 33 & $\begin{array}{l}\text { Armação vigas } 63,67, \\
72,77,66,75,83,91,7 \\
\left.101,62^{2}, 877\right)\end{array}$ & $\begin{array}{l}1: 50, \\
1: 20\end{array}$ & FAU-04PE-EST-DE0322.00_00 & --- & --- & --- & --- & --- & --- \\
\hline 12 / out. / 1962 & --- & J. C Figueiredo Ferraz & 50 & $\begin{array}{l}\text { Armação V V4, 52, } 29 \\
29 A, 41,40^{\circ} \text {. Fundaçẫo }\end{array}$ & $\begin{array}{l}1: 50, \\
1: 20\end{array}$ & FAU-04PE-EST-DE0323.00_00 & --- & $-\cdots$ & --- & --- & --- & --- \\
\hline 30 / out. / 1962 & 01 / mai. / 1966 & J. C Figueiredo Ferraz & 51 & $\begin{array}{l}\text { Armação Vigas 114-32- } \\
\text { 288-29b-29c-20r da } \\
\text { fundação }\end{array}$ & $\begin{array}{l}1: 50, \\
1: 20\end{array}$ & FAU-04PE-EST-DE0324.00_00 & --- & $-\cdots$ & modificado em maio 1966 & FPE e.1 & $-\cdots$ & --- \\
\hline 29 / out. / 1962 & --- & J. C Figueiredo Ferraz & 52 & $\begin{array}{l}\text { Arm. Vigas 13*, 29*, } \\
29^{* *}, 96,100,121,126, \\
124,132,102,103,104\end{array}$ & $\begin{array}{l}1: 50, \\
1: 20\end{array}$ & FAU-04PE-EST-DE0325.00_00 & --- & --- & --- & --- & --- & --- \\
\hline
\end{tabular}




\begin{tabular}{|c|c|c|c|c|c|c|c|c|c|c|c|c|}
\hline \multicolumn{6}{|c|}{ Dados do carimbo } & \multicolumn{4}{|c|}{ Sistematização } & \multicolumn{3}{|c|}{$\begin{array}{l}\text { Localizacão dos Arquivos } \\
\text { Biblioteca FAU }\end{array}$} \\
\hline Data & Modificação & Autor & Folha & Título & Escala & Vol. & $\begin{array}{l}\text { Tipo } \\
\text { desenho }\end{array}$ & $\begin{array}{l}\text { Pav./ } \\
\text { Vista }\end{array}$ & Obs. & $\begin{array}{l}\text { Cópias (PE } \\
\text { AR78/727.3) }\end{array}$ & $\begin{array}{l}\text { Originais }(P \\
\text { AR78/727.3) }\end{array}$ & PDF (727.3) \\
\hline--- & --- & J. C Figueiredo Ferraz & 68 & $\begin{array}{l}\text { Arm. das nervuras do } \\
\text { bloco B }\end{array}$ & $\cdots$ & FAU-04PE-EST-DE0326.00_00 & -- & -- & --- & -- & -- & -- \\
\hline $31 /$ jan. / 1963 & $01 /$ mai. / 1966 & J. C Figueiredo Ferraz & 78 & $\begin{array}{l}\text { Armação viga } 302 \mathrm{C} \text { e } \\
\text { nervura } 303 \mathrm{C} \text { Bloco } \mathrm{C}\end{array}$ & $\begin{array}{l}1: 50, \\
1: 20\end{array}$ & FAU-04PE-EST-DE0327.00_00 & --- & -- & Modificado em maio de 1966 & FPE $e .1$ & $\cdots$ & --- \\
\hline 01 / mai. / 1966 & -- & J. C Figueiredo Ferraz & 102 & 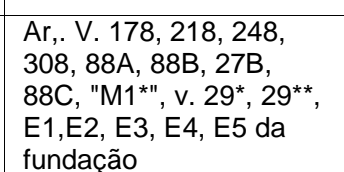 & $\begin{array}{l}1: 50, \\
1: 25, \\
1: 20\end{array}$ & FAU-04PE-EST-DE0328.00_00 & --- & --- & --- & --- & --- & --- \\
\hline--- & -- / set. / 1966 & J. C Figueiredo Ferraz & 79 & Armaçăo da viga $301 \mathrm{C}$ & $\begin{array}{l}1: 50, \\
1: 20\end{array}$ & FAU-04PE-EST-DE0329.00_00 & --- & --- & modificado em setembro de 1966 & FPE $e .1$ & --- & --- \\
\hline$--/$ set. / 1966 & $\cdots$ & J. C Figueiredo Ferraz & 104 & Armação viga 101A & $\begin{array}{l}1: 50, \\
1: 20\end{array}$ & FAU-04PE-EST-DE0330.00_00 & --- & --- & --- & $-\cdots$ & --- & --- \\
\hline-- / set. / 1966 & --- & J. C Figueiredo Ferraz & 105 & Armação viga 102A & $\begin{array}{l}1: 50, \\
1: 20\end{array}$ & FAU-04PE-EST-DE0331.00_00 & --- & --- & --- & FPE e.1 & --- & --- \\
\hline-- / set. / 1966 & -- & J. C Figueiredo Ferraz & 106 & Armação viga 105A & $\begin{array}{l}1: 50, \\
1: 20\end{array}$ & FAU-04PE-EST-DE0332.00_00 & -- & 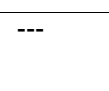 & $\cdots$ & FPE 0.1 & --- & -- \\
\hline$--/$ nov. / 1966 & --- & J. C Figueiredo Ferraz & 107 & Armação viga 301C & $\begin{array}{l}1: 50, \\
1: 20\end{array}$ & FAU-04PE-EST-DE0333.00_00 & --- & --- & --- & FPE e.1 & --- & --- \\
\hline --/ out. / 1966 & $\cdots$ & J. C Figueiredo Ferraz & 108 & $\begin{array}{l}\text { Armação viga } 301 \mathrm{C} \\
302 \mathrm{C} \text { e N } 303 \mathrm{C}\end{array}$ & $\begin{array}{l}\text { 1:50, } \\
1: 20\end{array}$ & FAU-04PE-EST-DE0334.00_00 & --- & --- & --- & FPE e.1 & --- & --- \\
\hline$--/$ jan. / 1968 & -- & J. C Figueiredo Ferraz & 131 & $\begin{array}{l}\text { Armação das vigas da } \\
\text { cobertura }\end{array}$ & $\begin{array}{l}1: 50, \\
1: 20\end{array}$ & FAU-04PE-EST-DE0335.00_01 & --- & --- & Esta folha anula e substitui a 109 & & --- & --- \\
\hline 25 / abr. / 1967 & --- & J. C Figueiredo Ferraz & 120 & $\begin{array}{l}\text { Armação vigas das } \\
\text { fundaçôes V95A, V95B, } \\
\operatorname{det} A\end{array}$ & $1: 20$ & FAU-04PE-EST-DE0336.00_00 & -- & --- & --- & FPE $e .1$ & --- & --- \\
\hline$--/$ mai. / 1967 & -- & J. C Figueiredo Ferraz & 121 & $\begin{array}{l}\text { Armacão p25-p34A } \\
\text { V115-V23 }\end{array}$ & $\begin{array}{l}1: 50, \\
1: 25\end{array}$ & FAU-04PE-EST-DE0337.00_00 & --- & --- & --- & FPE e.1 & --- & --- \\
\hline$--/$ mai. / 1967 & $\cdots$ & J. C Figueiredo Ferraz & 122 & $\begin{array}{l}\text { Rampa do } 1^{\circ} \text { ao } 2^{\circ} \\
\text { subsolo. Armacâo } \\
\text { rampa e nervurasas }\end{array}$ & $\begin{array}{l}1: 50, \\
1: 20\end{array}$ & FAU-04PE-EST-DE0338.00_00 & --- & -- & --- & -- & --- & --- \\
\hline$--/$ fev. / 1968 & -- & J. C Figueiredo Ferraz & 132 & $\begin{array}{l}\text { Armação das vigas da } \\
\text { cobertura }\end{array}$ & $\begin{array}{l}1: 50, \\
1: 20\end{array}$ & FAU-04PE-EST-DE0339.00_00 & --- & --- & --- & --- & --- & --- \\
\hline 14 / jan. / 1963 & --- & J. C Figueiredo Ferraz & 61 & $\begin{array}{l}\text { Armação dos pilares: } \\
\text { p23, p25, 204, p33, p26 } \\
\text { (da fundacâao a } \\
\text { cobertruara) }\end{array}$ & $\begin{array}{l}1: 50, \\
1: 25\end{array}$ & FAU-04PE-EST-DE0341.00_00 & --- & --- & --- & FPE e.1 & --- & --- \\
\hline-- / out. / 1966 & $--\cdot$ & J. C Figueiredo Ferraz & $61 \mathrm{~A}$ & $\begin{array}{l}\text { Armacão dos pilares: } \\
\text { p23, p24, p25, p26, p33 }\end{array}$ & $\begin{array}{l}1: 50, \\
1: 25\end{array}$ & FAU-04PE-EST-DE0341.00_01 & -- & --- & --- & FPE e.1 & --- & --- \\
\hline 12 / jan. / 1966 & --- & J. C Figueiredo Ferraz & 62 & $\begin{array}{l}\text { Armação dos pilares: } \\
\text { p6, p7 p8, p9, p10 p11 } \\
\text { p12, p13, p14, p17, p18, } \\
\text { p19, p20, p21, p22 } \\
\text { (tundação a cobertura) }\end{array}$ & $\begin{array}{l}1: 50, \\
1: 25\end{array}$ & FAU-04PE-EST-DE0342.00_00 & $\cdots$ & $\cdots$ & --- & FPE e.1 & $\cdots$ & --- \\
\hline -- / out. / 1966 & --- & J. C Figueiredo Ferraz & $62 \mathrm{~A}$ & 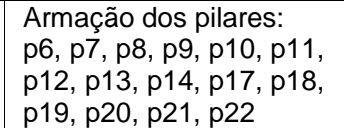 & $\begin{array}{l}1: 50, \\
1: 25\end{array}$ & FAU-04PE-EST-DE0342.00_01 & --- & --- & substitui o desenho 62 & FPE e.1 & --- & --- \\
\hline $16 /$ jan. / 1963 & --- & J. C Figueiredo Ferraz & 63 & $\begin{array}{l}\text { Armação dos pilares: } \\
\text { p27, p28, p29, p30, p31, } \\
\text { p32, p37, p38, p39, p40, } \\
\text { p41, p42, p43, p44, p45 }\end{array}$ & $\begin{array}{l}1: 50, \\
1: 25\end{array}$ & FAU-04PE-EST-DE0343.00_00 & --- & --- & --- & FPE e.1 & --- & --- \\
\hline
\end{tabular}




\begin{tabular}{|c|c|c|c|c|c|c|c|c|c|c|c|c|}
\hline \multicolumn{6}{|c|}{ Dados do carimbo } & \multicolumn{4}{|c|}{ Sistematização } & \multicolumn{3}{|c|}{$\begin{array}{l}\text { Localização dos Arquivos } \\
\text { Biblioteca FAU }\end{array}$} \\
\hline Data & Modificação & Autor & Folha & Título & Escala & Vol. & $\begin{array}{l}\text { Tipo } \\
\text { desenho }\end{array}$ & $\begin{array}{l}\text { Pav./ } \\
\text { Vista }\end{array}$ & Obs. & $\begin{array}{l}\text { Cópias (PE } \\
\text { AR78/727.3) }\end{array}$ & $\begin{array}{l}\text { Originais }(P \\
\text { AR78/727.3) }\end{array}$ & PDF (727.3) \\
\hline-- / out. / 1966 & --- & J. C Figueiredo Ferraz & $63^{A}$ & $\begin{array}{l}\text { Armação dos pilares: } \\
\text { p27, 228, p29, p30, p31, } \\
\text { p32, p37, p38, p39, p40, } \\
\text { p41, p42, p43, p44, p45 }\end{array}$ & $\begin{array}{l}1: 50, \\
1: 25\end{array}$ & FAU-04PE-EST-DE0343.00_01 & $-\cdots$ & $\cdots$ & $\cdots$ & FPE e.1 & --- & $-\cdots$ \\
\hline 06 / mai. / 1963 & $-\cdots$ & J. C Figueiredo Ferraz & $98 \mathrm{~A}$ & 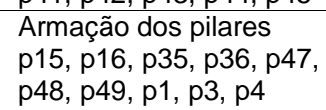 & $1: 25,1: 5$ & \begin{tabular}{|l|} 
FAU-04PE-EST-DE0344.00_01 \\
\end{tabular} & $-\cdots$ & --- & Substitui a folha 98. & & --- & --- \\
\hline--- & --- & J. C Figueiredo Ferraz & $98 \mathrm{~B}$ & 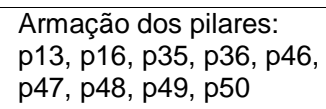 & $1: 25$ & FAU-04PE-EST-DE0344.00_02 & $-\cdots$ & --- & Substitui e anula as folhas $98 \mathrm{~A}$ e 101. & FPE e.1/ e.2 & F $1966 \mathrm{v} .2$ & F 1966 p.16 \\
\hline 14 / mai. / 1963 & $-\cdots$ & J. C Figueiredo Ferraz & 101 & $\begin{array}{l}\text { Armação dos pilares } \\
\mathrm{p} 46=\mathrm{p} 50, \mathrm{p} 1=\mathrm{p} 5\end{array}$ & 1:25 & FAU-04PE-EST-DE0345.00_00 & --- & --- & --- & $\cdots$ & --- & --- \\
\hline$--/$ out. / 1966 & $-\cdots$ & J. C Figueiredo Ferraz & $101 \mathrm{~A}$ & $\begin{array}{l}\text { Armação dos pilares } \mathrm{p} 1, \\
\mathrm{p2}, \mathrm{p3}, \mathrm{p} 4, \mathrm{p} 5\end{array}$ & $\begin{array}{l}1: 50, \\
1: 25\end{array}$ & FAU-04PE-EST-DE0345.00_01 & $-\cdots$ & --- & Substitui e anula as folhas $98 \mathrm{~A}$ e 101. & FPE e.1/ e.2 & F 1966 v.2 & F 1966 p.15 \\
\hline$--/$ dec. / 1967 & $-\cdots$ & J. C Figueiredo Ferraz & 130 & $\begin{array}{l}\text { Armação dos pilares: } \\
\text { p1, p2, p3, p4, p5 }\end{array}$ & 1:25 & FAU-04PE-EST-DE0345.00_02 & $-\cdots$ & --- & $\begin{array}{l}\text { A partir daqui, muda o carimbo da JCFF, } \\
\text { que passa a constar no número da obra } \\
\text { (01-328). }\end{array}$ & FPE e.1/ e.2 & F 1967 & F 1967 p.08 \\
\hline$--/$ out. / 1966 & $-\cdots$ & J. C Figueiredo Ferraz & 111 & $\begin{array}{l}\text { Armação dos pilares: } \\
\text { elevador e p. } 34\end{array}$ & $\begin{array}{l}1: 50, \\
1: 20\end{array}$ & FAU-04PE-EST-DE0346.00_00 & $-\cdots$ & --- & --- & --- & --- & --- \\
\hline $31 /$ jan. / 1963 & $08 /$ abr. / 1963 & J. C Figueiredo Ferraz & 89 & $\begin{array}{l}\text { Armação das paredes I } \\
\text { e II }\end{array}$ & 1:50 & FAU-04PE-EST-DE0351.00_00 & $-\cdots$ & $\cdots$ & Nota: "modificado em 8/4/63". & $\cdots$ & $\cdots$ & --- \\
\hline$--/$ jan. / 1967 & $\cdots$ & J. C Figueiredo Ferraz & 115 & Armação da parede I & $\begin{array}{l}1: 50, \\
1: 20\end{array}$ & FAU-04PE-EST-DE0351.01_00 & $-\cdots$ & $\cdots$ & $\begin{array}{l}\text { Contém duas cópias no original. Uma } \\
\text { delas com um carimbo: Diegoo ododriguez } \\
\text { Ruiz Construç̧os (largo Paissandu, } 72 \\
\text { sala 410) }\end{array}$ & FPE e.1/ e.2 & F 1967 & F 1967 p.06 \\
\hline--- & --- & J. C Figueiredo Ferraz & $115 \mathrm{~A}$ & Armação da parede I & $\begin{array}{l}1: 50, \\
1: 20\end{array}$ & FAU-04PE-EST-DE0351.01_01 & --- & --- & Nota: "esta folha substitui a n. 115" & --- & --- & --- \\
\hline$--/$ jan. / 1967 & --- & J. C Figueiredo Ferraz & 116 & Armação da parede II & $\begin{array}{l}1: 50, \\
1: 25\end{array}$ & FAU-04PE-EST-DE0351.02_00 & --- & $\cdots$ & --- & --- & --- & --- \\
\hline$--/$ jan. / 1967 & --- & J. C Figueiredo Ferraz & 114 & $\begin{array}{l}\text { Armação das paredes III } \\
\text { e IV }\end{array}$ & 1:50 & FAU-04PE-EST-DE0352.00_00 & --- & $-\cdots$ & --- & $\cdots$ & --- & --- \\
\hline$--/$ dec. / 1966 & $\cdots$ & J. C Figueiredo Ferraz & $3 A$ & $\begin{array}{l}\text { Armação dos cabeçotes } \\
\text { dos tubulueses e } \\
\text { artanques de pilares }\end{array}$ & 1:20 & FAU-04PE-EST-DE0361.00_01 & $-\cdots-$ & --- & $\begin{array}{l}\text { nota: "esta folha anula e substitui a folha } \\
\text { 3" }\end{array}$ & FPE e.1 & --- & --- \\
\hline $07 /$ dec. / 1962 & 01 / mai. / 1966 & J. C Figueiredo Ferraz & 53 & Arm. Muros arrimo & 1:25 & FAU-04PE-EST-DE0362.00_00 & --- & --- & Modificado em maio de 1966 & --- & --- & --- \\
\hline 13/ dec. / 1962 & $01 /$ mai. / 1966 & J. C Figueiredo Ferraz & 54 & $\begin{array}{l}\text { Armação } \mathrm{m} \text {. arrimo } \\
\text { consolos e blocos. } \\
\text { Fundaçăo }\end{array}$ & $\begin{array}{l}1: 50, \\
1: 25\end{array}$ & FAU-04PE-EST-DE0363.00_00 & $-\cdots$ & $\cdots$ & modificado em maio de 1966 & --- & --- & --- \\
\hline $20 /$ dec. / 1962 & $-\cdots$ & J. C Figueiredo Ferraz & 55 & Arm. Escadas e muros & $\begin{array}{l}1: 50, \\
1: 25\end{array}$ & FAU-04PE-EST-DE0364.00_00 & --- & --- & --- & $\cdots$ & --- & --- \\
\hline $27 /$ dec. / 1962 & $-\cdots$ & J. C Figueiredo Ferraz & 57 & $\begin{array}{l}\text { Armadura da escada do } \\
\text { blocon no nível-300 até } \\
+80 \text { (lado direito) }\end{array}$ & $\begin{array}{l}1: 50, \\
1: 25, \\
1: 10\end{array}$ & FAU-04PE-EST-DE0366.00_00 & $-\cdots-$ & $\cdots-$ & $-\cdots-$ & $\cdots$ & --- & $\cdots$ \\
\hline--- & --- & J. C Figueiredo Ferraz & 103 & $\begin{array}{l}\text { Armação das lajes e } \\
\text { vigas da fundação }\end{array}$ & $-\cdots$ & FAU-04PE-EST-DE0367.00_00 & --- & $\cdots$ & --- & --- & --- & -- \\
\hline $30 /$ jan. / 1963 & $\cdots$ & J. C Figueiredo Ferraz & 97 & Arm. Caixa d’água & $1: 20$ & FAU-04PE-EST-DE0371.00_00 & $-\cdots$ & --- & --- & --- & --- & --- \\
\hline-- & --- & J. C Figueiredo Ferraz & 99 & $\begin{array}{l}\text { Arm. Das escadas e } \\
\text { detalhes de emendas }\end{array}$ & 1:25 & FAU-04PE-EST-DE0372.00_00 & Planta, corte & --- & --- & --- & --- & --- \\
\hline
\end{tabular}




\begin{tabular}{|c|c|c|c|c|c|c|c|c|c|c|c|c|}
\hline \multicolumn{6}{|c|}{ Dados do carimbo } & \multicolumn{4}{|c|}{ Sistematização } & \multicolumn{3}{|c|}{$\begin{array}{l}\text { Localizacãa dos Arquivos } \\
\text { Biblioteca FAU }\end{array}$} \\
\hline Data & Modificação & Autor & Folha & Titulo & Escala & Vol. & $\begin{array}{l}\text { Tipo } \\
\text { desenho }\end{array}$ & $\begin{array}{l}\text { Pav./ } \\
\text { Vista }\end{array}$ & Obs. & $\begin{array}{l}\text { Cópias (PE } \\
\text { AR78/727.3) }\end{array}$ & $\begin{array}{l}\text { Originais (P } \\
\text { AR78/727.3) }\end{array}$ & PDF (727.3) \\
\hline 23/ jan. / 1963 & 01 / mai. / 1966 & J. C Figueiredo Ferraz & 64 & $\begin{array}{l}\text { Armação vigas escada e } \\
\text { banco do bloco A }\end{array}$ & $\begin{array}{l}1: 50 \\
1: 20\end{array}$ & FAU-04PE-EST-DE0373.00_00 & & $--\cdot$ & modificado em maio de 1966 & FPE e.1 & --- & --- \\
\hline--- & $\cdots$ & J. C Figueiredo Ferraz & $\cdots$ & Detalhe de ferragens & $\cdots$ & FAU-04PE-EST-DE0380.00_00 & Detalhe & --- & $\begin{array}{l}\text { carimbo muito claro... ilegivel ou em } \\
\text { branco }\end{array}$ & FPE e.1 & --- & --- \\
\hline--- & --- & J. C Figueiredo Ferraz & --- & --- & --- & FAU-04PE-EST-DE0381.00_X & $-\cdots-$ & --- & $\begin{array}{l}\text { Carimbo em branco. Contém duas } \\
\text { plantas em 1:200, das nervuras das } \\
\text { lajes, ealguns cortes com detalhes das } \\
\text { ferragens. Possui tabela quantificativa de } \\
\text { ferros }\end{array}$ & --- & Fv.1 & F p.06 \\
\hline 02 / jan. / 1963 & $01 /$ mai. / 1966 & J. C Figueiredo Ferraz & 58 & $\begin{array}{l}\text { Detalhe das nervuras do } \\
\text { bloco A no nível }+80 \\
\text { (lados esq e dir) }\end{array}$ & $1: 50$ & FAU-04PE-EST-DE0402.11_00 & Planta & 0 & modificado em maio de 1966 & FPE e.1 & --- & --- \\
\hline $02 /$ jan. / 1963 & 01 / mai. / 1966 & J. C Figueiredo Ferraz & 59 & $\begin{array}{l}\text { Detalhe das nervuras do } \\
\text { bloco A no nível } 80 \\
\text { (lados esq e dir) }\end{array}$ & 1:50 & FAU-04PE-EST-DE0402.12_00 & Planta & 0 & modificado em maio de 1966 & FPE e.1 & $\cdots$ & --- \\
\hline 02 / jan. / 1963 & 01 / mai. / 1966 & J. C Figueiredo Ferraz & 60 & $\begin{array}{l}\text { Detalhe das nervuras do } \\
\text { bloco } A \text { no nivel }+80 \\
\text { (lados esq e dir) }\end{array}$ & 1:50 & FAU-04PE-EST-DE0402.13_00 & Planta & 0 & modificado em maio de 1966 & FPE e.1 & --- & --- \\
\hline $30 /$ jan. / 1963 & 06 / set. / 1966 & J. C Figueiredo Ferraz & 65 & $\begin{array}{l}\text { Detalhe das vigas do } \\
\text { bloco } A \text { no nivel }+80 \\
\text { (lados esq e dir) }\end{array}$ & 1:50 & FAU-04PE-EST-DE0402.14_00 & --- & 0 & modificado em 6/9/1966 & FPE e.1 & --- & --- \\
\hline $30 /$ jan. / 1963 & 05 / set. / 1966 & J. C Figueiredo Ferraz & 66 & $\begin{array}{l}\text { Detalhe das vigas do } \\
\text { bloco } A \text { no nivel }+80 \\
\text { (lados direito) }\end{array}$ & 1:50 & FAU-04PE-EST-DE0402.15_00 & --- & 0 & modificado em 5/9/1966 & FPE e.1 & --- & 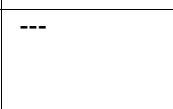 \\
\hline 15 / jan. / 1963 & --- & J. C Figueiredo Ferraz & 69 & $\begin{array}{l}\text { Detalhas das nervuras } \\
\ldots \text { no nivel }+270 \\
\text { (lados...) }\end{array}$ & $1: 50$ & FAU-04PE-EST-DE0402.21_00 & $\cdots$ & 0 & Carimbo rasgado, não é possível ler tudo & & --- & --- \\
\hline--- & --- & J. C Figueiredo Ferraz & 70 & $\begin{array}{l}\text { Detalhas das nervuras } \\
\text { do bloco } 8 \text { no nivel }+270 \\
\text { (lado direito) }\end{array}$ & 1:50 & FAU-04PE-EST-DE0402.22_00 & $-\cdots-$ & 0 & --- & --- & --- & --- \\
\hline--- & $\cdots$ & J. C Figueiredo Ferraz & 71 & $\begin{array}{l}\text { Detalhas das nervuras } \\
\text { do bloco B no nivel }+270 \\
\text { (lados esq e e dir.) }\end{array}$ & $\begin{array}{l}1: 50, \\
1: 20\end{array}$ & FAU-04PE-EST-DE0402.23_00 & 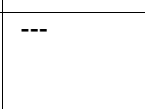 & 0 & --- & $\cdots$ & --- & $\cdots$ \\
\hline 08 / jan. / 1963 & --- & J. C Figueiredo Ferraz & 72 & $\begin{array}{l}\text { Detalhas das vigas e } \\
\text { nervuras do bloco B no } \\
\text { nivel }+270 \text { (lados esq. e } \\
\text { dir.) }\end{array}$ & $1: 50$ & FAU-04PE-EST-DE0402.24_00 & --- & 0 & --- & --- & $-\cdots$ & --- \\
\hline--- & --- & J. C Figueiredo Ferraz & 73 & $\begin{array}{l}\text { Detalhas das nervuras } \\
\text { do bloco B no nivel }+270 \\
\text { (lados esq. e dir.) }\end{array}$ & $\begin{array}{l}1: 50, \\
1: 20\end{array}$ & FAU-04PE-EST-DE0402.25_00 & $\cdots$ & 0 & --- & --- & --- & --- \\
\hline $30 /$ jan. / 1963 & $04 /$ nov. / 1966 & J. C Figueiredo Ferraz & 74 & $\begin{array}{l}\text { Detalhes das vigas do } \\
\text { bloco } B \text { no nível }+270\end{array}$ & 1:50 & FAU-04PE-EST-DE0402.26_00 & --- & 0 & modificado em 4/11/1966 & $\cdots$ & $\cdots$ & --- \\
\hline $30 /$ jan. / 1963 & 01 / set. / 1966 & J. C Figueiredo Ferraz & 75 & $\begin{array}{l}\text { Detalhes da armacăo da } \\
\text { viga 202-B (nivel 270) }\end{array}$ & $\begin{array}{l}1: 50, \\
1: 25\end{array}$ & FAU-04PE-EST-DE0402.27_00 & --- & 0 & modificado em setembro de 1966 & --- & $\cdots$ & --- \\
\hline 09 / jan. / 1963 & $01 /$ mai. / 1966 & J. C Figueiredo Ferraz & 76 & $\begin{array}{l}\text { Detalhas (sic) das } \\
\text { nervuras do bloco C no } \\
\text { nível }+460 \text { (lado esq e } \\
\text { dir) }\end{array}$ & 1:50 & FAU-04PE-EST-DE0403.11_00 & Planta & 1 & modificado em maio de 1966 & FPE e.1 & $\cdots$ & $\cdots$ \\
\hline--- & --- & J. C Figueiredo Ferraz & 77 & $\begin{array}{l}\text { Detalhas (sic) das } \\
\text { nervuras do bloco } \mathrm{C} \text { no } \\
\text { nivel }+460 \text { (lado esq e } \\
\text { dir) }\end{array}$ & $\begin{array}{l}1: 50, \\
1: 20\end{array}$ & FAU-04PE-EST-DE0403.12_00 & Detalhe & 1 & --- & FPE e.1 & $\cdots$ & --- \\
\hline--- & $01 /$ mai. / 1966 & J. C Figueiredo Ferraz & 80 & $\begin{array}{l}\text { Detalhas (sic) das } \\
\text { nervuras do bloco C no } \\
\text { nivel }+460 \text { (lado esq e } \\
\text { dir) }\end{array}$ & $1: 50$ & FAU-04PE-EST-DE0403.13_00 & Detalhe & 1 & modificado em maio de 1966 & FPE e.1 & $-\cdots$ & $\cdots$ \\
\hline--- & --- & J. C Figueiredo Ferraz & 81 & $\begin{array}{l}\text { Detalhas das nervuras } \\
\text { do bloco D no nivel } \\
+650 \text { (lados esq. e dir.) }\end{array}$ & $1: 50$ & FAU-04PE-EST-DE0403.21_00 & --- & 1 & --- & --- & --- & --- \\
\hline
\end{tabular}




\begin{tabular}{|c|c|c|c|c|c|c|c|c|c|c|c|c|}
\hline \multicolumn{6}{|c|}{ Dados do carimbo } & \multicolumn{4}{|c|}{ Sistematização } & \multicolumn{3}{|c|}{$\begin{array}{l}\text { Localizacão dos Arquivos } \\
\text { Biblioteca FAU }\end{array}$} \\
\hline Data & Modificação & Autor & Folha & Título & Escala & Vol. & $\begin{array}{l}\text { Tipo } \\
\text { desenho }\end{array}$ & $\begin{array}{l}\text { Pav. I } \\
\text { Vista }\end{array}$ & Obs. & $\begin{array}{l}\text { Cópias (PE } \\
\text { AR78/727.3) }\end{array}$ & $\begin{array}{l}\text { Originais }(P \\
\text { AR78/727.3) }\end{array}$ & PDF (727.3) \\
\hline-- & $01 /$ mai. / 1966 & J. C Figueiredo Ferraz & 82 & $\begin{array}{l}\text { Detalhas das nervuras } \\
\text { do boloco D no nível } \\
+650 \text { (lados esq. edir.) }\end{array}$ & $\begin{array}{l}1: 50, \\
1: 20\end{array}$ & FAU-04PE-EST-DE0403.22_00 & -- & 1 & modificado em maio de 1966 & -- & --- & -- \\
\hline--- & $\cdots$ & J. C Figueiredo Ferraz & 83 & $\begin{array}{l}\text { Detalhas das nervuras } \\
\text { do bloco D no nivel } \\
+650 \text { (lados esque dir) }\end{array}$ & $1: 50$ & FAU-04PE-EST-DE0403.23_00 & --- & 1 & --- & --- & --- & --- \\
\hline--- & 01 / out. / 1966 & J. C Figueiredo Ferraz & 84 & $\begin{array}{l}\text { Detalhes das vigas do } \\
\text { bloco D n n nivel la } 650 \\
\text { (lados esq. e dir.) }\end{array}$ & $1: 50$ & FAU-04PE-EST-DE0403.24_00 & --- & 1 & modificado em outubro de 1966 & --- & --- & --- \\
\hline--- & -- / out. / 1966 & J. C Figueiredo Ferraz & 85 & $\begin{array}{l}\text { Detalhas das vigas e } \\
\text { nervuras do bloco } \mathrm{D} \text { no } \\
\text { nivel }+650 \text { (lados esq. e } \\
\text { dir.) }\end{array}$ & 1:50 & FAU-04PE-EST-DE0403.25_00 & --- & 1 & modificado em outubro de 1966 & --- & --- & --- \\
\hline--- & --- & J. C Figueiredo Ferraz & 86 & $\begin{array}{l}\text { Detilhes das nervuras } \\
\text { do bloco E no nível }+840 \\
\text { (lado esq. e dir.) }\end{array}$ & $\begin{array}{l}1: 50 \\
1: 20\end{array}$ & FAU-04PE-EST-DE0404.11_00 & --- & 2 & --- & --- & --- & --- \\
\hline--- & $-\cdots$ & J. C Figueiredo Ferraz & 87 & $\begin{array}{l}\text { Detalhes das vigas e } \\
\text { nervuras do bloco E no } \\
\text { nivel }+840 \text { (lados esq. e } \\
\text { dir.) }\end{array}$ & 1:50 & FAU-04PE-EST-DE0404.12_00 & --- & 2 & --- & $-\cdots$ & --- & --- \\
\hline--- & -- / out. / 1966 & J. C Figueiredo Ferraz & 88 & $\begin{array}{l}\text { Detalhas (sic) das vigas } \\
\text { e nervuras do bloco } \mathrm{E} \\
\text { no nivel }+840 \text { (lado esq } \\
\text { e dirr) }\end{array}$ & 1:50 & FAU-04PE-EST-DE0404.13_00 & --- & 2 & modificado em outubro de 1966 & --- & --- & --- \\
\hline--- & --- & J. C Figueiredo Ferraz & 91 & $\begin{array}{l}\text { Detalhas das nervuras } \\
\text { do bloco } F \text { no nivel } \\
+1030 \text { (lados esq. e dir.) }\end{array}$ & 1:50 & FAU-04PE-EST-DE0404.21_00 & --- & 2 & --- & --- & --- & --- \\
\hline--- & --- & J. C Figueiredo Ferraz & 92 & $\begin{array}{l}\text { Detalhes das nervuras } \\
\text { do bloco F no nivel } \\
+1030 \text { (lados esq. e dir.) }\end{array}$ & $\begin{array}{l}1: 50, \\
1: 20\end{array}$ & FAU-04PE-EST-DE0404.22_00 & --- & 2 & --- & --- & --- & --- \\
\hline--- & --- & J. C Figueiredo Ferraz & 93 & $\begin{array}{l}\text { Detalhes das vigas e } \\
\text { nervuras do bloco F no } \\
\text { nível +1030 (lados esq. } \\
\text { e dir.) }\end{array}$ & $\begin{array}{l}1: 50, \\
1: 20\end{array}$ & FAU-04PE-EST-DE0404.23_00 & --- & 2 & 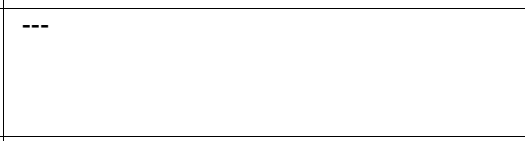 & --- & --- & --- \\
\hline $30 /$ jan. / 1963 & 01/ mai. / 1966 & J. C Figueiredo Ferraz & 67 & $\begin{array}{l}\text { Detalhes: viga 109A } \\
\text { protendida }\end{array}$ & $\begin{array}{l}1: 50, \\
1: 25, \\
1: 5,1: 1\end{array}$ & FAU-04PE-EST-DE0411_00 & Detalhe & --- & modificado em maio de 1966 & FPE e.1 & --- & --- \\
\hline 28 / jan. / 1963 & 01/ mai. / 1966 & J. C Figueiredo Ferraz & 94 & $\begin{array}{l}\text { Detalhes: vigas concreto } \\
\text { protendido tipos } A \text { e B }\end{array}$ & $\begin{array}{l}1: 50, \\
1: 25, \\
1: 5,1: 1\end{array}$ & FAU-04PE-EST-DE0412_00 & Detalhe & --- & modificado em maio de 1966 & FPE e.1 & --- & --- \\
\hline 24 / jan. / 1963 & -- & J. C Figueiredo Ferraz & 95 & $\begin{array}{l}\text { Detalhes: vigas conc. } \\
\text { Prot. Rampa }\end{array}$ & $\begin{array}{l}1: 50, \\
1: 25, \\
1: 5,1: 1\end{array}$ & FAU-04PE-EST-DE0413_00 & --- & --- & Rampa em concreto protendido & --- & --- & --- \\
\hline 19 / jun. / 1967 & --- & J. C Figueiredo Ferraz & 125 & $\begin{array}{l}\text { Fôrmas e alojamento } \\
\text { dos cabos } / \text { viga } \\
\text { protendida rampa }\end{array}$ & $1: 10,1: 5$ & FAU-04PE-EST-DE0414_00 & --- & --- & $\cdots$ & FPE e.1 & --- & --- \\
\hline 16 / ago. / 1967 & --- & J. C Figueiredo Ferraz & 128 & $\begin{array}{l}\text { Vigas protendidas } \\
\text { (rampa plano de } \\
\text { concretagem }\end{array}$ & $\begin{array}{l}\text { 1:100, } \\
1: 50, \\
1: 10\end{array}$ & FAU-04PE-EST-DE0415_00 & --- & --- & $\cdots$ & --- & --- & --- \\
\hline$--/$ set. / 1967 & --- & J. C Figueiredo Ferraz & $129 \mathrm{~A}$ & $\begin{array}{l}\text { Detalhe da junta dos } \\
\text { pilares } \mathrm{p3} \text {, p48 }\end{array}$ & $1: 20$ & FAU-04PE-EST-DE0421_01 & Detalhe & $\cdots$ & Substitui a folha 129. & FPE e.1/ e.2 & F 1967 & --- \\
\hline--- & --- & J. C Figueiredo Ferraz & 130 & Detalhe de concretagem & $\begin{array}{l}1: 200, \\
1: 50, \\
1: 20\end{array}$ & FAU-04PE-EST-DE0422_X & $\cdots$ & $\cdots$ & $\begin{array}{l}\text { Onúmero da folha }(130) \text { é o mesmo de } \\
\text { outra, porém o titulo é diferente. }\end{array}$ & --- & --- & --- \\
\hline 04 / jul. / 1962 & --- & $\begin{array}{l}\text { Escritório de } \\
\text { Coordenacăáo Técnica } \\
\text { Homero V. M. Lopes }\end{array}$ & 1 & Instalação hidráulica & --- & FAU-04PE-HID-DE0101.00_00 & Planta & -1 & 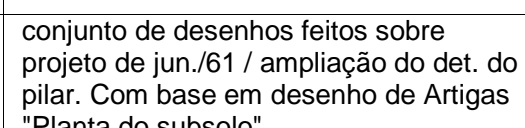 & $\begin{array}{l}\text { FHI e.1/FHI } \\
\text { e.2 }\end{array}$ & Fv.1 (1962) & F 1962 p.4 \\
\hline 04 / jul. / 1962 & --- & $\begin{array}{l}\text { Escritório de } \\
\text { Coordenacââ Técnica } \\
\text { Homero V. M. Lopes }\end{array}$ & 2 & Instalação hidráulica & $\cdots$ & FAU-04PE-HID-DE0102.00_00 & Planta & 0 & $\begin{array}{l}\text { Com base em desenho de Artigas } \\
\text { "Planta do } 1^{\circ} \text { pavimento" }\end{array}$ & $\begin{array}{l}\text { FHI e.1/FHI } \\
\text { e.2 }\end{array}$ & Fv.1 (1962) & F 1962 p.5 \\
\hline
\end{tabular}




\begin{tabular}{|c|c|c|c|c|c|c|c|c|c|c|c|c|}
\hline \multicolumn{6}{|c|}{ Dados do carimbo } & \multicolumn{4}{|c|}{ Sistematização } & \multicolumn{3}{|c|}{$\begin{array}{l}\text { Localização dos Arquivos } \\
\text { Biblioteca FAU }\end{array}$} \\
\hline Data & Modificação & Autor & Folha & Título & Escala & Vol. & $\begin{array}{l}\text { Tipo } \\
\text { desenho }\end{array}$ & $\begin{array}{l}\text { Pav./ } \\
\text { vista }\end{array}$ & Obs. & $\begin{array}{l}\text { Cópias (PE } \\
\text { AR78/727.3) }\end{array}$ & $\begin{array}{l}\text { Originais }(P \\
\text { AR78/727.3) }\end{array}$ & PDF (727.3) \\
\hline 04 / jul. / 1962 & --- & $\begin{array}{l}\text { Escritório de } \\
\text { Coordenacão Técnica } \\
\text { Homero V. M. Lopes }\end{array}$ & 3 & Instalação hidráulica & --- & FAU-04PE-HID-DE0103.00_00 & Planta & 1 & $\begin{array}{l}\text { Com basee em desenhoo de Artigas } \\
\text { "Planta do 2 pavimento" }\end{array}$ & $\begin{array}{l}\text { FHI e.1/FHI } \\
\text { e.2 }\end{array}$ & Fv.1 (1962) & F 1962 p.6 \\
\hline 04 / jul. / 1962 & $-\cdots$ & $\begin{array}{l}\text { Escritório de } \\
\text { Coordenacâa Ténnica } \\
\text { Homero V. M. Lopes }\end{array}$ & 4 & Instalação hidráulica & --- & FAU-04PE-HID-DE0104.00_00 & Planta & 2 & $\begin{array}{l}\text { Com base em desenho de Artigas } \\
\text { "Planta do } 30 \text { pavimento" }\end{array}$ & $\begin{array}{l}\text { FHI e.1/FHI } \\
\text { e.2 }\end{array}$ & Fv.1 (1962) & F 1962 p.7 \\
\hline 04 / jul. / 1962 & --- & $\begin{array}{l}\text { Escritório de } \\
\text { Coordenacâa Técnica } \\
\text { Homero V. M. Lopes }\end{array}$ & 5 & Instalação hidráulica & --- & FAU-04PE-HID-DE0105.00_00 & Planta & Cobertura & $\begin{array}{l}\text { Este desenho em especial é feito sobre } \\
\text { o desenho de fev. } 62 \text {. Com base em } \\
\text { desenho de Artigas "Planta da } \\
\text { cobertura" }\end{array}$ & $\begin{array}{l}\text { FHI e.1/FHI } \\
\text { e.2 }\end{array}$ & Fv.1 (1962) & F 1962 p.8 \\
\hline 04 / jul. / 1962 & --- & $\begin{array}{l}\text { Escritório de } \\
\text { Coordenacââ Ténnica } \\
\text { Homero V. M. Lopes }\end{array}$ & 7 & Instalação hidráulica & --- & FAU-04PE-HID-DE02.00_00 & Planta & --- & 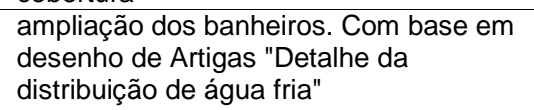 & $\begin{array}{l}\text { FHI e.1/FHI } \\
\text { e.2 }\end{array}$ & Fv.2 (1962) & F 1962 p.10 \\
\hline 04 / jul. / 1962 & --- & $\begin{array}{l}\text { Escritório de } \\
\text { Coordenacăâ Técnica } \\
\text { Homero V. M. Lopes }\end{array}$ & 6 & Instalação hidráulica & --- & FAU-04PE-HID-DE0201.00_00 & Planta & --- & $\begin{array}{l}\text { Com base em desenho de Artigas } \\
\text { "Detalhe da distribuição de esgoto" }\end{array}$ & $\begin{array}{l}\text { FHI e.1/FHI } \\
\text { e.2 }\end{array}$ & Fv.1 (1962) & F 1962 p.9 \\
\hline 04 / jul. / 1962 & --- & $\begin{array}{l}\text { Escritório de } \\
\text { Coordenacââ Ténnica } \\
\text { Homero V. M. Lopes }\end{array}$ & 9 & Instalação hidráulica & --- & FAU-04PE-HID-DE0204.00_00 & Isométrico & --- & $\begin{array}{l}\text { esquema vertical. Com base em } \\
\text { desenho de Artigas "esquema de água } \\
\text { fria" }\end{array}$ & $\begin{array}{l}\text { FHI e.1/FHI } \\
\text { e.2 }\end{array}$ & $\mathrm{Fv} .2(1962)$ & F 1962 p.12 \\
\hline 04 / jul. / 1962 & --- & $\begin{array}{l}\text { Escritório de } \\
\text { Coordenacââ Técnica } \\
\text { Homero V. M. Lopes }\end{array}$ & 10 & Instalação hidráulica & --- & FAU-04PE-HID-DE0205.00_00 & isométrico & $-\cdots$ & $\begin{array}{l}\text { esquema perspectiva. Com base em } \\
\text { desenho de Artigas "esquema de } \\
\text { esgoto" }\end{array}$ & $\begin{array}{l}\text { FHI e.1/FHI } \\
\text { e. } 2\end{array}$ & $\mathrm{Fv} .2(1962)$ & F 1962 p.13 \\
\hline 04 / jul. / 1962 & $\cdots$ & $\begin{array}{l}\text { Escritório de } \\
\text { Coordenacăa Técnica } \\
\text { Homero V. M. Lopes }\end{array}$ & 8 & Instalação hidráulica & $\cdots$ & FAU-04PE-HID-DE03.00_00 & Isométrico & $\cdots$ & $\begin{array}{l}\text { Esquema (sem planta). Com base em } \\
\text { desenho de ertrigas "sesenvolvimento do } \\
\text { encanamanto de ágau fria" }\end{array}$ & \begin{tabular}{|l} 
FHI e.1/FHI \\
e.2
\end{tabular} & Fv.2 (1962) & F 1962 p.11 \\
\hline
\end{tabular}


ANEXO V

PROCESSOS USP 



\begin{tabular}{|c|c|c|c|c|c|}
\hline \multicolumn{6}{|c|}{ Documentos em Processos USP - Ordem cronológica } \\
\hline \multirow[b]{2}{*}{ Data } & \multirow{2}{*}{$\begin{array}{c}\text { Remetente } \\
\text { Nome e Cargo }\end{array}$} & \multirow{2}{*}{$\begin{array}{l}\text { Destinatário } \\
\text { Nome e Cargo }\end{array}$} & \multirow{2}{*}{$\begin{array}{l}\text { Conteúdo } \\
\text { Assunto }\end{array}$} & \multicolumn{2}{|c|}{ Processo USP } \\
\hline & & & & Número & Folhas \\
\hline $17 / 11 / 59$ & $\begin{array}{l}\text { Carlos Alberto A. de } \\
\text { Carvalho Pinto } \\
\text { Governador do Estado } \\
\text { de São Paulo }\end{array}$ & -- & $\begin{array}{l}\text { Lei n. } 5.444 \text { de } 17 \text { de novembro de 1959: } \\
\text { Dispõe sobre medidas de caráter financeiro } \\
\text { relativas ao Plano de Ação do Governo, e dá } \\
\text { outras providências }\end{array}$ & 62.1 .660 .51 .9 & $4-7$ \\
\hline $30 / 05 / 60$ & $\begin{array}{l}\text { Antônio Barros de } \\
\text { Ulhôa Cintra } \\
\text { Reitor }\end{array}$ & $\begin{array}{l}\text { José de Fetis } \\
\text { Tabarelli Neto }\end{array}$ & $\begin{array}{l}\text { Encaminha minuta do contrato individual de } \\
\text { trabalho da USP com os Srs. Eng. Manoel da } \\
\text { Silva Rodrigues, Eng. Gilberto Rocha Mello, } \\
\text { José da Silva Nora, Pranas Radasauskas, } \\
\text { Bartolomeu Gabarron e Afonso José de } \\
\text { Oliveira }\end{array}$ & 60.1 .10846 .1 .0 & $2-5$ \\
\hline $04 / 07 / 60$ & $\begin{array}{l}\text { Carlos Alberto A. de } \\
\text { Carvalho Pinto } \\
\text { Governador do Estado } \\
\text { de São Paulo }\end{array}$ & $-\cdots$ & $\begin{array}{l}\text { Decreto n. } 36.699 \text { de } 3 \text { junho de 1960: Plano } \\
\text { de Ação: Cria o Fundo de Construção da } \\
\text { Cidade Universitária "Armando de Salles } \\
\text { Oliveira" e regulamenta sua aplicação }\end{array}$ & 62.1 .660 .51 .9 & $8-11$ \\
\hline $13 / 07 / 60$ & $\begin{array}{l}\text { Carlos Alberto A. de } \\
\text { Carvalho Pinto } \\
\text { Governador do Estado } \\
\text { de São Paulo }\end{array}$ & --- & $\begin{array}{l}\text { Decreto n. } 36.959 \text { de } 13 \text { de julho de 1960: } \\
\text { Plano de Ação: Regulamenta o Artigo 5o, item } \\
\text { "b" do Decreto n. } 36.699 \text {, de } 3 \text { de junho de } \\
1960\end{array}$ & 62.1 .660 .51 .9 & $12-13$ \\
\hline $18 / 07 / 60$ & $\begin{array}{l}\text { Antônio Barros de } \\
\text { Ulhôa Cintra } \\
\text { Presidente do } \\
\text { Conselho de } \\
\text { Administração do } \\
\text { Fundo (Reitor) }\end{array}$ & $\overline{---}$ & $\begin{array}{l}\text { Portaria n.1: Delega poderes ao Diretor } \\
\text { Executivo }\end{array}$ & 60.1 .19244 .1 .2 & 7 \\
\hline $10 / 08 / 60$ & $\begin{array}{l}\text { Antônio Barros de } \\
\text { Ulhôa Cintra } \\
\text { Presidente do } \\
\text { Conselho de } \\
\text { Administração do } \\
\text { Fundo (Reitor) }\end{array}$ & $\begin{array}{l}\text { Carlos Alberto A. de } \\
\text { Carvalho Pinto } \\
\text { Governador }\end{array}$ & $\begin{array}{l}\text { Encaminha relatório de atividades do Fundo e } \\
\text { solicita autorizações para contratações }\end{array}$ & 60.1 .19244 .1 .2 & 3 \\
\hline $10 / 08 / 60$ & $\begin{array}{l}\text { Paulo de Camargo e } \\
\text { Almeida } \\
\text { Diretor Executivo do } \\
\text { Fundo }\end{array}$ & $\begin{array}{l}\text { Antônio Barros de } \\
\text { Ulhôa Cintra } \\
\text { Presidente do } \\
\text { Conselho de } \\
\text { Administração do } \\
\text { Fundo (Reitor) }\end{array}$ & Primeiro relatório das atividades do Fundo & 60.1 .19244 .1 .2 & $4-6$ \\
\hline $24 / 08 / 60$ & $\begin{array}{l}\text { Antônio Barros de } \\
\text { Ulhôa Cintra } \\
\text { Presidente do } \\
\text { Conselho de } \\
\text { Administração do } \\
\text { Fundo (Reitor) }\end{array}$ & $\overline{---}$ & $\begin{array}{l}\text { Portaria n.2: Determina autorizações para } \\
\text { contratação de serviços }\end{array}$ & 60.1 .19244 .1 .2 & 8 \\
\hline $04 / 10 / 60$ & $\begin{array}{l}\text { Paulo de Camargo e } \\
\text { Almeida } \\
\text { Diretor Executivo do } \\
\text { Fundo }\end{array}$ & $\begin{array}{l}\text { Antônio Barros de } \\
\text { Ulhôa Cintra } \\
\text { Reitor }\end{array}$ & $\begin{array}{l}\text { Encaminha cópias de documentos referentes } \\
\text { ao Fundo }\end{array}$ & 60.1 .19244 .1 .2 & 2 \\
\hline $13 / 10 / 60$ & $\begin{array}{l}\text { Antônio Barros de } \\
\text { Ulhôa Cintra } \\
\text { Presidente do } \\
\text { Conselho de } \\
\text { Administração do } \\
\text { Fundo (Reitor) }\end{array}$ & $\begin{array}{l}\text { Carlos Alberto A. de } \\
\text { Carvalho Pinto } \\
\text { Governador }\end{array}$ & $\begin{array}{l}\text { Limite de valor que necessita autorização do } \\
\text { Governador para contratação }\end{array}$ & 60.1 .19244 .1 .2 & $12-13$ \\
\hline $22 / 05 / 61$ & $\begin{array}{l}\text { Carlos Alberto } \\
\text { Felizola Freire } \\
\text { Assessor } \\
\text { Administrativo }\end{array}$ & $\begin{array}{l}\text { Américo Lourenço } \\
\text { Masset Lacombe } \\
\text { Consultor Jurídico }\end{array}$ & $\begin{array}{l}\text { Solicita parecer da CJ sobre a contratação de } \\
\text { pessoas estranhas ao serviço público pelo } \\
\text { Fundo }\end{array}$ & 62.1 .660 .51 .9 & 2 \\
\hline
\end{tabular}




\begin{tabular}{|c|c|c|c|c|c|}
\hline \multirow[b]{2}{*}{ Data } & \multirow{2}{*}{$\begin{array}{c}\text { Remetente } \\
\text { Nome e Cargo }\end{array}$} & \multirow{2}{*}{$\begin{array}{l}\text { Destinatário } \\
\text { Nome e Cargo }\end{array}$} & \multirow{2}{*}{$\begin{array}{l}\text { Conteúdo } \\
\text { Assunto }\end{array}$} & \multicolumn{2}{|c|}{ Processo USP } \\
\hline & & & & Número & Folhas \\
\hline $22 / 05 / 61$ & $\begin{array}{l}\text { Américo Lourenço } \\
\text { Masset Lacombe } \\
\text { Consultor Jurídico }\end{array}$ & $\begin{array}{l}\text { Carlos Alberto } \\
\text { Felizola Freire } \\
\text { Assessor } \\
\text { Administrativo }\end{array}$ & $\begin{array}{l}\text { Esclarece que os contratos devem ser CLT e } \\
\text { não é necessário contrato escrito }\end{array}$ & 62.1 .660 .51 .9 & $3-4$ \\
\hline $22 / 11 / 62$ & $\begin{array}{l}\text { Carlos Alberto } \\
\text { Felizola Freire } \\
\text { Assessor } \\
\text { Administrativo }\end{array}$ & $\begin{array}{l}\text { Américo Lourenço } \\
\text { Masset Lacombe } \\
\text { Consultor Jurídico }\end{array}$ & $\begin{array}{l}\text { Consulta sobre continuidade dos contratos e } \\
\text { do próprio Fundo, uma vez que os } \\
\text { dispositivos legais que regulamentam o } \\
\text { Fundo é válido até } 31 / 12 / 1962\end{array}$ & 62.1 .660 .51 .9 & 14 \\
\hline $26 / 11 / 62$ & $\begin{array}{l}\text { Américo Lourenço } \\
\text { Masset Lacombe } \\
\text { Consultor Jurídico }\end{array}$ & $\begin{array}{l}\text { Carlos Alberto } \\
\text { Felizola Freire } \\
\text { Assessor } \\
\text { Administrativo }\end{array}$ & $\begin{array}{l}\text { Responde que o Fundo não será extinto e } \\
\text { que os contratos são por prazo indeterminado }\end{array}$ & 62.1 .660 .51 .9 & $15-17$ \\
\hline $03 / 12 / 62$ & $\begin{array}{l}\text { Paulo de Camargo e } \\
\text { Almeida } \\
\text { Diretor Executivo }\end{array}$ & $\begin{array}{l}\text { Antônio Barros de } \\
\text { Ulhôa Cintra } \\
\text { Reitor }\end{array}$ & $\begin{array}{l}\text { Informa sobre o processo e sugere que o } \\
\text { reitor encaminhe a matéria ao Governador } \\
\text { para que a prorrogação dos contratos seja } \\
\text { convertida em decreto }\end{array}$ & 62.1 .660 .51 .9 & $18-19$ \\
\hline $26 / 12 / 62$ & $\begin{array}{l}\text { Américo Lourenço } \\
\text { Masset Lacombe } \\
\text { Consultor Jurídico }\end{array}$ & $\begin{array}{l}\text { Carlos Alberto } \\
\text { Felizola Freire } \\
\text { Assessor } \\
\text { Administrativo }\end{array}$ & $\begin{array}{l}\text { Informa que apesar do Fundo não assinar } \\
\text { contratos com seus servidores a USP assinou } \\
\text { com alguns, dentre ele, Paulo de Camargo e } \\
\text { Almeida. A opinião é que esses contratos } \\
\text { antes com prazo determinado, passem a } \\
\text { vigorar com prazo indeterminado }\end{array}$ & 62.1 .660 .51 .9 & $20-21$ \\
\hline $28 / 12 / 62$ & $\begin{array}{l}\text { Paulo de Camargo e } \\
\text { Almeida } \\
\text { Diretor Executivo }\end{array}$ & $\begin{array}{l}\text { Antônio Barros de } \\
\text { Ulhôa Cintra } \\
\text { Reitor }\end{array}$ & $\begin{array}{l}\text { Sugere o encaminhamento da pauta ao } \\
\text { Governador para que seja prorrogado o prazo } \\
\text { do decreto, uma vez que foi encontrado artigo } \\
\text { que define sua abrangência para as obras } \\
\text { que possam ser "executadas e entregues } \\
\text { para pronta utilização até } 31 \text { de janeiro de } \\
1963 "\end{array}$ & 62.1 .660 .51 .9 & 22 \\
\hline $03 / 01 / 63$ & $\begin{array}{l}\text { Carlos Alberto A. de } \\
\text { Carvalho Pinto } \\
\text { Governador do Estado } \\
\text { de São Paulo }\end{array}$ & --- & $\begin{array}{l}\text { Decreto n. 41354: Altera o Decreto n. 36.959, } \\
\text { de } 13 \text { de julho de 1960, e o Decreto n. } \\
36.699 \text {, de } 3 \text { de junho de } 1960\end{array}$ & 62.1 .660 .51 .9 & $23-23 v$ \\
\hline $24 / 01 / 63$ & $\begin{array}{l}\text { Paulo de Camargo e } \\
\text { Almeida } \\
\text { Diretor Executivo do } \\
\text { Fundo para a } \\
\text { Construção da } \\
\text { CUASO }\end{array}$ & $\begin{array}{l}\text { Antônio Barros de } \\
\text { Ulhôa Cintra } \\
\text { Reitor }\end{array}$ & $\begin{array}{l}\text { Paulo Camargo de Almeida coloca seu cargo } \\
\text { à disposição do Reitor, visto que foi nomeado } \\
\text { pelo Governador e novas eleições } \\
\text { aproximam-se }\end{array}$ & 63.1 .3159 .1 .3 & $3-4$ \\
\hline $29 / 01 / 63$ & $\begin{array}{l}\text { Haroldo Eurico } \\
\text { Browne de Campos } \\
\text { Advogado }\end{array}$ & $\begin{array}{l}\text { Consultor Jurídico- } \\
\text { Chefe }\end{array}$ & $\begin{array}{l}\text { Parecer sobre o decreto de fundação do } \\
\text { FCCUASO e sobre a questão da autonomia } \\
\text { universitária }\end{array}$ & 63.1 .3159 .1 .3 & $5-11$ \\
\hline $04 / 02 / 63$ & --- & --- & $\begin{array}{l}\text { Trecho de ata de reunião do Conselho } \\
\text { Universitário que discute a necessidade de } \\
\text { substituição de Paulo de Camargo e Almeida } \\
\text { e do FCCUASO. Decidem mantê-los, Paulo } \\
\text { de Camargo e o FCCUASO, enquanto não } \\
\text { encontrarem um substituto ao cargo e não } \\
\text { fundarem uma nova instituição }\end{array}$ & 63.1 .3159 .1 .3 & $12-3$ \\
\hline $19 / 02 / 64$ & $\begin{array}{l}\text { Paulo de Camargo e } \\
\text { Almeida } \\
\text { Diretor Executivo } \\
\text { FCCUASO }\end{array}$ & $\begin{array}{l}\text { Luís Antônio da } \\
\text { Gama e Silva } \\
\text { Reitor }\end{array}$ & $\begin{array}{l}\text { Sobre o Plano de Recursos de } 1964 \text { e os } \\
\text { problemas advindos do corte orçamentário }\end{array}$ & 64.1 .6450 .1 .1 & $2-5$ \\
\hline $19 / 02 / 64$ & --- & --- & Plano de Recursos de 1964 & 64.1 .6450 .1 .1 & $6-13$ \\
\hline
\end{tabular}




\begin{tabular}{|c|c|c|c|c|c|}
\hline \multirow[b]{2}{*}{ Data } & \multirow{2}{*}{$\begin{array}{c}\text { Remetente } \\
\text { Nome e Cargo }\end{array}$} & \multirow{2}{*}{$\begin{array}{c}\text { Destinatário } \\
\text { Nome e Cargo }\end{array}$} & \multirow{2}{*}{$\begin{array}{l}\text { Conteúdo } \\
\text { Assunto }\end{array}$} & \multicolumn{2}{|c|}{ Processo USP } \\
\hline & & & & Número & Folhas \\
\hline $24 / 02 / 64$ & 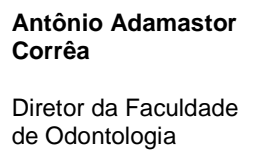 & $\begin{array}{l}\text { Paulo de Camargo e } \\
\text { Almeida } \\
\text { Diretor Executivo } \\
\text { FCCUASO }\end{array}$ & $\begin{array}{l}\text { Propõe revisão do Plano de Recursos de } \\
\text { 1964, incluindo a construção dos Institutos de } \\
\text { Antropologia e Histologia }\end{array}$ & 64.1 .6450 .1 .1 & $16-21$ \\
\hline $25 / 02 / 64$ & $\begin{array}{l}\text { Paulo de Camargo e } \\
\text { Almeida } \\
\text { Diretor Executivo } \\
\text { FCCUASO }\end{array}$ & $\begin{array}{l}\text { Luís Antônio da } \\
\text { Gama e Silva } \\
\text { Reitor }\end{array}$ & Revisão do Plano de Recursos de 1964 & 64.1 .6450 .1 .1 & $14-5$ \\
\hline $25 / 02 / 64$ & --- & --- & Plano de Recursos de 1964 revisado & 64.1 .6450 .1 .1 & $22-9$ \\
\hline $16 / 03 / 64$ & --- & --- & $\begin{array}{l}\text { Encaminhamento para aprovação do plano } \\
\text { Encaminhamentos. Aprovação do Plano em } \\
\text { 31/03/64. Assinam: Octavio Bella Serra, Hugo } \\
\text { de Almeida Leme, Lucie Penna de Carvalho } \\
\text { Lima, Tharcisio Damy de Souza Santos, Luiz } \\
\text { Ferreira Martins }\end{array}$ & 64.1 .6450 .1 .1 & 30 \\
\hline $13 / 04 / 64$ & --- & --- & $\begin{array}{l}\text { Trecho de ata da sessão do Conselho } \\
\text { Universitário que aprovou o Plano }\end{array}$ & 64.1 .6450 .1 .1 & 32 \\
\hline $14 / 04 / 64$ & $\begin{array}{l}\text { Julio Mario Stamato } \\
\text { Secretário Geral }\end{array}$ & $\begin{array}{l}\text { Paulo de Camargo e } \\
\text { Almeida } \\
\text { Diretor Executivo } \\
\text { FCCUASO }\end{array}$ & Informa a aprovação do Plano & 64.1 .6450 .1 .1 & 31 \\
\hline $02 / 07 / 64$ & $\begin{array}{l}\text { Paulo de Camargo e } \\
\text { Almeida } \\
\text { Diretor Executivo } \\
\text { FCCUASO }\end{array}$ & $\begin{array}{l}\text { Luís Antônio da } \\
\text { Gama e Silva } \\
\text { Reitor }\end{array}$ & $\begin{array}{l}\text { Informa a necessidade de contratação de } \\
\text { pessoal, contrariando a disposição do } \\
\text { Governo em cortar gastos e suspender } \\
\text { contratações. Pede a intervenção do Reitor } \\
\text { junto ao Governador para a liberação dessas } \\
\text { novas contratações, destacando a sua } \\
\text { provisoriedade e a facilidade de se encontrar } \\
\text { mão-de-obra barata quando necessário }\end{array}$ & 64.1 .17084 .1 .1 & $2-3$ \\
\hline $24 / 07 / 64$ & $\begin{array}{l}\text { Luís Antônio da } \\
\text { Gama e Silva } \\
\text { Reitor }\end{array}$ & --- & Autoriza a contratação & 64.1 .17084 .1 .1 & 4 \\
\hline $29 / 09 / 64$ & $\begin{array}{l}\text { Paulo de Camargo e } \\
\text { Almeida } \\
\text { Diretor Executivo } \\
\text { FCCUASO }\end{array}$ & $\begin{array}{l}\text { Luís Antônio da } \\
\text { Gama e Silva } \\
\text { Reitor }\end{array}$ & $\begin{array}{l}\text { Requere a doação de um filme sobre a } \\
\text { construção do campus à Escola de } \\
\text { Engenharia }\end{array}$ & 64.1 .25745 .1 .3 & 2 \\
\hline $21 / 01 / 65$ & Luiz Ferreira Martins & --- & $\begin{array}{l}\text { Proposta de revisão do orçamento, } \\
\text { priorizando recursos para institutos em } \\
\text { situação precária e já em exercício didático } \\
\text { Encaminhamentos. Leitura difícil; propostas } \\
\text { de revisão de prioridades do orçamento e do } \\
\text { loteamento das construções por Eurípedes... } \\
\text { e Octavio Bella Serra; discordância expressa } \\
\text { por Tharcisio Damy de Souza Santos }\end{array}$ & 65.1 .17666 .1 .1 & $\overline{11-11 v}$ \\
\hline $01 / 06 / 65$ & $\begin{array}{l}\text { Luís Antônio da } \\
\text { Gama e Silva } \\
\text { Reitor }\end{array}$ & --- & $\begin{array}{l}\text { Exoneração do Diretor-Executivo do } \\
\text { FCCUASO Reynaldo Ramos de Saldanha da } \\
\text { Gama }\end{array}$ & 65.1 .32613 .1 .2 & 3 \\
\hline $02 / 06 / 65$ & $\begin{array}{l}\text { Luís Antônio da } \\
\text { Gama e Silva } \\
\text { Reitor }\end{array}$ & --- & $\begin{array}{l}\text { Designação de Adalberto Mendes dos } \\
\text { Santos, Encarregado do Orçamento do } \\
\text { FCCUASO, ao cargo de Diretor-Executivo do } \\
\text { Fundo enquanto a vaga não fosse provida }\end{array}$ & 65.1 .32613 .1 .2 & 4 \\
\hline
\end{tabular}




\begin{tabular}{|c|c|c|c|c|c|}
\hline & Remetente & Destinatário & Conteúdo & Processo & ISP \\
\hline Data & Nome e Cargo & Nome e Cargo & Assunto & Número & Folhas \\
\hline 02/06/65 & $\begin{array}{l}\text { Luís Antônio da } \\
\text { Gama e Silva } \\
\text { Reitor }\end{array}$ & --- & $\begin{array}{l}\text { Designação de Adalberto Mendes dos } \\
\text { Santos, Encarregado do Orçamento do } \\
\text { FCCUASO, ao cargo de Diretor-Executivo do } \\
\text { Fundo enquanto a vaga não fosse provida }\end{array}$ & 65.1 .32613 .1 .2 & 5 \\
\hline $25 / 06 / 65$ & --- & --- & $\begin{array}{l}\text { Capa da proposta orçamentária para o } \\
\text { FCCUASO em } 1966\end{array}$ & 65.1 .17666 .1 .1 & 2 \\
\hline $05 / 07 / 65$ & $\begin{array}{l}\text { Adalberto Mendes } \\
\text { dos Santos }\end{array}$ & Reitor & Restituição de autos & 64.1 .17084 .1 .1 & 5 \\
\hline $12 / 07 / 65$ & $\begin{array}{l}\text { Julio Mario Stamato } \\
\text {--- }\end{array}$ & --- & $\begin{array}{l}\text { Conselho Universitário rejeita a proposta de } \\
\text { Luiz Ferreira Martins, Eurípedes... e Octavio } \\
\text { Bella Serra, aprovando o parecer de Tharcisio } \\
\text { Damy de Souza Santos }\end{array}$ & 65.1 .17666 .1 .1 & 12 \\
\hline $15 / 07 / 65$ & $\begin{array}{l}\text { Tharcisio Damy de } \\
\text { Souza Santos } \\
\text { Reitor em exercício }\end{array}$ & $\begin{array}{l}\text { Humberto Reis Costa } \\
\text { Secretário de Estado } \\
\text { dos Negócios de } \\
\text { Economia e } \\
\text { Planejamento }\end{array}$ & $\begin{array}{l}\text { Encaminhamento de proposta do orçamento } \\
\text { de } 1966\end{array}$ & 65.1 .17666 .1 .1 & 13 \\
\hline $16 / 07 / 65$ & $\begin{array}{l}\text { Tharcisio Damy de } \\
\text { Souza Santos } \\
\text { Reitor em exercício }\end{array}$ & $\begin{array}{l}\text { Humberto Reis Costa } \\
\text { Secretário de Estado } \\
\text { dos Negócios de } \\
\text { Economia e } \\
\text { Planejamento }\end{array}$ & $\begin{array}{l}\text { Proposta de cortes no orçamento de } 1966 \text { e } \\
\text { em quais obras eles ocorrerão }\end{array}$ & 65.1 .17666 .1 .1 & $14-15$ \\
\hline $27 / 07 / 65$ & $\begin{array}{l}\text { Adalberto Mendes } \\
\text { dos Santos }\end{array}$ & -- & $\begin{array}{l}\text { Informa ter tomado conhecimento do assunto } \\
\text { e sugere arquivamento dos autos }\end{array}$ & 65.1 .17666 .1 .1 & 16 \\
\hline $09 / 08 / 65$ & $\begin{array}{l}\text { Adalberto Mendes } \\
\text { dos Santos } \\
\text { Respondendo pelo } \\
\text { expediente }\end{array}$ & Reitor & $\begin{array}{l}\text { Solicita autorização para abertura de } \\
\text { concorrência para a construção da estrutura e } \\
\text { informa já haver recursos para a construção } \\
\text { entre } 65-66, \text { devendo contar com recursos } \\
\text { para acabamento em } 1967 \\
\text { Encaminhamentos. Reitor aprova e } \\
\text { encaminha para Anhaia Mello, que pede ao } \\
\text { Fundo para "informar à respeito das } \\
\text { providências tomadas". Adalberto informa que } \\
\text { o projeto "suntuoso" está a exigir } \\
\text { reformulação pelo vulto a despesa }\end{array}$ & 65.1 .3988 .51 .8 & $4-5$ \\
\hline $30 / 08 / 65$ & $\begin{array}{l}\text { Pedro Moacyr do } \\
\text { Amaral Cruz } \\
\text { Diretor FAU }\end{array}$ & $\begin{array}{l}\text { Tharcisio Damy de } \\
\text { Souza Santos } \\
\text { Reitor em exercício }\end{array}$ & $\begin{array}{l}\text { Anuncia que o projeto de Artigas e Ferraz não } \\
\text { foram aprovados e que as alterações } \\
\text { precisam ser feitas }\end{array}$ & 65.1 .3988 .51 .8 & $6-8$ \\
\hline $31 / 08 / 65$ & --- & Reitor & $\begin{array}{l}\text { Aprova o parecer do diretor da FAU e exige } \\
\text { as revisões }\end{array}$ & 65.1 .3988 .51 .8 & $9-9 v$ \\
\hline $13 / 09 / 65$ & $\begin{array}{l}\text { Adalberto Mendes } \\
\text { dos Santos } \\
\text { Respondendo pelo } \\
\text { expediente }\end{array}$ & Reitor & $\begin{array}{l}\text { Sugere a designação de uma comissão para } \\
\text { a revisão do projeto }\end{array}$ & 65.1 .3988 .51 .8 & 10 \\
\hline $20 / 09 / 65$ & $\begin{array}{l}\text { Luís Antônio da } \\
\text { Gama e Silva } \\
\text { Reitor }\end{array}$ & $\begin{array}{l}\text { Pedro Moacyr do } \\
\text { Amaral Cruz } \\
\text { Diretor FAU }\end{array}$ & Designa comissão de revisão do projeto & 65.1 .3988 .51 .8 & $11-13$ \\
\hline $11 / 10 / 65$ & $\begin{array}{l}\text { Pedro Moacyr do } \\
\text { Amaral Cruz; } \\
\text { Telêmaco de Macedo } \\
\text { Van Langendonck; } \\
\text { Oscar Costa } \\
\end{array}$ & $\begin{array}{l}\text { Luís Antônio da } \\
\text { Gama e Silva }\end{array}$ & $\begin{array}{l}\text { A comissão designada pelo reitor para } \\
\text { examinar o projeto apresenta suas } \\
\text { conclusões }\end{array}$ & 65.1 .3988 .51 .8 & $14-17$ \\
\hline
\end{tabular}




\begin{tabular}{|c|c|c|c|c|c|}
\hline \multirow[b]{2}{*}{ Data } & \multirow{2}{*}{$\begin{array}{c}\text { Remetente } \\
\text { Nome e Cargo }\end{array}$} & \multirow{2}{*}{$\begin{array}{l}\text { Destinatário } \\
\text { Nome e Cargo }\end{array}$} & \multirow{2}{*}{$\begin{array}{l}\text { Conteúdo } \\
\text { Assunto }\end{array}$} & \multicolumn{2}{|c|}{ Processo USP } \\
\hline & & & & Número & Folhas \\
\hline $22 / 10 / 65$ & $\begin{array}{l}\text { Luís Antônio da } \\
\text { Gama e Silva }\end{array}$ & $\begin{array}{l}\text { Pedro Moacyr do } \\
\text { Amaral Cruz }\end{array}$ & $\begin{array}{l}\text { Comunica o recebimento do parecer da } \\
\text { comissão }\end{array}$ & 65.1 .3988 .51 .8 & $18-19$ \\
\hline & Reitor & Diretor & & & \\
\hline $18 / 11 / 65$ & -- & --- & $\begin{array}{l}\text { Minuta do ato de nomeação de Adalberto } \\
\text { Mendes dos Santos }\end{array}$ & 65.1 .32613 .1 .2 & 7 \\
\hline $18 / 11 / 65$ & $\begin{array}{l}\text { Luís Antônio da } \\
\text { Gama e Silva } \\
\text { Reitor }\end{array}$ & --- & $\begin{array}{l}\text { Ato de nomeação de Adalberto Mendes dos } \\
\text { Santos }\end{array}$ & 65.1 .32613 .1 .2 & 8 \\
\hline $19 / 11 / 65$ & $\begin{array}{l}\text { Adalberto Mendes } \\
\text { dos Santos } \\
\text { Encarregado da DPEP }\end{array}$ & Diretor & $\begin{array}{l}\text { Solicita que o Arq. Vilanova Artigas apresente } \\
\text { carta-proposta para o remanejamento do } \\
\text { projeto e indica o Eng. Walter Nimir e o Arq. } \\
\text { Luciano Bernini para acompanhar os } \\
\text { trabalhos }\end{array}$ & 65.1 .3988 .51 .8 & 20 \\
\hline $19 / 11 / 65$ & $\begin{array}{l}\text { Luís Antônio da } \\
\text { Gama e Silva } \\
\text { Reitor }\end{array}$ & --- & $\begin{array}{l}\text { Aprovação de transformação que não fica } \\
\text { clara, possivelmente de maior submissão do } \\
\text { FCCUASO à Reitoria; designação de } \\
\text { Adalberto Mendes dos Santos ao cargo de } \\
\text { Diretor-Executivo do Fundo }\end{array}$ & 65.1 .32613 .1 .2 & 6 \\
\hline $19 / 11 / 65$ & $\begin{array}{l}\text { Luís Antônio da } \\
\text { Gama e Silva } \\
\text { Reitor }\end{array}$ & --- & $\begin{array}{l}\text { Proposta de reestruturação do Escritório } \\
\text { Técnico e Administrativo; criação do Conselho } \\
\text { Técnico Consultivo, sua regulamentação e } \\
\text { funções }\end{array}$ & 65.1 .32614 .1 .9 & $2-7$ \\
\hline $26 / 11 / 65$ & $\begin{array}{l}\text { Adalberto Mendes } \\
\text { dos Santos } \\
\text { Diretor Executivo } \\
\text { FCCUASO }\end{array}$ & $\begin{array}{l}\text { João Batista Vilanova } \\
\text { Artigas } \\
\text { Arquiteto }\end{array}$ & $\begin{array}{l}\text { Solicita que o Arq. Vilanova Artigas entre com } \\
\text { contato com o FCCUASO para tomar } \\
\text { conhecimento das modificações e apresentar } \\
\text { carta-proposta relativa a honorários } \\
\text { profissionais para o remanejamento }\end{array}$ & 65.1 .3988 .51 .8 & 21 \\
\hline $02 / 12 / 65$ & $\begin{array}{l}\text { Eng. Eduardo } \\
\text { Pessoa } \\
\text { Assessor Técnico }\end{array}$ & Encarregado da DP & $\begin{array}{l}\text { Solicita enviar ao arquiteto Artigas as plantas } \\
\text { com as alterações pedidas pela Faculdade } \\
\text { juntamente com a planta do estaqueamento } \\
\text { que indique as cotas de arrasamento }\end{array}$ & 65.1 .3988 .51 .8 & $27-27 v$ \\
\hline $10 / 12 / 65$ & $\begin{array}{l}\text { Adalberto Mendes } \\
\text { dos Santos } \\
\text { Diretor Executivo } \\
\text { FCCUASO }\end{array}$ & $\begin{array}{l}\text { João Batista Vilanova } \\
\text { Artigas } \\
\text { Arquiteto }\end{array}$ & $\begin{array}{l}\text { Encaminha um jogo de plantas com as } \\
\text { alterações e a planta de estaqueamento }\end{array}$ & 65.1 .3988 .51 .8 & 28 \\
\hline $13 / 12 / 65$ & --- & --- & Devolução de apenso & 65.1 .32614 .1 .9 & 8 \\
\hline $03 / 01 / 66$ & $\begin{array}{l}\text { Adalberto Mendes } \\
\text { dos Santos } \\
\text { Diretor Executivo } \\
\text { FCCUASO }\end{array}$ & $\begin{array}{l}\text { João Batista Vilanova } \\
\text { Artigas } \\
\text { Arquiteto }\end{array}$ & $\begin{array}{l}\text { Solicita resposta em relação ao ofício enviado } \\
\text { em } 10 / 12 / 66\end{array}$ & 65.1 .3988 .51 .8 & 29 \\
\hline $17 / 01 / 66$ & $\begin{array}{l}\text { João Batista } \\
\text { Vilanova Artigas } \\
\text { Arquiteto }\end{array}$ & $\begin{array}{l}\text { Adalberto Mendes } \\
\text { dos Santos } \\
\text { Diretor Executivo } \\
\text { FCCUASO }\end{array}$ & $\begin{array}{l}\text { Envia } 4 \text { cópias de novas plantas do projeto } \\
\text { com alterações em relação à proposta da } \\
\text { diretoria. Obs. As plantas possuem o carimbo } \\
\text { "Vilanova Artigas e Carlos Cascaldi" em } \\
\text { branco } \\
\text { Encaminhamentos. Plantas aprovadas por } \\
\text { Pedro Moacyr do Amaral Cruz em 19/1/1966 }\end{array}$ & 65.1 .3988 .51 .8 & $30-34$ \\
\hline
\end{tabular}




\begin{tabular}{|c|c|c|c|c|c|}
\hline \multirow[b]{2}{*}{ Data } & \multirow{2}{*}{$\begin{array}{c}\text { Remetente } \\
\text { Nome e Cargo }\end{array}$} & \multirow{2}{*}{$\begin{array}{l}\text { Destinatário } \\
\text { Nome e Cargo }\end{array}$} & \multirow{2}{*}{$\begin{array}{l}\text { Conteúdo } \\
\text { Assunto }\end{array}$} & \multicolumn{2}{|c|}{ Processo USP } \\
\hline & & & & Número & Folhas \\
\hline $19 / 01 / 66$ & $\begin{array}{l}\begin{array}{l}\text { Adalberto Mendes } \\
\text { dos Santos }\end{array} \\
\text { Diretor Executivo } \\
\text { FCCUASO }\end{array}$ & $\begin{array}{l}\text { João Batista Vilanova } \\
\text { Artigas } \\
\text { Arquiteto }\end{array}$ & $\begin{array}{l}\text { Informa que o anteprojeto enviado em 17/1/66 } \\
\text { foi integralmente aprovado pelo diretor da } \\
\text { FAU. Solicita o envio do projeto para o } \\
\text { Escritório Figueiredo Ferraz para o } \\
\text { remanejamento do projeto estrutural. } \\
\text { Continua esperando sugestões sobre as } \\
\text { simplificações solicitadas para a cobertura. } \\
\text { Solicita proposta com os honorários para os } \\
\text { trabalhos a serem desenvolvidos }\end{array}$ & 65.1 .3988 .51 .8 & 35 \\
\hline $15 / 02 / 66$ & $\begin{array}{l}\text { João Batista } \\
\text { Vilanova Artigas } \\
\text { Arquiteto }\end{array}$ & $\begin{array}{l}\begin{array}{l}\text { Adalberto Mendes } \\
\text { dos Santos }\end{array} \\
\text { Diretor Executivo } \\
\text { FCCUASO }\end{array}$ & $\begin{array}{l}\text { Comunica os honorários para o } \\
\text { remanejamento do projeto }\end{array}$ & 65.1 .3988 .51 .8 & 36 \\
\hline $15 / 02 / 66$ & $\begin{array}{l}\text { João Batista } \\
\text { Vilanova Artigas } \\
\text { Arquiteto }\end{array}$ & $\begin{array}{l}\begin{array}{l}\text { Adalberto Mendes } \\
\text { dos Santos }\end{array} \\
\text { Diretor Executivo } \\
\text { FCCUASO }\end{array}$ & Solicita adiantamento de parte dos honorários & 65.1 .3988 .51 .8 & 37 \\
\hline $17 / 02 / 66$ & $\begin{array}{l}\begin{array}{l}\text { Adalberto Mendes } \\
\text { dos Santos }\end{array} \\
\text { Diretor Executivo } \\
\text { FCCUASO }\end{array}$ & Assessoria Técnica & $\begin{array}{l}\text { Solicita parecer sobre a carta-proposta inicial } \\
\text { (pg.3, que não consta que processo). } \\
\text { Pondera o prazo de } 2 \text { meses, pois o Fundo } \\
\text { tem compromissos de indicar a obra com } \\
\text { urgência e necessita de obras para ocupar os } \\
\text { operários liberados do Prédio da História e } \\
\text { Geografia }\end{array}$ & 65.1 .3988 .51 .8 & 38 \\
\hline $28 / 02 / 66$ & $\begin{array}{l}\text { Eng. Roberto de } \\
\text { Araújo } \\
\text { Encarregado da } \\
\text { Divisão de Projetos }\end{array}$ & Assessor técnico & $\begin{array}{l}\text { Resgata a carta proposta original de Artigas } \\
\text { apresentada em } 3 / 2 / 1961 \text {. Recomenda a } \\
\text { aceitação da proposta de Artigas } 15 / 2 / 66 \text { e do } \\
\text { adiantamento solicitado }\end{array}$ & 65.1 .3988 .51 .8 & 39 \\
\hline $08 / 03 / 66$ & $\begin{array}{l}\text { Adalberto Mendes } \\
\text { dos Santos } \\
\text { Diretor Executivo } \\
\text { FCCUASO }\end{array}$ & Reitor & Submete o pagamento ao reitor & 65.1 .3988 .51 .8 & $40-40 v$ \\
\hline $28 / 03 / 66$ & $\begin{array}{l}\text { Adalberto Mendes } \\
\text { dos Santos } \\
\text { Diretor Executivo } \\
\text { FCCUASO }\end{array}$ & Reitor & $\begin{array}{l}\text { Esclarece os pagamentos já feitos ao } \\
\text { arquiteto sugere novo encaminhamento do } \\
\text { reitor em relação ao dado no ofício de } 8 / 3 / 66\end{array}$ & 65.1 .3988 .51 .8 & $41-41 v$ \\
\hline $31 / 03 / 66$ & $\begin{array}{l}\text { Adalberto Mendes } \\
\text { dos Santos } \\
\text { Diretor Executivo } \\
\text { FCCUASO }\end{array}$ & $\begin{array}{l}\text { João Batista Vilanova } \\
\text { Artigas } \\
\text { Arquiteto }\end{array}$ & $\begin{array}{l}\text { Retoma a relato telefônico de Artigas em que } \\
\text { este afirma ter entregue ao Escritório } \\
\text { Figueiredo Ferraz uma nova solução para a } \\
\text { cobertura, que foi aceita. Lembra que o } \\
\text { combinado era submeter a solução } \\
\text { encontrada ao Fundo, tendo em vista a } \\
\text { grande experiência do órgão em coberturas } \\
\text { de concreto em grandes vãos. Informa que } \\
\text { solicitaram a solução ao Escritório de } \\
\text { estrutura e que não considera a solução como } \\
\text { final até pronunciamento do Fundo }\end{array}$ & 65.1 .3988 .51 .8 & 42 \\
\hline $31 / 03 / 66$ & $\begin{array}{l}\begin{array}{l}\text { Adalberto Mendes } \\
\text { dos Santos }\end{array} \\
\text { Diretor Executivo } \\
\text { FCCUASO }\end{array}$ & $\begin{array}{l}\text { Escritório Técnico } \\
\text { Figueiredo Ferraz }\end{array}$ & $\begin{array}{l}\text { Cobram o agendamento de uma reunião do } \\
\text { Fundo com o Escritório para discutirem a } \\
\text { solução de Artigas para a cobertura }\end{array}$ & 65.1 .3988 .51 .8 & 43 \\
\hline
\end{tabular}




\begin{tabular}{|c|c|c|c|c|c|}
\hline \multirow[b]{2}{*}{ Data } & \multirow{2}{*}{$\begin{array}{c}\text { Remetente } \\
\text { Nome e Cargo }\end{array}$} & \multirow{2}{*}{$\begin{array}{l}\text { Destinatário } \\
\text { Nome e Cargo }\end{array}$} & \multirow{2}{*}{$\begin{array}{l}\text { Conteúdo } \\
\text { Assunto }\end{array}$} & \multicolumn{2}{|c|}{ Processo USP } \\
\hline & & & & Número & Folhas \\
\hline $31 / 03 / 66$ & $\begin{array}{l}\text { Adalberto Mendes } \\
\text { dos Santos } \\
\text { Diretor Executivo } \\
\text { FCCUASO }\end{array}$ & $\begin{array}{l}\text { Escritório Técnico } \\
\text { Figueiredo Ferraz }\end{array}$ & $\begin{array}{l}\text { Cobra pronunciamento sobre os ofícios } 236 \\
\text { de } 19 \text { de janeiro (comunica aprovação do } \\
\text { projeto e solicita urgência nas alterações) e } \\
747 \text { de } 1 \text { de março (enviado jogo de originais } \\
\text { da estrutura para alterações e solicitado prazo } \\
\text { para conclusão das alterações). Solicita } \\
\text { informações quanto ao andamento do projeto } \\
\text { e prazo de entrega }\end{array}$ & 65.1 .3988 .51 .8 & 44 \\
\hline $14 / 04 / 66$ & $\begin{array}{l}\begin{array}{l}\text { Adalberto Mendes } \\
\text { dos Santos }\end{array} \\
\text { Diretor Executivo } \\
\text { FCCUASO }\end{array}$ & Reitor & $\begin{array}{l}\text { Defende os honorários do arquiteto frente ao } \\
\text { despacho do Reitor no ofício de } 28 / 03 / 66\end{array}$ & 65.1 .3988 .51 .8 & 45 \\
\hline $25 / 04 / 66$ & $\begin{array}{l}\text { Adalberto Mendes } \\
\text { dos Santos } \\
\text { Diretor Executivo } \\
\text { FCCUASO }\end{array}$ & $\begin{array}{l}\text { João Batista Vilanova } \\
\text { Artigas } \\
\text { Arquiteto }\end{array}$ & $\begin{array}{l}\text { Oficializa a redução dos honorários de Artigas } \\
\text { de acordo com o combinado entre o arquiteto } \\
\text { e o Assessor Técnico, Eng. Eduardo Pessoa. } \\
\text { Solicita conformação do arquiteto }\end{array}$ & 65.1 .3988 .51 .8 & 46 \\
\hline $29 / 04 / 66$ & $\begin{array}{l}\text { João Batista } \\
\text { Vilanova Artigas } \\
\text { Arquiteto }\end{array}$ & $\begin{array}{l}\begin{array}{l}\text { Adalberto Mendes } \\
\text { dos Santos }\end{array} \\
\text { Diretor Executivo } \\
\text { FCCUASO }\end{array}$ & $\begin{array}{l}\text { Confirma a redução de honorários e retifica o } \\
\text { prazo de entrega do trabalho em função da } \\
\text { entrega dos cálculos estruturais } \\
\text { Encaminhamentos. Autoriza o pagamento do } \\
\text { adiantamento de Cr } \$ 2000.000 \text {. }\end{array}$ & 65.1 .3988 .51 .8 & $47-48$ \\
\hline $03 / 05 / 66$ & $\begin{array}{l}\text { José Carlos de } \\
\text { Figueiredo Ferraz } \\
\text { Escritório Técnico J. } \\
\text { C. de Figueiredo } \\
\text { Ferraz }\end{array}$ & $\begin{array}{l}\text { Carlos Eduardo de } \\
\text { Paula Pessôa } \\
\text { Assessor Técnico do } \\
\text { FCCUASO }\end{array}$ & $\begin{array}{l}\text { Justifica o atraso do envio do projeto } \\
\text { estrutural. Promete entregar em oito dias as } \\
\text { fundações, fôrmas refeitas, estudo da } \\
\text { cobertura e previsão de quantidades } \\
\text { Encaminhamentos. Ao setor de orçamento e } \\
\text { especificações: preparar especificações para } \\
\text { abertura de concorrência assim que receber } \\
\text { as plantas. Estudar as providências para } \\
\text { complementação da fundação, que segundo } \\
\text { Figueiredo Feraz, haverá túbulos } \\
\text { suplementares e estacas }\end{array}$ & 65.1 .3988 .51 .8 & $50-50 v$ \\
\hline $03 / 05 / 66$ & $\begin{array}{l}\begin{array}{l}\text { Adalberto Mendes } \\
\text { dos Santos }\end{array} \\
\text { Diretor Executivo } \\
\text { FCCUASO }\end{array}$ & $\begin{array}{l}\text { José Carlos de } \\
\text { Figueiredo Ferraz } \\
\text { Escritório Técnico J. C. } \\
\text { de Figueiredo Ferraz }\end{array}$ & $\begin{array}{l}\text { Acordo com o prazo de entrega comunicado } \\
\text { por telefone: } 11 / 5 / 66 \text { (reforço das fundações; } \\
\text { plantas de fôrmas corrigidas ou alteradas; } \\
\text { sugestão para cobertura) e } 31 / 5 / 66 \text { (detalhes } \\
\text { finais alterados). Cobra rigor nos prazos pois } \\
\text { a obra tem início programado para este ano }\end{array}$ & 65.1 .3988 .51 .8 & 53 \\
\hline $11 / 05 / 66$ & $\begin{array}{l}\text { Escritório Técnico J. } \\
\text { C. de Figueiredo } \\
\text { Ferraz }\end{array}$ & $\begin{array}{l}\text { Carlos Eduardo de } \\
\text { Paula Pessôa } \\
\text { Assessor Técnico do } \\
\text { FCCUASO }\end{array}$ & $\begin{array}{l}\text { Confirma entrega de oito desenhos originais } \\
\text { de Fôrmas }(2 A, 4 A, 5 A, 6 A, 7 A, 9 A, 12 A \text {, } \\
16 A) \text {, a devolução de vinte plantas antigas ( } 1 \text {, } \\
2,4,5,6,7,8,9,10,11,12,13,14,15,16 \text {, } \\
17,18,19,20 \text { e } 21 \text { ) e de uma carta } \\
\text { (informações e quantidades) }\end{array}$ & 65.1 .3988 .51 .8 & 51 \\
\hline $11 / 05 / 66$ & $\begin{array}{l}\text { José Carlos de } \\
\text { Figueiredo Ferraz } \\
\text { Escritório Técnico J. } \\
\text { C. de Figueiredo } \\
\text { Ferraz }\end{array}$ & $\begin{array}{l}\text { Carlos Eduardo de } \\
\text { Paula Pessôa } \\
\text { Assessor Técnico do } \\
\text { FCCUASO }\end{array}$ & Previsão de quantidade de Aço & 65.1 .3988 .51 .8 & 52 \\
\hline $16 / 05 / 66$ & $\begin{array}{l}\text { Adalberto Mendes } \\
\text { dos Santos } \\
\text { Diretor Executivo } \\
\text { FCCUASO }\end{array}$ & $\begin{array}{l}\text { José Carlos de } \\
\text { Figueiredo Ferraz } \\
\text { Escritório Técnico J. C. } \\
\text { de Figueiredo Ferraz }\end{array}$ & $\begin{array}{l}\text { Solicita presença no Escritório Técnico no dia } \\
\text { 20/5/66 para tratar do projeto de estrutura e } \\
\text { da solução para a cobertura }\end{array}$ & 65.1 .3988 .51 .8 & 61 \\
\hline $16 / 05 / 66$ & $\begin{array}{l}\text { Adalberto Mendes } \\
\text { dos Santos } \\
\text { Diretor Executivo } \\
\text { FCCUASO }\end{array}$ & $\begin{array}{l}\text { João Batista Vilanova } \\
\text { Artigas } \\
\text { Arquiteto }\end{array}$ & $\begin{array}{l}\text { Solicita presença no Escritório Técnico no dia } \\
\text { 20/5/66 para tratar do projeto de estrutura e } \\
\text { da solução para a cobertura }\end{array}$ & 65.1 .3988 .51 .8 & 62 \\
\hline
\end{tabular}




\begin{tabular}{|c|c|c|c|c|c|}
\hline \multirow[b]{2}{*}{ Data } & \multirow{2}{*}{$\begin{array}{c}\text { Remetente } \\
\text { Nome e Cargo }\end{array}$} & \multirow{2}{*}{$\begin{array}{l}\text { Destinatário } \\
\text { Nome e Cargo }\end{array}$} & \multirow{2}{*}{$\begin{array}{l}\text { Conteúdo } \\
\text { Assunto }\end{array}$} & \multicolumn{2}{|c|}{ Processo USP } \\
\hline & & & & Número & Folhas \\
\hline $17 / 05 / 66$ & $\begin{array}{l}\text { Adalberto Mendes } \\
\text { dos Santos } \\
\text { Diretor Executivo } \\
\text { FCCUASO }\end{array}$ & $\begin{array}{l}\text { José Carlos de } \\
\text { Figueiredo Ferraz } \\
\text { Escritório Técnico J. C. } \\
\text { de Figueiredo Ferraz }\end{array}$ & $\begin{array}{l}\text { Aponta ressalvas ao projeto estrutural que } \\
\text { impedem a abertura de concorrência. Anexa } \\
\text { lista de irregularidades nos desenhos }(2 A, 4 A \text {, } \\
7 A, 8,10,11,13,18)\end{array}$ & 65.1 .3988 .51 .8 & $63-65$ \\
\hline $18 / 05 / 66$ & $\begin{array}{l}\text { José Carlos de } \\
\text { Figueiredo Ferraz } \\
\text { Escritório Técnico J. } \\
\text { C. de Figueiredo } \\
\text { Ferraz }\end{array}$ & $\begin{array}{l}\begin{array}{l}\text { Adalberto Mendes } \\
\text { dos Santos }\end{array} \\
\text { Diretor Executivo } \\
\text { FCCUASO }\end{array}$ & $\begin{array}{l}\text { Honorários para modificações no projeto } \\
\text { estrutural de Cr } \$ 6.000 .000 \\
\text { Encaminhamentos. Em } 1961 / 62 \text { foi pago } \\
\text { Cr } \$ 3.901 .300 \text { (Cr } \$ 44.600 .000 \text { em valores } \\
\text { corrigidos) pelo projeto estrutural. O solicitado } \\
\text { pelas correções equivale à } 13,5 \% \text { do projeto } \\
\text { original. O parecer é favorável ao pagamento } \\
\text { e o julga razoável. }\end{array}$ & 65.1 .3988 .51 .8 & $56-56 v$ \\
\hline $20 / 05 / 66$ & $\begin{array}{l}\text { Eng. Walter Abrahão } \\
\text { Nimir } \\
\text { Estruturas }\end{array}$ & $\begin{array}{l}\text { Encarregado da } \\
\text { Divisão de Projetos }\end{array}$ & $\begin{array}{l}\text { Envia cópias das plantas de fôrma e envia } \\
\text { que está de posse de outro jogo de cópias }\end{array}$ & 65.1 .3988 .51 .8 & $57-57 v$ \\
\hline $25 / 05 / 66$ & $\begin{array}{l}\text { José Carlos de } \\
\text { Figueiredo Ferraz } \\
\text { Escritório Técnico J. } \\
\text { C. de Figueiredo } \\
\text { Ferraz }\end{array}$ & $\begin{array}{l}\text { Carlos Eduardo de } \\
\text { Paula Pessôa } \\
\text { Assessor Técnico do } \\
\text { FCCUASO }\end{array}$ & $\begin{array}{l}\text { Instruções sobre o concreto armado e sua } \\
\text { produção }\end{array}$ & 65.1 .3988 .51 .8 & $54-55$ \\
\hline $31 / 05 / 66$ & $\begin{array}{l}\text { Eng. Roberto de } \\
\text { Araújo } \\
\text { Encarregado da } \\
\text { Divisão de Projetos }\end{array}$ & Assessor técnico & $\begin{array}{l}\text { Acusa recebimento do projeto estrutural } \\
\text { remanejado, que foi considerado satisfatório. } \\
\text { Recomenda a aceitação da proposta de } \\
\text { honorários }\end{array}$ & 65.1 .3988 .51 .8 & $58-58 v$ \\
\hline $06 / 06 / 66$ & $\begin{array}{l}\text { Eng. Walter Abrahão } \\
\text { Nimir } \\
\text { Estruturas }\end{array}$ & $\begin{array}{l}-- \\
\text { Encarregado da } \\
\text { Divisão de Projetos }\end{array}$ & $\begin{array}{l}\text { Solicita originais que se encontram em poder } \\
\text { do Escritório Técnico J. C. Figueiredo Ferraz }\end{array}$ & 65.1 .3988 .51 .8 & 66 \\
\hline $08 / 06 / 66$ & $\begin{array}{l}\text { Adalberto Mendes } \\
\text { dos Santos } \\
\text { Diretor Executivo } \\
\text { FCCUASO }\end{array}$ & $\begin{array}{l}\text { José Carlos de } \\
\text { Figueiredo Ferraz } \\
\text { Escritório Técnico J. C. } \\
\text { de Figueiredo Ferraz }\end{array}$ & $\begin{array}{l}\text { Solicita o envio das plantas } 3,8 \mathrm{~A}, 54,61,62 \text {, } \\
63,67,89,90,94,95,98 \mathrm{~A}, 100 \text { e } 101 \text { para } \\
\text { anexo no edital de concorrência }\end{array}$ & 65.1 .3988 .51 .8 & $67-67 v$ \\
\hline $10 / 06 / 66$ & $\begin{array}{l}\begin{array}{l}\text { Adalberto Mendes } \\
\text { dos Santos }\end{array} \\
\text { Diretor Executivo } \\
\text { FCCUASO }\end{array}$ & $\begin{array}{l}\text { José Carlos de } \\
\text { Figueiredo Ferraz } \\
\text { Escritório Técnico J. C. } \\
\text { de Figueiredo Ferraz }\end{array}$ & $\begin{array}{l}\text { Acusa recebimento da proposta de honorário } \\
\text { para modificação do projeto estrutural e } \\
\text { informa o aceite da mesma. Cobra os últimos } \\
\text { detalhes }\end{array}$ & 65.1 .3988 .51 .8 & 59 \\
\hline $13 / 06 / 66$ & --- & $\begin{array}{l}\text { Eng. Walter Abrahão } \\
\text { Nimir } \\
\text { Estruturas }\end{array}$ & $\begin{array}{l}\text { Encaminha os originais }(3,54,61,62,63,89 \text {, } \\
90,94,95,98 \mathrm{~A}, 101)\end{array}$ & 65.1 .3988 .51 .8 & 60 \\
\hline $13 / 06 / 66$ & $\begin{array}{l}\text { Luciano Bernini } \\
\text { Arquiteto }\end{array}$ & $\begin{array}{l}\text {--- } \\
\text { Encarregado da } \\
\text { Divisão de Projetos }\end{array}$ & $\begin{array}{l}\text { Informa que desde o dia 26/5/66 está em } \\
\text { poder de vinte jogos de cópias do projeto } \\
\text { arquitetônico para serem enviados para } \\
\text { concorrência } \\
\text { Encaminhamentos. A abertura de } \\
\text { concorrência para obra foi adiada pelo Diretor } \\
\text { Executivo em alguns dias, até que fiquem } \\
\text { definidas as programações financeiras. } \\
\text { Aguardar comunicação. }\end{array}$ & 65.1 .3988 .51 .8 & $68-68 v$ \\
\hline $13 / 07 / 66$ & $\begin{array}{l}\begin{array}{l}\text { Adalberto Mendes } \\
\text { dos Santos }\end{array} \\
\text { Diretor Executivo } \\
\text { FCCUASO }\end{array}$ & $\begin{array}{l}\text { Pedro Moacyr do } \\
\text { Amaral Cruz } \\
\text { Diretor FAU }\end{array}$ & $\begin{array}{l}\text { Confirma a existência dos projetos, mas culpa } \\
\text { a falta de recursos pela demora no início da } \\
\text { obra }\end{array}$ & 66.1 .20458 .1 .8 & $6-7$ \\
\hline
\end{tabular}




\begin{tabular}{|c|c|c|c|c|c|}
\hline & Remetente & Destinatário & Conteúdo & Processo & ISP \\
\hline Data & Nome e Cargo & Nome e Cargo & Assunto & Número & Folhas \\
\hline $20 / 07 / 66$ & $\begin{array}{l}\text { João Batista } \\
\text { Vilanova Artigas } \\
\text { Arquiteto }\end{array}$ & $\begin{array}{l}\text { Adalberto Mendes } \\
\text { dos Santos } \\
\text { Diretor Executivo } \\
\text { FCCUASO }\end{array}$ & $\begin{array}{l}\text { Envia os originais do projeto, remanejado de } \\
\text { acordo com as ordens. Informa o recebimento } \\
\text { de } \mathrm{Cr} \$ 2.000 .000 \text { e lembra o saldo de } \\
\text { Cr } \$ 6.000 .000\end{array}$ & 65.1 .3988 .51 .8 & 69 \\
\hline $26 / 07 / 66$ & $\begin{array}{l}\text { Luciano Bernini } \\
\text { Arquiteto }\end{array}$ & $\begin{array}{l}\text { Encarregado da } \\
\text { Divisão de Projetos }\end{array}$ & $\begin{array}{l}\text { Aprova o projeto entregue por Artigas e } \\
\text { encerra a fase de remanejamentos. Propõe } \\
\text { que os detalhes que surgirem durante a obra } \\
\text { sejam apresentados à Artigas que ficou de } \\
\text { resolve-los em croquis, ficando o } \\
\text { desenvolvimento a cargo do Escritório } \\
\text { Técnico. Sugere a estipulação de um prazo } \\
\text { para aguardar as soluções do arquiteto, findo } \\
\text { o qual o Escritório Técnico tomarias as } \\
\text { providências } \\
\text { Encaminhamentos. Pagamento de } \\
\text { Cr } \$ 6.000 .000 \text { em honorários ao Arq. Artigas } \\
\text { pago em } 9 / 8 / 66\end{array}$ & 65.1 .3988 .51 .8 & $70-72$ \\
\hline $27 / 07 / 66$ & $\begin{array}{l}\text { Pedro Moacyr do } \\
\text { Amaral Cruz } \\
\text { Diretor FAU }\end{array}$ & $\begin{array}{l}\text { Luís Antônio da } \\
\text { Gama e Silva } \\
\text { Reitor }\end{array}$ & $\begin{array}{l}\text { Cobra ações para aprovação e liberação de } \\
\text { verbas para o início da construção. Aponta } \\
\text { que, em reunião, professores se eximiram de } \\
\text { examinar e criticar o projeto original da FAU; } \\
\text { em seu lugar, ele reexaminou o projeto } \\
\text { juntamente com dois engenheiros. Critica o } \\
\text { processo de execução do edifício pela } \\
\text { discussão se distanciar da construção e } \\
\text { adentrar a arte }\end{array}$ & 66.1 .20458 .1 .8 & $2-5$ \\
\hline $22 / 08 / 66$ & $\begin{array}{l}\text { Adalberto Mendes } \\
\text { dos Santos } \\
\text { Diretor Executivo } \\
\text { FCCUASO }\end{array}$ & $\begin{array}{l}\text { Luís Antônio da } \\
\text { Gama e Silva } \\
\text { Reitor }\end{array}$ & $\begin{array}{l}\text { Informa o reitor do pedido do diretor da FAU. } \\
\text { Comenta que as obras em concreto eram } \\
\text { melhor executadas pelo Fundo do que pela } \\
\text { iniciativa privada, que havia mal feito o prédio } \\
\text { da História e Geografia, o que os levou a } \\
\text { pintar o edifício. Aponta desejo de continuar a } \\
\text { obra } \\
\text { Encaminhamentos. Concorda e encaminha a } \\
\text { informação ao Diretor da FAU. Concorda com } \\
\text { os pontos levantados pelo Diretor em seu } \\
\text { primeiro ofício }\end{array}$ & 66.1 .20458 .1 .8 & $8-8 v$ \\
\hline $25 / 08 / 66$ & $\begin{array}{l}\text { Pedro Moacyr do } \\
\text { Amaral Cruz } \\
\text { Diretor FAU }\end{array}$ & $\begin{array}{l}\text { Luís Antônio da } \\
\text { Gama e Silva } \\
\text { Reitor }\end{array}$ & $\begin{array}{l}\text { Concorda com as propostas do Diretor } \\
\text { Executivo, quanto à realização da estrutura } \\
\text { de concreto pelo FCCUASO. Contudo, aponta } \\
\text { a necessidade de firma especializada para a } \\
\text { construção do concreto protendido } \\
\text { Encaminhamentos. Encaminha ao FCCUASO } \\
\text { para ciência e opinião }\end{array}$ & 66.1 .20458 .1 .8 & $9-10$ \\
\hline $25 / 08 / 66$ & $\begin{array}{l}\begin{array}{l}\text { Adalberto Mendes } \\
\text { dos Santos }\end{array} \\
\text { Diretor Executivo } \\
\text { FCCUASO }\end{array}$ & $\begin{array}{l}\text { João Batista Vilanova } \\
\text { Artigas } \\
\text { Arquiteto }\end{array}$ & $\begin{array}{l}\text { Conforme combinado com Bernini, estabelece } \\
\text { que os detalhes complementares de } \\
\text { arquitetura para execução serão fornecidos } \\
\text { em croquis e desenhos de acordo com a } \\
\text { necessidade. Informa que os desenhos já } \\
\text { enviados poderão sofrer modificações às } \\
\text { normas da firma vencedora. As modificações } \\
\text { deverão ser feitas pelo arquiteto, que não } \\
\text { receberá por isso }\end{array}$ & 65.1 .3988 .51 .8 & 73 \\
\hline $08 / 09 / 66$ & $\begin{array}{l}\text { Adalberto Mendes } \\
\text { dos Santos } \\
\text { Diretor Executivo } \\
\text { FCCUASO }\end{array}$ & $\begin{array}{l}\text { Pedro Moacyr do } \\
\text { Amaral Cruz } \\
\text { Diretor FAU }\end{array}$ & $\begin{array}{l}\text { Informa que a concorrência para a realização } \\
\text { das estruturas em concreto armado e } \\
\text { protendido seria aberta nos dias seguintes }\end{array}$ & 66.1 .20458 .1 .8 & 11 \\
\hline $09 / 09 / 66$ & $\begin{array}{l}\begin{array}{l}\text { Adalberto Mendes } \\
\text { dos Santos }\end{array} \\
\text { Diretor Executivo } \\
\text { FCCUASO }\end{array}$ & $\begin{array}{l}\text { Luís Antônio da } \\
\text { Gama e Silva } \\
\text { Reitor }\end{array}$ & $\begin{array}{l}\text { Informa que toda a obra seria realizada por } \\
\text { iniciativa privada, tendo em vista os } \\
\text { comentários do Diretor [f. 9-10] } \\
\text { Encaminhamentos. Aceita e pede } \\
\text { arquivamento }\end{array}$ & 66.1 .20458 .1 .8 & 12 \\
\hline $10 / 09 / 66$ & --- & --- & $\begin{array}{l}\text { Trecho do Diário Oficial com o anúncio da } \\
\text { concorrência para a construção da FAU }\end{array}$ & 66.1 .20458 .1 .8 & $\mathrm{~s} / \mathrm{n}^{\circ}(13)$ \\
\hline
\end{tabular}




\begin{tabular}{|c|c|c|c|c|c|}
\hline \multirow[b]{2}{*}{ Data } & \multirow{2}{*}{$\begin{array}{c}\text { Remetente } \\
\text { Nome e Cargo }\end{array}$} & \multirow{2}{*}{$\begin{array}{l}\text { Destinatário } \\
\text { Nome e Cargo }\end{array}$} & \multirow{2}{*}{$\begin{array}{l}\text { Conteúdo } \\
\text { Assunto }\end{array}$} & \multicolumn{2}{|c|}{ Processo USP } \\
\hline & & & & Número & Folhas \\
\hline $14 / 09 / 66$ & $\begin{array}{l}\text { Adalberto Mendes } \\
\text { dos Santos } \\
\text { Diretor Executivo } \\
\text { FCCUASO }\end{array}$ & $\begin{array}{l}\text { José Carlos de } \\
\text { Figueiredo Ferraz } \\
\text { Escritório Técnico J. C. } \\
\text { de Figueiredo Ferraz }\end{array}$ & $\begin{array}{l}\text { Solicita a entrega completa do projeto } \\
\text { estrutural para ser encaminhado à firma } \\
\text { vencedora }\end{array}$ & 65.1 .3988 .51 .8 & $74-74 v$ \\
\hline $15 / 09 / 66$ & $\begin{array}{l}\text { Pedro Moacyr do } \\
\text { Amaral Cruz } \\
\text { Diretor FAU }\end{array}$ & $\begin{array}{l}\begin{array}{l}\text { Adalberto Mendes } \\
\text { dos Santos }\end{array} \\
\text { Diretor Executivo } \\
\text { FCCUASO }\end{array}$ & $\begin{array}{l}\text { Agradece a iniciativa da concorrência para a } \\
\text { construção }\end{array}$ & 66.1 .20458 .1 .8 & $\mathrm{~s} / \mathrm{n}^{\circ}{ }^{\circ}(14)$ \\
\hline $18 / 11 / 66$ & $\begin{array}{l}\text { José Carlos de } \\
\text { Figueiredo Ferraz } \\
\text { Escritório Técnico J. } \\
\text { C. de Figueiredo } \\
\text { Ferraz }\end{array}$ & $\begin{array}{l}\begin{array}{l}\text { Adalberto Mendes } \\
\text { dos Santos }\end{array} \\
\text { Diretor Executivo } \\
\text { FCCUASO }\end{array}$ & $\begin{array}{l}\text { Anuncia a entrega dos originais }(22-53,55-60 \text {, } \\
64-66,68-88,91-93,96-97,99-100,102-111 \text {, } \\
39 A, 44 A, 42 A, 61 A, 62 A, 63 A) \text {. Já foram } \\
\text { entregues os originais }(1-21,2 A, 4 A, 5 A, 6 A \text {, } \\
7 A, 9 A, 12 A, 54,61-63,89-90,94-95,98 A \text {, } \\
\text { 101). Solicita, para reparos, a devolução dos } \\
\text { originais }(3,14,15,18,19,20) \text { e informa que } \\
\text { foram anulados os desenhos (56, 61-63, 89- } \\
90,96,98 A, 100-101)\end{array}$ & 65.1 .3988 .51 .8 & $75-75 v$ \\
\hline $18 / 11 / 66$ & $\begin{array}{l}\text { José Carlos de } \\
\text { Figueiredo Ferraz } \\
\text { Escritório Técnico J. } \\
\text { C. de Figueiredo } \\
\text { Ferraz }\end{array}$ & $\begin{array}{l}\begin{array}{l}\text { Adalberto Mendes } \\
\text { dos Santos }\end{array} \\
\text { Diretor Executivo } \\
\text { FCCUASO }\end{array}$ & $\begin{array}{l}\text { Solicita o pagamento de Cr } \$ 6.000 .000 \text { e envia } \\
\text { atura }\end{array}$ & 65.1 .3988 .51 .8 & $76-80$ \\
\hline $23 / 11 / 66$ & $\begin{array}{l}\begin{array}{l}\text { Adalberto Mendes } \\
\text { dos Santos }\end{array} \\
\text { Diretor Executivo } \\
\text { FCCUASO }\end{array}$ & $\begin{array}{l}\text { José Carlos de } \\
\text { Figueiredo Ferraz } \\
\text { Escritório Técnico J. C. } \\
\text { de Figueiredo Ferraz }\end{array}$ & $\begin{array}{l}\text { Envia as plantas solicitadas }(3,14,15,18,19 \\
\text { e 20) }\end{array}$ & 65.1 .3988 .51 .8 & 81 \\
\hline $24 / 11 / 66$ & $\begin{array}{l}\text { Eng. Walter Abrahão } \\
\text { Nimir } \\
\text { Estruturas }\end{array}$ & $\begin{array}{l}-- \\
\text { Encarregado do } \\
\text { Departamento de } \\
\text { Projetos }\end{array}$ & $\begin{array}{l}\text { Informa que os remanejamentos no projeto de } \\
\text { estrutura foram realizados, embora não seja } \\
\text { possível um exame detalhado no momento. } \\
\text { Sugere a liberação do pagamento de } \\
\text { honorários } \\
\text { Encaminhamentos. Pagamento de } \\
\text { Cr\$5.472.000 em honorários ao Escritório } \\
\text { técnico J. C. Figueiredo Ferraz pago em } \\
30 / 11 / 66\end{array}$ & 65.1 .3988 .51 .8 & $82-83$ \\
\hline $29 / 11 / 66$ & $\begin{array}{l}\begin{array}{l}\text { Adalberto Mendes } \\
\text { dos Santos }\end{array} \\
\text { Diretor Executivo } \\
\text { FCCUASO }\end{array}$ & --- & $\begin{array}{l}\text { Ata de reunião do Conselho de Administração } \\
\text { do FCCUASO. O reitor manifesta oposição } \\
\text { aos espaços livres no projeto da FAU e ao } \\
\text { custo elevado da estrutura. Professores } \\
\text { defendem a execução do projeto, mesmo se } \\
\text { "exótico", por representar a "Arquitetura } \\
\text { Brasileira" de seu tempo }\end{array}$ & 66.1 .20458 .1 .8 & $\begin{array}{l}\mathrm{s} / \mathrm{n}^{\circ}(15- \\
21)\end{array}$ \\
\hline $01 / 12 / 66$ & $\begin{array}{l}\begin{array}{l}\text { Adalberto Mendes } \\
\text { dos Santos }\end{array} \\
\text { Diretor Executivo } \\
\text { FCCUASO }\end{array}$ & $\begin{array}{l}\text { Pedro Moacyr do } \\
\text { Amaral Cruz } \\
\text { Diretor FAU }\end{array}$ & $\begin{array}{l}\text { Informa que, nesta data, o Fundo foi } \\
\text { autorizado a contratar a execução do edifício. } \\
\text { Esclarece que a firma vencedora está sendo } \\
\text { convidada a comparecer para assinar o } \\
\text { contrato para que as obras tenham início } \\
\text { imediato. Elogia a atuação do Diretor }\end{array}$ & 65.1 .3988 .51 .8 & 84 \\
\hline $01 / 12 / 66$ & $\begin{array}{l}\text { Adalberto Mendes } \\
\text { dos Santos } \\
\text { Diretor Executivo } \\
\text { FCCUASO }\end{array}$ & $\begin{array}{l}\text { Pedro Moacyr do } \\
\text { Amaral Cruz } \\
\text { Diretor FAU }\end{array}$ & $\begin{array}{l}\text { Comunica a autorização para contratação de } \\
\text { empresa que construirá a FAU. Aponta que o } \\
\text { projeto sofreu mudanças com a assistência } \\
\text { de Artigas }\end{array}$ & 66.1 .20458 .1 .8 & $s / n^{\circ}(22)$ \\
\hline $07 / 12 / 66$ & $\begin{array}{l}\text { Pedro Moacyr do } \\
\text { Amaral Cruz } \\
\text { Diretor FAU }\end{array}$ & $\begin{array}{l}\begin{array}{l}\text { Adalberto Mendes } \\
\text { dos Santos }\end{array} \\
\text { Diretor Executivo } \\
\text { FCCUASO }\end{array}$ & $\begin{array}{l}\text { Defini os motivos da urgência do novo prédio } \\
\text { e explica sua intervenção no projeto }\end{array}$ & 65.1 .3988 .51 .8 & $85-86 v$ \\
\hline $07 / 12 / 66$ & $\begin{array}{l}\text { Pedro Moacyr do } \\
\text { Amaral Cruz } \\
\text { Diretor FAU }\end{array}$ & $\begin{array}{l}\text { Adalberto Mendes } \\
\text { dos Santos } \\
\text { Diretor Executivo } \\
\text { FCCUASO }\end{array}$ & $\begin{array}{l}\text { Informa ter recebido o comunicado. Descreve } \\
\text { sua luta por uma construção de "menos } \\
\text { poesia e maior realidade" }\end{array}$ & 66.1 .20458 .1 .8 & $\begin{array}{l}\mathrm{s} / \mathrm{n}^{\circ}(23- \\
24)\end{array}$ \\
\hline
\end{tabular}




\begin{tabular}{|c|c|c|c|c|c|}
\hline & Remetente & Destinatário & Conteúdo & Processo & JSP \\
\hline Data & Nome e Cargo & Nome e Cargo & Assunto & Número & Folhas \\
\hline $13 / 12 / 66$ & $\begin{array}{l}\text { Adalberto Mendes } \\
\text { dos Santos } \\
\text { Diretor Executivo } \\
\text { FCCUASO }\end{array}$ & $\begin{array}{l}\text { Luís Antônio da } \\
\text { Gama e Silva } \\
\text { Reitor }\end{array}$ & $\begin{array}{l}\text { Aponta diminuição de verba para o orçamento } \\
\text { de } 1967 \text { e o cancelamento do saldo do ano de } \\
\text { 1966, o que seria uma complicação financeira } \\
\text { para os trabalhos de } 1967\end{array}$ & 67.1.5794.1.1 & $2-4$ \\
\hline $15 / 12 / 66$ & --- & --- & $\begin{array}{l}\text { Trecho do Diário Oficial com o anúncio da } \\
\text { contratação da Rizkallah para a execução do } \\
\text { edifício da FAU }\end{array}$ & 66.1 .20458 .1 .8 & $\mathrm{~s} / \mathrm{n}^{\circ}(25)$ \\
\hline $26 / 12 / 66$ & --- & -- & $\begin{array}{l}\text { Informe sobre o desenvolvimento do projeto } \\
\text { do edifício. Descreve rapidamente o projeto } \\
\text { feito por Artigas, sua revisão (permanecendo } \\
\text { contudo "exótico") e a contratação de } \\
\text { empresa privada para sua execução }\end{array}$ & 66.1 .20458 .1 .8 & $\begin{array}{l}\mathrm{s} / \mathrm{n}^{\circ}(26- \\
27)\end{array}$ \\
\hline $02 / 01 / 67$ & $\begin{array}{l}\text { José Carlos de } \\
\text { Figueiredo Ferraz } \\
\text { Escritório Técnico J. } \\
\text { C. de Figueiredo } \\
\text { Ferraz }\end{array}$ & $\begin{array}{l}\begin{array}{l}\text { Adalberto Mendes } \\
\text { dos Santos }\end{array} \\
\text { Diretor Executivo } \\
\text { FCCUASO }\end{array}$ & Entrega os originais $(3 \mathrm{~A}, 112,113)$ & 65.1 .3988 .51 .8 & $87-87 v$ \\
\hline $13 / 01 / 67$ & $\begin{array}{l}\text { José Carlos de } \\
\text { Figueiredo Ferraz } \\
\text { Escritório Técnico J. } \\
\text { C. de Figueiredo } \\
\text { Ferraz }\end{array}$ & --- & $\begin{array}{l}\text { Encaminha os originais }(98 \mathrm{~B}, 101 \mathrm{~A}, 114-116) \\
\text { e devolve }(14-15,18-20)\end{array}$ & 65.1 .3988 .51 .8 & $88-88 v$ \\
\hline $16 / 02 / 67$ & $\begin{array}{l}\text { Pedro Moacyr do } \\
\text { Amaral Cruz } \\
\text { Diretor FAU }\end{array}$ & $\begin{array}{l}\text { Luís Antônio da } \\
\text { Gama e Silva } \\
\text { Reitor }\end{array}$ & $\begin{array}{l}\text { Informa que na placa da obra da FAU não } \\
\text { consta o nome de Artigas }\end{array}$ & 66.1 .20458 .1 .8 & $\mathrm{~s} / \mathrm{n}^{0}(28)$ \\
\hline $20 / 02 / 67$ & --- & --- & $\begin{array}{l}\text { Ata do Conselho Universitário. João Alves } \\
\text { Meira ressalta a importância da construção do } \\
\text { Hospital Universitário }\end{array}$ & 67.1 .5794 .1 .1 & 17 \\
\hline $04 / 08 / 67$ & $\begin{array}{l}\text { Adalberto Mendes } \\
\text { dos Santos } \\
\text { Diretor Executivo } \\
\text { FCCUASO }\end{array}$ & $\begin{array}{l}\text { José Carlos de } \\
\text { Figueiredo Ferraz } \\
\text { Escritório Técnico J. C. } \\
\text { de Figueiredo Ferraz }\end{array}$ & $\begin{array}{l}\text { Informa que a obra está sendo executada } \\
\text { pela firma Construtora Alberto Nagib Riskallah } \\
\text { Ltda. Solicita a colaboração do escritório com } \\
\text { a empreiteira, fornecendo a indicação do } \\
\text { plano de concretagem das vigas protendidas }\end{array}$ & 65.1 .3988 .51 .8 & 89 \\
\hline $27 / 09 / 67$ & Eng. Vladimir Brega & Encarregado & $\begin{array}{l}\text { Solicita pronunciamento do calculista quanto } \\
\text { aos fios rompidos durante a protensão nos } \\
\text { cabos da rampa }\end{array}$ & 65.1 .3988 .51 .8 & 90 \\
\hline $27 / 09 / 67$ & $\begin{array}{l}\begin{array}{l}\text { Adalberto Mendes } \\
\text { dos Santos }\end{array} \\
\text { Diretor Executivo } \\
\text { FCCUASO }\end{array}$ & $\begin{array}{l}\text { José Carlos de } \\
\text { Figueiredo Ferraz } \\
\text { Escritório Técnico J. C. } \\
\text { de Figueiredo Ferraz }\end{array}$ & $\begin{array}{l}\text { Encaminha a solicitação de pronunciamento } \\
\text { em relação aos fios rompidos durante a } \\
\text { protensão }\end{array}$ & 65.1 .3988 .51 .8 & 91 \\
\hline $23 / 11 / 67$ & FCCUASO & -- & $\begin{array}{l}\text { Protocola o recebimento da folha } 115 \mathrm{~A} \text { em } \\
\text { substituição à } 115 \text { do Escritório Técnico J. C. } \\
\text { Figueiredo Ferraz }\end{array}$ & 65.1 .3988 .51 .8 & $92-92 v$ \\
\hline $28 / 11 / 67$ & $\begin{array}{l}\text { Eng. Homero Vieira } \\
\text { de Mello Lopes } \\
---\end{array}$ & $\begin{array}{l}\begin{array}{l}\text { Adalberto Mendes } \\
\text { dos Santos }\end{array} \\
\text { Diretor Executivo } \\
\text { FCCUASO }\end{array}$ & $\begin{array}{l}\text { Apresenta o orçamento referente ao projeto } \\
\text { das instalações elétricas ( } \mathrm{NCr} \$ 6.000)\end{array}$ & 65.1 .3988 .51 .8 & $93-96$ \\
\hline $05 / 12 / 67$ & $\begin{array}{l}\text { Eng. Roberto de } \\
\text { Araújo } \\
\text { Encarregado da } \\
\text { Divisão de Projetos }\end{array}$ & Assessor técnico & $\begin{array}{l}\text { Manifesta-se favorável a aceitação da } \\
\text { proposta (fls.93-94) e estabelece novos } \\
\text { prazos e condições de pagamento }\end{array}$ & 65.1 .3988 .51 .8 & 97 \\
\hline $06 / 12 / 67$ & $\begin{array}{l}\begin{array}{l}\text { Adalberto Mendes } \\
\text { dos Santos }\end{array} \\
\text { Diretor Executivo } \\
\text { FCCUASO }\end{array}$ & $\begin{array}{l}\text { Eng. Homero Vieira } \\
\text { de Mello Lopes }\end{array}$ & $\begin{array}{l}\text { Informa a aceitação das condições propostas } \\
\text { no orçamento e as alterações de prazos e } \\
\text { condição de pagamento }\end{array}$ & 65.1 .3988 .51 .8 & $98-99$ \\
\hline
\end{tabular}




\begin{tabular}{|c|c|c|c|c|c|}
\hline \multirow[b]{2}{*}{ Data } & \multirow{2}{*}{$\begin{array}{c}\text { Remetente } \\
\text { Nome e Cargo }\end{array}$} & \multirow{2}{*}{$\begin{array}{l}\text { Destinatário } \\
\text { Nome e Cargo }\end{array}$} & \multirow{2}{*}{$\begin{array}{l}\text { Conteúdo } \\
\text { Assunto }\end{array}$} & \multicolumn{2}{|c|}{ Processo USP } \\
\hline & & & & Número & Folhas \\
\hline $08 / 12 / 67$ & FCCUASO & --- & $\begin{array}{l}\text { Protocola o recebimento da folha } 130 \text { do } \\
\text { Escritório Técnico J. C. Figueiredo Ferraz }\end{array}$ & 65.1 .3988 .51 .8 & 100 \\
\hline $12 / 12 / 67$ & $\begin{array}{l}\text { José Carlos de } \\
\text { Figueiredo Ferraz } \\
\text { Escritório Técnico J. } \\
\text { C. de Figueiredo } \\
\text { Ferraz }\end{array}$ & $\begin{array}{l}\begin{array}{l}\text { Adalberto Mendes } \\
\text { dos Santos }\end{array} \\
\text { Diretor Executivo } \\
\text { FCCUASO }\end{array}$ & $\begin{array}{l}\text { Cobra NCr\$4.500 de honorários relativos à: } \\
\text { ajuste do estaqueamento devido à erro de } \\
\text { execução; assistência contínua e intensa à } \\
\text { firma empreiteira; execução de novas } \\
\text { pranchas (117-120, } 123-124,126-127) \text {; } \\
\text { modificação numa testada da fachada }\end{array}$ & 65.1 .3988 .51 .8 & $101-102 v$ \\
\hline $18 / 12 / 67$ & $\begin{array}{l}\text { Eng. Roberto de } \\
\text { Araújo } \\
\text { Encarregado da } \\
\text { Divisão de Projetos }\end{array}$ & Assessor técnico & $\begin{array}{l}\text { Faz um balanço de todos os desenhos } \\
\text { entregues pelo Escritório Técnico J. C. } \\
\text { Figueiredo Ferraz e conclui que o novo valor } \\
\text { cobrado corresponde à NCr\$204,5/desenho. } \\
\text { Pondera que o valor é um pouco elevado, } \\
\text { mas dentro da margem para o tipo de } \\
\text { trabalho. Conclui propondo a liberação do } \\
\text { pagamento, desde que condicionada ao } \\
\text { quitamento completo das dívidas com o } \\
\text { escritório, inclusive com os serviços que ainda } \\
\text { serão prestados no restante da obra } \\
\text { Encaminhamentos. Esclarece os motivos dos } \\
\text { trabalhos de revisão da fundação. Sugere } \\
\text { aprovação do parecer e encaminhamento de } \\
\text { ofício ao Escritório Técnico J. C. Figueiredo } \\
\text { Ferraz }\end{array}$ & 65.1 .3988 .51 .8 & $103-103 v$ \\
\hline $20 / 12 / 67$ & $\begin{array}{l}\text { José da Costa } \\
\text { Marques Filho } \\
\text { Encarregado da D. E. }\end{array}$ & Divisão de Projetos & $\begin{array}{l}\text { Encaminha os originais para o arquivo da } \\
\text { divisão e solicita } 4 \text { cópias de cada desenho ( } 1 \\
\text { para Artigas, } 2 \text { para a empreiteira e } 1 \text { para } \\
\text { fiscalização) }\end{array}$ & 65.1 .3988 .51 .8 & 105 \\
\hline \multirow[t]{2}{*}{$26 / 12 / 67$} & $\begin{array}{l}\text { Adalberto Mendes } \\
\text { dos Santos }\end{array}$ & $\begin{array}{l}\text { Escritório Técnico J. } \\
\text { C. de Figueiredo } \\
\text { Ferraz }\end{array}$ & $\begin{array}{l}\text { Questiona se os honorários cobrados (fl. 101) } \\
\text { incluirão os serviços a serem ainda prestados }\end{array}$ & 65.1 .3988 .51 .8 & 106 \\
\hline & $\begin{array}{l}\text { Diretor Executivo } \\
\text { FCCUASO }\end{array}$ & & & & \\
\hline $27 / 12 / 67$ & $\begin{array}{l}\text { José Carlos de } \\
\text { Figueiredo Ferraz } \\
\text { Escritório Técnico J. } \\
\text { C. de Figueiredo } \\
\text { Ferraz }\end{array}$ & $\begin{array}{l}\begin{array}{l}\text { Adalberto Mendes } \\
\text { dos Santos }\end{array} \\
\text { Diretor Executivo } \\
\text { FCCUASO }\end{array}$ & $\begin{array}{l}\text { Responde que o valor de NCr\$4.500 inclui os } \\
\text { trabalhos futuros. Enfatiza que não foi } \\
\text { cobrada a assistência técnica ou a patente de } \\
\text { protensão e que essas são contribuições } \\
\text { pessoais no âmbito universitário. Por fim, } \\
\text { esclarece que o projeto exigiu ônus do } \\
\text { escritório e foi uma estrutura das mais difíceis } \\
\text { já projetadas }\end{array}$ & 65.1 .3988 .51 .8 & $107-108$ \\
\hline \multirow[t]{2}{*}{$28 / 12 / 67$} & $\begin{array}{l}\text { Adalberto Mendes } \\
\text { dos Santos }\end{array}$ & $\begin{array}{l}\text { Escritório Técnico J. } \\
\text { C. de Figueiredo } \\
\text { Ferraz }\end{array}$ & $\begin{array}{l}\text { Concorda com o pagamento de } \mathrm{NCr} \$ 4.500 \\
\text { em honorários }\end{array}$ & 65.1 .3988 .51 .8 & $110-111$ \\
\hline & $\begin{array}{l}\text { Diretor Executivo } \\
\text { FCCUASO }\end{array}$ & & & & \\
\hline $29 / 12 / 67$ & $\begin{array}{l}\text { Adalberto Mendes } \\
\text { dos Santos } \\
\text { Diretor Executivo } \\
\text { FCCUASO }\end{array}$ & $\begin{array}{l}\text { João Batista Vilanova } \\
\text { Artigas } \\
\text { Arquiteto }\end{array}$ & $\begin{array}{l}\text { Encaminha cópias de plantas fornecidas pelo } \\
\text { Escritório Técnico J. C. Figueiredo Ferraz } \\
(98 \mathrm{~B}, 101 \mathrm{~A}, 115,129 \mathrm{~A}, 130)\end{array}$ & 65.1 .3988 .51 .8 & 109 \\
\hline $29 / 12 / 67$ & $\begin{array}{l}\text { Air Miranda } \\
\text { Encarregado }\end{array}$ & --- & $\begin{array}{l}\text { Protocola o recebimento dos originais } 129 \mathrm{~A}, \\
98 \mathrm{~B}, 101 \mathrm{~A}, \mathrm{e} 130 \text {. Encaminha os desenhos à } \\
\text { Construtora Alberto Nagib Rizkallah Ltda. }\end{array}$ & 65.1 .3988 .51 .8 & \\
\hline \multirow[t]{2}{*}{$03 / 01 / 68$} & $\begin{array}{l}\text { Roberto Sérgio M. } \\
\text { Carneiro }\end{array}$ & --- & Protocola despesa & 65.1 .3988 .51 .8 & 112 \\
\hline & $\begin{array}{l}\text { Encarregado Setor de } \\
\text { Orçamento }\end{array}$ & $\begin{array}{l}\text { Encarregado da } \\
\text { Direção Executiva }\end{array}$ & & & \\
\hline $22 / 01 / 68$ & $\begin{array}{l}\text { Eng. Homero Vieira } \\
\text { de Mello Lopes }\end{array}$ & $\begin{array}{l}\begin{array}{l}\text { Adalberto Mendes } \\
\text { dos Santos }\end{array} \\
\text { Diretor Executivo } \\
\text { FCCUASO }\end{array}$ & $\begin{array}{l}\text { Concorda com a condição de pagamento de } \\
\text { seus honorários, mas discorda do inicio do } \\
\text { prazo para entrega do trabalho }\end{array}$ & 65.1 .3988 .51 .8 & $113-114 v$ \\
\hline
\end{tabular}




\begin{tabular}{|c|c|c|c|c|c|}
\hline \multirow[b]{2}{*}{ Data } & \multirow{2}{*}{$\begin{array}{c}\text { Remetente } \\
\text { Nome e Cargo }\end{array}$} & \multirow{2}{*}{$\begin{array}{l}\text { Destinatário } \\
\text { Nome e Cargo }\end{array}$} & \multirow{2}{*}{$\begin{array}{l}\text { Conteúdo } \\
\text { Assunto }\end{array}$} & \multicolumn{2}{|c|}{ Processo USP } \\
\hline & & & & Número & Folhas \\
\hline 08/02/68 & FCCUASO & --- & $\begin{array}{l}\text { Protocola o recebimento da Construtora ANR } \\
\text { da folha } 131 \text { do Escritório Técnico J. C. } \\
\text { Figueiredo Ferraz }\end{array}$ & 65.1 .3988 .51 .8 & $115-115 v$ \\
\hline \multirow[t]{2}{*}{$21 / 02 / 68$} & $\begin{array}{l}\text { Adalberto Mendes } \\
\text { dos Santos }\end{array}$ & Ariosto Mila & $\begin{array}{l}\text { Felicita Ariosto Mila pela sua posse na } \\
\text { diretoria da FAU }\end{array}$ & 66.1 .20458 .1 .8 & $\mathrm{~s} / \mathrm{n}^{\circ}(29)$ \\
\hline & $\begin{array}{l}\text { Diretor Executivo } \\
\text { FCCUASO }\end{array}$ & Diretor FAU & $\begin{array}{l}\text { Encaminhamentos. Ariosto Mila agradece aos } \\
\text { votos e ao empenho na construção do edifício } \\
\text { da FAU }\end{array}$ & & \\
\hline $22 / 02 / 68$ & FCCUASO & --- & $\begin{array}{l}\text { Protocola o recebimento da Construtora ANR } \\
\text { da folha } 132 \text { do Escritório Técnico J. C. } \\
\text { Figueiredo Ferraz }\end{array}$ & 65.1 .3988 .51 .8 & $116-116 v$ \\
\hline \multirow[t]{2}{*}{$23 / 02 / 68$} & Ariosto Mila & $\begin{array}{l}\text { Adalberto Mendes } \\
\text { dos Santos }\end{array}$ & Agradece os votos & 66.1 .20458 .1 .8 & $s / n^{\circ}(30)$ \\
\hline & Diretor FAU & $\begin{array}{l}\text { Diretor Executivo } \\
\text { FCCUASO }\end{array}$ & & & \\
\hline $07 / 03 / 68$ & $\begin{array}{l}\text { Luciano Bernini } \\
\text { Arquiteto }\end{array}$ & $\begin{array}{l}\text { Encarregado da } \\
\text { Divisão de Projetos }\end{array}$ & $\begin{array}{l}\text { Solicita encaminhar ao Escritório Técnico } \\
\text { Homero V. Lopes os desenhos (níveis - } 3,00 / \text { - } \\
1,10 / 0,80 / 2,70 / 4,60 / 6,50 / 8,40 / 10,30 \text { ) para } \\
\text { feitura do projeto elétrico. Os desenhos } \\
\text { expressam o resultado de todas as reuniões } \\
\text { feitas costumeiramente às sextas-feiras com } \\
\text { o arq. Artigas. Informa que as plantas de } \\
\text { arquitetura ainda não são definitivas pois o } \\
\text { arquiteto ainda pretende alterá-las } \\
\text { Encaminhamentos. Solicita encaminha os } \\
\text { desenhos ao interessado, lembrando que } \\
\text { começa a contar o prazo de entrega }\end{array}$ & 65.1 .3988 .51 .8 & $117-117 v$ \\
\hline \multirow[t]{2}{*}{$07 / 03 / 68$} & $\begin{array}{l}\text { Adalberto Mendes } \\
\text { dos Santos }\end{array}$ & $\begin{array}{l}\text { Eng. Homero Vieira } \\
\text { de Mello Lopes }\end{array}$ & $\begin{array}{l}\text { Encaminha os desenhos de arquitetura para a } \\
\text { elaboração do projeto elétrico }\end{array}$ & 65.1 .3988 .51 .8 & 118 \\
\hline & $\begin{array}{l}\text { Diretor Executivo } \\
\text { FCCUASO }\end{array}$ & --- & & & \\
\hline $08 / 03 / 68$ & $\begin{array}{l}\text { José da Costa } \\
\text { Marques Filho } \\
\text { Encarregado da D. E. }\end{array}$ & $\begin{array}{l}\begin{array}{l}\text { Adalberto Mendes } \\
\text { dos Santos }\end{array} \\
\text { Diretor Executivo } \\
\text { FCCUASO }\end{array}$ & $\begin{array}{l}\text { Envia minuta de oficio à empreiteira e informa } \\
\text { que a mesma entregou o original da planta } \\
132\end{array}$ & 65.1 .3988 .51 .8 & 119 \\
\hline $11 / 03 / 68$ & $\begin{array}{l}\begin{array}{l}\text { Adalberto Mendes } \\
\text { dos Santos }\end{array} \\
\text { Diretor Executivo } \\
\text { FCCUASO }\end{array}$ & $\begin{array}{l}\text { Construtora Alberto } \\
\text { Nagib Rizkallah }\end{array}$ & $\begin{array}{l}\text { Confirma a entrega de duas cópias do } \\
\text { desenho } 132 \text { ao eng. Anuar Assad em } \\
\text { 23/2/68 }\end{array}$ & 65.1 .3988 .51 .8 & 120 \\
\hline $12 / 03 / 68$ & $\begin{array}{l}\text { Luciano Bernini } \\
\text { Arquiteto }\end{array}$ & $\begin{array}{l}\text { Encarregado da } \\
\text { Divisão de Projetos }\end{array}$ & $\begin{array}{l}\text { Foram entregues cópias dos desenhos } \\
\text { mencionados na folha } 117 \text { ao arq. Artigas e } \\
\text { ao eng. Homero Lopes para execução de } \\
\text { projeto elétrico e alterações de arquitetura. } \\
\text { Foi pedido urgência, uma vez que concluem- } \\
\text { se as obras de estrutura e deverá começar a } \\
\text { faze de acabamentos }\end{array}$ & 65.1 .3988 .51 .8 & 121 \\
\hline \multirow[t]{2}{*}{$12 / 03 / 68$} & $\begin{array}{l}\text { Adalberto Mendes } \\
\text { dos Santos }\end{array}$ & $\begin{array}{l}\text { João Batista Vilanova } \\
\text { Artigas }\end{array}$ & $\begin{array}{l}\text { Cobra urgência na revisão do projeto e } \\
\text { sugere simplificações }\end{array}$ & 65.1 .3988 .51 .8 & $122-123$ \\
\hline & $\begin{array}{l}\text { Diretor Executivo } \\
\text { FCCUASO }\end{array}$ & Arquiteto & & & \\
\hline \multirow[t]{2}{*}{$12 / 03 / 68$} & $\begin{array}{l}\text { Adalberto Mendes } \\
\text { dos Santos }\end{array}$ & $\begin{array}{l}\text { Eng. Homero Vieira } \\
\text { de Mello Lopes }\end{array}$ & Cobra o projeto de elétrica & 65.1 .3988 .51 .8 & $124-124 v$ \\
\hline & $\begin{array}{l}\text { Diretor Executivo } \\
\text { FCCUASO }\end{array}$ & --- & & & \\
\hline \multirow[t]{2}{*}{$20 / 03 / 68$} & Ariosto Mila & $\begin{array}{l}\text { Adalberto Mendes } \\
\text { dos Santos }\end{array}$ & $\begin{array}{l}\text { Informa que designou Artigas e Ferraz para } \\
\text { acompanhar o desenvolvimento da } \\
\text { construção }\end{array}$ & 65.1 .3988 .51 .8 & 125 \\
\hline & Diretor FAU & $\begin{array}{l}\text { Diretor Executivo } \\
\text { FCCUASO }\end{array}$ & & & \\
\hline
\end{tabular}




\begin{tabular}{|c|c|c|c|c|c|}
\hline & & & & Processo & USP \\
\hline Data & Nome e Cargo & Nome e Cargo & Assunto & Número & Folhas \\
\hline $26 / 03 / 68$ & $\begin{array}{l}\text { Adalberto Mendes } \\
\text { dos Santos } \\
\text { Diretor Executivo } \\
\text { FCCUASO }\end{array}$ & $\begin{array}{l}\text { Ariosto Mila } \\
\text { Diretor FAU }\end{array}$ & $\begin{array}{l}\text { Agradece a designação do diretor. Informa } \\
\text { que o Fundo está obrigado a acatar as } \\
\text { decisões do CCU e não pode aceitar } \\
\text { modificações sem a aprovação do mesmo. } \\
\text { (biblioteca no térreo e emprego de materiais } \\
\text { já aprovados em outras construções) }\end{array}$ & 65.1 .3988 .51 .8 & $126-127 v$ \\
\hline $26 / 03 / 68$ & $\begin{array}{l}\text { Luciano Bernini } \\
\text { Arquiteto }\end{array}$ & $\begin{array}{l}\text { Encarregado da } \\
\text { Divisão de Projetos }\end{array}$ & $\begin{array}{l}\text { Informa que Artigas comprometeu-se em } \\
\text { reunião na véspera a trazer na próxima sexta- } \\
\text { feira os detalhes básicos para os painéis. } \\
\text { Outros detalhes de alvenaria, sanitários, } \\
\text { caixilho, etc. serão elaborados pelo escritório } \\
\text { do Fundo e aprovados por Artigas } \\
\text { Encaminhamentos. Prosseguir tendo em visa } \\
\text { a necessidade de antecedência do projeto em } \\
\text { relação a obra, para que a DE possa tomar } \\
\text { providência, especialmente caixilho, pisos e } \\
\text { painéis }\end{array}$ & 65.1 .3988 .51 .8 & 130 \\
\hline $26 / 03 / 68$ & $\begin{array}{l}\text { Adalberto Mendes } \\
\text { dos Santos } \\
\text { Diretor Executivo } \\
\text { FCCUASO }\end{array}$ & $\begin{array}{l}\text { Ariosto Mila } \\
\text { Diretor FAU }\end{array}$ & $\begin{array}{l}\text { Entrega correspondência em Ariosto Mila } \\
\text { designa Artigas e Figueiredo Ferraz para o } \\
\text { acompanhamento da construção do edifício } \\
\text { da FAU. Informa a manutenção de mudanças } \\
\text { no projeto, como a passagem da biblioteca do } \\
\text { primeiro andar para o térreo } \\
\text { Encaminhamentos. Ariosto Mila encaminha o } \\
\text { ofício para Artigas e Figueiredo Ferraz, para } \\
\text { conhecimento. Ainda outro encaminhamento } \\
\text { para os autores, com assinatura } \\
\text { desconhecida }\end{array}$ & 66.1 .20458 .1 .8 & $\begin{array}{c}\mathrm{s} / \mathrm{n}^{\circ}(31- \\
32)\end{array}$ \\
\hline $01 / 04 / 68$ & Luciano Bernini & $\begin{array}{l}\text { Encarregado da } \\
\text { Divisão de Projetos }\end{array}$ & $\begin{array}{l}\text { Solicita o envio das plantas dos níveis -3,00/ - } \\
1,10 / 0,80 / 2,70 / 4,60 / 6,30 / 8,40 / 10,30, \\
\text { cobertura e cortes (AA, BB, CC, DD, EE, FF) } \\
\text { para o escritório de Homero Lopes para o } \\
\text { desenvolvimento do projeto elétrico }\end{array}$ & 65.1 .3988 .51 .8 & 128 \\
\hline $01 / 04 / 68$ & $\begin{array}{l}\text { Adalberto Mendes } \\
\text { dos Santos } \\
\text { Diretor Executivo } \\
\text { FCCUASO }\end{array}$ & Eng. Jorge A. Kayano & $\begin{array}{l}\text { Solicita projeto da ventilação forçada do } \\
\text { auditório }\end{array}$ & 65.1 .3988 .51 .8 & 134 \\
\hline $01 / 04 / 68$ & $\begin{array}{l}\text { Adalberto Mendes } \\
\text { dos Santos } \\
\text { Diretor Executivo } \\
\text { FCCUASO }\end{array}$ & -- & $\begin{array}{l}\text { Autoriza a elaboração do projeto de } \\
\text { ventilação forçada }\end{array}$ & 65.1 .3988 .51 .8 & 135 \\
\hline $02 / 04 / 68$ & $\begin{array}{l}\text { Antonio Carlos } \\
\text { Albignente } \\
\text { Encarregado do } \\
\text { Cópias e Arquivo }\end{array}$ & $\begin{array}{l}\text { Encarregado da } \\
\text { Divisão de Projetos }\end{array}$ & $\begin{array}{l}\text { Comunica que dois jogos de } 5 \text { plantas em } \\
\text { cópias transparentes custaram NCr } \$ 119,00 \\
\text { que deverão ser debitados ao Engenheiro } \\
\text { encarregado do projeto elétrico }\end{array}$ & 65.1 .3988 .51 .8 & 129 \\
\hline $02 / 04 / 68$ & $\begin{array}{l}\text { Eng. Roberto de } \\
\text { Araújo } \\
\text { Encarregado da } \\
\text { Divisão de Projetos }\end{array}$ & Diretor & $\begin{array}{l}\text { Encaminha } 2 \text { jogos de cópias normais e } 2 \\
\text { jogos de cópias transparentes (será cobrado } \\
\text { o valor de NCr } \$ 119,00 \text { ) para o Escritório } \\
\text { Homero Lopes }\end{array}$ & 65.1 .3988 .51 .8 & 136 \\
\hline $02 / 04 / 68$ & $\begin{array}{l}\text { Eng. Roberto de } \\
\text { Araújo } \\
\text { Divisão de Projetos }\end{array}$ & $\begin{array}{l}\text { Encarregado da } \\
\text { Divisão de Execução }\end{array}$ & $\begin{array}{l}\text { Encaminha os desenhos } \mathrm{H} 310 \text { e } 311 \\
\text { referentes às instalações hidráulicas de águas } \\
\text { pluviais } \\
\text { Encaminhamentos. Anexado orçamento } \\
\text { estimativo (total: } \mathrm{NCr} \$ 18.626,15 \text { ) }\end{array}$ & 65.1 .3988 .51 .8 & $141-144$ \\
\hline $03 / 04 / 68$ & $\begin{array}{l}\begin{array}{l}\text { Adalberto Mendes } \\
\text { dos Santos }\end{array} \\
\text { Diretor Executivo } \\
\text { FCCUASO }\end{array}$ & $\begin{array}{l}\text { Eng. Homero Vieira } \\
\text { de Mello Lopes }\end{array}$ & Envia as cópias e notifica o escritório & 65.1 .3988 .51 .8 & $137-137 v$ \\
\hline
\end{tabular}




\begin{tabular}{|c|c|c|c|c|c|}
\hline \multirow[b]{2}{*}{ Data } & \multirow{2}{*}{$\begin{array}{c}\text { Remetente } \\
\text { Nome e Cargo }\end{array}$} & \multirow{2}{*}{$\begin{array}{l}\text { Destinatário } \\
\text { Nome e Cargo }\end{array}$} & \multirow{2}{*}{$\begin{array}{l}\text { Conteúdo } \\
\text { Assunto }\end{array}$} & \multicolumn{2}{|c|}{ Processo USP } \\
\hline & & & & Número & Folhas \\
\hline $03 / 04 / 68$ & $\begin{array}{l}\text { Eng. Eduardo } \\
\text { Pessôa }\end{array}$ & Divisão de Projetos & $\begin{array}{l}\text { Pede esclarecimentos junto ao Eng. José } \\
\text { Marques sobre a possibilidade de um furo de } \\
\text { comunicação entre as } 2 \text { calhas laterais da } \\
\text { mesma viga principal da cobertura junto aos } \\
\text { pilares para facilitar a descida de águas } \\
\text { pluviais permitindo ainda outra tubulação no } \\
\text { mesmo pilar } \\
\text { Encaminhamentos. Poderá ser feito nos } \\
\text { pilares } 17,25,26,33 \text { e } 34 \text { e nas vigas V2. A } \\
\text { execução de furo de comunicação foi } \\
\text { autorizada por Castanho (F. Ferraz) por } \\
\text { telefone. Anexo croquis }\end{array}$ & 65.1 .3988 .51 .8 & $138-139$ \\
\hline $26 / 04 / 68$ & Luciano Bernini & $\begin{array}{l}\text { Encarregado da } \\
\text { Divisão de Projetos }\end{array}$ & $\begin{array}{l}\text { Informa que os desenhos de piso (6984, } \\
6995,6996,6997 \text { e } 6998) \text { e de caixilho ( } 6990 \text {, } \\
6991,6992,6993 \text { e } 6994) \text { estão prontos }\end{array}$ & 65.1 .3988 .51 .8 & $140-140 v$ \\
\hline $03 / 05 / 68$ & $\begin{array}{l}\text { Eng. José da Costa } \\
\text { Marques Milho } \\
\text { Encarregado da D.E. }\end{array}$ & S.E.O.C. & $\begin{array}{l}\text { Solicita providências para as concorrências } \\
\text { de piso e caixilhos }\end{array}$ & 65.1 .3988 .51 .8 & 145 \\
\hline $23 / 05 / 68$ & $\begin{array}{l}\text { Eng. Homero Vieira } \\
\text { de Mello Lopes }\end{array}$ & $\begin{array}{l}\begin{array}{l}\text { Adalberto Mendes } \\
\text { dos Santos }\end{array} \\
\text { Diretor Executivo } \\
\text { FCCUASO }\end{array}$ & $\begin{array}{l}\text { Envia originais do anteprojeto das instalações } \\
\text { elétricas para execução de cópias. Os } \\
\text { originais e uma cópia deverão ser devolvidos } \\
\text { (aprovado) para elaboração do projeto) }\end{array}$ & 65.1 .3988 .51 .8 & 146 \\
\hline $27 / 05 / 68$ & $\begin{array}{l}\text { Eng. Roberto de } \\
\text { Araújo } \\
\text { Divisão de Projetos }\end{array}$ & Diretor & $\begin{array}{l}\text { Solicita encaminhar o jogo de cópias do } \\
\text { projeto elétrico ao escritório de Artigas e que } \\
\text { esse, depois de examinar, devolva ao eng. } \\
\text { Homero Lopes } \\
\text { Encaminhamentos. Bernini solicita } \\
\text { encaminhar as plantas para Artigas examiná- } \\
\text { las (conforme solicitado por ele) }\end{array}$ & 65.1 .3988 .51 .8 & 147 \\
\hline $28 / 05 / 68$ & $\begin{array}{l}\begin{array}{l}\text { Adalberto Mendes } \\
\text { dos Santos }\end{array} \\
\text { Diretor Executivo } \\
\text { FCCUASO }\end{array}$ & $\begin{array}{l}\text { João Batista Vilanova } \\
\text { Artigas } \\
\text { Arquiteto }\end{array}$ & $\begin{array}{l}\text { Encaminha o jogo de cópias do anteprojeto } \\
\text { de elétrica para ser analisado }\end{array}$ & 65.1 .3988 .51 .8 & $148-148 v$ \\
\hline $11 / 06 / 68$ & --- & -- & $\begin{array}{l}\text { Ata de reunião do Conselho de Administração } \\
\text { do FCCUASO. Discute a construção da } \\
\text { subestação elétrica do campus. Descreve a } \\
\text { mudança do projeto da FAU por Artigas, que } \\
\text { colocou de novo a biblioteca no 10 andar à } \\
\text { revelia do Conselho do FCCUASO, que seria } \\
\text { o órgão decisório. A mudança é defendida "de } \\
\text { maneira feliz" por Ariosto Mila, embora os } \\
\text { outros participantes ataquem a baixa } \\
\text { proporção aluno/área e o térreo vazio. Fica } \\
\text { decidido o encaminhamento da questão à } \\
\text { Congregação da FAU. Apresenta a } \\
\text { construção de pavilhões e transferência para } \\
\text { o campus das faculdades de Odontologia e } \\
\text { Veterinária; a construção do edifício da } \\
\text { Geologia; a construção de estacionamentos } \\
\text { na Química. Discute se a Escola de Educação } \\
\text { Física do Estado poderia utilizar o ginásio da } \\
\text { USP em construção; se já era possível cobrar } \\
\text { a locação dos restaurantes em funcionamento } \\
\text { no campus; aumento do salário dos } \\
\text { servidores do FCCUASO; a programação de } \\
\text { recursos para } 1969\end{array}$ & 66.1 .20458 .1 .8 & $\begin{array}{c}\mathrm{s} / \mathrm{n}^{\circ}(33- \\
41)\end{array}$ \\
\hline $12 / 06 / 68$ & $\begin{array}{l}\begin{array}{l}\text { Adalberto Mendes } \\
\text { dos Santos }\end{array} \\
\text { Diretor Executivo } \\
\text { FCCUASO }\end{array}$ & $\begin{array}{l}\text { Ariosto Mila } \\
\text { Diretor FAU }\end{array}$ & $\begin{array}{l}\text { Reafirma os argumentos pronunciados na } \\
\text { reunião de } 11 \text { de junho de } 1968 \text {, apontando a } \\
\text { desobediência do projeto às decisões do } \\
\text { Conselho e os problemas vindos do térreo } \\
\text { "com grande espaço ocioso" }\end{array}$ & 66.1 .20458 .1 .8 & $\begin{array}{c}\mathrm{s} / \mathrm{n}^{\circ}(42- \\
43)\end{array}$ \\
\hline
\end{tabular}




\begin{tabular}{|c|c|c|c|c|c|}
\hline & Remetente & Destinatário & Conteúdo & Processo & JSP \\
\hline Data & Nome e Cargo & Nome e Cargo & Assunto & Número & Folhas \\
\hline $20 / 06 / 68$ & $\begin{array}{l}\text { João Batista } \\
\text { Vilanova Artigas } \\
\text { Arquiteto }\end{array}$ & $\begin{array}{l}\text { Ariosto Mila } \\
\text { Diretor FAU }\end{array}$ & $\begin{array}{l}\text { Defende a biblioteca no } 1^{0} \text { andar, por não } \\
\text { aumentar a área construída e ser melhor para } \\
\text { a conservação dos livros. Coloca que as } \\
\text { modificações propostas pelo Conselho } \\
\text { versavam a construção de pequenas áreas e } \\
\text { da sala da Congregação, indicações que } \\
\text { foram atendidas }\end{array}$ & 66.1 .20458 .1 .8 & $\mathrm{~s} / \mathrm{n}^{\circ}(44)$ \\
\hline $17 / 07 / 68$ & $\begin{array}{l}\begin{array}{l}\text { Adalberto Mendes } \\
\text { dos Santos }\end{array} \\
\text { Diretor Executivo } \\
\text { FCCUASO }\end{array}$ & $\begin{array}{l}\text { Ariosto Mila } \\
\text { Diretor FAU }\end{array}$ & $\begin{array}{l}\text { Cobra resposta ao Fundo por parte da } \\
\text { Congregação sobre as mudanças realizadas } \\
\text { por Artigas no projeto do edifício }\end{array}$ & 66.1 .20458 .1 .8 & $\mathrm{~s} / \mathrm{n}^{0}(45)$ \\
\hline $22 / 07 / 68$ & $\begin{array}{l}\text { Pedro Moacyr do } \\
\text { Amaral Cruz } \\
\text { Ex-Diretor da FAU }\end{array}$ & --- & $\begin{array}{l}\text { Declaração de voto contrário às alterações } \\
\text { realizadas por Artigas }\end{array}$ & 66.1 .20458 .1 .8 & $\mathrm{~s} / \mathrm{n}^{0}(46)$ \\
\hline $23 / 07 / 68$ & $\begin{array}{l}\text { Abvolt - } \\
\text { Equipamentos } \\
\text { Digitais Ltda. }\end{array}$ & $\begin{array}{l}\text { Adalberto Mendes } \\
\text { dos Santos } \\
\text { Diretor Executivo } \\
\text { FCCUASO }\end{array}$ & $\begin{array}{l}\text { Informa o êxito na concepção de uma nova } \\
\text { tecnologia de instalação elétrica inteiramente } \\
\text { desenvolvida dentro da USP. Pede permissão } \\
\text { para que essa tecnologia seja instalada na } \\
\text { FAU }\end{array}$ & 66.1 .20458 .1 .8 & $\mathrm{~s} / \mathrm{n}^{\circ}(47)$ \\
\hline $24 / 07 / 68$ & $\begin{array}{l}\text { Ariosto Mila } \\
\text { Diretor FAU }\end{array}$ & $\begin{array}{l}\begin{array}{l}\text { Adalberto Mendes } \\
\text { dos Santos }\end{array} \\
\text { Diretor Executivo } \\
\text { FCCUASO }\end{array}$ & $\begin{array}{l}\text { Informa a anuência da Congregação às } \\
\text { modificações propostas por Artigas }\end{array}$ & 66.1 .20458 .1 .8 & $\mathrm{~s} / \mathrm{n}^{0}(48)$ \\
\hline $29 / 07 / 68$ & $\begin{array}{l}\text { Adalberto Mendes } \\
\text { dos Santos } \\
\text { Diretor Executivo } \\
\text { FCCUASO }\end{array}$ & $\begin{array}{l}\text { Abvolt - } \\
\text { Equipamentos } \\
\text { Digitais Ltda. }\end{array}$ & $\begin{array}{l}\text { Rejeita a oferta da firma, já que a obra da } \\
\text { FAU já estaria em grau avançado, em caráter } \\
\text { de urgência, e o especialista contratado para } \\
\text { as instalações era externo ao Fundo }\end{array}$ & 66.1 .20458 .1 .8 & $\mathrm{~s} / \mathrm{n}^{\circ}(49)$ \\
\hline $31 / 07 / 68$ & $\begin{array}{l}\text { Abvolt - } \\
\text { Equipamentos } \\
\text { Digitais Ltda. }\end{array}$ & Diretor FAU & $\begin{array}{l}\text { Informa Ariosto Mila das correspondências } \\
\text { trocadas com o FCCUASO e envia relação de } \\
\text { obras que usam o sistema }\end{array}$ & 66.1 .20458 .1 .8 & $\mathrm{~s} / \mathrm{n}^{0}(50)$ \\
\hline $31 / 07 / 68$ & $\begin{array}{l}\text { Abvolt - } \\
\text { Equipamentos } \\
\text { Digitais Ltda. }\end{array}$ & $\begin{array}{l}\text { Ariosto Mila } \\
\text { Diretor FAU }\end{array}$ & $\begin{array}{l}\text { Relação de obras que usam o sistema de } \\
\text { comando à distância da Abvolt }\end{array}$ & 66.1 .20458 .1 .8 & $\begin{array}{l}\mathrm{s} / \mathrm{n}^{0}(51- \\
55)\end{array}$ \\
\hline $07 / 08 / 68$ & $\begin{array}{l}\text { Adalberto Mendes } \\
\text { dos Santos } \\
\text { Diretor Executivo } \\
\text { FCCUASO }\end{array}$ & $\begin{array}{l}\text { Ariosto Mila } \\
\text { Diretor FAU }\end{array}$ & $\begin{array}{l}\text { Com a proximidade da conclusão das obras, } \\
\text { requere relação de móveis a serem } \\
\text { comprados para a FAU }\end{array}$ & 66.1 .20458 .1 .8 & $\mathrm{~s} / \mathrm{n}^{\circ}(56)$ \\
\hline $19 / 08 / 68$ & $\begin{array}{l}\text { Ariosto Mila } \\
\text { Diretor FAU }\end{array}$ & $\begin{array}{l}\text { João Batista Vilanova } \\
\text { Artigas } \\
\text { Arquiteto }\end{array}$ & $\begin{array}{l}\text { Solicita o atendimento da requisição de } \\
\text { Adalberto Mendes dos Santos, quanto ao } \\
\text { mobiliário a ser comprado para o edifício }\end{array}$ & 66.1 .20458 .1 .8 & $\mathrm{~s} / \mathrm{n}^{\circ}(57)$ \\
\hline $20 / 08 / 68$ & $\begin{array}{l}\text { João Batista } \\
\text { Vilanova Artigas } \\
\text { Arquiteto }\end{array}$ & $\begin{array}{l}\text { Ariosto Mila } \\
\text { Diretor FAU }\end{array}$ & $\begin{array}{l}\text { Informa o envio da relação, realizada junto } \\
\text { com Abraão Sanovicz e da qual Ariosto Mila } \\
\text { já teria ciência. A relação havia sido recebida } \\
\text { pelo arquiteto Bernini e um segundo } \\
\text { funcionário (nome ilegível) }\end{array}$ & 66.1 .20458 .1 .8 & $\begin{array}{l}\mathrm{s} / \mathrm{n}^{0}(58- \\
59)\end{array}$ \\
\hline $26 / 08 / 68$ & $\begin{array}{l}\begin{array}{l}\text { Adalberto Mendes } \\
\text { dos Santos }\end{array} \\
\text { Diretor Executivo } \\
\text { FCCUASO }\end{array}$ & $\begin{array}{l}\text { Ariosto Mila } \\
\text { Diretor FAU }\end{array}$ & $\begin{array}{l}\text { Convocação e pauta para reunião do } \\
\text { Conselho do FCCUASO }\end{array}$ & 66.1 .20458 .1 .8 & $\begin{array}{l}\mathrm{s} / \mathrm{n}^{\circ}(62- \\
63)\end{array}$ \\
\hline
\end{tabular}




\begin{tabular}{|c|c|c|c|c|c|}
\hline & & & & Processo & JSP \\
\hline Data & Nome e Cargo & Nome e Cargo & Assunto & Número & Folhas \\
\hline $11 / 10 / 68$ & $\begin{array}{l}\text { Ariosto Mila } \\
\text { Diretor FAU }\end{array}$ & -- & $\begin{array}{l}\text { Comunica instauração de comissão para } \\
\text { decidir a utilização da Vila Penteado quando a } \\
\text { FAU se mudar para o campus }\end{array}$ & 66.1 .20458 .1 .8 & $s / n^{0}(64)$ \\
\hline $25 / 11 / 68$ & $\begin{array}{l}\text { Ariosto Mila } \\
\text { Diretor FAU }\end{array}$ & $\begin{array}{l}\text { Abrahão Sanovickz } \\
\text { Professor }\end{array}$ & $\begin{array}{l}\text { Pede uma relação de móveis a serem obtidos } \\
\text { para as áreas administrativas da nova FAU, } \\
\text { que deveriam ser exemplos significativos de } \\
\text { design }\end{array}$ & 66.1 .20458 .1 .8 & $\mathrm{~s} / \mathrm{n}^{\circ}(65)$ \\
\hline $04 / 12 / 68$ & $\begin{array}{l}\text { Abrahão Sanovickz } \\
\text { Professor }\end{array}$ & $\begin{array}{l}\text { Ariosto Mila } \\
\text { Diretor FAU }\end{array}$ & $\begin{array}{l}\text { Relação de móveis, com identificação, } \\
\text { descrição e quantificação. Apresenta um } \\
\text { memorial de defesa }\end{array}$ & 66.1 .20458 .1 .8 & $\begin{array}{l}\mathrm{s} / \mathrm{n}^{\circ}(66- \\
85)\end{array}$ \\
\hline $06 / 12 / 68$ & $\begin{array}{l}\text { Adalberto Mendes } \\
\text { dos Santos } \\
\text { Diretor Executivo } \\
\text { FCCUASO }\end{array}$ & $\begin{array}{l}\text { Ariosto Mila } \\
\text { Diretor FAU }\end{array}$ & $\begin{array}{l}\text { Estima o fim da obra da FAU para fevereiro } \\
\text { de } 1969 \\
\text { Encaminhamentos. Ariosto Mila indica ciência }\end{array}$ & 66.1 .20458 .1 .8 & $\mathrm{~s} / \mathrm{n}^{0}(86)$ \\
\hline $30 / 12 / 68$ & --- & FCCUASO & $\begin{array}{l}\text { Sobre o equipamento de exaustão nas } \\
\text { oficinas da FAU }\end{array}$ & 66.1 .20458 .1 .8 & $\begin{array}{l}\mathrm{s} / \mathrm{n}^{\circ}(87- \\
88)\end{array}$ \\
\hline $09 / 01 / 69$ & $\begin{array}{l}\text { Adalberto Mendes } \\
\text { dos Santos } \\
\text { Diretor Executivo } \\
\text { FCCUASO }\end{array}$ & $\begin{array}{l}\text { Ariosto Mila } \\
\text { Diretor FAU }\end{array}$ & $\begin{array}{l}\text { Encaminha proposta de exaustores feita pela } \\
\text { Anemotérmica - Engenharia e Indústria Ltda. }\end{array}$ & 66.1 .20458 .1 .8 & $\mathrm{~s} / \mathrm{n}^{\circ}(89)$ \\
\hline $03 / 02 / 69$ & $\begin{array}{l}\text { Amelco S.A. } \\
\text { Indústria Eletrônica }\end{array}$ & $\begin{array}{l}\text { Ariosto Mila } \\
\text { Diretor FAU }\end{array}$ & $\begin{array}{l}\text { Orçamento de equipamentos eletrônicos } \\
\text { (amplificadores, microfones, alto-falantes etc.) } \\
\text { Encaminhamentos. Ariosto Mila encaminha o } \\
\text { orçamento a Artigas }\end{array}$ & 66.1 .20458 .1 .8 & $\begin{array}{l}\mathrm{s} / \mathrm{n}^{\circ}(90- \\
91)\end{array}$ \\
\hline $03 / 02 / 69$ & $\begin{array}{l}\text { Amelco S.A. } \\
\text { Indústria Eletrônica }\end{array}$ & $\begin{array}{l}\text { Ariosto Mila } \\
\text { Diretor FAU }\end{array}$ & $\begin{array}{l}\text { Orçamento de equipamentos eletrônicos } \\
\text { (cabos, fontes etc.) }\end{array}$ & 66.1 .20458 .1 .8 & $s / n^{0}(92)$ \\
\hline $06 / 02 / 69$ & $\begin{array}{l}\text { João Batista } \\
\text { Vilanova Artigas } \\
\text { Arquiteto }\end{array}$ & $\begin{array}{l}\text { Ariosto Mila } \\
\text { Diretor FAU }\end{array}$ & $\begin{array}{l}\text { Confirma a validade dos orçamentos enviados } \\
\text { pela Amelco S.A. Indústria Eletrônica }\end{array}$ & 66.1 .20458 .1 .8 & $s / n^{0}(93)$ \\
\hline $13 / 02 / 69$ & $\begin{array}{l}\begin{array}{l}\text { Adalberto Mendes } \\
\text { dos Santos }\end{array} \\
\text { Diretor Executivo } \\
\text { FCCUASO }\end{array}$ & $\begin{array}{l}\text { Ariosto Mila } \\
\text { Diretor FAU }\end{array}$ & $\begin{array}{l}\text { Prevê a conclusão do edifício para o } 25 \text { de } \\
\text { fevereiro. Justifica o atraso na obra pelas } \\
\text { dificuldades financeiras, escassez e elevação } \\
\text { do preço do cimento, e fortes chuvas na } \\
\text { segunda quinzena de janeiro }\end{array}$ & 66.1 .20458 .1 .8 & $\begin{array}{l}\mathrm{s} / \mathrm{n}^{\circ}(94- \\
95)\end{array}$ \\
\hline $25 / 03 / 69$ & $\begin{array}{l}\text { Helio Lourenço de } \\
\text { Oliveira } \\
\text { Vice-Reitor em } \\
\text { exercício }\end{array}$ & $\begin{array}{l}\text { Ariosto Mila } \\
\text { Diretor FAU }\end{array}$ & $\begin{array}{l}\text { Informa o recebimento de ofício comunicando } \\
\text { o fim das obras da FAU }\end{array}$ & 66.1 .20458 .1 .8 & $\mathrm{~s} / \mathrm{n}^{0}(96)$ \\
\hline $18 / 06 / 69$ & $\begin{array}{l}\text { Alfredo Buzaid } \\
\text { Vice-Reitor em } \\
\text { exercício }\end{array}$ & $\begin{array}{l}\begin{array}{l}\text { Adalberto Mendes } \\
\text { dos Santos }\end{array} \\
\text { Diretor Executivo } \\
\text { FCCUASO }\end{array}$ & $\begin{array}{l}\text { Solicita a relação de nomes, salários e } \\
\text { funções dos servidores do Fundo. Aponta não } \\
\text { ser necessária a relação de trabalhadores } \\
\text { braçais ligados às obras }\end{array}$ & 69.1 .12921 .1 .7 & 3 \\
\hline $23 / 06 / 69$ & $\begin{array}{l}\begin{array}{l}\text { Adalberto Mendes } \\
\text { dos Santos }\end{array} \\
\text { Diretor Executivo } \\
\text { FCCUASO }\end{array}$ & $\begin{array}{l}\text { Alfredo Buzaid } \\
\text { Vice-Reitor em } \\
\text { exercício }\end{array}$ & $\begin{array}{l}\text { Encaminha a relação nominal dos servidores } \\
\text { com respectivos salários }\end{array}$ & 69.1 .12921 .1 .7 & $4-8$ \\
\hline
\end{tabular}




\begin{tabular}{|c|c|c|c|c|c|}
\hline & Remetente & Destinatário & Conteúdo & Processo & ISP \\
\hline Data & Nome e Cargo & Nome e Cargo & Assunto & Número & Folhas \\
\hline $30 / 06 / 69$ & $\begin{array}{l}\text { Adalberto Mendes } \\
\text { dos Santos } \\
\text { Diretor Executivo } \\
\text { FCCUASO }\end{array}$ & $\begin{array}{l}\text { Alfredo Buzaid } \\
\text { Vice-Reitor em } \\
\text { exercício }\end{array}$ & $\begin{array}{l}\text { Devido à redução do orçamento do Fundo, } \\
\text { sugere a passagem da execução das obras } \\
\text { para a iniciativa privada. Ainda para reduzir } \\
\text { gastos, propõe a demissão de funcionários } \\
\text { com cargos altos e o rebaixamento de } \\
\text { salários. Aponta que as indenizações não } \\
\text { diminuem a validade das demissões, e } \\
\text { propõe o uso do FGTS para pagamento de } \\
\text { parte das indenizações (no caso de } \\
\text { funcionários que optaram por não recolher } \\
\text { esse imposto). Pede autorização para realizar } \\
\text { essas medidas }\end{array}$ & 69.1.12921.1.7 & $9-12$ \\
\hline $01 / 07 / 69$ & $\begin{array}{l}\begin{array}{l}\text { Adalberto Mendes } \\
\text { dos Santos }\end{array} \\
\text { Diretor Executivo } \\
\text { FCCUASO }\end{array}$ & $\begin{array}{l}\text { Alfredo Buzaid } \\
\text { Vice-Reitor em } \\
\text { exercício }\end{array}$ & $\begin{array}{l}\text { Encaminha os custos das obras na CUASO. } \\
\text { Aponta a dificuldade de calcular o preço do } \\
\text { metro quadrado das obras }\end{array}$ & 69.1 .12921 .1 .7 & $14-19$ \\
\hline $01 / 07 / 69$ & $\begin{array}{l}\begin{array}{l}\text { Adalberto Mendes } \\
\text { dos Santos }\end{array} \\
\text { Diretor Executivo } \\
\text { FCCUASO }\end{array}$ & $\begin{array}{l}\text { Alfredo Buzaid } \\
\text { Vice-Reitor em } \\
\text { exercício }\end{array}$ & $\begin{array}{l}\text { Preços por metro quadrado (o preço do metro } \\
\text { quadrado da FAU está ligeiramente mais alto } \\
\text { do que o de outros edifícios) }\end{array}$ & 69.1 .12921 .1 .7 & $20-21$ \\
\hline $02 / 07 / 69$ & $\begin{array}{l}\begin{array}{l}\text { Adalberto Mendes } \\
\text { dos Santos }\end{array} \\
\text { Diretor Executivo } \\
\text { FCCUASO }\end{array}$ & $\begin{array}{l}\text { Alfredo Buzaid } \\
\text { Vice-Reitor em } \\
\text { exercício }\end{array}$ & $\begin{array}{l}\text { Encaminha o número de causas trabalhistas } \\
\text { existentes no Fundo }\end{array}$ & 69.1 .12921 .1 .7 & 22 \\
\hline $02 / 07 / 69$ & $\begin{array}{l}\begin{array}{l}\text { Adalberto Mendes } \\
\text { dos Santos }\end{array} \\
\text { Diretor Executivo } \\
\text { FCCUASO }\end{array}$ & $\begin{array}{l}\text { Alfredo Buzaid } \\
\text { Vice-Reitor em } \\
\text { exercício }\end{array}$ & $\begin{array}{l}\text { Relação dos processos trabalhistas de } 1967, \\
1968 \text { e } 1969\end{array}$ & 69.1 .12921 .1 .7 & $23-28$ \\
\hline $02 / 07 / 69$ & $\begin{array}{l}\begin{array}{l}\text { Adalberto Mendes } \\
\text { dos Santos }\end{array} \\
\text { Diretor Executivo } \\
\text { FCCUASO }\end{array}$ & $\begin{array}{l}\text { Alfredo Buzaid } \\
\text { Vice-Reitor em } \\
\text { exercício }\end{array}$ & $\begin{array}{l}\text { Envia informações sobre os empregados do } \\
\text { Fundo; aponta o papel do Fundo na } \\
\text { manutenção da CUASO; discute a origem da } \\
\text { energia elétrica usada na CUASO }\end{array}$ & 69.1 .12921 .1 .7 & $29-35$ \\
\hline $02 / 07 / 69$ & $\begin{array}{l}\text { Roberto Sérgio M. } \\
\text { Carneiro } \\
\text { Encarregado do Setor } \\
\text { de Orçamento }\end{array}$ & --- & $\begin{array}{l}\text { Discriminação de despesas para manutenção } \\
\text { da Cidade Universitária }\end{array}$ & 69.1 .12921 .1 .7 & 36 \\
\hline $05 / 12 / 69$ & $\begin{array}{l}\text { José Roberto Franco } \\
\text { da Fonseca } \\
\text { Chefe do Gabinete }\end{array}$ & --- & $\begin{array}{l}\text { Exoneração do Diretor-Executivo do } \\
\text { FCCUASO Adalberto Mendes dos Santos e } \\
\text { designação provisória de Luciano Bernini para } \\
\text { o cargo }\end{array}$ & 65.1 .32613 .1 .2 & 9 \\
\hline $08 / 12 / 69$ & $\begin{array}{l}\text { Maria Cecília } \\
\text { Amadesi } \\
\text { Chefe de Seção }\end{array}$ & -- & Cumprimento do Memorando da folha 9 & 65.1 .32613 .1 .2 & 10 \\
\hline $08 / 12 / 69$ & $\begin{array}{l}\text { Miguel Reale } \\
\text { Reitor }\end{array}$ & --- & $\begin{array}{l}\text { Dispensa de Adalberto Mendes dos Santos } \\
\text { do cargo de Diretor-Executivo do FCCUASO }\end{array}$ & 65.1 .32613 .1 .2 & 11 \\
\hline $08 / 12 / 69$ & $\begin{array}{l}\text { Miguel Reale } \\
\text { Reitor }\end{array}$ & --- & $\begin{array}{l}\text { Designação de Luciano Bernini para Diretor- } \\
\text { Executivo do FCCUASO }\end{array}$ & 65.1 .32613 .1 .2 & 12 \\
\hline $28 / 10 / 70$ & $\begin{array}{l}\text { José Roberto Franco } \\
\text { da Fonseca } \\
\text { Chefe do Gabinete }\end{array}$ & $\begin{array}{l}\text { Luiz Gonzaga Pinto e } \\
\text { Silva Júnior } \\
\text { Diretor Geral do } \\
\text { Departamento de } \\
\text { Administração }\end{array}$ & $\begin{array}{l}\text { Pedido de designação permanente de } \\
\text { Luciano Bernini para Diretor-Executivo do } \\
\text { FCCUASO }\end{array}$ & 65.1 .32613 .1 .2 & 13 \\
\hline $29 / 10 / 70$ & --- & --- & $\begin{array}{l}\text { Atendimento do pedido de designação } \\
\text { permanente de Luciano Bernini para Diretor- } \\
\text { Executivo do FCCUASO }\end{array}$ & 65.1 .32613 .1 .2 & 14 \\
\hline
\end{tabular}




\begin{tabular}{|c|c|c|c|c|c|}
\hline \multirow[b]{2}{*}{ Data } & \multirow{2}{*}{$\begin{array}{c}\text { Remetente } \\
\text { Nome e Cargo }\end{array}$} & \multirow{2}{*}{$\begin{array}{l}\text { Destinatário } \\
\text { Nome e Cargo }\end{array}$} & \multirow{2}{*}{$\begin{array}{l}\text { Conteúdo } \\
\text { Assunto }\end{array}$} & \multicolumn{2}{|c|}{ Processo USP } \\
\hline & & & & Número & Folhas \\
\hline \multirow[t]{2}{*}{$30 / 10 / 70$} & Miguel Reale & $\begin{array}{l}\text { Luiz Gonzaga Pinto e } \\
\text { Silva Júnior }\end{array}$ & $\begin{array}{l}\text { Designa Luciano Bernini para Diretor } \\
\text { Executivo do FCCUASO }\end{array}$ & 65.1 .32613 .1 .2 & 15 \\
\hline & Reitor & $\begin{array}{l}\text { Diretor Geral do } \\
\text { Departamento de } \\
\text { Administração }\end{array}$ & & & \\
\hline $\mathrm{s} / \mathrm{d}$ & -- & -- & $\begin{array}{l}\text { Previsão de prazos para execução de } 56 \\
\text { desenhos, organizados nas categorias: } \\
\text { Plantas; Cortes; Caixilhos; Painéis; Piso; } \\
\text { Domo; Sanitários }\end{array}$ & 65.1 .3988 .51 .8 & $131-132$ \\
\hline$s / d$ & $\begin{array}{l}\text { Luciano Bernini } \\
\text { Arquiteto }\end{array}$ & -- & $\begin{array}{l}\text { Relação dos mobiliário requisitado para a } \\
\text { FAU }\end{array}$ & 66.1 .20458 .1 .8 & $\begin{array}{l}\mathrm{s} / \mathrm{n}^{0}(60- \\
61)\end{array}$ \\
\hline$s / d$ & -- & --- & $\begin{array}{l}\text { Programação de obras e previsão } \\
\text { orçamentária de } 1967\end{array}$ & 67.1 .5794 .1 .1 & $5-16$ \\
\hline $\mathrm{s} / \mathrm{d}$ & --- & --- & Revisão orçamentária para 1965 & 65.1 .17666 .1 .1 & $3-10$ \\
\hline$s / d$ & --- & --- & & 69.1.12921.1.7 & 13 \\
\hline & Luciano Bernini & $\begin{array}{l}\text { Eng. Roberto de } \\
\text { Araujo } \\
\text { Encarregado da } \\
\text { Divisão de Projetos }\end{array}$ & $\begin{array}{l}\text { Informa em reunião com os Engs. Elétricos } \\
\text { notou-se a necessidade de sistema de } \\
\text { ventilação forçada no auditório. Foi sugerida a } \\
\text { consulta à firma do Eng. Jorge A. Kayano }\end{array}$ & 65.1 .3988 .51 .8 & 133 \\
\hline
\end{tabular}

